\title{
A TRADIÇÃO POLÍCROMA NO ALTO RIO MADEIRA
}

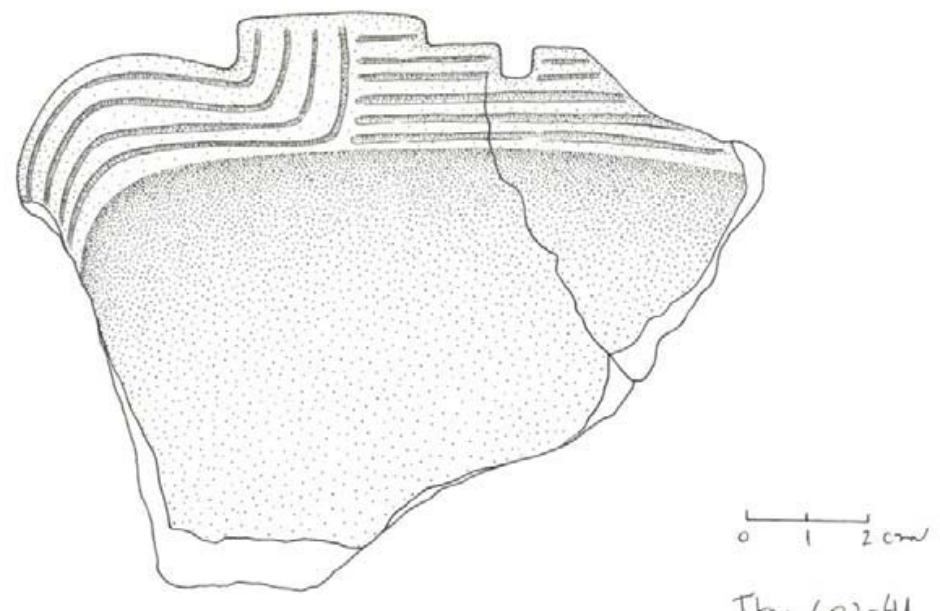

Ita. $602-41$

Fernando Ozorio de Almeida

Volume 1

São Paulo 


\title{
A TRADIÇÃO POLÍCROMA NO ALTO RIO MADEIRA
} Volume 1
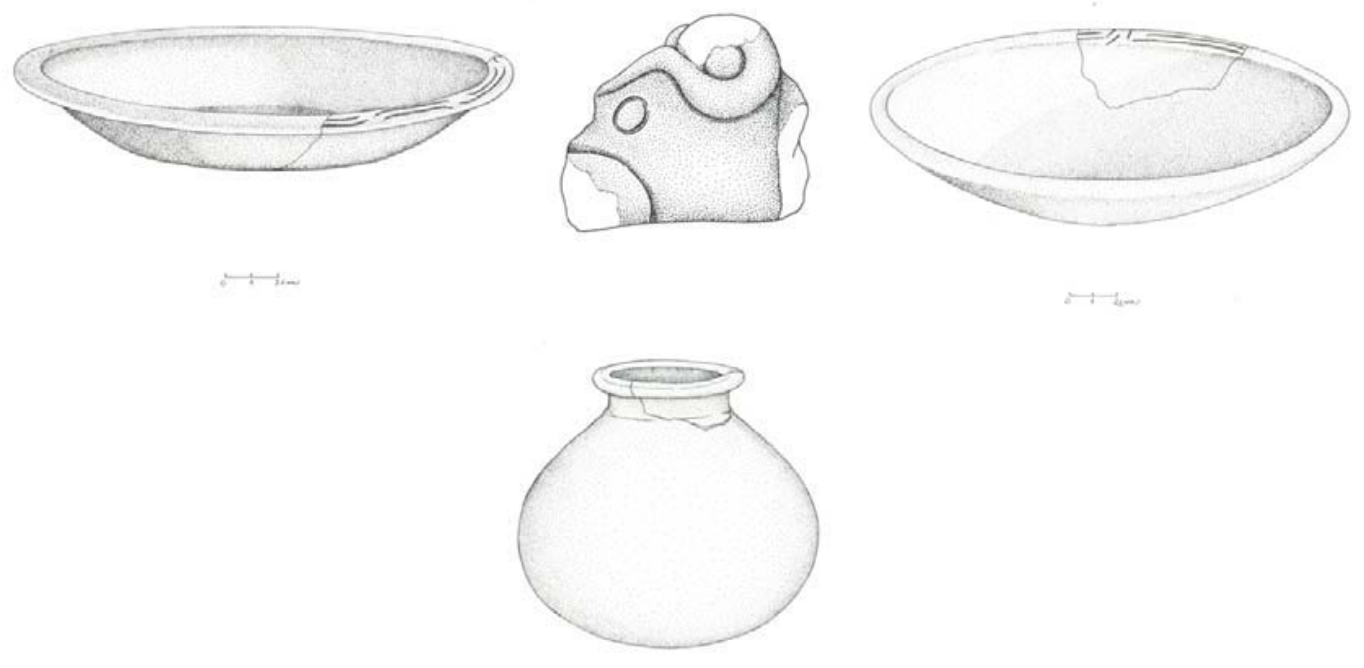

Tese apresentada ao Programa de PósGraduação em Arqueologia do Museu de Arqueologia e Etnologia da Universidade de São Paulo para obtenção do título de Doutor em Arqueologia

\author{
Área de Concentração: Arqueologia \\ Orientador: Prof. Dr. Eduardo Góes Neves
}

Linha de Pesquisa: Processos de Formação e Transformação Social

São Paulo 


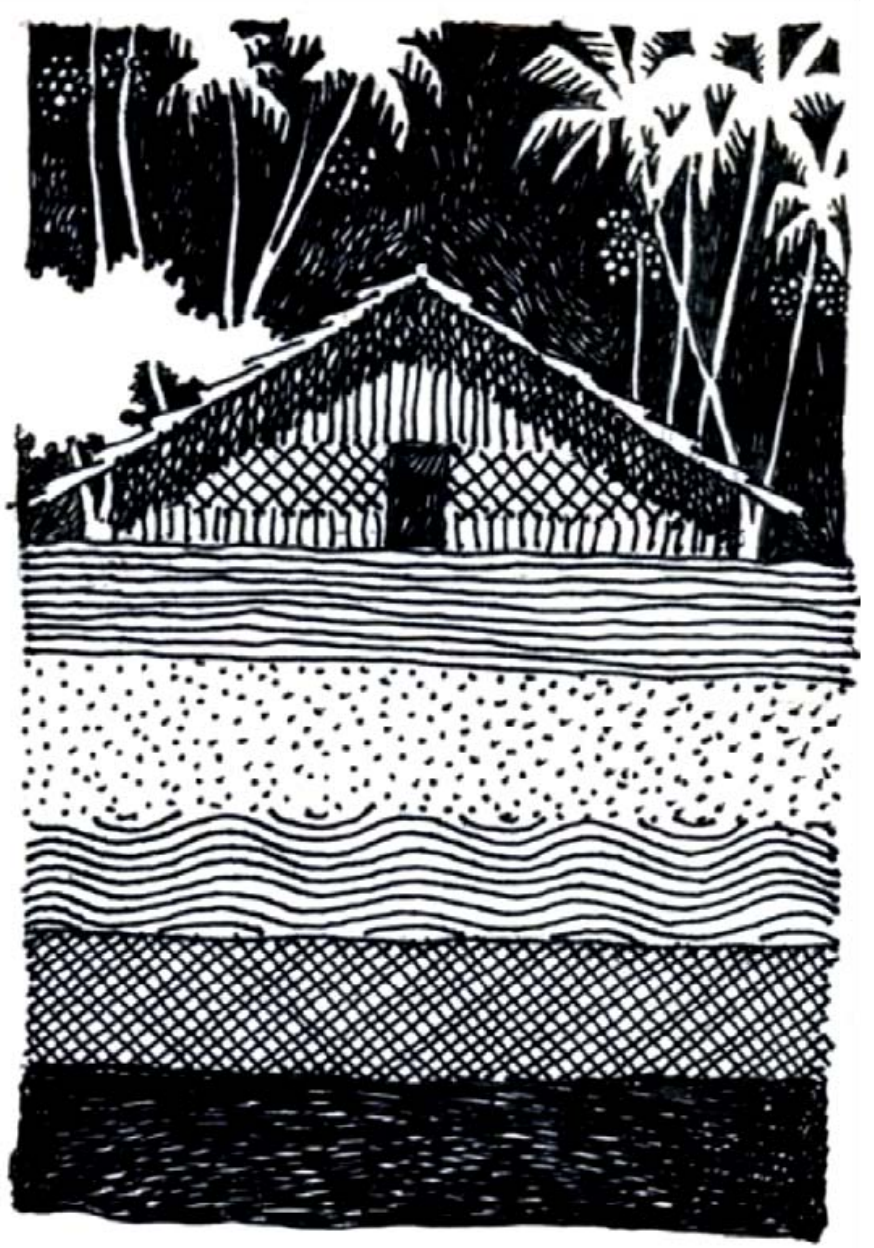

\section{ARQUEOTROP}

laboratório de arqueologia dos trópicos 
To my old folk back in England...

Didders,

Nancy, and

auntie Joan

(Miss you) 


\section{RESUMO}

Nesta tese, buscou-se realizar interpretações contextualizadas visando à compreensão da história de longa duração das antigas populações ceramistas do alto rio Madeira, sob a perspectiva da Ecologia Histórica. Tais interpretações foram realizadas a partir de uma análise comparativa de cinco sítios arqueológicos da região sudoeste da Amazônia. O método comparativo continuou sendo utilizado de maneira a possibilitar uma discussão sobre diferentes Estilos e Tradições amazônicas. O objetivo final foi contribuir para o conhecimento historiográfico relativo a populações falantes de línguas do tronco Tupi, em especial os Tupi-Guarani, bem como apresentar dados cronológicos e estilísticos que permitissem repensar a chamada Tradição Polícroma da Amazônia.

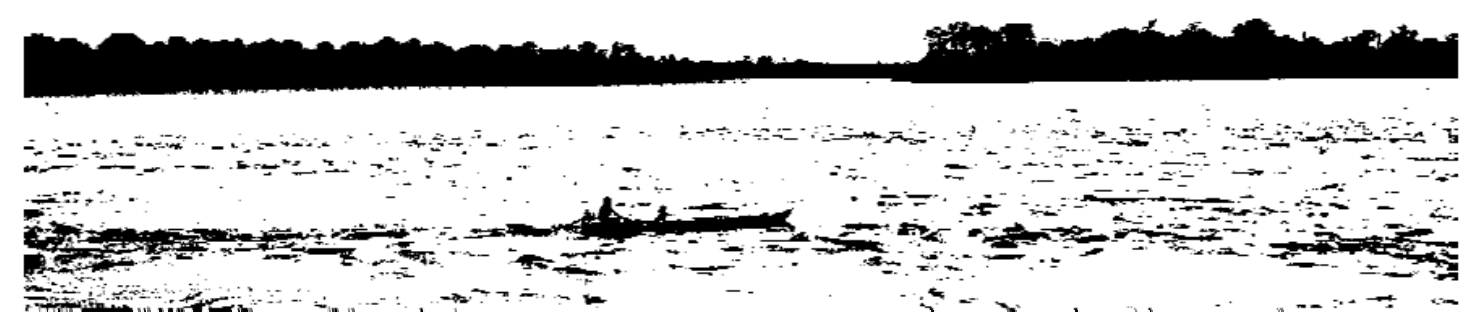

Encontro dos rios Madeira e Jamari

Palavras Chave: Arqueologia do Alto Rio Madeira, Tradição Polícroma da Amazônia, Subtradição Tupinambá da Amazônia, Tronco linguístico Tupi, Família linguística Tupi-Guarani . 


\section{ABSTRACT}

Based on contextualized interpretations, this thesis sought to make a contribution to the comprehension of the history (longue durée) of pottery-producing indigenous populations of the upper Madeira region, from the perspective of Historical Ecology. The comparison of five archaeological sites from this region (southwestern Amazonia) formed the basis for these interpretations. The comparative method was further used so as to make possible an extensive discussion about different archaeological Styles and Traditions in Amazonia. The final aim was to contribute to the historiographical knowledge of ancient speakers of languages of the Tupi stock, specially the Tupi-Guarani family, and to present stylistic and chronological data which would enable the rethinking of the so-called Polychrome Tradition of Amazonia.

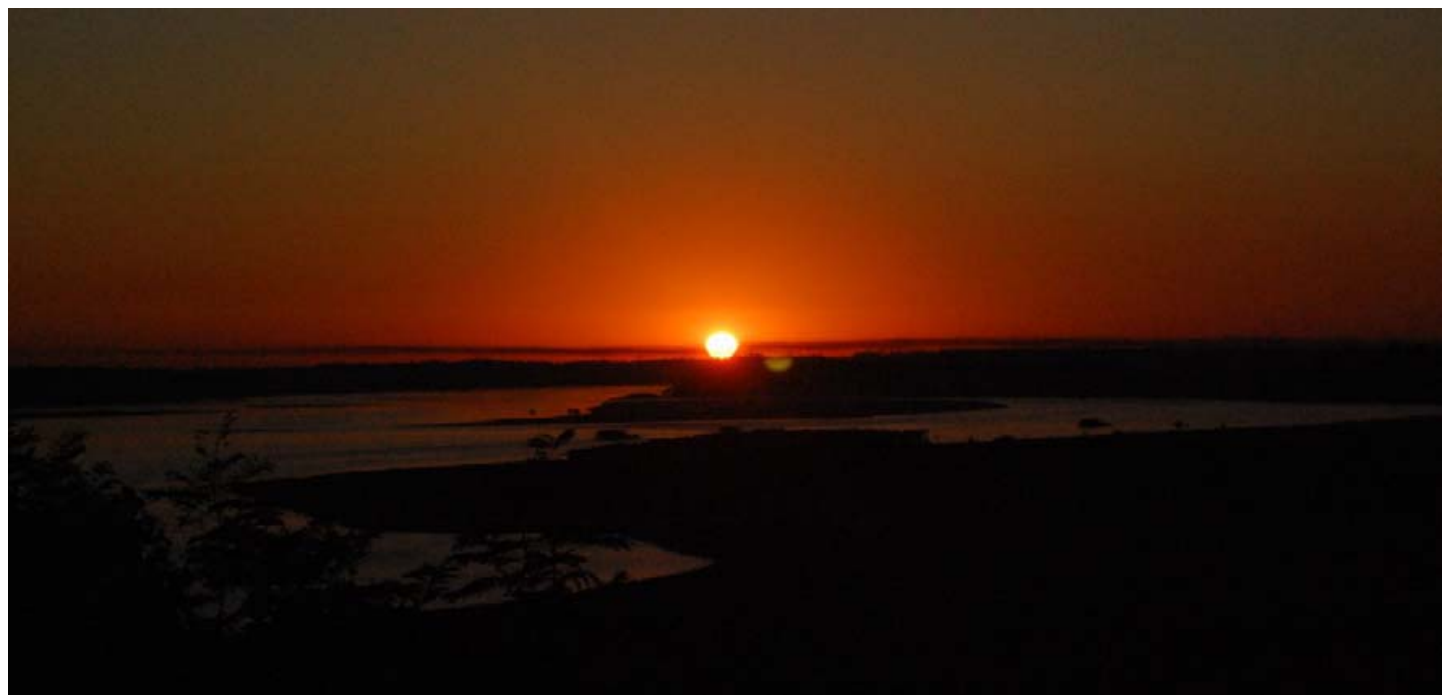

Vista do alto rio Madeida

Key Words: Upper Madeira River Archaeology, Polychrome Tradition of Amazonia, Tupinambá Sub-Tradition of Amazonia, Tupi language stock, Tupi-Guarani language family. 


\section{AGRADECIMENTOS}

Essa Pesquisa foi financiada com recursos da CAPES e da FAPESP.

Os meses finais de uma tese de doutorado são sempre marcados por uma boa dose de reclusão e solidão, que são suportáveis apenas porque no resto do tempo é possível conviver com amigos e colegas que fazem valer a pena. Esta tese é resultado das contribuições de muitas pessoas com quem tive o privilégio do contato nos últimos onze anos, quando comecei na arqueologia. Também pelo apoio que recebo da minha família.

A maior de todas as contribuições vem do meu orientador e amigo Eduardo Neves, cujo maior mérito é a capacidade impar de aglutinar aficionados em arqueologia amazônica em seu entorno: o nosso grupo só é possível graças a ele. Eduardo também me forneceu condições incríveis de realizar pesquisas no alto Madeira, com uma considerável possibilidade de campo, seis etapas em quatro anos. É uma honra ter um orientador que não reprime o aluno que se arrisca a pensar grande, ou mesmo que pensa diferente dele (nesse caso o aluno eventualmente pode sofrer um leve bullyng!). Desejo vida longa à minha parceria com o professor e com a equipe do ARQUEOTROP.

Gostaria de agradecer especialmente a Eduardo Tamanaha, Márjorie Lima (ESSE CASAL VAlE OURO!), Rafael Pedott, Lorena Garcia, Rodrigo Suñer, Márcia Arcuri, Guilherme Mongeló, Jaqueline, Belletti, Carlos Zimpel, Eduardo Bespalez, Silvana Zus e, Daniella Amaral, Bruna Rocha, Vinícius Honorato, Manuel Arroyo-Kalin (que me ensinou a fazer analogias entre frutas e indústrias cerâmicas), Claide Moraes, Anne Rapp Py-Daniel, Maurício Silva, Carla Gibertoni, Felippo Stanpanoni, Marta Cavallini, Michelle Tizuka, Silvia Cunha Lima: Amigos que estiveram presentes em vários momentos dessa pesquisa.

Cristiana Barreto, nos últimos anos, deu uma imensa contribuição para nosso grupo de amazonólogos e com quem aprendi muito. Fabíola Silva foi uma das mais importantes pessoas na minha formação. Transmitiu-me alguns dos seus conhecimentos teóricos, leu e comentou grande parte do que escrevi, o que incluí uma versão preliminar do Capítulo 1. Outra ilustre ajuda veio do professor Chico Noelli, com quem tive o prazer de um longo debate sobre o Capítulo 2 dessa tese. As discordâncias que possuímos não alteram a grande admiração que possuo por esse pesquisador. É uma grande honra ter Chico, Fabíola e seus alunos (Ângelo, Chumbinho, Melian e Lorena), como interlocutores nos debates tupinológicos. 
Glória Kock leu e forneceu preciosos comentários sobre o Capítulo 3. Paulo De Blasis e Astolfo Araújo estiveram presentes na banca de qualificação e contribuíram para uma série de pontos dessa Tese. Rafael Pedott realizou uma pré-análise do material lítico (com contribuição de Ricardo Monma). Ligia Lima analisou os vestígios botânicos do sítio Itapirema (com contribuição de Myrtle Schock). Nigel Smith me passou preciosa bibliografia sobre biritologia. Stephen Ronstain por questionar a cronologia. Lavínia Fávero fez aquela revisão de texto que só ela sabe e que deu uma imensa contribuição para a fluidez e coesão da redação. Marcos Brito fez os mapas com a perfeição de sempre. Erêndira Oliveira e Paulo Arena fizeram os desenhos da cerâmica. Serginho Morcegão da Silveira fez os 3Ds e Eduardo Kazuo fez tanta coisa que já não lembro mais (croquis, mapas pranchas). Um agradecimento especial também para a Dra. Lúcia Barroso e os alunos Ricardo Messias e Jiang Pu, do Centro de Estatística Aplicada (CEA) da USP, que deram uma imensa ajuda no processamento dos dados.

Estagiaram comigo no MAE, em ordem cronológica: Ana Azeredo, Ligia Trombetta Lima, Agda Sardinha, a baronesa Camila von Losinfiendt, Márcio Figueiredo, Rodrigo Suñer, Diogo Bob Borges (curta temporada). Também me ajudaram (muito) no final Thiago Kater e Breno Feijó. Desses, foi Agda Sardinha que ganhou o prêmio de resistência, e ainda me salvou com as fotos.

Agradeço aos professores do MAE: Mabel Flemming,Verônica Wesoloski, Maria Cristina Bruno. Colegas do MAE: Patti Fisher, Bernardo Lacale, Camila Jacome, Atorre, Fabio Guaraldo, Fabi, João Saldanha, Rafael (estagiário Lab1) Regina Resende, as Tati’s, Estevam Argos, Laura Furquin, Irmina Doneux, Thiago Trindade, Roberto Peralta, Caroline Caromano, Leandro Cascón, Renatão, Cabrón, Cida Santos, Paulinho, Dária, Regivaldo, Luis, Fatiminha, Chica, Cristina, Sandra, Taia, Sandrinha, Vanuza, Regina, Cléber, Mônica, Ader, Nica, Valdeir, dona Nice, Maria José, Fabinho, Denise (Dal Pino). Um agradecimento para todo o pessoal da biblioteca (Eliana, Eleuza, Aberto, Gilberto, Washington) e em especial para Hélio Miranda, um profissional fora de série e que qualquer pesquisador gostaria de ter por perto (não existe texto impossível de ser encontrado!). Em São Paulo, meu agradecimento também vai para Lucia Juliani, Rucirene Miguel, Rodimar, Samuel Almeida e Leandro Duran (quem torce paro Guarani fica para o fim da lista).

Em Rondônia, gostaria de agradecer especialmente a Carlos Augusto Zimpel, Silvana Zuse, e Michelle Tizuka. Constantes companheiros durante os trabalhos de campo e grandes parceiros nos estudos rondonienses. Renato Kipnis foi de imensa generosidade ao permitir 
nossa escavação no sítio Teotônio, quando ainda possuía a autorização para a região. Em muitos outros momentos, o Dr. K. ajudou com equipamento ou pessoal durante alguns campos. Gostaria de agradecer a toda equipe da Scientia envolvida na UHE Santo Antônio (Juliana Santi, Ednair Nascimento, Miguelito), em especial aos companheiros Pantanal e Coralzinho que trabalharam comigo. No grandioso hotel Porto, um abraço para Dona Marilene e Cia. No IPHAN de Rondônia, agradeço a Danilo Curado, Beto Bertagna, Monica Castro e Francilene Rocha, que fizeram dessa instituição uma grande aliada das nossas pesquisas. Tenho muito a agradecer aos professores Maria Coimbra e José Garcia, nossos parceiros em Presidente Médici. Meus agradecimentos também ao pessoal da FUNAI de JiParaná, aos índios Gavião por permitirem nossa visita, e por Denny Moore pelo convite à aldeia. Em Ariquemes, gostaria de agradecer ao professor Washington Heleno. Em São Carlos, gostaria de agradecer ao Xanas Bar pela música de qualidade e ambiente familiar.

Fizeram campo comigo, em ordem cronológica: João Aires, Isaias (Soldado 20), Eduardo Neves, Claide Moraes, Manuel Arroyo-Kalin, seu Silvio, o pequeno Renãzinho, Rodrigo Suñer, Natália Zanella, Cheque Ouro, Cacau, Thiago Trindade, Antônia Damasceno, Alessandra Dantas, Allana Rodrigues, seu Raimundo, Caetano, Eduardo Kazuo, Jaq Belletti, Maria Coimbra, José Garcia, Vinícius Honorato, Bruna Rocha, Ricardo Monma, Rafael Brandi, Cleiciane da Silva, Soldado Rodrigo Catchup, Guilherme Mongeló, Carlos Zimpel, Silvana Zuse, Michelle Tizuka, Chico Pugliesi, André (Pugliesi?), Maurício Silva, Ana Izabela Bertolo, Brenda Miranda, Emanuella Oliveira, Andréia, e Odair José. Agradeço também a Bob Marley, também conhecido como Diogo Borges, pelo trabalho em Médici. Também agradeço à ala jovem da família Neves (Adriana, Luca, Carl e Pedro!).

No Pará, agradeço a Maura Silveira, Vera Guapindaia, Edithe Pereira, Marcos Magalhães, João Aires, Carlos Barbosa, Amauri, Michael Hanski, Daniel Lopes, Regina Maria, Morgan Schmidt, Jorge Mardok, Irislane Moraes, Wesley Charlinho de Oliveira, Priscila Oliveira, Dirse Kern, Marlon Prado e Noé Von Atzingen. No Amazonas, agradeço a Raoni Valle (agora em Santarém), Helena Lima (agora em Belém), Leandro Camilo, Myrtle Shock e aos alunos do curso técnico de arqueologia da UEA. Erika Laborda (CEUC-AM) foi a responsável pela logística na viagem feita a Maués (2011). No mundo antropológico agradeço a Felipe Vander Velden, Nicole Soares, Luciana França e João Dal Poz.

$\mathrm{Na}$ Inglaterra gostaria de agradecer a Stephen Shennan, José Oliver, e Bill Sillar (UCL). Shennan teve a bondade de me ceder às planilhas e as fotos do material do sítio Teotônio que analisamos em 2005, no MARSUL. O Dr. Graeme Barker me aceitou para um 
período de visitas de três meses no McDonald Institute, Universidade de Cambridge. A lição mais importante aprendida com o Dr. Barker foi de que as conclusões finais não importam e sim a viagem para chegar até elas. E sem dúvida foi uma viagem. Sarah Harrop, secretária do Dr. Barker, extremamente gentil e me ajudou muito na estadia no departamento. Ainda em Cambridge, gostaria de agradecer aos amigos Barbara Housmair, Catalin Popa, Magda Naum e Eduardo Macchi. Assim como a Clive e Sue Owen, que me hospedaram em sua casa. Carol Baltar e Aleix Altimiras-Martin também foram extremamente acolhedores.

A árdua batalha de escrever um doutorado foi acompanhada diariamente pela minha esposa Daniella (lhe amo!), que há quinze anos vem me acompanhando com amor, incentivo, paciência e também com a bibliografia no final (o mais importante!). Cida, valeu por cuidar da gente. Meus cachorrinhos Valentino e Lola Nights foram igualmente companheiros diários e de presença crucial nos momentos finais de redação (e solidão). Além disso, Titino foi um sábio conselheiro, um verdadeiro guia espiritual:

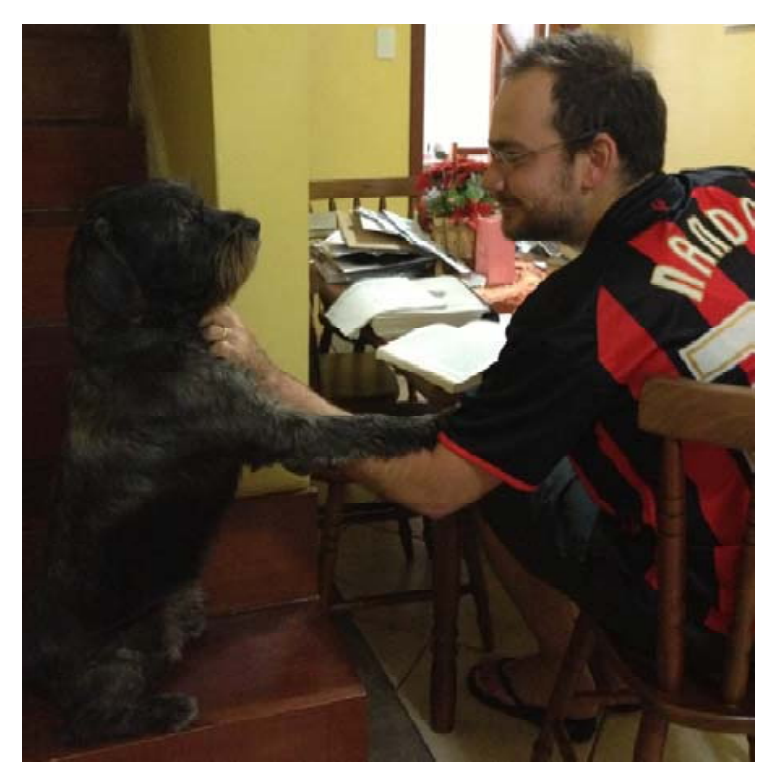

Meus pais seguem como um grande exemplo, cujo apoio é impossível de mensurar. Minhas irmãs, minhas amigas mais antigas, também estão sempre comigo, independente da distância. Além de tornarem minha vida melhor graças aos pequenos delinquentes que elas colocaram no mundo (Matteo, Elia e Martim). Meu padrasto Fernando Cerdeira ajudou também com as formas cerâmicas (apesar de argentino, ele tem coração). Tenho também muito prazer em ter na minha prima Joana uma companheira nos estudos de cultura material. Um grande beijo também para minha vó Zelita e para toda a família Ozorio de Almeida Seabra Pyne Lazaretti Furtado Horta Novo. 
Por fim, além dos meus avós ingleses, perdi outros dois amigos durante o período de doutorado, André Penin e Claidevon Moraes. Apesar da ausência, todos seguem sempre comigo em meus pensamentos e deixam muitas saudades. 


\section{Índice - Volume 1}

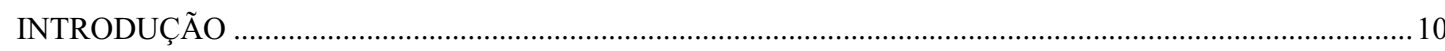

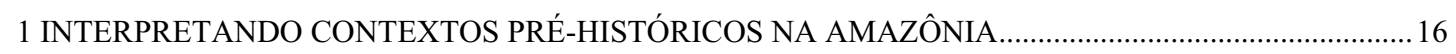

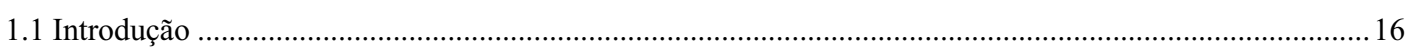

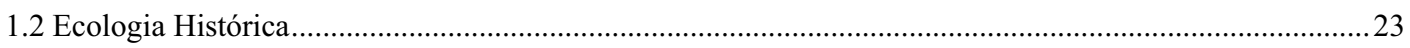

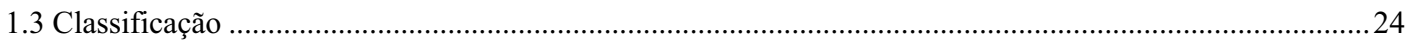

1.4 Ferramentas auxiliares para a interpretação arqueológica: etnologia, história indígena, linguística............30

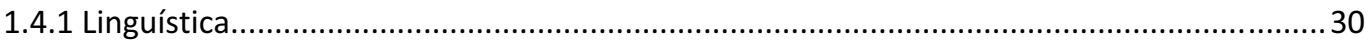

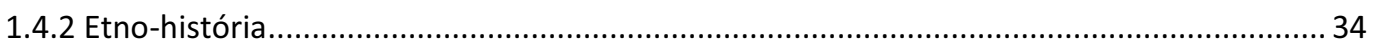

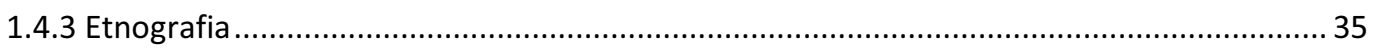

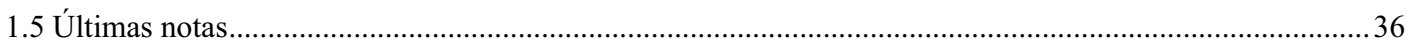

2 TUPIS, TUPINAMBÁS E A TRADIÇÃO POLÍCROMA NA AMAZÔNIA ...................................................38

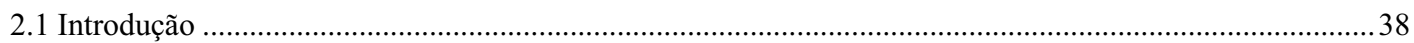

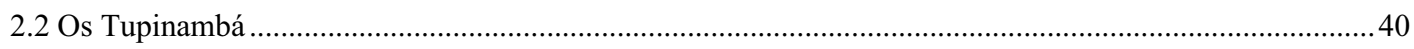

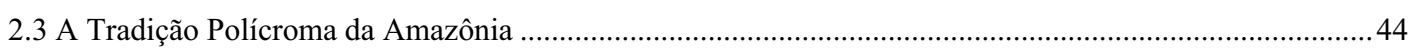

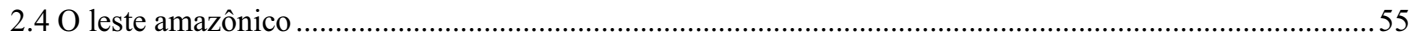

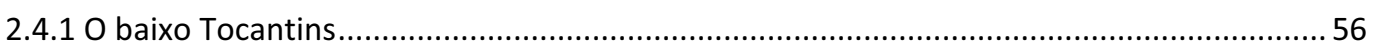

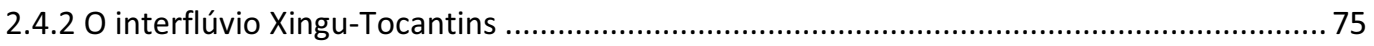

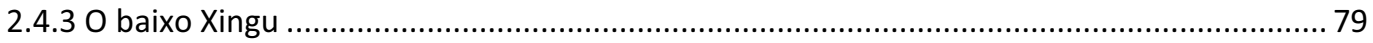

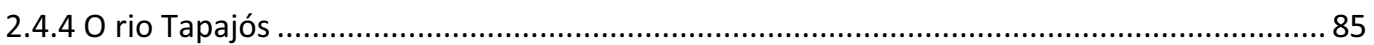

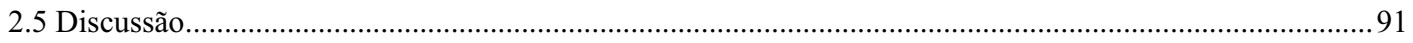

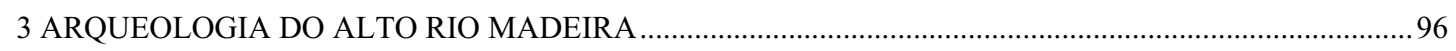

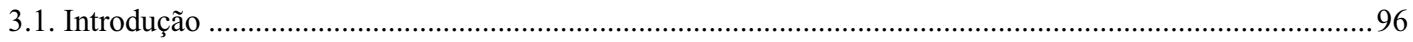

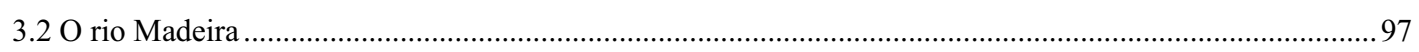

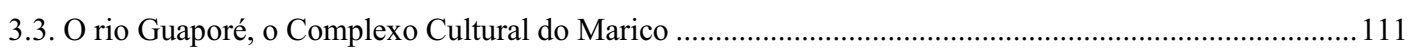

3.4 Rio Jamari

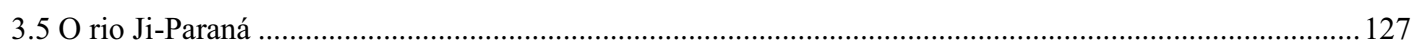

3.6 Alguns Tupi do alto Madeira: etnografias alcoolizantes no sudoeste amazônico.................................133

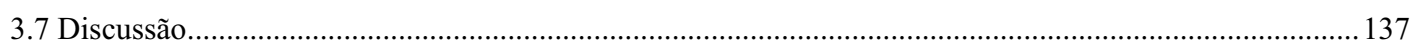

4 LEVANTAMENTO E ESCAVAÇÃO ARQUEOLÓGICA NO ALTO MADEIRA E BAIXO JAMARI..... 140

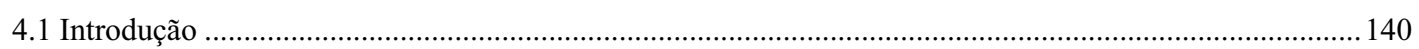

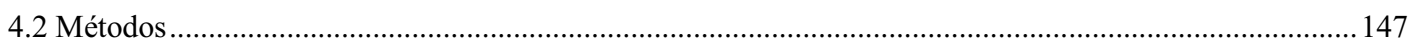

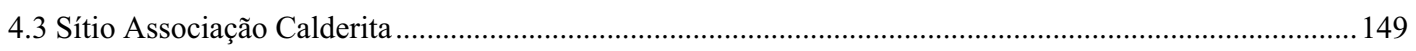

4.3.1 A falta de sítios entre os rios Jamari e Candeias: uma buffer zone? ............................. 149 


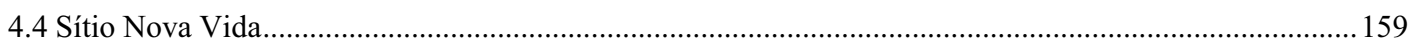

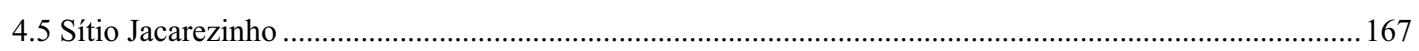

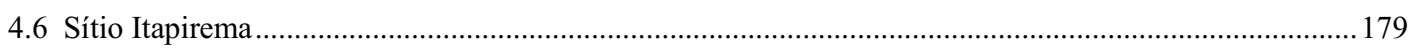

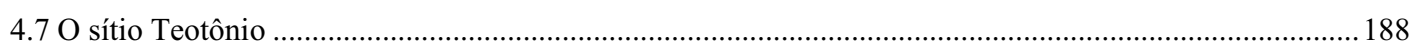

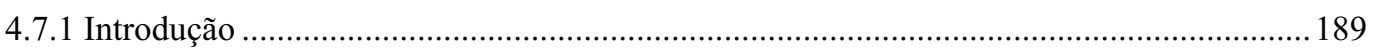

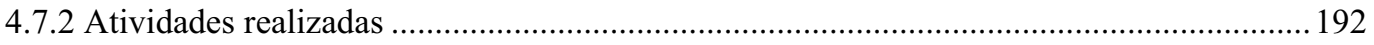

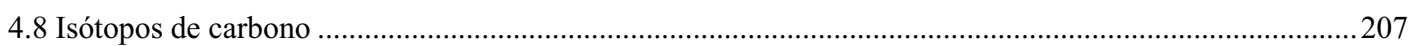

4.9 Esety e Eryse: levantamento e escavação arqueológica nos rios Madeira e Jamari...................................208

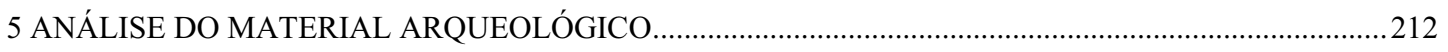

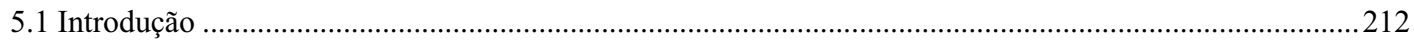

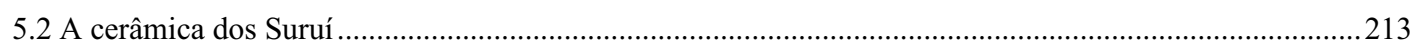

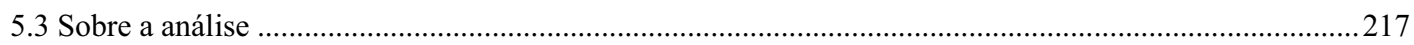

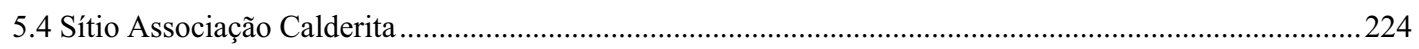

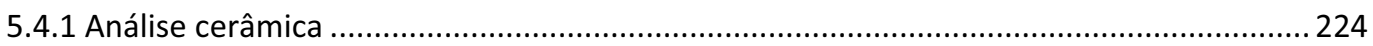

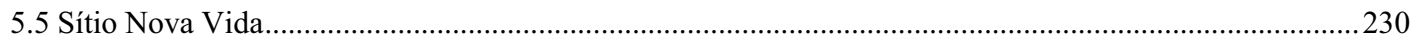

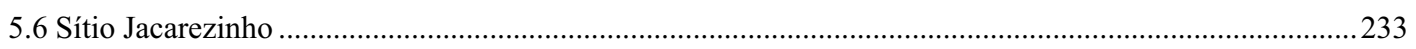

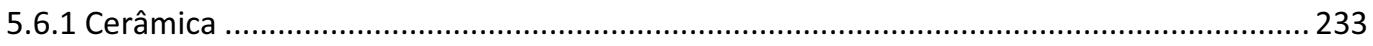

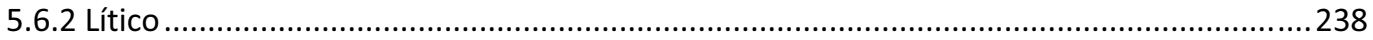

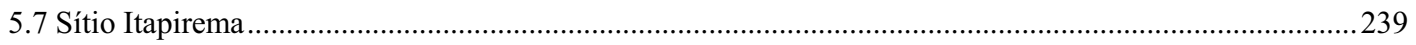

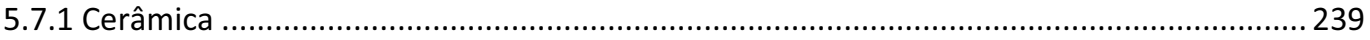

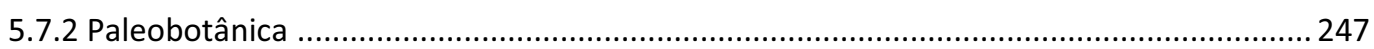

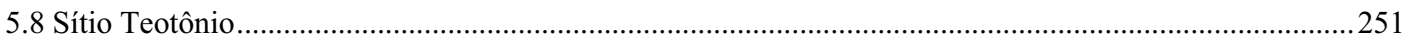

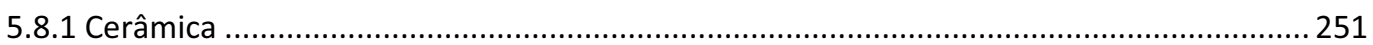

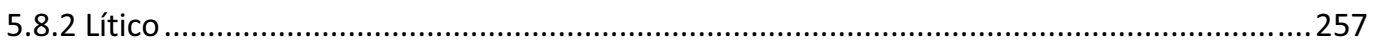

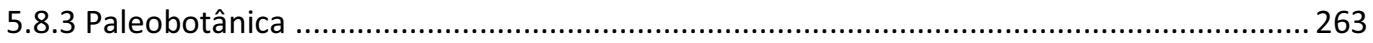

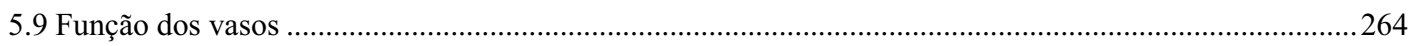

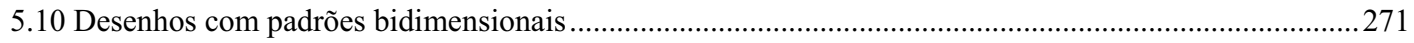

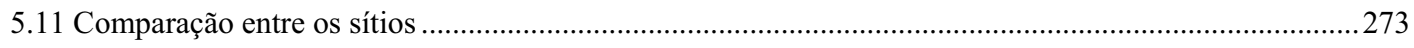

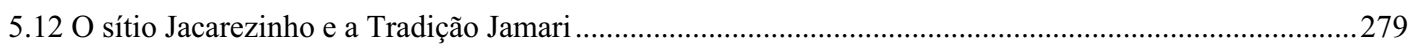

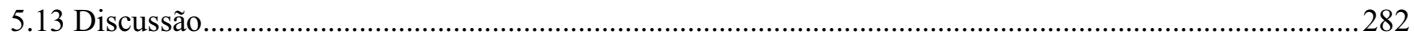

6 UMA CONFUSÃO DE CORES NAS MARGENS DOS RIOS DA AMAZÔNIA: REINTERPRETANDO A

TPA 


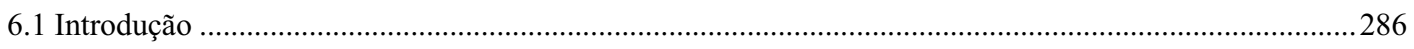

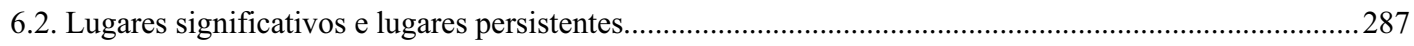

6.3 Cachoeiras, lugares significativos e persistentes..................................................................................28

6.4 Nas profundezas do sumidouro do Teotônio............................................................................................292

6.5 Os sítios Itapirema e Associação Calderita e a Tradição Polícroma da Amazônia....................................301

6.6 O sítio Teotônio e as antigas Tradições ceramistas da Amazônia ...............................................................306

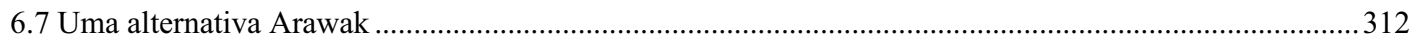

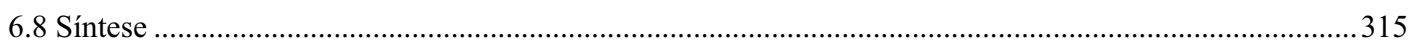

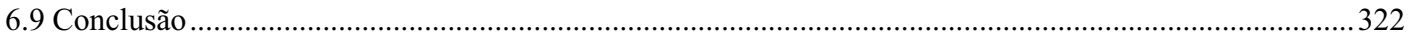

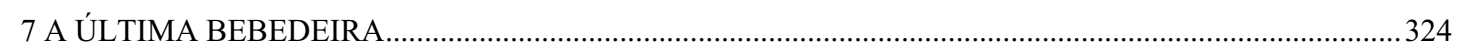

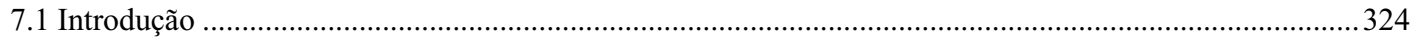

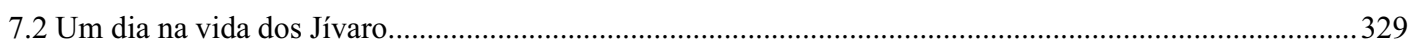

7.3 Os fermentados nas sociedades indígenas Amazônicas........................................................................... 330

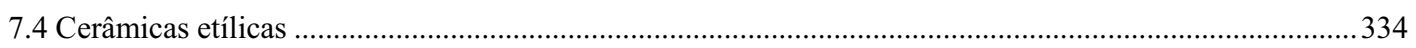

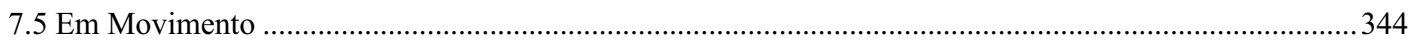

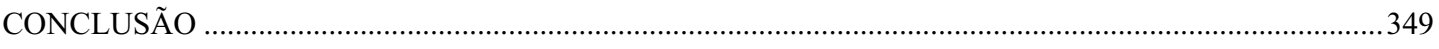

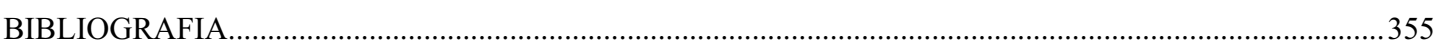

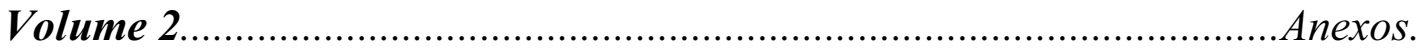




\section{Índice de Figuras}

Figura 1: Localização da área de pesquisa (fonte: mapadaamerica.com)

Figura 2: As dez famílias linguísticas que compões o Tronco Tupi (fonte: RODRIGUES e CABRAL, 2012).

Figura 3: Distinção geográfica entre a Tradição Polícroma e os grupos Tupi e Tupinambá amazônicos...39

Figura 4: Confronto de grupos Tupinambá descritos por Staden (1974 [1557]).............................................42

Figura 5: Cerâmica da fase Aristé, Tradição Polícroma, encontrada no litoral do Amapá ...........................44

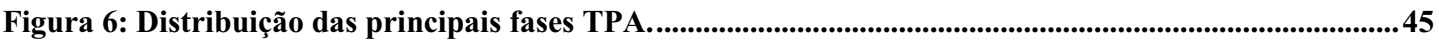

Figura 7: Urnas da Tradição Polícroma no rio Napo e no baixo rio Madeira ................................................... 47

Figura 8: Posicionamento da Tradição Polícroma no quadro cronológico das Tradições amazônicas........48

Figura 9: Material da fase Napo, Tradição Polícroma no alto Amazonas....................................................49

Figura 10: Tigela com acanalado sobre flange labial, Subtradição Guarita ..................................................50

Figura 11: Exemplos de urnas Marajoara (fonte: Barreto, 2008). ........................................................................52

Figura 12: As antigas cerâmicas da Amazônia, como a encontrada no rio Branco.........................................54

Figura 13: Dispersão aproximada dos grupos falantes de línguas Tupi...........................................................55

Figura 14: Artefato polido encontrado no sítio São José............................................................................................62

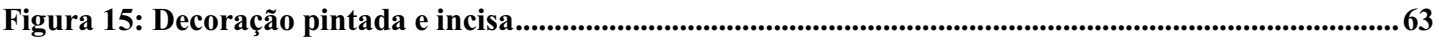

Figura 16: Formas compostas ou complexas do sítio Bom Jesus 6. ...............................................................64

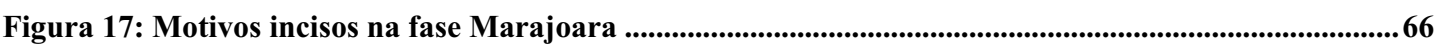

Figura 18: Tigelas rasas do sítio Cavalo Branco .......................................................................................................70

Figura 19: Cerâmica pintada pertencente ao sítio Santa Cruz ......................................................................74

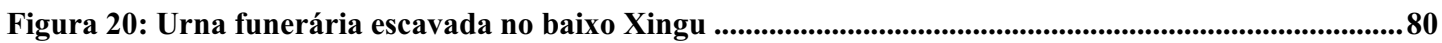

Figura 21: Formas Yudjá-Juruna, semelhantes às recorrentes formas Tupi-Guarani com ombros ...........82

Figura 22: Adaptação da desconstrução da grega. ...............................................................................................................85

Figura 23: Grupos indígenas identificados no rio Madeira ........................................................................101

Figura 24: Mapa apontando a entrada de grupos Pano, Txapakura, Kagwahiva e Mura ............................105

Figura 25: Cerâmica incisa e modelada encontrados em geoglífos da região do Guaporé (......................... 106

Figura 26: Gravuras rupestres encontradas no trecho encachoeirado do rio Madeira ..................................108

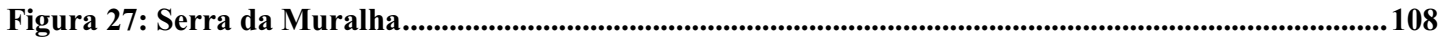

Figura 28: Fases, Subtradições ou Tradições cerâmicas encontradas nas margens do alto Madeira ........110

Figura 29: Cachoeira de Samuel a partir do porto do Jamari ...............................................................................120

Figura 30: Cerâmica da Subtradição Jatuarana encontrada em sítios Jamari 124

Figura 31: Perfil com terra preta enterrada (fase Massangana)................................................................124

Figura 32: Mapa (sem escala) apontando a presença da Tradição Jamari no rio Madeira .........................125

Figura 33: Croqui da aldeia dos Uru-Eu-Wau-Wau, no alto Jamari .............................................................126

Figura 34: Contraste entre a planície aluvial onde se encontra o sítio Barro Roxo.........................................127 
Figura 35: Gravura rupestre (em arenito) do sítio Cachoeira Alta

Figura 36: Fragmento corrugado encontrado na região do alto rio Ji-Paraná ................................................130

Figura 37: Lâmina de machado polida encontrada em barranco de estrada.................................................130

Figura 38: Estatueta cerâmica encontrada no sítio Laranjeiras .............................................................................132

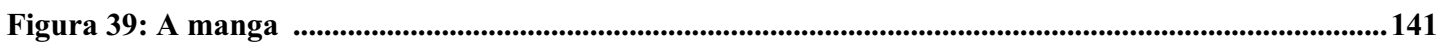

Figura 40: Mapa com localização dos sítios arqueológicos do alto Madeira ....................................................146

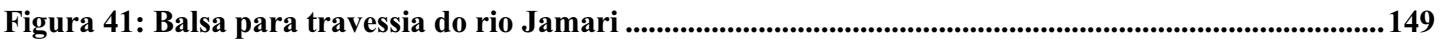

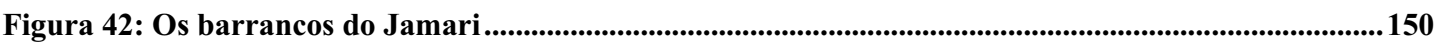

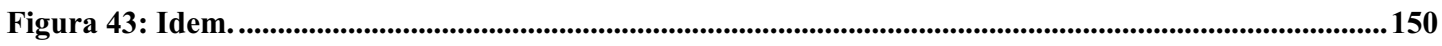

Figura 44: Vista do sítio Associação Calderita ...............................................................................................151

Figura 45: Estrutura de forno encontrada................................................................................................................151

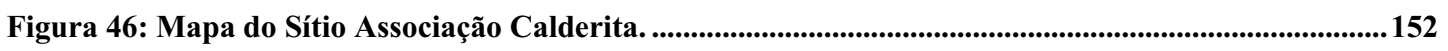

Figura 47: Vista geral da unidade N1030/N1031 E1002 ...........................................................................................154

Figura 48: Perfil oeste da unidade N1030/N1031 E1002 …..........................................................................154

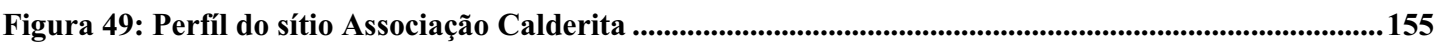

Figura 50: Mapa (Surfer) de densidade cerâmica e cor do solo do sítio Associação Calderita....................157

Figura 51: Vista da estrada que corta o sítio Nova Vida..................................................................................159

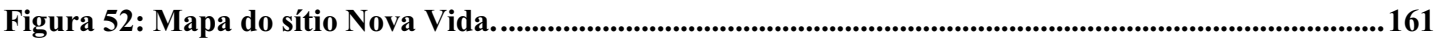

Figura 53: Rebaixamento de unidade N1023 E962 no sítio Nova Vida ......................................................163

Figura 54: Abertura da unidade N1080 E958..........................................................................................................164

Figura 55: Expondo material in situ, na unidade $N 1080$ E958, nível 50-60cm............................................164

Figura 56: Camada escura enterrada na unidade N1023 E962 (Perfil W)..................................................164

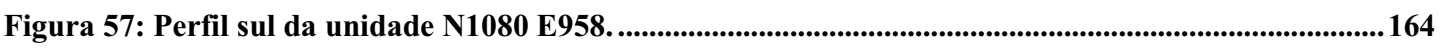

Figura 58: Mapa de densidade e cor do sedimento do sítio Nova Vida (programa Surfer)..........................165

Figura 59: Perfíl da unidade N1080 E958.................................................................................................................. 166

Figura 60: A discreta entrada para o igarapé que leva ao lago do Jacarezinho ...........................................168

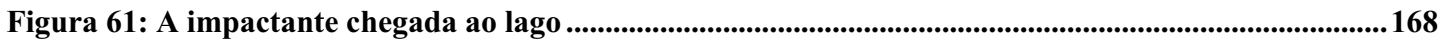

Figura 62: A discreta entrada para o igarapé que leva ao lago do Jacarezinho ...........................................169

Figura 63: Mapa do sítio Jacarezinho. .............................................................................................................................170

Figura 64: Perfil leste da unidade N996/N995 E1000 ................................................................................172

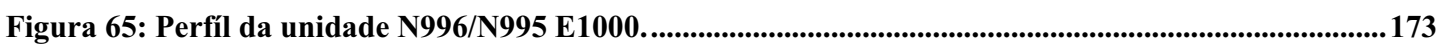

Figura 66: Distribuição do material cerâmico no sítio Jacarezinho (programa Surfer)...............................176

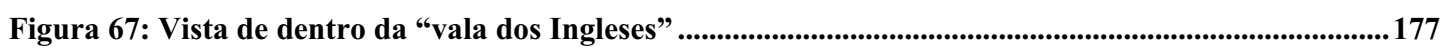

Figura 68: Fachada de casarão de antigo barão da borracha, sítio Aliança...................................................177

Figura 69: Cruz de ferro, a única restante em cemitério do sítio Aliança .........................................................177

Figura 70: Localização do sítio Aliança................................................................................................................................178

Figura 71: Coleta de superfície em área quadriculada, sítio Itapirema .........................................................180

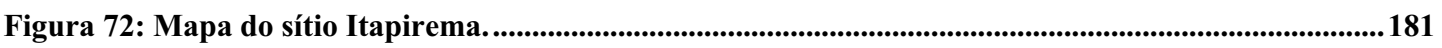

Figura 73: Escavação de duas unidades 1 x 1m (N1034 E999, N1038 E996), sítio Itapirema ......................183

Figura 74: Escavação de unidade 1 x 1m (N1034 E999), sítio Itapirema ..........................................................183 
Figura 75: Arqueólogos demonstram a diferença de nível topográfico em montículo artificial .184

Figura 76: Marcação de duas unidades 1 x 0,5m, em montículo do sítio Itapirema.......................................185

Figura 77: Escavação de unidade 1 x 0,5m (N954 E583), em montículo do sítio Itapirema ..........................185

Figura 78: Reconstituição (Surfer) do montículo no qual foram abertas unidades, no sítio Itapirema.... 185

Figura 79: Perfíl da unidade N954 E589, N954 E588. ...............................................................................186

Figura 80: Perfíl da unidade N954 E583..........................................................................................................................187

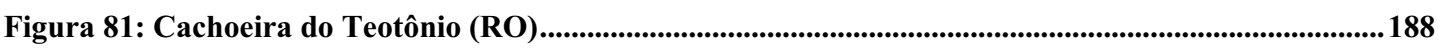

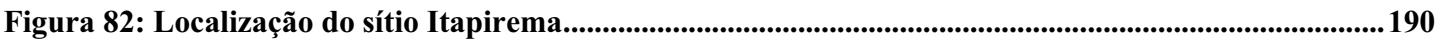

Figura 83: Barranco onde foi observada mancha de sedimento escuro .............................................................192

Figura 84: Sítio Teotônio, impactado pela abertura de estrada, terraplanagem ............................................193

Figura 85: Marcação de camadas para desenho do perfil da unidade N10045 E9986 ....................................194

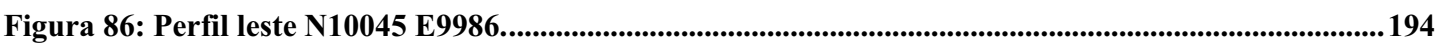

Figura 87: Mapa do sítio Teotônio.......................................................................................................................195

Figura 88: Sondagem N9980 E10040, que levou à abertura da unidade N9979 E10041 ...............................197

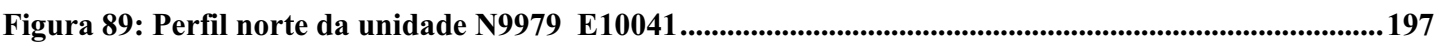

Figura 90: Perfil da unidade N9979 E1041........................................................................................................198

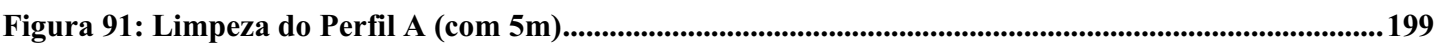

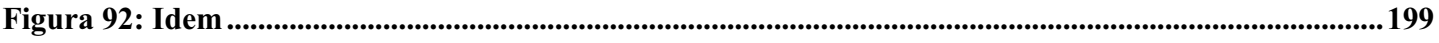

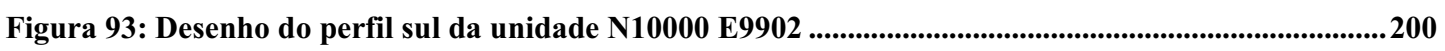

Figura 94: Perfil sul da unidade N10000 E9902 ..................................................................................................200

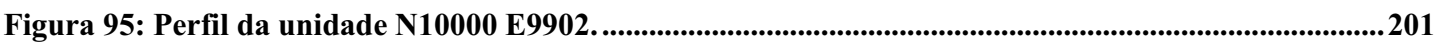

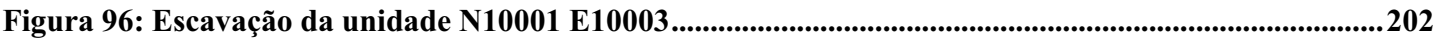

Figura 97: Feição de terra preta (escorada na laterita) encontrada no perfil leste da unidade ..................202

Figura 98: Perfil norte da unidade N10001 E10003 .......................................................................................202

Figura 99: Perfil leste da unidade N10001 E10003 onde foi identificada a Feição 1 .....................................202

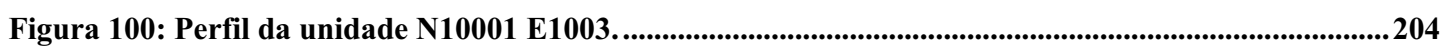

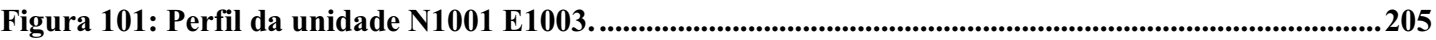

Figura 102: Mais do que um exemplo de reciclagem de um pote cerâmico.....................................................216

Figura 103: Vaso Suruí para preparo...................................................................................................................................217

Figura 104: Vaso Suruí para serviço. ..................................................................................................................................217

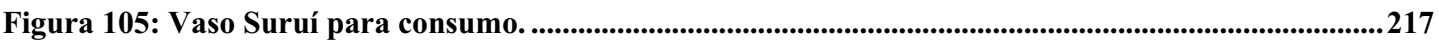

Figura 106: Vaso Suruí para consumo ....................................................................................................................217

Figura 107: Numeração dos fragmentos cerâmicos ..................................................................................218

Figura 108: Medição da relação entre o tamanho da borda e o tamanho da reconstituição .........................222

Figura 109: Bolota de argila com careta/monstro.........................................................................................224

Figura 110: Fragmento cerâmico do sítio Associação Calderita com engobo vermelho e fuligem .............225

Figura 111: Fragmento cerâmico arredondado ..............................................................................................................233

Figura 112: Lâmina de machado fragmentada encontrada no sítio Jacarezinho .........................................238

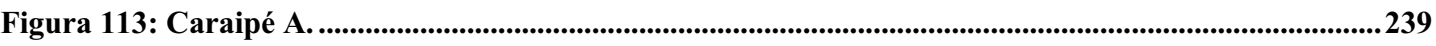

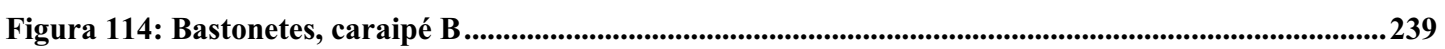


Figura 115: Fragmento Ita-303-41 - borda com presença de dois tipos distintos de argil (foto: acervo PALMA).

Figura 116: Fragmento Ita-303-104 - engobo branco e craquelado na face externa......................................241

Figura 117: Fragmento Ita-802-16 - incisões...............................................................................................................246

Figura 118: Fragmento Ita-322-1 - figura modelada zoomórfica ...................................................................247

Figura 119: Tomografia computadorizada de raio-X de alta resolução de semente de Arecaceae ............248

Figura 120: Provável semente de milho encontrada no sítio Itapirema. ........................................................250

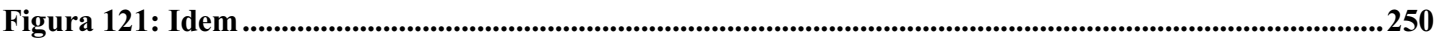

Figura 122: Fragmento Te-703-1, com marca de folha ................................................................................252

Figura 123: Fragmentos com pintura vermelha e branca do sítio Teotônio.....................................................256

Figura 124: Fragmentos com decorações incisas e serrunguladas..................................................................257

Figura 125: Material lítico proveniente da camada III, da unidade N10001 E10003 ..................................259

Figura 126: Micro lascas de quartzo hialino encontradas no nível 70-80cm da unidade N10001 E10003 261

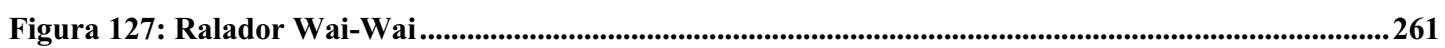

Figura 128: Possível percutore lítico de quartzo encontrados no sítio Teotônio.............................................262

Figura 129: Possível percutore lítico de quartzo encontrados no sítio Teotônio ...........................................262

Figura 130: Quebra-coquinho de granito encontrado no sítio Teotônio.........................................................262

Figura 131Quebra-coquinho de granito encontrado no sítio Teotônio .........................................................262

Figura 132Calibrador encontrado no sítio Teotônio. .......................................................................................262

Figura 133: Calibrador encontrado no sítio Teotônio .............................................................................................262

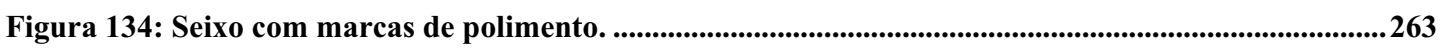

Figura 135: Peça de granito com marcas de pigmento em uma das faces (fotos: Fernando Ozorio de

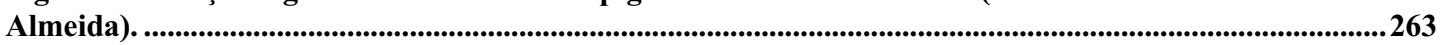

Figura 136: Vasos com flanges labiais e decorações incisas.............................................................................267

Figura 137: Fragmentos Ita-617-7/8, possivelmente utilizados para consumo substâncias alucinógenas.268

Figura 138: Possível fragmento de vaso em forma de cálice......................................................................................269

Figura 139: Fragmento Ita-502-35 - tigela com pintura vermelha ..............................................................269

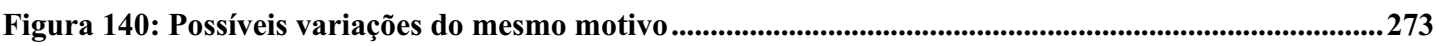

Figura 141: Fragmento Te-321-41 no qual se pode observar pigmento .........................................................277

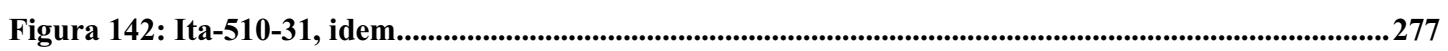

Figura 143: Fragmentos da Tradição Jamari......................................................................................................280

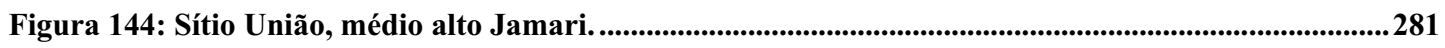

Figura 145: Fragmentos cerâmicos do sítio União (foto: Fernando Ozorio de Almeida, 2010)...................281

Figura 146: “Às visitas os Ariquême oferem o seu 'totó' .....................................................................................282

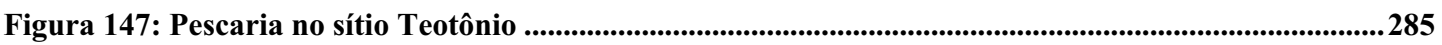

Figura 148: A transmissão horizontal de elementos cerâmicos.............................................................................299

Figura 149: Motivos grandes são feitos para ser vistos à distância...................................................................300

Figura 150: Possível representação zoomorfa do sítio Itapirema. ....................................................................305

Figura 151: Esquematização de processos verticais de transmissão................................................................307

Figura 152: Processo de transformação da cerâmica policrômica, chegando à Tradição Polícroma. .......311 
Figura 153: Modelo de expansão para grupos Arawak

Figura 154: Núcleos de redes das antigas populações amazônicas. .........................................................................321

Figura 155: Vasos Guarani para preparo e consumo de fermentados ........................................................336

Figura 156: Vaso Jívaro para a preparação (acima) e consumo de cerveja (demais) ....................................337

\section{Indice de Tabelas}

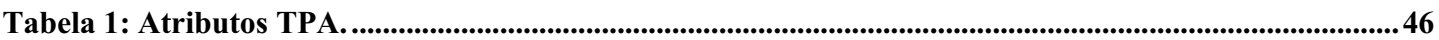

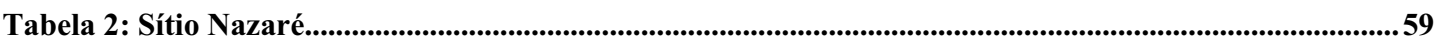

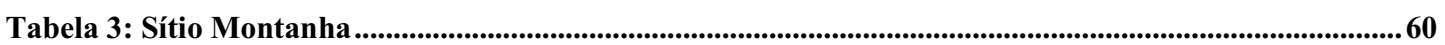

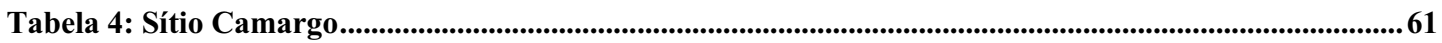

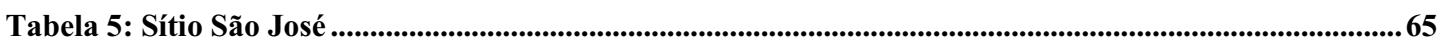

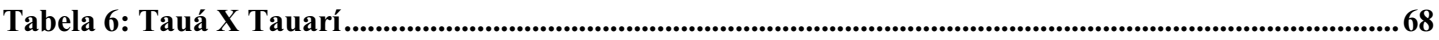

Tabela 7: Compilação de datações para sítios da Subtradição Tupinambá da Amazônia ............................78

Tabela 8: Ocupações pré-coloniais no alto rio Madeira ...............................................................................107

Tabela 9: Atributos cerâmicos da Subtradição Jatuarana ......................................................................................111

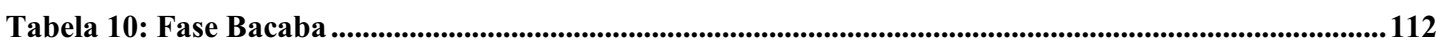

Tabela 11: Relação de datas da fase Corumbiara .................................................................................................115

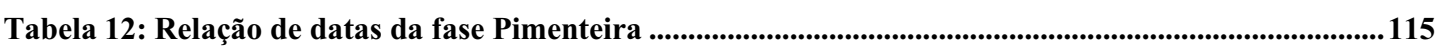

Tabela 13: Comparação entre a cerâmica Tupari ..............................................................................................................118

Tabela 14: Quadro cronológico dos sítios pré-cerâmicos do baixo Jamari.....................................................121

Tabela 15: Quadro cronológico dos sítios cerâmicos do baixo Jamari.................................................................. 122

Tabela 16: Relação das fases e Tradições identificadas por Miller no médio rio Ji-Paraná ( .......................128

Tabela 17: Datações do sítio Encontro (fonte: ZIMPEL, 2009: 149)................................................................131

Tabela 18: Sítios identificados e/ou estudados pelo PALMA................................................................................. 144

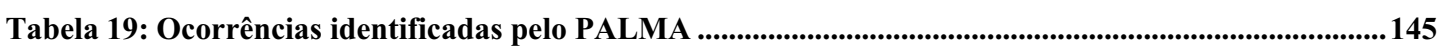

Tabela 20: Sondagens positivas do sítio Associação Calderita. ..............................................................................153

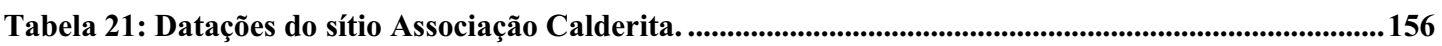

Tabela 22: Sondagens positivas do sítio Nova Vida....................................................................................................... 162

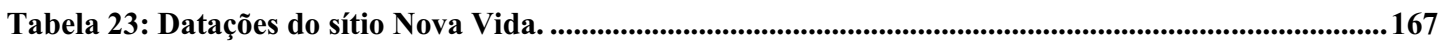

Tabela 24: Sondagens positivas do sítio Jacarezinho.................................................................................171

Tabela 25: Datações do sítio Jacarezinho............................................................................................................174

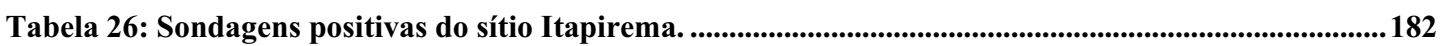

Tabela 27: Datações do sítio Itapirema. .................................................................................................................188

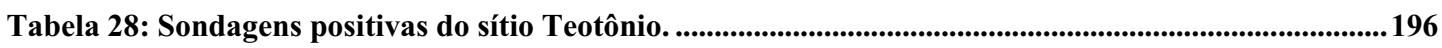

Tabela 29: Relação das datas provenientes do sítio Teotônio..............................................................................206

Tabela 30: Relação dos isótopos estáveis obtidos por meio das datações do PALMA..................................207

Tabela 31: Síntese da análise cerâmica do sítio Associação Calderita. ...........................................................226 
Tabela 32: Relação das formas do sítio Associação Calderita.

Tabela 33: Comparação entre os atributos cerâmicos das duas ocupações do sítio A.Calderita................229

Tabela 34: Comparação entre as formas cerâmicas dos níveis $20-30 \mathrm{~cm}$ e $30-50 \mathrm{~cm}$.......................................230

Tabela 35: Síntese da análise cerâmica do sítio Nova Vida...................................................................................232

Tabela 36: Síntese da análise cerâmica do sítio Jacarezinho.......................................................................2235

Tabela 37: Relação das formas do sítio Jacarezinho. ..................................................................................................2236

Tabela 38: Comparação dos atributos cerâmicos das duas ocupações do sítio Jacarezinho. .......................237

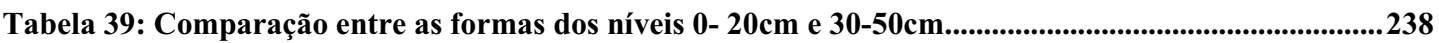

Tabela 40: Síntese da análise cerâmica do sítio Itapirema.................................................................................243

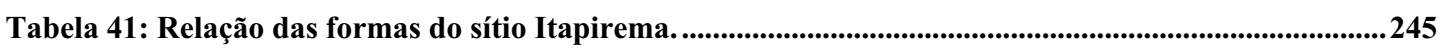

Tabela 42: Relação das sementes carbonizadas analizadas por Ligia Trombetta Lima...............................250

Tabela 43: Síntese da análise cerâmica do sítio Teotônio...................................................................................254

Tabela 44: Relação das formas do sítio Teotônio.....................................................................................................256

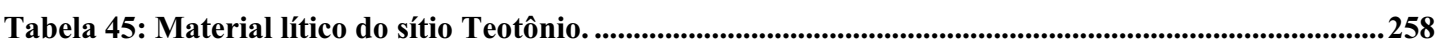

Tabela 46: Frequência de material lítico e cerâmico na unidade N10001 E10003 do sítio Teotônio..........260

Tabela 47: Frequência em que as diferentes matérias-primas líticas .............................................................260

Tabela 48: Porcentagens de carvão e sementes na unidade N10001 E10003 do sítio Teotôni ......................264

Tabela 49: Comparação entre os vasos Shipibo ................................................................................................266

Tabela 50: Boxplot com as capacidades volumétricas estimadas dos sítios estudados.................................270

Tabela 51: Relação das unidades mínimas dos sítios estudados..........................................................................272

Tabela 52: Divisão preliminar dos sítios estudados. ......................................................................................278

Tabela 53: Cronologia do sítio Jacarezinho, dentro da Tradição Jamari.......................................................280

Tabela 54: Quadro cronológico provisório para o sítio Teotônio. .............................................................293

Tabela 55: Quadro cronológico provisório para o complexo do Teotôn ...........................................................295

Tabela 56: Sintese do material cerâmico do sítio Teotônio escavado por Eurico Miller................................296

Tabela 57: Comparação entre os tipos de formas dos sítios Associação Calderita, Itapirema e da fase

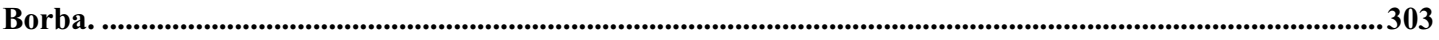

Tabela 58: Comparação entre as fases Açutuba e Pocó (adaptado de LIMA et al., 2006).............................306

Tabela 59: Comparação entre agrupamentos com decoração policrômica na Amazônia............................309 


\section{INTRODUÇÃO}

O objetivo do presente estudo é oferecer uma contribuição para a compreensão dos antigos povos produtores de cerâmica pertencentes à Tradição Polícroma Amazônica (TPA), na região do alto curso do rio Madeira. Essa contribuição será realizada de forma explicitamente enviesada por meio de um ponto de vista tupinológico, de alguém que busca compreender as histórias dos diferentes grupos Tupi e Tupi-Guarani da América do Sul.

Esse não é um viés aleatório. Autores como Lathrap (1970) e Brochado (1984, 1989; BROCHADO e LATHRAP, 1982) viram uma estreita relação, ou uma correlação, entre a Tradição Polícroma e os grupos falantes do tronco Tupi (cf. NOELLI, 1996a, 1998, 2008a). Viram também uma relação diacrônica entre essa Tradição e, por consequência, desse tronco linguístico, com grupos falantes de línguas da família Tupi-Guarani, produtores de cerâmicas das Subtradições Tupinambá e Guarani. De acordo com essa visão, portanto, a antiga Tradição Polícroma corresponderia aos antigos falantes do Tupi.

Dessa forma, visto que dados linguísticos (MIGLIAZZA, 1982; RODRIGUES, 1964, 1985; URBAN, 1992, 1996) apontam o sudoeste amazônico como o centro da dispersão dos povos Tupi e que dados arqueológicos (MILLER, 1992, 1999) indicam que no alto rio Madeira são encontradas as datas mais antigas para a Tradição Polícroma (700 a.C), parece mais do que justificado escolher essa região como foco de estudo.

Questões como essas serão exploradas a partir da análise de cinco sítios arqueológicos escavados na bacia do alto rio Madeira, no Estado de Rondônia. Três desses sítios se encontram no próprio rio Madeira, e outros dois no baixo Jamari, primeiro grande afluente do Madeira, abaixo de sua área encachoeirada. Do material coletado nesses sítios, escolheu-se como ponto fulcral dessa pesquisa a análise dos fragmentos cerâmicos arqueológicos. 


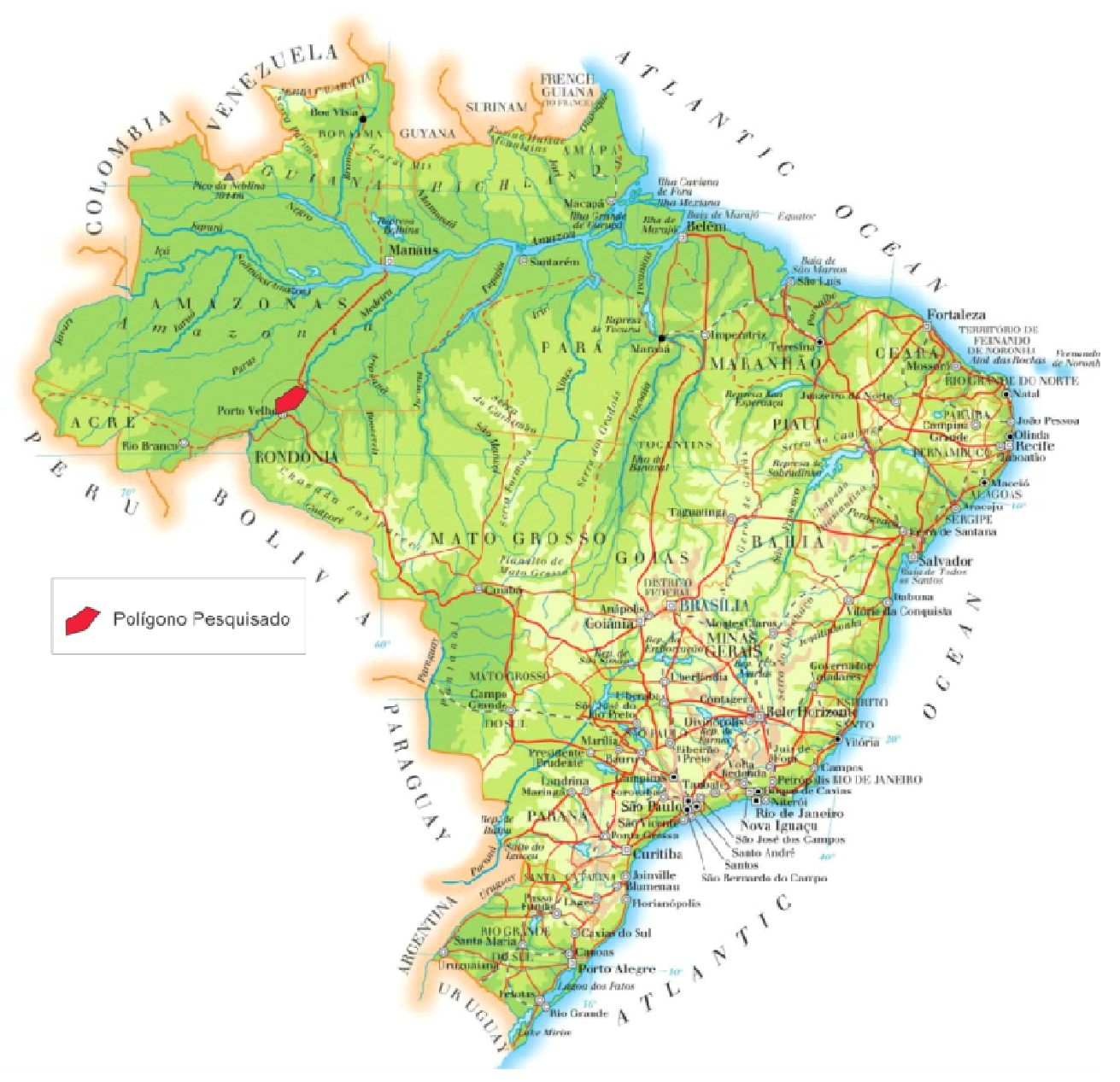

Figura 1: Localização da área de pesquisa (fonte: mapadaamerica.com).

Entretanto, há muitas outras questões que permeiam o Projeto Alto Madeira (PALMA), no qual este estudo está inserido. Em primeiro lugar, as margens desse rio e de seus afluentes possuem uma longa e (aparentemente) contínua ocupação, de mais de 10 mil anos. Cenário que contrasta com o que foi criado para Amazônia central, onde (também aparentemente) ocorreu um longo hiato de ocupação entre 5000 a.C. e 1000 a.C. (NEVES, 2008; HECKENBERGER e NEVES, 2009). Segundo, alguns dos sítios ocupados no alto Madeira (MILLER, 1992, 1999, 2009; MILLER et al. 1992), durante o suposto hiato da Amazônia central, apresentam um período que um neo-evolucionista poderia chamar de "transitório", ou melhor, de "formativo". Sítios que seriam intermediários entre um estágio nômade, baseado na caça e na coleta, e outro sedentário, baseado no cultivo de alimentos (relacionado ao surgimento das primeiras terras pretas). O que leva ao terceiro ponto-chave de interesse pela pré-história da região: o cultivo de alimentos. Estudos de genética botânica 
(CLEMENT, 1999; CLEMENT et al., 2010; OLSEN e SCHAAL, 1999) apontam que foi no sudoeste amazônico que ocorreu a domesticação da mandioca (Manihot esculenta) e da pupunha (Bactris gasipaes), dois dos importantes alimentos cultivados nas terras baixas sulamericanas (cf. ARROYO-KALIM, 2010; NEVES, 2005).

Pode-se dizer que a arqueologia de Rondônia é uma arqueologia das origens: origem ou etnogênese (cf. RENFREW, 1987: 211-249) dos Tupi, das terras pretas, da domesticação de cultivares, da Tradição Polícroma Amazônica e, para os que defendem as antigas datas do Abrigo do Sol (MILLER, 1987c), do início da ocupação humana na Amazônia.

A maior parte dessas questões, devido à imensa profundidade temporal e amplitude, foge do escopo deste doutorado. Ainda assim, às vezes tangenciam este texto. O próprio universo tupinológico orbita, mas não adentra na semântica policroma. Não se sabe, de partida, se o objeto pertence a um contexto Tupi. O contexto deste observador, por outro lado, certamente é Tupi e Tupinambá.

$\mathrm{O}$ rio Madeira, principal afluente do Amazonas, é formado pela junção de dois grandes complexos fluviais, o Guaporé/Mamoré, e o Beni/Madre de Dios. Os rios Beni e Madre de Dios são formados nos Andes, o rio Guaporé nasce no sudeste mato-grossense, e o rio Mamoré se forma a partir do encontro dos rios Chaparé, Ichilo e Grande, nas terras baixas bolivianas. Os principais afluentes do alto curso do rio Madeira são os rios Abunã, JaciParaná, Jamari e Ji-Paraná ${ }^{1}$. Apenas o rio Abunã é afluente da margem esquerda do Madeira.

A bacia do rio Madeira é formada por planícies e depressões (do Madeira, do JiParaná e do Ituxi-Jari), em geral relacionadas com os depósitos aluviais de argila e silte, carregados por esse rio deveras dinâmico. Dinâmica essa que não só é continuamente remodelada por processos de deposição, como também de erosão, uma vez que o rio Madeira fornece $50 \%$ da carga sedimentar transportada para o rio Amazonas, apesar de contribuir com apenas 15\% do volume de água (TIZUKA, 2012: 254). Junto dessa água barrenta de sedimentos provenientes dos Andes e das próprias margens do Madeira, é comum encontrar uma grande quantidade de troncos de árvores, frutos da mesma dinâmica erosiva, cuja presença dá nome ao rio.

\footnotetext{
${ }^{1} \mathrm{O}$ rio Ji-Paraná pode ser considerado pertencente ao médio rio Madeira, mas será mantido no presente recorte devido ao seus dados quanto a diferentes grupos Tupi
} 
A área-foco de pesquisa, o alto Madeira, é conhecida pelas suas cachoeiras, termo que no presente estudo incluirá também corredeiras e quedas d'água ${ }^{2}$. Entretanto, apenas as cachoeiras de jusante (Teotônio e Santo Antônio) se encontram dentro do recorte de pesquisa, assim como (e em especial) o trecho seguinte do rio Madeira, entre Santo Antônio e o baixo rio Jamari. Essas cachoeiras de jusante estão entre as que conduzem maior carga de água no mundo (LATRUBESSE, 2012: 24), uma das muitas razões que levaram ao interesse de ocupação humana nessa região há milhares de anos.

Interesse de ocupação que permanece. Atualmente, abaixo das cachoeiras de jusante, que desapareceram devido à implantação da Usina Hidroelétrica (UHE) Santo Antônio, encontram-se a cidade de Porto Velho, assim como o início da bacia sedimentar amazônica propriamente dita. Fato apontado por Ferreira (2005: 15), que, com propriedade, lembra a ligação da ocupação humana recente da Amazônia com as áreas de cachoeira: "Nessas grandes cachoeiras que levam suas águas ao Amazonas, localizam-se as cidades: Alcobaça no Tocantins, Vitória no Xingu, Itaituba no Tabajós, Porto Velho no Madeira. A Grande Planície Amazônica termina nessas localidades junto às cachoeiras".

Segundo o mapa geomorfológico 1:1.000.000 do IBGE (2006), a maior parte do polígono onde se encontra a área de pesquisa pertence à depressão de Porto Velho (Domínio Morfoestrutural de Bacias e Coberturas Sedimentares Fanerozóicas). Essa unidade possui um modelo de dissecação do tipo diferencial, com um conjunto de formas de relevo com topos tabulares (planos), conformando feições e rampas suavemente inclinadas e lombadas, esculpidas em rochas sedimentares e cristalinas, denotando eventual controle estrutural. $\mathrm{O}$ clima é do tipo Equatorial Continental Úmido, caracterizado por uma pluviosidade média anual entre 2.000 e $2.300 \mathrm{~mm}$, por possuir apenas uma curta estação seca (junho-agosto) e temperatura elevada $\left(24^{\circ} \mathrm{C}\right.$ e $\left.27^{\circ} \mathrm{C}\right)$ durante todo o ano. Tal clima quente e úmido está diretamente ligado à formação de solos em geral muito espessos e lixiviados, que se desenvolvem em ambientes de intenso intemperismo químico e possuem baixa fertilidade natural (DANTAS; ADAMY, 2010: 39).

\footnotetext{
${ }^{2}$ Segundo Ferreira (2005: 20), entre o rio Mamoré e o alto rio Madeira existem dez corredeiras (Guajará-Mirim, Guajará-Açú, Lajes, Periquitos, Araras, Pederneiras, Três Irmãos, Morrinhos, Macacos e Chocolatal), sete cachoeiras (Bananeiras, Pau Grande, Madeira, Misericórdia, Paredão, Caldeirão do Inferno e Santo Antônio) e três saltos (Ribeirão, Jirau e Teotônio).
} 
Miller (1999) indica que o sudoeste amazônico possuía a mais rica diversidade biótica e abiótica da América do Sul, onde a densa Floresta Tropical muitas vezes dá lugar a vegetações mais abertas, de campo ou cerrado, em especial nas áreas com topografia mais alta. Ainda assim, como o recorte estudado pertence a um contexto de baixo relevo, pode-se indicar uma relativa homogeneidade da vegetação, caracterizada como Floresta Ombrófila Aberta (SAESA, 2009: 10-11). Essa, por sua vez, encontra-se degradada ao extremo, sobretudo na margem direita do rio Madeira, no entorno da BR-364, onde a floresta foi quase suprimida para a abertura de áreas de pastagens. Fato explicado por adesivos que costumam estar colados nos fundos das imensas caminhonetes que trafegam pela BR, nos quais se lê: "Rondônia, Estado natural da pecuária".

\section{Divisão dos capítulos}

Além desta introdução, a presente tese de doutorado possui outros sete capítulos. $\mathrm{O}$ Capítulo 1 aponta os pressupostos teóricos, os métodos e as ferramentas auxiliares utilizados para a compreensão do objeto de estudo: a Tradição Polícroma da Amazônia, no alto rio Madeira, interpretada à luz de sua relação com os contextos de grupos falantes de línguas Tupi, em especial Tupi-Guarani. Para tanto, nos quatro capítulos seguintes, serão tecidas as descrições dos contextos necessários para a realização das interpretações. No Capítulo 2, será apresentado um contexto mais bem conhecido - o do leste amazônico - onde será possível comparar pares como Tupi e Tupinambá, cerâmica Tupinambá e da Tradição Polícroma da Amazônia, grupos ribeirinhos e de terra firme. No Capítulo 3, será realizada uma descrição sucinta do contexto histórico, etnográfico e arqueológico da bacia do rio Madeira. No Capítulo 4, serão apresentadas as atividades de campo realizadas, com ênfase nas atividades de escavação dos cinco sítios escavados pelo PALMA, com as datações obtidas para estes sítios. No Capítulo 5, será realizada a descrição do material arqueológico, em especial da cerâmica, proveniente desses sítios e a divisão dos sítios em agrupamentos, com respeito às respectivas indústrias cerâmicas.

De posse desses dados, será realizada uma análise mais apurada dos sítios que foram relacionados à Tradição Polícroma Amazônica e à Subtradição Jatuarana. O que esses sítios têm em comum, suas diferenças e sua contribuição para a compreensão das ocupações de 
grupos ceramistas no alto Madeira e da TPA como agrupamento classificatório são as questões que Capítulo 6 pretende responder.

Por fim, no Capítulo 7, será realizada uma discussão sobre o papel das bebidas fermentadas nas sociedades indígenas da Amazônia, seguida de uma síntese geral dos dados apresentados e de como eles contribuíram para a compreensão das propostas feitas no início dessa tese de doutorado. 


\title{
1 INTERPRETANDO CONTEXTOS PRÉ-HISTÓRICOS NA AMAZÔNIA
}

\begin{abstract}
As the American Sociologist Daniel Bell observed at the time, 'The use of the hyphenated prefix post- indicates [a] sense of living interstitial time'. As a description of the real world - 'post-war', 'post-imperial', and most recently 'postindustrial'- the term had its uses, even if left uncertain what might follow. But when applied to categories of thought - as in 'post-Marxist', 'post-structuralist 'and, most elusively of all, 'post-modern' it merely added to the obscurities of an already confused time (JUDT, 2010: 478).
\end{abstract}

\subsection{Introdução}

O presente estudo pretende seguir a mesma proposta teórico-metodológica presente na dissertação de mestrado do autor (ALMEIDA, 2008). Nela, se advogou pela utilização de um método indutivo ${ }^{3}$ para a compreensão de uma história de longa duração dos grupos Tupi(nambá) no sudeste amazônico. No entanto, outras prerrogativas presentes na dissertação e na tese, mas não explicitadas na primeira, serão aqui mais bem trabalhadas. Da mesma forma, serão introduzidos os conceitos teóricos que dão sentido a essas prerrogativas.

O primeiro ponto é que se propõe aqui realizar um contínuo exercício de comparação. Desde cacos de tipos diferentes, encontrados no mesmo nível da mesma unidade de escavação do sítio Teotônio, passando por indústrias cerâmicas separadas por cachoeiras, até regiões imensas e longínquas, como o sudoeste e sudeste amazônico. As comparações ocorrem nas mais distantes escalas, o que pode gerar tensões no momento de mudança de escala (e.g. sair de uma amostra de matérial de $1 \mathrm{~m}^{3}$ para uma questão pan-amazônica). Essas tensões devem ser vistas como estímulos para que as lacunas sejam preenchidas, e as interpretações, refeitas, e devem ser minimizadas à medida que as comparações tendem a ocorrer entre objetos semelhantes (e.g. cerâmica) e devidamente contextualizados.

Assim, o significado dessas comparações só pode ser inferido se os contextos nos quais os objetos estão presentes forem considerados (NEVES, 2012: 42-43). É por meio da compreensão do contexto que surge a sensitividade para detectar a diversidade e desafiar significados sociais locais. O contexto, por si só, é um tipo de interpretação baseado na

\footnotetext{
${ }^{3} \mathrm{O}$ método indutivo é baseado na noção de que o acúmulo de conhecimento reside na experiência. Ou seja, o conhecimento científico ganha significado em virtude da base empírica (BELL e WALKER, 1992: 12).
} 
definição de similaridades e diferenças, ou melhor, na variabilidade. A interpretação, com relação a contexto, é sempre relacional (SHANKS e HODDER, 1998: 82).

Além disso, aqui se defende o uso de uma arqueologia interpretativa, hermenêutica, para desvendar aspectos da histórica cultural de longa duração no contexto da ocupação do alto rio Madeira por grupos produtores de material cerâmico pertencente à Tradição Polícroma. Essa arqueologia interpretativa possui uma série de pressupostos: (I) em primeiro plano está a pessoa e o trabalho de quem interpreta; (II) a arqueologia é concebida como praticada no presente por meio de traços materiais do passado; (III) as práticas sociais, incluindo a arqueologia, estão voltadas aos significados, e (IV) a prática interpretativa é um processo contínuo, não havendo uma explicação final ou definitiva de como era o passado (SHANKS e HODDER, 1998: 70). Da mesma forma, a estratégia interpretativa tem como objetivo determinar: (I) que tipos de evidência são levados em conta; (II) o que deve ser considerado um fato relevante; (III) o que conta como uma contra-evidência relevante, e (IV) a forma pela qual as evidências são articuladas em um discurso (TILLEY, 1993: 7). Por fim, o (V) grande objetivo da interpretação é ver o significado de algo que não é óbvio, que é desconhecido (GEERTZ, 1973; HODDER, 1987a, 1996; TILLEY, 1993).

No entanto, conforme lembrado por Tilley (1993: 4), não há uma arqueologia interpretativa. Para tanto, deveria existir uma arqueologia não interpretativa (ainda que alguns trabalhos do passado e do presente da arqueologia brasileira pretendam se encaixar nessa categoria). Assim, em vez de afirmar que este é um trabalho de arqueologia interpretativa, seria mais coerente afirmar que este é um trabalho de arqueologia contextual.

Três contextos: como o objetivo desse trabalho é compreender melhor o período de ocupação de populações produtoras de cerâmica da Tradição Polícroma da Amazônia no alto rio Madeira e se há uma relação entre esses grupos e os de falantes de línguas Tupi (em especial os Tupi-Guarani), três contextos serão trabalhados: (I) o da Tradição Polícroma, que se encontra em estudos arqueológicos realizados por quase toda a bacia amazônica; (II) o dos Tupi/Tupi-Guarani, encontrado em estudos multidisciplinares em áreas extensas do continente sul-americano, e, o mais importante, (III) o contexto histórico da própria bacia do rio Madeira.

Hodder define que o contexto de um objeto é formado pela totalidade relevante do seu ambiente, definindo relevante como as relações do objeto que contribuem para seu significado (1987a: 4-5). O autor (p. 2) lembra que o termo contextual é frequentemente tido como sinônimo de particular, por uma falta de interesse em uma teoria mais abrangente. $\mathrm{O}$ 
próprio Geertz (1973: 14) faz essa associação ao indicar "culture is not a Power, something to which social events, behaviors, institutions, or processes can be causally attributed; it is a context (grifo nosso), something within which they can be intelligibly - that is, thickly described'. No entanto, o mesmo autor relativiza essa ideia ao indicar que o conhecimento geral só pode ser atingido por meio de um denso campo de particularidades (1968: 22). Dessa forma, conforme Hodder (1987a: 2), o termo arqueologia contextual é mais correto do que arqueologia particularista, por implicar uma relação entre teoria e dados, colocando um em relação ao outro.

Outras definições também são emprestadas da proposta contextual feita por Hodder. Por exemplo, cultura é visto como um conceito aditivo: "It is the sum of values, beliefs, rules and behavior patterns that are held in common by a group, at whatever scale" (1987a: 4). Uma visão coerente com a proposta de interpretação estilística oferecida por Sackett (1977, 1991), já utilizada em nossa pesquisa (ALMEIDA, 2008). Sackett associa Estilo com as escolhas, dentre as opções de equivalentes funcionais, feitas por pessoas no contexto do grupo ao qual pertencem. As escolhas realizadas dentro de um grupo dificilmente terão um correlato com outro grupo não relacionado historicamente com o primeiro (visão que será questionada durante o texto). No entanto, Sackett não oferece um mecanismo de compreensão de como as escolhas ocorrem (CHILDS, 1991: 336; SHANKS e TILLEY, 1993). Utilizando a noção de estrutura, definida como qualquer esquema organizatório oculto (GEERTZ, 1973), é possível argumentar que as escolhas são feitas dentre esses esquemas desenvolvidos cultural e socialmente:

The organizational schemes are universal in the sense that they might have general beginnings, held in common with others, and in the sense that we can all come to an understanding of them. But they are also particular and unique, created out of circumstances by the human mind (HODDER, 1987b: 2).

Essa visão estrutural, ou estruturante (structuration approach), provém da relação dialética entre estrutura e ação, na qual a ação é o resultado das regras que reversamente organiza. Segundo Robb (2010: 495), essa é a dualidade da estrutura. Tal dualidade é a base do conceito de habitus formulado por Bourdieu (1977, 1989, 1990) para designar as estruturas culturais aprendidas (e ensinadas) que operam nas ações do ser humano (DIETLER e HERBICH, 1998: 246). Essas estruturas, que fazem parte de um arraigado sistema de disposições, fornecem a base para um improviso regulado. A partir do habitus, as pessoas 
desenvolveriam reflexos para lidar com novas situações, por vezes de maneiras contraditórias ou incoerentes (cf. LEMONIER, 1993). O habitus não seria uma doutrina explícita, mas o resultado de comportamentos pequenos e concretos que ele mesmo ordena e exemplifica (BOURDIEU, 1977, 1989, 1990). Mudanças no comportamento podem levar a mudanças no habitus, na estrutura, assim como - conforme veremos nas premissas da Ecologia Histórica a mudança do habitus leva à mudança do habitat (SAUER, 1941: 8) e da compreensão do mundo, da cosmologia. Em ambos os casos, não é o objeto nem o sujeito que interessa, mas a relação entre ambos.

Bourdieu elaborou grande parte da sua teoria antropológica a partir dos trabalhos realizados no fim dos anos 1950 com grupos Kabyle, habitantes do interior da Argélia. Durante esses estudos, constatou a existência de uma ordem social que era reproduzida com uma impressionante eficácia sem que, no entanto, os Kabyle tivessem qualquer consciência dela. Esse processo só era possível por meio da organização das práticas sociais, combinando o simbólico e o material em uma consciência "politética", que orientava de maneira prática as ações das pessoas por meio de experiências repetidas no dia a dia. Essa estrutura era uma mídia de instrução, organizando as formas com as quais o mundo aparecia para os membros dessa sociedade e as maneiras com as quais cada integrante poderia imaginar a si mesmo, executar e improvisar ações. Essa ordem social não admitiria a existência de divisões entre diferentes campos de atividade. O parentesco, a religião e a agricultura, por exemplo, não seriam classes distintas, ao contrário do que ocorre na sociedade moderna, na qual família, arte e religião não costumam se misturar. O habitus internaliza a história e a torna natural, e o mundo passa a ser compreendido como algo que deve ser, conforme ele foi dado ao individuo ou ao coletivo (CALHOUN, 2011: 3-4, 24).

Nesse contexto, as atividades educativas (de transmissão) possuiriam um caráter contraditório, uma vez que apresentam as ferramentas para adaptar e transformar a ordem vigente, ao mesmo tempo em que reforçam e legitimam essa ordem (CALHOUN, 2011: 5). Conforme mencionado, a aquisição do conhecimento não seria monotética, a simples repetição de ideias e ações, mais politética, uma coerente reprodução de elementos combinados, sem a necessidade de que nenhum desses elementos esteja presente o tempo todo. Além disso, o conhecimento politético permite a existência de múltiplos significados para um mesmo objeto (p. 21). Como resultado, a própria identidade cultural do grupo estudado, no tempo e espaço, deve ser considerada politética (DEGOY, 2008: 199). 
Tais elementos politéticos com certeza estão presentes no campo estilístico que, por sua vez, também passa a ser um elemento que auxilia a construção da identidade social e a inserção desse corpo social frente aos outros ${ }^{4}$ (CHERNELA, 2008: 130). Portanto, é por meio da análise do Estilo que os arqueólogos buscam compreender as estruturas que regem as práticas de uma determinada sociedade. O problema passa a ser como chegar às praticas e às estruturas das sociedades pretéritas apenas com pequenas amostras de vestígios arqueológicos e os dados contextuais que os cercam, os quais o tempo e o dinheiro propiciam a chance de estudar. Para resolver esse problema, o único caminho que pode evidenciar a teia de relações enterrada em contextos de terra preta é uma rica erudição etno-arqueológica sobre sociedades tradicionais ou indígenas, em especial as das terras baixas, principalmente a partir de estudos que foquem na transmissão de conhecimento.

A continuidade de práticas e ideias no mundo material não pode se resumir à transmissão de conhecimento de geração para geração, uma forma de conservadorismo nativo, uma propensão de imitar o Estilo de uma geração anterior. Claro que, em uma sociedade tradicional, a tendência é que parte dos elementos politéticos permaneça, mas, ainda assim, o grau de permanência vai variar com o contexto e com as diferentes histórias individuais e coletivas. A repetição politética tende a fixar os significados e reduzir a autonomia para a inovação (CHERNELA, 2008: 144). Para que o Estilo (e a identidade) seja reconhecido, precisa ser reconhecível, não podendo ser alterado de forma drástica (p. 148). Por exemplo, um grupo Tupinambá que decide transformar seu Estilo (material ou não), incorporando inovações internas e externas, corre o risco de não ser mais reconhecido como Tupinambá e ser deixado de fora da grande rede que caracterizou esses grupos, uma rede definida pelas relações de alteridade e predação (cf. VIVEIROS DE CASTRO, 1986).

A própria noção de identidade, criada socialmente dentro do âmbito das comunidades da prática (community of practice), tende a reforçar as permanências. Segundo Bowser e Patton (2008: 108), a noção de comunidades da prática provém da ideia de que o aprendizado envolve socialização dentro de um grupo para a aquisição de uma nova dimensão de identidade social. $\mathrm{O}$ aprendizado não possui significado fora do campo da prática (INGOLD, 1996: 26). Assim, as atividades educativas não envolvem apenas a transmissão de informação de um indivíduo para o outro, e sim uma motivação para que o indivíduo se torne integrante do coletivo, atingindo a competência prática definida pelo grupo

\footnotetext{
${ }^{4}$ É necessário lembrar que diferentes formas de mídia podem sinalizar as fronteiras do grupo, não sendo necessariamente o vestígio arqueológico um deles (STARK, 1998: 9).
} 
e ganhando um papel neste frente a essa competência (BOWSER e PATTON, 2008: 108). Além disso, não se pode perder de vista o fato de que essa transmissão de conhecimento, materializado no Estilo, ocorre devido às linhagens linguísticas, a transmissão vertical passada de geração para geração (HEGGARTY, 2007: 316).

Por outro lado, nem tudo vai de acordo com a estrutura da ordem vigente. Por exemplo, tensões podem surgir à medida que membros mais novos de grupos podem querer estabelecer sua identidade por meio da prática. Tensão essa que pode reestruturar o status quo e levar, no campo material, às descontinuidades e mudanças observadas pelos arqueólogos (BOWSER e PATTON, 2008: 108). A difusão de elementos entre coletivos distintos (transmissão horizontal), claro, também pode levar a variações, assim como os próprios ruídos que ocorrerão durante a transmissão do conhecimento (HEGGARTY, 2007: 316). Resumindo o argumento que será retomado adiante: por mais que a ligação entre cultura material e língua seja extremamente complexa, variando conforme o contexto, não se pode negar que existe uma relação entre a transmissão de conhecimento, a linguagem e os elementos estilísticos.

Toda essa discussão é uma busca pela compreensão das escolhas estilísticas históricas empreendidas por determinados grupos. Os Estilos, por sua vez, refletem os elementos conscientes e inconscientes presentes nas escolhas técnicas (STARK, 1998:6), que são as ações humanas (tradicionais) que levam à produção e à utilização de coisas (artefatos) (DIETLER e HERBICH, 1998: 235). O Estilo é derivado das escolhas técnicas, transmitidas vertical ou horizontalmente, que são condicionadas pelas forças sociais (estruturas) e pelas relações que condicionam a cultura material (p. 236). Compreender a permanência, a ausência e a alternância dos elementos estilísticos é buscar compreender a pergunta-chave dos estudos arqueológicos - o significado da variabilidade material.

Como então definir o conceito de Estilo, chave para a compreensão do modo de vida das populações pretéritas? Das dezenas de textos lidos até hoje sobre o tema, a mais bela, por ser a mais simples, definição vem de Alfred Gell (apud. Barcelos Neto 2008: 38), que identifica Estilo como um eixo de coerência. Seguindo o argumento do presente estudo, seria necessário desenvolver o conceito para algo como "uma coerência de elementos politéticos no tempo e espaço" ou apelar para a eloquência de Peter Roe, que define Estilo como "an intentional structured system of selecting certain dimensions of form, process or principle, function, significance, and affect from among known, alternate possibilities to create pleasing variability within a behavioral-artefactual corpus" (1995: 31). 
Resta definir os elementos que possuem maior potencial para fornecer informações sobre o Estilo, os que mais interessam para o presente estudo. (I) conforme explicitado acima, é necessário repetir que os Estilos são contextuais, não são genéricos (HODDER, 1986: 3-6); (II) os Estilos são históricos, e as escolhas feitas no presente tendem a ser coerentes com as escolhas feitas no passado: "historicity gives style its affective content, its powers of emotional evocation of a group's past" (ROE, 1995: 30); (III) o Estilo possui diversas funções em níveis diferentes: "dependending on the knowledge of the audience, style may signal personal, family, village, or ethnic identity as it is defined in local, regional, national or international arenas" (DEBOER, 1990: 83); (IV) os elementos mais importantes do Estilo, para os que buscam a compreensão exploratória das histórias de grupos no tempo e espaço, são aqueles que possuem maior caráter comunicativo ${ }^{5}$ ou emblêmico (WIESSNER, 1983, 1991; WOBST, 1977), e (V) os elementos estilísticos mais duradouros tendem a ser aqueles que envolvem o maior período para serem aprendidos, nos quais a transmissão é mais acentuada, como a construção de vasilhas cerâmicas com grandes dimensões ou formatos complexos (GOSSELAIN, 1998: 102; 2008: 158-161), assim como se supõe que os elementos estilísticos relacionados com as esferas sociais menos sujeitas a mudanças também tendem a mudar menos. No caso Tupi-Guarani, será indicado que é no campo ritual, por seu caráter cíclico quase atemporal, que esses grupos aparentemente possuíram uma maior coerência de elementos politéticos nos vasos cerâmicos. No decorrer do tempo, alguns elementos politéticos possuem mais chance de se perder ou de permanecer do que outros.

Em síntese, a presente abordagem é calcada na estrutura e nas práticas (materializadas no Estilo) estruturadas e estruturantes que levam à mudança do Estilo. Tal perspectiva só é possível se a noção de Estilo for ampla e abrangente, sem separação entre características decorativas e funcionais ou entre elementos adjuntos e instrumentais (CHILTON, 1998: 133; DIETLER e HERBICH, 1998: 238). A proposta deste trabalho é montar uma série de complexas redes de elementos estilísticos e, com a comparação entre essas redes, buscar sobreposições que indiquem possíveis "relações de parentesco". O objetivo é a compreensão de histórias de longa duração, que pode ser alcançado pela utilização de premissas presentes na Ecologia Histórica.

\footnotetext{
${ }^{5}$ Dietler e Herbich (1998: 244) discordam dessa visão comunicativa de Estilo proposta por Wobst e outros, indicando que o Estilo não comunica como uma linguagem, sendo muito menos direto, mais complexo e ambíguo do que um texto produzido por um autor. Por outro lado, pode-se argumentar que os elementos comunicativos estilísticos estão muito mais livres das intencionalidades subjetivas e (possivelmente) enganadoras de um texto escrito (cf. NEVES, 2012).
} 


\subsection{Ecologia Histórica}

Segundo Denevan (2006: 153) a expressão Ecologia Histórica se popularizou nos anos 1990, mas ela vem sendo utilizada desde, pelo menos, os anos 1970. Trata-se de uma corrente interdisciplinar que abrange estudos em antropologia, arqueologia, geografia, história, sociologia, demografia e ciências físicas e biológicas, que avançou em tópicos trabalhados pela ecologia humana, pela geografia cultural e histórica, pela história ambiental e pela ecologia da paisagem.

O axioma dessa proposta teórico-metodológica, ou desse programa de pesquisa, é que o ser humano, em sua trajetória histórica no mundo, interferiu com resultados materiais e mensuráveis no meio biótico (ambiente) - que antes evoluía basicamente por meio da seleção natural - e que tais mudanças impostas à natureza se refletem, por outro lado, nas culturas, sociedades e línguas humanas através do tempo. O produto dessa colisão entre natureza e cultura, dessa relação dialética entre o homem e o meio ambiente, é a paisagem: “(..) landscapes are the geographical context in which socioecosystems operate and are altered by socioecological processes" (BARTON et al., 2004: 257).

A paisagem é uma totalidade que abrange as pessoas e o ambiente que as circunda: como uma unidade de análise multi-escalar, diacrônica e holística (BALÉE e ERICKSON, 2006: 1-3; cf. BALÉE, 1994, 1995; ERICKSON, 2003). Essa abordagem diacrônica, no entanto, não deve ser compreendida como um processo homogêneo na sua longa duração, mas como uma série de "pulsações" que variam de acordo com as áreas geográficas e com os grupos em questão (NEVES, 2012: 150; NEVES e PERTERSEN, 2006: 280).

Por mais que o presente estudo, no âmbito da Ecologia Histórica, dê destaque para o papel do ser humano na sua relação com o ambiente em que vive, vale indicar que não se deseja superestimar esse papel. Assim como os humanos não podem ser vistos como consumidores passivos ou vorazes exploradores de ecossistemas, os ecossistemas não podem ser tidos somente como pano de fundo para a agência humana ou apenas como um combustível para o desenvolvimento de economias humanas (BARTON et al., 2004: 254).

Conforme bem lembrado por Stalh (2006: 127), a Ecologia Histórica e a arqueologia compartilham uma relação mútua, mas assimétrica, uma vez que a Ecologia Histórica em muito depende dos métodos e das técnicas da arqueologia para gerar inferências sobre as mudanças durante sua longa duração. Assim, no presente estudo, as interpretações 
contextuais que visam à compreensão da história de longa duração das antigas populações ceramistas do alto rio Madeira - sob a perspectiva da Ecologia Histórica são realizadas a partir de uma análise estruturante de diferentes Estilos cerâmicos, em especial do(s) Estilo(s) cerâmico(s) presente(s) na Tradição Polícroma da Amazônia.

Os paradigmas da Ecologia Histórica foram (e estão sendo) construídos em grande parte por estudos de manejo de plantas (e.g. BALÉE, 1994; BALÉE e MOORE, 1994) e na formação dos solos antropogênicos, as chamadas terras pretas (e.g. ARROYO-KALIM, 2010, 2011; KAMPF e KERN, 2005; KERN, 1988, 1996; NEVES et al., 2004; PETERSEN et al., 2001). Conforme salientado, o sudoeste amazônico, onde se encontra a bacia do alto rio Madeira, é uma área ímpar para estudos de Ecologia Histórica, uma vez que possui algumas das primeiras plantas domesticadas do continente e as terras pretas mais antigas datadas até o presente. A compreensão de como se relacionam esses processos com a imensa variabilidade cultural na pré-história da região é, sem dúvida, um dos grandes objetivos daqueles que estudam a arqueologia da região. Para que se chegue a essa compreensão, entretanto, é necessário que os métodos de classificação empregados estejam explicitados.

\subsection{Classificação}

A arqueologia é uma ciência (humana) que estuda o registro arqueológico (cf. NEVES, 2012; SCHIFFER, 1987), em geral pensado como composto por vestígios materiais de antigas populações. No caso da Ecologia Histórica, não seria errado dizer que se estudam os vestígios materiais referentes às relações humano-humano, humano-ambiente, humanoobjeto, objeto-objeto. No entanto, há casos nos quais vestígios materiais não são o objeto central do estudo arqueológico. Um estudo de cronologia, por exemplo, não é um estudo de cultura material e ainda assim é arqueológico. Seguindo Schiffer (1987), pode-se dizer que, para adentrar o registro arqueológico, o objeto só precisa ser depositado em um local onde ele (a priori) não vá ser mais utilizado (uma lixeira, um depósito, uma área de descarte no quintal de uma casa etc.) por seu antigo proprietário. Ou seja, pode-se estudar o registro arqueológico de populações ainda vivas (não só das antigas), talvez no próprio quintal onde ainda moram. Por exemplo, o jardim do Museu de Arqueologia e Etnografia (MAE-USP) - onde todos os dias arqueólogos fazem seu intervalo do café - não deixa de ser um sítio arqueológico, já que possui vestígios (lascas, micro lascas, estilhas, núcleos de lascamento, algumas bitucas de 
cigarro etc.) de atividades experimentais que ali ocorrem ocasionalmente. Nada impediria que esse material fosse classificado.

A classificação é qualquer "atividade que tenha como produto uma ordem ou ordens, qualquer procedimento que leve à criação de unidades" (DUNNEL, 2007: 67). Para classificar o registro arqueológico, não há uma fórmula para cada tipo de material que se queira ordenar. Tudo depende das perguntas que forem feitas. A classificação de objetos deve sempre ter um propósito e uma maneira de pôr em prática esse propósito. Não há um jeito certo ou errado de classificar as coisas, mas há jeitos melhores ou piores de atingir propósitos específicos, uma vez decididos quais são esses propósitos (ADAMS e ADAMS, 1991:4-5).

O primeiro passo para uma boa classificação é definir os termos que guiam os agrupamentos. Em um sentido amplo, classificar é definir (ADAMS e ADAMS, 1991: 64). Essas definições devem fornecer às classes, simultaneamente, coesão interna e isolamento externo (CORMARK, 1971: 329). Além disso, as definições devem instruir o uso de instrumentos conceituais que permitam duas ou mais pessoas utilizar conscientemente o mesmo instrumento com um grau de consistência quanto aos propósitos com os quais esses instrumentos foram designados (ADAMS e ADAMS, 1991: 15).

Apesar de muitos estudiosos em arqueologia brasileira terem criticado a terminologia que sintetiza as classes criadas, é raro encontrar hoje pesquisadores que se preocupam com definições terminológicas. Por exemplo, ao longo de sua formação, arqueólogos amazônicos utilizaram grande número classes, ou agrupamentos, para definir seus conjuntos artefatuais (tais como Tradições, Subtradições, fases, Horizontes, Estilos, Tipos), mas são poucos os que, como os antigos (e.g. CRUXENT e ROUSE, 1958; MEGGERS e EVANS, 1970) se dão o trabalho de definir os termos: "ocorre, no entanto, que o exacerbamento dessas críticas [aos antigos métodos culturalistas históricos] está levando também a uma doença oposta à intoxicação, que é a inanição classificatória" (NEVES, 2010: 565).

Tradição: referente a Estilos (incluindo técnicas) politéticos com persistência temporal e abrangência espacial. Um conjunto de fases distribuídas por áreas vastas e com grande amplitude cronológica.

Subtradição: frequentemente usada e raramente definida, tende a indicar um conjunto de fases (ou sítios) em uma região mais restrita (e.g. a bacia de um rio). Pressupõe a existência de uma Tradição que a englobe. A discussão desse conceito será retomada adiante.

Fase: é um conjunto de atributos recorrentes em uma área restrita (e.g. um trecho de rio), em um período que é determinado pela manutenção de uma coerência politética nos elementos estudados. Assim, o presente uso de fase possui um caráter mais espacial (o tamanho e a quantidade de sítios relacionados encontrados em uma área) do que temporal, ainda que o 
último seja fundamental. Não se restringe a um único coletivo ou grupo étnico.

Horizonte: é um contínuo espacial representado por traços culturais e conjuntos cuja natureza e modo de ocorrência permitem assumir uma dispersão rápida e ampla.

(Compilados e remodelados a partir de CHYMZ et al., 1976; NEVES, 2006; WILLEY e PHILIPS, 1958)

Antes de definir os termos, é preciso que o pesquisador olhe para os objetos que deseja classificar e decida se as classes de atributos que está criando existem "naturalmente" (se eles são êmicas) ou se são ferramentas analíticas "artificiais", criadas pelos pesquisadores. Há cinquenta anos, essa tarefa seria semelhante a escolher entre os Tipos naturais de Spaulding (1953) e os artificiais de Ford (1954; 1962; cf. ADAMS e ADAMS, 1991: 67; O'BRIEN e LEONARD, 2001: 6; WILLEY e PHILIPS, 1958: 13). Os integrantes do Programa Nacional de Pesquisas Arqueológicas (PRONAPA), entre eles o arqueólogo Eurico Miller, que classificou a imensa maioria do material da bacia do alto Madeira até o presente, utilizaram com insistência o método Ford para criar Tipos, fases, Tradições e lançar suas interpretações a respeito da Tradição Polícroma da Amazônia (e.g. EVANS e MEGGERS, 1968; MEGGERS e EVANS, 1957; MILLER, 1992; MILLER et al., 1992; PEROTA, 1992; cf. NOELLI, 1999-2000). Por outro lado, alguns arqueólogos das terras baixas que trabalharam com histórias de longa duração, como Brochado (1984; BROCHADO et al., 1990; LA SALVIA e BROCHADO, 1989; WEBER, 1975; cf. NOELLI, 2008b) ou com contextos etno-arqueológicos (DEBOER e LATHRAP, 1977; HECKENBERGER, 2005; LATHRAP, 1962; NEVES, 1998; ROE, 1982, 1995), por inúmeras vezes conseguiram se aproximar de categorias mais êmicas, que correspondem a escolhas e comportamentos ${ }^{6}$. Resumindo e simplificando, o grupo dos pronapistas buscou, de forma muitas vezes criticada $^{7}$, organizar os vestígios arqueológicos em classes artefatuais que eram compreendidas dentro do próprio universo das classes analíticas ${ }^{8}$. Os Tipos, fases e Tradições

\footnotetext{
${ }^{6}$ Os pronapistas também achavam que havia uma relação entre escolha e comportamento que definiria o grupo arqueológico.

${ }^{7}$ O campo classificatório representa apenas uma das muitas críticas feitas ao PRONAPA. Noelli (1999-2000) faz uma extensa explanação dessas críticas, com ênfase na irrelevância dada pelos membros do PRONAPA aos dados históricos e etnológicos que permitissem a realização de histórias de longa duração de grupos indígenas, indicando um "preconceito etnocêntrico" por parte dos mentores do programa (pp. 223-224). O autor cita também, entre outros, o fato de que o padrão unilinear do PRONAPA excluía pesquisadores com propostas alternativas ao mainstream de concessão de verbas para o apoio à pesquisa, assim como das publicações (p. 221). Outra crítica feita pelo autor ao PRONAPA é o distanciamento que os dados produzidos possuíam com o publico geral, criado por "esquemas interpretativos ininteligíveis e criptografados" (p.262).

${ }^{8}$ Com o passar do tempo, alguns pronapianos, como o próprio Miller, mudaram a orientação de algumas de suas classes (Tradições e fases) para ligá-las a grupos indígenas vivos, também no sentido da longa duração. Assim, apesar de Miller (com. pessoal) não observar a ligação entre os Tupi e a Tradição Polícroma da Amazônia,
} 
eram o fim e não o meio (cf. CHILTON, 1998: 132; DIAS e SILVA, 2001; NEVES, 2010, 2012: 60). O segundo grupo buscou, por meio de uma visão de história indígena, compreender os vestígios materiais a partir de grupos indígenas do presente ou de uma densa compreensão de registros históricos (NOELLI, 1999-2000, 2008b).

O presente estudo é simpático a uma classificação mais êmica dos artefatos. No entanto, ao contrário dos exemplos citados, a Tradição Polícroma da Amazônia não possui relatos históricos detalhados ${ }^{9}$ ou mesmo grupos vivos que ainda produzam esse tipo de cerâmica, por meio dos quais seja possível delinear categorias criadas pelos próprios produtores dos vasos. Dessa forma, resta apenas uma saída intermediária, conciliando as duas abordagens classificatórias. Então, seguindo Adams e Adams, pode-se dizer que modalidades são criadas como fruto da relação entre o ser humano e a natureza, mas são os classificadores que fazem escolhas entre essas modalidades para um propósito particular seu. "It is also we who have to draw arbitrary boundaries between modalities, if they are to be used in sorting categories, where often enough there are no such boundaries in nature" (1991: 68).

Por que utilizar o conceito de Subtradição? O conceito de Subtradição possui um uso coerente com agrupamentos classificatórios de sítios que ocupam vastas áreas, mas que podem ser inseridos em agrupamentos ainda mais amplos. Por exemplo, esse termo foi adequadamente utilizado por Miller na descrição da Subtradição Jatuarana, do alto Madeira, identificada em sítios localizados a mais de $500 \mathrm{~km}$ desse rio, mas que pertence à Tradição Polícroma da Amazônia, com distribuição pan-amazônica. Uma ideia semelhante à de Lathrap e Brochado, que propuseram inserir as Subtradições Guarani e Tupinambá na Tradição Polícroma da Amazônia (proposta não compartilhada pelo presente estudo, que indica que as Subtradições Tupinambá do litoral, Tupinambá da Amazônia e Guarani pertencem a uma grande Tradição Tupi-Guarani). Quando Noelli indica que "as subtradições também foram descartadas por Brochado" (2008b: 34), ele se refere às Subtradições pintada, corrugada e escovada, atribuídas de forma errônea pelos pronapistas a uma evolução estilística dos "Tupiguarani", não significa que ele abandonou os conceitos de Tradição e Subtradição, utilizados por ele de maneira êmica, para se referir aos grupos Tupi e aos Tupinambá e Guarani (respectivamente).

Por outro lado, é no momento de cruzar os elementos politéticos para fazer comparações que surge a possibilidade de utilizar uma metodologia mais lathrapiana (cf. RAYMOND, 2009: 516-517). Segundo Brochado e Lathrap (1982; cf. NOELLI, 2008b: 38),

conforme sugeriram Brochado e Lathrap, ele aponta (2009) para a existência de uma Tradição arqueológica ligada a cada uma das famílias do tronco Tupi (os falantes do Tupi-Guarani estariam ligados à Tradição Tupiguarani, os Tupi-Mondé, à Tradição Tupimondé, e assim por diante). Voltaremos a esse tópico.

${ }^{9}$ A exceção clássica é a descrição do encontro de Orellana com os Omágua (grupos Tupi-Guarani do alto Amazonas) (CARVAJAL, 1941 [1542]). 
para realizar comparações cerâmicas, como a proposta no presente estudo, é necessário reconstruir o máximo possível e interligar as diversas fontes do Estilo, quer elas residam na forma do vaso, na decoração ou no antiplástico utilizado.

De qualquer forma, seguindo Neves $(2010 ; 2012)$, o presente estudo defende a necessidade da permanência dos tradicionais conceitos culturalistas históricos. Por mais que se possa falar hoje em cerâmica Guarani, não se pode falar (de forma êmica) em cerâmica Polícroma ou Zonada-Hachurada como se houvesse certeza de que essas representem arqueologicamente grupos culturais e/ou linguísticos. Assim, será mantida a nomenclatura clássica, com o intuito de aprimorá-la por meio da abordagem politética e dos resultados obtidos a partir comparações entre diferentes fases, Subtradições e Tradições.

A classificação politética no campo antropológico/arqueológico possuiria a desvantagem de fazer que as comparações se tornem mais complexas e até, em uma escala ampla e detalhada, impraticáveis. Por outro lado, as classificações politéticas possuiriam a vantagem de serem altamente informativas, por gerarem menos riscos de exclusões arbitrárias de elementos significativos, e seriam mais "fiéis" ao contexto original do qual o material classificado é proveniente. Premissas que, se confirmadas, pagariam o preço relativo ao aumento na dificuldade de realizar tais comparações (NEEDHAM, 1975: 358).

Depois de uma série de referências ao conceito de politético, é chegado o momento de realizar uma explicação mais detalhada desse termo, em especial dentro das classificações cerâmicas que serão apresentadas. Para tal, será emprestada a descrição das Polythetic Features (características politéticas), adaptada por David Clark (1978; cf. ADAMS e ADAMS, 1991; NEEDHAM, 1975). Para o autor, é possível definir um grupo de entidades a partir de uma série de propriedades de forma que: (I) cada entidade possua um número alto, mas não especifico, de um conjunto particular de atributos; (II) cada atributo seja compartilhado por um alto número de entidades; (III) nenhum atributo necessariamente pertença a todas as entidades do grupo (CLARK, 1978: 36-37).

Assim, por exemplo, se a cerâmica da Subtradição Guarani é reconhecida por possuir como atributos diagnósticoso antiplástico de caco moído, formas angulares, decorações corrugadas, unguladas e pintadas, e a cerâmica da Tradição Polícroma da Amazônia é reconhecida por possuir antiplástico de caraipé, formas angulares, com presença de flanges, bordas reforçadas e decorações pintadas e acanaladas, isso não quer dizer que a ausência de 
qualquer um desses atributos signifique que o material não pertença a esses agrupamentos. Daí o fato de as características não serem mono e sim politéticas.

Os atributos escolhidos para estas comparações politéticas são, em geral, os que possibilitam ao estudioso mais bem compreender a relação entre a estrutura e as práticas dos povos que fabricaram estes artefatos. Além de comparar listas de atributos encontrados em indústrias intra e intersítios, assim como de agrupamentos regionais, pretende-se, como uma forma de dar mais consistência a esses conjuntos de elementos, criar Tipos. Um Tipo, de maneira ampla, consiste em uma "coisa", somada às ideias que temos dessa coisa, somada às palavras e/ou imagens com as quais expressamos essas ideias (LEACH, 1976: 17-22). Se um Tipo é uma coisa, pode ser utilizado para exemplificar qualquer coisa, de tipos de lingerie a tipos de ideia. No entanto, dentro da arqueologia, os Tipos geralmente pertencem uma categoria taxonômica específica, localizada acima dos atributos e abaixo das fases, Tradições etc. Cada Tipo é formado por uma série de atributos, e cada Estilo, fase ou Tradição pode possuir uma série de Tipos.

No presente estudo, os Tipos criados serão incipientes, uma vez que as amostras dos sítios não permitem criar Tipos "fechados" sustentados por níveis de frequência. Isso ocorre especialmente pelo fato de a forma cerâmica ser a base tipológica (e.g. BROCHADO, 1984; ROUSE, 1960; WEBER, 1975: 106-107), o nível mais alto na hierarquia dos elementos a ser comparados. Opção que requer cuidado, já que não foram trabalhadas peças inteiras, e sim reconstituições provenientes de fragmentos. Assim, em vez de criar designações tipológicas como semi-esférico inciso, será feita apenas uma referência às possibilidades de tratamento de superfície que cada uma das formas pode possuir ${ }^{10}$. Trata-se de um pequeno avanço no método adotado durante a última pesquisa (ALMEIDA, 2008; Capítulo 2 da presente tese) na qual, em geral, as formas e os tratamentos de superfície foram abordados em separado. A ideia é que, com a continuação das análises no alto Madeira - quem sabe com uma maior amostra de vasos inteiros -, será possível investir em Tipos mais consistentes, mas não engessados e engessantes.

Para sumarizar e amarrar a discussão, é necessário voltar rapidamente ao conceito de Estilo, já que é nele que se encontra um sintetizador para o conjunto de classes em todos os níveis da taxonomia. As escolhas estilísticas estão presentes desde a escolha dos elementos ou atributos que serão transformados em artefatos e chegam à recorrência de determinados

\footnotetext{
${ }^{10}$ Por meio do cruzamento de elementos dentro do banco de dados produzido.
} 
Tipos artefatuais no tempo e espaço, que podem gerar a criação de uma Tradição. Dessa forma, para o arqueólogo que busca correlacionar Estilos (encontrados nos Tipos, fases, Subtradições, Tradições) com populações humanas dentro da longa duração, é de extrema importância identificar os elementos - os que sobreviveram no registro arqueológico - que permitiram que esses grupos se diferenciassem na época em que os artefatos estudados foram utilizados.

\subsection{Ferramentas auxiliares para a interpretação arqueológica: etnologia, história indígena, linguística}

\subsubsection{Linguística}

The dialectical relationship between language and culture is historical and can only be understood through history (SANTOS GRANERO, 2002: 27).

Há uma grande empatia entre arqueólogos e linguistas, já que compartilham muitos medos e inseguranças. A vida dos linguistas parece ainda mais complicada que a dos arqueólogos - as cronologias léxico-estatísticas são bem menos confiáveis do que as arqueológicas (HEGGARTY, 2007: 321) -, a não ser que o arqueólogo decida construir suas hipóteses calcadas inteiramente em modelos linguísticos, o que em muitos casos se torna em uma amarra epistemológica que deixa o arqueólogo à mercê do aperfeiçoamento ou mesmo da rejeição do modelo por outros linguistas (e não por arqueólogos). No entanto, é quase impossível para alguém que trabalha com grupos de ceramistas indígenas no sudoeste amazônico desprezar as ferramentas que a linguística fornece. Ainda mais se há um interesse do pesquisador pela temática Tupi.

Fica claro, de partida, que este é um estudo arqueológico inspirado nos trabalhos de autores como Heckenberger (2005; HECKENBERGER et al., 2003), NEVES $(2011,2012)$ e Noelli (1996a, 1996b, 1998, 2008a; cf. URBAN, 1996), que objetiva compreender a história dos grupos Tupi de maneira coerente com os dados linguísticos, a partir da bacia do alto rio Madeira, e que busca:

(...) o estabelecimento de um diálogo entre a arqueologia e a etnologia indígena. Tal diálogo, nem sempre harmônico e às vezes até conflituoso, parte da premissa 
de que a variabilidade cultural na Amazônia indígena, embora grande, é limitada e, mais importante, se manifesta de maneira regular no tempo e espaço no registro arqueológico. Essas regularidades trazem os fundamentos para construção de uma história indigena de longa duração construída a partir da Arqueologia. Trata-se de uma tarefa que apenas inicia, apesar de uma tradição de pesquisas de mais de cinquenta anos, mas cujos resultados podem ser promissores (NEVES, 2012: 61).

Há uma grande vantagem e uma imensa dificuldade na execução dessa tarefa. A grande facilidade provém do fato de que, hoje, quase todos os linguistas interessados no tema das origens Tupi (e.g. MIGLIAZZA, 1982; RODRIGUES, 1964, 1985; URBAN, 1992, 1996; WALKER, et al. 2012) concordam que o sudoeste amazônico possuiu - como ainda possui populações falantes de línguas do tronco ou macro-família Tupi. Para os linguistas, então, o sudoeste amazônico é o "berço" dos Tupi. Facilidade que, no entanto, não pode ser tomada como verdade absoluta. Por exemplo, Heggarty (2007: 336) aponta que um olhar para os locais de terras altas e de selva onde o Quechua se conserva melhor hoje não é, de forma alguma, um guia confiável para identificar a "terra natal" da qual esse língua se expandiu, mas apenas um reflexo de quão remotos são esses locais. Se partirmos do pressuposto de que o sudoeste amazônico é a "terra natal" (um termo que, no longo prazo, acaba não significando nada ${ }^{11}$ ) de grupos Tupi, é necessário considerar a hipótese contrária, de que o local seja outro.

É então dessa quase certeza proveniente dos dados linguísticos que advém a imensa dificuldade na tarefa de utilizar os mesmos dados. Isso porque ela remete a uma cronologia profunda, talvez com mais de 5 mil anos - na qual o terreno de pesquisa dos arqueólogos e linguistas fica bastante inseguro (cf. HEGGARTY, 2007: 318).

Por exemplo, uma coisa é dizer que a cerâmica corrugada-polícroma, encontrada no baixo Tocantins (ALMEIDA, 2008) e datada entre os séculos VIII e XVII, é relacionada com os falantes de línguas da família Tupi-Guarani documentados a partir do mesmo século XVII nessa mesma região. Outra coisa é fazer algo semelhante a respeito das várias famílias Tupi do sudoeste amazônico, que talvez habitem a região há mais de 5 mil anos, sobre as quais a maior parte da documentação escrita não possui mais de 100 anos. Por outro lado, a

\footnotetext{
${ }^{11} \mathrm{Na}$ terminologia arqueológica e linguística, incluindo a do presente estudo, é constante a presença de termos como "terra natal" ou "local de origem" de um determinado grupo linguístico e/ou cultural. Tais termos só servem a propósito do argumento, pois não significam que uma língua nasça ou seja gerada em algum lugar. Significam apenas a época na qual uma família começou a se dividir e a se expandir a partir de um determinado local. Da mesma forma, falar em "datar uma língua" é um tanto absurdo, uma vez que as línguas estão em constante mudança. O que se data, na linguística, é quando ocorre a divisão de uma língua em duas ou mais sublinhagens (HEGGARTY, 2007: 316-317).
} 
comparação linguística dos nomes das vasilhas cerâmicas feitas por Noelli (1999-2000; 2008b) indica que ocorre uma grande homogeneidade entre os diversos grupos Tupi-Guarani - sejam eles Tupinambá da Amazônia, Tupinambá do litoral ou Guarani - o que é uma consistente indicação com base linguística de que os Tupi-Guarani já fabricavam seus principais utensílios cerâmicos quando começaram a se dividir e a se expandir.

O estado da arte da arqueologia Tupi no começo do século XXI é que não se sabe como a variabilidade linguística, responsável pela diferenciação das famílias dentro do tronco, se comporta na esfera material. Não se sabe nem se há internamente, para cada família, a mesma coerência ou constância de certos atributos politéticos no tempo e espaço, assim como se sabe que ocorre com a família Tupi-Guarani. Com exceção dos Tupi-Guarani, a cladística entre línguas e cultura material, dentro do macro-universo Tupi, quase não existe. Uma exceção a essa afirmação seria o trabalho de síntese de Miller (2009), que indica haver uma Tradição arqueológica para cada uma das famílias do tronco Tupi. Nessa visão, a mesma coerência temporal encontrada na cultura material dos Tupi-Guarani seria encontrada em todas as demais famílias Tupi. Sugestão que é possível - e que serviria com perfeição aos propósitos do presente estudo -, mas que de forma alguma é comprovada por Miller, se restringindo por hora a ser apenas a mais simples e simpática possibilidade.

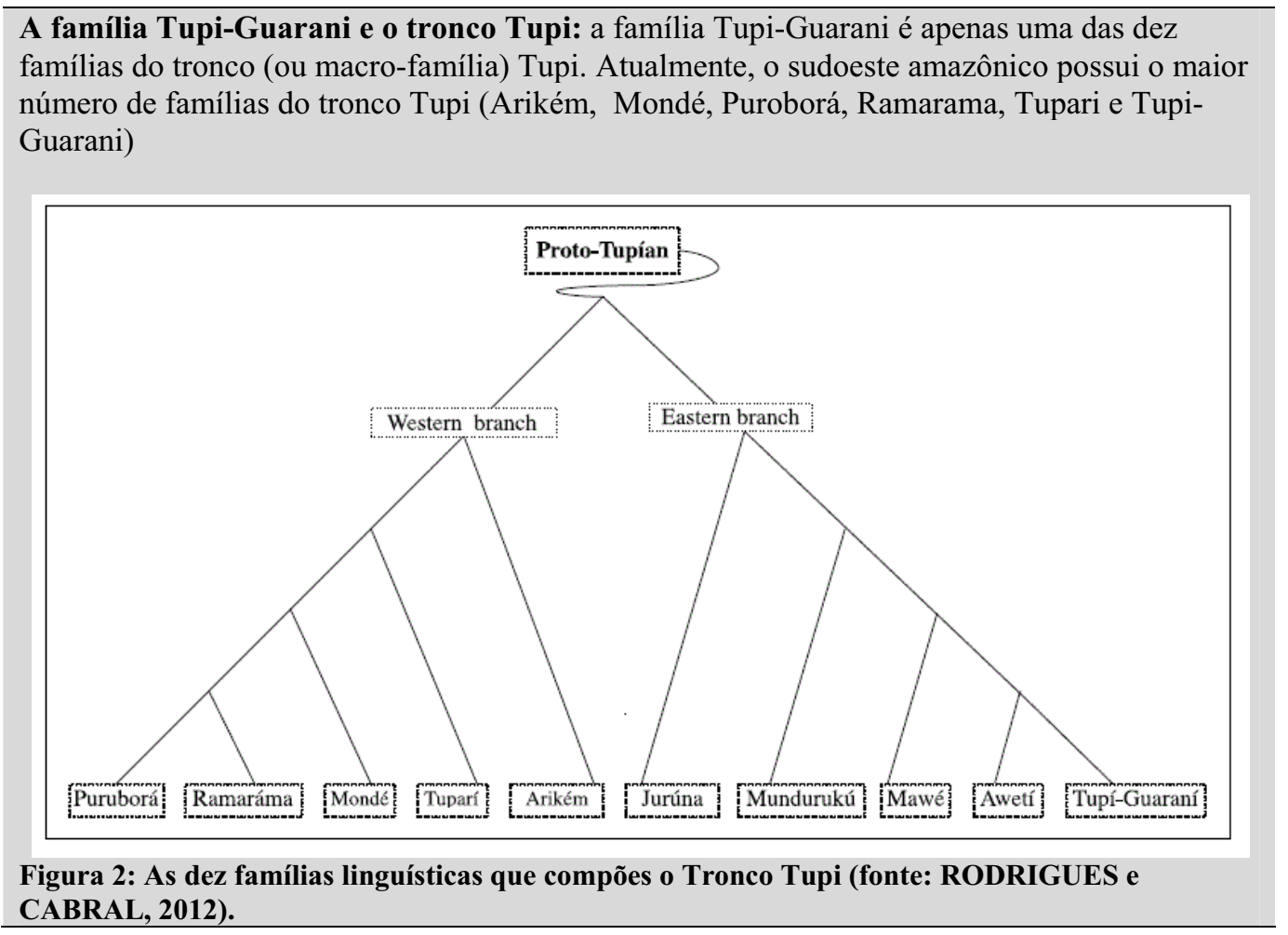


Para complicar só mais um pouco, seria importante lembrar que a região ocidental da Amazônia não só possui a maior variedade de línguas Tupi, como também a maior variedade linguística (e etnográfica) da América do Sul (cf. LATHRAP, 1970; TAYLOR, 1999). Isso significa que, no entorno desse mosaico Tupi, existe um mosaico ainda maior de grupos pertencentes a outras famílias (e.g. Arawak, Pano, Txapakura). Dentro dessa duração extremamente longa dos Tupi no sudoeste amazônico, não é apenas necessário conhecer os diferentes Tupi, como também os diferentes não Tupi, assim como a forma como ocorreram os processos de diferenciação entre esses grupos e qual é a parte desse mosaico relacionada com o objeto central de estudo desta pesquisa: a Tradição Polícroma no alto rio Madeira.

Um bom ponto de partida será fazer o exercício de utilizar a oposição entre os conceitos - formulados por Renfrew (1992, 2000, 2002) - de área de dispersão (spread zone) e área de mosaico (mosaic zone), da mesma forma que ocorreria a oposição entre os Tupi do sudoeste amazônico (que formam um mosaico) e os Tupi-Guarani (que se espalharam de forma uniforme:

I suggest that there were contrasting geographical patterns when a region had undergone a language displacement as a result of some dispersal process, or when, after initial colonization, there was a long period of stability resulting in a mosaic of small language units (...) (RENFREW, 2000: 24).

Para caracterizar minimamente esse mosaico, será de grande valia o uso dos dados históricos, assim como estudos etnográficos (e.g. DEBOER, 1990; DEBOER e LATHRAP, 1979; ROE, 1982) e arqueológicos (e.g. BROCHADO, 1984; ROUSE, 1987), que visaram à compreensão entre língua e cultura material no contexto amazônico. Para chegar a uma caracterização consistente, no entanto, levará décadas de estudos intensivos.

Outro tema caro para Renfrew (1987; BELLWOOD e RENFREW, 2003) é a relação da expansão de línguas com a agricultura. Conforme já apontado, o sudoeste amazônico é tido como um antigo centro de domesticação de alimentos como a mandioca e a pupunha. Por mais que a relação entre o início do cultivo de alimentos como a mandioca esteja intimamente conectada (de acordo com muitos dos arqueólogos interessados) com a expansão de grupos como os Tupi, ninguém sabe ao certo como essa operação se deu, se é que existiu 
de alguma maneira. O presente estudo, longe de resolver essa questão, pretende trabalhar com algumas das variantes envolvidas nesse processo.

\title{
1.4.2 Etno-história
}

\begin{abstract}
A reaproximação com a história, por parte da arqueologia contemporânea, é particularmente proveitosa no caso de pesquisas realizadas em contextos de sociedades ágrafas, como ocorre nas terras baixas da América do Sul. Tal reaproximação permite um diálogo direto com a etnologia e a etno-história (...) (NEVES, 2010: 563).
\end{abstract}

Desde o século XVI até meados do século XX, foi gerado um número extenso e heterogêneo de relatos históricos sobre os grupos indígenas que viviam na bacia do rio Madeira (e.g. ACUÑA, 1994 [1641]; BETENDORF, 1910 [1698]; DANIEL, 1976; FONSECA, 1860; FRITZ, 1918; HERIARTE, 1976; NORONHA, 1862 [1768]; SPIX e MARTIUS, 1976). Quem utiliza tamanha quantidade de dados, no meio desse oceano informativo interdisciplinar, fatalmente estará se distanciando de uma visão crítica com relação a esses dados.

Um modo de atenuar esse problema no curto prazo - contando que no longo prazo haverá um fortalecimento dessa visão crítica - é o uso de fontes secundárias. No caso do sudoeste Amazônico, há uma série delas (e.g. CYPRIANO, 2007; HUGO, 1959; MENÉNDEZ, 1981/1982), além dos clássicos etnográficos, que trabalham com relato e síntese (e.g. LEVI-STRAUSS, 1948, 1976; MÉTRAUX, 1979; NIMUENDAJÚ, 1948a, 1948b; ROQUETE PINTO, 1975 [1919]). Se na arqueologia dessa região é possível identificar no trabalho de Zimpel (2009) uma síntese da extensa e mal divulgada obra de Eurico Miller (1978, 1980 1987a, 1987b, 1987c, 1987d, 1992, 1999), pode-se encontrar no campo da história indígena uma série de autores que já fizeram muito do trabalho de síntese de dados ${ }^{12}$. Esses trabalhos não serão desprezados. Muito pelo contrário, é na discussão de uma questão de etno-historiadores que reside uma questão fundamental para a problemática aqui trabalhada. Trata-se do debate entre Nimuendajú e Menéndez sobre a antiguidade da

\footnotetext{
12 Vide Tamanaha (2012), para um uso pontual e adequado de fontes secundárias.
} 
presença dos Kawahib (grupo Tupi-Guarani) no alto rio Madeira, que grosso modo resume a possibilidade da cerâmica polícroma do alto Madeira ser ligada ou não a um contexto Tupi (Capítulos 2 e 3).

\subsubsection{Etnografia}

São três os grandes interesses, no âmbito do presente trabalho, das leituras feitas a partir da etnografia da bacia do alto rio Madeira. A primeira contribuição vem do fato de que grande parte da etnografia produzida no atual Estado de Rondônia detalha - principalmente devido à colonização tardia da região - a história dos contatos entre os indígenas e do invasor "branco" (e.g. LEONEL, 1988; VILAÇA, 2010). Tem-se na etnografia um poderoso aliado no árduo processo de construção do(s) contexto(s) histórico(s) da região. No entanto, por falta de tempo e espaço, esses dados serão pouco utilizados por ora.

Os estudos etnográficos também são essenciais para dar cor e vida ao mosaico cultural a ser construído. Como muitos dos contatos foram feitos apenas em períodos recentes, parte das descrições etnográficas remete a grupos ainda pouco influenciados pela expansão colonial. Alguns grupos mantiveram intactos muitos dos antigos costumes, como a produção de cerâmica pelos Suruí, grupo Tupi-Mondé (MINDLIN, 1985, 2006; VIDAL, 2012), e outros ainda possuem pessoas de idade avançada que ainda lembram dos artefatos materiais que deixaram de ser produzidos.

No entanto, ao contrário do estudo anterior (ALMEIDA, 2008), que utilizou de forma conspícua os dados etnográficos de grupos Tupi-Guarani de terra firme do leste amazônico, a presente pesquisa, realizada com sítios relacionados a grandes drenagens (alto Madeira e baixo Jamari), não possui o mesmo arcabouço etnográfico regional para lidar com grupos ribeirinhos, por isso lança mão de exemplos e modelos de outros contextos indígenas ribeirinhos da Amazônia.

Para compreender se existe, e qual é, a ligação entre a Tradição Polícroma da Amazônia e o contexto Tupi/Tupi-Guarani, é necessário começar a construir um esboço de síntese que permita aos estudiosos compreenderem o que há de comum nesse universo Tupi, além de línguas que, em geral, são inteligíveis. Existe de fato uma base cosmológica comum 
entre os diferentes Tupi e Tupi-Guarani? Ou, em outras palavras, existe uma estrutura estruturante comum para os Tupi/Tupi-Guarani? No caso dos Tupi-Guarani, estudos como os de Noelli (1996a; 1999-2000), Fausto (1992) e Viveiros de Castro $(1986,2002)$ fornecem dados suficientes para responder de maneira afirmativa. Resta saber se o mesmo ocorre com a mesma coerência em um agrupamento mais amplo, que abranja também todos os demais grupos Tupi e, quiçá, os antigos produtores de cerâmicas da Tradição Polícroma. Só de posse dessa resposta é que será possível observar se essa coerência também se estende para os grupos produtores de cerâmica TPA.

\begin{abstract}
Cosmology details the involvement of man with cosmological time, space and relationships. It emphasizes that humans are inextricable elements of their surroundings, and must function together with all the constituents of the cosmos to insure its maintenance and perpetuation. This end is achieved through the ritual reexamination and/or reinterpretation of the ancestral past. The hidden world of mythic time coexists with the observable world and can therefore be entered, witnessed, and understood. In a similar manner, ecological maintenance is achieved through a constant interaction with cosmological components, as well as the application of conservation-oriented exploitative techniques (STAHL, 1984: 4344).
\end{abstract}

\title{
1.5 Últimas notas
}

Apesar de ambiciosa, a proposta de realizar uma pesquisa dentro de um universo tão grande de ideias, modelos, disciplinas (etc.) é a única possível para responder a pergunta sobre a relação entre a Tradição Polícroma da Amazônia e os Tupi. Ao longo deste capítulo, foram apresentados os pressupostos teóricos, os métodos classificatórios e as ferramentas auxiliares que podem ajudar a responder essa pergunta. Foi defendido o uso de uma arqueologia contextual que buscasse dialogar com os estudos produzidos ao longo dos anos pela arqueologia amazônica, refinando-os e utilizando-os para pensar em questões ainda pouco debatidas na arqueologia do sudoeste da Amazônia. Também se argumentou, a partir dos pressupostos da Ecologia Histórica, em favor da utilização de um viés interdisciplinar para a interpretação dos contextos em questão. Acredita-se que tal viés possa ser útil para reequilibrar a forma que a história pré-colonial do sudoeste amazônico é analisada, colocando as relações entre o ser humano e o ambiente em foco e retirando do ambiente o papel 
determinante das possibilidades de ação do ser humano, como por tantos anos se argumentou nas pesquisas da bacia do alto rio Madeira. 


\section{TUPIS, TUPINAMBÁS E A TRADIÇÃO POLÍCROMA NA AMAZÔNIA}

Sua vocação estaria no caminho, que convida ao movimento (BUARQUE DE HOLANDA, 1994: 9).

\subsection{Introdução}

Neste capítulo, será apresentada uma visão alternativa à de Brochado (1984) e Lathrap (1970), que viam as Subtradições Tupinambá e Guarani como extensões fluviais dos grupos da Tradição Polícroma da Amazônia (TPA). Para tanto, foi decidido utilizar o contexto "seguro" do leste amazônico, no qual haveria uma clara divisão ecológica entre os grupos Tupinambá amazônicos, habitantes de áreas encachoeiradas e de interflúvio, e os produtores de cerâmica pertencente à Tradição Polícroma, os grupos canoeiros que habitariam as margens dos grandes rios navegáveis.

A base para esse exercício comparativo foi o artigo escrito por Meggers et al. (1987), no qual os autores advogam por essa distinção ecológica nos baixos cursos dos rios Tocantins e Xingu, ainda que sem a preocupação de pormenorizar tais distinções quanto à variabilidade cerâmica, tampouco de indicar que as áreas de terra firme possuíam potencial de sustentar processos culturais relevantes, como aqui se defende.

A hipótese inicial a ser testada é a de que os grupos TPA se expandiram por vias fluviais, pela calha do rio Amazonas, e os grupos Tupinambá amazônicos se expandiram principalmente por terra, por grandes extensões de áreas ao sul da calha do Amazonas, na periferia meridional da Floresta Tropical. Nesse sentido, os Tupinambá amazônicos possuiriam muito em comum com vários dos demais grupos do tronco Tupi localizados no sudoeste Amazônico, grupos que hoje habitam áreas de terra firme (Fig. 3). 


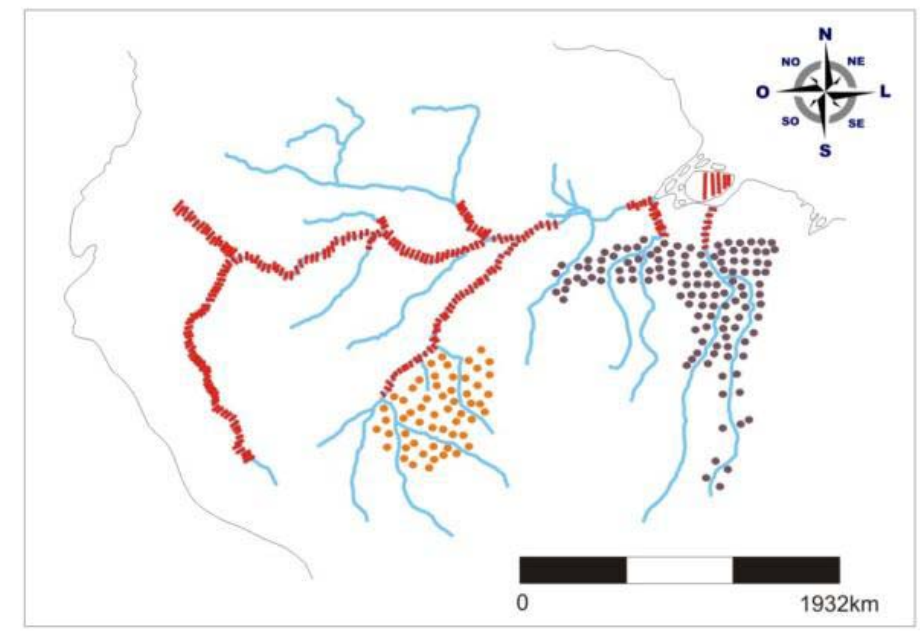

LEGENDA

::::: Tupi

:!:!: Tupinambá Amazônico

E三ミ三 Tradição Polícroma da Amazônia

Figura 3: Distinção geográfica entre a Tradição Polícroma e os grupos Tupi e Tupinambá amazônicos utilizados como base para o estudo comparativo proposto (mapa: Eduardo Tamanaha/Fernando Ozorio de Almeida).

Para testar essa hipótese, foi necessário dividir esse capítulo em três partes. A primeira se resume a um panorama geral sobre os grupos Tupi-Guarani, dos motivos que levaram tantos pesquisadores a estudá-los e das características mais recorrentemente a eles associadas. A segunda aplica essa proposta para a Tradição Polícroma da Amazônia. E, na terceira, será utilizado o sudeste amazônico - os rios Tocantins, Xingu e Tapajós e o interflúvio Tocantins-Xingu - como área-piloto para a comparação entre Tupi-Guarani e TPA.

A ideia era que essas comparações enriqueceriam e, de certa maneira, consolidariam as características desses dois agrupamentos de forma que, ao sair do sudeste para adentrar o sudoeste amazônico - um contexto que possivelmente apresentaria uma grande variabilidade cerâmica e uma profundidade cronológica mais extensa - haveria o conhecimento sólido para lidar com as questões levantadas na área central de pesquisa deste trabalho: o alto Madeira.

Além disso, é necessário admitir de antemão que havia uma expectativa de que, em determinados contextos ribeirinhos, seria possível visualizar uma correlação, ainda que 
preliminar, entre a TPA e alguns grupos Tupi, não Tupi-Guarani - como os Juruna e os Munduruku - o que, veremos, não se confirma. Não apenas por que os escassos dados apontam indústrias distintas por parte desses Tupi em relação à TPA, como também pela própria inconsistência da Tradição Polícroma nessas regiões.

Entretanto, o processo pré-colonial de ocupação dos Tupi-Guarani no sudeste Amazônico é um fato. O material da Subtradição Tupinambá amazônica pode ser encontrado em uma vasta região entre o rio Tapajós e o interior maranhense. Não por coincidência, foi a solidez desse contexto Tupi-Guarani amazônico que permitiu identificar a inconsistência desse contexto Polícromo. Inconstância que, involuntariamente, passou a ser o guia na interpretação da TPA.

\subsection{Os Tupinambá}

Desde meados do século XIX, estudiosos buscam compreender os processos e os mecanismos que permitiram aos grupos falantes de línguas da família Tupi-Guarani ocupar vastas áreas das terras baixas da América do Sul. As pesquisas foram iniciadas por von Martius, mas é von den Steinen quem observa semelhanças linguísticas e culturais que permitem unificar os diversos grupos Tupinambá e Guarani (NOELLI, 1996a, 1998, 2008a).

A bibliografia arqueológica é quase unânime em datar o início das expansões Tupinambá e Guarani entre 500 a.C. e o início da era cristã (BROCHADO, 1984, CORRÊA, 2009, SCATAMMACHIA, 1981, 1990). Como ocupavam extensas áreas da costa brasileira, os Tupinambá foram os primeiros grupos a fazer contato com os europeus, gerando uma extensa lista de relatos históricos (e.g. ABBEVILLE, 1975[1614]; CARDIN, 2009 [15831601]; ÉVREUX, 2002 [1615]; LERY, 1967 [1578]; SOARES DE SOUZA, 2001 [1587]; STADEN, 1974 [1557]; THEVET, 1978). Essas crônicas, apesar de distintas, fornecem descrições semelhantes.

Uma das sínteses clássicas dos dados históricos desses grupos cultural e linguisticamente relacionados foi a produzida por Alfred Métraux para o Handbook of South American Indians vol. III (1948a). A designação Tupinambá, utilizada por Métraux, cobria todos os índios falantes de línguas da família Tupi-Guarani, desde a boca do Amazonas até 
Cananéia, nas proximidades do trópico de Capricórnio, assim como alguns grupos que habitavam áreas próximas ao litoral.

Um dos primeiros comentários de Métraux foi que, por mais próxima que fosse a relação entre esses grupos, havia paradoxalmente uma ligação de ódio entre um grupo e outro. Animosidade que era colocada em prática durante os intermináveis conflitos entre os grupos que, por sua vez, terminavam em um clímax ritualístico: os derrotados sendo servidos como prato principal. A descrição de Métraux continua, indicando que a subsistência desses grupos era baseada na agricultura, e que a mandioca seria a principal planta cultivada. Além da agricultura, eles viveriam da coleta, caça e pesca.

As aldeias eram localizadas em topos de morro, por quatro a oito casas dispostas em torno de uma praça central, cada uma comportando até duzentas pessoas. Algumas aldeias possuíam valas e paliçadas para defesa. As casas comunais eram ocupadas por pessoas relacionadas por sangue ou casamento. Cada casa comunal possuiria um chefe. Acima de todos, estaria o chefe da aldeia (MÉTRAUX 1948a).

Ainda de acordo com Métraux, dentro de cada casa seriam encontradas redes para dormir, bancos de madeira, cestaria e cerâmica. Outros objetos seriam os ornamentos de pena, o estojo peniano, contas, colares, arcos e flechas e os barcos. Em muitos casos, a relação dos Tupinambá com as canoas que produziam foi central para a interpretação das dinâmicas desses grupos. Na visão de Métraux, as canoas serviriam para pescar, para atacar inimigos e, por que não, para se expandir rapidamente.

Essa visão era coerente com o panorama tecido por Nodenskiöld, que via nas três grandes bacias hidrográficas na América do Sul (Amazonas, Orinoco e Paraná) uma rede de conexões que teria permitido grandes movimentos populacionais pelo continente. Panorama que seria adaptado por Lowie e Steward para o Handbook, sintetizando o conceito de Floresta Tropical (NEVES, 2008: 360). Tal visão também estava presente no modelo cardíaco. Esse modelo, elaborado por Lathrap (1970) e desenvolvido por Brochado (1984, 1989), oferecia uma proposta para a compreensão dos grupos indígenas nas terras baixas da América do Sul, com destaque para os Tupinambá e para os Guarani.

Esses grupos, representados arqueologicamente pela Subtradição Tupinambá e pela Subtradição Guarani (respectivamente), seriam descendentes de antigas populações do tronco Tupi que teriam se expandido a partir da Amazônia central. Nessa região, assim como por quase toda calha do rio Amazonas e por alguns dos seus principais afluentes, esses antigos 
grupos Tupi produziriam vestígios materiais ligados à Tradição Polícroma Amazônica. Nessa perspectiva, e do ponto de vista arqueológico, as Subtradições Tupinambá e Guarani seriam duas bifurcações que deixaram o agrupamento amazônico (i.e. a TPA) para ocupar o litoral brasileiro, áreas de mata atlântica, o sul do Brasil e o entorno deste e algumas outras regiões (NOELLI, 1996a, 1998, 2008a). Essas bifurcações possuiriam uma cultura material deveras semelhante, o que permite falar em uma Tradição Tupi-Guarani ${ }^{13}$. Além disso, nessa visão, todo esse processo teria ocorrido seguindo vias fluviais ou costeiras ${ }^{14}$ (Fig. 4).

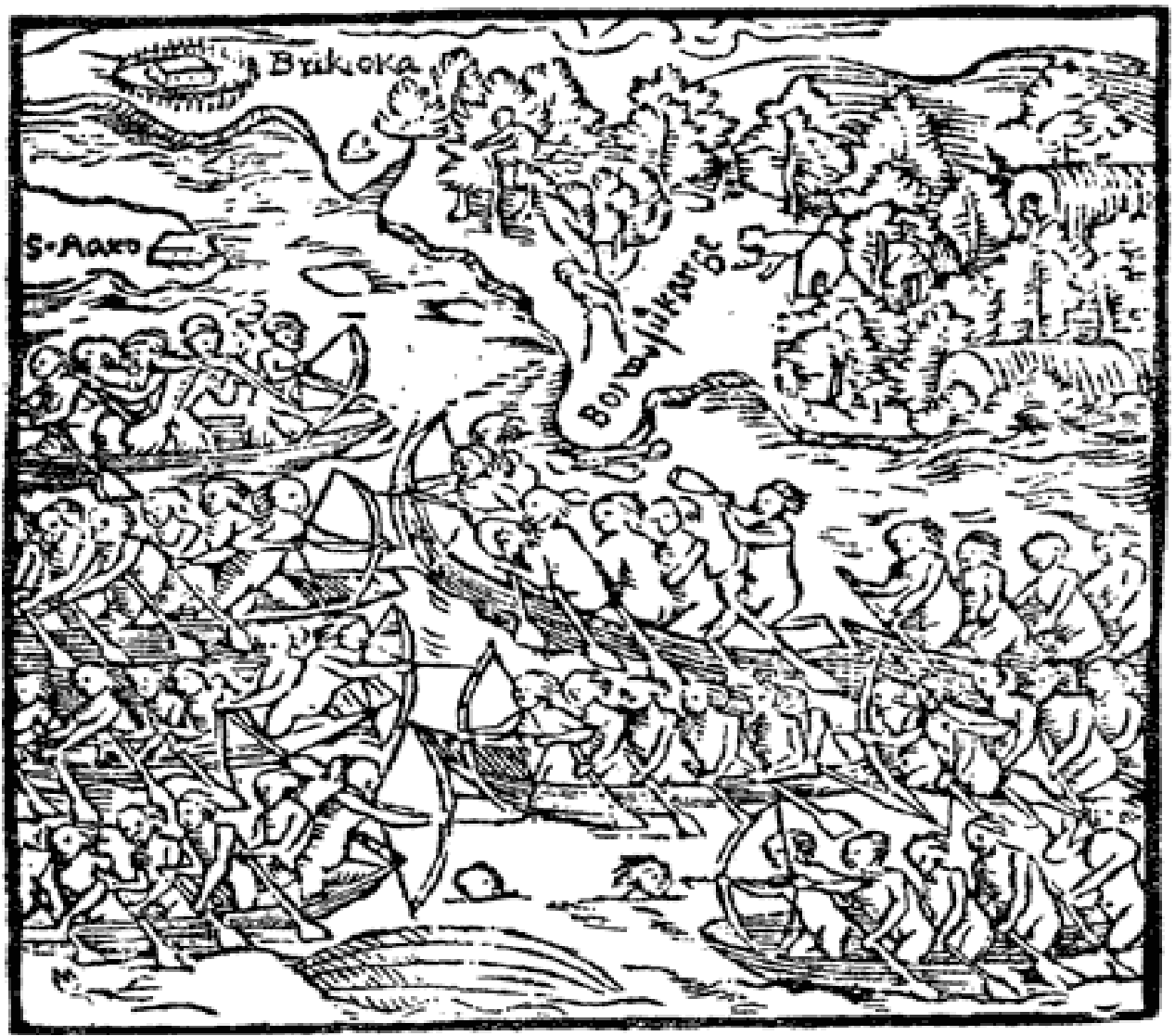

Figura 4: Confronto de grupos Tupinambá descritos por Staden (1974 [1557]).

13 Termo curiosamente negligenciado por Lathrap e, até certo ponto, combatido por Brochado, que não concordavam com o agrupamento.

14 Tamanha era a obsessão de Lathrap pelas expansões "canoeiras" ("The distribution of Arawakan-speakers argues that the canoes were the major means of dispersal." [1970: 73]) que ele chega a desdenhar da sugestão feita por seu principal linguista de referência, Noble (1965), por este indicar que a família Arawak era originária do oeste amazônico: "the area pin-pointed by Noble is one of the least likely regions for the development of water transport since all the streams are rapid and rocky" (LATHRAP, 1970: 74). 
Não foi atribuída relevância alguma à terra firme. Brochado e Lathrap não acreditavam que a terra firme pudesse sustentar processos históricos indígenas relevantes, como o que parece ter ocorrido com os grupos Tupinambá da Amazônia ${ }^{15}$. No seu famoso, apesar de não publicado, artigo os autores aceitam que:

(...) populations in the terra firme are failed populations. They can add as an harrassment to the populations in the várzea (the floodplains). They can act as a mechanism through which the várzea populations exploit the resources of the terra firme. (...) However, the populations of the terra firme, with a few exceptions, remained static in both demographic and evolutionary sense (BROCHADO e LATHRAP, 1982).

No entanto, Brochado quase não possuía dados sobre os Tupinambá da Amazônia que habitavam extensas áreas de terra firme na região sudeste dessa floresta. O estudo dos vestígios arqueológicos desses grupos (ALMEIDA, 2008; ALMEIDA e GARCIA, 2008; ALMEIDA e NEVES, não publicado; GARCIA, 2012a) levou à criação de uma nova classe denominada de Subtradição Tupinambá da Amazônia que, somada às Subtradições Guarani e Tupinambá do litoral (os que habitavam a costa brasileira e áreas adjacentes) e, possivelmente, com outros grupos falantes de línguas Tupi-Guarani (e.g. do Brasil central, ou da Zona da Mata), formariam a grande Tradição Tupi-Guarani.

A cerâmica da Tradição Tupi-Guarani: os atributos politéticos da Tradição Tupi-Guarani são o uso de antiplástico de caco moído e/ou mineral, a presença de vasos compostos (um ângulo na parede) ou complexos (dois ou mais ângulos nas paredes), com base convexa ou ovalada, vasilhas com decorações plásticas corrugadas, unguladas, digitadas, raspadas, escovadas, quase sempre encontradas no exterior do vaso, assim como decorações pintadas em vermelho, preto e branco, que aparecem como banhos, faixas e/ou motivos geométricos, dentro ou fora dos vasos. Urnas funerárias também são comuns e em geral consistem na reutilização de uma grande panela (yapepó, em Guarani) coberta por uma tampa (cambuchi, em Guarani), vasos relacionados ao preparo e consumo de bebidas alcoólicas (BUARQUE, 2010; LA SALVIA e BROCHADO, 1989; NOELLI e BROCHADO, 1998).

O que não significa uma total falta de relação entre os grupos falantes de TupiGuarani com os produtores de cerâmica da Tradição Polícroma da Amazônia. A questão é saber que relação é essa. Para compreender melhor essa problemática, será apresentado o

15 Essa visão negativa das áreas de interflúvio foi, ao menos temporariamente, compartilhada por Roosevelt (1989: 32). Mais tarde, essa autora (1994) adotou uma visão mais heterogênea quanto às possibilidades da terra firme. 
contexto do leste amazônico. No entanto, primeiro é necessário conhecer um pouco melhor a Tradição Polícroma.

\subsection{A Tradição Polícroma da Amazônia}
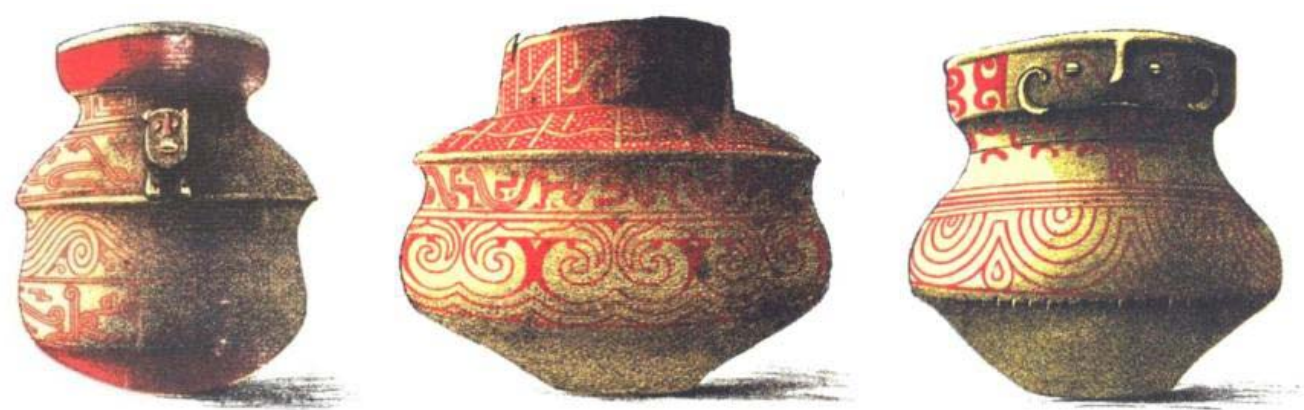

Figura 5: Cerâmica da fase Aristé, Tradição Polícroma, encontrada no litoral do Amapá (fonte: GOELDI, 2009 [1900]).

Segundo a literatura, fragmentos cerâmicos pertencentes à Tradição Polícroma seriam encontrados por quase toda a bacia amazônica (e.g. BOLIAN, 1975; BROCHADO, 1984, 1989; BROCHADO e LATHRAP, 1980; EVANS e MEGGERS, 1968; HECKENBERGER et al. 1998; HILBERT, 1968; HOWARD, 1947; LATHRAP, 1970; MEGGERS e EVANS, 1957, 1961; NEVES, 2008; NOELLI, 1996a, 1996b, 1998, 2008a, 2008b; ROOSEVELT, 1980, 1991; WEBER, 1975). Essa Tradição é caracterizada por vasos com pasta clara, temperados com caraipé ${ }^{16}$ (caco moído na fase Marajoara), com ângulos nas paredes (carenas, ombros e bordas cambadas), com presença de flanges labiais e mesiais (apenas em algumas regiões da Amazônia) e decorações acanaladas e/ou polícrômicas (incluindo banhos de engobo) que cobrem as flanges ou as bordas e paredes dos vasos. Os sítios dessa Tradição muitas vezes possuem enterramentos secundários em urnas: os do médio e alto Amazonas caracterizados por um rosto antropomorfo com uma tiara (NEVES, 2012: 225; Fig. 7). Essas urnas com tiara são encontradas desde o rio Napo (Equador) até o médio Amazonas, incluindo o baixo Madeira, e em geral carregam um rico complexo decorativo, combinando motivos geométricos (bidimensionais) e figuras iconográficas (tridimensionais). É, grosso modo, no duo policromia-enterramento secundário em urnas que residia a base da analogia feita por Brochado e Lathrap entre a cerâmica TPA e a dos Tupi-Guarani. 


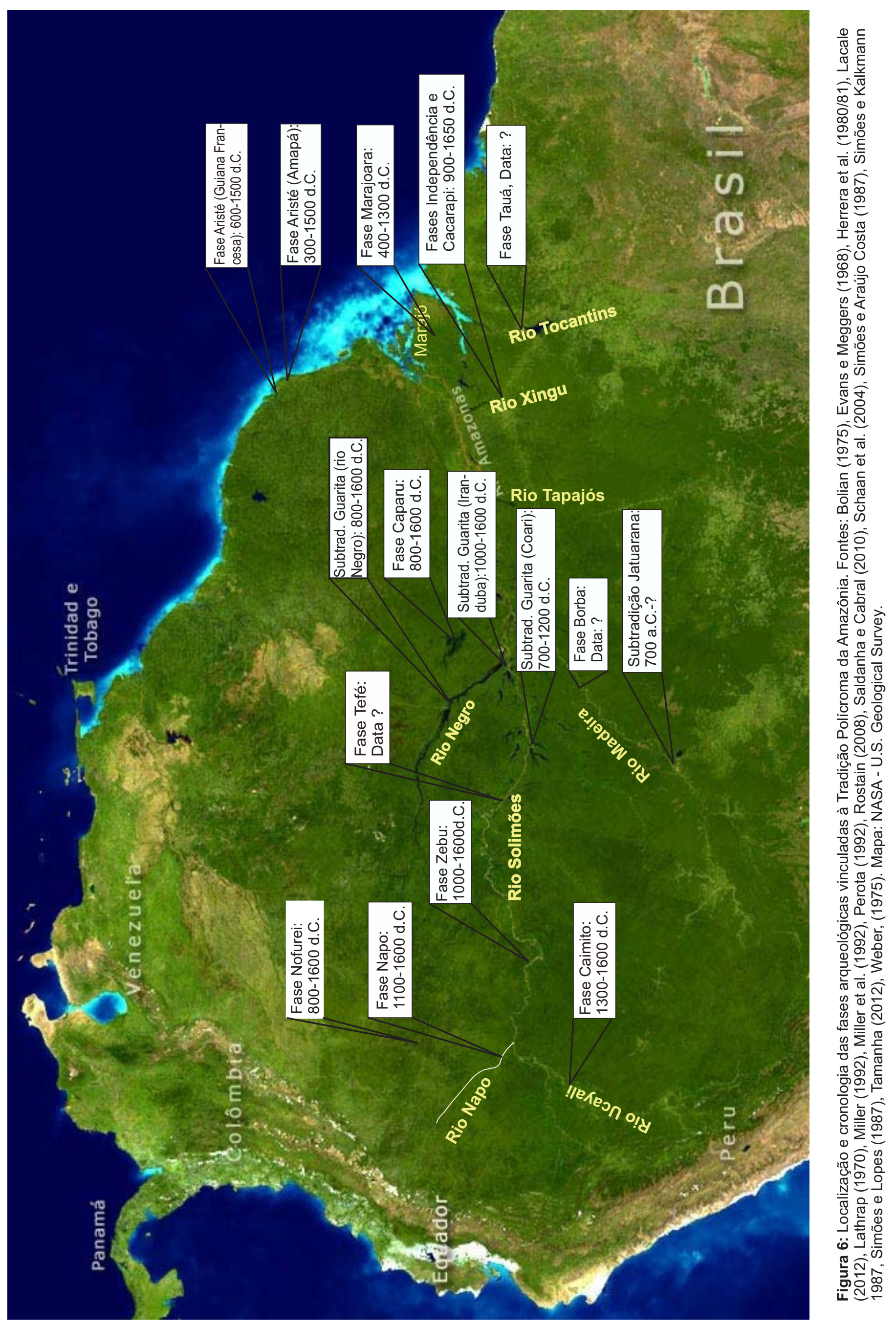




\begin{tabular}{|c|c|c|c|c|c|c|c|c|c|c|c|c|c|c|c|c|c|c|c|c|c|c|}
\hline \multirow{3}{*}{\begin{tabular}{|c} 
ELEMENTOS CERÂMICOS \\
TRADIÇÃO POLÍCROMA DA AMAZÔNIA
\end{tabular}} & \multicolumn{22}{|c|}{ Sítios Arqueológicos e Regiões } \\
\hline & \multicolumn{22}{|c|}{ Terras Baixas } \\
\hline & & & & 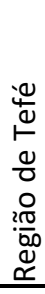 & 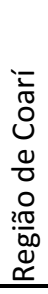 & $\begin{array}{l}\frac{\pi}{0} \\
\frac{\pi}{2} \\
\frac{\pi}{0} \\
\frac{0}{20} \\
\frac{20}{00}\end{array}$ & 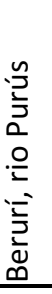 & 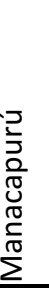 & 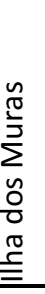 & $\begin{array}{l}\frac{\pi}{50} \\
\sum^{0} \\
\frac{\pi}{0} \\
\frac{1}{0} \\
0\end{array}$ & 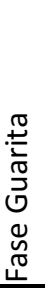 & 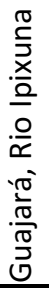 & 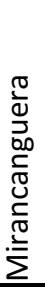 & 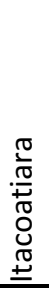 & 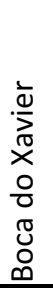 & 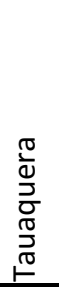 & 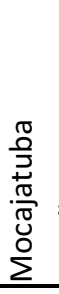 & & & & & \\
\hline Pintura em negativo & & $x$ & & & & & & & & & & & & & & & & & & & & \\
\hline Pintura branca sobre vermelho & & $\mathrm{x}$ & & & & & & & & & & & & & & & & & & & & \\
\hline Urna antropomórfica Tipo B & & $x$ & & ? & & & & & & & & & & & & & & & & & & \\
\hline Borda acanalada & & $x$ & & & $x$ & $x$ & & $x$ & & & & & & $x$ & & & & & & & & \\
\hline Acanalado & & $x$ & $x$ & $x$ & $x$ & $x$ & $\mathrm{x}$ & $x$ & $x$ & $x$ & $x$ & $x$ & $x$ & $x$ & $x$ & $x$ & & $x$ & & & & \\
\hline Tempero de areia & $x$ & $x$ & & & & & & & & $x$ & & & & & & $x$ & & & $x$ & $x$ & & \\
\hline Forma Quadrada & & $x$ & $x$ & $x$ & ? & $x$ & $x$ & $x$ & $x$ & & $\mathrm{x}$ & & & & & & $?$ & $?$ & & & ? & \\
\hline Urna antropomórfa (membros no entorno do pote) & & $\mathrm{x}$ & & $\mathrm{x}$ & & & & & & & & & $\mathrm{x}$ & & & & & & & & $\mathrm{x}$ & \\
\hline Carena espessa & & $x$ & $x$ & & $x$ & $x$ & & $x$ & $x$ & $x$ & $x$ & & & & & & & & $x$ & $x$ & $x$ & \\
\hline Base anelar & & $x$ & & & $x$ & & $x$ & & & $x$ & $\mathrm{x}$ & $x$ & $\mathrm{x}$ & $x$ & & & $x$ & $x$ & $x \quad x$ & $x$ & $x$ & \\
\hline Incisão, retocada em branco & & $\mathrm{x}$ & & & & & & & & & & & & & & & $\mathrm{x}$ & & & & & \\
\hline Pintura vermelha e preta sobre $b$ & & $x$ & $?$ & & $x$ & & & $x$ & & $x$ & $x$ & & $x$ & $x$ & & & & $x$ & $x$ & $x$ & $x$ & \\
\hline Pintura Vermelha sobre branco & & $x$ & $x$ & $x$ & $x$ & & & $x$ & & $x$ & $x$ & $x$ & & $x$ & & & $x$ & & & & $x$ & \\
\hline Incisão com única linha & & $x$ & $x$ & & $x$ & $x$ & & $x$ & $x$ & $x$ & $x$ & $x$ & $x$ & $x$ & $x$ & $x$ & $x$ & $x \quad x$ & $x \quad x$ & $x$ & $x$ & \\
\hline Excisão & & $x$ & & $x$ & $x$ & $x$ & & $x$ & $x$ & & & & & $x$ & & $x$ & $x$ & $x \quad x$ & $x \quad x$ & $x$ & $x$ & \\
\hline Excisão, retocada em branco & & $x$ & & & & & & & $?$ & & & & & & & & & & & & $x$ & \\
\hline Vaso com borda extrovertida reforçada & & $x$ & $x$ & & $x$ & & & $x$ & & $x$ & $x$ & & & $x$ & $x$ & $x$ & $x$ & $x \quad x$ & $x \quad x$ & $x$ & $x$ & $x$ \\
\hline Urna antropomorfa, membros ausentes ou estilizados & & $x$ & $\mathrm{x}$ & & & & $x$ & & & & & $x$ & $x$ & $x$ & & & & & & & $x$ & \\
\hline Tempero de cinza queimada & & $x$ & & & $\mathrm{x}$ & $x$ & & & & & & & & & & & & & & & & \\
\hline Borda Dobrada & & $x$ & & & $x$ & $x$ & & $x$ & & & & & & & & & & & & & & \\
\hline Urna antropomórfica, tampa de cabeça & & $x$ & & & & & $x$ & & & & & $x$ & $x$ & & & & $x$ & $x$ & $x$ & $x$ & & \\
\hline Incisão em linha dupla & & $x$ & ? & $x$ & ? & $x$ & & $x$ & & & $x$ & & & $x$ & $x$ & & $x$ & $x$ & $x \quad x$ & $x$ & ? & \\
\hline Tempero de caraipé & & $x$ & & & $x$ & $x$ & & $x$ & & $x$ & $x$ & $x$ & & $x$ & $x$ & $x$ & & & & & & $x$ \\
\hline Engobo branco sobre incisão & & $x$ & & & $x$ & & $x$ & $x$ & & $x$ & $x$ & $x$ & & $x$ & $x$ & & $x$ & $x \quad x$ & $x \quad x$ & $x$ & $x$ & \\
\hline Borda lobulada & & $x$ & $x$ & & $x$ & & & $x$ & & $x$ & $x$ & $x$ & $x$ & $x$ & $x$ & & & & & & $x$ & \\
\hline Pintura "pseudo negativa" & & $x$ & & & $x$ & & & & & & & $x$ & $x$ & & & & $x$ & & & & & \\
\hline Incisão com retoque vermelho em engobo branco & & $x$ & $?$ & & & & & & & & $?$ & & $x$ & & & & & & & & & \\
\hline Flange Mesial & & & $\mathrm{x}$ & & $\mathrm{x}$ & $x$ & & $x$ & & $x$ & $x$ & $\mathrm{x}$ & & $\mathrm{x}$ & $x$ & & & $\mathrm{x}$ & $x$ & $x$ & & \\
\hline Adornos & & & $x$ & $x$ & $x$ & & & $x$ & & & $x$ & $x$ & $x$ & $x$ & & $x$ & $x$ & $x \quad x$ & $x \quad x$ & $x$ & & \\
\hline Tempero de Cauixí & & & & $x$ & $x$ & $x$ & & $x$ & & & $x$ & $x$ & $x$ & $x$ & $x$ & $x$ & $x$ & $x \quad x$ & $x \quad x$ & $x$ & & \\
\hline Pintura vermelha e laranja sobre engobo branco & & & & & $x$ & & & $x$ & & & $x$ & & & $x$ & & & $x$ & & & & $x$ & \\
\hline Tempero de caco moído & $x$ & & & & & $?$ & & $x$ & & & & $x$ & & & & $x$ & & & $x$ & $x$ & $x$ & \\
\hline Borda vazada (oca) & & & & & & & & & & & & & & $\mathrm{x}$ & & $x$ & & & & $x$ & & \\
\hline
\end{tabular}

Tabela 1: Atributos cerâmicos da Tradição Polícorma da Amazônia (Fonte: EVANS E MEGGERS, 1968) 
Foi apontado na Introdução que o alto Madeira, com data de 700 a.C., possuiria a ocupação mais antiga relacionada à Tradição Polícroma (MILLER, 1992, 1999). Curiosamente, o local com as próximas datas mais antigas (400 d.C.) está na boca do Amazonas, na ilha de Marajó e no litoral do Amapá (SALDANHA e CABRAL, 2010; ROSTAIN, 2008; SCHAAN, 2004; SCHAAN e SILVA, 2004). A região intermediária, a Amazônia central, possui datas próximas do ano 1000 d.C. (HECKENBERGER et al., 1998; NEVES, 2012; TAMANAHA, 2012). Essa é apenas uma das muitas questões envolvendo a Tradição Polícroma que restam ser respondidas.

Desde o final do século XIX, a cerâmica Polícroma é conhecida dos pesquisadores, o que ocorreu devido ao atrativo contexto dos tesos marajoaras e da estética da cerâmica homônima (e.g. BARBOSA RODRIGUES, 1891; GOELDI, 2009a [1900], 2009b [1906]; cf. FERREIRA, 2009; SANJAD e SILVA, 2009). No entanto, é Howard (1947) quem sistematiza os dados da cerâmica Polícroma, denominando-a uma divisão, e é ele o primeiro a inserir essa cerâmica em um contexto mais amplo. A Divisão Polícroma seria formada por cinco Estilos cerâmicos (Napo, Miracanguera, Maracá, Marajó e Chimay) encontrados do oeste ao leste amazônico (cf. BROCHADO e LATHRAP, 1982).

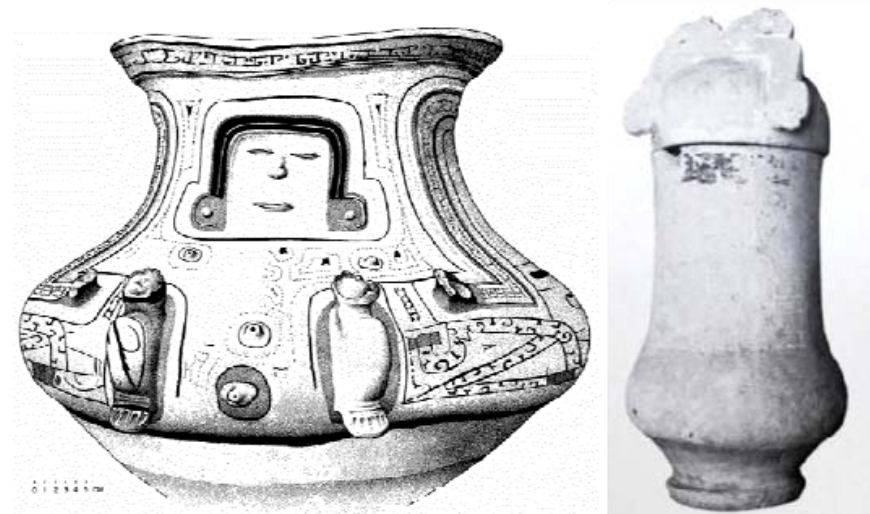

Figura 7: Urnas da Tradição Polícroma no rio Napo e no baixo rio Madeira (fonte: EVANS e MEGGERS, 1968).

Na mesma época em que Howard publicou suas divisões, Steward observou que o Estilo cerâmico de grupos etnográficos do alto Amazonas, como os Shipibo (língua Pano), os Kokama e Omágua (Tupi-Guarani) e os Jívaro (língua isolada), são “definitely related to that of Marajo and the lower Amazon, having geometric designs formed of widely spaced, heavy lines, which are outlined by one or more fine lines... [though] it lacks the incised lines, the occasional zoomorphic motives, and the modeled decoration of Marajo" (1948: 522-524). 
Tal interpretação serviu de plano de trabalho para as pesquisas de Meggers e Evans (1957; EVANS e MEGGERS, 1968) no alto e baixo Amazonas, enviados pelo próprio Steward (NEVES, 2012: 227).

Assim, durante os anos 1950 e 1960, o casal Meggers e Evans (1961: 379-380, Fig. 8) retrabalharam a categoria analítica de Howard, com base no estudo de coleções de museus ${ }^{17} \mathrm{e}$ nas escavações na ilha de Marajó (1957) e no rio Napo (Fig. 9), no Equador (EVANS e MEGGERS, 1968). O que chama a atenção foi a "sutil" mudança na forma de abordar a questão adotada pelo casal. Ao passo em que Steward fez uma comparação grupos etnográficos e uma cerâmica arqueológica, Meggers e Evans deixaram de lado a questão etnográfica (cf. NOELLI, 1999-2000: 222) e trataram de fazer comparações apenas no nível material. Essa guinada teórico-metodológica deixou em aberto a questão levantada por Steward sobre a possível relação entre diversos grupos da Amazônia ocidental e essa Tradição.

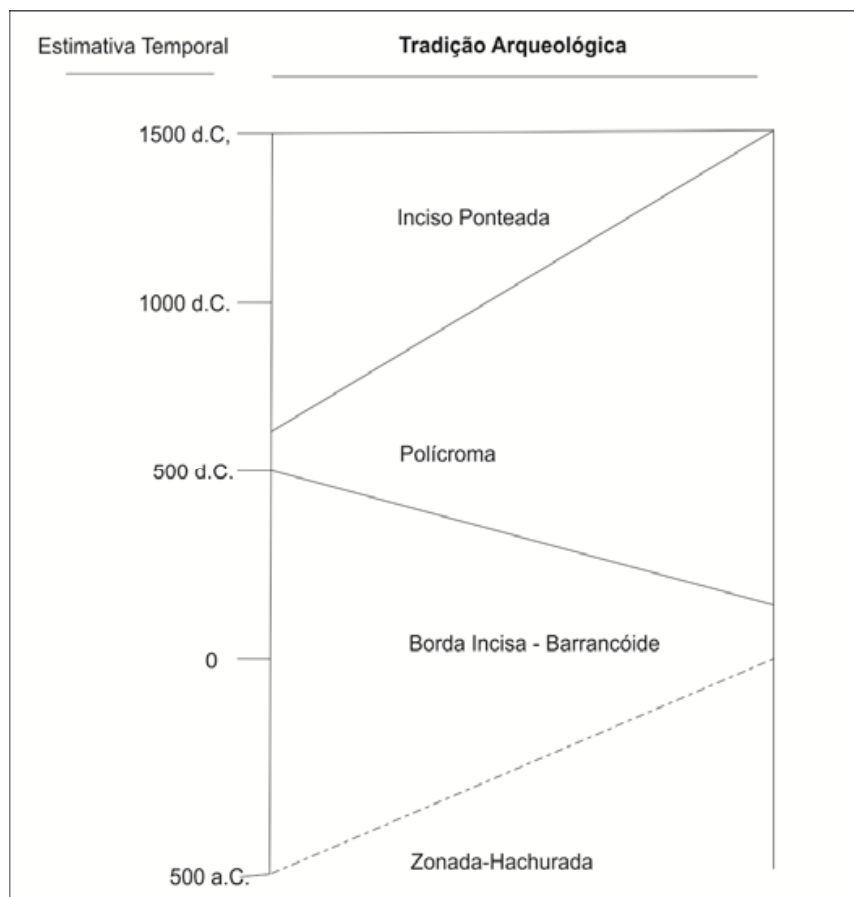

Figura 8: Posicionamento da Tradição Polícroma no quadro cronológico das Tradições amazônicas, traçado por Meggers e Evans, ainda sem a presença da antiga data de 700 a.C. para 0 alto Madeira (adaptado de MEGGERS e EVANS, 1961: 382). 
Devido à amplitude geográfica na qual essa cerâmica Polícroma foi identificada na Amazônia, Meggers e Evans acabam por considerá-la um Horizonte ${ }^{18}$ arqueológico. Mesmo com poucas datações absolutas, os autores levantaram a hipótese de que a cerâmica Polícroma seria originária do oeste amazônico, dos Andes colombianos, sendo mais antiga do que na região oriental (1961: 380). Essa última receberia, então, uma série de ondas migratórias vindas do oeste, que se fixariam do médio Solimões ao baixo Amazonas. Os migrantes, no entanto, não manteriam a complexa estrutura sociopolítica que trouxeram - e que estava espelhada na sofisticada cerâmica - devido a fatores ambientais limitadores (1957: 593-608).
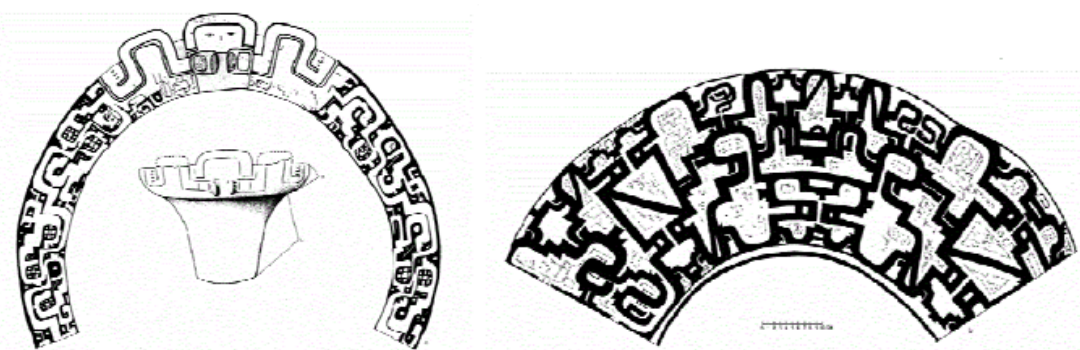

Figura 9: Material da fase Napo, Tradição Polícroma no alto Amazonas, compilado por Evans e Meggers (1968). Ao centro, pode-se ver a recorrente figura com uma tiara encontrada até a região de Itaquatiara, no médio Amazonas.

Lathrap $(1968,1970)$ discorda parcialmente dessa visão da Floresta Tropical como ambiente pouco propício para o desenvolvimento de populações humanas. Parcialmente porque, conforme visto, essa condição negativa ficou renegada aos grupos de terra firme, que não possuiriam as férteis áreas de várzea para plantar, tampouco a riqueza de proteína animal proveniente dos rios. Por outro lado, a cronologia recente obtida por Lathrap para as indústrias cerâmicas do rio Ucayali (no alto Amazonas) levaram-no a indicar que essa região não estaria relacionada com a área inicial de dispersão dos Tupi e da TPA. Lathrap (1970: 7479) sugere que o centro de difusão a Amazônia central, devido à posição ímpar desta no entroncamento da rede migratória-expansionista-difusionista sul americana e pelo ilimitado potencial das várzeas para o cultivo de alimentos (e.g. a mandioca).

Chega-se então ao primeiro dos dois maiores problemas relacionados ao estudo da Tradição Polícroma da Amazônia, um problema de cunho antropológico. Trata-se da ligação dessa cultura arqueológica com grupos etnográficos. Visto que Steward não realizou um

$18 \mathrm{Ou}$ seja, estes autores advogaram uma série de movimentos rápidos e de curta duração - daí denominar o Estilo de Horizonte Polícromo e não de Tradição. 
estudo aprofundado da ligação multiétnica (e multidisciplinar) entre diversos grupos do alto Amazonas e a cerâmica Marajoara e que Meggers se esquivou do assunto, seria possível, por eliminação, concordar com a ligação Tupi-TPA feita por Lathrap. No entanto, essa relação não é estabelecida com simplicidade. Veremos, no decorrer deste e do próximo capítulo, que os Tupi às vezes possuem semelhanças, e possíveis exemplos de correlação (os KokamaOmágua?), com a TPA, mas essa correlação nem sempre é regra. Além disso, a suposta ligação entre os grupos etnográficos (Pano, Jívaro) do alto Amazonas e essa Tradição continua implícita no trabalho de muitos pesquisadores (e.g. ROOSEVELT, 1991: 79), significando que a questão não está resolvida e precisa ser debatida.

O centro de dispersão sugerido por Lathrap (1970: 74-79; BROCHADO, 1984) também não se concretizou como tal. Durante estudos posteriores realizados pelo Projeto Amazônia Central, logo se constatou que a cerâmica da Subtradição Guarita (TPA, Fig. 10) possuía datas muito recentes (começo do segundo milênio AD) para ser o berço da expansão Polícroma (HECKENBERGER et al., 1998).

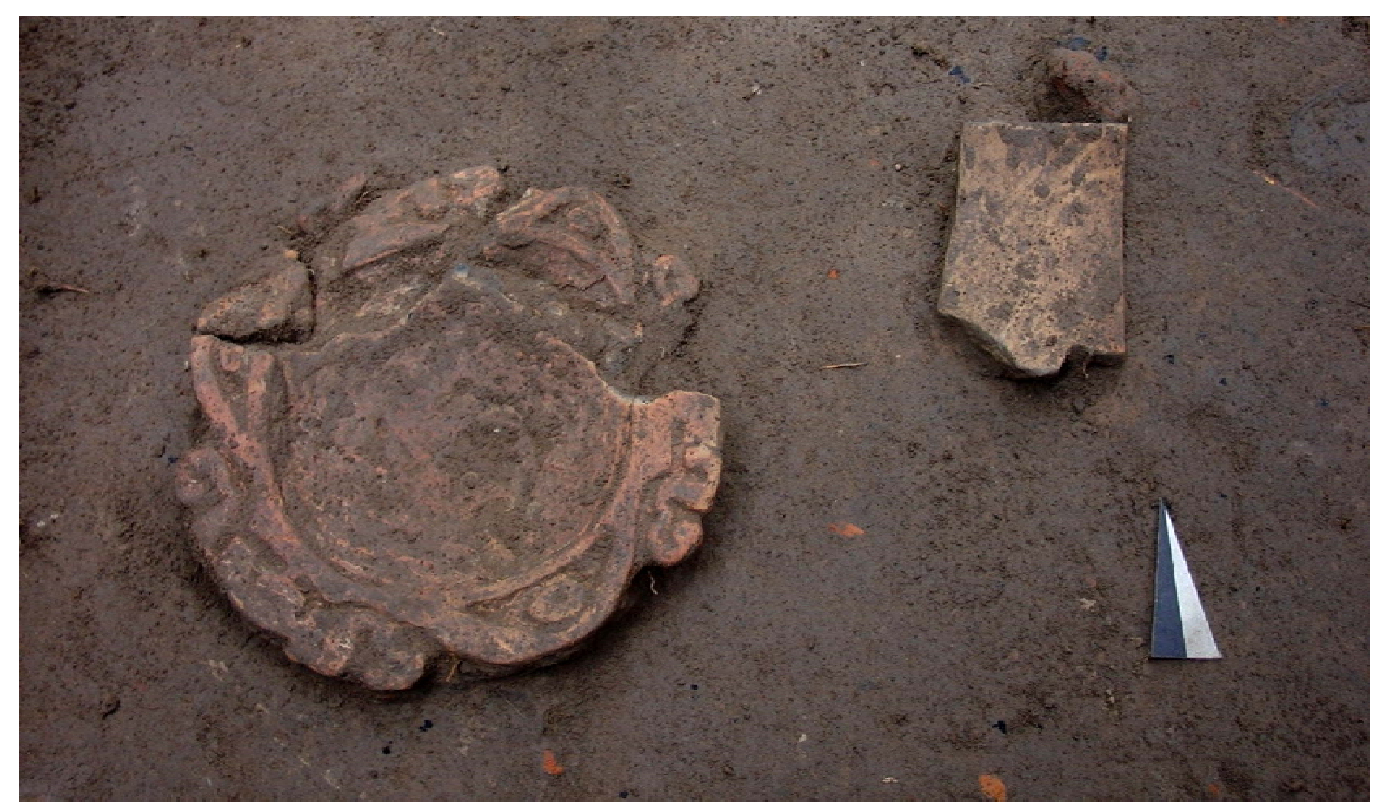

Figura 10: Tigela com acanalado sobre flange labial, Subtradição Guarita, Tradição Polícroma (foto: Fernando Ozorio de Almeida).

Além de contestar o local de origem da expansão cárdica de Brochado e Lathrap, outra contribuição importante do Projeto Amazônia Central foi a produção de uma grande quantidade de dados sobre a Subtradição Guarita (e.g. MACHADO, 2005; MORAES, 2006; TAMANAHA, 2012; NEVES, 2007, 2008, 2012), em especial sobre a tecnologia cerâmica, 
mas também sobre outros dados contextuais, como o formato do sítio e a formação do registro arqueológico.

A partir dos dados relativos à distribuição da cerâmica, dos marcadores geoquímicos do solo e de dados etno-históricos (CARVAJAL, 1941 [1542]; PORRO, 1995), autores como Moraes (2006, 2010), Neves (2010), Rebellato (2007) e Tamanaha (2012) indicam que as populações relacionadas à Tradição Polícroma da Amazônia central (Subtradição Guarita) construiriam suas casas de forma linear, paralela ao rio, ao contrário dos grupos da fase Paredão (Tradição Barrancoide), que habitariam a Amazônia central em um período anterior e aparentemente construíam suas aldeias em formas circulares (MORAES, 2010; MORAES e NEVES, 2012; NEVES, 2012). Além disso, é provável que os diversos grupos anteriores à chegada da Subtradição Guarita possuíssem ocupações longas e estáveis, formando grandes pacotes de terra preta ${ }^{19}$, mas os sítios unicomponenciais Guarita em geral possuíam apenas um fino pacote de sedimento antropogênico (TAMANAHA, 2012; cf. BOLIAN, 1975) ou às vezes nem isso (LIMA, 2008). A dimensão espacial dos sítios Guarita também era inferior à dos grupos que estes sucederam (NEVES, 2012: 230).

Os dados da Amazônia central sugerem que os grupos da Subtradição Guarita realizavam ocupações de curta duração. Além disso, o surgimento de paliçadas e valas defensivas nos sítios não TPA da Amazônia central e a mudança abrupta no material arqueológico de sítios multicomponenciais, na época da entrada dos grupos da Subtradição Guarita na região (i.e. sécs. XII e XIII), indicam uma provável mudança cultural calcada em relações conflituosas e o fim de uma aparente estabilidade social milenar na região (NEVES, 2009, 2011, 2012; MORAES e NEVES, 2012). Nesse contexto de ruptura, é provável que o manejo ambiental indexado pela terra preta e a abundância que ela simboliza fossem prêmios pela conquista da região por parte destes grupos ${ }^{20}$, argumento análogo ao proposto por Balée (1987: 248) em relação aos Tupi-Guarani.

Se, no caso da Amazônia central, verifica-se uma (quase) predação por terra preta claro que não se resume só a isso - em outros contextos vinculados a grupos produtores da Tradição Polícroma verificou-se a ocorrência de ocupações temporalmente extensas no mesmo local. O exemplo mais claro é o dos tesos na ilha de Marajó, onde a fase Marajoara

19 A formação da terra preta em geral é relacionada a longos processos de deposição, intencional ou não, de matéria orgânica no solo (e.g. cinzas de fogueiras, restos de alimentos, dejetos humanos).

20 O que não está claro, na verdade. Neves (2012: 248) indica que os sítios Lago Grande (confluência NegroSolimões) e Vila Nova (baixo Madeira), nos quais foram identificadas valas defensivas, não foram reocupados (ou o foram de maneira esparsa) pelos grupos invasores. 
(TPA) é relacionada a ocupações que duraram centenas de anos (400-1300 d.C.). O sítio Teotônio, no alto Madeira, com cerâmica vinculada à Tradição Polícroma e datas que podem variar de 700 a.C. (MILLER, 1992, 1999) até o período colonial, poderia ser outro exemplo.

A presença de urnas funerárias está ligada a dois importantes pontos para a compreensão da variabilidade da TPA. Por um lado, conforme Barreto (2008: 96): " $a$ permanência temporal e a abrangência geográfica com que os traços estilísticos das urnas funerárias ocorrem na Amazônia parece também conferir uma certa unidade cosmológica aos povos fabricantes do que se convencionou chamar de Tradição Polícroma".
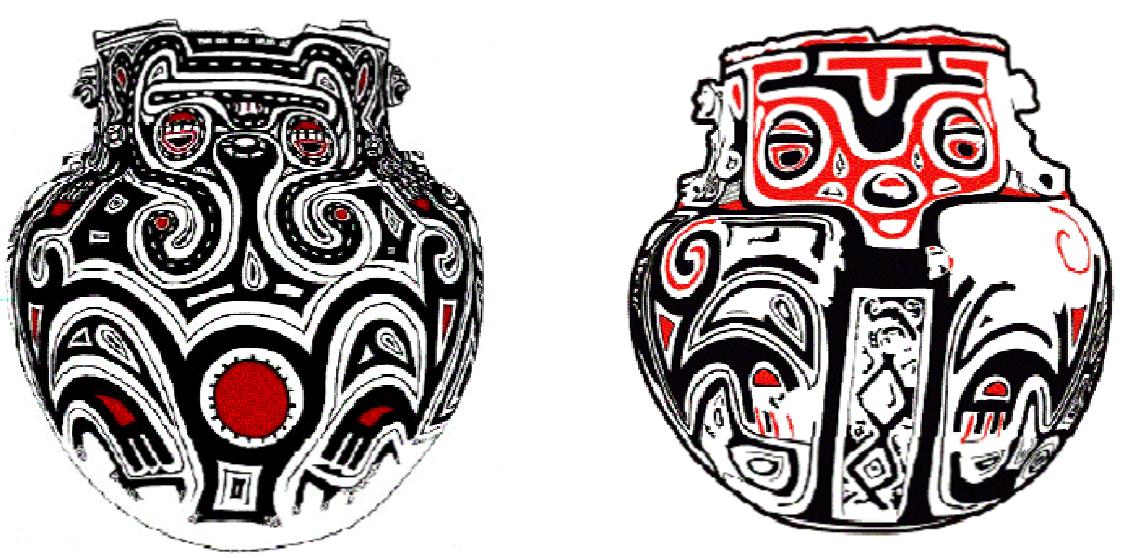

Figura 11: Exemplos de urnas Marajoara (fonte: Barreto, 2008).

Por outro lado, fica claro para o estudioso da TPA que, apesar da "certa unidade cosmológica" e da recorrência dos "traços estilísticos", há uma grande variabilidade nos Estilos decorativos das urnas funerárias. A cerâmica Maracá (Amapá), por exemplo, possui decorações policrômicas que permitiram sua associação com a Tradição Polícroma da Amazônia (GUAPINDAIA, 2001: 169; Fig. 12), ainda que a maioria absoluta das urnas antropomorfas ou zoomorfas dessa fase possua uma caráter único, particular ${ }^{21}$ (Fig. 12). As urnas do alto rio Madeira parecem utilizar apenas padrões geométricos (bidimensionais) policrômicos (e.g. MOUTINHO e ROBRAHN-GONZÁLEZ, 2010: 61-62; ZUSE, 2010: 84), ao passo que no baixo curso desse rio já aparecem os apliques modelados que, somados aos motivos pintados, dão uma conotação tridimensional às peças (e.g. NEVES, 2012: 236). As urnas Marajoara (e.g. BARRETO, 2008; MEGGERS e EVANS, 1957; ROOSEVELT, 1991; SCHAAN, 2001; Fig. 11), por sua vez, abrangem quase toda a variabilidade estilística

21 Fato também observado por Guapindaia (2001: 169). 
possível, tanto nas formas, quanto nas decorações. Imensa variabilidade cerâmica que é encontrada apenas em antigos complexos cerâmicos amazônicos como as fases Pocó e Açutuba.

A fase Pocó nasceu a partir de escavações realizadas por Hilbert e Hilbert (1980) no rio Trombetas, baixo Amazonas, sendo mais tarde estudada por Guapindaia (2008). A fase Açutuba, por sua vez, foi criada a partir de um desmembramento da fase Manacapuru (Borda Incisa-Barrancoide), da Amazônia central (LIMA, 2008; LIMA et al., 2006). Recentemente, materiais cerâmicos encontrados com essas características no médio e alto Solimões (rio Caquetá, na fronteira Brasil-Colômbia) e no baixo rio Branco (afluente do rio Negro) indicam que se trata de um fenômeno de ampla distribuição espacial:

\begin{abstract}
Essas informações, ainda preliminares, mostram que os materiais Pocó-Açutuba têm uma ampla distribuição pela Amazônia, se espalhando, de oeste para leste, ao longo de uma linha reta de mais de $1.600 \mathrm{~km}$, desde La Pedrera até Santarém, e, de norte a sul, de mais de $700 \mathrm{~km}$, desde o baixo rio Branco até a região de Manaus. Tal padrão amplo permite que essas ocupações sejam tratadas como uma tradição distinta, a tradição Pocó, ou pelo menos como um componente distinto da tradição Borda Incisa (NEVES, 2012: 147-148).
\end{abstract}

Não seria errado dizer que quase todos os elementos que definem a Tradição Polícroma (caraipé, formas abertas, flanges, acanalados e policromia) estão presentes nessas fases mais antigas que, além disso, possuem muitos elementos comuns com outros agrupamentos (e.g. Borda Incisa-Barrancoide), em especial quanto aos apliques modelados zoo e antropomorfos. Para o presente estudo, essas convergências de elementos entre as Tradições Pocó e Polícroma necessitam ser minimamente dominadas. Por exemplo, é necessário ter em mente que, mesmo que a Tradição Pocó possua decorações pintadas, ela não pertence à Tradição Polícroma (NEVES, 2012: 146; cf. NEVES 2006), nome infeliz e problemático.

O que leva ao segundo grande problema encontrado pelos estudos atuais da Tradição Polícroma, um problema arqueológico: a confusão de elementos estilísticos e tecnológicos semelhantes de agrupamentos distintos cronologicamente (Tradição Pocó e TPA), decorrente da imensa variabilidade dos agrupamentos antigos (Pocó); confusão que se espelha em uma complexa sequência de datas, que possuem baixa coerência geográfica para quem observa a sua distribuição espacial em um foco ampliado. 


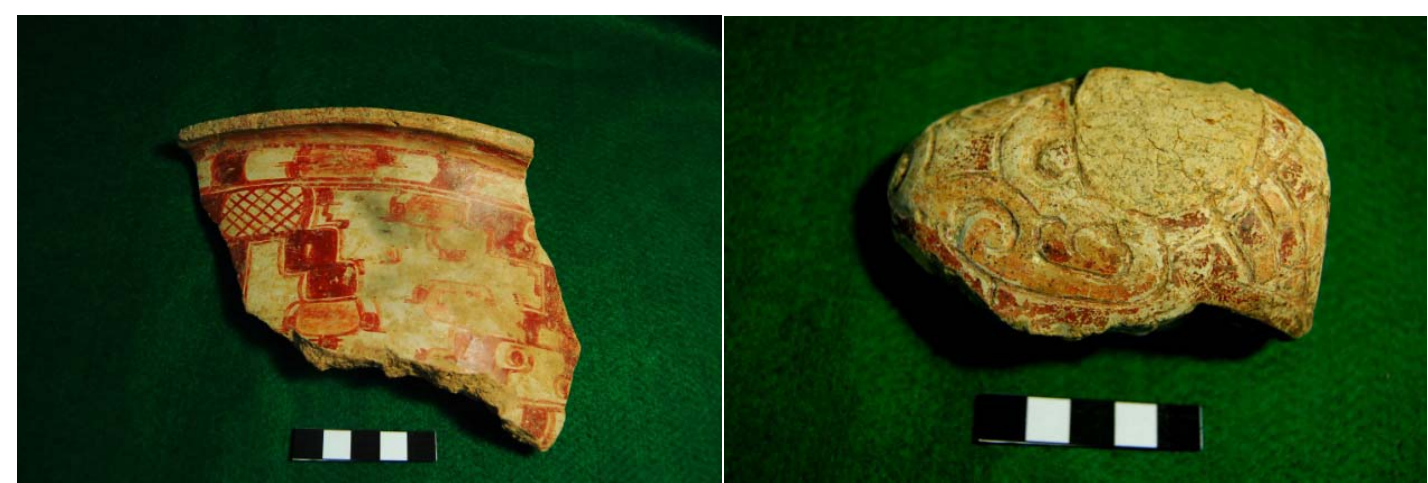

Figura 12: As antigas cerâmicas da Amazônia, como a encontrada no rio Branco, bacia do rio Negro. Policrômicos, mas não polícromos (fotos: Fernando Ozorio de Almeida).

Nesse sentido, foi recentemente sugerido que a fase Marajoara seria fruto dessa confusão (NEVES, 2012), uma vez que sua extensa variabilidade estilística e suas datas recuadas $^{22}$ a aproximariam muito mais da Tradição Pocó do que da Tradição Polícroma, na qual se encontra inserida desde os primeiros trabalhos de síntese sobre as cerâmicas arqueológicas amazônicas. Se assim for, poderia ser o fim da Tradição Polícroma no baixo Amazonas:

No one has argued with the existence of relationships between Napo and Marajoara, although evidence presented by Evans and Meggers for such relations is rather significantly based on vague similarities in designs layouts and decorative techniques (Weber 1975: 424-25).

Nunca houve de fato uma expansão da Tradição Polícroma pelo baixo Amazonas e estuário, o que eventualmente levará que se considere que a fase Marajoara foi um fenômeno local e híbrido da foz do Amazonas, tributário de diferentes complexos locais antigos, relacionado apenas indiretamente à tradição polícroma (NEVES, 2012: 258).

Proposta que necessita de um minucioso estudo comparativo entre a cerâmica Marajoara e as cerâmicas TPA do alto e médio Amazonas. Além disso, conforme veremos, existem outras fases do baixo Amazonas - nos baixos rios Tocantins e Xingu - que foram relacionados à TPA e continuarão sendo, até segunda ordem ou até o fim deste capítulo. $\mathrm{O}$ presente estudo pode contribuir indiretamente para a "questão Marajoara".

$22 \mathrm{O}$ que só poderia ser proposto caso as datas antigas da Tradição Polícroma no alto Madeira estivessem erradas. Verificaremos (Capítulos 4 a 6) que, de fato, Neves (2012) possuía essa informação. 


\subsection{O leste amazônico}

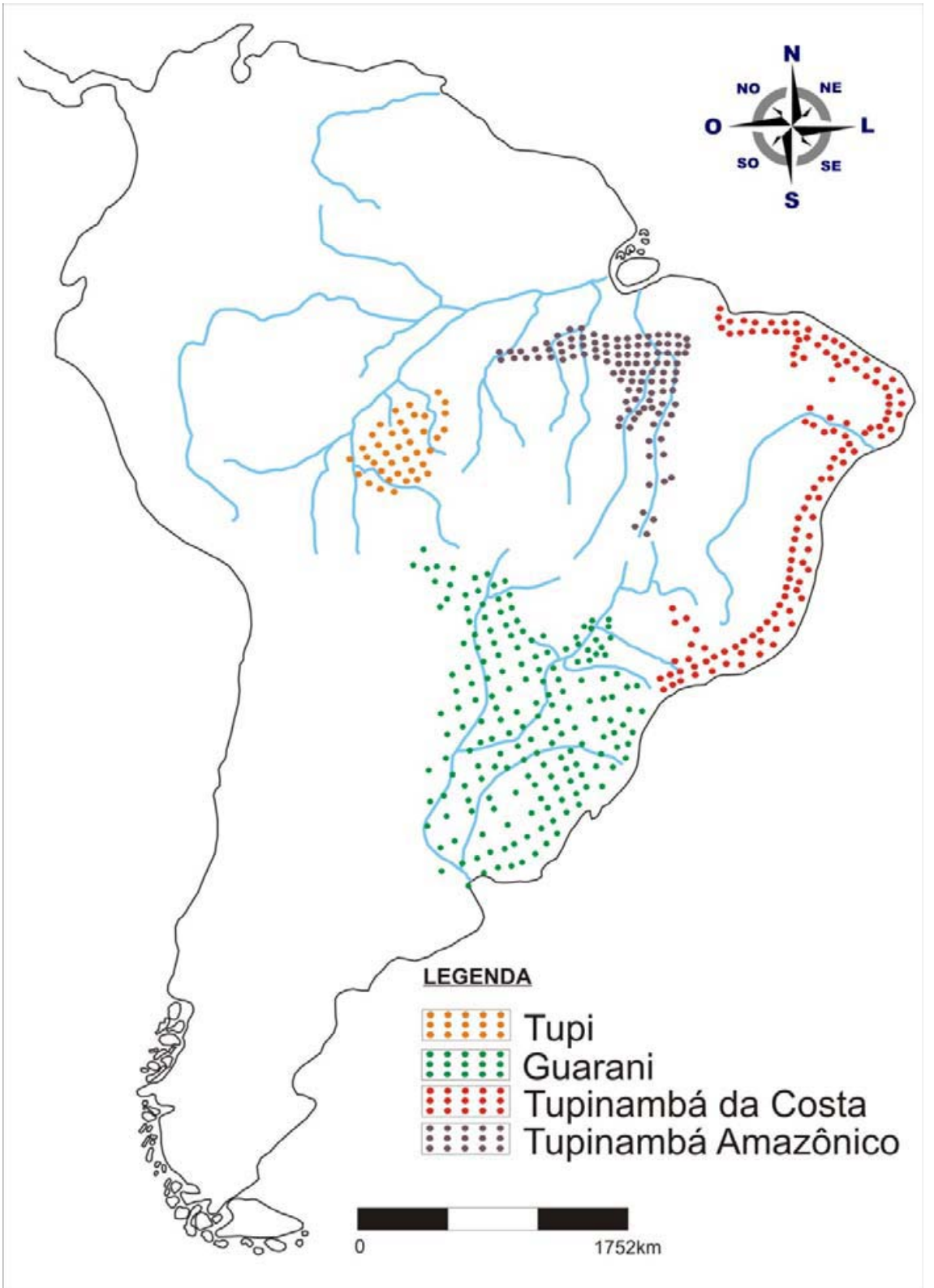

Figura 13: Dispersão aproximada dos grupos falantes de línguas Tupi na época do contato (Mapa: Eduardo Tamanaha/Fernando Ozorio de Almeida).

O leste amazônico é uma região ideal para discutir a relação entre a cerâmica da Subtradição Tupinambá da Amazônia e a cerâmica da Tradição Polícroma da Amazônia, pois elas se encontram, respectivamente, nas fases Tauarí e Tauá, no baixo Tocantins, e nas fases Arara e Pacajá (Tupinambá) e nas fases Independência e Cacarapí (Tradição Polícroma) no baixo Xingu. Na região de interflúvio entre esses dois rios, na terra firme, pode-se encontrar a 
fase Itacaiúnas, pertencente à Subtradição Tupinambá. Pouco se sabe sobre a arqueologia dos grupos do rio Tapajós.

Esse recorte geográfico se aproxima muito da chamada Área Cultural TocantinsXingu, observada por Galvão (1960), com a diferença que o presente recorte se expande para a bacia do Tapajós (a oeste) e do Gurupi (a leste). Além disso, diferentemente de Galvão, que caracteriza essa Área Cultural como Jê, baseado na distribuição de grupos indígenas na primeira metade do século XX (1900-1959), os dados arqueológicos apontam que a mesma área era culturalmente distinta nos mil anos anteriores à chegada dos europeus, sendo ocupada por grupos de língua Tupi-Guarani, produtores de cerâmica Tupinambá da Amazônia (cf. GARCIA, 2012a).

\subsubsection{O baixo Tocantins}

O rio Tocantins nasce na serra do Paraná, no Brasil central. Desse ponto até a sua foz, no rio Pará, percorre cerca de 2.600 quilômetros em sentido sul-norte. O baixo Tocantins se restringe ao trecho entre a foz do rio Araguaia, nas proximidades da atual cidade de Marabá, e a sua própria foz. Trata-se de uma área de Floresta Tropical que quase desapareceu devido ao desmatamento. Algumas centenas de quilômetros para leste, essa vegetação é substituída pela Floresta Transicional do Maranhão. Para o sul, essa vegetação se transforma no cerrado do Planalto Central. O clima da região possui duas estações distintas: verão (o período seco, na metade no ano) e inverno (o período de chuva, no final e começo de cada ano). A topografia pode ser descrita como um complexo de baixos relevos (AB'SABER, 2004: 94).

É possível encontrar vestígios arqueológicos relacionados aos Tupinambá em quase toda a extensão desse rio e regiões de entorno (ALMEIDA, 2008; OLIVEIRA, 2005; PONTIM, 2011; ROBRAHN-GONZÁLEZ, 1996; SIMÕES e ARAÚJO COSTA, 1987). No entanto, parece ser no entorno do encontro dos rios Tocantins e Araguaia que ocorre o maior número de sítios relacionados a esse grupo. É também na região de interflúvio entre os rios Tocantins e Xingu que se encontra hoje a maior quantidade de grupos falantes de línguas Tupi-Guarani.

O primeiro estudioso a descrever material arqueológico do baixo Tocantins foi Nimuendajú (2000), que chegou a escavar sítios na região a jusante da cachoeira de Tucuruí 
nos anos 1930 (cf. EVANS e MEGGERS, 1968). Nos anos 1960, começou um longo e intermitente período de pesquisas realizadas pelo Museu Paraense Emílio Goeldi. Uma das primeiras incursões foi a de Frikel (FIGUEIREDO, 1965) ao longo do rio Itacaiúnas, na margem esquerda do baixo Tocantins, seguida pela expedição de Simões (et al. 1973) no rio Pau d' Arco, situado na margem esquerda do rio Araguaia. A fase mais intensa de estudos começou em 1976 (SIMÕES, 1976), como parte do Programa Nacional de Pesquisas Arqueológicas para a Bacia do Amazonas (PRONAPABA), e continuou nos anos seguintes, quando o Museu Goeldi foi incumbido da pesquisa na área a ser impactada pela construção da hidrelétrica de Tucuruí (SIMÕES, 1977; ARAÚJO-COSTA, 1978; LOPES, 1979).

A pesquisa na área da hidrelétrica de Tucuruí gerou a uma publicação de síntese (SIMÕES e ARAÚJO COSTA, 1987) na qual três fases arqueológicas (Tauarí, Tucurí e Tauá) foram descritas. A fase Tauarí foi relacionada aos sítios localizados entre o encontro dos rios Tocantins e Araguaia, ao sul, e algumas dezenas de quilômetros abaixo da atual cidade de Marabá, para o Norte. A fase Tauá foi relacionada a sítios encontrados a jusante da cachoeira de Tucuruí até a cidade de Nazaré dos Patos, e a fase homônima à cachoeira foi relacionada a sítios na região intermediária (idem, Anexo 1). A fase Tucuruí não foi reanalisada e não será tratada no presente capítulo.

Os sítios da fase Tauá foram, em geral, encontrados em terraços em topo de barranco e possuíam material disposto ao longo das margens do rio, de forma paralela a ele, com áreas variando entre $10 \times 20 \mathrm{~m}$ e $80 \times 300 \mathrm{~m}$. O material arqueológico foi encontrado a $70 \mathrm{~cm}$ de profundidade em dois sítios. Foram identificados sepultamentos secundários em urnas funerárias. O material lítico era composto por lâminas de machado (picoteados ou polidos), raspadores, facas e batedores. Simões e Araújo Costa analisaram mais de 19 mil fragmentos cerâmicos de sítios relacionados a essa fase.

Cerca de $19 \%$ desse material possuía decoração. A cerâmica foi manufaturada por meio da técnica do roletado, com uso de antiplástico mineral e, em menor quantidade, de caco moído e caraipé. O tratamento de superfície em geral era refinado, e a decoração, quando presente, possuía grande variabilidade: foram observadas pinturas policrômicas, ainda que menos representativas quantitativa e qualitativamente do que as decorações plásticas, com grande quantidade de motivos incisos e acanalados, como também de figuras zoomorfas. As bases dos vasos eram planas, convexas, anelares ou em pedestal. Foram observados fragmentos de bordas vazadas. As paredes eram finas na maioria dos casos, com espessura em geral entre 0,7 e $0,9 \mathrm{~cm}$. Algumas formas apresentaram carenas ou ombros, mas 
a maioria possuía contorno simples ou inflectido. As formas apresentadas por Simões e Araújo Costa (p. 21) em geral eram fundas, com formato esférico ou semi-esférico. Meggers (et. al., 1987) e Miller (et al., 1992) relacionaram essa fase à Tradição Polícroma da Amazônia. Esses autores preferiram seguir a indicação de Nimuendajú (2000) de que se tratava de um material semelhante ao Marajoara (TPA), do que a interpretação feita por quem de fato analisou o material (SIMÕES e ARAÚJO COSTA, 1987) e o relacionou ao Estilo Inciso-Ponteado.

Três sítios da fase Tauá tiveram uma parcela de seu material cerâmico analisado recentemente e podem ajudar a compreender melhor a variabilidade interna dessa fase (Tabelas 2 a 4; Anexo 2). 


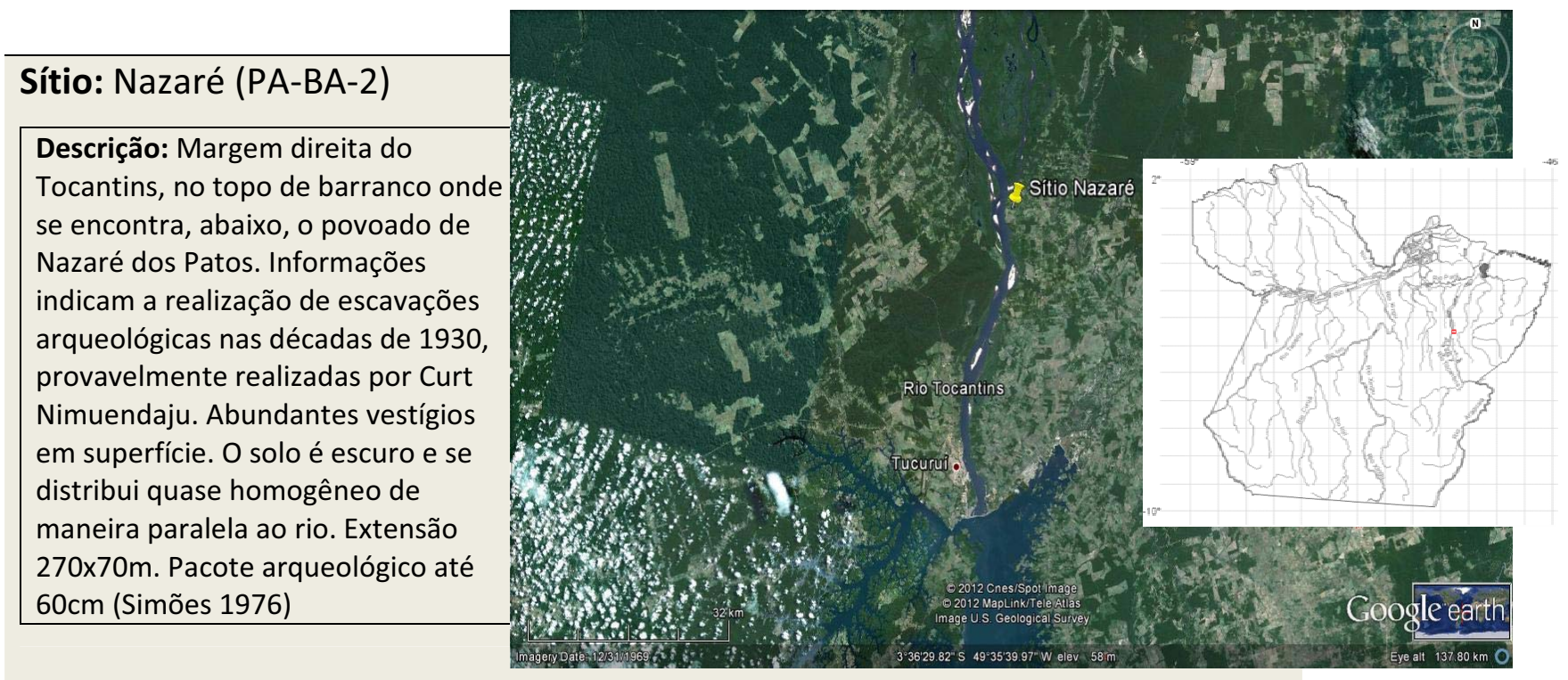

Fragmentos Analisados pelo PALMA: 106 fragmentos do Corte 2

Níveis: sup., $0-10 \mathrm{~cm}, 10-20 \mathrm{~cm}, 40-50 \mathrm{~cm}, 50-60 \mathrm{~cm}, 60-70 \mathrm{~cm}, 80-90 \mathrm{~cm}, 90-100 \mathrm{~cm}, 100-120 \mathrm{~cm}$.

Categoria: 50 parede, 44 borda, 8 base, 1 carena, 1 asa + aplique, 1 aplique, 1 flange

Antiplástico: 95 mineral, 9 caco moído, 1 caraipé+caco moído, 1 caraipé/carvão

Cor: 19 branco, 35 ocre, 24 laranja, 5 vermelho, 13 cinza, 8 preto, 4 marrom

Queima: 53 núcleo claro, 21 núcleo preto, 27 núcleo escuro com faixas claras $\mathrm{AF}, 5$ outro

Alisamento Face Interna: 95 fino, 5 médio, 2 grosso, 4 não identificado

Alisamento Face Externa: 87 fino, 9 médio, 2 grosso, 2 polidos, 6 não identificado

Tratamento de Superfície FI: 5 engobo vermelho, 34 engobo branco, 17 barbotina, 50 não identificado

Tratamento de Superfície FE: 16 engobo vermelho, 17 engobo branco, 4 barbotina, 69 não identificado

Morfologia da Borda e Flange: 36 direta, 3 extrovertida, 3 introvertida, 2 extrovertida com ponto angular, 1 cambada

Inclinação da Borda: 8 vertical, 4 inclinada interna, 33 inclinada externa

Espessura da Borda: 34 normal, 5 vazada , 7 outros

Lábio: 29 arredondado, 15 plano, 1 não identificado

Base: 6 plana, 1 plano-convexo, 1 anelar, 1 pedestal

Espessura do Fragmento: 4 menor que $6 \mathrm{~mm}$, 93 entre $6 \mathrm{~mm}$ e $10 \mathrm{~mm}, 17$ entre 11 e $15 \mathrm{~mm}, 1$ maior que $1,5 \mathrm{~mm}$

Decoração Plástica: 5 corrugado, 28 incisão fina, 5 incisão larga, 8 exciso/acanalado, 7 incisoponteado, 4 outros

Decoração Pintada: 7 vermelho, 2 branco, 2 branco e preto

Motivo Decorativo: 8 horizontal, 17 complexa, 6 curcilinea,

9 horizontal e ondular

Local de Decoração FI: 8 parede, 4 borda, 1 lábio

Local de Decoração FE: 25 parede, 4 labio, 25 borda

PALMA

Sítio Nazaré

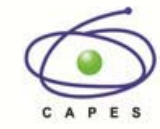

QAAPEP

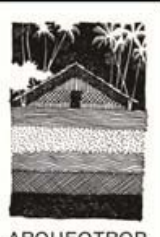

ARQUEOTROP

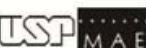




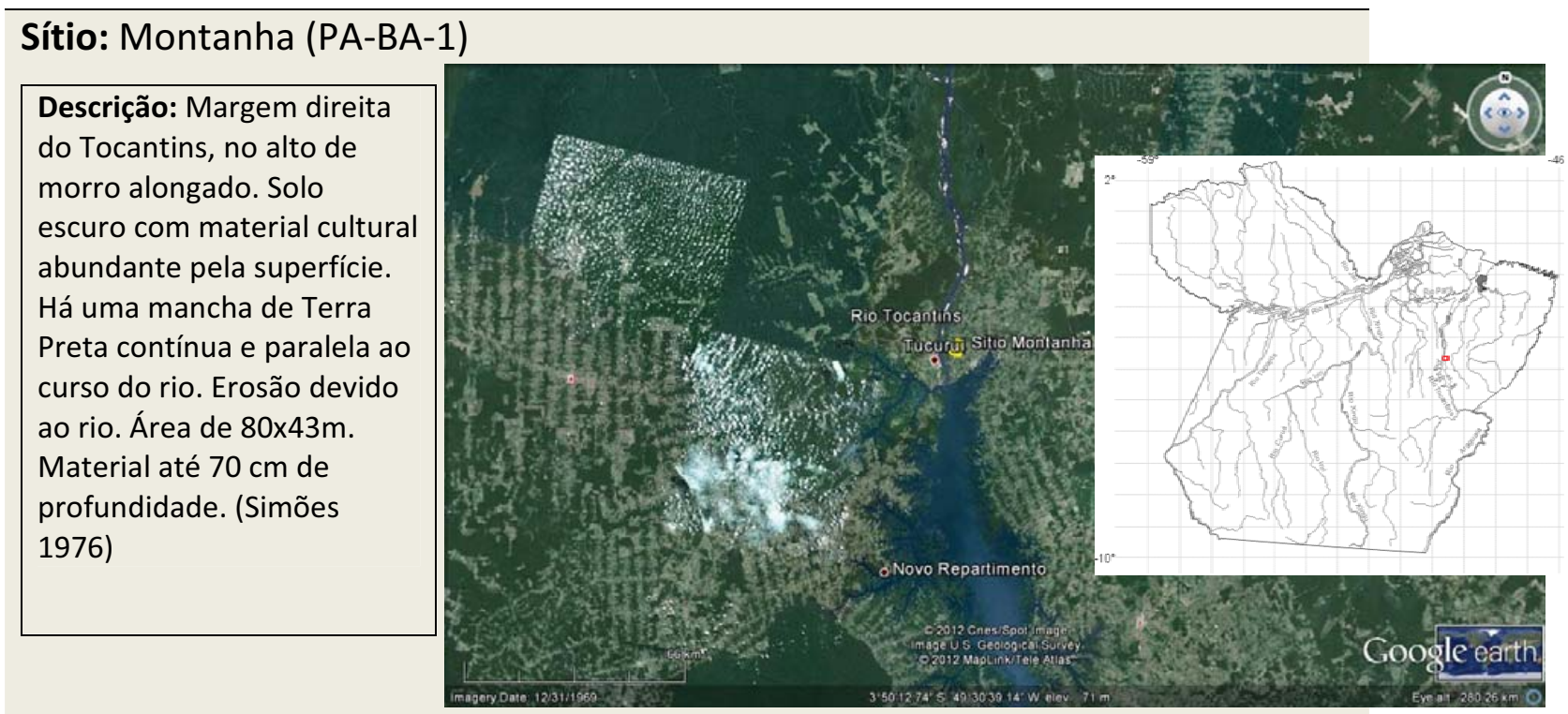

Fragmentos Analisados: 54 Fragmentos

Níveis: $10-20 \mathrm{~cm}, 20-30 \mathrm{~cm}, 30-40 \mathrm{~cm}$

Categoria: 26 parede, 15 borda, 6 base, 3 flange, 2 carena, 2 aplique

Antiplástico: 52 mineral, 1 caraipé, 1 caco moído

Cor: 2 branco, 15 ocre, 16 laranja, 5 vermelho, 14 cinza, 1 preto, 1 marrom

Queima: 13 núcleo claro, 19 núcleo preto, 18 núcleo preto com faixas claras $A F, 4$ outros

Alisamento Face Interna: 43 fino, 5 médio, 6 não identificado

Alisamento Face Externa: 40 fino, 7 médio, 7 não identificado

Tratamento de Superfície FI: 1 engobo vermelho, 11 engobo branco, 1 barbotina

Tratamento de Superfície FE: 4 vermelho, 15 branco

Morfologia da Borda e Flange: 13 direta, 3 extrovertida, 1 cambada, 1 extrovertida com ponto angular

Inclinação da Borda: 2 vertical, 15 externa, 1 interna

Espessura da Borda: 12 normal, 3 vazada, 3 reforçada externa

Lábio: 8 arredondado, 8 plano, 2 apontado

Base: 5 plana, 1 anelar

Espessura do Fragmento: 2 menor que $6 \mathrm{~mm}, 43$ entre $6 \mathrm{~mm}$ e $10 \mathrm{~mm}, 11$ entre 11 e $15 \mathrm{~mm}, 1$ maior que $1,5 \mathrm{~mm}$

Decoração Plástica: 22 incisão fina, 8 incisão larga, 5 acanalado, 6 outro

Decoração Pintada: 3 pintura vermelha

Motivo Decorativo: 9 horizontal, 5 ondular, 4 complexo, 8 curvilínea

Local de Decoração FI: 2 lábio, 6 borda, 2 parede

Local de Decoração FE: 6 borda, 23 parede, 1 base

PALMA

Sítio Montanha

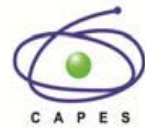

ARQUEOTRO

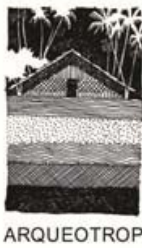

TSP $\cdots \cdots$ 


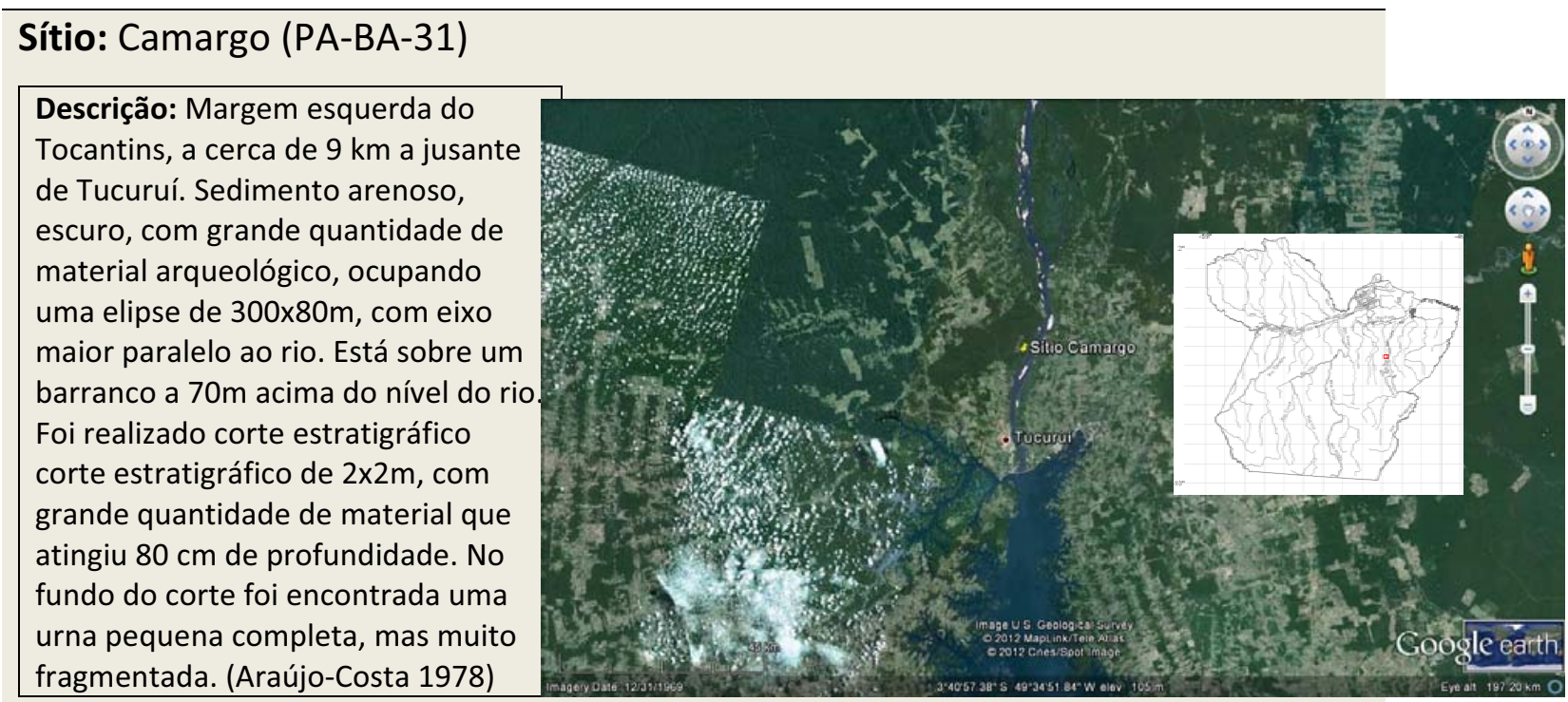

Fragmentos Analisados pelo PALMA: 180 fragmentos do Corte 1

Níveis: $0-10 \mathrm{~cm}, 10-20 \mathrm{~cm}, 20-30 \mathrm{~cm}, 30-40 \mathrm{~cm}, 40-50 \mathrm{~cm}$

Categoria: 99 parede, 53 borda, 10 base, 1 roda de fuso, 5 carena, 2 flanges labial, 1 asa, 5 aplique, 1 borda com asa, 1 não identificado

Antiplástico: 158 mineral, 15 caco moído, 6 caraipé/carvão, 1 argila moída

Cor: 34 branco, 50 ocre, 57 laranja, 9 vermelho, 19 cinza, 4 preto, 7 marrom

Queima: 72 núcleo claro, 42 núcleo preto, 57 núcleo escuro com faixas claras $A F, 9$ outro

Alisamento Face Interna: 154 fino, 9 médio, 2 grosso, 6 polidos, 9 não identificado

Alisamento Face Externa: 154 fino, 14 médio, 3 grosso, 4 polidos, 5 não identificado

Tratamento de Superfície FI: 5 engobo vermelho, 34 engobo branco, 141 não identificado

Tratamento de Superfície FE: 28 engobo vermelho, 46 engobo branco, 106 não identificado

Morfologia da Borda e Flange: 33 direta, 11 extrovertida, 5 introvertida, 5 extrovertida com ponto angular, 2 não identificada

Inclinação da Borda: 5 vertical, 13 inclinada interna, 32 inclinada externa, 6 não identificada

Espessura da Borda: 45 normal, 4 reforçada externa , 7 outros

Lábio: 25 arredondado, 30 plano, 1 apontado

Base: 10 plana

Espessura do Fragmento: 9 menor que $6 \mathrm{~mm}, 159$ entre $6 \mathrm{~mm}$ e $10 \mathrm{~mm}$, 7 entre 11 e $15 \mathrm{~mm}, 4$ maior que $1,5 \mathrm{~mm}$

Decoração Plástica: 23 incisão fina, 11 incisão larga, 7 ponteado, 4 digitado

Decoração Pintada: 24 vermelho, 10 vermelho e preto, 6 outros

Motivo Decorativo: 43 horizontal, 11 complexa, 11 curcilinea

Local de Decoração FI: 23 parede, 1 borda, 1 lábio

Sítio Camargo

Local de Decoração FE: 45 parede, 8 labio, 4 borda
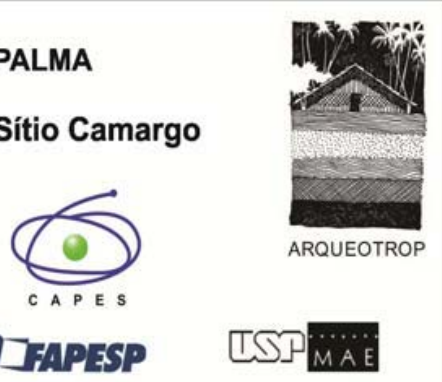
A fase Tauarí foi relacionada a seis sítios ribeirinhos do baixo Tocantins e a (pelo menos) outros oito sítios de terra firme escavados depois. Os sítios ribeirinhos supostamente possuíam planta elíptica alongada acompanhando o rio, e os sítios de terra firme em geral possuíam uma distribuição randômica (voltaremos a esse ponto). O menor sítio, encontrado nas margens do rio Tocantins, possuía 20 x 10m, e o maior, localizado na terra firme, possuía $450 \times 500 \mathrm{~m}$. Apesar de as escavações terem encontrado pacotes arqueológicos de até $1 \mathrm{~m}$ de profundidade, esses sítios em geral eram rasos, com pacotes de terra preta com cerca de $30 \mathrm{~cm}$ de profundidade. Simões e Araújo Costa apontam evidências de sepultamentos secundários em urnas (ALMEIDA, 2008; SCIENTIA, 2008). O material lítico, realizado em geral sobre suporte de seixos de silexito ou quartzo/quartzito, era composto por lascas unipolares ou bipolares, núcleos, machados polidos e uma suposta ponta de projétil (SIMÕES e ARAÚJO COSTA, 1987: 12) (Fig. 14).

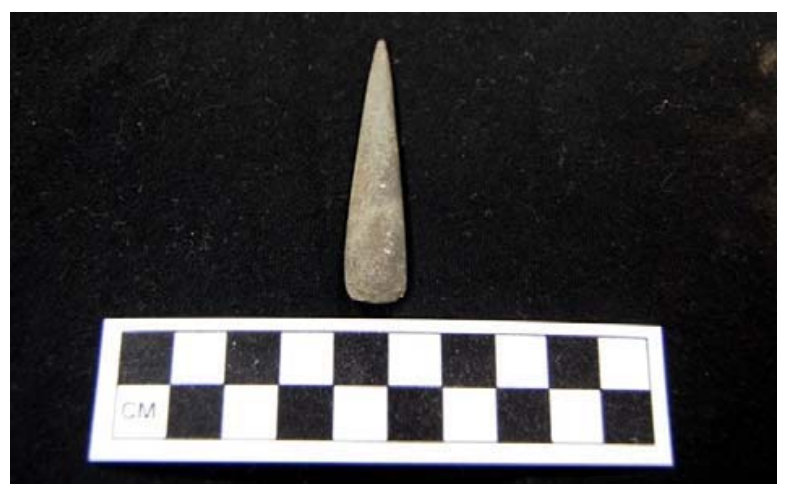

Figura 14: Artefato polido encontrado no sítio São José, que Simões e Araújo Costa acreditam ser uma ponta de projétil (foto: Fernando Ozorio de Almeida).

A cerâmica da fase Tauarí pode ser descrita como manufaturada com antiplástico mineral e, em menor quantidade, com caraipé e/ou carvão. Os acabamentos de superfície (alisamento) em geral não foram tão bem feitos quanto os encontrados na fase Tauá, sendo por vezes mal executados. A ocasional presença de grandes pedaços de antiplástico mineral, com comprimento maior que $5 \mathrm{~mm}$, ajuda a dar um aspecto mais rústico a essa cerâmica. No entanto, as pinturas policrômicas foram muito mais presentes nessa fase do que nas outras duas, aparecendo em motivos feitos por todo o interior do vaso ou, às vezes, na parte superior da face externa do vaso, entre o ombro e a borda (Fig. 15). 


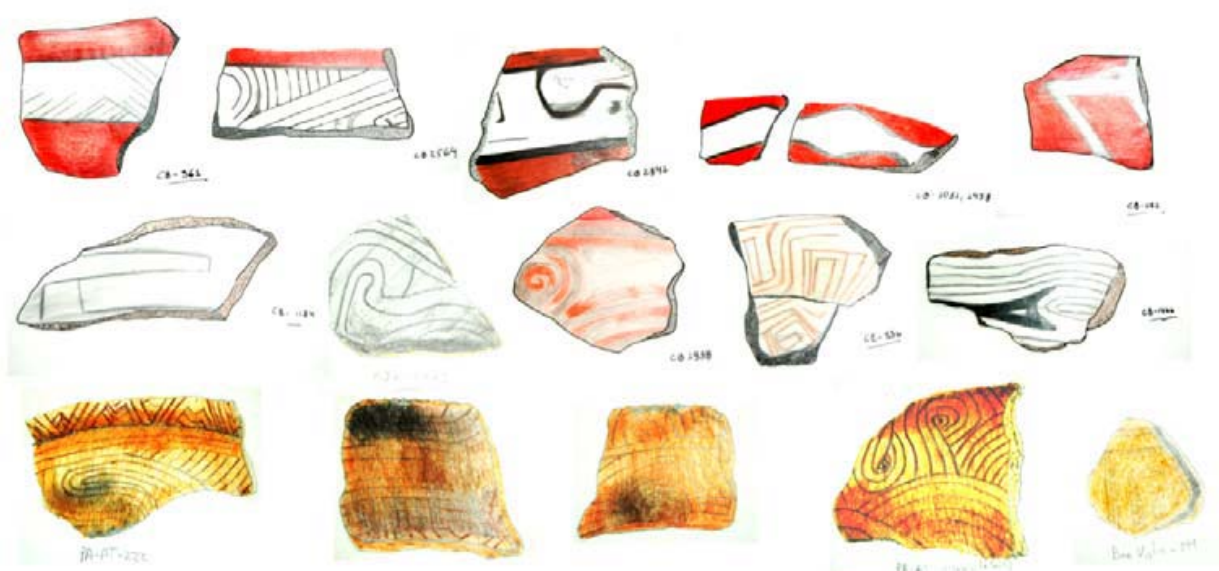

Figura 15: Decoração pintada e incisa nos fragmentos cerâmicos de sítios pertencentes à fase Tauarí (desenhos: Fernando Ozorio de Almeida e Lorena Garcia).

Diferenças entre as fases Tauarí e Tauá também foram observadas no campo das decorações plásticas, como a presença constante de sequências corrugadas e unguladas na fase Tauarí. Por vezes, a decoração corrugada era tão mal executada que era difícil ter certeza se ela era uma decoração ou apenas um alisamento grosseiro. Em comparação com a fase Tauá, os motivos incisos foram menos frequentes, mas ainda sim apareceram. As bases em geral eram convexas, as paredes com frequência possuíam inflexões, e as bordas às vezes eram vazadas. A espessura das paredes variou muito mais nessa indústria do que na fase Tauá. Os assadores também foram observados nessa fase e em geral possuíam um tratamento grosseiro ou um corrugado na face externa. Simões e Araújo Costa publicaram uma data de radiocarbono para essa fase: $1550+-70$ d.C. 

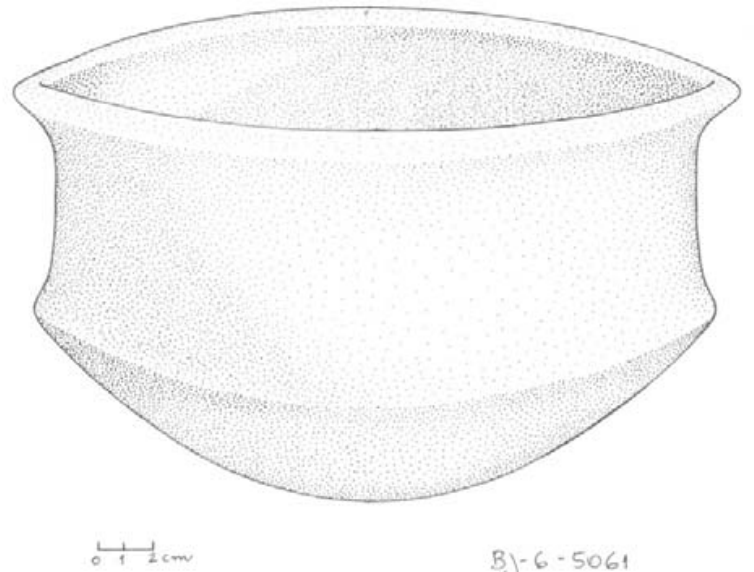

Bj $-6-5061$
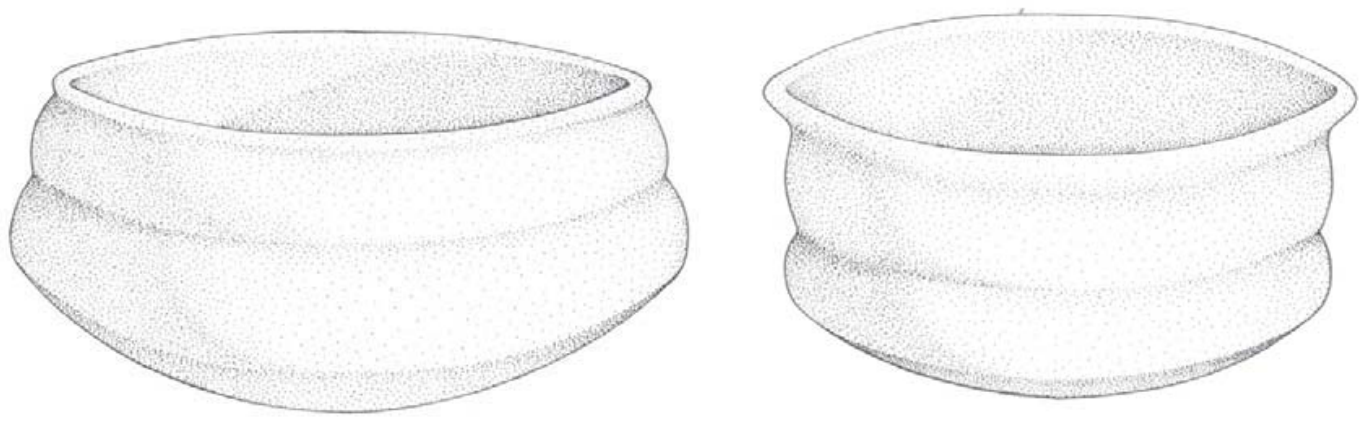

$\stackrel{4}{2} \mathrm{~cm}$

$35 \cdot 6 R-880$

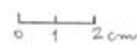

B) $-6 R \quad 1208$

Figura 16: Formas compostas ou complexas do sítio Bom Jesus 6, fase Tauarí (Desenhos Erêndira Oliveira).

Foi re-analisada uma amostra de um dos sítios escavados por Simões e Araújo Costa. Trata-se do sítio São José, encontrado à beira do rio Itacaiúnas, próximo à foz desse rio com o Tocantins, dentro da cidade de Marabá (Tabela 5; Anexo 3). 


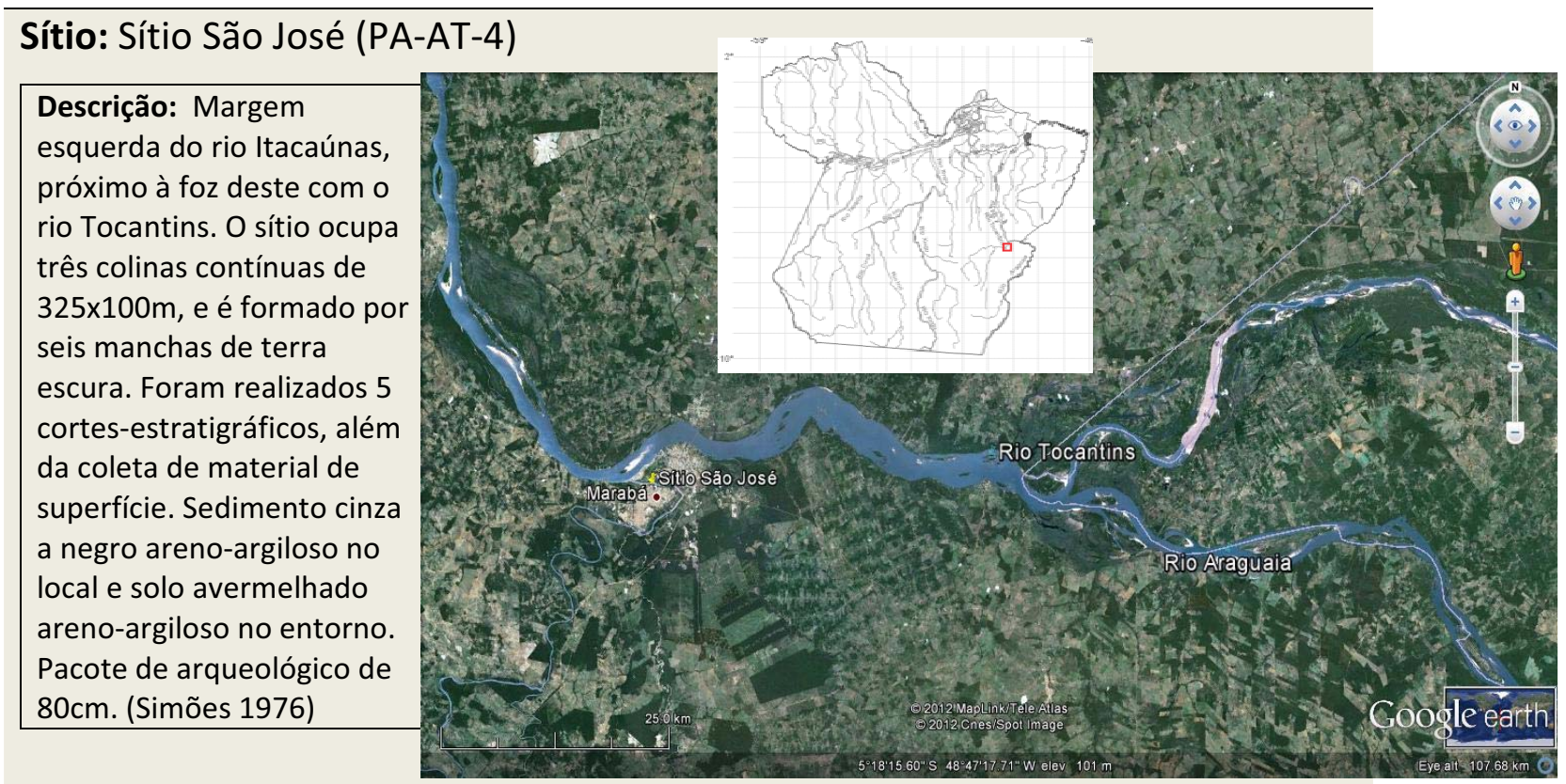

\section{Fragmentos Analisados pelo PALMA: 120}

Níveis: $0-10,10-20,20-30 \mathrm{~cm}$

Categoria: 63 parede, 40 borda, 15 carena, 1 flange

Antiplástico: 86 mineral, 6 caraipé, 18 caco moído, 3 carvão, 2 cauixi, 5 outro

Cor: 32 ocre, 66 laranja, 2 vermelho, 13 cinza, 1 preto, 6 marrom

Queima: 23 núcleo claro, 38 núcleo preto, 55 núcleo escuro com faixas claras $\mathrm{AF}, 4$ outro

Alisamento Face Interna: fino, 9 médio, 2 grosso, 6 polidos, 9 não identificado

Alisamento Face Externa: 91 fino, 16 médio, 1 grosso, 2 polidos, 10 não identificado

Tratamento de Superfície FI: 7 engobo vermelho, 4 engobo branco, 4 barbotina, 1 esfumarado, 104 não identificado

Tratamento de Superfície FE: 65 engobo vermelho, 5 engobo branco, 3 barbotina, 47 não identificado

Morfologia da Borda: 34 direta, 4 extrovertida, 4 cambada

Inclinação da Borda: 5 vertical, 1 inclinada interna, 35 inclinada externa, 6 não identificada

Espessura da Borda: 33 normal, 7 reforçada externa, 1 contraída

Lábio: 29 arredondado, 10 plano, 1 biselado, 1 não identificado

Espessura do Fragmento: 3 menor que $6 \mathrm{~mm}, 82$ entre $6 \mathrm{~mm}$ e $10 \mathrm{~mm}, 32$ entre 11 e $15 \mathrm{~mm}, 3$ maior que $1,5 \mathrm{~mm}$

Decoração Plástica: 10 corrugado, 5 incisos, 8 entalhado,

Decoração Pintada: 3 vermelha, 1 branca, 1 vermelha e branca

Motivo Decorativo: 1 horizontal, 4 transversal

Local de Decoração FI: 3 parede, 2 lábio, 1 borda + carena

Local de Decoração FE: 11 parede, 5 lábio, 4 borda

PALMA

Sítio São José

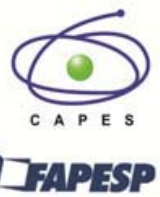


De um determinado ponto de vista, a variabilidade na decoração plástica é a única grande variável entre as fases Tauá e Tauarí. A fase Tauá possuía bases anelares e em pedestal, como também diferentes usos de pinturas policrômicas. De resto, ambas possuem o mesmo antiplástico, a mesma quantidade (quase excessiva) de antiplástico na pasta, o mesmo tipo de alisamento e espessura.

Da mesma forma, se colocadas lado a lado as formas dos vasos Tauá e Tauarí, incluindo as posteriormente estudadas por Almeida (2008), é possível observar que todas as formas Tauá possuem um correlato Tauarí (Tabela 6). Esta, além do mais, possui outras formas não presentes na fase Tauá, incluindo as formas complexas. O mesmo não pode ser dito das decorações plásticas. Estas são de fato distintas nos dois agrupamentos, em especial quanto aos apliques modelados presentes na fase Tauá, que possuem uma presença qualitativa (e não quantitativa) que não pode deixar de ser notada. O que parece crucial, nesse sentido, é a ausência de modelados antropomorfos, incluindo vasilhas antropomorfizadas - o que seria esperado de uma fase ligada ao contexto Marajoara. Da mesma forma, alguém que compara os modelados zoomorfos e, em especial, os filetes aplicados ponteados da fase Tauá com a fase Marajoara e com o antigo material Inciso-Modelado regional descrito por Garcia (2012a) e Almeida (2013), com certeza verá uma semelhança muito maior com o contexto Inciso-Modelado. O próprio repertório reduzido de formas, encontrado na fase Tauá e nos estudos desses dois autores, parece aproximar mais a fase Tauá dos elementos da cerâmica antiga Inciso-Modelada do que do sofisticado repertório Marajoara (cf. BARRETO 2008; MEGGERS e EVANS, 1957; SCHAAN, 2001, 2004). A maior e quase única semelhança entre as fases "Polícromas" Marajoara e Tauá são os motivos incisos na cerâmica (Fig. 17).
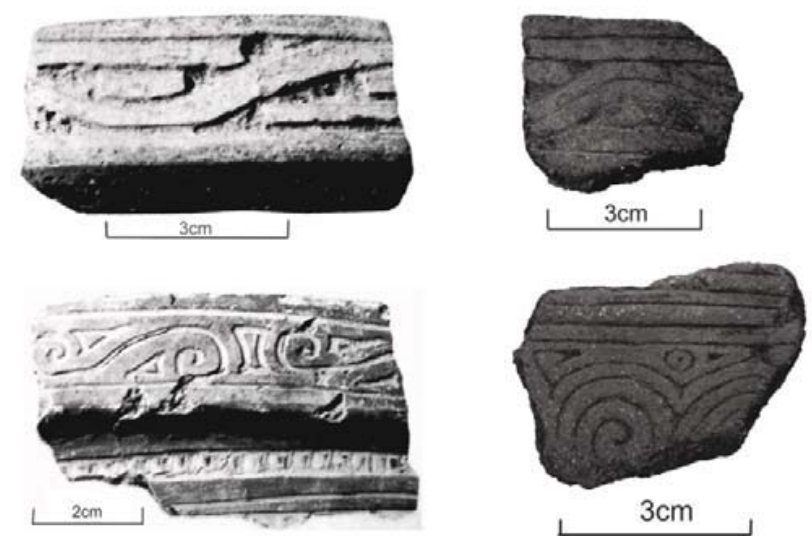

Figura 17: Motivos incisos na fase Marajoara (fonte: EVANS e MEGGERS, 1968) e na fase Tauá (fotos: Fernando Ozorio de Almeida). 
Resumindo, ao tentar opor os Tupinambá (fase Tauarí) das áreas de terra firme e encachoeiradas do rio Tocantins e os supostos Polícromos (fase Tauá) “canoeiros" ribeirinhos do baixo curso desse rio, obteve-se um resultado inesperado quanto a um dos pressupostos. Não foram identificados os elementos que permitissem inserir a fase Tauá no contexto Polícromo, nem mesmo em agrupamento com a cerâmica Marajoara. O que leva à pergunta: o que é, então, a fase Tauá? Trata-se de um agrupamento regional que possui elementos da Subtradição Tupinambá, da antiga cerâmica Inciso-Modelada do leste amazônico, algumas características Marajoara, como os motivos incisos e as bordas vazadas, e, eventualmente, um elemento TPA, como o padrão linear de ocupação nas margens navegáveis dos grandes rios.

Apontar qual desses elementos que constituem a fase Tauá é o mais preponderante é impossível com a amostra analisada. No entanto, é pode-se sugerir que ela não faz parte da Tradição Polícroma, como apontado por Meggers et al. (1987) e Miller (1992) e, simultaneamente, inserir um ponto de interrogação quanto aos critérios que definem os grupos pertencentes à Tradição Polícroma no leste da Amazônia. Constatação que inviabiliza a utilização dos Tauá como exemplo da suposta normativa TPA, canoeira, frente à heterogeneidade Tupinambá. Se a fase Tauá possui elementos da Subtradição Tupinambá, acrescida de outras heterogeneidades estilísticas, então heterogêneas são suas possibilidades.

Resta, então, apontar os dados provenientes das análises dos novos sítios da fase Tauarí. Tal análise partiu do estudo do sítio Cavalo Branco, identificado na média vertente de um morro com superfície alongada, nas proximidades do igarapé Ipuxuna, que deságua no rio Tocantins. Em linha reta, por terra, esse sítio se encontra a cerca de $15 \mathrm{~km}$ desse rio. 


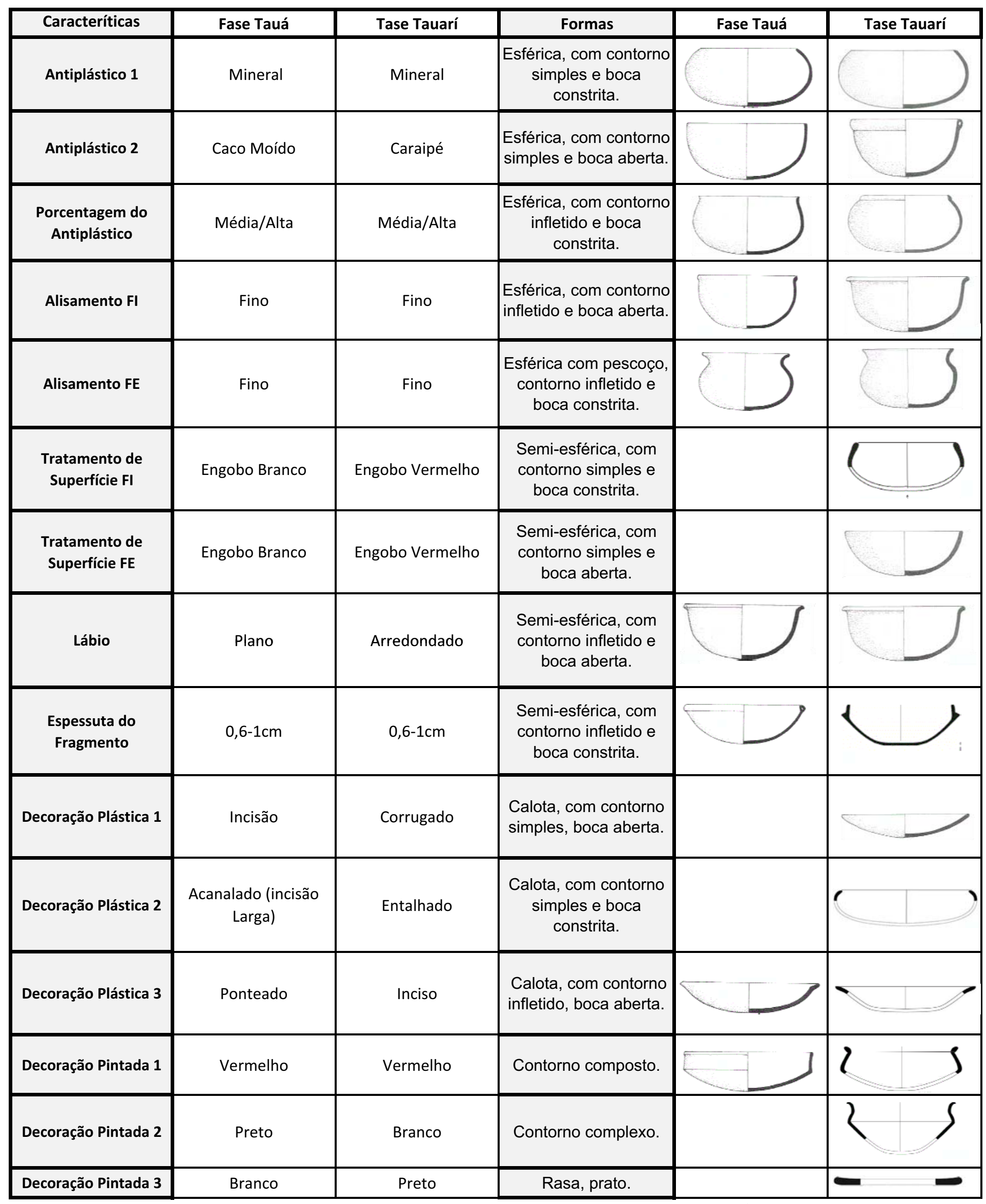

Tabela 6: Comparação entre a fase Tauá e a Fase Tauarí (Fonte: ALMEIDA, 2008; SIMÕES e ARAÚJO COSTA, 1987) 
O sítio possui cerâmica espalhada por uma área de $140.000 \mathrm{~m}^{2}$, mas as maiores densidades de material foram relacionadas a duas manhas de terra preta, uma com o dobro do tamanho da outra (Área I, $21.200 \mathrm{~m}^{2}$, e Área II, $10.200 \mathrm{~m}^{2}$ ). Dados cronológicos indicam que essas áreas foram ocupadas em momentos distintos: a primeira ocupação na Área I teria ocorrido no séc. VIII (725+-65 d.C.); a Área II teria sido ocupada no séc. XII (1150+-60 d.C.); seguida de uma ocupação na Área I por volta do séc. XIV (1270+-40 d.C. e 1330+-70 d.C.). É possível que outras ocupações tenham ocorrido depois, já que o topo da estratigrafia não foi datado. Outra incerteza é quanto à duração das ocupações. No entanto, se considerados o padrão de movimentação dos Tupinambá, não necessariamente relacionado com o padrão de fertilidade (cf. CARNEIRO 1995; NEVES, 1995), pode-se supor que não durassem muito mais do que cinco anos.

Os atributos cerâmicos são semelhantes aos de outros sítios de terra firme resgatados e analisados junto com o sítio Cavalo Branco, tais como os sítios Bom Jesus 1, 2, 4, 5, 6 e 7 e os sítios Bela Vista e Nova Ipixuna 3. Foram encontrados os mesmos atributos da fase Tauarí (ALMEIDA, 2008, 2011).

Foi a análise de sítios relacionados a essa fase que levaram à criação da chamada Subtradição Tupinambá da Amazônia (ALMEIDA e NEVES, não publicado). Isso ocorreu após uma exaustiva comparação entre os atributos da cerâmica da fase Tauarí e a descrição dos atributos das Subtradições Tupinambá do litoral e Guarani. Algumas semelhanças eram evidentes, como a utilização de antiplástico mineral, os vasos angulares, as decorações corrugadas e unguladas, assim como a utilização de pigmentos vermelho, preto e branco na forma de banhos, faixas (delimitando áreas do caso) e motivos. Além disso, pode-se acrescentar que não só o aparecimento de determinados atributos indicou a semelhança entre essas Subtradições, como também a combinação desses atributos. Por exemplo, em uma série de sítios da fase Tauarí (e.g. Bom Jesus 2, Cavalo Branco, Bom Jesus 6) foram observados tigelas rasas, com ombros e faixas vermelhas delimitando esses ombros e com motivos vermelhos feitos sobre superfície coberta por pigmento branco, entre o ombro desse vaso e a borda (Fig. 18). Tal combinação foi observada com frequência na cerâmica Guarani (LA SALVIA e BROCHADO, 1989), sob o nome da cambuxi caguabá (MONTOYA, 2002 [1640]; cf. NEUMANN, 2008, 2010; NOELLI, 1999-2000, 2008b) e na cerâmica Tupinambá do litoral (BROCHADO, 1991; cf. BUARQUE 2010; CORRÊA, 2009), e é relacionada com a ingestão de bebidas alcoólicas (NOELLI e BROCHADO, 1998). 

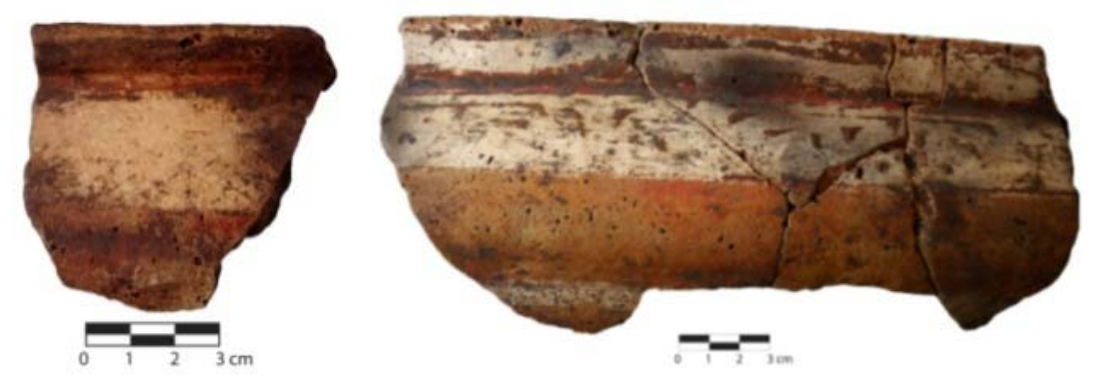

Figura 18: Tigelas rasas do sítio Cavalo Branco, com faixas vermelhas e brancas delimitando as inflexões do vaso, assim como motivos pintados (fonte: Almeida 2008).

Por outro lado, algumas diferenças também ficaram claras, tais como a ausência de caco moído - antiplástico presente nas Subtradições Tupinambá do litoral e Guarani, mas ausente na fase Tauarí - uma variabilidade maior de espessuras nos motivos pintados, com possibilidades mais largas na Subtradição Amazônica, e a espessura das paredes. Quanto à última, há de se enfatizar que, apesar de indicado que havia uma grande variação na espessura das paredes dos vasos Tupinambá da Amazônia, essa espessura pode ser considerada fina se comparada com as outras duas Subtradições. Além disso, o uso de motivos incisos parece muito mais presente na fase Tauarí do que nas demais Subtradições e parece haver um uso distinto da decoração corrugada nesta fase, não necessariamente cobrindo todo o exterior do vaso, como ocorre nas Subtradições Tupinambá do litoral e Guarani, mas também em áreas especificas, como na borda (ALMEIDA, 2008).

Resumindo, estava claro que, se as indústrias cerâmicas possuíam muitas semelhanças, a variabilidade era tamanha que exigia uma denominação à parte. Isso significa que esses grupos (essas Subtradições) são historicamente ligados e, ao mesmo tempo, a historicamente distanciados de tal maneira que uma diferenciação terminológica é necessária. Conforme afirmado acima, no início da análise dos novos sítios da fase Tauarí havia apenas uma data isolada de 1550+-70 d.C. A confirmação dessa ocupação tardia significaria que os grupos indígenas que hoje falam línguas da família Tupi-Guarani no sudeste amazônico seriam prováveis descendentes dos grupos Tupinambá do litoral, migrando para o interior em decorrência da ocupação europeia da costa brasileira, nos séculos XVI e XVII ${ }^{23}$ (LARAIA, 1984/85: 26). No entanto, as novas datações para a fase Tauarí indicaram que havia grupos Tupi-Guarani do sudeste Amazônico centenas de anos antes da chegada dos europeus e da consequente migração dos Tupinambá da costa para o interior da Floresta Amazônica.

23 Hipótese improvável se inseridos os dados linguísticos nessa discussão. 
Ao que tudo indica, nos séculos que precederam a chegada dos europeus, os Tupinambá criaram um núcleo no encontro dos rios Tocantins e Araguaia e desenvolveram um Estilo cerâmico particular, significativamente influenciado pelos vizinhos de entorno, como os grupos Tauá, rio abaixo, ou os grupos Jê do Brasil central (e.g. Tradição Urú) e da Floresta Transicional do Maranhão (Timbira pré-colonial?). As últimas datas da cronologia (séc. XVII) parecem se conectar bem com as informações etno-históricas - como a menção do Padre Vieira (1997 [1659]) de que o médio Tocantins era a terra dos Tupinambá - que por sua vez conectam os Tupinambá arqueológicos aos atuais falantes de línguas Tupi-Guarani da região (ALMEIDA, 2008).

A comparação intra-sítios da Subtradição Tupinambá da Amazônia confirma que a variabilidade parece mais uma questão de frequência do que de presença/ausência de atributos. Em alguns sítios (e.g. Cavalo Branco), a decoração ungulada seria a mais frequente, em outros sítios (e.g. Bom Jesus 2), a decoração incisa seria mais popular. Em alguns sítios (e.g. Nova Ipixuna 3), havia predomínio de engobo branco, em outros, o predomínio era do engobo vermelho (e.g. Bom Jesus 2). Quase todos os sítios da Subtradição Tupinambá da Amazônia analisados possuíam um coerente repertório de formas inflectidas e angulares, o que destoou de outros sítios de terra firme do sudeste amazônico, como os sítios Belo Horizonte e Frade, que possuíam formas mais simples. Estes dois sítios, pode-se sugerir, talvez estejam relacionados com um contexto Jê-Timbira pré-colonial. Corroboram essa sugestão essa cerâmica simples, com uso de antiplástico de caraipé, que em alguns aspectos lembra a cerâmica Urú, e, em especial, uma disposição circular dos fragmentos cerâmicos, o que remete a uma aldeia circular Timbira (ALMEIDA, 2008; cf. LADEIRA, 1983). Essa disposição circular parece contrastar com uma disposição aleatória dos Tupinambá da Amazônia. Voltaremos a esse ponto.

Entretanto, houve em alguns casos ausência de certos atributos, tais como a quase ausência de fragmentos com motivos pintados nos sítios Nova Ipixuna 3 e Bom Jesus 7. Em tais casos, foi sugerido que a variabilidade era decorrente de sítios com diferentes funções. Isso por que a ausência de determinados atributos estava em geral relacionada a sítios pequenos, de acampamento temporário (ALMEIDA e GARCIA, 2008). É possivel que isso tenha ocorrido mesmo nos grandes sítios. Com base nos dados de densidade lítica e cerâmica, na variabilidade de formas e de atributos decorativos, inferiu-se que a pequena mancha de terra preta (Área II) do sítio Cavalo Branco era uma reocupação pelo mesmo grupo, mas com uma diferente função (ALMEIDA, 2008; ALMEIDA e GARCIA, 2008). 
Algo semelhante pode ser observado no padrão de reocupação dos atuais grupos TupiGuarani da região. Os Araweté, que vivem em áreas de terra firme no interflúvio XinguTocantins tendem a se dispersar, durante o período seco, na forma de pequenos grupos forrageiros, ou trekkers, que produzem estruturas de acampamento provisórios. Parte das estruturas ocorre em antigas áreas de roça, que também podem ser aproveitadas para a criação de uma nova aldeia (VIVEIROS DE CASTRO, 1986: 312).

Diferentemente dos Araweté e de outros grupos da região, como os Tapirapé (BALDUS, 1970; WAGLEY, 1977) que fragmentam suas aldeias, os Ka'apor vivem de maneira muito mais sedentária. As aldeias, localizadas nas proximidades do rio Gurupi, na fronteira Pará-Maranhão, são abandonadas apenas depois de preparada uma nova aldeia. Ainda assim, os Ka'apor construiriam estruturas temporárias em áreas de plantação. Estruturas que se pareceriam com uma pequena aldeia, locais que poderiam servir para uma futura área de habitação (RIBEIRO, 2006: 400).

Outro ponto relacionado aos padrões de reocupação dos grupos Tupi-Guarani etnográficos do sudeste amazônico foi apresentado por Balée. Esse autor indica que os maiores beneficiários do manejo florestal dos Ka'apor não são seus descendentes, mas seus maiores inimigos, os também Tupi-Guarani Guajá, que possuem uma economia dependente das palmeiras presentes em áreas “perturbadas” pelos Ka'apor (BALÉE, 1994: 140).

Se está claro que os sítios da Subtradição Tupinambá da Amazônia são reocupados, pode-se esperar, com base nos dados etnográficos, que alguns dos sítios tenham sido ocupados por grupos diferentes, mas semelhantes. Tal ideia ainda necessita ser mais bem testada, mas ela já foi sugerida em pelo menos um caso (ALMEIDA, 2008).

Outro caso de interesse provém dos também Tupi-Guarani Parakanã ${ }^{24}$, que vivem na terra firme, não muito distante da margem esquerda do rio Tocantins. Esse grupo de dividiu em dois nos anos 1890, um permanecendo fiel a uma economia mais sedentária, baseada principalmente na horticultura (Parakanã Oriental), e o outro (Parakanã Ocidental) adotou um modo de vida mais móvel, abandonando a horticultura, adotando um modo de vida trekker e passando a depender da caça e coleta (FAUSTO, 2001: 59). O grupo Ocidental, então, passou a exercer uma relação de dependência do grupo (inimigo) Oriental, muito semelhante à relação entre os Guajá e os Ka'apor.

24 Os Parakanã são um dos últimos grupos observados utilizando o tembetá lítico, adorno Tupi-Guarani típico de pedra polida, utilizado (principalmente) abaixo do lábio (VIDAL, 1985a). 
Resumindo, é possível indicar que os atuais grupos Tupinambá (falantes do TupiGuarani) do sudeste Amazônico tenderam a ter um complexo de estruturas no entorno de suas aldeias, assim como ocorreu com os Guarani (NOELLI, 1993, 1999-2000) e os Tupinambá do litoral (Assis 1996). Ao que parece, a relação desses grupos Tupi-Guarani com essas estruturas era cíclica, ainda que apenas até certo ponto. O espaço reocupado nunca é igual ao que era antes e, mesmo quando o local é reocupado para uma mesma função, é resultado de uma relação contínua e íntima entre o ser humano e a natureza ${ }^{25}$. Além disso, o fato de que os grupos reocupam não significa que eles não prossigam ocupando, estendendo seus limites territoriais. É provável que a fissão de grupos, como ocorreu com os Parakanã ou com os grupos Tupinambá da costa maranhense do século XVII (ABBEVILLE, 1975[1614]), tenha levado à exploração de novos territórios. Mesmo que os grupos não tenham se fragmentado, um simples e lento crescimento demográfico levaria ao aumento das estruturas temporárias (acampamentos de verão e estruturas ligadas às roças), que poderia aumentar as possibilidades de eventuais mudanças da aldeia e até aumentar o território dominado por esse grupo.

Fica claro que se está descrevendo algo muito semelhante ao que Brochado (1989) denominou de um processo de enxameamento, uma alternativa às propostas migratórias, uma vez que as regiões de onde os grupos saíam não ficavam vazias e sim continuam a crescer até que novos contingentes humanos teriam que sair novamente (NOELLI, 2008b: 34). Um modelo muito mais condizente com uma expansão terrestre do que fluvial-linear.

(...) fato é que essa própria mobilidade (...) irá, por sua vez, condicionar a situação implicada na ideia de "fronteira". Fronteira, bem entendido, entre paisagens e populações, hábitos, instituições, técnicas, até idiomas heterogêneos que aqui se defrontam (BUARQUE DE HOLANDA, 1994: 12).

Ou seja, a etnografia indica que uma mesma área pode ser ocupada de maneira constante por um mesmo grupo de diferentes formas ou por grupos diferentes (talvez nem tão diferentes assim) com uma diversidade de possibilidades funcionais. Arqueologicamente, seria possível partir do tamanho dos sítios para inferir a funcionalidade da sua ocupação. Conforme apontado acima, Simões e Araújo-Costa (1987: 12) indicam que os sítios da fase Tauarí variam de 10 x 20m a 324 x 95m e, nas análises referentes aos projetos de linhas de

25 Não é à toa que o estudo dos grupos Tupi-Guarani serviu como grande parte da base para que Balée e Erickson fundassem a Ecologia Histórica. 
transmissão (SCIENTIA, 2008, 2011), sugerem que alguns sítios chegariam a ser dez vezes maiores que os outros e que um mesmo sítio poderia ser reocupado com distintas funções. Está claro que apenas por meio da escavação de amplas áreas nesses sítios será possível testar essas hipóteses de forma adequada, ainda que tenha sido indicado (ALMEIDA e GARCIA, 2008) que, além do tamanho dos sítios, a densidade de material, o tipo de ferramentas líticas encontradas, o volume e a função sugerida dos vasos (e.g. é provável que vasos para festas rituais não estivessem presentes em acampamentos temporários) podem levar a um nível inicial de inferência.

Os dados cronológicos do sítio Cavalo Branco, que o situam entre os sécs. VIII e XIV, são respaldados pelas datações de outros sítios Tupinambá. Por exemplo, o sítio Nova Ipixuna 3 possui datas de 740+-70 d.C. e 1560+-90 d.C. Essas datas fortalecem tanto o início quanto o final da cronologia do sítio Cavalo Branco. O sítio Bela Vista possui uma única data de 480+- a.C, que diverge desse contexto Tupinambá (ALMEIDA, 2008; SCIENTIA, 2008, 2011). No entanto, essa data não destoa tanto das datas do interflúvio Xingu-Tocantins (listadas adiante). Ainda assim, mesmo que a data do sítio Bela Vista não se confirme, os dados do interflúvio Xingu-Tocantins indicam que há uma grande possibilidade de a cronologia Tupinambá ser mais antiga do que o séc. VIII.

Parece de extrema importância para o tema aqui tratado apontar que o baixo Araguaia (que deságua no baixo Tocantins) e as áreas de terra firme em volta desse rio devem ser vistas como uma ramificação da ocupação Tupinambá nessa região (ALMEIDA, 2010a; cf. KERN et al., 1992). Os trabalhos realizados por Simões (et al., 1973) na bacia do Araguaia e as diferentes coleções cerâmicas provenientes desse rio, encontradas no acervo da Fundação Casa da Cultura de Marabá (Fig. 19), fornecem a base dessa indicação. No entanto, os sítios e a cerâmica desse rio ainda precisam ser descritos e datados.
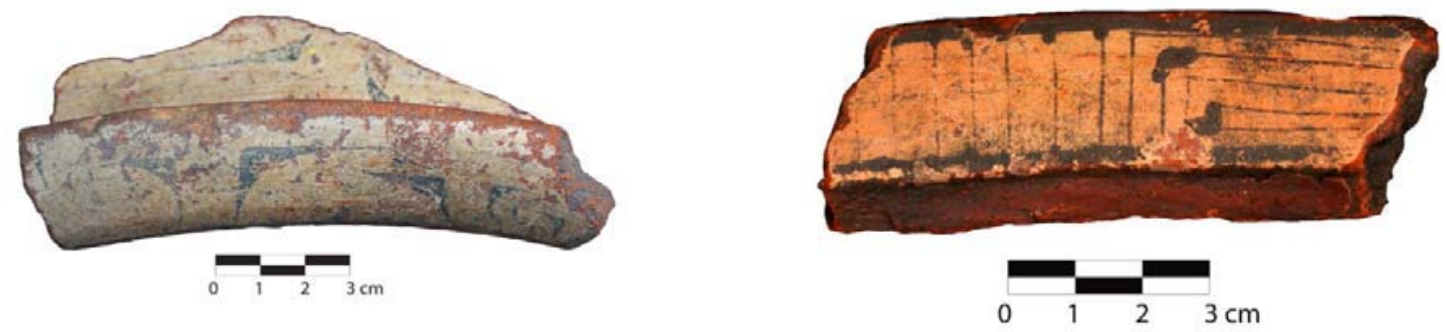

Figura 19: Cerâmica pintada pertencente ao sítio Santa Cruz, localizado no rio Araguaia (foto: Fernando Ozorio de Almeida/ Acervo FCCM). 


\subsubsection{O interflúvio Xingu-Tocantins}

$\mathrm{Na}$ vasta região de interflúvio entre os rios Xingu e Araguaia se encontra uma província geológica formada por vestígios pré-cambrianos de serras devastadas, que cobrem uma área superior a $4.000 \mathrm{~km}^{2}$, conhecida como serra dos Carajás. Essa é uma região bem conhecida arqueologicamente (nos padrões amazônicos), devido a décadas de estudos de licenciamento relacionados às atividades de mineração que ali ocorrem. A serra dos Carajás faz parte do Planalto Dissecado do sul paraense, que é sustentado por uma crosta laterítica formada por metais vulcânicos. Trata-se de um incrível mosaico de grupos geológicos, pertencentes ao complexo Xingu e a grupos distintos do super grupo Itacaiúnas (AB'SABER, 2004; W. OLIVEIRA, 2007: 45-47). Algumas serras possuem altitude superior a 800m acima do nível do mar. Os dois principais rios relacionados à serra são o Itacaiúnas e o Paraupebas (bacia do rio Tocantins).

A vegetação da serra dos Carajás é composta por uma combinação de Floresta Tropical e de cerrado. Os habitantes da serra sem dúvida aproveitaram das vantagens dessa variação de vegetação: desde os primeiros grupos caçadores-coletores (KIPNIS et al., 2005; MAGALHÃES, 2005, W. OLIVEIRA, 2007), passando pelos grupos Tupinambá précoloniais, até os grupos Kaiapó-Xikrin que hoje vivem na região (GARCIA, 2012a; SILVA, 2008).

Desde os anos 1980 até o presente, o Museu Goeldi vem realizando trabalhos de pesquisa na região. Conforme mencionado, nos anos 1960 teria ocorrido a visita do Frei Protásio Frikel à região, cuja coleta de material arqueológico gerou a criação das fases Itacaiúnas e Carapanã por Figueiredo (1965). Esse autor descreveu a cerâmica dessas fases como roletadas, com antiplástico mineral, grande variação na espessura dos potes, presença de decoração pintada (vermelha e branca) ou plástica (corrugados). A fase Itacaiúnas foi considerada parte da Tradição "Tupiguarani”" (SIMÕES, 1972), o mesmo ocorrendo com a fase Carapanã, com a ressalva de que essa fase também possuía algumas características da Tradição Inciso-Modelada (Barrancoide), como a presença de apliques modelados zoomorfos (SIMÕES et al., 1973). O estudo realizado por Garcia (2012a) indicou que essa caracterização da fase Carapanã não se sustenta (vide abaixo).

A cerâmica da serra do Sossego, que também faz parte da serra dos Carajás, foi descrita como predominantemente simples (i.e. sem decoração) e manufaturada com o uso de 
antiplástico mineral. As raras decorações se resumiram a corrugados e motivos incisos e alguns banhos com pigmento vermelho. Alguns adornos zoomorfos também foram observados. Na região, também foi indicada a presença de vasos enterrados debaixo do pacote de terra preta, ainda que não tenham sido denominados urnas funerárias. Em alguns sítios, foram observadas possíveis áreas de depósito de restos cerâmicos (lixeiras). Por fim, foi feita referência à presença de artefatos polidos líticos (lâminas de machado, almofarizes, mãos de pilão) e de uma grande quantidade de sementes (PEREIRA et al., 2008: 52-53).

As mesmas autoras (pp. 53-54) fizeram uma descrição semelhante aos vestígios arqueológicos encontrados na Floresta Nacional Tapirapé-Aquiri (também parte da região da serra dos Carajás). A cerâmica era roletada, possuía antiplástico mineral e decoração predominantemente plástica (e.g. corrugados, ungulados, incisões, espatulados). Também foram mencionados apliques modelados zoomorfos, assim com ferramentas líticas, como lâminas de machado e raspadores lascados. As fotografias e as figuras com a reconstituição dos vasos indicam a presença de vasilhas com contorno composto (um ângulo na parede) ou complexo (mais de um ângulo na parede), muito semelhantes aos vasos arqueológicos da fase Tauarí, do baixo Tocantins.

No entanto, apesar de o material arqueológico encontrado na serra dos Carajás ser muito semelhante ao material do baixo Tocantins, este último aparenta possuir muito mais atributos relacionados ao tratamento de superfície do que o material de Carajás, em especial no campo das decorações pintadas. O que é uma tendência e não uma regra. Uma exceção é o sítio NV-14 (também na área de Carajás), que parece possuir mais da metade dos seus fragmentos cerâmicos com pintura, alguns apenas com um simples banho vermelho, mas outros com elaborados motivos. Esse sítio também possui uma série de possíveis urnas funerárias (uma característica clássica dos Tupinambá do litoral e dos Guarani), assim como uma incomparável amostra (em um contexto amazônico) de vestígios faunísticos (NOVAES e KIPNIS, 2009), que podem gerar ricos dados sobre a dieta desses grupos.

É necessário admitir, no entanto, que até o momento as comparações têm que ficar em um âmbito superficial, uma vez que o material cerâmico da serra dos Carajás ainda não foi analisado intensamente. Ainda assim, esse panorama vem mudando. Por exemplo, os estudos realizados por Garcia (2012a) ofereceram uma grande contribuição para a discussão das cerâmicas pré-coloniais dessa região de interflúvio, uma vez que essa autora retira a fase Carapanã do contexto Tupinambá e a define como uma ocupação anterior à chegada dos Tupi-Guarani, com características plenas de uma cerâmica Inciso-Modelada. 
Essa visão é duplamente produtiva, pois diferencia os dois contextos cerâmicos e indica que os Tupinambá não foram os únicos ocupantes da terra firme. Um dos problemas é uma mistura de atributos na cerâmica de alguns sítios e a falta de pacotes bem definidos em sítios multicomponenciais. Apesar de a cronologia dessa cerâmica mais antiga ainda não estar muito clara, essa mistura de atributos parece indicar que os grupos produtores desse material e os Tupinambá podem ter convivido por algum tempo nessa região. Garcia (2012a: 228) apresenta duas datações de radiocarbono, 1060 a.C. e 160 d.C., para essa cerâmica antiga (Inciso-Modelada).

A cronologia dessa região de interflúvio é bem mais consistente do que a do baixo Tocantins. Além da antiga data publicada por Figueiredo (1965), 280+-80 d.C., para um material Tupinambá do rio Itacaiúnas, há uma data antiga publicada por Simões (1986) para a bacia do mesmo rio (390+-85 d.C.). As datações de termoluminescência obtidas por Pereira (et al., 2008) indicam que a serra do Sossego foi ocupada em um período posterior. As autoras publicam uma data para o século VII (650+-130 d.C.), uma série de datas entre o século XII (1240+-70) e XV (1430+-55) e uma data mais recente, do século XVII (1690+-25 d.C.). É no trabalho de Silveira (et al., 2008) que se encontra uma extensa lista de datações de radiocarbono e termoluminescência. As autoras dividem as datações em três períodos: (I) antigo, relacionado a grupos caçadores-coletores, com datas variando entre 3800 a.C. e 1800 a.C.; (II) intermediário, com datas variando entre 500 a.C. e 500 d.C., e (III) tardio entre 500 d.C. e 1500 d.C. No entanto, não mencionam como se encaixa a ocupação dos Tupinambá nesse quadro cronológico. Problema que foi resolvido por Garcia (2012a), que correlacionou os Tupinambá aos sítios pesquisados por Silveira, por meio de comunicações pessoais com a arqueóloga. De posse desses dados, Garcia conseguiu montar o seguinte quadro cronológico da ocupação Tupinambá do interflúvio Xingu-Tocantins (Tabela 7).

Ao observar a Tabela 7, pode-se notar que há uma cronologia consistente para sítios da Subtradição Tupinambá da Amazônia nessa região de interflúvio, que vai desde o século IV da era cristã até o século XVIII. Apesar de ainda haver uma longa distância da citada data de 480+-20 a.C. do sítio Bela Vista (baixo Tocantins), esse intervalo já é bem menor do que na listagem das datas do baixo Tocantins, ainda que as datações da região de Carajás estejam longe de provar que elas estão corretas. 


\begin{tabular}{|c|c|c|c|c|}
\hline Sítios & Datação d.C. & Método & Hidrografia & Referência bibliográfica \\
\hline Bitoca 1 & 1730 & $\mathrm{TL}$ & Itacaiúnas & Silveira et al. 2008 \\
\hline Estrada & 1690 & TL & Itacaiúnas & Silveira et al. 2008 \\
\hline Bitoca 1 & 1620 & TL & Itacaiúnas & Silveira et al. 2008 \\
\hline Bitoca 1 & 1580 & TL & Itacaiúnas & Silveira et al. 2008 \\
\hline Bitoca 2 & 1550 & TL & Itacaiúnas & Silveira et al. 2008 \\
\hline Bitoca 1 & 1500 & TL & Itacaiúnas & Silveira et al. 2008 \\
\hline Aldeia Xikrin & 1500 & TL & Itacaiúnas & Silva et al. 2007 \\
\hline Bitoca 1 & 1490 & TL & Itacaiúnas & Silveira et al. 2008 \\
\hline P-32 & 1490 & TL & Itacaiúnas & Silveira et al. 2008 \\
\hline Bitoca 2 & 1470 & TL & Itacaiúnas & Silveira et al. 2008 \\
\hline Bitoca 1 & 1450 & TL & Itacaiúnas & Silveira et al. 2008 \\
\hline Bitoca 1 & 1440 & TL & Itacaiúnas & Silveira et al. 2008 \\
\hline Sequeirinho & 1430 & TL & Itacaiúnas & Pereira et al. 2008 \\
\hline Domingos & 1420 & TL & Itacaiúnas & Pereira et al. 2008 \\
\hline Bitoca 1 & 1410 & TL & Itacaiúnas & Silveira et al. 2008 \\
\hline Estrada & 1410 & TL & Itacaiúnas & Silveira et al. 2008 \\
\hline Bitoca 2 & 1400 & TL & Itacaiúnas & Silveira et al. 2008 \\
\hline 4 Alfa & 1390 & TL & Itacaiúnas & Silveira et al. 2008 \\
\hline 4 Alfa & 1360 & TL & Itacaiúnas & Silveira et al. 2008 \\
\hline PA-AT-244 & 1360 & TL & Itacaiúnas & Pereira et al. 2008 \\
\hline Sequeirinho & 1280 & TL & Itacaiúnas & Pereira et al. 2008 \\
\hline Bitoca 2 & 1245 & TL & Itacaiúnas & Silveira et al. 2008 \\
\hline PA-AT-244 & 1240 & TL & Itacaiúnas & Silveira et al. 2008 \\
\hline NV-XVII & 1230 & C14 & Itacaiúnas & Scientia Consultoria \\
\hline NV-XIV & 1200 & C14 & Itacaiúnas & Scientia Consultoria \\
\hline Onça Puma 5 & 1190 & C14 & Itacaiúnas & Scientia Consultoria \\
\hline Bitoca 1 & 1150 & TL & Itacaiúnas & Silveira et al. 2008 \\
\hline NV-XVII & 1030 & C14 & Itacaiúnas & Scientia Consultoria \\
\hline NV-XIV & 1020 & C14 & Itacaiúnas & Scientia Consultoria \\
\hline Bitoca 1 & 1000 & $\mathrm{TL}$ & Itacaiúnas & Silveira et al. 2008 \\
\hline Onça Puma 3 & 920 & C14 & Itacaiúnas & Scientia Consultoria \\
\hline Bitoca 2 & 890 & TL & Itacaiúnas & Silveira et al. 2008 \\
\hline Bitoca 2 & 825 & TL & Itacaiúnas & Silveira et al. 2008 \\
\hline Bitoca 2 & 800 & TL & Itacaiúnas & Silveira et al. 2008 \\
\hline Onça Puma 4 & 760 & C14 & Itacaiúnas & Scientia Consultoria \\
\hline Bitoca 2 & 740 & TL & Itacaiúnas & Silveira et al. 2008 \\
\hline Bitoca 2 & 706 & TL & Itacaiúnas & Silveira et al. 2008 \\
\hline Bitoca 2 & 670 & TL & Itacaiúnas & Silveira et al. 2008 \\
\hline Domingos & 650 & TL & Itacaiúnas & Pereira et al. 2008 \\
\hline Bitoca 2 & 615 & TL & Itacaiúnas & Silveira et al. 2008 \\
\hline Domingos & 550 & TL & Itacaiúnas & Pereira 2009, com. pess. \\
\hline Bitoca 2 & 505 & TL & Itacaiúnas & Silveira et al. 2008 \\
\hline \multirow[t]{2}{*}{ Bitoca 2} & 450 & TL & Itacaiúnas & Silveira et al. 2008 \\
\hline & 390 & C14 & Itacaiúnas & Simões 1986 \\
\hline \multirow[t]{2}{*}{ Bitoca 1} & 356 & TL & Itacaiúnas & Silveira et al. 2008 \\
\hline & 270 & C14 & Itacaiúnas & Figueiredo 1965 \\
\hline
\end{tabular}

Tabela 7: Compilação de datações para sítios da Subtradição Tupinambá da Amazônia na região de interflúvio Xingu-Tocantins (adaptado de GARCIA, 2012a). 
De qualquer forma, essas datas permitem perguntar sobre a "improvável" (vide PROUS, 1992) possibilidade de a região leste da Amazônia ser o berço da expansão dos grupos Tupi-Guarani. Ainda que os dados arqueológicos estejam distantes de sustentar essa hipótese, existem linguistas que pensam o contrário. Mello e Kneip (2006) argumentam que, ao passo que a maioria dos linguistas (e.g. MIGLIAZZA, 1982; RODRIGUES, 1964, 1985; URBAN, 1992, 1996) vê o sudoeste da Amazônia como o provável centro de dispersão dos grupos Tupi, essa região possui apenas um subgrupo da família Tupi-Guarani. Os demais grupos dessa região (sudoeste) são Tupi, não Tupi-Guarani. Por outro lado, a região do baixo rio Tocantins possui 14 grupos etnográficos diferentes de falantes Tupi-Guarani, distribuídos em quatro subgrupos. Isto é, a expansão dos Tupi-Guarani não precisa ter ocorrido no mesmo local onde os grupos Tupi - a maioria dos quais não expandiu - se dispersaram.

Essa hipótese precisa ser considerada com cuidado, uma vez que está longe de ser sólida (cf. HEGGARTY, 2007, para os problemas com a linguística). O problema básico é que as datas do sudeste brasileiro (próximas ao início da era cristã) são mais antigas do que as do sudeste amazônico (cf. CORRÊA, 2009). Outra questão seria explicar o papel dos Guarani nesse cenário. Problema que se repete, em menor grau, no oeste amazônico. Não há grupos Guarani nas proximidades do sudeste amazônico, ao contrário do que ocorre com os Tupinambá do litoral. Faltam vestígios para comprovar uma expansão Guarani a partir dessa região, se é que a saída destes da Amazônia foi uma expansão (cf. Capítulo 7).

Portanto, fica em aberto o questionamento que tal proposta e os dados arqueológicos apresentados levantam: se a diversidade cultural (e.g. MILLER, 2009) e linguística (RODRIGUES e CABRAL, 2012) dentro do tronco Tupi levam os pesquisadores a considerar o sudoeste Amazônico como centro de dispersão dos Tupi, por que a diversidade cultural (e.g. ALMEIDA, 2008; GARCIA, 2012a) e linguística dentro da família TupiGuarani não pode levar pesquisadores a considerar o sudeste amazônico como centro de dispersão dos grupos dessa família?

\subsubsection{O baixo Xingu}

Assim como o rio Tocantins, a nascente do rio Xingu se encontra no Planalto Central brasileiro. O rio Xingu flui desde a serra do Roncador por quase $2.000 \mathrm{~km}$ até a ilha do 
Garupá, no rio Amazonas. O baixo trecho do rio tem início na foz do rio Iriri, localizado na margem esquerda do Xingu. A vegetação é basicamente de Floresta Tropical.

Os estudos arqueológicos publicados até hoje sobre o baixo Xingu provêm das pesquisas realizadas por Celso Perota nos anos 1970 (1977; 1978; 1992; Anexo 4). Os sítios considerados "Tupiguarani” (Subtradição Tupinambá da Amazônia) foram apenas um dos vários agrupamentos arqueológicos identificados por Perota. A mais antiga das classes identificadas pelo autor é a da Tradição Mina. Essa Tradição, encontrada no baixo Amazonas e no litoral paraense e maranhense, possui datas que ultrapassam 3000 a.C. (BANDEIRA, 2008; SILVEIRA e SCHAAN, 2005; SIMÕES, 1981). Para o rio Xingu, Perota obteve duas datas de radiocarbono (1220+-120 a.C. e 300+-70 d.C.). Por outro lado, a Tradição IncisoPonteada (fase Curuá) possui uma conologia mais recente: 1675+-75 d.C. e 1775+-55 d.C., ainda que a descrição deixe transparecer que outras datas foram deixadas de fora (PEROTA, 1992: 213-15).

Perota também identificou sítios pertencentes à Tradição Polícroma da Amazônia a jusante da primeira grande cachoeira rio acima do rio Xingu. Essa Tradição, que não é citada nas descrições da região de interflúvio Xingu-Tocantins, tece 12 datas de radiocarbono publicadas por Perota (pp. 212-13), situadas entre 900+-50 d.C. e 1650+-60 d.C.

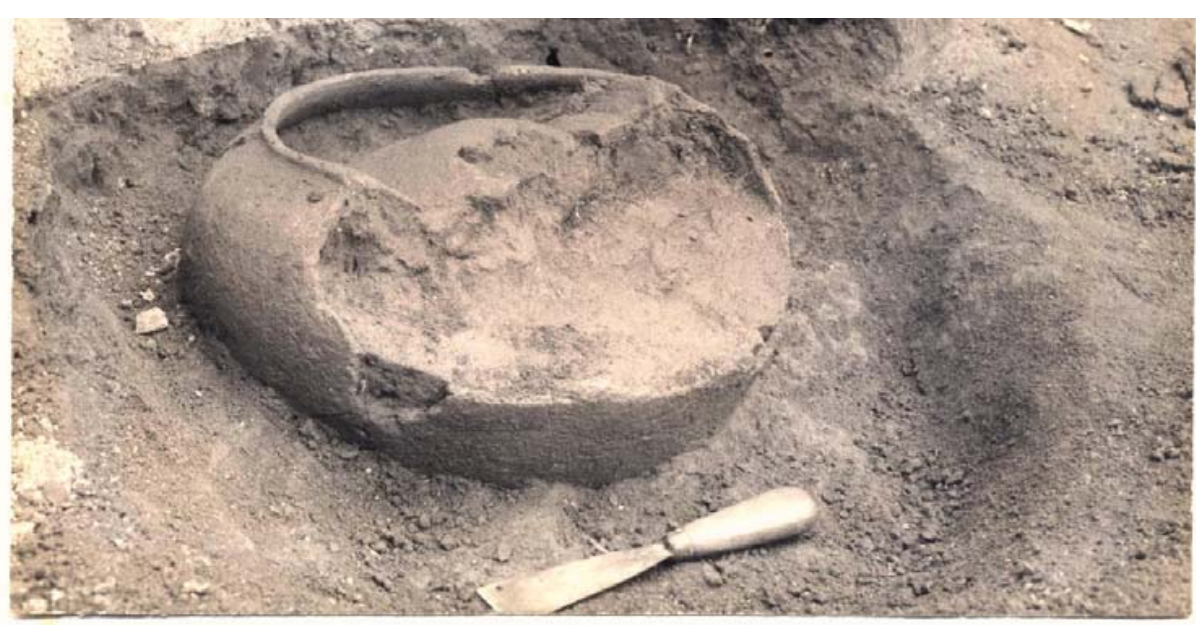

Figura 20: Urna funerária escavada no baixo Xingu (sítio PA-AL-19) (fonte: PEROTA, 1978).

Segundo Meggers (et al., 1987), haveria uma repetição do contexto do baixo Tocantins no baixo Xingu, onde a cachoeira mais a jusante desses rios separaria a Tradição Polícroma da Tradição "Tupiguarani”. 
No rio Xingu, a Subtradição Tupinambá é representada pelas fases Arara e Pacajá. A cerâmica dessa fases possui antiplástico mineral, muitas vezes com um alisamento de superfície grosseiro, decorações corrugadas e pintadas e uma grande variedade de formas cerâmicas $^{26}$ (Perota 1992: 215). A Tradição Polícroma, por sua vez, é representada pelas fases Independência e Cacarapí. A cerâmica dessas fases seria mais sofisticada do que a das fases Tupinambá, com um tratamento de superfície mais refinado e uso de caraipé e cauixi como antiplástico. Dentre as formas observadas, Perota indica a presença de bordas planas, que talvez nada mais sejam do que as flanges labiais recorrentes na Tradição Polícroma. Essas fases também seriam caracterizadas por uma rica variedade de decorações pintadas (em vermelho e preto) e por decorações plásticas, com destaque para os motivos incisos e apliques modelados (Perota 1992: 212-13).

Tendo essas descrições em vista, seria interessante - com base na experiência semitraumática do baixo Tocantins - perguntar sobre a caracterização da Tradição Polícroma no baixo Xingu? Nesse sentido, havia o objetivo de analisar as fases Independência e Cacarapí, junto com as coleções Tauá do baixo Tocantins. No entanto, ao contrário do que foi pressuposto, o material dessas fases não se encontrava no Museu Emílio Goeldi, e sim no IPHAN do Espirito Santo, levado por Perota. Fato que tornou a tarefa comparativa proposta mais complexa.

Como trabalhar com esse suposto material TPA do baixo Xingu, se a própria classificação TPA está sendo questionada? Na ausência de uma solução palpável para esse problema, resta apontar que os levantamentos realizados por Silva et al. (2011), a serem analisados por Garcia (2012b), sobre a Terra Indígena Koatinemu (baixo Xingu), apontam uma cerâmica com decoração Inciso-Modelada (incluindo filetes ponteados) extremamente semelhante à encontrada na fase Tauá, com a diferença de que a cerâmica do baixo Xingu parece apresentar ainda mais características da Subtradição Tupinambá (e.g. corrugados).

Tais apontamentos permitem especular que há uma relação entre as fases "Polícromas" do baixo Xingu (Independência e Cacarapí) com as "Polícromas" do baixo Tocantins, o que, por consequência, colocaria em dúvida a inserção dessas fases xinguanas na Tradição Polícroma da Amazônia.

Pertencentes ou não à Tradição Polícroma, pode-se pensar em uma eventual relação entre as fases Independência e Cacarapí e os Yudjá-Juruna, grupo Tupi pertencente à família 
linguística homônima que é historicamente (até o século XVII) ligada ao contexto do baixo Xingu (e.g. CODREAU, 2009 [1897], NIMUENDAJÚ, 1948c). A cerâmica desse grupo possuiria os seguintes atributos semelhantes a essas fases: antiplástico caraipé, fino tratamento de superfície e pinturas policrômicas ${ }^{27}$ (OLIVEIRA e GALVÃO, 1969). Essa cerâmica possuiria uma forma de vaso tipicamente Tupi-Guarani, uma vasilha rasa com ombro, semelhante a um cambuxi-caguabá Guarani, que seria utilizada para o consumo de água e fermentados (Fig. 21). No entanto, alguns desses vasos com ombro dos Yudjá possuiriam apliques modelados zoomorfos, o que destoa dos vasos Tupi-Guarani em geral, mas semelhante à Tradição Tauá. Além disso, a coleção apresentada por Oliveira e Galvão (1969) também possui uma série de formas que se mesclam com essas figuras zoomorfas, parecendo muito mais com uma cerâmica Waujá - grupo Arawak do alto Xingu (BARCELOS NETO, 2008) - do que Tupi-Guarani (cf. influências Arawak, nos Capítulos 6 e 7).

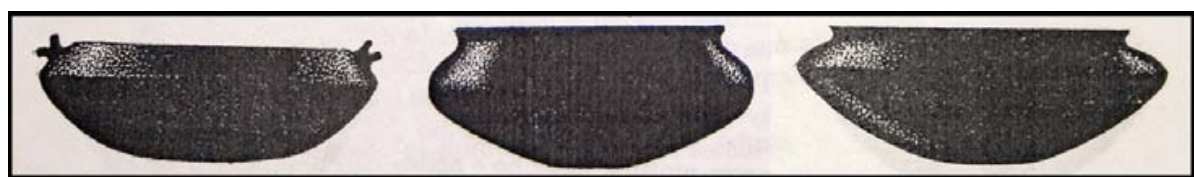

Figura 21: Formas Yudjá-Juruna, semelhantes às recorrentes formas Tupi-Guarani com ombros, mas com o aplique modelado, o que às aproxima da fase Tauá, que também possui essas formas acompanhadas dessas decorações (fonte: OLIVEIRA e GALVÃO, 1969: 9).

Vidal (1985b) faz uma análise da arte gráfica dos Juruna-Yudjá e destaca a "alta elaboração gráfica da pintura tracejada no corpo, com tinta de jenipapo e, com outras tintas, na cerâmica, tecidos e outros artefatos" (p. 75). A autora indica motivos em grega aplicados sobre as costas dos homens, mulheres e crianças (p. 76). Da mesma forma, a autora aponta um padrão sinuoso em forma de "S", que seria comum tanto na pintura corporal quanto na cerâmica (p. 76). Os demais padrões de pintura corporal observados por Vidal não seriam encontrados nos demais artefatos (pp. 76-79). Por fim, indica que "a cerâmica Juruna recebe sempre engobo em barro vermelho sobre o qual se aplica um pontilhado em barro branco que ladeia os tracejados em negro" (p. 82).

Resumindo, os poucos dados sobre a cerâmica Juruna-Yudjá, e sobre a arte gráfica desse grupo em geral, apontam alguns elementos em comum com a cerâmica da Tradição Tupi-Guarani (vasilha rasa com ombro e decoração corporal em grega), alguns elementos TPA (o antiplástico de caraipé e a policromia) e outros elementos dissonantes de ambas essas 
Tradições (apliques zoomorfos e demais tipos de motivos pintados), o que impossibilita qualquer outra conclusão que não seja que esse grupo possui um Estilo cerâmico híbrido, que parece ser condizente com as fases Independência e Cacarapí e análogo à heterogeneidade encontrada no baixo Tocantins, na fase Tauá.

O que não impede a exploração dos Juruna-Yudjá e das semelhanças entre Tupi e Tupi-Guarani. Por exemplo, tanto os grupos Juruna-Yudjá como os Tupinambá (da Amazônia e do litoral) são conhecidos por serem grupos belicosos e canibais que costumavam devorar seus inimigos (LIMA, 2005). No caso dos Juruna-Yudjá, o ritual antropofágico não ocorria apenas com a degustação do inimigo Tupinambá (FERNANDES, 1963, 1970; VIVEIROS DE CASTRO, 1986, 2002), mas também com a ingestão de bebidas alcoólicas (o cauim), que também permitiriam ao indivíduo Juruna-Yudjá viver, morrer e se tornar o outro (LIMA, 2005: 255). A ingestão de bebidas fermentadas está ligada às relações de alteridade e predação que formam a base das sociedades Tupi-Guarani, assim como (aparentemente) de outros grupos Tupi. A cauinagem é o "palco para uma multiplicidade de gestos e palavras que celebram comportamentos tidos como muito antigos (...)” (LIMA, 2005: 286).

Por outro lado, Lima observa diferenças cosmológicas entre os Yudjá e os Tupinambá. Por exemplo, os Yudjá possuem duas “sociedades dos mortos", e os Tupinambá só possuem uma. A presença do urubu rei na cosmologia Yudjá parece trazer esse grupo mais para perto de grupos amazônicos não relacionados linguisticamente, como os Tapajó (cf. GOMES, 2001, 2002, 2005, 2007), do que dos Tupinambá. Se a comparação YudjáTupinambá indica que há semelhanças entre os diferentes grupos Tupi, ela também indica que há diferenças. Não se sabe o quanto as diferenças linguísticas se espelham em diferenças culturais. Ainda assim, a comparação dá algumas pistas sobre as comparações entre Tupi e Tupinambá e entre várzea e terra firme.

Quando Viveiros de Castro (1986) comparou os Araweté com os Tupinambá do litoral, argumentou que, com exceção da cosmologia, tudo parecia variar entre esses grupos. Se esse de fato é o caso, seria possível argumentar, seguindo um tipo de fato social total ${ }^{28}$ (MAUSS, 2003 [1925]; cf. RIVIÉRE, 1995: 18), que esse relevante "ponto em comum" deve ter influenciado outros aspectos dessas sociedades. Isso fica claro quando se olha para os Asuriní, grupos Tupi-Guarani que habitam o interflúvio Xingu-Tocantins. Os objetos rituais

28 Em homenagem à professora Márcia Angelina Alves. 
dos Asuriní (aqueles envolvidos em assuntos cosmológicos) carregam desenhos geométricos, como o vaso cerâmico usado para tomar as bebidas fermentadas, o chocalho xamânico e a flauta. Armas, como as flechas, também recebiam esses tipos de desenho. Os motivos podiam aparecer tecidos ou pintados na cerâmica e nos corpos (MÜLLER, 1985; 1990). O corpo humano é para os Asuriní o suporte natural para os motivos pintados e incisos, assim como ocorre com os Tupinambá do litoral (ABBEVILLE, 1975 [1614]; ÉVREUX, 2002 [1615]), e essa nomenclatura é facilmente transferível do corpo humano para o pote cerâmico (MÜLLER, 1985; 1990). As incisões e o sangue decorrente delas, análogos à pintura vermelha, são símbolos que remetem ao sacrifício de inimigos e conferem ao matador um status de prestígio no grupo, ao mesmo tempo que o purificam (MÜLLER, 1985; 1990; FERNANDES, 1970: 306).

Os motivos geométricos possuem grande variabilidade e já foram foco de estudos intensivos de outros autores (e.g. PROUS, 2005; 2010; LIMA, 2005; 2010), bastando um exemplo para o momento. O motivo conhecido como grega é com frequência encontrado na cerâmica Asuriní, Guarani e Tupinambá (do litoral e da Amazônia). Müller (1990: 250) aponta que esse motivo remete ao corpo humano (devorador e devorado no ritual antropofágico), uma união com os heróis míticos do passado (Fig. 22). Uma fusão muito semelhante à observada nos Araweté, nos quais o matador, o morto e os deuses míticos se encontram e amalgamam (VIVEIROS DE CASTRO, 1986) em um clímax ritualístico intensificado por fermentados alcoólicos, o que só ocorre no momento em que as linguagens verbais, simbólicas e indéxicas convergem (cf. Capítulo 7). A cultura material possuiria importantes funções nesse contexto. É de esperar que esse ritual seja um pano de fundo perfeito para que determinados objetos exibam o lado mais comunicativo do seu Estilo, profundamente relacionado aos processos de integração social (WOBST, 1977; cf. WIESSNER, 1983, 1991). Essa função estilística encontrada nos artefatos (incluindo o próprio corpo) comunicaria uma espécie de percepção sintética dos diálogos entre as sociedades Tupinambá (e Tupi-Guarani em geral) o exterior, seja ele o inimigo ou um mundo cosmológico: "o código visual comunica a compreensão e percepção existencial que é consciente em um nivel que escapa o discurso verbal pela simples razão de ser impossivel verbalizar tudo de uma vez só" (LAGROU, 2007: 126). 


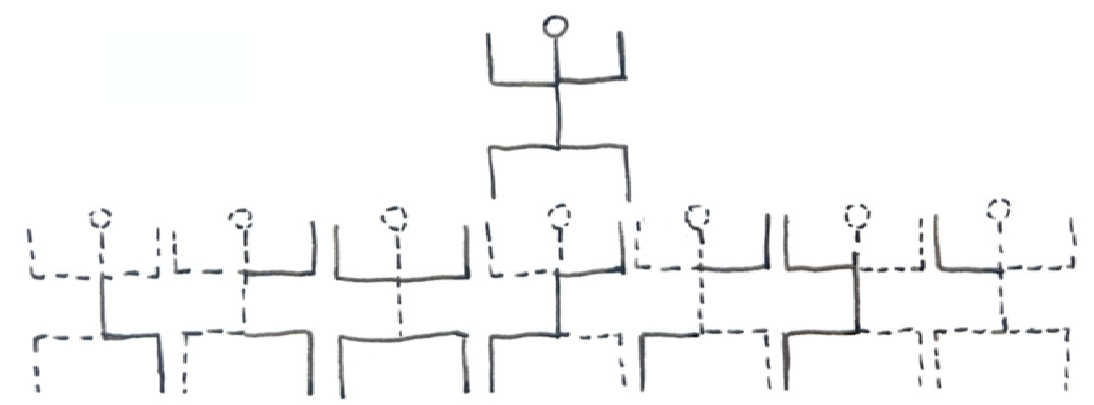

Figura 22: Adaptação da desconstrução da grega feita por Berta Ribeiro (1989) mostra sua relação com a figura humana.

Resumindo, se a antropologia mostra que os conceitos de alteridade e predação são os pilares das sociedades Tupinambá, e que esses pilares se encontram em sua plenitude durante o ritual antropofágico que caracteriza esses grupos, então é nos artefatos relacionados a esses rituais que os arqueólogos devem concentrar seus esforços. Pelo menos os que desejam realizar uma discussão pan-Tupi(nambá). Seguindo esse raciocínio, se é a intenção deste estudo perguntar qual a relação entre os Tupinambá e os grupos da Tradição Polícroma da Amazônia, então se deve perguntar se havia nos grupos produtores dessa cerâmica artefatos com função comunicativa (ritualística) semelhante à encontrada nos grupos Tupinambá. Voltaremos a esse ponto (Capítulo 7).

\subsubsection{O rio Tapajós}

O rio Tapajós é o último grande rio amazônico, nesta caminhada leste-oeste pelas terras firmes da Amazônia, que se origina no Planalto Central brasileiro. Devido à baixa quantidade de informações que esse rio possui sobre as ocupações de grupos Tupi-Guarani, decidiu-se por inserir o rio todo na discussão, desde a confluência entre os rios Juruena e Teles Pires até a sua boca, no rio Amazonas.

Essa diminuta fonte de informações sobre os Tupinambá da Amazônia ocorreu apesar de haver um grande número de publicações sobre a arqueologia do rio. Isso por que o foco dos estudiosos (e.g. GOMES, 2002, 2007; PALMATARY, 1960; STENBORG et al., 2012) era o contexto tapajônico, o dos grupos que habitavam a foz do rio Tapajós à época das primeiras excursões de europeus pelo rio Amazonas. A Tradição Polícroma, que é encontrada 
em todos os demais grandes rios da bacia do Amazonas, quase não é mencionada no rio Tapajós, o que confere à região um status de hiato espacial nas áreas de ocupação desses grupos ribeirinhos (NEVES, 2008, 2012). Fato que pode ser resultante de uma baixa quantidade de estudos em áreas mais distantes da boca desse rio ${ }^{29}$.

Os Kaiabi são um grupo de língua pertencente à família Tupi-Guarani que hoje habita áreas dos rios Xingu e Tapajós (Teles Pires), mas considera uma área ao sul do Tapajós (no nordeste do atual Estado do Mato Grosso) sua terra natal (SILVA e STUCHI, 2010: 52). Berta Ribeiro relata que os Kaiabi aprenderam a técnica da tecelagem sarjada (twilled) dos Juruna, mas não adotaram a mesma padronagem de motivos "certamente porque ela é privativa de outro contexto cultural" (1989: 49), mas transpuseram os desenhos altamente elaborados que possuíam para a cestaria. Fica a dúvida sobre se esses desenhos eram realizados na cerâmica Kaiabi (aparentemente não). Os Kaiabi também servem de exemplo do modo Tupi-Guarani de explorar o território, com a predileção por lugares que já haviam sido ocupados para a implantação de novas aldeias, áreas de roça e acampamentos temporários (SILVA e STUCHI, 2010: 56-57).

O alto Tapajós é pouco conhecido arqueologicamente. Há pouco tempo, no entanto, em companhia de Vinícius Honorato, Bruna Rocha (2012: 21-24) levantou 24 sítios e escavou quatro na região, nas proximidades da atual cidade de Itaituba. Apesar de ter realizado apenas uma análise preliminar do material, calcada em especial na análise dos tratamentos de superfície das peças (ou decorações), a autora chegou a conclusões interessantes. Dentre essas conclusões, a mais relevante para o presente estudo provém da análise do sítio Terra Preta do Mangabal. Esse sítio não possui o mesmo tipo de decoração Inciso-Ponteado-Modelado dos outros dois sítios, mas uma recorrente decoração losangular que parece possuir analogia direta com a decoração corporal observada com frequência nos Munduruku.

Essa possível cerâmica Munduruku seria também caracterizada por possuir antiplástico mineral, por vezes acompanhado de cauixi, uma queima em geral oxidante (superfícies claras), espessura muito fina (em torno de $5 \mathrm{~mm}$ ), apliques modelados e decoração ungulada. Os motivos incisos seriam sempre realizados na face externa do vasos. Os lábios possuiriam, por vezes, decoração serrilhada (ROCHA, 2012: 35).

29 Uma exceção interessante pode ser encontrada em um artigo publicado por Roosevelt (2009), no qual a autora indica a existência de sítios com cerâmica vinculada à TPA no baixo Tapajós. No entanto, esses sítios ainda não foram estudados, não havendo qualquer dado sobre a cerâmica ou a cronologia e havendo sempre o risco de confusão do material cerâmico com o material policrômico Tapajônico. 
A autora aponta que a posição dessa possível cerâmica Munduruku, na parte superior do pacote de terra preta, pode indicar que a ocupação de integrantes desse grupo, nesse sítio, seria subsequente a uma ocupação anterior, estendendo a predileção Tupi-Guarani e TPA pela reocupação de locais para os Munduruku (p. 51).

Os Munduruku, junto com os Kuruáya (baixo Xingu), são os únicos representantes da família Munduruku, uma das dez famílias Tupi (não Tupi-Guarani), e são conhecidos por serem canoeiros, assim como os Juruna-Yudjá. A partir do final do século XVIII ${ }^{30}$, os Munduruku manejaram alianças benéficas com os colonos neo-brasileiros - em principio benéficas para ambos os lados - que os levaram a combater lado a lado inimigos comuns (e.g. os Mura). Assim, nesse período que se encerra com a Guerra da Cabanagem (anos 1830), os Munduruku foram um dos poucos grupos indígenas que não encolheram ou desapareceram demograficamente devido ao contato com os neo-brasileiros. Pelo contrário, se expandiram por grandes extensões dos rios Tapajós, Madeira, Xingu e Amazonas (ORTON, 1948).

Os Munduruku possuíam como principais inimigos outros grupos Tupi, tais como os Mawé (Sateré-Mawé). Ao que parece, os Mawé eram ecologicamente distintos dos Munduruku por ocuparem áreas de terra firme (NIMUENDAJÚ, 1948). Bates (2009 [1873]: 144) defende que esses dois grupos já foram o mesmo e teriam se separado recentemente, o que levaria a pensar em um fenômeno semelhante ao dos Parakanã e dos Ka'apor com os Wajá. Hipótese de difícil confirmação, apesar de ambos os grupos serem conhecidos pelo hábito de colecionar cabeças de inimigos, o que não ocorre nos grupos Tupi-Guarani. Se a predação e a alteridade (a predação ocorre de preferência com um grupo semelhante) se repetem ao sair do contexto Tupi-Guarani para o macro contexto Tupi, a forma com que essa predação ocorre parece variar.

Os Mawé servem de exemplo de um grupo Tupi "sob suspeita". Isso porque autores como Susnik (1975) e Mano (1996) acreditam que esses grupos podem ter sido tupinizados. O último autor indica que o etnônimo Mawé se refere a uma série de grupos que na época colonial estavam espalhados pela não tão restrita área entre as bocas do rio Madeira e Tapajós (e.g. os Andirazes, os Maraguá, os Sapupé) (pp. 34-35). Mano traça alguns paralelos com os Tupi-Guarani, como a arte plumária e o arco (mas não as flechas). Por outro lado, o formato redondo das antigas casas Mawé, a presença da zarabatana, a cestaria em espiral, a

30 Segundo Menéndez (1981/82: 358) “a relação Munduruku-branco caracteriza-se pelas contínuas hostilidades até 1795. A paz com o branco não foi inconveniente para o processo de expansão desses indígenas, que continuou até alcançar seu clímax na primeira metade do século XIX. (...). A partir de 1795, os Munduruku passam a ser a 'ponta de lança' para a ocupação da área pelo branco." 
mumificação por dissecação dos cadáveres e o uso do pariká, indicariam a presença de elementos Karib e Arawak: “(...) pode-se efetivamente dizer agora que os Mawé se classificam melhor na categoria Tupi impuro ou mesclado" (p. 45). A hipótese levantada pelo autor é a de que os Mawé seriam descendentes dos Tupinambarana (os falsos Tupinambá), grupos diversos que "sofreram um processo de tupinização e que por fim acabaram se organizando em torno de normas e instituições comuns" (p. 42). Curiosamente, o autor aponta que "é ilustrativo lembrarmos o fato dos Mawé, após mais de trezentos anos de contato ininterrupto, mantêm sua identidade étnica a um lado aglutinadora de toda a sociedade e, por outro, excludente a todas as outras sociedades, inclusive a brasileira" (p. 58). Os seja, uma série de grupos (supostamente) tupinizados em um curto período de tempo de repente encontra uma unidade étnica que até então não existia e se mantém fiel aos valores adquiridos pelos próximos séculos. Não faz sentido. Parece que o primeiro erro cometido por Mano foi o de fazer uma comparação entre os Mawé (Tupi, não Tupi-Guarani) e os grupos Tupi-Guarani, como se houvesse uma unidade cultural para todo o agrupamento macro Tupi, o que ainda está longe de ser identificado. O fato de os Mawé serem predominantemente de terra firme também vai contra a possibilidade de esses grupos terem sido tupinizados de forma rápida, já que o acesso a eles é mais difícil. Um quadro mais coerente seria que os Mawé manteriam intensos contatos, desde o período pré-colonial, com os grupos que ocupavam as margens dos grandes rios, entre eles grupos Arawak e Karib, que influenciaram os Mawé tanto em aspectos linguísticos, quanto em outros aspectos culturais (como os listados acima). Vale apontar que os Mawé são mais um grupo Tupi sobre cuja cerâmica quase não há informação. A única referência, mais uma vez, vem de Nimuendajú (1948d), que aponta fragmentos escuros e simples. $\mathrm{O}$ mesmo autor também encontrou uma série de urnas funerárias no rio Maués-Açú que podem ser relacionadas a esse grupo. A descrição também é de um material bastante simples:

"Em Maués, as bordas das inúmeras urnas funerárias são encontradas na
superficie da principal rua do local. A maior parte destas possui diâmetro superior
a $70 \mathrm{~cm}$. O chão aqui está tão batido que mal vale a pena realizar a escavação,
ainda mais porque elas são grosseiras e sem decoração, de acordo com os
habitantes locais (Nimuendajú, 2004: 158, nossa tradução)".

O fato de os Munduruku e os Mawé não falarem línguas da mesma família linguística parece argumentar contra a hipótese de uma separação recente de ambos ${ }^{31}$. Quase todos os 
grupos Tupi da várzea amazônica (Munduruku, Kokama-Omágua e Yudjá) possuem línguas ininteligíveis entre si, apesar de serem do mesmo tronco linguístico. Isso pode significar que os grupos Tupi das margens dos grandes rios amazônicos vivenciaram histórias mais dinâmicas. Dinâmicas que pressionaram a língua, e provavelmente outros aspectos culturais, a se modificar de forma muito mais rápida da que ocorreu com os (muito mais coesos) Tupinambá da Amazônia, mais isolados na terra firme (Capítulo 6). Os Kokama-Omágua do alto Amazonas, por exemplo, apesar de possuírem semelhanças léxicas com a família TupiGuarani, possuíam morfologia, fonologia e sintaxe muito mais próximas de uma matriz Arawak (CABRAL, 1995; CABRAL e RODRIGUES, 2003)

Outro ponto que ajuda a compreender o quão complexa é a problemática TupiTupinambá vem do fato de que a única grande expansão Tupi do período colonial (além da dos Munduruku) foi a da própria língua Tupi-Guarani. Essa foi a principal língua colonial na bacia amazônica até o fim do século XIX, na forma simplificada de uma língua geral, o Nheengatu (BORGES, 1994), e acabou por adentrar regiões que talvez nem mesmo os Tupinambá penetraram, como o rio Negro (e.g. RIBEIRO, 1995: 19).

\footnotetext{
Uma aporia Kokama-Omágua: o debate sobre os Kokama-Omágua esteve no cerne das recentes discussões sobre a relação TPA-Tupi-Guarani. Ele é encontrado no debate entre Noelli (1996a, 1996b) e Urban (1996), no qual este (Urban) também (como Cabral) sugere uma tupinização dos Omágua. Eduardo Neves, que em determinado momento mostrou dúvidas com relação aos Omágua falarem Tupi-Guarani (HECKENBERGER et al., 1998), recentemente (Neves 2012) adotou uma postura diferente ao indicar que a pressão colonial portuguesa até meados do século XVII não teria adquirido força suficiente para inserir uma língua geral em áreas longínquas como o alto Amazonas. Como os argumentos de ambos os lados parecem lógicos, e como não há mais Omáguas falantes de Tupi-Guarani, a questão é de difícil solução.
}

O que parece se delinear, até aqui, é um aparente distanciamento entre os grupos Tupi, não Tupi-Guarani, da Tradição Polícroma da Amazônia. Nos três exemplos observados até aqui (Mawé, Juruna e Munduruku), apenas os Juruna-Yudjá apresentam a possibilidade de possuir cerâmica policrômica, mas nesse caso parece haver uma semelhança maior com estilos Tupi-Guarani e Inciso-Modelados do que com a cerâmica TPA. Claro que os dados são muito escassos, e que a cerâmica simples dos Mawé pode ser decorrente de um enfraquecimento da produção desse tipo de utensílio em um período pós-contato. A análise das formas, programada para o próxima etapa de estudos de Bruna Rocha, também se torna fundamental para a compreensão dessa suposta cerâmica Munduruku. Resta esperar que a abordagem dos outros grupos Tupi, no próximo capítulo, traga mais clareza à questão. 
A disposição das aldeias é outro ponto que pode ser discutido a partir dos Munduruku. Arnaud (1974) indicou que os Munduruku organizavam suas aldeias de forma circular, assim como os grupos Jê do Brasil central. No entanto, durante o período colonial, foi observado que alguns Munduruku passaram a organizar sua aldeia de forma semelhante à das vilas neobrasileiras da região. Fenômeno muito parecido com o observado com os Tenetehara (TupiGuarani do interior do Maranhão). Esses grupos costumavam arrumar a aldeia de maneira semelhante ao dos vizinhos Timbira (também Jê), que predominavam nessa região. Pouco depois da instalação da vila de Barra do Corda, localizada próximo à aldeia Tenetehara, decidiram imitar a disposição em linhas paralelas das casas dessa vila. Fato que foi ironizado pelos Timbira, que consideravam tal mudança impensável (LADEIRA, 1983).

Os dados etnográficos apontam uma falta de padrão na aldeia Tupinambá. Viveiros de Castro (1986: 275), ao comparar as aldeias circulares do Brasil central com a aldeia Araweté, indica que essa se parece mais com uma favela. A mesma sensação de aleatoriedade com relação à aldeia dos Tupinambá da Amazônia foi descrita por autores como Gallois (1986), em relação aos Waiãpi, e Vidal (1983) e Fausto (2001), em relação aos Parakanã, e está implícita nas descrições feitas por Ribeiro (2006) e Andrade (1992) dos grupos Ka'apor e Asurini do Tocantins, respectivamente. Os Asurini do Xingu, por sua vez, habitariam uma única casa grande (SILVA, 2000).

Os dados arqueológicos sobre os sítios Tupinambá da Amazônia indicam que a mesma falta de padrão pode ter ocorrido nos sítios pré-coloniais. A análise da distribuição do material cerâmico dos sítios do baixo Tocantins indicou que apenas um sítio (Bom Jesus 2) possuía uma possível distribuição circular de material. Nos demais sítios Tupinambá, a distribuição do material não obedeceu a nenhum padrão. Ao contrário do que foi observado nos sítios não Tupinambá analisados no interior maranhense, que possuíam padrão circular (indício de que copiavam elementos do contexto Jê Timbira que os circundava). Curiosamente, o sítio Grajaú, um sítio Tupinambá estudado nesse contexto (Timbira?) maranhense possuía um padrão circular. Assim como os Tenetehara imitavam o padrão de aldeia dos Timbira e depois dos neobrasileiros e como os Tapirapé (Tupi-Guarani do Brasil central) parecem ter imitado seus vizinhos Jê, o grupo Tupinambá que habitou o sítio Grajaú pode ter imitado a disposição circular dos grupos de entorno ${ }^{32}$ (ALMEIDA, 2008; SCIENTIA, 2008).

\footnotetext{
${ }^{32}$ Fora da Amazônia, os sítios Tupi-Guarani escavados por Pallestrini (1972/73, 1975) no vale do Paranapanema (São Paulo) também apresentam manchas randômicas de sedimento escuro.
} 
Viveiros de Castro (1986) defende que essa qualidade metamórfica dos Tupinambá está ligada à sua visão de mundo voltada para fora (para o inimigo, para o outro), em oposição aos grupos Jê, cuja estrutura social é baseada em oposições simétricas que são, e necessitam ser, representadas na disposição da aldeia. Questões que indicam que a tradicional aldeia circular Tupinambá costeira, encontrada nas xilogravuras dos cronistas (e.g. STADEN, 1974; cf. ASSIS, 1996; MÉTRAUX 1948a), não pode ser uma premissa aceita sem questionamento nos estudos arqueológicos.

Voltando aos Munduruku, seria relevante apontar as urnas funerárias encontradas em uma aldeia desse grupo localizada no rio Cururú, no alto Tapajós. As urnas, escavadas por Frikel logo abaixo de um pacote de $50 \mathrm{~cm}$ de terra preta e analisadas por Hilbert (1958), foram utilizadas para enterros secundários. Apesar de $95 \%$ do material cerâmico terem sido considerados simples, Hilbert observou a presença de pintura vermelha e relatou a menção de Frikel à presença de fragmentos de pintura vermelha sobre engobo branco. Hilbert indica que as urnas funerárias lembravam tanto as dos Tupinambá do litoral quanto as dos Guarani e sugere que elas podem ter sido feitas pelos grupos Parintintin, grupos Tupi-Guarani que habitavam a região do alto Tapajós antes de terem sido expulsos da área pelos Munduruku, já no período colonial.

A presença dos Kagwahiva, subgrupo Tupi-Guarani ao qual pertencem os Parintintin, a montante das primeiras cachoeiras do rio Tapajós, é o último ponto a ser explorado nesse capítulo (e retomado no próximo). Nimuendajú (1948a: 283) indica que os Kagwahiva seriam um grande grupo coeso antes de serem expulsos da região pelos Munduruku. Durante o processo que levou a essa expulsão, os Kagwahiva teriam se fragmentado em diversos pequenos grupos que teriam migrado (por terra, ao que parece) em direção à bacia do rio Madeira, se assentando em partes das bacias dos rios Ji-Paraná e Marmelos (p. 284). Proposta que será problematizada no próximo capítulo.

\subsection{Discussão}

À época da chegada dos portugueses ao Brasil, havia grupos produtores de cerâmica da Tradição Polícroma da Amazônia em várias partes da Amazônia, como no alto Madeira (capítulos 3 a 6), a Amazônia central e, supostamente, nos baixos Xingu e Tocantins. No mesmo momento, os Guarani ocupariam o sul do país e áreas de entorno, na Argentina, 
Paraguai, Uruguai e Bolívia, e os Tupinambá do litoral ocupariam grande parte da costa brasileira. Durante mais de um século, inúmeros pesquisadores tentaram compreender como os grupos pertencentes à família Tupi-Guarani se expandiram por áreas tão vastas (NOELLI, 1996a; SUSNIK 1975). Alguns deles, como Brochado (1984, 1989) e Lathrap (1970), buscaram relacionar esses grupos Tupinambá e Guarani à Tradição Polícroma da Amazônia.

Neste capítulo, foi realizada a apresentação de um novo e politético agrupamento dentro da família linguística e da Tradição arqueológica Tupi-Guarani. Tratam-se dos Tupinambá da Amazônia (Subtradição Tupinambá da Amazônia). Essa Subtradição está ligada aos grupos falantes de línguas Tupi-Guarani do sudeste Amazônico. A denominação Tupinambá da Amazônia é em parte derivada da indicação feita por Vieira $(1655,1659)$ de que o médio Tocantins era a terra das nações Tupinambá e em parte devida à relação cosmológica que Viveiros de Castro (1986) observou existir entre os Araweté (Tupi-Guarani da Amazônia) e os Tupinambá do litoral. Os proponentes dessa designação (E. Neves e o presente pesquisador) possuem consciência de que esse agrupamento (Subtradição Tupinambá) não possui a homogeneidade cultural e linguística observada nos Guarani (e.g. NOELLI, 1993), tampouco a dos Tupinambá do litoral, como se viu no relato produzido por Métraux. Essa Subtradição parece abranger pelo menos dois subconjuntos linguísticos (IV e V) designados por Rodrigues (1984/85: 39-40; cf. Anexo 5), mas pode ser ainda mais ampla. No entanto, não parece ser necessário que os agrupamentos arqueológicos e linguísticos se encaixem com perfeição, até por que o próprio Rodrigues (p. 48) admite que seus subconjuntos são mais um ensaio do que uma classificação rigorosa. Uma classificação mais aprimorada, tanto da arqueologia quanto da linguística, depende de um desenvolvimento interdisciplinar de ambas.

As datações aproximam a ocupação Tupi-Guarani no sudeste amazônico ao início da era cristã (ALMEIDA, 2008; GARCIA, 2012a). Partes das áreas ocupadas por esses grupos já eram ocupadas por grupos com cerâmica Inciso-Modelada - isto é, os de língua Tupi-Guarani não foram os únicos ocupantes da terra firme na Amazônia meridional - como no interior maranhense (ALMEIDA, 2013), possivelmente no interflúvio Xingu-Tapajós e com certeza no interflúvio Tocantins-Xingu. No último caso, está clara a influência estilística que os grupos antigos exerceram sobre a Subtradição Tupinambá da Amazônia (GARCIA, 2012a).

À época da conquista, esses grupos Tupi-Guarani ainda possuiriam núcleos de ocupação no médio-baixo Tocantins e Xingu e no interflúvio entre esses dois rios. A partir de então, no século XVI, passaram a sofrer com incursões bandeiristas descendo (BALDUS, 
1970: 20) ou de colonos belenenses subindo o Tocantins (OLIVEIRA, 1986) em busca de escravos (VIEIRA, 1655, 1659). Entre os séculos XVIII e XX, ocorreu uma gradativa expansão da pecuária, vinda principalmente do interior do Maranhão, que empurrou os grupos Timbira dessa região para o baixo Tocantins e, por consequência, os Tupi-Guarani dessa região para o oeste (LARAIA e DA MATA, 1967: 28). Da mesma forma, a pressão sobre os grupos Jê do Planalto Central, como os Kayapó, levou parte desses grupos para o norte, "comprimindo", como consequência, nessa direção os Tupi-Guarani do Xingu e do interflúvio Xingu-Tocantins (GARCIA, 2012a; SILVA, 2000).

Essa pressão, vinda de inúmeras frentes, as frequentes epidemias (COELHO, 1990: 163; d'AZEVEDO, 1999: 190-191) e os terríveis efeitos provocados pela política de descimientos e diretórios, assim como os ciclos da castanha e da borracha, levou à retração ou desaparecimento de muitos grupos Tupi-Guarani, assim como um provável aumento na mobilidade desses grupos. Um exemplo emblemático é o dos Waiãpi, que empreenderiam uma migração fulminante diante dessa pressão - como muitos Tupinambá do litoral e Guarani (MÉTRAUX, 1927) - se deslocando do médio Xingu para a região das Guianas (incluindo o Amapá) e o nordeste paraense.

Foi a análise dos vestígios das ocupações pretéritas dos atuais falantes de línguas Tupi-Guarani do sudeste amazônico que possibilitou a comparação entre os Tupinambá e a TPA, comparação que demonstrou haver um quadro mais complexo do que a simples extensão fluvial dos grupos Tupi-Guarani a partir de um contexto TPA. Inesperadamente, essa complexidade acabou se estendendo para os próprios elementos cerâmicos que levaram autores como Meggers e Miller a inserir sítios e fases (e.g. fase Tauá) na Tradição Polícroma.

Ao que parece, os sítios Tupinambá não possuíam um padrão único, e grande parte das variações possíveis seriam decorrentes de contingências históricas. Em volta das aldeias Tupinambá, havia uma série de estruturas ligadas a atividades temporárias desses grupos, de acampamentos de caça e/ou pesca a áreas de roça. Os dados etnográficos apontam que essas estruturas temporárias também serviam para guiar as mudanças das aldeias. Por outro lado, pouco se sabe o padrão de reocupação da TPA, a não ser no conexto da Subtradição Guarita em que está clara (em geral) uma preedileção por espaços ocupados por outros grupos. A própria dúvida lançada sobre a filiação polícroma das fases dos baixos Xingu e Tocantins (Tauá, Carcarapi e Independência) criou uma dificuldade interpretativa extra: essas fases possuem ao mesmo tempo muitas semelhanças e diferenças com outros agrupamentos! As maiores semelhanças entre essas fases e a bibliografia TPA de outras regiões são o padrão 
linear ribeirinho e finos pacotes de terra preta, que permitem indicar um padrão de grande mobilidade e uma predileção por áreas já ocupadas por outros grupos (cf. TAMANAHA, 2012; LIMA, 2008; MORAES, 2010; NEVES, 2008). O que não deixa de ser um ponto em comum com os Tupinambá da Amazônia. Ao estudar sítios de terra firme, Denevan (2001; cf. KÄMPF, 2005: 289) indica que esses sítios com pacotes de terra preta "não tão preta", com menor dimensão e profundidade, podem ser fruto de ocupações mais curtas.

Não foi descartada a possibilidade de uma relação entre a TPA e um macro contexto Tupi (provavelmente não Tupi-Guarani). Conforme visto, há (ainda) alguns grupos canoeiros Tupi nas margens dos grandes rios da Amazônia. Os dados são escassos, mas as informações coletadas sobre as cerâmicas Juruna-Yudjá, Mawé e Munduruku tendem mais a distanciar esses Tupi (em especial os Mawé e Munduruku) da TPA do que aproximar, mas existem outras possibilidades (Capítulo 6).

Se, no começo deste estudo, a ideia era de que a TPA era predominantemente Tupi, com alguns expoentes não Tupi (e.g. rio Negro), está claro que não serão os grupos do baixo Amazonas que irão confirmar essa hipótese. Trata-se de uma questão em aberto. Ainda assim, a grande diferenciação linguística desses grupos, a grande variabilidade no material arqueológico e a possibilidade de essa Tradição ter entrado em locais aos quais os falantes de Tupi não chegaram parecem indicar um panorama mais heterogêneo dos grupos canoeiros ribeirinhos e, por consequência, da própria Tradição Polícroma da Amazônia, do que dos grupos de terra firme (Tupinambá).

Fato é que a Tradição Polícroma está em xeque, pelo moenos no baixo Amazonas. Conforme mencionado, as pesquisas arqueológicas têm apontado uma confusão entre antigas cerâmicas com decorações pintadas (e mais uma série de atributos) e a Tradição Polícroma. Um dos possíveis resultados dessa reinterpretação é a não inserção das fases do baixo Amazonas nessa Tradição (NEVES, 2012). Se tal proposta estiver correta, as fases antes dos baixos Xingu e Tocantins, que antes eram consideradas TPA, perderiam esse status, junto com a fase Marajoara. O que não resolveria por completo a situação. A análise da fase Tauá (ex-TPA do baixo Tocantins) mostrou que essa fase se constituía mais de elementos híbridos da Subtradição Tupinambá da Amazônia (formas), da cerâmica Inciso-Modelada antiga do sudeste amazônico (decoração Inciso-Ponteada e apliques zoomorfos) e da fase Marajoara do que uma extensão simplificada da última. Mesmo se forem isoladas do contexto TPA, as fases do baixo Amazonas (Aristé, Maracá, Marajoara, Tauá) parecem heterogêneas e complexas, ainda que tenha sido observadas semelhanças entre as cerâmicas dos baixos 
Tocantins (Tauá) e Xingú (Carcarapi e Independência). Portanto, se a ideia inicial era partir do contexto "seguro" da Amazônia oriental para o contexto "complexo" da Amazônia ocidental, verificou-se que tal proposta não se confirmou. Os dados mostram um quadro de interpretação muito mais difícil.

Em resumo, a proposta deste capítulo era gerar uma síntese alternativa ao modelo cardíaco, propondo duas histórias sincrônicas - uma TPA, ao longo dos grandes afluentes do Amazonas, e outra basicamente de terra firme, relacionada aos Tupinambá da Amazônia em vez da relação diacrônica TPA-Tupinambá e Guarani. Houve mais felicidade na construção da história Tupinambá do que da TPA. Sugeriu-se que o sucesso dos Tupinambá em realizar processos de expansão por terra firme se deve à sua volatilidade interna. Essa volatilidade, na longa duração, sem dúvida produziu processos históricos relevantes. Para compreender os processos de expansão dos grupos Tupi-Guarani não se pode virar as costas para a terra firme. 


\section{ARQUEOLOGIA DO ALTO RIO MADEIRA}

\subsection{Introdução}

O objetivo deste capítulo é apresentar dados para a compreensão das ocupações humanas ceramistas da bacia do alto rio Madeira durante o período pré-colonial. Trata-se de uma área com uma imensa diversidade cultural e linguística. Atenção especial será dada aos dados provenientes dos rios Madeira e Jamari, por serem as áreas onde o PALMA realizou intervenções arqueológicas, mas os rios Guaporé e Ji-Paraná também serão discutidos.

O ponto de partida será a síntese produzida por Anne Christine Taylor (1999) sobre o oeste amazônico. Segundo a autora, a região ocidental da bacia amazônica possui uma diversidade cultural e linguística quantitativamente análoga aos ambientes onde essas culturas se desenvolveram (p. 191; cf. STEWARD, 1948: 507). No período colonial (a partir do séc. $\mathrm{XVI}$ ), Taylor indica que tanto as sociedades indígenas "mansas" como as "selvagens" "33 possuíam características muito uniformes, como um padrão disperso de assentamento. As economias seriam baseadas na combinação da caça, coleta e uma horticultura de coivara, com predomínio da mandioca doce (cf. STEWARD, 1948: 517).

Politicamente, os grupos se organizariam de forma acéfala, com um alto grau de autonomia local (comunitário). Os sistemas religiosos seriam marcados por um baixo grau de exteriorização e formalismo, com poucos rituais coletivos de grande escala. Entretanto, ao mesmo tempo, haveria um sofisticado sistema xamânico, com ramificações transpassando por variados grupos culturais (TAYLOR, 1999: 195). Um possível sinal de que essa autonomia talvez seja fenômeno recente.

Terra da cerâmica, terra da chicha: ao descrever os grupos do oeste amazônico - mais especificamente das montañas peruanas, equatorianas e bolivianas - Steward (1948: 522) indica que todos os grupos produzem (ou produziam) cerâmica. $\mathrm{O}$ autor também aponta que a chicha - a cerveja local feita a partir do milho ou da mandioca - é (ou era) consumida por todas as tribos.

\footnotetext{
${ }^{33}$ Segundo Taylor (1999: 195) as sociedades mansas seriam os grupos "domesticados" pelas missões (principalmente os grupos ribeirinhos), e as sociedades selvagens seriam caracterizadas pela sua belicosidade e resistência militar ao domínio europeu (principalmente grupos de interflúvio).
} 
Taylor observa que haveria dois tipos de rede operando entre os grupos da Amazônia ocidental no período anterior à solidificação desse modelo autônomo. A primeira, relacionada a grupos ribeirinhos, seria especializada em trocas de longa distância. Taylor cita como exemplo os Piro, os Conibo e os Omágua, que comercializariam objetos desde as terras altas andinas até as áreas da Amazônia central (cf. LATHRAP, 1973). Uma segunda rede entre os grupos ribeirinhos e os grupos de interflúvio (cf. PORRO, 1995: 127) complementaria e estenderia os circuitos ribeirinhos de longa distância (TAYLOR, 1999: 199). Esses circuitos regionais foram quebrados durante o período colonial, fazendo que as sociedades recorressem a níveis de organização locais, gerando um crescente distanciamento entre as sociedades das terras baixas e as das terras altas. Por fim, Taylor aponta que o quadro da parte mais recente do período colonial possui forma oposta ao mosaico cultural e linguístico apontado por Steward, Métraux e Lathrap em relação à era pré-colombiana tardia. Os efeitos do período colonial teriam levado a uma modificação no desenho da distribuição cultural e linguística, criando zonas mais homogêneas (p. 208).

Uma paisagem abrupta, geométrica e policrômica: na maior parte das terras baixas fora da Amazônia, falar em cerâmica indígena com motivos geométricos feitos com pintura policrômica é praticamente sinônimo de falar em cerâmica Tupi-Guarani. Na região oeste amazônica, das montañas peruanas, equatorianas e bolivianas (o famoso sopé dos Andes), tal menção pode significar qualquer coisa. Afinal, nessa região, quase todos os grupos (e.g. Pano, Jívaro, Arawak, Tupi) produzem ou produziam cerâmica com motivos geométricos policrômicos. Segundo Steward (1948: 522), as formas mais comuns são os grandes vasos para cocção e tigelas para o consumo de chicha. Os motivos geométricos pintados seriam encontrados apenas nas tigelas.

\subsection{0 rio Madeira}

Partindo do grande panorama da Amazônia ocidental descrito por Taylor e fechando um pouco o foco na região do alto Madeira, é possível observar uma amostra do grande mosaico cultural delineado pela autora. Não por mera coincidência, Miller ${ }^{34}$ indica que, na região sudoeste amazônica, no entorno do alto rio Madeira, "essas tradições e fases culturais, algumas pan-amazônicas, outras microrregionais, foram tão diversas e numerosas quão numerosos e diversos foram os ecossistemas e nichos ecológicos, desde o Pleistoceno"

\footnotetext{
${ }^{34}$ No mesmo ano em que Taylor escreve sua síntese.
} 
(1999: 333-34). Para esse autor, o sudoeste amazônico serviria como um laboratório para estudos ambientais, uma vez que essa região possui ecossistemas de várzea e terra firme, florestas, savanas, planícies de inundação e pantanais (1999: 331).

Conforme visto, o rio Madeira é formado pela junção de dois grandes complexos fluviais, o Guaporé/Mamoré e o Beni/Madre de Dios. Os principais afluentes do alto curso do rio Madeira são os rios Abunã, Jaci-Paraná, Jamari e Ji-Paraná. Desses, apenas o rio Abunã é afluente da margem esquerda do Madeira.

O trecho encachoeirado do rio se concentra a montante da atual cidade de Porto Velho, local onde se encontrava, até pouco tempo atrás ${ }^{35}$, a cachoeira de Santo Antônio, implodida e transformada em usina hidrelétrica. A região da cachoeira de Santo Antônio é chave para a compreensão das ocupações humanas na bacia do Madeira, tanto no período colonial e recente - quando algumas das mais importantes missões jesuíticas do rio Madeira ali se instalaram ${ }^{36}$ (FERREIRA, 2005; HUGO, 1959; O.OLIVEIRA, 2007) - quanto no período pré-colonial (MILLER, 1992, 1999; ZUSE, 2010).

A bacia do alto rio Madeira recebeu apenas um interesse marginal por parte da colonização europeia até pelo menos meados do século XIX, sendo que muitas partes do interior dessa região, em especial no entorno da serra dos Pacaás Novos e dos altos cursos dos rios Jaci-Paraná, Jamari e Ji-Paraná, ficaram praticamente isolados de contato com colonos até depois da segunda metade do século XX.

A história colonial do alto rio Madeira se encaixa no conceito de pulsações históricas sugerido por Neves e Pertersen (2006: 280). As primeiras incursões, como a realizada por Raposo Tavares ${ }^{37}$ entre 1647-1650, teriam um objetivo prospectivo, a fim de reconhecer o território e identificar áreas para exploração de minério (FERREIRA, 2005: 20; HUGO, 1959: 7). Enquanto os minerais não haviam sido encontrados, a maior preocupação dos jesuítas e colonos, a partir da segunda metade do século XVII, era a manutenção territorial e exploração (ou salvação) da mão de obra nativa (ALMEIDA, 1860; HUGO, 1959: 27).

\footnotetext{
${ }^{35}$ A UHE Santo Antônio começou a ser construída em 2008.

${ }^{36}$ Hugo indica que a missão de Santo Antônio não possuía um lugar fixo, sendo transferida de lugar conforme as circunstâncias: "só muito mais tarde veio designar o local geográfico da primeira cachoeira do rio Madeira, antes era chama de Aroya pelos índios, São João pelos portugueses" (1959: 59).

${ }^{37}$ O bandeirante teria deixado a vila de São Paulo em 1647 e seguido pelo rio Paraná, passando pelo Guaporé e descendo por toda a extensão do Madeira até chegar em Belém, em 1650. Setenta e dois anos depois, Francisco de Melo e Palheta realizaria o caminho inverso, partindo de Belém e subindo toda a extensão do rio Madeira (FERREIRA, 2005: 26).
} 
Um segundo e mais intenso período de ocupação ocorreria entre 1719 e 1777 . A primeira data marca a descoberta de ouro na região de Cuiabá $(1719)^{38}$ e a retomada da busca pelo melhor trajeto para escoar o minério para a metrópole ${ }^{39}$. A partir daí, sim, passou a haver uma preocupação por parte das autoridades portuguesas com o contrabando de minerais (CYPRIANO, 2007: 69), que leva estas autoridades a estimular o povoamento e a consolidação das fronteiras frente ao inimigo espanhol.

Nesse período, foi criada a capitania do Mato Grosso (1748), cuja capital era a cidade de Vila Bela da Santíssima Trindade, na margem direita do rio Guaporé, rio acima de onde seria erguido o forte Príncipe da Beira, entre 1776 e 1783 (O. OLIVEIRA, 2007: 19-34). No entanto, à época em que o forte foi concluído, a mesma da Expedição Filosófica de Alexandre Rodrigues Ferreira (1974 [1788]), a ocupação colonial da região já se encontrava em franca decadência. Um exemplo disso é o posto militar fundado em 1753, na margem direita da cachoeira do rio Madeira, que acabaria recebendo o (primeiro) nome de seu criador: Theotônio Gusmão. Segundo Keller (1874: 47), o local possuía uma posição defensiva estratégica - com certeza aproveitada pelas populações pré-coloniais que ali habitaram - e "were of first necessity of that water road, as well as for securing the supply of provisions, and the protection gained against the wild Indians (...)". Tal posto também foi abandonado depois de não muito tempo ${ }^{40}$.

Um novo impulso ocorreu a partir da segunda metade do século XIX, quando foi iniciado o ciclo da borracha e começou a construção da ferrovia Madeira-Mamoré, cujo intuito principal era o de fortalecer o comércio com a Bolívia, abrindo a este país uma passagem para o comércio do Atlântico (FERREIRA, 2005). Foi o primeiro momento em que o interior do atual estado de Rondônia foi efetiva (e gradualmente) ocupado pela frente colonial (HUGO, 1959), fato que fica claro nas descrições que o então general Rondon e sua equipe fizeram já no fim da primeira década do século XX, quando a linha telegráfica chegou à região da recém fundada cidade de Porto Velho (MAGALHÃES, 1916; RONDON, 1948; ROQUETTE-PINTO, 1975 [1919]). A essa altura, mais um ciclo de crescimento estaria encerrado, assim como os próprios trabalhos da ferrovia Madeira-Mamoré, inaugurada em 1912.

\footnotetext{
${ }^{38}$ Em 1725 seria feita a descoberta de ouro em Goiás.

${ }^{39}$ Monções de Cuiabá a Belém.

${ }^{40} \mathrm{O}$ esfriamento do ímpeto de defesa das fronteiras foi cristalizado pelo Tratado de Santo Idelfonso (1777), que marcou definitivamente os limites territoriais da América portuguesa.
} 
Novas pulsações coloniais ocorreram também durante a Segunda Guerra Mundial, com o segundo ciclo da borracha, e entre os anos 1970 e 1980, com a política de ocupação da Amazônia do regime militar (LEONEL, 1995), incluindo a desastrosa implantação da Usina Hidrelétrica de Samuel (cf. MILLER et al., 1992). Por fim, a última guinada "rumo ao progresso" ocorreu nos últimos cinco anos (2008-2012) com a implantação de duas outras usinas hidrelétricas, de Santo Antônio e Jirau, período em que foi possível vivenciar a mudança provocada pela injeção de adrenalina dos bilhões de reais gastos nas obras. Adrenalina essa que parece agora baixar, devolvendo lentamente Porto Velho ao antigo marasmo: agora um lugar repleto de shopping centers, mas sem água tratada.

É durante o século XX que ocorre a imensa maioria dos relatos a respeito dos grupos indígenas da região do alto Madeira. Por exemplo, é nas descrições da equipe de Rondon que é possível encontrar os primeiros relatos dos grupos Tupi-Arikém, assim como dos falantes de línguas Txapakura (cf. VILAÇA, 2010) e dos índios Nambikwara, grupo isolado linguisticamente, que ficou conhecido no mundo todo com a etnografia realizada nos anos 1930 por Lévi-Strauss (1976). Nessa expedição, o famoso antropólogo também realizou uma descrição dos Tupi-Kagwahiva, os Tupi-Guarani de Rondônia.

No entanto, Lévi-Strauss não é a única celebridade relacionada à descrição dos povos indígenas da região. Nimuendajú (1948a) é um dos que visitaram o baixo rio Madeira, em ocasião que descreveu os Parintintin, também Kagwahiva. Do lado boliviano, no alto Madeira, na região situada entre os rios Beni e Madre de Dios, pode-se citar os trabalhos Erland Nordenskiöld (e.g. 1924) e Alfred Métraux (1948b). Para o leste, os primeiros registros (à distância) dos índios Cinta-Larga (Tupi-Mondé) foram realizados durante a expedição ao chamado rio da Dúvida empreendida pelo general Rondon e pelo ex-presidente norte americano Ted Roosevelt (MILLARD, 2005; ROOSEVELT, 1976).

O período mais intenso da etnografia foi iniciado no fim dos 1970, com os trabalhos de Carmem Junqueira (1984/1985) sobre os Cinta-Larga e, especialmente, Betty Mindlin (1984/1985, 1985, 2006), sobre os Suruí, também Tupi-Mondé. O contato com muitos grupos é tão recente que uma grande quantidade de material etnográfico continua sendo produzido, parte do qual será citada adiante.

Por outro lado, e ao contrário do que ocorre com muitos dos habitantes indígenas dos afluentes e das áreas de terra firme do alto Madeira, a identificação dos grupos que habitavam a margem propriamente dita desse rio é uma tarefa mais complexa. Os relatos são ao mesmo 
tempo escassos e pouco informativos quanto a esse trecho do rio - não se sabe se os grupos citados pelas crônicas são relacionados cultural e linguisticamente ou não. Por exemplo, Menéndez (1981/82: 319), que estuda o período histórico da região Madeira-Tapajós, indica a existência de 85 grupos registrados nessa região no início do século XVIII. Nas margens do rio Madeira, um número bem menor de grupos seria registrado ${ }^{41}$ (Fig. 23).

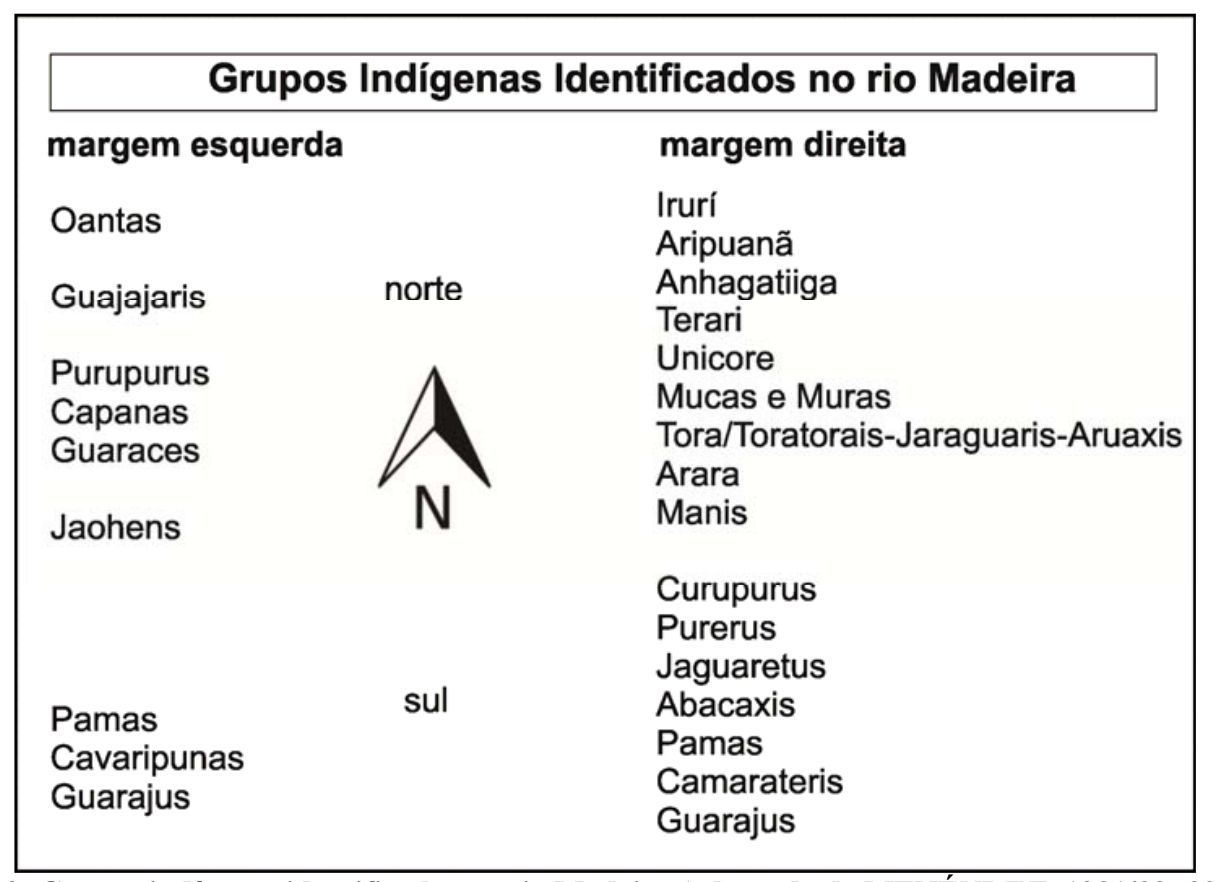

Figura 23: Grupos indígenas identificados no rio Madeira (adaptado de MENÉNDEZ, 1981/82: 320).

Segundo Menéndez (1981-82: 370) os Pama, os Kavaripuna (Karipuna), os Camarateri e os Guaraju seriam os grupos da área encachoeirada do rio Madeira, mas pouco se sabe sobre eles. Os Pama e os Karipuna estabeleceram algum contato com os jesuítas e, durante o século XVIII, teriam tido contato intenso com os viajantes que passaram pela região (cf. FERREIRA, 2005: 31, sobre o encontro da expedição de Francisco de Melo Palheta com os Karipuna). Assim como Taylor, Menéndez observa uma complexa teia de comunicações entre estes distintos grupos:

Os movimentos especificos que acabamos de descrever mostram que as diferentes tribos encontram-se envolvidas, mesmo antes da chegada do branco, numa rede de relações em que comércio, alianças, situações de denominação-subordinação, guerra e expansão territorial constituíam uma constante. Esse conjunto de relações intercambiais confere à região um alto grau de mobilidade que parece configurar-

\footnotetext{
${ }^{41}$ Hugo (1959: 26) indica um números maior de grupos nas margens do Madeira (32) mas não apresenta a lista.
} 
se como um de seus traços distintivos. Intercâmbio, hostilidades e um processo emergente de aculturação intertribal estão à base de toda essa intensa movimentação que os primeiros cronistas souberam captar vertendo-as nos seus relatos (1981/82: 368).

$\mathrm{O}$ autor argumenta que a mobilidade seria o elemento comum que integra o todo etnográfico da região entre os rios Madeira e Tapajós, e que essa mobilidade não deve ser compreendida como causada exclusivamente pela entrada da frente colonial. Para Menéndez, é difícil visualizar um cenário com a disposição espacial dos diferentes grupos no período anterior ao contato, ainda mais pelo fato de esse contato ter gerado áreas de vácuo nas margens dos grandes rios, que passaram a ser ocupadas por populações da terra firme atraídas pelo comércio com o branco. Além disso, os descimientos (aldeamentos jesuíticos) também contribuíram para alterar a localização de diversos coletivos agrupados nesses locais e fomentar as migrações decorrentes do fim desses estabelecimentos (1981/82: 377-379).

Assim, ao olhar para o alto Madeira no Mapa Etnohistórico de Nimuendajú (1944), o que se vê é uma maciça entrada de grupos exógenos na região durante o período colonial. A bacia do rio Madeira não é apenas uma zona de dispersão, mas também uma zona residual, de assentamento de grupos alóctones (NICHOLS, 1992). Do oeste, a partir do eixo dos rios Madre de Dios e Beni, viria uma onda de grupos de língua Pano, enquanto uma série de

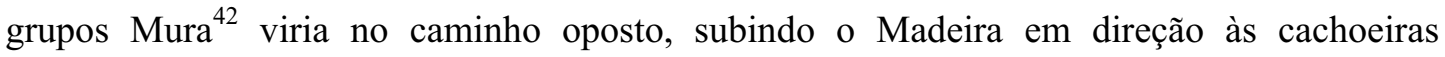
(HUGO, 1959: 46; MENÉNDEZ, 1981/82). Os grupos de língua Txapakura (e.g. os Torá) viriam do Guaporé, em um sentido sudoeste-nordeste para a região de interflúvio ao sul da calha do alto Madeira (VILAÇA, 2010). Os grupos Arikém e Karitiana (Tupi-Arikém) estariam nessa região à época da chegada de Rondon ao alto Madeira, em 1910 (MAGAlHÃES, 1930; ROQUETTE-PINTO, 1975; Anexo 6), mas não se sabe há quanto tempo estavam ali (cf. VAN DER VELDEN, 2010).

$\mathrm{Na}$ verdade, há certa confusão quanto à data de entrada desses grupos na região (colonial ou pré-colonial) e quanto à extensão dos movimentos empreendidos. Confusão potencializada pelo fato de que grupos de línguas diferentes receberam o mesmo etnônimo. Por exemplo, os grupos Karipuna foram considerados por Métraux (1948b: 449), Nimuendaju (1944) e Hugo (1959) índios de língua Pano que habitariam a região das

\footnotetext{
${ }^{42}$ Segundo Amoroso (1994: 11), ocorreu durante o período colonial uma delimitação exagerada do tamanho do território e da quantidade de ataques praticados pelos "Mura", assim como o próprio etnônimo, que abrange de forma inadequada povos não Mura (uma "murificação"). "Estes Mura foram os piores de todos!" - diria o exagerado Hugo (1959: 42).
} 
cachoeiras do rio Madeira, ali tendo sido contatados por Keller (1874: 48). Entretanto, a mesma referência (KELLER, 1874) é hoje utilizada pelo Instituto Socioambiental (ISA) para designar um grupo também denominado de Karipuna, mas de língua Tupi-Guarani. Por fim, o etnônimo também foi regionalmente utilizado por Spix (1938 apud. MENÉNDEZ, 1984/85: 275) para designar um subgrupo Mawé ${ }^{43}$.

Conforme apontado nos Capítulos 1 e 2, a presença de grupos Tupi-Guarani no alto Madeira é cercada de incertezas. Por um lado, Nimuendajú (1948a: 283) argumenta pelo desmembramento e pela migração histórica (final do séc. XVIII) dos Kagwahiva (TupiGuarani) empurrados para o Madeira em consequência de pressões Munduruku. Por outro, Menéndez defende que esses grupos já estariam no alto Madeira antes disso (1981/82: 367) ressaltando, entretanto, que a economia de terra firme dos Parintintin (cf. SUSNIK, 1975) os credenciaria ao papel de grupos de interflúvio que preencheram as áreas de vácuo criadas pela colonização nas margens do Madeira (1984/85: 280-281). Ou seja, os Kagwahiva, $a$ priori, não seriam os antigos produtores de cerâmica da Tradição Polícroma do alto Rio Madeira.

A mesma nebulosidade paira sobre a história dos Tupinambarana no baixo curso do rio Madeira. Esse grupo foi identificado por Acuña (1994 [1641]), que indicou se tratar de populações Tupinambá que teriam migrado a partir de Pernambuco (CYPRIANO, 2007; HERIARTE, 1874; MENÉNDÉZ, 1981/82). No entanto, essa migração colonial Tupinambá para a ilha de Tupinambarana nunca foi comprovada por dados arqueológicos (e tais pesquisas nunca foram realizadas!). E, como o próprio nome diz, os Tupinambarana são os "falsos (ana) Tupinambá", o que gera dúvida sobre a verdadeira história desses grupos.

Mesmo que comprovada a ligação entre os Tupinambarana e os Tupinambá do litoral - o que, na visão de Menéndez, é fato consumado que "não deixa dúvida" (1984/85: 275276) - crucial para o presente estudo seria identificar os grupos que habitavam o baixo Madeira antes dos Tupinambá chegarem (e os subjugarem), já que possibilitaria ligar tais grupos à Tradição Polícroma encontrada por quase toda a extensão desse rio ${ }^{44}$. O que se sabe

\footnotetext{
${ }^{43}$ Porro confirma que se trata de uma denominação comum a diversas nações: "em 1639 havia Caripuná na margem direita do baixo Solimões (abaixo do Purus e acima de Manacapuru). (...) Em 1714 são mencionados Cauaripuna na margem esquerda do Madeira, acima da $6^{a}$ cachoeira (Rodrigues). O termo Caripuna também designa os europeus" (2007: 31-32).

${ }^{44}$ Nesse sentido, a pesquisa realizada por Claide Moraes (2010) possui um contexto muito mais profícuo para a realização do cruzamento com dados históricos. Esse arqueólogo realizou um extenso levantamento arqueológico na região do baixo Madeira e confirmou o predomínio de sítios da fase Borba na parte superior da
} 
é que estes grupos pré-Tupinambarana, aparentemente, falavam línguas distintas dos seus algozes, ou seja, não falavam Tupi-Guarani (HERIARTE, 1874; MENÉNDEZ, 1984/85: 279).

A história indígena do rio Madeira está em aberto. Os não Tupi mais comentados pela historiografia do médio-baixo curso desse rio são os Iruri, grupos conhecidos por terem principais (HUGO, 1959: 22) e estender suas ocupações por vastas áreas do médio e baixo Madeira (CYPRIANO, 2007: 63-67; MENÉNDEZ, 1981/82). É, em parte, em cima do vácuo deixado pelo colapso desse grupo que ocorreu a citada expansão dos grupos Mura e Parintintin, durante os séculos XVIII e XIX. No entanto, não há indícios de que esses grupos ocupavam a boca do Madeira à época da chegada dos Tupinambarana.

No extremo oposto do rio Madeira, há mais dúvidas quanto à história cultural dos grupos Tupi-Guarani. Tratam-se dos grupos Sirionó (Guarani), que habitam terras bolivianas banhadas pelos rios Beni e Madre de Dios (formadores do Madeira). Esses também teriam se fragmentado em pequenos grupos, empreendendo uma série de movimentos no sudoeste amazônico durante o período colonial (HOLMBERG, 1948: 455-456; 1969). É possível que estejam associados à presença de cerâmica arqueológica pintada e corrugada ${ }^{45}$ no rio Madre de Dios (MAQQUE, 2005). Por outro lado, esses atributos cerâmicos também estariam relacionados à cerâmica produzida por grupos Pano (de novo), em áreas da Amazônia ocidental. Ou seja, há uma recorrência não só indústrias policrômicas distintas, mas também cerâmicas corrugadas não Tupi-Guarani (cf. BROCHADO, 1984; LATHRAP, 1970; ROE, 1973; ZIMPEL, 2009). Constatação que obriga a ter cuidado extra ao lidar com cerâmicas corrugadas nessa região da Amazônia, além de domínio da literatura sobre os Pano.

Há menos incertezas com relação a outros aspectos dos grupos Pano. Por exemplo, os Pacavara, que ocupavam áreas do alto rio Madeira, assim como nos rios Beni, Mamoré, Abunã e Madre de Dios, moravam em casas comunais e se locomoviam em canoas feitas de casca de árvore (cf. KELLER, 1874: 114). Esses grupos plantavam milho, banana e mandioca doce, e com esta faziam sua chicha. Ao que parece, sua cerâmica seria simples, apenas com eventuais marcas de folhas. Eles também realizariam enterramentos (mal enterrados) em urnas funerárias (KELLER, 1874: 124; MÉTRAUX, 1948b: 449-452). Nesse sentido, é

estratigrafia dos sítios. Essa fase foi definida por Simões e Lopes (1987) e pertence à Tradição Polícroma da Amazônia. Ela será novamente abordada durante a análise do material cerâmico dos Capítulos 5 e 6 .

${ }^{45}$ Não datada. 
incrível a quantidade de atributos materiais que os grupos Pano historicamente possuíam em comum não só com os citados Tupi-Guarani, mas também com uma série de outros grupos de língua distinta na Amazônia ocidental (Capítulo 7). Isso ao mesmo tempo em que os grupos Pano possuiriam uma grande variabilidade artefatual interna (MÉTRAUX, 1948b: 452; ROE, 1982; STEWARD, 1948: 522-524), o que pode estar relacionado à forma com que esses grupos se dispersaram, conforme aponta Lathrap:

\begin{abstract}
(...) the major axis of Panoan distribution is neither riverine nor coastal: it extends across the upper watersheds of several major rivers, the Madre de Dios, the Purus, the Juruá, and the Ucayali. The total distribution suggests that the major Panoan expansion was on foot rather than by watercraft, an impression strengthened by the fact that many Panoan groups have poorly developed watercraft or lack them completely (1970: 81).
\end{abstract}

Resumindo, compreender o papel desempenhado pelos grupos Pano é imprescindível para interpretar a história de longa duração da região. A partir de tal compreensão pode-se elaborar um plano de trabalho em macro escala para a Amazônia ocidental - que tenha em mente a existência dos dois tipos de rede de contato (e comércio) sugeridos por Taylor (1999: 199). Isso significa observar os grupos de língua Pano de maneira análoga aos grupos Tupi (especialmente Tupi-Guarani) na Amazônia meridional: como redes de conexões perpendiculares ao mainstream ribeirinho. Em ambos os casos (Pano ocidentais e TupiGuarani meridionais), as ligações interfluviais tendem a ser caminhos muito mais curtos do que as longas jornadas por rios que andam paralelos. Fitzcarraldo que o diga.

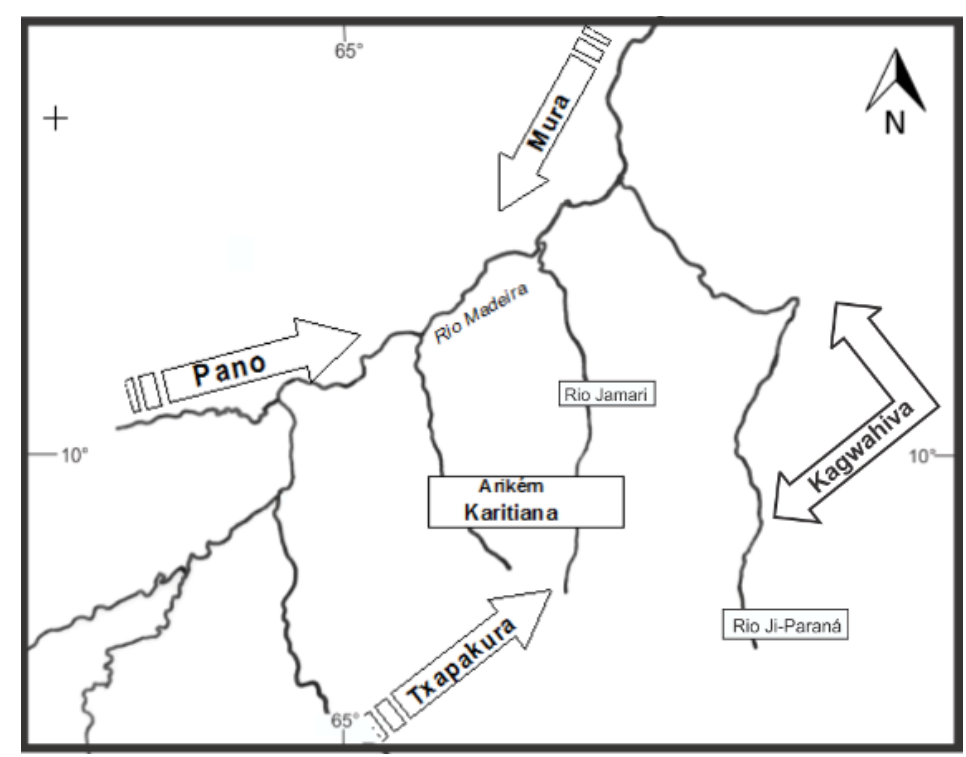

Figura 24: Mapa apontando a entrada de grupos Pano, Txapakura, Kagwahiva e Mura na região do alto Madeira durante o período colonial (adaptado de NIMUENDAJÚ, 1944). 
Muitos antigos grupos Arawak do entorno do alto Madeira também participariam dessa rede perpendicular de conexões (HILL e HORNBORG 2011; SANTOS-GRANERO 2002). Utilizando a cidade de Porto Velho como referência, é possível observar grupos Arawak: (I) ao norte e nordeste (e.g. os Apurinã do rio Purús); (II) para oeste (e.g.os Campa/Ashaninka e Piro que habitam os formadores do rio Amazonas); (III) para o sudoeste (e.g. os Mojo e Bauré, localizados nos formadores do rio Madeira); (IV) para o sul e sudeste (e.g. os Parecí, localizados próximos às cabeceiras dos rios Paraguai, Guaporé e Juruena) (GOW 2002; MÉTRAUX 1948b; 1948c; RENARD-CASEVITZ 2002).

Chama a atenção o fato dos índios Ashaninka (Arawak) tradicionalmente manufaturarem pratos com motivos pintados em vermelho e com marcas de unhas (ungulados), enquanto os Piro produziam vasilhas corrugadas para cocção e algumas tigelas pintadas. Elementos que se assemelham mais à cerâmica dos Shipibo-Conibo do alto Amazonas (língua Pano) e dos Tupi-Guarani (STEWARD e MÉTRAUX 1948: 545) do que de grupos Arawak (cf. LATHRAP 1970). Entretanto, atributos cerâmicos tipicamente associados a grupos de língua Arawak, como decorações Inciso-Modeladas, também ocorrem no contexto do alto Madeira em contextos relacionados aos geoglífos da bacia do Guaporé ${ }^{46}$, como atestam os fragmentos existentes no Museu Regional de Rondônia.

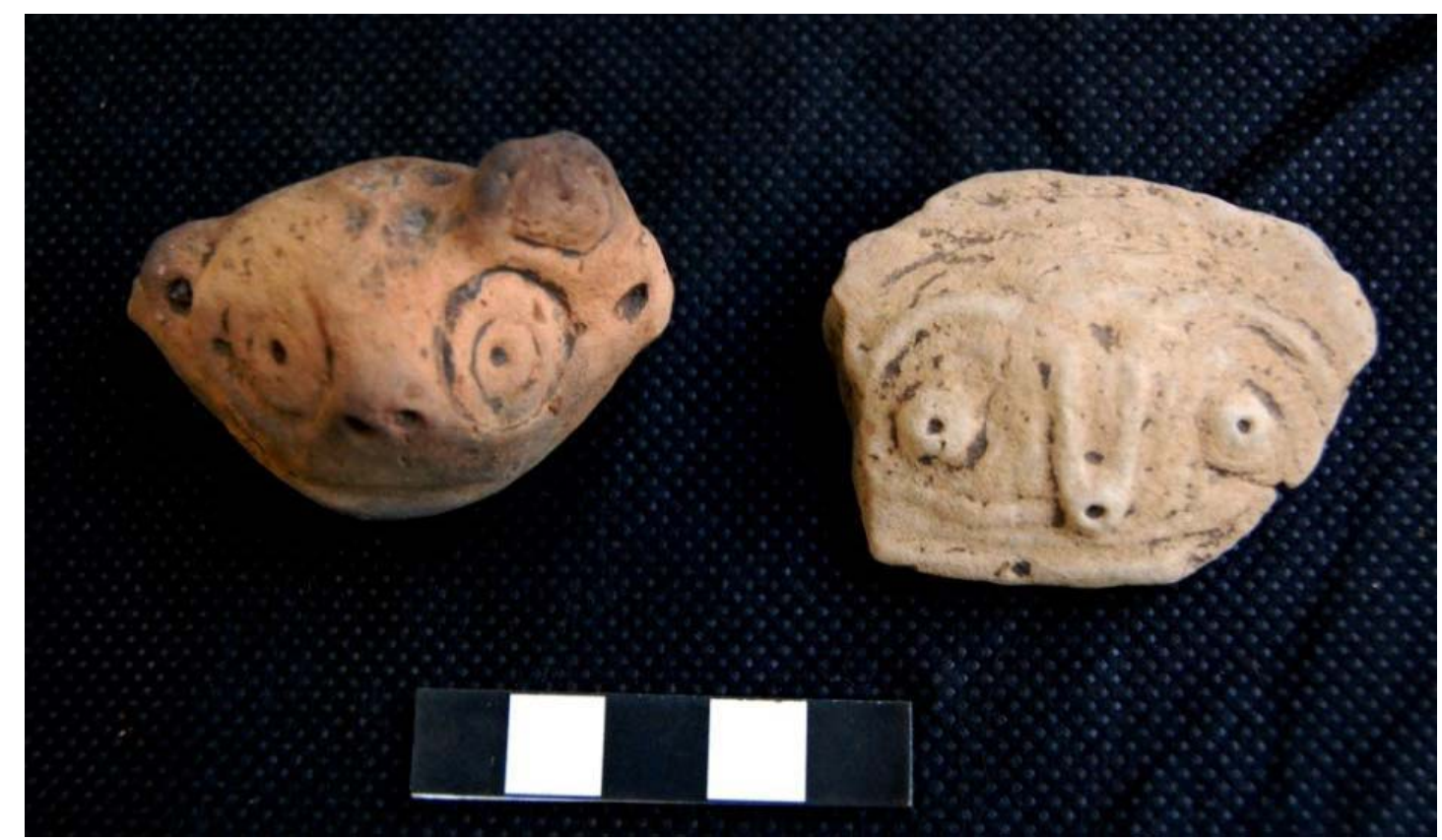

Figura 25: Cerâmica incisa e modelada encontrados em geoglífos da região do Guaporé (Foto: Eduardo Neves, coleção do Museu Regional de Rondônia).

\footnotetext{
${ }^{46}$ Tema do projeto de mestrado que vem sendo desenvolvido por Thiago Trindade (MAE-USP).
} 
Até o momento, as únicas publicações sobre a arqueologia do alto Madeira foram realizadas por Eurico Miller, que aponta uma antiga ocupação das margens desse rio ${ }^{47}$. A cerâmica identificada em áreas no entorno do baixo Abunã pertence à fase Pederneiras (sem Tradição definida). Essa fase seria constituída por dois sítios-habitação relacionados a outros dois sítios oficina-lítica e dois rupestres. Os sítios possuiriam pacotes de terra preta de até $40 \mathrm{~cm}$ e dimensões restritas (no máximo, 110 x 190m). A cerâmica seria predominantemente manufaturada com antiplástico de caraipé e areia, os vasos possuiriam contornos simples, e as raras decorações plásticas seriam restritas a incisões e ponteados. Miller cita apenas a presença de percutores para a indústria lítica (1992: 226-227).

\begin{tabular}{|c|c|c|c|}
\hline $\begin{array}{l}\text { Material (fase/ } \\
\text { Subtradição/ } \\
\text { Tradição) } \\
\end{array}$ & Local & $\begin{array}{c}\text { Idade } \\
\text { Convencional }\end{array}$ & Descrição do material \\
\hline $\begin{array}{l}\text { Ribeirão } \\
\text { (2 sítios) }\end{array}$ & $\begin{array}{l}\text { Alto } \\
\text { Madeira, } \\
\text { cachoeira } \\
\text { do Ribeirão }\end{array}$ & $\mathrm{s} / \mathrm{d}$ & $\begin{array}{l}\text { Cerâmica temperada com areia grossa e } \\
\text { fina, com mica. Vasilhame de formas } \\
\text { simples (bastante simétricas), de tigelas } \\
\text { rasas a vasos globulares de fundo } \\
\text { arredondado. Superfície bem alisada. }\end{array}$ \\
\hline $\begin{array}{l}\text { Pederneiras } \\
(4 \text { sítios })\end{array}$ & $\begin{array}{l}\text { Rios } \\
\text { Madeira, } \\
\text { Abunã e }\end{array}$ & $\mathrm{s} / \mathrm{d}$ & $\begin{array}{l}\text { Cerâmica simples, com caraipé, e raras } \\
\text { decorações incisas e ponteadas. }\end{array}$ \\
\hline $\begin{array}{l}\text { Jaci-Paraná } 48 \\
(2 \text { sítios })\end{array}$ & Jaci-Paraná & $\mathrm{s} / \mathrm{d}$ & $\begin{array}{l}\text { Cerâmica com pasta moderadamente } \\
\text { arenosa, com tempero de caraipé. Formas } \\
\text { simples, sem presença de decoração. }\end{array}$ \\
\hline Muralha (cerâmico) & Rio Madeira & 660 d.C. & Cerâmica simples. \\
\hline $\begin{array}{l}\text { Muralha } \\
\text { (pré-cerâmico) }\end{array}$ & Rio Madeira & 325 a.C. & Não descrito. \\
\hline $\begin{array}{l}\text { Jatuarana } \\
\text { (32 sítios) }\end{array}$ & Rio Madeira & $\begin{array}{l}780 \text { a.C. - séc. } \\
\text { XVIII }\end{array}$ & Material TPA, detalhado na Tabela 9. \\
\hline $\begin{array}{l}\text { Girau } \\
\text { (6 sítios) }\end{array}$ & Rio Madeira & +- 4050 a.C. 49 & $\begin{array}{l}\text { Lascas, percutores, núcleos, possíveis } \\
\text { raspadores em quartzo, sílex e rochas } \\
\text { graníticas alteradas. }\end{array}$ \\
\hline $\begin{array}{l}\text { Periquitos } \\
\text { (material obtido em } \\
\text { garimpos) }\end{array}$ & Rio Madeira & 10.000 a.C. & $\begin{array}{l}\text { Percutores com marcas de uso, lascas e } \\
\text { um biface lanceolado ou pré-forma (sic) } \\
\text { em quartzito, sílex e outras rochas } \\
\text { bastante alteradas. }\end{array}$ \\
\hline
\end{tabular}

Tabela 8: Ocupações pré-coloniais no alto rio Madeira (fonte: MILLER, 1987a, 1992).

\footnotetext{
${ }^{47}$ A presença de um paleocanal datado em 10.000 a.C., ao que parece relacionado aos esqueletos de paleoíndios identificados por garimpeiros no rio Madeira, seria a indicação das ocupações mais antigas desse rio. Essa ocupação estaria relacionada ao Complexo Cultural Periquitos. Miller (1992: 227), em um momento evolucionista e politicamente incorreto, indica que os grupos Nambikwara e Mura-Pirahã seriam remanescentes dessas tradições pré-ceramistas.

${ }^{48}$ A fase Jaci-Paraná é relacionada ao rio homônimo, mas foi inserida na descrição do rio Madeira uma vez que esse rio (e fase) não será trabalhado em detalhe no presente estudo.

${ }^{49}$ Estimado por Miller (1992: 226).
} 


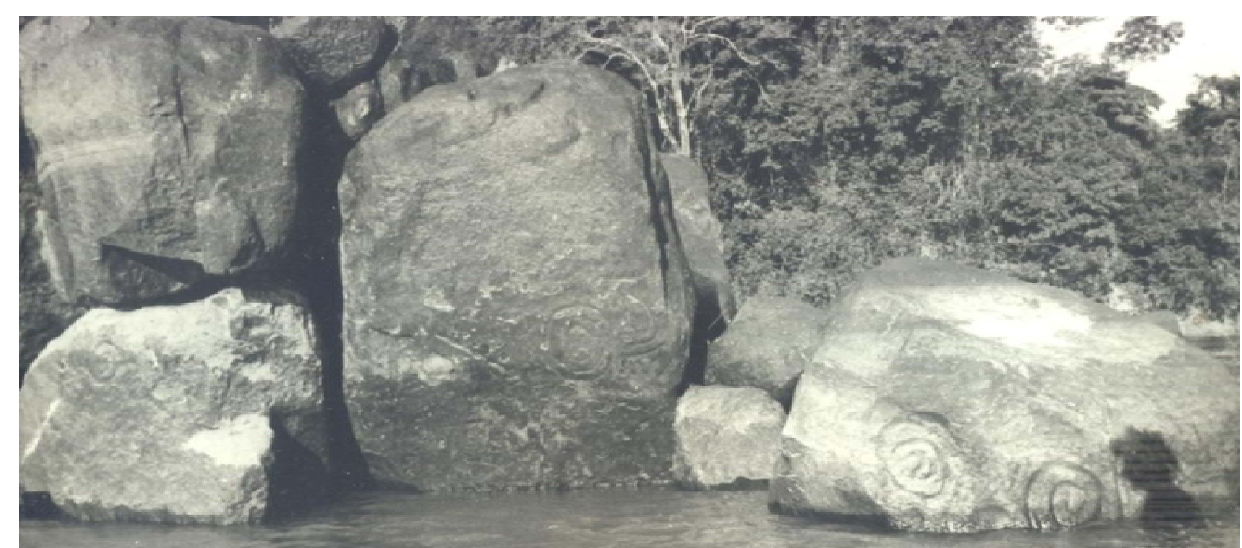

Figura 26: Gravuras rupestres encontradas no trecho encachoeirado do rio Madeira (foto: Carlos Augusto,[sobrenome?], circa 1970).

Ainda nas proximidades do rio Abunã, o arqueólogo gaúcho identificou "muralhas $(120 \times 100 \mathrm{~cm})$, irregulares, toscas e sub-circulares, com até $380 \mathrm{~cm}$ de periferia" no topo de "pirocas" graníticas (MILLER, 1987a: 13; 1992: 227). Trata-se da serra da Muralha, visitada pelo presente pesquisador e por Carlos Zimpel no ano de 2011 (Fig. 27). Apesar de Miller ter identificado sedimentos ${ }^{50}$ no interior da muralha, com evidências de dois níveis de ocupação distintos, não identificamos em nossa visita a existência de qualquer sedimento em profundidade vinculado à muralha. Essa, afinal, estava no topo de um imenso afloramento granítico. Miller até apresenta datas para suas duas ocupações. A ocupação mais antiga seria pré-cerâmica (300 a.C.), e a mais recente, composta por cerâmica simples (séc. VII).

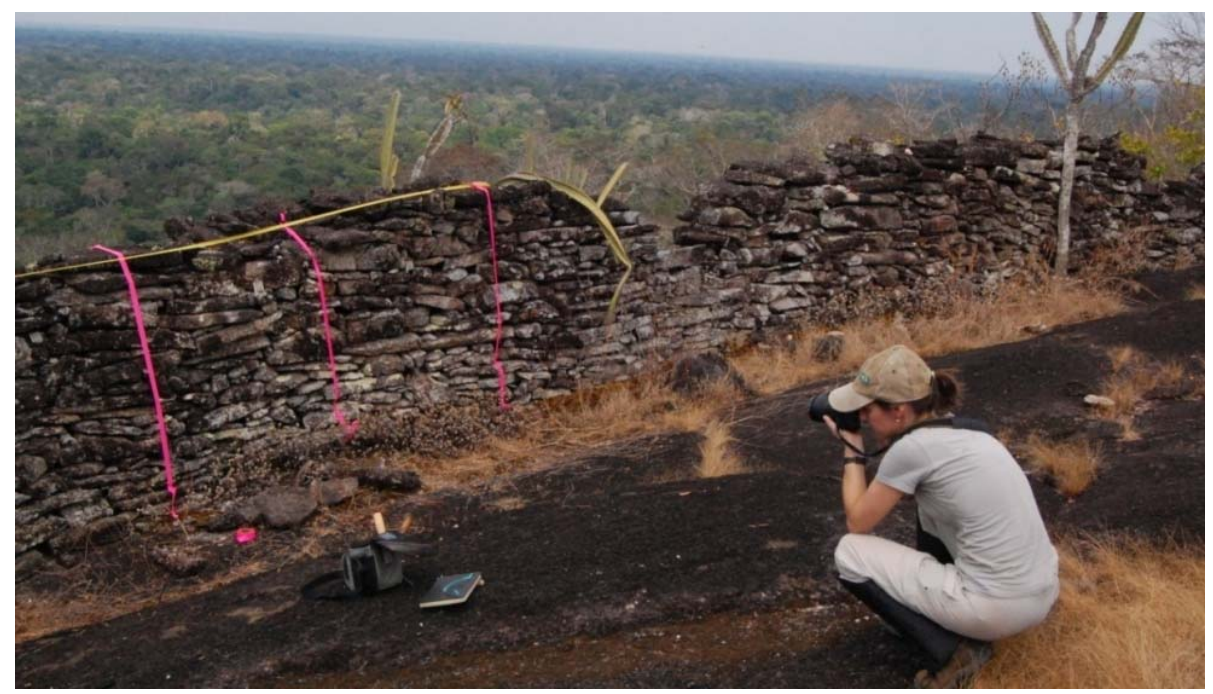

Figura 27: Serra da Muralha (foto: Fernando Ozorio de Almeida, 2010).

\footnotetext{
${ }^{50} \mathrm{O}$ autor alega ter escavado uma unidade de 1 × 2 × 1,7m (MILLER, 1987a: 13).
} 
Um breve desvio a partir do curso do rio Madeira leva à fase Jaci-Paraná, localizada no rio homônimo, cuja cerâmica seria caracterizada por possuir antiplástico caraipé, formas com contorno simples e ausência de decoração (MILLER, 1992: 226-27). Miller não apresenta nenhuma data para essa fase. Para o presente projeto, o detalhe mais importante sobre esse rio é o fato de aparentemente haver um intervalo espacial e cultural entre a Subtradição Jatuarana, que ocupa a maior parte da calha do baixo-alto Madeira, e a fase JaciParaná, localizada em um dos afluentes do Madeira, intervalo que também acontece (veremos no Capítulo 4) no rio Jamari. Miller (1999: 334) reconhece essa diferenciação. Para futuros trabalhos, seria interessante realizar uma comparação entre essa fase e a Tradição Jamari, uma vez que ambas são caracterizadas por uma cerâmica não decorada.

Descendo o rio, a partir das cachoeiras de montante (Teotônio e Santo Antônio) estão os sítios da Tradição Polícroma da Amazônia, regionalmente conhecida como Subtradição Jatuarana. Tratam-se dos sítios que são objeto central dessa tese.

Miller definiu essa Subtradição a partir do material coletado em 32 sítios-habitação, de sítios-oficina lítica associados aos sítios-habitação e de um sítio-cemitério, espalhados por uma extensão de $550 \mathrm{~km}$ do alto e médio Madeira. Os sítios dessa Subtradição estariam vinculados a pacotes de terra preta, com até 210 centímetros de profundidade, por vezes com distribuição de material que acompanha o eixo maior do rio e diâmetro horizontal atingindo até $2.100 \mathrm{~m}$. A datação mais antiga, 700 a.C. ${ }^{51}$, seria proveniente de uma amostra coletada 30cm acima da base da camada de terra preta do sítio Teotônio (MILLER, 1992: 224).

Não haveria terra preta no sítio-cemitério encontrado por Miller. Os enterramentos seriam secundários, realizados em urnas antropomorfas (p. 223). Em trabalhos mais recentes, relacionados à implantação da UHE Jirau, rio acima da cachoeira de Santo Antônio, outros sítios-cemitério foram identificados, também desvinculados de terra preta (MOUTINHO e ROBRAHN-GONZÁLEZ, 2010). Esses estudos apontam uma aparente ausência de sítioshabitação Jatuarana (e terra preta) na região do entorno da cachoeira do Jirau. Essa informação, se confirmada, poderia indicar uma tendência desses grupos a enterrar os mortos longe das aldeias. Isto é, de forma distinta dos ambíguos Karipuna, que habitaram a mesma região no período colonial e realizavam enterramentos em urnas dentro da aldeia (KELLER, 1874: 124). Tais dados preliminares sugerem também que os grupos Jatuarana talvez

\footnotetext{
${ }^{51}$ Miller (1992: 224) apresenta também uma segunda datação antiga, proveniente do sítio Igapó 1: 400 a.C.
} 
ocupassem apenas áreas ribeirinhas ao lado e abaixo das cachoeiras de jusante (Teotônio e Santo Antônio), utilizando as cachoeiras de montante apenas para eventuais rituais funerários.

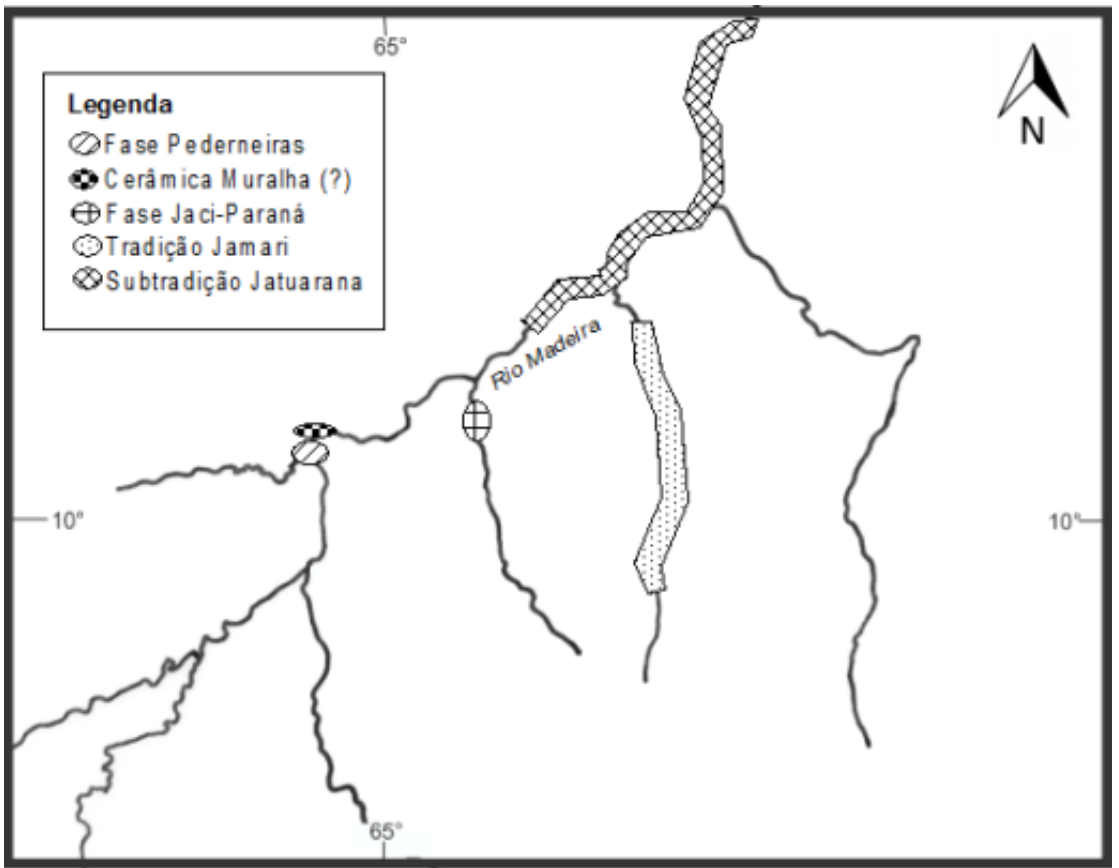

Figura 28: Fases, Subtradições ou Tradições cerâmicas encontradas nas margens do alto Madeira ou no baixo curso dos afluentes deste rio.

O material lítico englobaria lâminas de machado polidas, algumas contas de colar, alisadores e laterita cortante (MILLER, 1980: 31; 1992: 224). A cerâmica da Subtradição Jaturarana seria pouco arenosa e manufaturada com uso de antiplástico caraipé. $O$ acabamento de superfície seria elaborado, com presença de brunidura (esfumarado) e engobos branco e vermelho. Algumas formas possuiriam contornos compostos, com presença de bordas recortadas. Também haveria assadores. Além das tradicionais decorações da Tradição Polícroma (i.e. policromia, incisos e acanalados), Miller observa técnicas decorativas que fazem a Subtradição Jatuarana destoar dessa Tradição: ponteados, ungulados, pinçados, serrungulados, estampados, carimbados, apliques zoo e antropomorfos (Tabela 9). A presença desses elementos será discutida nos Capítulos 5 e 6 . 


\begin{tabular}{|c|c|}
\hline Categoria & Atributos \\
\hline Antiplástico & Caraipé (predominante), cauixí, carvão e areia. \\
\hline Pasta & Compactada mas porosa, pouco arenosa. \\
\hline $\begin{array}{l}\text { Tratamentos de } \\
\text { superfície }\end{array}$ & Polimento, brunidura, envernizado. \\
\hline Formas & $\begin{array}{l}\text { Tigelas com contorno simples ou composto; bordas introvertidas, } \\
\text { diretas e dobradas tipo "prato", podendo ser acasteladas (?) ou } \\
\text { recortadas; assadores; formas carenadas (compostas). }\end{array}$ \\
\hline Decorações plásticas & $\begin{array}{l}\text { Exciso raspado, inciso, ponteado, ponteado arrastado, ungulado, } \\
\text { pinçado, serrungulado, acanalado fino, estampado, carimbado, } \\
\text { apliques zoo e antropomorfos. }\end{array}$ \\
\hline Decorações pintadas & $\begin{array}{l}\text { Engobo vermelho e branco, monocromias (em positivo ou } \\
\text { negativo), cores preta, sépia escuro, marrom, magenta, vermelho, } \\
\text { laranja, amarelo e creme, que por vezes são acompanhadas por } \\
\text { decorações plásticas. }\end{array}$ \\
\hline Outros & Contas vazadas e arredondadas, rodas de fuso, abrasadores. \\
\hline
\end{tabular}

Miller também percebe algumas mudanças na indústria Jaturarana através do tempo, entre elas: "maior popularidade das técnicas plásticas no início da sequência e maior popularidade dos aspectos crômicos no final (...)" (1992: 224). Essa observação também será retomada no Capítulo 6 e será essencial para a compreensão do sítio Teotônio e, por consequência, da cronologia da Subtradição Jatuarana.

Ao que parece, o predomínio da Subtradição Jatuarana a jusante das últimas cachoeiras do alto rio Madeira não ocorreu de forma homogênea. Outros grupos também habitaram essa região no período pré-colonial. Por exemplo, no presente estudo, será apresentado o sítio Nova Vida (Capítulos 4 a 6), encontrado no alto Madeira, mas que não pode ser inserido nessa Tradição. Da mesma forma, os estudos desenvolvidos por Zuse (2010) em sítios relacionados à cachoeira de Santo Antônio parecem indicar que havia uma significativa diversidade cultural nessa área.

\subsection{O rio Guaporé, o Complexo Cultural do Marico}

O rio Guaporé pertence a um contexto de terras baixas, onde ocorre um mosaico de meandros abandonados, muito semelhante ao que se observa no rio Madeira. Trata-se de um conjunto de processos intensos de erosão e deposição de sedimentos, cuja dinâmica leva à 
migração do rio e à formação de lagos de meandro, em geral circundados por planícies fluviais (CPRM, 2007; IBGE, 2006).

As margens do rio Guaporé possuem uma das cerâmicas mais antigas do sudoeste da Amazônia $^{52}$. Trata-se da fase Bacabal, encontrada nos sambaquis do pantanal do Guaporé, com datas próximas a 2000 a.C.. Entretanto, Miller (1999: 335) desvincula essa fase da formação dos sambaquis ${ }^{53}$, indicando que esses seriam fruto de ocupações de grupos préceramistas $^{54}$. Se as datas estiverem corretas, ajudarão a fundar discussões sobre o aparecimento e a dispersão da cerâmica no sudoeste amazônico, essenciais para a compreensão de antigos processos de migração/expansão, assim como do próprio surgimento de cerâmica elaborada ${ }^{55}$.

\begin{tabular}{|c|l|c|l|}
\hline $\begin{array}{c}\text { Material } \\
\text { (fase) }\end{array}$ & \multicolumn{1}{|c|}{ Local } & Idade & \multicolumn{1}{c|}{ Descrição do material } \\
\hline Bacabal & $\begin{array}{l}\text { Pantanal do } \\
\text { Guaporé }\end{array}$ & $\begin{array}{l}1970+-85 \text { a.C. } \\
1630+-105 \text { a.C. }\end{array}$ & $\begin{array}{l}\text { Vasos com marcas de folhas nas bases, engobo } \\
\text { vermelho, presença de asas simples ou bastante } \\
\text { estilizadas (com apliques zoomorfos), e decoração } \\
\text { excisa e incisa. As bases são plano-circulares e as } \\
\text { bordas são elipsoides. Também ocorre a presença } \\
\text { de machados polidos, mãos de pilão, almofarizes, } \\
\text { mós, adornos de valvas perfuradas. }\end{array}$ \\
\hline
\end{tabular}

Tabela 10: Fase Bacabal, representando as antigas ocupações ceramistas do pantanal do Guaporé (fonte: MILLER, 1999).

No entanto, para o presente estudo, o mais importante aspecto geográfico ligado ao rio Guaporé é sua proximidade do rio Paraguai e, por consequência, dos rios Paraná e Prata. Quase todos os estudiosos interessados na expansão dos grupos Tupinambá e Guarani (e.g. BROCHADO, 1984; MÉTRAUX, 1927; MILLER, 1983; NEVES, 2012; NOELLI, 1996a, 1998, 2008a; RODRIGUES e CABRAL, 2012; SCHMITZ, 1991) notaram essa ligação geográfica entre as duas mais importantes bacias hidrográficas do continente sul-americano,

\footnotetext{
${ }^{52}$ Para a região do alto Guaporé, Miller (1987) apresenta também algumas das datas mais antigas, e controversas, da ocupação humana na América do Sul. Trata-se da data de 13.000 a.C., proveniente do Abrigo do Sol, relacionado pelo autor a alguns dos primeiros habitantes da Amazônia (cf. MEGGERS e MILLER, 2003).

${ }^{53}$ Os sambaquis possuiriam formato semi-circular, com diâmetro variando entre $63 \mathrm{~m}^{2}(8 \times 10 \mathrm{~m})$ e $12.800 \mathrm{~m}^{2}$ (105 x 145m) e mais de 4m de profundidade (MILLER, 1999: 335).

${ }^{54}$ Trata-se da fase Sinimbu, com uma única data apresentada por Miller (1999: 335): 4365+-105 a.C.

${ }^{55}$ Alguns sambaquis amazônicos, como o sítio Taperinha do baixo Tapajós (ROOSEVELT, 1995) e os da fase Mina (SIMÕES, 1981), encontrados no litoral do Salgado, possuem cerâmica "utilitária" (pouco elaborada quanto aos tratamentos de superfície), ao passo que outras cerâmicas antigas do leste amazônico, como a do sambaqui Bacanga (BANDEIRA, 2008), apresentam material com rico acabamento de superfície.
} 
do Amazonas e do Paraná, e o potencial explanatório desse elo para a compreensão dos movimentos de expansão desses grupos.

Uma sucinta descrição do contexto do rio Guaporé também é válida por ser ilustrativa de duas questões pertinentes para o presente estudo. Em primeiro lugar, a região do médio Guaporé possui populações falantes de línguas Tupi-Guarani. Assim como os Kagwahiva, os Pauserna (Tupi-Guarani do Guaporé) parecem ter migrado para o sudoeste amazônico e não a partir dele (MÉTRAUX, 1979; RAMIREZ, 2006). Segundo, o entorno do rio Guaporé possui hoje uma das maiores diversidades linguísticas do mundo (CREVELS e VAN DER VOORT, 2008) e cujos correlatos arqueológicos são de complexa compreensão (cf. LIMA, 2011; MILLER, 1983).

Segundo Crevels e van der Voort (2008: 151-152), a região do médio Guaporé possui mais de 50 línguas, representando oito troncos linguísticos e 11 grupos isolados. Essa diversidade linguística inclui grupos Arawak, Txapakura, Jabuti, Nambikwara, Pano e Tupi (famílias Tupi-Guarani, Tupari e Mondé). Sem contar com os Palmella, um grupo Karib que teria habitado a região no século XIX, mas teria desaparecido (MALDI, 1991: 228).

Durante os trabalhos relacionados à criação da Área Indígena Rio Branco ${ }^{56}$, foi identificada a presença de índios isolados na região. Uma equipe enviada pela Fundação Nacional do Índio (FUNAI) à região acabou por identificar uma série de acampamentos com presença de um tipo específico de cestaria feito com fibra de tucum, denominado marico. Esse tipo de cestaria seria comum a grande parte dos grupos que habitam a região, indicando um sistema de redes de troca denominado por Maldi (1991) de Complexo Cultural Marico.

Esse complexo não seria caracterizado apenas pela troca de cestaria, mas também por um uso comum de bebidas fermentadas (chicha) de milho e mandioca doce (mandioca brava ausente) e pelo uso xamânico de alucinógenos. Tanto Maldi (1991) quanto Crevels e van der Voort (2008) acreditam que esse sistema de redes de troca seria muito antigo.

É difícil saber ao certo quais desses grupos seriam encontrados na região no período pré-colonial. Lévi-Strauss (1948; cf. GALVÃO, 1960) divide o Guaporé culturalmente, sendo o lado ocidental (Llanos de Mojos) predominantemente Arawak (cf. DENEVAN, 1966) e o oriental possuiria grupos Tupi ao sul e Txapakura ao norte. Indícios apontam uma grande evasão de grupos ocidentais no século XVIII, em decorrência da dissolução da poderosa

\footnotetext{
${ }^{56}$ Em 1980 (MALDI, 1991).
} 
província jesuítica de $\operatorname{Mojos}^{57}$. Essa província reuniu uma série de grupos sob a proteção dos religiosos e findou com a expulsão dos jesuítas em 1768 (MALDI, 1991: 223).

Talvez um dia os dados arqueológicos contribuam para a distinção dos grupos regionais antes e depois do início do período colonial e antes e depois do fim da província de Mojos. No entanto, o que foi observado de início pelos escassos estudos nas margens do Guaporé é que haveria uma grande homogeneidade na cerâmica dos sítios arqueológicos. Miller (1983), que não é conhecido por sua parcimônia em criar fases arqueológicas, cita apenas duas para o médio Guaporé, as fases Corumbiara e Pimenteira.

Os sítios da fase Corumbiara seriam encontrados em ambas as margens do médio Guaporé, desde a foz do rio Mequéns até a baía da Laranjeira. Miller indica que esses sítios seriam relacionados a "valas e taipas, como trincheiras, em número de uma a três, mais ou menos concêntricas, arqueadas, com as extremidades próximas ao rio, corito ou planície de inundação" (1983: 127-128). Essas valas poderiam ser uma variação do que se conhece hoje por geoglifos (SCHAAN et al., 2008, 2009; SAUNALUOMA e SCHAAN, 2012). Os geoglifos do Guaporé seriam diferentes dos encontrados no Acre, uma vez que os primeiros possuem pacotes de terra preta com alta densidade cerâmica e presença de fragmentos cerâmicos com decoração elaborada. Essa decoração seria caracterizada pela presença de motivos incisos e ponteados que seriam executados em áreas restritas do vaso. Haveria também filetes aplicados, pigmentos branco e vermelho, esfumarados, apliques modelados zoo ou antropomorfos e "estatuetas" antropomorfas. Outros atributos dessa cerâmica seriam antiplástico de cauixi, mineral e caraipé, queimas raramente completas, formas (um total de 26) com contornos simples, inflectidos, compostos e (raramente) complexos, assim como pratos, os chamados assadores. Todos os sítios possuiriam urnas funerárias. Miller observa ainda uma baixa presença de material lítico, presença de lâminas de machado, trituradores e percutores (1983: 135-181). O autor associa esse material aos grupos Tupari (uma família linguística distinta do tronco Tupi) e relaciona cinco datações para essa fase (Tabela 11).

\footnotetext{
57 "No século XVI, os conquistadores espanhóis invadiram o rio da Prata, subiram o rio Paraguai, e instalaram-se em Assunção. (...). Pouco a pouco, a esperança de descobrir ouro desapareceu e, nos séculos XVII e XVIII, as ordens religiosas conseguiram do rei de Espanha o controle absoluto das terras baixas da atual Bolivia. Os franciscanos instaram suas missões ao norte dos Yungas de Apolo, entre o Beni e o Madre de Dios, enquanto os jesuitas estabeleceram verdadeiras teocracias nas Savanas de Mojos, na Chiquitania e com os indios Guarani do Paraguai” (RAMIREZ, 2006: s/p.)
} 


\begin{tabular}{llll}
\hline Sítio & Nível (cm) & Datação (AP) & Datação (AD) \\
\hline RO-CO-06 & $30-40$ & $585+-55$ & 1365 \\
RO-PN-03 & $30-40$ & $490+-60$ & 1460 \\
RO-PN-02 & $40-50$ & $195+-45$ & 1755 \\
RO-PN-03 & $50-60$ & $380+-60$ & 1570 \\
RO-PN-03 & $70-80$ & $1655+-65$ & 295 \\
\hline
\end{tabular}

Tabela 11: Relação de datas da fase Corumbiara (fonte: MILLER, 1983: 189-190).

Miller (1983) não acredita na data mais antiga da fase, que de fato destoa das demais. No entanto, o autor recua as datas intermediárias até o século X, para coincidir com o que ele considera ser um clímax agroclimático.

A fase Pimenteira, por sua vez, estaria localizada entre os rios Piolho (Brasil) e Três de Julho (Bolívia). Os elementos da cerâmica dessa fase seriam uma cópia do que foi descrito para a fase Corumbiara: valas, terra preta, urnas funerárias, fragmentos cerâmicos com antiplástico de caraipé, cauixi e mineral, filetes aplicados, motivos incisos e ponteados, figuras zoomorfas, lâminas de machado, trituradores e percutores. Miller reitera a semelhança entre essas fases, como quando indica que a maioria das 14 formas cerâmicas da fase Pimenteira aparece na fase Corumbiara (p. 255). A diferença entre essas cerâmicas seria basicamente geográfica. $\mathrm{O}$ autor, que relaciona o material Pimenteira ao dos Pauserna (grupo Tupi-Guarani), apresenta as seguintes datações para essa fase:

\begin{tabular}{llll}
\hline Sítio & Nível $(\mathbf{c m})$ & Datação (AP) & Datação (AD) \\
\hline RO-CO-04 & $35-45$ & $2465+-55$ & 515 a.C. \\
RO-CO-03 & $30-40$ & Moderno & - \\
RO-CO-05 & $35-45$ & $240+-40$ & 1710 \\
\hline
\end{tabular}

Tabela 12: Relação de datas da fase Pimenteira (fonte: MILLER, 1983: 189-190).

Mais uma vez, Miller descarta a data antiga (515 a.C.), assim como o fez com a data moderna. A data intermediária (1710 d.C.), ele relativiza. Como seu objetivo é contradizer a hipótese de Métraux (1927) de que os Pauserna foram os Guarani (sem cerâmica da Subtradição Guarani) que migraram do Itatim (Paraguai), o início da fase Pimenteira só poderia (na visão de Miller) ser pré-colonial. O argumento é que, uma vez que os dados arqueológicos do Itatim indicam que os grupos de lá possuiriam uma cerâmica "Tupiguarani" e que a fase Pimenteira não pertencia à Tradição “Tupiguarani”, então os Pauserna (supostos produtores da fase Pimenteira) não seriam oriundos de migrações ocorridas no período colonial. No entanto, dados linguísticos levantados por Ramirez (2006) parecem confirmar a ligação dos Pauserna com os Guarani do sul, dando apoio à proposta de Métraux e 
contradizendo Miller. Além do mais, a maior contradição vem do próprio Miller (2009), que defende que cada família do tronco Tupi possui um estilo artefatual distinto (cada família possuiria sua própria Tradição arqueológica), ao mesmo tempo em que indica que duas famílias do tronco Tupi do médio Guaporé (os Tupi-Guarani e os Tupari) produziriam material inserido em duas fases "pertencentes a uma única tradição" (1983: 268).

O fato de Miller apontar que os Pauserna ocuparam sítios com material Pimenteiras apenas confirmaria o hábito dos grupos Tupi-Guarani de ocupar áreas de antigas aldeias (deles ou de outrem). Nada indica que esses grupos ainda possuíam cerâmica após o período de influência missioneiro. Sem contar o fato de que o início da ocupação dos grupos dessa fase só ocorreria a partir de 900 d.C., auge de um suposto episódio de progressiva ascensão da temperatura e umidade: "Antes desse ótimo agro-climático para a lavoura de coivara, somente pequenos bandos de caçadores-coletores itinerantes poderiam sobreviver nas planícies do médio Guaporé". Isso ao mesmo tempo em que admite que "há pelo menos 2.000 anos, havia indígenas agricultores no Refúgio do Guaporé" (1983: 39, grifo do autor). Ora, se o próprio autor trabalha com a hipótese de que a região em questão possui o diferencial da estabilidade climática (o Refúgio), como é possível utilizar eventos de instabilidade para justificar qualquer tipo de modificação econômica, social ou cultural ${ }^{58}$ ?

Como o rio Guaporé não é a área-foco deste estudo, não é possível oferecer dados suficientes e construir um quadro consistente para ocupar o lugar da hipótese inconsistente de Miller. No entanto, é possível realizar um esboço preliminar, que pode ser mais bem trabalhado pelos pesquisadores da região no futuro. O primeiro ponto é postular a possibilidade de que a fase Pimenteira não exista. Todos os elementos que compõem essa fase pertencem à fase Corumbiara. O único valor heurístico da fase Pimenteira era sua ligação com os grupos Pauserna para contradizer a hipótese de Métraux, o que parece não ser válido. $\mathrm{O}$ segundo ponto é indicar a suposta grande semelhança entre atributos estilísticos encontrados na cerâmica da fase Corumbiara e nos complexos cerâmicos do alto Guaporé,

\footnotetext{
${ }^{58}$ Estudos de isótopos estáveis (FREITAS et al., 2001; PESSENDA et al., 1998; VIDOTTO et al., 2007) realizados na bacia do alto Madeira, assim como estudos paleo-botânicos realizados na Amazônia ocidental (PIPERNO e PERSALL, 1998), tendem a indicar um período mais seco durante o Holoceno Médio (6000-2000 a.C.) e a retração de áreas de floresta nesse período (e.g. a região de Humaitá, no médio Madeira). A partir de 1000 a.C. haveria um aumento na umidade até os níveis atuais. No entanto, muitos autores (cf. PERSALL, 1998) indicam o problema de realizar ligações diretas entre a mudança de temperatura e umidade e grandes mudanças de comportamento humano, como a do início do processo de domesticação de alimentos. Em microambientes, outros fatores (e.g. a dinâmica de rio, da qual o Madeira, sabemos, é um dos exemplos mais emblemáticos) poderiam ser muito mais decisivos na formação da vegetação do que o duo temperatura/umidade (ROSSETTI et al., 2010: 130).
} 
como os sítios Guapé (W9 $^{59}$ (WT, 2001) e Capão do Canga ${ }^{60}$ (LIMA, 2011, 2012). A principal dessas semelhanças estilísticas é a utilização de decoração em zonas distintas do vaso (bojo superior da face externa) para a execução de decorações plásticas, com a distinção de que as cerâmicas do alto Guaporé possuiriam um predomínio de motivos incisos (zonadoshachurados?) e as cerâmicas do médio Guaporé seriam predominantemente decoradas com motivos ponteados.

Essas decorações, ao que parece, não ocorriam nos vasos que os Tupari faziam em meados do século XX. Tal constatação pode ser feita a partir do grande número de fotografias tiradas por Caspar $(1953,1958)$ no seu período entre os Tupari ${ }^{61}$, quando o autor - em geral sem intenção e com uma felicidade rara até para trabalhos etno-arqueológicos - capturou uma série de momentos nos quais os Tupari utilizam seus vasos cerâmicos. Um evento único de "fossilização" do chamado contexto sistêmico da cultura material (cf. BINFORD, 1981; SHIFFER, 1985): material em seu contexto de utilização (SCHIFFER, 1987).

Com o inventário de formas cerâmicas feito a partir das fotos de Caspar, é possível testar se de fato ocorre a ligação Corumbiara-Tupari sugerida por Miller (1983) (Tabela 13; Anexo 7). Se confirmada, essa relação indicaria que os Tupari habitam a bacia do Guaporé há mais de mil anos. Trata-se de um exercício preliminar, que utiliza apenas os contornos dos vasos e exclui a (fundamental) comparação volumétrica, assim como outros atributos tecnológicos (e.g. antiplástico, espessura).

\footnotetext{
${ }^{59}$ Datados entre 1330-1660 d.C. (WÜST, 2001).

${ }^{60}$ Datados a partir de 800 d.C. (LIMA, 2012).

${ }^{61}$ Vale lembrar que as seleções fotográficas das versões alemã (1953) e brasileira (1958) da obra de Caspar trazem diferentes coletâneas imagéticas, com poucas fotos repetidas.
} 


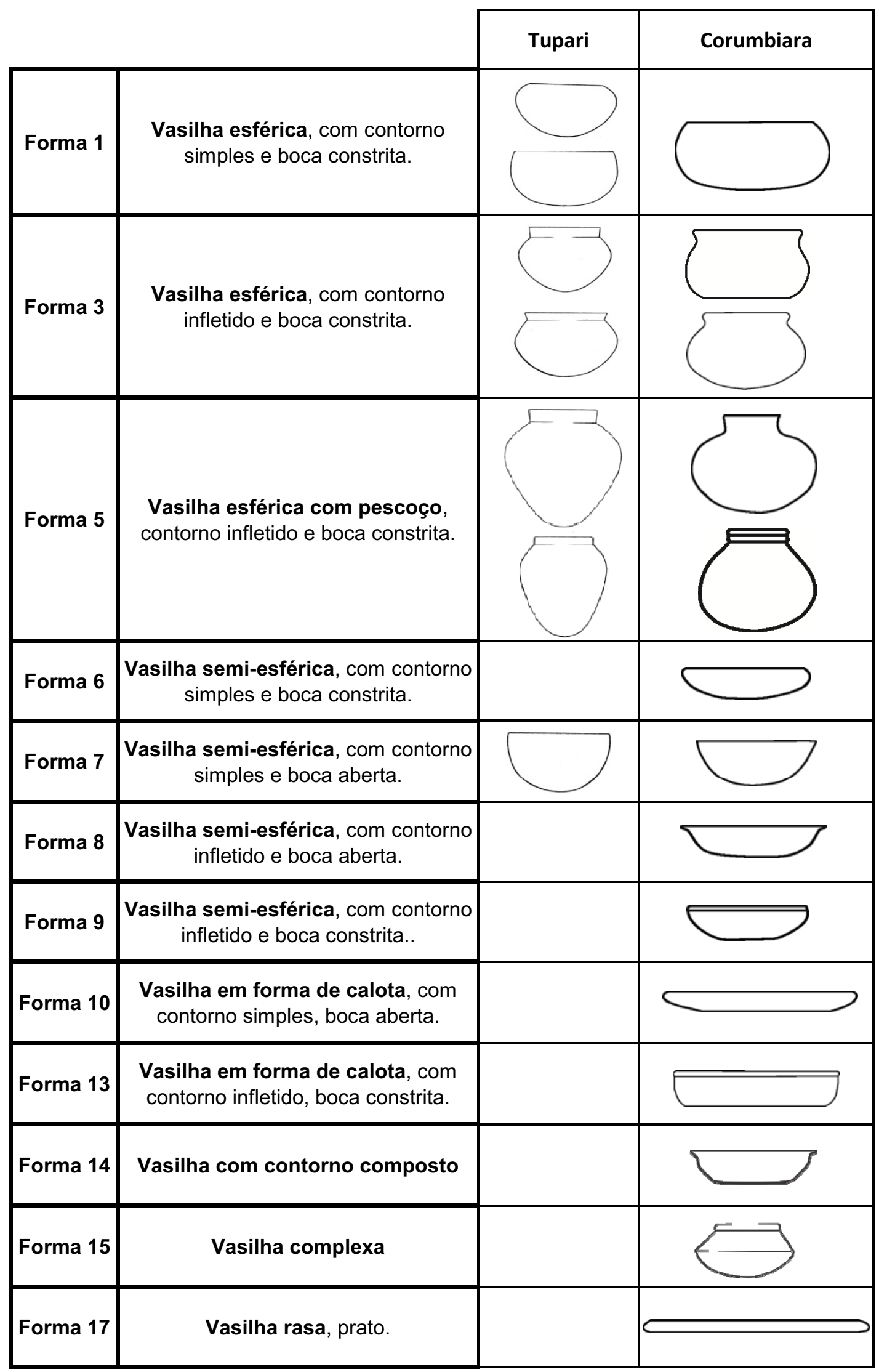

Figura 13: Compararação entre a cerâmica Tupari e a fase Corumbiara (Fonte CASPAR, 1958; MILLER, 1983). 
A primeira semelhança entre ambas é a presença de formas ligadas ao preparo (formas 3 e 5) e ao consumo individual (forma 7) de bebidas fermentadas, funções centrais nas sociedades Tupari (cf. abaixo e Capítulo 5). Há uma significativa diferença entre as formas de preparo, sendo que as formas Tupari (aparentemente) possuem fundo cônico, e as formas Corumbiara, fundos planos ou convexos. Nesse ponto é necessário desculpar Miller: como a imensa maioria dos arqueólogos, ele trabalhou com fragmentos, sendo a inferência da base dos vasos uma das tarefas mais complexas. Por fim, um exemplar (forma 1) de consumo coletivo (Prancha 2, Anexo 7) só aparece na cerâmica Tupari (Tabela 13).

Outras semelhanças entre Corumbiara e Tupari estão na forma 1, assim como na forma 15 Corumbiara, que parece uma versão complexa da forma 3 dos Tupari, claramente utilizada para ser levada ao fogo. O próprio caráter "escuro" da cerâmica Tupari parece análogo à descrição de Miller (1983: 135-181) de vasos da fase Corumbiara: uma cerâmica mal queimada com presença tratamentos de enegrecimento na superfície.

Dentre as diferenças entre os dois agrupamentos, além da ausência de decorações na cerâmica Tupari (incisões, ponteados, pinturas e apliques zoo e antropomorfos), as fotos de Caspar não indicam a existência de assadores como os identificados por Miller na cerâmica Corumbiara (Forma 17). A imagética Tupari também parece carecer de formas abertas semiesféricas, em forma de calota, ou compostas (Formas 8, 10 e 14), presentes no universo Corumbiara.

A ausência de decoração na cerâmica Tupari parece crucial para a resolução dessa questão. Antes de Miller realizar pesquisas no Guaporé, a região do rio Corumbiara havia sido pesquisada pelo arqueólogo amador Ary Pinheiro, que observou nas decorações incisomodeladas um traço tipicamente Arawak, correlação até hoje utilizada por arqueólogos (incluindo o presente pesquisador) (Silva 2012).

Em resumo, pode-se dizer que a correspondência entre a cerâmica Tupari e a Corumbiara ainda não pôde ser estabelecida a partir dessa comparação (se é que um dia será). As formas apresentam algumas semelhanças, mas os elementos decorativos Corumbiara não foram observados na cerâmica Tupari. Ou seja, a inferência de Miller, nesse caso, possui elementos suficientes para justificar futuras pesquisas. Para tanto, será necessário também que se conheça melhor as diferentes cerâmicas existentes na bacia do Guaporé, já que a cerâmica Corumbiara (a priori) se restringe às margens desse rio. 
Uma amostra da presença de outras indústrias cerâmicas nas áreas de interflúvio na bacia desse rio pode ser encontrada no relatório de licenciamento da BR-329 (MILLER, 1987b), ligando Presidente Médici (rio Ji-Paraná) a Costa Marques (rio Guaporé). Nesse relatório, o autor chega a indicar a presença de sete fases pertencentes a 12 sítios arqueológicos $^{62}$, a maioria relacionada à bacia do Guaporé. $\mathrm{O}$ trabalho realizado por Lima (2011: 627) também aponta uma diversidade cultural na região do alto Guaporé. O autor indica a presença de cinco diferentes agrupamentos de grupos ceramistas pré-coloniais na região do alto Guaporé: Tradição Una, cerâmica Córrego do Banhado, cerâmica Capão do Canga, Tradição Uru e Tradição "Tupiguarani”".

No entanto, Lima (p. 606) indica que a presença dos Tupi-Guarani na região é atestada apenas por alguns fragmentos intrusivos com engobo branco ou creme encontrados nos sítios de outras indústrias tecnológicas (e.g. Capão do Canga). Além disso, a data utilizada (séc. XIV) não é proveniente desse material e sim dos trabalhos no Brasil central realizados por Wüst e Barreto (1999). Ainda assim, tais dados atestam uma variabilidade de indústrias cerâmicas indígenas na bacia do Guaporé, que precisam ser dominadas para interpretações mais "antropológicas" do registro arqueológico, incluindo a possibilidade (exemplificada pelas cestarias de Marico) de existência de contextos multi-étnicos ${ }^{63}$ (Capítulo 6).

\subsection{Rio Jamari}

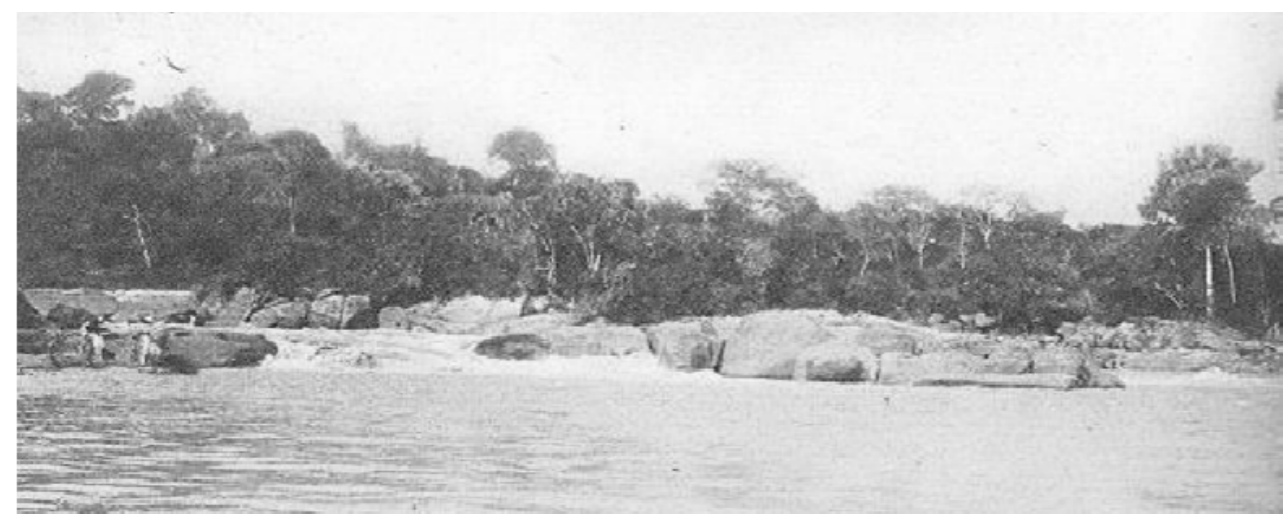

Figura 29: Cachoeira de Samuel a partir do porto do Jamari (fonte: RONDON, 1948).

\footnotetext{
${ }^{62}$ Miller (1987b) apresenta apenas a datação C14 de uma fase (Machupo B): 885 d.C.

${ }^{63}$ Um padrão alto-xinguano?
} 
Se comparada com a Amazônia central, que abrange um imenso número de grandes rios que, grosso modo, correm em um mesmo sentido (o do rio Amazonas), a área da serra dos Pacaás Novos ${ }^{64}$, no interior de Rondônia, é muito mais merecedora do título de coração fluvial. Isso porque possui um padrão de drenagem radial, com rios fluindo em praticamente todas as direções. Dentre os principais rios que nascem na serra dos Pacaás Novos e deságuam no rio Madeira, podemos apontar o Jaci-Paraná, o Candeias e o Jamari.

O rio Jamari foi o objeto inicial dos levantamentos do PALMA, uma vez que sobre ele havia uma grande quantidade de dados proporcionados pelo resgate de sítios arqueológicos impactados pela instalação da hidrelétrica de Samuel (i.e. MILLER et al., 1992). O que mais chamou a atenção nesses estudos foi a cronologia gerada, com poucos intervalos, na qual há quase 8.000 anos de ocupações contínuas. Dados que contrastavam com os obtidos na Amazônia central, onde foi observado um longo hiato cronológico durante o Holoceno médio (NEVES, 2005, 2012).

A cronologia do médio Jamari é composta por três frases pré-cerâmicas e quatro fases cerâmicas. As duas fases líticas mais antigas, Itapipoca e Pacatuba, possuíam uma dissonância em relação à fase lítica mais recente (Massangana). Isso porque, além do surgimento de material polido na fase Massangana, essa fase estaria associada a pacotes de terra preta, o que remeteria a um modo de vida mais sedentário, provavelmente ligado a uma agricultura incipiente (MILLER et al., 1992).

\begin{tabular}{|l|l|l|}
\hline \multicolumn{1}{|c|}{ Identificação } & \multicolumn{1}{|c|}{ Idade } & \multicolumn{1}{c|}{ Material (lítico) } \\
\hline $\begin{array}{l}\text { Fase Massangana } \\
(9 \text { sítios })\end{array}$ & $2830 \pm 90-690 \pm 60$ a.C. & $\begin{array}{l}\text { Material lascado incluindo raspadores, } \\
\text { lâminas de machado, almofarizes, núcleos e } \\
\text { percutores. Matéria prima composta por } \\
\text { rochas cristalinas, calcedônia, quartzo e } \\
\text { laterita. }\end{array}$ \\
\hline $\begin{array}{l}\text { Fase Pacatuba } \\
(4 \text { sítios })\end{array}$ & $4140 \pm 10-3260 \pm 70$ a.C. & $\begin{array}{l}\text { Raspadores, lascas, micro-lascas, percutores } \\
\text { e núcleos. Matéria prima composta por } \\
\text { calcedônia, quartzo, rochas cristalinas e } \\
\text { basalto. }\end{array}$ \\
\hline $\begin{array}{l}\text { Fase Itapipoca } \\
\text { (3 sítios) }\end{array}$ & $6370 \pm 100-5020 \pm 60$ a.C. & $\begin{array}{l}\text { Raspadores, percutores, lascas sem retoque } \\
\text { e núcleos esgotados. Matéria prima } \\
\text { composta por calcedônia, quartzo, rochas } \\
\text { cristalinas e basalto. }\end{array}$ \\
\hline
\end{tabular}

Tabela 14: Quadro cronológico dos sítios pré-cerâmicos do baixo Jamari (fonte: MILLER et al., 1992).

\footnotetext{
${ }^{64}$ A serra dos Pacaás Novos atinge 1.126m de altitude (pico do Jarú), o que não deixa de ser considerável para uma região amazônica.
} 


\begin{tabular}{|l|l|l|}
\hline \multicolumn{1}{|c|}{ Identificação } & \multicolumn{1}{|c|}{ Idade } & \multicolumn{1}{c|}{ Material (cerâmica) } \\
\hline $\begin{array}{l}\text { Fase Matapi } \\
(25 \text { sítios })\end{array}$ & $1720 \pm 80$ d.C. & $\begin{array}{l}\text { Antiplástico de areia ou caraipé. Tigelas } \\
\text { rasas e medianas, vasos hemisféricos e } \\
\text { globulares. Sem decoração. }\end{array}$ \\
\hline $\begin{array}{l}\text { Fase Cupuí } \\
(16 \text { sítios })\end{array}$ & $600 \pm 60$ d.C. & $\begin{array}{l}\text { Antiplástico de areia ou caraipé, banho } \\
\text { vermelho. Tigelas rasas a mediamente } \\
\text { profundas, vasos hemisféricos e globulares. } \\
\text { Decoração incisa e escovada. }\end{array}$ \\
\hline $\begin{array}{l}\text { Fase Jamari } \\
(37 \text { sítios })\end{array}$ & $\begin{array}{l}800 \pm 140 \text { a.C. }-1530 \pm 50 \text { d.C. } \\
(42 \text { datas de } 13 \text { sítios })\end{array}$ & $\begin{array}{l}\text { Antiplástico de areia ou caraipé. Cerâmica } \\
\text { com “decoração pintada, incisa e acanalada" } \\
\text { (contestável), lítico polido. }\end{array}$ \\
\hline $\begin{array}{l}\text { Fase Urucurí } \\
(17 \text { sítios })\end{array}$ & $\begin{array}{l}550 \pm 90 \text { - } 280 \pm 50 \text { a.C. } \\
(10 \text { datas de } 7 \text { sítios })\end{array}$ & $\begin{array}{l}\text { Antiplástico de areia ou caraipé, banho } \\
\text { vermelho e rara decoração pintada e incisa. } \\
\text { Tigelas rasas a profundas, vasos } \\
\text { hemisféricos e globulares, bordas diretas, } \\
\text { indiretas e extrovertidas. }\end{array}$ \\
\hline
\end{tabular}

Tabela 15: Quadro cronológico dos sítios cerâmicos do baixo Jamari (fonte: MILLER et al., 1992).

Todas as quatro fases cerâmicas subsequentes estariam ligadas a sítios de terra preta e formariam a chamada Tradição Jamari. Essa Tradição seria caracterizada pelo uso de caraipé como antiplástico, eventual uso de engobo vermelho e rara decoração.

Os sítios da fase Matapi foram encontrados sobre barrancos altos (de 8 a 32m) com forma circular (diâmetro de 80 a 250m) ou elipsoide (120 x 70m a 550 x 200m), com pacotes de até $50 \mathrm{~cm}$ que, por vezes, recobriam sítios da fase Jamari. O material lítico seria composto por lâminas de machado picoteadas ou lascadas, percutores, moedores, pedras-bigorna e hematira (para corante).

Os sítios da fase Urucurí seriam encontrados sobre barrancos ( 9 a 33m acima do rio, no período de estiagem), com disposição circular (diâmetro de 80 a 300m) ou elipsoide (120 x $70 \mathrm{~m}$ a $550 \times 210 \mathrm{~m}$ ), com pacotes de até $90 \mathrm{~cm}$ de profundidade, que por vezes recobriam ocupações Massangana. O material lítico seria restrito a lâminas de machado (picoteadas, polidas ou lascadas).

Os sítios pertencentes à fase Cupuí também foram encontrados sobre barrancos altos (15 a 26m acima do nível do rio, durante o período de estiagem), com forma circular (diâmetro de 100 a $160 \mathrm{~m})$ ou elipsoide ( $130 \times 100 \mathrm{~m}$ a 320 x 130m e, excepcionalmente, 820 x $260 \mathrm{~m}$ ) e pacote arqueológico atingindo $50 \mathrm{~cm}$ de profundidade. O material lítico seria composto por lâminas de machado (picoteadas, polidas ou lascadas) e percutores. 
A fase Jamari é provavelmente a mais complicada ${ }^{65}$ por possuir os elementos mais destoantes da Tradição homônima. Todos esses elementos estão dentro de categorias decorativas, tais como a presença de decorações pintadas, incisas, excisas, acanaladas, ponteadas, serrunguladas, escovadas e modeladas (zoomórficas). As fotos apresentadas por Miller (p. 55) mostram decorações incisas na face interna de flanges labiais e bordas reforçadas com pigmentos vermelho e branco, muito semelhantes às da Tradição Polícroma da Amazônia e dissonantes da Tradição Jamari. No entanto, ao olhar para a sequência seriada produzida por Miller (et al. 1992: 61) para essa fase, é possível notar que esses elementos dissonantes são irrisórios nos sítios da fase Jamari (Anexo 8).

Dessa forma, a impressão gerada é a de que, em uma fase com muitos sítios (37), alguns apresentaram elementos exógenos, possivelmente resultantes de contatos com os povos da Subtradição Jatuarana (no baixo Jamari e no alto Madeira). Miller, que conhecia o material Jatuarana de pesquisas anteriores $(1980,1987 a)$, em vez de relativizar os elementos dissonantes e separá-los no momento de construir suas tipologias, os incorpora. Ou seja, se um dos 37 sítios dessa fase apresentou um único fragmento de borda polícroma, então esse fragmento formará um dos tipos que define a fase, mesmo que não se repita em nenhum dos outros sítios ${ }^{66}$.

Feito o erro, fica claro que Miller se complica a cada momento que pretende utilizar as fases da Tradição Jamari em discussões mais amplas. Por exemplo, ao mesmo tempo em que insere essas fases na Tradição Jamari (MILLER et al., 1992: 39) e faz uma distinção ecológica entre o rio Madeira (Subtradição Jatuarana) e seus afluentes (micro-Tradições regionais, como a Tradição Jamari), o autor (MILLER, 1999: 334) indica a existência de um sítio Cupuí nas margens do Madeira. Da mesma forma, ele liga a fase Urucurí à Subtradição Jatuarana (ZIMPEL, 2009: 165). Para quem mergulha nessa confusão, para quem observa as fotos de cerâmica polícroma encontrada nos sítios da Tradição Jamari (MILLER et al., 1992) e não presta atenção na sequência seriada dessas fases, é muito fácil pensar que há alguma relação cladística entre a Tradição Jamari e a Subtradição Jatuarana. No entanto, como será visto com mais detalhes no Capítulo 5, essa relação não deve ser muito mais do que a de

\footnotetext{
${ }^{65}$ Complicado mesmo é compreender a linha de raciocínio de Miller (et al., 1992: 41) ao descrever que, na fase Jamari, "extensas diferenças na frequência relativa do Jamari Vermelho exigiram a construção de duas sequências seriadas. Datas de Carbono-14 e locais de assentamento entremeados indicam que elas representam uma comunidade composta por duas famílias exógamas (sic.) matrilocais. Uma vez que os tipos de cerâmica são os mesmos, uma única descrição é proporcionada para a fase”.

${ }^{66} \mathrm{Se}$ os atributos da fase Jamari apontados por Miller fossem de fato representativos da fase Jamari, o que não parece ser o caso, seria necessário chegar à conclusão de que a fase Jamari não pertence à Tradição Jamari.
} 
eventuais contatos entre grupos estilisticamente distintos. Como também será visto no Capítulo 5, um sítio "Jamari” que Miller relaciona ao rio Madeira, na altura da boca do rio Jamari, não pertence à Tradição homônima desse rio ${ }^{67}$.

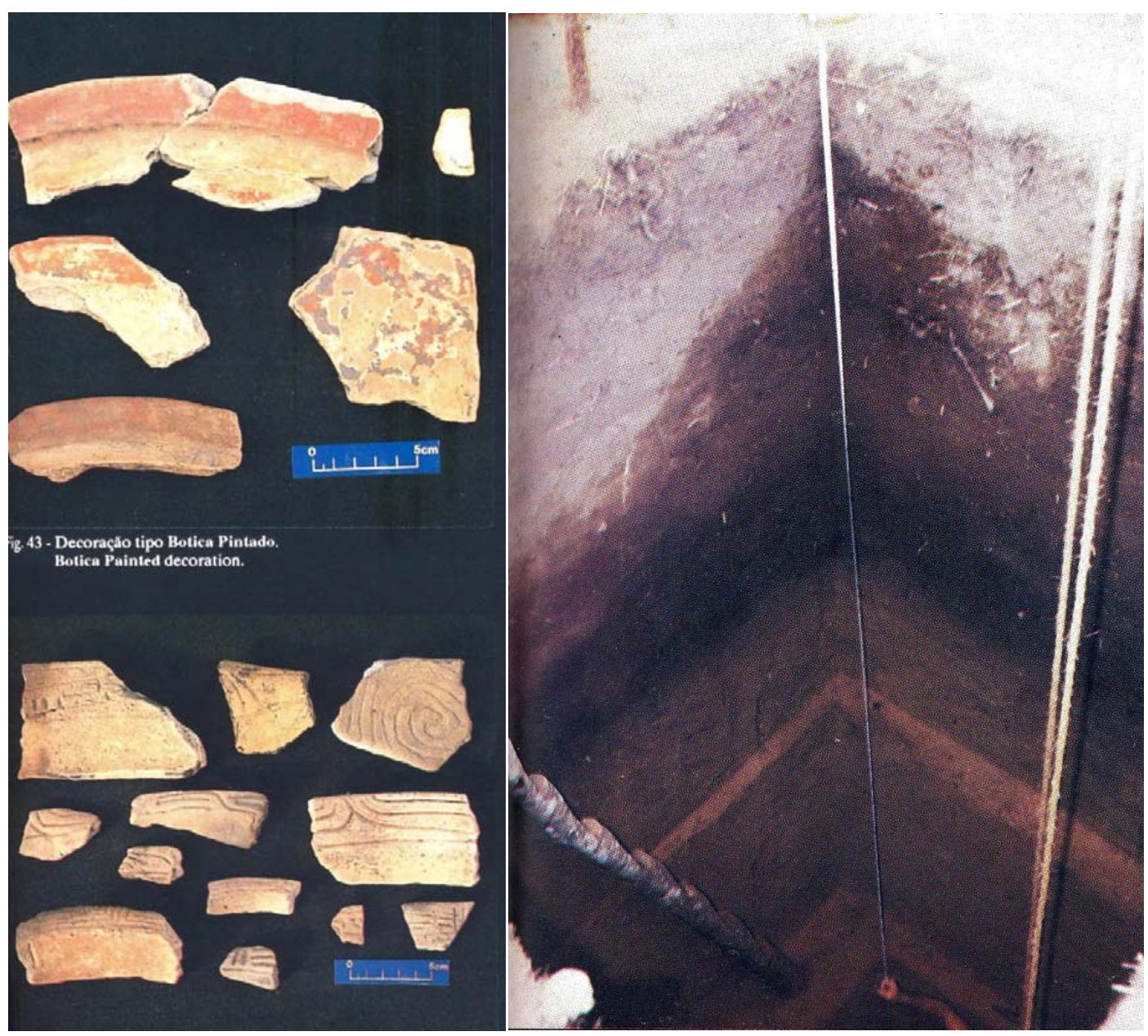

Figura 30: Cerâmica da Subtradição Jatuarana encontrada em sítios Jamari (fonte: MILLER et al., 1992).

Figura 31: Perfil com terra preta enterrada (fase Massangana) presente em todos os estudos arqueológicos na bacia do Madeira (fonte: MILLER et al., 1992).

O material da Tradição Jamari possui poucos atributos em comum com os da Subtradição Jatuarana. Talvez a utilização de antiplástico de caraipé seja o maior traço em comum. A Subtradição Jatuarana é uma cerâmica com espessura fina, com presença de formas compostas ou complexas e recorrente uso de decorações plásticas (acanalados, incisos) e pintadas (em vermelho, preto, branco), ao passo que os fragmentos da Tradição

\footnotetext{
${ }^{67}$ Veremos nos Capítulos 4 a 6 que esse sítio (São Carlos ou Itapirema) pertence à Subtradição Jatuarana.
} 
Jamari são mais espessos, de formas simples e com raras decorações, restritas ao ocasional uso de engobo vermelho sobre as peças.

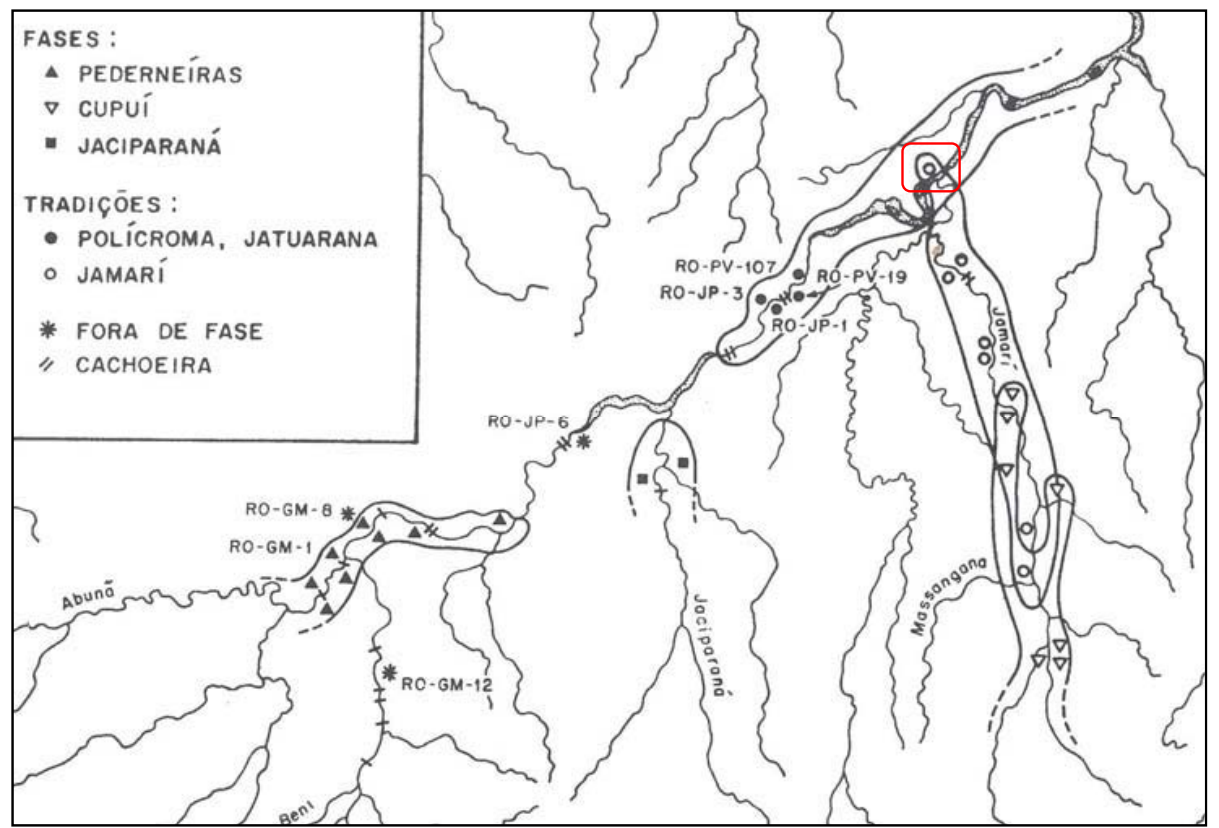

Figura 32: Mapa (sem escala) apontando a presença da Tradição Jamari no rio Madeira, destacada em vermelho (fonte: Miller 1992).

Se retirados os elementos exógenos Jatuarana das fases do médio Jamari, resta apenas uma descrição muito homogênea do tamanho dos sítios, do pacote de terra preta e dos materiais lítico e cerâmico. As distinções entre as fases, então, são basicamente cronológicas.

Assim, para um pesquisador que pretende estudar os sítios do médio ou baixo Jamari - ainda mais um que é proibido de ter contato com o que resta do material da Tradição Jamari, até hoje conservado de uma maneira precária dentro da UHE Samuel - o mais recomendável é dar um passo para trás e considerar que todo o material pertence apenas à Tradição Jamari, sem distinguir entre as fases. Essas, por possuírem uma variabilidade cronológica, apenas geram uma distinção que tem mais a complicar do que a esclarecer. Dessa forma, pelo menos no presente trabalho, o material cerâmico do médio Jamari será tratado apenas como pertencente à Tradição Jamari.

Se as classificações cerâmicas e estratigráficas de Miller geraram alguma confusão, em outros assuntos a contribuição desse pesquisador é mais do que significativa. Tal é o caso da etnobotânica, utilizada por ele de forma pioneira. A relação que Miller $(1992,1999)$ traça entre os sítios com terra preta da região e determinadas palmeiras (i.e. marajá, Pyrenoglyphis marajá, e urucurí, Attalea excelsa Mart.) permitiu que esses sítios fossem encontrados 
mesmo em áreas com baixo potencial informativo por parte da população local. Segundo o autor, o marajá ocuparia o centro do sítio, ou o lugar com maior densidade cerâmica, e o urucurí estaria, em geral, disperso pelo sítio, delimitando-o (1992). Nos estudos de campo, a relação urucurí-terra preta foi de extrema valia para a identificação de sítios junto a ribeirinhos tanto no rio Madeira (sítio Itapirema e Novo Engenho Velho ${ }^{68}$ ) quanto nos levantamentos no médio Jamari. No baixo Jamari, contudo, não ocorreu essa correlação. Por fim, Miller também relaciona a presença do tucumã (Astrocaryum tucuma), da pupunha (Guilielma gasipaes) e do babaçu (Orbygnia martiana) a áreas de sítios arqueológicos.

O pluricentralismo Uru-Eu-Wau-Wau do alto Jamari: Assim como ocorreu com muitos etnólogos nas aldeias dos grupos Tupi-Guarani (Capítulo 2), a sensação de França (2012) ao chegar às aldeias Uru-Eu-Wau-Wau (grupo Kagwahiva, Tupi-Guarani do alto Jamari), era de uma "frouxidão" na organização espacial das casas, dos terreiros e dos pátios. A autora designa o fenômeno de pluricentralismo, e cada um desses centros estaria organizado de acordo com os laços de parentesco (FRANÇA, 2012: 157). Nimuendajú (1924), ao visitar aldeias abandonadas dos Parintintin (Tupi-Kagwahiva), parece confirmar a disposição aleatória das casas por parte desses grupos. Por fim, os Uru-Eu-Wau-Wau são conhecidos por fabricar uma chicha (kaminã) combinando castanhas e mandioca. Segundo França (2012: 135-36), antigamente a bebida era muito mais consumida - e muito mais forte.

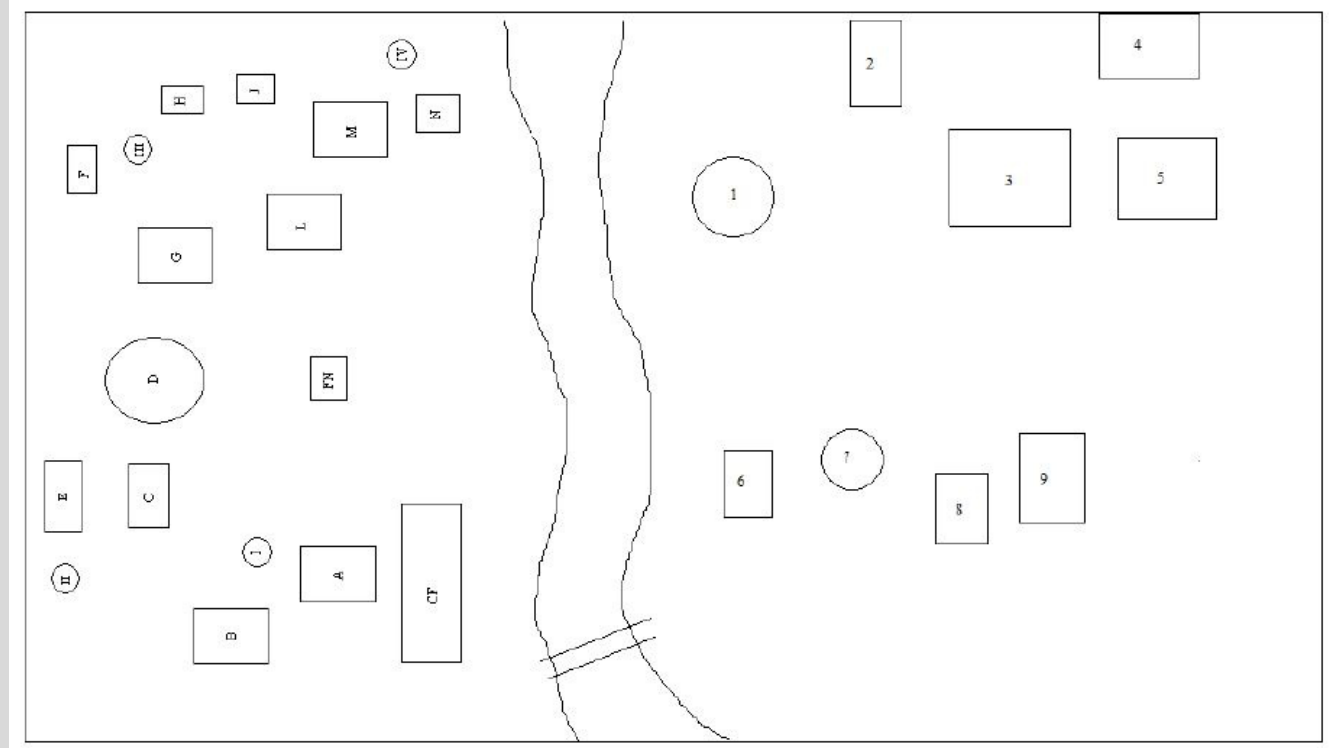

Figura 33: Croqui da aldeia dos Uru-Eu-Wau-Wau, no alto Jamari, que mostra uma disposição aleatória das casas (fonte: FRANÇA, 2012).

\footnotetext{
${ }^{68}$ Esse sítio não faz parte dos levantamentos arqueológicos do PALMA, e sim do diagnóstico arqueológico, realizado pelo presente aluno, relativo à implementação da Usina Hidrelétrica de Santo Antônio.
} 
Também relevante para o presente estudo é a hipótese de Miller de que a sequência cronológica da arqueologia do médio Jamari seria correlata à história dos grupos Arikém (família Tupi-Arikém) que habitavam o médio Jamari à época da entrada de Rondon na região, no início do século XX. Segundo o autor, a história de ocupação desse grupo no médio Jamari remeteria à fase Pacatuba (6000 AP), passando pela fase Massangana (4500 AP) e pela Tradição Jamari (2500AP-230 AP) (MILLER, 2009: 83). Essa hipótese é, pelo menos, mais provável do que as teorias ambientais do autor. No entanto, Miller não se dá o trabalho de mostrar elementos que permaneceram entre cada uma dessas fases culturais, em especial entre as fases líticas e cerâmicas. Também não cita nenhum relato histórico que descreva a cerâmica Arikém. Além disso, falta uma maior quantidade de datas ainda mais recentes - a datação mais recente remete ao século XVII - uma vez que houve uma grande movimentação de grupos na época colonial, particularmente no ciclo da borracha, a partir do século XIX. Por fim, é curioso o autor ter empurrado a cronologia até a ocupação Pacatuba e ter deixado a fase Itapipoca, mais antiga e com descrição quase idêntica à da fase Pacatuba, de fora.

\subsection{O rio Ji-Paraná}

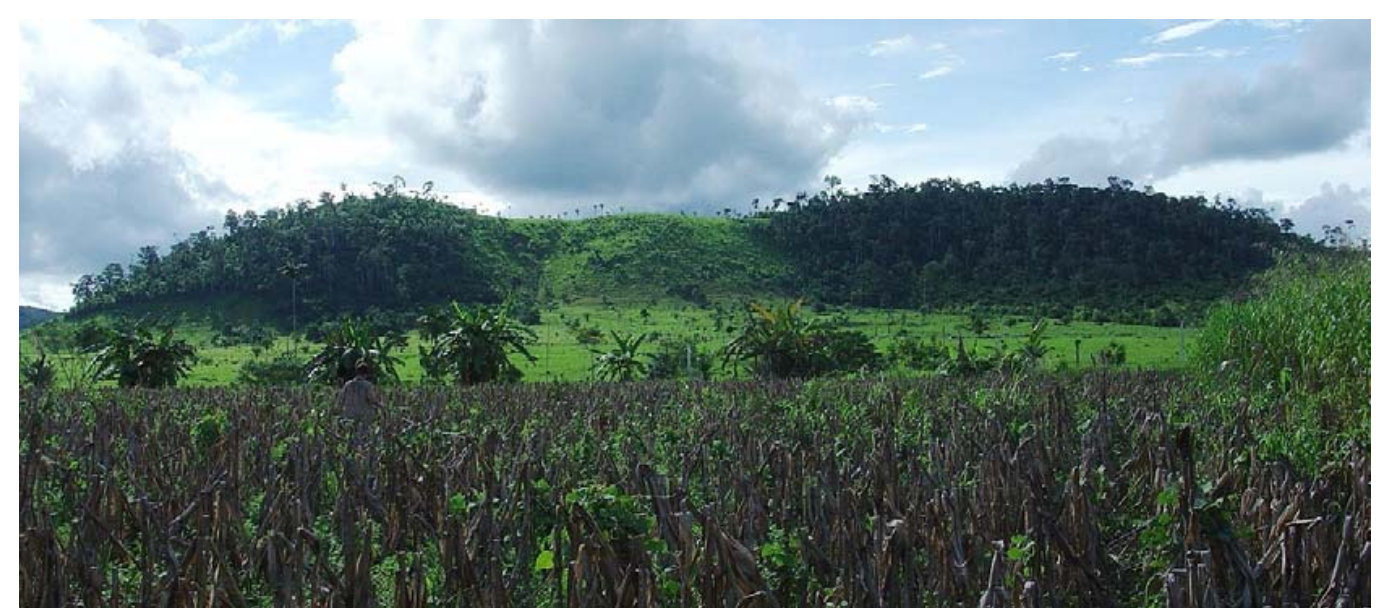

Figura 34: Contraste entre a planície aluvial onde se encontra o sítio Barro Roxo e as serras graníticas que o circundam o sítio, no alto Ji-Paraná (foto: Fernando Ozorio de Almeida, 2009).

O rio Ji-Paraná (ou Machado) é o último a ser trabalhado nesta contextualização regional. Nasce na serra dos Parecis e possui uma extensão aproximada de $800 \mathrm{~km}$. O trecho com maior número de cachoeiras se situa entre a foz de dois importantes afluentes, o Urupá e o Machadinho. Em grande parte do percurso, são encontrados afloramentos de rochas, que 
podem formar ilhas. Assim como no Jamari, a topografia de entorno do alto e médio curso do Ji-Paraná é muito mais acidentada do que o baixo curso, com serras predominantemente graníticas que formam conjuntos de relevo com topos estreitos e alongados.

A bacia desse rio é rica em dados sobre grupos falantes de distintas famílias linguísticas do tronco Tupi. Mais uma vez, é Miller (1987a, 1987b, 1987d; 1986/87) que traz as primeiras informações sobre a arqueologia local. Os dados fornecidos pelo arqueólogo indicam uma divisão ecológica entre grupos TPA localizados do encontro do rio Ji-Paraná com o Madeira até as primeiras cachoeiras rio acima - e outros grupos que ocupavam a parte encachoeirada do rio. Na descrição dos sítios levantados na região, Miller indica surpresa pelo fato de ter encontrado mais fases "não Tupiguarani" do que "Tupiguarani": das sete fases criadas pelo autor, só uma era "Tupiguarani”. Por outro lado, a única fase "Tupiguarani" possui o mesmo número de sítios do que todas as demais fases juntas.

\begin{tabular}{|l|l|l|}
\hline \multicolumn{1}{|c|}{ Identificação } & \multicolumn{1}{|c|}{ Idade } & \multicolumn{1}{c|}{ Material (cerâmica) } \\
\hline $\begin{array}{l}\text { Tradição } \\
\text { "Tupiguarani” } \\
\text { Fase Urupá } \\
\text { (6 sítios) }\end{array}$ & $\mathrm{s} / \mathrm{d}$ & $\begin{array}{l}\text { Vasos e tigelas, com eventual presença de carenas. Decorações } \\
\text { unguladas, corrugadas, serrunguladas, roletadas, engobo branco e } \\
\text { vermelho. Bases convexas ou plano-cônicas. O antiplástico é } \\
\text { mineral. }\end{array}$ \\
\hline $\begin{array}{l}\text { Fase Quiíba } \\
(1 \text { sítio })\end{array}$ & $\mathrm{s} / \mathrm{d}$ & $\begin{array}{l}\text { Vasilhame simples, com parede fina, às vezes com perfurações } \\
\text { opostas junto à borá. Não há fragmentos decorados. O } \\
\text { antiplástico é mineral. }\end{array}$ \\
\hline $\begin{array}{l}\text { Fase Imbirussu } \\
(1 \text { sítio })\end{array}$ & $\mathrm{s} / \mathrm{d}$ & $\begin{array}{l}\text { Cerâmica simples, com rara presença de decoração incisa. } \\
\text { Presença de tigelas e vasilhas globulares. O antiplástico é } \\
\text { mineral. }\end{array}$ \\
\hline $\begin{array}{l}\text { Fase Jaru } \\
(1 \text { sítio })\end{array}$ & $\mathrm{s} / \mathrm{d}$ & $\begin{array}{l}\text { Decorações incisas retas, rasas e pouco profundas. Tigelas } \\
\text { pequenas a médias com contorno simples, inflectido ou } \\
\text { composto. O antiplástico é mineral. }\end{array}$ \\
\hline $\begin{array}{l}\text { Fase Graúna } \\
(1 \text { sítio })\end{array}$ & $\mathrm{s} / \mathrm{d}$ & $\begin{array}{l}\text { Material muito erodido, de difícil descrição (incluindo as } \\
\text { formas). A única decoração é roletada. O antiplástico é mineral. }\end{array}$ \\
\hline $\begin{array}{l}\text { Fase Inimbó } \\
(1 \text { sítio })\end{array}$ & $\mathrm{s} / \mathrm{d}$ & $\begin{array}{l}\text { Marca de corda realizada sobre a parte superior da borda. } \\
\text { Decorações entalhadas, ponteadas e unguladas. O antiplástico é } \\
\text { mineral. }\end{array}$ \\
\hline $\begin{array}{l}\text { Fase Ironçaba } \\
(1 \text { sítio) }\end{array}$ & $\mathrm{s} / \mathrm{d}$ & $\begin{array}{l}\text { A única decoração (raramente) presente é acanalada. Presença de } \\
\text { assadores. O antiplástico é de caraipé ou mineral. }\end{array}$ \\
\hline
\end{tabular}

Tabela 16: Relação das fases e Tradições identificadas por Miller no médio rio Ji-Paraná (fonte: MILLER, 1986/1987).

Durante as etapas de campo do PALMA no alto Madeira e baixo Jamari, foram realizadas três visitas à região do alto Ji-Paraná, quando foi estabelecida uma parceria com o Museu Regional de Arqueologia de Rondônia, localizado na cidade de Presidente Médici. Nas visitas, os professores Maria Coimbra e José Garcia, responsáveis pelo Museu, nos 
levaram a uma série de sítios por eles levantados ${ }^{69}$. Muitos desses sítios possuem, no interior ou no arredor, afloramentos (geralmente de arenito) com gravuras rupestres e/ou bacias de polimento. As gravuras rupestres (Fig. 33) foram foco do estudo de mestrado por parte da professora Maria Coimbra Garcia (2010) e não serão discutidas em detalhe no presente texto.

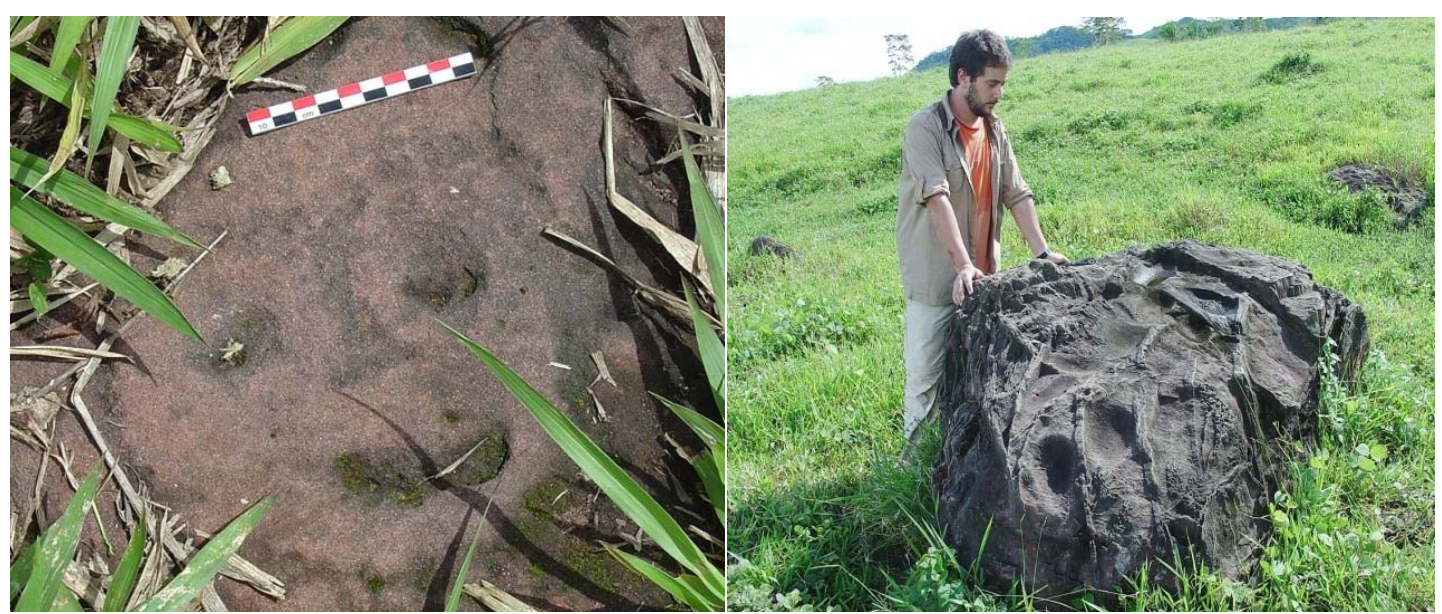

Figura 35: Gravura rupestre (em arenito) do sítio Cachoeira Alta e bacia de polimento do sítio Barro Roxo, no alto Ji-Paraná (fotos: Fernando Ozorio de Almeida, 2009).

A semelhança com o contexto do baixo Tocantins logo chamou a atenção. Isso devido à maciça presença de sítios de terra firme ao longo da extensa rede de drenagem formada pelos igarapés afluentes do rio Ji-Paraná, que recortam o terreno acidentado dessa região. Os levantamentos preliminares no alto curso desse rio sugerem uma superioridade quantitativa de sítios de terra firme em relação aos sítios encontrados nas margens da drenagem principal (ALMEIDA, 2010b). Os sítios, ao que parece, não possuem áreas tão grandes quanto os do baixo Tocantins, mas a tendência a uma rasa estratigrafia (entre $20 \mathrm{e}$ $50 \mathrm{~cm}$ de profundidade) parece se repetir. Outra impressão foi a de que havia mais sítios nessa região do que no baixo Tocantins, o que faz sentido caso sejam comprovadas as antigas datas para grupos ceramistas (Tupi?) na região.

\footnotetext{
${ }^{69}$ Atualmente, dois pesquisadores do Programa de Pós-Graduação do MAE-USP realizam estudos em parceria com o Museu Regional. O objetivo de Rodrigo Suñer é realizar atividades exploratórias nos sítios da região, e o trabalho realizado por Maurício Silva busca compreender o próprio contexto de implantação do Museu Regional.
} 


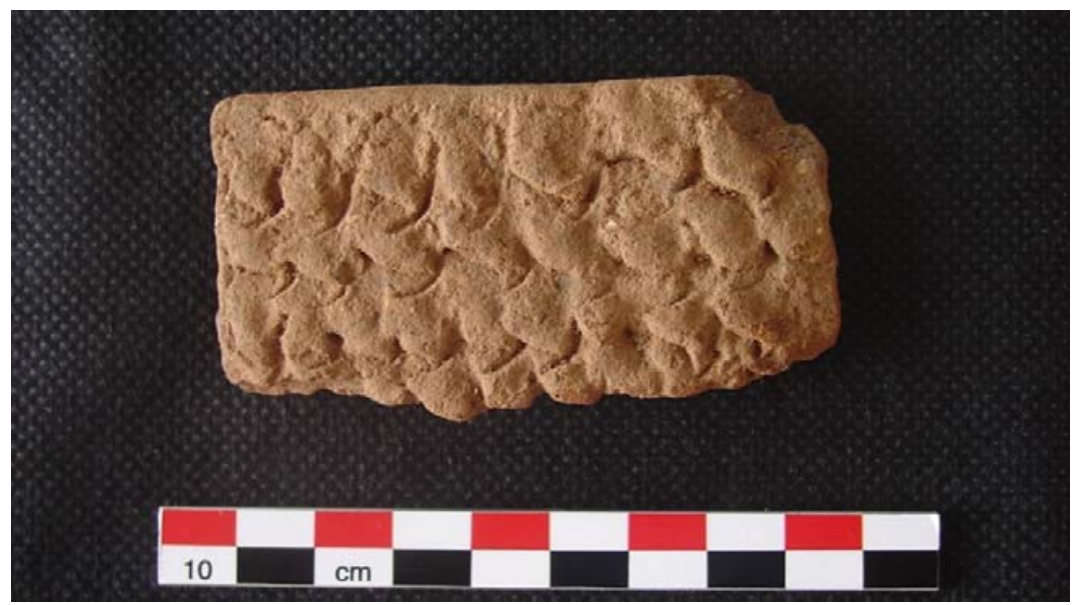

Figura 36: Fragmento corrugado encontrado na região do alto rio Ji-Paraná (foto: Fernando Ozorio de Almeida/Acervo Museu Regional de Rondônia, 2009).

O material proveniente desses sítios possui uma significativa quantidade de elementos que Miller chamaria de "Tupiguarani” (Fig. 35). Além desse autor, Cruz (2008) e Zimpel (2009) realizaram estudos com sítios da região. Todos os três pesquisadores tecem descrições semelhantes para o material cerâmico dos sítios estudados por eles. A cerâmica seria manufaturada com roletes e possuiria predominância de antiplástico mineral. Os tratamentos de superfície não eram abundantes, se restringindo à presença de corrugados e ungulados, no campo plástico, e à presença de engobo branco, no campo das pinturas. Por outro lado, ao contrário de Miller, Cruz e Zimpel indicam uma quase ausência de formas com ângulos ${ }^{70}$. As tipologias de forma apresentadas, em geral, têm uma baixa variabilidade. Dentre as formas, destaca-se a presença, no Museu Regional, de uma urna funerária com formato muito semelhante ao que La Salvia e Brochado (1989) chamariam de um yapepó Guarani.

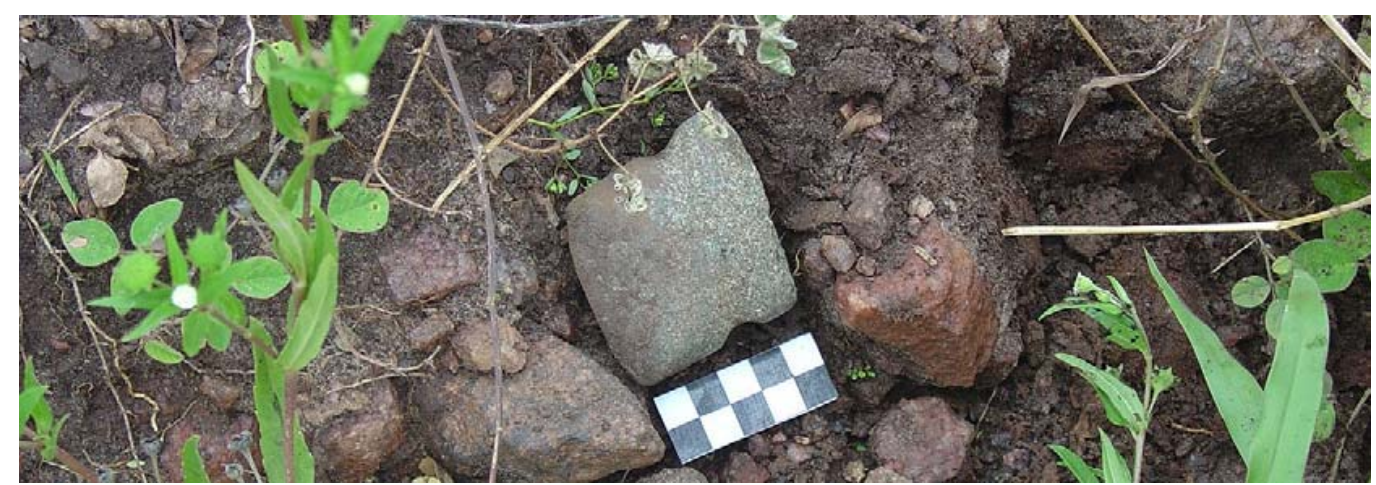

Figura 37: Lâmina de machado polida encontrada em barranco de estrada que evidencia materiais do sítio Rainha da Paz (foto: Fernando Ozorio de Almeida, 2009).

\footnotetext{
${ }^{70}$ Dos seis sítios apresentados por Cruz (2008), apenas o Nova Arizona apresenta uma forma carenada.
} 
Além disso, os autores apontam uma imensa quantidade e variedade de objetos polidos, em especial lâminas de machado (CRUZ, 2008; ZIMPEL, 2009) - o que rapidamente se confirma com a visita a qualquer sítio da região ou ao Museu Regional de Rondônia. Outro ponto que chama a atenção na arqueologia da região são as datas antigas. Zimpel apresenta datas recuadas ao extremo para o sítio Encontro (Tabela 17). Se tais datas estiverem corretas, o sítio possui uma das cerâmicas corrugadas mais antigas da América do Sul.

\begin{tabular}{lll}
\hline Nível & Idade (a.C.) & Idade (cal.) \\
\hline $40-50 \mathrm{~cm}$ & $1900+-80$ & $4255+-185$ \\
$\mathbf{6 0 - 7 0} \mathrm{cm}$ & $2020+-70$ & $4425+-200$ \\
\hline
\end{tabular}

Tabela 17: Datações do sítio Encontro (fonte: ZIMPEL, 2009: 149).

Está claro que os dados arqueológicos apresentados por Miller, Zimpel e Cruz são coerentes com a hipótese linguística de que o sudoeste da Amazônia seria a "terra natal" dos Tupi, ainda que os mesmos dados sejam insuficientes para oferecer uma visão consistente do papel dos Tupi-Guarani nesse contexto. Por exemplo, Miller apresenta uma data ainda mais antiga, de 3000 a.C., que ele relaciona a um "Proto-Tupiguarani”, se encaixando com perfeição na (mesma) data proposta pelos estudos léxico-estatísticos realizados por Aryon Rodrigues (1964; RODRIGUES e CABRAL, 2012).

A vinculação dessa data a esse contexto "Proto-Tupiguarani" é problemática. Primeiro, conforme visto (Capítulo 1), os dados linguísticos são muito valiosos, mas não devem ser levados ao pé da letra, principalmente as estimativas cronológicas. Segundo, o autor dá a entender que os Tupi-Guarani teriam sido dos primeiros a se separar do macro agrupamento Tupi e que, 3000 anos a.C., esses Tupi-Guarani já possuiriam seu tool kit cerâmico completo - o que é possível, mas improvável. Os dados apresentados por Cruz e Zimpel e o material presente no Museu Regional indicam elementos em comum com uma cerâmica Tupi-Guarani, mas estão longe de indicar que, de fato, se trata de uma cerâmica Tupi-Guarani. O que em parte ocorre devido à falta de dados contextuais sobre grupos TupiGuarani na região do rio Ji-Paraná, que também é assolada pela indefinição da cronologia Kagwahiva. Da mesma forma, não há dados históricos e etnográficos suficientes para que a imensa variabilidade de material cerâmico da região seja compreendida. Os dados produzidos por Miller ilustram bem o fato de que a cerâmica "Tupiguarani” é apenas uma entre muitos outros Estilos cerâmicos da região (cf. Capítulo 7). 


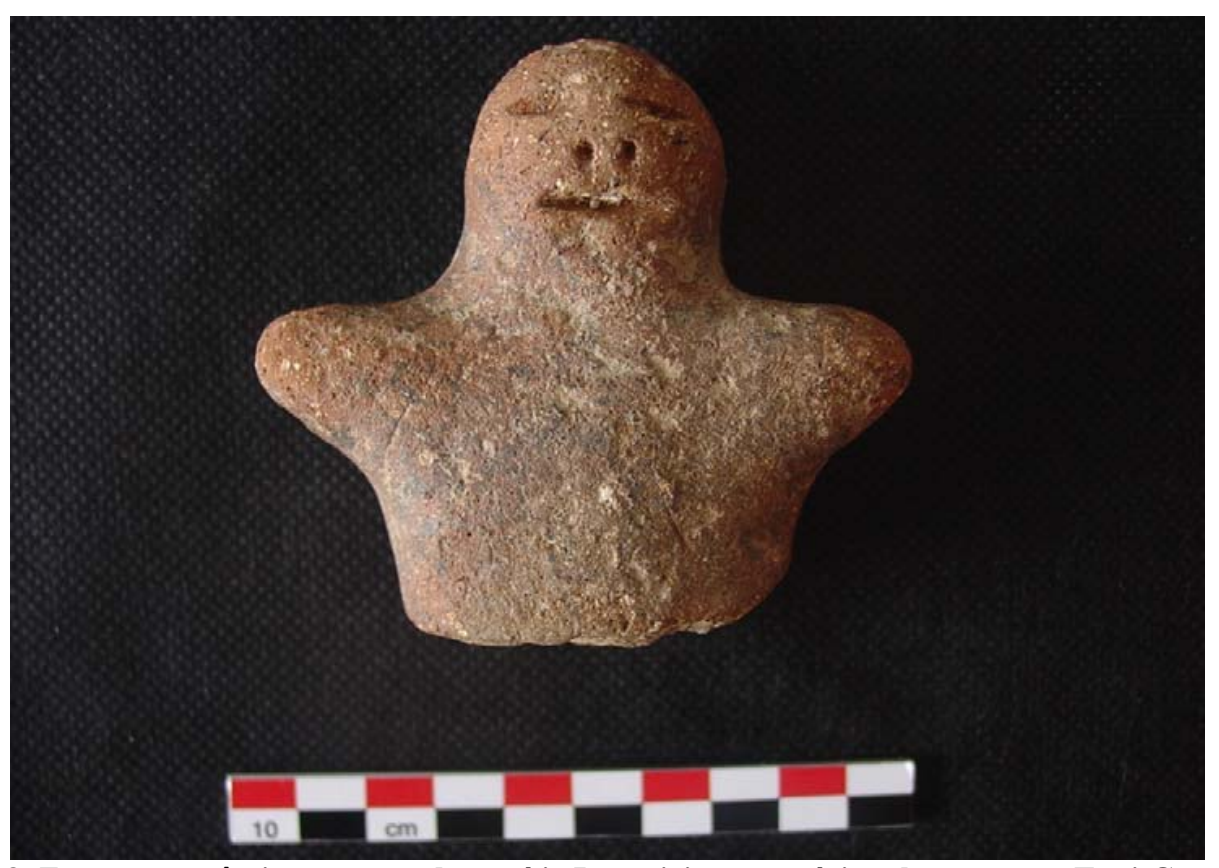

Figura 38: Estatueta cerâmica encontrada no sítio Laranjeiras, um típico elemento não Tupi-Guarani presente nos sítios da região do alto Ji-Paraná (foto: Fernando Ozorio de Almeida/Acervo Museu Regional de Rondônia).

Para complicar ainda mais, grupos de língua Tupi-Mondé, como os Gavião e os CintaLarga $^{71}$, identificam os fragmentos cerâmicos pintados e corrugados encontrados nos sítios como sendo "dos seus antepassados". Ou seja, se a análise da cerâmica arqueológica proveniente de áreas bem contextualizadas (litoral e sul do Brasil) parece fornecer uma distinção consistente entre grupos Tupi-Guarani e não Tupi-Guarani, por outro lado, os dados provenientes de análises cerâmicas dentro do macro contexto Tupi do sudoeste amazônico ainda não permitem diferenciar internamente esse agrupamento. Por fim, como visto no início deste capítulo, a presença de quase todos os elementos que formariam a Tradição Tupi-Guarani (e.g. vasos com ângulos, policromia, corrugados, urnas funerárias) em contextos não Tupi no sudoeste amazônico (e.g. Pano e Jívaro) é só mais um indicador da complexidade de realizar análises arqueológicas cladísticas nessa região.

\footnotetext{
${ }^{71}$ Os Cinta-Larga também alegam que as urnas funerárias (extremamente semelhantes à que está exposta no Museu Regional) encontradas junto à cachoeira de Dardanelos, no rio Aripuanã, sejam de seus antepassados.
} 


\subsection{Alguns Tupi do alto Madeira: etnografias alcoolizantes no sudoeste amazônico}

We ate maize kernels that had been grilled on a pottery plate and drank maize chicha - a beverage halfway between beer and soup - from half-calabashes coated inside with some black substance and decorated on the outside with carved or burnt lines zigzags, circles and polygons (LÉVI-STRAUSS, 1976: 435).

In the absence of tobacco, we were about to be welcomed in the village with what the sixteenth-century travelers called cahoim - the Tupi-Kawahib call it Kaui - that is, a chicha drinking session (LÉVI-STRAUSS, 1976: 435).

Os grupos falantes do tronco Tupi do alto Madeira podem ser vistos como exemplos didáticos do espírito "cervejeiro" caracterizado por Steward (1948: 522) com relação aos grupos indígenas da Amazônia ocidental. Nesse e em outros quesitos, muitos desses Tupi apresentam mais ou menos semelhanças com relação aos Tupi-Guarani. Foram separados alguns exemplos Mondé e Tupari.

As aldeias Cinta-Larga podem ser encontradas atualmente a algumas dezenas de quilômetros a oeste do rio Ji-Paraná, entre os rios Roosevelt e Aripuanã, na fronteira entre Rondônia e o Mato Grosso. Esse grupo, de língua Tupi-Mondé, foi estudado por Dal Poz (1991, 1993, 2004). O autor descreve que os Cinta Larga possuiriam um sistema patrilinear no qual todos os filhos homens, suas esposas e seus filhos morariam juntos até a morte do pai, o chefe da casa. A partir de então, os irmãos se separariam e construiriam sua própria aldeia. A esse processo de fragmentação, soma-se o fato de os Cinta-Larga, além de combater grupos não Tupi (e.g. os Nambikwara), entrarem em conflito com frequência com outros grupos Tupi-Mondé, como os Suruí e os Zoró, e outros Cinta-Larga (cf. BRUNELLI, 1986).

Dado esse caráter de dispersão, fragmentação, transitoriedade e isolamento, o autor questiona quais operações produziriam um efeito contrário nos Cinta-Larga, o de uma totalidade social. Segundo Dal Poz (1993: 181-82) essa integração ocorreria durante os rituais festivos, que seriam relacionados ao erguimento de uma nova casa ou à guerra, tanto no planejamento do ataque, quanto para comemorar o sucesso em um combate. O autor indica que um evento desses levaria um ano para ser preparado, sendo necessário que o anfitrião tenha plantado uma grande roça de milho, mandioca ou cará para a produção de bebida fermentada suficiente para sustentar dezenas de pessoas durante os dias de festa (cf. CHAPELLE, 1982: 96). Quem aceita o convite para a festança automaticamente se 
compromete a realizar um evento igual em sua casa no próximo ano (DAL POZ 1993: 182$83)$.

Dal Poz (p.192) observa uma analogia entre a caça e a guerra, sendo que o ritual antropofágico de antigamente foi substituído pela morte de uma caça (um porco do mato ou um macaco), criada pela mulher ou pela filha do anfitrião e morta pelos convidados (como ocorria com um cativo Tupinambá, estilo Hans Staden). Ao matar a caça, os convidados acabam por matar de forma ritual o próprio anfitrião, dentro da tradicional confusão entre predação e alteridade, assassino e assassinado, encontrada com frequência nas sociedades Tupi: "A máquina ritual está toda aqui: por meio de movimentos repetidos à exaustão, sob formas variadas, a festa buscaria compulsivamente congraçar dois grupos opostos, numa tentativa de unir o que está separado, apaziguar o que é hostil” (DAL POZ, 1993: 200).

Outra etnografia Tupi foi fornecida por Nicole Soares-Pinto (2009), que estudou os Wajurú, grupo Tupi-Tupari. A autora reforça a ideia de frouxidão espacial dos Tupi ao apontar que os Wajurú mudaram o formato da aldeia para imitar as cidades dos brancos, com casas dispostas em linhas paralelas, ao redor de "ruas". Ela também indica um alto índice de fragmentação das aldeias desses grupos, que se dispersavam pelo mato quando, por exemplo, ocorria a morte de alguém (p. 90).

Com relação aos rituais festivos, a autora indica que "nos tempos antigos todos os indios eram brabos e, (...), se amansavam reciproca e temporariamente nas festas da chicha" (p. 43) e que, mesmo hoje, o grau de fermentação da chicha é proporcional ao grau de interação entre as pessoas: quanto mais forte a bebida, mais pessoas ela vai reunir. Se for fraca, trata-se de um evento doméstico, mas se for azeda (forte), é uma festa. Segundo Soares-Pinto, os produtos da roça não são vistos como alimentos, na melhor das hipóteses, servem de acompanhamento. A fome é saciada por meio da caça, e o papel básico da mandioca é servir na produção de fermentados (p. 111).

A mandioca e a bebida proveniente dela estariam presentes em diferentes partes do universo Wajurú. Os trabalhos coletivos, por exemplo, são pagos com a bebida. Além disso, durante a fase inicial do casamento, uma nora precisa reiteradamente ajudar a sogra a produzir chicha para conseguir sua independência. Mesmo após cumpridas as obrigações da nora com sua sogra, sua casa só se torna emancipada depois de apresentar seu próprio pilão de moer chicha. Da mesma forma, um pai de família ganha prestígio por possuir muitas filhas, isto é, muitos locais diferentes para beber chicha. A autora indica uma ambiguidade na 
chicha muito semelhante à encontrada no ethos do grupo. Ao mesmo tempo em que a bebida é vista de forma análoga ao leite, um formador de pessoas, ela é fonte de destruição, fomentando o espírito homicida entre os homens e as decorrentes brigas entre cunhados (pp. $166,191)$.

Franz Caspar (1958), o fotógrafo das formas cerâmicas Tupari, corrobora a ideia do excesso festivo desses grupos. Nos relatos de bebedeiras, ocorrem cômicas descrições de tentação e medo relacionadas às investidas de mal intencionadas e embriagadas moças índias, e das consequentes reações de irritação e ameaça dos não menos ébrios concorrentes locais. Pobre Franz!

No momento, cabe apontar a existência, no conjunto Tupari, de dois tipos de vasos muito comuns na cerâmica Tupi-Guarani (BROCHADO, 1991; LA SALVIA e BROCHADO, 1989; NOELLI e BROCHADO, 1998). Trata-se da grande panela que vai ao fogo, o yapepó dos Guarani (só que menos anguloso do que este), assim como a tigela utilizada para servir as bebidas fermentadas, o cambuchí caguaba dos Guarani. O que chama a atenção nessa comparação é a aparente falta de tratamentos de superfície nesse duo cerâmico Tupari em relação ao que usualmente é observado nos vasos Tupi-Guarani: os yapepós são, em geral, relacionados a decorações corrugadas, e os cambuchís costumam receber pintura polícroma (LA SALVIA e BROCHADO, 1989). Entretanto, as diferenças não param aí.

A terminologia desses vasos se mantém com uma incrível fidelidade nos diferentes grupos Tupi-Guarani (NOELLI, 1999-2000: 259, 2008a: 30; Anexo 9), o que não se repete no contexto mais amplo, do tronco Tupi (Anexo 9; cf. CRUZ, 2009). O mesmo ocorre com a denominação da cerveja, uniformemente chamada de cauim pelos Tupi-Guarani, mas com diferentes nomes no universo Tupi. Por exemplo, os Suruí, grupo Tupi-Mondé estudado por Mindlin $(1985,2006)$, também conhecidos por grandes festas cervejeiras sazonais, algumas das quais (e.g. hoietê) destinadas a permitir "à aldeia comunicar-se com o reino dos mortos" (2006: 33), também possuem vasos para o preparo e consumo da bebida fermentada (cf. Capítulo 5). No entanto, esses vasos, além de não possuir as decorações tradicionalmente encontradas nos vasos Tupi-Guarani, não possuem nem as formas análogas a esses e (ao que parece) dos Tupari. O nome dos vasos também difere: a panela de preparo se chama itxirah ou itxirgup, e a talha de beber se chama lobeah ou lobeup. Apesar de produzir a cerveja a partir de milho, como os Tupari, os Arikém e grande parte da Amazônia ocidental, os Suruí não denominam a bebida de chicha e sim de makaloba. 
A diferenciação do nome das panelas, do nome dado à bebida fermentada, do produtobase para a cerveja (milho para a maioria dos Tupi de Rondônia e mandioca para a maioria dos Tupi-Guarani) e dos tratamentos de superfície dos vasos são fortes argumentos para confirmar a hipótese de Miller (2009: 84-85) de que, quando os Tupi começaram a se separar (3000 a.C., segundo a linguística), eles não possuiriam cerâmica e (pode-se acrescentar), é provável que não possuíssem uma produção de bebidas fermentadas ${ }^{72}$. A própria relação de muitos grupos Tupi com a chicha de milho parece apontar uma ligação muito mais estreita com os Andes e com o noroeste sul-americano do que com a mandioca que, suposta e ironicamente (OLSEN e SCHAAL, 1999; CLEMENT 1999a, 1999b; CLEMENT et al., 2010), foi domesticada na própria bacia do rio Madeira. Uma incrível forma de indicar que os dados interdisciplinares, por vezes, simplesmente não se encaixam. A isso se soma, por exemplo, a semelhança entre os vasos para o preparo de chicha (ou cauim) dos Tupari, dos Tupi-Guarani e de vasos encontrados em lugares como o alto Ji-Paraná (a urna do Museu Regional; cf MILLER, 2009: 126 e 130). Seja qual for a explicação para essa confusão, ela não é óbvia.

Outro fator contrário à hipótese de uma ramificação Tupi pré-cerâmica (ou précauim), é a maneira com que esses grupos lidam com seus fermentados. Pôde-se ver no exemplo do ritual Cinta-Larga uma semelhança com um ritual alcoólico e antropofágico dos Tupinambá do litoral e, provavelmente, de um ritual Araweté (Tupi-Guarani da Amazônia oriental), Tupari do Guaporé ou Yudjá-Juruna (Tupi da Amazônia oriental). Outro ponto comum que se percebe nos diversos relatos - dos Uru-Eu-Wau-Wau (FRANÇA, 2012), dos Cinta-Larga (DAL POZ, 1993), dos Wajurú (SOARES PINTO, 2009) ou dos Tupari isolados documentados por Carelli (2009) - é uma grande aversão ao agrupamento, que tem como um dos poucos antídotos o consumo da chicha. Tratam-se de claros exemplos das sociedades contra o Estado de Clastres (2003), percebidos por França (2012). Tratam-se também de exemplos das sociedades político e economicamente autônomas, mas com extensas redes rituais e xamânicas apontadas por Taylor (1999) - ainda que as etnografias Wajurú, Suruí e Cinta-Larga contradigam a autora quanto à dimensão que podem atingir esses rituais.

É difícil ter certeza o quanto dessa tendência à fragmentação é resultado do contato com a frente colonial. No entanto, como bem foi apontado por Clastres (2003), essa tendência

\footnotetext{
${ }^{72}$ Para cada acerto, um erro: Miller (2009) consegue advogar que, no mesmo momento em que os Tupi começaram a se separar (3000 a.C.), eles não teriam cerâmica, e os (proto) Tupi-Guarani já possuiriam uma indústria cerâmica formada.
} 
faz parte de um ethos Tupi-Guarani que, ao que parece, se repete em escala mais ampla, no tronco Tupi. O que não se sabe é se cada grupo aprendeu isso no seu tempo ou se essa é uma forma mais antiga de ver o mundo, passada de geração em geração (uma Tradição). Ademais, conforme visto, as bebedeiras não só juntavam como separavam: quando a separação era inevitável, o aglutinador viraria solvente, e a festa alcoólica proporcionaria motivos concretos e triviais para que se consumasse a cisão.

\subsection{Discussão}

A bacia do alto Madeira, no período pré-colonial, foi um grande mosaico cultural, tanto cronológica quanto espacialmente. Até hoje, após muitas décadas de iniciada a desastrosa colonização da região pelos "civilizados", é possível observar uma grande diversidade cultural e linguística, ainda que muitos grupos estejam ameaçados de desaparecer. É mais do que claro que o mosaico atual é bastante diferente daquele que existia na época em que os europeus chegaram ao continente sul-americano. O que se observa, então, é uma série de quebra-cabeças que precisam der encaixados horizontal e verticalmente. Por mais que a montagem desses quebra-cabeças tridimensionais seja uma tarefa muito complexa, é ainda mais complexo tentar compreender o quadro todo a partir de algumas poucas peças provenientes do centro do mosaico.

Assim, se os rios Jamari e Madeira (este, entre o Jamari e a cachoeira de Teotônio), são o objeto central do presente estudo, rios como o Guaporé e o Ji-Paraná forneceram dados fundamentais para a compreensão do entorno do alto Madeira, como também auxiliaram na discussão do pano de fundo deste estudo, a relação entre os Tupi e os Tupi-Guarani, e a relação destes com a Tradição Polícroma da Amazônia. No rio Madeira, fomos apresentados, enfim, à Subtradição Jatuarana, principal foco deste estudo, assim como aos diversos problemas históricos que dificultam relacionar essa Subtradição a um grupo específico. A partir do rio Guaporé, ficou cristalizada a sensação de que os grupos Guarani que hoje habitam a bacia do alto Madeira parecem possuir uma história recente na região - se eles voltaram a um lugar onde seus antepassados viveram é uma outra história. Nas descrições sobre esse rio, também foi indicada uma possível correlação entre as cerâmicas dos Tupari e da fase Corumbiara. Por fim, pôde-se compreender, a partir da revisão bibliográfica do rio Ji- 
Paraná, que é nessa região que reside o maior potencial estilístico e cronológico para a compreensão da história Tupi na região.

A descrição do médio Jamari também forneceu a base bibliográfica para a realização de pesquisas arqueológicas no baixo curso desse rio. Foi realizada uma primeira tentativa de desvencilhar a Tradição Jamari da Subtradição Jatuarana. Advogou-se que Jamari e Jatuarana não são agrupamentos caracterizados por um "antecedente" comum, mas apenas por eventuais relações entre grupos geograficamente próximos. A análise dos sítios Associação Calderita e Jacarezinho (Capítulos 4 e 5) trará outros elementos para justificar essa conclusão. A cachoeira de Samuel, veremos, não foi uma fronteira cultural absoluta, mas com certeza funciona para estabelecer uma distinção mais grosseira entre os agrupamentos. Para um leigo na arqueologia da região, essa questão pode parecer irrelevante. No entanto, desde o início das pesquisas no baixo Jamari, houve dúvida a respeito da relação cultural entre esses agrupamentos.

Poder-se-ia pensar que a abertura demasiada do foco complicaria mais do que facilitaria a compreensão da arqueologia regional. Mas como trabalhar os elementos politéticos TPA e Tupi(-Guarani) sem levar em conta os demais grupos que compartilham elementos estilísticos com estes agrupamentos? O exemplo mais significativo é o dos grupos de língua Pano. Conforme apontado, com base no mapa etno-histórico de Nimuendajú (1942), alguns destes grupos teriam realizado movimentos a partir dos rios Beni e Madre de Dios para o alto Madeira, durante o período colonial. Métraux (1948b) indica que esses grupos (no período histórico) possuiriam cerâmica simples (sem decorações), mas fragmentos arqueológicos pintados e corrugados identificados no rio Madre de Dios, área ligada à ocupação dos Pano meridionais, podem indicar que a cerâmica pré-colonial desses grupos era distinta (com decorações). Por outro lado, essa cerâmica pode não ter nada a ver com os Pano, e estar relacionada aos Guarani ou a outro grupo Tupi.

Caso confirmado o quadro arqueológico esboçado por Miller (1992, 1999), com um predomínio milenar TPA (Subtradição Jatuarana) nas margens do alto Madeira, e a proposta etno-histórica (Nimuendajú 1942) que infere uma entrada tardia de grupos Pano na região, haveria elementos semelhantes, incertos e inversos à da histórica cultural do Ucayali, tecida por Lathrap e seus alunos. Semelhantes no sentido de que, em ambos os casos, os grupos Pano preenchem o vácuo deixado por grupos produtores de cerâmica TPA no período colonial. Incertos quanto à ligação TPA-Tupi-Guarani apontada para o Ucayali (os Kocama seriam Tupi-Guarani produtores de cerâmica TPA), mas sobre a qual não se tem 
conhecimento no alto Madeira. E inversos no sentido de que, no Ucayali, os grupos Pano (teoricamente) tomaram de volta um território (dos Kocama) que já era deles, o que, a priori, não ocorreu no alto Madeira.

No caso do Ucayali, os grupos Pano (Tradição Cumancaya) ocupariam grandes extensões desse rio até por volta de 1000 d.C., quando passaram a ser empurrados rio acima pelos Kocama que vinham do médio Amazonas (LATHRAP, 1970; ROE, 1973; WEBER, 1975). Brochado (1984) recua o período de contato entre esses grupos (TPA e Cumancaya) no alto Amazonas, com o intuito de explicar uma suposta transição entre a cerâmica TPA e a cerâmica da Subtradição Guarani. Isso porque a cerâmica Cumancaya possui uma série de elementos existentes na cerâmica Guarani que não estão presentes na cerâmica TPA, como a presença de antiplástico de caco moído, as grandes urnas funerárias piriformes e corrugadas (as mesmas utilizadas para o preparo de fermentados), e as vasilhas para consumo de bebidas alcoólicas, com ombros e motivos pintados geométricos restritos ao bojo superior do vaso. Com isso em mente, torna-se evidente que as semelhanças observadas por Brochado (1984) entre o material Pano e o material da Tradição Tupi-Guarani possuem um significado que pode ser vital para a compreensão da história cultural dos grupos do sudoeste amazônico. 


\title{
4 LEVANTAMENTO E ESCAVAÇÃO ARQUEOLÓGICA NO ALTO MADEIRA E BAIXO JAMARI
}

\author{
An anthropologist (or archaeologist) tends, no matter what its ostensible subject, to \\ be but an expression of his research experience, or, more accurately, of what his \\ research experience has done to him (GEERTZ, 1973: vi).
}

O pormenor é essencial. No entanto, os pormenores do trabalho de outras pessoas são outra coisa (LEACH, 1976: 10).

\subsection{Introdução}

Neste capítulo será apresentada uma descrição das atividades de levantamento e escavação arqueológica realizadas na região do alto rio Madeira e baixo Jamari, durante seis etapas de campo, entre fevereiro de 2008 e agosto de 2011. Junto das descrições, será feita a discussão de problemáticas suscitadas pela sequência de atividades, de maneira a conectar os sítios pesquisados com a contextualização realizada (Capítulo 3) e, principalmente, com as análises de laboratório (Capítulos 5 e 6). Para isso, considerou-se necessário apresentar as datações dos sítios à medida que esses fossem descritos.

O arqueólogo Vinícius Honorato, conhecido como Girino (produtor da Tadpole Beer), estava andando no mato, cabisbaixo, olhando para o seu GPS. Estava procurando o próximo ponto da linha de sondagens, realizadas a cada 50metros, em um trabalho que de levantamento arqueológico relacionado à implantação da Usina Hidrelétrica de Santo Antônio, no rio Madeira. De repente Vinícius olha para traz: um dos auxiliares havia desaparecido, de novo. Furioso, Vinicius volta todo o caminho à procura Z, o auxiliar fugitivo. Após alguns minutos andando Vinicius observa um vulto se aproximando. Era ele. Impaciente, Vinícius espera a explicação pela "escapada”.

- Desculpe, estava apertado, fui ao banheiro!

Vinícius nota então que uma manga da camisa do sujeito havia desaparecido:

- O que aconteceu com a manga? (Silêncio)

Curiosamente, dias depois, o auxiliar perdeu o bolso da camisa e a outra manga. 


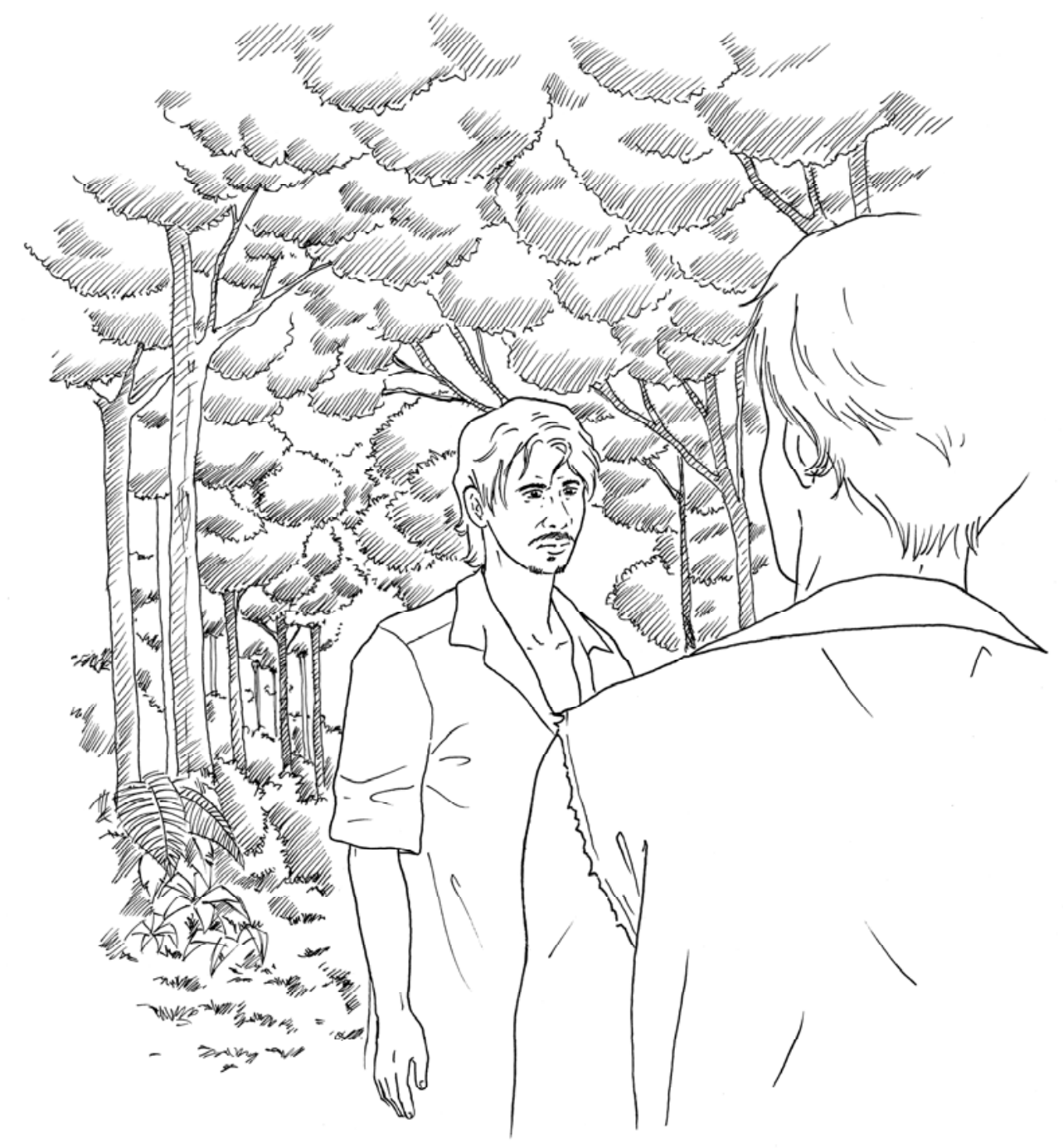


Mais ou menos no mesmo dia do incidente da manga da camisa, no dia 7 de agosto de 2008, a equipe Coral - formada pelo presente pesquisador e três auxiliares, Pantanal, Coralzinho e Jerry Adriano - estava em outra linha de sondagens. Ao saber que era o dia do meu aniversário, Jerry resolveu fazer uma homenagem:

- Não! - gritei.

Mas era tarde: Jerry tinha cortado uma palmeira para me dar o palmito de presente. Cortou um pedaço de aproximadamente $1 \mathrm{~m}$. Vendo que nenhuma das pontas estava boa, Jerry cortou um toco de cada lado. Ainda não estava bom. Uma aparada aqui, outra ali: nada. A sequência se repetiu até que um pedaço com cerca de $10 \mathrm{~cm}$ de altura sobrou na mão na mão de Jerry. Ele mudou a estratégia e fez um corte longitudinal. O palmito estava podre!

- O que vale é a intenção, Jerry!

Minutos depois, fui avisado pelo rádio que haveria uma reunião com os engenheiros da obra. Encerrei então as atividades prospectivas da equipe Coral e parti com João Paulo Atuí (o Purú), que coordenava o campo comigo, para Porto Velho. Chegamos ao escritório da Madeira Energia. Entramos em uma sala repleta de senhores gordos, com partes do peito peludo de fora e relógios que deviam pesar, no mínimo, 500g. Os engenheiros demandavam que parássemos de fazer o levantamento para executar o salvamento do sítio Novo Engenho Velho, local para onde ribeirinhos seriam deslocados por causa das obras da UHE Santo Antônio. Depois de quatro horas de reunião, concordamos. Na saída, comentei com Purú que devíamos cercar o sítio. Os engenheiros não esperariam nossa liberação! De fato, no outro dia, quando a equipe chegou para cercar o sítio, o trator já estava lá, pronto para começar a destruição.

Naquele momento, depois de cinco anos de muitas alegrias e algumas tristezas com a arqueologia de contrato, eu estava esgotado. Em um mês em Porto Velho (julho-agosto de 2008) eu havia quase morrido engasgado com um bife na garganta, levado um tapa na nuca (de graça) de um imbecil e me estressado com um contingente imenso de trabalhadores, para os quais, naquele momento, não havia tarefas suficientes para dar. Tive de desenvolver uma arte de criar funções:

- Você, escava a unidade!

- Você, pra peneira!

- Você, carrega os baldes! 
- Você, constrói um tapiri ${ }^{73}$ !

- Você... Você, ah, vai esculpir um macaquinho de madeira!

No entanto, meus dias de sofrimento estavam contados. Pouco depois, o professor Eduardo Neves chegou acompanhado dos arqueólogos Claide Moraes e Manuel ArroyoKalim. Neves assumiu o comando das escavações da hidrelétrica, e eu parti com Claide e Manuel para o sítio Associação Calderita, no rio Jamari. Uma semana depois de ter 50 auxiliares à disposição, estávamos em uma equipe de quatro pessoas, cavando nós mesmos as sondagens, debaixo do sol escaldante, passando mal, mas com a alegria de poder finalmente "pôr a mão na massa".

A escavação do sítio Associção Calderita ocorreu na segunda das seis etapas de campo do PALMA. Na primeira (fevereiro de 2008), foi realizado um levantamento arqueológico nos rios Madeira (entre a boca do rio Jamari e a atual cidade de Porto Velho) e Jamari, que resultou na identificação do sítio Associação Calderita. Na segunda etapa (agosto de 2008), foram realizadas mais atividades de levantamento em ambos os rios, levando à identificação do sítio Nova Vida, na margem direita do rio Madeira, além da delimitação e amostragem do sítio Associação Calderita. Na terceira (fevereiro de 2009), foram realizados novos levantamentos nos rios Madeira e Jamari, resultando na identificação dos sítios Jacarezinho, Barranco e Casarão (rio Jamari), além da escavação do sítio Nova Vida. A quarta etapa (junho julho 2009) manteve a mesma proposta, com levantamentos nos dois rios, levando à identificação dos sítios Itapirema e Aliança (no rio Madeira) e à escavação do sítio Jacarezinho. Na quinta (fevereiro/março de 2010), foram realizadas visitas a alguns sítios levantados por Miller no médio Jamari, no intuito de conhecer melhor o material e os tipos de implantação dos sítios na paisagem, além da escavação do sítio Itapirema. Na sexta e última etapa de campo (julho 2011) foram realizadas escavações no sítio Teotônio, que já havia sido trabalhado por Miller (1992) e pela Scientia Consultoria (2009-2010). Além disso, na segunda, quinta e sexta etapas de campo foram realizadas atividades no alto rio Ji-Paraná, com o intuito de abrir uma segunda frente de trabalho no sudoeste amazônico. No entanto, tais atividades não serão descritas nesta dissertação. Elas podem ser encontradas no memorial de qualificação do presente aluno (ALMEIDA, 2010c) e nos estudos a serem desenvolvidos por M. Silva (2011), Suñer (2010) e Trindade (2012). Abaixo, pode-se observar o quadro com todos os sítios e ocorrências levantados nos rios Madeira e Jamari (Fig. 40).

\footnotetext{
${ }^{73}$ Abrigo feito com palhas de palmeira.
} 


\begin{tabular}{|c|c|c|c|c|}
\hline Sítio & $\begin{array}{l}\text { Coordenada } \\
\text { UTM 20L }\end{array}$ & Tipo de Sítio & Hidrografia & Observações \\
\hline $\begin{array}{l}\text { Associação } \\
\text { Calderita } \\
\text { A }\end{array}$ & $442601 / 9045002$ & $\begin{array}{l}\text { Cerâmico } \\
\text { pré-colonial } \\
\text { (terra preta) }\end{array}$ & $\begin{array}{l}\text { Margem direita } \\
\text { do rio Jamari, } \\
\text { próximo à foz } \\
\text { do rio } \\
\text { Candeias. }\end{array}$ & Escavado, 2008. \\
\hline Aliança & $439739 / 9047871$ & $\begin{array}{l}\text { Casarão } \\
\text { histórico }\end{array}$ & $\begin{array}{l}\text { Margem direita } \\
\text { do rio Madeira, } \\
\text { vala dos } \\
\text { Ingleses. }\end{array}$ & $\begin{array}{l}\text { É provável que } \\
\text { este sítio tenha } \\
\text { sido identificado } \\
\text { por Miller. Não } \\
\text { escavado. }\end{array}$ \\
\hline Barranco & $447010 / 9053086$ & $\begin{array}{l}\text { Cerâmico } \\
\text { pré-colonial } \\
\text { (terra preta) }\end{array}$ & $\begin{array}{l}\text { Margem } \\
\text { esquerda do } \\
\text { rio Jamari. }\end{array}$ & Não escavado. \\
\hline Belmonte & $407827 / 9044929$ & $\begin{array}{l}\text { Cerâmico } \\
\text { pré-colonial } \\
\text { (erodido pelo } \\
\text { rio) }\end{array}$ & $\begin{array}{l}\text { Margem direita } \\
\text { do rio Madeira. }\end{array}$ & $\begin{array}{l}\text { Localizado por E. } \\
\text { Neves em } 2001 . \\
\text { Há um sítio } \\
\text { homônimo } \\
\text { encontrado por } \\
\text { Miller na margem } \\
\text { esquerda do rio. } \\
\text { Não escavado. }\end{array}$ \\
\hline Casarão & $447010 / 9053086$ & $\begin{array}{l}\text { Cerâmico } \\
\text { pré-colonial, } \\
\text { (sem terra } \\
\text { preta) }\end{array}$ & $\begin{array}{l}\text { Margem } \\
\text { esquerda do rio } \\
\text { Jamari. }\end{array}$ & Não escavado. \\
\hline Itapirema & $444322 / 9066675$ & $\begin{array}{l}\text { Cerâmico } \\
\text { pré-colonial } \\
\text { (terra preta) }\end{array}$ & $\begin{array}{l}\text { Margem } \\
\text { esquerda do rio } \\
\text { Madeira, foz do } \\
\text { rio Jamari. }\end{array}$ & $\begin{array}{l}\text { Provavelmente é o } \\
\text { sítio Carlos } \\
\text { localizado por } \\
\text { Miller. } \\
\text { Escavado, } 2010 \text {. }\end{array}$ \\
\hline Jacarezinho & $448692 / 9052250$ & $\begin{array}{l}\text { Cerâmico } \\
\text { pré-colonial } \\
\text { (terra preta) }\end{array}$ & $\begin{array}{l}\text { Lago do } \\
\text { Jacarezinho, } \\
\text { margem } \\
\text { esquerda do } \\
\text { rio Jamari. }\end{array}$ & Escavado, 2009. \\
\hline Nova Vida & $430774 / 9046164$ & $\begin{array}{l}\text { Cerâmico } \\
\text { pré-colonial } \\
\text { (terra preta) }\end{array}$ & $\begin{array}{l}\text { Margem direita } \\
\text { do Rio } \\
\text { Madeira. }\end{array}$ & Escavado, 2009. \\
\hline Teotônio & $383186 / 9020164$ & $\begin{array}{l}\text { Cerâmico } \\
\text { pré-colonial } \\
\text { (terra preta) }\end{array}$ & $\begin{array}{l}\text { Margem direita } \\
\text { do rio Madeira, } \\
\text { cachoeira } \\
\text { homônima. }\end{array}$ & $\begin{array}{l}\text { Sítio escavado por } \\
\text { Miller, nos anos } \\
1970 \text { e 1980, e } \\
\text { pela Scientia } \\
\text { Consultoria, em } \\
2009 .\end{array}$ \\
\hline
\end{tabular}

Tabela 18: Sítios identificados e/ou estudados pelo PALMA (fotos: Fernando Ozorio de Almeida). 


\begin{tabular}{|l|l|l|l|}
\hline Ocorrência & \multicolumn{1}{|c|}{$\begin{array}{c}\text { Coordenada } \\
\text { UTM 20L }\end{array}$} & Hidrografia & \multicolumn{1}{c|}{ Descrição } \\
\hline Jamari 1 & $447598 / 9041073$ & Rio Jamari & $\begin{array}{l}\text { Foram detectados fragmentos } \\
\text { cerâmicos em terreno arenoso no } \\
\text { topo de barranco, margem direita do } \\
\text { rio Jamari. No entanto, as } \\
\text { intervenções em subsuperfície não } \\
\text { levaram à identificação de material } \\
\text { arqueológico. }\end{array}$ \\
\hline Remanso & $402177 / 9045941$ & $\begin{array}{l}\text { Rio Madeira, } \\
\text { igarapé } \\
\text { Remanso }\end{array}$ & $\begin{array}{l}\text { Possível sítio Remanso, levantado } \\
\text { por E. Neves, em 2001. No entanto, } \\
\text { foram encontrados apenas alguns } \\
\text { fragmentos cerâmicos. }\end{array}$ \\
\hline Jamari 2 & $447862 / 9066277$ & Rio Jamari & $\begin{array}{l}\text { A ocorrência se resume a alguns } \\
\text { fragmentos cerâmicos encontrados } \\
\text { em terraço, na margem esquerda do } \\
\text { rio Jamari. }\end{array}$ \\
\hline Jamari 3 & $444786 / 9048942$ & Rio Jamari & $\begin{array}{l}\text { No local, uma área levemente } \\
\text { elevada, na margem esquerda do rio } \\
\text { Jamari e na margem direita de um } \\
\text { igarapé, havia alguns fragmentos } \\
\text { cerâmicos na superfície, nas } \\
\text { proximidades de uma habitação. }\end{array}$ \\
\hline Candeias 1 & $432080 / 9039218$ & Rio Candeias & $\begin{array}{l}\text { Localizado no topo de barranco } \\
\text { alto, em área coberta por pasto, de } \\
\text { frente a um lago na margem } \\
\text { esquerda do rio Candeias. Foram } \\
\text { encontrados apenas dois fragmentos } \\
\text { cerâmicos em uma superfície } \\
\text { cuidadosamente inspecionada. }\end{array}$ \\
\hline
\end{tabular}

Tabela 19: Ocorrências identificadas pelo PALMA (fotos: Fernando Ozorio de Almeida). 

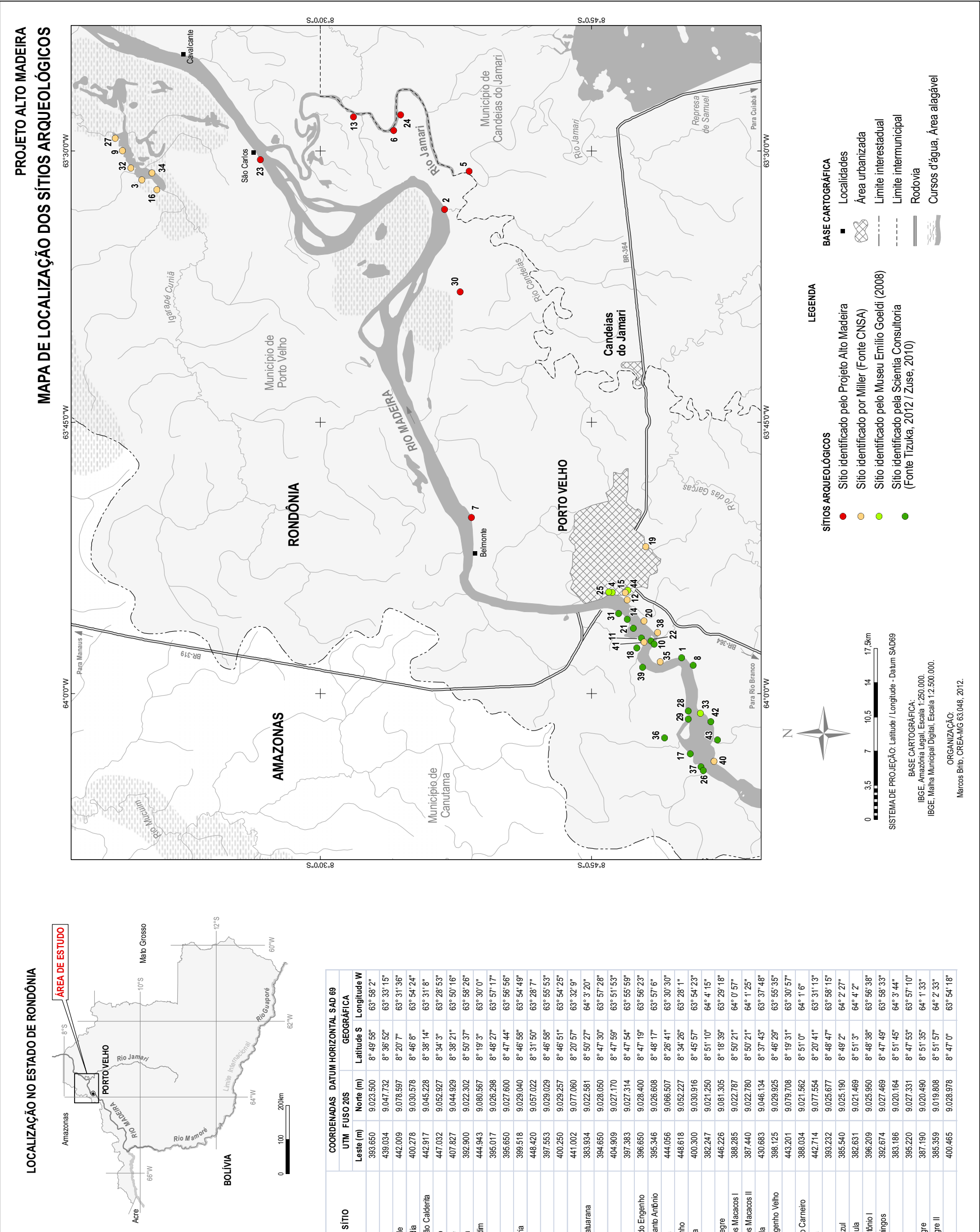

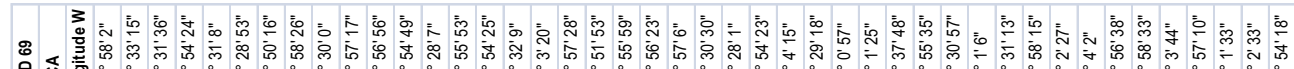

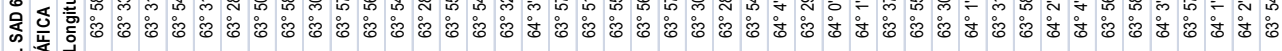
충

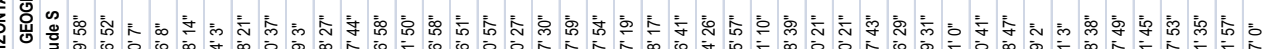

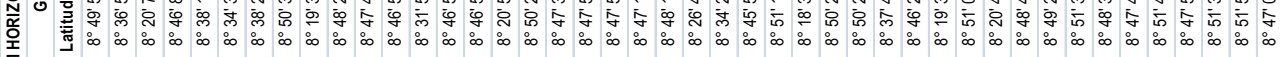

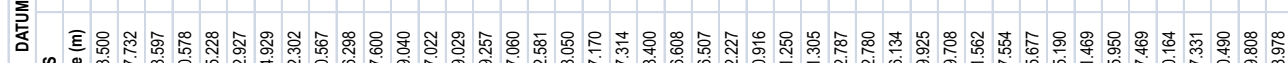

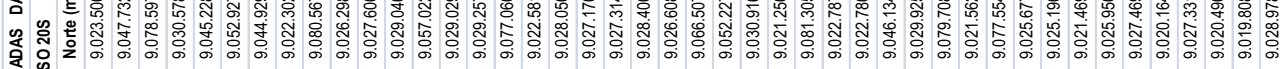

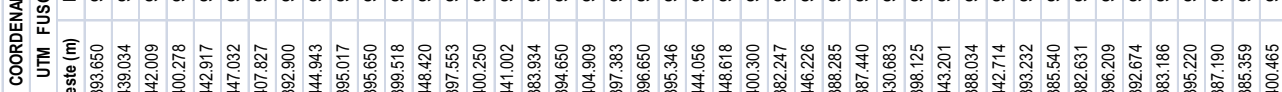

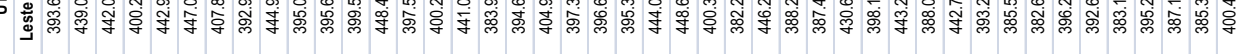

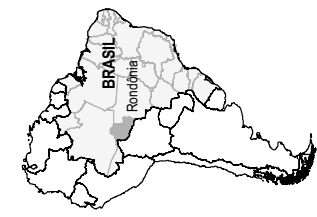

읗

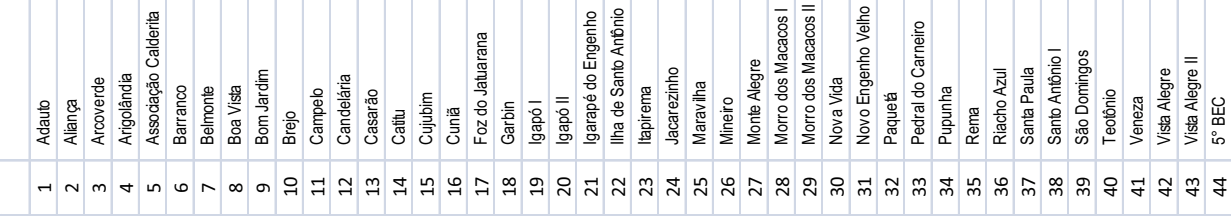




\subsection{Métodos}

Nas atividades de campo, foi utilizada a mesma base metodológica empregada pelo Projeto Amazônia Central (PAC) ${ }^{74}$ desde 1995, já descrita por NEVES (2000). De forma resumida, consistiu no levantamento não sistemático dos sítios, localizados por meio de informações orais, verificação de cortes de estrada, barrancos de beira de rio ou lago, visita a áreas de roça ou outros locais com sedimento exposto. Nos sítios considerados relevantes para o presente estudo, foram plotadas linhas de sondagens (com boca de lobo) com espaçamento regular (grid), em geral de $20 \times 20 \mathrm{~m}$ ou $40 \times 40 \mathrm{~m}$. As sondagens foram escavadas em níveis artificiais de $20 \mathrm{~cm}$ até $1 \mathrm{~m}$ de profundidade. As informações estratigráficas e de distribuição espacial obtidas pelas sondagens foram registradas em fichas e croquis esquemáticos.

Nessas atividades, utilizou-se nível topográfico e/ou bússola, e foi estabelecido um sistema de coordenadas cartesianas que divide o sítio em quadras de $1 \mathrm{~m}^{2}$. As quadras formavam as unidades básicas de escavação e foram realizadas com o uso de colher de pedreiro e ferro de cova, em níveis artificiais de $10 \mathrm{~cm}$, invariavelmente até o encontro da camada estéril $^{75}$ ou de substrato rochoso. Tanto nas sondagens quanto nas unidades, foi realizado o peneiramento (malha de $6 \mathrm{~mm}$ ) de todo o material escavado (cf. NEVES, 2012: 50). Foram abertas de duas a quatro unidades de $1 \mathrm{~m}^{2}$ por sítio. Como um objetivo das unidades foi o de obter uma amostragem mínima de material para a análise, foram priorizadas as áreas mais densas e profundas dos sítios, incluindo possíveis montículos. Uma única tentativa de realizar uma unidade de controle fora da área mais densa foi realizada no sítio Nova Vida, com resultados que estimularam adiar esse tipo de intervenção para estudos futuros (vide abaixo).

As unidades também são a chave para a compreensão vertical (ou cronológica) do sítio (NEVES, 2005). Isso foi feito por meio do desenho de croquis, que buscaram mostrar as mudanças de densidade de material, cor e textura do solo e possíveis interferências antrópicas (feições) ou bióticas nas camadas escavadas (cf. ARAÚJO, 1995).

\footnotetext{
${ }^{74}$ Coordenado pelo Prof. Dr. Eduardo Góes Neves.

${ }^{75}$ Nesse caso procedia-se à execução de uma sondagem no centro da unidade, com o intuito de verificar a existência de materiais mais profundos.
} 
Durante as escavações, as seguintes informações foram anotadas nos sacos de material: (I) nome do projeto; (II) nome do sítio; (III) número da unidade ou sondagem (baseado no sistema cartesiano que forma o grid); (IV) nível; (VI) data; (VII) pesquisador responsável pela coleta; (VIII) material coletado (e.g. cerâmica, lítico, fauna), e (IX) PN (número de procedência). O número de procedência é um número sequencial, que visa a sintetizar as demais informações anotadas. Ao olhar para a ficha de um PN, o pesquisador encontrará todas as informações do material relacionado a esse número (unidade/sondagem, nível, data, pesquisador responsável e material coletado). Peças individuais (e.g. coletas de perfil), coletas para datação e conjuntos também podem receber números de procedência à parte (NEVES, 2012: 48). O uso dessa metodologia auxilia no momento da perda ou da detecção de algum erro na anotação de um saco de material. Além das informações anotadas nos sacos de material e fichas de PN, fez-se (desde o inicio dos trabalhos do PALMA) uma terceira anotação, as etiquetas de campo, que possuem todas as informações citadas acima, e são inseridas dentro dos sacos de material, evitando - na eventualidade de as anotações dos sacos de material serem apagadas - que ocorra perda de informação.

Vale apontar que, em todos os sítios, foram realizadas coletas de superfície em locais com boa visibilidade do solo. Tais coletas ocorreram de forma sistemática apenas no sítio Itapirema, onde foi criado um quadriculamento. Nos demais sítios, optou-se pelo uncontrolled grab bag approach (ZEIDLER, 1995: 13), que privilegia áreas perturbadas nas quais o controle sistemático é irrelevante. No último caso, foram coletados basicamente os materiais cerâmicos considerados diagnósticos (ver Capítulo 5) e peças líticas (quando presentes). O objetivo foi aumentar a amostragem de forma qualitativa e, com isso, melhorar a caracterização das indústrias líticas e cerâmicas desses sítios.

Os métodos utilizados caracterizam uma intervenção exploratória dos sítios, com o objetivo de produzir uma base de conhecimento sobre a história cultural dos grupos que habitaram a região do alto Madeira. Desde o início desta pesquisa, foi acordado entre o presente aluno e seu orientador que intervenções intensivas só seriam pertinentes no momento em que esse contexto geral, exploratório, estivesse minimamente definido. Com o término da presente pesquisa ${ }^{76}$, acredita-se que já exista a possibilidade (para futuros estudos) de realizar intervenções mais intensivas em determinados sítios (e.g. Teotônio e Itapirema), assim como de seguir na realização das inesgotáveis atividades exploratórias.

\footnotetext{
${ }^{76}$ Assim como, e principalmente, a partir da imensa quantidade de dados sobre a arqueologia da região a ser apresentada por Zuse (2010).
} 


\subsection{Sítio Associação Calderita}

\subsubsection{A falta de sítios entre os rios Jamari e Candeias: uma buffer zone?}

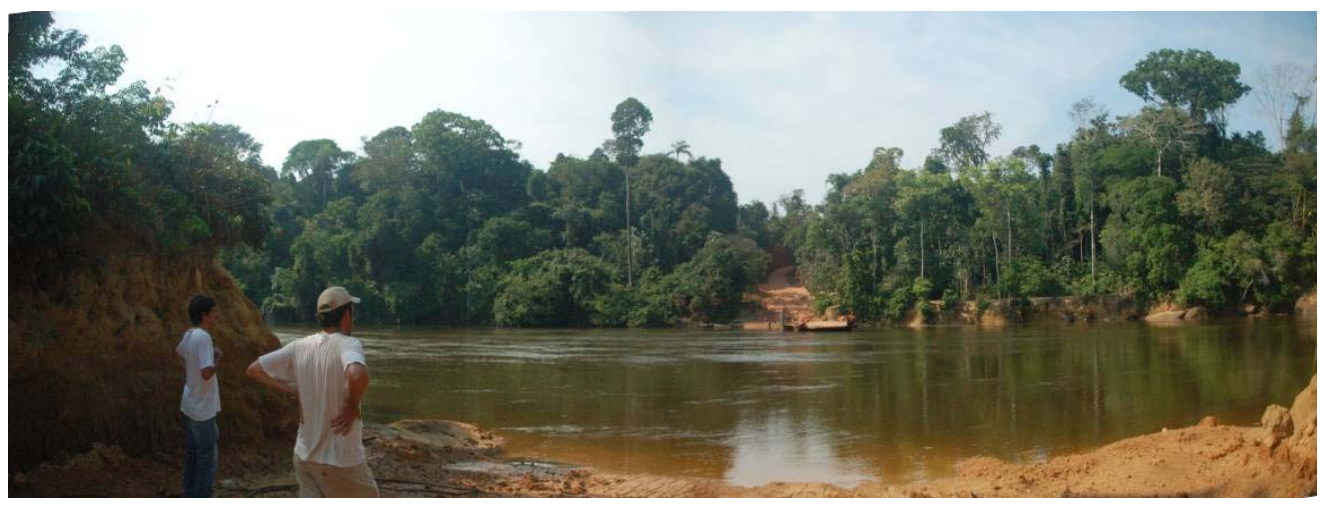

Figura 41: Balsa para travessia do rio Jamari, poucos quilômetros abaixo da represa de Samuel (foto:Manuel Arroyo Kalim, 2008).

Antes de embarcar nas escavações da UHE Santo Antônio, eu havia passado dez longos dias do inverno amazônico com o arqueólogo João Aires no meio de atoleiros, estradas cortadas por igarapés e muita chuva. Conseguimos uma rabeta para descer parte do rio Jamari e levantar sítios arqueológicos. Partimos na madrugada do dia 27 de fevereiro de 2008 em companhia do barqueiro Isaías, também conhecido como Soldado 20. Nosso objetivo era descer até a confluência com o rio Candeias, $45 \mathrm{~km}$ rio abaixo. No caminho, fomos parando em áreas de fácil acesso, boa visibilidade do solo ou com moradores. No entanto, logo notamos que o rio corria muito encaixado, com grandes barrancos em ambas as margens e poucas drenagens secundárias. Isto é, havia poucos locais de fácil acesso e visibilidade. Notamos também que esse trecho do rio era pouco habitado. Uma variável que afeta a outra: a baixa ocupação humana gera poucos lugares com boa visibilidade (e.g. áreas de arado) e acessibilidade (e.g. escadas para subir os barrancos). Quando inquiridos sobre a presença de material arqueológico, os ribeirinhos pareciam (quase todos) ter uma resposta ensaiada:

- Isso vocês só vão encontrar no Amazonas ou no rio Machado (Ji-Paraná). 


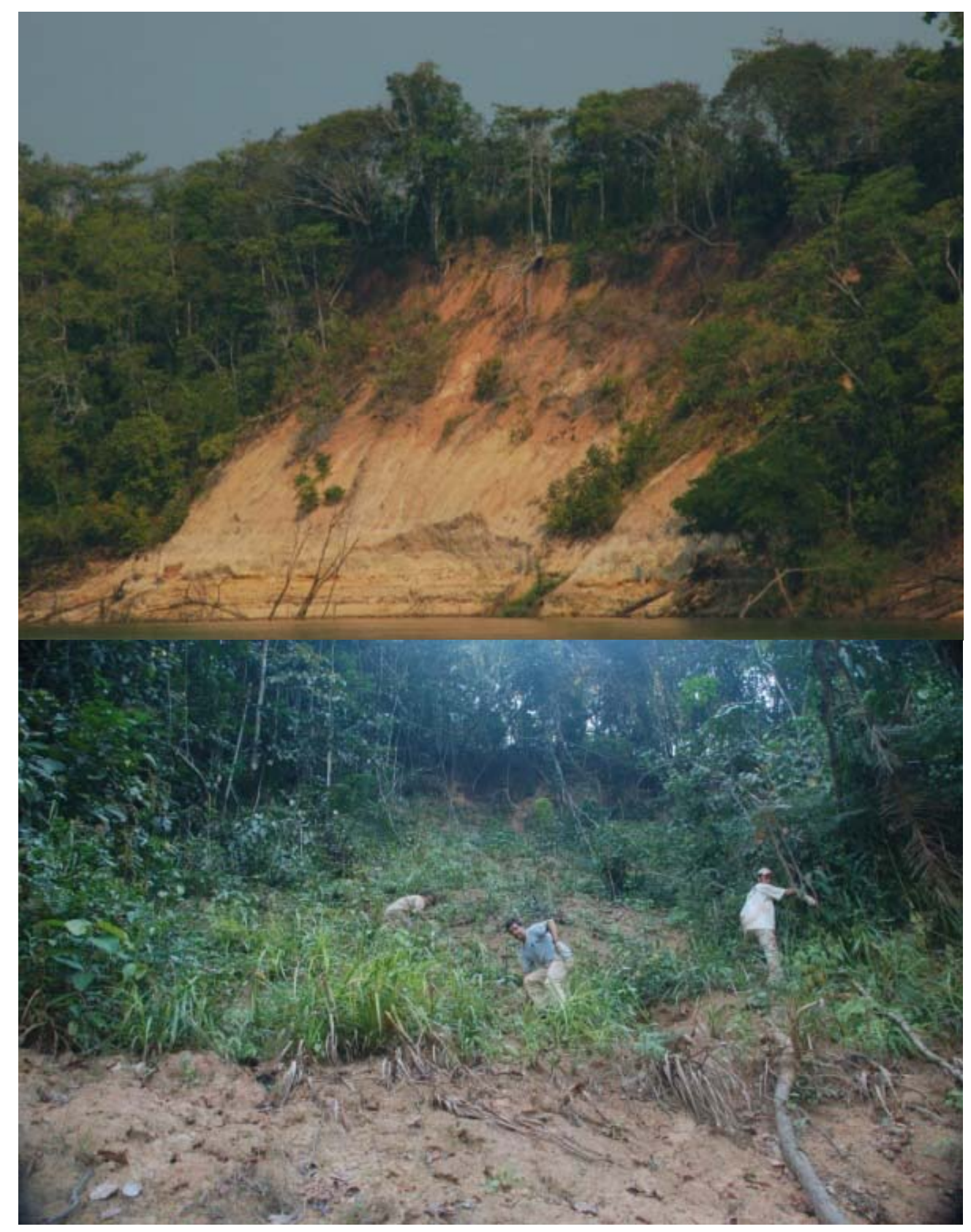

Figura 42: Os barrancos do Jamari e a dificuldade de acesso a áreas com maior potencial arqueológico (fotos: Manuel Arroyo-Kalim e Claide Moraes, 2008).

Figura 43: Idem.

Em resumo, entre a cachoeira de Samuel e o encontro dos rios Candeias e Jamari não foi encontrado nenhum sítio arqueológico. No curto trecho levantado (nessa etapa) a jusante da foz do rio Candeias, foi identificado apenas o sítio Associação Calderita, o que justifica ele ter sido o sítio escolhido para ser escavado na etapa seguinte de campo. 


\subsubsection{Escavação do sítio Associação Calderita}

Este sítio foi nomeado Associação Calderita em referência à designação dada pelos ribeirinhos ao local. Sua localização, $4 \mathrm{~km}$ sudeste do rio Madeira (por terra), encontra-se em planície em topo de barranco (+-20m em julho), em área de roça abandonada ${ }^{77}$, com grande número de palmeiras, algumas centenas de metros a jusante do encontro dos rios Jamari (na margem direita deste) e Candeias. Além de cerâmica indígena, o sítio possuía indicações de ocupações mais recentes, como uma estrutura de forno (Fig. 43), provavelmente de grupos caboclos ligados à extração de borracha.

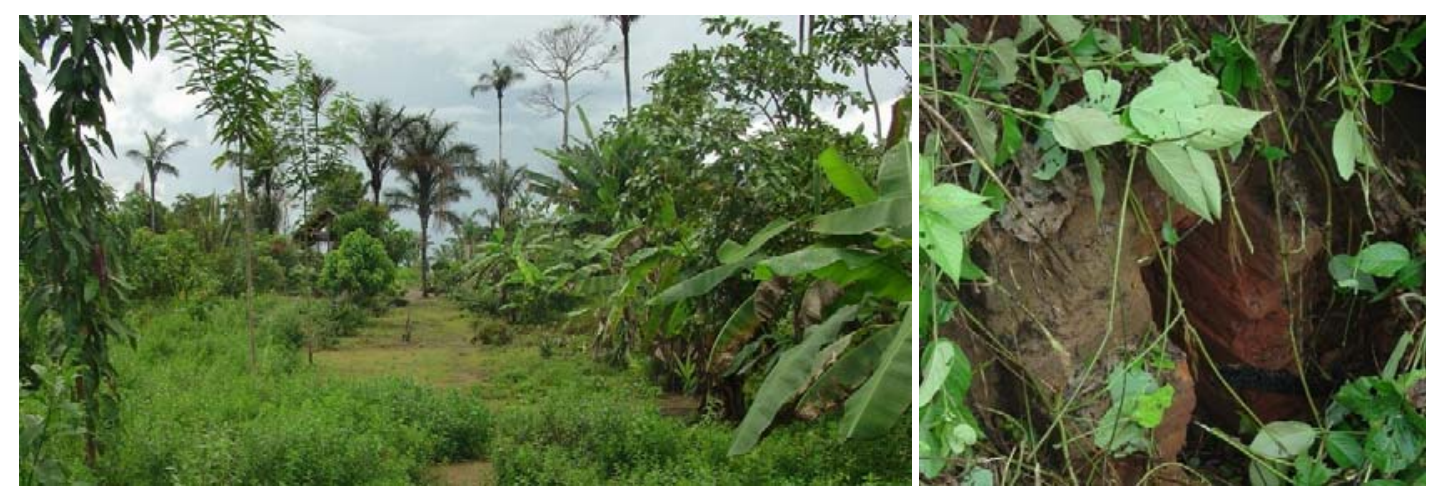

Figura 44: Vista do sítio Associação Calderita (foto: Fernando Ozorio de Almeida, 2008). Figura 45: Estrutura de forno encontrada (foto: Fernando Ozorio de Almeida, 2008).

$\mathrm{O}$ sítio foi delimitado por meio de 18 sondagens, escavadas em uma malha de $40 \mathrm{x}$ $40 \mathrm{~m}$, e teve sua área estimada em 2,4ha. (Fig. 46). Um total de aproximado de 270 fragmentos foi obtido com a execução dessas sondagens. Foi observado que a camada de terra preta, de textura predominantemente argilo-arenosa, possuía em média de 20 a $30 \mathrm{~cm}$ de profundidade. A homogeneidade da espessura da camada de terra preta, facilitada pela baixa variação topográfica dentro do sítio, só foi quebrada em um local onde foi identificado um montículo. Pertencendo essa elevação topográfica a um local que não seria interceptado pela malha de sondagens $(40 \times 40 \mathrm{~m})$ optou-se por diminuir o espaçamento da malha para interceptar o local. Essa sondagem (N1030 E1000) possibilitou identificar uma área onde a mancha de terra preta era mais espessa $(+-50 \mathrm{~cm})$, com grande densidade cerâmica.

\footnotetext{
${ }^{77}$ A periferia sul do sítio já se encontrava em um terreno com roça limpa, e a periferia leste estava coberta por uma floresta secundária.
} 


\section{SÍTIO ARQUEOLÓGICO ASSOCIAÇÃO CALDERITA}

Município de Candeias do Jamari - RO

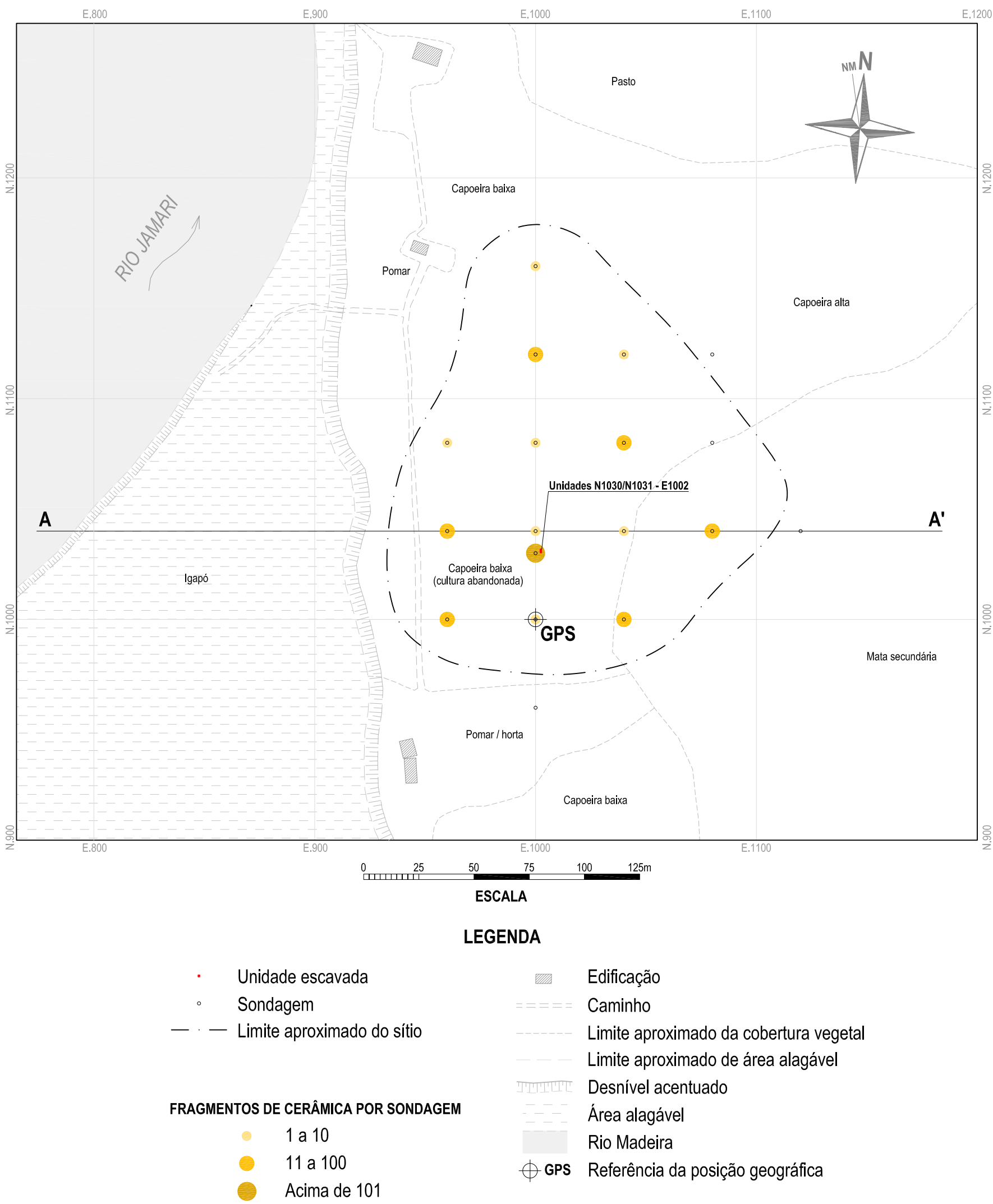

Área aproximada: 2,5ha

GPS: $\quad 442.937 \mathrm{~m} \mathrm{E} / 9.045 .195 \mathrm{~m} \mathrm{~N}$

Projeção Universal Transversa de Mercator - Datum SAD 69 - Zona 20L

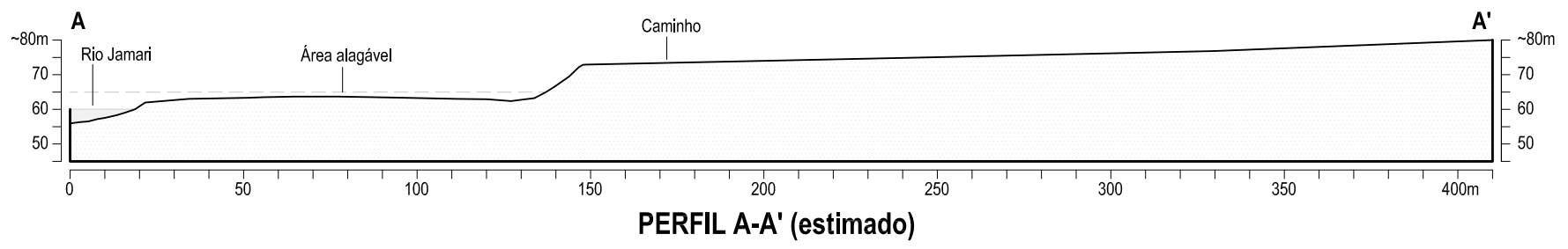




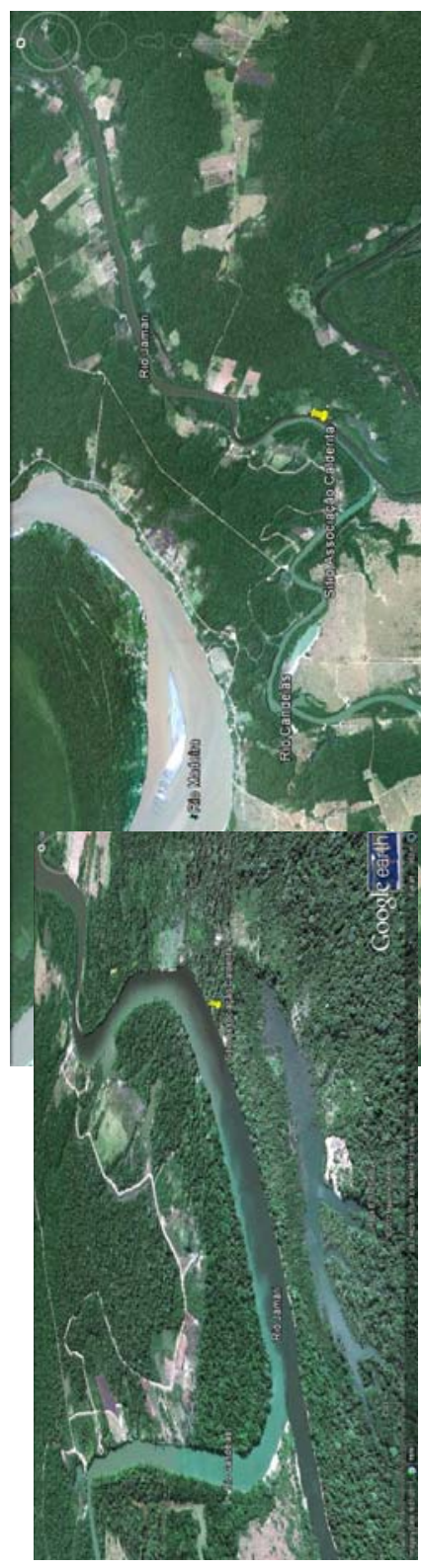

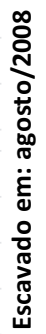

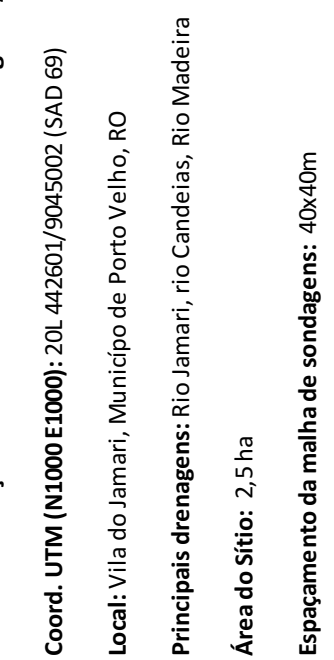
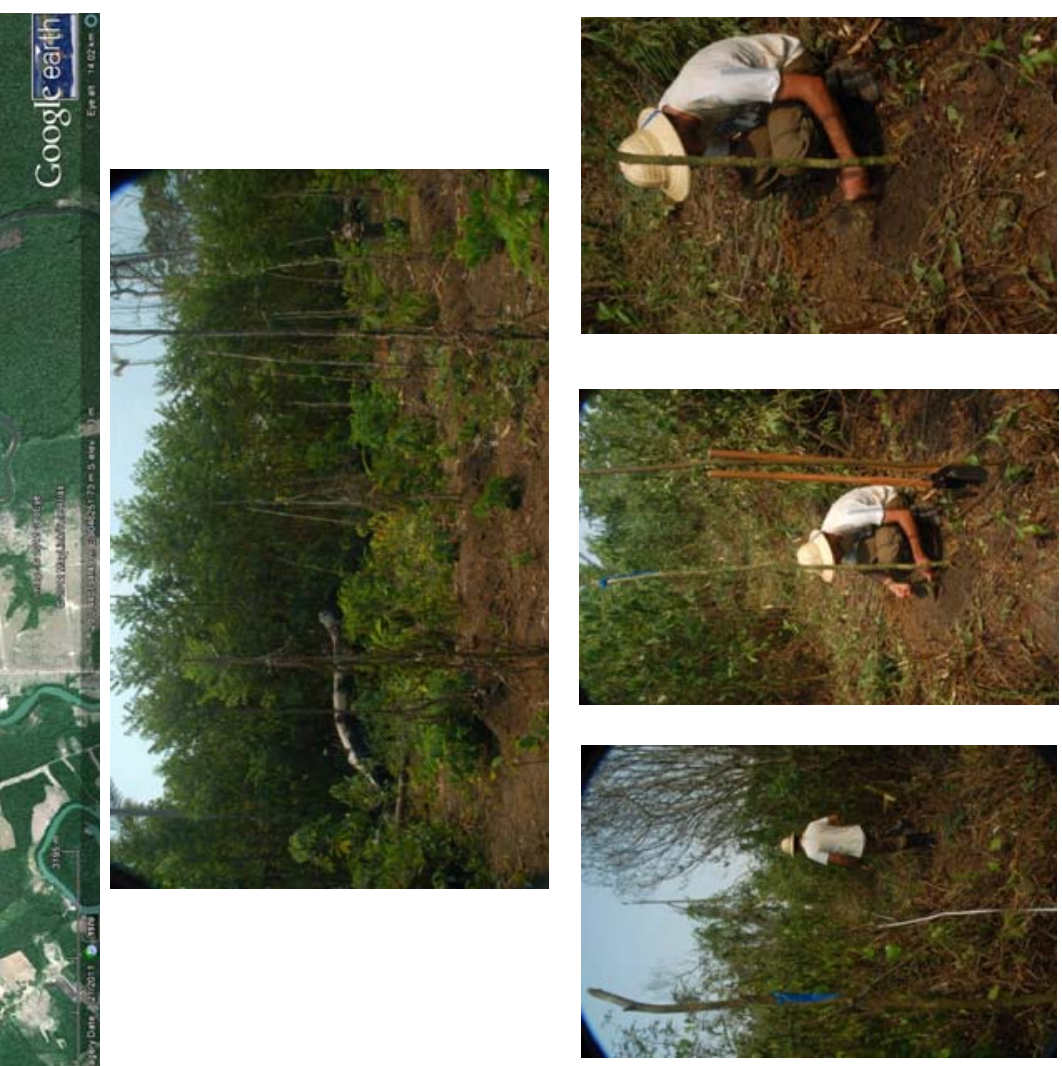

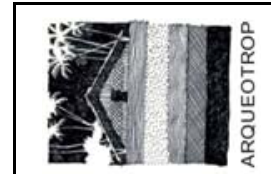

$\sqrt{0:}$
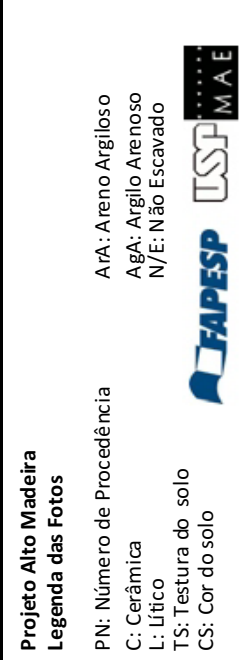
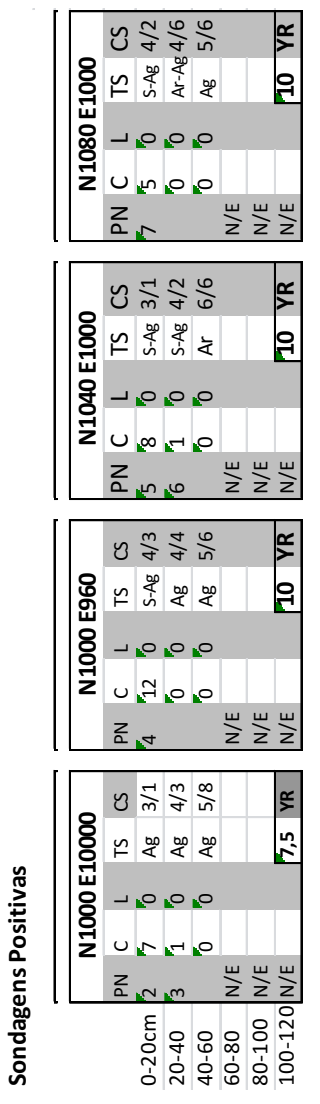
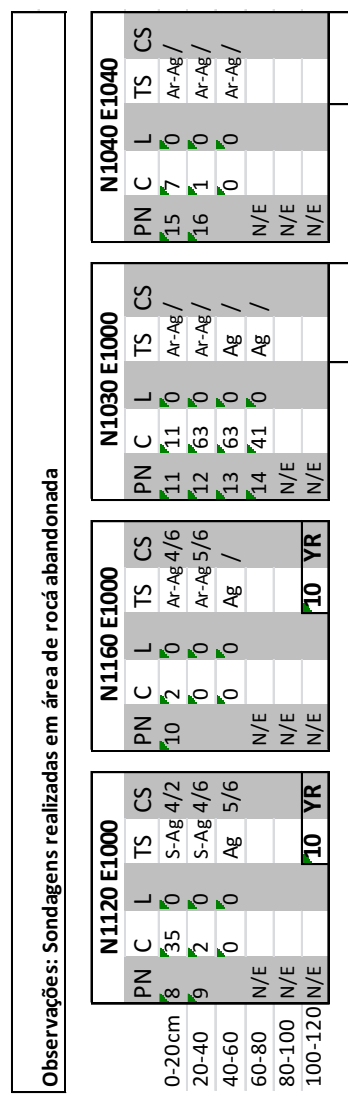
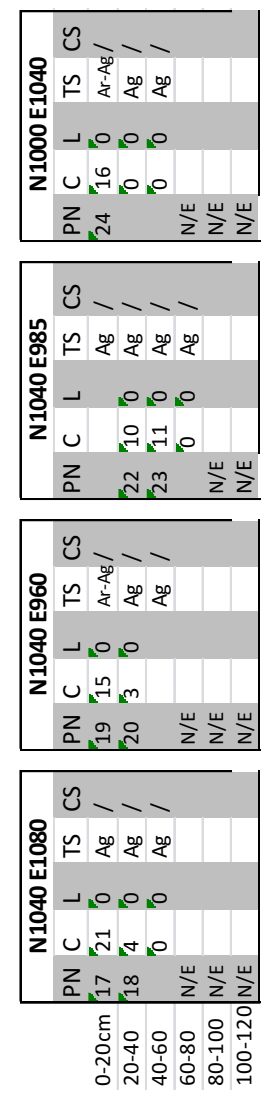

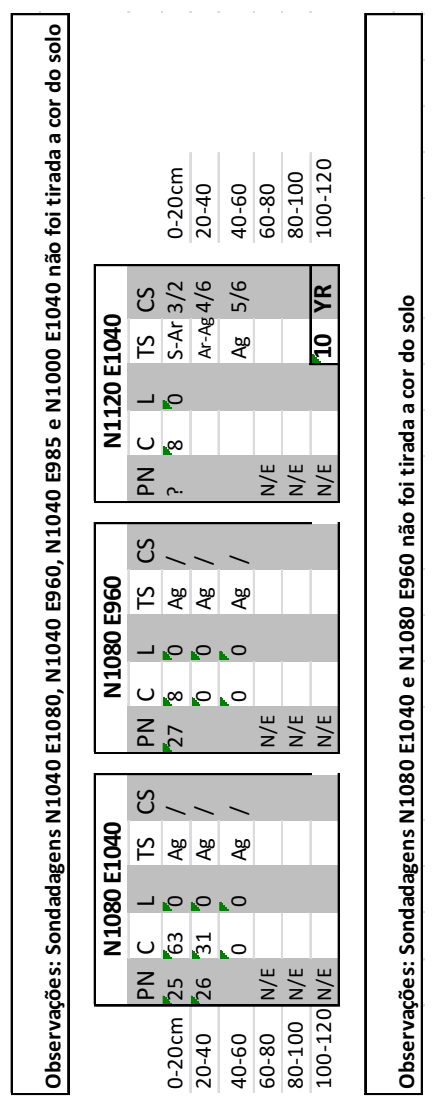


A área do montículo foi considerada ideal para a abertura de uma unidade de $2 \times 1 \mathrm{~m}$ (N1030/N1031 E1002), escavada com colher de pedreiro até os $60 \mathrm{~cm}$ de profundidade (Figs. 47 a 49). Foi realizada uma sondagem no centro das duas unidades que confirmou o fim da camada arqueológica. Foram obtidos aproximadamente 2.400 fragmentos cerâmicos a partir da escavação dessas unidades.

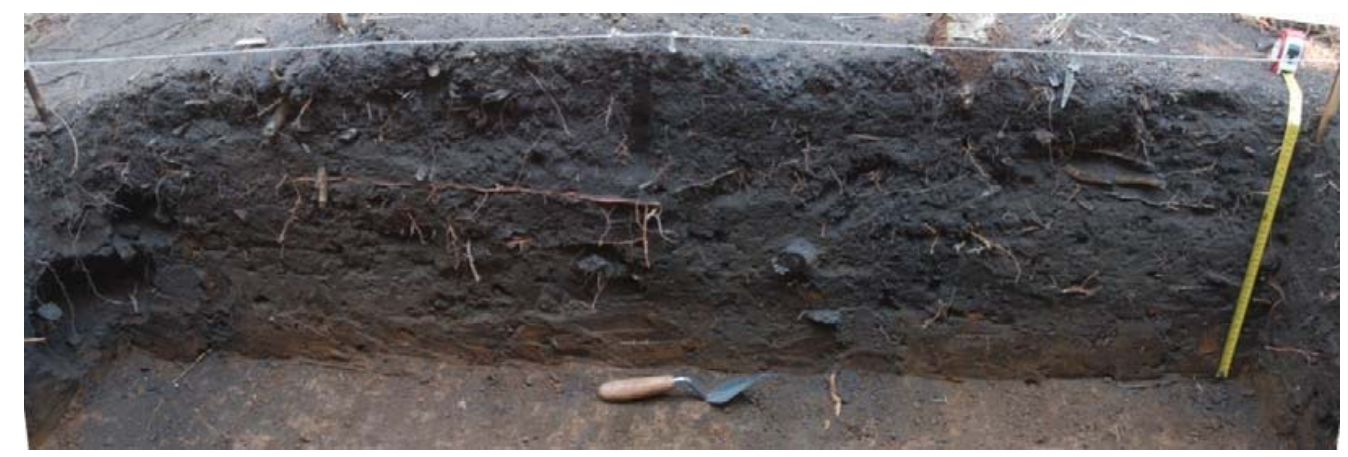

Figura 47: Vista geral da unidade N1030/N1031 E1002 (Foto Manuel Arroyo-Kalin, 2008).

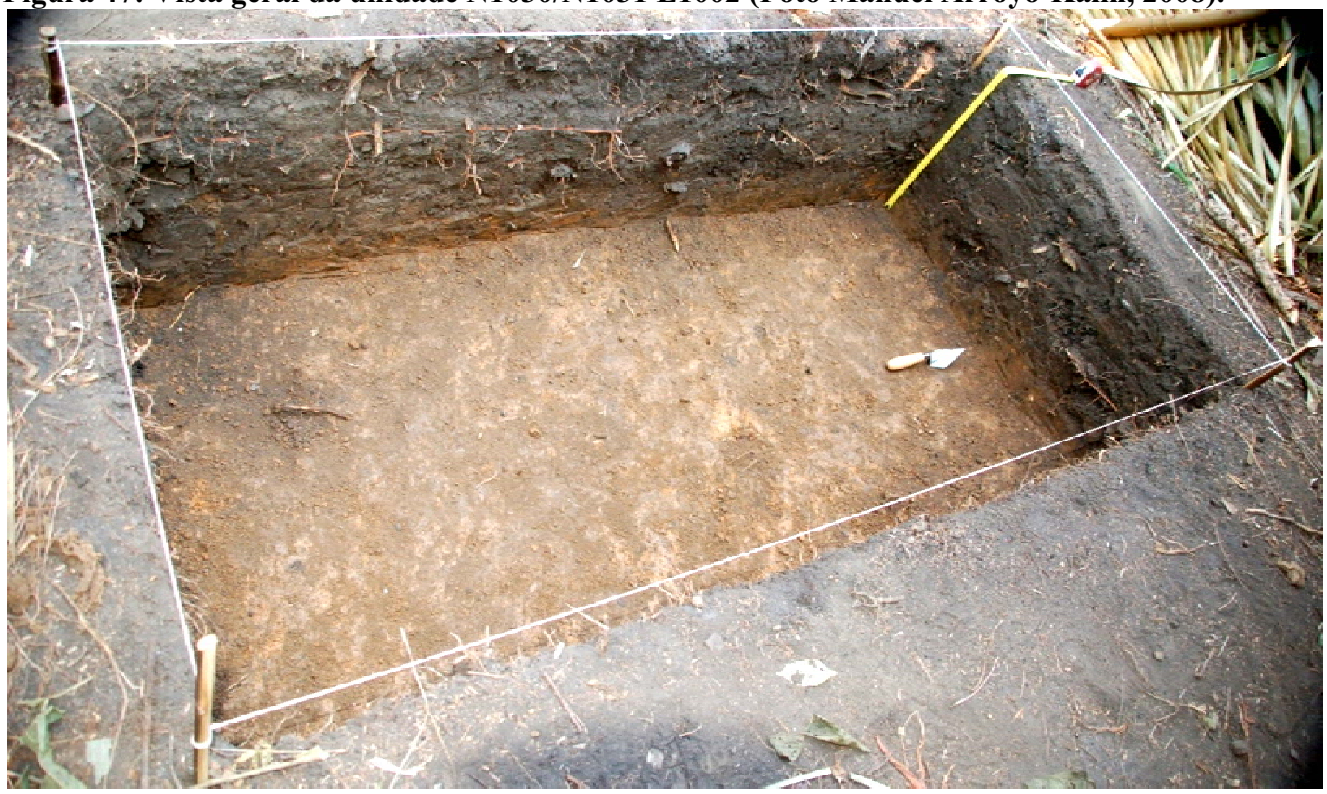

Figura 48: Perfil oeste da unidade N1030/N1031 E1002 (foto: Manuel Arroyo-Kalim, 2008). 


\title{
PROJETO ALTO MADEIRA \\ SÍTIO ARQUEOLÓGICO ASSOCIAÇÃO CALDERITA
}

\author{
UNIDADES N.1030/1031 - E.1002
}

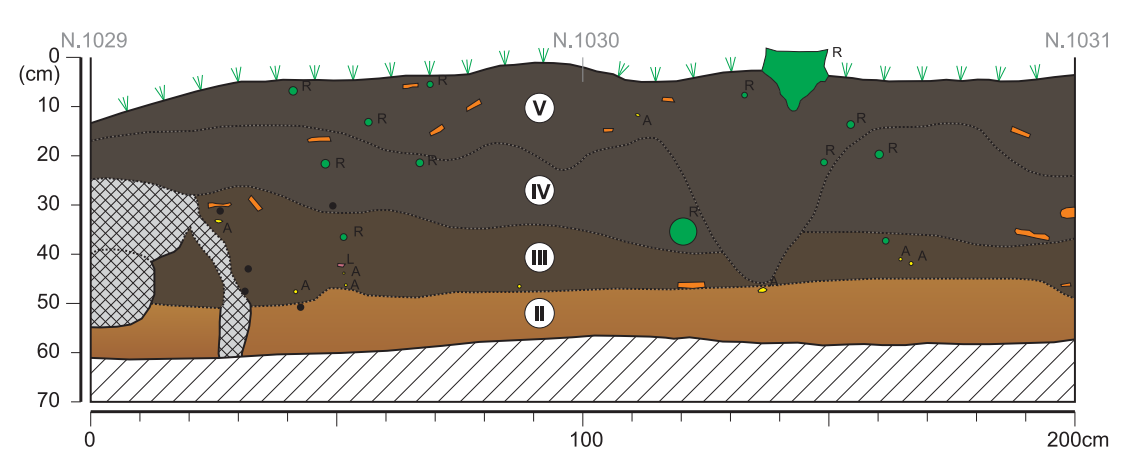

PERFIL OESTE - LINHA E.1001m

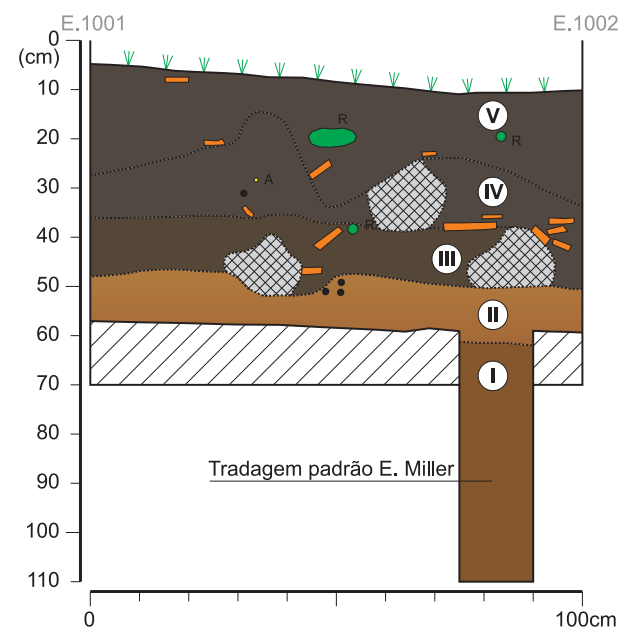

PERFIL NORTE - LINHA N.1031m

\section{LEGENDA}

- Cerâmica

- Carvão

${ }^{A}$ Argila

- Laterita

$0^{R} \quad$ Raiz

*.: Bioturbação

w* Superfície

- Limite de camada definido

.......... Limite de camada difuso

(v) Sedimento argilo-arenoso, orgânico, com elevado número de raízes, levemente mais escuro e solto do que a camada IV. Os fragmentos cerâmicos também foram encontrados em quantidade inferior às camadas III e IV. Essa camada foi vinculada à cor 10YR 3/1 "very dark gray" (tabela Munsell).

(1v Sedimento argilo-arenoso, solto, orgânico, com elevada presença de raízes. Os fragmentos cerâmicos foram encontrados em abundância. Foram observados também vestígios de carvão. Essa camada se apresentou com coloração mais acinzentada que a camada III, e foi vinculada à cor 10YR 3/1 "very dark gray" (tabela Munsell).

III Sedimento argilo-arenoso, orgânico, levemente compactado. Foram observados dois pontos com intensa bioturbação. Foram observados fragmentos cerâmicos em abundância (trata-se da camada mais densa), assim como, em menor quantidade, espículas de carvão. Essa camada foi vinculada à cor 10YR 3/2 "very dark grayish brown" (tabela Munsell).

(II) Sedimento argiloso, composto em $85 \%$ por argila de cor 7.5YR 4/6 "strong brown" e 15\% de argila de cor 10YR5/6 "yellowish brown" (tabela Munsell), extremamente compactado, massivo, com espículas de carvão (sem cerâmica). Transição entre os horizontes AB e BA.

(1) Sedimento argiloso, composto em $25 \%$ por solo orgânico proveniente dos níveis III e IV. Trata-se de um sedimento extremamente compactado, massivo, de cor 7.5 YR 5/6 "strong brown" (tabela Munsell).

Área não escavada. 
As datações da unidade N1030/N1031 E1002 permitiram identificar dois episódios de ocupação do sítio Associação Calderita. Duas datas (RO-AC-54-1/55-1), entre 30 e 50cm, parecem indicar um mesmo período de ocupação, por volta de 1100 d.C. A outra data (ROAC-53-1), entre 20 e $30 \mathrm{~cm}$, indica uma ocupação mais recente, próxima a 1350 d.C.

\begin{tabular}{|c|c|c|c|c|c|c|c|}
\hline Sítio & $\overline{\text { Nível }}$ & Amostra & № Beta & $\begin{array}{l}\text { Forma } \\
\text { de } \\
\text { Datação }\end{array}$ & $\begin{array}{l}\text { Material } \\
\text { Datado }\end{array}$ & $\begin{array}{l}\text { Idade } \\
\text { Convenci } \\
\text { onal }\end{array}$ & Calibragem 2 sigma \\
\hline $\begin{array}{l}\text { Associação } \\
\text { Calderita }\end{array}$ & $20-30 \mathrm{~cm}$ & $\frac{\mathrm{RO}-\mathrm{AC}-}{\underline{53-1}}$ & $\underline{258150}$ & AMS & $\begin{array}{l}\text { material } \\
\text { orgânico de } \\
\text { cerâmica }\end{array}$ & $\begin{array}{l}620+/- \\
40 \mathrm{AP}\end{array}$ & $\begin{array}{l}\text { Cal AD } 1280 \text { to } 1410 \\
\text { (Cal BP } 670 \text { to } 540)\end{array}$ \\
\hline $\begin{array}{l}\text { Associação } \\
\text { Calderita }\end{array}$ & $30-40 \mathrm{~cm}$ & $\frac{\mathrm{RO}-\mathrm{AC}-}{\underline{54-1}}$ & $\underline{258149}$ & AMS & $\begin{array}{l}\text { material } \\
\text { orgânico de } \\
\text { cerâmica }\end{array}$ & $\begin{array}{l}980+/- \\
40 \mathrm{AP}\end{array}$ & $\begin{array}{l}\text { Cal AD } 990 \text { to } 1160 \text { (Cal } \\
\text { BP } 960 \text { to } 790)\end{array}$ \\
\hline $\begin{array}{l}\text { Associação } \\
\text { Calderita }\end{array}$ & $40-50 \mathrm{~cm}$ & $\begin{array}{l}\text { RO-AC- } \\
\underline{55-1}\end{array}$ & 258151 & AMS & $\begin{array}{l}\text { material } \\
\text { orgânico de } \\
\text { cerâmica }\end{array}$ & $\begin{array}{l}940+/- \\
40 \mathrm{AP}\end{array}$ & $\begin{array}{l}\text { Cal AD } 1020 \text { to } 1200 \\
\text { (Cal BP } 930 \text { to } 750)\end{array}$ \\
\hline
\end{tabular}

Tabela 21: Datações do sítio Associação Calderita.

Os mapas de densidade e cor do sedimento do sítio, feitos no programa Surfer, indicaram a existência de uma grande concentração cerâmica (Fig. 50). As reocupações do sítio, no entanto, dificultam a interpretação desses mapas ${ }^{78}$. Uma hipótese indicaria uma única casa situada sobre a grande área de densidade do sítio. A outra, que parece mais coerente com o mapa, indicaria uma casa na frente da área com maior densidade, e os vestígios materiais estariam no entorno da casa (cf. SCHMIDT e HECKENBERGER, 2009).

\footnotetext{
${ }^{78}$ A solução para esse problema deveria ser a produção de gráficos Surfer referentes aos diferentes níveis de ocupação (vide sítio Jacarezinho, abaixo). No entanto, falta nitidez para distinguir as diferentes ocupações. Além disso, como a unidade foi realizada em um montículo, mesmo que a unidade informasse de forma precisa os níveis artificiais para a comparação espacial, dificilmente esses níveis seriam espelhados no restante do sítio, fora do montículo.
} 


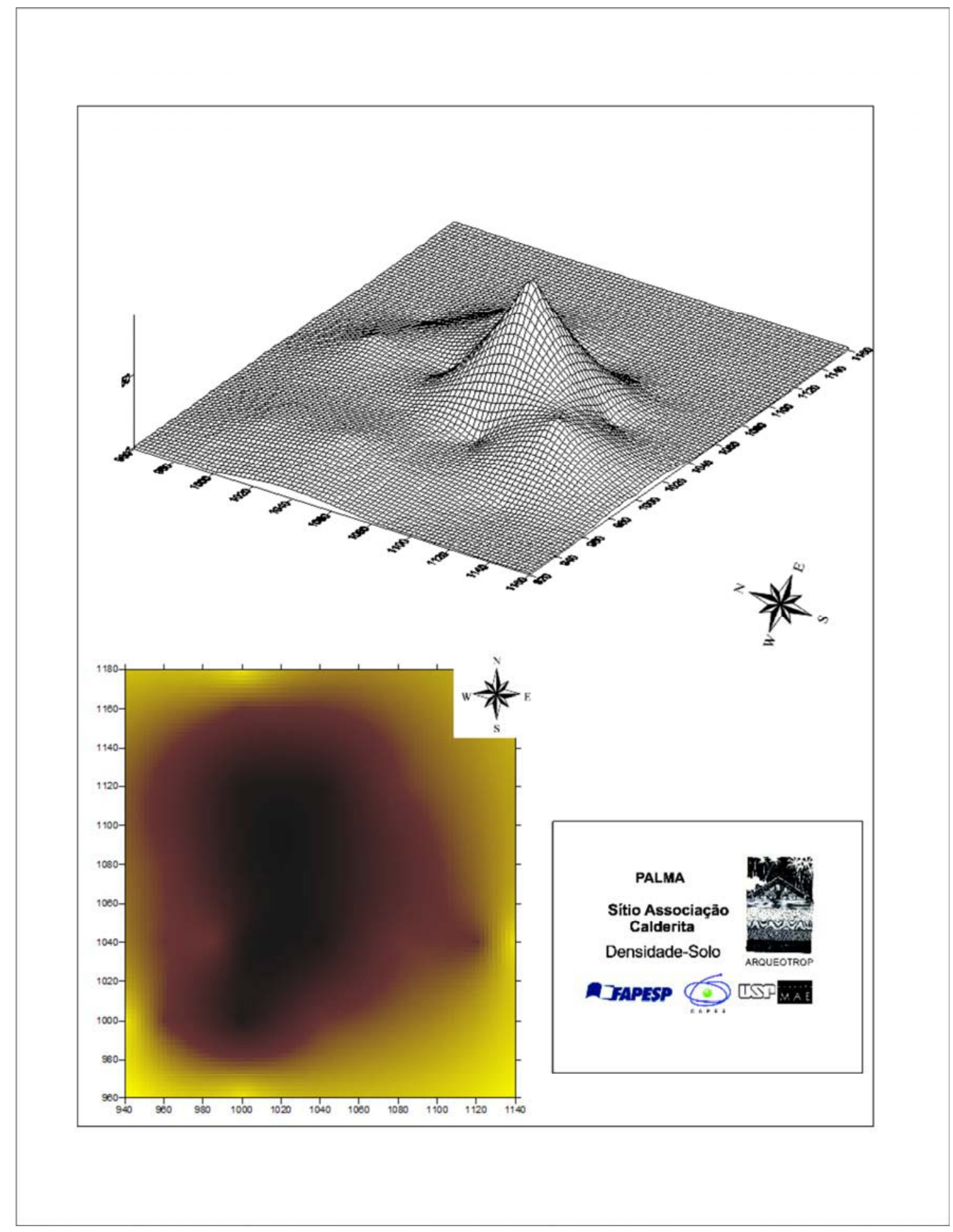




\subsubsection{Comentários}

Chega-se a mais uma problemática que pode ser testada em estudos futuros: compreender o porquê da não identificação de sítios arqueológicos nas margens do rio Jamari entre a cachoeira de Samuel e o encontro desse rio com o Candeias ${ }^{79}$. Há três alternativas que poderiam explicar essa ausência ${ }^{80}$ : (I) o trecho do rio Jamari entre a barragem de Samuel e o encontro com o rio Candeias possui poucos moradores, i.e., baixo potencial para um levantamento extensivo como o proposto por esse projeto; (II) nesse mesmo trecho o rio Jamari segue encaixado no relevo, com grandes barrancos que dificultam ou impossibilitam a verificação de áreas potenciais, e (III) fatores culturais ou naturais desestimularam a presença densa de grupos pré-coloniais.

Uma possível resposta, congruente com a terceira alternativa, seria que o trecho do baixo Jamari entre a cachoeira de Samuel e a foz do rio Candeias representa uma espécie de buffer zone entre os grupos do médio Jamari (Tradição Jamari) e os grupos do alto Madeira (Subtradição Jatuarana). Segundo DeBoer (1981: 365), uma buffer zone é uma área desabitada que separa dois ou mais grupos. $\mathrm{O}$ autor deixa claro que a área é desabitada por pertencer a um contexto de terra de ninguém, um espaço que poderia ser utilizado por qualquer um dos grupos em questão, mas que não o é para que não haja uma competição direta pelo espaço. Uma buffer zone pode ser uma área para reduzir a interação e o conflito entre dois grupos competitivos e antagônicos por meio do simples distanciamento espacial. DeBoer (1981: 367) aponta que tal fenômeno teria ocorrido no rio Ucayali (alto Amazonas) durante o período pré-colonial, quando havia áreas separando os grupos da Tradição Cumancaya e os grupos da Tradição Caimito (TPA), e teria se repetido no período colonial, entre os grupos Kokama-Omágua (Tupi-Guarani?) e Shipibo-Conibo (Pano) (cf. TAMANAHA, 2012). Antes de explorar essa possibilidade, é vital apresentar os demais sítios amostrados.

\footnotetext{
${ }^{79}$ Em duas outras oportunidades prospectamos esse segmento do rio (vide abaixo).

${ }^{80}$ Sem perder de vista as palavras de Lathrap: "I would hold that negative evidence from rapid site surveys, along routes which are presently more accessible, is not reliable. The failure of such initial surveys to find remains of a particular culture is not good evidence that people of that culture did not migrate through or occupy the region in question" (1968: 77, grifo do autor).
} 


\subsection{Sítio Nova Vida}

No final da etapa de campo na qual foi escavado o sítio Associação Calderita, ocorreu a identificação do sítio Nova Vida. Esse sítio dista $3 \mathrm{~km}$ sul do rio Madeira e $12 \mathrm{~km}$ oeste do rio Jamari e foi encontrado devido à presença de sedimento escuro (acinzentado) na beira da estrada vicinal que liga a cidade de Porto Velho à agrovila do Jamari. Depois se constatou, por meio da observação de imagens de satélite (Google Earth), que o sítio se encontrava (aparentemente) em um meandro abandonado do rio Madeira. Sem tempo nem permissão do proprietário da fazenda onde se encontrava o sítio para realizar escavações, optou-se por fazer apenas algumas coletas de fragmentos cerâmicos de superfície, assim como executar cinco sondagens oportunísticas (com boca-de-lobo) na beira da estrada.

A partir dessas atividades, foi possível perceber que se tratava de um sítio com baixa densidade de material cerâmico, e que este era extremamente simples. Fatores que, somados à geografia do sítio (ocupando um meandro abandonado do rio Madeira), sugeriram se tratar de um sítio antigo (cf. LATHRAP, 1968). Com essas questões em mente e sem opção - mais nenhum sítio arqueológico foi identificado nessa etapa de campo - decidiu-se que esse seria o sítio escavado na etapa de campo seguinte.

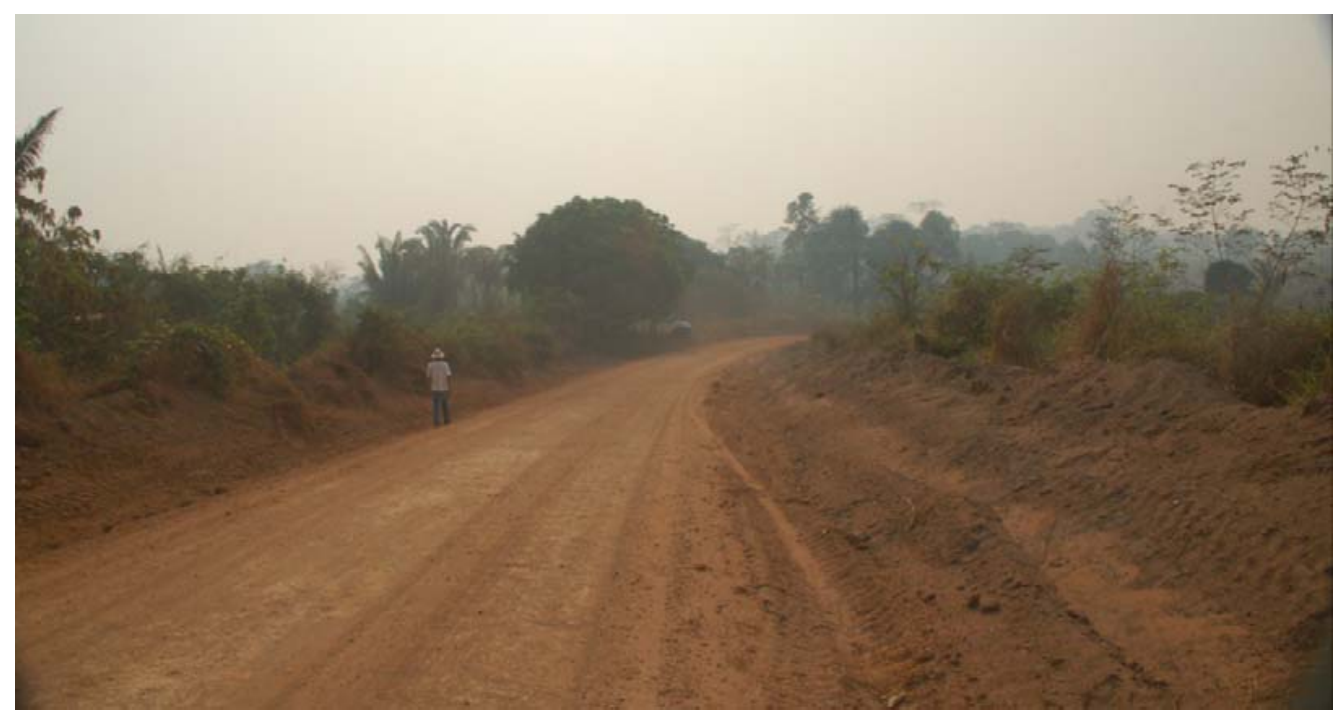

Figura 51: Vista da estrada que corta o sítio Nova Vida (foto: Manuel Arroyo-Kalim, 2008).

$\mathrm{Na}$ etapa de escavação realizada em fevereiro de 2009 , delimitou-se o sítio por meio de uma malha de sondagens espalhadas a cada $20 \mathrm{~m}$, resultando em um total de 79 intervenções, das quais 43 possuíam material arqueológico (Fig. 52, Tabela 22). A área 
trabalhada era coberta por pasto, com algumas palmeiras e árvores exógenas (e.g. limoeiros). A partir das sondagens, que renderam um total de 381 fragmentos cerâmicos, foi realizada a delimitação do sítio, que possuía forma irregular e 3,4ha de área.

As sondagens também permitiram observar uma considerável variação na espessura e na profundidade da camada arqueológica nas diferentes partes do sítio: as áreas com topografia mais elevada com material nos níveis superiores, e as áreas mais baixas com fragmentos cerâmicos apenas em níveis profundos, cobertos por colúvio (Fig. 56). O sedimento, com textura predominantemente arenosa na camada antropogênica, se tornava argiloso com o fim dessa camada. Em quadras sem material, o sedimento foi observado com textura argilosa desde o início. Por fim, foi identificada a partir das sondagens uma área com sedimento escuro, com densidade superior à do restante do sítio (área delimitada na Fig. 52).

Foram abertas, então, duas unidades de $1 \mathrm{~m}^{2}$, uma delas (N1023 E962) de controle, em uma área periférica do sítio Nova Vida, com uma baixa densidade de material cerâmico indicado pelas sondagens mais próximas, e outra na área com sedimento escuro (N1080 E958). Ambas as unidades foram escavadas com ferro de cova, enxadeco e colher de pedreiro, em níveis artificiais de $10 \mathrm{~cm}$.

A unidade N1023 E962 foi escavada devido ao resultado da sondagem N1020 E960, que apontou uma possível camada de barro queimado a $90 \mathrm{~cm}$, e devido à sua posição na topografia do sítio, de frente (ao $\mathrm{sul}^{81}$ ) para a área com sedimento escuro em uma depressão (concavidade) de alta vertente, o que geomorfologicamente poderia ser descrito como um (pequeno) anfiteatro. Por meio dessa unidade, foi possível observar com mais atenção uma amostra da estratigrafia periférica do sítio onde a maior densidade dos vestígios arqueológicos aparecia a partir dos $40 \mathrm{~cm}$ (vide camada III, Fig. 53). Foram coletados carvões na peneira para datação $(\mathrm{C} 14)$.

A escavação dessa unidade, rebaixada até $120 \mathrm{~cm}$, não confirmou a presença da camada de terra queimada. Além disso, a baixa quantidade de fragmentos obtidos nessa unidade, um total de 164 fragmentos, foi outro indicador de que unidades de controle fora das áreas de maior densidade, apesar de importantes, não tendem a ser frutíferas em intervenções extensivas, como as da presente pesquisa (vide croqui Anexo 10).

\footnotetext{
${ }^{81} \mathrm{O}$ norte na mancha de terra preta era o barranco que terminava em área alagável que se supõe seja o antigo meandro do rio Madeira.
} 


\section{SÍTIO ARQUEOLÓGICO NOVA VIDA}

Município de Porto Velho - RO

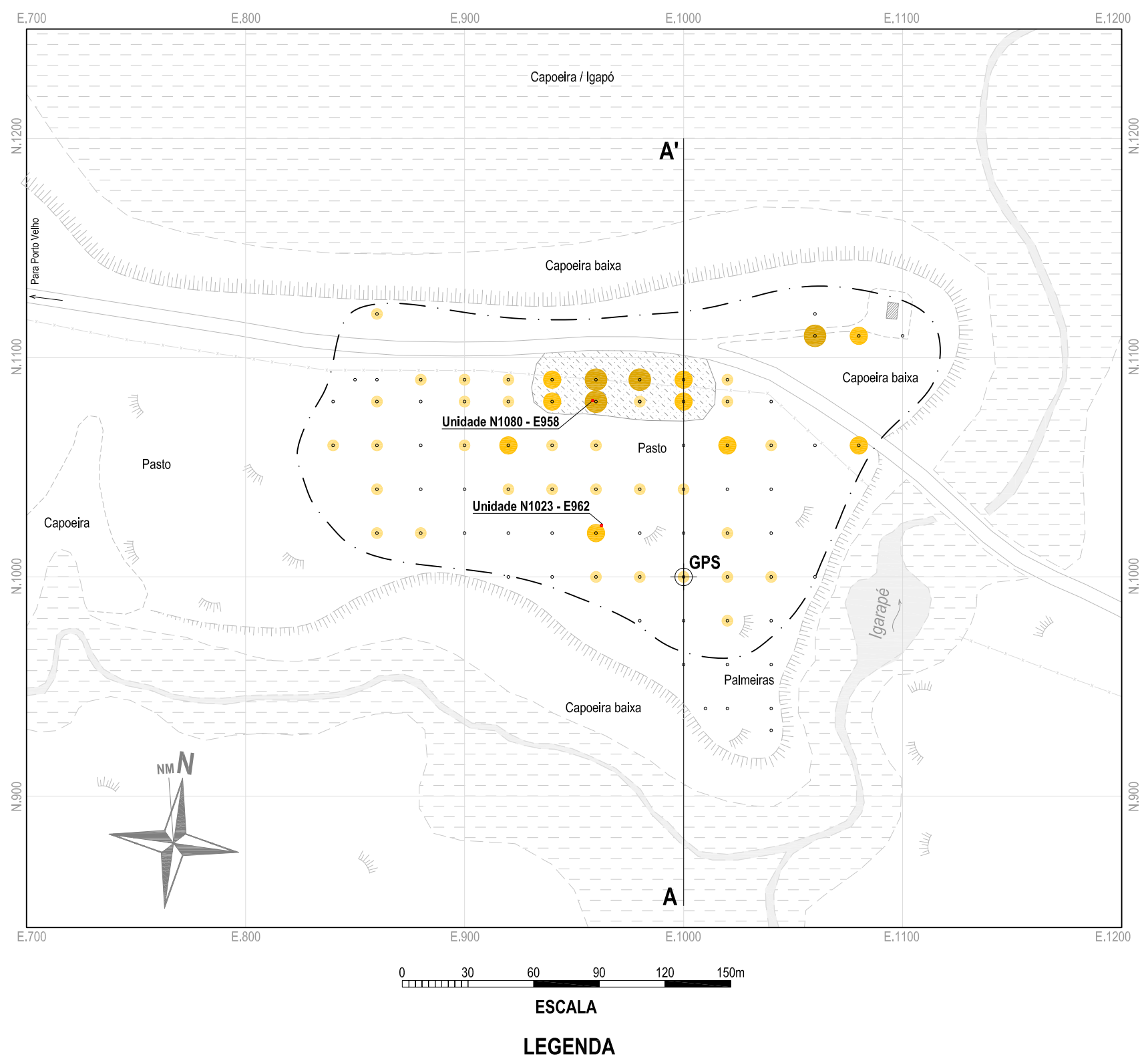

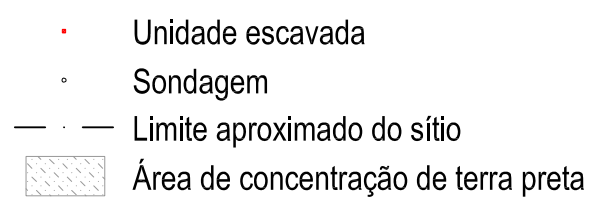

FRAGMENTOS DE CERÂMICA POR SONDAGEM

1 a 10

11 a 25

Acima de 26
Edificação

Estrada

Caminho

Cerca

Limite aproximado da cobertura vegetal

Limite aproximado de área alagável Desnível

Desnivel acentuado

Área alagável

Igarapé

†PS Referência da posição geográfica

Área aproximada: 3,4 ha

GPS: $430.774 \mathrm{~m} \mathrm{E} / 9.046 .164 \mathrm{~m} \mathrm{~N}$

Projeçāo Universal Transversa de Mercator - Datum SAD 69 - Zona $20 \mathrm{~L}$

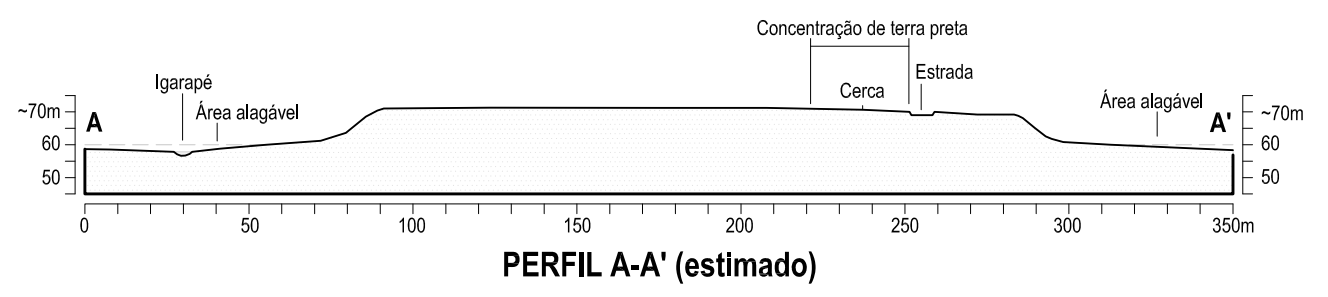



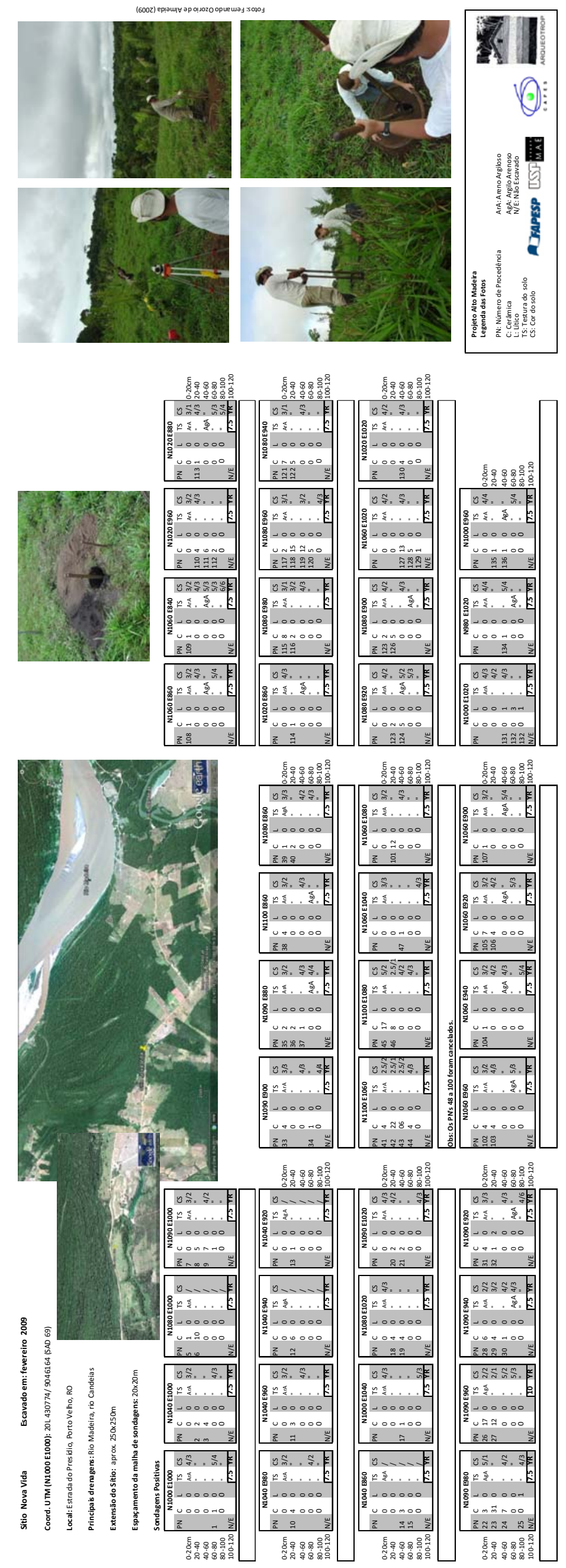


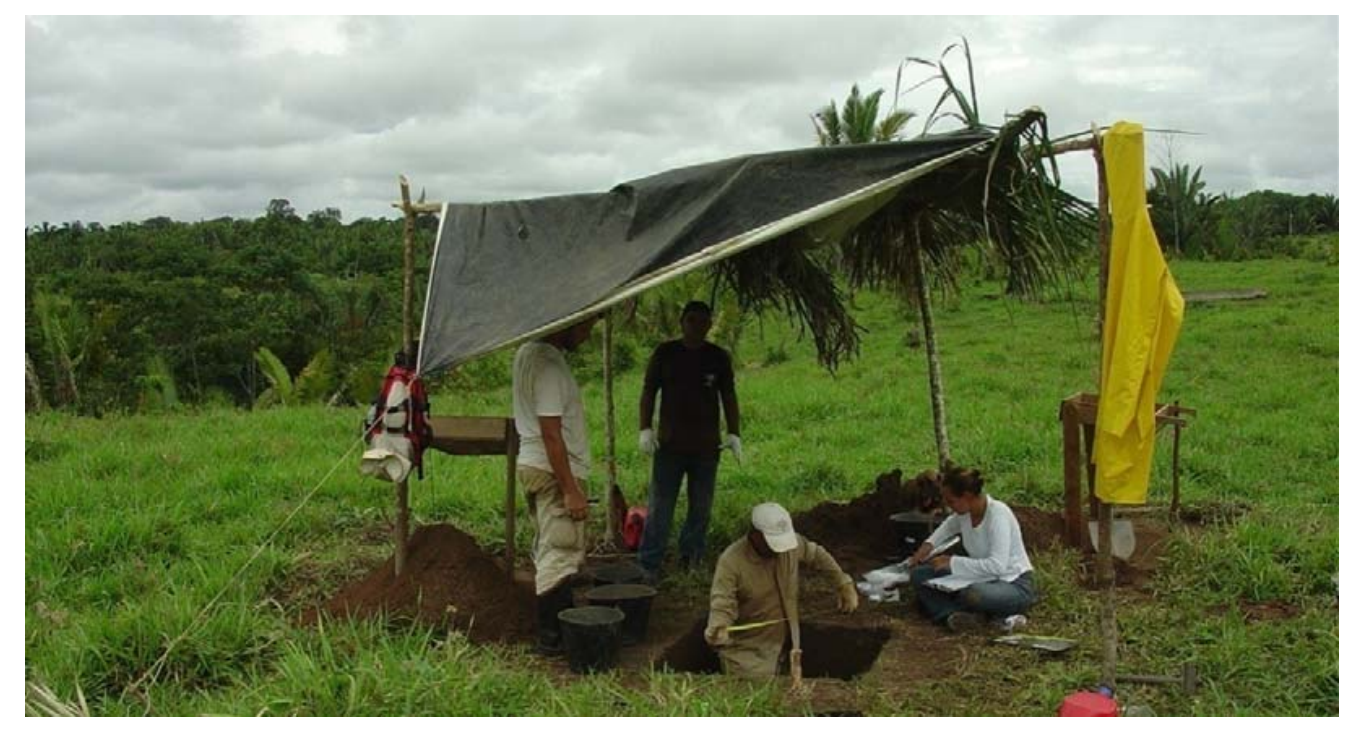

Figura 53: Rebaixamento de unidade N1023 E962 no sítio Nova Vida (foto: Fernando Ozorio de Almeida, 2009).

A unidade N1080 E958, por sua vez, foi escavada no local mais denso do sítio, onde foi identificado o sedimento mais escuro (10YR 2/1 black, escala Munsell). Observou-se que a maior quantidade de fragmentos cerâmicos coincidiu com a camada de solo mais escuro, grosso modo entre 20 e $60 \mathrm{~cm}$ (camada III, Fig. 54). Foram obtidos aproximadamente 450 fragmentos com a escavação dessa unidade, rebaixada até $100 \mathrm{~cm}$ de profundidade. No nível $50 \mathrm{~cm}$, foi possível coletar carvões (in loco), para datações radiocarbônicas.

Durante o rebaixamento do nível $60-70 \mathrm{~cm}$ dessa unidade ${ }^{82}$ foram identificadas quatro feições arqueológicas. Essas feições poderiam ser buracos de estacas ou de postes o que, se confirmado, daria grande sustento à hipótese de que se tratava de uma área de habitação. No entanto, com o prosseguimento da escavação, ficou claro que se tratavam de fenômenos de bioturbação: todas as feições ganharam um caráter irregular quanto à espessura e inclinação. Dessa forma, as feições foram todas descartadas.

\footnotetext{
${ }^{82}$ Os perfis das unidades N1023 E962 e N1080 E958 ainda estão sendo digitalizados.
} 

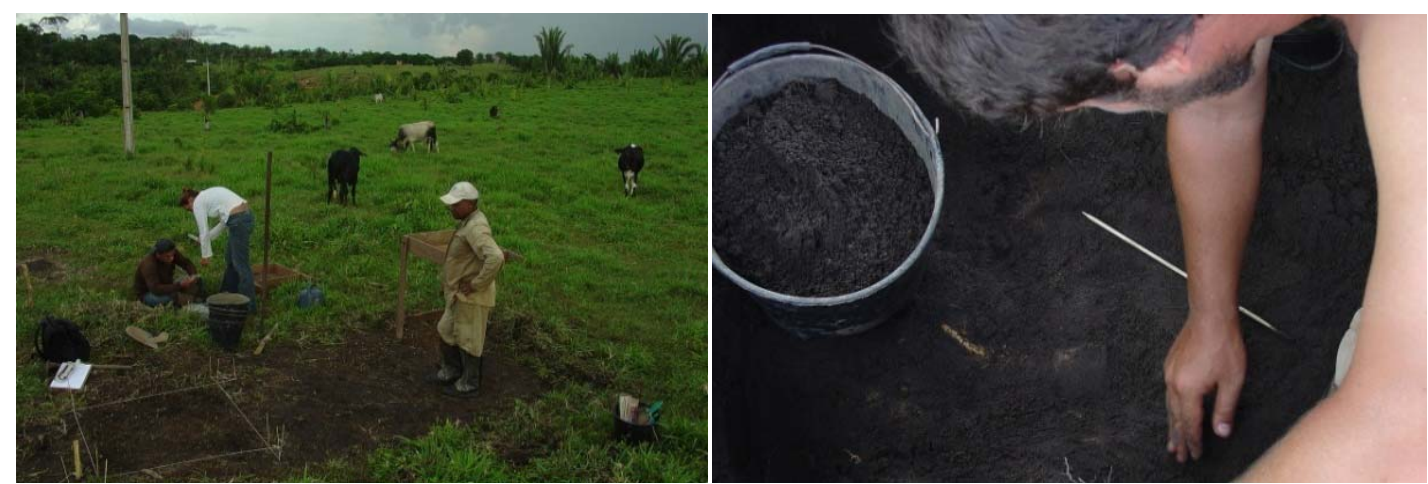

Figura 54: Abertura da unidade N1080 E958 (foto: Fernando Ozorio de Almeida, 2009).

Figura 55: Expondo material in situ, na unidade $N 1080$ E958, nível 50-60cm (foto: Fernando Ozorio de Almeida, 2009).

Ainda assim, os dados de densidade de material e cor do sedimento corroboram a sugestão de que essa deveria ser a área de habitação do sítio. Além disso, esse local possui uma disposição diferenciada: trata-se da área mais plana, mais alta, e de frente para a área alagável do que se supõe ser o meandro abandonado do rio Madeira. Por outro lado, tal sugestão indicaria que uma parte de grande relevância do sítio foi impactada (destruída) pela abertura da estrada vicinal, já que o sedimento escuro e a maior densidade de material foram observados dos dois lados da pista.

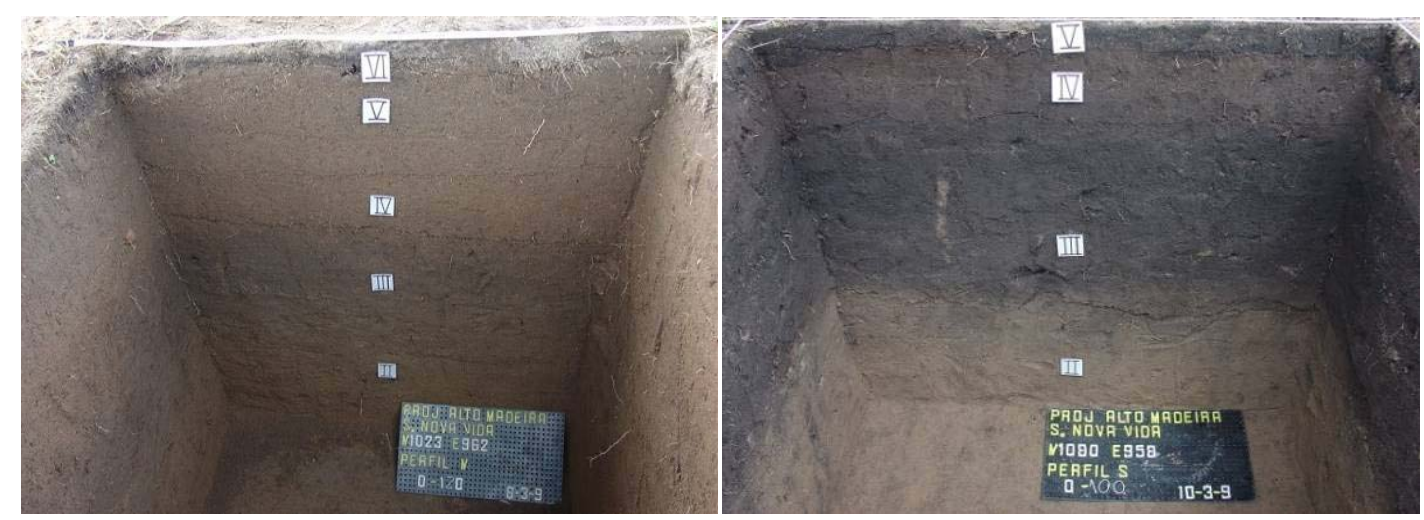

Figura 56: Camada escura enterrada na unidade N1023 E962 (Perfil W).

Figura 57: Perfil sul da unidade N1080 E958. (fotos: Fernando Ozorio de Almeida, 2009). 

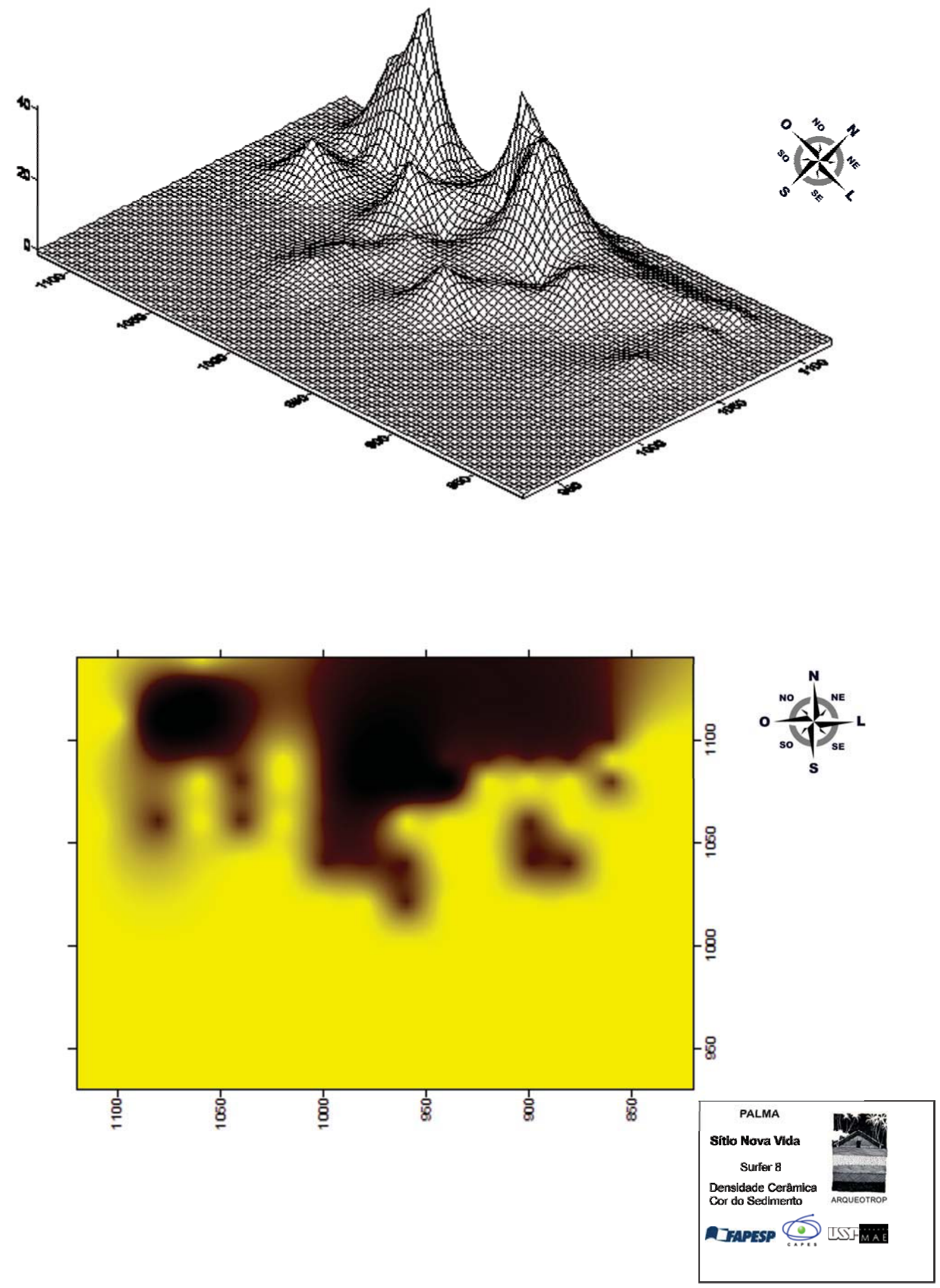


\section{PROJETO ALTO MADEIRA SÍTIO ARQUEOLÓGICO NOVA VIDA}

PERFIL SUL - Unidade N1080 E958

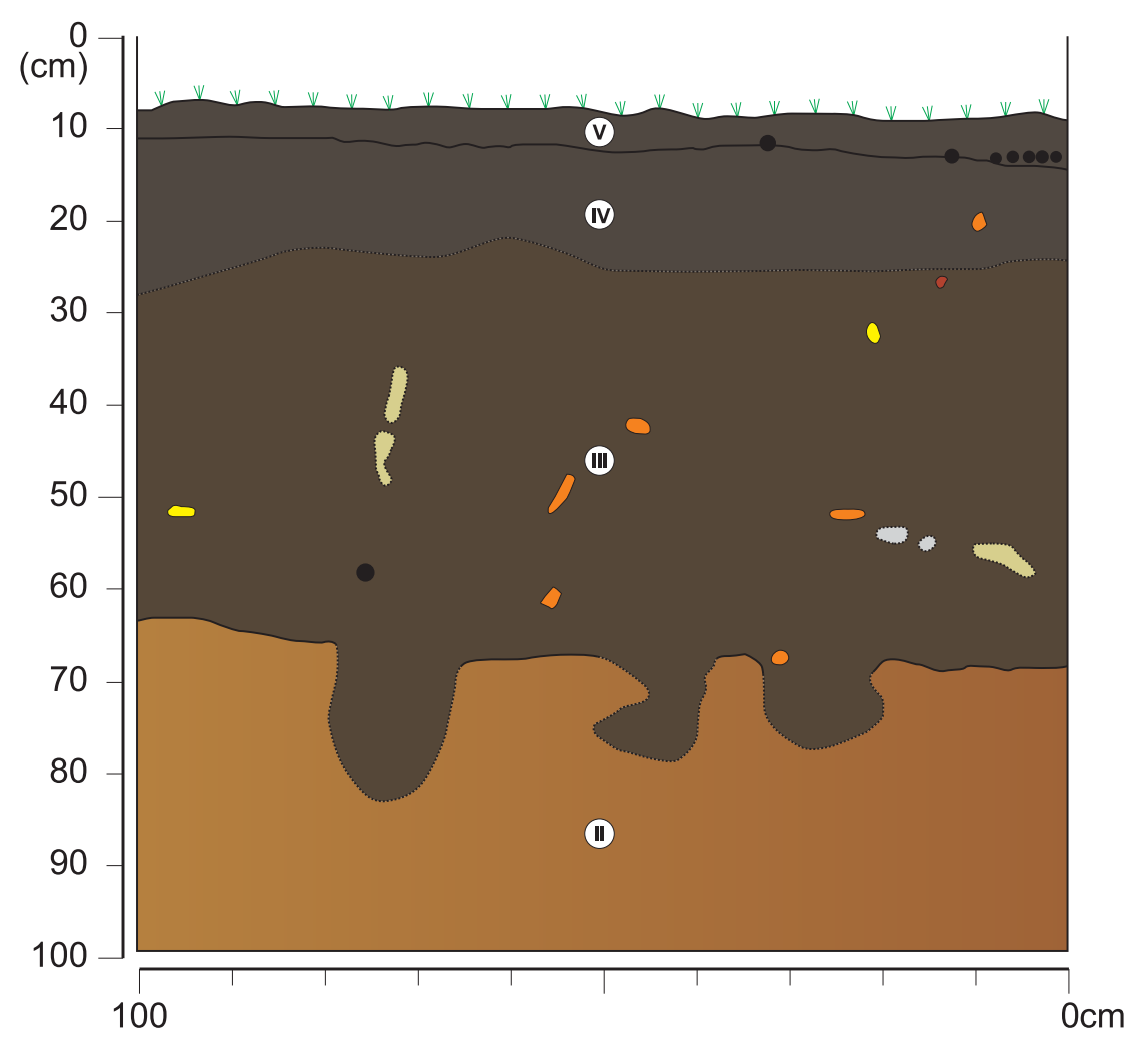

\section{LEGENDA}

- Cerâmica

- Carvão

- Bolota de Argila

B Bioturbação

Lente de areia clara

- Rocha

w Superficie

L Limite de camada definido

Limite de camada difuso

(v) Sedimento areno-argiloso, orgânico, levemente solto, com elevado número de raízes. Não foram identificados vestígios arqueológicos. O sedimento, de cor 10YR 2/1 "black" (tabela Munsell), se apresenta levemente mais escuro e solto do que a camada IV.

(1v) Sedimento areno-argiloso, levemente orgânico, solto, com média-alta presença de vestígios arqueológicos. Essa camada foi vinculada à cor 10YR 2/2 "very dark brown"(tabela Munsell).

III Sedimento areno-argiloso, orgânico, solto, com elevada presença de material arqueológico. Foram observadas lentes de areia clara, prováveis frutos de bioturbações. Essa camada foi vinculada à cor 10YR 2/1 "black" (tabela Munsell).

(II) Sedimento argilo-arenoso, solto, pouco orgânico, e com baixa presença de material arqueológico. Foi observada uma fina lente de carvões na porção SW dessa camada. O sedimento, que representa uma transição entre os horizontes $\mathrm{AB} / \mathrm{BA}$, foi vinculado à cor 7.5YR 4/3 "brown" (tabela Munsell). 
Durante o período de escavações do sítio Nova Vida, uma primeira amostra de cerâmica do sítio, proveniente das coletas realizadas na etapa anterior, havia sido mandada para datação. Como mencionado, a localização e as características da cerâmica criaram uma expectativa quanto à antiguidade do sítio, talvez ultrapassando o início da era cristã. Entretanto, a primeira datação apontou para uma ocupação recente, $1520+-40$ d.C., fato que causou certa decepção.

Decidiu-se mandar uma amostra mais bem contextualizada para uma segunda datação. Dessa vez foi escolhida uma amostra (carvão) da unidade escavada em área de terra preta (N1080 E958), em um nível profundo $(50 \mathrm{~cm})$. Os resultados apontaram uma data bem mais próxima das expectativas: $160+-60$ d.C. Como essa amostra não estava na base da camada arqueológica, é possível que a cronologia do sítio seja ainda mais recuada.

\begin{tabular}{|c|c|c|c|c|c|c|c|}
\hline$\overline{\text { Sítio }}$ & Nivel & Amostra & № Beta & $\begin{array}{l}\text { Forma } \\
\text { de } \\
\text { Datação }\end{array}$ & $\begin{array}{l}\text { Material } \\
\text { Datado }\end{array}$ & $\begin{array}{l}\text { Idade } \\
\text { Convencio } \\
\text { nal }\end{array}$ & Calibragem 2 sigma \\
\hline $\begin{array}{l}\text { Nova } \\
\text { Vida }\end{array}$ & Sup. & RO-NV-2-1 & $\underline{258152}$ & $\mathrm{AMS}^{83}$ & $\begin{array}{l}\text { material } \\
\text { orgânico } \\
\text { de } \\
\text { cerâmica }\end{array}$ & $\begin{array}{l}430+/- \\
40 \mathrm{BP}\end{array}$ & $\begin{array}{l}\text { Cal AD } 1420 \text { to } 1500 \\
\text { (Cal BP } 530 \text { to } 440) \text {, Cal } \\
\text { AD } 1600 \text { to } 1610 \text { (Cal } \\
\text { BP } 350 \text { to } 340)\end{array}$ \\
\hline $\begin{array}{l}\text { Nova } \\
\text { Vida }\end{array}$ & 50cm & "Ro-NV-204-01 & $\underline{280928}$ & C14 & Carvão & $\begin{array}{l}1790+/- \\
60 \mathrm{BP}\end{array}$ & $\begin{array}{l}\text { Cal AD } 80 \text { to } 390 \text { (Cal } \\
\text { BP } 1870 \text { to } 1560)\end{array}$ \\
\hline
\end{tabular}

Tabela 23: Datações do sítio Nova Vida.

\subsection{Sítio Jacarezinho}

$\mathrm{Na}$ mesma etapa da escavação do sítio Nova Vida, foi realizado mais um levantamento extensivo no rio Jamari, entre a foz do rio Candeias e as proximidades da boca do próprio Jamari, um trecho de aproximadamente $35 \mathrm{~km}$. Nesse segmento do rio, foram identificados três sítios arqueológicos: Jacarezinho, Casarão e Barranco. A quantidade de material em superfície, a tonalidade da terra preta, a localização e a logística (a menos pior), foram os elementos que levaram à escolha do sítio Jacarezinho como o próximo a ser escavado. A escavação ocorreu entre junho e julho de 2009.

O sítio Jacarezinho foi encontrado na margem do lago homônimo, um local discreto (Figs. 60 e 61) e atraente pela farta quantidade de peixes do lago, pela presença de um grande igarapé navegável (também homônimo) e pela proximidade dos rios Jamari e Madeira. O igarapé e o lago delimitavam grande parte do sítio (sudoeste, oeste, noroeste, norte e

\footnotetext{
${ }^{83}$ Espectometría de Massas com Acelerador
} 
nordeste). Até pouco tempo o único morador do local, o Sr. José da Silva, utilizava a área com terra preta para a plantação de diversos cultivares (e.g. mandioca, mamão). No entanto, ele abandonou a horta, que hoje é dividida em capoeira e mata secundária, e vive da pesca abundante do lago (e de uma nada abundante aposentadoria).
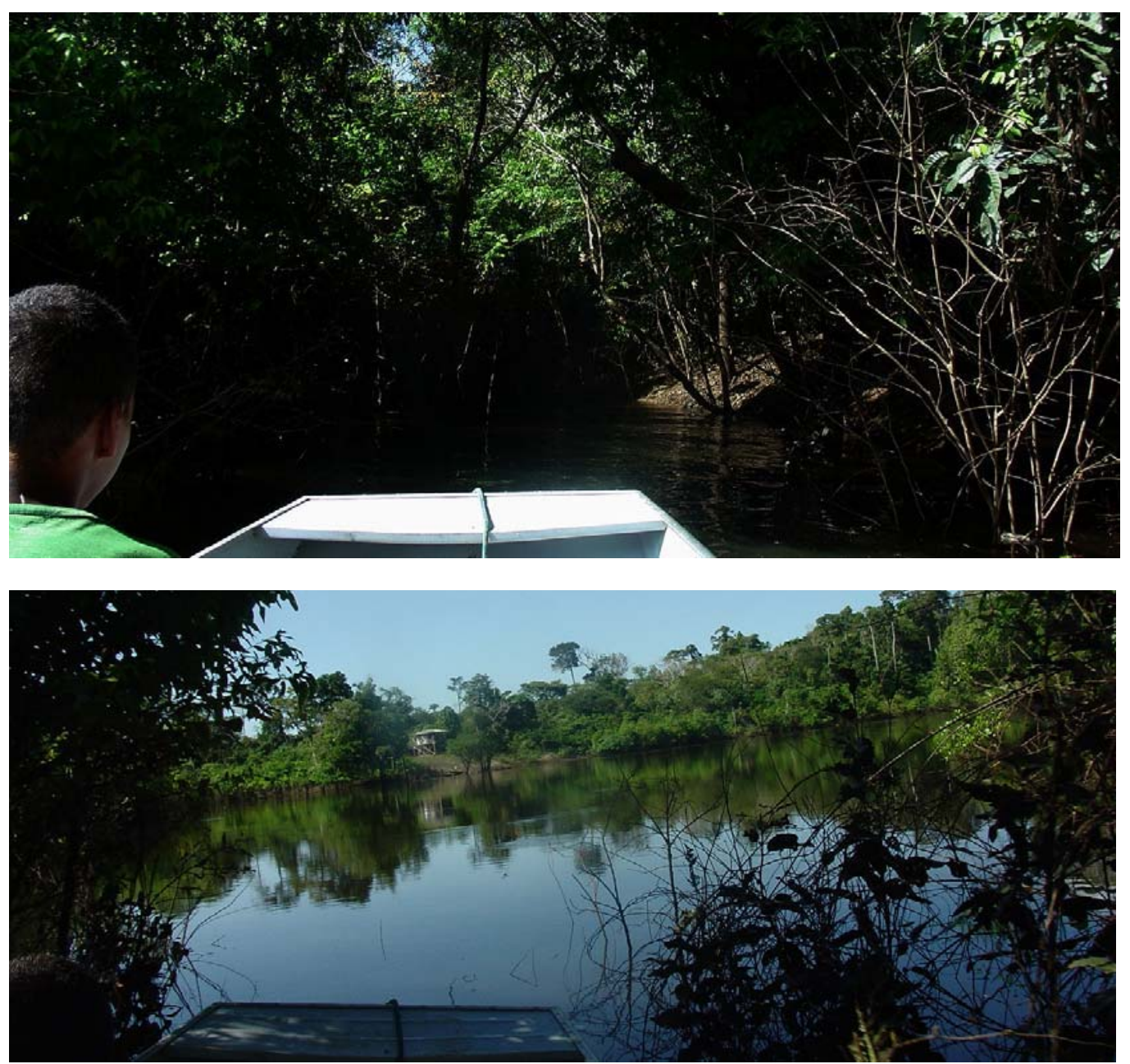

Figura 60: A discreta entrada para o igarapé que leva ao lago do Jacarezinho (foto: Fernando Ozorio de Almeida, 2009).

Figura 61: A impactante chegada ao lago (foto: Fernando Ozorio de Almeida, 2009).

Num primeiro momento, foi executada uma malha de sondagens de $20 \times 20 \mathrm{~m}$ na área mais densa do sítio. No entanto, como a periferia do sítio se mostrou extensa, o número de pessoas trabalhando era reduzido, e o custo logístico (carro+voadeira) era muito elevado, optou-se por aumentar o espaçamento do grid para 40 x 40m na periferia do sítio. No setor leste, não foi finalizada a delimitação, uma vez que não havia autorização para entrar na 
fazenda onde se localizava esse setor $^{84}$. A maior parte do restante do sítio foi delimitada topograficamente (água e/ou barranco). Assim, não há uma estimativa precisa da área total do sítio, mas os dados projetam uma área mínima de 8,3 ha $\left(83.000 \mathrm{~m}^{2}\right)$ e máxima de 10 ha $\left(100.000 \mathrm{~m}^{2}\right)$.

Foram executadas 88 sondagens, das quais apenas sete foram estéreis, e foi obtido um total de 3.282 fragmentos (Fig. 62, Tabela 24). Houve sondagens (e.g. N1000 E1000) que renderam mais de 200 fragmentos. Nas sondagens, foi observado um comportamento regular quanto à textura do sedimento, que nos primeiros níveis (até $+-40 \mathrm{~cm}$ ) era areno-argiloso. Com o aprofundamento das sondagens, em geral escavadas até $1 \mathrm{~m}$ de profundidade, foi observada uma diminuição na granulometria do sedimento: predominantemente arenoso nos níveis superiores e argiloso nos inferiores. O sedimento da área com terra preta possuía coloração próxima a 5YR 2.5/2 dark reddish brown (escala Munsell) e, às vezes, 10YR 2/1 black. O sedimento da periferia do sítio possuía coloração próxima a 7.5YR 4/2 brown. O sedimento da área de terra preta em geral se encontrava muito mais solto do que nas áreas adjacentes a esta.

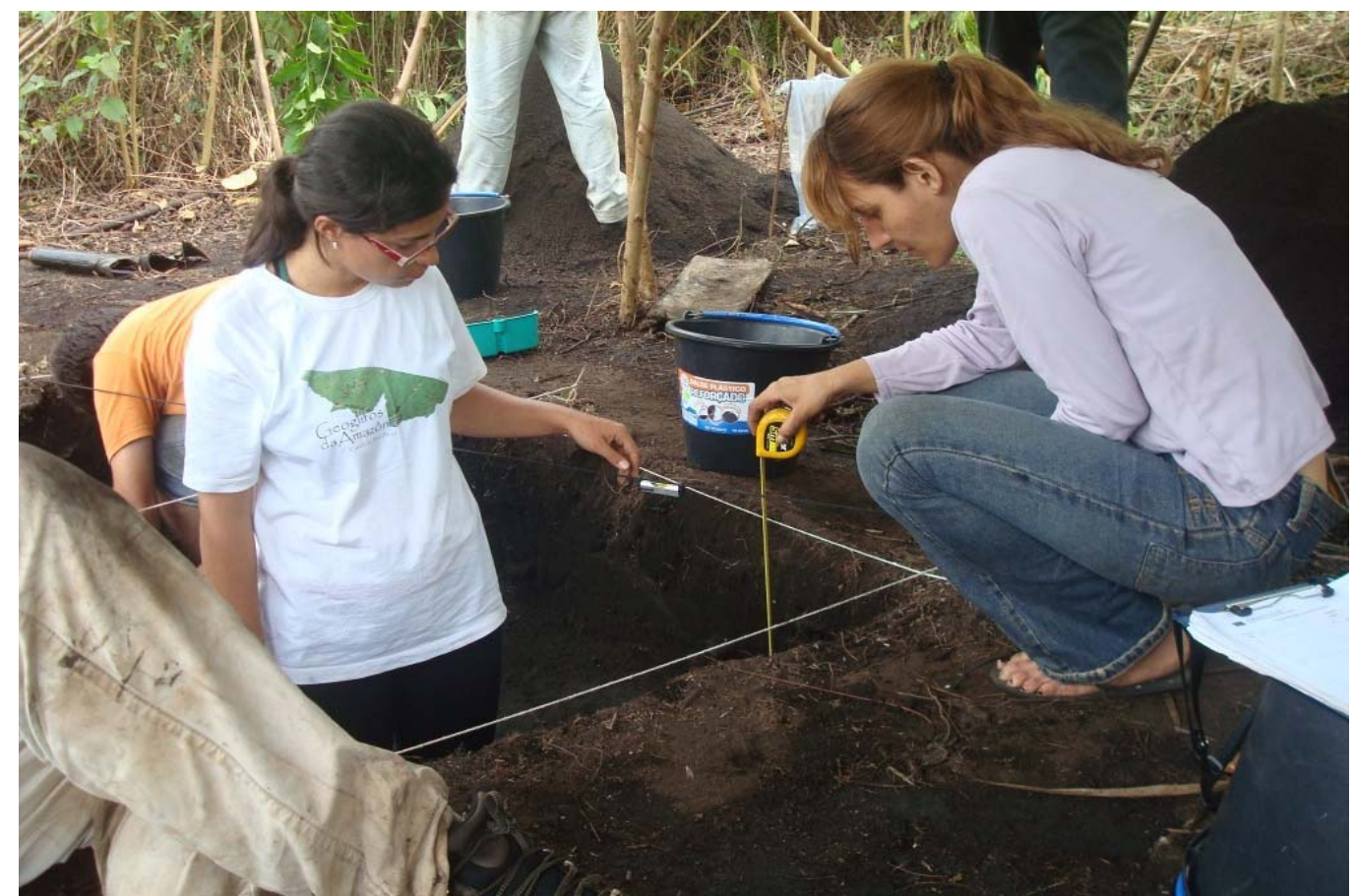

Figura 62: A discreta entrada para o igarapé que leva ao lago do Jacarezinho, a impactante chegada ao lago (fotos: Fernando Ozorio de Almeida, 2009).

\footnotetext{
${ }^{84}$ Os caminhamentos de superfície e os dados das sondagens próximas, entretanto, apontam que o sítio não se expandia muito por esse setor.
} 


\section{SÍTIO ARQUEOLÓGICO JACAREZINHO}

Município de Porto Velho - RO

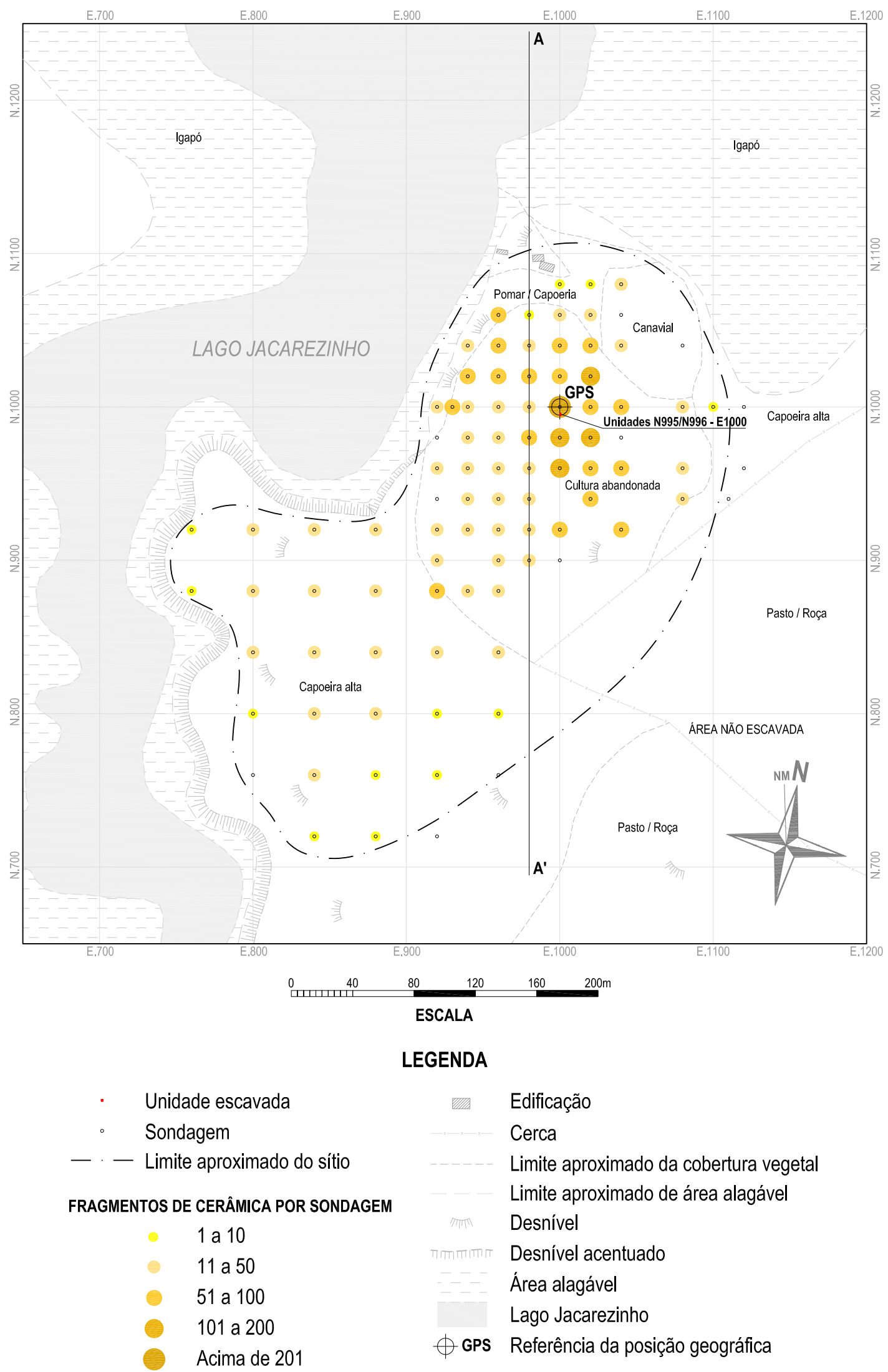

Área aproximada: 8,3ha

GPS: $448.733 \mathrm{~m} \mathrm{E} / 9.052 .164 \mathrm{~m} \mathrm{~N}$

Projeçäo Universal Transversa de Mercator - Datum SAD 69 - Zona 20L

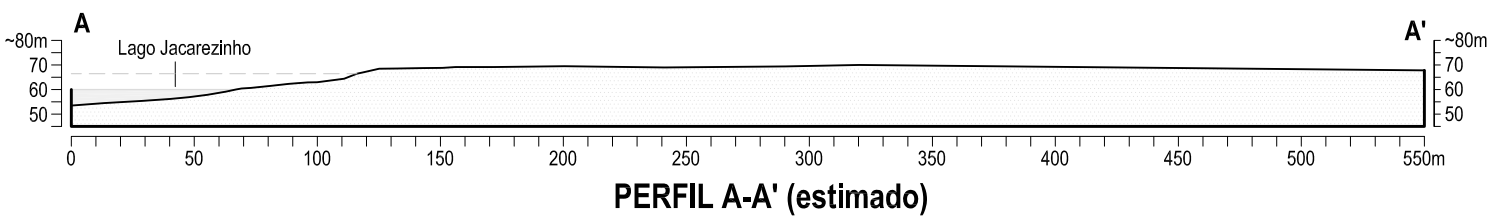




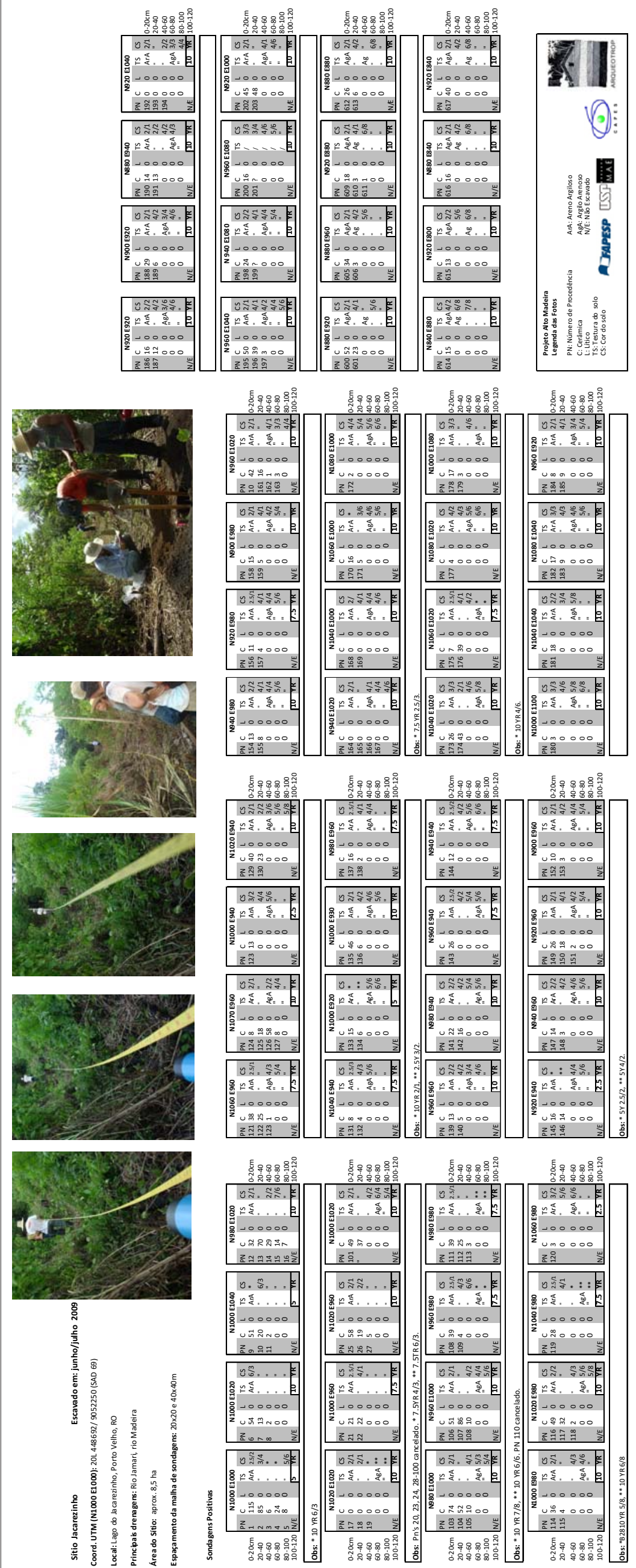


Com a abertura das sondagens, pôde-se observar uma coerência entre a quantidade de material e a coloração do sedimento, como também entre a quantidade do material e a espessura da terra preta. Curiosamente, o local com maior quantidade de fragmentos, onde havia a maior espessura de terra preta e onde foi executada a abertura da unidade $2 \times 1 \mathrm{~m}$, ocorreu no entorno ponto inicial do grid (N1000 E1000). A escavação da unidade (N996/N995 E1000) revelou um sedimento escuro 10YR 2/1 black, que atingiu cerca de $55 \mathrm{~cm}$ de profundidade e 3.000 fragmentos cerâmicos (Fig. 63). Essa unidade apresentou um elevadíssimo número de raízes na camada de terra preta. As raízes deixaram o sedimento solto, dificultando a manutenção de cerâmicas no perfil arqueológico, e podem ser as responsáveis pela inversão de duas das datações (Figs. 64 e 65).

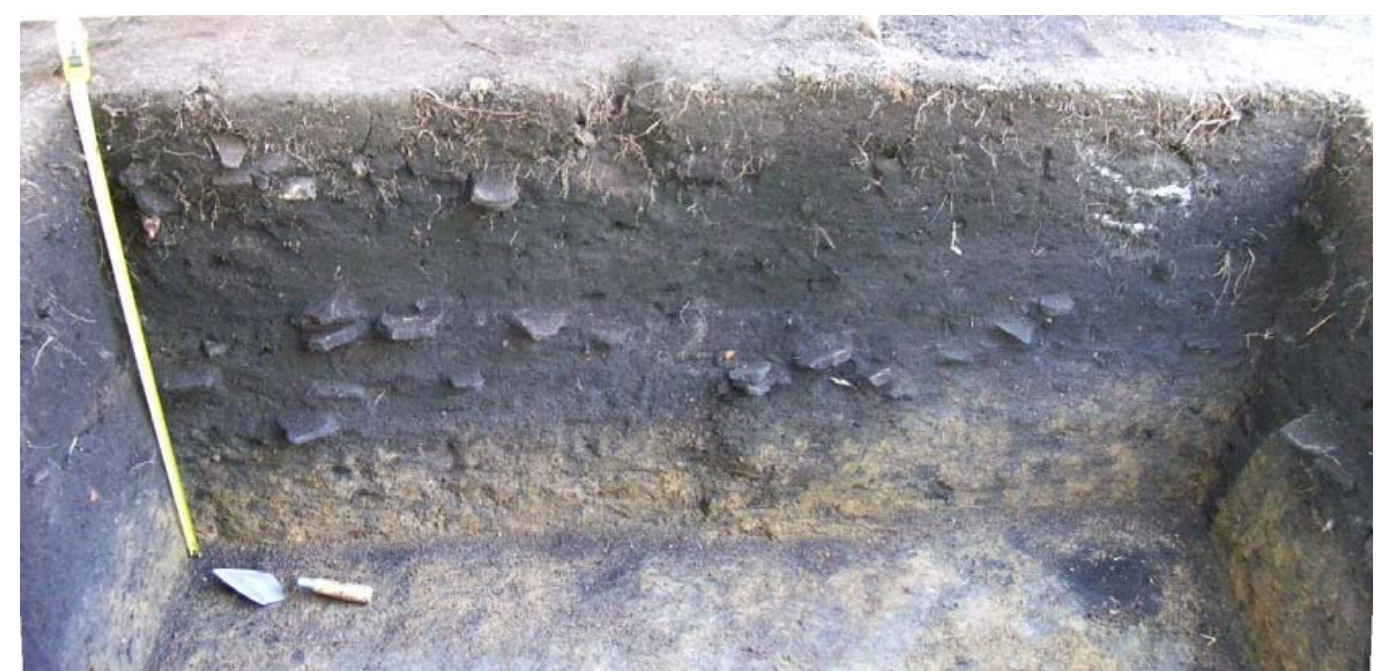

Figura 64: Perfil leste da unidade N996/N995 E1000 (foto: Fernando Ozorio de Almeida, 2009). 


\section{PROJETO ALTO MADEIRA \\ SÍTIO ARQUEOLÓGICO JACAREZINHO}

PERFIL OESTE - Unidade N996 e N995 E1000

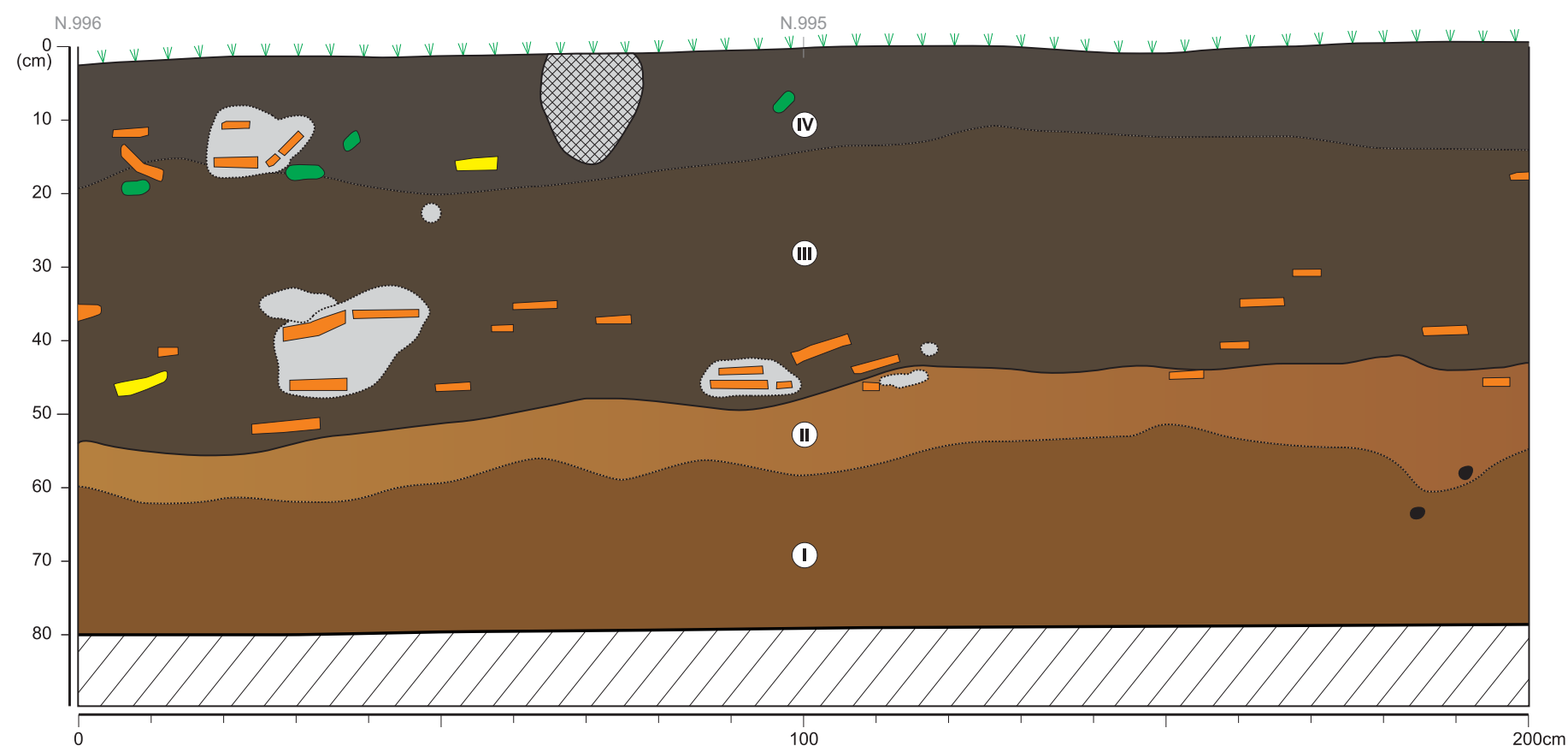

LEGENDA

- Cerâmica

- Carvão

- Material lítico

Terra queimada

- Raiz

- Buraco

$\Downarrow$ V Superficie

L Limite de camada definido

............ Limite de camada difuso

(iv) Sedimento areno-argiloso, com média densidade cerâmica (que se encontra bastante fragmentada devido à ação antrópica recente: roçado). Por estar próximo à superfície apresenta muitas raízes (de todos os tamanhos). O sedimento, de cor 10YR 2/2 "very dark brown" (tabela Munsell), se apresenta com uma coloração levemente mais clara que a camada III.

(II) Sedimento areno-argiloso, com alta densidade cerâmica (que foi encontrada menos fragmentada que a camada IV). Há presença de pontos de terra queimada (bolotas de argila?). Essa camada foi vinculada à cor 10YR 2/1 "black" (tabela Munsell).

(II) Sedimento argilo-arenoso. Trata-se da camada de transição entre a camada arqueológica e o latossolo (AB/BA). Apresenta reduzida quantidade de material cerâmico, proveniente de bioturbações ou percolações da camada superior. O sedimento possui cor predominante 10YR 4/2 "dark grayish brown" (85\%), assim como $2.5 \mathrm{Y} 7 / 8$, em menor quantidade $(15 \%)$.

(1) Sedimento argiloso. Trata-se do latossolo amarelo, e arquelógicamente estéril. Possui pequenas manchas de sedimento escuro, proveniente de percolações das camadas superiores. O sedimento possui cor predominante $2.5 \mathrm{Y}$ $7 / 8$ (75\%), assim como 10YR 4/2 "dark grayish brown", em menor quantidade (25\%).

Camada não escavada. 
Foram realizadas três datações por AMS para o sítio Jacarezinho, todas provenientes da unidade 2 x 1m (N996/N995 E1000).

\begin{tabular}{|c|c|c|c|c|c|c|c|}
\hline Sítio & Nivel & Amostra & № Beta & $\begin{array}{l}\text { Forma } \\
\text { de } \\
\text { Datação }\end{array}$ & $\begin{array}{l}\text { Material } \\
\text { Datado }\end{array}$ & $\begin{array}{l}\text { Idade } \\
\text { Convencio } \\
\text { nal }\end{array}$ & Calibragem 2 sigma \\
\hline Jacarezinho & $\begin{array}{l}20- \\
30 \mathrm{~cm}\end{array}$ & $\begin{array}{l}\text { Ro-Ja-304- } \\
\underline{01}\end{array}$ & $\underline{280926}$ & AMS & $\begin{array}{l}\text { material } \\
\text { orgânico } \\
\text { na } \\
\text { cerâmica }\end{array}$ & $\begin{array}{l}660+/- \\
40 \mathrm{BP}\end{array}$ & $\begin{array}{l}\text { Cal AD } 1270 \text { to } 1400 \\
\text { (Cal BP } 680 \text { to } 550)\end{array}$ \\
\hline Jacarezinho & $\begin{array}{l}40-50 \\
\mathrm{~cm}\end{array}$ & $\begin{array}{l}\text { Ro-Ja-306- } \\
\underline{01}\end{array}$ & $\underline{280927}$ & AMS & $\begin{array}{l}\text { material } \\
\text { orgânico } \\
\text { na } \\
\text { cerâmica }\end{array}$ & $\begin{array}{l}860+/- \\
40 \mathrm{BP}\end{array}$ & 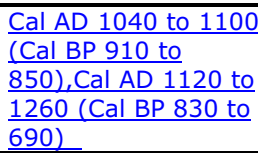 \\
\hline Jacarezinho & $\begin{array}{l}30-40 \\
\mathrm{~cm}\end{array}$ & $\begin{array}{l}\text { Ro-Ja-205- } \\
\underline{01}\end{array}$ & $\underline{\underline{280925}}$ & AMS & $\begin{array}{l}\text { material } \\
\text { orgânico } \\
\text { na } \\
\text { cerâmica }\end{array}$ & $\begin{array}{l}980+/- \\
40 \mathrm{BP}\end{array}$ & $\begin{array}{l}\text { Cal AD } 990 \text { to } 1160 \\
\text { (Cal BP } 960 \text { to } 790)\end{array}$ \\
\hline
\end{tabular}

Tabela 25: Datações do sítio Jacarezinho.

Observando a Tabela 25 e o perfil (Fig. 65), é possível notar duas distintas áreas de concentração de material. A camada superior estaria entre 0 e $25 \mathrm{~cm}$ (camada IV, nas proximidades da camada III), e a camada inferior, entre 30 e $55 \mathrm{~cm}$ (camada III, nas proximidades da camada II). Feita essa observação, pode-se indicar que a datação mais recente (1300 d.C.) estaria na base da camada superior, e as duas outras datações pertenceriam à ocupação mais antiga, no nível inferior. Indicação que relativiza a inversão das datas mais antigas, ainda mais se utilizadas as datações calibradas: a primeira calibragem da datação Ro-Ja-306-01 é bastante próxima à calibragem da datação Ro-Ja-205-01. Ambas se encontram próximas a 1100 d.C.

Fica indicada a sugestão de que o sítio Jacarezinho possui (pelo menos) duas ocupações pré-coloniais. A primeira teria acontecido por volta de 1100 d.C. A segunda, por volta de 1300 d.C. Resta saber a duração dessas ocupações - que a análise cerâmica indicará estarem relacionadas a um mesmo grupo (Capítulo 5). A espessura da camada de terra preta, a densidade cerâmica observada e as condições propícias ao assentamento humano do lago do Jacarezinho apontam ocupações duradouras.

Se utilizadas as sondagens que delimitaram (quase todo) o sítio e a divisão de camadas de ocupação inferida a partir do perfil da unidade N996/N995 E1000 (Fig. 66), é possível sugerir que há uma grande diferença entre a extensão do assentamento da primeira para a segunda ocupação. Como as sondagens são feitas utilizando níveis artificiais de $20 \mathrm{~cm}$, 
essa comparação foi feita entre os níveis $0-20 \mathrm{~cm}$ e $40-60 \mathrm{~cm}$. O nível $20-40 \mathrm{~cm}$ foi excluído por interceptar as duas camadas. No entanto, é possível que a exclusão desse nível gere uma pequena distorção quanto à ocupação mais antiga, uma vez que ambos (o nível $20-40 \mathrm{~cm}$ e a ocupação antiga) parecem estar (mais) relacionados.

O resultado dos gráficos Surfer mostra que o assentamento mais antigo ocuparia uma área de entorno de 2 ha, e a ocupação mais recente toda a área do sítio, com mais de 8 ha. $\mathrm{O}$ dado permite duas interpretações, a serem testadas no futuro. A primeira, tendo em mente algo semelhante ao padrão de ocupação dos grupos Tupi-Guarani apresentado no Capítulo 2, é a de que o sítio Jacarezinho teria sido um acampamento temporário, provavelmente ligado a atividades de pesca e à preparação do terreno para a segunda ocupação, na forma de uma grande aldeia sedentária, espalhada pela margem do lago e do igarapé que leva ao lago. A segunda interpretação seria a de que o sítio foi um local de habitação permanente nas duas ocupações, e que nos 200 anos de intervalo houve um significativo aumento populacional do grupo em questão. 


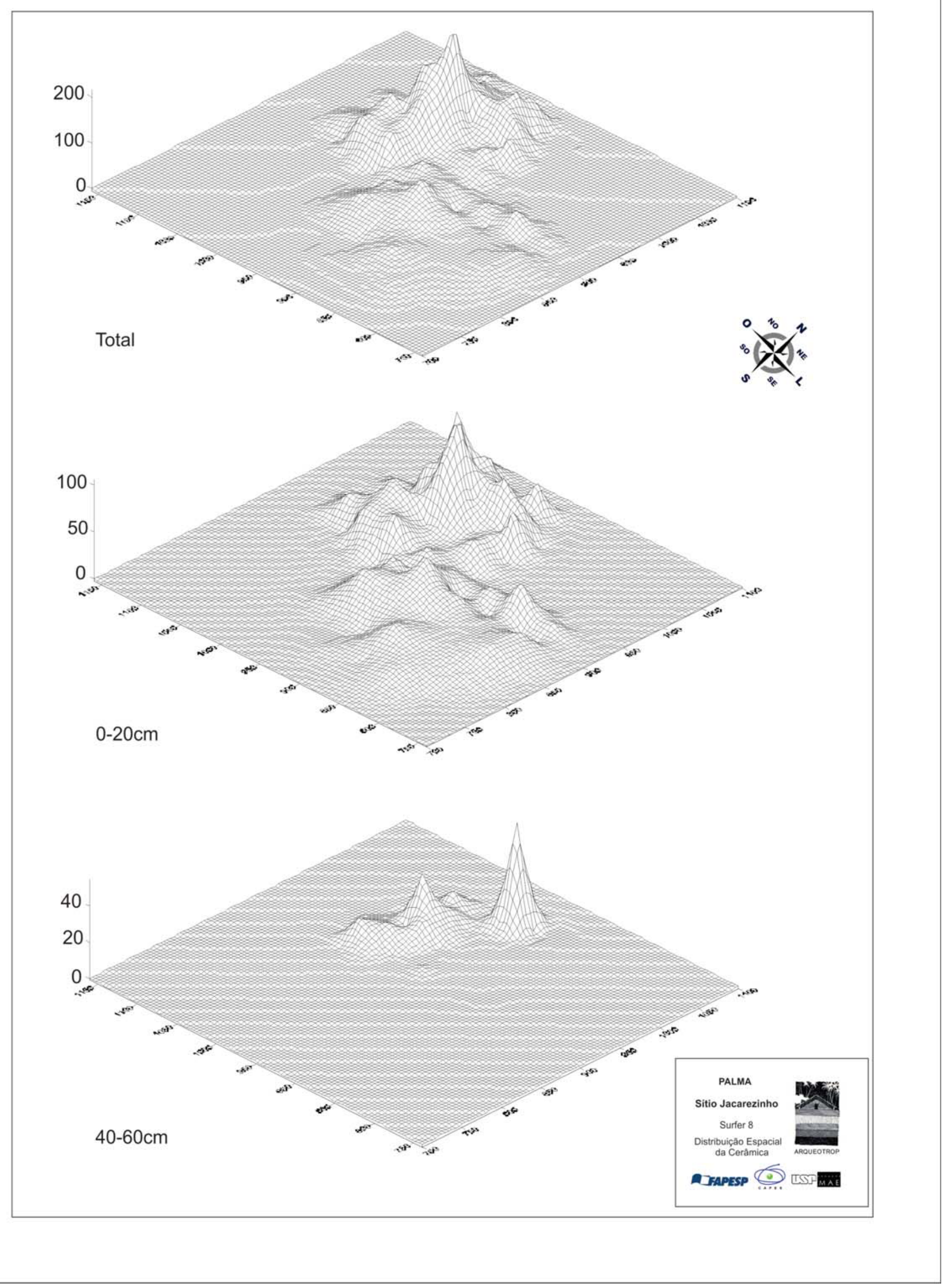


No final dessa etapa de campo, seguindo informações orais coletadas, foi verificada a existência de um sítio histórico denominado Aliança. Tratam-se das ruínas de uma casa, com uma data de 1911 inscrita nela, e um cemitério associado (Fig. 68 e 69). Essa casa se encontra em um terraço fluvial nas margens do rio Madeira, mas também próxima aos rios Candeias e Jamari (Fig. 70).

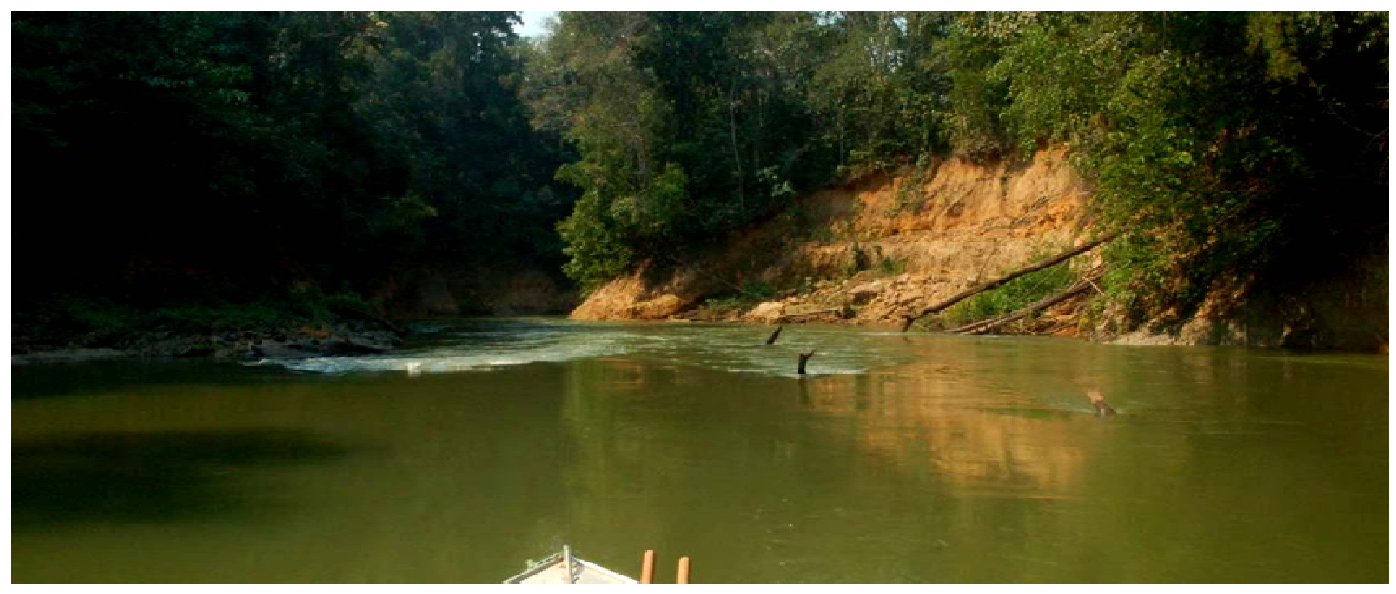

Figura 67: Vista de dentro da "vala dos Ingleses" (foto: Manuel Arroyo-Kalim, 2008).

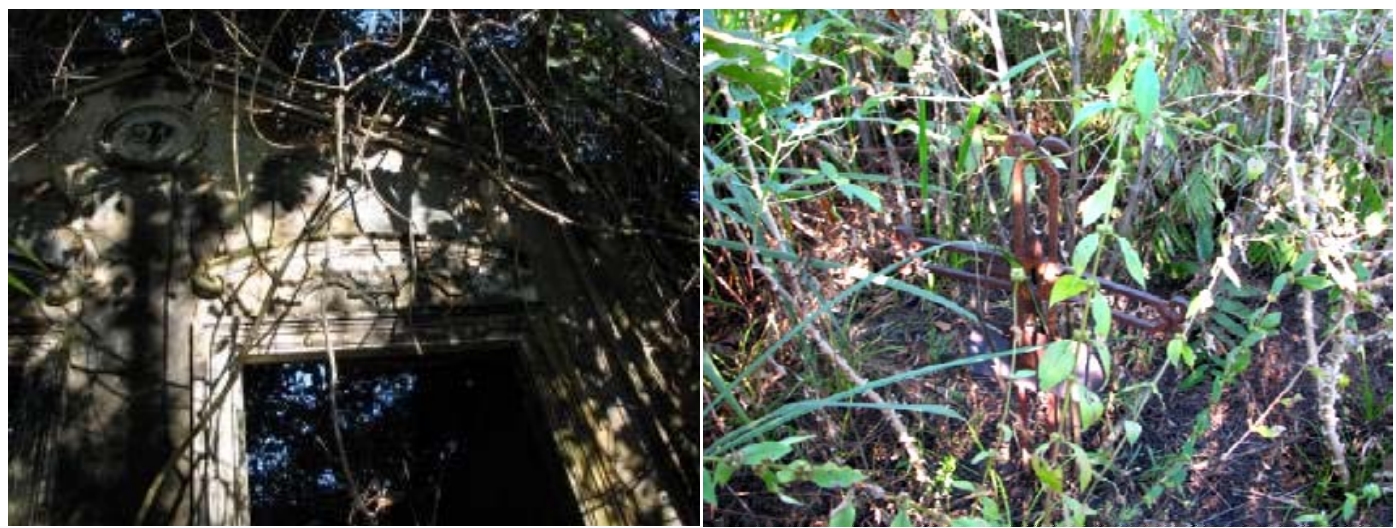

Figura 68: Fachada de casarão de antigo barão da borracha, sítio Aliança (foto: Fernando Ozorio de Almeida, 2009).

Figura 69: Cruz de ferro, a única restante em cemitério do sítio Aliança (foto: Fernando Ozorio de Almeida, 2009). 


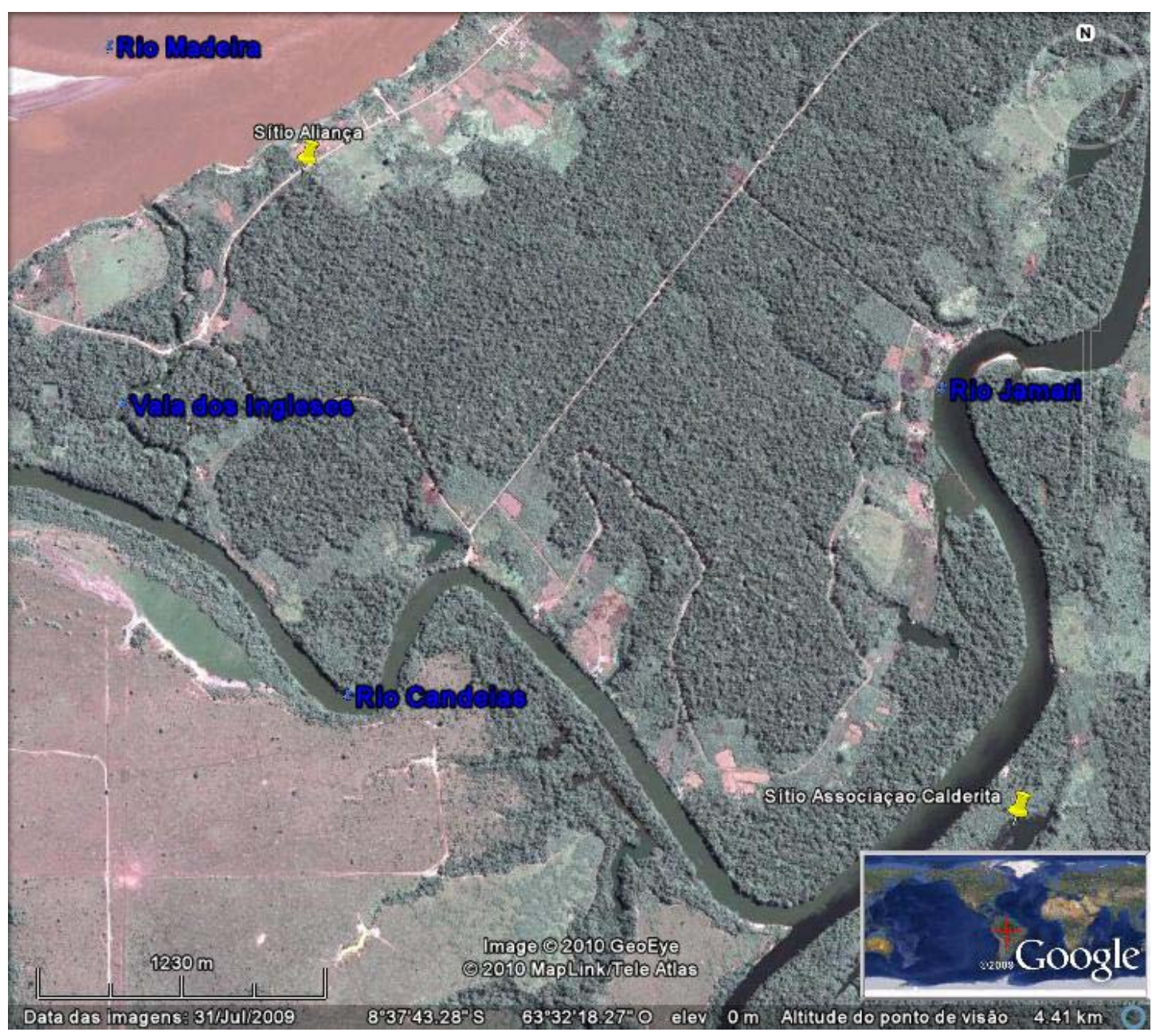

Figura 70: Localização do sítio Aliança (fonte: Google Earth).

Segundo informações obtidas com moradores locais, a casa pertencia ao "barão da borracha" (não identificado) responsável pela construção da "vala dos Ingleses ${ }^{85}$ ", canal artificial aberto para encurtar o escoamento da produção de borracha dos baixos Jamari e Candeias, na primeira metade do século XX (Fig. 67). A abertura da vala aproveitou um dos meandros do baixo rio Candeias que distava pouco mais de $1 \mathrm{~km}$ do rio Madeira (vide Fig. 70), encurtando em mais de $40 \mathrm{~km}$ o escoamento de borracha por esse rio.

O sítio Aliança, além das ruínas da casa do "barão" possuía a base (alicerce) de outras habitações no entorno. Aos fundos, em uma área coberta por mato (uma roça abandonada),

\footnotetext{
${ }^{85}$ Segundo Danilo Curado (IPHAN-RO), o seringal e a vala dos Ilgleses não tem haver com inglês nenhum, e sim com uma família tradicional de nordestisnos (relacionados a um senador da república) que se mudou para Humaitá (AM) no fim do século XIX. Dr. Martins, um dos filhos do senador, comprou o já existente Seringal Aliança, construiu o casarão e mandou abrir a vala (à base de dinamite e picareta).
} 
encontrava-se o antigo cemitério. Segundo meu guia, o cemitério possui apenas uma cruz, de ferro, já que uma série de cruzes de madeira foi destruída pela queima de roçados.

- Por que você acha que só havia essa cruz de ferro no meio de tantas cruzes de madeira? - perguntou meu guia, com fingida inocência.

- Deve ser a cruz do barão, retruquei.

- Isso mesmo, disse ele.

Eu havia passado no teste.

\subsection{Sítio Itapirema}

O sítio Itapirema foi encontrado em levantamento realizado em junho de 2009. Encontra-se do distrito de São Carlos, na margem esquerda do rio Madeira, do lado oposto à foz do rio Jamari. Trata-se de uma comunidade bem cuidada com aspecto tranquilo e simpático, pertencente ao município de Porto Velho (dista 70km por estrada), que serve aos porto-velhences como área de veraneio ou de fim de semana.

Durante o levantamento, pensou-se que se tratavam de dois pequenos sítios (Itapirema e Prosperidade), distantes quase $1 \mathrm{~km}$ entre si. A área onde os sítios foram identificados é uma barra de sedimento (silto-argiloso), uma restinga fluvial, com $200 \mathrm{~m}$ de largura média, delimitada pelo rio Madeira ao sul e pelo lago do Cuniã ao norte. A localização do sítio, no encontro dos rios Madeira e Jamari, a aparente espessa camada de terra preta (observada em um buraco de fossa recém aberto), a presença de cerâmica com pintura policrômica na superfície e a facilidade logística (podia-se dormir sobre o sítio) justificaram a sua escavação. A planície na qual está localizado o sítio está coberta por pasto e possui grande diversidade de palmeiras (e.g. bacuri, açaí). A maior parte do sítio fica fora da área urbana da comunidade, em uma fazenda de criação extensiva de gado.

Logo no início das escavações do sítio Itapirema, foi decidido que dois pesquisadores realizariam testes aleatórios, com enxada e boca de lobo, pelo caminho que ligava os dois sítios. Surpreendentemente, os pesquisadores revelaram que o material cerâmico foi encontrado de forma ininterrupta, desde o sítio Itapirema, por uma área que se estendia além do sítio Prosperidade. Isto é, tratava-se de um (imenso) sítio e não dois. Naquele momento, já havia sido realizado um quadriculamento em uma área com pequenas elevações topográficas, rica em fragmentos cerâmicos em superfície. A proposta era escavar uma série de unidades 
dentro desse quadriculamento. Descoberta a extensão do sítio, optou-se por mudar a metodologia: apenas duas unidades e uma coleta de superfície aproveitando o quadriculamento. $\mathrm{O}$ quadriculamento contou com 46 unidades para coleta de superfície, que renderam um total de 580 peças (Fig. 71).

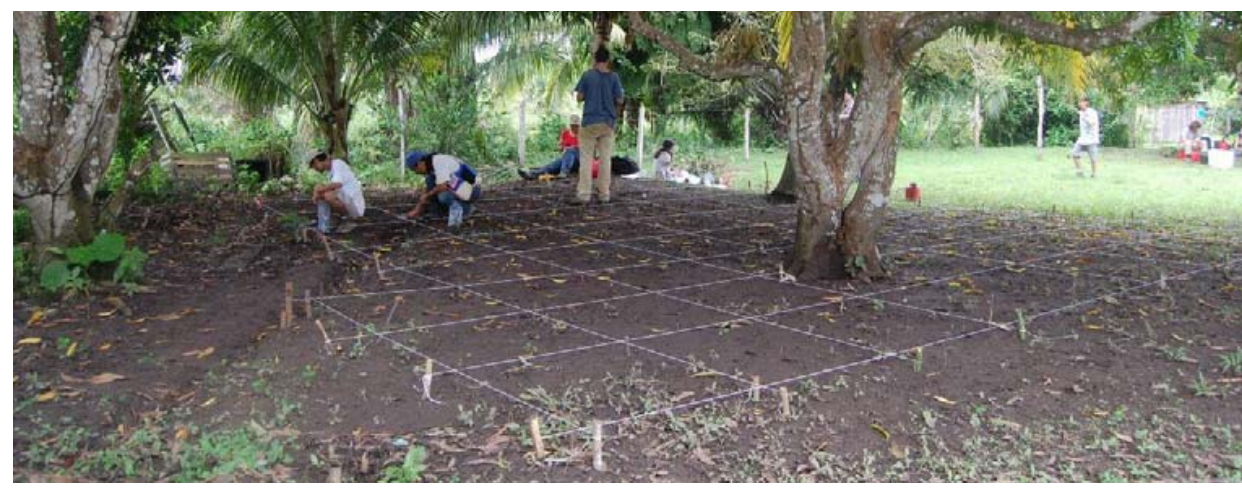

Figura 71: Coleta de superfície em área quadriculada, sítio Itapirema (foto: acervo PALMA).

Como o sítio já estava delimitado ao sul (pelo Madeira),ao norte (por área alagada) e ao leste (pelo cemitério da cidade, que não ousaríamos sondar), restava delimitar o sítio a oeste. Na impossibilidade de implantar uma malha sistemática por toda essa área (falta de tempo e pessoal para delimitar um sítio tão grande), optou-se por traçar apenas algumas linhas que indicariam a extensão do sítio e locais interessantes para abrir novas unidades. As linhas principais possuíram espaçamento de $20 \times 20 \mathrm{~m}$ ou $40 \times 40 \mathrm{~m}$. Como grande parte do terreno era alagável, o espaçamento menor entre as sondagens foi empregado quando áreas mais altas fossem constatadas.

Foram escavadas um total de 71 sondagens nesse sistema, das quais 19 foram estéreis, rendendo cerca de 1.200 fragmentos cerâmicos. As sondagens estéreis ocorreram entre sondagens positivas, o que sugere que a ocupação, mesmo sendo extensa, deve ter ocorrido de forma semelhante à da atual vila de São Carlos: com casas espaçadas, espalhadas de forma linear pela área menos suscetível a alagamentos (Fig. 72, Tabela 26).

As duas primeiras unidades escavadas, N1034 E999 e N1038 E996, apresentaram resultados bastante semelhantes. Ambas possuíam grande densidade de fragmentos cerâmicos, dispostos de forma horizontal, em um pacote arqueológico de terra preta (10YR $3 / 1$ very dark grey) de aproximadamente $50 \mathrm{~cm}$. Ambas foram interrompidas antes de $1 \mathrm{~m}$ de profundidade e antes de atingidas as camadas estéreis em cerâmica, devido à água que surgiu na base da escavação. A partir dessas duas unidades, foram obtidos cerca de 7.700 fragmentos cerâmicos (Figs 73 e 74; Anexo 11). 


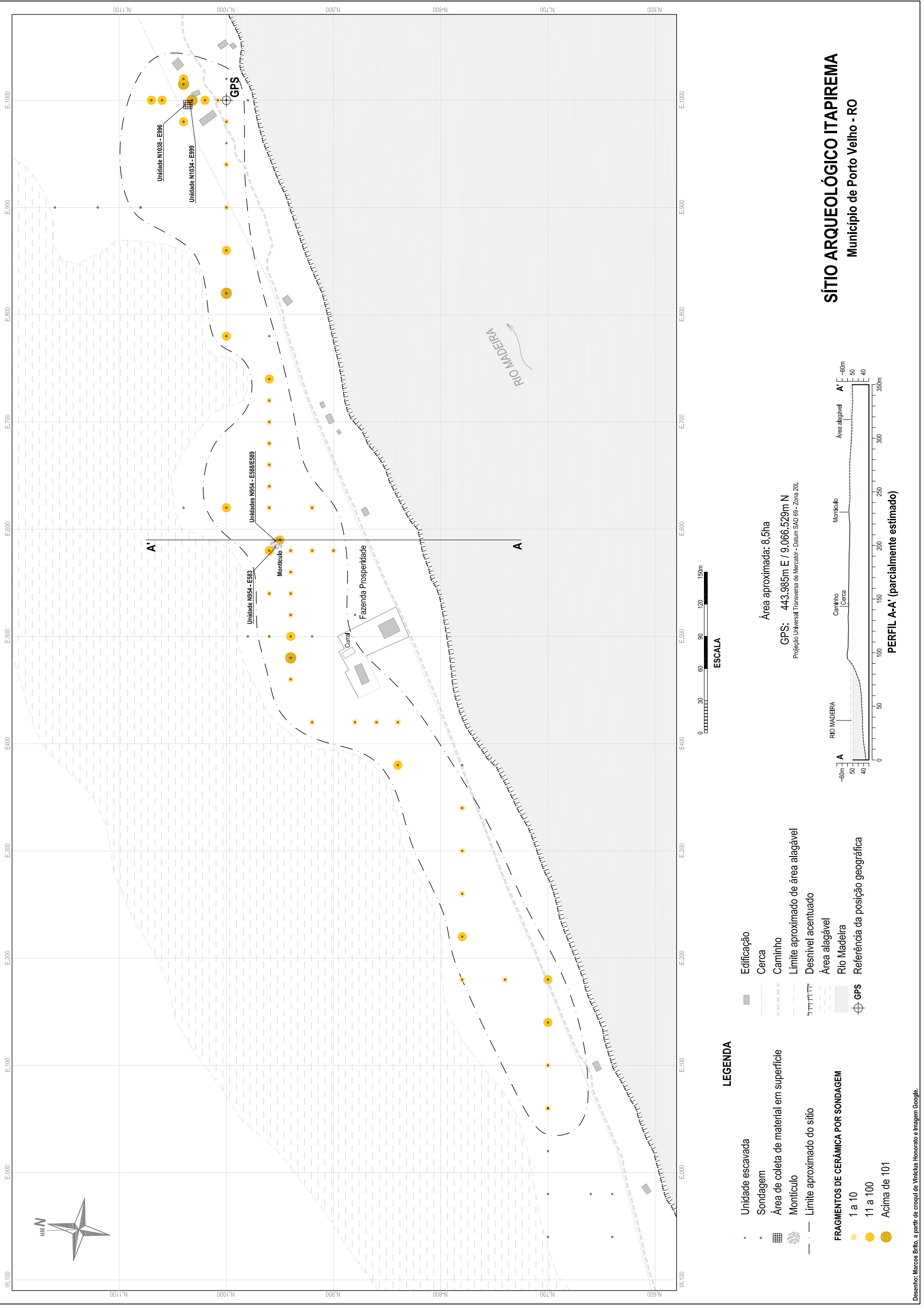



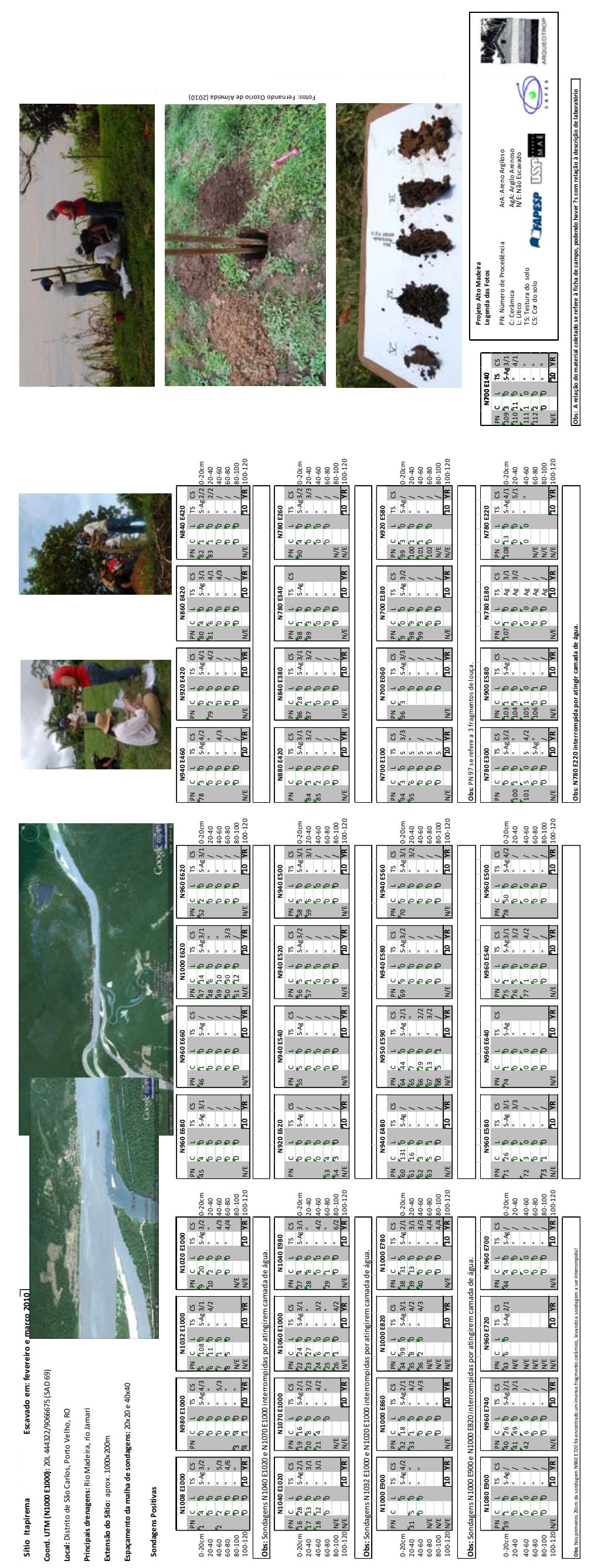

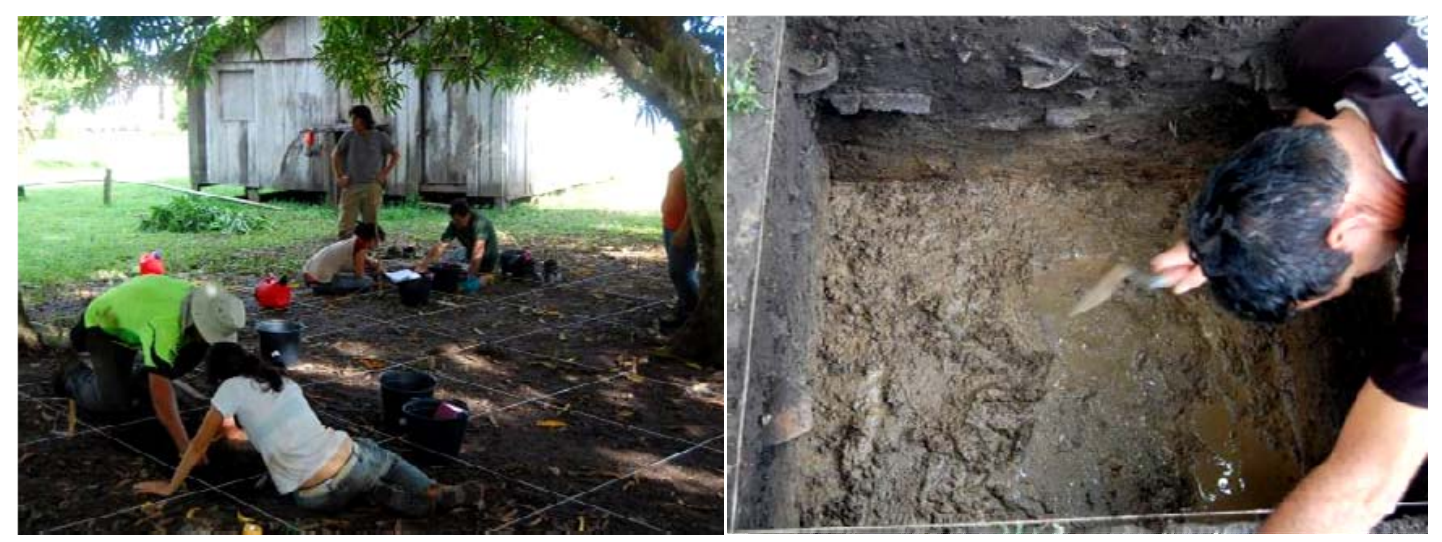

Figura 73: Escavação de duas unidades 1 x $1 \mathrm{~m}$ (N1034 E999, N1038 E996), sítio Itapirema (foto: acervo PALMA).

Figura 74: Escavação de unidade 1 x 1m (N1034 E999), sítio Itapirema (foto: acervo PALMA).

Enquanto essas unidades eram escavadas, havia outra equipe piqueteando e sondando o restante do sítio. Após realizar sondagens positivas em locais distantes mais de $1.100 \mathrm{~m}$ a leste do ponto inicial (N1000 E1000), optou-se por empregar uma metodologia assistemática, em razão do equipamento utilizado para o piqueteamento: um nível de bolha. Como o nível já havia sido relocado dezenas de vezes, temeu-se que a soma dos pequenos erros gerados em cada relocagem pudesse modificar o alinhamento do grid e, por consequência, descaracterizar as intervenções. Foram realizadas, então, mais 11 sondagens assistemáticas (plotadas no GPS), que seguiam apenas critérios topográficos (áreas altas, não alagáveis). Das 11 sondagens, duas tiveram resultado positivo quanto à presença de cerâmica. Ou seja, o sítio Itapirema não está inteiramente delimitado.

Uma elevação topográfica foi constatada durante o piqueteamento das sondagens, nas proximidades do ponto N960 E580 (Fig. 75). Essa elevação possuía cerca de 60cm de altura e dimensões irregulares (+-20m de largura e $+-30 \mathrm{~m}$ de comprimento). Foi marcado um ponto no centro da elevação (N950 E590), cuja sondagem apontou uma grande quantidade de cerâmica (>100 frag.). Decidiu-se, então, que essa seria a área para novas intervenções. 


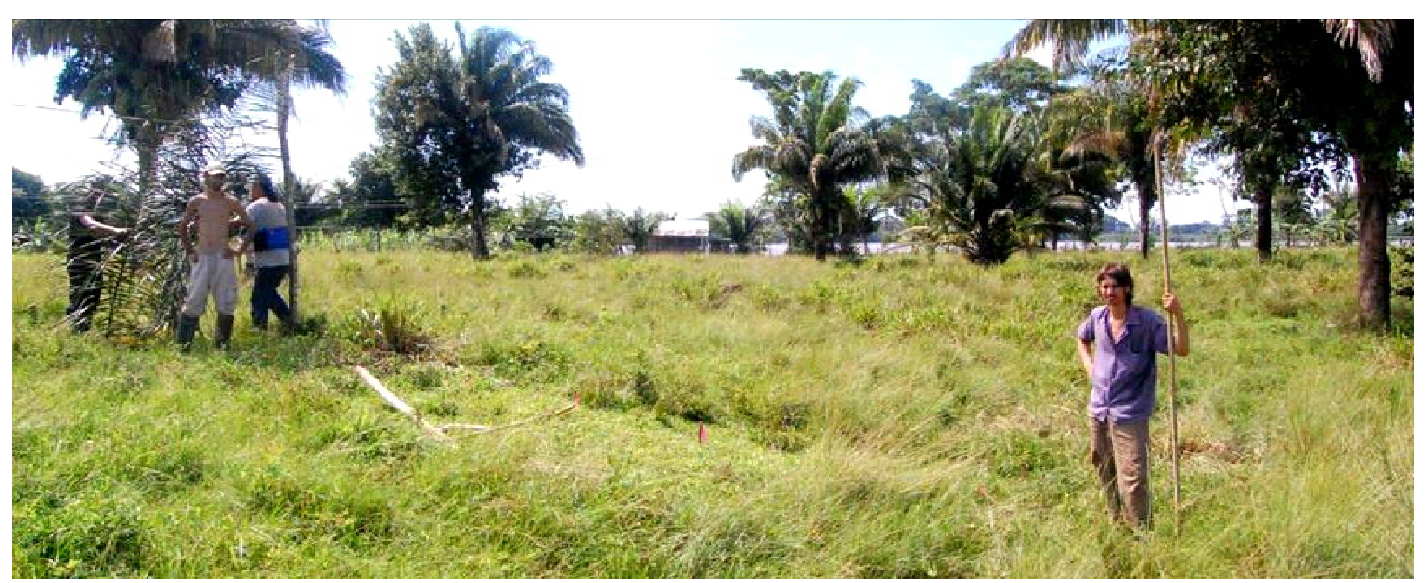

Figura 75: Arqueólogos demonstram a diferença de nível topográfico em montículo artificial (foto: Fernando Ozorio de Almeida, 2010).

A partir das discussões de campo, decidiu-se que um corte leste-oeste na parte mais abrupta do montículo seria a estratégia para observar o seu comportamento da base ao topo (Fig. 76). No entanto, não havia tempo suficiente para abrir uma trincheira inteira (o responsável pela fazenda pressionava para que saíssemos o mais rápido possível). Optou-se por piquetear uma trincheira com dimensões de 10 x 0,5m, mas só escavar as duas unidades mais altas (N954 E589 e N954 E588) e uma unidade na região mais baixa (N954 E583). A escolha de utilizar unidades com $0,5 \mathrm{~m}$ de largura $(0,5 \mathrm{x} 1 \mathrm{~m})$, em vez de $1 \mathrm{x} 1 \mathrm{~m}$ teve como objetivo diminuir o tamanho da amostragem, que já atingira uma quantidade significativa de fragmentos com a escavação das unidades anteriormente descritas. Apenas arqueólogos de porte físico pequeno puderam entrar nessas unidades de dimensões reduzidas.

As escavações dessas unidades confirmaram que se tratava de um montículo artificial, construído em essência por sedimento e cerâmica (Fig. 78). Utilizando um mesmo datum para nivelar as unidades (i.e. a unidade N954 E583 começou no nível 40-50cm), foi possível observar que as unidades tiveram uma base comum, $90 \mathrm{~cm}$ do datum, de pacote de terra preta. Tanto nas unidades mais altas quanto na mais baixa foram observados fragmentos em posições verticais e transversais. Além disso, ao contrário das unidades N1034 E999 e N1038 E996, que renderam ao menos uma dezena de conjuntos cerâmicos remontáveis, as unidades N954 E589, N954 E588 e N954 E583 apresentaram poucos conjuntos. O que leva a crer que a cerâmica havia sido revirada, e os fragmentos, desarticulados, para construir o montículo.

A escavação dessas unidades rendeu aproximadamente 5.000 fragmentos cerâmicos. A unidade mais rasa (N954 E583), localizada no pé do montículo, foi a que produziu maior quantidade de fragmentos, indicando que uma quantidade maior de sedimento deve ter sido 
utilizada na parte superior do montículo (Figs. 77 e 80). Finalizadas essas unidades, foram encerradas as atividades no sítio Itapirema.

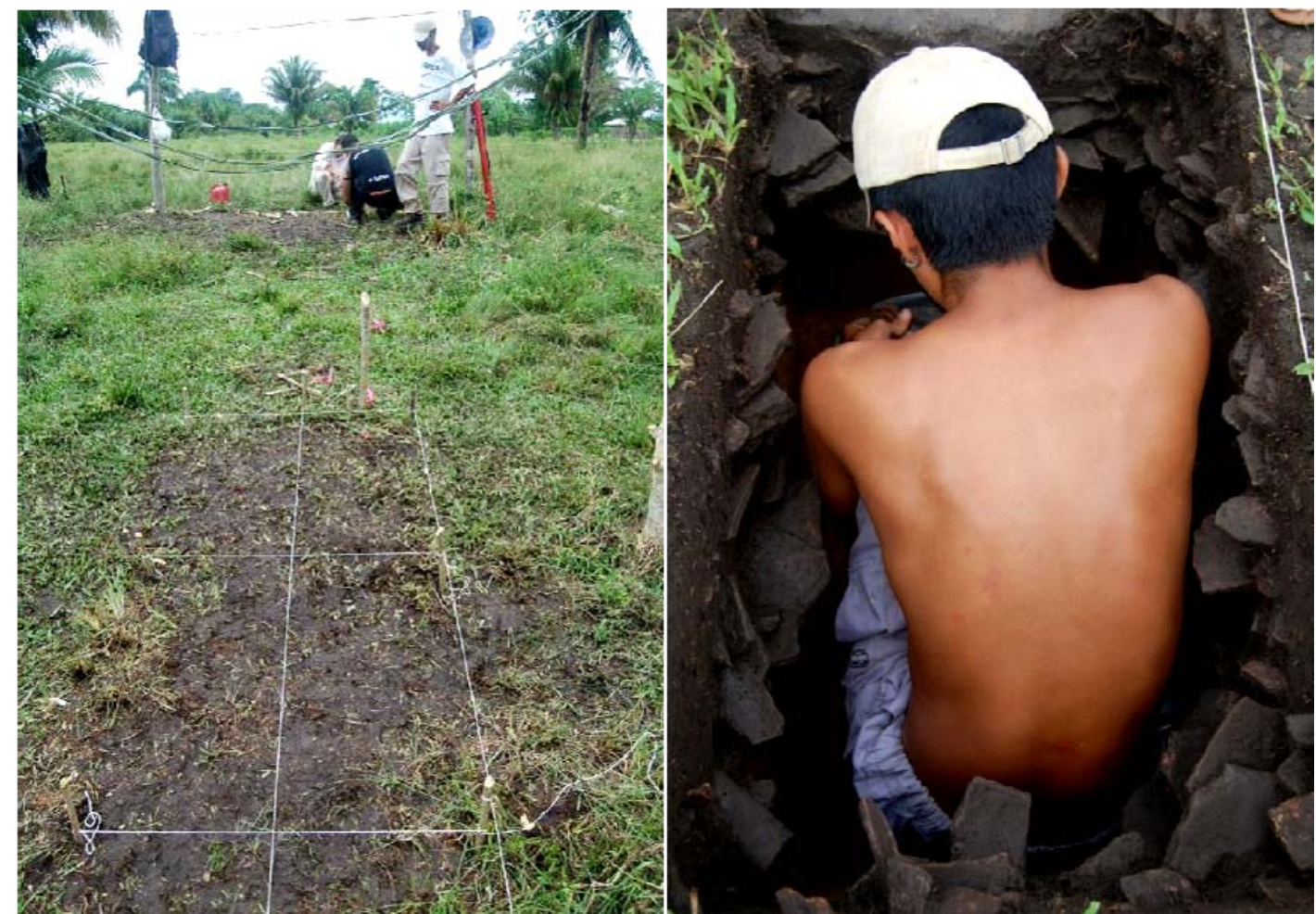

Figura 76: Marcação de duas unidades 1 x 0,5m, em montículo do sítio Itapirema (fotos: Fernando Ozorio de Almeida, 2010).

Figura 77: Escavação de unidade 1 x 0,5m (N954 E583), em montículo do sítio Itapirema (fotos: Fernando Ozorio de Almeida, 2010).
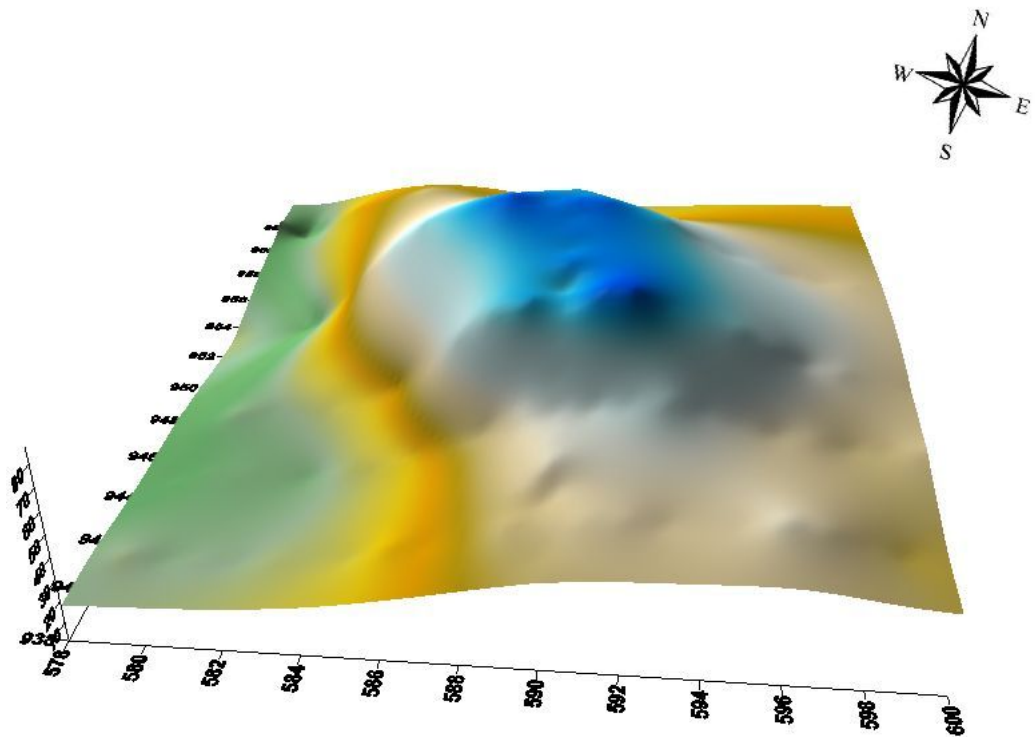

Figura 78: Reconstituição (Surfer) do montículo no qual foram abertas unidades, no sítio Itapirema. 

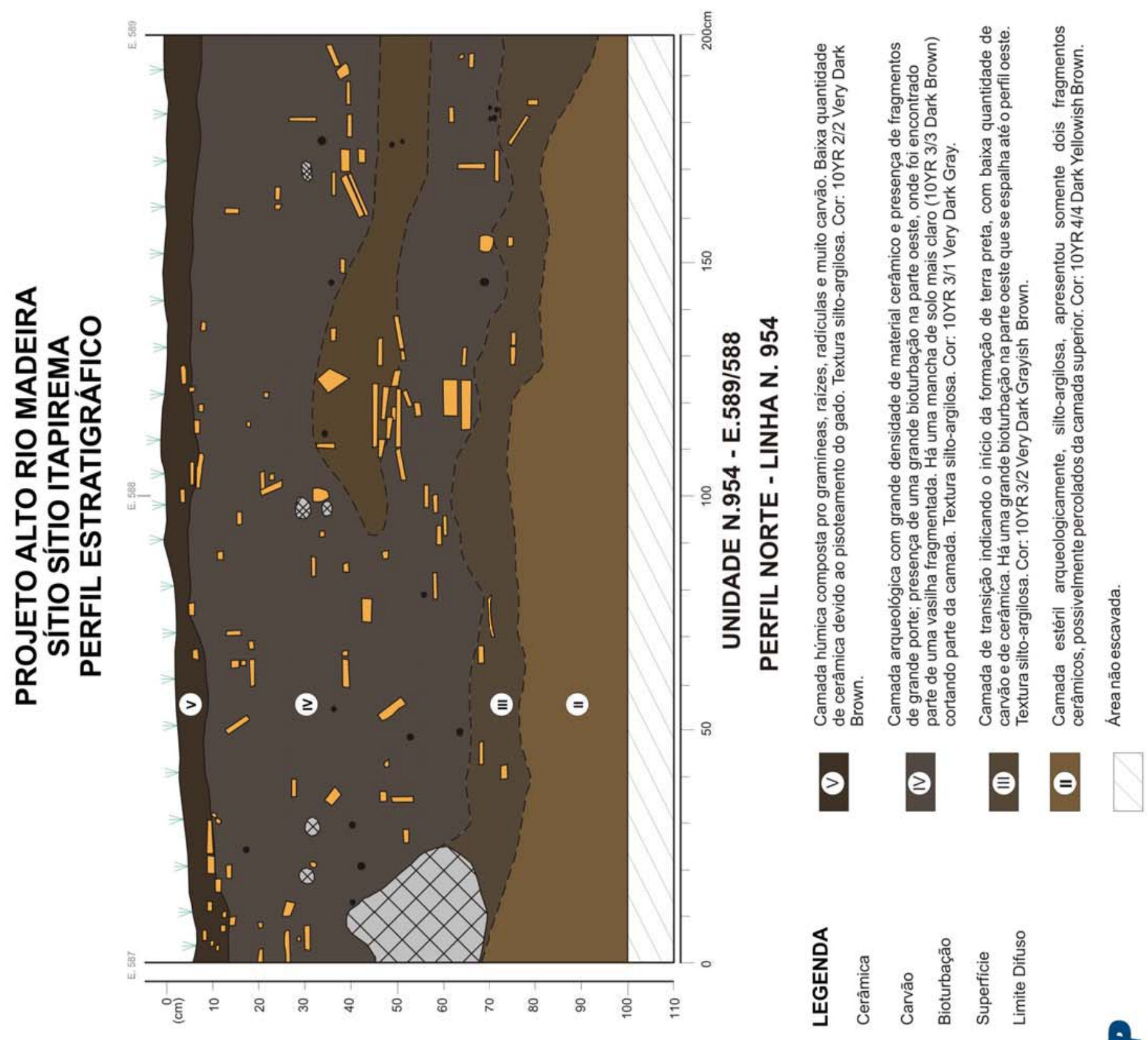

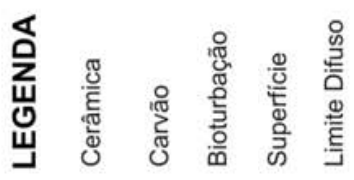

- 8

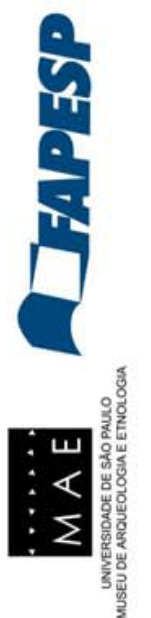




\section{PROJETO ALTO RIO MADEIRA SÍTIO SÍTIO ITAPIREMA PERFIL ESTRATIGRÁFICO}

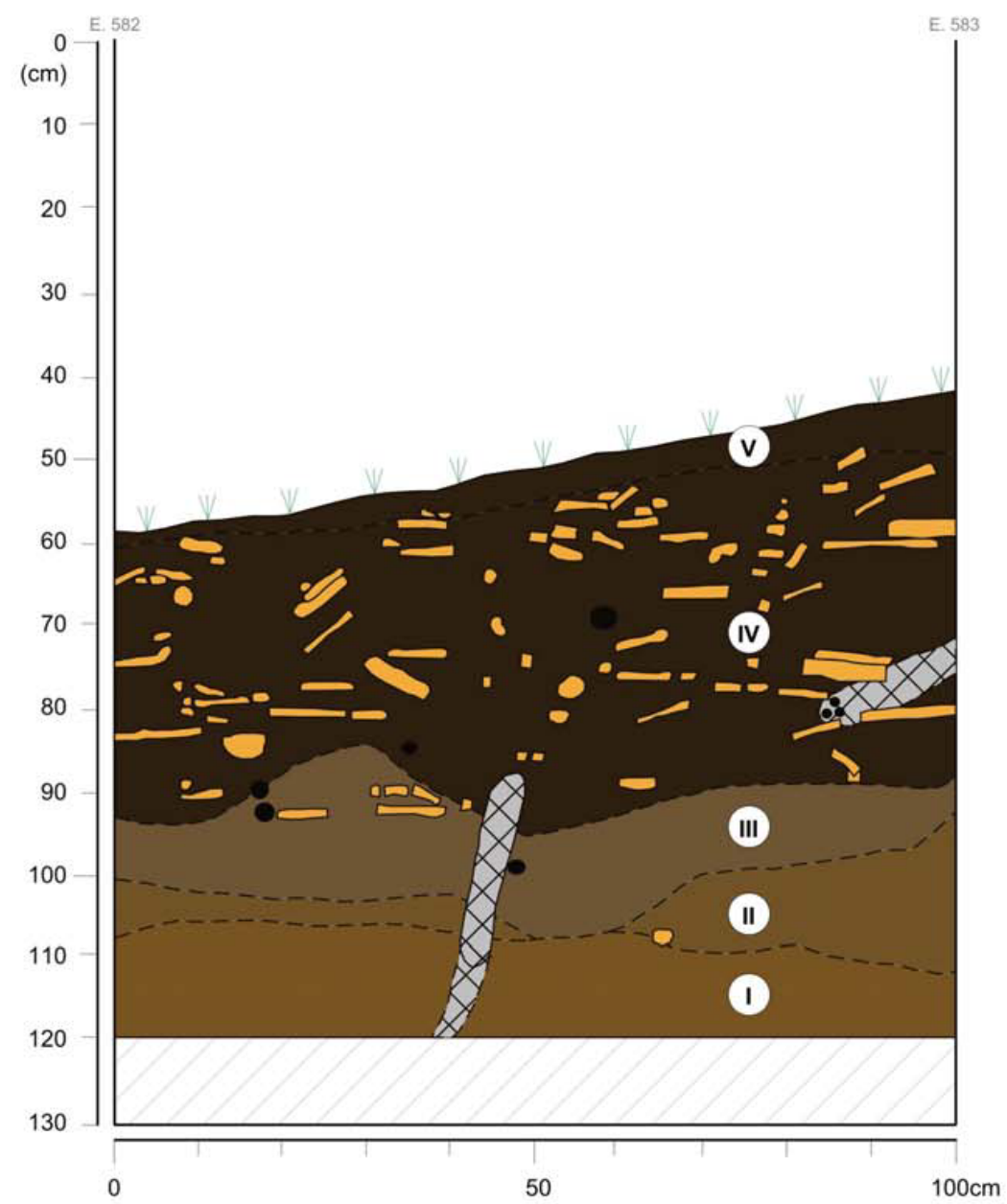

UNIDADE N.954 - E.583

PERFIL NORTE - LINHA N. 954

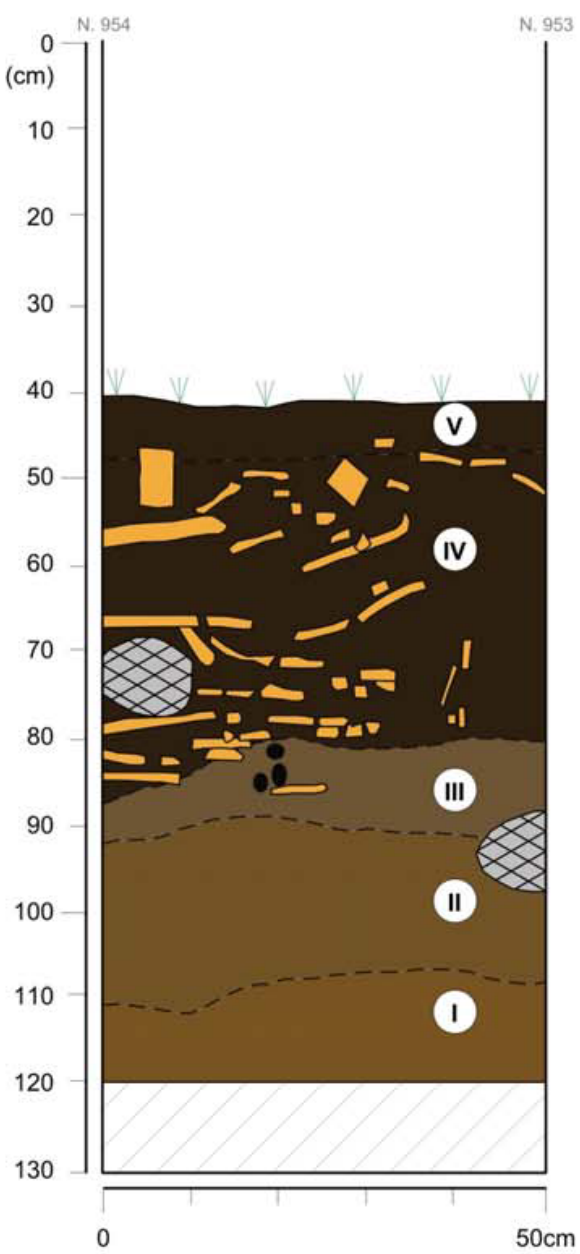

UNIDADE N.954 - E.583 PERFIL LESTE - LINHA E. 583

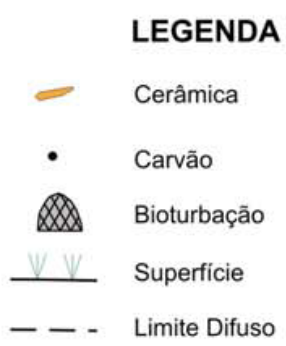

Camada húmica composta pro gramineas, raizes, radiculas e muito carvão. Baixa quantidade de cerâmica devido ao pisoteamento do gado. Textura argilo-siltosa. Cor: 10YR 2/2 Very Dark Brown.

Camada arqueológica com grande densidade de material cerâmico, presença de raizes e carvōes oriundo de bioturbaçōes. Textura argilo-siltosa. Cor: 10YR 2/2 Very Dark Brown.

Camada de transição indicando o inicio da formação de terra preta, com presença de carvão e baixa quantidade de cerâmica. Textura silto-argilosa. Cor: 10YR 4/3 Brown.

Camada estéril arqueologicamente, siltosa, possivelmente associada a uma deposição fluvial, presença de vestigios orgânicos oriundos dessa deposição. Cor: 10YR 4/4 Dark Yellowish Brown.

Latossolo estéril arqueologicamente, baixa quantidade de carvões e presença de bioturbações. Textura silto-argilosa. Cor: 10 YR 4/6 Dark Yellowish Brown.

Área não escavada. 
Até o momento, o sítio Itapirema possui três datações, todas em torno de 1300 d.C. (Tabela 27). A proximidade das datas, coletadas em dois locais distintos, indica que ao menos uma parte do extenso sítio é contemporânea (a parte escavada) e não fruto de sucessivas ocupações. Além disso, as duas datações contemporâneas no mesmo montículo, mas espaçadas em $30 \mathrm{~cm}$, permitem inferir que o montículo deve ter sido construído de uma vez só. Uma futura datação semelhante no topo (praticamente) confirmaria essa inferência.

As datações também contribuem para compreender a dinâmica do rio Madeira. Tudo indica que a barra de sedimento onde o sítio se encontra é relativamente recente, com datação não muito mais antiga do que a ocupação humana, talvez deslocada da margem setentrional do lago do Cuniã (o antigo meandro) para o novo local de passagem do rio. As datações recentes aproximam os dados arqueológicos dos etno-históricos.

\begin{tabular}{|c|c|c|c|c|c|c|c|}
\hline$\overline{\text { Sítio }}$ & Nivel & Amostra & № Beta & $\begin{array}{c}\text { Forma } \\
\text { de } \\
\text { Datação }\end{array}$ & $\begin{array}{l}\text { Material } \\
\text { Datado }\end{array}$ & $\begin{array}{c}\text { Idade } \\
\text { Convencio } \\
\text { nal }\end{array}$ & Calibragem 2 sigma \\
\hline Itapirema & $\begin{array}{l}70-80 \\
\mathrm{~cm}\end{array}$ & ITA-517-01 & $\underline{280924}$ & $\begin{array}{l}\text { Radiomé } \\
\text { trica }\end{array}$ & $\begin{array}{l}\text { Material } \\
\text { orgânico } \\
\text { na } \\
\text { cerâmica }\end{array}$ & $\begin{array}{l}620+/- \\
60 \mathrm{BP}\end{array}$ & $\begin{array}{l}\text { Cal AD } 1270 \text { to } 1430 \\
\text { (Cal BP } 680 \text { to } 520) \\
\end{array}$ \\
\hline Itapirema & $\begin{array}{l}40-50 \\
\mathrm{~cm}\end{array}$ & ITA-510-01 & $\underline{280923}$ & $\begin{array}{l}\text { Radiomé } \\
\text { trica }\end{array}$ & $\begin{array}{l}\text { Material } \\
\text { orgânico } \\
\text { na } \\
\text { cerâmica }\end{array}$ & $\begin{array}{l}590+/- \\
40 \mathrm{BP}\end{array}$ & $\frac{\text { Cal AD } 1290 \text { to } 1420}{\text { (Cal BP } 660 \text { to } 530)}$ \\
\hline Itapirema & $45 \mathrm{~cm}$ & ITA-306-01 & $\underline{280922}$ & AMS & $\begin{array}{l}\text { Material } \\
\text { orgânico } \\
\text { na } \\
\text { cerâmica }\end{array}$ & $\begin{array}{l}540+/- \\
40 \mathrm{BP}\end{array}$ & $\begin{array}{l}\text { Cal AD } 1310 \text { to } 1360 \\
\text { (Cal BP } 640 \text { to } \\
590) \text {,Cal AD } 1390 \text { to } \\
1440 \text { (Cal BP } 560 \text { to } \\
\text { 510) }\end{array}$ \\
\hline
\end{tabular}

Tabela 27: Datações do sítio Itapirema.

\subsection{O sítio Teotônio}

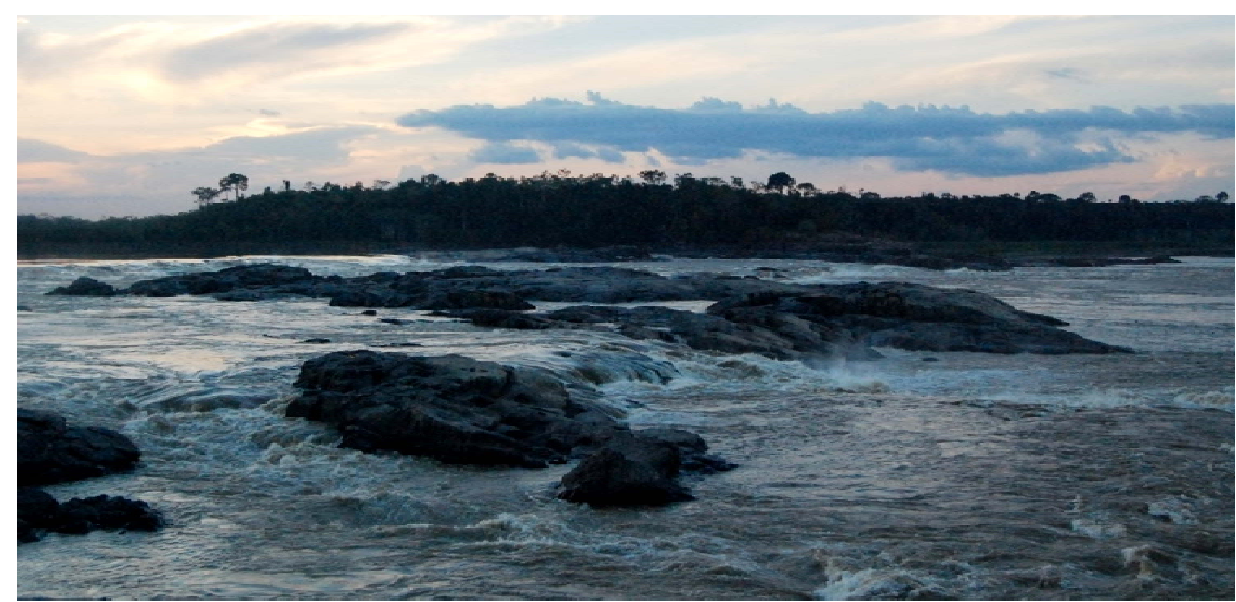

Figura 81: Cachoeira do Teotônio (RO), dias antes de desaparecer devido à construção da UHE Santo Antônio (foto: Fernando Ozorio de Almeida, 2010). 


\subsubsection{Introdução}

Após cinco etapas de campo e a escavação de quatro sítios arqueológicos realizei o memorial de qualificação de doutorado. A discussão da pesquisa com a banca examinadora possibilitou um balanço dos objetivos iniciais e do potencial que os dados obtidos possuíam para sustentar inferências palpáveis frente aos problemas propostos. Naquele momento, foi possível chegar às seguintes conclusões: (I) a abertura de uma segunda frente de atividades no alto-médio rio Ji-Paraná (ALMEIDA, 2010b) exigiria custo financeiro e tempo (para escavações, atividades de laboratório e processamento de dados) superiores ao prazo de entrega da tese; (II) a baixa quantidade de sítios analisados (supostamente) ligados à Tradição Jamari (cf. Capítulo 5) não era suficiente para um refinamento classificatório dessa Tradição, e (III) a cronologia recente dos sítios relacionados à Subtradição Jatuarana (Capítulos 5 e 6) escavados no baixo Jamari (sítio Associação Calderita) e no encontro desse rio com o Madeira (sítio Itapirema) não trazia subsídios para confirmar a hipótese de que o alto Madeira possuía a cerâmica mais antiga relacionada à Tradição Polícroma Amazônica.

Após a escavação do sítio Itapirema, e depois de recebidas as datações que apontavam que o sítio teria sido habitado entre os séculos XIV e XV da era cristã, foi sugerido (ALMEIDA, 2010c, seguindo LATHRAP, 1968) que a escavação de sítios em meandros abandonados (lagos de meandro) do rio Madeira aumentaria a possibilidade de identificar antigas ocupações na região. Os sítios levantados por Miller no lago do Cuniã ${ }^{86}$, situado ao fundo (norte) do distrito de São Carlos (e do sítio Itapirema) pareciam ideais para encontrar essas ocupações antigas da Subtradição Jatuarana (Fig. 82). Os sítios, além do mais, permitiriam um diálogo interessante com os dados provenientes do sítio Itapirema.

No entanto, o lago do Cuniã apresenta dificuldades logísticas. O acesso é complexo, e a área, escassamente habitada. Em um primeiro momento, uma equipe média ou grande de arqueólogos seria inviável. Os trabalhos teriam de ser divididos em duas etapas. Uma de prospecção (visita aos sítios e escolha dos mais pertinentes para intervenção) e preparação de uma logística junto aos moradores locais, e uma segunda etapa na qual seriam realizadas as atividades de escavação nos sítios. Isto em um momento que a presente pesquisa de

\footnotetext{
${ }^{86}$ A Superintendência regional do IPHAN-RO gentilmente forneceu uma lista com a descrição de todos os sítios arqueológicos levantados no município de Porto Velho, na qual estão os sítios do lago do Cuniã (vinculados por Miller à sub-Tradição Jatuarana).
} 
doutorado chegava ao último terço de sua duração, quando não se podia mais contar com recursos provenientes do Projeto Temático coordenado por Eduardo Góes Neves. Foi então que surgiu uma opção a essa proposta: o sítio Teotônio.

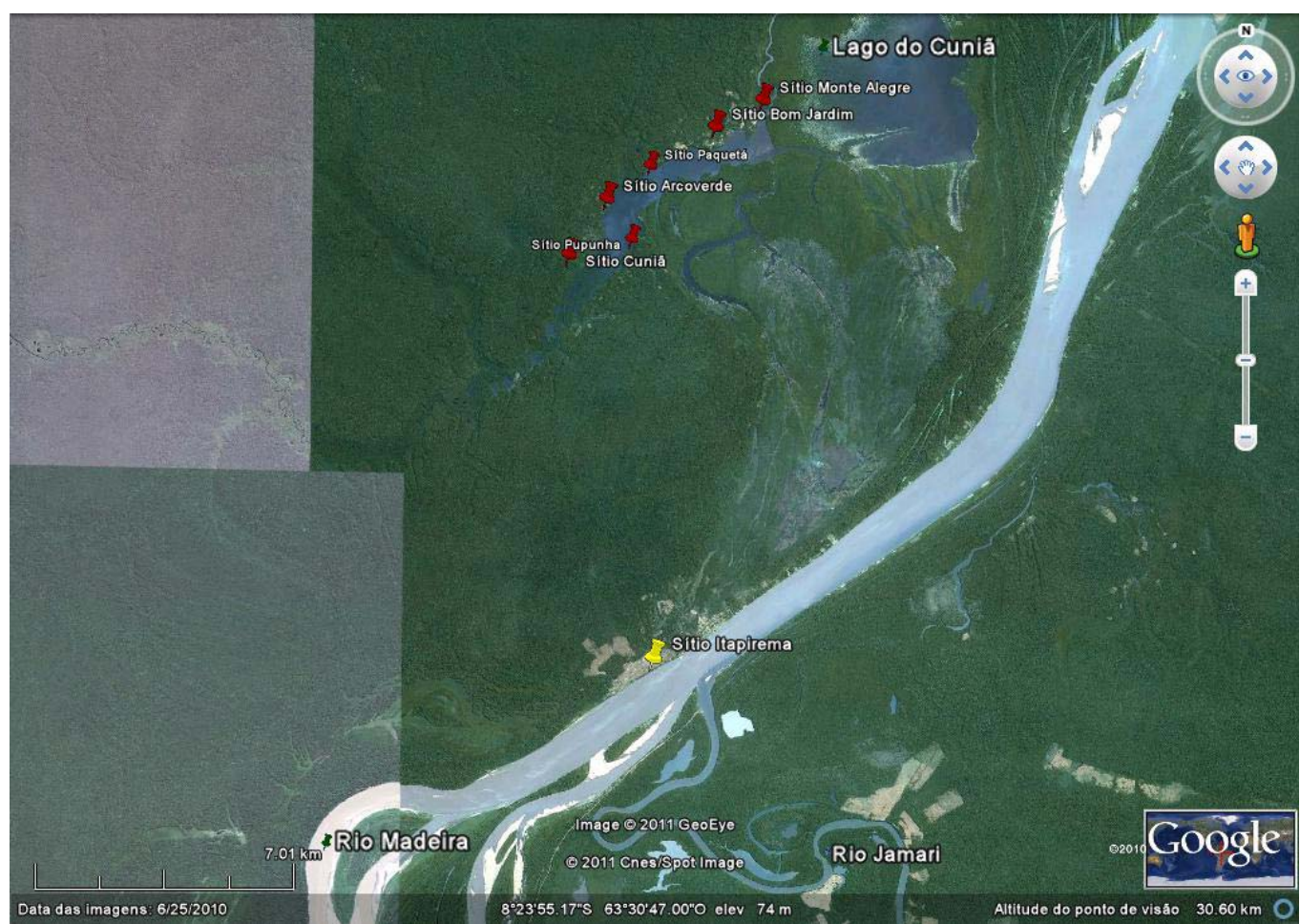

Figura 82: Localização do sítio Itapirema e dos sítios levantados por Miller no lago do Cuniã (fonte: Google Earth).

Esse sítio, como apontado, possuia a datação mais antiga relacionada à Subtradição Jatuarana (700 a.C.), data muito antiga se comparada às obtidas para os sítios escavados pelo PALMA no baixo Jamari e no sítio Itapirema ${ }^{87}$. Da mesma forma, os trabalhos de arqueologia de contrato realizados em outros sítios do alto Madeira em razão da instalação da UHE Santo Antônio tampouco obtiveram datas tão antigas para grupos ceramistas (ZUSE, 2010).

Outro dado proveniente das pesquisas na área de impacto dessa hidrelétrica foi a presença de outra cerâmica, abaixo da ocupação da Tradição Polícroma (Jatuarana), em um ou dois sítios (ZUSE, com. pessoal). Ou seja, era momento de considerar a possibilidade de o sítio Teotônio também possuir uma ocupação cerâmica pré-Jatuarana, não identificada por Miller, que datou essa cerâmica antiga pensando ser parte da ocupação Jatuarana.

\footnotetext{
${ }^{87}$ Pressupondo também que o sítio Nova Vida não está diretamente relacionado à Subtradição Jatuarana.
} 
A decisão de trabalhar no sítio Teotônio foi tomada quando descobrimos (Neves e eu) que esse sítio não seria intensivamente escavado em razão do licenciamento da UHE Santo Antônio, já que estava acima da cota de inundação da hidrelétrica. Foi feito então o convite para Carlos Augusto Zimpel Neto, professor de Arqueologia na Universidade Federal de Rondônia (UNIR), para a elaboração de uma parceria entre o Museu de Arqueologia e Etnologia (MAE-USP) e a UNIR para a escavação do sítio. Parceria que proporcionaria aos alunos do curso de Arqueologia realizar atividades de campo. Estabelecida a parceria (ainda informal), foi realizado o pedido para o arqueólogo Renato Kipnis, responsável pela portaria do Instituto do Patrimônio Histórico e Artístico Nacional (IPHAN) para a área onde se encontra o sítio, para a realização atividades no local. Kipnis cordialmente deu sua anuência.

O sítio Teotônio (RO-JP-01) está localizado na margem direita do rio Madeira na altura da cachoeira homônima ${ }^{88}$. Se a cachoeira da Santo Antônio era (não é mais, foi destruída pela implantação da UHE) o primeiro obstáculo para quem sobe o rio Madeira, a cachoeira do Teotônio era o primeiro obstáculo de fato intransponível, mesmo para o mais hábil navegador. Daí a importância geográfica do sítio. Na margem oposta da cachoeira encontra-se o sítio Santa Paula (E. SILVA, 2011), também relacionado à Subtradição Jatuarana (Tradição Polícroma), o que sugere um domínio total (no caso de contemporaneidade dos sítios) dos grupos dessa Tradição no local. Esse sítio possui datações que o situam em 400 d.C. (E. SILVA, 2011: 8-9), uma significativa diferença de 1.300 anos com relação à datação do sítio Teotônio (cf. Capítulo 6).

O sítio Teotônio se encontra em uma planície, localizada cerca de 30m acima do nível do rio Madeira (mês de julho) ${ }^{89}$, com leve declividade (sentido NW-SE). No momento da escavação (julho/agosto de 2011) o sítio estava dividido em terrenos pertencentes a três proprietários e possuía vegetação de mata secundária e capoeira (no terreno do Sr. Paulão, que abrange as porções Noroeste a Sul do sítio) e por capoeira média e alta (terreno do falecido Sr. Paulinho Doido, que abrange a porção Norte e Nordeste do sítio). No terreno do Sr. Márcio (porção leste e sudeste do sítio), quase não havia vegetação alguma, com a exceção de um pasto ralo.

Em uma área localizada a cerca de $1 \mathrm{~km}$ a sudeste do sítio, foi identificada a presença de uma mancha de sedimento escuro. Segundo Francisco Pugliese (com. pessoal), durante as

\footnotetext{
${ }^{88} \mathrm{O}$ sítio se encontra aproximadamente $100 \mathrm{~km}$ rio acima da foz do rio Jamari.

${ }^{89}$ Antes do alagamento causado pela implantação da UHE Santo Antônio.
} 
pesquisas relacionadas à implantação da UHE Santo Antônio, foi realizada uma série de intervenções em subsuperfície no local, sem que nenhum vestígio cerâmico ou lítico fosse encontrado e associado a esse sedimento escuro (Fig. 85). Baseado na bibliografia disponível sobre os solos antrópicos amazônicos (e.g. GRAHAM, 2006; KÄMPF e KERN, 2005; KERN, 1988, 1996; NEVES et al., 2003; PETERSEN et al., 2001), não seria absurdo dizer que se trata de uma área de terra mulata, uma antiga área de roça ligada a uma ou mais ocupações humanas ocorridas no sítio Teotônio (Fig. 83).

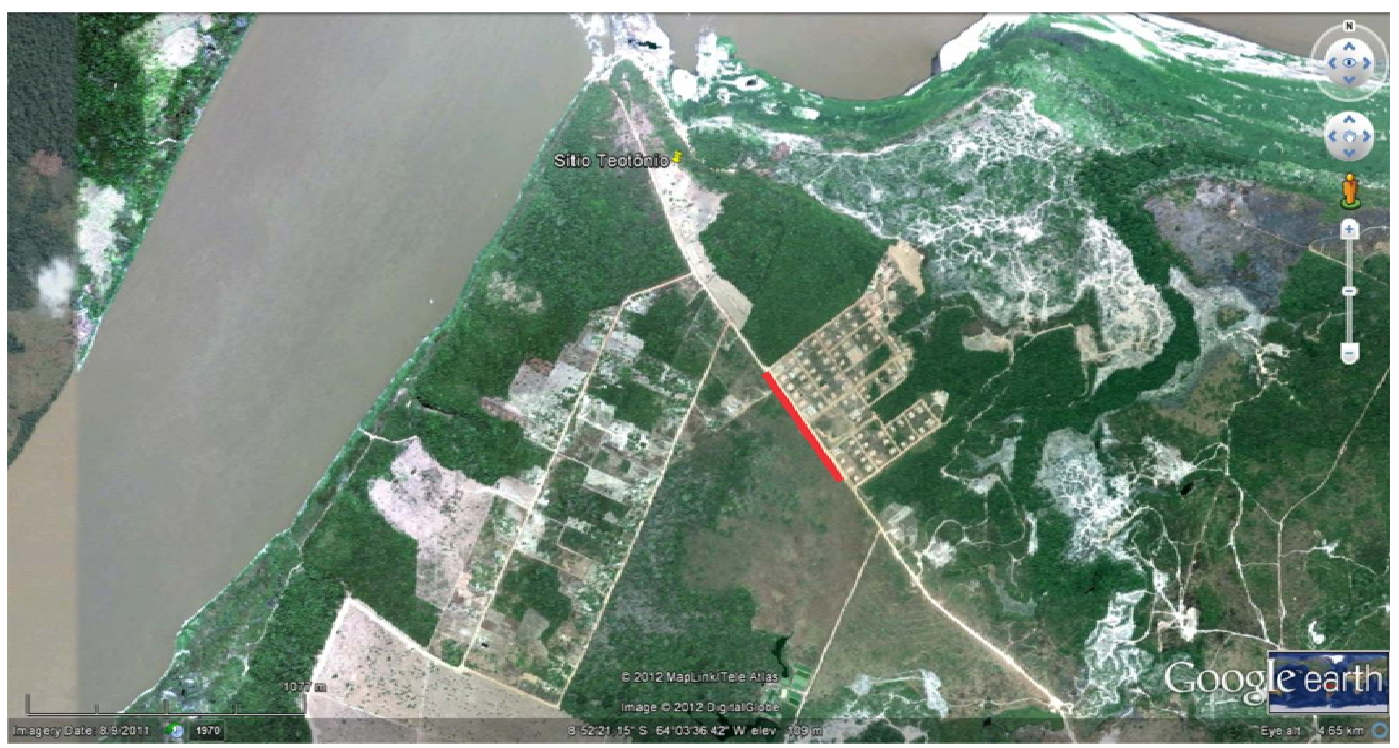

Figura 83: Barranco onde foi observada mancha de sedimento escuro, sem material cerâmico, no entorno imediato do sítio Teotônio (fonte: Google Earth).

\subsubsection{Atividades realizadas}

Os trabalhos de campo seguiram a mesma estratégia empregada nos outros sítios. No entanto, os problemas causados pelos impactos recentes (terraplanagens, abertura de estradas vicinais e acessos a fazendas e retirada ilegal de terra preta para venda; vide Fig. 84) levaram a uma questão que guiaria nossa metodologia: como compreender o processo de formação arqueológica de um sítio impactado? A resposta ficou a cargo da identificação de áreas pouco impactadas, para gerar uma cronologia confiável do sítio. Uma delimitação completa do sítio ficaria com um status secundário nas atividades, visto que poderia ser realizada em intervenções futuras. 


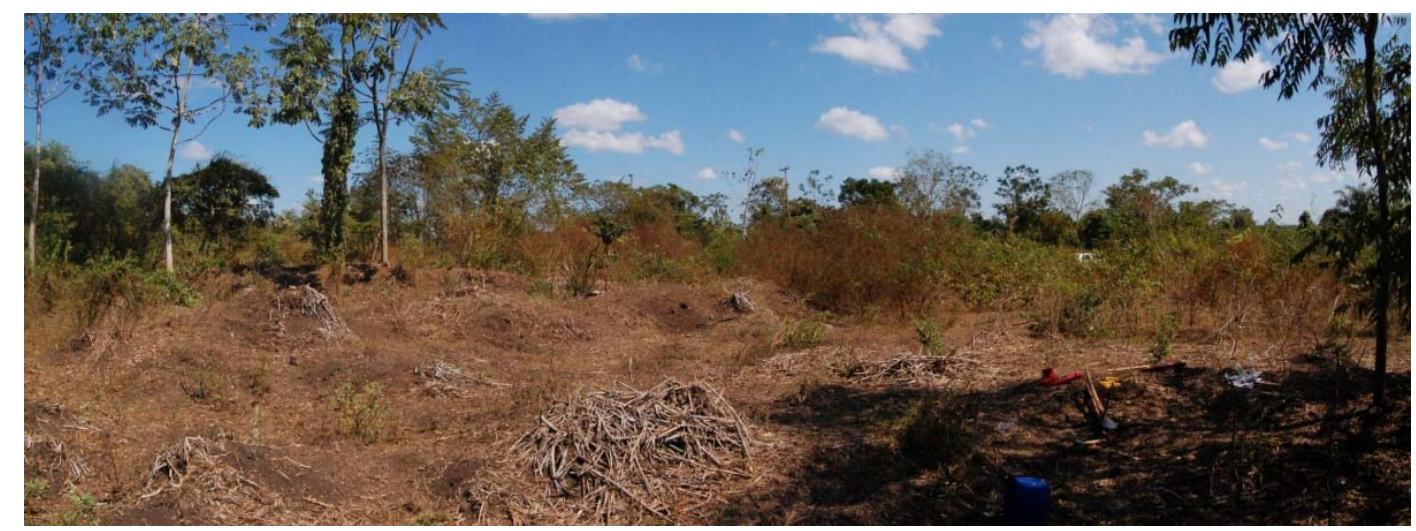

Figura 84: Sítio Teotônio, impactado pela abertura de estrada, terraplanagem e retirada de terra preta para venda (foto: Fernando Ozorio de Almeida, 2011).

Mais uma vez houve a preocupação de não gerar um grande acervo material. Uma das formas de obter as informações cronológicas desejadas sem gerar grande quantidade de material foi buscar locais para possíveis limpezas de perfil e observar a estratigrafia. Buscouse tirar proveito das áreas impactadas do sítio. Enquanto uma malha de sondagens de $20 \mathrm{x}$ $20 \mathrm{~m}$ era aberta, na busca de áreas pouco perturbadas para a abertura de unidades, foi realizada a limpeza de perfil em local na beira da estrada vicinal que corta o sítio (N10045 E9986).

Nesse perfil, foi possível identificar uma camada (V) marrom-acinzentada, de cerca de $20 \mathrm{~cm}$ de espessura, com material revirado (fragmentos cerâmicos em posições verticais e transversais e laterita). Abaixo dessa e de uma camada de transição (IV), pôde-se observar a camada de terra preta (III), com cerca de $40 \mathrm{~cm}$ de espessura e material aparentemente pouco revirado (fragmentos cerâmicos na horizontal, sem a presença de laterita). Por fim, havia outra camada de transição (II), cinza-escura, com cerca de $50 \mathrm{~cm}$ de espessura, e a camada estéril (I), caracterizada por grandes blocos de laterita (óxido de ferro) (Figs. 85 e 86). Durante a limpeza do perfil, foi percebida uma diferenciação entre o material cerâmico da camada III (com pintura policrômica e antiplástico de caraipé) e o da camada II (com antiplástico mineral, um tratamento de superfície mais rústico e decorações plásticas distintas). A camada II deveria possuir a cerâmica mais antiga (do que a Jatuarana), que se procurava. 


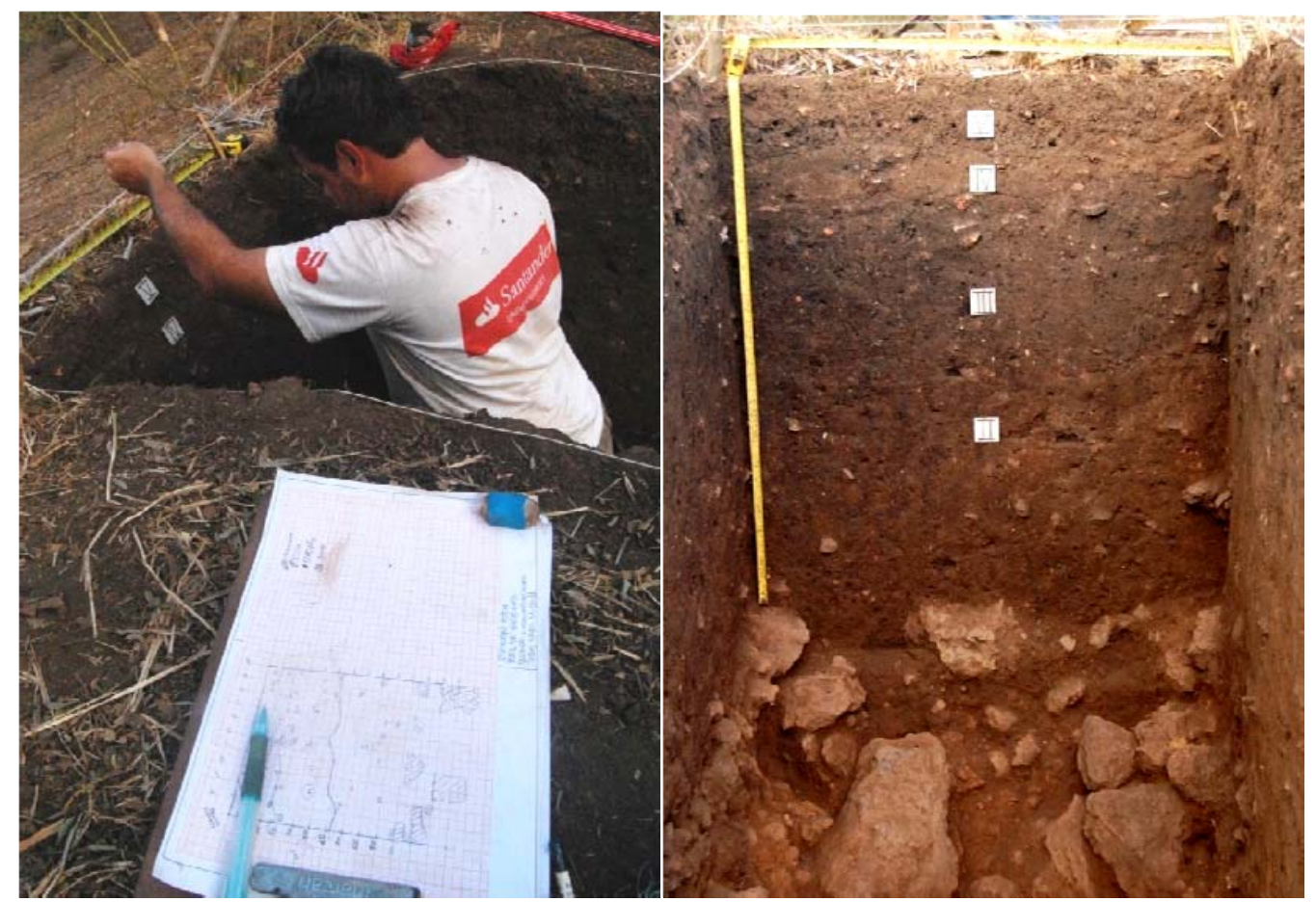

Figura 85: Marcação de camadas para desenho do perfil da unidade N10045 E9986.

Figura 86: Perfil leste N10045 E9986. (fotos: Fernando Ozorio de Almeida, 2011).

A metodologia de campo foi sendo modelada de acordo com as circunstâncias. Em princípio, apenas um dos três proprietários das fazendas onde o sítio se encontra permitiu as pesquisas. Nesse momento, optou-se por fazer uma malha mais intensiva, de $20 \times 20 \mathrm{~m}$. Com a subsequente e tardia liberação das demais áreas, decidiu-se por fazer apenas algumas linhas de sondagem e adiar a delimitação do sítio. Foi escavado um total de 57 sondagens, que renderam 3845 fragmentos cerâmicos (Fig. 87, Tabela 28). 


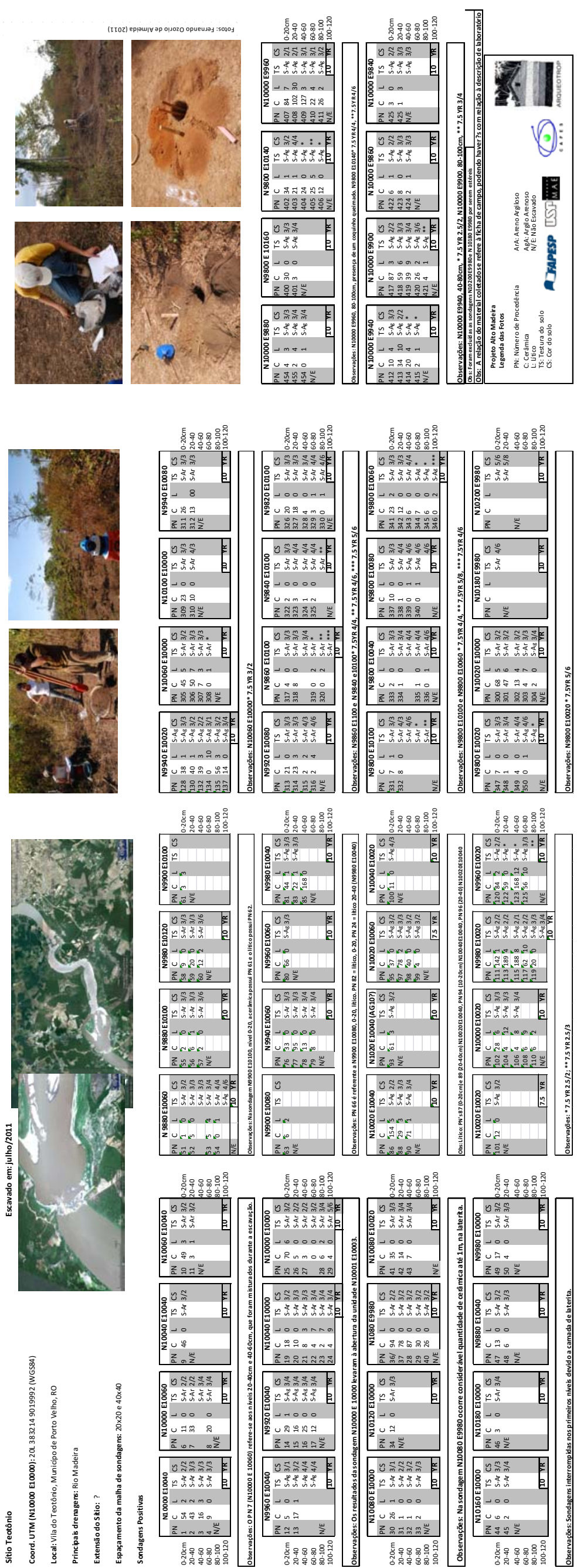
$\mathrm{Na}$ área com maior densidade de sondagens, constatou-se que a camada arqueológica era "contida" por afloramentos laterísticos. Em algumas áreas (norte) a laterita era encontrada na superfície, resultando em sondagens rasas. Em áreas mais ao sul, essa camada ferrosa era encontrada a partir de $60 \mathrm{~cm}$. Independente da profundidade da sondagem, o material arqueológico foi encontrado muito fragmentado. Uma exceção foi a sondagem N9980 E10400, que apontou a presença de um material cerâmico mais bem preservado, a uma profundidade aproximada de $45 \mathrm{~cm}$. Foi essa informação que levou à abertura de uma unidade de escavação no local (N9979 E10041). A unidade apontou a existência de uma camada estéril de laterita (I, início a $50 \mathrm{~cm}$ de profundidade), uma camada de transição entre a terra preta arqueológica e a laterita (II, entre $30 \mathrm{~cm}$ e $50 \mathrm{~cm}$ de profundidade), a camada arqueológica em si, com presença de fragmentos líticos, cerâmicos e presença (média-baixa) de carvões (III, entre $10 \mathrm{~cm}$ e $30 \mathrm{~cm}$ de profundidade) e uma camada escura com material arqueológico revirado (IV, entre $10 \mathrm{~cm}$ e a superfície) (Figs. 89 e 90).

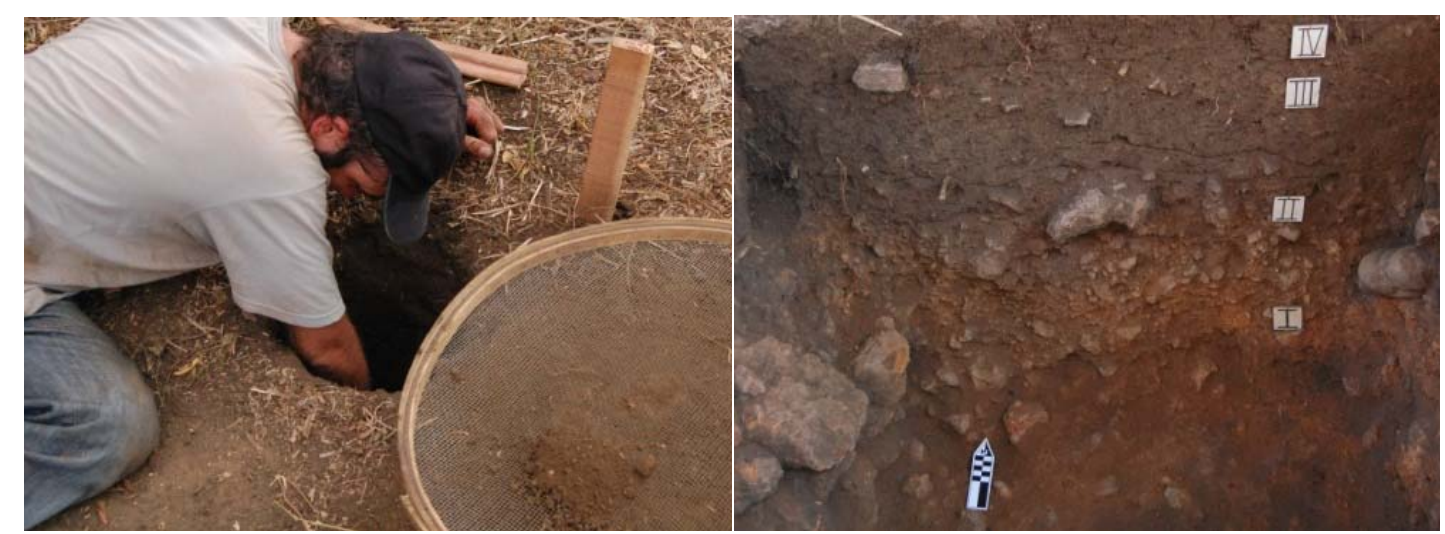

Figura 88: Sondagem N9980 E10040, que levou à abertura da unidade N9979 E10041 (foto: Fernando Ozorio de Almeida, 2011).

Figura 89: Perfil norte da unidade N9979 E10041 (foto: Fernando Ozorio de Almeida, 2011).

Apesar de essa unidade ter possibilitado a coleta de material, inclusive de uma camada de carvão associada à cerâmica, não gerou material cerâmico mais bem preservado como esperado. 


\section{PROJETO ALTO MADEIRA SÍTIO TEOTÔNIO PERFIL ESTRATIGRÁFICO}

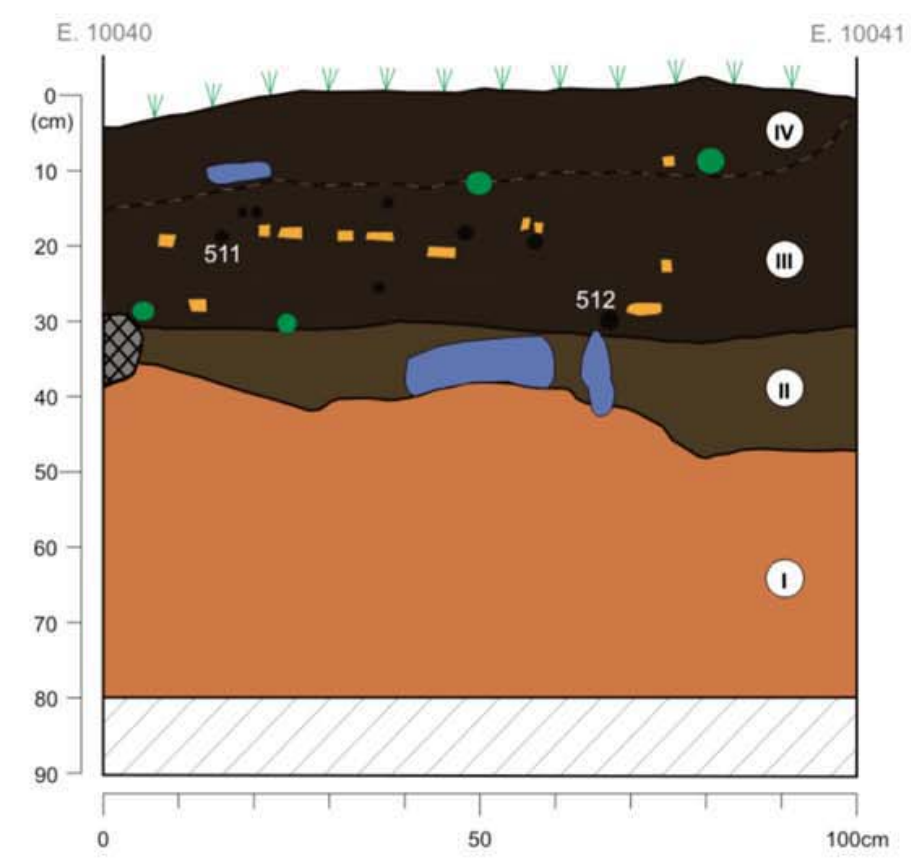

UNIDADE N. 9979 - E. 10041

PERFIL NORTE - LINHA N. 9979

LEGENDA

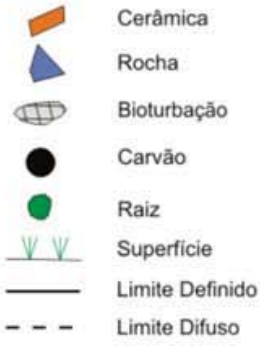

Camada de Terra Preta com compactaçăo média, silto-argiloso (mais silte que no sedimento da camada III), com grande presença de radiculas, e média presença de material arqueológico. Cor: 10YR 2/1 "black"

III Camada de Terra Preta silto-argilosa, espessa, com grande quantidade de vestigios arqueológicos (cerâmica e carvão). Sedimento de compactação média. A parte superior da camada possui alguns fragmentos cerâmicos na vertical $\mathrm{e}$ transversal, indicando reviramento. Cor: 10YR 2/1 "black"

Sedimento escuro silto-argiloso, compacto, com pouca presença de material cerâmico, mas com predominância de grandes rochas e laterita friável. Cor: 10YR $3 / 2$ "very dark brown"

Camada estéril, formada basicamente por laterita de coloração amarela. Não foram identificados vestigios arqueológicos. Cor: 7.5YR 6/8 "reddish yellow"

Área não escavada. 
Outra intervenção que gerou apenas resultados restritos foi o chamado Perfil $\mathrm{A}^{90}$, localizado em uma área escavada (por trator) para a implantação de uma piscina, na chácara do Sr. Márcio. A limpeza de perfil foi realizada em uma extensão de 5m da piscina (Figs. 91 e 92). Depois de realizada a limpeza, foi observado que o sedimento no local havia sido muito revirado. A camada de terra preta se encontrava misturada com um latossolo, provavelmente proveniente do fundo da piscina. Assim, optou-se por não realizar coletas de carvão para datação no local. Foi realizado o desenho de um croqui do perfil para controle (Anexo 12) e uma coleta semi-sistemática (sem nível) de material cerâmico (aproximadamente 360 fragmentos).

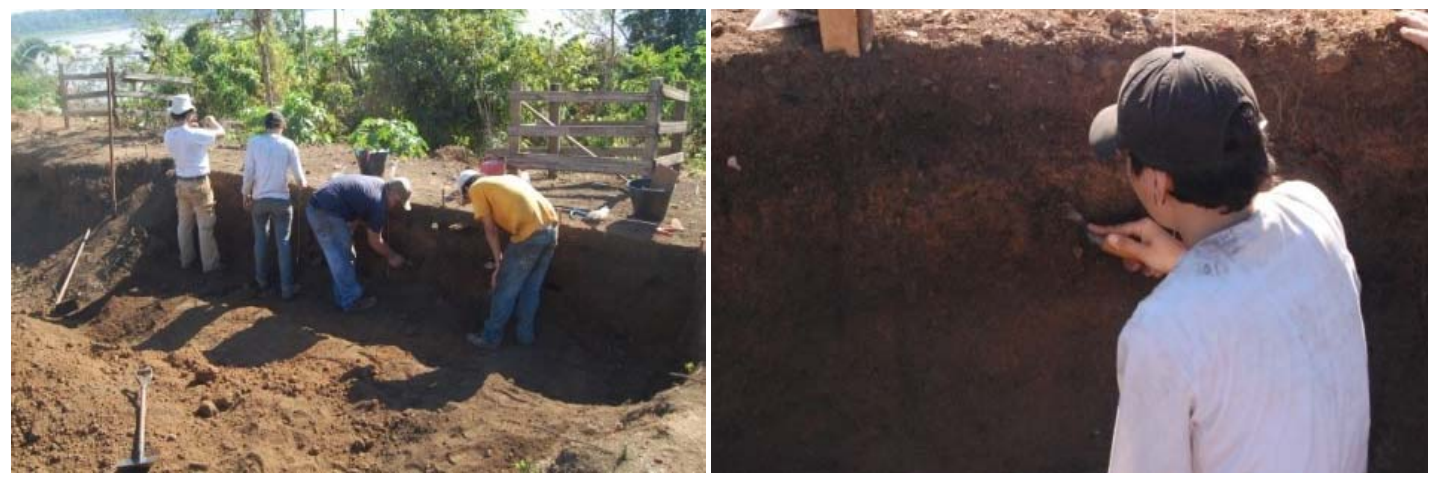

Figura 91: Limpeza do Perfil A (com 5m) em área do sítio Teotônio onde estava sendo construída uma piscina.

Figura 92: Idem (fotos: Fernando Ozorio de Almeida, 2011).

A porção oeste do sítio, tardiamente liberada pelo Sr. Paulão, rendeu melhores resultados. Por falta de tempo e devido à vegetação de capoeira fechada, cuja limpeza é muito lenta, optou-se por realizar a abertura de apenas uma linha com $120 \mathrm{~m}$, que levou à escavação de seis sondagens. A sondagem com terra preta mais profunda e com maior quantidade de material (N10000 E9900) levou à abertura da unidade N10000 E9902. Por meio dessa unidade, foi possível verificar a informação, obtida junto a um antigo morador da localidade, de que a porção oeste do sítio (ou maior parte dela) era a única que não havia sido impactada por maquinário. Na unidade N10000 E9902, a camada estéril (I), formada por lateritas desarticuladas, foi observada entre $70 \mathrm{~cm}$ e $90 \mathrm{~cm}$. A camada II, com cerca de $10 \mathrm{~cm}$ de profundidade (entre $60 \mathrm{~cm}$ e $70 \mathrm{~cm}$ ), possuía coloração escura, material cerâmico e principalmente lítico. A camada III, formada por $40 \mathrm{~cm}$ de terra preta, possuía grande densidade de cerâmica e, em menor escala, de material lítico. Por fim, observou-se a camada

\footnotetext{
${ }^{90}$ A denominação Perfil $A$ ocorreu devido ao fato de esse não estar alinhado com a malha estabelecida em campo (com norte magnético).
} 
IV, também de terra preta, mas com grande quantidade de raízes e de material cerâmico (Figs. 93 a 95).

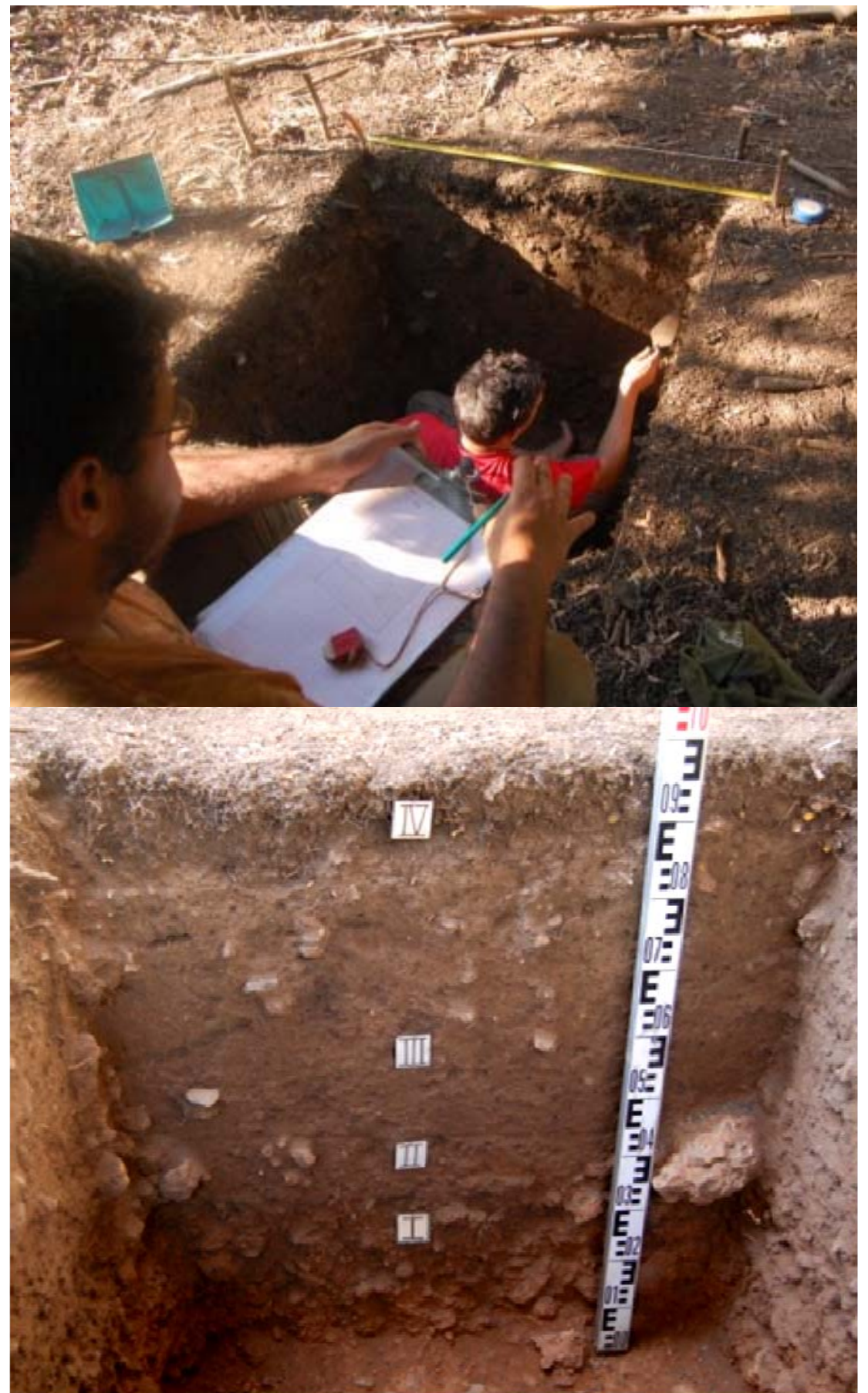

Figura 93: Desenho do perfil sul da unidade N10000 E9902 (foto: Fernando Ozorio de Almeida, 2011). Figura 94: Perfil sul da unidade N10000 E9902 (foto: Fernando Ozorio de Almeida, 2011). 


\section{PROJETO ALTO MADEIRA SÍTIO TEOTÔNIO PERFIL ESTRATIGRÁFICO}

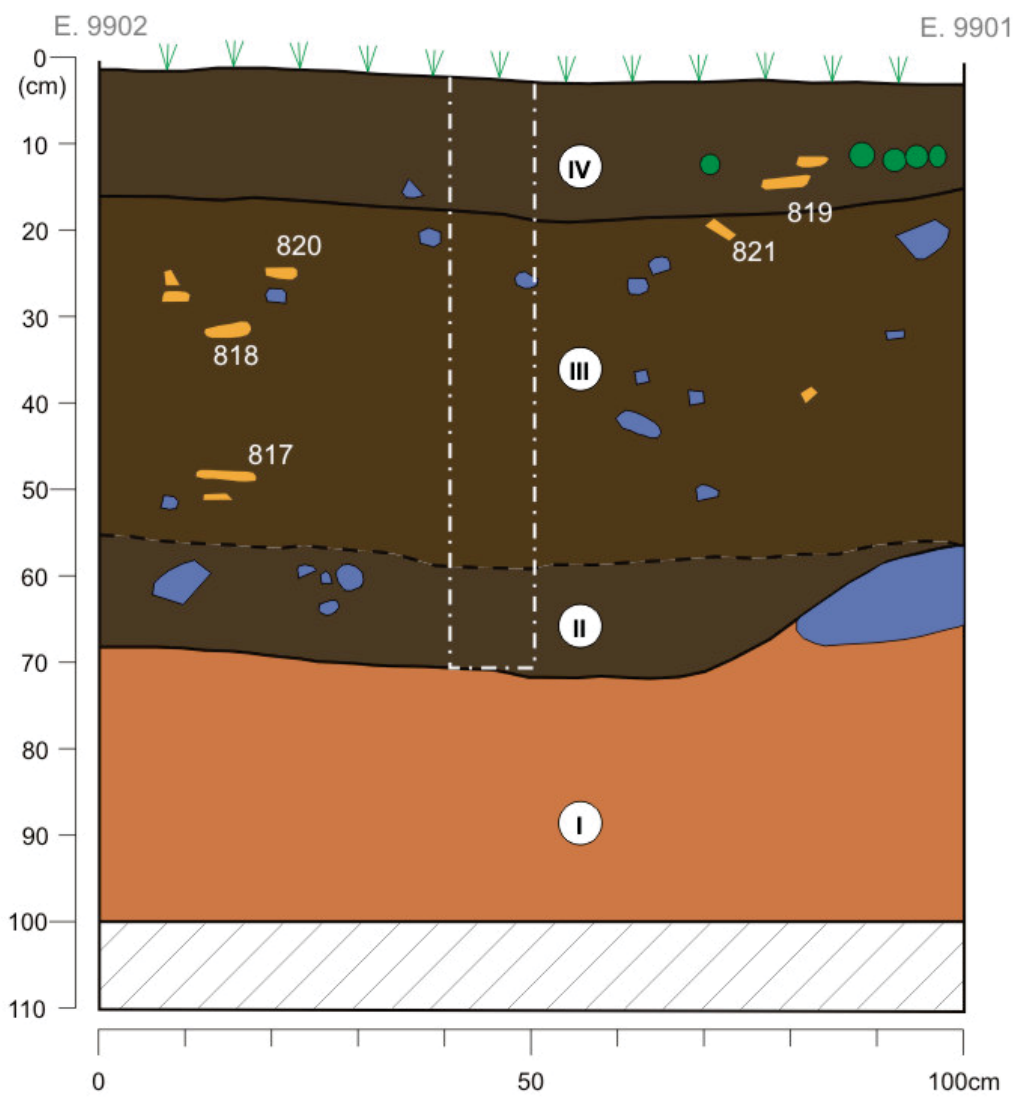

UNIDADE N. 10000 - E. 9902

PERFIL SUL - LINHA N. 10001

\section{LEGENDA}

Cerâmica

Rocha

Raiz

Superficie

Limite Definido

Limite Difuso

Coluna de Sedimento

(II)

Sedimento escuro, silto-argiloso, levemente compactado, com grande presença de radículas, com média presença de fragmentos cerâmicos. Cor: 10YR 3/2 "very dark graysh brown" fragmentos cerâmicos, que estão geralmente dispostos paralelamente à superfície. Foi notada uma baixa presença de fragmentos de carvão (presentes nas camadas II e III). Foi observada uma grande quantidade de laterita nesta camada, com quantidade semelhante à da cerâmica. O sedimento, que se encontra menos agregado que o da camada IV, possui coloração 10YR 3/3 "dark brown".

Sedimento escuro, silto-argiloso, algumas radículas, com presença de fragmentos líticos e quase ausência de cerâmica (o que a diferencia da camada III). Havia presença de laterita cuja com tamanho variando entre $20 \mathrm{~mm}$ a $70 \mathrm{~mm}$. Cor: $10 \mathrm{YR} 3 / 2$ "very dark graysh brown"

Camada composta por blocos de laterita angulosos, de diversos tamanhos, variando entre $5 \mathrm{~mm}$ a $200 \mathrm{~mm}$. Camada in situ, de formação anterior à ocupação humana no local, caracterizando-a como estéril arqueologicamente. Cor: 7.5YR 6/8 "reddish yellow"

Área não escavada 
A unidade N10001 E10003 é a última a ser descrita (Fig. 96). Foi aberta devido ao resultado da sondagem N10000 E10000, escavada até $140 \mathrm{~cm}$ de profundidade sem interrupção por laterita. Além disso, essa sondagem apresentou fragmentos cerâmicos na camada $80-100 \mathrm{~cm}$, depois de um nível sem material $(60-80 \mathrm{~cm})$. Ou seja, a sondagem era um indício de que no local poderia haver a cerâmica mais antiga que se procurava.
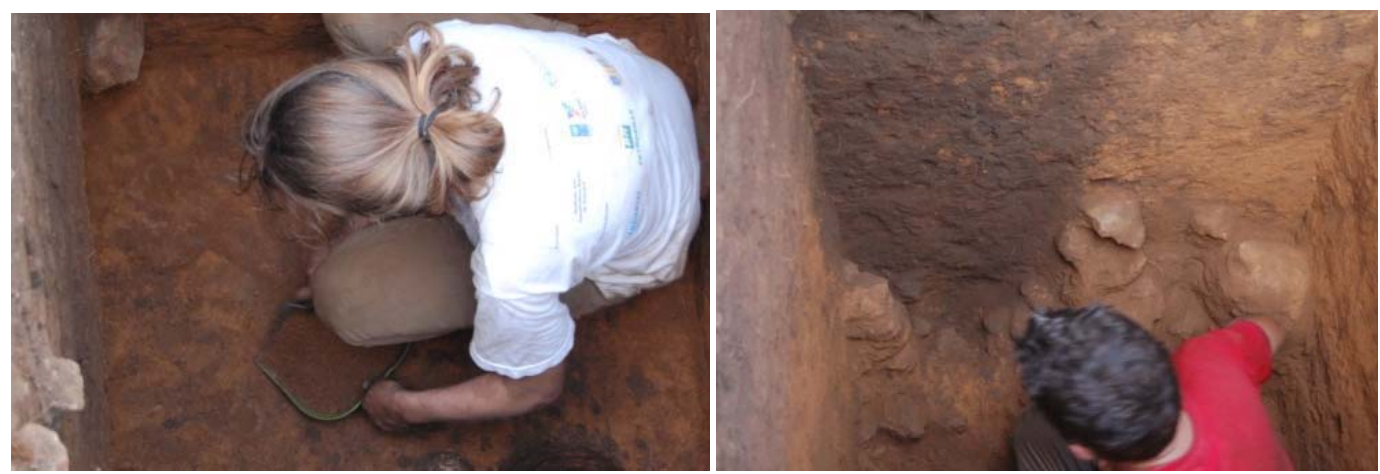

Figura 96: Escavação da unidade N10001 E10003.

Figura 97: Feição de terra preta (escorada na laterita) encontrada no perfil leste da unidade N10001 E10003 (fotos: Fernando Ozorio de Almeida, 2011).

Nessa unidade foi observada uma Feição (F1, situada no perfil leste, entre $110 \mathrm{~cm}$ e $200 \mathrm{~cm}$ de profundidade), uma mancha de terra preta que entrava na camada de latossolo (Figs. 97 e 99). A Feição, considerada como um evento único (escavada à parte), estava escorada na laterita, o que pode sugerir que se trata de um poste ou mastro.

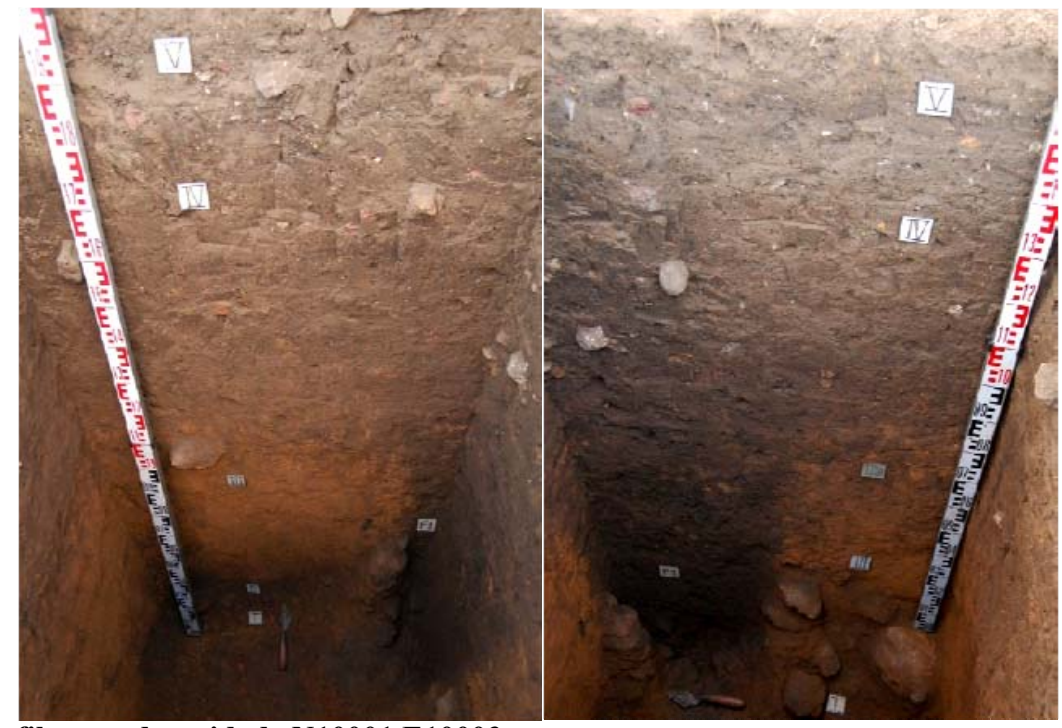

Figura 98: Perfil norte da unidade N10001 E10003.

Figura 99: Perfil leste da unidade N10001 E10003 onde foi identificada a Feição 1 (fotos: Fernando Ozorio de Almeida, 2011). 
Nesta unidade, que atingiu $205 \mathrm{~cm}$ de profundidade, foram observadas cinco camadas distintas. A primeira camada (I, 200-205cm de profundidade), estéril, era formada por blocos desarticulados de laterita (óxido de ferro ou siltito). A seguir, foi observada uma camada de sedimento escuro (II, entre $190 \mathrm{~cm}$ e $200 \mathrm{~cm}$ de profundidade). Essa camada pode ter sua formação ligada à Feição 1, já que ela se encontra na base desta (e.g. uma bioturbação que espalhou parte do sedimento encontrado dentro da Feição). Em seguida, foi identificada a camada III (entre $100 \mathrm{~cm}$ e $190 \mathrm{~cm}$ ), formada por sedimento amarelado. Nessa camada foi encontrado material lítico ${ }^{91}$ e alguma cerâmica (fragmentos menores que $1 \mathrm{~cm}$ ), provavelmente intrusiva. Na base da camada IV $(20 \mathrm{~cm}$ a $100 \mathrm{~cm})$, formada por terra preta, também foi observada uma grande presença de material lítico, e a cerâmica foi quase ausente. Observou-se que o material lítico era constituído por lascas de quartzo hialino. O restante da camada IV era formado em especial por fragmentos cerâmicos (policrômicos) e por material lítico em menor quantidade. Ou seja, em uma mesma camada foram identificadas duas ocupações arqueológicas: na base da terra preta, uma ocupação pré-cerâmica (vide Capítulo 5), e no restante, uma ocupação ceramista. Por fim, a camada V (superfície até $20 \mathrm{~cm}$ de profundidade) encontrava-se revirada, com fragmentos cerâmicos desarticulados (muitos na posição vertical ou transversal) (Figs. 100 e 101).

\footnotetext{
${ }^{91}$ As análises de laboratório indicaram que o material lascado era recente (Capítulo 5), produzido pelo contato do "ferro de cova" dos arqueólogos com o afloramento ferroso do local.
} 


\section{PROJETO ALTO MADEIRA SÍTIO TEOTÔNIO PERFIL ESTRATIGRÁFICO}

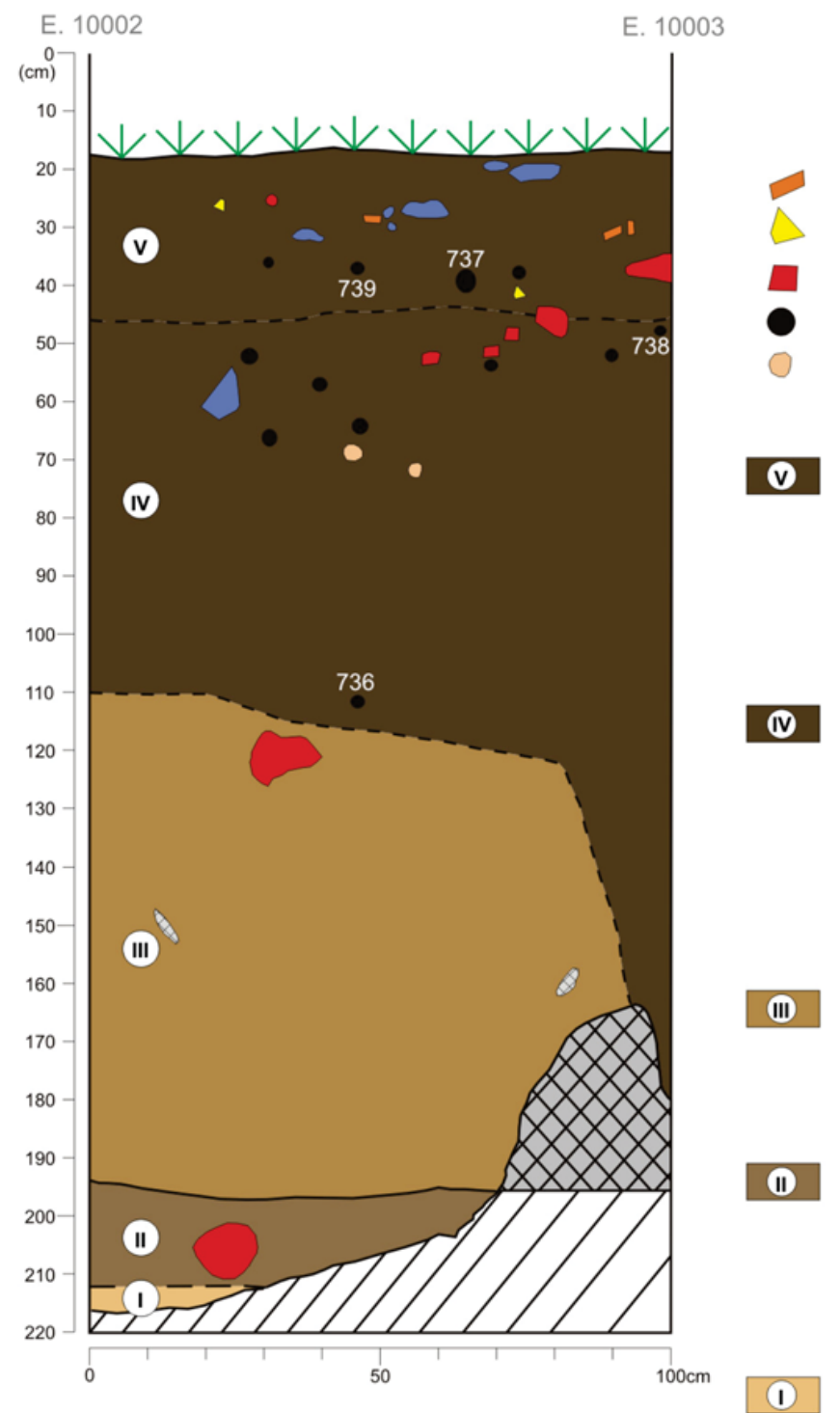

UNIDADE N. 10001 - E. 10003

PERFIL NORTE - LINHA N. 10001
LEGENDA

$\begin{array}{lll}\text { Cerâmica } & & \text { Granitoide } \\ \text { Litico } & & \text { Bioturbação } \\ \text { Laterita } & & \\ \text { Carvão } & - & \text { Superfície } \\ \text { Terra queimada } & -- & \text { Limite Definido Difuso }\end{array}$

Camada de Terra Preta, silto-argilosa, solta, com presença de radículas e material lítico e cerâmico. Camada muito semelhante à camada IV, com a diferença que a cerâmica da camada $V$ estava (muitas vezes) possuía disposição vertical $\mathrm{e}$ transversal à superficie, indicando que se trata de uma camada revirada. Cor: 10YR 3/3 "dark brown"

Camada de Terra Preta, silto-argilosa, com baixa compactação, bastante espessa (chegando a $600 \mathrm{~mm}$ de profundidade). Possui fragmentos cerâmicos (muito fragmentados) e líticos na parte superior, enquanto que na parte inferior só há fragmentos líticos em grande quantidade. Fato que indica que esta camada pode possuir mais de uma ocupação. Cor: 10YR 3/3 "dark brown"

Camada de sedimento argilo-siltoso, com baixa compactação, com presença de carvão e de material lítico. Praticamente não há cerâmica. Corresponde ao sedimento natural da região. Cor: 10YR 6/6 "brownish yellow"

Camada com sedimento argilo-siltoso, com baixa compactação, média quantidade de fragmentos de carvão $\mathrm{e}$ alguns micro fragmentos de cerâmica. É possivel que o sedimento escuro, tenha sido transportado da camada arqueológica. Cor: 10YR 5/4 "yellowish brown"

Camada estéril, formada por blocos compactos, e geralmente desagregados, de laterita. $\mathrm{O}$ tamanho da laterita varia de poucos $\mathrm{mm}$ a $100 \mathrm{~mm}$. O sedimento vinculado a esta laterita varia de cor, entre 10YR 8/6 "yellow" e 10 YR 6/6 "brownish yellow"

Área não escada 


\section{PROJETO ALTO MADEIRA SÍTIO TEOTÔNIO PERFIL ESTRATIGRÁFICO}

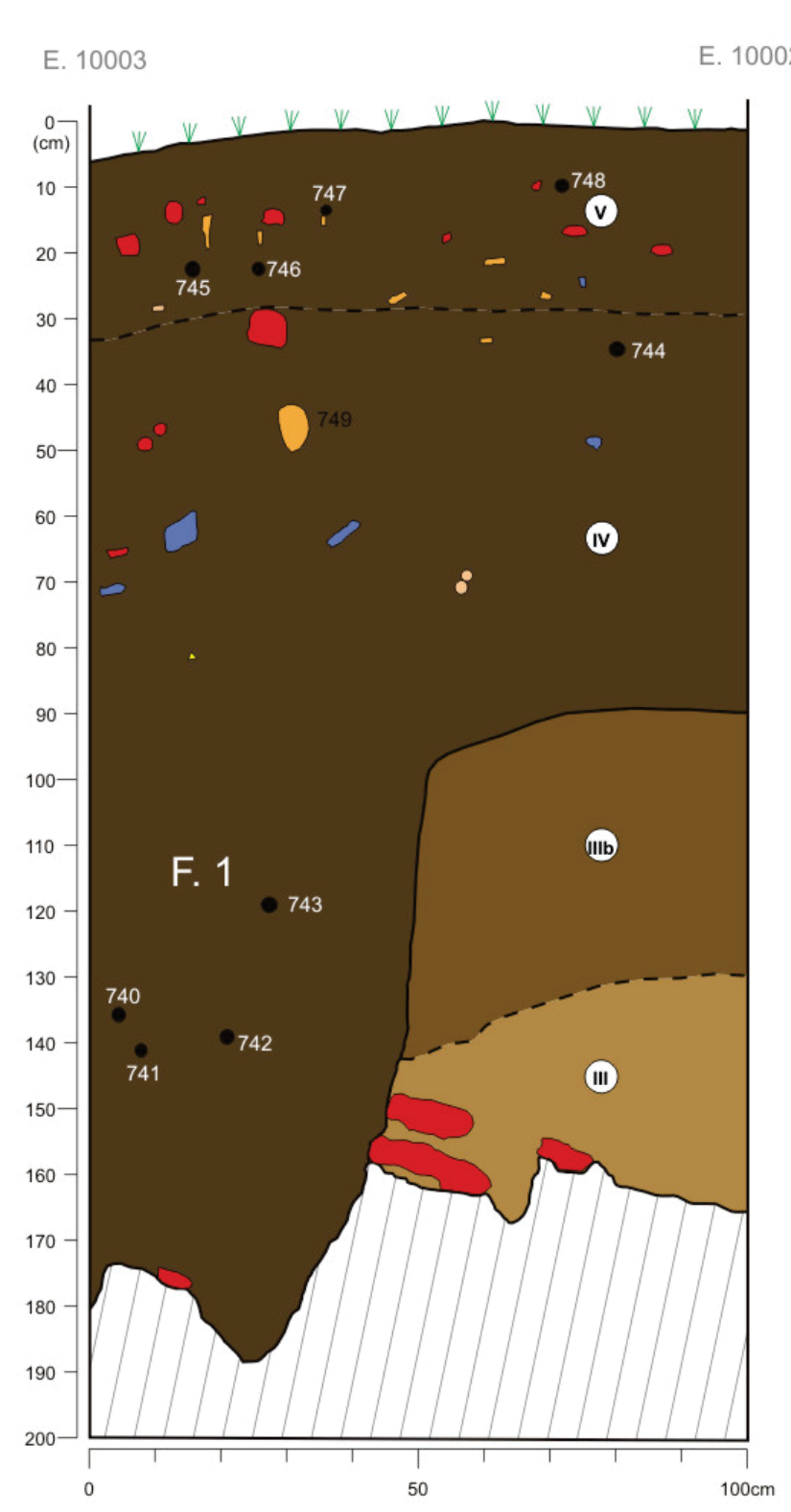

UNIDADE N. 10001 - E. 10003 PERFIL LESTE - LINHA E. 10003
(

LEGENDA

$\begin{array}{lll}\text { Cerâmica } & 0 & \text { Granitoide } \\ \text { Lítico } & \vee \vee & \text { Superfície } \\ \text { Laterita } & - & \text { Limite Definido } \\ \text { Carvão } & --- & \text { Limite Difuso }\end{array}$

Camada de Terra Preta, silto-argilosa, solta, com presença de radículas e material lítico e cerâmico. Camada muito semelhante à camada IV, com a diferença que a cerâmica da camada $\mathrm{V}$ estava (muitas vezes) possuía disposição vertical e transversal à superfície, indicando que se trata de uma camada revirada. Cor: 10YR 3/3 "dark brown"

Camada de Terra Preta, silto-argilosa, com baixa compactação, bastante espessa (chegando a $600 \mathrm{~mm}$ de profundidade). Possui fragmentos cerâmicos (muito fragmentados) e líticos na parte superior, enquanto que na parte inferior só há fragmentos líticos em grande quantidade. Fato que indica que esta camada pode possuir mais de uma ocupação. Cor: 10YR 3/3 "dark brown"

Camada mesclada de sedimento amarelo, argilo-siltoso, com sedimento escuro, silto-argiloso, ambos desagregados, com baixa compactação. A camada foi denominada de Illb por parecer ser uma transição entre as camadas III e IV e por não ser observada em todos os perfis da unidade. Esta camada possui baixa quantidade de fragmentos cerâmicos e média quantidade de peças líticas. Cor: 10YR 4/6 "dark yellowish brown" e 10YR 6/6 "brownish yellow"

Camada de sedimento argilo-siltoso, com baixa compactação, com presença de carvão e de material lítico. Praticamente não há cerâmica. Corresponde ao sedimento natural da região. Cor: 10 YR6/6 "brownish yellow"

Área não escavada

Formada por sedimento escuro, silto-argiloso, disposto em forma cilíndrica com diâmetro máximo de $500 \mathrm{~mm}$ e com pelo menos $850 \mathrm{~mm}$ de profundidade. Aparentemente a feição possui base cônica, com diâmetro aproximado de $300 \mathrm{~mm}$. O contorno da feição, muito bem definido, da base até $400 \mathrm{~mm}$ acima, é delimitada por lateritas. Observou-se a presença de carvão, lítico e cerâmica misturados no sedimento. Trata-se de um prosseguimento da camada IV, que possui coloração 10YR 2/2 "very dark brown" 
Foram realizadas quatro datações para o sítio Teotônio. Como o principal objetivo da escavação do sítio Teotônio foi testar a antiguidade da ocupação de Tradição Polícroma na bacia do alto Madeira, foram selecionadas amostras (Te-709-1; Te-805-1) que possibilitassem datar a base (ou início) da ocupação Jatuarana do sítio. Entretanto, a amostra 805-1 foi aparentemente contaminada, uma vez que apresentou uma data próxima do presente. Restou apenas a amostra 709-1 para datar a base da ocupação Jatuarana (Tabela 29).

\begin{tabular}{|c|c|c|c|c|c|c|c|}
\hline Sítio & Nivel & Amostra & № Beta & $\begin{array}{l}\text { Forma } \\
\text { de } \\
\text { Datação }\end{array}$ & $\begin{array}{l}\text { Material } \\
\text { Datado }\end{array}$ & $\begin{array}{l}\text { Idade } \\
\text { Convencio } \\
\text { nal }\end{array}$ & Calibragem 2 sigma \\
\hline Teotônio & $\begin{array}{l}50-60 \\
\mathrm{~cm}\end{array}$ & Te-709-1 & $\underline{323281}$ & AMS & Carvão & $\begin{array}{l}1250+/- \\
30 \mathrm{BP}\end{array}$ & $\begin{array}{l}\text { AD } 680 \text { a } 830 \\
\text { AD } 840 \text { a } 870\end{array}$ \\
\hline Teotônio & $\begin{array}{l}110- \\
120 \\
\mathrm{~cm}\end{array}$ & Te-716-1 & $\underline{323282}$ & AMS & Carvão & $\begin{array}{l}3170+/- \\
30 \mathrm{BP}\end{array}$ & 1500 a $1410 \mathrm{BP}$ \\
\hline Teotônio & $37 \mathrm{~cm}$ & Te-805-1 & 323283 & AMS & Carvão & Presente & Presente \\
\hline Teotônio & $65 \mathrm{~cm}$ & Te-832-1 & $\underline{323284}$ & AMS & Carvão & $\begin{array}{l}1550+-30 \\
\text { BP }\end{array}$ & $4=430$ a 580 AD \\
\hline
\end{tabular}

Tabela 29: Relação das datas provenientes do sítio Teotônio.

A amostra 716-1 se refere a uma coleta realizada dentro da Feição 1. Conforme será observado com mais detalhe no Capítulo 5, foram encontradas apenas micro lascas líticas dentro da Feição, o que sugere que ela é resultado da (possível) ocupação pré-ceramista (com terra preta) descrita acima, relativa à base da camada IV da Unidade N10001 E10003.

A data resultante, 1200 a.C., parece sugerir que a cronologia elaborada por Miller $(1992,1999)$ pode estar errada, uma vez que a datação de 700 a.C. publicada pelo autor está muito mais próxima da suposta ocupação pré-ceramista do que da datação da base do nível Jatuarana (700 d.C.).

Além disso, a datação da amostra 832-1 aponta mais um componente no complexo arqueológico do sítio Teotônio. Conforme relatado, durante a limpeza de perfil N10045 E9986, foi observada presença de fragmentos de uma suposta cerâmica mais antiga. Novos indícios quanto a essa cerâmica mais antiga foram obtidos apenas em laboratório e serão trabalhados com mais cuidado nos Capítulos 5 e 6 . No entanto, pode-se adiantar que a essa cerâmica distinta (832-1) também foi identificada em uma camada da unidade N10000 E9902, a partir de $45-70 \mathrm{~cm}$ de profundidade, e foi datada de 500 d.C. 


\subsection{Isótopos de carbono}

Uma vez que as datações foram apresentadas com a descrição dos sítios, pode-se fazer um rápido apanhado sobre os dados de isótopos de carbono provenientes dessas datas.

Carlos Zimpel, em sua dissertação de mestrado, emprega de maneira pioneira para a bacia do alto Madeira (médio Ji-Paraná) dados relativos aos isótopos estáveis. Esse "método fornece registros suficientes para a determinação de espécies de plantas entre os tipos de floresta $\left(C_{3}\right)$ ou cerrado ( $\left.C_{4}\right)$ " (ZIMPEL, 2009: 150). As plantas provenientes de ambientes de floresta teriam valores isotópicos mais baixos, entre $-20,0 \%$ e $-32,0 \%$, e as espécies relacionadas com vegetação de cerrado teriam valores entre $-9,0 \%$ e $-17,0 \%$. As amostras apresentadas pelo autor indicam presença de vegetação de floresta $(-24,5 \%$, e $-28,7 \%$ ), para datas em torno de 2000 a.C. Da mesma forma, as amostras provenientes do material datado pelo PALMA indicam baixos valores isotópicos, conforme tabela abaixo:

\begin{tabular}{|l|l|l|}
\hline Sítio & $\begin{array}{l}\text { Data } \\
\text { (convencional) }\end{array}$ & $\mathbf{\delta 1 3 C}$ \\
\hline Nova Vida & $1520+-40$ d.C. & $24,8 \% \circ$ \\
\hline Itapirema & $1410+-40$ d.C. & $27,4 \%$ \\
\hline Itapirema & $1360+-40$ d.C. & $27,9 \%$ \\
\hline Associação Calderita & $1330+-40$ d.C. & $26,6 \%$ \\
\hline Itapirema & $1330+-60$ d.C. & $26,3 \%$ \\
\hline Jacarezinho & $1290+-60$ d.C. & $25,7 \% \circ$ \\
\hline Jacarezinho & $1090+-40$ d.C. & $25 \%$ \\
\hline Associação Calderita & $1010+-40$ d.C. & $28,1 \% \circ$ \\
\hline Associação Calderita & $970+-40$ d.C. & $27,1 \%$ \\
\hline Jacarezinho & $970+-40$ d.C. & $26,5 \% \circ$ \\
\hline Teotônio & $700+-30$ d.C. & $26,8 \%$ \\
\hline Teotônio & $400+-30$ d.C. & $27,4 \% \circ$ \\
\hline Nova Vida & $160+-60$ d.C. & $25,1 \% \circ$ \\
\hline Teotônio & $1220+-30$ a.C. & $25,1 \% \circ$ \\
\hline
\end{tabular}

Tabela 30: Relação dos isótopos estáveis obtidos por meio das datações do PALMA.

Vale lembrar que parte (10 das 14) das datações dessa tabela foi obtida a partir do material orgânico (caraipé) encontrado dentro da cerâmica. Não se pode descartar a possibilidade de, em um suposto cenário pretérito de cerrado, os ceramistas terem obtido esse antiplástico de áreas distantes, via trocas ou expedições. No entanto, as quatro datações mais antigas foram obtidas por carvões (AMS), reduzindo consideravelmente o período datado pelo caraipé e, por consequência, a possibilidade de erro na inferência de que houve uma 
certa estabilidade na vegetação nos últimos 3.000 anos. Além disso, se for expandida a área geográfica para a região do médio Ji-Paraná com o intuito de acrescentar os dados provenientes por Zimpel (2009), seria possível sugerir que, nos últimos 4.000 anos, o alto Madeira possuiu vegetação de floresta. O mesmo ocorre se utilizadas as 25 datações publicadas por Saunaluoma e Schaan (2012: 8), também com uma cronologia de 4.000 anos, e com isótopos com valores que sugerem uma vegetação de floresta.

\subsection{Esety e Eryse ${ }^{92}$ : levantamento e escavação arqueológica nos rios Madeira e Jamari}

Neste capítulo foi realizada a descrição das atividades de campo realizadas pelo PALMA. Os trabalhos começaram em fevereiro e em agosto de 2008, com certo toque de glamour, já que parte dos levantamentos foram realizados no latifúndio de Suzana Vieira, irmã da famosa atriz global (a atriz copiou o nome da irmã). Residindo no Jungle Hotel de Suzana (verdadeira), terminávamos (Claide, Manuel, eu e, às vezes, o professor Eduardo) o dia à beira do Jamari tentando compreender a falta de sítios entre a cachoeira de Samuel e a foz do rio Candeias.

O que é uma maneira de relatar que as pesquisas no alto Madeira, em especial no baixo Jamari, demoraram a engrenar. No entanto, os levantamentos, mesmo quando apresentavam baixo aproveitamento, sempre renderam ao menos um sítio para ser escavado. Fato que leva a crer que a opção por intercalar levantamentos e escavações extensivas foi produtiva e gerou resultados. Isso levando em conta que se trata da primeira pesquisa do PALMA na região e que foi produzido um conhecimento razoável sobre os sítios cerâmicos do alto Madeira, baixo e médio Jamari e alto Ji-Paraná (cf. ALMEIDA, 2010b, 2011), que será de utilidade para o trabalho de outros pesquisadores na área.

O sítio Associação Calderita, identificado próximo à foz do rio Candeias, no baixo Jamari, foi o primeiro a ser escavado. Esse sítio marca uma espécie de "fronteira cultural" (termo ambíguo) entre os grupos do médio e alto Jamari (Tradição Jamari) e do alto Madeira (Subtradição Jatuarana). Veremos adiante (Capítulo 6) que o sítio Associação Calderita pode ser inserido na Subtradição Jatuarana. Tal constatação faz esse sítio se encaixar no panorama

\footnotetext{
${ }^{92}$ Rios Madeira e Jamari na língua Kartiana (DEMOLIN, 1983).
} 
traçado por Miller quanto à presença dessa Subtradição no rio Jamari: “[d]urante a estiagem, provavelmente parcelas da população Jatuarana penetrariam o rio Jamari até a cachoeira de Samuel, [à] procura de tartaruga" (MILLER et al., 1992: 225). Esse sítio possui dimensões reduzidas (2,5ha) e, talvez, uma função de acampamento temporário, como está implícito na argumentação feita por Miller. A análise da cerâmica desse sítio (Capítulo 5) permitirá verificar se a hipótese é verdadeira ou não. As datações apontaram para a provável existência de duas ocupações, 1100 d.C. e 1350 d.C.

Se essa "fronteira cultural" existiu de fato, certamente foi fluida. A presença do sítio Jacarezinho, a ser inserido na Tradição Jamari (Capítulo 5), em área rio abaixo do sítio Calderita, seria a maior prova de tal fluidez. Ambos os sítios (Calderita e Jacarezinho) possuem datações muito próximas, no início do segundo milênio AD. O sítio Jacarezinho, encontrado no lago homônimo, era um sítio com extensa área (entre 8,3ha e 10ha) e densa camada de material arqueológico (média de mais de $40 \mathrm{~cm}$ de material). Foi possível ver que esse sítio foi ocupado em duas situações distintas, a primeira um pouco depois de 1000 d.C. e a segunda depois de 1300 d.C. No campo não foram percebidas diferenças tecno-estilísticas entre a cerâmica profunda, referente à ocupação mais antiga, e a cerâmica mais recente dos níveis superiores, mas essa questão será retomada no próximo capítulo.

A maior densidade de material estava nos primeiros $20 \mathrm{~cm}$, e a área onde foi encontrada cerâmica nos níveis superiores parece mais extensa do que a área com cerâmica nos níveis mais profundos. No entanto, o sítio está inserido em uma série de micro compartimentos topográficos distintos, o que dificulta uma interpretação precisa. Ainda assim, a quantidade de material cerâmico, a dimensão do sítio e a coloração da terra preta permitem apontar que o sítio foi densamente habitado, pelo menos na ocupação mais recente.

Áreas de lago, como as do sítio Jacarezinho, são atraentes pela abundância de pesca. No caso desse sítio, esse atrativo é potencializado pelas extensas matas de igapó (inundáveis) localizadas no seu entorno. Tais áreas são conhecidas pela alta densidade de pesca, que ali se concentra em busca de frutas e coquinhos que caem das árvores e palmeiras (LATRUBESSE, 2012: 13), assim como de matéria orgânica (vegetal e animal) em decomposição (cf. WEBER, 1975: 11). Além disso, o sítio Jacarezinho possui uma localização ímpar, extremamente próxima ao rio Jamari, mas acessível apenas por um discretíssimo corte d'água. 
Os seis sítios localizados por Miller (1978) no lago do Cuniã (Fig. 82) podem ser outro indício de ocupação lacustre na bacia no alto rio Madeira. No entanto, conforme apontado, esses sítios podem ter sido sítios ribeirinhos que mudaram para o status lacustre à medida que o rio Madeira "migrou" para o sul devido ao processo de depósito de sedimento que gerou a área "pantanosa" do lago e a área "seca" onde hoje se encontram o distrito de São Carlos e o sítio Itapirema. Nesse segundo quadro, é bem possível que os habitantes dos sítios do recém formado lago tenham se transferido para a "nova" margem do rio, fundando o sítio Itapirema. O que faria das datas recentes desse sítio, entre os séculos XIII e XIV, excelentes marcadores cronológicos para a dinâmica do rio. A confirmação dessa ideia dependeria da intervenção nos sítios do lago do Cuniã.

Não é de se estranhar, pela localização ímpar do sítio Itapirema, que esse foi o sítio com maior extensão (uma ocupação linear com no mínimo 1000 x 200m) pesquisado pelo PALMA. Nele também foi encontrada a maior amostragem de material cerâmico (vide Capítulos 5 e 6). As intervenções arqueológicas apontaram a presença de montículos, que talvez tenham sido construídos para deixar as áreas de habitação mais altas no período das chuvas, já que o entorno dos montículos costuma ficar alagado. As datações mencionadas sugeriram uma única e densa ocupação que deve ter durado do século XIII até a época do contato, no século XVII.

Outro sítio que pode dar informações sobre a dinâmica do rio Madeira é o Belmonte, não escavado por ter praticamente desaparecido devido ao efeito erosivo do rio Madeira. $\mathrm{O}$ mesmo pode ter ocorrido com um suposto sítio na boca do rio Jamari ${ }^{93}$, na margem esquerda desse rio, que não foi encontrado no local indicado.

A dinâmica do rio Madeira é de compreensão complexa, até para pesquisadores muito mais preparados para tal tarefa (e.g. TIZUKA, 2013). Por exemplo, moradores de São Carlos indicam que o rio Madeira engoliu cerca de $20 \mathrm{~m}$ de largura da margem do rio onde está o distrito nos últimos 15 anos. Ou seja, o rio não migra de forma sistemática e está erodindo o mesmo sedimento que há alguns séculos depositou.

O diálogo com pesquisadores que trabalharam intensivamente na região a montante da cachoeira de Santo Antônio (e.g. Tizuka e Zuse) resultou na percepção de que essa dinâmica de mudança de curso é muito menos intensa nessa área de montante do que a jusante da cachoeira, o que não deixa de ser esperado, visto que a última possui uma geologia mais

\footnotetext{
${ }^{93}$ Indicado por uma fonte segura, um antigo auxiliar de Miller.
} 
recente e muito menos consolidada para enfrentar a força do rio. É necessário ter essa ideia em mente na hora de comparar a densidade de sítios abaixo e acima de Santo Antônio. A dinâmica do rio Madeira pode explicar a baixa densidade de sítios entre Santo Antônio e a boca do Jamari: sítios desapareceram pela erosão ou foram encobertos pelo sedimento ou foram deixados para trás em meandros abandonados (cf. ROE, 1973: 3).

Neste capítulo, foi apresentado o sítio Nova Vida, localizado em um aparente meandro abandonado do rio Madeira. A partir da data mais antiga desse sítio, pode-se considerar que o rio Madeira margearia o sítio Nova Vida por volta do século II. Este sítio, apesar de ser mais extenso (3,4ha) do que o Associação Calderita, por exemplo, ficou caracterizado por uma baixa quantidade de material arqueológico e por possuir uma cerâmica diferente da dos demais sítios apresentados que, aparentemente, não se encaixa em nenhuma das Tradições arqueológicas da região (Capítulos 5 e 6).

Por fim, se as pesquisas demoraram a engrenar - falta de sítios no Jamari, baixa densidade do sítio Nova Vida -, no momento em que o imenso sítio Itapirema foi escavado, a situação já havia se alterado de forma drástica para melhor. $\mathrm{O}$ anticlímax ficou restrito ao campo cronológico, já que a única data razoavelmente antiga (século II, do sítio Nova Vida) parecia não pertencer ao contexto da Tradição Polícroma, foco central dessa pesquisa. Tal desconforto foi fundamental para a decisão de voltar a escavar o sítio Teotônio que, afinal, havia criado toda a expectativa cronológica. A nova cronologia para esse sítio, empurrando a ocupação ceramista mais de 1.000 anos para frente (de 700 a.C. para 700 d.C.; cf. Capítulo 6), mostrou não se tratar de um desconforto infundado e foi essencial para pautar as discussões sobre o material arqueológico a ser realizada nos próximos capítulos. O que não significa que a história cultural do sítio Teotônio está resolvida. Os diferentes resultados das poucas intervenções realizadas indicam que esse sítio necessita ser escavado com intensidade e ter sua delimitação concluída. As análises cerâmicas e líticas dos Capítulos 5 e 6 auxiliarão na compreensão da complexidade desse sítio que é um dos sítios mais importantes para a compreensão da pré-história amazônica. 


\section{ANÁLISE DO MATERIAL ARQUEOLÓGICO}

Therefore, the archaeological description should not concentrate on irrelevant, accidental characteristics of the artifact which the artisan could not control, but on the stylistically meaningful aspects (ROE, 1973: 21).

\subsection{Introdução}

O objetivo deste capítulo é apresentar os resultados da análise dos materiais arqueológicos coletados nos sítios escavados no alto Madeira e baixo rio Jamari (Capítulo 4). A cerâmica é o material preponderante, mas serão realizadas sucintas descrições do material lítico do sítio Teotônio - o único que apresentou uma indústria lítica considerável - e serão apresentados alguns dados paleobotânicos.

A proposta é fazer comparações entre as indústrias cerâmicas, de forma que sejam visualizados elementos que permitam a divisão desses sítios em agrupamentos. Foi observado no Capítulo 3 que o recorte de pesquisa possui duas classes arqueológicas: a Subtradição Jatuarana e a Tradição Jamari. Assim, é importante compreender quais sítios analisados pertencem a cada um desses agrupamentos e se há algum sítio que não pode ser relacionado a nenhum dos dois. O que não se trata de uma tarefa simples, uma vez que a documentação do material que gerou essas classificações é escassa. Pelo contrário, trata-se de uma dupla tarefa: os sítios que serão inseridos nos agrupamentos levarão à redefinição destes.

A discussão arqueológica será realizada à luz dos dados etno-históricos e (principalmente) etnográficos, sempre levando em consideração o objetivo maior deste estudo: compreender as relações entre a Tradição Polícroma da Amazônia e os contextos de grupos falantes de línguas do tronco Tupi, em especial os Tupi-Guarani. Dessa forma, considerou-se pertinente iniciar a discussão sobre atributos cerâmicos analisados a partir de um exemplo etnográfico local, o dos Suruí. 


\subsection{A cerâmica dos Suruí}

Assim como os Asuriní, os Suruí são dos últimos remanescentes Tupi que ainda fabricam utensílios de cerâmica. No entanto, ao contrário dos Asuriní, os Suruí não são um grupo da família Tupi-Guarani e sim da família Tupi-Mondé. Atualmente, as aldeias desse grupo se encontram na Terra Indígena Sete de Setembro, no leste rondoniense (na fronteira com o Mato Grosso), às margens do rio Branco, afluente do rio Roosevelt.

A cerâmica dos Suruí foi estudada por Jean Vidal (2011), que confirma a tradição Tupi de que a manufatura cerâmica é um campo feminino. Vidal relata que as oleiras se organizam para expedições em busca de argila, que obedecem a algumas regras préestabelecidas. Por exemplo, é proibido às mulheres grávidas ou menstruadas participar das expedições $^{94}$ e até mesmo saber a localização onde a argila foi coletada, para evitar que as panelas se quebrem durante a queima (VIDAL, 2011: 43).

As mulheres partem cedo pela manhã, de forma discreta, e realizam a procura da argila em silêncio, fazendo sondagens (pequenas escavações) para checar se o local possui argila adequada. Quando acreditam ter encontrado esse local, as oleiras começam a escavar. As primeiras camadas $(+-20 \mathrm{~cm})$ são descartadas, e o material pode ser extraído até que o lençol freático seja atingido. Cada mulher cava seu próprio buraco. A argila retirada é limpa e armazenada em pequenas bolas, dentro de uma cestaria que é produzida ali mesmo, a partir de folhas de um açaizal (cf. BOWSER, 2002: 119). Ao que parece, as oleiras seguem uma rígida postura corporal, mesmo no momento em que estão descansando, e tal postura será espelhada na postura do vaso, na sua forma e simetria (VIDAL, 2011: 44-50).

O dia seguinte é gasto na procura de outros instrumentos necessários para a confecção dos vasos, como as sementes pipibad utilizadas para alisar, raspar e levantar o vaso durante sua confecção. A manufatura ocorre na aldeia, em local de livre acesso, onde as pessoas se reúnem e conversam. As crianças podem participar e ter contato com a argila, nem que seja apenas para brincar com ela (p. 53). Nesse momento, o que ocorre não é a transmissão de informação a respeito de um padrão específico de fazer cerâmica, de geração para geração, e sim uma coordenação da percepção e da ação de indivíduos, que pode ser verbal ou apenas

\footnotetext{
${ }^{94}$ O mesmo ocorre com as oleiras Asuriní, descritas por Silva (2000). Neumann (2008: 41), que em seu estudo emprega uma elegante abordagem dos objetos como corpos (as vasilhas são seres), sugere que as mulheres menstruadas ou grávidas não podem participar do processo de produção cerâmica exatamente pelo fato de não estarem aptas a (re)produzir.
} 
uma imitação de movimentos (INGOLD, 2000: 358). No caso dos Suruí, fica clara a "mensagem" de gênero implícita nessas práticas, uma vez que cabe às meninas fazer miniaturas dos vasos. Os meninos, em geral, se contentam em lambuzar o corpo com a argila (VIDAL 2011: 64).

A plasticidade ideal da argila é obtida com uma combinação de movimentos, na qual a água é adicionada, e o barro, pressionado, ou melhor, batido, com as mãos. Nenhum tipo de antiplástico é acrescido, o que é um fator comum entre as cerâmicas arqueológicas corrugadas do rio Ji-Paraná ${ }^{95}$ (ZIMPEL, 2009: 68) e do sudeste amazônico (ALMEIDA, 2008; GARCIA, 2012a). Os vasos são criados a partir de roletes de argila, com a base formada por um rolete em espiral. Para facilitar o processo de construção dos vasos grandes, as oleiras fazem uma espécie de molde de areia onde é encaixado o fundo do vaso para secar antes de o restante do vaso ser erguido. Nos vasos pequenos, esse molde não é utilizado (VIDAL, 2011: 56-58).

Independente do tamanho, os vasos sempre possuem uma parede de espessura fina. Para que os vasos grandes não desabem durante a manufatura, usam-se gravetos na parte interna, escorando as paredes. No lado externo, uma fita (de fibra ou pano) é amarrada no entorno do pote para evitar que a peça se deforme durante a secagem, processo que ocorre durante as várias etapas da manufatura do vaso. Os tratamentos de superfície começam com o alisamento das faces, que resulta no desaparecimento dos roletes nas superfícies. O alisamento, realizado com as sementes coletadas ou com um seixo de rio, pode ser feito com movimentos mais rápidos e fortes para criar uma superfície polida (cf. a análise do sítio Teotônio, abaixo). No caso do mem-moyá, o prato utilizado para preparar o beiju de milho, a face externa do vaso não é alisada nem polida ${ }^{96}$ (pp. 58-61).

A secagem pode levar dias e deve ocorrer até que as peças fiquem em "ponto de couro". O primeiro estágio da queima da peça não é propriamente um momento de fogo, mas de fumaça, uma queima em baixa temperatura. Para que não haja grandes variações no fogo e, por consequência, na temperatura - a queima deve ocorrer em locais protegidos de vento.

\footnotetext{
${ }^{95}$ Rio que é muito próximo à Terra Indígena Sete de Setembro.

${ }^{96}$ Rice (1987) aponta os benefícios funcionais que uma superfície mal alisada (ou com um acabamento com corrugados ou cestaria) pode trazer para cerâmicas que são levadas ao fogo. Assunto que foi discutido quando abordamos os sítios Tupinambá da Amazônia (ALMEIDA, 2008).
} 
Para a queima em si (segundo estágio), um novo tipo de madeira é selecionado ${ }^{97}$ - o breu branco (Burseráceas arbóreas) -, material adequado para fazer fogo e não fumaça. As cascas da árvore são colocadas no entorno da(s) vasilha(s), formando uma cabana. No momento da queima, não há mais crianças, conversa nem brincadeira (pp. 61-68; cf. MINDLIN, 1985: 68). Assim, os Suruí parecem se conformar a uma tendência mais ou menos universal, de que é no momento da construção do vaso que ocorre um maior grau de interação (verbal ou manual), entre a artesã e sua aprendiz (GOSSELAIN, 1998: 101): um clímax para as sociedades da prática.

A última etapa de queima pode se misturar à execução do tratamento de superfície, quando a cerâmica é novamente levada a uma "fogueira de fumaça" que deixa a face interna do vaso esfumarada (VIDAL, 2011: 68). Arnold (1997: 23) indica que paredes enegrecidas são adequadas para vasos utilizados para cozimento, uma vez que elas retêm o calor, indicação confirmada pelas oleiras Suruí. O lado externo do vaso Suruí também recebe (ainda quente) um tratamento de superfície (resina) que consiste em uma mistura de água com entrecasca de jatobá (VIDAL, 2011: 68-72; cf. BOWSER, 2002: 121). Não ocorrem outros tipos de tratamento de superfície, como corrugados e motivos pintados. Tal ausência, frustrante para os arqueólogos acostumados às pinturas e decorações plásticas Tupi-Guarani e TPA, é didática para lembrar que a cerâmica não é a única mídia disponível para os motivos pintados (Fig. 102).

Dessa forma, quando o ceramólogo monta sua ficha de análise, deve ter em mente detectar escolhas, tais como as realizadas pelas oleiras Suruí. É fácil encontrar escolhas análogas às dessas ceramistas na literatura etnográfica ou arqueológica. No entanto, seguindo Sackett (1977, 1991), dificilmente haverá exemplos muito semelhantes ao dos Suruí no conjunto de elementos (politéticos) de outros grupos (etnográficos e/ou arqueológicos). Caso tais exemplos sejam encontrados, seria prudente perguntar se não há uma relação entre eles.

\footnotetext{
${ }^{97}$ A escolha de diferentes tipos de madeira, encontrada no exemplo etnográfico dos Suruí, é análoga ao contexto etno-arqueológico descrito por Arnold (1997: 30-31).
} 


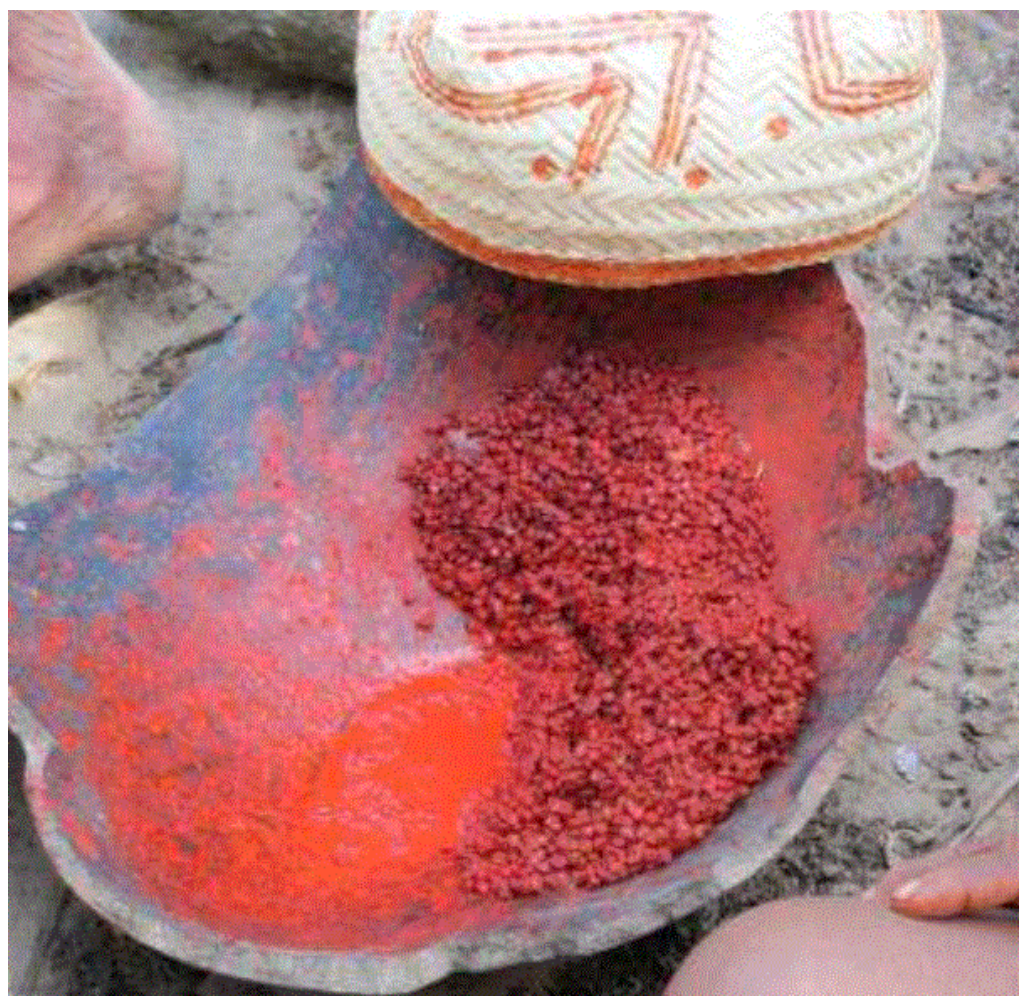

Figura 102: Mais do que um exemplo de reciclagem de um pote cerâmico para obtenção de pigmento vermelho a partir de urucum (cf. BOWSER, 2002: 113), a imagem indica que é na cestaria, e não na cerâmica, que os Suruí desenham seus motivos pintados (fonte: VIDAL, 2012: 78).

Se comparada, por exemplo, a cerâmica Suruí com os elementos clássicos da Tradição Tupi-Guarani, algumas semelhanças entre ambas seriam identificadas, como a técnica de manufatura acordelada e a queima a céu aberto em fogueiras. Ambos os conjuntos também possuem vasos para cocção ou para assar alimentos, assim como para armazenar e ingerir bebidas fermentadas. Por outro lado, uma série de diferenças também seria percebida, como a ausência de caco moído na cerâmica Suruí ${ }^{98}$, a falta de ângulos nas paredes dos vasos Suruí em comparação com a cerâmica Tupi-Guarani, assim como a ausência de decoração plástica e pintada na cerâmica Suruí. Como a maior parte da cerâmica arqueológica das terras baixas sul-americanas é feita por meio da técnica de roletes e é queimada a céu aberto, nossa comparação grosseira aponta ser provável que os elementos dissonantes sejam mais significativos do que os elementos em comum. Isto é, uma comparação expedita como essa não indicaria um vínculo direto entre a cerâmica Suruí e a Tradição Tupi-Guarani. Por outro lado, coincidência ou não, tanto os Suruí (VIDAL, 2011) quanto os Tupi-Guarani

\footnotetext{
${ }^{98}$ O que, conforme foi visto, também ocorre na Subtradição Tupinambá da Amazônia.
} 
(BROCHADO, 1991; LA SALVIA e BROCHADO, 1989; NOELLI e BROCHADO, 1998) possuem um conjunto completo, porém não muito semelhante, de vasos para o preparo, serviço e consumo de bebidas alcoólicas (Figs. 103 a 106). Retomaremos esse tema adiante.

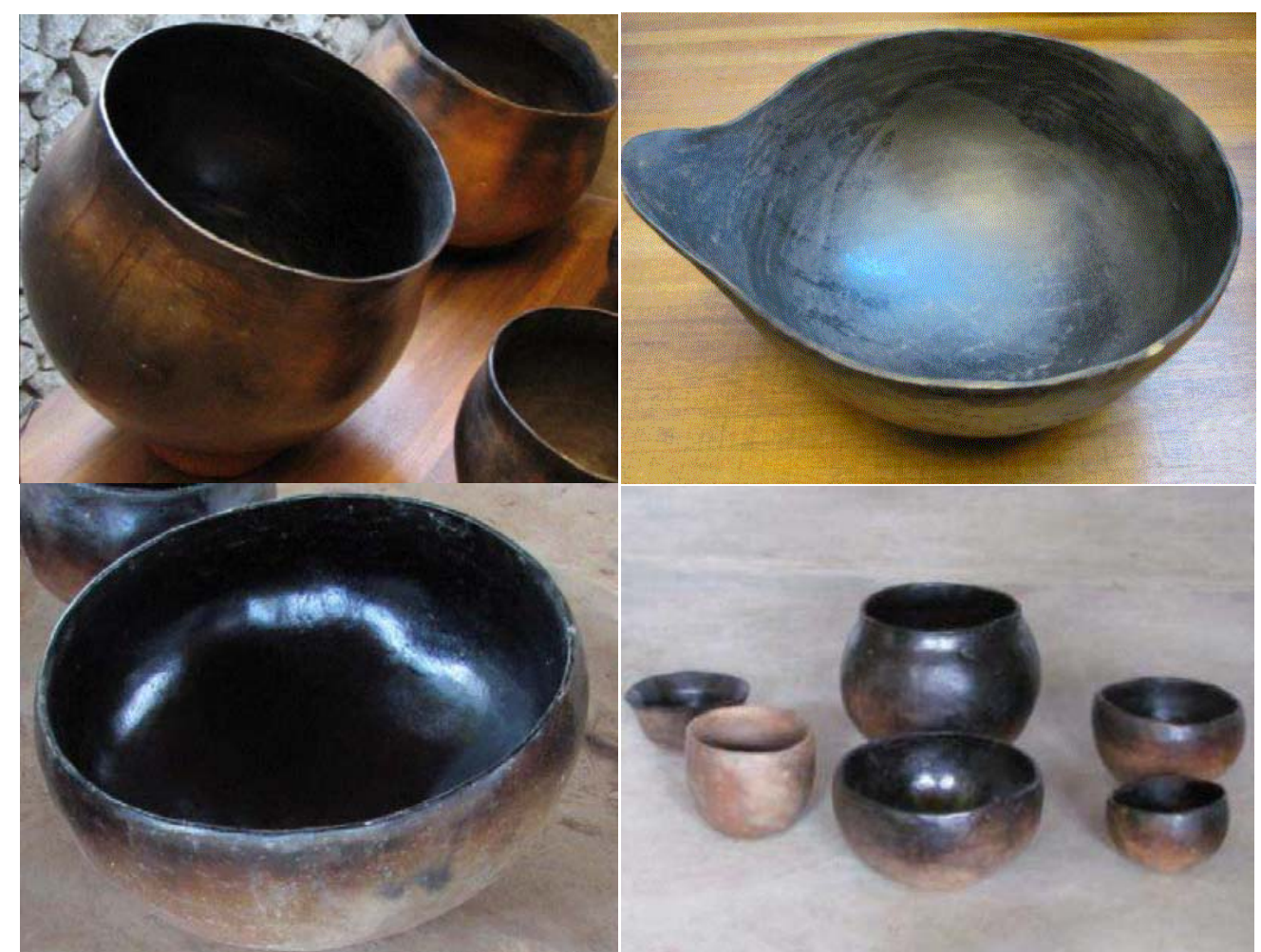

Figura 103: Vaso Suruí para preparo. Figura 104: Vaso Suruí para serviço.

Figura 105: Vaso Suruí para consumo. Figura 106: Vaso Suruí para consumo (fotos: Vidal, 2011).

\subsection{Sobre a análise}

Independente da filiação cultural, a análise dos fragmentos cerâmicos obtidos por meio da intervenção nos sítios arqueológicos expostos no capítulo anterior busca detectar as escolhas feitas pelas ceramistas durante as várias etapas da produção do vaso (cf. Capítulo 1). No entanto, nem todos os fragmentos foram analisados. Fragmentos de parede sem tratamento de superfície foram apenas quantificados e pesados para a realização de inferências sobre a distribuição de material (vertical e horizontal) pelos sítios. Ou seja, os fragmentos denominados diagnósticos são os que oferecem informações sobre os tratamentos de superfície e a forma dos vasos (cf. ROE, 1973: 25; Anexo 13). Para a análise dos 
fragmentos dos sítios escavados pelo PALMA, foram também separados fragmentos com fuligem, por uma questão amostral.

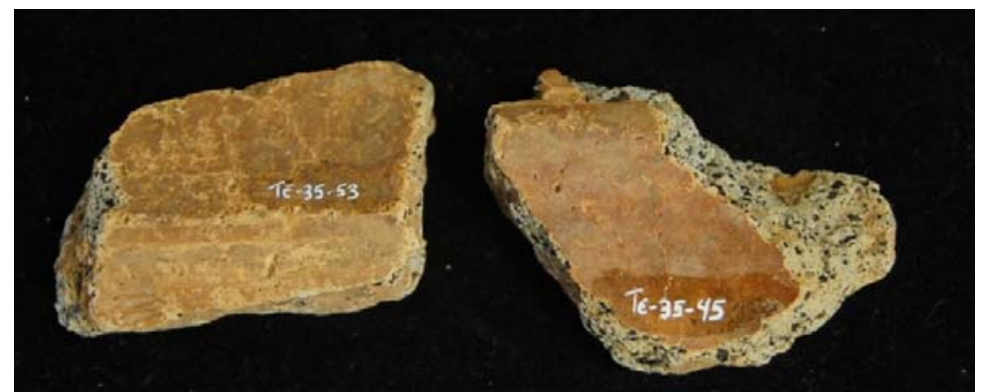

Figura 107: Numeração dos fragmentos cerâmicos (foto: Fernando Ozorio de Almeida).

Cada fragmento diagnóstico recebe um código com as iniciais do sítio ao qual pertence (e.g. "Te" para Teotônio), o número de proveniência (a unidade e o nível onde o fragmento foi obtido ${ }^{99}$ ) e um número de 1 a $\infty$ que diferencia cada um dos fragmentos diagnósticos relativos a cada PN (Número de Procedência, cf. Capítulo 4; Fig. 107).

Durante o estudo dos fragmentos, todos esses dados são anotados na ficha de análise. Inseridos os dados de proveniência, o primeiro campo a ser preenchido identifica a que parte do vaso pertence o fragmento analisado, se é uma borda, por exemplo. A seguir, busca-se identificar a técnica utilizada para a construção do vaso. Conforme apontado acima, a maioria das indústrias cerâmicas das terras baixas possui técnica de manufatura roletada, com a sobreposição de roletes, assim como ocorre com os Suruí. No entanto, há exemplos amazônicos (ALMEIDA, 2013; HECKENBERGER, 2005) de cerâmicas arqueológicas modeladas. Da mesma forma, no contexto não tão distante dos Andes (e.g. LIMA, 2010) os vasos são feitos a partir de moldes. Ocorre, por vezes, de a técnica de manufatura contar com o reforço de placas de argila (e.g. ALMEIDA, 2008; GARCIA, 2012a).

O antiplástico misturado à pasta também tende a ser um importante fator de escolha das ceramistas, podendo ser mineral (e.g. quartzo e hematita), vegetal (e.g. caraipé e carvão) e até animal (e.g. concha moída e cauixi). É também frequente o uso de cacos triturados de cerâmica ou argilas distintas. Os minerais presentes na argila (anotados separadamente) podem oferecer informação sobre a fonte de argila escolhida pelas oleiras. Diferentes fontes tendem a ter diferentes composições mineralógicas. Além disso, o tamanho e a quantidade do antiplástico às vezes estão relacionados a escolhas culturais. Por exemplo, na Amazônia é

\footnotetext{
${ }^{99}$ Por exemplo, Te-349 significa que o fragmento foi obtido no sítio Teotônio no nível 40-60 da sondagem N9800 E10020.
} 
comum que a cerâmica cabocla possua caraipé, assim como ocorre com a cerâmica indígena, mas em maior quantidade e com pedaços de maior tamanho. Mesmo em grupos que não inserem antiplásticos, como os Suruí, é comum que ocorra uma "limpeza" da argila para retirada de sujeira e grandes grãos minerais (cf. BOWSER, 2002: 119).

A cor do fragmento, analisada a seguir, também pode dar indícios da fonte de matériaprima escolhida e da temperatura em que o vaso foi queimado. Na cerâmica da Tradição Polícroma da Amazônia, é comum encontrar fragmentos com coloração clara (branca ou ocre). É ainda incerto o quanto dessa claridade se deve à argila e o quanto se deve à temperatura de queima. No entanto, é nítido que havia uma predileção por cerâmicas claras por parte das ceramistas TPA. Como contraponto, pode-se indicar a cerâmica Una, pertencente a um contexto Macro-Jê do Brasil central (e.g. HENRIQUES JR., 2006; PROUS, 1992; ROBRAHN-GONZÁLES, 1996), onde as cerâmicas possuem uma coloração predominantemente escura. Tal coloração tende a ser obtida com uma queima em ambiente redutor, com pouca entrada de oxigênio. Vale indicar que, por mais haja uma tendência de as cerâmicas indígenas arqueológicas serem mal queimadas (com núcleo escuro), ocorrem exemplos, como o da cerâmica da fase Paredão da Amazônia central, em que um dos traços diagnósticos é uma pasta bem queimada (MORAES, 2006).

O próximo aspecto analisado, o estado de conservação, em geral não faz parte das possibilidades de escolha das oleiras, e sim dos processos (tafonômicos) que ocorrem após a peça cerâmica deixar de ser utilizada e entrar no contexto arqueológico. No entanto, o estado de conservação também pode ser decorrente do uso da peça, como o que ocorre a partir do contato e atrito de instrumentos (e.g. uma colher) durante a cocção de alimentos. Um exemplo é a cerâmica da Subtradição Guarani, na qual é comum que grandes panelas (tipo yapepó) possuam erosão na parede interna dos vasos. Tais erosões tendem a ser fruto da reação da superfície da peça à presença de bebidas fermentadas (NEUMANN, 2008: 119121).

Em seguida, é analisado o tipo de alisamento aplicado ao vaso, se fino, médio grosseiro ou polido. O polimento consiste na utilização de uma ferramenta para dar um aspecto lustroso à parede do vaso. Vimos que os Suruí utilizam um seixo de rio ou uma semente para atingir esse objetivo. Por vezes, esses seixos são encontrados nos sítios arqueológicos. A função de polimento pode ser detectada nesses seixos a partir de uma sequência peculiar de estrias que tende a ocorrer na superfície das rochas. O tipo de alisamento pode ajudar na inferência da funcionalidade do vaso e até de áreas de atividade. 
Por exemplo, a presença de fragmentos com alisamento médio ou grosseiro, associado com lâminas de machado, dentro de uma pequena mancha de terra preta no sítio Cavalo Branco permitiu inferir que a área havia sido utilizada como acampamento de roça.

O tipo de alisamento do vaso tende a ser coerente com a presença ou ausência de decorações plásticas ou pintadas. É muito mais difícil desenhar elaborados motivos pintados sobre uma superfície irregular. Mesmo os arqueólogos, que apenas escrevem a numeração nos fragmentos, se irritam quando têm de fazê-lo em peças com alisamento grosseiro. Assim, os banhos de pigmento - vermelho, branco ou marrom (barbotina) - tendem a ocorrer em superfícies bem alisadas, até por que, de outra forma, não adeririam à superfície de maneira homogênea.

Outro tratamento de superfície utilizado pelos Suruí é o esfumarado ${ }^{100}$, um enegrecimento da face interna do vaso, em geral feito por meio do contato de um vegetal sobre a superfície quente do vaso. Esses tratamentos de superfície costumam possuir a função de impermeabilizar a peça, o que inclui impedir que determinadas partículas da pasta (como o antiplástico cauixi) entrem em contato com o conteúdo do vaso (vide abaixo discussão sobre o sítio Itapirema). No entanto, eles podem servir também como base para decorações plásticas ou pintadas, como ocorre, por exemplo, na cerâmica da fase Marajoara. Pode-se perguntar se não seria nesse campo (o dos tratamentos de superfície) que deveria haver uma categoria "resina". Afinal é esse o tratamento que os Suruí, e grupos como os Asuriní (MÜLLER, 1990; SILVA, 2000), utilizam na sua cerâmica. No entanto, esse tratamento de superfície, por ser orgânico - assim como pode ocorrer, por exemplo, com o uso de pigmento vermelho vegetal (e.g. urucum) - tende a desaparecer durante o processo de deposição dos fragmentos (cf. ALMEIDA, 2008).

Se um tratamento de superfície sugere, por exemplo, que um vaso foi utilizado para armazenar água, a presença de fuligem pode indicar que o vaso foi levado ao fogo. Chegamos então à categoria "sinais de uso", referente à presença de fuligem e películas na face interna do vaso. Películas que podem representar vestígios de alimento, possíveis indicadores da dieta do grupo em questão. Conforme visto no exemplo Suruí, a construção das formas é um momento central para a manufatura do vaso e a manutenção das comunidades da prática. Mesmo nos grandes vasos, havia uma predileção por paredes com espessura fina ${ }^{101}$,

\footnotetext{
${ }^{100}$ No presente estudo, o esfumarado é visto como um sinônimo de "esfumaçado" ou "brunido".

${ }^{101}$ A espessura do fragmento também é uma categoria observada durante a análise dos fragmentos cerâmicos.
} 
característica comum a cerâmicas Inciso-Modeladas amazônicas (e.g. ALMEIDA, 2013; LIMA, 2008; MORAES, 2006), mas que não tende a ser uma característica dos Tupinambá do litoral (e.g. BUARQUE 2010; BUARQUE et al. 2003) nem dos Guarani (LA SALVIA e BROCHADO, 1989).

Durante a análise dos fragmentos arqueológicos do alto Madeira, as formas dos vasos foram obtidas a partir dos dados provenientes da borda (forma, inclinação, espessura, tipo de lábio e diâmetro da boca) e das bases ${ }^{102}$ (forma e diâmetro). São reconstituídos apenas vasos com inclinação confiável e cujo diâmetro da boca seja de pelo menos $3 \%$ do total estimado da boca. A divisão das formas segue critérios geométricos, com base na quantidade de ângulos na parede dos vasos. Dessa divisão, surgem cinco categorias iniciais: vasilhas simples (sem ângulos na parede), compostas (um ângulo na parede), complexas (dois ou mais ângulos na parede ou um ângulo e uma inflexão), com boca angular (e.g. as vasilhas retangulares Tupinambá) e rasas (pratos).

As vasilhas com contorno simples, que pode incluir a presença de inflexões, são as mais numerosas da amostra estudada e se encontram subdivididas em outras três categorias, a partir da relação entre a altura do vaso e o diâmetro da boca: esféricas, semi-esféricas e em forma de calota (ALMEIDA, 2008; GARCIA, 2012a; SCIENTIA, 2008; Anexo 14). As vasilhas compostas e complexas são classificadas, seguindo La Salvia e Brochado (1989: 117), a partir da subdivisão dos segmentos formados pelos ângulos nas paredes do vaso. Os vasos rasos, ou pratos, não são subdivididos.

Foi apontado (Capítulo 1) que a morfologia cerâmica seria o elemento principal para a comparação politética das coleções arqueológicas analisadas. No entanto, a realidade arqueológica mostra que o principal elemento é também um dos mais subjetivos, devido ao fato de que estudos extensivos como o presente dificilmente possuem formas inteiras e têm de depender das reconstituições a partir de fragmentos de bordas. Ainda assim, pode-se dizer que há vasos mais confiáveis do que os outros. Por exemplo, um vaso imenso para armazenagem de alimentos obtido a partir de um fragmento de borda de três centímetros não possui a mesma confiabilidade de um pequeno vaso do qual é encontrado um segmento que vai da borda até parte do bojo inferior, cuja parte inferida da forma é mínima. No sentido de controlar essa volatilidade da amostragem, buscou-se realizar medidas que comparassem o

\footnotetext{
${ }^{102}$ Como é raro um mesmo fragmento possuir borda e base, a reconstituição da peça tende a ser feita a partir da borda, e a base passa a ser inferida a partir dos tipos predominantes durante a análise. Em um momento mais adiantado da análise, em que há uma tipologia mais consistente, baseada em formas completas, tal tipologia passa a ser o guia para as reconstituições.
} 
total da borda com relação ao total inferido da peça (Fig. 108). Esse procedimento torna possível realizar comparações entre reconstituições mais confiáveis e observar a diferença dos resultados com relação à comparação com todas as reconstituições.

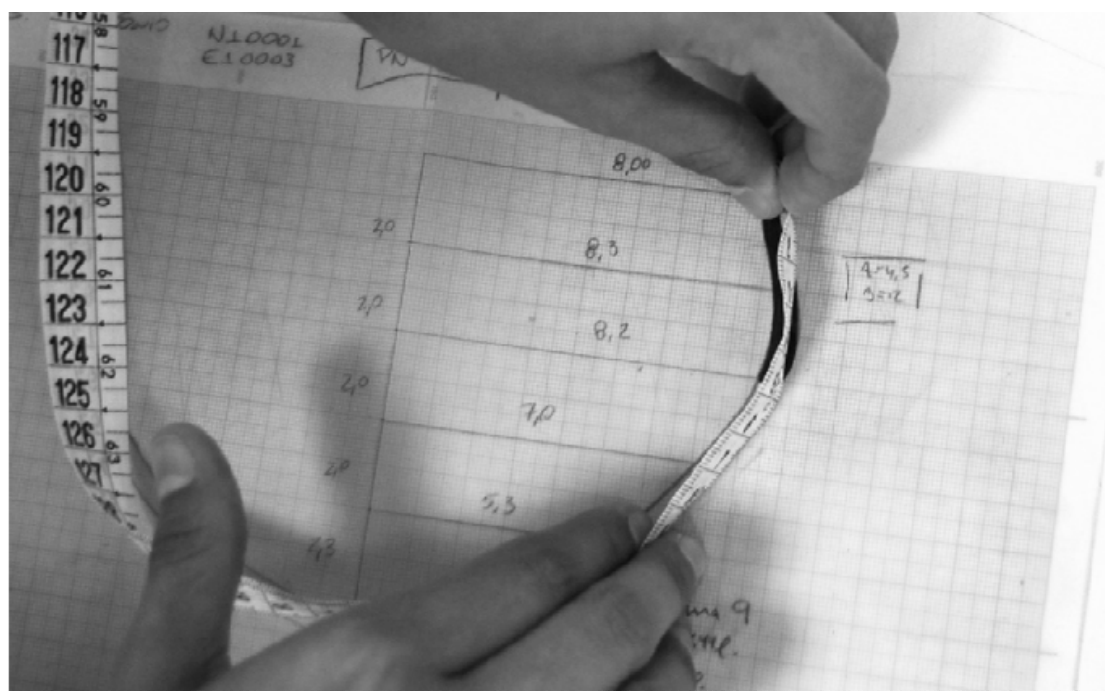

Figura 108: Medição da relação entre o tamanho da borda e o tamanho da reconstituição (foto: Fernando Ozorio de Almeida, 2012).

Por fim, chegamos às decorações, se é que assim podemos denominá-las. Afinal, não parece apropriado chamar as escarificações geométricas (incisões realizadas com dentes de cotia) no corpo do guerreiro Tupinambá, com a função (entre outras) de limpar o sangue do matador e sinalizar o status de bravura deste guerreiro de uma mera decoração. Da mesma forma, a "decoração" incisa ou pintada que esteja no vaso com bebida fermentada utilizado em rituais, com o mesmo motivo corporal do guerreiro (vide MÜLLER, 1990), e talvez com a mesma simbologia, pode ser simplesmente chamada de "decoração"? Ao presente pesquisador não parece uma nomenclatura muito produtiva, apesar de a ficha de análise utilizada nesta pesquisa (por falta de palavra melhor) possuir os campos "decoração plástica" e "decoração pintada".

Trata-se de uma insatisfatória solução para um complexo problema. Uma alternativa seria agrupar as "decorações" na categoria "tratamentos de superfície", o que sem dúvida não seria incorreto. No entanto, a divisão entre os tratamentos de superfície e as decorações tende a respeitar uma divisão grosseira entre o que poderíamos chamar de "funções utilitárias" (tratamentos impermeabilizantes, como o engobo) e funções "simbólicas" ou "emblemáticas" (como as pinturas e incisões). Por outro lado, os engobos podem servir de base para as pinturas, as marcas de unha, incisões e corrugados podem ser utilizados para juntar roletes e 
como demarcadores estilísticos (cf. ALMEIDA, 2008). Ou seja, admite-se que está sendo utilizada uma divisão artificial entre elementos que ocorre pela simples comodidade de facilitar comparações com outros estudos (inclusive do presente aluno), assim como se admite que o uso do termo "decoração" pode conter uma série de significados que vão muito além do caráter passivo expressado pelo termo.

Os cruzamentos dos dados intra e inter-sítios foram feitos individualmente, comparando atributos isolados e também por meio de técnicas estatísticas. Tais técnicas foram empregadas a partir de uma cooperação com o Centro de Estatística Aplicada (CEA) da USP, sendo os trabalhos coordenados pela professora Lúcia Barroso e executados pelos alunos Ricardo Messias e Jiang Pu.

As técnicas estatísticas utilizadas para a interpretação dos dados dos sítios escavados pelo PALMA foram assim definidos por Barroso et al. (2012; Anexo 15):

Análise de correspondência: método de análise multivariada especialmente delineada para o estudo de dados categorizados, cujo objetivo é identificar a dependência entre indivíduos e as variáveis das categorias em estudo, com base em representações gráficas. Ou seja, essa análise permite identificar as características mais marcantes entre os sítios (vide GREENACRE, 2007).

Análise de agrupamentos: compara agrupamentos de unidades amostrais (e.g. características dos fragmentos cerâmicos de dois níveis) para a observação de semelhanças e diferenças. A utilização dessa técnica depende de uma medida de distância entre as unidades amostrais. Para o presente estudo, foi desenvolvida uma distância que não levasse à exclusão dos dados faltantes e, ao mesmo tempo, levasse em conta o grande número de categorias de cada variável. Após calculadas as distâncias entre as peças, pode-se utilizar vários métodos para agrupá-las. Para o presente estudo, foi utilizado o método do vizinho mais distante (vide BUSSAB, MIAZAKI e ANDRADE, 1990).

ANOVA: formada por uma série de modelos estatísticos e técnicas associadas de análise de variação onde uma variável específica é dividida em diferentes componentes que oferecem diferentes fontes de variação. Uma técnica complementar à ANOVA é o teste de Tuckey, cujo objetivo é comparar as médias de todos os grupos formados pelos fatores, duas a duas, de modo conjunto. Essa análise é utilizada para evidenciar em quais grupos ocorrem diferenças quando o teste de ANOVA indica que existe efeito de algum fator (vide NETER et al., 1990). 


\subsection{Sítio Associação Calderita}

\subsubsection{Análise cerâmica}

Os 707 fragmentos cerâmicos que formam a coleção diagnóstica do sítio Associação Calderita podem ser divididos em paredes, bordas e bases. A técnica de manufatura predominante foi a acordelada. Das quatro peças consideradas modeladas, pode-se destacar uma bolota de argila. Apesar de bolotas em geral serem apenas contabilizadas e pesadas, foi aberta uma exceção, uma vez que foi observada uma "careta" na bolota de argila (Fig. 109).

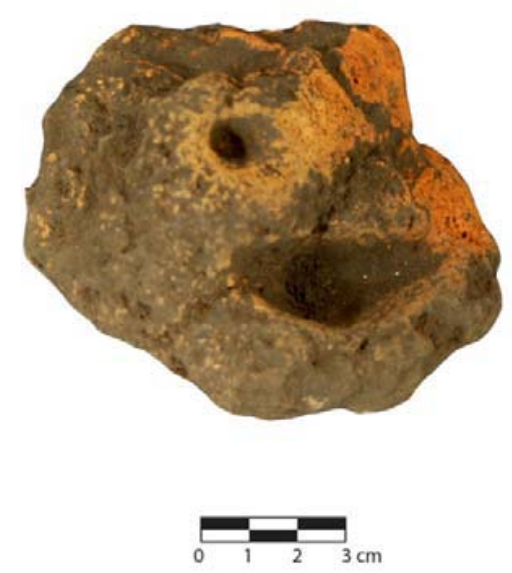

Figura 109: Bolota de argila com careta/monstro (foto: acervo PALMA).

O caraipé foi o antiplástico predominante, sendo encontrado sozinho ou com outros antiplásticos em mais de $90 \%$ dos fragmentos analisados. Os caraipés, em geral, possuíam tamanho entre 1 e $3 \mathrm{~mm}$, e compunham entre $10 \%$ e $20 \%$ da pasta dos fragmentos. A cor da pasta, por sua vez, variou principalmente entre o amarelo e o laranja. O tom claro da superfície contrastou com a queima incompleta (núcleo escuro) identificada na maior parte dos fragmentos. Em alguns, foi observada a nítida presença de dois tipos distintos de argila, algo que também ocorreu no sítio Itapirema.

Cerca de um terço dos fragmentos estava erodido em ambas as faces, o maior índice entre todos os sítios analisados, o que levou a uma alta frequência de peças sem identificação de alisamento, em especial na face interna (FI). Apenas um quarto do material analisado não possuía nenhum tipo de erosão. Foi observado que, mesmo com predominância de 
acabamento fino, houve o maior índice entre os sítios de fragmentos com alisamento médio (12\%). Por outro lado, um percentual semelhante de peças (13\%) possuía a face externa (FE) polida.

A grande presença de fragmentos com engobo vermelho, identificado em quase metade da amostra, foi um dos elementos que mais chamou a atenção nesse sítio. O engobo branco e o esfumarado foram pouco observados, e a presença de barbotina foi um pouco mais significativa, encontrada em cerca de $10 \%$ dos fragmentos. Foram observadas três peças com estrias de alisamento, duas peças com marcas de folha e uma com marca de cestaria.

O material cerâmico do sítio Associação Calderita possuiu um alto índice de peças com fuligem, principalmente na face externa do vaso. Quase metade dos fragmentos que possuíam fuligem também possuíam engobo, o que significa que as peças pintadas desse sítio também iam para o fogo (Fig. 110).

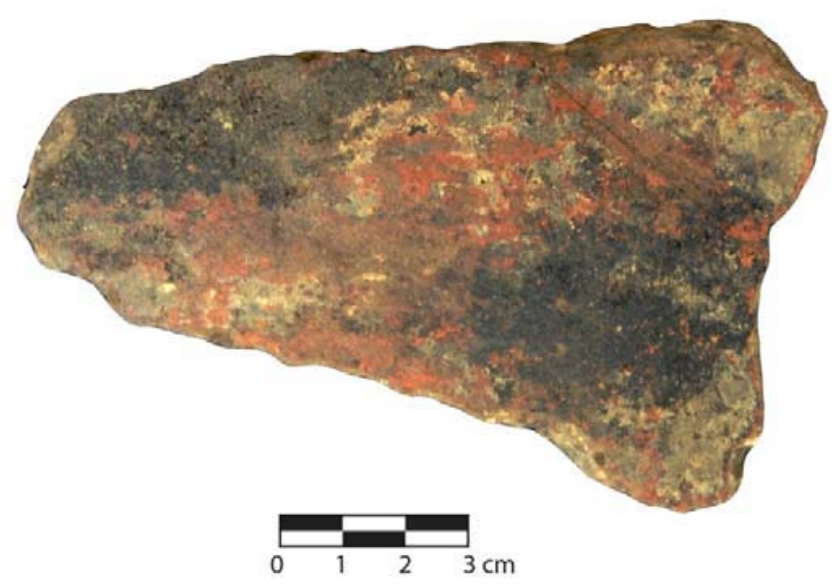

Figura 110: Fragmento cerâmico do sítio Associação Calderita com engobo vermelho e fuligem (foto: Acervo PALMA).

A espessura dos fragmentos variou entre 0,4 e 4,3cm (a bolota), com uma média aproximada de $1 \mathrm{~cm}$. As bases, com espessura em torno de 1,5cm, eram em geral mais grossas do que as paredes e bordas. No entanto, não foram observados reforços nas bases, ao contrário do que foi comum identificar nas bordas. 
Sítio: Associação Calderita

Categoria: 549 paredes, 137 bordas, 18 bases, 2 carenas, 1 bolota de argila

Técnica de Manufatura: 344 acordeladas, 4 modeladas, 2 uso de placas, $\mathrm{NI}=357$ frag.

Antiplástico: 347 mineral + caraipé, 173 caraipé, 81 caraipé+carvão, 45 mineral+caraipé+carvão, 61 outros

Espessura do Antiplástico: 46 frag. $<1 \mathrm{~mm}, 499$ frag. $=>1 \mathrm{~mm}$ e $<3 \mathrm{~mm}, 139$ frag. $=>3 \mathrm{~mm}$ e $<5 \mathrm{~mm}$; 20 frag. $=>5 \mathrm{~mm}, \mathrm{NI}=3$ frag.

Porcentagem do Antiplástico: 41 frag. 5\%, 362 frag. 10\%, 261 frag. 20\%, 39 frag. 30\%, NI = 4 frag. Cor: 34 branco, 321 ocre, 186 laranja, 7 vermelho, 70 cinza, 17 preto, 67 marrom, $\mathrm{NI}=5$ frag.

Queima: 119 completa (oxidada), 58 FI clara e FE escura, 112 Fl escura e FE clara, 4 núcleo claro fino, 200 núcleo escuro espesso, 34 núcleo escuro fino, 166 núcleo totalmente escuro, NI = 4 frag.

Estado de Conservação: 167 não erodido, 223 erodido AF, 184 erodido FI, 80 erodido FE, 12 craquelê $\mathrm{AF}, 10$ craquelê $\mathrm{FE}, 3$ craquelê FI, 24 outros

Alisamento Face Interna: 384 fino, 87 médio, 3 grosso, 54 polido, NI = 179

Alisamento Face Externa: 484 fino, 84 médio, 10 grosso, 89 polidos, $\mathrm{NI}=40$

Tratamento de Superfície FI: 35 eng. verm., 2 eng. branco, 21 barbotina, 19 esfumarado, $\mathrm{NI}=630$

Tratamento de Superfície FE: 340 eng. verm., 6 eng. branco, 57 barbotina, 16 esfumarado, $\mathrm{NI}=288$

Marcas: 1 cestaria, 3 estrias de alisamento, 2 folha, $\mathrm{NI}=701$

Sinais de Uso: 284 fuligem FE, 17 fuligem FI, 2 película de alimento $\mathrm{FI}, 1$ reciclagem, $\mathrm{NI}=403$

Morfologia da Borda e Flange: 94 direta, 29 extrov., 5 introvertida, 5 ext. com ponto ang., $\mathrm{NI}=4$

Inclinação da Borda: 17 vertical, 37 inclinada interna, 69 inclinada externa, NI = 14

Espessura da Borda: 90 normal, 14 contraída, 7 reforçada FE, 5 reforçada FI, 21 outros

Lábio: 96 arredondado, 29 plano, 11 apontado, $\mathrm{NI}=1$

Base: 11 plana, 2 convexa, $\mathrm{NI}=5$

Diâmetro da Base: 3 frag. $>5$ e $<=10 \mathrm{~cm}, 1$ frag. $>10$ e $<=15 \mathrm{~cm}$

Espessura do Fragmento: 22 menor que 0,6cm, 492 entre 0,6 e 1,0cm, 172 entre 1,1 e 1,5cm, 21

maior que $1,5 \mathrm{~cm}, \mathrm{NI}=0$

Decoração Plástica: 4 incisão fina

Decoração Pintada: 9 vermelho, 4 branco, 2 outras

Motivo Decorativo: 8 horizontal, 2 complexa, 2 curvilínea,

1 transversal, 1 vertical longa, 1 outra

Local de Decoração FI: 1 parede, 2 borda, 1 lábio

Local de Decoração FE: 10 parede, 1 borda, 1 bojo inferior

PALMA

Sítio Associação

Calderita

Análise Cerâmica

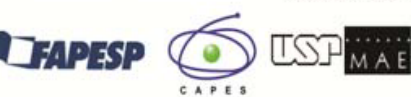


A maioria das 137 bordas analisadas possuía morfologia direta, com inclinação externa, e um quarto da amostra era extrovertida (com ou sem ponto angular), números bastante semelhantes aos observados no sítio Teotônio. A espessura das bordas foi, em geral, considerada normal, mas $11 \%$ da amostra possuíam algum tipo de reforço, e $10 \%$ eram contraídas. O lábio arredondado foi o mais observado.

O diâmetro da boca dos vasos variou entre 9 e $50 \mathrm{~cm}$, com média de $19 \mathrm{~cm}$. As bordas representaram de $3 \%$ a $25 \%$ da boca do vaso, com média de 5,8\%. Foram identificadas apenas 18 bases na coleção, a maioria delas plana, com diâmetro variando entre 7 e $12 \mathrm{~cm}$. A baixa quantidade de bases ( $3 \%$ do material diagnóstico) parece apontar o predomínio de vasos com fundos convexos.

O sítio Associação Calderita possuiu a maior relação de diferença entre a altura do fragmento e altura inferida pela reconstituição (média de 18,5\% do perfil inferido do vaso), o que sugere que se tenha mais cautela com as formas desse sítio do que com as dos demais. Foram identificadas 11 formas cerâmicas nesse sítio, com a predominância de formas semiesféricas, com boca aberta, contorno simples ou inflectido, como também de formas esféricas com contorno simples e boca constrita. Análises de correspondência (Anexo 15 G) também associam esse sítio a vasilhas abertas (esféricas, semi-esféricas e calotas). Não houve nenhuma reconstituição que gerasse uma forma composta ou complexa, mas como foram identificadas duas carenas na coleção, fica indicada a presença, ao menos, de formas compostas. Os volumes variaram de 0,2 a 201 .

Houve uma baixa frequência de fragmentos com decoração plástica no sítio Associação Calderita: apenas incisões, identificadas em quatro fragmentos. Apesar da grande quantidade de fragmentos com engobo vermelho, houve uma pequena quantidade de peças com motivos pintados. Foi observado um total de 15 fragmentos com decoração pintada em vermelho, branco ou combinação de ambos. Os motivos foram identificados principalmente nas paredes externas dos vasos, seguidos pelas bordas internas. 


\begin{tabular}{|c|c|}
\hline \multicolumn{2}{|r|}{ Tipologia Cerâmica do Sítio Associação Calderita } \\
\hline Forma 1 & $\begin{array}{l}\text { Vasilha esférica, com contorno simples e boca constrita. Borda direta ou } \\
\text { introvertida, com inclinação interna ou vertical, espessura normal ou } \\
\text { contraída, lábio normal, expandido ou reforçado interno, lábio arredondado, } \\
\text { plano ou apontado. O diâmetro da boca varia de } 12 \text { a } 24 \mathrm{~cm} \text {, e o volume, de } \\
0,7 \text { a } 13,41 \text {. Tratamento de superfície: engobo vermelho (FE). Antiplástico: } \\
\text { caraipé, carvão, mineral. }\end{array}$ \\
\hline & $\begin{array}{l}\text { Vasilha esférica, com contorno simples e boca aberta. Borda direta, } \\
\text { inclinação vertical, espessura normal e lábio plano. Diâmetro da boca de } \\
15 \mathrm{~cm} \text { e volume de } 2,31 \text {. Tratamento de superfície: engobo vermelho (FE e } \\
\text { FI). Antiplástico: caraipé, mineral. }\end{array}$ \\
\hline Forn & $\begin{array}{l}\text { Vasilha esférica, com contorno inflectido e boca constrita. Borda direta ou } \\
\text { extrovertida, inclinação interna ou externa, espessura normal ou contraída, } \\
\text { lábio arredondado ou plano. O diâmetro da boca varia de } 10 \text { a } 30 \mathrm{~cm} \text {, e o } \\
\text { volume, de } 1,3 \text { a } 1201 \text {. Tratamento de superfície: engobo vermelho (FE). } \\
\text { Antiplástico: caraipé, carvão, mineral. }\end{array}$ \\
\hline & $\begin{array}{l}\text { Vasilha esférica com pescoço, contorno inflectido e boca constrita. Borda } \\
\text { extrovertida, inclinada externa, reforçada externa, com lábio apontado. } \\
\text { Diâmetro da boca de } 17 \mathrm{~cm} \text { e volume de } 151 \text {. Tratamento de superfície: - } \\
\text { Antiplástico: caraipé, mineral. }\end{array}$ \\
\hline For & $\begin{array}{l}\text { Vasilha semi-esférica, com contorno simples e boca constrita. Borda direta } \\
\text { ou introvertida, inclinada interna, espessura normal ou contraída, lábio } \\
\text { arredondado ou plano. O diâmetro da boca varia de } 14 \text { a } 34 \mathrm{~cm} \text {, e o volume, } \\
\text { de } 1,2 \text { a } 12,21 \text {. Tratamento de superfície: engobo vermelho (FE e FI, } \\
\text { especialmente FE). Antiplástico: caraipé, mineral. }\end{array}$ \\
\hline Fo & $\begin{array}{l}\text { Vasilha semi-esférica, com contorno simples e boca aberta. Borda direta, } \\
\text { inclinada interna ou externa, espessura normal, reforçada em ambas as faces } \\
\text { ou contraída, lábio arredondado ou plano. O diâmetro da boca varia de } 12 \text { a } \\
32 \mathrm{~cm} \text {, e o volume, de } 0,3 \text { a } 8,21 \text {. Tratamento de superfície: engobo vermelho } \\
\text { em ambas as faces (AF), engobo branco (FE), barbotina (AF), esfumarado } \\
\text { (FI). Antiplástico: caraipé, carvão, mineral. }\end{array}$ \\
\hline For & $\begin{array}{l}\text { Vasilha semi-esférica, com contorno inflectido e boca aberta. Borda direta, } \\
\text { extrovertida (com ou sem ponto angular), inclinação vertical, interna ou } \\
\text { externa, espessura normal ou reforçada externa, lábio arredondado ou plano. } \\
\text { O diâmetro da boca varia de } 16 \text { a } 26 \mathrm{~cm} \text {, e o volume, de } 0,5 \text { a } 4,31 \text {. } \\
\text { Tratamento de superfície: incisões (borda FE), pintura vermelha e branca } \\
\text { (FE), engobo vermelho (AF), barbotina (AF). Antiplástico: caraipé, mineral. }\end{array}$ \\
\hline Fori & $\begin{array}{l}\text { Vasilha semi-esférica, com contorno inflectido e boca constrita. Borda } \\
\text { extrovertida, com inclinação vertical e espessura contraída e lábio apontado. } \\
\text { Diâmetro da boca de } 14 \mathrm{~cm} \text { e volume de } 1,51 \text {. Tratamento de superfície: } \\
\text { engobo vermelho (FE). Antiplástico: caraipé. }\end{array}$ \\
\hline Forma 10 & $\begin{array}{l}\text { Vasilha em forma de calota, com contorno simples, boca aberta. Borda } \\
\text { direta ou extrovertida, inclinação externa, interna ou vertical, espessura } \\
\text { normal, lábio arredondado, plano ou apontado. O diâmetro da boca varia de } \\
14 \text { a } 44 \mathrm{~cm} \text {, e o volume, de } 0,3 \text { a } 4,81 \text {. Tratamento de superfície: esfumarado } \\
\text { (FE). Antiplástico: caraipé, carvão, mineral. }\end{array}$ \\
\hline Forma 12 & $\begin{array}{l}\text { Vasilha em forma de calota, com contorno inflectido, boca aberta. Borda } \\
\text { extrovertida ou direta, inclinação externa, espessura normal, lábio } \\
\text { arredondado. O diâmetro da boca varia de } 12 \text { a } 22 \mathrm{~cm} \text {, e o volume, de } 0,2 \text { a } \\
\text { 1,5l. Tratamento de superfície: barbotina (FI), esfumarado (FE). } \\
\text { Antiplástico: caraipé, mineral. }\end{array}$ \\
\hline
\end{tabular}




\begin{tabular}{|c|l|}
\hline Forma 17 & $\begin{array}{l}\text { Vasilha rasa, prato. Borda direta, inclinada externa e espessura normal. } \\
\text { Diâmetro de } 50 \mathrm{~cm} . \text { Tratamento de superfície: barbotina (FE). Antiplástico: } \\
\text { caraipé, mineral. }\end{array}$ \\
\hline
\end{tabular}

Tabela 32: Relação das formas do sítio Associação Calderita.

Foi inferido, no Capítulo 4, que o sítio Associação Calderita possuía duas ocupações, uma em situada 1100 d.C. (duas datas provenientes dos níveis $30-40 \mathrm{~cm}$ e $40-50 \mathrm{~cm}$ ) e outra de 1300 d.C. (uma data proveniente do nível 20-30cm). A comparação desses níveis (unidades N1030 E1002 e N1031 E 1002), no entanto, não mostra diferença com relação aos elementos preponderantes, com a exceção da inclinação da borda: predominantemente externa no nível 20-30cm e interna nos níveis de 30 a 50cm (Tabela 33). Essa diferença deve ser minimizada, uma vez que, em ambos os níveis, a distância quantitativa entre as variáveis foi baixa.

\begin{tabular}{|c|c|l|l|l|l|l|l|}
\hline $\begin{array}{c}\text { Nível } \\
\text { (cm) }\end{array}$ & $\begin{array}{c}\text { Datação } \\
\text { conven- } \\
\text { cional }\end{array}$ & $\begin{array}{l}\text { Quant. } \\
\text { de frag. }\end{array}$ & Antiplástico & $\begin{array}{c}\text { Trat. de } \\
\text { sup. FE }\end{array}$ & $\begin{array}{c}\text { Morfolo- } \\
\text { gia da } \\
\text { borda }\end{array}$ & $\begin{array}{c}\text { Inclinação } \\
\text { da borda }\end{array}$ & Lábio \\
\hline $20-30$ & 1350 d.C. & 202 & $\begin{array}{l}\text { Caraipé }+ \\
\text { mineral }\end{array}$ & $\begin{array}{l}\text { Engobo } \\
\text { vermelho }\end{array}$ & Direta & Externa & Arredondado \\
\hline $30-40$ & 1100 d.C. & 267 & $\begin{array}{l}\text { Caraipé }+ \\
\text { mineral }\end{array}$ & $\begin{array}{l}\text { Engobo } \\
\text { vermelho }\end{array}$ & Direta & Interna & Arredondado \\
\hline $40-50$ & & &
\end{tabular}

Tabela 33: Comparação entre os atributos cerâmicos das duas ocupações do sítio Associação Calderita.

Uma comparação entre as formas cerâmicas relacionadas às duas ocupações também mostra apenas diferenças sutis entre ambos os níveis, como o elevado número de formas 7 do nível 20-30cm, ou da forma 1 dos níveis $30-50 \mathrm{~cm}$, assim como a presença da forma 9 nesse nível, ausente no nível 20-30cm (Tabela 34).

A análise de agrupamentos - feita a partir das variáveis antiplástico, decoração plástica, decoração pintada, tratamento de superfície FE e forma do material cerâmico das unidades N1030/1031 E1002 - confirmou a inexistência de grupos distintos para cada uma das datações (BARROSO et al., 2012: 36; Anexo $15 \mathrm{~J}$ ). Ou seja, os dados apontam com clareza que o sítio foi ocupado duas vezes por grupos com cerâmica muito semelhante ou, mais provável, pelo mesmo grupo. 


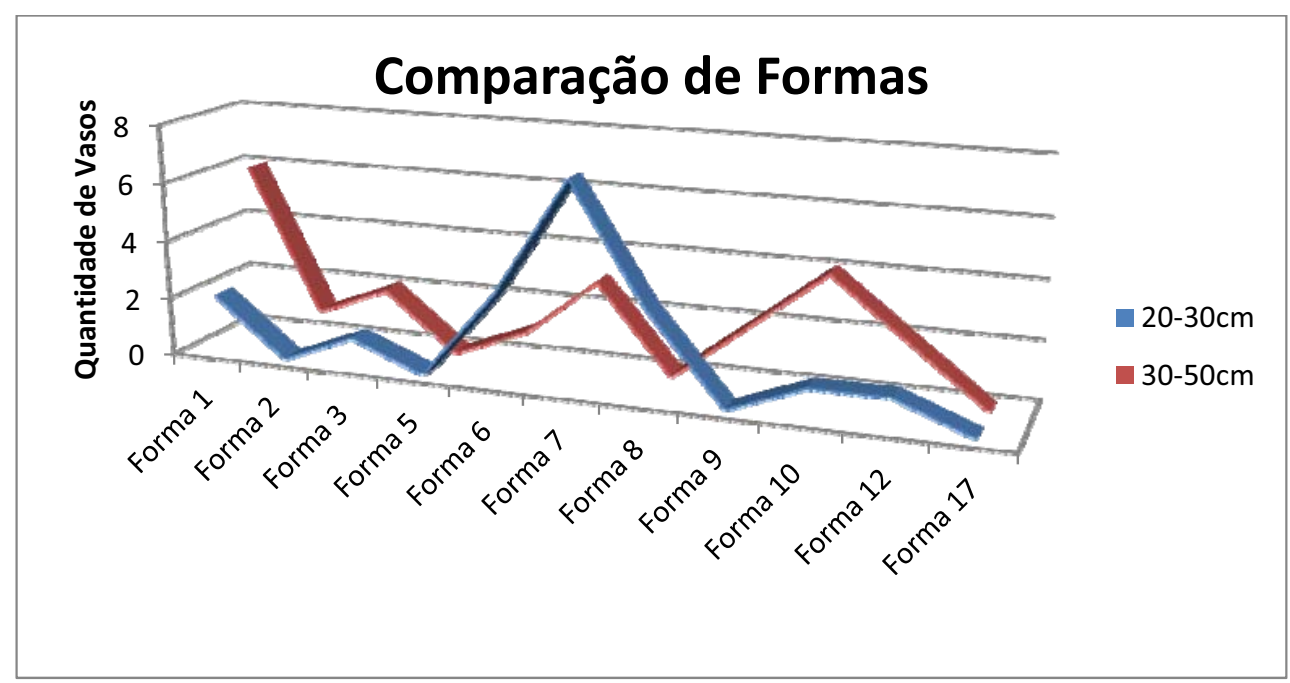

Tabela 34: Comparação entre as formas cerâmicas dos níveis $20-30 \mathrm{~cm}$ e $30-50 \mathrm{~cm}$ das unidades N1030 E1002 e N1031 E1002.

\subsection{Sítio Nova Vida}

Apesar da considerável quantidade de intervenções (79 sondagens e 2 unidades), o sítio Nova Vida apresentou uma baixa densidade de material em comparação com os demais sítios e com sítios amazônicos a céu aberto em geral. Se a quantidade de material foi baixa, a quantidade de diagnósticos foi ínfima: um total de 68 fragmentos. A baixa quantidade de diagnósticos se explica, em parte, devido à alta frequência de fragmentos erodidos. Apenas 12 fragmentos (18\% do total) não apresentavam nenhum tipo de erosão, a frequência mais baixa entre os sítios analisados. Cabe aqui apontar também a significativa presença de fragmentos craquelados em uma ou ambas as faces, cerca de $15 \%$ da amostra, a maior porcentagem entre os sítios. Da mesma forma, somente quatro fragmentos possuíam queima completa (7\%), o que faz da cerâmica do sítio Nova Vida a mais mal queimada do universo estudado, e o que ajuda a compreender o caráter friável desse material, que levou a altas frequências de erosão.

As peças analisadas se resumiram a fragmentos de parede, borda e base, com técnica de manufatura acordelada identificada em apenas $10 \%$ da coleção. O antiplástico predominante foi o caraipé. A ausência desse antiplástico foi constatada em apenas dois fragmentos, nos quais só havia mineral na pasta. Quando identificado, o caraipé estava 
sozinho ou acompanhado de antiplástico mineral e/ou carvão. O antiplástico, em geral, possuía espessura entre 1 e $3 \mathrm{~mm}$. No entanto, é necessário apontar que esse sítio possuiu as maiores frequências de peças com antiplástico entre 3 e $5 \mathrm{~mm}(25 \%)$ e maior ou igual a $5 \mathrm{~mm}$ (12\%), mais um indício de que essa cerâmica seja "rústica". A porcentagem desse antiplástico na pasta, por sua vez, foi bem distribuída, havendo uma pequena concentração de peças com o antiplástico representando entre $5 \%$ e $10 \%$ da pasta.

A superfície das peças possuía cores entre um amarelo/laranja e um cinza/ marrom. Nas peças não erodidas, foram em geral identificadas superfícies com alisamento fino. Curiosamente, esse sítio possui (junto com o sítio Associação Calderita) uma das maiores frequências de alisamento médio na face interna (12\%), ao mesmo tempo em que possui uma das maiores frequência de fragmentos polidos na face externa (13\%), também como o sítio Associação Calderita.

O tratamento de superfície predominante foi a barbotina (engobo marrom), identificada na face externa de 11 fragmentos (16\%). Foram observados fragmentos com engobo vermelho ou esfumarado, mas em baixa quantidade. Três quartos dos fragmentos analisados não possuíam tratamento de superfície. Por outro lado, cerca de $40 \%$ da amostra possuía vestígios de fuligem em pelo menos uma das faces.

As espessura dos fragmentos variou entre 0,5 e $2 \mathrm{~cm}$, com média aproximada de $1,2 \mathrm{~cm}$, que diminui para $0,85 \mathrm{~cm}$ se retirados os fragmentos de base. As bordas do sítio Nova Vida eram diretas ou extrovertidas, em geral com inclinação externa e espessura normal. Também foram identificados dois fragmentos com reforço e outros dois com a borda contraída. Todas as nove bases da coleção eram planas. O grau de fragmentação e erosão das bordas impediu que fossem realizadas reconstituições das vasilhas. Ainda assim, como não foram observadas carenas, pode-se supor que as vasilhas possuíam contorno simples ou, por vezes, inflectidos, conforme parece sugerir a curvatura de alguns fragmentos de borda e parede analisados.

Não foi observado nenhum tipo de decoração pintada. As decorações plásticas se resumiram a cinco fragmentos com decoração incisa. Apesar de essa decoração possuir traços bastante irregulares, em comparação com os demais sítios (com exceção do Jacarezinho), esses traços em geral formavam motivos horizontais, transversais ou verticais longos. 


\section{Sítio: Nova Vida}

Categoria: 37 paredes, 22 bordas, 9 bases

Técnica de Manufatura: 7 acordeladas, 1 uso de placas, $\mathrm{NI}=60$ frag.

Antiplástico: 2 mineral, 22 caraipé, 39 mineral+caraipe, 4 caraipé+carvão+mineral, 1 caraipé+ carvão

Espessura do Antiplástico: 9 frag. $<1 \mathrm{~mm}, 34$ frag. $=>1 \mathrm{~mm}$ e $<3 \mathrm{~mm}, 17$ frag. $=>3 \mathrm{~mm}$ e $<5 \mathrm{~mm} ; 8$ frag. $=>5 \mathrm{~mm}$

Porcentagem do Antiplástico: 27 frag. 5\%, 19 frag. 10\%, 11 frag. 20\%, 11 frag. 30\%, Cor: 32 ocre, 19 laranja, 7 cinza, 3 preto, 5 marrom

Queima: 5 completa (oxidada), 7 FI clara e FE escura, 15 FI escura e FE clara, 1 núcleo claro fino, 14 núcleo escuro espesso, 2 núcleo escuro fino, 122 núcleo totalmente escuro, $\mathrm{NI}=4$ frag.

Estado de Conservação: 1 não erodido, 12 erodido AF, 10 erodido FI, 6 erodido $\mathrm{FE}$, 9 craquelê AF, 2 craquelê FE, 1 craquelê FI, 13 outros.

Alisamento Face Interna: 39 fino, 8 médio, 2 polido, $\mathrm{NI}=19$

Alisamento Face Externa: 47 fino, 5 médio, 9 polidos, $\mathrm{NI}=7$

Tratamento de Superfície FI: 2 engobo vermelho, 1 barbotina, 1 esfumarado, $\mathrm{NI}=64$

Tratamento de Superfície FE: 3 engobo vermelho, 11 barbotina, 4 esfumarado $\mathrm{NI}=50$

Marcas: $\mathrm{NI}=68$

Sinais de Uso: 22 fuligem $\mathrm{FE}, 5$ fuligem $\mathrm{Fl}, 1$ película de alimento $\mathrm{FI}, 1$ outro, $\mathrm{NI}=39$

Morfologia da Borda e Flange: 13 direta, 6 extrovertida, $\mathrm{NI}=3$

Inclinação da Borda: 2 vertical, 3 inclinada interna, 14 inclinada externa, $\mathrm{Ni}=3$

Espessura da Borda: 17 normal, 2 contraída, 1 reforçada interna, 1 reforçada externa, $\mathrm{NI}=1$

Lábio: 21 arredondado, $\mathrm{NI}=1$

Base: 9 plana

Diâmetro da Base: $\mathrm{NI}=9$

Espessura do Fragmento: 2 menor que 0,6cm, 38 entre 0,6 e 1,0cm, 19 entre 1,1 e 1,5cm, 8 maior que $1,5 \mathrm{~cm}, \mathrm{NI}=1$

Decoração Plástica: 5 incisão fina, 1 entalhado, NI = 62

PALMA

Decoração Pintada: $\mathrm{NI}=68$

Motivo Decorativo: 2 horizontal + vertical longa, 1 transversal, 1 horizontal + transversal Local de Decoração FI: 1 lábio Local de Decoração FE: 3 parede, 1 lábio

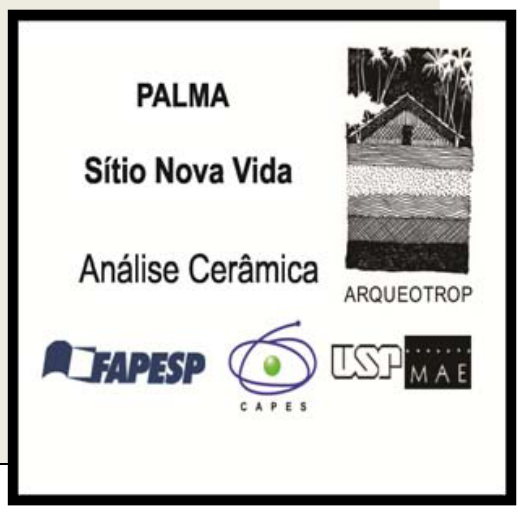




\subsection{Sítio Jacarezinho}

\subsubsection{Cerâmica}

A coleção obtida a partir das intervenções no sítio Jacarezinho possuía 925 diagnósticos: fragmentos de parede, borda e base. As exceções foram um único fragmento de carena, uma asa e duas peças arredondadas (reciladas) que podem ser contas ou rodas de fuso não finalizadas (Fig. 111). Foi possível observar a técnica de manufatura acordelada em 391 fragmentos (42\%) e a de sobreposição de placas em outros 12 fragmentos.

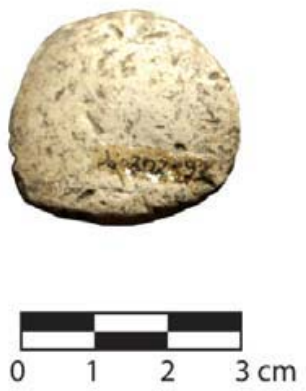

Figura 111: Fragmento cerâmico arredondado, que pode ser uma conta ou uma roda de fuso não finalizada (foto: Acervo PALMA).

O caraipé foi o antiplástico predominante, sendo encontrado em quase $90 \%$ da amostra analisada. Esse antiplástico foi observado, em geral, sozinho, mas houve uma expressiva quantidade de fragmentos nos quais o caraipé foi combinado com carvão (189 peças). O carvão foi, além disso, praticamente o único antiplástico observado em fragmentos que não possuíam caraipé, cerca de $10 \%$ do total. Foi observado, em alguns fragmentos cerâmicos, um tipo distinto de caraipé (caraipé B), assim como ocorreu no sítio Itapirema (vide abaixo), ainda que sua presença no sítio Jacarezinho tenha sido ínfima. A maioria dos antiplásticos possuía espessura entre 1 e $3 \mathrm{~mm}$ e constituía entre $5 \%$ e $10 \%$ da pasta das peças.

Cerca de $40 \%$ do total de fragmentos possuíam coloração amarelada. Houve uma quantidade bem próxima de fragmentos laranja, marrom e cinza, cada uma das cores representando cerca de $15 \%$ do total. Quase metade das peças possuía núcleo totalmente escuro, havendo baixa frequência de fragmentos com queima completa (8\%). 
Um pouco mais da metade dos fragmentos não possuía nenhum tipo de erosão, frequência inferior apenas à do sítio Teotônio, o que indica que os fragmentos cerâmicos do sítio Jacarezinho estavam bem conservados. Além disso, como veremos abaixo, apesar de o material cerâmico desse sítio não possuir decorações ou formas elaboradas, os vasos não são de forma alguma "mal feitos". Pelo contrário, a cerâmica do sítio Jacarezinho possuía as maiores frequências de fragmentos bem alisados. Cerca de $73 \%$ das faces internas e $84 \%$ das faces externas dos fragmentos possuía alisamento fino, e 5\% dos fragmentos eram polidos.

Houve baixa quantidade de fragmentos com tratamentos de superfície. A maior presença foi a de engobo marrom (barbotina) e esfumarados, encontrados, respectivamente, em $15 \%$ e $5 \%$ das faces externas. Os engobos branco e vermelho foram quase ausentes na coleção. Em alguns fragmentos com engobo vermelho, foi nítida a diferença de pasta (cor mais clara, queima mais completa, espessura mais fina) com relação à indústria cerâmica do sítio, sugerindo que o material seria exógeno.

Mais de 40\% dos fragmentos diagnósticos do sítio Jacarezinho possuíam fuligem na face externa. Dado que aponta uma grande quantidade de vasos para a cocção de alimentos por parte dos antigos habitantes do sítio. A espessura dos fragmentos variou entre $0,4^{103} \mathrm{e}$ $3,5 \mathrm{~cm}$, com média geral de $1,1 \mathrm{~cm}$.

Foram analisadas 323 bordas nesse sítio, que possuiu a maior quantidade de bordas com morfologia direta, apontando vasos com contorno simples. Também houve presença significativa de bordas introvertidas $-6 \%$ pode parecer pouco, mas é a maior frequência entre os sítios analisados - sendo que 13 das 19 dessas bordas possuíam fuligem, o que corrobora uma associação razoavelmente clara entre formas fechadas e funções ligadas ao fogo.

A reconstituição das bordas do sítio Jacarezinho gerou oito formas tipológicas. A predominância foi de vasilhas abertas semi-esféricas (forma 7) ou em forma de calota (forma 10). Foram reconstituídos cinco pratos (assadores?), a maior amostra dessa forma entre os sítios estudados.

\footnotetext{
${ }^{103}$ Há indicação de uma peça com $0,2 \mathrm{~cm}$ que não deve ser considerada por causa da elevada erosão na face interna, que deve ter mascarado a espessura do fragmento.
} 


\section{Sítio: Jacarezinho}

Categoria: 575 paredes, 323 bordas, 24 bases, 1 carena, 1 outros

Técnica de Manufatura: 391 acordeladas, 12 uso de placas, NI = 522 frag.

Antiplástico: 21 mineral, 515 caraipé, 96 carvão, outros 291

Espessura do Antiplástico: 187 frag. $<1 \mathrm{~mm}, 604$ frag. =>1mm e $<3 \mathrm{~mm}, 113$ frag. =>3mm e $<5 \mathrm{~mm}$; $21 \mathrm{frag} .=>5 \mathrm{~mm}$

Porcentagem do Antiplástico: 321 frag. 5\%, 371 frag. 10\%, 180 frag. 20\%, 53 frag. 30\%

Cor: 30 branco, 377 ocre, 143 laranja, 14 vermelho, 110 cinza, 58 preto, 145 marrom

Queima: 77 completa (oxidada), 19 FI clara e FE escura, 69 FI escura e FE clara, 2 núcleo claro fino, 239 núcleo escuro espesso, 42 núcleo escuro fino, 438 núcleo totalmente escuro, $\mathrm{NI}=1$ frag.

Estado de Conservação: 471 não erodido, 125 erodido AF, 206 erodido FI, 42 erodido FE, 27 craquelê $\mathrm{AF}, 19$ craquelê $\mathrm{FE}, 7$ craquelê $\mathrm{FI}, 27$ outros

Alisamento Face Interna: 679 fino, 75 médio, 2 grosso, 42 polido, NI = 127

Alisamento Face Externa: 774 fino, 49 médio, 4 grosso, 44 polidos, $\mathrm{NI}=54$

Tratamento de Superfície FI: 9 eng. verm., 2 eng. branco, 96 barbotina, 27 esfumarado, NI = 791

Tratamento de Superfície FE: 13 eng. verm., 9 eng. branco, 135 barbotina, 43 esfumarado , NI=725

Marcas: 26 furo, 4 estrias de alisamento, 1 marcas de dedo, $\mathrm{NI}=892$

Sinais de Uso: 393 fuligem FE, 35 fuligem $\mathrm{FI}, 1$ película de alimento $\mathrm{FI}, 26$ outros, $\mathrm{NI}=470$

Morfologia da Borda e Flange: 265 direta, 23 extrovertida, 19 introvertida, $\mathrm{NI}=16$

Inclinação da Borda: 64 vertical, 62 inclinada interna, 162 inclinada externa, NI = 35

Espessura da Borda: 276 normal, 24 contraída, 6 reforçada interna, 3 reforçada externa, 2 outros, $\mathrm{NI}=12$

Lábio: 275 arredondado, 35 plano, 2 apontado, 2 biselado , $\mathrm{NI}=9$

Base: 16 plana, 2 plano-convexo, 2 convexa, $\mathrm{NI}=4$

Diâmetro da Base: 6 frag. $>5$ e $<=10 \mathrm{~cm}, 2$ frag. $>10$ e $<=15 \mathrm{~cm}$

Espessura do Fragmento: 15 menor que $6 \mathrm{~mm}, 526$ entre $6 \mathrm{~mm}$ e $10 \mathrm{~mm}, 276$ entre 11 e $15 \mathrm{~mm}, 83$ maior que $1,5 \mathrm{~mm}, \mathrm{NI}=25$

Decoração Plástica: 4 incisão fina, $\mathrm{NI}=925$

Decoração Pintada: $\mathrm{NI}=925$

Motivo Decorativo: 1 trançado

PALMA

Local de Decoração FI : 1 lábio

Local de Decoração FE: 2 parede, 1 base

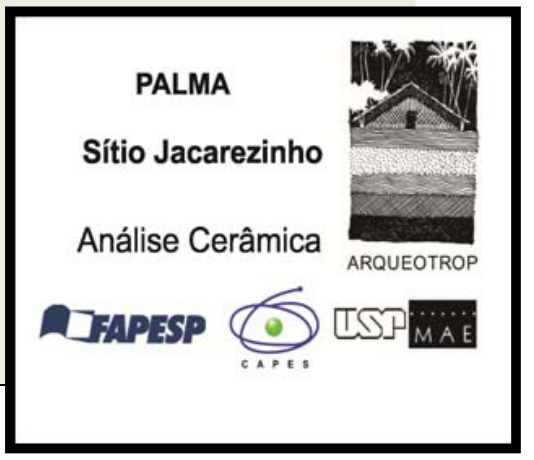




\begin{tabular}{|c|c|}
\hline \multicolumn{2}{|r|}{ Tipologia Cerâmica do Sítio Jacarezinho } \\
\hline Forma 1 & $\begin{array}{l}\text { Vasilha esférica, com contorno simples e boca constrita. Borda direta ou } \\
\text { introvertida, com inclinação interna ou vertical, espessura normal ou } \\
\text { contraída, lábio plano ou biselado. O diâmetro da boca varia de } 10 \text { a } 30 \mathrm{~cm} \text {, e } \\
\text { o volume, de } 0,5 \text { a } 20,71 \text {. Tratamento de superfície: barbotina (FE e FI). } \\
\text { Antiplástico: caraipé, mineral. }\end{array}$ \\
\hline Forn & $\begin{array}{l}\text { Vasilha esférica, com contorno simples e boca aberta. Borda direta, inclinada } \\
\text { vertical, com espessura normal e lábio arredondado ou plano. O diâmetro da } \\
\text { boca varia de } 10 \text { a } 26 \mathrm{~cm} \text {, e o volume, de } 0,2 \text { a } 5,11 \text {. Tratamentos de superfície: } \\
\text { - } \\
\text { Antiplástico: caraipé, carvão. }\end{array}$ \\
\hline Forma 3 & $\begin{array}{l}\text { Vasilha esférica, com contorno inflectido e boca constrita. Borda direta ou } \\
\text { extrovertida, inclinação vertical, interna ou externa, espessura normal ou } \\
\text { contraída, lábio arredondado, plano ou apontado. O diâmetro da boca varia de } \\
8 \text { a } 22 \mathrm{~cm} \text {, e o volume, de } 0,7 \text { a } 2,31 \text {. Tratamento de superfície: esfumarado } \\
\text { (FI). Antiplástico: caraipé, carvão, mineral. }\end{array}$ \\
\hline & $\begin{array}{l}\text { Vasilha esférica com pescoço, contorno inflectido e boca constrita. Borda } \\
\text { extrovertida, inclinada externa, espessura normal e lábio arredondado. } \\
\text { Diâmetro da boca de } 12 \mathrm{~cm} \text {, e volume de } 2,151 \text {. Tratamento de superfície: - } \\
\text { Antiplástico: caraipé, carvão. }\end{array}$ \\
\hline Form & $\begin{array}{l}\text { Vasilha esférica com pescoço, contorno inflectido e boca constrita. Borda } \\
\text { direta ou introvertida, com inclinação vertical, interna ou externa, espessura } \\
\text { normal ou expandida, lábio arredondado ou plano. O diâmetro da boca varia } \\
\text { de } 13 \text { a } 40 \mathrm{~cm} \text {, e o volume, de } 0,1 \text { a } 14,71 \text {. Tratamento de superfície: barbotina } \\
\text { (FE e FI). Antiplástico: caraipé, carvão, mineral. }\end{array}$ \\
\hline Forma 7 & $\begin{array}{l}\text { Vasilha semi-esférica, com contorno simples e boca aberta. Borda direta ou } \\
\text { extrovertida, com boca vertical ou externa, espessura normal ou contraída, } \\
\text { lábio arredondado ou plano. O diâmetro da boca varia de } 10 \mathrm{a} 40 \mathrm{~cm} \text {, e o } \\
\text { volume, de } 0,2 \text { a 12,2l. Tratamento de superfície: barbotina (AF), esfumarado } \\
\text { (AF). } \\
\text { Antiplástico: caraipé, carvão, mineral, argila moída. }\end{array}$ \\
\hline Forma 10 & $\begin{array}{l}\text { Vasilha em forma de calota, com contorno simples e boca aberta. Borda } \\
\text { direta, introvertida ou extrovertida, espessura normal ou contraída, lábio } \\
\text { arredondado ou plano. O diâmetro da boca varia de } 9 \text { a } 36 \mathrm{~cm} \text {, e o volume, de } \\
0,2 \text { a } 5,21 \text {. } \\
\text { Tratamento de superfície: barbotina (AF), esfumarado (AF). Antiplástico: } \\
\text { caraipé, carvão, argila moída. }\end{array}$ \\
\hline $\begin{array}{c}\text { Forma } 11 \\
\text { S/Reconstituição }\end{array}$ & $\begin{array}{l}\text { Vasilha em forma de calota, com contorno simples e boca constrita. Borda } \\
\text { direta, inclinada externa, espessura normal, com lábio contraído. Diâmetro da } \\
\text { boca de } 26 \mathrm{~cm} \text { (sem volume calculado). Tratamento de superfície: - } \\
\text { Antiplástico: caraipé, mineral. }\end{array}$ \\
\hline Forma 17 & $\begin{array}{l}\text { Vasilha rasa (prato). Borda direta, inclinada externa, espessura normal e lábio } \\
\text { arredondado. Diâmetro entre } 48 \text { e } 54 \mathrm{~cm} \text {. Tratamento de superfície: barbotina } \\
\text { (FE e FI). Antiplástico: caraipé, carvão. }\end{array}$ \\
\hline
\end{tabular}


O sítio Jacarezinho não possuiu nenhum fragmento com decoração pintada. A decoração plástica se resumiu a quatro fragmentos com incisões, encontradas nas paredes externas das peças.

No Capítulo 4, foram apresentadas as três datações por AMS feitas para o sítio, e a partir delas se inferiu que o local havia sido ocupado durante dois eventos do período précolonial. Pôde-se observar também que a segunda ocupação, ao que parece, ocorreu em uma área muito maior do que a primeira, mas não ficou claro se o sítio foi reocupado por um grupo distinto ou não. Durante a análise de laboratório, não foram observadas diferenças entre o material diagnóstico dos diferentes níveis, o que se confirma se comparada praticamente qualquer variável dos níveis $0-20 \mathrm{~cm}$ (1300 d.C.) e $30-50 \mathrm{~cm}(1100$ d.C.) das unidades N995 E1000 e N996 E1000, locais onde foi coletado o material datado (Tabela 38).

\begin{tabular}{|l|l|l|l|l|l|l|l|}
\hline $\begin{array}{c}\text { Níveis } \\
\text { (cm) }\end{array}$ & $\begin{array}{c}\text { Datação } \\
\text { convencio- } \\
\text { nal }\end{array}$ & $\begin{array}{c}\text { Quant. } \\
\text { de frag. }\end{array}$ & $\begin{array}{c}\text { Antiplás- } \\
\text { tico }\end{array}$ & $\begin{array}{c}\text { Trat. de } \\
\text { sup. FE }\end{array}$ & $\begin{array}{c}\text { Morfolo- } \\
\text { gia da } \\
\text { borda }\end{array}$ & $\begin{array}{c}\text { Inclinação } \\
\text { da borda }\end{array}$ & \multicolumn{1}{|c|}{ Lábio } \\
\hline $0-10$ & 1300 d.C. & 229 & Caraipé & $\begin{array}{l}\text { Barbotina } \\
\text { Esfuma- } \\
\text { rado }\end{array}$ & Direta & Externa & Arredondado \\
\hline $\begin{array}{l}30-40 \\
40-50\end{array}$ & 1100 d.C. & 268 & Caraipé & $\begin{array}{l}\text { Esfuma- } \\
\text { rado }\end{array}$ & Direta & Externa & Arredondado \\
\hline
\end{tabular}

Tabela 38: Comparação dos atributos cerâmicos das duas ocupações do sítio Jacarezinho.

Se observada a Tabela 38, pode-se notar essa semelhança entre o material das duas ocupações. A única pequena diferença é que, nos níveis $0-20 \mathrm{~cm}$, há um número próximo de fragmentos com esfumarado (25) e barbotina (32) como tratamento de superfície na face externa das peças, o que não ocorre nos níveis $30-50 \mathrm{~cm}$, onde há predomínio de fragmentos com barbotina. Quando comparadas as formas cerâmicas das duas ocupações, pode-se perceber com clareza uma semelhança entre os níveis (predomínio das formas 7 e 10). No entanto, os níveis $30-50 \mathrm{~cm}$ possuem uma série de formas $(3,5,17)$ que não aparecem nos níveis $0-20 \mathrm{~cm}$, ainda que em todos os casos se trate apenas de um exemplar (Tabela 39). 


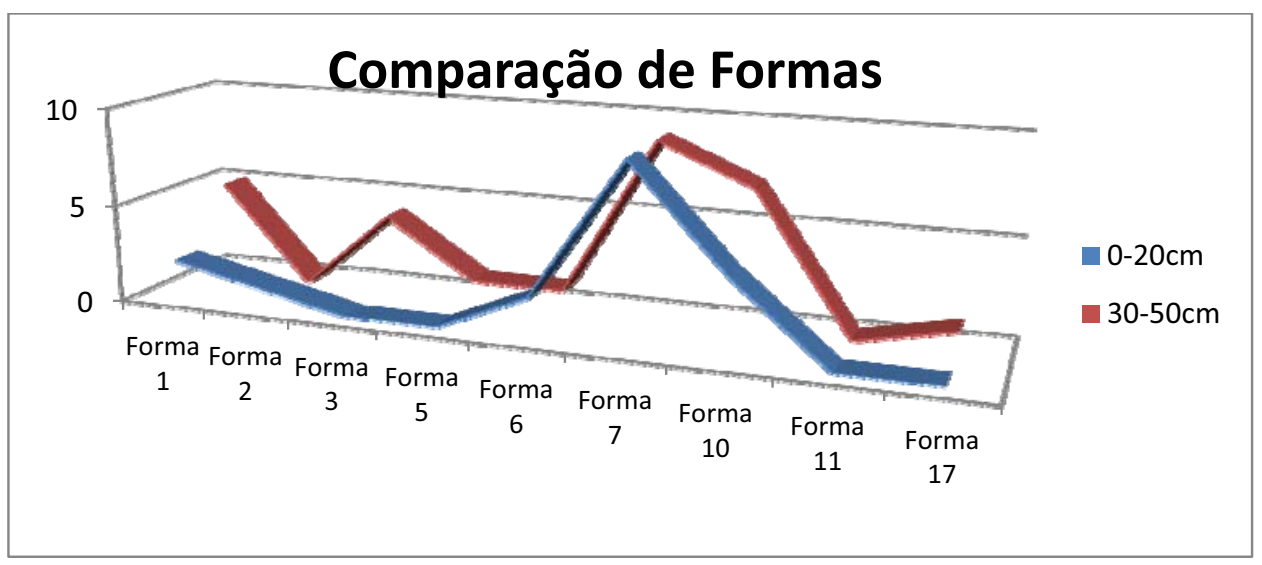

Tabela 39: Comparação entre as formas dos níveis $0-20 \mathrm{~cm}$ e 30-50cm das unidades $\mathrm{N995}$ E1000 e $\mathrm{N996}$ E1000.

A análise de agrupamentos - feita a partir das variáveis antiplástico, decoração plástica, decoração pintada, tratamento de superfície FE e forma do material diagnóstico das unidades N995 E1000 e N996 E1000- também confirmou a inexistência de grupos distintos em cada uma das datações (BARROSO et al., 2012: 37; Anexo $15 \mathrm{~K}$ ). Dessa forma, os dados cerâmicos indicam com clareza que o sítio foi ocupado por um único grupo, em duas ocasiões.

\subsubsection{Lítico}

Assim como os demais sítios, com exceção do Teotônio, o Jacarezinho apresentou uma amostra praticamente nula de material lítico. A exceção foi uma lâmina de machado polida fragmentada, com matéria-prima de granito e marcas de encabamento (Fig. 112).

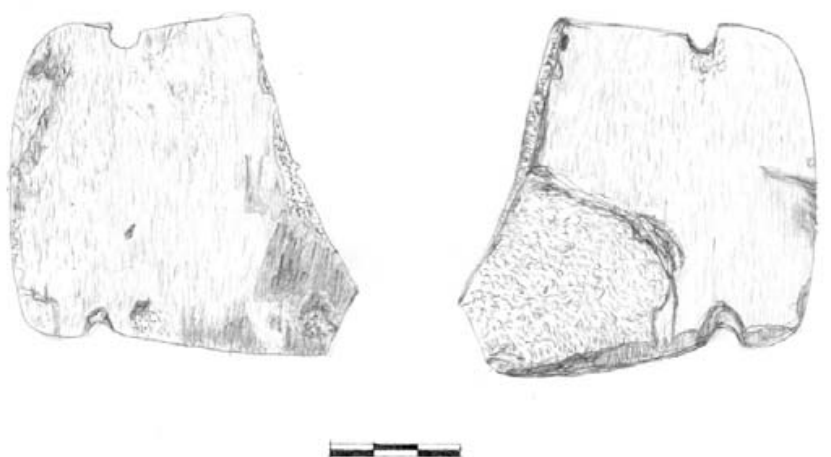

Figura 112: Lâmina de machado fragmentada encontrada no sítio Jacarezinho (desenho: Paulo Arena). 


\subsection{Sítio Itapirema}

\subsubsection{Cerâmica}

O sítio Itapirema possuiu a maior quantidade de fragmentos diagnósticos (2.088 peças) entre os sítios analisados, o que se deve à maior quantidade de intervenções realizadas em campo, à densidade de material e, principalmente, à sofisticação da sua cerâmica (mais fragmentos decorados, mais diagnósticos). Sem dúvida, trata-se da indústria cerâmica mais elaborada (em relação à forma e à decoração) dentre os sítios estudados.

A amostra encontrava-se dividida entre fragmentos de parede, borda (e flange), base, carenas e uma peça modelada (estatueta?). Não foi possível identificar a técnica de manufatura em cerca de $50 \%$ dos fragmentos. A outra metade da amostra ficou dividida em 861 fragmentos acordelados (41\%), 15 fragmentos modelados (1\%) e 160 fragmentos feitos com sobreposição de placas (8\%).

O sítio Itapirema foi o único que não possuiu predominância do antiplástico caraipé, superado em frequência pelo cauixi, presente em quase $85 \%$ dos fragmentos (combinado ou não com o caraipé). Apesar de não ser o antiplástico predominante, o caraipé foi identificado em duas distintas formas: caraipé A e caraipé B (Figs. 113 e 114).

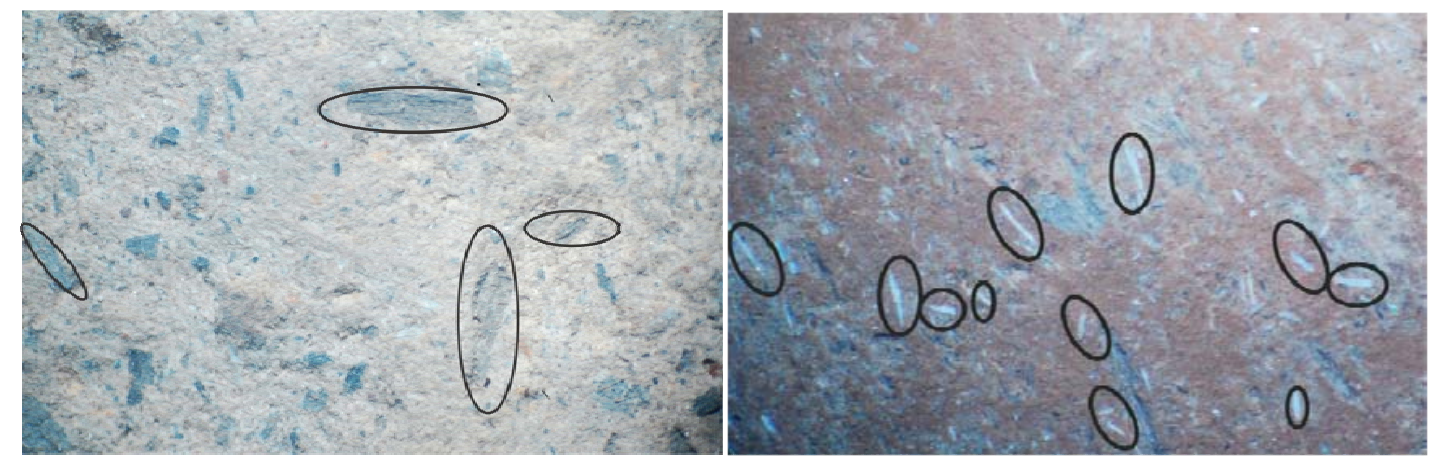

Figura 113: Caraipé A.

Figura 114: Bastonetes, caraipé B (fotos: Fernando Ozorio de Almeida, sem escala).

A predominância do cauixi como antiplástico levou também a uma diferenciação quanto à espessura (menor ou igual a $1 \mathrm{~mm}$ ) e à quantidade de partículas de antiplástico na pasta (em torno de 30\%). Isso porque as espículas de cauixi possuem dimensão reduzida e, em geral, são encontradas em grande quantidade na pasta cerâmica. 
Assim como nos demais sítios, a cor predominante das pastas foi o amarelo/ocre. No entanto, o sítio Itapirema possuiu uma quantidade de fragmentos com superfície branca $(10 \%)$ e uma distribuição relativamente próxima de fragmentos entre as diferentes cores de superfície, variando entre 5\% (marrom, menos frequente) e 30\% (amarelo, mais frequente). Essa variação de cores podia ser observada em um mesmo fragmento, já que em vários momentos foi observada a presença de mais de uma argila na pasta cerâmica (Fig. 115). Há documentação etnográfica do uso de mais de um tipo de argila na Amazônia, como nos vasos dos Shipibo-Conibo, habitantes do rio Ucayali, que utilizam até três tipos de argila em um mesmo vaso. Nesse exemplo, a mistura de argilas ocorre apenas em determinados tipos de vaso, como os para servir alimentos e bebidas fermentadas (DEBOER e LATHRAP, 1979: 116-119). Nenhum dos 17 fragmentos do sítio Itapirema identificados com mistura de argila gerou uma reconstituição do vaso, sendo impossível testar a relação entre tal mistura e as funções inferidas por DeBoer e Lathrap.

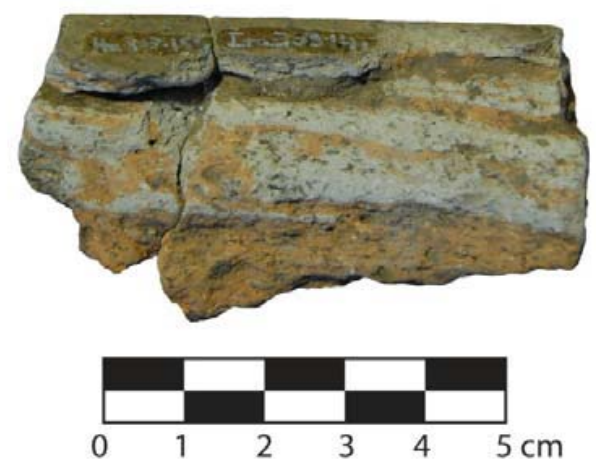

Figura 115: Fragmento Ita-303-41 - borda com presença de dois tipos distintos de argila (foto: acervo PALMA).

O sítio Itapirema também apresentou a maior frequência de peças bem queimadas dentre todos os sítios. Do total analisado, $36 \%$ das peças possuíam queima completa, e outros $18 \%$ possuíam apenas um fino núcleo escuro. Por consequência, esse é o sítio que possuiu menor frequência de fragmentos com núcleo totalmente escuro: 17\%.

Quanto ao estado de conservação, pode-se indicar que $43 \%$ dos fragmentos não estavam erodidos, ao passo que $26 \%$ dos fragmentos possuíam erosão em ambas as faces, e $21 \%$ apresentavam erosão apenas na face interna. Houve poucos fragmentos craquelados (Fig. 116). As superfícies dos fragmentos eram bem alisadas: o alisamento fino na face interna foi observado em $71 \%$ do total, e o na face externa, em $83 \%$. No entanto, apesar de bem alisados, e apesar da indicação de que se tratava da cerâmica mais "sofisticada" dentre 
os sítios analisados, o sítio Itapirema possuiu a menor frequência de fragmentos polidos, de $1 \%$ para ambas as faces.

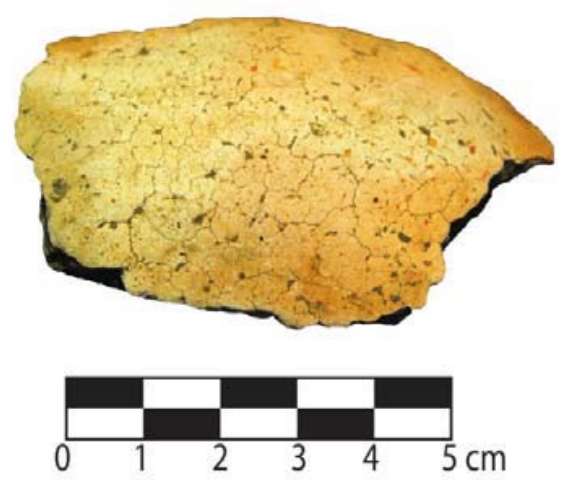

Figura 116: Fragmento Ita-303-104 - engobo branco e craquelado na face externa (foto: Fernando Ozorio de Almeida).

Por outro lado, o sítio possuiu a maior frequência de fragmentos com tratamentos de superfície na face interna, e a segunda maior frequência de tratamentos na face externa, depois do sítio Associação Calderita. Dentre os tratamentos da face externa, pode-se dar destaque à presença de barbotina, observada em $10 \%$ dos fragmentos, e do esfumarado, em $9 \%$ dos fragmentos. Os engobos vermelho e branco, que foram pouco identificados na face interna dos fragmentos, possuíam frequência muito maior na face externa, $21 \%$ e $14 \%$, respectivamente.

Durante a análise, especulou-se se a presença do esfumarado na face interna teria relação com o cauixi da pasta, uma maneira de impermeabilizar o vaso de forma a não deixar os alimentos entrarem em contato com as espículas da esponja (gerando desarranjo estomacal). No entanto, uma comparação entre ambas as categorias mostrou que, se o cauixi estava presente em quase $85 \%$ dos fragmentos, se encontrava em cerca de $75 \%$ dos fragmentos com esfumarado na face interna. Resultado insatisfatório para uma conclusão, deixando a questão em aberto.

Foram observados 16 fragmentos com estrias de alisamento, 10 fragmentos com furos nas paredes ou bordas e seis fragmentos com marcas de folhas. Apenas um fragmento possuía marcas de dedo. $\mathrm{O}$ sítio Itapirema apresentou a maior porcentagem de fragmentos sem fuligem, cerca de $80 \%$ da amostra. Apenas $10 \%$ da amostra possuíam fuligem na face externa, ante a pelo menos $40 \%$ nos sítios Associação Calderita e Jacarezinho. Os dados sugerem uma baixa quantidade de vasos levados ao fogo. Por outro lado, foram identificados 
fragmentos com película de alimento na face interna. Parte desses fragmentos está sendo analisada por André Colonese, da Univeridade de York (Grã-Bretanha).

A espessura dos fragmentos variou de 0,3 a $2,8 \mathrm{~cm}$, com média de $1 \mathrm{~cm}$. Trata-se de uma média intermediária com relação aos demais sítios: fragmentos mais espessos do que os dos sítios Teotônio e Associação Calderita e mais finos do que os do sítio Jacarezinho.

O sítio Itapirema possuiu a menor diferença entre a altura dos fragmentos de borda e as reconstituições geradas a partir dessas bordas: as bordas possuíam em média $25 \%$ do perfil inferido da vasilha. Logo, se observou que o sítio Itapirema possuía um grande número de formas abertas. Do total, $75 \%$ das bordas eram inclinadas externas. Da mesma forma, o sítio possuiu a maior frequência de fragmentos extrovertidos, $43 \%$, dos quais um terço são bordas extrovertidas com ponto angular. Pode-se dizer que as vasilhas rasas e abertas, com ponto angular, recorrentemente decoradas com incisões na face interna, eram as mais representativas desse sítio, fato identificado pela análise de correspondência (BARROSO et al., 2012: 31; Anexo 15 G). Vasos introvertidos ou apenas com a boca fechada foram pouco representativos na amostra.

Apesar de quase metade das bordas analisadas possuir espessura normal, em cerca de $30 \%$ das bordas havia algum tipo de reforço. O sítio Itapirema possuiu a maior frequência de bordas com reforço na face externa $(20 \%)$. Outro elemento que chamou a atenção foi a presença (rara) de bordas recortadas. Os lábios foram predominantemente arredondados (53\%), ainda que tenha sido identificada uma alta presença de lábios planos (32\%).

O sítio Itapirema apresentou uma grande quantidade de bases (143). As planas foram as mais observadas. No entanto, o que chamou a atenção foi a grande presença de bases côncavas, 11 ou $8 \%$ do total. Apesar de não parecer um número significativo - essas bases não são encontradas com frequência em sítios arqueológicos brasileiros (cf. PROUS, 1992) trata-se do sítio com maior quantidade de bases côncavas que o presente pesquisador já analisou. $\mathrm{O}$ diâmetro da base variou entre 4 e $24 \mathrm{~cm}$, com média de $12 \mathrm{~cm}$. 
Sítio: Itapirema

Categoria: 1275 paredes, 628 bordas ou flanges, 143 bases, 36 carenas, 5 outros

Técnica de Manufatura: 861 acordeladas, 15 modeladas, 160 uso de placas, $\mathrm{NI}=1052$ frag.

Antiplástico: 681 cauixí, 278 caraipé, 273 mineral + cauixi, 137 mineral + cauixi +caraipé,130 mineral + caraipé, 120 cariapé e cauixi, 84 mineral+cauixi+argila moída, 388 , outros $\mathrm{NI}=47$

Espessura do Antiplástico: 1074 frag. $<1 \mathrm{~mm}, 848$ frag. $=>1 \mathrm{~mm}$ e $<3 \mathrm{~mm}, 140$ frag. $=>3 \mathrm{~mm}$ e $<5 \mathrm{~mm} ; 21$ frag. $=>5 \mathrm{~mm}, \mathrm{NI}=5$

Porcentagem do Antiplástico: 88 frag. 5\%, 498 frag. 10\%, 643 frag. 20\%, 855 frag. 30\%, NI = 4 Cor: 217 branco, 636 ocre, 352 laranja, 180 vermelho, 330 cinza, 109 preto, 197 marrom, NI=67 Queima: 742 completa (oxidada), 78 FI clara e FE escura, 202 FI escura e FE clara, 25 núcleo claro fino, 209 núcleo escuro espesso, 376 núcleo escuro fino, 365 núcleo totalmente escuro, $\mathrm{NI}=26$ frag. Estado de Conservação: 889 não erodido, 551 erodido AF, 447 erodido FI, 121 erodido FE, 28 craquelê FE, 52 outros

Alisamento Face Interna: 1488 fino, 177 médio, 12 grosso, 22 polido, $\mathrm{NI}=389$

Alisamento Face Externa: 1590 fino, 153 médio, 16 grosso, 27 polido, NI = 157

Tratamento de Superfície FI: 71 eng. verm., 29 eng. branco, 199 barbotina, 196 esfum., NI = 1590

Tratamento de Superfície FE: 433 eng. verm., 300 eng. branco, 167 barb., 140 esfum., NI = 1545

Marcas: 16 estrias de alisamento, 6 marcas de folha, 10 furos, 1 marca de dedo, 3 outros, $\mathrm{NI}=2052$

Sinais de Uso: 201 fuligem FE, 130 fuligem FI, 6 película de alimento $\mathrm{FI}, 49$ outros , NI=1701

Morfologia da Borda e Flange: 220 direta, 173 extrovertida, 7 introvertida, 93 extrovertida com ponto angular, 13 extrovertida com ondulação, $\mathrm{NI}=102$

Inclinação da Borda: 41 vertical, 17 inclinada interna, 457 inclinada externa, outros 38, NI = 85

Espessura da Borda: 307 normal, 120 reforçada ext., 32 reforça int., 26 contraída, outros 38, NI = 85

Lábio: 325 arredondado, 196 plano, 34 apontado, 11 biselado, NI = 42

Base: 97 plana, 11 côncava, 10 plano-convexo, 4 anelar, $\mathrm{NI}=21$

Diâmetro da Base: 4 frag. $<=5 \mathrm{~cm}, 26$ frag. $>5$ e <=10cm, $41 \mathrm{frag} .>10$ e $<=15 \mathrm{~cm}, 11 \mathrm{frag} .>15 \mathrm{~cm}$

Espessura do Fragmento: 57 menor que 0,6cm, 1287 entre 0,6 e 1,0cm, 579 entre 1,1 e 1,5cm, 119 maior que $1,5 \mathrm{~cm}, \mathrm{NI}=46$

Decoração Plástica: 99 inciso fino, 42 inciso largo/acanalado, 1 digitado, 1 filete aplicado, NI = 1945

Decoração Pintada: 183 vermelho, 8 branco, 22 outras, $\mathrm{NI}=1875$

Motivo Decorativo: 101 horizontal, 12 complexa, 12 curcilinea,

2 angular, 8 grega, 1 vertical curta, $\mathrm{NI}=1933$

Local de Decoração Fl: 8 parede, 61 borda, 28 lábio, 16 outros Local de Decoração FE: 126 parede, 11 lábio, 68 borda, 8 bojo superior 20 outros, $\mathrm{NI}=1855$

PALMA

Sítio Itapirema

Análise Cerâmica

DAPESP

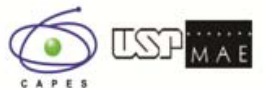




\begin{tabular}{|c|c|}
\hline \multicolumn{2}{|r|}{ Tipologia Cerâmica do Sítio Itapirema } \\
\hline Forma 1 & $\begin{array}{l}\text { Vasilha esférica, com contorno simples e boca constrita. Borda direta ou } \\
\text { extrovertida, com inclinação interna ou vertical, normal ou reforçada e } \\
\text { lábio plano. O diâmetro da boca varia de } 13 \text { a } 46 \mathrm{~cm} \text {, e o volume, de } 2 \text { a } 401 \text {. } \\
\text { Tratamento de superfície: pintura vermelha (FE), engobo branco (FE), } \\
\text { barbotina (FI). Antiplástico: cauixi, mineral, argila moída, caraipé. }\end{array}$ \\
\hline Forma 2 & $\begin{array}{l}\text { Vasilha esférica, com contorno simples e boca aberta. Borda direta, } \\
\text { inclinada interna, com espessura normal e lábio arredondado. Diâmetro da } \\
\text { boca de } 20 \mathrm{~cm} \text { e volume de } 2,41 \text {. Tratamento de superfície: engobo } \\
\text { vermelho (FE). Antiplástico: cauixi, argila moída, caraipé. }\end{array}$ \\
\hline & $\begin{array}{l}\text { Vasilha esférica, com contorno inflectido e boca constrita. Borda direta, } \\
\text { extrovertida, extrovertida com ponto angular, extrovertida com ondulação, } \\
\text { inclinação externa ou vertical, espessura normal, expandida, reforçada } \\
\text { externa, interna ou em ambas as faces, lábio arredondado, plano ou } \\
\text { apontado. O diâmetro da boca varia de } 13 \text { a } 56 \mathrm{~cm} \text {, e o volume. de } 1,2 \text { a } 641 \text {. } \\
\text { Tratamento de superfície: incisão (FI), acanalado (AF), pintura vermelha } \\
\text { (AF), engobo vermelho (AF), engobo branco (FE), esfumarado (FE). } \\
\text { Antiplástico: cauixi, mineral, argila moída, caraipé, carvão. }\end{array}$ \\
\hline Fo & $\begin{array}{l}\text { Vasilha esférica, com contorno inflectido e boca aberta. Borda direta, } \\
\text { extrovertida, extrovertida com ponto angular, extrovertida com ondulação, } \\
\text { inclinação externa, espessura normal, reforçada interna e externa, contraída } \\
\text { lábio arredondado, plano ou apontado. O diâmetro da boca varia de } 20 \text { a } \\
60 \mathrm{~cm} \text {, e o volume, de } 13 \text { a } 511 \text {. Tratamento de superfície: decoração pintada } \\
\text { (FE), engobo vermelho (FE), barbotina (FI), esfumarado (FI). Antiplástico: } \\
\text { cauixi, mineral, argila moída, caraipé. }\end{array}$ \\
\hline $\mathbf{F}$ & $\begin{array}{l}\text { Vasilha esférica com pescoço, contorno inflectido e boca constrita. Borda } \\
\text { extrovertida (com ou sem ponto angular), inclinação externa, espessura } \\
\text { normal, reforçada interna, externa ou em ambas as faces, lábio arredondado } \\
\text { ou plano. O diâmetro da boca varia de } 9 \text { a } 32 \mathrm{~cm} \text {, e o volume, de } 1,3 \text { a } 17,71 \text {. } \\
\text { Tratamento de superfície: acanalado (FI), pintura vermelha e branca (AF), } \\
\text { engobo vermelho (FE), barbotina (AF). Antiplástico: cauixi, mineral, argila } \\
\text { moída, caraipé. }\end{array}$ \\
\hline Form & $\begin{array}{l}\text { Vasilha semi-esférica, com contorno simples e boca constrita. Borda } \\
\text { extrovertida com ponto angular, inclinada externa, reforçada interna e lábio } \\
\text { arrendondado. Diâmetro da boca de } 26 \mathrm{~cm} \text { e volume de } 24,71 \text {. Tratamento } \\
\text { de superfície: - Antiplástico: cauixi, caraipé. }\end{array}$ \\
\hline Forr & $\begin{array}{l}\text { Vasilha semi-esférica, com contorno simples e boca aberta. Borda direta ou } \\
\text { extrovertida, inclinação interna, vertical ou externa, espessura normal ou } \\
\text { reforçada externa, lábio arredondado, plano ou biselado. O diâmetro da } \\
\text { boca varia de } 9 \text { a } 52 \mathrm{~cm} \text {, e o volume, de } 0,2 \text { a } 321 \text {. Tratamento de superfície: } \\
\text { incisão (AF), pintura vermelha (FE), engobo vermelho (FE), engobo branco } \\
\text { (FE), barbotina (FI), esfumarado (FI). Antiplástico: cauixi, mineral, argila } \\
\text { moída, carvão. }\end{array}$ \\
\hline Forma 8 & $\begin{array}{l}\text { Vasilha semi-esférica, com contorno inflectido e boca aberta. Borda direta, } \\
\text { extrovertida, extrovertida com ponto angular, extrovertida com ondulação, } \\
\text { inclinação externa, espessura normal, expandida, reforçada interna, externa, } \\
\text { em ambas as faces ou contraída, lábio arredondado, plano ou biselado. O } \\
\text { diâmetro da boca varia de } 7 \text { a } 50 \mathrm{~cm} \text {, e o volume, de } 0,05 \text { a } 24,51 \text {. } \\
\text { Tratamento de superfície: inciso (AF), acanalado (AF), pintura vermelha } \\
\text { (AF), pintura branca (AF), engobo vermelho (AF), engobo branco (AF), } \\
\text { barbotina (FI), esfumarado (FI). Antiplástico: cauixi, mineral, caraipé, } \\
\text { carvão. }\end{array}$ \\
\hline
\end{tabular}




\begin{tabular}{|c|c|}
\hline Forma 9 & $\begin{array}{l}\text { Vasilha semi-esférica, com contorno inflectido e boca constrita. Borda } \\
\text { extrovertida, inclinada externa, reforçada interna e lábio arredondado. } \\
\text { Diâmetro da boca de } 22 \mathrm{~cm} \text { e volume de } 4,21 \text {. Tratamento de superfície: - } \\
\text { Antiplástico: cauixi, mineral. }\end{array}$ \\
\hline Forma 10 & $\begin{array}{l}\text { Vasilha em forma de calota, com contorno simples e boca aberta. Borda } \\
\text { direta ou extrovertida, com inclinação externa, espessura normal, reforçada } \\
\text { interna, externa, em ambas as faces ou contraída, lábio arredondado, plano } \\
\text { ou apontado. O diâmetro da boca varia de } 14 \text { a } 38 \mathrm{~cm} \text {, e o volume, de } 0,4 \text { a } \\
3,21 \text {. Tratamento de superfície: inciso (AF), pintura vermelha (AF), pintura } \\
\text { branca (FE), engobo vermelho (FE), engobo branco (FE), barbotina (FE). } \\
\text { Antiplástico: cauixi, mineral, caco moído, caraipé. }\end{array}$ \\
\hline Forma 12 & $\begin{array}{l}\text { Vasilha em forma de calota, com contorno inflectido e boca aberta. Borda } \\
\text { direta, extrovertida (com ou sem ponto angular), inclinação externa, } \\
\text { espessura normal, expandida, reforçada externa, interna ou em ambas as } \\
\text { faces, lábio arredondado, plano, apontado ou biselado. O diâmetro da boca } \\
\text { varia de } 12 \text { a } 42 \mathrm{~cm} \text {, e o volume, de } 0,1 \text { a } 111 \text {. Tratamento de superfície: } \\
\text { inciso (AF), acanalado (FI), pintura vermelha (AF), engobo vermelho (AF), } \\
\text { engobo branco (AF), barbotina (AF), esfumarado (FI). Antiplástico: cauixi, } \\
\text { mineral, argila moída, caraipé. }\end{array}$ \\
\hline Forma 14 & $\begin{array}{l}\text { Vasilha com contorno composto. Borda extrovertida (com ou sem ponto } \\
\text { angular), inclinada externa, espessura, normal, externa ou interna, lábio } \\
\text { arredondado ou plano. O diâmetro da boca varia de } 12 \text { a } 44 \mathrm{~cm} \text {, e o volume, } \\
\text { de } 0,7 \text { a } 30,21 \text {. Tratamento de superfície: inciso (AF), pintura vermelha } \\
\text { (AF), pintura branca (FE), engobo vermelho (AF), barbotina (AF), } \\
\text { esfumarado (FI). } \\
\text { Antiplástico: cauixi, mineral, argila moída, caraipé. }\end{array}$ \\
\hline Forma 15 & $\begin{array}{l}\text { Vasilha com contorno complexo. Borda extrovertida com ponto angular, } \\
\text { inclinada externa, reforçada interna e lábio arredondado. Diâmetro da boca } \\
\text { de } 24 \mathrm{~cm} \text { e volume de } 5,11 \text {. Tratamento de superfície: - Antiplástico: cauixi, } \\
\text { mineral, caraipé. }\end{array}$ \\
\hline $\begin{array}{c}\text { Forma } 16 \\
\text { S/Reconstituição }\end{array}$ & $\begin{array}{l}\text { Vasilha angular (triangular/quadrangular). Sem reconstituição. Tratamento } \\
\text { de superfície: acanalado (FI), engobo vermelho (FE). Antiplástico: caraipé, } \\
\text { cauixi. }\end{array}$ \\
\hline Forma 17 & $\begin{array}{l}\text { Vasilha rasa (prato). Borda direta, inclinada externa, com espessura normal, } \\
\text { reforçada interna, externa ou contraída, lábio arredondado ou plano. O } \\
\text { diâmetro da boca varia de } 22 \text { a } 60 \mathrm{~cm} \text {. Tratamento de superfície: engobo } \\
\text { branco (FI), esfumarado (FE). Antiplástico: cauixi, mineral, argila moída, } \\
\text { caraipé, carvão. }\end{array}$ \\
\hline
\end{tabular}

Tabela 41: Relação das formas do sítio Itapirema.

O sítio Itapirema possuía uma grande quantidade (145) de fragmentos decorados, seja por meio de pinturas e/ou de decorações plásticas. No entanto, o que se percebeu no campo plástico foi uma grande quantidade com pequena variedade. Isto é, as decorações se restringiram a motivos incisos, finos ou largos (acanalados) em quase $99 \%$ dos fragmentos com decoração plástica. A decoração pintada se resumiu ao duo vermelho e branco, com grande predominância de pigmento vermelho, identificado em 205 dos 213 fragmentos com decoração pintada. Os locais de decoração também foram bastante restritos, em especial as 
incisões, quase sempre feitas na face interna de uma borda extrovertida com ponto angular (Fig. 117).
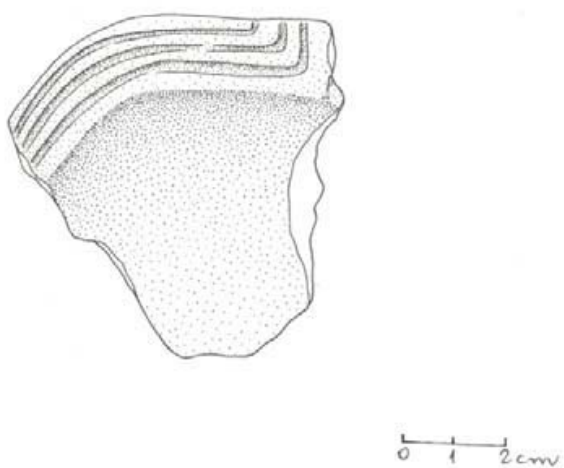

Figura 117: Fragmento Ita-802-16 - incisões realizadas na face interna de uma borda extrovertida com ponto angular e formato angular (desenho: Erêndira Oliveira).

Essas bordas extrovertidas com ponto angular também podem ser designadas flanges labiais $^{104}$. Em alguns casos foi observado que, além da decoração incisa, as flanges eram recortadas, o que aumentava o efeito estético. Foi observado em bordas recortadas, como no fragmento Ita-602-41, peça com formato angular (quadrangular?), que algumas incisões na face interna eram interrompidas pelos recortes na borda, ao passo que outras incisões contornavam os recortes.

A maioria dessas flanges recortadas e decoradas na face interna da borda eram tigelas rasas, em forma de calota. Em alguns casos, como o fragmento Ita-617-8, que possuía pintura vermelha e branca e uma perfuração em vez dos motivos incisos, a flange parecia ser desproporcional em relação ao restante do vaso, que aparentava ser uma tigela muito rasa e de pequeno diâmetro.

O sítio Itapirema possuiu a única peça modelada (figura tridimensional). Trata-se do fragmento Ita-322-1, uma provável representação de uma cabeça zoomórfica (Fig. 118). A peça possuiu incisões que caracterizam o zoomorfo, assim como pigmentos branco (engobo) e vermelho, este último bastante desgastado. Como a peça está fragmentada, é difícil ter certeza se ela possuía uma continuação, mas tudo indica que sim.

\footnotetext{
${ }^{104}$ No presente estudo, a diferença entre uma flange e uma borda reforçada é que a borda possui um único rolete aplicado a mais, e a flange, dois ou mais.
} 

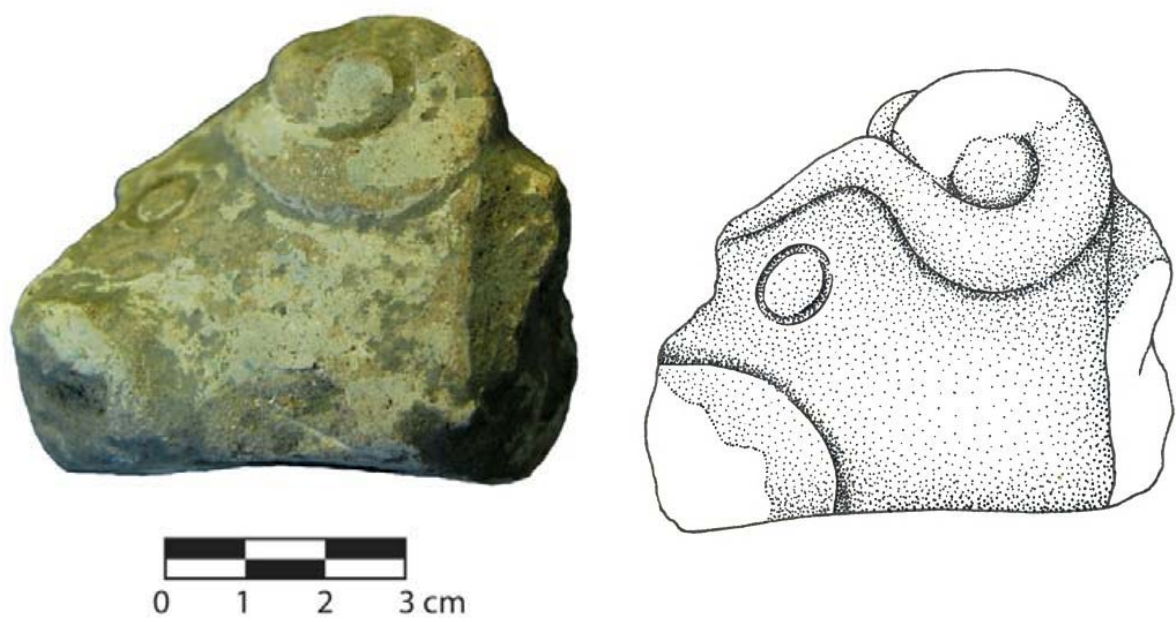

Figura 118: Fragmento Ita-322-1 - figura modelada zoomórfica (cabeça) fragmentada (foto: Fernando Ozorio de Almeida/desenho: Erêndira Oliveira).

No Capítulo 4, foram apresentadas as três datações realizadas para o sítio Itapirema. A proximidade das datas e a aparente uniformidade do pacote arqueológico (sem nenhuma amostra de interrupção) foram os elementos preponderantes para que se inferisse que o sítio havia sido ocupado uma única e longa vez durante o período pré-colonial, por volta de 1300 d.C. Durante a análise da cerâmica no laboratório, não foram percebidas variações que pudessem confirmar uma reocupação do sítio, tampouco variações espaciais dentro dele. Ainda assim, dada a grande extensão do sítio (com diâmetro superior a $1.000 \mathrm{~m}$ ), decidiu-se fazer testes estatísticos utilizando sondagens de três áreas diferentes dos sítios: a primeira (Região 1) contendo sondagens do setor oeste; a segunda (Região 2) na área de entorno do montículo escavado (no centro); e a terceira (Região 3), situada entre as duas anteriores (Anexo $15 \mathrm{H}$ ). A análise de agrupamentos não detectou diferenças significativas entre as regiões (BARROSO et al., 2012: 34; Anexo $15 \mathrm{H}$ ), o que permite concluir que a área do sítio foi ocupada pelo mesmo grupo.

\subsubsection{Paleobotânica}

Durante a escavação do sítio Itapirema, foram feitas algumas coletas, na peneira (malha $6 \mathrm{~mm}$ ), de vestígios botânicos carbonizados, encontrados principalmente na área do montículo escavado. Esse material foi acondicionado, descrito e analisado por Lígia 
Trombetta Lima, então estagiária ligada à presente pesquisa, hoje aluna de pós-graduação em Arqueologia na Universidade de Cambridge (Grã-Bretanha).

O material paleoetnobotânico identificado por Lima foi dividido em duas categorias: carvão lenhoso e material carpológico (frutos e sementes); sendo que apenas a segunda categoria foi trabalhada. As sementes foram fotografadas, contabilizadas, pesadas e classificadas morfologicamente (Tabela 42). Segundo Lima, dos oito tipos de sementes identificados, seis pertencem à família Arecaceae (palmeiras). A identificação foi baseada nas seguintes características diagnósticas: formato do endocarpo e do endosperma (ambos preservados), com a presença de três depressões no endocarpo (poro verdadeiro e poros falsos - óvulos abortados) e marcas das fibras mesocárpicas (BCF. LACK et al., 2006) (Fig. 119).

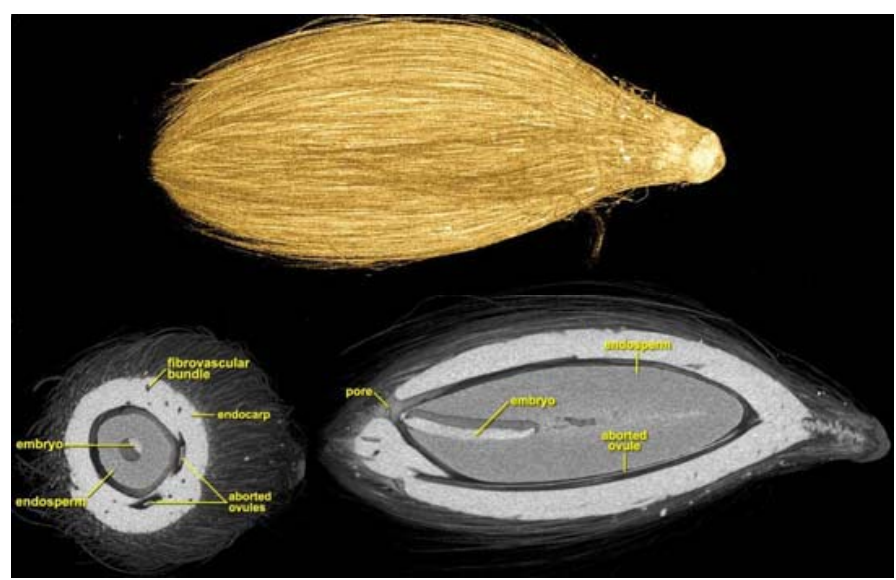

Figura 119: Tomografia computadorizada de raio-X de alta resolução de semente de Arecaceae (Syagrus flexuosa - coco-de-vaqueiro), indicando as características morfológicas citadas (fonte: www.digimorph.org).

A grande variedade de espécies estimada para essa família na região das terras baixas (GOULDING et al., 1996: 117-131), em contraste com a escassez de estudos taxonômicos sistemáticos disponíveis (cf. MOURA et al., 2010), dificulta identificações mais específicas, como gênero ou espécie. No entanto, a boa preservação do material (inclusive do endosperma carbonizado) sugere que, com o avanço dos estudos taxonômicos, o refinamento da identificação botânica desse material seja possível (LIMA, com. pessoal).

A preservação excepcional das amostras poderia pôr em dúvida seu caráter arqueológico. O tipo de solo encontrado nas unidades estudadas tem sua composição bastante influenciada pelo regime de águas (e.g. LIMBREY, 1975), o que pode facilitar o movimento do material presente no solo (cf. LYMAN, 1994). No entanto, trabalhos etnobotânicos realizados na Amazônia apontam uma longa interação entre essa família botânica e diferentes 
grupos humanos no ambiente amazônico (CLEMENT, 2006; GOULDING e SMITH, 2007). Esses estudos usam amostras modernas para propor a interação recuada baseada em estimativas temporais de distribuição e dispersão das espécies (cf. GOULDING e SMITH, 2007). Segundo Lima, o fato de todas as sementes estarem carbonizadas por completo permite uma boa preservação morfológica em contexto arqueológico. Isso se deve à perda acelerada de água, que retarda de maneira considerável alguns processos de decomposição ao preservar apenas o esqueleto da amostra, a celulose (BROTHWELL e POLLARD, 2001), de difícil processamento para boa parte das bactérias presentes no solo. As sementes de Arecaceae identificadas no sítio Itapirema são dados concretos da presença dessas plantas em contexto arqueológico e, com estudos de amostras modernas, corroboram a interação recuada entre humanos e indivíduos dessa família botânica.

\begin{tabular}{|c|c|c|c|c|c|}
\hline PN & $\begin{array}{c}\text { Quan } \\
\text { tidade }\end{array}$ & Peso & $\begin{array}{l}\text { Identifica } \\
\text { ção }\end{array}$ & $\begin{array}{c}\text { Tipo } \\
\text { morfológico }\end{array}$ & Descrição \\
\hline 508 & 9 & 1,47 & Arecacea & Faa & $\begin{array}{l}\text { Fragmentos de parede densa, carbonizada, } \\
\text { com estrias e um poro falso próximo ao } \\
\text { verdadeiro. Ovalado de um lado, com } \\
\text { barriga e formato de gota. A extremidade } \\
\text { oposta às depressões (no mínimo duas) } \\
\text { termina em ponta. Semente assimétrica, } \\
\text { preenchida por um material menos denso. }\end{array}$ \\
\hline 508 & 1 & 1,78 & Arecaceae & Fab & $\begin{array}{l}\text { Semente carbonizada, de parede densa e } \\
\text { estrias na superfície. Com numerosas faces } \\
\text { achatadas, possui três depressões (poros): } \\
\text { dois falsos e um verdadeiro. Possui } \\
\text { pequenos furos pontilhados na extremidade } \\
\text { oposta às depressões. }\end{array}$ \\
\hline 510 & 1 & 2,1 & Arecaceae & Fab & \\
\hline 510 & 12 & 2,99 & & Fac & $\begin{array}{l}\text { Fragmentos carbonizados, com curvatura e } \\
\text { paredes de alta densidade, alternadas com } \\
\text { aberturas arredondadas orientadas na } \\
\text { vertical, similar à lenha, mas sem } \\
\text { distribuição organizada. Por vezes, as } \\
\text { curvaturas maiores (lóculos) surgem } \\
\text { seguidas, sendo observadas até duas por } \\
\text { fragmento. }\end{array}$ \\
\hline 510 & 1 & 0,91 & Arecaceae & Fad & $\begin{array}{l}\text { Semente carbonizada, de formato ovalado, } \\
\text { com uma extremidade arredondada e outra } \\
\text { em ponta. Possui três depressões (poros), } \\
\text { duas redondas e uma que parece a junção de } \\
\text { dois círculos: duas falsas e uma verdadeira. } \\
\text { Com pequenas estrias espalhadas pela } \\
\text { superfície, possui faces achatadas e formato } \\
\text { assimétrico. Com um material arredondado } \\
\text { menos denso em seu interior, também } \\
\text { carbonizado. }\end{array}$ \\
\hline
\end{tabular}




\begin{tabular}{|c|c|c|c|c|c|}
\hline 517 & 2 & 1.21 & Arecaceae & $\mathrm{Fab}$ & \\
\hline 803 & 2 & 0.60 & Arecaceae & Fae & $\begin{array}{l}\text { Fragmento carbonizado que se partiu em } \\
\text { dois na limpeza. Tem um poro (microfilo) } \\
\text { em um fragmento e uma depressão ao } \\
\text { centro do outro. Possui um material } \\
\text { fragmentado, também carbonizado e menos } \\
\text { denso, alojado na sua curvatura interior. }\end{array}$ \\
\hline 605 & 3 & 0.79 & & Faf & $\begin{array}{l}\text { Fragmentos carbonizados, em formato de } \\
\text { gota. Lados aparentemente simétricos, } \\
\text { afilados em cima e arredondados em baixo. }\end{array}$ \\
\hline 605 & 3 & 0.62 & Arecaceae & Fag & $\begin{array}{l}\text { Semente carbonizada, com três depressões } \\
\text { visíveis: dois poros aparentes, um falso e } \\
\text { um verdadeiro e, oposto a eles, mais } \\
\text { próximo do falso, hilo na mesma ponta. } \\
\text { Formato ovalado, levemente mais fino } \\
\text { embaixo. }\end{array}$ \\
\hline 605 & 6 & 3.92 & Arecaceae & $\begin{array}{l}\text { Fah, possível } \\
\text { Fab. }\end{array}$ & $\begin{array}{l}\text { Sementes carbonizadas, possuem três poros: } \\
\text { dois falsos e um verdadeiro. Formada por } \\
\text { uma face arredondada e ao menos uma face } \\
\text { achatada. }\end{array}$ \\
\hline 607 & 1 & 1.32 & Arecaceae & Faa & \\
\hline 608 & 4 & 2.30 & Arecaceae & $\mathrm{Fab}$ & \\
\hline
\end{tabular}

Tabela 42: Relação das sementes carbonizadas analizadas por Ligia Trombetta Lima.

Além das sementes de palmeiras analisadas, havia na coleção macro-botânica do sítio Itapirema um vestígio diferenciado que intrigou Ligia Lima. Foi feita então uma consulta à Dra. Myrtle Shock (UFAM), que inferiu haver grande possibilidade desse vestígio ser um grão de milho (Zea mays), um dado de suma importância para os estudos paleo-etno-botânicos da região do alto rio Madeira (Figs. 120 e 121).

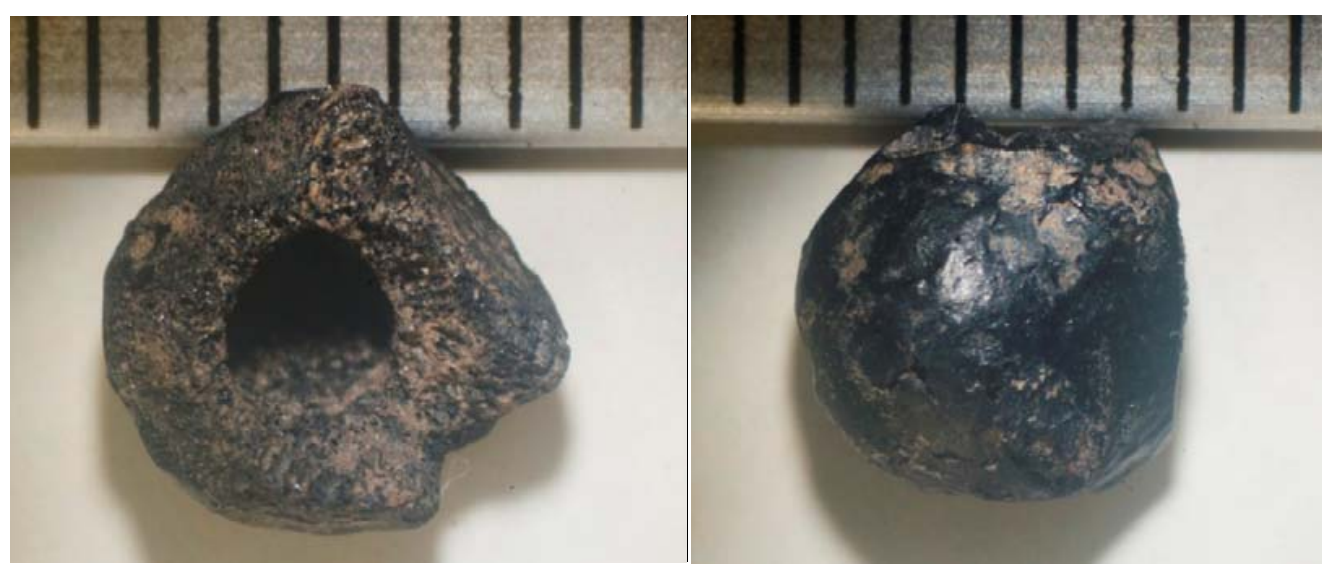

Figura 120: Provável semente de milho encontrada no sítio Itapirema. . Figura 121: Idem (Fotos: Fernando Ozorio de Almeida, 2013). 


\subsection{Sítio Teotônio}

\subsubsection{Cerâmica}

O sítio Teotônio possuiu a segunda maior amostra de fragmentos analisada e o contexto interpretativo mais complexo, provavelmente por ter sido reocupado por diferentes grupos. Por exemplo, no capítulo anterior, foi observada uma possível ocupação mais antiga que o material policrômico (Jatuarana) encontrado nos níveis superiores. Da mesma forma, foi apontada a escavação, durante os trabalhos realizados pela Scientia Consultoria nesse sítio, de uma urna funerária, com paredes espessas e verticais, temperadas com cauixi. Essa urna, assim como alguns fragmentos escavados pelo PALMA com características semelhantes (paredes espessas com cauixi), também não parecem se encaixar no contexto policrômico (Jatuarana) que predomina vertical e espacialmente no sítio. Assim, desde o início da análise, houve a preocupação de pensar se os dados seriam apresentados como um todo ou se deveria haver uma triagem ou separação de dados, para evitar que o material fosse todo classificado junto, gerando ruído. Entretanto, como os supostos elementos exógenos representavam uma baixa porcentagem dentro da amostra (menos de 10\%) e como não se sabe com clareza o que Miller tinha em mente ao definir a Subtradição Jatuarana, decidiu-se por apresentar o material do sítio como um todo, para em seguida (abaixo e Capítulo 6) compreender o significado desses aparentes fragmentos exógenos.

Os 1.007 fragmentos diagnósticos foram divididos em paredes, bordas (e flanges), bases, um aplique e um apêndice. Esse sítio possuiu a maior frequência (52\%) de fragmentos nos quais foi possível observar a técnica de manufatura acordelada. $\mathrm{O}$ caraipé foi o antiplástico predominante, sendo identificado em mais de $80 \%$ dos fragmentos, sozinho ou combinado com carvão, cauixi ou mineral. Foram encontrados 25 fragmentos temperados apenas com mineral, uma das características da suposta cerâmica pré-Jatuarana, representando meros $2 \%$ do total. Da mesma forma, foram registrados 22 fragmentos só com cauixi, um possível terceiro componente cerâmico, outros $2 \%$ do total. $\mathrm{Na}$ indústria do sítio como um todo, foi observada grande homogeneidade na espessura do antiplástico: $84 \%$ da amostra possuía espessura entre 1 e $3 \mathrm{~mm}$. Do total, 395 fragmentos possuíam $20 \%$ de antiplástico na pasta, e outros 354 fragmentos possuíam 10\%. 
Mais uma vez, a cor predominante da superfície dos fragmentos foi o amarelo/ocre (40\%), com índices das demais cores variando entre 5\% (preto) e 13\% (cinza). O sítio Teotônio apresentou $30 \%$ de fragmentos com queima completa, a segunda maior frequência entre os sítios, atrás do sítio Itapirema. No entanto, o sítio Teotônio também possuiu a segunda maior frequência (39\%) de fragmentos com queima totalmente escura, atrás do sítio Jacarezinho, o que em parte explica o grau de fragmentação do material. Foram observados poucos fragmentos craquelados (12).

O sítio Teotônio apresentou a amostra mais bem preservada entre os sítios analisados. Do total, $67 \%$ dos fragmentos foram considerados não erodidos, e em apenas $12 \%$ dos fragmentos havia erosão em ambas as faces. $\mathrm{O}$ alisamento fino foi predominante, sendo identificado na face interna de $73 \%$ dos fragmentos e na face externa de $79 \%$ dos fragmentos. Fragmentos polidos, com alisamento médio ou grosso, possuíram baixa frequência na face externa, entre $1 \%$ e $6 \%$. Foi observado um número mais significativo de fragmentos com alisamento médio na face externa, atingindo $8 \%$ da amostra.

O tratamento de superfície mais comum no interior dos vasos foi o engobo marrom (barbotina), observado em $7 \%$ dos fragmentos, seguido do esfumarado, identificado em $5 \%$ das peças. Na face externa, houve a predominância dos engobos branco, marrom e vermelho, observados em $12 \%, 8 \%$, e $7 \%$ dos fragmentos, respectivamente.

Estrias de alisamento, talvez relacionadas à suposta ocupação cerâmica mais antiga, foram identificadas em $4 \%$ dos fragmentos. Foram identificados também cinco fragmentos com marcas de folha (Fig. 122), três com marca de dedo, dois com furo e um fragmento com possível marca de cestaria. Vestígios de fuligem foram encontrados na face externa de 275 (27\%) fragmentos e na face interna de 18 fragmentos ( $2 \%)$.

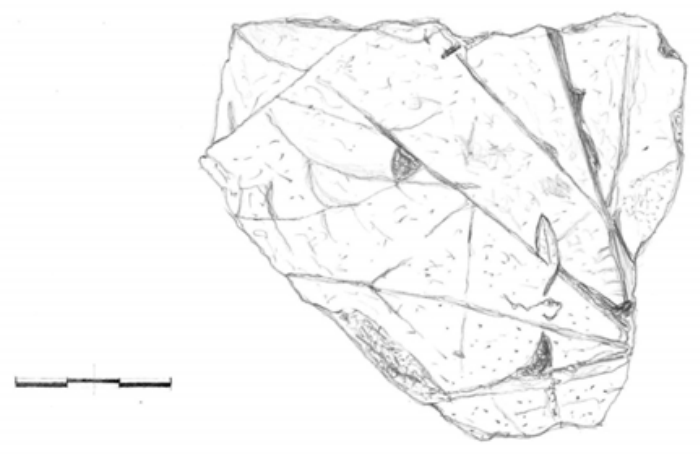

Figura 122: Fragmento Te-703-1, com marca de folha (desenho: Paulo Arena). 
A espessura dos fragmentos do sítio Teotônio variou de 0,2 a $2 \mathrm{~cm}$, com média geral de $0,74 \mathrm{~cm}$. Trata-se da média de espessura mais baixa entre os sítios estudados, indicando que os vasos do sítio Teotônio, como os dos Suruí, em geral possuíam espessura muito fina.

A maioria das bordas do sítio Teotônio era direta (68\%). As bordas extrovertidas somaram $22 \%$ do total, e as bordas extrovertidas com ponto angular somaram outros $4 \%$. Tais proporções são semelhantes às do sítio Associação Calderita. Houve predomínio de bordas inclinadas externamente (70\%), com espessura normal $(80 \%)$. Os lábios eram, em geral, arredondados $(76 \%)$.

Foram identificados apenas 16 fragmentos de base, das quais seis eram planas, três côncavas, três convexas, uma plano-convexa, e outras 3 cuja morfologia não foi identificada. A baixa quantidade de bases indica uma predominância de vasos com bases convexas. 


\section{Sítio: Teotônio}

Categoria: 566 paredes, 399 bordas (e flanges), 16 bases, 23 carenas, 1 alça, 1 aplique, NI = 1

Técnica de Manufatura: 527 acordeladas, 3 modeladas, 8 uso de placas, $\mathrm{NI}=469$ frag.

Antiplástico: 25 mineral, 241 caraipé, 252 caraipé+carvão, 176 mineral+caraipé, 157

mineral+carvão+caraipé, 26 carvão, 22 cauixí, 108 outros

Espessura do Antiplástico: 124 frag. $<1 \mathrm{~mm}, 843$ frag. $=>1 \mathrm{~mm}$ e $<3 \mathrm{~mm}, 35$ frag. $=>3 \mathrm{~mm}$ e $<5 \mathrm{~mm} ; 4$ frag. $=>5 \mathrm{~mm}, \mathrm{NI}=1$

Porcentagem do Antiplástico: 84 frag. 5\%, 354 frag. 10\%, 395 frag. 20\%, 173 frag. 30\%, NI = 1

Cor: 76 branco, 398 ocre, 124 laranja, 75 vermelho, 135 cinza, 50 preto, 65 marrom, NI = 84

Queima: 301 completa (oxidada), 29 Fl clara e FE escura, 56 Fl escura e FE clara, 3 núcleo claro fino, 138 núcleo escuro espesso, 38 núcleo escuro fino, 393 núcleo totalmente escuro, NI = 5 frag.

Estado de Conservação: 674 não erodido, 117 erodido AF, 151 erodido FI, 39 erodido FE, 26 outros Alisamento Face Interna: 732 fino, 61 médio, 9 grosso, 42 polido, NI = 163

Alisamento Face Externa: 793 fino, 81 médio, 15 grosso, 48 polidos, $\mathrm{NI}=70$

Tratamento de Superfície FI: 25 eng. verm., 36 eng. branco, 71 barbotina, 46 esfumarado, NI= 829

Tratamento de Superfície FE: 75 eng. verm., 117 eng. branco, 76 barbotina, 37 esfumarado, NI=702

Marcas: 35 estrias de alisamento, 5 marcas de folha, 2 furos, 3 marcas de dedo, 1 marca de cestaria

Sinais de Uso: 275 fuligem FE, 18 fuligem FI, 1 reciclagem, 20 outros, $\mathrm{NI}=693$

Morfologia da Borda e Flange: 267 direta, 86 extrovertida, 4 introvertida, 15 extrovertida com ponto angular, 1 extrovertida com ondulação, $\mathrm{NI}=18$

Inclinação da Borda: 38 vertical, 58 inclinada interna, 275 inclinada externa, $\mathrm{NI}=20$

Espessura da Borda: 312 normal, 33 ref. ext., 17 contraída, 9 ref. int., 4 expandida, NI = 10

Lábio: 299 arredondado, 70 plano, 2 biselado, $\mathrm{NI}=9$

Base: 6 plana, 1 plano-convexo, 3 côncava, 3 convexa, $\mathrm{NI}=3$

Diâmetro da Base: 3 frag. $>5$ e $<=10 \mathrm{~cm}, 3$ frag. $>10$ e $<=15 \mathrm{~cm}, 2$ frag. $>15 \mathrm{~cm}, \mathrm{NI}=8$

Espessura do Fragmento: 143 menor que 0,6cm, 804 entre 0,6 e 1,0cm, 60 entre 1,1 e 1,5cm, 13 maior que $1,5 \mathrm{~cm}$ (conta não bate com tabela da estatística)

Decoração Plástica: 2 corrugado, 36 incisão fina, 28 incisão larga, 3 entalhados, NI = 937

Decoração Pintada: 72 vermelho, 4 branco, 1 preto, 16 outros

Motivo Decorativo: 30 horizontal, 1 complexa, 3 ângular, 2 espiral,

PALMA

2 transversal, 1 vertical curta, 1 vertical longa, $\mathrm{NI}=955$

Sítio Teotônio

Local de Decoração FI: 4 parede, 16 borda, 4 lábio

Local de Decoração FE: 89 parede, 2 labio, 22 borda, 1 base,

5 bojo superior, 5 outros

Análise Cerâmica

QAPESP
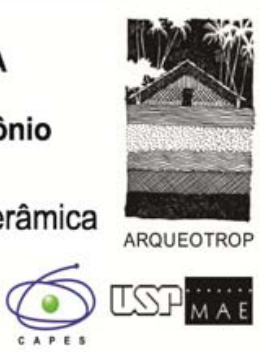


\begin{tabular}{|c|c|}
\hline \multicolumn{2}{|r|}{ Tipologia Cerâmica do Sítio Teotônio } \\
\hline Forma 1 & $\begin{array}{l}\text { Vasilha esférica, com contorno simples e boca constrita. Borda direta ou } \\
\text { introvertida, com inclinação interna, externa ou vertical, espessura normal } \\
\text { ou expandida, lábio arredondado, plano ou apontado. O diâmetro da boca } \\
\text { varia de } 14 \text { a } 48 \mathrm{~cm} \text {, e o volume, de } 1,9 \text { a } 9,71 \text {. Tratamento de superfície: } \\
\text { engobo vermelho (AF), esfumarado (AF). Antiplástico: caraipé, carvão, } \\
\text { mineral, argila moída, cauixi. }\end{array}$ \\
\hline Forma 2 & $\begin{array}{l}\text { Vasilha esférica, com contorno simples e boca aberta. Borda direta ou } \\
\text { extrovertida, com inclinação externa ou vertical, espessura normal ou } \\
\text { reforçada externa, lábio arredondado a plano. O diâmetro da boca varia de } \\
18 \text { a } 32 \mathrm{~cm} \text {, e o volume, de } 1,31 \text { a } 121 \text {. Tratamento de superfície: - } \\
\text { Antiplástico: mineral, caraipé. }\end{array}$ \\
\hline Fo & $\begin{array}{l}\text { Vasilha esférica, com contorno inflectido e boca constrita. Borda direta ou } \\
\text { extrovertida (com e sem ponto angular), inclinação interna, externa e } \\
\text { vertical, espessura normal ou reforçada interna ou externamente, lábio } \\
\text { arredondado, plano e apontado. O diâmetro da boca varia de } 8 \text { a } 40 \mathrm{~cm} \text {, e o } \\
\text { volume, de } 0,3 \text { a } 34,51 \text {. Tratamento de superfície: barbotina (FE), } \\
\text { esfumarado (AF). Antiplástico: caraipé, carvão, mineral, argila moída, } \\
\text { cauixi. }\end{array}$ \\
\hline Fo & $\begin{array}{l}\text { Vasilha esférica com pescoço, contorno inflectido e boca constrita. Borda } \\
\text { extrovertida, inclinada externa, com espessura normal e lábio plano ou } \\
\text { arredondado. O diâmetro da boca varia de } 15 \text { a } 28 \mathrm{~cm} \text {, e o volume, de } 5,3 \text { a } \\
\text { 9,11. Tratamento de superfície: incisão (FE), pintura vermelha e branca (FE). } \\
\text { Antiplástico: caraipé, carvão, mineral, cauixi. }\end{array}$ \\
\hline Fo & $\begin{array}{l}\text { Vasilha semi-esférica, com contorno simples e boca constrita. Borda direta } \\
\text { ou extrovertida com ponto angular, inclinação interna, externa ou vertical, } \\
\text { espessura normal, contraída ou reforçada externa, lábio arredondado ou } \\
\text { plano. O diâmetro da boca varia de } 10 \text { a } 52 \mathrm{~cm} \text {, e o volume, de } 0,3 \text { a } 41,11 \text {. } \\
\text { Tratamento de superfície: esfumarado (FI). Antiplástico: caraipé, carvão, } \\
\text { mineral, argila moída, cauixi. }\end{array}$ \\
\hline Forma & $\begin{array}{l}\text { Vasilha semi-esférica, com contorno simples e boca aberta. Borda direta ou } \\
\text { extrovertida, com inclinação externa, vertical ou aberta, espessura normal, } \\
\text { reforçada externa ou contraída, lábio arredondado, plano, apontado ou } \\
\text { biselado. O diâmetro da boca varia de } 7 \text { a } 52 \mathrm{~cm} \text {, e o volume, de } 0,1 \text { a } 22,11 \text {. } \\
\text { Tratamento de superfície: incisão (AF), pintura vermelha (AF), engobo } \\
\text { branco (AF). Antiplástico: caraipé, carvão, mineral. }\end{array}$ \\
\hline Forma 8 & $\begin{array}{l}\text { Vasilha semi-esférica, com contorno inflectido e boca aberta. Borda direta, } \\
\text { extrovertida (com ou sem ponto angular), inclinação externa, vertical ou } \\
\text { interna, espessura normal, reforçada (externamente ou em ambas as faces) } \\
\text { ou contraída, lábio arredondado. O diâmetro da boca varia de } 12 \text { a } 36 \mathrm{~cm} \text {, e o } \\
\text { volume, de } 0,4 \text { a 9,2l. Tratamento de superfície: acanalado (AF), pintura } \\
\text { vermelha (AF), engobo branco (AF), barbotina (AF), esfumarado (FI). } \\
\text { Antiplástico: caraipé, carvão, mineral, caco moído, cauixi. }\end{array}$ \\
\hline Forma & $\begin{array}{l}\text { Vasilha semi-esférica, com contorno inflectido e boca constrita. Borda } \\
\text { direta, inclinada externa, espessura normal e lábio arredondado. Diâmetro da } \\
\text { borda de } 16 \mathrm{~cm} \text { e volume de } 1,51 \text {. Tratamento de superfície: - Antiplástico: } \\
\text { carvão. }\end{array}$ \\
\hline Forma 1 & $\begin{array}{l}\text { Vasilha em forma de calota, com contorno simples e boca aberta. Borda } \\
\text { direta ou extrovertida, inclinada externa, espessura normal ou reforçada } \\
\text { (interna ou externamente), lábio arredondado, plano ou biselado. O diâmetro } \\
\text { da boca varia de } 12 \text { a } 32 \mathrm{~cm} \text {, e o volume, de } 0,1 \text { a } 4,31 \text {. Tratamento de } \\
\text { superfície: pintura vermelha (FE), engobo branco (FE), barbotina (AF). }\end{array}$ \\
\hline
\end{tabular}




\begin{tabular}{|c|c|}
\hline & Antiplástico: caraipé, carvão, mineral, argila moída. \\
\hline Forma 12 & $\begin{array}{l}\text { Vasilha em forma de calota, com contorno inflectido e boca aberta. Borda } \\
\text { direta ou extrovertida com ponto angular, inclinação externa, espessura } \\
\text { normal ou reforçada interna, lábio plano ou arredondado. O diâmetro da } \\
\text { boca varia de } 14 \text { a } 20 \mathrm{~cm} \text {, e o volume, de } 0,7 \text { a } 4,11 \text {. Tratamento de } \\
\text { superfície: pintura vermelha (FE). Antiplástico: caraipé, carvão, mineral, } \\
\text { argila moída. }\end{array}$ \\
\hline Forma 14 & $\begin{array}{l}\text { Vasilha com contorno composto. Borda extrovertida, inclinada externa, } \\
\text { espessura normal e lábio plano. Diâmetro } 15 \mathrm{~cm} \text { e volume de } 0,81 \text {. } \\
\text { Tratamento de superfície: - Antiplástico: caraipé. }\end{array}$ \\
\hline
\end{tabular}

Tabela 44: Relação das formas do sítio Teotônio.

Mesmo com frequências de decorações semelhantes às do sítio Itapirema, houve uma aparente maior variabilidade no sítio Teotônio. Uma possível explicação é a presença dessas distintas indústrias cerâmicas dentro da coleção. No entanto, tal fato não resume a questão.

A bicromia em vermelho e branco foi a decoração mais recorrente no sítio e, por vezes, era acompanhada de incisões finas ou largas (acanalados). As pinturas eram em geral executadas na face externa do vaso e foram mais identificadas em fragmentos de parede, o que parece indicar que essa decoração talvez fosse executada em toda a parte exterior do vaso. Assim como nos sítios Associação Calderita e Itapirema, a pintura vermelha podia ser feita sobre o engobo branco, como também o contrário (Fig. 123). Também como esses sítios, havia uma variação de espessura dos motivos pintados, com destaque para os motivos largos (espessura maior que $3 \mathrm{~cm}$ ). Faixas delimitando campos também foram observadas.
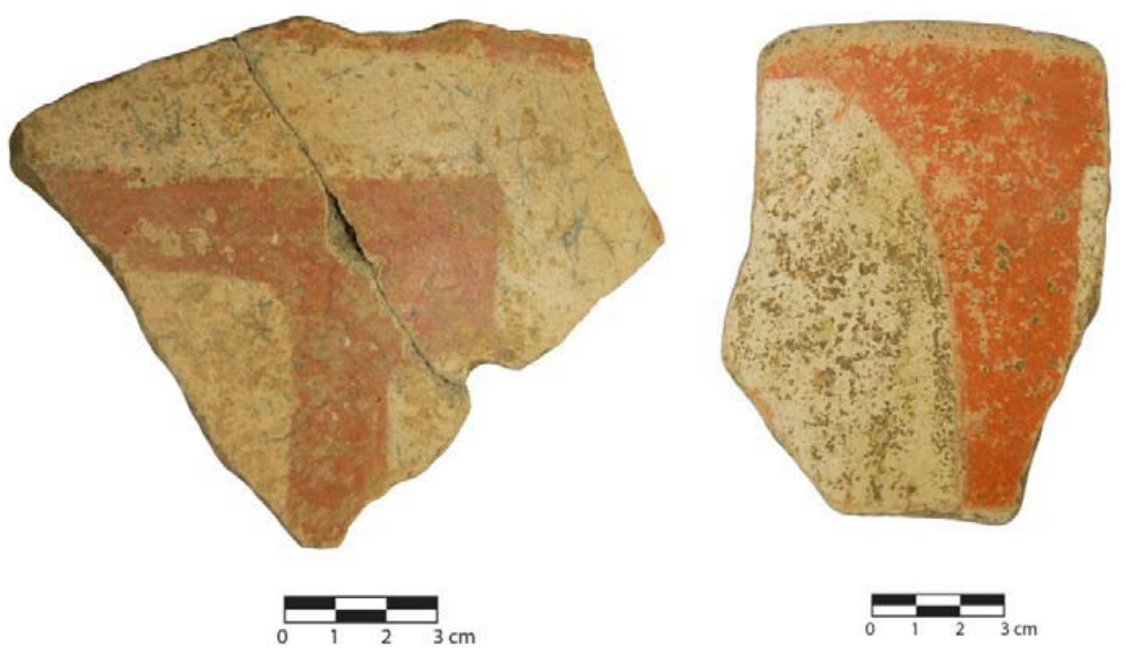

Figura 123: Fragmentos com pintura vermelha e branca do sítio Teotônio (fotos: Fernando Ozorio de Almeida). 
Incisões finas ou largas, realizadas preferencialmente na parte interna da borda, foram as decorações plásticas mais presentes no material desse sítio. A diferença na maneira de executar as incisões foi um dos indicadores da existência de uma ocupação cerâmica mais antiga (pré-Jatuarana?). As incisões e acanalados vinculados à cerâmica policrômica eram regulares e bem executados, ao passo que, na hipotética ocupação mais antiga, essas decorações possuíam espessura e alinhamento irregulares. A hipotética cerâmica antiga também possuiria outras decorações não Jatuarana, como sequências de pequenos entalhados e decorações serrunguladas, sempre na face externa e, por vezes, delimitando ângulos na parede dos vasos (Fig. 124). No Capítulo 6, será retomado o debate sobre a suposta ocupação antiga do sítio Teotônio.
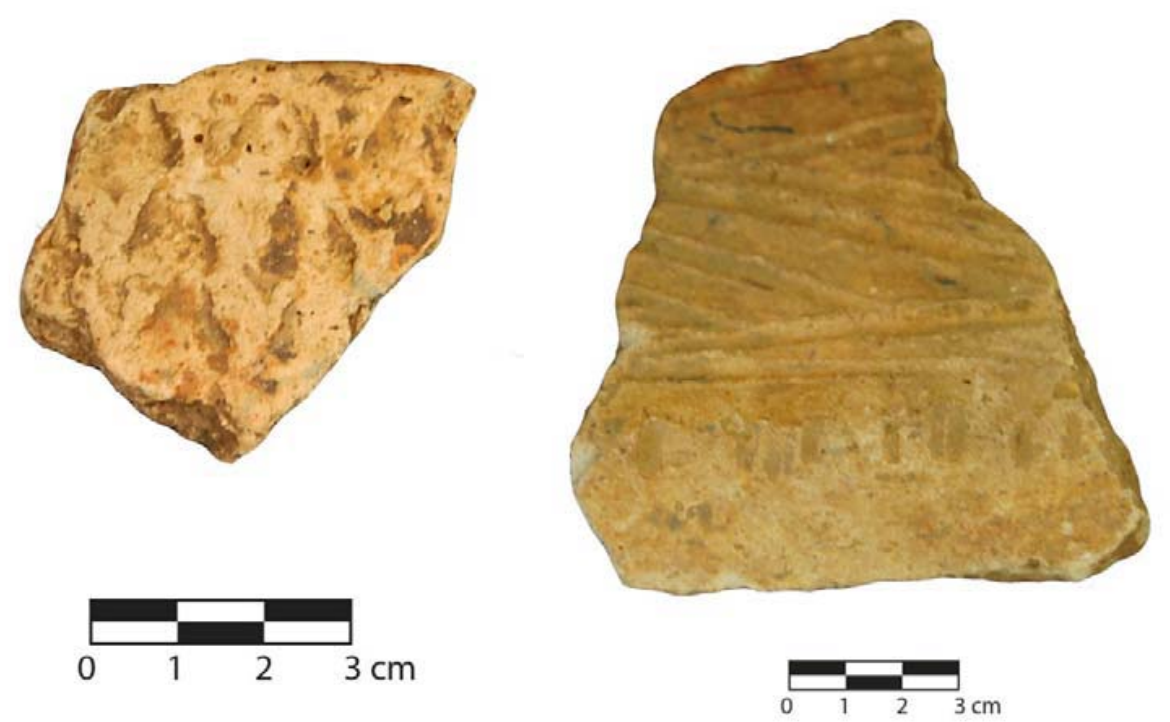

Figura 124: Fragmentos com decorações incisas e serrunguladas, pertencentes à hipotética ocupação ceramista antiga do sítio Teotônio (fotos: Fernando Ozorio de Almeida).

\subsubsection{Lítico}

O sítio Teotônio foi o único a apresentar uma quantidade significativa de material lítico. A análise intensiva desse material, cerca de 4.500 peças, é o foco de pesquisa de Guilherme Mongeló (2012) e será descrita aqui apenas de forma resumida. A pré-triagem, realizada por Rafael Pedott, teve como objetivo dividir o material quanto à matéria-prima e 
ao comprimento da peça. Todo o material coletado em campo foi contabilizado nessa descrição, incluindo muitos detritos de rochas de origem natural (não antrópica), o que significa que uma triagem mais criteriosa deve reduzir significativamente o universo amostral.

A pré-triagem permitiu identificar peças de quartzo (I - leitoso e quartzito; II hialino), basalto, granito/gnaisse, óxido de ferro ${ }^{105}$ e outras poucas de sílex. Pode-se observar, a partir do Tabela 45, que o quartzo (de pequenas dimensões) foi a matéria-prima predominante.

\begin{tabular}{|l|r|r|r|r|r|r|}
\hline Matéria Prima & \multicolumn{1}{|l|}{ PP $^{\mathbf{1 0 6}}$} & P & M & G & GG & Total \\
\hline I-Quartzo & 2572 & 932 & 11 & 2 & 1 & 3518 \\
\hline II-Quartzo hialino & 454 & 29 & & & & 483 \\
\hline III-Basalto & 4 & 1 & 3 & 2 & & 10 \\
\hline IV-Granito e Gnaisse & 36 & 26 & 10 & 7 & 7 & 86 \\
\hline V- Sílex & 3 & 2 & & & & 5 \\
\hline VI- Óxido de Ferro & 174 & 184 & 20 & 2 & 12 & 392 \\
\hline VII -Não identificado & 8 & 22 & 5 & 3 & & 38 \\
\hline Total & 3251 & 1196 & 49 & 16 & 20 & 4532 \\
\hline
\end{tabular}

Tabela 45: Material lítico do sítio Teotônio.

A partir do mapa geológico da área da cachoeira do Teotônio, é possível observar que parte da matéria-prima do material lítico encontrado no sítio se encontra no próprio local ou no entorno imediato. O granito, embasamento rochoso que predomina na cachoeira, é o exemplo mais claro, assim como o quartzo (proveniente de veios internos aos afloramentos) e o material siltoso/ferroso (CPRM 2005). Ao que parece, as peças de basalto e sílex são exógenas.

A indústria lítica do sítio Teotônio se resume a detritos de lascamento com formas prismáticas, alguns dos quais com várias marcas de retiradas, e muitos com presença de talão cortical. Também foram observados talões esmagados, puntiformes e lineares, o que sugere a ocorrência de lascamento bipolar (RICARDO MONMA, com. pessoal).

O trabalho de curadoria e triagem do material lítico desse sítio permitiu que algumas questões fossem trabalhadas, mesmo sem a ocorrência de uma análise mais aprofundada. Por exemplo, ao observar que o material lítico coletado na camada III da unidade N10001

\footnotetext{
105 O sítio Teotônio se encontra sobre um afloramento com aparência muito semelhante a um óxido de ferro, mas que geologicamente estaria mais próximo de um siltito.

${ }^{106} \mathrm{PP}=1 \mathrm{~mm}$ a $10 \mathrm{~mm} ; \mathrm{P}=11 \mathrm{~mm}$ a $30 \mathrm{~mm} ; \mathrm{M}=31 \mathrm{~mm}$ a $50 \mathrm{~mm} ; \mathrm{G}=51 \mathrm{~mm}$ a $70 \mathrm{~mm} ; \mathrm{GG}=71 \mathrm{~mm}$ a $90 \mathrm{~mm}$.
} 
E10003 era recente, fruto de lascamento feito pelos próprios arqueólogos ${ }^{107}$ (o contato do ferro de cova com o afloramento rochoso), Rafael Pedott contribuiu para refutar a possibilidade de que se tratava de uma camada arqueológica (Fig. 125). Ao que parece, parte das lascas de quartzo das outras camadas apresentou lascamentos recentes, indicando que também são fruto das intervenções arqueológicas (RICARDO MONMA, com. pessoal).

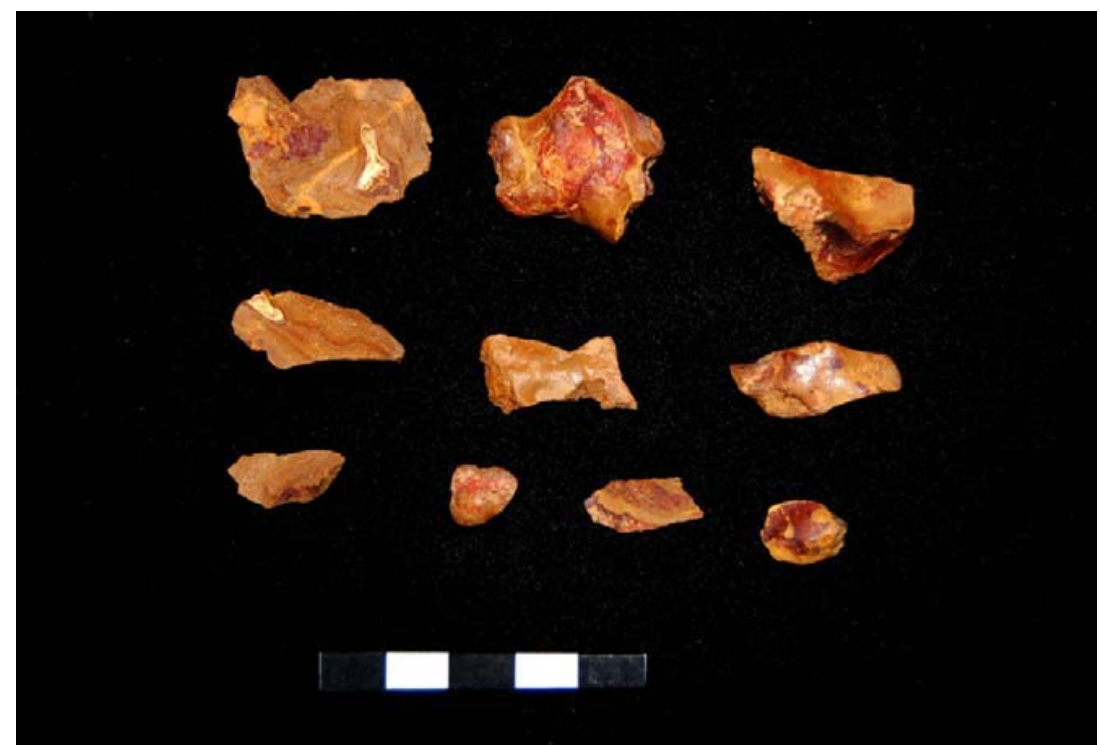

Figura 125: Material lítico proveniente da camada III, da unidade N10001 E10003, lascado pelos arqueólogos durante a escavação da unidade (foto: Fernando Ozorio de Almeida).

No capítulo anterior, também foi sugerida a presença de uma camada pré-cerâmica na unidade N10001 E10003, não observada nas demais unidades. A partir da Tabela 46, é possível observar o aumento do material lítico nas camadas onde o material cerâmico possui frequência baixa ou nula $(50-90 \mathrm{~cm})$, o que corrobora a hipótese da existência de uma ocupação pré-cerâmica associada à camada de terra preta.

\footnotetext{
${ }^{107}$ Em vista disso, nas próximas etapas de campo serão recrutados profissionais mais gabaritados.
} 


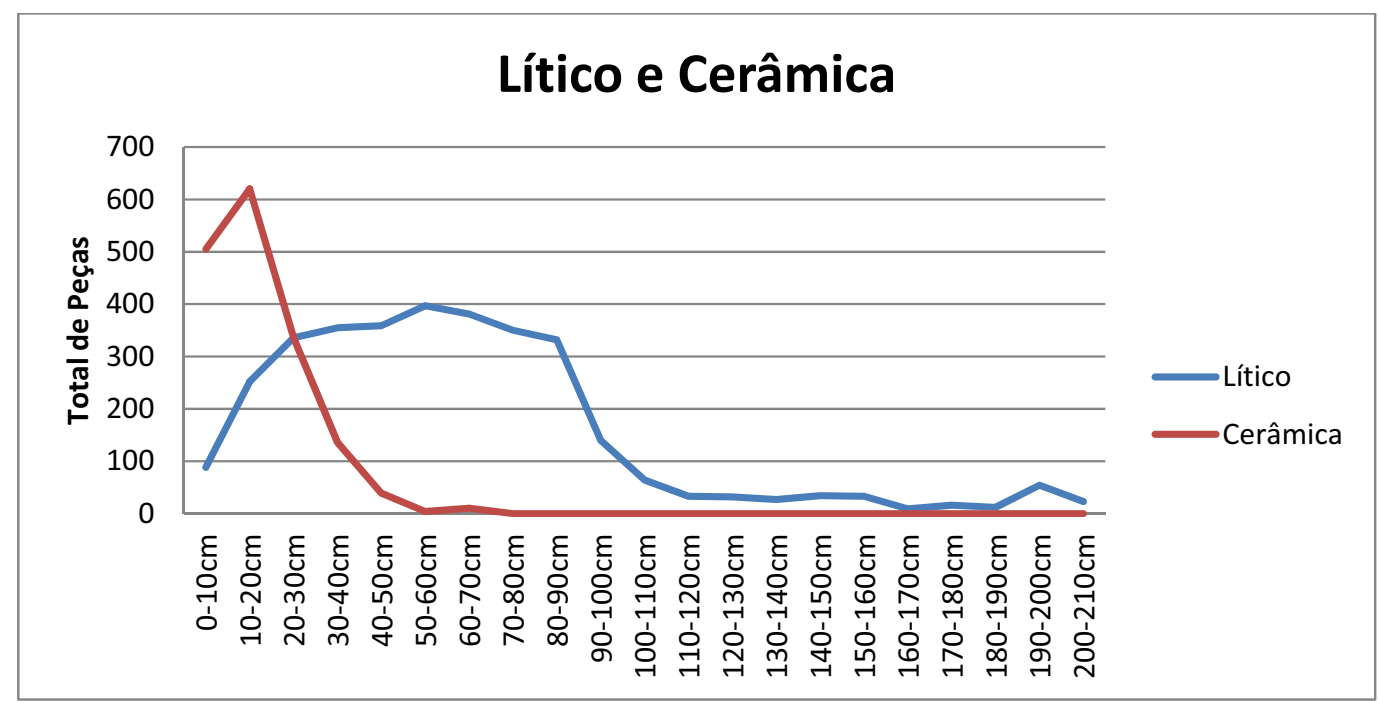

Tabela 46: Frequência de material lítico e cerâmico na unidade N10001 E10003 do sítio Teotônio.

Essa ocupação pré-cerâmica estaria associada principalmente a micro lascas ou detritos de lascamento de quartzo. No entanto, é importante ressaltar que a presença de quartzo já é alta nas camadas cerâmicas $(0-60 \mathrm{~cm})$. Ainda assim, se observada apenas a frequência do quartzo hialino (Tabela 47), um material mais adequado para o lascamento (no contexto do sítio), pode-se observar que os picos de frequência ocorrem nos níveis $60-70 \mathrm{~cm}$ e 100-110cm, relacionados à suposta ocupação pré-cerâmica.

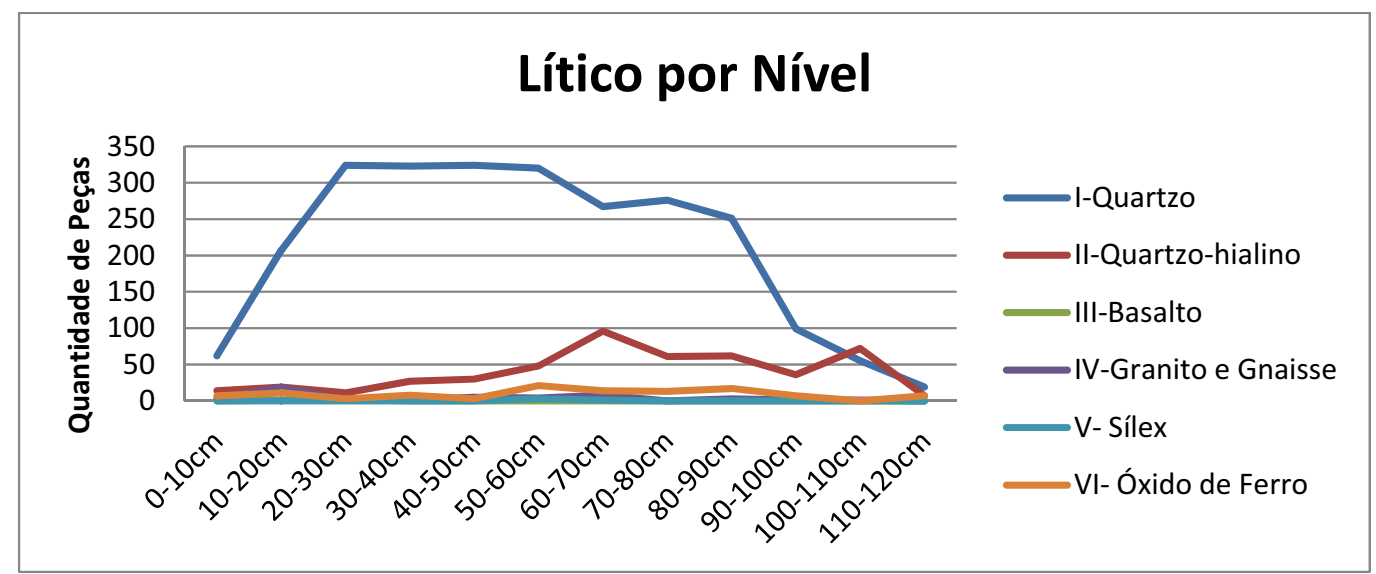

Tabela 47: Frequência em que as diferentes matérias-primas líticas foram encontradas na unidade N10001 E10003 do sítio Teotônio.

Ao que parece, essa ocupação pré-cerâmica está associada à data de 1150 a.C. (Capítulo 4), já que a Feição 1 (unidade N10001 E10003, Fig. 101), onde foi coletada a amostra de carvão que gerou essa data, apresentou apenas micro lascas de quartzo hialino, 
sem presença de cerâmica. Uma coleta de segurança no sedimento fora da Feição, na mesma profundidade dessa $(+-140 \mathrm{~cm})$, se mostrou estéril, reduzindo a possibilidade de o material lítico ser natural. A ligação dessa data com uma ocupação pré-cerâmica sugere que a datação feita por Miller de 700 a.C. está muito mais ligada a um contexto pré-cerâmico do que Jatuarana.

Segundo Rafael Pedott (com. pessoal), uma possibilidade explanatória para a grande presença de micro lascas ou detritos de lascamento de quartzo (Fig. 126), sem artefatos formais associados a eles, seria de que parte destas micro lascas (seja do período cerâmico ou do possível período pré-cerâmico) estaria associada a raladores de alimentos (e.g. mandioca) (Fig. 127). O material lítico serviria como "dentes" de raladores feitos com tábuas de madeira. Objetos como esses foram observados em uso na Amazônia por grupos Baníwa (CHERNELA, 2008: 141; RIBEIRO, 1995: 26), Içana (OLIVER, 2001: 76) e Wai-Wai (MEGGERS, 1987: 134). Trata-se de uma hipótese a ser testada em estudos futuros ${ }^{108}$.
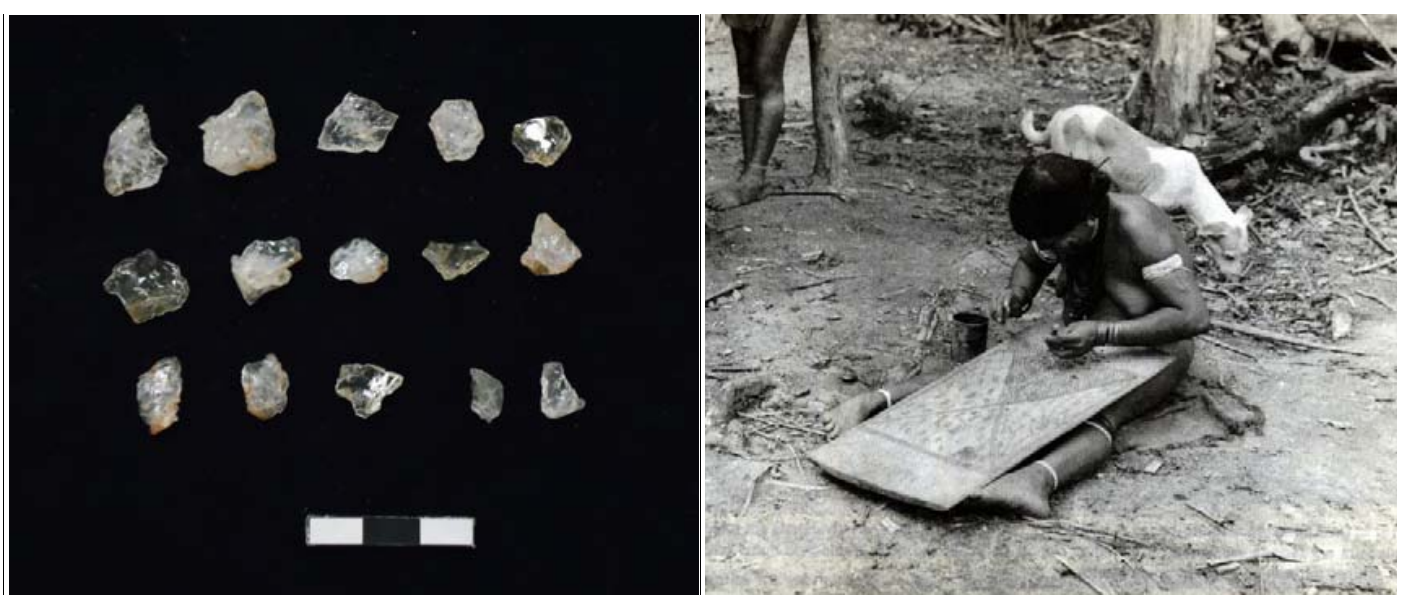

Figura 126: Micro lascas de quartzo hialino encontradas no nível $70-80 \mathrm{~cm}$ da unidade $\mathbf{1 0 0 0 1}$ E10003 (foto: Fernando Ozorio de Almeida). Figura 127: Ralador Wai-Wai observado por Meggers (1987).

Conforme apontado, não foi identificado nenhum artefato lítico lascado e não foi encontrado (aparentemente) nenhum núcleo. No entanto, foram identificados possíveis percutores para atividades de lascamento (Figs. 128 e 129). Também foi identificado, em uma coleta de superfície, um quebra-coquinho de granito com marcas de picoteamento e duas protuberâncias em lados opostos da peça, uma das quais bastante discreta (Figs. 130 e 131).

\footnotetext{
${ }^{108}$ Os relatos de Franz Keller sobre os Karipuna que habitavam área próxima à cachoeira de Teotônio podem ser instrutivos sobre o uso de outros materiais para funções "tradicionalmente líticas", como as pontas de flecha de bambu e conchas de rio com bordas afiadas que "evidently appear to be quite effective to them (Karipuna) as our own knives" (1874: 123).
} 


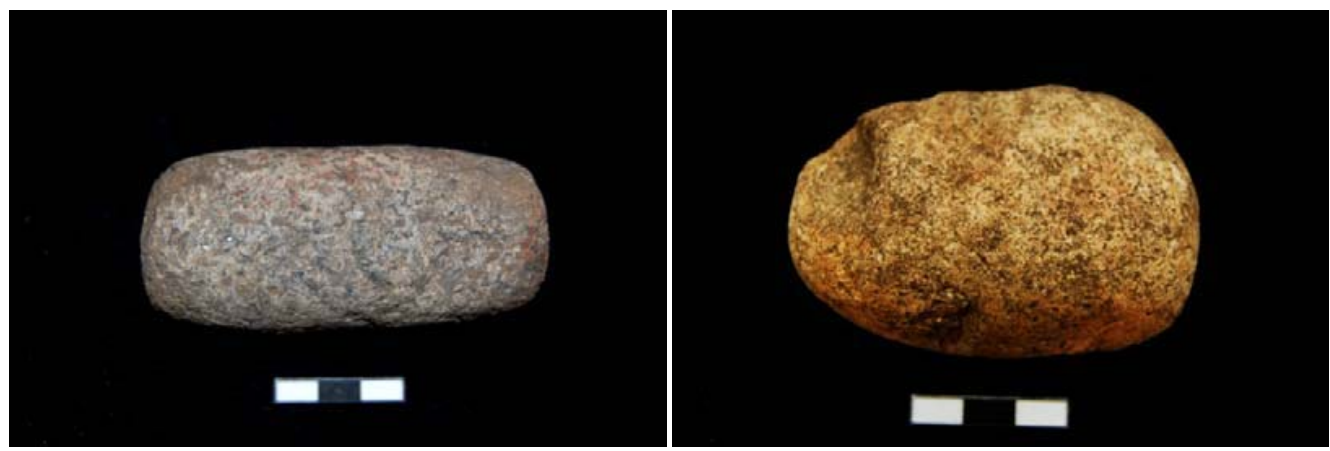

Figura 128: Possível percutor lítico de quartzo encontrados no sítio Teotônio.

Figura 129: Possível percutor lítico de quartzo encontrados no sítio Teotônio (fotos: Fernando Ozorio de Almeida).

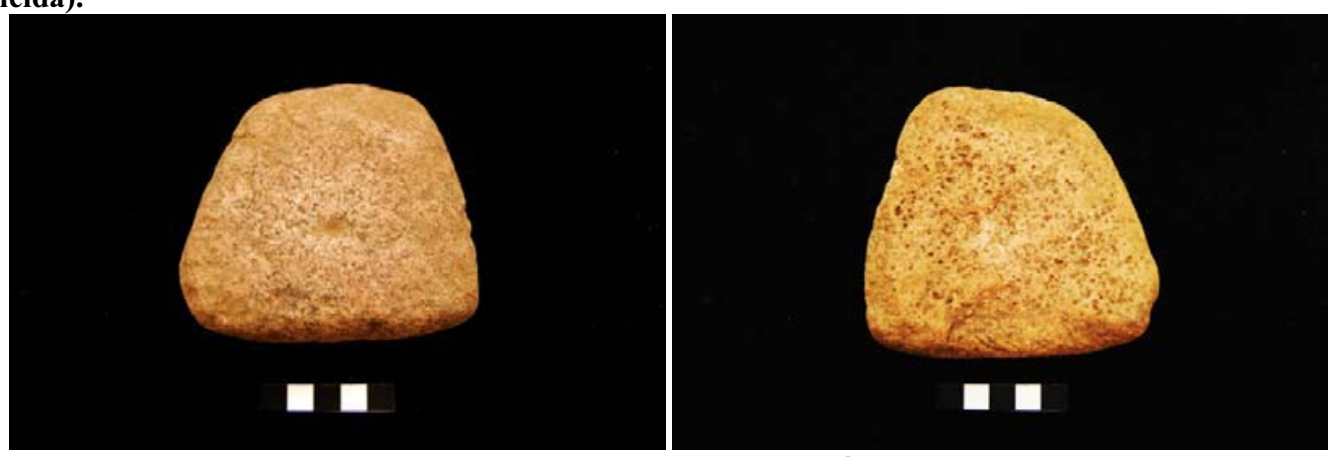

Figura 130: Quebra-coquinho de granito encontrado no sítio Teotônio.

Figura 131: Quebra-coquinho de granito encontrado no sítio Teotônio (fotos: Fernando Ozorio de Almeida).

Foram coletados também dois calibradores feitos de rochas sedimentares, um deles com um sulco e o outro com três (Figs. 132 e 133). Por fim, pode-se sugerir que algumas peças líticas estão associadas a contextos de produção cerâmica. Por exemplo, foi coletado um seixo com partes de sua superfície polida e pigmento vermelho em parte da superfície (Fig. 134), sugerindo que pode ter sido utilizado para o polimento do vaso e para a obtenção de pigmento (vide também Fig. 135).
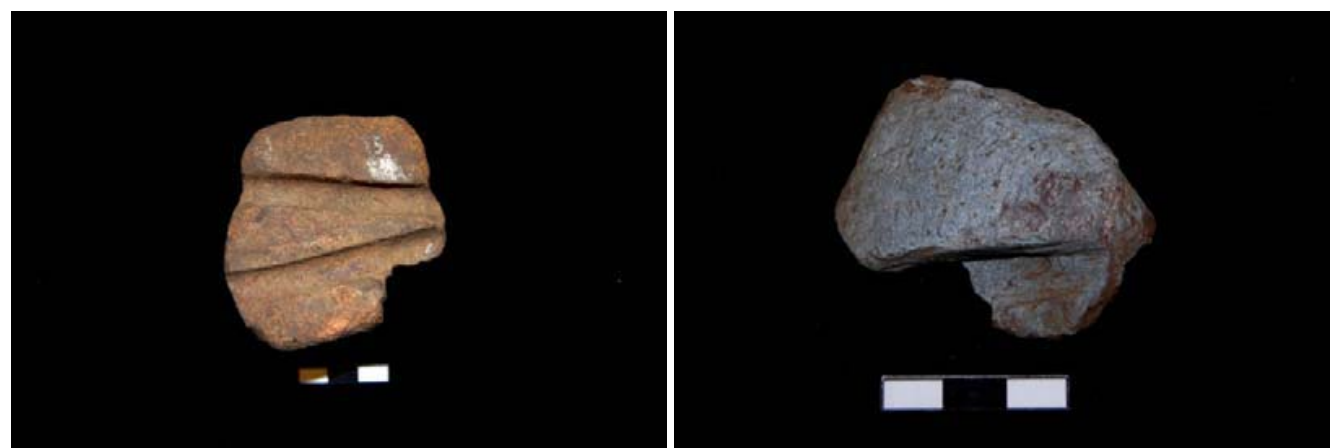

Figura 132Calibrador encontrado no sítio Teotônio.

Figura 133: Calibrador encontrado no sítio Teotônio (fotos: Fernando Ozorio de Almeida). 

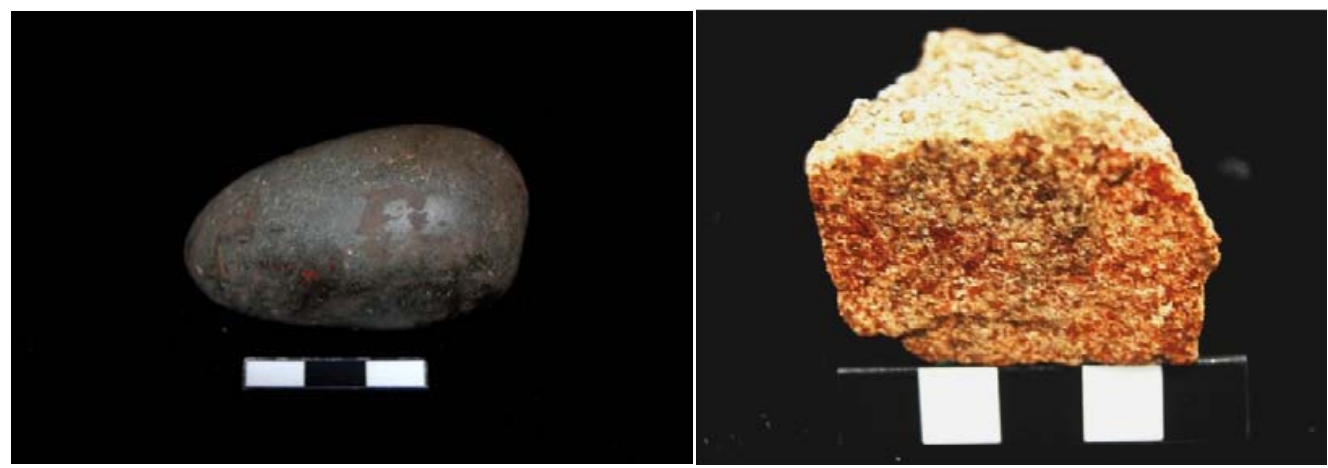

Figura 134: Seixo com marcas de polimento.

Figura 135: Peça de granito com marcas de pigmento em uma das faces (fotos: Fernando Ozorio de Almeida).

\subsubsection{Paleobotânica}

As atividades de campo do PALMA levaram à realização de um trabalho de fim de curso sobre a paleobotânica do sítio Teotônio por Glenda Félix (Universidade de São Lucas, RO), sob supervisão do professor Carlos Zimpel (UNIR, RO) e de Michelle Tizuka (Scientia Consultoria). Os estudos foram realizados a partir da flotação de uma coluna de sedimento coletada no perfil norte da unidade N10001 E10003.

A flotação do sedimento apontou a presença de vestígios de carvão e sementes, em especial nos níveis superiores da escavação $(0-50 \mathrm{~cm})$, relacionados à ocupação cerâmica (FÉLIX, 2012: 27). No entanto, a presença de carvão se manteve significativa nos níveis relacionados à ocupação pré-cerâmica $(60-110 \mathrm{~cm})$ (Anexo 17). Os dados quantitativos referentes às sementes também apontaram um predomínio nos níveis superiores, especialmente nos primeiros $20 \mathrm{~cm}$ (Tabela 48). Ainda assim, uma quantidade significativa de pedaços de semente foi identificada nos níveis pré-cerâmicos de terra preta, em especial no nível 80-90cm (p. 41; Anexo 17). Foram identificadas sete morfologias para as sementes, sem que fosse possível identificar um nível no qual estivessem concentradas. O tamanho reduzido dos vestígios flotados e a falta de uma coleção de referência (de sementes e antracológica) impediram a pesquisadora de relacionar as sementes e os carvões a determinada família, gênero ou espécie vegetal, restando apenas a sugestão de que parte delas poderia ser relacionadas a palmeiras, família Arecaceae (pp. 47-48). 

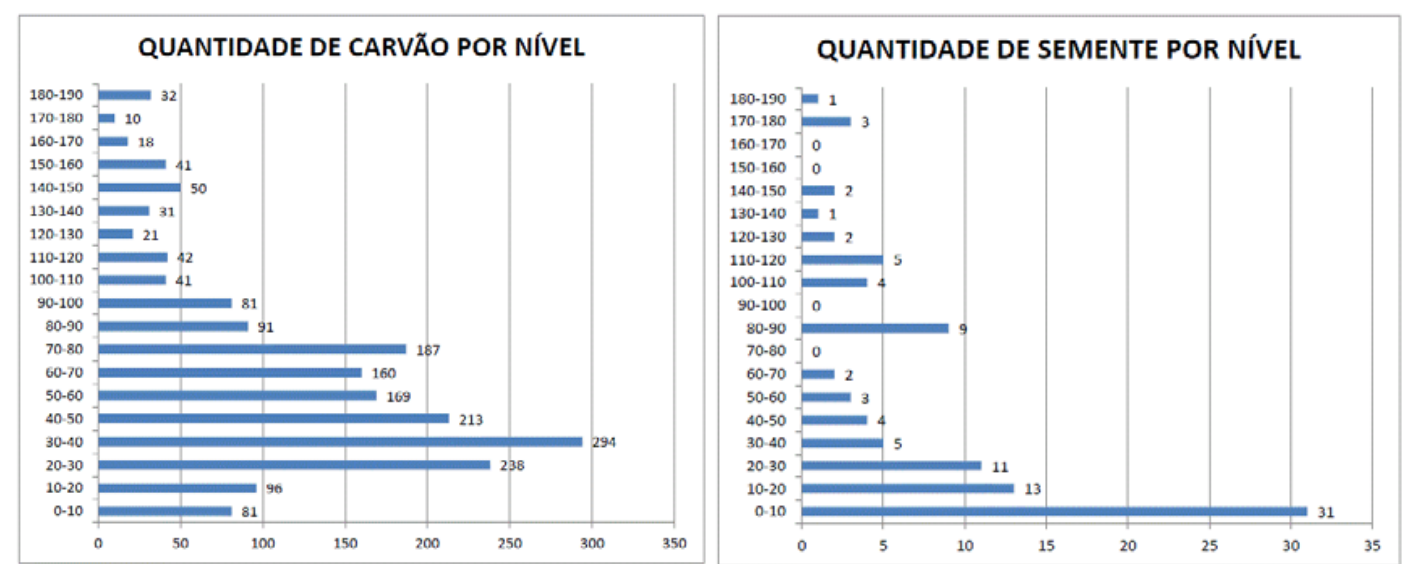

Tabela 48: Porcentagens de carvão e sementes na unidade N10001 E10003 do sítio Teotônio (fonte: FÉLIX, 2012).

\subsection{Função dos vasos}

Ao descrever as funcionalidades da cerâmica Suruí, Vidal indica que os vasos são todos "utilitários", como a itxirah, uma das maiores panelas, que é utilizada para o cozimento de alimentos. O autor oferece como exemplo as sopas de cará e de milho, assim como variedades de caça, e indica que essas panelas eram usadas antigamente "para preparar makaloba, bebida fermentada consumida durante rituais especificos" (2011: 72). Indiretamente, o autor contraria a ideia de oposição entre cerâmica "utilitária" e "ritual". A mera existência de vasos decorados não significaria a distinção dessas esferas. Por exemplo, na comunidade multiétnica de Conambo, na Amazônia ocidental, os vasos para o consumo de fermentados sempre possuem pinturas policrômicas, não havendo distinção entre os de uso cotidiano e os para eventos festivos (BOWSER, 2002).

Designar a função dos vasos é sempre uma tarefa complexa, ainda mais a partir de fragmentos. Sempre se corre o risco de que diferentes vasos possam servir para a mesma função, e diferentes funções possam ser atribuídas ao mesmo vaso. Assim, para não gastar muito tempo inferindo todas as possibilidades funcionais das reconstituições dos vasos, será feita uma discussão direcionada ao universo das bebidas fermentadas. Conforme visto, tratase de um papel fundamental dos vasos Suruí (VIDAL, 2011: 114) e de outros grupos Tupi. Tanto nos grupos Suruí, nos Tupi-Guarani (e.g. NOELLI e BROCHADO, 1998), quanto em outros grupos amazônicos, como os Shipibo (DEBOER, 2003; DEBOER e LATHRAP, 1979), as funções dos vasos relacionados ao preparo e ao consumo de bebidas fermentadas se 
resumem a três: preparo, serviço e consumo (individual ou coletivo) (cf. D. AMARAL em SCIENTIA, 2008).

Muito mais do que relacionar a forma de um sítio e uma determinada função, busca-se apontar que os sítios analisados - com exceção do Nova Vida, que não possui reconstituições - possuíam vasos potencialmente relacionados às funções de preparo, serviço e consumo de bebidas. Para conclusões mais contundentes, será necessária uma maior quantidade de vasos inteiros e análises de resíduos no interior desses.

Uma simples comparação com a coleção Shipibo (DEBOER e LATHRAP, 1979) confirma a potencial existência de um conjunto de vasos para consumo de bebidas alcoólicas nos sítios estudados, ainda que com algumas nítidas diferenças, a mais clara no campo decorativo. Em todos os sítios do alto Madeira, a quantidade de decorações em todos os vasos com funções ligadas a fermentados é menor do que a dos vasos Shipibo. Nesse aspecto, os vasos para bebidas Shipibo se aproximam muito mais dos vasos análogos Tupi-Guarani, fato notado por Brochado (1984). Nesse sentido, talvez haja uma relação maior dos sítios do alto Madeira com os vasos Suruí do que com o duo Shipibo e Tupi-Guarani.

A semelhança entre os vasos Shipibo e Tupi-Guarani também se repete na quantidade de ângulos dos vasos (carenas e ombros), ao que parece muito mais frequentes do que nos vasos dos sítios do alto Madeira. Um exemplo disso são os vasos shrania, utilizados para o serviço de bebidas Shipibo (retirar do vaso de preparo para o vaso de consumo), cuja forma só encontra correlatos nos sítios Itapirema e Teotônio. Ao que parece, há uma grande variabilidade de alternativas para a execução da função de serviço. Foram observados, por exemplo, os vasos de serviço Suruí (toruk), pequenas tigelas com uma asa lateral (VIDAL, 2011: 87). Há indicação de que os Tupari (Anexo 7) utilizavam uma cabaça para essa função, como os Arikém (Fig. 146) que tembém utilizam essa cuia (cabaça) para o consumo de bebidas, um dado importante que pode relativizar a seleção de vasos de consumo do sítio Jacarezinho (vide baixo). Assim, entre os vasos do alto Madeira indicados para a função de serviço, além dos vasos angulosos dos sítios Teotônio e Itapirema, foram selecionados apenas vasos fundos, com pescoço.

Os vasos para consumo individual (definido aqui como tigelas com volume menor ou igual a 11) e coletivo (maior que 11) de fermentados Shipibo possuem formas análogas a vasos da fase Cumancaya com essa função (LATHRAP, 1970; ROE, 1973) e semelhanças com vasos das fases Caimito e Napo (TPA; cf. EVANS e MEGGERS, 1968; WEBER, 1975) 
e da Tradição Tupi-Guarani (BROCHADO, 1984). Em todos os casos, se trata de vasos com formas constritas, que aparecem (com menos ângulos) nos sítios analisados do alto Madeira, com exceção do sítio Itapirema.

\begin{tabular}{|c|c|c|c|c|}
\hline Forma/Função & Preparo & Serviço & Consumo coletivo & $\begin{array}{l}\text { Consumo } \\
\text { Individual }\end{array}$ \\
\hline $\begin{array}{c}\text { Shipibo } \\
\text { (fonte: DEBOER } \\
\text { e LATHRAP, } \\
\text { 1979) }\end{array}$ & $\begin{array}{l}\text { Vasos piriformes } \\
\text { com ângulos, } \\
\text { inflexões e } \\
\text { grandes volumes. } \\
\text { Decorações no } \\
\text { bojo superior. } \\
\end{array}$ & $\begin{array}{l}\text { Vasos com } \\
\text { volumes médios, } \\
\text { com ângulos e } \\
\text { inflexões. } \\
\text { Decoração? }\end{array}$ & $\begin{array}{l}\text { Vasos com volume } \\
\text { médio, boca constrita } \\
\text { e decorações } \\
\text { pintadas. }\end{array}$ & $\begin{array}{l}\text { Vasos com volume } \\
\text { médio, boca constrita } \\
\text { e decorações } \\
\text { pintadas. }\end{array}$ \\
\hline $\begin{array}{c}\text { Sítios } \\
\text { analisados } \\
\text { (função inferida) }\end{array}$ & $\begin{array}{l}\text { Vasos globulares } \\
\text { com grandes } \\
\text { volumes, inflexões } \\
\text { e ângulos (às } \\
\text { vezes) }\end{array}$ & $\begin{array}{l}\text { Vasos com } \\
\text { volumes médios, } \\
\text { com ângulos e } \\
\text { inflexões (sítios } \\
\text { Itapirema e } \\
\text { Teotônio). Vasos } \\
\text { fundos com } \\
\text { pescoço. Às vezes } \\
\text { decorados. }\end{array}$ & $\begin{array}{l}\text { Vasos com volume } \\
\text { médio, boca aberta ou } \\
\text { constrita (sítios } \\
\text { Associação Calderita } \\
\text { e Teotônio). Raras } \\
\text { decorações pintadas } \\
\text { ou incisas. }\end{array}$ & $\begin{array}{l}\text { Vasos com volume } \\
\text { médio e boca aberta. } \\
\text { Raras decorações } \\
\text { pintadas ou incisas. }\end{array}$ \\
\hline
\end{tabular}

Tabela 49: Comparação entre os vasos Shipibo relacionados ao preparo e consumo de bebidas fermentadas e os vasos dos sítios analisados, que potencialmente possuem a mesma função.

Foi visto que esse sítio possuiu a cerâmica com maior quantidade e qualidade de tratamentos de superfície dentre os sítios analisados. No entanto, suas formas abertas, com flange labial, não parecem adequadas para o consumo de bebidas alcoólicas (cf. DEBOER, 2003: 298). Para não falar dos vasos com bordas recortadas, que poderiam ser perigosos de manejar por pessoas alcoolizadas (Fig. 136). 

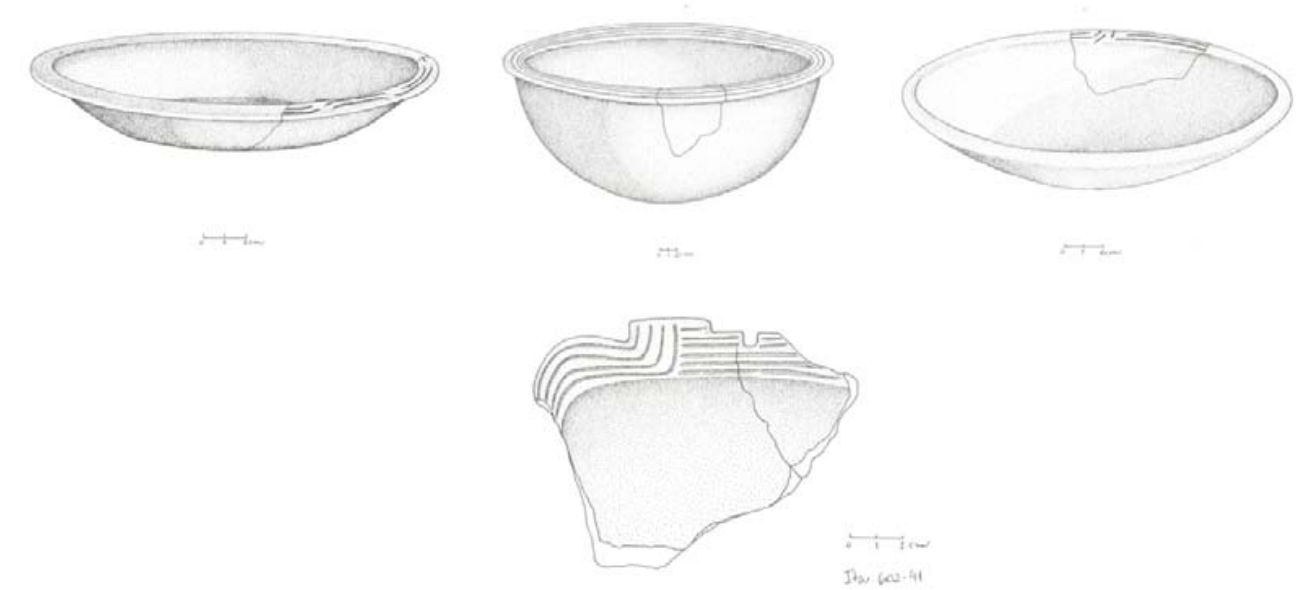

Figura 136: Vasos com flanges labiais e decorações incisas, inadequados para o consumo de bebidas fermentadas (desenhos: Erêndira Oliveira).

Dessa forma, como esses vasos não possuem volume ou forma (fechada) para ir ao fogo - são muito "caprichados" para tal função e raramente apresentam fuligem - ou para armazenar alimentos e não possuem forma para o serviço ou consumo de bebidas, resta sugerir que deveriam ser utilizados para o consumo de alimentos sólidos. Um exemplo didático de que, por mais que se advogue a importância das bebidas alcoólicas na vida cotidiana e ritual dos grupos amazônicos pré-coloniais, essas não são de maneira alguma as únicas importantes.

Nesse sentido, outro vaso com borda recortada e decoração policrômica poderia ser exemplo de um diferente elemento ritual. Trata-se dos fragmentos Ita-617-7/8 (Fig. 137), que possuem uma imensa flange, com uma combinação de recortes e policromia que talvez remeta a uma figura zoomórfica. Seu diâmetro da boca e volume (não calculados) parecem tão pequenos $(<0,11)$ que sua utilização para o consumo de bebidas ou alimentos sólidos parece improvável. Pode-se sugerir que tal vaso parece muito mais adequado ao consumo de substâncias alucinógenas, como o paricá, etnograficamente observado entre os Mura do baixo rio Madeira (RODRIGUES FERREIRA, 1974: 63). 


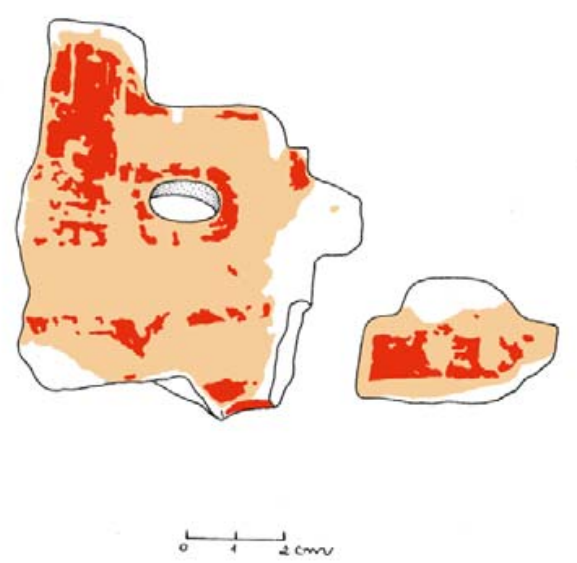

Figura 137: Fragmentos Ita-617-7/8, possivelmente utilizados para consumo substâncias alucinógenas (desenho: Erêndira Oliveira).

Uma possível forma ligada ao consumo de fermentados e que pôde ser apenas indiretamente inferida (por não ter reconstituição) é a de cálice, isto é, uma tigela com pedestal. Foi observada no sítio Itapirema a presença de dois fragmentos (Ita-310-1 e Ita-413115) cuja morfologia indica serem o segmento do cálice que liga a tigela à base, com aberturas dos dois lados (Fig. 138). Vasos em forma de cálice são comuns na cerâmica arqueológica tapajônica (GOMES, 2002: 223-227) - talvez os mais policrômicos vasos dessa cerâmica não TPA - ainda que a boca demasiadamente aberta de muitos desses vasos os torne inadequados para o consumo de fermentados. Por outro lado, na Amazônia equatoriana, vasos com essa morfologia (e decoração policrômica) são utilizados para o consumo de chicha (BOWSER 2002: 84). 

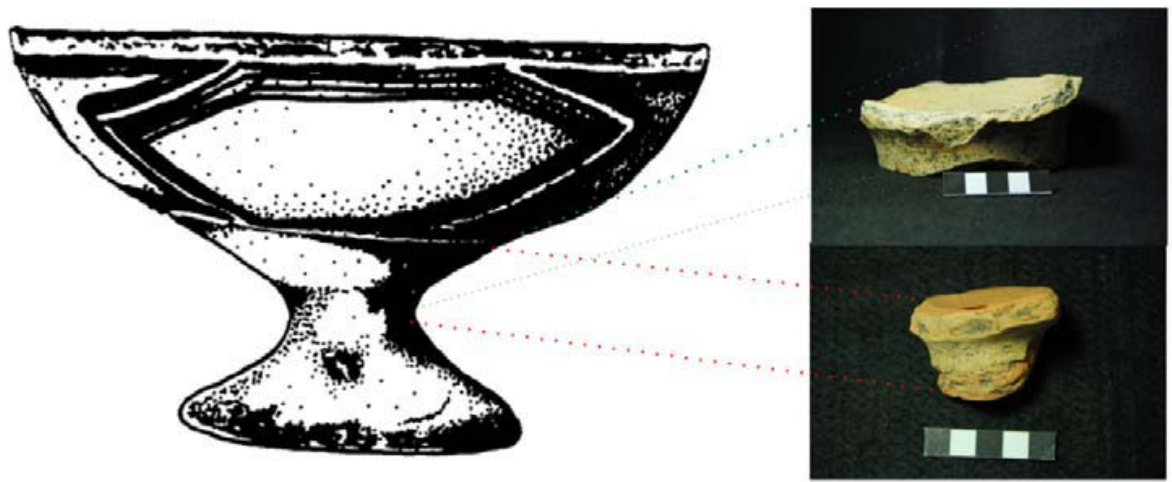

Figura 138: Possível fragmento de vaso em forma de cálice encontrado no sítio Itapirema em comparação a um exemplar Conambo (fonte: Bowser, 2002: 84).

No seu trabalho com os grupos Quecha e Jívaro (Achuar) da comunidade de Conambo, Bowser (2002: 72) observa que as tigelas para o consumo de chicha - em geral abertas, com espessura fina e pintura policrômica - costumavam ser descartadas após a quebra ou quando as bordas se tornavam muito desgastadas. Esse pode ser o caso do fragmento (semi-completo) Ita-502-35, bastante desgastado no bojo superior (Fig. 139).

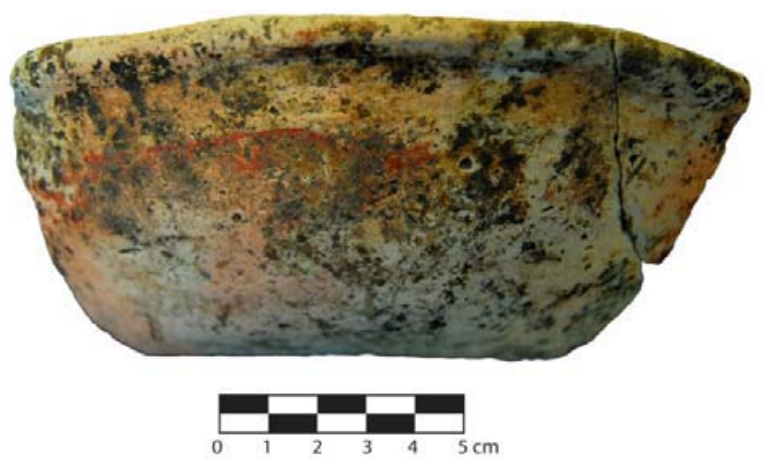

Figura 139: Fragmento Ita-502-35 - tigela com pintura vermelha possivelmente utilizada para consumo de bebidas (foto: Fernando Ozorio de Almeida).

Observando os (supostos) vasos para preparo de bebidas dos sítios analisados pode-se notar que o sítio Teotônio possuiu os vasos com maiores volumes (201 e 351), o que confere ao sítio um possível status de centro ritual-festivo. No entanto, os sítios Itapirema e Associação Calderita também possuíram alguns vasos (supostamente) de preparo, com volumes entre 101 e 201, o que pode indicar que fossem eventuais locais festivos. Essa informação é especialmente interessante no caso do sítio Associação Calderita, devido à sua 
pequena dimensão (2,5 ha). A presença de grandes vasos para consumo de bebidas pode indicar que se trata mais de um sítio-habitação de pequena área - e, por consequência, de pequena população - do que de um sítio-acampamento temporário, como foi sugerido no capítulo anterior. Se observada a coleção completa de reconstituições cerâmicas dos sítios, pode-se notar que o sítio Itapirema possuiu a maioria dos vasos com grande capacidade volumétrica, chegando a 641 (Tabela 50).

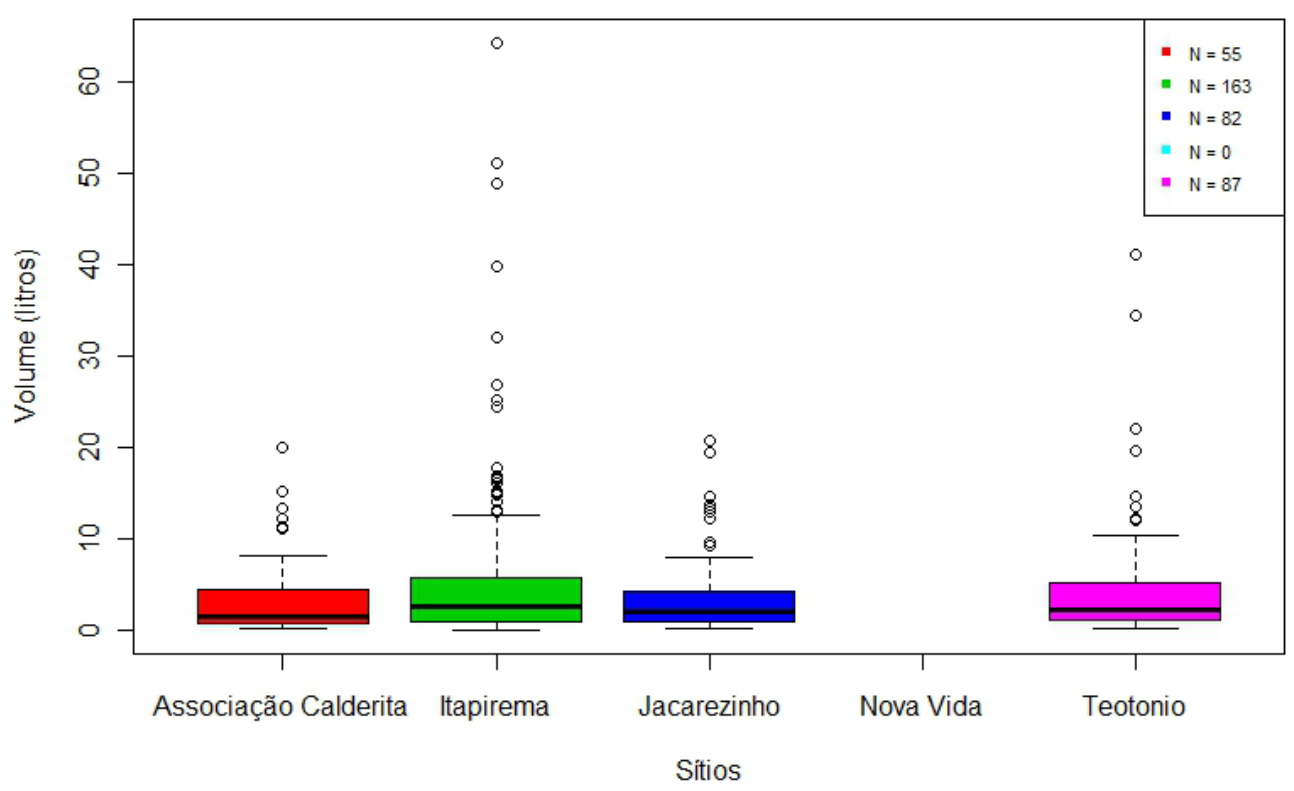

Tabela 50: Boxplot com as capacidades volumétricas estimadas dos sítios estudados.

Também digno de nota é o fato de que a suposta cerâmica antiga do sítio Teotônio (acima e Capítulo 6) possuiu alguns exemplares de vasos introvertidos, provavelmente não muito profundos (não reconstituídos devido ao tamanho reduzido das peças), e em geral portadores de decorações plásticas (e.g. incisões e acanalados). O que talvez signifique a presença de vasos para consumo de fermentados (individuais ou coletivos) desde as primeiras ocupações por grupos ceramistas nesse sítio (500 d.C.). 


\subsection{Desenhos com padrões bidimensionais}

Com exceção de uma figura tridimensional zoomorfa encontrada no sítio Itapirema, as decorações incisas e pintadas formaram padrões bidimensionais. Tais padrões só não foram observados no sítio Jacarezinho, já que decorações incisas e pintadas foram ausentes nesse sítio. Conforme visto na descrição dos sítios Associação Calderita, Itapirema e Teotônio, os motivos incisos eram em geral executados na face interna da borda ou flange, ao passo que os motivos pintados foram observados predominantemente na parede externa dos vasos. Seja pelo tamanho reduzido dos fragmentos, seja pela erosão de uma pintura que não penetrou de forma correta na pasta da vasilha (vide abaixo), foram poucos os fragmentos onde foi observada uma grande quantidade de motivos associados. Entretanto, em muitos fragmentos foi possível identificar as chamadas unidades mínimas dos desenhos bidimensionais, que nada mais são do que as unidades que compõem um motivo. Em muitos fragmentos, essas unidades talvez sejam até menos que mínimas, uma vez que a quebra das peças dificultou a compreensão da forma dos motivos.

Assim como outros estudos relacionados a sítios da Tradição Polícroma (BOLIAN, 1975; BARRETO, 2008, 2010; SCHAAN, 1996; WEBER, 1975), foi observado que essas unidades mínimas eram (em geral) utilizadas respeitando relações de simetria e regularidade (e.g. no traço da linha e na distância de uma linha para outra), utilizando com frequência técnicas como rotação e espelhamento. No material dos sítios analisados pelo PALMA (em parte pelos motivos expostos) os padrões formados eram "simples", com não mais de três unidades mínimas (Tabela 51, Anexo 19).

Apesar de a lista da Tabela 51 apresentar uma aparente variedade de motivos, pode-se inferir que grande parte de tal variação é devida aos diferentes modos de fazer um mesmo motivo, assim como às diferentes formas de quebra dos vasos (e de seus motivos). O que resulta em uma série de possíveis motivos que parecem ser parte de um mesmo e incrivelmente recorrente motivo de trapézio aberto (Fig. 140), que varia quanto à espessura, pronunciamento dos ângulos (mais ou menos arredondados), rotação, espelhamento e simetria. 

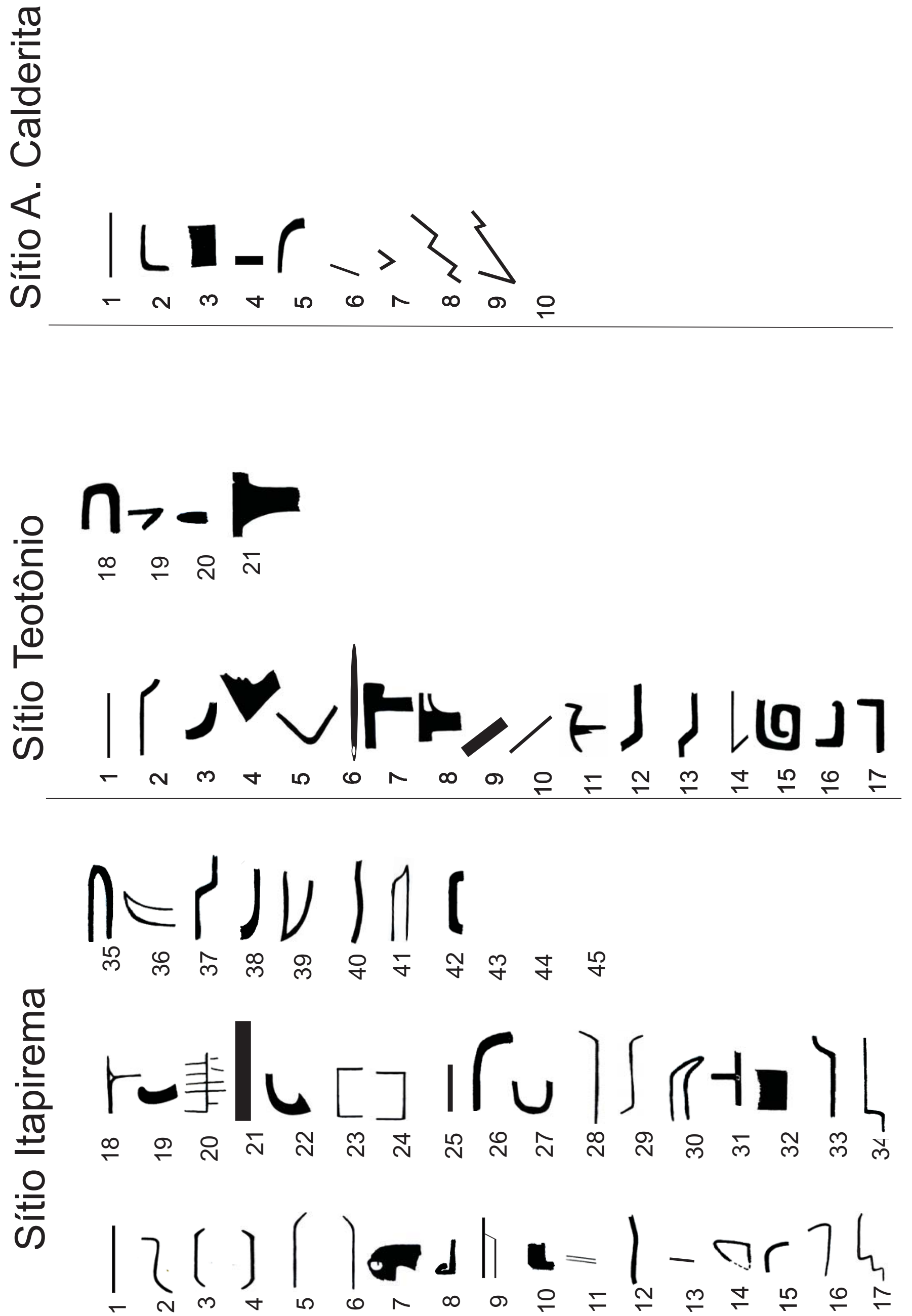
Tal inferência se refere apenas aos sítios Teotônio e Itapirema, já que a amostragem dos demais sítios não permite inferências mais aprofundadas. Pode-se apontar também uma significativa preferência das(os) oleiras(os) do sítio Itapirema pela execução de motivos incisos ou pintados com espessura fina frente a motivos espessos (pintados ou acanalados) encontrados na cerâmica do sítio Teotônio.

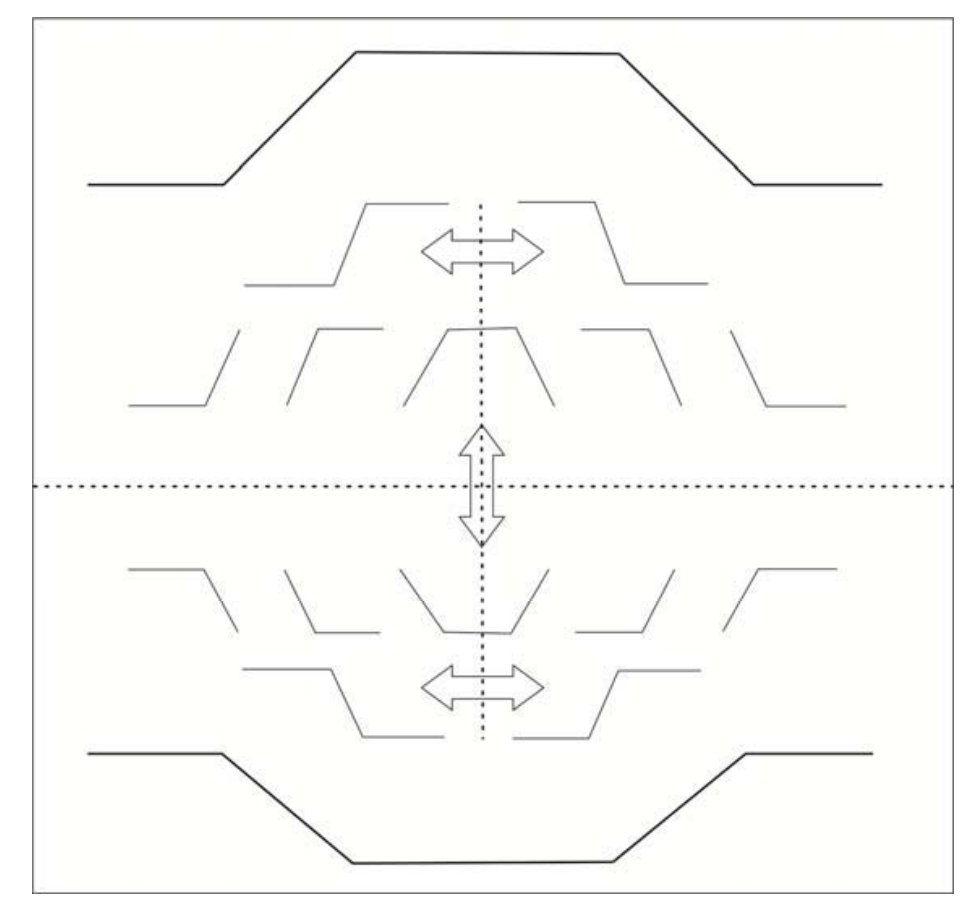

Figura 140: Possíveis variações do mesmo motivo, encontradas nos sítios Teotônio e Itapirema.

\subsection{Comparação entre os sítios}

As comparações de frequência e as análises estatísticas apontaram uma considerável heterogeneidade entre os sítios. Em uma série de atributos, todos os sítios se parecem, e em outros, todos os sítios se distinguem. Ao contrário do material da Subtradição Tupinambá da Amazônia, no qual ocorriam apenas pequenas diferenças de frequência entre os sítios (Capítulo 2), no alto Madeira não há nenhum sítio extremamente semelhante ao outro, mas há sítios mais próximos.

Se, por exemplo, fosse feita uma analogia entre os sítios e uma cesta de frutas, seria possível sugerir que os sítios Associação Calderita e Itapirema seriam respectivamente uma maçã e uma pera, ao passo que os sítios Nova Vida e Jacarezinho seriam uma banana e um 
mamão. Qualquer um pode identificar que se trata de frutas diferentes, mas se pedíssemos para uma criança pequena fazer um agrupamento, certamente ela faria um entre a maçã e a pera. O sítio Teotônio, como veremos (abaixo, Capítulo 6), está mais para uma salada de frutas, com um provável predomínio de maçãs e peras, além de uma série de outras frutas, contando talvez com um pouco de banana no fundo da tigela e, se muito, um leve gosto de mamão (cf. Capítulo 6). A comparação dos sítios será feita de maneira sucinta, mas a relação completa de gráficos pode ser encontrada no Anexo 15.

Em todos os sítios analisados, observou-se a presença do caraipé como antiplástico. Esse só não foi o antiplástico preponderante no sítio Itapirema, onde houve uma maior quantidade de fragmentos com cauixi (a combinação cauixi com caraipé também sendo muito frequente nesse sítio). Nos sítios Jacarezinho e Nova Vida, o caraipé foi o antiplástico hegemônico, e nos demais sítios (em especial o Teotônio), foram observadas possibilidades de combinação do caraipé com cauixi e carvão. Em todos os sítios, o caraipé possuía dimensão média de 1 a $3 \mathrm{~mm}$, e era encontrado em baixa quantidade na pasta. Foi observada a presença de um segundo tipo de caraipé (caraipé B) em alguns fragmentos do sítio Jacarezinho e, com frequência muito maior, no sítio Itapirema.

A cor dos fragmentos também não foi um bom demarcador para distinguir os sítios, devido ao predomínio de tonalidades amarelo/ocre nos fragmentos de todas as indústrias. A análise da queima parece aproximar os sítios Teotônio e Itapirema (maior porcentagem de fragmentos com queima completa) de um lado, os sítios Nova Vida e Jacarezinho (menor porcentagem) de outro, e o sítio Associação Calderita entre as duplas. Todos os sítios, menos o Nova Vida ${ }^{109}$ possuíam vasos cerâmicos bem alisados.

Todos os sítios também possuíam predominância de formas diretas. Nesse campo, o que parece diferenciar os sítios é a frequência de bordas extrovertidas e introvertidas, elementos que diferenciam o sítio Jacarezinho dos demais: possuiu muito menos bordas extrovertidas e maior porcentagem de bordas introvertidas. Ainda na variável morfologia, a grande presença de bordas extrovertidas com ponto angular do sítio Itapirema também pode ser vistas como um diferencial.

Um dos atributos diagnósticos da Tradição Polícroma da Amazônia é a presença de bordas reforçadas, em geral na face externa. $\mathrm{O}$ sítio que mais apresentou bordas reforçadas foi o Itapirema, com quase $30 \%$ das bordas reforçadas (internamente e externamente),

\footnotetext{
${ }^{109} \mathrm{O}$ grande número de fragmentos erodidos do sítio Nova Vida pode ter influenciado nesse aspecto.
} 
seguido à distância pelos sítios Associação Calderita e Teotônio. Esse é mais um elemento que diferencia o sítio Jacarezinho, que possui a menor frequência de bordas reforçadas. $\mathrm{O}$ Nova Vida possuiu uma quantidade muito baixa de bordas (22, duas com reforço) para viabillizar uma inferência. Todos os sítios possuíram predominância de lábios arredondados. Nesse caso, o segundo tipo de lábio mais frequente (plano) aproxima mais uma vez os sítios Itapirema, Teotônio e Associação Calderita.

A frequência das bases também mostrou números muito próximos em todos os sítios (menos o Nova Vida) quanto às morfologias predominantes (plana e convexa). No entanto, a já indicada presença das "arqueologicamente raras" bases côncavas nos sítios Itapirema e Teotônio não deve deixar de ser notada.

A comparação das formas cerâmicas, ponto fulcral da presente proposta analítica, não permitiu a visualização de relações sólidas inter-sítios, incluindo a impossibilidade de utilizar o Nova Vida, que não possuiu reconstituições. Por exemplo, a forma 12 do sítio Itapirema destacada estatisticamente pela análise de correspondência (BARROSO et al., 2012: 31; Anexo $15 \mathrm{H}$ ) - possuiu baixas frequências nos demais sítios. Os sítios com cerâmica policrômica (Associação Calderita, Itapirema e Teotônio, vide abaixo) só possuíram frequências parecidas quanto à forma 10. As formas 6 e 7 possuíram frequências semelhantes nos sítios Associação Calderita, Teotônio e Jacarezinho, sítios que possuíram a forma 17, ausente no sítio Itapirema.

Isto é, se os sítios fossem agrupados a partir da simples comparação morfológica, o resultado mais provável seria a exclusão do sítio Itapirema frente aos demais, que provavelmente formariam um grupo não muito homogêneo. Foram realizados dois testes de confiabilidade (técnica descrita acima), utilizando reconstituições nas quais as bordas representavam: (I) no mínimo $15 \%$ da reconstituição, e (II) no mínimo $25 \%$ das reconstituições (Anexo 16). Os resultados foram muito semelhantes ao da comparação utilizando todas as reconstituições, com poucas semelhanças entre os sítios e ênfase nas diferenças do sítio Itapirema frente aos demais. Dados que demonstram uma grande coerência nas reconstituições, independentemente do tamanho do fragmento.

No campo dos tratamentos de superfície nas faces externas dos vasos, pode-se indicar que a barbotina (engobo marrom) foi encontrada de maneira bastante uniforme em todos os sítios. Segundo os dados estatísticos de análise de correspondência (BARROSO et al., 2012: 31), a presença de engobo branco parece aproximar os sítios Teotônio e Itapirema. Da mesma 
forma, a frequência de engobo vermelho aproxima os sítios Associação Calderita e Itapirema. As pinturas vermelhas e brancas, por sua vez, também estão presentes nestes (e apenas nestes) três sítios. A pintura preta é praticamente ausente, se restringindo a dois fragmentos do sítio Teotônio e um do sítio Itapirema. O que seria um forte argumento para classificar esses sítios como bicrômicos e não como policrômicos. No entanto, o pigmento vermelho possui tantas variações (laranja, vermelho, vinho, marrom), que a policromia é mais do que óbvia.

As semelhanças entre as decorações pintadas nesses sítios (Associação Calderita, Itapirema e Teotônio) podem ser assim listadas: (I) pintura vermelha sobre branca; (II) pintura branca sobre vermelha; (III) intercalação de linhas finas e espessas (faixas); (IV) uso de pigmento mais escuro para delimitar faixas; (V) uso de incisões para delimitar faixas; (VI) motivos finos e espessos; (VII) decorações dentro e (VIII), preponderantemente, fora do vaso.

A aderência do pigmento na pasta indica que a maioria dos fragmentos recebeu a pintura ou o banho de pigmento (engobo) antes da queima, resultando na preservação de um número considerável de peças. No entanto, foi observada a ocorrência, em fragmentos dos três sítios (Associação Calderita, Itapirema e Teotônio), de um pigmento que não aderiu inteiramente à pasta, resultando em pinturas erodidas ou craqueladas (Figs. 141 e 142). Há algumas possibilidades de explicação para esse fenômeno, como uma queima em baixa temperatura da cerâmica com o banho ou uma aplicação pós queima (de forma semelhante à utilizada pelos Suruí para aplicar resina nos vasos) ou, ainda, por meio da utilização de uma argila mais plástica (depurada) durante a manufatura do vaso, levando ao craquelamento durante a secagem ou queima (LIMA, com. pessoal). Seja qual forem as respostas, fica claro que os grupos que habitaram esses sítios possuíam uma variedade de alternativas para gerar diferentes efeitos. Nesse caso, mesmo às custas da durabilidade das pinturas, pode-se pensar que os vasos com essas grossas capas de pigmento não aderido à pasta causariam um impacto visual muito maior. 


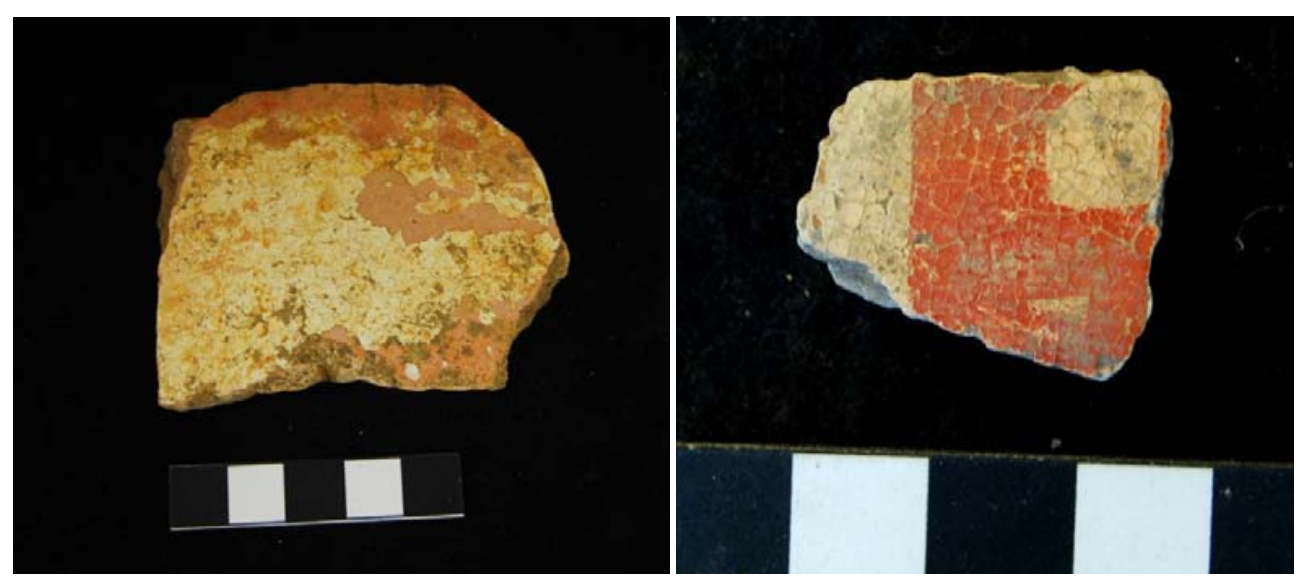

Figura 141: Fragmento Te-321-41 no qual se pode observar pigmento com pouca aderência à peça, levando ao craquelamento.

Figura 142: Ita-510-31, idem (fotos: Fernando Ozorio de Almeida).

As decorações incisas e acanaladas (incisões largas) também são outro ponto em comum entre os sítios Teotônio, Itapirema e Associação Calderita, este último com a ausência de acanalados. O local das incisões nos vasos desses sítios também foi geralmente $\mathrm{o}$ mesmo, na face interna da borda ou flange.

Também foram identificados fragmentos com incisões no sítio Nova Vida. Nesse caso, percebeu-se uma diferença significativa entre este sítio e o trio Teotônio, Itapirema e Associação Calderita, uma vez que as incisões da cerâmica Nova Vida eram irregulares e foram todas identificadas na parede externa do fragmento, ao passo que as decorações incisas do trio eram regulares e foram em geral realizadas na parte interior da borda. No entanto, incisões irregulares foram observadas nas paredes de fragmentos profundos do sítio Teotônio, a hipotética ocupação pré-Jatuarana, apontando a necessidade de uma comparação um pouco mais aprofundada entre esta e o sítio Nova Vida (Capítulo 6).

Dessa forma, na ausência de resultados mais significativos nas comparações morfológicas, foram os tratamentos de superfície e as decorações os principais vetores que levaram à separação dos sítios Itapirema, Teotônio e Associação Calderita dos demais. O que não significa que o presente estudo tenha recorrido a um agrupamento monotético. Esses três sítios possuem uma série de elementos comuns (cor, queima, alisamento, espessura, morfologia da borda, reforço na borda) além dos tratamentos de superfície. Os tratamentos de superfície e as decorações são apenas o maior diferencial desse agrupamento, que não só não é monotético, como é exageradamente politético. 
Resta pensar na possibilidade de relação entre os sítios Nova Vida e Jacarezinho. Foi dito que esses sítios possuem uma cerâmica com queima incompleta, caraipé, sem ângulos nos vasos e (praticamente) sem decorações. No entanto, um rápido manuseio nas peças desses dois sítios permite ao observador uma distinção clara entre as duas indústrias. Primeiro, a cerâmica do sítio Jacarezinho possui um acabamento mais fino, resultando em uma baixa quantidade de fragmentos erodidos (51\% contra $18 \%$ de fragmentos não erodidos). Esse acabamento mais fino está, muitas vezes, ligado ao tamanho do antiplástico na pasta. Em comparação com o sítio Jacarezinho, o Nova Vida possui o dobro de fragmentos com antiplástico entre 3 e $4,9 \mathrm{~mm}$ ( $12 \%$ contra $25 \%$ da amostra, respectivamente), e seis vezes mais fragmentos com antiplástico maior ou igual a $5 \mathrm{~mm}(2 \%$ contra $12 \%$ da amostra).

A espessura dos fragmentos também diferencia os dois sítios. Apesar de a média do Jacarezinho ser, ao que parece, inferior à do Nova Vida - contando todos os fragmentos analisados - essa diferença se deve ao fato de o último sítio possuir (proporcionalmente) muitos fragmentos de base, que acabaram por mascarar a espessura geral das peças. Se selecionados apenas os fragmentos de parede, será possível ver que a média do sítio Jacarezinho permanece a mesma $(1,05 \mathrm{~cm})$ ao passo que a média do Nova Vida cai para $0,85 \mathrm{~cm}$, comparação que se confirma se comparadas as espessuras dos lábios: média de $0,69 \mathrm{~cm}$ no Jacarezinho e $0,56 \mathrm{~cm}$ no sítio Nova Vida. Dados que confirmam as observações de laboratório de que a cerâmica do sítio Jacarezinho era a mais espessa da coleção.

Por fim, apesar de não possuir reconstituições, a morfologia e a inclinação das bordas do sítio Nova Vida apontam uma indústria de vasos mais abertos do que os encontrados no sítio Jacarezinho. Em síntese, os sítios Nova Vida e Jacarezinho não devem ser agrupados.

Dessa forma, os cinco sítios analisados ficaram assim divididos:

\begin{tabular}{|c|c|}
\hline Sítios & Situação \\
\hline Associação Calderita & \\
\hline Itapirema & Agrupados \\
\hline Teotônio & \\
\hline Nova Vida & Isolado \\
\hline Jacarezinho & Isolado \\
\hline
\end{tabular}

Tabela 52: Divisão preliminar dos sítios estudados.

A variabilidade técnico-estilística identificada entre os sítios agrupados, assim como a possível filiação desses sítios à Tradição Polícroma da Amazônia, serão temas do Capítulo 6. Como se cogitou a possibilidade de ligação entre o sítio Nova Vida e a hipotética ocupação 
antiga do sítio Teotônio, a conclusão sobre esse também será adiada para o próximo capítulo, restando para este capítulo a interpretação final do sítio Jacarezinho.

\subsection{O sítio Jacarezinho e a Tradição Jamari}

O sítio Jacarezinho parece ser o único elo entre os sítios escavados pelo PALMA e a Tradição Jamari, criada por Miller para sítios do médio curso do rio Jamari. Se filtrado o ruído policrômico e inciso encontrado em alguns fragmentos de alguns sítios dessa Tradição, conforme proposto no Capítulo 3, é possível identificar uma imensa semelhança entre a indústria cerâmica desse sítio e a dessa Tradição.

Tanto o material cerâmico do sítio Jacarezinho quanto o da Tradição Jamari possuem predominância de antiplástico de caraipé. As fotos apresentadas por Miller et al. (1992: 5657) mostram que a cerâmica, apesar da ausência de decorações, ainda assim é bem acabada, com fino alisamento. Mostra também uma pasta de cor ocre/amarelado, predominante na indústria do sítio Jacarezinho, e aparenta mostrar fragmentos espessos (entre 1,1,-1,5cm), como os do sítio Jacarezinho. Os banhos de engobo ou, principalmente, barbotina, são outros elementos presentes na cerâmica Jacarezinho que podem ser encontrados ou nas descrições ou nas fotos da cerâmica da Tradição Jamari. Em ambos os casos, ao que parece, há um predomínio de formas sem ângulos e constritas. Miller (et al., 1992: 39-47) indica que alguns sítios da Tradição Jamari são lacustres, o que é congruente com os dados do sítio Jacarezinho, encontrado no lago homônimo (Fig. 146).

Pensando em futuros estudos na região e tendo em vista a discussão sobre a buffer zone do baixo Jamari (Capítulo 4) e a localização do sítio Jacarezinho, seria interessante investigar se a presença dos sítios da Tradição Jamari de fato se limita às áreas mais discretas e de acesso restrito nesse trecho do rio, como áreas de lago ou que preservam certa distância da drenagem principal do rio Jamari. A escavação dos sítios Barranco e Casarão, detectados pelo PALMA (Capítulo 4) talvez ofereçam subsídios nesse sentido, se é que esses sítios realmente podem ser atribuídos a ocupações indígenas. 


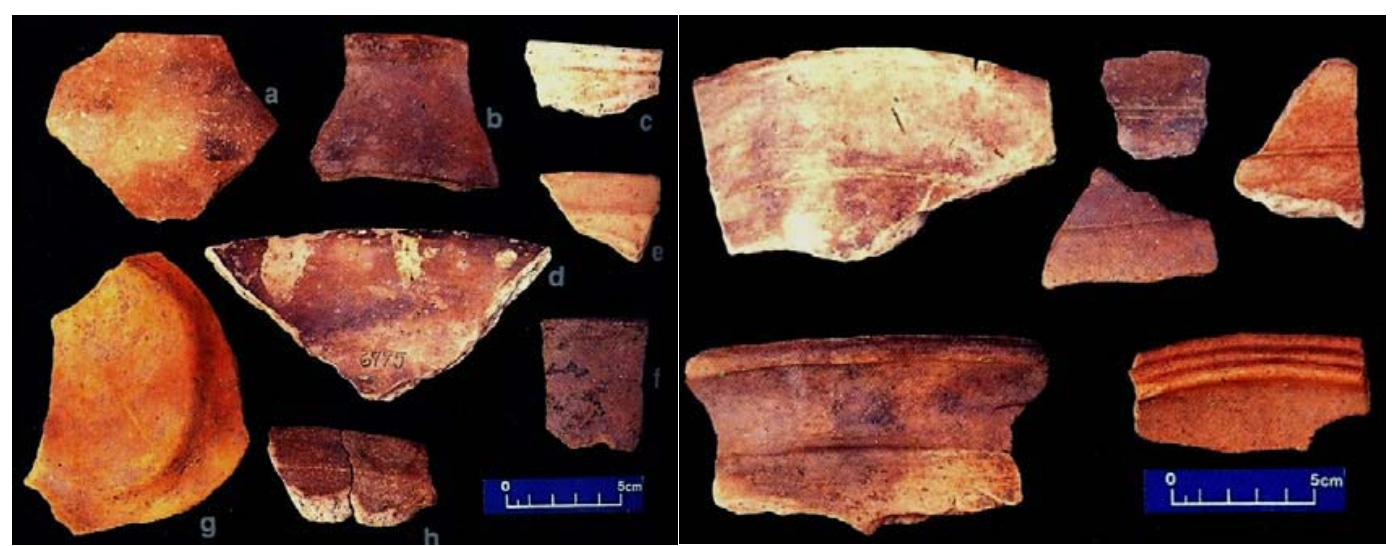

Figura 143: Fragmentos da Tradição Jamari, com aspecto semelhante ao observado no sítio Jacarezinho (fonte: MILLER et al., 1992: 56).

Inserido na Tradição Jamari, o sítio Jacarezinho oferece importantes dados cronológicos para uma das maiores lacunas dessa tradição, situada no começo do segundo milênio da era cristã. Por outro lado, o início (550 a.C.) e o fim dessa cronologia (1720 d.C.) permanecem, a priori, inalterados (Tabela 53).

\begin{tabular}{|c|c|}
\hline Sítio/Fase & Datação (Idade Convencional) \\
\hline Matapi & $1720+-80$ d.C. \\
\hline Matapi & 1530 d.C. (?) \\
\hline Jamari & $1480+-70$ d.C. \\
\hline Jacarezinho & $1290+-40$ d.C. \\
\hline Jacarezinho & $1090+-40$ d.C. \\
\hline Jacarezinho & $970+-40$ d.C. \\
\hline Cupuí & $600+-60$ d.C. \\
\hline Jamari & $120+-70$ a.C. \\
\hline Jamari & $180+-50$ a.C. \\
\hline Urucuri & $330+-100$ a.C. \\
\hline Urucuri & $460+-50$ a.C. \\
\hline Urucuri & $550+-90$ a.C. \\
\hline
\end{tabular}

Tabela 53: Cronologia do sítio Jacarezinho, dentro da Tradição Jamari (a partir de MILLER et al. 1992).

Apesar de não expandir a cronologia da Tradição Jamari, o sítio Jacarezinho estende essa Tradição geograficamente do médio para o baixo Jamari. Restando saber se essa Tradição também se encontrava rio acima, em direção ao alto Jamari.

Durante os trabalhos de campo do PALMA, ocorreram duas oportunidades de visitar o Museu Marechal Rondon de Ariquemes (RO) e, em uma dessas etapas, foi possível visitar 
alguns sítios arqueológicos da região ${ }^{110}$ (Figs. 144 e 145). A partir do contato com esse material, foi possível perceber que, apesar de essa cerâmica também ser "simples" (sem decorações ou formas angulosas), apresentava algumas diferenças em relação à cerâmica da Tradição Jamari. Diferenças que parecem ter se confirmado nos trabalhos arqueológicos realizados por Schwengber e Zimpel (2012) na região de Ariquemes ${ }^{111}$.

A cerâmica identificada por esses autores possui uma pasta com uma quantidade muito grande de antiplástico mineral, ao passo que o material do sítio Jacarezinho e da Tradição Jamari era temperado com caraipé. Esse antiplástico mineral deu à cerâmica do altomédio Jamari um aspecto grosseiro, mal alisado, deixando a pasta mais pesada. Conforme visto, o material da Tradição Jamari, incluindo o do sítio Jacarezinho, possuía uma superfície bem alisada, e o antiplástico vegetal lhe conferia uma certa leveza. A cor da cerâmica do altomédio Jamari variava entre tons mais escuros marrom-avermelhados (o que pode ser decorrente do sedimento avermelhado da região), e a cerâmica da Tradição Jamari era predominantemente clara, com tons ocre-amarelados. A espessura também parece ser distinta: o material do alto-médio Jamari possuía uma espessura fina $(0,6-1 \mathrm{~cm})$, ao passo que o material do sítio Jacarezinho era mais espesso (1,1-1,5cm). Apesar de pouco frequentes, os banhos de engobo e, em especial, de barbotina, estão presentes na Tradição Jamari e no sítio Jacarezinho, mas não foram identificadas na cerâmica do alto-médio Jamari ${ }^{112}$ (ALMEIDA, 2010b: 29-35; MILLER et al., 1992: 32-65; SCHWENGBER e ZIMPEL, 2012: 69-131).
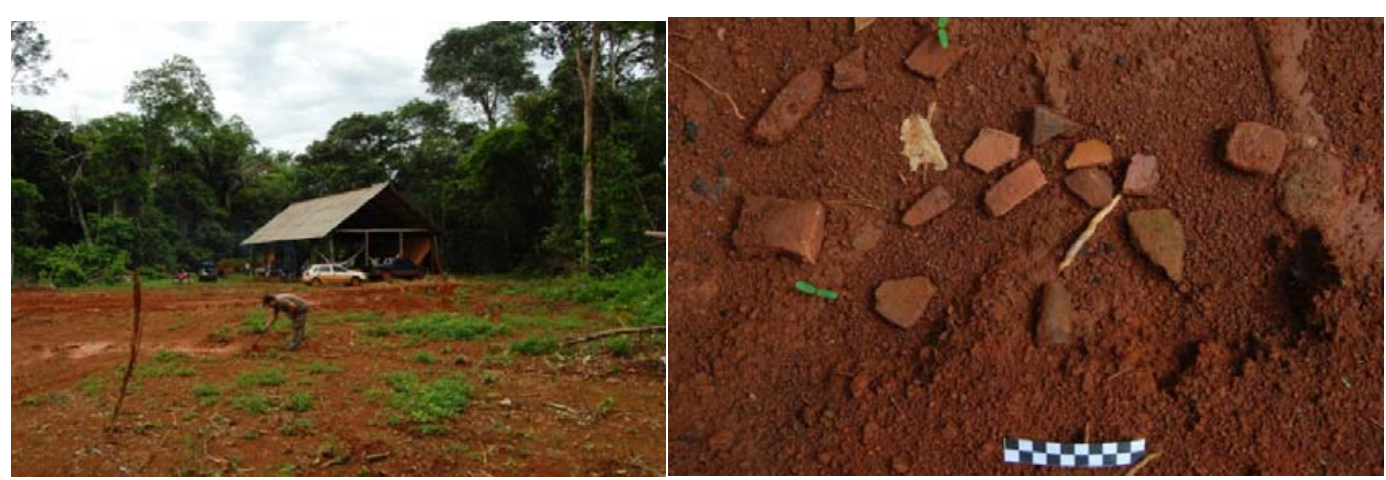

Figura 144: Sítio União, médio alto Jamari.

Figura 145: Fragmentos cerâmicos do sítio União (foto: Fernando Ozorio de Almeida, 2010).

\footnotetext{
${ }^{110}$ Com auxílio do Prof. Washigton Cavalcante, responsável pelo Museu.

${ }^{111}$ Relativos à implantação da Pequena Central Hidrelétrica (PCH) - Jamari, no município de Ariquemes.

${ }^{112}$ Schwengber e Zimpel (2012: 132) apresentam três datações radiocarbônicas para os sítios do alto-médio Jamari: 1040+-10 d.C. (sítio Mato Grosso); 1290+-30 d.C. (sítio Jamari); 1490+-30 d.C. (sítio Rawel).
} 
Resumindo, parece haver mais semelhanças entre os sítios do médio Jamari (Tradição Jamari) com o baixo curso desse rio (sítio Jacarezinho) do que rio acima, nas proximidades da cidade de Ariquemes. Ainda assim, em todos os casos se trata de uma cerâmica não decorada de morfologia simples. Nesse sentido, se levada em conta a hipótese proposta por Miller (2009) de que a Tradição Jamari estaria ligada aos grupos de língua Tupi-Arikém e se observado o mapa de etnias da região elaborado por Roquette-Pinto (1975 [1919], Anexo 6), haveria a possibilidade de testar se essa cerâmica do médio-alto Madeira estaria ligada aos grupos Arikém propriamente ditos, ao passo que a cerâmica mais ao norte (Tradição Jamari) estaria ligada aos grupos Karitiana.

Caso confirmada a ligação entre a Tradição Jamari e os antigos falantes de línguas Tupi-Arikém, seria necessário repensar a divisão de vasos para serviço e consumo de fermentados do sítio Jacarezinho, uma vez que (pelo menos em um período recente) estes grupos utilizavam cuias (cabaças) com hastes para servir e consumir a chicha (Fig. 146).

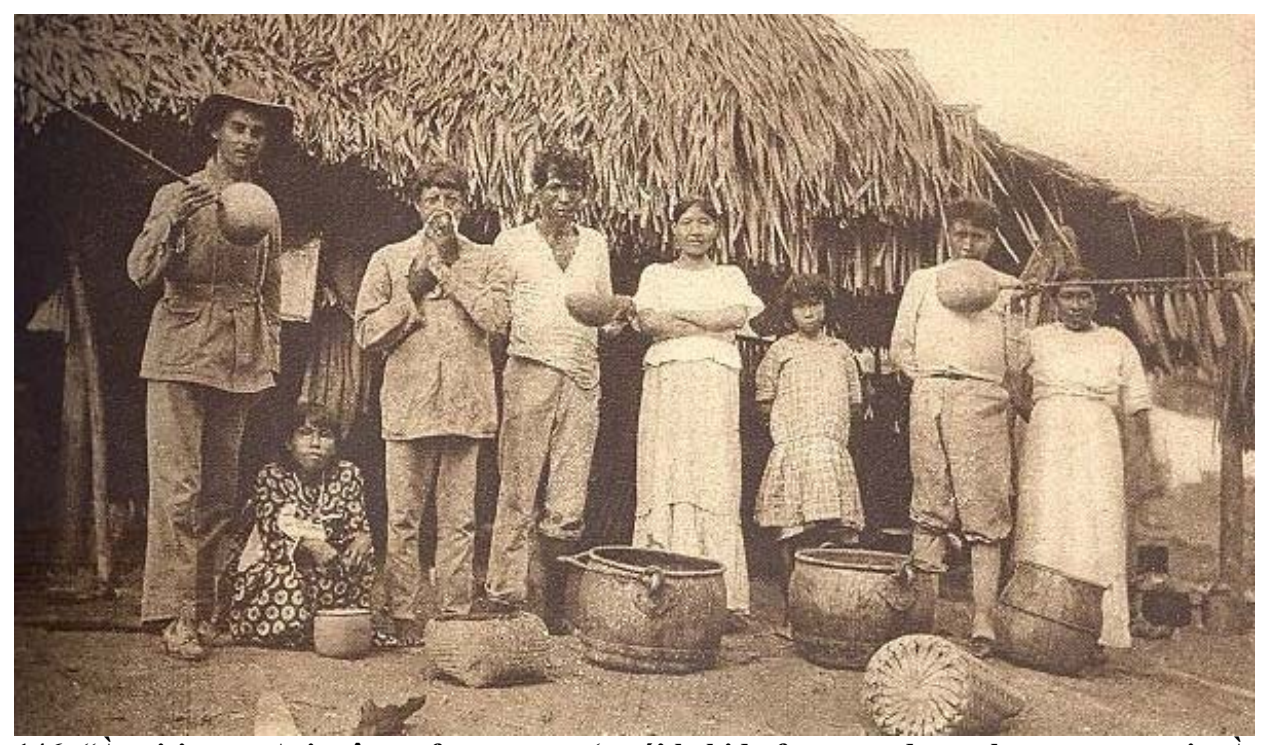

Figura 146: "Às visitas os Ariquême oferem o seu 'totó' bebida fermentada qual a nossa cerveja. À esquerda, o Dr. Caio Spínola, encarregado do Pôsto Rodolfo Miranda, é um dos homenageados. Êles bebem, esse totó em uma cuia presa a um longo cabo". (Foto e legenda: Magalhães 1916).

\subsection{Discussão}

Se não bastassem as confusões apontadas no Capítulo 2 ao confrontar a Subtradição Amazônica com as supostas fases TPA no sudeste amazônico, a descrição e a comparação da cerâmica dos sítios escavados e analisados pelo PALMA no alto Madeira também mostrou 
uma grande heterogeneidade nos elementos politéticos. A morfologia, chave para a organização tipológica das indústrias cerâmicas, não se mostrou adequada para a realização do agrupamento de sítios, restando utilizar o segundo atributo na hierarquia taxonômica - o dos tratamentos de superfície (e decorações) - para realizar a separação dos sítios.

As análises estatísticas tiveram papel importante na identificação dessa variabilidade, tornando necessária uma discussão mais aprofundada (Capítulo 6) sobre a relação dos sítios que, de outra forma, podia ter sido ignorada ao denominar todos os sítios com policromia de Subtradição Jatuarana ou Tradição Polícroma da Amazônia. Antes disso, as análises comparativas no sudeste Amazônico (rio Tocantins) já haviam sugerido cuidado e prudência ao lidar com as antigas classificações. Ou seja, apesar das decorações e dos tratamentos de superfície serem os elementos centrais no agrupamento de três sítios - Itapirema, Teotônio e Associação Calderita - e no isolamento dos sítios Nova Vida e Jacarezinho, essa variabilidade intra-sítios terá de ser mais bem compreendida (Capítulo 6).

O sítio Jacarezinho foi, até aqui, o único a ser relacionado a uma Tradição arqueológica específica, a Tradição Jamari. Esse sítio auxiliou a fortalecer uma parte intermediária e com poucas datas dessa Tradição, no início do segundo milênio d.C. Além disso, a confirmação da ligação desse sítio com essa Tradição parece dar fluidez às fronteiras culturais que separavam os grupos do rio Madeira (Subtradição Jatuarana) dos grupos do médio Jamari (Tradição Jamari): uma ruptura na suposta buffer zone. Foi sugerido ser possível que as diferenças de material entre o médio-baixo Jamari e o médio-alto Jamari representem a diferenciação entre dois grupos Tupi-Arikém conhecidos historicamente na região: os Arikém propriamente ditos e os Karitiana. Hipótese que corroboraria a ligação entre a Tradição Jamari e os Tupi-Arikém feita por Miller (2009), mas que precisa ser testada com cuidado.

Outra proposta feita por Miller $(1992,1999)$ fortalecida pela análise dos sítios do PALMA foi a da relação dos sítios com as palmeiras. Miller apontou a presença de determinadas palmeiras (urucurí e marajá) como indicadores paisagísticos de sítios arqueológicos na região, e as análises botânicas feitas nos sítios estudados mostram a recorrente presença de sementes carbonizadas de palmeiras (a definir) no período précolonial. Ou seja, fornecem novos subsídios para estabelecer a antiga relação entre o ser humano e essa família botânica na região conhecida pela domesticação da pupunha, uma das raras palmeiras na Amazônia que sofreu tal processo. 
A análise preliminar do material lítico do sítio Teotônio também parece ter revelado interpretações consistentes. Primeiro, foi descartada a ocorrência de uma suposta ocupação pré-cerâmica no latossolo, como havia sido cogitado em campo. Por outro lado, a camada de sedimento escuro apenas com material lítico, presente na unidade N10001 E 10003, parece estar de fato ligada a uma ocupação pré-cerâmica. Os dados paleobotânicos apresentados para esse sítio contribuíram para essa inferência. Além dos $50 \mathrm{~cm}(60-110 \mathrm{~cm})$ de material lítico sem cerâmica nessa unidade, o que mais contribui para essa interpretação - independente de uma análise mais cuidadosa do material lítico - é o próprio contexto do alto Madeira. Afinal, é nessa região que foi identificada a Tradição Massangana, uma indústria lítica de terra preta (MILLER et al., 1992), na região do médio-baixo Jamari (cf. Capítulo 3).

Da mesma forma, a identificação de uma camada pré-cerâmica em terra preta no sítio Garbin, com datas de quase 6.000 anos (SUZE, 2010: 37-38), nos estudos arqueológicos relacionados ao licenciamento da UHE Santo Antônio, é o indicador de que o fenômeno se repete nas margens do rio Madeira. As indústrias líticas dos sítios Teotônio, Garbin e dos sítios Massangana do médio-baixo Jamari são muito semelhantes: uma indústria com peças de simples confecção, com matéria-prima de quartzo (leitoso e hialino), blocos de granito e lateritas com marcas de abrasão ${ }^{113}$ (MILLER et al., 1992: 37-38; SUZE, 2010: 37-38). Ou seja, é provável que no futuro próximo um estudo lítico mais aprofundado desses contextos venha expandir espacial e cronologicamente o que hoje se conhece como Tradição Massangana (cf. Capítulo 3): com data de 4000 a.C. para o período inicial (Garbin) e de 700 a.C. (a data de MILLER, 1992 para o Teotônio) para o período final.

O último ponto a ser der discutido é a relação desses sítios pré-cerâmicos em terra preta com as cachoeiras. Foi observado que o sítio Teotônio se encontra na margem direita da cachoeira homônima, e pode-se ver na figura 40 que o sítio Garbin está na margem esquerda da cachoeira de Santo Antônio. Dos sítios Massangana do rio Jamari, pelo menos um, Samuel 1 (coordenadas UTM 201 450137/9032941), pode ser encontrado ao lado da cachoeira homônima.

Cachoeiras como a de Teotônio podem ser vistas como ecótonos, áreas com abundância de alimentos. Miller (1999: 333; cf. NEVES, 2001: 269 para as cachoeiras do Uaupés), por exemplo, relaciona as áreas a jusante das cachoeiras como limites (e

\footnotetext{
${ }^{113} \mathrm{O}$ que é intrigante nesse sentido, e que terá que ser resolvido nos futuros estudos do material lítico dos sítios Teotônio e Garbin, é o significado da aparente semelhança tecnológica e de matéria-prima empregada entre os materiais das camadas pré-cerâmicas e cerâmicas.
} 
concentração) de peixe-boi (Trichechus inungüis), pirarucu (Arapaima gigas) e tartaruga (Podoctenemis expansa). Da mesma forma, estudos realizados na região das cachoeiras de Teotônio e Santo Antônio indicam que atividades de pesca nessa região entre 1979 e 1989 renderam entre 900 e 1.500 toneladas de peixe por ano (GOULDING et al., 1996: 109). Ou seja, trata-se de um local que se diferencia pela fartura proteica. Fato que permite pensar na possibilidade de persistência de grupos não agricultores habitando a área da cachoeira do Teotônio de maneira sedentária, em uma espécie de sambaqui sem conchas. Nesse quadro, seria a estabilidade e a persistência de grupos nesses locais estratégicos que levaria a uma eventual mudança na paisagem, com um manejo contínuo do entorno. Resumindo, talvez a persistência em determinados locais seja um fator tão ou mais importante para compreender os processos de sedentarização das populações amazônicas do que "Optimuns Climáticos" ou mudanças ambientais dessa ordem (e.g. MILLER, 1983, 1992, 1999, 2009) que restringiam as populações a simples e incapazes coadjuvantes de "motivos de força maior". Sendo assim, torna-se necessário compreender um pouco mais o que se quer dizer com "lugar persistente".

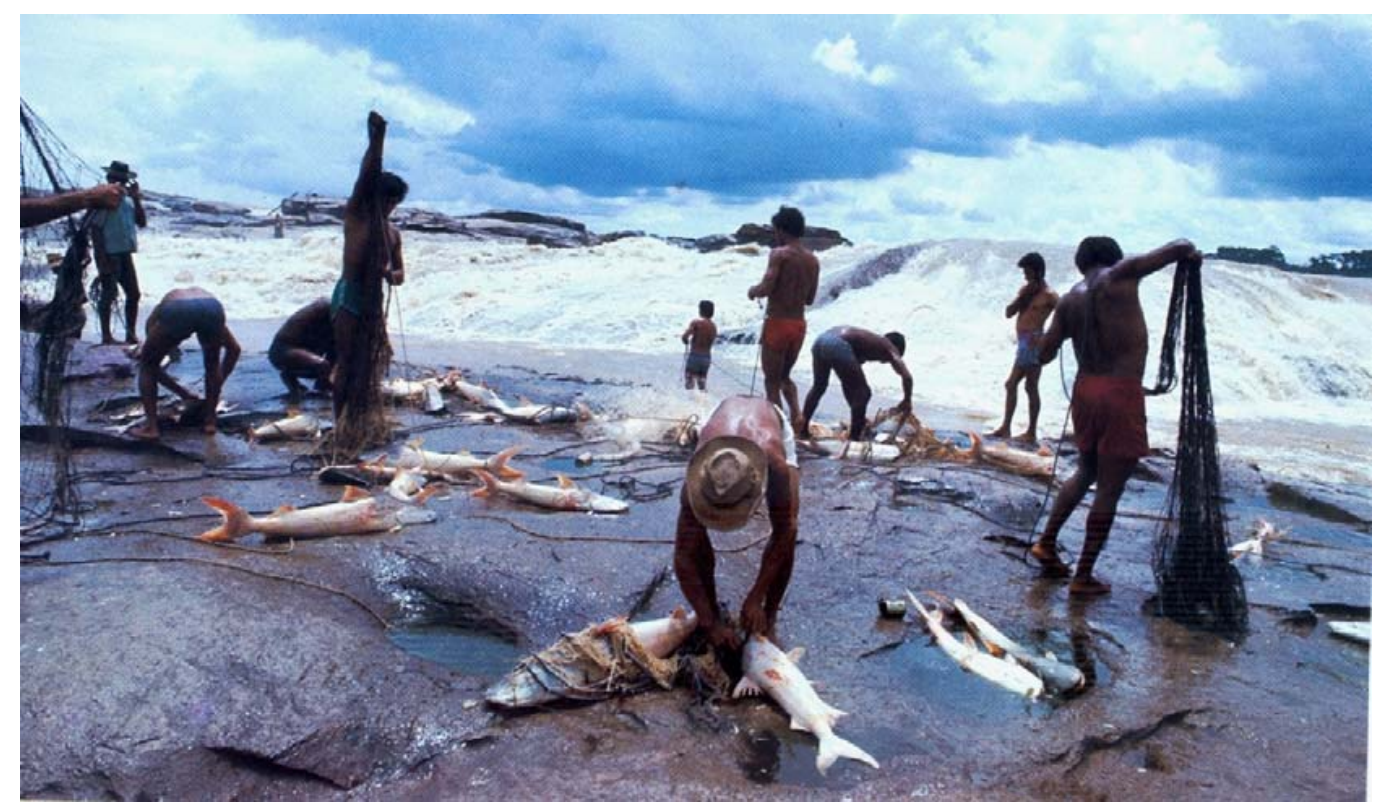

Figura 147: Pescaria no sítio Teotônio (fonte: GOULDING et al., 1996). 


\title{
6 UMA CONFUSÃO DE CORES NAS MARGENS DOS RIOS DA AMAZÔNIA: REINTERPRETANDO A TPA
}

\begin{abstract}
A grande questão que resta ser resolvida, contudo, é a da relação entre o maior fluxo de informação, e a decorrente diversidade estilística, e as mudanças na organização social destas sociedades pré-coloniais (BARRETO, 2008: 11).
\end{abstract}

\subsection{Introdução}

Neste capítulo, o sítio Teotônio será abordado a partir dos conceitos de lugar significativo e lugar persistente. A questão sobre a suposta ocupação mais antiga desse sítio será retomada, à luz das novas análises feitas com base no material escavado há três décadas por Eurico Miller. Entretanto, pode-se adiantar a existência de uma heterogeneidade de cenários, visualizados a partir dos dados obtidos com as atividades realizadas pelo PALMA e por Miller no sítio Teotônio, que impossibilitam uma inferência mais consistente sobre esse sítio. Ainda assim, serão oferecidos planos de trabalho para que estudos futuros possam resolver a questão.

Tendo como ponto de partida a observação do sítio Teotônio como centro do contexto do alto Madeira, será apresentada a primeira de duas propostas interpretativas para a história pré-colonial dos grupos ceramistas do alto Madeira. Em seguida, será trabalhada a relação dos sítios Itapirema e Associação Calderita com a Tradição Polícroma da Amazônia. Para tanto, será utilizada a bibliografia sobre sítios dessa Tradição, localizados no alto e médio Amazonas e no baixo rio Madeira. Nesse quesito, sim, os dados são mais consistentes.

A partir da discussão sobre a Tradição Polícroma em relação ao sítio Teotônio e às antigas tradições ceramistas da Amazônia, na qual se percebe uma confusão de estilos policrômicos, será apresentada a segunda proposta interpretativa para a arqueologia da região. Apesar da falta de resultados conclusivos, os dados são mais do que suficientes para apontar que o alto Madeira é uma área-chave para a compreensão da história dos grupos indígenas do sudoeste da Amazônia. 


\subsection{Lugares significativos e lugares persistentes}

Em uma das mais elegantes e criativas romantizações históricas já escritas, $O$ povo das Montanhas Negras (1991), o escritor Raymond Williams narra uma cronologia de 25.000 anos da sua terra natal, as Montanhas Negras, atual País de Gales. Em cada capítulo do livro, o autor descreve um acontecimento que ajuda a compreender o modo de vida dos habitantes das Montanhas Negras em uma determinada época, desde a organização política, econômica e social, até as crenças, a visão de mundo e os rituais desses grupos. Durante a narrativa, há uma cuidadosa descrição da cultura material de cada época, de forma que o leitor se assegura que a rica imaginação de Williams possui uma consistente base de dados arqueológicos.

Muitas vezes, os eventos narrados denotam mudanças, como a chegada de um estrangeiro e o consequente surgimento de uma peste que dizima a população local. Em outros momentos, o autor aponta possíveis mudanças que não se concretizam. Um exemplo é a história de Aron, um rapaz franzino que não possui capacidade física para a caça e desafia a lógica (reestruturar a estrutura) do grupo de caçadores ao qual pertence, prendendo um pequeno porco que encontra para criá-lo e matá-lo apenas quando tiver necessidade. Infelizmente, o grupo de Aron não estava pronto para tal mudança, tampouco para permitir que uma caça permanecesse viva dentro da aldeia.

Williams também explora diferenças espaciais, como no capítulo $A$ viagem para $o$ encontro Rio-Mar, que relata uma história que teria ocorrido por volta de 2600 a.C. Trata-se da viagem de Gordin e Tarc, dois pastores das Montanhas Negras que decidem viajar para o local denominado Rio-Mar com o intuito de trocar chifres de ovelhas por nódulos de sílex, para a fabricação de ferramentas. Os dois partem de manhã cedo, vão seguindo um pequeno riacho e só deixam as montanhas para trás muitas horas depois. Fora das montanhas, onde o riacho se torna um pequeno rio, eles encontram outra aldeia de pastores, de língua e cultura semelhante à deles, onde pernoitam. No dia seguinte, ainda seguindo o rio, Gordin e Tarc se encontram com outro grupo. Dessa vez não se tratam de semelhantes e sim de um pequeno grupo de caçadores. Pequenos em número, mas não em tamanho. Williams deixa claro que o porte físico dos caçadores é muito mais avantajado do que o da dupla de pastores, diferença que é ironizada pelos caçadores. Esses, além do mais, possuem línguas distintas, e suas canoas rústicas indicam que dominam a tecnologia da navegação. 
Apesar das diferenças linguísticas, os caçadores compreendem o propósito da viagem de Gordin e Tarc e decidem ajudá-los, levando-os de canoa até o Rio-Mar no dia seguinte. Durante o percurso, os dois personagens percebem que a água vai ganhando um gosto salgado, e que o rio fica cada vez mais largo. Eles passam por outras comunidades, com casas iguais às deles, ainda que com dimensões maiores. Essas comunidades também falam a mesma língua de Gordin e Tarc, que estranham o fato de os aldeões serem indiferentes à chegada de estranhos: não há medo de ataque, e os cachorros não latem.

Percepção que se acentua ainda mais quando os personagens finalmente alcançam o povoado do Rio-Mar, na foz do rio, e se assustam com a quantidade de pessoas, a maior concentração de gente já vista por eles. Ao se apresentar para os principais do povoado do Rio-Mar, também de língua compreensível, um dos homens nota a absurda semelhança física entre Gordin e outro morador local. Postos lado a lado, toda a aldeia ri dos falsos gêmeos. Acontece então um debate sobre a razão da semelhança entre ambos. Percebe-se que há uma mitologia comum entre a dupla de "caipiras" das Montanhas Negras e os "cosmopolitas" do Rio-Mar. Entretanto, essa mitologia não fornece uma explicação lógica para a semelhança física de dois entes espacialmente distantes, que precisa ser reinterpretada para que os fatores históricos que podem ter levado a essa semelhança sejam compreendidos.

Por fim, ocorre a troca. Só que essa não é feita com os membros do Rio-Mar, mas com outros estrangeiros que lá se encontram - e lá se encontram porque o solstício é o momento em que as pessoas realizam trocas. Os estrangeiros falam línguas diferentes e possuem uma variabilidade biotípica muito maior do que Gordin e Tarc já haviam visto. O uso que darão aos chifres será revelado apenas para os que se aventurarem a ler o próximo capítulo, mas pouco importa no momento.

\subsection{Cachoeiras, lugares significativos e persistentes}

"Pathways order human-land interactions in two ways, first they link cores sequentially and hierarchically, and, second, they determine the confines where people can engage repeatedly in particular experiences and activities" (Zedeño e Stoffle 2003: 61).

Histórias como essa não são difíceis de serem convertidas e inseridas em diferentes contextos. Na Amazônia pré-colonial, por exemplo, com as devidas contingências, pode-se 
pensar em um grupo indígena de terra firme, seguindo um curso d'água até se tornar um volumoso igarapé, um rio secundário, primário, chegando ao equivalente local do Rio-Mar, que poderia ser um sítio no encontro dos rios Negro e Solimões (cf. NEVES, 2012). Se não há registro desse tipo de viagem, há inúmeras evidências de redes de contato para o comércio. No entanto, simplificar esses encontros a "manutenções de redes de comércio" é muito pouco para alguém que lê um romance rico em detalhes como o de Williams.

Em alguns momentos dessa tese, foram observados aspectos dos rituais de grupos Tupi, de como eles marcam ciclos, organizam o tempo e possibilitam o contato com o desconhecido, com a alteridade, e, por consequência, permitem que o praticante conheça melhor a si mesmo, se identifique. No entanto, essa busca do conhecimento de si e do outro não se restringe apenas a uma dinâmica temporal, como também espacial, havendo certos lugares no espaço que favorecem experiências e processos cognitivos que tornam esses lugares significativos:

People create places through behavioral interactions with nature and the supernatural; they cognize their experiences by developing spatial referents for their actions through material modification and verbal and metaphoric inscription. On the basis of these cognitive processes, people develop senses of place and attachments to place that motivate, structure, and transform their interactions with material worlds in patterned ways (ZEDEÑO e BOWSER, 2009: 5).

Um lugar significativo, ao contrário de um sítio, não precisa ser fruto de modificação humana. É o reconhecimento da existência de tal lugar por um indivíduo ou coletivo que define sua significância e sua relação com outros lugares (ZEDEÑO e BOWSER, 2009: 6). Lugares significativos, como uma cachoeira, um geoglifo (SCHAAN et al., 2008) ou um afloramento rochoso com gravuras rupestres (e.g. VALLE, 2012; ZUCCHI, 2002: 208) estão, muitas vezes, intimamente ligados a paisagens conflitantes (e.g. um rio que deixa de ser navegável por causa da cachoeira ou um rio que desemboca no mar) e tendem a ter seu significado derivado, em parte, da posição dentro da rede de lugares e coletivos dentro dessas paisagens (RODMAN, 1992; ZEDEÑO e BOWSER, 2009: 9). A ocorrência de redes remete, por sua vez, à existência de distintos indivíduos ou agrupamentos e, por consequência, diferentes camadas de significância que determinado lugar recebe através do tempo e do espaço (ZEDEÑO e BOWSER, 2009: 10). Dentro dessa rede, é possível incluir participantes estrangeiros sazonais, que talvez não tenham contato com determinado lugar significativo mais de uma vez na vida, mas que interpretarão tal lugar à sua maneira e podem ocasionar 
comportamentos que contribuam para a gradual modificação física e construção dos significados do lugar.

Um eventual continuum na longa duração do uso de um lugar significativo pode transformá-lo em um lugar persistente (MOORE e THOMPSON, 2012: 267; SCHLANGER, 1992: 92; ZEDEÑO e BOWSER, 2009: 12). Tal persistência tende a ter uma relação íntima com fatores como a concentração física de recursos que tornem o lugar atraente para uso, remetendo ao conceito de território (ZEDEÑO e ANDERSON, 2010: 12); como também à manutenção desse território por meio da combinação de práticas e emoções - e.g. rituais funerários ou de iniciação - através de um período de tempo estendido (MOORE e THOMPSON, 2012: 268, 278), remetendo ao conceito de territorialidade (ZEDEÑO e ANDERSON, 2010: 12).

Um claro exemplo amazônico de um lugar significativo e persistente, coerente com a "romântica" narrativa das Montanhas Negras e do Rio-Mar, seria um grande teso Marajoara (e.g. MEGGERS e EVANS, 1957; ROOSEVELT, 1991; SCHAAN, 2004), com uma sequência milenar de reocupações por diferentes grupos, incluindo a fase Marajoara. Na já citada área de confluência entre os rios Negro e Solimões, Neves (2012: 230) aponta o sítio Hatahara, conhecido pelos montículos funerários, e por quatro ocupações distintas durante centenas de anos, como um lugar persistente.

No extremo oeste amazônico, nas terras baixas bolivianas (Llanos de Mojos), pode-se encontrar no Loma de Salvatierra, habitado continuamente entre os séculos V e XIII, outro exemplo de lugar significativo e persistente. O que chama a atenção é que esse sítio possui cinco fases que não marcam rupturas na sua ocupação, e sim graduais mudanças técnicoestilísticas na cerâmica de um grupo que habitou de forma contínua o mesmo local (JAIMESBETANCOURT, 2012: 162-163). Ao que parece, esse sítio é um entroncamento de caminhos que transportaram as ideias (cf. BARRETO, 2008, 2010; ROE, 1995) que moldaram as formas de ver o mundo daquele grupo que habitou o teso.

O complexo do Teotônio, formado por uma impressionante cachoeira, cercada por um sítio arqueológico em cada flanco (sítios Teotônio e Santa Paula), localizada no maior afluente do rio Amazonas, também pode ser considerado um lugar significativo (cf. ZUSE, 2011: 66). Além disso, a probabilidade de o local ter sido ocupado quase ininterruptamente durante (pelo menos) os últimos 3.000 anos, aliada à imensa variabilidade de material 
cerâmico que foi e será descrito (fruto das redes de troca?), permite apontar com segurança que se trata de um lugar persistente.

Até o momento, foram observadas duas características das cachoeiras. A primeira é de "fronteira" ou divisor cultural, separando grupos do baixo Tocantins assim como, com as devidas ressalvas, os grupos da Tradição Jamari e Jatuarana, na região do médio e baixo Jamari (Capítulos 2, 4 e 5). A segunda característica é a abundância de recursos (pesca), o que não ocorre com todas as cachoeiras, mas que deve ser um diferencial dessas com relação às respectivas áreas de entorno, pelo menos na Amazônia.

Nesse sentido, foi sugerido que as cachoeiras do Teotônio e de Samuel estão relacionadas a ocupações sedentárias de grupos pré-ceramistas que não necessariamente eram agricultores. Independente da intensidade com que os diferentes grupos se relacionaram com os recursos vegetais e animais no entorno, fato é que há indícios de mais de 3.000 anos de ocupação do sítio Teotônio, cronologia que pode ser ainda mais antiga nas cachoeiras de Santo Antônio e Samuel.

Tendo em vista a antiguidade da ocupação desses locais não é de estranhar que a mitologia de muitos grupos aponte uma origem ligada às áreas de cachoeira. Pode-se citar como exemplo os Baníwa, grupo de língua Arawak do rio Negro (RIBEIRO, 1995: 19). Em outros grupos, como os Jívaro, as cachoeiras estão ligadas a processos de iniciação masculina, nos quais o rapaz é apresentado ao lado oculto (ao seu arután, espírito ligado à morte e à vontade de matar), um aspecto-chave da cultura Jívaro (HARNER, 1972: 136-139).

Trata-se de uma terceira característica ligada às cachoeiras, assim como ao conceito de territorialidade: tais lugares fornecem subsídios interpretativos para a compreensão do mundo (o eu e o outro), o que também significa oferecer ferramentas para a criação e a manutenção da identidade do grupo que ocupa ou frequenta esses lugares. A quarta característica das cachoeiras, vistas como lugares significativos e persistentes, é uma espécie de antítese da primeira (fronteira cultural) e foi exemplificada pela história do Rio-Mar, pelos tesos de Marajó e Llano de Mojos e pelos sítios Hatahara e Teotônio. Trata-se, claro, de observar esses locais como núcleos, entroncamentos de caminhos fluviais e terrestres que formam os nós nas redes da Amazônia pré-colonial descritas no Capítulo 3. 
(...) both communication through the flow of people and information across the landscape and appropriation of cores are rationalized and intertwined in the landscape ethos that simultaneously informs territory formation and is transformed by it (ZEDEÑO e ANDERSON 2010: 16).

Para uma melhor compreensão do que seriam esses núcleos pré-coloniais amazônicos, assim como para uma discussão de questões classificatórias deixadas em aberto no capítulo anterior, será retomada a interpretação do sítio Teotônio.

\subsection{Nas profundezas do sumidouro do Teotônio}

Desde os primeiros trabalhos arqueológicos feitos por Miller no alto rio Madeira, no final dos anos 1970, o sítio Teotônio aparece com certo destaque nas descrições sobre a préhistória regional. Conforme visto, isso ocorreu devido a uma data muito antiga, 700 a.C., encontrada por Miller (1992: 224) 30cm acima da base de terra preta, e por ele vinculada à Subtradição Jatuarana e à Tradição Polícroma da Amazônia.

Entretanto, a retomada dos trabalhos no sítio Teotônio sugeriu a existência de camadas com materiais mais antigos do que a ocupação com cerâmica policrômica (Capítulos 4 e 5). Na unidade N10001 E10003, foi observada uma camada lítica em terra preta, datada em 1100 a.C. Nessa mesma unidade, foi realizada uma datação para a base da camada cerâmica (Jatuarana?) que apontou a data de 700 d.C. Em síntese, por meio dessa unidade, foi possível sugerir que a datação feita por Miller estava vinculada a uma camada pré-cerâmica, em terra preta, e não à ocupação com cerâmica policrômica, que seria empurrada 1.000 anos para a frente.

Além disso, foi identificada em uma segunda unidade (N10000 E9902) e numa limpeza de perfil (N10045 E9986) uma suposta cerâmica mais antiga: sem decorações pintadas, com decorações plásticas "rústicas" e predominantemente temperada com antiplástico mineral. Uma amostra de carvão vinculada a essa camada $(65 \mathrm{~cm}$ de profundidade) foi datada em 400 d.C. Uma amostra de carvão na base da camada com cerâmica policrômica $(37 \mathrm{~cm})$ estava, ao que parece, contaminada e apresentou uma data próxima do presente. Esses dados levariam à construção do seguinte quadro provisório: 


\begin{tabular}{|l|l|l|}
\hline \multicolumn{1}{|c|}{ Ocupação } & \multicolumn{1}{c|}{ Idade Convencional } & \multicolumn{1}{c|}{ Fonte } \\
\hline Cerâmica policrômica & $700+-30$ d.C. & PALMA \\
\hline Cerâmica pré-policrômica & $400+-30$ d.C. & PALMA \\
\hline Lítico pré-cerâmico (?) & $780+-75$ a.C. & MILLER, 1992 \\
\hline Lítico pré-cerâmico & $1120+-30$ a.C. & PALMA \\
\hline
\end{tabular}

Tabela 54: Quadro cronológico provisório para o sítio Teotônio.

Durante as análises de laboratório, pensou-se que essa cerâmica mais antiga poderia ter uma média de espessura mais fina do que a da cerâmica policrômica dos níveis superiores. Com isso em mente, foi realizada uma análise estatística ANOVA para avaliar se havia alguma diferença entre a espessura dos fragmentos no nível $50-60 \mathrm{~cm}$ da unidade N10000 E9902, onde estaria concentrado o suposto material mais antigo, e os demais níveis superiores. A análise não apontou diferenças significativas entre os níveis (BARROSO et al., 2012: 39; Anexo 15 L), o que pode ser decorrente da utilização de amostras do nível 40$50 \mathrm{~cm}$, onde há elementos das duas cerâmicas.

Por outro lado, a análise de agrupamentos - baseada nas variáveis morfologia da borda, antiplástico, porcentagem do antiplástico, decoração plástica, decoração pintada e tratamento de superfície FE - sugeriu uma diferenciação entre os níveis superiores e o nível 50-60cm (BARROSO et al., 2012: 34-35), indo de encontro a observações de campo e laboratório, ainda que uma inferência mais segura dependa de uma maior amostra dos níveis mais profundos.

A baixa densidade dessa suposta cerâmica mais antiga lembrou, de certa forma, o contexto do sítio Nova Vida (Capítulos 3 e 4). A própria cerâmica, decorada apenas com incisões irregulares, poderia ser vista como um possível elo entre essas indústrias, na ausência de formas reconstituídas em ambas. A espessura fina das paredes, observada em ambos os casos, poderia ser outro elemento de semelhança. Além disso, as datas desse contexto antigo (400 d.C.) e desse sítio (200 d.C.) são razoavelmente próximas, o que possibilitaria especular que se trata de uma antiga ocupação do alto Madeira, "substituída" pela chegada dos grupos produtores de cerâmica policrômica.

As baixas amostragens do sítio Nova Vida e da suposta cerâmica antiga do sítio Teotônio, no entanto, não permitem uma comparação mais profunda entre ambas, de forma que a relação é só uma hipótese a ser testada no futuro. O ponto a ser levantado é que as análises da unidade N10000 E9902 estão mais próximas de indicar duas ocupações de grupos cerâmicos do que, como quis Miller, uma única Subtradição (Jatuarana) com "maior 
popularidade de técnicas plásticas no início da sequência e maior popularidade de técnicas crômicas no final" (1992: 224).

Nas pesquisas que vêm sendo desenvolvidas por Silvana Zuse (2011), é possível encontrar outros elementos que contribuem para a interpretação das primeiras ocupações cerâmicas no alto Madeira ${ }^{114}$. Trata-se de uma ocupação antiga - a datação é análoga à do sítio Nova Vida - identificada pela arqueóloga no sítio Morro dos Macacos 1, caracterizada pelo tempero mineral, decorações incisas largas e por vasilhas rasas (p. 102). Essa cerâmica se difere da cerâmica policrômica com antiplástico de caraipé encontrada nos níveis superiores: um contexto muito semelhante ao do sítio Teotônio.

Entretanto, se observada a amostragem feita por Miller no Teotônio - uma unidade de $2 \times 2 \mathrm{~m}$ realizada em local desconhecido do sítio - nota-se que a interpretação do autor não estava errada. Essa constatação foi feita a partir de uma nova análise dos níveis mais profundos da unidade escavada por Miller no sítio Teotônio por Stephen Shennan (University College London) e pelo presente pesquisador, no ano de 2005. A unidade foi analisada a partir do nível 60-70cm, chegando até $230 \mathrm{~cm}$ de profundidade (Tabela 56, Anexo 21).

De forma resumida, o que se observou a partir da análise da unidade escavada por Miller é a presença de uma série de elementos plásticos - corrugados, serrungulados, ungulados, escovados, ponteados, entalhados, filetes aplicados - em todos os níveis (principalmente os mais profundos), associados a outros fragmentos com pintura policrômica e incisões na face interna da borda. Trata-se de uma variedade de elementos plásticos muito maior do que a que a observada na unidade N10000 E9902, que foi vinculada à suposta ocupação cerâmica pré-policrômica. Quando o sítio Teotônio foi comparado a uma salada de frutas (Capítulo 5), era essa variedade de elementos plásticos e pintados da unidade escavada por Miller que se tinha em mente.

Um dos caminhos para a compreensão do sítio Teotônio é a análise do sítio Santa Paula, localizado na margem esquerda da cachoeira do Teotônio, de frente ao sítio homônimo. Dada a proximidade e a relação com a cachoeira, pode-se considerar que os dois sítios - incluindo áreas periféricas de terra mulata (Capítulo 4) e os polidores encontrados na cachoeira - fazem parte do complexo do Teotônio. O sítio Santa Paula possui cerâmica muito

\footnotetext{
${ }^{114}$ Conforme visto no Capítulo 4, foram justamente as observações feitas Zuse a respeito da existência de ocupações pré-Jatuarana que levaram a equipe do PALMA (incluindo a própria arqueóloga) a retomar as escavações no sítio Teotônio.
} 
semelhante à do sítio Teotônio e foi recentemente estudado como pesquisa de iniciação científica por Edileno Duran Silva (2011).

Além da cerâmica incisa e policrômica análoga à indústria do sítio Teotônio, o sítio Santa Paula possui os mesmos elementos "exógenos" encontrados no Teotônio, incluindo uma sofisticada cerâmica inciso-modelada (E. SILVA, 2011: 21-22). Além disso, as fotos da análise apresentam cerâmicas com incisões irregulares e espessas, semelhantes às encontradas na cerâmica da suposta ocupação antiga do sítio do Teotônio (p. 22). Entretanto, o pesquisador não indica que essa cerâmica seria de uma ocupação distinta da ocupação com cerâmica policrômica. As datações obtidas para esse sítio são muito próximas (uma delas idêntica) das obtidas para a suposta cerâmica antiga do sítio Teotônio (Tabela 55), ainda que tenham sido obtidas a partir de uma série de diferentes níveis $(103 \mathrm{~cm}, 181 \mathrm{~cm}, 203 \mathrm{~cm}$, segundo ZUSE, 2011). Essa diferença de níveis contradiz a existência de uma fina camada de cerâmica antiga, ao mesmo tempo que causa certa inquietação quanto ao motivo de datas tão próximas no tempo mas tão espaçadas na estratigrafia (um montículo construído rapidamente?).

\begin{tabular}{|l|l|l|}
\hline \multicolumn{1}{|c|}{ Ocupação } & \multicolumn{1}{c|}{ Idade Convencional } & \multicolumn{1}{c|}{ Fonte } \\
\hline Cerâmica policrômica & $700+-30$ d.C. & PALMA \\
\hline Cerâmica & $430+-40$ d.C. & SILVA, 2011; ZUSE, 2011 \\
\hline Cerâmica & 420 d.C. & SILVA, 2011; ZUSE, 2011 \\
\hline Cerâmica & $400+-30$ d.C. & SILVA, 2011; ZUSE, 2011 \\
\hline Cerâmica pré-policrômica & $400+-30$ d.C. & PALMA \\
\hline Lítico pré-cerâmico (?) & $780+-75$ a.C. & MILLER, 1992 \\
\hline Lítico pré-cerâmico & $1120+-30$ a.C. & PALMA \\
\hline
\end{tabular}

Tabela 55: Quadro cronológico provisório para o complexo do Teotônio, incluindo as datações do sítio Santa Paula. Pode-se notar que as datas fornecidas por E. Silva (2011) e Zuse (2011) são mais próximas da suposta ocupação cerâmica antiga do sítio Teotônio do que da ocupação recente. 


\section{Sítio: Teotôno (RO-JC-01)}

Descrição: Trata-se do material escavado por Eurico Miller $(1980,1992)$ nesse sítio e depositado no MARSUL (Museu Arqueológico do Rio Grande do Sul). Este material se refere aos níveis inferiores de uma unidade de $2 \times 2 \mathrm{~m}$ aberta por Miller, e foi analisado em 2005 pelo Dr. Stephen Shennan e pelo presente aluno.

\section{Fragmentos Analisados: 719}

Níveis: $190-230 \mathrm{~cm}, 180-190 \mathrm{~cm}, 170-180 \mathrm{~cm}, 160-170 \mathrm{~cm}, 150-160 \mathrm{~cm}, 140-150 \mathrm{~cm}, 130-140 \mathrm{~cm}, 120-$ $130 \mathrm{~cm}, 110-120 \mathrm{~cm}, 100-110 \mathrm{~cm}, 90-100 \mathrm{~cm}, 80-90 \mathrm{~cm}, 70-80 \mathrm{~cm}, 60-70 \mathrm{~cm}$

Categoria: 396 parede, 262 borda, 18 base, 7 carena, 32 outros

Técnica de manufatura: 4 acordelada, 2 modelada, 711 não identificada

Antiplástico: 510 caraipé, 38 mineral + caraipé, 35 mineral, 12 outro, 124 não identificado.

Espessura do Antiplástico: 402 frag. $<1 \mathrm{~mm}, 253$ frag. $=>1 \mathrm{~mm}$ e $<3 \mathrm{~mm}, 39 \mathrm{frag}$. $=>3 \mathrm{~mm}$ e $<5 \mathrm{~mm}$; $11 \mathrm{frag} .=>5 \mathrm{~mm}$

Queima: 111 núcleo claro, 413 núcleo preto, 176 núcleo escuro com faixas claras $\mathrm{AF}, 19$ outro Estado de Conservação: 437, não erodido, 27 erodido FE, 32 erodido FI, 223 erodido AF

Alisamento: 542 alisado em ambas as faces, 70 alisamento $\mathrm{FE}, 71$ alisamento $\mathrm{FI}, 36$ não identificado Polimeto: 34 polimento $\mathrm{FE}, 35$ polimento $\mathrm{FI}, 19$ polimento $\mathrm{AF}$, 1 face de polimento não identificada Engobo: 33 engobo vermelho, 83 engobo branco, 5 engobo laranja, 11 esfumarado, 19 barbotina Marcas: 1 cestaria

Sinais de Uso: 10 fuligem $\mathrm{FE}, 1$ fuligem $\mathrm{FI}, 4$ fuligem em $\mathrm{AF}$

Morfologia da Borda e Flange: 134 direta, 102 extrovertida, 5 introvertida, 18 extrovertida com ponto angular, 2 extrovertida com ondulação

Inclinação da Borda: 71 vertical, 58 inclinada interna, 116 inclinada externa, 16 não identificada

Espessura da Borda: 156 normal, 48 expandida, 17 reforçada interna, 30 reforçada externa, 10 reforçada $A F$

Lábio: 156 arredondado, 87 plano, 26 apontado 5, biselado

Diâmetro da boca: 6 a 10cm: 20 frag., 10 a 20cm: 60 frag. 22 a 30cm: 47 frag., 32 a 42cm: 26 frag.

Base: 1 convexa, 4 plana, 2 côncava, 4 anelar, 8 pedestal

Espessura do Fragmento: 241 menor que $6 \mathrm{~mm}, 445$ entre $6 \mathrm{~mm}$ e $10 \mathrm{~mm}, 12$ entre 11 e $15 \mathrm{~mm}, 5$ maior que 1,5mm, 16 não identificado

Decoração Plástica: 19 corrugado, 308 incisão fina, 35 ungulado, 150 exciso/acanalado), 37 escovado, 26 ponteado, 19 outros

Decoração Pintada: 111 vermelho, 103 branco, 7 preto, 19 outro Local de Decoração: 455 parede, 128 borda, 31 lábio, 55 outro

PALMA

Sítio Teotônio

Cerâmica: Unidade Miller

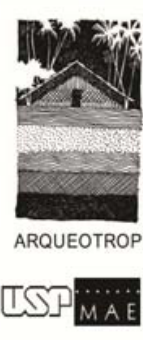


Foi apontado acima que a pesquisa realizada por Zuse (2011) no alto Madeira parece conter elementos mais coerentes com os dados obtidos pelo PALMA no sítio Teotônio do que com os dados obtidos pela escavação feita por Miller. Isto é, em comparação com o contexto do sítio Morro dos Macacos 1, optaríamos por identificar duas ocupações cerâmicas distintas (uma plástica e outra policrômica) no sítio Teotônio, em vez de uma cerâmica com imensa variabilidade, como sugere Miller (1992).

Por outro lado, ao olhar as pranchas de fotos da cerâmica do sítio Teotônio escavada por Miller, Zuse (com. pessoal) logo identificou diversos elementos (especialmente decorativos) que também estariam presentes de forma dispersa em uma série de sítios por ela estudados na região, como os sítios Garbin, Morro dos Macacos 1 e Veneza. Por exemplo, as incisões com motivos de volutas ou espirais, assim como ungulados e serrungulados, possuiriam correlatos no sítio Veneza (ZUSE, 2011: 72). Os motivos com pinturas espessas e motivos escalonados (em escada) possuiriam correlato no sítio Ilha do Santo Antônio, assim como as incisões irregulares que caracterizam supostas ocupações antigas dos dois sítios (p. 84). Os mesmos motivos espessos e escalonados seriam encontrados no sítio Morro dos Macacos 1 (p. 96). Ponteados e incisões curtas possuiriam correlatos no sítio Garbin (p. 99).

No capítulo anterior, foram identificadas semelhanças entre o sítio Teotônio e os sítios Itapirema e Associação Calderita, especialmente quanto aos tratamentos de superfície, como incisões e pinturas/engobos vermelhos e brancos. Atributos que aparecem, com maior ou menor frequência, nos sítios analisados por Zuse (2011). Também foram apresentadas algumas semelhanças entre a cerâmica (antiga) do sítio Teotônio e a cerâmica do sítio Nova Vida. Com base na análise descritiva das variáveis, sem a manipulação ou visualização das indústrias cerâmicas, os pesquisadores responsáveis pelas estatísticas indicaram que os sítios Teotônio e Jacarezinho "possuem grande quantidade de variáveis com distribuições semelhantes apesar de serem distantes (espacialmente) um do outro ${ }^{115, "}$ (BARROSO et al., 2012: 41). Por outro lado, foi possível observar (Capítulo 5), a partir da comparação entre as formas cerâmicas dos sítios analisados pelo PALMA, que havia poucas semelhanças intersítios. Da mesma forma, uma análise ANOVA a partir da espessura dos fragmentos apontou que o sítio Teotônio se diferenciava de todos os demais (p. 38). Qual seria o significado de

\footnotetext{
${ }^{115}$ Tais semelhanças se referem aos campos técnica de manufatura, cor da superfície, alisamento da face externa, inclinação da borda, espessura da borda, lábio e morfologia da base. Curiosamente, é improvável que o agrupamento feito pelos estatísticos se repetisse com qualquer pessoa que manipulasse o material desses dois sítios.
} 
tamanha variabilidade ocorrendo (talvez ao mesmo tempo) com uma significativa quantidade de semelhanças entre o sítio Teotônio e os sítios do alto Madeira?

É impossível oferecer uma resposta definitiva para essa pergunta com a quantidade de dados disponível até o momento ${ }^{116}$. Ainda assim, sempre é possível traçar algumas linhas interpretativas. A primeira é coerente com o quadro heterogêneo obtido a partir da nova análise da unidade escavada por Miller, assim como da caracterização do sítio Teotônio como lugar significativo e persistente. Nessa visão, o sítio Teotônio pode ser um núcleo, ou um entroncamento, na rede de caminhos aquáticos e terrestres amazônicos, um lugar para a realização de trocas comerciais (e.g. matéria-prima lítica, conchas, adornos, cultivares de várzea e terra firme), rituais festivos de iniciação, troca de mulheres, antropofagia (?), alianças políticas ou simples festanças com bebedeiras para facilitar futuras negociações em qualquer um desses campos.

Em situações como essas não seria de estranhar que os visitantes trouxessem presentes - as dádivas de Mauss (2003 [1925]) - para os anfitriões. Claro que a retribuição dos visitantes poderia se dar de forma análoga à dos Cinta-Larga (Dal Poz, 1993; Capítulo 3), realizando um ritual festivo semelhante em um período próximo. Entretanto, uma característica dos lugares significativos é a recorrência muito maior de eventos do em que núcleos secundários e terciários das redes de comunicação. A questão logística e significativa (e.g. a presença da cachoeira, incluindo a abundância de recursos aquáticos) assegura o desequilíbrio. Os grupos do povoado do Rio-Mar dificilmente participariam de uma cerimônia nas Montanhas Negras.

Dentre os possíveis presentes estaria, claro, a presença de vasos cerâmicos. Esses seriam talvez presentes mais frequentes por parte de grupos próximos ao complexo do Teotônio, como os ocupantes do entorno da cachoeira do Santo Antônio analisados por Zuse ou os habitantes do sítio Itapirema. Quanto maior a distância, maior a possibilidade de quebra dos vasos, em especial no caso dos visitantes vindos de áreas de interflúvio. Além do presente material, a presença de determinados elementos estilísticos "exógenos" também poderia ser explicada pelo contato e pela troca verbal entre oleiras de diferentes grupos em eventos no sítio (cf. BOWSER, 2002), o que também serve para explicar a presença de elementos “exógenos" nos sítios que não são entroncamentos primários na rede de contatos.

\footnotetext{
${ }^{116}$ De posse de uma amostragem consideravelmente superior de cerâmica analisada, é provável que Zuse possua mais condições de oferecer uma resposta mais sólida para tal questão.
} 
O resultado esquematizado dessa linha interpretativa, relacionada à transmissão horizontal de elementos, e que explicaria semelhanças de um sítio com vários outros sem ser igual a nenhum, pode ser visto na Fig. 148. Um pré-requisito para testar tal hipótese seria a contemporaneidade dos diversos sítios com o sítio Teotônio: quanto maior for a sincronia entre indústrias diferentes, maior a possibilidade de terem ocorrido episódios históricos com padrões de ocupação multi-étnicos no alto Madeira. Tal contemporaneidade ainda não foi confirmada. Ainda sim, visto que o sítio Teotônio deve ter sido um lugar persistente, com grupos habitando o local por centenas de anos, não é difícil pensar que - digamos, durante os 1.000 anos antes da chegada dos europeus - qualquer ocupação ceramista no alto Madeira deve ter sido contemporânea desse sítio.

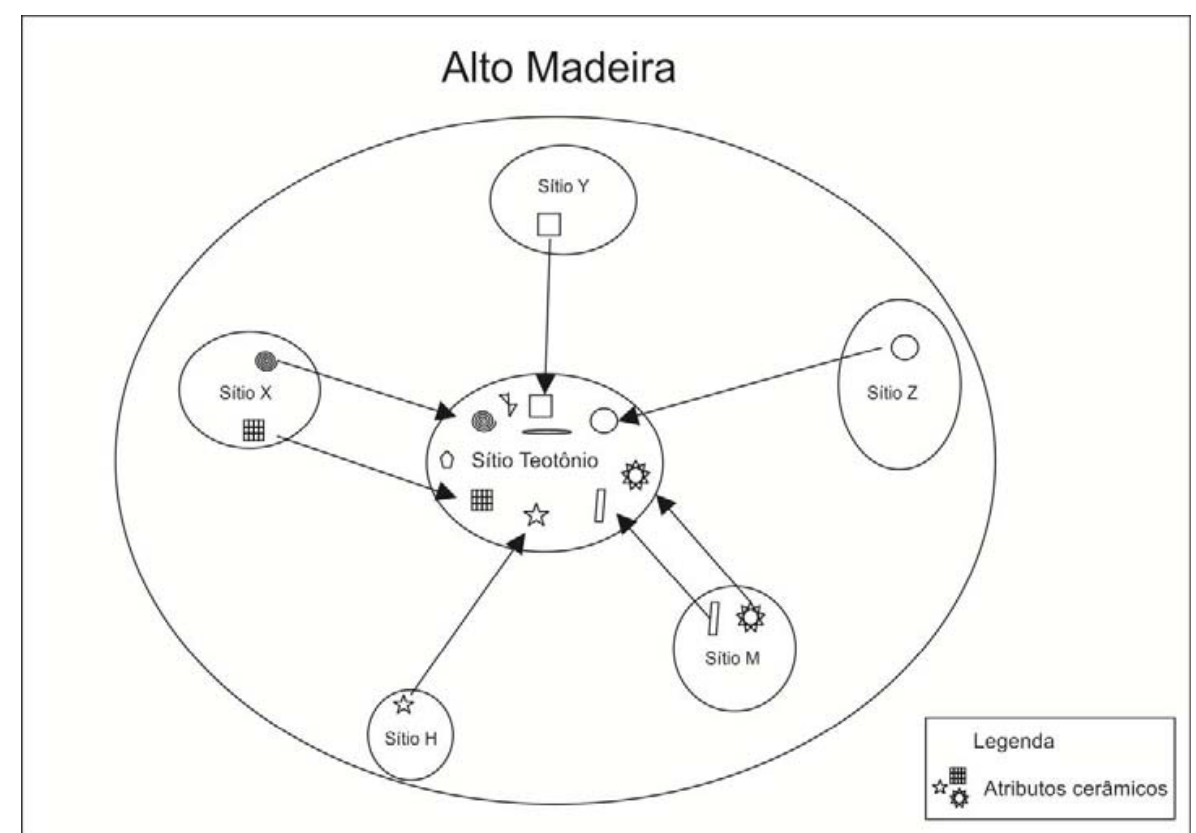

Figura 148: A transmissão horizontal de elementos cerâmicos poderia explicar a diversidade estilística do sítio Teotônio.

Um elemento da cerâmica do sítio Teotônio que contribui para essa linha interpretativa são os motivos com linhas espessas, comentados no Capítulo 5. A partir do trabalho elaborado por Edmund Hall (1966) e de sua experiência etnográfica na Amazônia ocidental, Bowser (2002: 246; cf. WOBST 1977) indica que desenhos externos devem ser grandes e simples em vasos utilizados em contextos comunitários, para que sejam vistos à distância (Fig. 149). Trata-se exatamente de um dos elementos que mais chama a atenção na cerâmica do sítio Teotônio, presente em quantidade muito menor em outros sítios da região, como o Itapirema. 


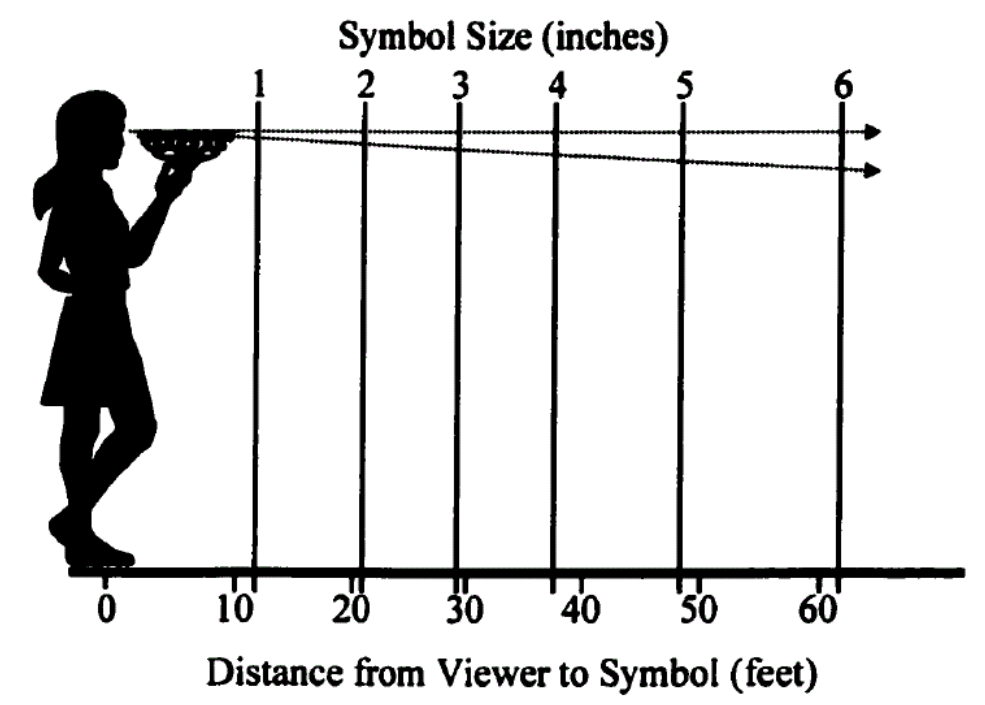

Figura 149: Motivos grandes são feitos para ser vistos à distância (fonte: Bowser 2002).

Outro exemplo de lugar persistente e significativo no sudoeste amazônico que possui vasos pintadas com motivos espessos - aparentes tigelas para consumo de fermentados - é o já citado contexto do Loma Salvatierra. Esse sítio possuía áreas específicas para imensos jarros aparentemente utilizados para armazenagem de chicha (de milho, segundo a análise feita em raladores de cerâmica), áreas que às vezes coincidiam com locais funerários (JAIMES-BETANCOURT, 2012: 163; cf. HOWARD, 1947: 64). Mais uma vez, o que se vê é uma estreita ligação entre cerâmica, chicha e mundo ritual. Conforme visto, esse sítio, ocupado por um período aproximado de 800 anos, possui cinco fases cerâmicas, sem rupturas: um aparente grupo em constante mudança. A variabilidade da cerâmica parece ainda maior do que a do sítio Teotônio, ainda que, para ambos os sítios, sirva a máxima de que "quanto mais complexa a cerâmica (em termos de combinações técnico-estilísticas), maior o nivel de integração entre as redes regionais" (BARRETO, 2010: 200).

Resta apresentar a segunda proposta interpretativa para o sítio Teotônio e o contexto cerâmico pré-colonial do alto Madeira. Antes disso, no entanto, será necessário testar, de uma vez por todas, se os sítios analisados com decoração pintada (Itapirema, Associação Calderita e Teotônio) de fato fazem parte da Tradição Polícroma da Amazônia. Comecemos pelos sítios menos problemáticos. 


\subsection{Os sítios Itapirema e Associação Calderita e a Tradição Polícroma da Amazônia}

A discussão dos dados cerâmicos realizada até aqui evitou trabalhar a relação entre os sítios analisados pelo PALMA e a Tradição Polícroma da Amazônia. Conforme visto no Capítulo 5, apenas os sítios Itapirema, Teotônio e Associação Calderita (com decorações incisas e policrômicas, bordas reforçadas etc.) são passíveis de inserção nessa Tradição. Foi possível ver que o sítio Teotônio possui um contexto complicado, com imensa variabilidade cerâmica, o que torna imperativo separá-lo, por enquanto, da discussão sobre a TPA.

Desde o início das pesquisas do PALMA, houve uma preocupação com a realização de uma análise comparativa entre a cerâmica encontrada e a cerâmica TPA da Amazônia central (Subtradição Guarita; cf. Capítulo 2), uma tentativa de compreensão de um suposto contexto TPA pouco conhecido a partir de outro bastante estudado. Tal análise resultou em um trabalho de iniciação científica realizado por Ana Azeredo (2011, FAPESP 2009/547385), que comparou as variáveis das indústrias cerâmicas dos sítios Associação Calderita, o primeiro a ser escavado pelo PALMA, e o pacote arqueológico da fase Guarita do sítio Hatahara, o mais estudado da Amazônia central (cf. LIMA, 2008; MACHADO, 2005; MORAES, 2006; TAMANAHA, 2012). Ambos os sítios possuem datas relativamente próximas ao início do segundo milênio da era cristã.

A análise apontou que, apesar de uma série de pequenas variações - como a preferência de engobo vermelho no sítio Associação Calderita frente ao engobo branco no sítio Hatahara -, as indústrias eram bastante semelhantes: uso de caraipé, cor da pasta amarelada, predominância de formas abertas, bordas reforçadas, flanges com incisões na face interna, pintura vermelha e branca (AZEREDO, 2012; Anexo 20). Ou seja, essa análise preliminar justificou o prosseguimento dos estudos e uma comparação mais ampla entre os sítios Itapirema e Associação Calderita com outros sítios da Amazônia central e ocidental.

O caminho mais simples para trabalhar a relação geográfica entre esses sítios e a Tradição Polícroma é o fluvial, em direção ao baixo rio Madeira, onde se encontra a fase Borba, considerada por Simões e Lopes (1987: 122) pertencente à Subtradição Guarita (cf. Capítulo 3). Os autores indicam que a cerâmica dessa fase é temperada com caraipé e cauixi, sozinhos ou combinados. Esses antiplásticos também foram identificados no sítio Itapirema, que possui predomínio de cauixi. No sítio Associação Calderita, o caraipé foi praticamente o único antiplástico identificado. 
Os estudos clássicos sobre a Tradição Polícroma (EVANS e MEGGERS, 1968; HILBERT, 1968; LATHRAP, 1970) tendem a vincular esse agrupamento ao uso do antiplástico de caraipé, ainda que todos apontem o uso do cauixi. Em seus estudos no médio Solimões, Tamanaha (2012) descreve um amplo uso de ambos os antiplásticos por parte dos grupos TPA, com diferentes frequências, mas sem alterar a forma ou função do vaso ou a decoração (2012: 127).

A fase Borba também possui um predomínio - $25 \%$ do total, segundo Simões e Lopes (1987: 124) - de formas rasas (calotas) com bordas extrovertidas com ponto angular ou flanges (forma 12 da presente tipologia), que também foram muito frequentes no sítio Itapirema (mas pouco no sítio Associação Calderita). Apesar de indicarem a presença de decorações incisas, excisas e acanaladas na cerâmica Borba, Simões e Lopes (p. 118) não indicam a predominância dessas decorações na face interna da flange, como foi comum observar nos sítios Itapirema e Associação Calderita. A comparação entre os tipos de formas dos dois sítios e os dessa fase mostram uma grande proximidade entre as indústrias ${ }^{117}$ (Tabela 57). Cada sítio teve apenas uma forma ausente, que estava presente nas outras duas indústrias: a fase Borba não possuía formas com pescoço (forma 5), o sítio Itapirema não possuía formas semi-esféricas, inflectidas e contraídas (forma 9), e o sítio Associação Calderita não possuía formas complexas (forma 14).

As bordas reforçadas externamente foram encontradas nos sítios Associação Calderita e Itapirema, assim como nos sítios da fase Borba (SIMÕES e LOPES, 1987: 119), característica que também pode ser observada na Amazônia central (HILBERT, 1968; NEVES, 2012), nos rios Ucayali e Napo (EVANS e MEGGERS, 1968; LATHRAP, 1970; WEBER, 1975) e no médio Solimões (COSTA, 2012; TAMANAHA, 2012). As bordas recortadas também estão presentes no sítio Itapirema, na fase Borba e em toda a extensão do Solimões (cf. Fig. 10, Capítulo 2). No sítio Associação Calderita, esse tipo de borda não foi identificado.

\footnotetext{
${ }^{117}$ Pode-se perguntar como isso é possível, visto que no capítulo anterior se argumentou que havia pouca homogeneidade na comparação das formas entre os sítios. Nesse caso, a comparação não era apenas no quesito presença/ausência de formas, e sim de frequência, o que de fato mostrou uma diferenciação maior do que a comparação tipológica feita neste capítulo.
} 


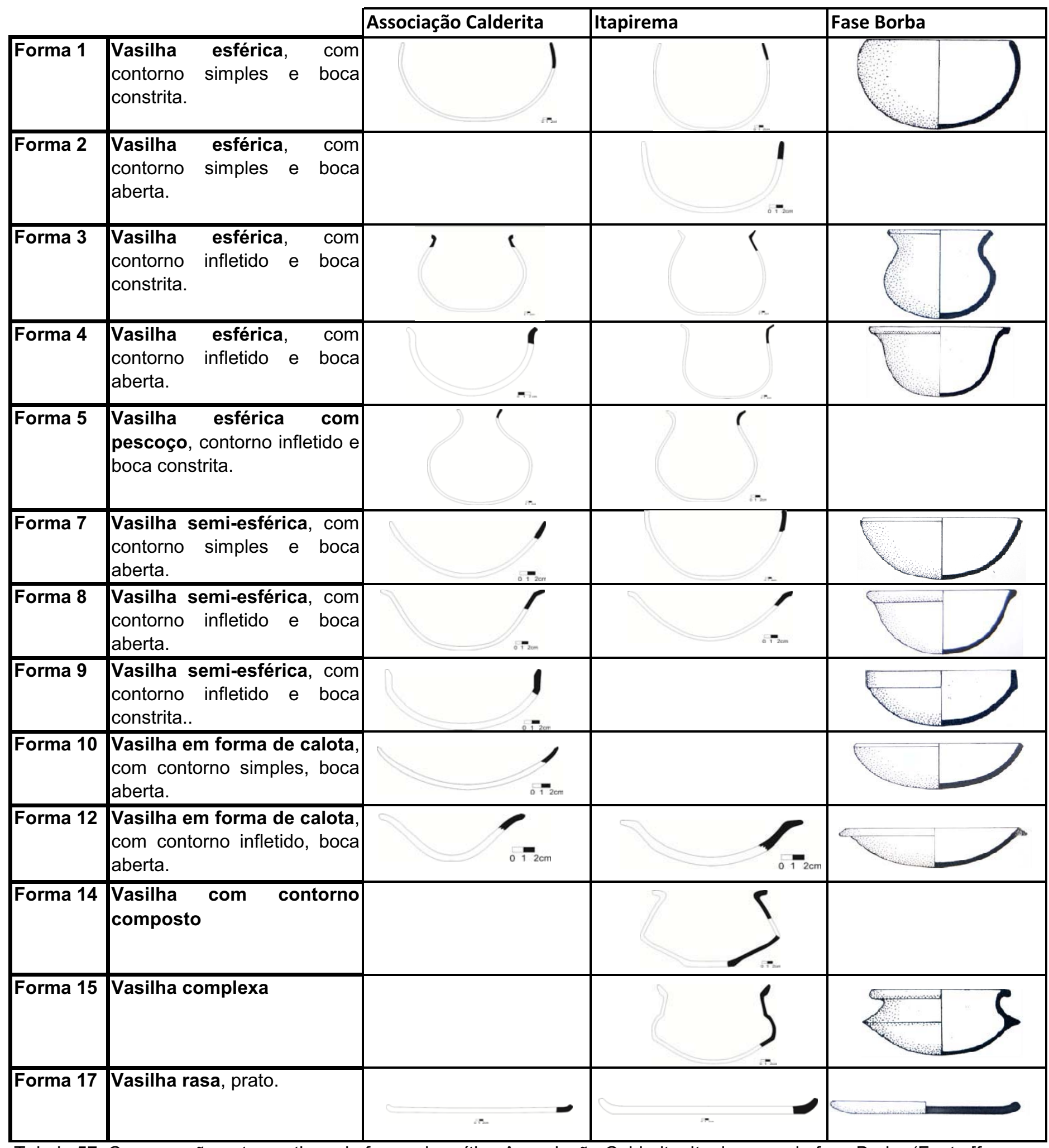

Tabela 57: Comparação entre os tipos de forma dos sítios Associação Calderita, Itapirema e da fase Borba (Fonte [fase Borba]: Simões e Lopes, 1987). 
As flanges mesiais são atributos diagnósticos da Tradição Polícroma, em especial na região da Amazônia central ${ }^{118}$ (cf. HILBERT, 1968; MORAES, 2006, TAMANAHA, 2012), mas ocorrem também no alto Amazonas (EVANS e MEGGERS, 1968; LATHRAP, 1970; WEBER, 1975). Essas flanges não são comuns nas fases do baixo Amazonas (e.g. Marajoara, Tauá, Aristé) nem foram identificadas nos sítios analisados pelo PALMA no alto Madeira. No entanto, Zuse (2011: 72) identifica a presença de flanges mesiais nos sítios por ela estudados, restando saber se estão ligadas à cerâmica policrômica. Da mesma forma, essas flanges estão presentes na fase Borba (SIMÕES e LOPES, 1987: 119), o que não exclui a hipótese de que a ausência delas no material dos sítios analisados pelo PALMA pode estar ligada ao tamanho limitado da sua amostragem.

Outro elemento ausente da amostra coletada pelo PALMA, mas que certamente está presente no Alto Madeira, são as urnas funerárias com pinturas policrômicas. Tais urnas foram identificadas na região da cachoeira do Jirau (MOUTINHO e ROBRAHNGONZÁLEZ, 2010), na cachoeira de Santo Antônio (ZUSE, 2011) e no baixo Madeira (EVANS e MEGGERS, 1968; NEVES, 2012). Entretanto, ao contrário das urnas encontradas no baixo Madeira, médio Amazonas (cf. BARRETO, 2008; NEVES, 2012), médio Solimões (TAMANAHA, 2012) e alto Amazonas (EVANS e MEGGERS, 1968; LATHRAP, 1970), as urnas do alto Madeira (MOUTINHO e ROBRAHN-GONZÁLEZ, 2010; ZUSE, 2011) não possuem a tradicional sequência de apliques formando um rosto antropomorfo com uma tiara (cf. Fig. 7, Capítulo 2).

O que é comum nas urnas de todas essas regiões, inclusive nas do alto Madeira, são as formas cilíndricas (cf. Fig. 7, Capítulo 2) com tampa e os motivos espessos pintados sobre engobo branco (com baixa presença de pigmento preto no alto Madeira), incluindo uma frequente presença de motivos escalonados. Se levada em consideração a inferência sobre os motivos espessos do sítio Teotônio - ideais para grandes festividades - tal relação entre pinturas espessas e rituais poderia se estender para todas as áreas citadas, incluindo o sítio Itapirema, o baixo Madeira e os sítios do alto ao médio Amazonas. Nesse sentido, não é de estranhar que esses motivos espessos estejam praticamente ausentes do sítio Associação Calderita, o mais distante do mainstream ritualístico.

\footnotetext{
${ }^{118}$ Um dos vasos diagnósticos da Subtradição Guarita, da Amazônia central, é uma forma constrita, com flange mesial e decoração acanalada no bojo superior e/ou na flange (cf. TAMANAHA, 2012). Essa combinação de elementos não foi identificada no alto Madeira.
} 
Outra característica comum nos sítios da Tradição Polícroma da Amazônia ocidental e central é a presença de pinturas nas quais o motivo forma uma figura zoomorfa, com duas cabeças, interpretada por Moraes e Neves (2012: 136) como "ornitomorfos" e por Weber (1975: 334) como uma serpente bicéfala. O grau de fragmentação da cerâmica dos sítios analisados não permite uma visualização precisa, mas essas figuras zoomorfas também parecem estar presentes na cerâmica do alto Madeira (Fig. 150).

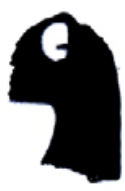

Figura 150: Possível representação zoomorfa do sítio Itapirema análoga às tradicionalmente encontradas na Tradição Polícroma da Amazônia central e ocidental (fotos: Fernando Ozorio de Almeida).

Na descrição da fase Borba, não é possível compreender se os sítios são lineares, mas tal característica é percebida no sítio Itapirema, como também nos sítios da Amazônia central (MORAES, 2010). Ao contrário da maioria dos sítios Guarita da Amazônia central, os sítios Itapirema e Associação Calderita são unicomponenciais, não parecendo ter havido aproveitamento de áreas previamente manejadas por outros grupos (cf. MORAES e NEVES, 2012; NEVES, 2012). Desde o alto Amazonas até a Amazônia central (incluindo o baixo Madeira), o padrão de ocupação TPA é o da reocupação (para exceções, vide TAMANAHA, 2012). O que talvez seja um indício de que esses grupos TPA de fato teriam começado a se expandir a partir do alto rio Madeira. Fato que necessitaria de uma confirmação cronológica, o que será discutido adiante.

Em síntese, Moraes e Neves (2012: 136) argumentam que existiam códigos comuns, impressos na forma e na decoração das cerâmicas, que eram compartilhados, e provavelmente ressignificados por povos vivendo desde o médio Madeira até a região do rio Napo, no Equador. A partir da presente análise comparativa, pode-se argumentar que esses elementos politéticos também se estendem ao alto Madeira. Há um eixo de coerência de elementos escolhidos pelas antigas artesãs, um Estilo, que é comum em uma região formada pelo triângulo que possui como arestas o alto Madeira, a Amazônia central e a Amazônia ocidental $^{119}$. É esse eixo que se reconhece aqui como Tradição Polícroma da Amazônia. Por consequência, os sítios Itapirema e Associação Calderita podem ser inseridos na

\footnotetext{
${ }^{119}$ Coerência não identificada na suposta TPA do baixo Amazonas, conforme visto no Capítulo 2.
} 
Tradição Polícroma, e, pela geografia, na Subtradição Jatuarana. Tendo isso em mente, é possível retornar para o problemático sítio Teotônio.

\subsection{O sítio Teotônio e as antigas Tradições ceramistas da Amazônia}

Sentada à mesa do laboratório 1 do MAE-USP, que hoje é conhecido como ARQUEOTROP, Helena Lima, em algum momento do início dos anos 2000, começou a se perguntar sobre diferenças técnico-estilísticas na cerâmica por ela estudada. A cerâmica em questão era a fase Manacapuru, encontrada na Amazônia Central, e as diferenças observadas por ela levaram à criação de uma nova fase arqueológica: a fase Açutuba (LIMA, 2008; LIMA et al., 2006; LIMA e NEVES, 2011). Em comparação com a fase Manacapuru, Lima (et al., 2006) chegou à seguinte diferenciação (Tabela 58):

\begin{tabular}{|l|l|l|}
\hline \multicolumn{1}{|c|}{ Atributos } & \multicolumn{1}{c|}{$\begin{array}{c}\text { Fase Açutuba } \\
\mathbf{3 0 0} \text { A.C.-360 d.C. }\end{array}$} & \multicolumn{1}{|c|}{$\begin{array}{r}\text { Fase Manacapuru } \\
\mathbf{6 0 0} \text { d.C. }\end{array}$} \\
\hline Queima & Oxidada & Não-Oxidada \\
\hline Cauixi como tempero & Presente & Presente \\
\hline Caraipé como tempero & Presente & Ausente \\
\hline Formas abertas & Mais frequentes & Menos frequentes \\
\hline Formas fechadas & Menos frequentes & Mais frequentes \\
\hline Incisões retilíneas simples ou duplas & Ausentes & Presentes \\
\hline Incisões curvilíneas simples ou duplas & Mais frequentes & Menos frequentes \\
\hline Excisão sobre engobo vermelho & Presente & Ausente \\
\hline Ponteado & Ausente & Presente \\
\hline Acanalado & Presente & Ausente \\
\hline Apêndices zoomorfos modelados & Presente & Presente \\
\hline Flanges labiais & Presentes & Ausente \\
\hline Flanges mesiais & Presentes & Presente \\
\hline Engobo vermelho & Presente & Ausente \\
\hline Engobo branco & Presente & Raro \\
\hline Pintura Policrômica & Presente & Ausente \\
\hline
\end{tabular}

Tabela 58: Comparação entre as fases Açutuba e Pocó (adaptado de LIMA et al., 2006).

A comparação feita por Lima (et al., 2006: 44) apontou uma maior quantidade de elementos estilísticos na fase Açutuba em comparação à fase Manacapuru. O que chama a atenção, e o que torna relevante contar essa história, é a semelhança de atributos entre o componente mais antigo (Açutuba) e uma ocupação ainda mais recente (que a Manacapuru) na Amazônia central: a Subtradição Guarita, pertencente à Tradição Polícroma da Amazônia. 
Semelhança que ocorre ao mesmo tempo em que há uma clara ruptura entre as ocupações intermediárias - Manacapuru e Paredão, ambas parte da mesma Tradição (Borda Incisa/Barrancoide) - e a ocupação Guarita (LIMA e NEVES, 2011; MORAES e NEVES, 2012; NEVES, 2010, 2012). Ou seja, ao passo que, nas passagens entre as fases Açutuba, Manacapuru e Paredão, há a continuação de uma série de elementos, a fase Guarita marca um rompimento na transmissão vertical dos elementos e guarda muitas semelhanças com a cerâmica mais antiga (Fig. 151).

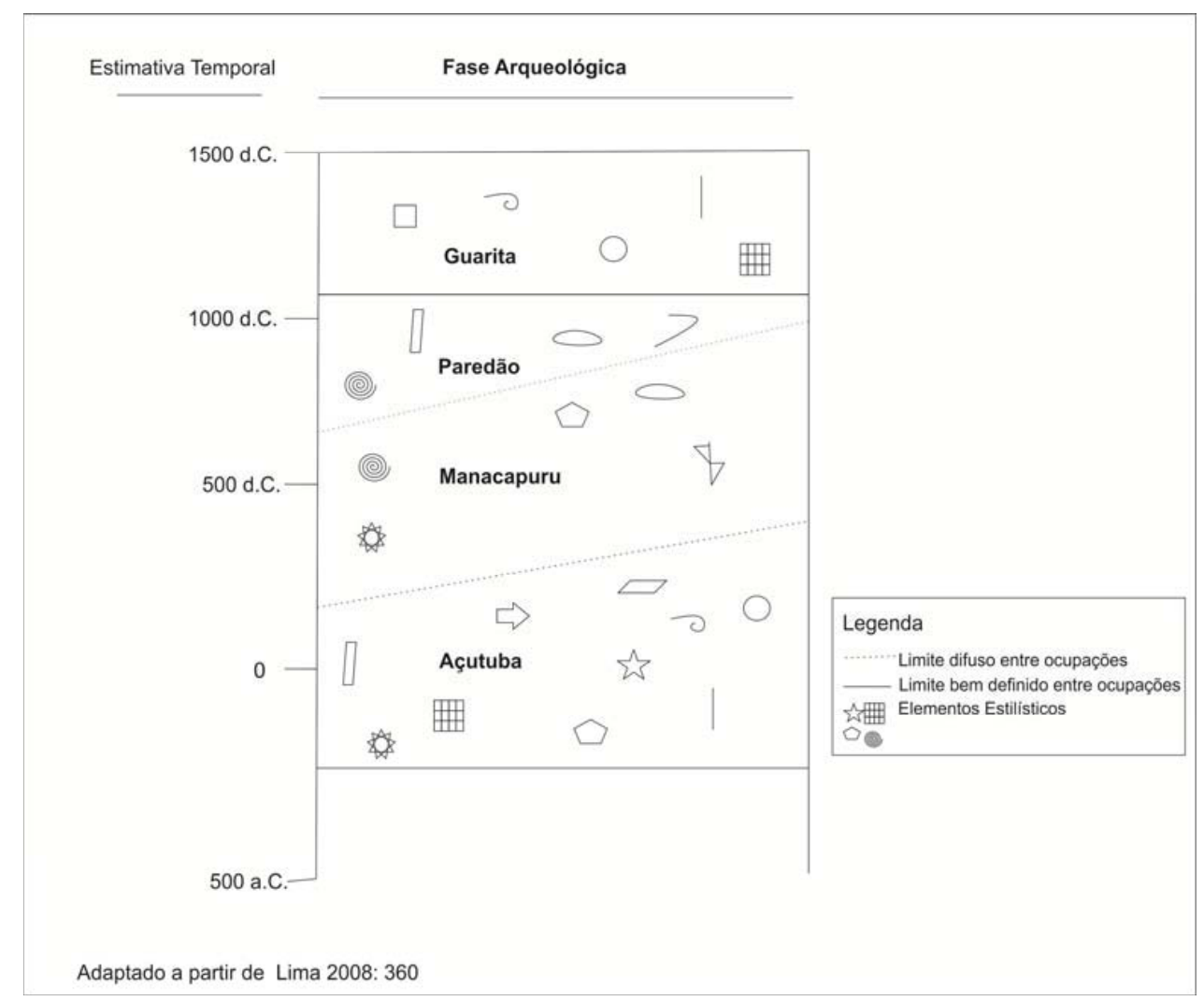

Figura 151: Esquematização de processos verticais de transmissão e ruptura de elementos cerâmicos. Nota-se que, apesar da diferenciação completa entre as fases Guarita e Paredão, quase todos os elementos Guarita existem na cerâmica Açutuba.

Durante as descrições realizadas no Capítulo 2, foi observado que um dos problemas da Tradição Polícroma da Amazônia era o fato de haver um estilo cerâmico mais antigo, com grande variabilidade técnico-estilística e muitos elementos em comum com a Tradição Polícroma da Amazônia, incluindo a policromia. Trata-se do que Neves (2006: 55, 2012: 147-48) denomina de Tradição Pocó que, além da fase Açutuba (LIMA, 2008, 2010; LIMA e NEVES, 2011), abrange uma fase homônima no baixo Amazonas, no rio Trombetas (GUAPINDAIA, 2008; HILBERT e HILBERT, 1980), assim como no médio Solimões 
(COSTA, 2012; cf. Capítulo 2). As datas dessa Tradição variam de 1000 a.C. (baixo Amazonas) a 300 d.C. (Amazônia central).

O que mais chama a atenção com relação a essa Tradição é que ela possui elementos estilísticos presentes em quase todas as demais cerâmicas amazônicas ${ }^{120}$, incluindo um quase onipresente conjunto funerário - em geral constituído por uma grande vasilha para preparo e tampada por outra pequena vasilha de preparo ou um tigela para consumo de fermentados. Além da cerâmica Manacapuru e da cerâmica TPA, é possível encontrar exemplos de semelhanças entre a Tradição Pocó e a cerâmica Cumancaya, ligada aos grupos Pano no alto Amazonas (LATHRAP, 1970; DEBOER, 1990, 1991; DEBOER e LATHRAP, 1979; ROE, 1973, 1982) ou à Tradição Tupinambá da Amazônia (ALMEIDA, 2008, 2011; GARCIA, 2012a; SIMÕES e ARAÚJO COSTA, 1987). Outro exemplo poderia ser a cerâmica Jívaro do oeste amazônico (vide Capítulo 7), ainda que faltem elementos para uma comparação mais precisa com essa cerâmica.

${ }^{120}$ Um provável exemplo contrário é a cerâmica Inciso-Ponteada, encontrada na região de Santarém, no baixo Amazonas. 

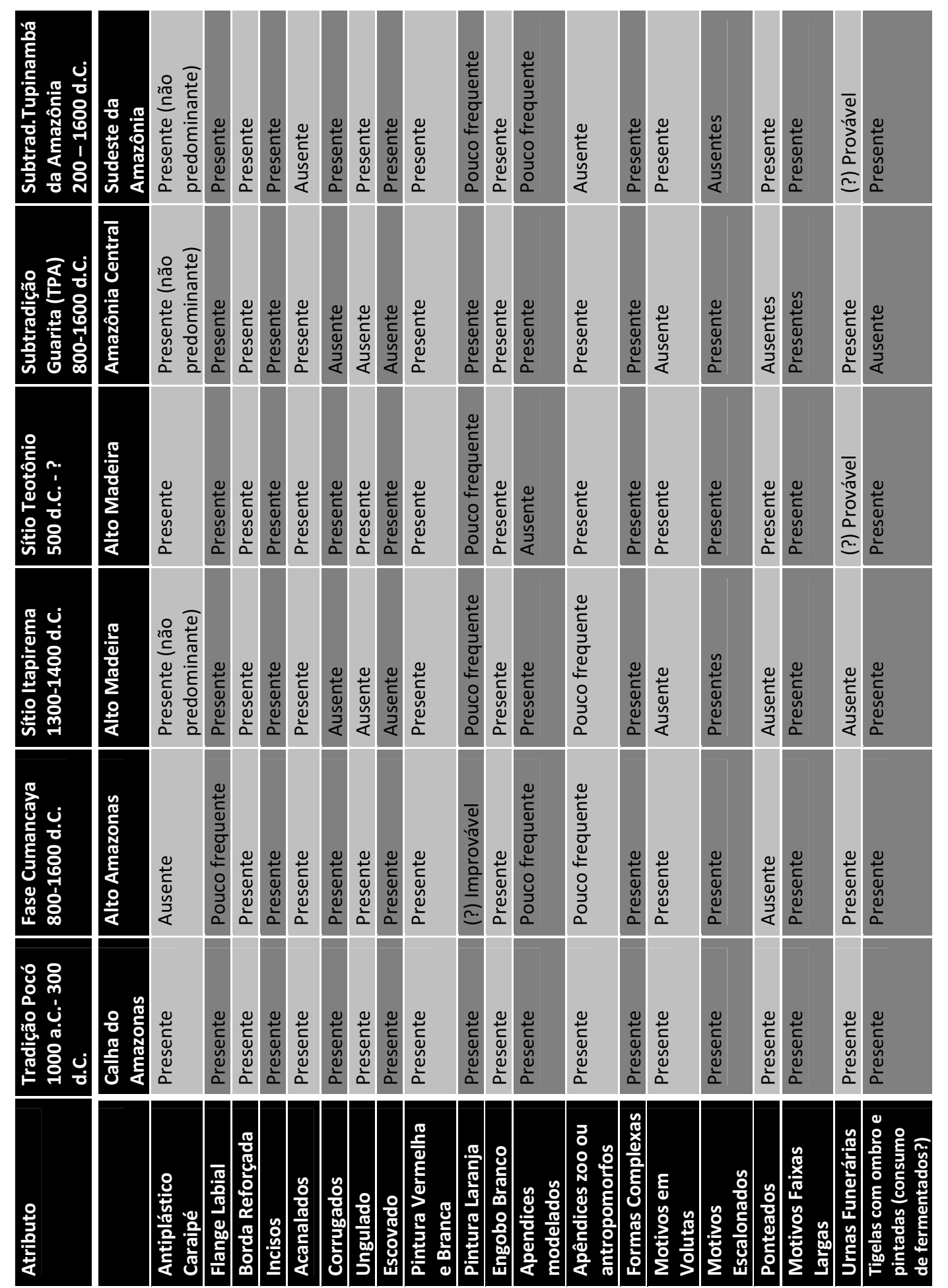
Ao observar a Tabela 59, pode-se notar que o sítio Teotônio ${ }^{121}$ é o que possui maior quantidade de atributos em comum com os atributos Pocó, o que permitiria sugerir uma relação: o sítio Teotônio surgindo como um fenômeno meridional dessa Tradição. Trata-se da segunda linha interpretativa a ser explorada, na qual o quadro de diversidade do sítio Teotônio é fruto mais de uma imensa variabilidade trazida (de fora) por parte de um dos grupos que habitou o sítio, do que de trocas em redes de comércio. Por esse ponto de vista, os elementos encontrados na cerâmica seriam difundidos principalmente para fora do núcleo ao invés do contrário (como proposto na primeira hipótese). Trata-se de uma forma possível para explicar uma série de pequenas mas significativas semelhanças entre o sítio Teotônio e os sítios de entorno. Essa linha explica também o fato, já percebido por Miller (1992), de que a cerâmica policrômica chega com a maior parte do seu conjunto cerâmico já consolidado no alto Madeira.

Além disso, tal hipótese poderia explicar o surgimento da Tradição Polícroma no alto Madeira: como uma reinterpretação, provavelmente por parte de grupos autóctones, do Estilo (alóctone) do grupo que estava no principal entroncamento da rede de contatos do alto Madeira. Após subir o rio Madeira, com um grupo disposto a explorar relações de troca (simbólica e econômica), a cerâmica policrômica desceria o rio - a primeira cerâmica do que viria a ser chamado de Tradição Polícroma da Amazônia - com o intuito principal de explorar o outro lado da moeda das relações amistosas de troca, que é a predação, a obtenção dos elementos exógenos à força (cf. GOW, 2002; MORAES e NEVES, 2012; NEVES, 2010, 2012). Se esse foi o caso, os grupos da fase Paredão da Amazônia central que sofreram com as incursões guerreiras dos produtores de cerâmica TPA (Guarita) devem ter logo percebido que os invasores possuíam uma cerâmica parecida com o material enterrado em profundidade no sedimento das aldeias onde moravam (Fig. 152).

Essa hipótese apresenta uma série de problemas. Primeiro, há dúvida quanto à existência ou não de uma ocupação policrômica antiga no sítio Teotônio e quanto à diferença entre os elementos dessa e da ocupação ceramista anterior (cerâmica com incisão simples). Por exemplo, a decoração serrungulada parece mais relacionada com essa suposta ocupação (incisão simples) do que com a ocupação seguinte. Esse foi um dos atributos que levaram Costa (2012), trabalhando no médio Solimões, a separar uma cerâmica pré-Pocó do material da Tradição Pocó encontrado acima na estratigrafia.

\footnotetext{
${ }^{121}$ Utilizando as amostras analisadas pelo PALMA e as novas análises do material estudado por Miller.
} 


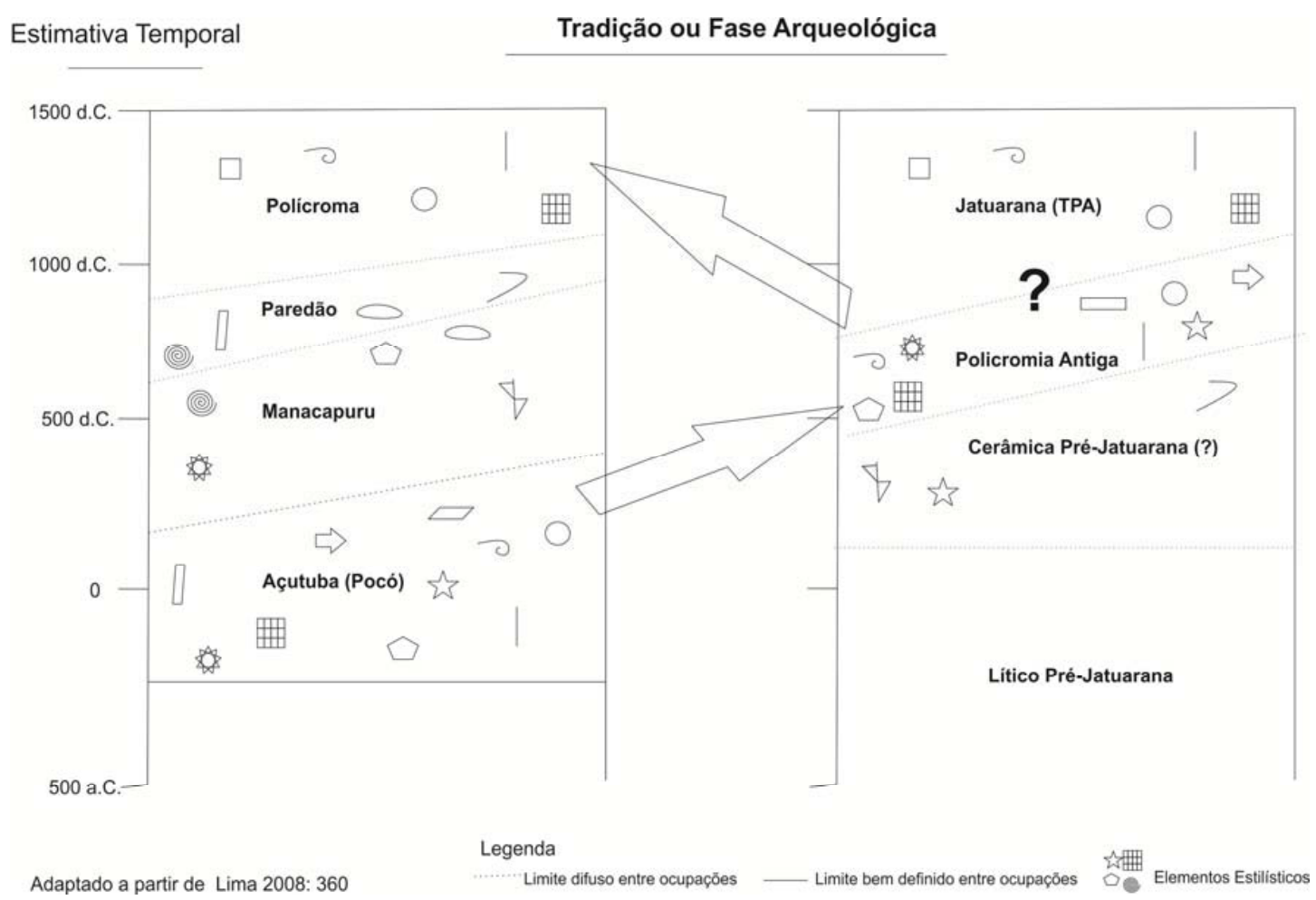

Figura 152: Processo de transformação da cerâmica policrômica, chegando à Tradição Polícroma. A primeira sequência estratigráfica se refere à Amazônia Central, a segunda ao alto Madeira.

Segundo, também não se sabe se o eventual processo de surgimento da cerâmica TPA ocorreu no alto Madeira, como também se a parte final da ocupação pré-colonial do sítio Teotônio está ligada à TPA ou se é um prosseguimento da cerâmica antiga ${ }^{122}$. Esses dois problemas levam à questão do início da cronologia policrômica. $\mathrm{Na}$ inexistência da antiga ocupação do sítio, a cronologia da cerâmica policrômica do sítio Teotônio começa no século V. Caso contrário, começaria em data próxima ao século VIII, o que tornaria a dispersão dos grupos TPA em direção à calha do Amazonas um fenômeno extremamente rápido. Além disso, ainda permanece para ser reavaliada a datação de 400 a.C. do sítio Igapó 1, relacionada por Miller (1992: 224) à Subtradição Jatuarana. Uma data que, ao que tudo indica, será desvinculada dessa Subtradição, por estar isolada.

Um terceiro problema é que, apesar de ter sido demonstrado que os atributos desses sítios, fases e Tradições se repetem, eles podem ser combinados de infinitas maneiras, tendo resultados finais completamente diferentes. O fato de a própria Tradição Pocó ainda ser

\footnotetext{
${ }^{122}$ Resposta que seria mais facilmente respondida caso o Prof. Shennan e o presente pesquisador tivessem reanalisado os níveis superiores da unidade do sítio Teotônio escavada por Miller.
} 
pouco compreendida só complica qualquer esforço comparativo. O que torna imperativo reafirmar: não há dados que permitam inferir que o sítio Teotônio pertença à Tradição Pocó, mas há elementos que permitem que se cogite essa possibilidade. Da mesma forma, mesmo sendo responsáveis por fundar a Tradição Jatuarana, os dados sítio Teotônio devem ser utilizados com ressalva quando discutida a Tradição Polícroma, já que ainda não está claro o papel desse sítio dentro desse macroagrupamento.

Seja qual for a solução dessa questão, chama a atenção a presença de um duo de agrupamentos arqueológicos relativamente antigos (i.e. anteriores ao início da era cristã) nos três principais rios da Amazônia. Esse duo é, grosso modo, formado por uma cerâmica Inciso-Pintada e outra Inciso-Modelada encontradas, respectivamente, nas Tradições Saladoide e Barrancoide do rio Orinoco; na Tradição Pocó e na fase Manacapuru da Amazônia Central; e nas cerâmicas do sítio Teotônio e do médio Guaporé (cf. Capítulo 3), no rio Madeira. Essa distinção poderia também se estender para as áreas de interflúvio do sudeste amazônico (GARCIA, 2012a; cf. Capítulo 2).

Em síntese, por meio do sítio Teotônio e de sua comparação com o contexto antigo de cerâmicas policrômicas amazônicas, foi possível pensar nos dois grandes problemas que cercam os estudos sobre a Tradição Polícroma (cf. Capítulo 2): a confusão entre cerâmicas policrômicas antigas e recentes e a presença de uma série de elementos comuns em grupos espalhados por imensas regiões que não necessariamente tiveram contato.

\subsection{Uma alternativa Arawak}

Foram apresentadas duas propostas interpretativas para a compreensão da ocupação de grupos ceramistas de grupos do alto Madeira. Tanto a hipótese "multi-estilística" (multiétnica?) quanto a hipótese do surgimento de estilos a partir de outros não são excludentes e podem ser resultado de processos envolvendo redes de trocas (econômicas e simbólicas) no alto Madeira. Independente de qual estiver mais correta (se é que alguma está), dentro de um macro contexto amazônico, essas hipóteses remetem a um padrão de ocupação de grupos de língua Arawak.

Em primeiro lugar, esses grupos são conhecidos por macro dispersões territoriais ribeirinhas relacionadas a formações sociais regionais ou interregionais, organizadas em 
torno de lugares sagrados ou significativos (HILL e SANTOS-GRANERO, 2002: 16). Essas formações regionais nada mais são do que a extensa rede de comunicações ou trocas comerciais ou cerimoniais, como a que se sugeriu para o contexto do alto Madeira. Exemplos como o do alto rio Negro apontam que cachoeiras estão dentre as possibilidades mais óbvias para uma conversão e apropriação da paisagem em territórios recém ocupados por grupos Arawak (ZUCCHI, 2002: 206).

A preferência por exercer relações de interação pacífica dentro de grandes centros regionais - frente ao tradicional ethos de predação de grupos como os Tupi, os Pano e os Jívaro - está vastamente documentada na Amazônia (CHERNELA, 2008; GOW, 2002: 152; HECKENBERGER, 2002; 2005; 2010: 21; HILL e SANTOS-GRANERO, 2002; HORNBORG, 2005; NEVES, 1998; RIBEIRO, 1995; WHITEHEAD, 1999). Os contextos do alto rio Negro e do alto Xingu indicam que essa rede de relações não se restringia, de forma alguma, a participantes Arawak, mas se estendia a todos os grupos e entorno.

\begin{abstract}
Arawakan peoples tend to form regional societies (...), reproduced through formal networks of interaction, including inter marriage, exchange, ceremonial interdependence and diffused patterns of sociality within and between these communities. This pattern, called regionality here, has an essential regional dimension, and the symbolic reproduction of society depends on institutionalized intercommunity ritual and interaction (HECKENBERGER, 2002: 114-15).
\end{abstract}

Durante o Capítulo 3, foi observada a presença de grupos Arawak em áreas no entorno do alto Madeira, no atual Estado do Acre (e.g. GONÇALVES, 1991), na Amazônia peruana (e.g. GOW, 2002; WEISS, 1972) e boliviana (e.g. RENARD-CASEVITZ, 2002), incluindo a área do rio Guaporé, no alto Madeira (HECKENBERGER, 2010: 21). É difícil saber o local de origem desses grupos, mas os dados linguísticos e arqueológicos apontam para o noroeste Amazônico (NEVES, 1998: 361; HECKENBERGER, 2002: 103; ZUCCHI, 2002: 200). Ao contrário de Lathrap (1970; cf. BROCHADO, 1984), que defendeu que a expansão Arawak foi resultante de um crescimento populacional decorrente da abundância de recursos da várzea amazônica, hoje se pensa que os movimentos de dispersão seriam resultantes da fragmentações de grupos causada por competição por poder ou disputa por recursos humanos, simbólicos ou econômicos (HECKENBERGER, 2002: 116-117). Arqueologicamente, essa dispersão estaria relacionada ao que se pensa como um Universo Borda Incisa (LIMA, 2008; LIMA e NEVES, 2011; NEVES, 2012), que abrangeria as cerâmica do duo (Inciso-Pintado/Inciso-Modelado) Pocó/Manacapuru, Saladoide/Barrancoide 
(cf. ROUSE e CRUXENT, 1963), assim como a Tradição Linhas Paralelas (Inciso-Pintada?), estabelecida por Zucchi (2002; 2010; cf. NEVES, 1998). Assim como não está clara a relação entre a cerâmica do sítio Teotônio e esse Universo estilístico e linguístico, são obscuras as relações e sobreposições dessas Tradições entre si.

Especula-se que esses grupos começaram a se dispersar pelo noroeste amazônico durante o primeiro milênio a.C. (NEVES, 1998: 361), tendo formado novos núcleos de dispersão no médio Orinoco, na Amazônia central e, talvez, no alto rio Madeira, antes de 500 d.C. (HECKENBERGER, 2002: 106-107; Fig. 153). Hipótese que casaria com o papel de núcleo regional do sítio Teotônio. Se levada em conta também a presença de cerâmica IncisoModelada no rio Guaporé (cf. Capítulo 3), seria até possível pensar que o duo Arawak tenha dominado a região das cachoeiras do alto Madeira: os Inciso-Pintados (e.g. Teotônio) nas cachoeiras de jusante e os Inciso-Modelados nas cachoeiras de montante, o que é ainda mais especulativo. Tal hipótese, por mais precária que seja, fornece uma solução coerente para o fato de grupos linguísticos diferentes (Pano, Jívaro, Tupi-Guarani), por vezes morando em regiões longínquas, possuírem tantos atributos estilísticos semelhantes: reinterpretações e apropriações de um conjunto estilístico comum por grupos que, provavelmente, vieram da terra firme para as proximidades de um núcleo (Arawak) de trocas simbólicas e econômicas.

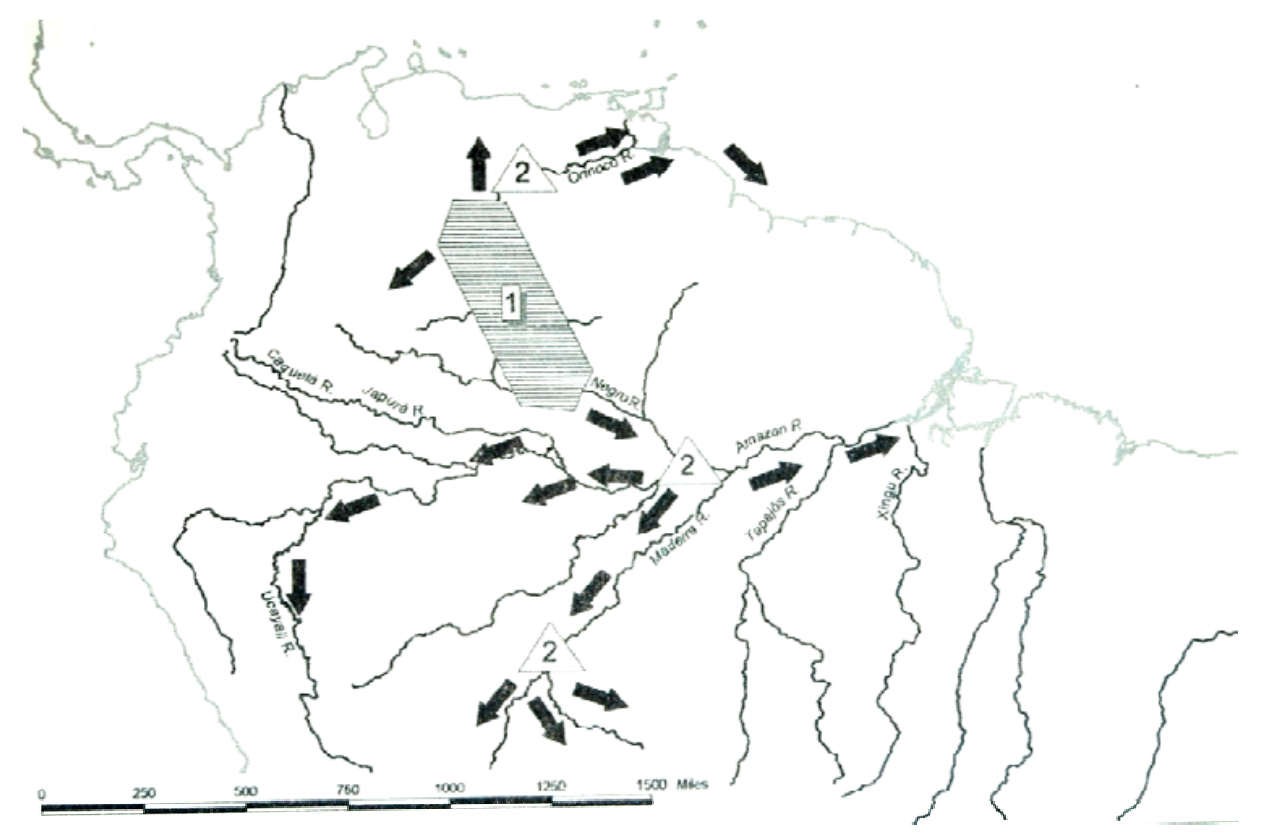

Figura 153: Modelo de expansão para grupos Arawak a partir do noroeste amazônico, no qual o alto Madeira é tido com um dos possíveis centros secundários de dispersão (fonte: HECKENBERGER, 2002). 
É claro que os Tupi também transformavam a paisagem, criando lugares significativos. Os petroglifos da bacia do alto Ji-Paraná talvez sejam um exemplo disso (GARCIA, 2010). Também é possível ter havido um núcleo de grupos Tupi no alto Madeira, ainda mais quando se pensa que os Tupi são os grupos historicamente mais relacionados à região. Nesse sentido, seria possível citar, por exemplo, o entorno do encontro dos rios Araguaia, Itacaiúnas e Tocantins, no sudeste amazônico, como um núcleo de grupos de língua Tupi-Guarani. O que parece uma diferença crucial, nesse caso, é a (aparente) ausência de outras indústrias no centro desse núcleo: as influências aparecem mais na periferia (e.g. interior maranhense) e não dentro do núcleo, como parece indicar o contexto do alto Madeira. Muito mais do que "organizador" de um centro multi-étnico, o que de fato parece coerente com o contexto Tupi é a proposta predatória dos grupos TPA que descem o Madeira, aterrorizando os grupos dos grandes rios amazônicos. Como diria Brochado (1984): "Here come the cannibals".

\subsection{Síntese}

Por que os grupos falantes de línguas Tupi-Guarani (e os Yudjá-Juruna) possuíam uma sofisticada decoração cerâmica ausente na cerâmica dos demais sítios Tupi? Da mesma forma, pode-se perguntar: por que a cerâmica dos Shipibo-Conibo, fase Cumancaya do alto Amazonas, possui uma sofisticada decoração policrômica-corrugada se comparada com a cerâmica simples de outros grupos Pano (LATHRAP, 1976: 198)?

Segundo a hipótese aqui proposta, os Tupi-Guarani e os Shipibo-Conibo seriam exemplos dos contatos de grupos "autóctones" com populações migrantes (antigos Arawak?), portadoras de uma cerâmica ainda mais sofisticada (quanto ao número de elementos), que estabeleceram núcleos de redes de troca em lugares-chave da paisagem amazônica, como as cachoeiras. Sabe-se que, durante os 1.000 anos que antecederam a era cristã, esses grupos, produtores da cerâmica da Tradição Pocó, se fixaram ao longo da calha do rio Amazonas. Fora alguns indícios de cerâmica (mais) antiga no médio Solimões, esses grupos Pocó, ao que parece, foram a "ocupação inicial" ceramista (agricultora?) dessas regiões. Um processo de deriva no qual o Estilo, em um primeiro momento, não encontra influências para se modificar e tampouco influenciaria a modificação de outros Estilos. 
Por outro lado, caso parte desses grupos portadores de cerâmica Pocó, ou de um Estilo semelhante ao dessa Tradição, tenha entrado na região do alto rio Madeira, em meados do primeiro milênio da era cristã, tais populações teriam encontrado uma região minimamente habitada. Os dados do médio Jamari (500 a.C.) e do rio Ji-Paraná (2000 a.C.) indicam isso, assim como os dados do sítio Nova Vida, das supostas ocupações antigas nas cachoeiras do Teotônio e de Santo Antônio e, é provável, de outros sítios estudados por Zuse. Ou seja, ao contrário do processo de deriva que ocorreu na calha do Amazonas, no alto Madeira teria ocorrido, devido a um processo de redes de trocas comerciais e simbólicas, uma intensa "mistura" de populações, informações e estilos cerâmicos. Evidências dessa "mistura" ocorrem em escala fechada no complexo do Teotônio ${ }^{123}$, em escala local nos sítios de entorno (e.g. cachoeira de Santo Antônio) e em escala regional, como na cerâmica pintada que aparece de maneira intrusiva nas indústrias do médio Jamari.

É impossível saber se essa hipotética rede de trocas durou algumas décadas ou centenas de anos. Um dos possíveis resultados desse processo de interação foi o surgimento de novos Estilos cerâmicos, mais simples (com menos atributos) do que o da antiga cerâmica policrômica (Pocó), mas com certeza mais sofisticados (com mais atributos) do que aqueles que se observam nas antigas Tradições ceramistas locais. De posse desse novo Estilo cerâmico, e possivelmente de outros elementos adquiridos por meio desse ciclo de interações (e.g. uma tecnologia de navegação mais sofisticada), pode-se sugerir que alguns dos antigos grupos habitantes do rio Madeira desceram o rio com uma proposta mais bélica do que amistosa. Especula-se, a partir dessa hipótese e da bibliografia etnográfica e linguística, que esses grupos vindos de fora (produtores de cerâmica policrômica antiga) sejam falantes de línguas Arawak, e que ao menos parte dos grupos locais que formaram a rede sejam antigos falantes de línguas do tronco Tupi. Um correlato etnográfico dessa hipótese pode ser encontrado no alto Xingu, onde os grupos de língua Tupi-Guarani são um no meio de uma variedade de grupos linguísticos que se encontram no entorno de um núcleo de grupos Arawak (cf. HECKENBERGER, 2005).

Caso essa hipótese esteja correta, há uma série de dúvidas quanto a esse processo de mistura e formação de novos Estilos, em especial o que viria a ser a Tradição Polícroma, e se tal fenômeno teria ocorrido no sítio Teotônio ou não. Outro problema é cronológico, referente à incerteza quanto às ocupações antigas do complexo do Teotônio (sítios Teotônio e Santa

\footnotetext{
${ }^{123}$ Um exemplo disso está em uma imensa urna funerária retirada nesse sítio, sem decoração e com paredes verticais (SILVA, 2012).
} 
Paula), decorrente de um hiato de cerca de 300 anos entre a data (mais confiável) da base da ocupação do sítio Teotônio (700 d.C.) e dos sítios Jatuarana (1000 d.C. para o sítio Associação Calderita), o que talvez seja resolvido com as pesquisas realizadas por Zuse ou em sítios em antigos meandros, como os sítios do lago do Cuniã (cf. Capítulo 4).

Tal incerteza cronológica cresce quando se pensa que, por volta de 700 d.C., há datas ligadas à Tradição Polícroma no médio Solimões, no lago de Tefé (COSTA, 2012), exigindo uma data ainda mais recuada para que o alto Madeira seja apontado como centro da expansão da Tradição Polícroma ${ }^{124}$. Por outro lado, tal incerteza é atenuada se a história da Tradição Polícroma não for pensada como uma expansão linear e gradativa (NEVES, 2012; TAMANAHA, 2012) ou decorrente de um grande e rápido crescimento populacional, e sim como um frenético processo de movimentos de mudança, dispersão, idas e vindas e reocupações de territórios. Tática que seria uma espécie adaptação ribeirinha de um padrão (acelerado) de movimentação de interflúvio.

Com esse modelo em vista, pode-se olhar para os sempre problemáticos Kokama e Omágua, do alto Amazonas, de uma forma diferente. Se o grande problema classificatório desses grupos é a combinação de um vocabulário Tupi com uma sintaxe Arawak (CABRAL, 1995; CABRAL e RODRIGUES, 2003; URBAN, 1996), a questão se esvai, porque é esperado que a expansão Tupi (Tradição Polícroma) tenha se apropriado arqueologicamente de uma sintaxe estilística Arawak. Nesse sentido, outro dado que corrobora a presente hipótese é a prática da deformação craniana tanto pelos Karitiana, Tupi-Arikém do alto Madeira (SOUZA, 1994), quanto pelos Omágua do alto Amazonas (PORRO, 1995; RODRIGUES FERREIRA, 1974 [1788]), ligação que foi sugerida por van der Velden (não publicado). Por fim, a presença de milho no sítio Itapirema (Capítulo 5), e nas descrições sobre a economia dos Kokama e Omágua (MÉTRAUX 1948d: 691), é mais um elemento que liga o alto Madeira, o alto Amazonas e a TPA, e que credencia a possibilidade de o milho ser o principal alimento cultivado pelos grupos da TPA ${ }^{125}$.

Uma vez que o alto Amazonas foi inserido na discussão, torna-se pertinente apontar o papel dessa região na hipótese proposta. Ao que parece, essa região é de interpretação ainda mais complexa do que o alto Madeira. Nas fases descritas por Lathrap (1970), pode-se

\footnotetext{
${ }^{124}$ Um atalho alternativo seria um movimento a partir do rio Purús.

${ }^{125}$ Entretanto, mais uma vez é necessário ter cuidado, uma vez que Métraux aponta que os Kokama e Omágua também cultivavam mandioca amarga, o que permitiria igualmente se pensar que foram os grupos TPA que teriam difundido a mandioca do alto Madeira para o alto Amazonas.
} 
perceber com clareza que o pesquisador teve problemas classificatórios semelhantes aos do presente estudo. Por exemplo, na cerâmica Kotosh Waira-Jirca, na bacia do Huanuco (alto Amazonas), o autor observou uma complexa combinação de elementos que pode ser decorrente da fusão de pelo menos duas tradições e de um contato com populações espalhadas em amplos territórios das terras baixas peruanas (p. 106).

Em sua síntese regional das antigas culturas cerâmicas do alto Amazonas, o autor (pp. 110-111) defende serem de grande significância as semelhanças observadas nos vasos de serviço da maioria dos complexos por ele apresentados, incluindo tigelas com fino acabamento, bases convexas, carenas nas laterais e frequentes decorações. Segundo Lathrap, essas mesmas características seriam encontradas em cerâmicas do baixo rio Orinoco, na Amazônia setentrional:

The basic set of vessel forms and a tendency do red and white painting is common to all these complexes, and there is no doubt that a valid historical relationship exists among them; the ceramic tradition embracing them has been designated Saladoid by Cruxent and Rouse (...) (Lathrap 1970: 110-111, grifo nosso).

Trata-se, claro, do equivalente Inciso-Pintado da Tradição Pocó encontrado no rio Orinoco e com idade mínima, estimada por Lathrap, de 1000 a.C. Portanto, se levado em conta que Lathrap não possuía os dados referentes à Tradição Pocó, pode-se concluir que a presente interpretação é muito semelhante à feita por Lathrap em relação ao alto Amazonas, ainda mais se incluída a inferência do autor de que se trata de um padrão de dispersão Arawak (p. 112). Os Shipibo-Conibo, por sua vez, e a cerâmica arqueológica Cumancaya, ligada a esses grupos, seriam um exemplo de grupos Pano que, mais cedo ou mais tarde (provavelmente mais tarde), tiveram algum contato com essa rede do alto Amazonas.

A parte mais relevante dessa história de núcleos regionais, lugares persistentes e redes de contato cabe aos Tupi e aos Tupi-Guarani. Isso porque é possível identificar uma série de processos de movimentação e ocupação dos espaços por parte desses grupos, mesmo antes da suposta chegada dos grupos Arawak no alto Madeira. Conforme visto, as cerâmicas de grupos de interflúvio ou de rios secundários na região do alto Madeira chegam a datas entre 2000 a.C. (ZIMPEL, 2009) e 3000 a.C. (MILLER, 2009), enquanto a presença dos TupiGuarani no sudeste amazônico tem datas próximas ao início da era cristã (FIGUEIREDO, 1965; GARCIA, 2012a), o que indica um milenar processo de ocupação da Amazônia 
meridional pelos Tupi e pelos Tupi-Guarani. A questão dos movimentos (expansões e migrações) dos Tupi e Tupi-Guarani será discutida no próximo capítulo.

Há uma grande diferença entre a cerâmica dos Tupi-Guarani e a de (quase) todos os demais grupos Tupi, em especial na variabilidade decorativa. Pelo menos no estilo cerâmico, os Tupi-Guarani estão para os Tupi assim como os Shipibo-Conibo estão para os demais falantes de língua Pano. Ao contrário do que é sabido sobre os Shipibo-Conibo, e também sobre os produtores de cerâmica da Tradição Polícroma da Amazônia, não se tem ideia de onde teria ocorrido o processo de contato dos antigos produtores de cerâmica policrômica (Pocó, Saladoide etc.) com os Tupi-Guarani, se é que isso de fato aconteceu.

Um palpite razoável para o local desse encontro seria o baixo Xingu. Primeiro, tratase de uma região com uma imensa variabilidade de Estilos (fases, Tradições) cerâmicos (PEROTA, 1992), mais ou menos análoga à do alto Madeira (o que não ocorre, por exemplo, no baixo rio Tocantins). O componente Tupi-Guarani é, com certeza, um deles, assim como uma extremamente dúbia cerâmica policrômica (cf. Capítulo 2). Segundo, há indícios da presença da Tradição Pocó no baixo Amazonas, chegando a 1000 a.C. Terceiro, apesar de Perota não apresentar datas antigas para os sítios da Subtradição Tupinambá da Amazônia no baixo Xingu, sabe-se que na região de interflúvio Xingu-Tapajós essas datas são bastante recuadas, próximas ao início da era cristã (FIGUEIREDO, 1965; GARCIA, 2012a). Além disso, há uma imensa variabilidade linguística interna (MELO e KNEIP, 2006; RODRIGUES, 1984/85), que também atesta a grande antiguidade da ocupação Tupi-Guarani na região. Quarto, o fato de os grupos Tupi-Guarani do alto Tapajós, como os Kayabi (SILVA e STUCHI, 2010), possuírem, ao que parece, uma cerâmica sem decoração pode indicar que os Tupi-Guarani desse rio tenham ficado de fora (não estavam mais conectados à rede ou não se interessaram em estabelecer essa conexão) da metamorfose estilística que os outros Tupi-Guarani do sudeste Amazônico, desde o baixo Xingu ao baixo Tocantins, sofreram.

Resta atribuir um papel para os Yudjá-Juruna (os Tupi não Tupi-Guarani do baixo Xingu) nessa história, o que é bastante complicado dentro desse quadro hipotético. Seria bom demais para ser verdade que os Juruna, assim como talvez tenha ocorrido com os produtores de TPA do alto Madeira, tenham dado um passo além dos Tupi-Guarani dentro das apropriações oferecidas no hipotético núcleo de contatos do baixo Xingu. Os Yudjá, além de se apropriar de alguns elementos estilísticos dos produtores de cerâmica Pocó (e.g. tigelas 
carenadas, policromia e apliques zoomorfos), teriam se apropriado do modo de vida canoeiro desses grupos e também teriam se expandido por via fluvial.

Se isso de fato tiver acontecido, pode significar inclusive que os Yudjá fizeram parte do grande agrupamento Tupi-Guarani do sudeste amazônico, mas sua escolha pelo modo de vida canoeiro os desconectou dos últimos, levando a um distanciamento na língua e no Estilo de fazer cerâmica. Além disso, e por fim, se é provável que os grupos produtores de cerâmica polícroma acabaram com séculos de estabilidade no médio e alto Amazonas, em especial a partir do segundo milênio da era cristã, talvez algo muito semelhante tenha ocorrido no baixo Amazonas com os grupos Yudjá-Juruna e outros grupos relacionados. Os Tupi, obcecados pelo movimento, ao adquirir sofisticadas técnicas de produção e condução de canoas, colocariam em marcha uma frenética sequência de movimentos que poriam fim à prosperidade do baixo Amazonas, inclusive, quem sabe, à quase milenar fase Marajoara (400-1300 d.C.). 


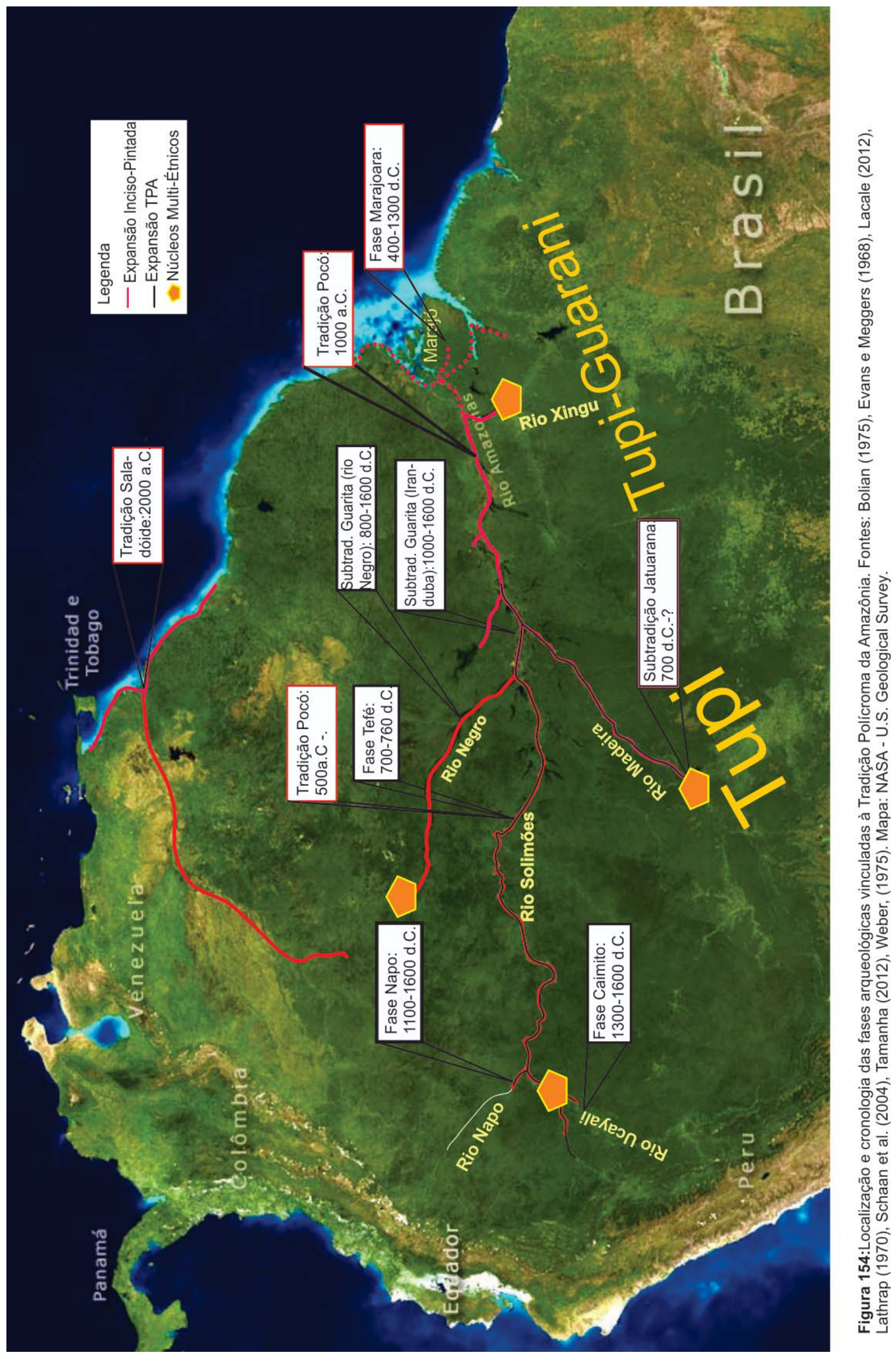




\subsection{Conclusão}

Por mais que o grande quadro hipotético aqui construído - muito maior do que se imaginou no início de sua construção - seja extremamente especulativo e possua uma série de problemas e perguntas, é um quadro que se encaixa bem na compreensão da história précolonial da Amazônia, pelo menos desde o início da era cristã. E ainda responde aos problemas antropológicos e arqueológicos da Tradição Polícroma apontados no Capítulo 2.

Entretanto, dentro desse grande quadro, foram apresentadas conclusões bem menos especulativas. A principal delas foi apontar que os sítios Associação Calderita e Itapirema fazem parte da Subtradição Jatuarana e, consequentemente, da Tradição Polícroma da Amazônia. Não foi possível chegar à mesma conclusão com relação ao sítio Teotônio, que também se pensava fazer parte dessa Tradição. Na verdade, esse sítio foi, pelo menos por enquanto, subtraído da Subtradição Jatuarana e da TPA devido à sua imensa variabilidade e às diferenças com relação ao material dos sítios Associação Calderita e Itapirema. A partir da heterogeneidade do sítio Teotônio, da sua longa cronologia (persistência), e do seu caráter significativo, assim como da grande variabilidade inter-sítios que parece existir no alto Madeira, foi possível postular que a região foi um grande núcleo de contatos, e as diferenças estilísticas da cerâmica podem refletir diferenças nas línguas e em outros aspectos culturais.

Desde os estudos realizados por Eurico Miller, está claro que os grupos produtores de cerâmica pintada do sítio Teotônio vieram de outra região. Os dados arqueológicos sobre as cerâmicas incisas e pintadas dos rios Orinoco (Tradição Saladoide) e Amazonas (Tradição Pocó) auxiliam a sugerir que grupos com cerâmicas semelhantes teriam subido o rio Madeira e se instalado na cachoeira do Teotônio. O modelo de ocupação desses grupos sugeriu que se tratavam de grupos Arawak.

Foi possível observar que os ocupantes do sítio Teotônio manufaturaram grandes vasos, com grandes motivos pintados, ideais para serem vistos de longe, dentro das grandes festas ritualísticas que devem ter ocorrido no local. A qualidade das pinturas cerâmicas deve ter sido apenas um de muitos aspectos que chamaram a atenção dos diversos grupos que desceram dos rios secundários e interflúvios - entre eles, com certeza, grupos Tupi - para fazer trocas e participar de festividades. Outros aspectos talvez tenham chamado muito mais a atenção de outros visitantes, como a fartura de pesca no local ou, quem sabe, as grandes canoas dos anfitriões. 
Stephen J. Gould (1985), para explicar as mudanças nos seres vivos através do tempo, costumava comparar a evolução a um episódio de guerra: períodos imensos de tédio para alguns instantes de terror. Talvez menos paradoxal do que esse exemplo, a instalação de núcleos regionais na Amazônia sem dúvida deve ter dinamizado muito as relações entre os grupos locais, e o estabelecimento de redes de comunicação fez fluir uma grande quantidade de informação que, talvez em poucas décadas, gerou mais transformações do que nos séculos anteriores. O principal resultado desses contatos, aqui se especulou, foi o surgimento de um fenômeno de movimentos populacionais de grupos portadores de cerâmica hoje conhecida como Tradição Polícroma da Amazônia. O padrão dessa dispersão, e não a cerâmica produzida por esses grupos, é o principal indicador de que se trata de um fenômeno ligado a falantes de línguas Tupi, que podem ter se apropriado do conhecimento adquirido nos contatos da rede regional nos seus movimentos pelos rios amazônicos. Talvez aí é que tenham começado de fato os instantes do terror.

Por fim, a partir do quadro hipotético do alto Madeira, foi observado que fenômenos muito semelhantes podem ter ocorrido em outras partes da Amazônia, o que explicaria uma série de semelhanças entre grupos que não parecem em nada relacionados. Correta ou não essa hipótese, pode-se dizer que a maior contribuição do presente estudo é afirmar que, caso tenha ocorrido a partir do alto Madeira, a dispersão de grupos da Tradição Polícroma foi extremamente rápida, em data próxima a 700 d.C.. Muitos séculos antes disso, é provável que de forma muito mais lenta, uma série de (outros) grupos Tupi e, em especial, Tupi-Guarani, vinha colonizando vastas áreas da Amazônia meridional, o que será um dos tópicos do capítulo final. 


\section{A ÚLTIMA BEBEDEIRA}

Havia chicha bastante para afogar o aborrecimento (CASPAR, 1958: 99).

Uma parte das mulheres, enquanto isso, ocupa-se de aquecer a bebida, seu principal oficio (MONTAIGNE, 2009: 57).

Beers are a vital subsistence food. Their consumption can also place the cosmological participant in closer contact to the hidden space (STAHL, 1984: 65).

Outra característica que se tornou quase universal, porque satisfaz a uma necessidade biológica, é a manufatura de bebidas ligeiramente alcoólicas (MEGGERS, até ela, 1987: 145).

I consumed vast quantities of it (LÉVI-STRAUSS, sobre sua rotina cervejeira entre os Tupi-Kawahiva, 1974: 469).

Drunkness also expresses culture in so far as it always takes the form of highly patterned, learned comportment which varies from culture to culture: pink elephants in one region, green snakes in another (DOUGLAS, 1987: 4).

\subsection{Introdução}

Neste último capítulo, será realizada uma revisão dos tópicos discutidos até aqui, utilizando um foco mais aberto, de forma a inseri-los em discussões mais amplas sobre a arqueologia das terras baixas. Isso será feito a partir da discussão sobre o consumo de bebidas fermentadas, amplamente difundido nas sociedades indígenas amazônicas. Um tema extenso, que possui uma série de campos analíticos (e.g. cognição, saúde, sociabilidade), muitos já razoavelmente debatidos, em especial pelas ciências médicas e pela antropologia. $\mathrm{Na}$ arqueologia, esse é um tema bastante recente (vide exceções em BRAIDWOOD, 1953; KATZ e VOIGHT, 1986), tendo sido negligenciado pela escola processualista norteamericana e pouco aprofundado até hoje na arqueologia brasileira (vide exceção em NEUMANN, 2010; NOELLI e BROCHADO, 1998). Portanto, mais do que realizar uma discussão intensiva sobre o tópico dos fermentados, pretende-se abordar o assunto da perspectiva da Ecologia Histórica, de maneira que haja um diálogo com os assuntos aqui trabalhados. Não se trata, de forma alguma, de um assunto escolhido de forma aleatória dentro de uma imensidão de possibilidades. Trata-se, sim, para alguém que estuda cerâmica 
arqueológica, de algo que está presente em (quase) todos os lugares da Amazônia há milhares de anos. Foram os potes que trouxeram o assunto à tona, o que também significa que o viés ceramológico deixará de fora da discussão outros elementos que alteram a mente, comuns a muitas sociedades indígenas sul-americanas, como o tabaco, a coca e o ayahuasca.

Tampouco se pretende argumentar que se trata da resposta para todas as questões da arqueologia amazônica, um optimum climático ou uma várzea fértil pós-moderna. Pretendese apenas discutir um elemento central nas transformações das sociedades amazônicas através do tempo, um elemento que potencializa o acesso à comunicação com outros grupos e com o lado obscuro, possibilita a compreensão de muitas questões não evidentes, podendo tanto assegurar a estabilidade quanto levar a mudanças (JENNINGS e BOWSER, 2009: 2). Isto é, não se defende que a produção em grande escala de fermentados levou a um episódio de formação (o período Formativo) das sociedades indígenas amazônicas e sim a possibilidades ilimitadas de transformação (cf. GOLDSTEIN et al., 2008: 141).

O álcool ocorre naturalmente na natureza, e o ser humano não é o único animal que se aproveita de seus benefícios. Durante um dos menos politicamente incorretos experimentos já realizados, foi observada uma propensão à embriaguez nos chimpanzés dado o livre acesso a bebidas. Constatou-se também que os machos consumiam aproximadamente o dobro das fêmeas, um indivíduo chegando a beber uma quantidade equivalente a quatro garrafas de vinho em um dia. Com o passar do tempo, percebeu-se que as bebedeiras ficaram padronizadas (com horários mais ou menos fixos), mas os chimpanzés permaneciam quase sempre embriagados. Testes com ratos mostraram resultados semelhantes: os animais se reuniam em torno da fonte de álcool sempre algum tempo antes do horário de serem alimentados. A cada três ou quatro dias, os ratos aumentavam sua média de consumo (MCGOVERN, 2009: 10).

Além da sensação prazerosa que causa, o álcool pode aliviar a dor, parar uma infecção, saciar a fome e curar doenças. Antes do advento da medicina moderna, o álcool era o principal paliativo do ser humano. No caso da cerveja, o processo de fermentação aumenta o conteúdo proteico e vitamínico (especialmente de vitamina B) encontrado naturalmente no produto-base e adiciona sabor e aroma a esse produto (MCGOVERN, 2009: xi e 267). A utilização de água fervida no processo de fermentação (que acelera esse processo) permite que se beba um liquido mais seguro do que a água, sujeita a contaminação por dejetos humanos até nas áreas mais escassamente habitadas (STANDAGE, 2005: 15). Mesmo quando a água não é fervida, o próprio álcool ajuda a eliminar as impurezas. 
A cerveja pode ser obtida a partir de uma série de grãos, tubérculos e frutos. As frutas, por exemplo, especialmente em climas tropicais, podem fermentar ainda na árvore, devido ao calor e à umidade (MCGOVERN, 2009: 7). Esse fenômeno é aproveitado tanto por seres humanos (e.g. BROCHADO, 1991: 80, sobre os Tupinambá e os cajus) quanto por outros animais frugívorostíferos, como passarinhos e macacos. Outra fonte antiga de álcool utilizada pelo ser humano é o mel, que fermenta se armazenado em água, transformando-se em hidromel. Pode-se especular, então, que qualquer porção mal armazenada de frutas ou mel, sujeita à umidade (e.g. água da chuva), poderia ter fornecido bebidas alcoólicas de forma fortuita na Antiguidade. Entretanto, frutas são sazonais e nem sempre se encontra mel em grande quantidade, o que os torna fontes inconstantes de fermentados (STANDAGE, 2005: $15)$.

Mesmo inconstantes, os fermentados estavam presentes na "revolução cognitiva" que o ser humano atravessou nos últimos 30.000 anos, como nas pinturas rupestres criadas durante o Paleolítico europeu ou pelos primeiros paleo-índios americanos. Em ambos os casos, as criações "expressivas", que incluíam uma promissora manipulação de argila (pigmentos) e fogo (RICE, 1999), estão relacionadas a alterações no estado de consciência em eventos festivos (LEWIS-WILLIAMS, 2002: 170) que podem estar relacionadas a fermentados. Uma vez que o hardware (cérebro) humano estava "pronto" há dezenas de milhares de anos (mais ou menos 100.000 anos antes do presente), foram as mudanças no software, na interpretação do mundo a partir de sistema de crenças e comportamentos ocorrida nos últimos 30.000 anos, que teria levado aos grandes feitos da espécie (INGOLD, 2000; RAPPAPORT, 1999; VALLE, 2012; cf. HAYDEN, 1995; RICE, 1999 sobre o sofware horizon cerâmico).

O debate sobre o papel dos fermentados apareceu primeiro entre os egiptólogos e pesquisadores da Mesopotâmia antiga. Entretanto, no começo dos anos 1950, Robert Braidwood (1953) perguntou a uma série de estudiosos se era possível o ser humano ter sobrevivido no passado com uma dieta baseada em cerveja e se a cerveja estaria por trás da 
domesticação dos alimentos. A resposta, quase unânime, foi "não". Atualmente, essa perspectiva começa a mudar. Claro que é difícil saber o que veio primeiro, o pão ou a cerveja, talvez o pão, que só precisava ser levado ao sol para ficar pronto (o preparo da cerveja é um pouco mais complicado), ainda que seja cada vez mais comum autores advogarem pela cerveja (e.g. HAYDEN, 1990, 2001 sobre alimentos festivos). O fato de quase todos os grãos ou tubérculos mais produzidos no mundo, como a cevada (Hordeum vulgare), o trigo (Triticum spp.), o arroz (espécies Ozyra), o milho (Zea mays), a mandioca (Manihot esculenta), a batata doce (Ipomoea batatas), o sorgo (Sorghum bicolor) e até a batata (Solanum tuberosum) possuírem versões alcoólicas deve ter influenciado os especialistas a rever seus conceitos ${ }^{126}$. Assim como a constatação de que a versão líquida desses alimentos em geral é mais nutritiva do que a versão sólida (possui mais vitamina B) (MCGOVERN, 2009: 72).

É interessante pensar que tanto o pão quanto a cerveja são variáveis sólidas e liquidas de uma "papa" ou mingau. Sabe-se hoje que o contato dos grãos (como os clássicos trigo e cevada do médio oriente ${ }^{127}$ ) com a umidade gera a formação de enzimas de diástase, que convertem o amido do grão em maltose (açúcar). Em seguida, uma variedade de fungos, bactérias e maltes transformam os açúcares em álcool (JENNINGS e BOWSER, 2009: 15; STANDAGE, 2005: 14). Se o "quem veio primeiro?" é ainda incerto, sabe-se que, tanto na Mesopotâmia quanto no Egito antigos, as bebidas fermentadas de trigo e cevada (cerveja) foram muito consumidas (por homens, mulheres e crianças, ricos e pobres).

Mesmo sendo difícil avaliar o papel dos fermentados na domesticação dos alimentos, sabe-se que a partir dos últimos 3 mil anos eles estão (quase) sempre presentes. A cerveja servia como moeda (líquidos, sendo facilmente divisíveis, são ótimas moedas), pagando inclusive os trabalhadores que construíram as pirâmides do Egito. As placas de barro contendo os primeiros escritos do cuneiforme (3500-3100 a.C.), a mais antiga forma de escrita do mundo (proto-Sumérios ou proto-Elamitas da Mesopotâmia), apresentam uma significativa quantidade de vasos simbolizando a cerveja, significando que essa fazia parte da

\footnotetext{
${ }^{126}$ Muitos desses alimentos possuem uma variação de espécies e uma série de nomes científicos, sendo apenas citados os mais comuns.

${ }^{127} \mathrm{O}$ processo é praticamente idêntico para o milho e a mandioca nas Américas.
} 
redes de trocas locais e coletas de impostos ${ }^{128}$ (MCGOVERN, 2009: 62; STANDAGE, 2005 : 29-37).

Além de servir como pagamento, o que ocorre até hoje em sociedades indígenas amazônicas (cf. Capítulo 3), os fermentados possuem outros valores simbólicos. Assim como um aperto de mão sinaliza que a mão não está armada (é um sinal de paz), o compartilhamento de um pote de bebida indica que essa não está envenenada nem é imprópria para o consumo (STANDAGE, 2005: 18). Em outras palavras, dividir uma tigela de fermentado é um símbolo universal de hospitalidade (JENNINGS e BOWSER, 2009: 4-5). Da mesma forma, oferecer uma festa com uma grande quantidade de fermentados pode ser um sinal de status. Segundo Hayden (2001: 29-30), uma festança alcoólica pode: (I) mobilizar mão de obra; (II) criar relações de cooperação dentro de grupos ou entre grupos; (III) criar relações de cooperação entre grupos sociais diferentes; (IV) criar excedente (possivelmente lucro); (V) atrair potenciais parceiros, mão de obra, aliados ou trocas de bens, assim como divulgar o sucesso do grupo; (VI) gerar poder político (controle de recursos e mão de obra) por meio da criação de uma rede de dívidas recíprocas; (VII) levar ao uso do excedente produzido pela população geral para a manutenção de uma elite; (VIII) propiciar pedidos de favores; (IX) compensar por transgressões (cf. JENNINGS e BOWSER, 2009: 56 , para conclusões semelhantes).

Alguns desses aspectos serão abordados adiante, no contexto amazônico. Primeiro, será utilizado um texto como um exemplo ilustrativo da proposta interpretativa. Em seguida, os temas centrais desta tese (Tupi, Tupi-Guarani e TPA) serão retomados à luz das discussões sobre fermentados, incluindo uma comparação preliminar dos vasos (arqueológicos e etnográficos) para preparo e consumo dessas bebidas. Apesar da dificuldade em inserir vasos de diferentes períodos nas categorias "tigela" e "panela" (BROCHADO, 1991: 43) e da desproporção nas amostras dos diferentes grupos citados, esse esboço comparativo é válido para pensar nas semelhanças e diferenças entre esses grupos ${ }^{129}$. Mais uma vez, a proposta é mais voltada a abrir campos explanatórios do que fornecer conclusões substanciais sobre qualquer um dos temas tratados.

\footnotetext{
${ }^{128}$ Testes químicos realizados em vasos cerâmicos da mesma época, com forma semelhante à simbolizada nas placas, confirmaram que esses eram utilizados para o consumo de cerveja (MCGOVERN, 2009: 69).

${ }^{129}$ Para uma discussão sistemática sobre forma e função dos vasos Tupinambá e Guarani vide Noelli (19992000) e Corrêa (2009).
} 


\subsection{Um dia na vida dos Jívaro}

Durante os anos de 1956-57, duas décadas antes do casal Taylor-Descola (cf. Capítulo 3), o antropólogo americano Michael Harner passou uma longa temporada entre os Jívaro (Achuar), na Amazônia equatoriana, resultando na criação do livro The Jivaro: people of the sacred waterfalls (1972). Dentre uma série de didáticas descrições - muitas relevantes do ponto de vista arqueológico -, essa etnografia retrata a quantidade de cerveja de mandioca consumida por esses grupos, especialmente por parte dos chefes das casas. Como exemplo, Harner descreve o que seria um dia na vida de um chefe de família Achuar:

O marido se levanta da cama de sua esposa ${ }^{130}$ em torno das duas horas da manhã, vai até o lado masculino da casa e se senta em um banco. Lava sua boca com água fresca de uma cabaça que está ao seu lado. Chama sua esposa, dizendo: "traga cerveja". Ela esquenta um pouco de água, mistura com cerveja de mandioca e traz um pote para ele. Ela serve a ele e a um visitante (homem) que porventura tenha pernoitado ali, iluminada pela luz de uma vela de resina. Em seguida, ela retorna para o seu lado da casa e cozinha banana e mandioca. Ela serve para cada pessoa uma tigela dessa comida. Enquanto isso, o marido está fiando um tecido de algodão e conversando em voz baixa com o visitante. A esposa traz mais cerveja e serve.

Ela volta para o seu lado da casa e permanece sentada, descansando ao lado do fogo, por aproximadamente uma hora. Ela então retorna trazendo mais cerveja. Como os homens não terminam rapidamente de beber, ela permanece agachada ao lado do marido, escutando a conversa (ela acabou de comer um pouco de mandioca no lado feminino da casa). Ela volta para lá, onde permanece por cerca de meia hora, e traz mais cerveja. Ela retorna para o seu lado da casa de novo e, depois de aproximadamente meia hora, retorna com mais cerveja. Dessa vez ela fica e conversa um pouco como seu marido e depois retorna para sua área. Já está quase amanhecendo.

O marido chama a esposa para trazer cerveja. Ela traz um grande vaso de cerveja e a serve continuamente até o amanhecer. Ele então a informa que está indo caçar e coloca cerveja dentro do seu cantil de cabaça, levando um pouco de mandioca cozida em uma bolsa de rede. Pega sua espingarda e sai para caçar com a esposa e com os seus cães de caça. As crianças ficam em casa.

Eles voltam para casa aproximadamente às duas horas da tarde, tendo matado uma cotia. Assim que chegam, o homem pede à mulher para trazer cerveja, o que ela faz. Ele então descarna a cotia, e ela a cozinha em uma panela (pote). Após ter cozinhado, ela leva a panela para o centro da casa e retira toda a carne, depositando-a sobre folhas frescas de bananeira. Chama os homens (o marido e o eventual visitante) para vir comer. Eles se levantam, pegam seus bancos e se dirigem às folhas de bananeira. Todas as crianças se aproximam e se agacham em volta da comida. A esposa serve um pedaço de carne para cada criança, assim como uma tigela à parte de carne para o visitante.

${ }^{130} \mathrm{O}$ chefe da casa dorme à noite em uma cama junto com a esposa, do lado feminino da casa, e descansa durante o dia em uma cama do lado masculino da casa. 
Quando tudo foi comido, os homens se levantam e retornam com seus bancos para o local onde estavam sentados. Lavam suas mãos e bocas com água da cuia. Então o marido se levanta e pede à mulher para trazer cerveja. Tendo tomado a cerveja, ele se deita na cama do lado masculino da casa até aproximadamente cinco da tarde, enquanto sua esposa vai até a roça, pega mais mandioca e cozinha. Ele se levanta e pede para sua esposa trazer cerveja. Ela carrega a cerveja em tigelas de cabaça. O marido pede para ela trazer mandioca e carne.

Depois dessa refeição, a esposa traz um pequeno pote de cerveja. Os homens tomam apenas duas porções cada e depois conversam. A conversa dura aproximadamente vinte minutos, e eles se servem de novo de cerveja. A esposa permanece do lado do marido durante a conversa, às vezes participando dela. Depois de servi-los pela segunda vez, a esposa retorna para o seu lado da casa, enquanto os homens conversam até o escurecer. A esposa traz então uma vela de resina e acende. Eles conversam mais e bebem cerveja de novo. Finalmente eles terminam o pote de cerveja, e a esposa retorna para o seu lado da casa com ele. Ela vai para a sua cama, enquanto os homens continuam sua conversa. Ela descansa em torno de meia hora, até que o marido a chama de novo para servir cerveja. Ela traz um pote. Os homens bebem, e ela permanece com eles. Quando eles finalmente terminam a cerveja, a esposa retorna para seu lado da casa, lava os potes e as cabaças de serviço e os guarda. Então ela vai se deitar. Depois de meia hora, os homens também vão para a cama, o marido se juntando à esposa do lado feminino da casa, enquanto o visitante descansa sobre a cama diurna do marido no lado masculino da casa" (HARNER 1972: 52-54, tradução nossa).

E minha esposa reclama que eu bebo muito e que ela trabalha demais.

\subsection{Os fermentados nas sociedades indígenas Amazônicas}

Segundo a descrição de Harner (1972), os Jívaro não consomem água pura. Essa serve apenas para que as pessoas se lavem e para cozinhar alimentos. $\mathrm{O}$ autor enfatiza que os Jívaro consideram a cerveja muito superior à água pura, que eles só bebem em momentos de emergência, como quando os cantis de cerveja secam durante expedições de caça (p. 51). Conforme visto, não se trata apenas de uma questão de paladar: o processo de ferver a água e o próprio álcool eliminam impurezas que podem causar doenças. O relato também é didático ao apontar que a cerveja é um alimento, refrescante e rico em vitaminas e calorias, e que pelo menos a consumida no dia-a-dia - não possui um alto teor alcoólico (cf. MEGGERS, 1987: 145). Caso contrário, a caça com certeza não seria muito proveitosa. Por outro lado, o que não fica explícito é que os demais membros da casa também consomem uma significativa quantidade de cerveja. Harner estima que uma mulher beba de um a dois galões $(3,8$ a 7,51) de cerveja por dia, e uma criança, cerca de meio galão $(1,91)$. Os homens beberiam uma nada modesta quantidade de três a quatro galões (11,4 a 151) diários (p. 52). 
O relato também revela que outros produtos vegetais (sólidos) são consumidos durante o dia. Entretanto, chama a atenção a imensa desproporção dos demais produtos vegetais frente à onipresença das bebidas fermentadas. É uma repetição do que foi visto entre os Tupari, para os quais o único alimento é a carne - os produtos de roça (com exceção da chicha) são acompanhamentos (SOARES-PINTO, 2009: 111; Capítulo 3) - e das observações etnográficas sobre os Apiaká (Tupi-Guarani), que têm a caça como o alimento forte, o vegetal como o alimento fraco, e a cerveja como o "forte que enfraquece" (WENZEL, 1986: 56).

O cauim, como era conhecida a cerveja dos grupos Tupi-Guarani, era feito à base de mandioca (doce ou amarga) ou milho, podendo receber ingredientes extras, como mel ou frutas, para aumentar os teores de açúcar e, por consequência, de álcool (NOELLI e BROCHADO, 1998: 119). Assim como nas sociedades Jívaro, o preparo da bebida ${ }^{131}$ e o cultivo das roças é uma função feminina, traço recorrente em outras sociedades indígenas das terras baixas sul-americanas e das terras altas andinas (e.g. JENNINGS e CHATFIELD, 2008: 200). Nas sociedades das quatro maiores famílias linguísticas da Amazônia - Jívaro, Tupi-Guarani, Carib e Arawak - o status de um chefe de família muitas vezes está relacionado à quantidade de mulheres que "possui" (poligamia e/ou uma grande quantidade de filhas) e, por consequência, à quantidade de cerveja produzida e ao potencial de realizar grandes eventos festivos (cf. HARNER, 1972: 80 sobre os Jívaro; SOARES-PINTO, 2009: 106 sobre os Tupari; WHITEHEAD, 1999: 402 sobre os Arawak e Carib das Guianas). Fenômeno que se repete em muitas partes do mundo, como nas sociedades Luo, do Kenia:

(...) feasting is gendered asymmetry in terms of labor and benefits. Specifically, female labor (producing and processing the agricultural supplies essential for feasts) often largely supports a system of feasting which men are the primary beneficiaries in the political arena. This is one of the main reasons why there is a linkage between polygyny and male political power (...) (DIETLER, 2001: 91).

Esse desequilíbrio entre os gêneros é particularmente explícito em alguns grupos, como os Shipibo-Conibo do alto Amazonas, para os quais a principal festa (e bebedeira), celebrava a clitoridectomia (retirada do clitóris) de garotas que chegaram à idade de se casar.

\footnotetext{
${ }^{131}$ Autores como Viveiros de Castro (2002) e Sztutman (2008) indicam que as crianças Tupinambá não beberiam cauim, uma vez que só as pessoas casadas têm essa permissão. Entretanto, esses autores talvez tenham cometido uma generalização errônea dos cronistas, uma vez que há exemplos de crianças Tupinambá consumindo cauim, como em um dos retratos clássicos produzidos por de Bry (apud BUARQUE, 2010: 169).
} 
Trata-se de uma "precaução" masculina para evitar a volta do tempo mitológico em que os papéis eram invertidos (pré-agricultura?): as mulheres estavam no controle e possuíam pênis (uma versão expandida do clitóris que, por isso, deve ser retirado) (DEBOER, 2001: 218; Cf. ROE, 1982). O fardo feminino ligado ao cultivo de alimentos e ao preparo de fermentados também é retratado na mitologia dos índios Campa (Ashaninka) do sudoeste amazônico. Kashiri, nome dado tanto à lua quanto à cerveja (em Arawak), apresenta a mandioca e seu cultivo a uma garota (em período de reclusão) do grupo, que engravida de Kashiri, dando luz ao sol, que a queima viva. É interessante notar que Kashiri, além de ser um símbolo do sofrimento feminino, é o responsável pelo início do canibalismo entre os Campa (WEISS, 1972: 162-163).

Apesar desse evidente desequilíbrio, não se trata apenas de chegar a uma conclusão marxista de inserir as mulheres na categoria "classe explorada" (e.g. HODDER, 1994: 79), já que, em muitos casos, elas compartilham o prestígio do marido (DIETLER, 2001: 92). Da mesma forma, ao controlar o fluxo de bebidas, as mulheres podem participar e influenciar em importantes decisões políticas, especialmente em debates ocorrendo em nível doméstico (BOWSER, 2002: 240,276; JENNINGS e CHATFIELD, 2008: 216).

Tanto os grupos Tupi-Guarani quanto os demais Tupi parecem se encaixar bem nessa desigual divisão por gênero. Entretanto, ao invés de celebrar a derrota das mulheres, como os Shipibo-Conibo, esses grupos parecem comemorar a "vitória" masculina ${ }^{132}$. Afinal de contas, conforme visto (Capítulo 2), o clímax ritualístico dos Tupi-Guarani era o ritual antropofágico, uma celebração ao homem guerreiro e caçador, ou melhor, o homem predador (cf. VIVEIROS DE CASTRO, 1986). O que era feito às custas de uma sobrecarga das mulheres (cf. MONTAIGNE, 2009: 57), o que permite supor que, antes da produção em larga escala dos fermentados, essa balança era menos desigual.

O ritual antropofágico Tupinambá pode ser visto, então, como um símbolo da manutenção do status quo desses grupos. Ideia que fica clara ao observar a incrível semelhança entre as crônicas históricas desses grupos (ABBEVILLE, 1975; CARDIN, 2009; ÉVREUX, 2002; SOARES DE SOUZA, 2001; STADEN, 1974; THEVET, 1978). Uma persistência na estrutura desses grupos, incluindo a cultura material, que levou Noelli (1993; 1999-2000: 247) a taxá-los de "sociedades prescritivas”, avessas a mudanças.

\footnotetext{
${ }^{132}$ Nem tanto se pensarmos que a antropofagia era o método feminino de obtenção da imortalidade, e para os homens eram necessárias distinção no combate e "coragem na hora fatal" (VIVEIROS DE CASTRO, 2002: 257).
} 
Essa questão (a)temporal é explorada por Viveiros de Castro (2002: 248; CUNHA e VIVEIROS DE CASTRO, 2009: 90), que liga os rituais de bebedeira à memória, que por sua vez é voltada ao tema da vingança. Trata-se do aspecto comunicativo das bebedeiras: seu excesso, combinado à exaustiva repetição de danças e cantos dias a fio, proporciona condições de alteração de consciência para o diálogo com os antepassados, com o lado obscuro $^{133}$, a fermentação fornecendo o caminho para ligar as ideias de predação e transformação (SZTUTMAN, 2008: 235; Capítulo 2). Segundo Sztutman (p. 242), o ritual alcoólico e antropofágico é um momento de abertura com relação ao "outro" e ao mundo, uma vez que é nele que se diluem as fronteiras que separam categorias como as que existem entre o eu e o outro, um parente e um estrangeiro, um humano e um não humano e um conterrâneo e um inimigo: claro e obscuro se transformam em cromatismo. O ápice dessa busca pela alteridade e atemporalidade ocorreria em uma série de enunciados litúrgicos, quando o prisioneiro a ser morto e devorado declara já ter comido muitos parentes de seus algozes e que será vingado (VIVEIROS DE CASTRO, 1986, 2002; cf. STADEN, 1974: 181182):

\begin{abstract}
Whereas acts and substances represent substantially that which is present, the words of liturgy can connect that which is present to the past, or even the beginning of time, and to the future, or even to time's end. In their invariance itself the words of liturgy implicitly assimilate the current event into an ancient ageless category of events, something that speechless gesture or mortal substance of expendable objects alone cannot (RAPPAPORT, 1999: 152).
\end{abstract}

Conforme observado no Capítulo 2, o ritual Tupinambá é cercado de símbolos (figuras geométricas bidimensionais) que se repetem por toda a parte: no corpo do matador e da vítima, no chocalho xamânico, nas flechas e nos vasos cerâmicos. Depois da reclusão à qual o matador tem que se sujeitar, esses símbolos ganham um caráter eterno e tridimensional ao serem cravados (incisos) na pele do matador. Evento que ocorre, assim como todos os rituais de passagem dos Tupinambá e demais Tupi-Guarani, ao sabor de uma imensa quantidade de fermentados (NOELLI e BROCHADO, 1998: 118; SZTUTMAN, 2008: 235):

The most abstract products of human thought and feeling are thus made substantial and in being made substantial, are being made comprehensible. When that sign is carved on the body the abstract is not only made substantial but immediate: nothing

\footnotetext{
${ }^{133}$ É curioso que o aspecto da comunicação com os antepassados não figura na lista de Hayden (2001) das possibilidades geradas pelas festanças.
} 
can be experienced more immediately than the sensations of one's own body - and if the mark is indelible (...) it is ever present (RAPPAPORT, 1999: 149).

Um dos pontos centrais da interpretação realizada por Viveiros de Castro (2002: 249) é que a derrocada dos Tupinambá pelos colonos, em especial pelos jesuítas, se deus às custas de um ataque não só ao ritual canibalístico, mas também às próprias bebedeiras, sendo a tarefa de impedir as bebedeiras muito mais complexa do que a de impedir o canibalismo. Nesse sentido, tendo em vista os argumentos quanto aos benefícios do consumo de fermentados, é interessante notar que a sabotagem dos jesuítas à vida ritual e às bebedeiras dos Tupi-Guarani, resultando (entre outros aspectos) na quebra das redes existentes entre os grupos, possui um contraponto ecológico: os Tupi-Guarani (adultos) voltaram a beber água. Aldeados, com escassas possibilidades de movimento e sujeitos às mazelas de uma sedentarização forçada (cf. COIMBRA JR. et al., 2004) os Tupinambá perderam os benefícios vitamínicos dos fermentados e ficaram expostos não só às impurezas de seus dejetos, mas também a um coquetel de doenças europeias, muitas das quais transmitidas pela água.

Com o fim das bebedeiras, acabou, para muitos grupos, a simbiótica e milenar relação dessas bebedeiras com os vasos e as tigelas utilizados para o preparo e consumo dos fermentados presente nas sociedades Tupi-Guarani (vide abaixo). Também acabou o cromatismo que permitia discernir as formas no mundo obscuro e no contato com o outro (SZTUTMAN, 2008: 243), que se tornava palpável e policrômico, igual às suas tigelas.

\subsection{Cerâmicas etílicas}

As fermented brews are key ritual ingredients enabling access to the hidden world, their receptacles are often emphasized with elaborate and cosmologically significant color and design (STAHL, 1984: 102).

Pesquisas arqueológicas apontam que é no leste da Amazônia que se encontram as cerâmicas mais antigas sul-americanas, a cerâmica Taperinha e a Tradição Mina, com datas que chegam a 6000 a.C. (BANDEIRA, 2008, 2010; SIMÕES, 1981; ROOSEVELT, 1995; 1999; ROOSEVELT et al., 1991). Entretanto, parece ser no oeste que se encontram os mais antigos vasos ligados ao preparo e ao consumo de fermentados, datados por volta de 3000 
a.C. (DEBOER, 2003: 299-303; RAYMOND, 1993: 39 apud DEBOER, 2003; STAHL, 1984: 196-197). Segundo Stahl (1984: 217), a cerâmica Valdívia, encontrada em áreas próximas ao litoral equatoriano, apresenta vasos com decoração escovada, corrugada e ungulada, assim como tigelas com decoração incisa elaborada e engobo vermelho (que também aparece na cerâmica Mina). Ou seja, desde os primeiros vasos (dos quais se tem notícia) para consumo de fermentados, ocorre uma divisão (há alguns exemplos do contrário) entre vasos para preparo (corrugados, ungulados, escovados) e tigelas para consumo (pintadas). Essa divisão seria observada com notável constância - abrangendo infinitas variações de formatos e de desenhos plásticos e crômicos - em um universo de falantes de diferentes línguas, dentro e fora da Amazônia.

É incrível como esse duo panela corrugada/tigela pintada sobreviveu no tempo e espaço - uma verdadeira Tradição da Floresta Tropical - enquanto a cerâmica rústica Mina aparentemente foi desaparecendo: mesmo incerta, a ausência de vasos para preparo e consumo de fermentados parece provável (cf. formas Mina em BANDEIRA, 2010). Portanto, se hoje é reconhecido que a domesticação de alimentos ocorreu a partir de uma relação simbiótica, ou co-evolutiva, entre o ser humano e as plantas (RINDOS, 1984; cf. ARROYOKALIN, 2008; BARKER, 2006), pode-se dizer, com certo exagero ${ }^{134}$, que houve uma relação simbiótica entre a cerâmica (ou determinados tipos de vasos e estilos cerâmicos) e o consumo de fermentados nas sociedades ameríndias pré-coloniais. Suposição que pode, inclusive, fornecer um caminho para a compreensão da imensa variabilidade interna Jê (e.g. ROBRAHN-GONZÁLES, 1996) frente a certa homogeneidade Tupi-Guarani: a cerâmica Jê não é (tradicionalmente) um componente ritual nem tende a carregar um estilo que está difundido - o pervasive style de DeBoer (1991: 148) - em outros campos da sociedade, como em outros objetos ou no próprio corpo (cf. MÜLLER, 1990; Capítulo 2).

Também chama a atenção o potencial de separar e dividir grupos a partir da variabilidade desse duo. Por exemplo, na comunidade multi-étnica de Conambo (Equador), formada majoritariamente por grupos de língua Quechua ${ }^{135}$ e Jívaro, todas as mulheres

\footnotetext{
${ }^{134}$ Os Jê são um exemplo de grupos que produziam cerâmica, mas não bebidas fermentadas (SZTUTMAN, 2008: 222).

${ }^{135}$ Os Incas, falantes de línguas Quechua, também utilizavam vasos policrômicos padronizados para consumo de chicha para expressar identidade. Os desenhos dos potes possuíam diferentes mensagens para cada região império: uma para a região central e outra para periferia, onde o Inca tinha que fazer sua presença ser sentida de maneira mais clara. Tanto os Incas quanto as populações colonizadas por eles consumiam cotidiana e ritualmente grande quantidade de chicha. Para marcar sua influência e presença, além de influenciar nos
} 
(maduras) produziam tigelas pintadas para o consumo de chicha, ainda que diferenças estilísticas permitissem distinguir quais tigelas eram ligadas a cada metade (BOWSER e PATTON, 2008: 110). Na ocorrência de casamentos entre metades, a esposa, ao mudar para a casa do marido, tendia a mudar de estilo, adotando o padrão da sogra. Um exemplo de que os laços políticos podem ser mais fortes do que os laços étnicos (BOWSER, 2002: 198). Além disso, verificou-se que esses grupos costumavam enterrar seus mortos nos grandes vasos para preparo de fermentados (p. 138), característica análoga à dos grupos Tupinambá e Guarani. No caso desses Tupi-Guarani, ocorrem exemplos de tigelas para consumo utilizadas como tampa ou acompanhamento das urnas (BUARQUE, 2010), como se servissem para não faltar bebida ao falecido.

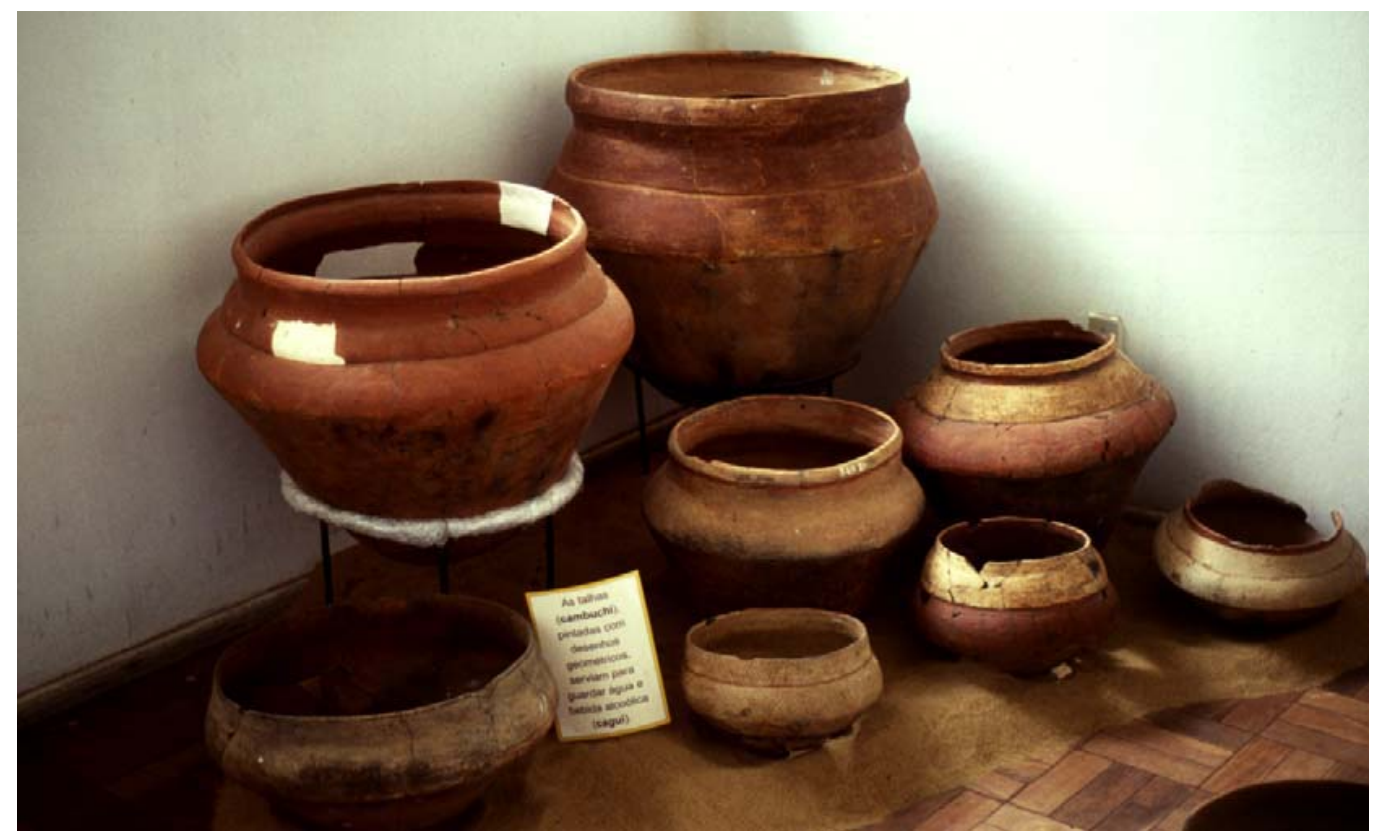

Figura 155: Vasos Guarani para preparo e consumo de fermentados (foto: Stephen Shennan, a partir do acervo do Museu de Arqueologia do Rio Grande do Sul - MARSUL).

A fabricação de cerâmica, incluindo os vasos de preparo e consumo de cerveja, era uma atividade feminina, tanto nos grupos Tupi-Guarani quanto nos grupos Jívaro. Em ambos, percebe-se que eram os vasos destinados ao consumo de fermentados que mais recebiam decorações policrômicas. Segundo Harner (1972: 66), os vasos para o preparo da cerveja - os maiores produzidos pelos Jívaro - possuíam decoração nos seus pescoços, e os grandes vasos de consumo de cerveja possuíam decoração por toda a face interna. Nos pequenos vasos de

motivos policrômicos, o Inca destinava uma considerável parcela dos alimentos coletados como imposto (o milho, em especial), para festanças de chicha (BRAY, 2008: 108-110). 
consumo, essas decorações ocorriam na face externa do vaso. $\mathrm{O}$ autor indica que os motivos pintados seriam simples padrões em zigue-zague. No entanto, tal descrição parece destoar da sofisticada cerâmica policrômica apresentada por Karsten (1935), que esteve com os Jívaro nos anos 1930, o que aponta uma variabilidade interna entre os Jívaro e/ou uma possível simplificação no processo de manufatura dos vasos (Fig.156).
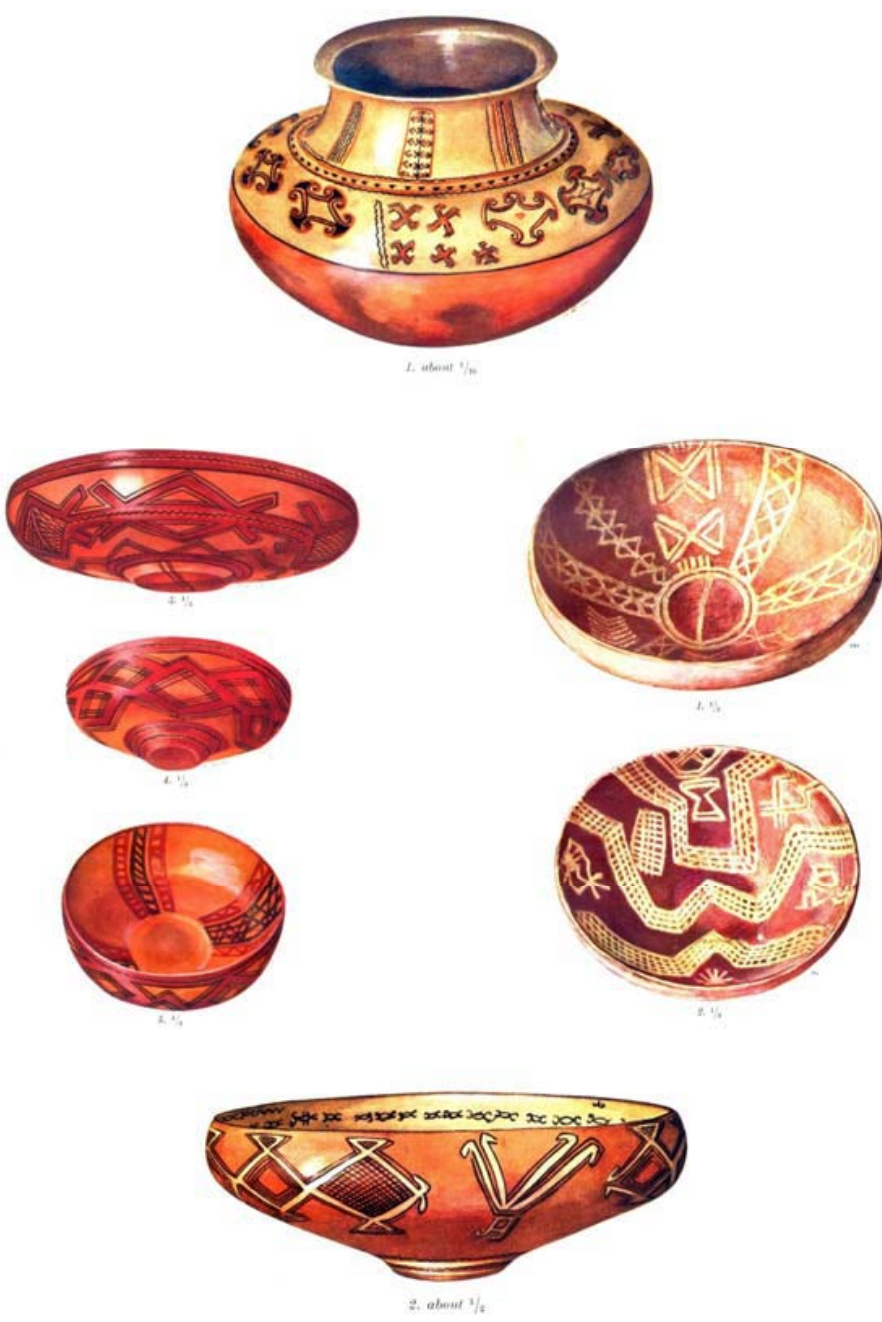

Figura 156: Vaso Jívaro para a preparação (acima) e consumo de cerveja (demais) (fonte: KARSTEN, 1935).

O significado dos motivos pintados nos vasos para preparo e consumo da cerveja está longe de ser aleatório. Conforme observado no exemplo Quetchua/Jívaro da comunidade de Conambo, o Estilo é um forte elemento cultural para esses grupos, um marcador de identidade. Foi também observado, nas sociedades Tupi e Tupi-Guarani (LIMA, 2005; Capítulo 2) que os fermentados simbolizavam uma forma de morrer análoga ao ritual canibal, 
da mesma forma que podem simbolizar o leite materno e a vida (SOARES PINTO, 2008; Capítulo 3). Nesse último sentido, não é de estranhar que a saliva - o componente exógeno essencial para a fermentação do milho e da mandioca, ao contrário das frutas, que já possuem maltose - seja vista como elemento vital para os Asuriní, já que dá vida tanto ao cauim quanto à própria cerâmica, ao ser utilizada durante o alisamento dos vasos (NEUMANN, 2008: 35; MÜLLER, 1990: 183). Entretanto, um lado mais sombrio e mórbido é frequente nos motivos pintados das vasilhas da Subtradição Tupinambá do litoral, incluindo partes humanas devoradas nos rituais antropofágicos, como representações de intestinos (BUARQUE, 2010: 169-170).

É evidente que nem todos os grupos precisam expressar identidade em vasos e tigelas para o consumo de fermentados. Foi observado (Capítulo 5) que os grupos de língua TupiArikém talvez não tivessem tigelas cerâmicas para o consumo de fermentados, e sim cuias (cabaças) com hastes para esse fim. Também foi observado que os Suruí (Tupi-Mondé analisados no Capítulo 4) preferem realizar motivos pintados na produção de cestaria do que na cerâmica. Na cerâmica arqueológica "Tupi” escavada no alto-médio Ji-Paraná (CRUZ, 2008; ZIMPEL, 2009), tampouco há tigelas policrômicas, e quase não há exemplos de tigelas carenadas (com ombros), nos moldes Tupi-Guarani. O que, ainda assim, não serve para justificar que esses grupos (Tupi não Tupi-Guarani) não tinham suas identidades reafirmadas pelo consumo de fermentados. A própria utilização de uma cuia com haste, caso tenha sido uma antiga tradição, poderia ser um diferenciador cultural dos Arikém em relação aos outros grupos.

A utilização de diferentes formas cerâmicas não decoradas (e.g. entre os Tupari e os Suruí) ou de diferentes termos para designar os vasos e a cerveja (Capítulo 3), assim como variações no próprio produto vegetal que serve de base para o fermentado, podem ter servido para antagonizar identidades. Por exemplo, no império andino Wari (600-1100 d.C.), o uso de um vegetal alternativo ao milho, a partir dos frutos da árvore Schinus molle, teria sido um diferenciador deste grupo em relação aos demais (GOLDSTEIN et al., 2008). O que, até certo ponto, pode ter ocorrido na região do alto Madeira, onde alguns grupos optaram pela utilização da mandioca, ali domesticada (CLEMENT, 1999, 2010; OLSEN e SCHAAL, 1999), outros pelo milho, introduzido de fora (pelos Arawak?), assim como outros vegetais e outras combinações. A pupunha, por exemplo, a única palmeira domesticada da América do Sul, possui origem genética creditada à região do alto rio Madeira (OLSEN e SCHAAL, 
1999) e é fonte de bebidas fermentadas dos índios Campa (Arawak), encontrados na mesma região (WEISS, 1972: 163).

Pode-se supor, então, que uma composição politética de elementos ligados ao consumo de fermentados pode ter, em muitos casos, permitido aos diversos grupos Tupi do sudoeste amazônico se diferenciar uns dos outros e de outros grupos não Tupi, mesmo sem a ocorrência de tigelas policrômicas. Por outro lado, a presença das panelas para preparo ${ }^{136} \mathrm{de}$ fermentados aparece no registro etnográfico dos Suruí e dos Tupari (Tabela 60), assim como nos sítios arqueológicos do alto curso dos rios Ji-Paraná ${ }^{137}$ e Roosevelt (MILLER, 2009: 125126), na forma de urnas funerárias. Como a cronologia dessa região (alto Ji-Paraná e alto Roosevelt) é bastante recuada, com datas de até 2000 a.C. (ZIMPEL, 2009), há fortes indícios de que as urnas, e provavelmente as decorações corrugadas encontradas em geral nos sítios onde essas foram recuperadas, são elementos comuns a todos (ou quase todos) os grupos Tupi. Nesse sentido, as urnas da Tradição Tupi-Guarani parecem muito mais próximas das de seus parentes linguísticos Tupi do que de seus parentes estilísticos Arawak ribeirinhos (Tabela 60). Isso significa que, mesmo antes da dispersão dos Arawak para formar uma série de núcleos amazônicos, os antigos falantes de línguas Tupi vinham colonizando a Amazônia meridional de forma muito lenta (se comparada à dispersão TPA), em meio às festas e aos rituais antropofágicos que caracterizam essas sociedades.

A vida de interflúvio, entretanto, não era elementar. Durante os Capítulos 2 e 3 foi observada a existência de uma rede de contatos perpendiculares aos existentes nos cursos dos grandes rios amazônicos. $\mathrm{Na}$ Amazônia meridional pré-colonial, essa rede seria formada principalmente por grupos do tronco Tupi - no sudoeste Amazônico - e da família TupiGuarani - no sudeste -, assim como produtores de cerâmica Inciso-Modela. No interflúvio Xingu-Tocantins, por exemplo, o contato desses grupos confundiu e ainda confunde os estudiosos, como a fase Carapanã, uma suposta cerâmica híbrida entre a Tradição TupiGuarani e a cerâmica Inciso-Modelada (FIGUEIREDO, 1965; SIMÕES et al., 1973), reavaliada por Garcia (2012a) como apenas Inciso-Modelada (Capítulo 2). Nas regiões de interflúvio da Amazônia ocidental, o cenário é ainda mais heterogêneo, uma verdadeira

\footnotetext{
${ }^{136}$ Segundo Rice (1999: 31), em muitos contextos (pelo mundo) a cocção pode ter sido a primeira funcionalidade dos vasos.

${ }^{137}$ A presença de estatuetas antropomorfas cerâmicas na região do alto Ji-Paraná (encontradas no Museu Regional de Rondônia) também pode estar ligada ao consumo de bebidas. Reichell-Dolmatoff (1961: 239), descreve o uso xamânico de estatuetas antropomorfas (de madeira) no alto rio Negro, utilizadas para proteger a cerveja de milho de influências malignas durante a etapa de fermentação.
} 
confusão corrugada, uma vez que esse elemento é encontrado tanto em grupos de língua Tupi, quanto de língua Pano, Arawak e Jívaro ${ }^{138}$ (cf. STEWARD e MÉTRAUX, 1948), um forte indício de relações entre esses grupos. É o que argumentam autores como SantosGranero (2002: 31-32) e Hornborg e Hill (2011: 135), que sugerem que, enquanto os grupos Pano ribeirinhos adotaram um modo de vida (dos também ribeirinhos) Arawak do rio Ucayali (no alto Amazonas), os grupos Arawak dos interflúvios (como os Piro) teriam uma cultura muito mais próxima da dos Pano de terra firme, com quem priorizavam relações de interação. O que poderia nesse caso ser traduzido no duo paradoxal "corrugado multi-étnico de terra firme" versus "policrômico multi-étnico ribeirinho". Um cenário, para algum tupinólogo acostumado apenas com os arqueologicamente bem definidos Tupinambá do litoral e Guarani do Sul, de imenso caos. O que torna necessário retornar a um terreno mais seguro.

Foi observado que as tigelas (em geral pintadas) para consumo e as panelas (em geral corrugadas) para preparo são os elementos que menos variam na Tradição Tupi-Guarani. Vasos com forma de tigela, com "ombro" e pintura vermelha sobre engobo branco, são característicos das Subtradições Tupinambá da Amazônia, Tupinambá do litoral e Guarani, assim como as grandes vasilhas angulosas e por vezes com decoração corrugada. Exemplos de variações (inter Subtradições) seriam a baixa frequência de corrugados nas panelas Tupinambá e a baixa frequência de panelas com fundos cônicos na Subtradição Tupinambá da Amazônia, o que pode ser decorrente do reduzido número de vasos completos encontrados dessa Subtradição. Outro exemplo são as tigelas quadrangulares nos sítios relacionados aos Tupinambá do litoral, supostamente ausentes nas demais Subtradições. Entretanto, Lorena Garcia (com. pessoal) indica a existência de tigelas quadrangulares no baixo Xingu. Nesse sentido, é bastante comum os pesquisadores do sudeste amazônico (e.g. o presente autor, L. GARCIA e F. SILVA) verem na Subtradição Tupinambá da Amazônia ${ }^{139}$ elementos recorrentes em apenas uma das demais Subtradições, o que mais uma vez remete ao sudeste amazônico como possível local a partir do qual as Subtradições Tupinambá e Guarani começaram a se dispersar.

Ao olhar para a cerâmica da Tradição Polícroma da Amazônia - tendo em mente a variabilidade de elementos das tigelas e panelas para fermentados da Tradição Tupi-Guarani

\footnotetext{
${ }^{138}$ Outro grupo que poderia ser inserido nessa rede de interflúvio é o dos Wari (família Txapakura, não confundir com os do império Wari citados acima), encontrados hoje na bacia do rio Mamoré (alto Madeira). Esse grupo também possui muitas semelhanças com os Tupi, como o canibalismo e o canibalismo simbólico por meio do consumo de bebidas alcoólicas (VILAÇA, 2010: 97).

${ }^{139}$ Garcia e Silva, entretanto, não utilizam a mesma terminologia.
} 
- fica claro que se tratam de dois agrupamentos distintos (Tabela 60). Primeiro (I), não há um padrão de tigelas com ombros e decorações pintadas sobre os ombros na TPA. Na verdade, é difícil apontar qual seria a tigela para consumo de bebidas nas Subtradições Guarita e Jatuarana (só há uma reconstituição de tigela com ombro no sítio Itapirema). Essas tigelas com decoração policrômica só aparecem com grande frequência no alto Amazonas, ainda que, nesse caso, se assemelhem às produzidas por outros ocupantes dessa região como as da Fase Cumancaya e as dos atuais Jívaro. Além disso (II), as urnas funerárias TPA (as supostas panelas para preparo de fermentados) possuem formato distinto da Tradição Tupi-Guarani: as urnas TPA em geral possuem formato cilíndrico, com um bojo inferior avantajado, ao passo que os yapepó (panelas Guarani) tendem a ter o bojo superior avantajado (Tabela 60). Por fim (III), muitas panelas-urna Tupi-Guarani possuem decoração corrugada, elemento ausente na cerâmica TPA. Por outro lado, é raro as urnas Tupi-Guarani possuírem decoração policrômica e, mesmo quando está presente, essa decoração é encontrada apenas na parte superior do vaso (cf. PROUS, 2010). Essa rica utilização da policromia na TPA, muitas vezes combinada com apliques modelados com desenhos antropomorfos, faz inclusive pensar se essas urnas de fato eram também levadas ao fogo (como no caso Tupi-Guarani). Ao que parece, esse tipo de vaso TPA nasceu com apenas um uso em vista, o de ser urna, ao passo que os Tupi-Guarani fizeram valer mais o esforço manufatureiro desses grandes vasos e os teriam utilizado em mais de uma função.

Os produtores (ou a maior parte deles) de cerâmica da Tradição Polícroma da Amazônia não parecem ter utilizado os vasos para preparo e consumo de bebidas fermentadas como elementos de identidade ${ }^{140}$, ao contrário do que ocorreu com os produtores (ou a maior parte deles) de cerâmica da Tradição Tupi-Guarani, da fase Cumancaya (Shipibo-Conibo) e os Jívaro. Portanto, do ponto de vista de uma análise preliminar que usa cerâmicas arqueológicas para preparo e consumo de fermentados, não há uma ligação direta entre a Tradição Polícroma da Amazônia e a Tradição Tupi-Guarani. O que se propõe aqui é que os elementos cerâmicos comuns à TPA e à Tradição Tupi-Guarani são fruto de contatos em diferentes locais e momentos com uma vasta rede pan-amazônica, provavelmente orquestrada por grupos de língua Arawak. Rede que também teria influenciado o Estilo cerâmico de uma série de grupos de línguas diferentes, como os atuais grupos Jívaro e os Shipibo-Conibo (Fase Cumancaya).

\footnotetext{
${ }^{140}$ A análise do sítio Itapirema (Capítulo 5) indicou que os vasos mais elaborados desse sítio estariam ligados ao serviço e consumo de alimentos sólidos e não líquidos.
} 


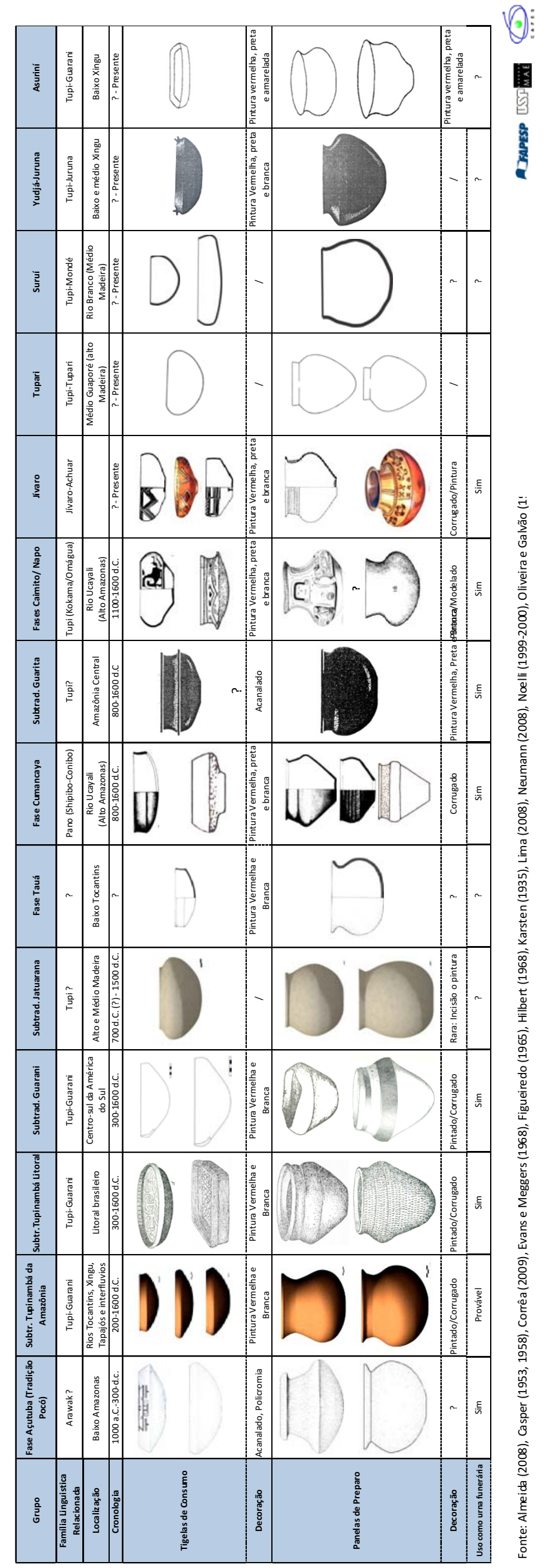


A diferenciação estilística entre a TPA e a Tradição Tupi-Guarani, no entanto, não desqualifica a possibilidade de a TPA estar relacionada a grupos de língua Tupi. Pelo contrário, uma futura confirmação do alto Madeira como local de origem da dispersão dos grupos TPA, um local historicamente ligado a grupos Tupi (MENÉNDEZ, 1981/82), somada ao caráter belicoso dessa dispersão e à sua "ponta de lança" Kokama-Omágua, levará com certeza à conclusão de que a TPA era relacionada, sim, a grupos de língua Tupi.

A ligação estilística entre as cerâmicas da Tradição Tupi-Guarani, da fase Cumancaya, dos Jívaro e das antigas indústrias Pocó/Saladoide ${ }^{141}$ significa, claro, que entre o repertório das antigas cerâmicas Inciso-Pintadas amazônicas havia tigelas policrômicas. No caso Tupi-Guarani, foi sugerido (Capítulo 6) o contato desses grupos com uma das ramificações dos grupos com cerâmicas Inciso-Pintadas, provavelmente em data próxima ao início da era cristã. Se essa hipótese estiver correta, significa que as mais antigas cerâmicas da Tradição Tupi-Guarani não se encontram no alto Ji-Paraná, conforme postulou Miller (2009). É muito provável que, dentre os contatos da suposta rede do alto Madeira, estavam os grupos do alto Ji-Paraná, e é possível que a imensa produção de lâminas de machado (Capítulo 3) que dá nome a esse rio (Ji-Paraná = rio Machado) tinha a ver com isso. Entretanto, a cerâmica da região do rio Ji-Paraná não apresenta a policromia característica da Tradição Tupi-Guarani, e a presença de falantes Tupi-Guarani (Kagwahiva) nessa região data do período colonial.

No baixo Xingu, há presença de policromia na cerâmica da Tradição Tupi-Guarani, com datas relativamente antigas, em regiões não muito distantes (FIGUEIREDO, 1965; GARCIA, 2012a; PEREIRA et al., 2008; SILVEIRA et al., 2012) e uma grande variedade de grupos falantes de Tupi-Guarani. Dessa forma, e com esse possível panorama que coloca a região de entorno do baixo Xingu como centro de origem da dispersão dos Tupi-Guarani em mente, seria de vital importância reconsiderar as datas mais antigas (anteriores ao início da era cristã) obtidas por Silveira (et al., 2008), que poderiam resolver a questão.

A hipótese de que a formação do Estilo (posteriormente Tradição) Tupi-Guarani aconteceu no entorno do baixo rio Xingu (em rituais de cachoeira?) e que esse local pode, assim, estar ligado à dispersão dos grupos Guarani e Tupinambá, possui o atrativo extra de não ser apenas mais um dentro de um histórico de palpites de tupinólogos em busca da glória

\footnotetext{
${ }^{141}$ O que talvez sirva como argumento de que a antiga cerâmica Inciso-Pintada do alto Madeira não pertencia à Tradição Pocó, e sim a uma variante dela, uma vez que a indústria do sítio Teotônio também não possui tigelas policrômicas. Fato inteiramente aceitável se pensado que há uma considerável variabilidade entre as cerâmicas das Tradições Pocó e Saladoide.
} 
de acertar o "local de origem" desse grupos. Trata-se exatamente do local de origem sugerido por um dos primeiros tupinólogos, Karl von den Steinen (1942; cf. NOELLI, 1996a), apenas com uma calibragem do trecho central desse fenômeno (o baixo Xingu, ao invés do alto, como pensara Steinen):

Será, portanto, de importância decisiva para o problema da emigração tupi, saber se nas cabeceiras do Xingu, no Planalto Central, onde mais ou menos se encontra o ponto geográfico central da irradiação tupi, ainda existam tribos tupi. Admitindo que ali ainda elas existam, será necessário saber quais dialetos tupi se aproximam principalmente dessas tribos incólumes de qualquer civilização até hoje, através de sua linguagem, se colocam numa categoria próxima dos primeiros tupinambás, encontrados antigamente pelos descobridores (STEINEN, 1942: 374, grifo nosso).

\subsection{Em Movimento}

Carneiro $(1961,1995)$ apontou para a possibilidade de grandes aldeias sedentárias em áreas de interflúvio, sobrevivendo à base de uma agricultura de coivara (corte e queima). Apesar da viabilidade dessa vida mais sedentária, o autor (1996: 63-64) argumenta pela predisposição ao movimento por parte dos grupos de interflúvio, principalmente devido ao modo de vida caçador que estes grupos mantiveram, mesmo após começarem a cultivar alimentos. Por trás dessas constatações Carneiro realiza uma elegante equalização entre propostas antagônicas. De um lado, encontrava-se a visão ecológica defendida por Meggers (1987, 1998), em que o ambiente amazônico era restritivo quanto ao desenvolvimento de populações humanas. De outro lado, havia uma série de outras interpretações ecológicas, como as de Lathrap e Roosevelt, em que as várzeas amazônicas possuiriam condições quase ilimitadas para o desenvolvimento de sociedades humanas (cf. Capítulo 2).

Essa dicotomia está igualmente presente em um debate quanto aos movimentos de grupos Tupi-Guarani para fora da Amazônia. Por um lado, autores como Meggers (1974, 1977, 1979, 1982), Miller (1983, 2009), e o mais conciliador Schmitz (1991), defenderam que eventos climáticos (como o Optimum Climáticum tão caro a Miller) de contração e expansão da floresta tropical amazônica, teriam levado à migração dos grupos Tupi-Guarani para o sul, sudeste e nordeste brasileiro, a partir do sudoeste amazônico. Por outro lado, autores como Lathrap (1970), Brochado (1984, 1989; BROCHADO e LATHRAP 1982), e Noelli (1993, 1996a, 1998, 2008b), creditavam a dispersão de grupos Tupi-Guarani a 
movimentos de expansão ligados a processos de aumento populacional, partindo da Amazônia Central e gradualmente ocupando as margens dos grandes rios dentro e fora da Amazônia incluindo os rios Madeira, Paraguai e Paraná, assim como o litoral brasileiro e, a partir destes, colonizando áreas de interflúvio. Segundo Noelli, o termo migração "seria mais adequado para definir as movimentações que os mesmos (Tupi-Guarani) realizaram, motivados pela pressão de outros grupos, como por exemplo após 1500, dos europeus" (1996a: 10).

Apesar das evidentes contribuições feitas por Lathrap, Brochado e Noelli - sendo a mais importante delas a retomada de bases etnográficas e etno-históricas para a interpretação dos dados arqueológicos - esses autores acabaram por adotar uma posição demasiadamente antagônica com relação à visão determinista de Meggers e Miller, extrapolando para o lado oposto (ilimitadas possibilidades de processos de desenvolvimento social, econômico e político por parte dos Tupi-Guarani). Entretanto, ao contrário do que ocorreu com o debate pan-amazônico entre Meggers e Lathrap, e depois entre Meggers e Roosevelt, que foi equalizado por autores como Carneiro (1995), Gomes (2008) e Neves (1998, 2008, 2010, 2011, 2012), a arqueologia Tupi-Guarani ainda carece de uma reavaliação dos prós e contras dessas diferentes propostas.

Um dos problemas nas interpretações realizadas por Lathrap, Brochado e Noelli reside no caráter demasiadamente processual, de longa duração, das explanações. Sabe-se que, apesar do know-how em estudos de longa duração ser o grande trunfo para a arqueologia se sentar à mesa da antropologia, essa mesma capacidade pode se tornar uma maldição, à medida que as possibilidades contingenciais, de eventos, são descartadas em prol de explanações ligadas apenas a processos de longa duração (MORRIS, 2000: 5). Como ensinam os múltiplos exemplos de bebedeiras Tupi-Guarani, basta uma discussão trivial durante uma festa para alterar o status quo de uma hora para outra, separando famílias, tornando amigos em inimigos, transformando cunhados em alvos para rituais canibais, levando a mudanças na economia e na política e, é possível, forçando grandes mudanças territoriais.

Tendo em mente questões como a quebra do monopólio da longa duração, é possível contribuir para reestabelecer um equilíbrio epistemológico e avançar dentro de macro discussões sobre os Tupi e os Tupi-Guarani. Até o momento, a maior dessas contribuições é um novo olhar sobre os grupos de interflúvio (ALMEIDA, 2008, GARCIA, 2012a; PEREIRA et al., 2008; MAGALHÃES, 1994; SILVEIRA et al., 2008), assunto bastante 
debatido no presente estudo. Outra questão que avançou muito com os trabalhos de Lathrap, Brochado e Noelli, mas que necessita ser reavaliada,é a da oposição entre migração e expansão.

Conforme apontado, na visão desses autores, a história Tupi-Guarani é uma história de expansão, sendo as migrações muito mais ligadas à catástrofe pós-contato. Ao falar dessas migrações, Noelli se refere aos famosos movimentos messiânicos ocorridos durante os primeiros séculos da colonização europeia (séculos XVI e XVII), realizados por grupos TupiGuarani, em busca da chamada terra sem mal (CLASTRES, 1978; MÉTRAUX, 1979). Nessas ocasiões, muitos grupos Tupi-Guarani teriam sido coagidos por líderes religiosos a fugir dos europeus. Talvez rios tenham sido utilizados, mas a migração Tupinambá entre o Pernambuco e o Maranhão (ABBBEVILLE, 1975 [1614]) e a migração Guarani para o Peru (CLASTRES, 1978: 61; NORDENSKIÖLD, 1917) foram feitas basicamente a pé, por terra. Exemplos de migrações amazônicas dos Tupi-Guarani seriam a discutida (e discutível) viagem dos Tupinambá do litoral para a ilha de Tupinambarana (CYPRIANO, 2007; HERIARTE, 1874; MENÉNDEZ, 1981/82) e a migração dos Waiãpi, do rio Xingu para a região do rio Oiapoque, no atual estado do Amapá (GALLOIS, 1986: 59, 78).

Em todos esses casos, o que chama a atenção é o fato de diferentes grupos, geograficamente distantes (com exceção dos dois exemplos Tupinambá), adotarem a mesma estratégia em face de um eminente colapso: migrar para longe. Tal recorrência não deve ser desprezada e pode ser uma pista para a compreensão desses grupos, ainda mais se levado em consideração o seu modo de vida predador, no qual o "sucesso" de um grupo - ocupação de melhores territórios (BALÉE, 1987) ou captura de mulheres (CLASTRES, 1998) - ocorria, muitas vezes, às custas do infortúnio de outro. Além disso, durante uma longa história de ocupação amazônica, não faltariam concorrentes, Tupi ou não Tupi, levando a tensões que, em momentos agudos e na eminência do colapso, levariam grupos a se fragmentar e/ou migrar, talvez guiados pelo "antídoto cosmológico" que esses Tupi-Guarani possuíam para esses momentos: buscar a terra sem mal.

Um incremento na mobilidade não necessariamente levaria a movimentos de longa distância. Os exemplos etnográficos dos Guajá, dos Urubu-Ka'apor (BALÉE, 1994) e dos Parakanã ocidentais e orientais (FAUSTO, 2001) refletem eventos recentes que com certeza ocorreram também no passado (NEVES, 2012: 68). A etnografia Parakanã é didática inclusive para mostrar que a adoção de uma estratégia mais móvel por parte dos grupos 
orientais lhes forneceu uma vantagem sobre os grupos ocidentais, fazendo que sofressem menos baixas.

Portanto, quando os arqueólogos e linguistas simplesmente não conseguem responder perguntas como "Por onde os Guarani se expandiram na Amazônia?" (o que também vale para os Tupinambá do litoral) ou "Como é possível que os Guarani possuam datas tão próximas aos grupos Tupi-Guarani amazônicos, se estão tão distantes?", talvez seja o caso de cogitar a hipótese da migração. Essa hipótese só pode ser comprovada pela maneira mais difícil, a ausência de outras opções, o que não é alento para os estudiosos, mas serve de estímulo para pesquisas detalhadas.

Além disso, outro benefício de pensar que curtos momentos de migração podem ter intercalado longos momentos de expansão é que esse viés ajuda a compreender questões como a do porquê do sucesso expansivo dos Tupinambá do litoral e dos Guarani frente aos Tupinambá da Amazônia e dos demais grupos Tupi, mesmo esses grupos possuindo modos de vida tão semelhantes. Se são tão semelhantes dos demais, a razão do sucesso dos Tupinambá do litoral e dos Guarani deve estar ligado a um processo de deriva, uma descolagem dos demais grupos a partir de uma ou mais migrações. Descolados para regiões nas quais os habitantes possuem modos de vida distintos, como os sambaquieiros do litoral sul-sudeste brasileiro, os migrantes Tupi-Guarani teriam se beneficiado de um processo de seleção natural (para manter a terminologia darwinista), se beneficiando (entre outros) das terras férteis do sul e sudeste para cultivar grandes plantações e, portanto, fazer grandes festas e grandes bebedeiras. Sem a pressão de pares amazônicos, tendo que lidar apenas com grupos que não estavam preparados para lidar com grupos "predadores" (que chegaram "de repente"), os Tupi-Guarani finalmente passaram a executar os processos expansivos tão caros às propostas de Lathrap, Brochado e Noelli. Além disso, outra probabilidade é que a própria separação dos Tupi-Guarani do antigo núcleo Tupi da bacia do alto rio Madeira também tenha ocorrido em decorrência de uma migração ou de um processo de deriva.

Esse viés interpretativo serve para desmontar de vez a caracterização feita por Noelli (1993; 1999-2000: 247), de que os Guarani (como os demais Tupi-Guarani) seriam sociedades prescritivas, avessas a mudanças (cf. NEUMANN, 2008). Foi observada uma série de exemplos (Capítulos 2 e 3) de grupos Tupi ou Tupi-Guarani que "imitaram" o padrão de casas de seus vizinhos (indígenas ou não). A partir do contexto do sudeste amazônico, foi possível observar uma série de influências dos grupos Inciso-Modelados nas cerâmicas Tupi 
(e.g. GARCIA, 2012a; SIMÕES e ARAÚJO COSTA, 1987; Capítulo 2). Nessa região, também é possível citar o contexto etnográfico do alto Xingu, com a adoção de elementos Arawak pelos Tupi-Guarani (HECKENBERGER, 2002, 2005, 2010, 2011). Também no sudeste amazônico, foi sugerido que grupos Tupi-Guarani teriam se apropriado de elementos estilísticos de portadores de antigas cerâmicas Inciso-Pintadas (antigos falantes de Arawak?), na constituição do que viria a ser conhecido como Tradição Tupi-Guarani. É possível que um evento análogo tenha ocorrido no alto Madeira, com grupos Tupi se apropriando de elementos estilísticos de (outras) antigas cerâmicas Inciso-Pintadas, na constituição do que viria a ser conhecido como Tradição Polícroma da Amazônia. Portanto, mesmo que nem todas essas hipóteses se concretizem em futuros estudos, é possível ter certeza de que, mesmo que os diversos grupos Tupi não tenham mudado incessantemente através do tempo, eles tampouco eram grupos prescritivos.

A razão para a baixa variabilidade das Subtradições Guarani e Tupinambá do litoral é a mesma que tornou possível o sucesso expansivo desses grupos: a deriva. Em geral isolados de grupos com modos de vida semelhantes (canibais, guerreiros, cervejeiros), os Tupinambá e Guarani não tiveram alternativa a não ser se voltar para si próprios (quem se interessaria em ir a uma abstêmia festa Jê?), fortalecendo as estruturas estruturantes, tendo menos possibilidades de mudar por não ter com quem beber. 


\section{CONCLUSÃO}

Nesta pesquisa de doutorado, foram analisados cinco sítios arqueológicos localizados na região do alto rio Madeira e do baixo Jamari. A partir dessa análise, centrada em especial nos fragmentos cerâmicos, foi possível inferir que:

(I) A antiga cronologia para a Subtradição Jatuarana, pertencente à Tradição Polícroma da Amazônia (TPA), de 700 a.C. (MILLER, 1992), não se sustenta. Essa data está provavelmente relacionada a grupos pré-cerâmicos que habitaram o sítio Teotônio desde pelo menos 1120 a.C.;

(II) A partir dos dados provenientes do sítio Nova Vida e de uma camada com cerâmica profunda do sítio Teotônio, o alto Madeira, entre 200 d.C. (Nova Vida) e 400 d.C. (Teotônio), era habitado por grupos que produziam uma cerâmica com formas simples (sem ângulos), decorada apenas com elementos plásticos (e.g. incisões);

(III) Foi só a partir da segunda metade do primeiro milênio d.C. que grupos produtores de cerâmica policrômica surgiram na região. Esses grupos se fixaram, entre outros locais, no complexo do Teotônio, formado pelo sítio e pela cachoeira homônimos e pelo sítio Santa Paula, localizado na margem oposta (esquerda) do rio. Entretanto, não se tratam de grupos produtores de cerâmica TPA, e sim de antigos grupos produtores de cerâmica Inciso-Pintada, talvez relacionados à Tradição Pocó, encontrada no rio Amazonas, e à Tradição Saladoide, encontrada no rio Orinoco. Essa inferência baseou-se na grande variabilidade da cerâmica do sítio Teotônio em comparação com os sítios TPA do alto Madeira e da Amazônia central;

(IV) Os grupos produtores de cerâmica Inciso-Pintada, possivelmente antigos falantes de línguas Arawak, estabeleceram um núcleo na região das cachoeiras de jusante do rio Madeira (Teotônio e Santo Antônio), criando uma rede de contatos com os grupos de entorno e assumindo o papel de principal entroncamento dela: uma provável rede multi-étnica. Tal inferência baseou-se no fato de o sítio Teotônio possuir uma significativa quantidade de semelhanças e diferenças estilísticas com relação aos demais sítios estudados na região; 
(V) Os elementos estilísticos que caracterizariam a Subtradição Jatuarana no alto Madeira, e posteriormente a TPA na Amazônia ocidental, seriam provenientes do contato de (alguns dos) grupos autóctones, talvez falantes de línguas Tupi, com essa rede de contatos da região das cachoeiras. Após incorporados os elementos estilísticos (e.g. cerâmica policrômica e técnicas/tecnologias mais sofisticadas de navegação fluvial) dos grupos Inciso-Ponteados do entroncamento, e após mesclar tais elementos a um modo de vida belicoso (que caracteriza tanto os Tupi quanto a maioria dos grupos de terra firme apresentados no texto), os produtores de cerâmica TPA se dispersariam (expandindo e migrando) pelo médio e baixo Madeira e por todo o rio Solimões. Se essa hipótese estiver correta, o processo de contato e transformação estilística dos grupos locais teria de haver ocorrido antes de 700 d.C. para se encaixar no quadro cronológico para a TPA do rio Solimões;

(VI) Os sítios Itapirema e Associação Calderita fazem parte da TPA, Subtradição Jatuarana. Essa inferência provém da grande quantidade de semelhanças entre os elementos cerâmicos desses sítios e os da Amazônia central e do alto Amazonas. O sítio Associação Calderita possui datas entre 1100 e 1350 d.C. e teria sido ocupado duas vezes pelo mesmo grupo. O Itapirema possui datas entre 1300 e 1400 d.C. e foi provavelmente ocupado uma única vez durante o período pré-colonial. Análises estatísticas contribuíram para confirmar a homogeneidade espacial desse sítio, que possui uma extensão aproximada de $1 \mathrm{~km}$;

(VII) O sítio Jacarezinho faz parte da Tradição Jamari. Tal inferência é resultado da comparação dos elementos cerâmicos desse sítio com os sítios da Tradição Jamari, encontrados no médio curso do rio homônimo. Esse sítio foi ocupado duas vezes pelo mesmo grupo e possui datas entre 1100 e 1300 d.C., consolidando um período intermediário dessa Tradição, que possui datas entre 500 a.C. e 1700 d.C.;

(VIII) A Tradição Jamari não faz parte da Tradição Polícroma da Amazônia. Essa inferência foi baseada especialmente na análise do sítio Jacarezinho e na visita a sítios analisados por Miller (et al. 1992) no médio Jamari. O material policrômico encontrado na Tradição Jamari provém da provável participação dos produtores da cerâmica dessa Tradição na rede de contatos do alto Madeira. Por outro lado, foi sugerida a presença de uma possível buffer zone separando os grupos da Tradição Jamari e da Subtradição Jatuarana (TPA). O que ocorreu ao mesmo tempo em que a presença do sítio Jacarezinho nas proximidades do rio Madeira (baixo Jamari) sugere 
rompimentos temporários dessa buffer zone. Dados que podem significar momentos alternados de proximidade e distância entre os grupos da drenagem principal (rio Madeira) e da drenagem secundária (rio Jamari);

(IX) A hipótese de Miller (2009), que liga a Tradição Jamari aos falantes de línguas da família Tupi-Arikém, continua sendo uma possibilidade a ser trabalhada. Não foi possível avançar muito nesse ponto, mas foi sugerido que as diferenças técnicoestilísticas entre a cerâmica do médio-baixo Jamari e do médio Jamari talvez representem os grupos Arikém e Karitiana, respectivamente.

A partir da análise da bibliografia arqueológica, etnográfica, etno-histórica e linguística dos rios Guaporé e Ji-Paraná, também pertencentes à bacia do alto rio Madeira, foi possível inferir que:

(I) No período pré-colonial, talvez tenha havido na região de entorno do rio Guaporé outros núcleos de redes de contato (multi-étnicos). Existe ainda hoje uma imensa diversidade linguística na área e evidências materiais (cestas de maricos) de resquícios dessas redes. A semelhança de algumas formas cerâmicas até recentemente utilizadas pelos Tupari (língua Tupi-Tupari) com as formas da fase Corumbiara, que possui decorações plásticas ausentes na cerâmica Tupari, talvez seja um outro indício dessa rede do rio Guaporé. A presença de grupos de língua Arawak (e de cerâmica Inciso-Modelada), conhecidos antropologicamente por um caráter (ethos) de intermediador de relações com outros grupos (de outras línguas ou não), seria o último elemento para argumentar a favor dessa hipótese;

(II) A ausência de diferenças entre as fases Corumbiara e Pimenteira sugere que a fase Pimenteira não exista. Essa fase foi criada por Miller (1983) com o intuito de vinculála a uma antiga presença de grupos Guarani na região. Entretanto, estudos linguísticos e etno-históricos indicam que essa presença Guarani seria decorrente de movimentações desses grupos durante o período colonial;

(III) A hipótese de Miller (2009) de que a área do médio e alto rio Ji-Paraná é chave para a compreensão da história dos grupos Tupi continua consistente. As datas com mais de 2000 a.C. para cerâmicas corrugadas na região são o elemento que mais contribui para essa hipótese. Entretanto, essa região não possui elementos técnicoestilísticos ou etno-históricos que permitam ligar essa cerâmica mais especificamente 
aos grupos Tupi-Guarani, como sugeriu Miller. Essa antiga cerâmica corrugada talvez esteja ligada a outros grupos Tupi da região (e.g. os Tupi-Maué).

Foi realizada uma análise bibliográfica da arqueologia, etno-história, etnografia e linguística dos rios Tapajós, Xingu e Tocantins. O rio Tocantins também contou com os dados outrora produzidos pelo presente pesquisador, assim como de novas análises do material da fase Tauá, supostamente ligada à Tradição Polícroma da Amazônia. A partir desse conjunto de análises, foi possível inferir que:

(I) Grupos de língua Tupi-Guarani, produtores de cerâmica pertencente à Subtradição Tupinambá da Amazônia, ocuparam extensas áreas entre esses rios e nas suas margens. A cronologia mais antiga para esses grupos está no interflúvio XinguTocantins, com datas que chegam a 200 d.C. Entretanto, existem datas (e.g. SILVEIRA et al., 2008) que podem recuar essa ocupação para alguns séculos a.C.;

(II) Assim como os grupos de língua Pano da Amazônia ocidental, os grupos TupiGuarani e muitos dos demais Tupi parecem ter estabelecido redes de contato perpendiculares às grandes drenagens amazônicas;

(III) A imensa variabilidade material encontrada na região das cachoeiras do baixo Xingu sugere que essa região também pode ter sido um entroncamento de redes de contato entre grupos indígenas no período pré-colonial. Da mesma forma como foi sugerido para o surgimento da TPA, especulou-se que seria a partir de uma rede de contatos (nesse caso, do baixo Xingu), também orquestrada por grupos com cerâmica Inciso-Pintada (Arawak?), que os Tupi-Guarani teriam adquirido uma série de elementos estilísticos que caracterizariam a grande Tradição Tupi-Guarani. A presença de tigelas policrômicas na Tradição Tupi-Guarani e a ausência dessas tigelas na cerâmica da maioria dos demais Tupi seriam indícios desse contato dos TupiGuarani com redes fluviais de grupos fluviais. Esse processo possuiria um correlato no alto Amazonas, onde alguns grupos Pano (e.g. os Shipibo e os Conibo) adquiram elementos dessa antiga cerâmica Inciso-Pintada (que também teriam formado um entroncamento nessa região), enquanto outros grupos Pano (dos interflúvios) permaneceriam com uma cerâmica menos elaborada (e.g. sem policromia);

(IV) Um dos possíveis desdobramentos dessa rede de contatos seria o descolamento dos Yudjá-Juruna dos demais Tupi-Guarani, que levariam consigo, em sua dispersão 
(expansão, migração?) pelo baixo Amazonas, uma cerâmica híbrida, com elementos modelados e formas e pinturas semelhantes às da Tradição Tupi-Guarani. Essa mistura estilística possuiria correlação linguística, levando à diferenciação entre as famílias Juruna e Tupi-Guarani;

(V) Outro possível desdobramento dessa rede de contatos do baixo Xingu seria a dispersão (migração?) dos grupos Guarani e de grupos Tupinambá para fora da Amazônia, levando à expansão desses grupos (beneficiados pela deriva) por vastas áreas da América do Sul. A grande variabilidade técnico-estilística e linguística dos Tupi-Guarani do sudeste da Amazônia (identificada por von den Steinen já no séc. XIX) é o maior indício de que ocorreram processos e eventos decisivos na história desses grupos nessa região;

(VI) As novas análises do material da fase Tauá apontam que essa fase, de maneira semelhante ao que foi visto com a cerâmica etnográfica dos Yudjá-Juruna, possui elementos da Subtradição Tupinambá da Amazônia, de antigas Tradições IncisoModeladas do leste da região e alguns elementos da fase Marajoara. O que sugere que essa cerâmica não pode ser inserida na Tradição Polícroma da Amazônia, contradizendo Meggers et al. (1987).

Por fim, a partir desse conjunto de inferências, pode-se chegar às seguintes conclusões:

(I) O alto Madeira continua sendo o provável centro de dispersão dos grupos TPA. Entretanto, essa dispersão seria recente, a partir da segunda metade do primeiro milênio d.C.;

(II) As Subtradições Tupinambá (do litoral) e Guarani não são Subtradições da TPA. Assim como a Subtradição Tupinambá da Amazônia, são fenômenos paralelos e mais antigos que a TPA;

(III) Essa conclusão não desqualifica a relação entre a TPA e os grupos de língua Tupi. Pelo contrário, o suposto local de origem da dispersão (alto Madeira) e o seu caráter belicoso - e não os elementos técnico-estilísticos dessa cerâmica - são os principais indícios de que essa relação existe; 
(IV) Parece haver uma coerência muito maior dentro da TPA na Amazônia ocidental do que na Amazônia oriental. A desqualificação da fase Tauá como pertencente à TPA (no baixo Tocantins) foi a maior contribuição do presente estudo para essa questão, sugerindo que Neves (2012) pode estar certo ao defender a exclusão dos grupos orientais (fases Marajoara, Aristé, Tauá, Idenpendência etc.) da TPA;

(V) As cachoeiras são áreas-chave para a compreensão do período pré-colonial da Amazônia. Tratam-se de lugares que durante milênios foram ocupados de maneira persistente por grupos indígenas, que transformaram tais lugares (entre outros) em entroncamentos de redes de contato. Essas cachoeiras vêm sistematicamente desaparecendo em razão da política energética (voltada para a construção de hidrelétricas) em voga no Brasil, sem a devida consideração sobre o valor histórico que tais lugares possuem. Uma perda irreparável em nome do progresso. 


\section{BIBLIOGRAFIA}

AB'SABER, A.N.

2004 Amazônia: do Discurso a Práxis. São Paulo: Edusp.

ABBEVILLE, C. d'

1975 [1614] História da Missão dos Padres Capuchinhos na Ilha do Maranhão e Terras Circunvizinhas. Belo Horizonte/São Paulo: Itatiaia/Edusp.

ACUÑA, C. de

1994 [1641] Novo Descobrimento do Grande Rio das Amazonas. Rio de Janeiro: Agir.

ADAMS, W.Y.; ADAMS, E.W.

1991 Archaeological Typology and Practical Reality: a dialectical approach to the artifact classification sorting. Cambridge: Cambridge University Press.

ALMEIDA, C.M.

1860 Memórias para a História do Extinto Estado do Maranhão. Rio de Janeiro: Typ. do Comércio, de Brito e Braga.

ALMEIDA, F.O.

2008 O Complexo Tupi da Amazônica Oriental. Dissertação de Mestrado, MAE-USP..

2010a Escrevendo um Capítulo da História Cultural Tupinamá através da variabilidade cerâmica. Bolem Técnico da Fundação Casa da Cultura de Marabá, 5: 41-55.

2010b As Expansões Tupinambá no Sul da Bacia do Amazonas. Primeiro Relatório Anual FAPESP (Processo 2008/58419-9). São Paulo.

2010c Ocupações Pré-Coloniais na Bacia do Alto rio Madeira. Relatório para Qualificação de Doutorado. MAE-USP.

2011 As Expansões Tupinambá no Sul da Bacia do Amazonas. Segundo Relatório Anual FAPESP (Processo 2008/58419-9). São Paulo.

2013 Cerâmica Antiga na Periferia Leste da Amazônia. Manuscrito aceito para publicação, Amazônica - Revista de Antropologia.

ALMEIDA, F.O.; GARCIA, L.G.

2008 Aspectos do Espaço Tupinambá. Revista de Arqueologia, 21(2): 97-119.

ALMEIDA, F.O.; NEVES, E.G.

(manuscrito não publicado) A Hemorragia Tupinambá.

AMOROSO, M.R.

1994 Documentos de Henrique João Wilkens: introdução. In Relatos da Fronteira Amazônica no século XVIII: Alexandre Rodrigues Ferreira / Henrique João Wilkes. AMOROSO, M.R.; FARAGE, N. (Org.). São Paulo: NHIII/USP-FAPESP.

ANDRADE, L. 
1992 A Marca dos Tempos: Identidade, Estrutura e Mudança entre os Asuriní do Trocará. In Grafismo Indígena, Estudos de antropologia Estética. VIDAL, L. B. (org.), Nobel, São Paulo, p. 117-132.

ARAUJO, A.G.M .

1995 Peças que descem, peças que sobem e o fim de Pompéia: algumas observações sobre a natureza flexível do registro arqueológico. Revista do Museu de Arqueologia e Etnologia, 5: $3-25$.

ARAUJO-COSTA, F.

1978 Relatório Preliminar - 3a Parte: Pesquisa Arqueológica no Baixo Rio Tocantins (PA). Belém, Museu Paraense Emílio Goeldi.

ARNOLD, D.E.

1997 Ceramic Theory and Cultural Process. Cambridge: Cambridge University Press.

ARROYO-KALIN, M.

2008 Steps Towards an Ecology of Landscape: A Geoarchaeological Approach to the Study of Anthropogenic Dark Earths in the Central Amazon Region, Brazil. PhD Dissertation, University of Cambridge.

2010 Origin and Domestication of Native Amazonian Crops. Diversity, 2: 72-106.

2012 Slash-burn-and-churn: Landscape history and crop cultivation in pre-Columbian Amazonia. Quaternary International, 249: 4-18.

ASSIS, V.S.

1996 Da Espacialidade Tupinambá. Dissertação de Mestrado, PUC-RS.

AZEREDO, A.C.

2011 A Variabilidade da Cerâmica Arqueológica da Tradição Polícroma Amazônica: um estudo de caso entre um sítio do Alto Madeira e um sítio da Amazônia Central. Relatório (Final) FAPESP de Iniciação Científica. São Paulo, MAE-USP.

AZEVEDO, I.L.

1999 Grão Pará: suas missões e a colonização. Belém: Secult

BALDUS, $\mathrm{H}$.

1970 Tapirapé: Tribo Tupi do Brasil Central. São Paulo: Brasiliana-Editora Nacional/EDUSP.

BALÉE, W.

1987 The Ecology of Ancient Tupi Warfare. In Warfare, Culture and Environment. FERGUSON, R.B. (Ed.). Orlando: Academic Press, pp. 241-265.

1994 Footprints of the Forest: Ka'apor Ethnobotany - the historical ecology of plant domestication by an Amazonian people. New York: Columbia University Press.

1995 Historical Ecology of Amazonia. In Indigenous Peoples and the Future of Amazonia: an Ecological Anthropology of an Endagered World. SPONSEL, L. (Ed.). Tucson \& London: Tucson Arizona Press, pp. 97-110.

BALLÉE, W.; ERICKSON, C. 
2006 Time, Complexity and Historical Ecology. In Time and Complexity in Historical Ecology. BALÉE, W.; ERICKSON, C. (Eds.). New York: Columbia University Press, pp. 120.

BALÉE, W.; MOORE, D.

1994 Language, Culture, and Environment: Tupi-Guarani Plant Names Over Time. In Amazonian Indians: from prehistory to present. ROOSEVELT, A. (Ed.). Tucson: University of Arizona Press, pp. 363-380.

BANDEIRA, A.M.

2008 Ocupações Humanas Pré-Históricas no Litoral Maranhense: um estudo de caso sobre o sambaqui Bacanga na ilha de São Luis - Maranhão. Dissertação de Mestrado, MAE-USP.

2010 Ocupações Pré-Históricas de Pescadores-Coletores-Caçadores e Ceramistas no Litoral Equatorial Amazônico: a antiguidade cerâmica em foco. In Arqueologia Amazônica 2. PEREIRA, E. e GUAPINDAIA, V. (Eds.). Belém: MPEG, pp. 147-172.

BARCELOS NETO, A.

2008 Apapaatai: rituais de máscaras no alto Xingu. São Paulo: FAPESP/EDUSP.

BARKER, G.

2006 The agricultural revolution in Prehistory: Why did Foragers become farmers? Oxford: Oxford University Press.

BARRETO, C.N.G.B.

2008 Meios Místicos de Reprodução Social: Arte e Estilo na Cerâmica Funerária da Amazônia Antiga. Tese de Doutorado, MAE-USP.

2010 Cerâmica e Complexidade Social na Amazônia Antiga: uma perspectiva a partir de Marajó. In Arqueologia Amazônica 1. PEREIRA, E.; GUAPINDAIA, V. (Eds.). Belém: MPEG; IPHAN; SECULT, pp. 193-212.

BARROSO, L.P.; MESSIAS, R.M.; PU, J.

2012 Relatório de análise estatística sobre o projeto: “A Expansão Tpinambá ao Sul da Bacia do Amazonas". São Paulo. IME-USP.

BARTON, C.M.; BERNABEU, J.; AURA, J.E.; GARCIA, O.; SCHMICH, S.; MOLINA, L.

2004 Long Term Sociology and Contingent Landscapes. Journal of Archaeological Method and Theory, 11: 253-295.

BATES, H.W.

2009 [1873] The Naturalist on the River Amazon. Cambridge: Cambridge University Press.

BELL, M.; WALKER, M.

1992 Late Quaternary Environmental Change: Physical and Human Perspectives. Longman Scientific \& Tecnical.

BETENDORF, J.F.

1910 [1698] Crônica da Missão dos Padres da Companhia de Jesus no Estado do Maranhão. Rio de Janeiro.

BINFORD, L.R. 
1981 Behavioral Archaeology and the "Pompeii Premise". Journal of Anthropological Research, 37(3): 195-208.

BLACK M. J.; BEWLEY J.D.; HALMER P. (Eds.)

2006 The Encyclopedia of Seeds: Science, Technology and Uses. United Kingdom: CABI Publishing.

BOLIAN, C.E.

1975 Archaeological Excavations in the Trapecio of Amazonas: the Polychrome Tradition. $\mathrm{PhD}$ Dissertation. University of Illinois at Urbana Champain.

BOURDIEU, P.

1977 Outline of a Theory of Practice. Cambridge: Cambridge University Press.

1989 Social Space and Symbolic Power. Sociological Theory, 7(1) : 14-25.

1990 The Logic of Practice. Stanford: Stanford University Press.

BOWSER, B.J.

2002 The Perceptive Potter: an Ethnographical Study of Pottery, Ethnicity, and Political Action in Amazonia. PhD Dissertation. University of California, Santa Barbara.

BOWSER, B.J.; PATTON, J.Q.

2008 Learning and the Transmission of Pottery Style. In Cultural Transmission and Material Culture. STARK, M.; BOWSER, B.J, HORNE, L. (Eds.). Tucson: University of Arizona Press, pp. 105-129.

BRAIDWOOD, R.J. (Symposium Org.)

1953 Did Man Once Live By Beer Alone ? American Antropologist, 55: 515-534.

BROCHADO, J.P.

1984 An Ecological Model of the Spread of Pottery and Agriculture into Eastern South America. PhD Dissertation: University of Illinois at Urbana Champain.

1989 A Expansão dos Tupi e da Cerâmica da Tradição Polícroma Amazônica. Dédalo: 65-82.

1991 What did the Tupinambá Cook in their Vessels? A Humble Contribution to Ethnographic Analogy. Revista de Arqueologia, 6: 40-88.

BROCHADO, J.P.; LATHRAP, D.W.

1982 Chronologies in the New World. Manuscrito não-publicado.

BROCHADO, J.P.; MONTICELLI, G.; NEUMANN, E.S.

1990 Analogia Etnográfica na Reconstrução gráfica das Vasilhas Guarani Arqueológicas. Veritas, 35 (140): 727-743.

BROTHWELL D. R.; POLLARD A. M. (Eds.)

2001 Handbook of Archaeological Sciences. Chichister: John Wiley and Sons.

BRUNELLI, G.

1986 Warfare in the Polonoroeste: Indigenous Peoples Fight to Save Their Lands. Cultural Survival Quarterly, 10 (2) : 37-40.

BUARQUE, A. 
2010 As estruturas funerárias das aldeias Tupinambá da região de Araruama, RJ. In $O s$ Ceramistas Tupiguarani, volume III - eixos temáticos. PROUS, A.; LIMA, T.A. (Orgs.). Belo Horizonte: Superintendência do Iphan de Minas Gerais, pp. 179-172.

BUARQUE, A., RODRIGUES-CARVALHO, C.; SILVA E.C.

2003 Programa funerário dos Tupinambá em Araruama, RJ-Sítio Bananeiras. Revista do MAE, 13: 39-55.

BUARQUE-DE-HOLLANDA, S.

1994 Caminhos e Fronteiras. São Paulo: Companhia das Letras.

BUSSAB, W.O; MORETTIN, P.A.

2011 Estatísitca Básica. São Paulo: Saraiva.

BUSSAB, W.O; MIAZAKI, E.S.; ANDRADE, D.F.

1990 Introdução à Análise de Agrupamentos. $9^{\circ}$ Simpõsio Nacional de Probabilidade e Estatística, Associação Brasileira de Estatística.

CABRAL, A.S.

1995 Contact Induced Language Change in the Western Amazon: The Non-Genetic Origin of the Kokama Language. PhD Dissertation. University of Pittsburgh.

CABRAL, A.S.; RODRIGUES, A.d'.

2003Evidências de crioulização abrupta em Kokáma? Papia, 13: 180-186.

CALHOUN, C.

2011 For the Social History of the Present: Bourdieu as Historical Sociologist. In Bourdieu, Theory and Historical Sociology. GORSKI, P. (Ed.). Durham: Duke University Press.

CARDIN, F.

2009 Tratado da Terra e Gente do Brasil. São Paulo: Hedra.

CARNEIRO, R.L

1961 Slash-and-Burn Cultivation among the Kuikuru and its Implications for Cultural Development in Amazon Basin. In The Evolution of Cultural Systems in Native South America: causes and consequences, a symposium. WILBERT, J. (Ed.). Antropologica, supplement Publication, 2. Caracas: Sociedad de Ciencias Naturales La Salle, pp. 47-67.

1995 The History of Ecological Interpretations of Amazonia: does Roosevelt have it right? In Indigenous Peoples and the Future of Amazonia: an Ecological Anthropology of an Endagered World. SPONSEL, L. (Ed.). Tucson \& London: Tucson Arizona Press, pp. 45-70.

CASPAR, F.

1953 Tupari: unter índios im urwald brasiliens friedr. Viewg \& Sohn: Brauschweig.

1958 Tupari: entre os índios nas florestas brasileiras. Melhoramentos.

CASTRO, T.P.

2012. Djeoromitxí: Notes on Phonology and Simple Noun Phrase Structure. Master of Arts Dissertation, University of Texas, Austin.

CHAPELLE, R. 
1982 Os Índios Cintas-Largas. São Paulo: Itatiaia/Edusp.

CHERNELA, J.

2008 Translating Ideologies: tangible meaning and spatial politics in the northwest Amazonia of Brazil. In Cultural Transmission and Material Culture. STARK, M.; BOWSER, B.J, HORNE, L. (Eds.). Tucson: University of Arizona Press, pp. 130-149.

CHILDS, S.T.

1991 Style, Technology and Iron Smelting Furnaces in Bantu-Speaking Africa. Journal of Anthropological Archaeology, 10: 332-359.

CHILTON, E.S.

1998 The Cultural Origins of Technical Choice: Unraveling Algonquinan and Iroquian Traditions in the Northeast. In The Archaeology of Social Boundaries. STARK, M.T. (Ed.). Washington: Smithsonian Institution Press, pp. 132-160.

CHMYZ, I. (ed.)

1976 [1966] Terminologia Arqueológica Brasileira para Cerâmica. Universidade Federal do Paraná, Cadernos de Arqueologia, 1: 121-147.

CLARK, D.L.

1978 Analytical Archaeology. New York: Columbia University Press.

CLASTRES, $\mathrm{H}$.

1978 Terra Sem Mal. São Paulo: Brasiliense.

CLASTRES, P.

1998 Chronicle of the Guayaki Indians. London: Faber and Faber.

2003 A Sociedade Contra o Estado: pesquisas de antropologia política. São Paulo: Cosac \& Naify.

CLEMENT, C.R.

1999a 1492 and the Loss of Amazonian Crop Genetic Resources in the relation between domestication and human population decline. Economic Botany 53(2): 188-202.

1999b 1492 and the Loss of Amazonian Crop Genetic Resources II: crop biogeography at contact. Economic Botany 53(2): 203-216.

2006 Domesticação de paisagens e plantas amazônicas: a interação de etnobotânica, genética moleculare arqueologia. In Pueblos, plantas y paisajes Antiguos en la selva tropical amazónica. MORCOTE, G.; MORA, S.; FRANKY, C. (Eds.). Bogotá: Editorial Universidad Nacional, pp. 97-112.

CLEMENT, C.R.; CRISTO-ARAÚJO, M.; EeCKENBRUGGE, G.C.; PEREIRA, A.A.; PICANÇO-RODRIGUES, D.

2010 Origin and Domestication of Native Amazonian Crops. Diversity, 2: 72-106.

CODREAU, H.A.

2009 [1897] Voyage au Xingú. Cambridge: Cambridge University Press.

COELHO, E.M.B.

1990 A Política Indigenista no Maranhão Provincial. São Luis: Sioge. 
COIMBRA Jr., C.A.; FLOWERS, N.M.; SALZANO, F.; SANTOS, R.V.

2004 The Xavanté in Transitio: health, ecology, and bioanthropology in Central Brazil. Ann Arbor: University of Michigan Press.

CORMARK, R.M.

1971 A Review of Classification. Journal of Royal Statistical Society, 134: 321-353.

CORRÊA, A.A.

2009 Tetama nas Matas Mineiras: Sítios Tupi na Microrregião de Juiz de Fora - MG. Dissertação de Mestrado, MAE-USP.

COSTA, B.L.

2012 Levantamento Arqueológico na Reserva de Desenvolvimento Sustentável Amanã Estado do Amazonas. Dissertação de Mestrado, MAE-USP.

CPRM

2005 Mapa Geológico de Influência Direta do Santo Antônio. (escala 1:100.000).

2007 Mapa Geológico e de Recursos Minerais do Estado de Rondônia (escala 1:1.000.000).

CREVELS, M.; VAN DER VOORT, $\mathrm{H}$.

2008 The Guaporé-Mamoré as a Linguistic Area. In From Linguistic Areas do Areal Linguistics. MUYSKEN, P. (Ed.). Amsterdam/Philadelphia: John Benjamins Public Company, pp. 151-180.

CRUXENT, J.M.; ROUSE, I.

1959 An Archaeological Chronology of Venezuela. Washington D.C.: Pan America Union.

CRUZ, D.

2008 Lar Doce Lar? Arqueologia Tupi na bacia do Ji-Paraná (RO). Dissertação de Mestrado, MAE-USP.

CUNHA, M.C.; VIVEIROS DE CASTRO, E.B.

2009 Vingança e Temporalidade: os Tupinambá. In Cultura com Aspas. CUNHA, M.C. São Paulo: Cosacnaify.

CYPRIANO, D.A.C.A.

2007 Almas, Corpos e Especiarias: a expansão colonial nos rio Tapajós e Madeira. Pesquisas - Antropologia, 65: 1-170.

DAL POZ, J.

1991 No País dos Cinta-Largas: uma etnologia do ritual. Dissertação de Mestrado, FFLCHUSP.

1993 Homens, Animais e Inimigos: simetrias entre mito e rito nos Cinta Larga. Revista de Antropologia, 36: 177-205.

2004 Dádivas e Dívidas na Amazônia: parentesco, economia, e ritual entre os Cinta-Larga. Tese de Doutorado, IFCH-UNICAMP.

DANIEL, J. 
1976 Tesouro Descoberto no rio Amazonas. Separata dos Anais da Biblioteca Nacional, 95. Rio de Janeiro: Biblioteca Nacional.

DANTAS, M.E.; ADAMY, A.

2010 Compartimentação Geomorfológica. In Geodiversidade do Estado de Rondônia. ADAMY, A. (Ed.). Porto Velho: CPRM.

DeBOER, W.R.

1981 Buffer Zones in Cultural Ecology of Aboriginal Amazonia: an Ethnoarchaeological Approach. American Antiquity 46(2): 364-377.

1990 Interaction, Imitation, and Communication as Expressed in Style: The Ucayali Experience. In Uses of Style in Archaeology. CONKEY M.W. \& HASTORF C.A.(Eds). Cambridge: Cambridge University Press, p. 82-104.

1991 The decorative Burden: design, medium, and change. In Ceramic Ethnoarchaeology. LONGACRE, W. (Ed.). Tucson: University of Tucson Press, pp. 144-161.

2001 The Big Drink: feast and forum in the upper Amazon. In Feasts: archaeological and ethnographical perspectives on food, politics and power. DIETLER, M.; HAYDEN, B. (Eds.). Tuscaloosa: University of Alabama Press, pp. 215-239.

DeBOER, W.R.; LATHRAP, D.W.

1979 The Making and Breaking of Shipibo-Conibo Ceramics. In Ethnoarchaeology: implications of Ethnography for Archaeology. KRAMER, C. (Ed.). New York: Columbia University Press, pp. 102-138.

DEGOY, L.

2008 Technical Traditions and Cultural Identity: an ethnoarchaeological study of Andhara Pradesh potters. In Cultural Transmission and Material Culture. STARK, M.; BOWSER, B.J, HORNE, L. (Eds.). Tucson: University of Arizona Press, pp. 199-222.

DENEVAN W.M.

1966 The Aboriginal Cultural Geography of the Llanos de Mojos of Bolivia. Ibero Americana, 48. Berkley: University of California Press.

2001 Cultivated Landscapesof Native Amazonia and the Andes. Oxford: Oxford University Press.

2006 Pre-European Forest Cultivation in Amazonia. In Time and Complexity in Historical Ecology: studies in the neotropical lowlands. BALÉE, W.; ERICKSON, C. (Eds.). Columbia University Press: New York, pp. 57-86.

DIAS A.S.; SILVA. F. A.

2001 Sistema Tecnológico e Estilo: as implicações desta interrelação no estudo das indústrias líticas do sul do Brasil. Revista do MAE, 11: 95-108.

DIETLER M.

2001 Theorizing the Feast: rituals of consumption, commensal politics, and power in African contexts. In Feasts: archaeological and ethnographical perspectives on food, politics and power. DIETLER, M.; HAYDEN, B. (Eds.). Tuscaloosa: University of Alabama Press, pp. $65-114$.

DIETLER M.; HERBICH I. 
1998 Habitus, Techniques and Style: an integrated approach to social understanding of material culture and boundaries. In The Archaeology of Social Boundaries. STARK, M.T. (Ed.). Washington: Smithsonian Institution Press, pp. 232-263.

DOUGLAS, $\mathrm{M}$.

1987 A distinctive anthropological perspective. In Constructive Drinking: Perspectives on Drink from Antropology. DOUGLAS, M. (Ed.). Cambridge: Cambridge University Press, pp. 3-15.

DUNNEL, R.C.

2007 Classificação em Arqueologia. São Paulo: Edusp.

ERICKSON, C.L.

2003 Historical Ecology and Future Explorations. In Amazonian Dark Earths: Origins, Properties, Management. LEHMANN, J.; KERN, D.C.; GLASER, B.; WOODS, W. (Eds.). Dortrecht, Netherlands: Kluwer Academic, pp. 455-500.

EVANS, C.; MEGGERS, B.J.

1968 Archaeological Investigations on the Rio Napo, Eastern Ecuador. Smithsonian Contributions to Anthropology, vol. 6.

ÉVREUX, Y. d'

2002 [1615] Viagem ao Norte do Brasil. Rio de Janeiro: Leite Ribeiro.

FERREIRA, L.M.

2009 "Ordenar o Caos": Emílio Goeldi e a Arqueologia Amazônica. Boletim do Museu Paraense Emílio Goeldi, Ciências Humanas, 4(1): 71-94.

FERREIRA, M.R.

2005 A Ferrovia do Diabo. São Paulo: Melhoramentos.

FIGUEIREDO, N.A.

1965 Cerâmica Arqueológica do Rio Itacaiúnas. Boletim do Museu Paraense Emílio Goeldi, Antropologia, 27: 1-17.

FONSECA, J.G.

1860 Primeira Exploração dos rios Madeira e Guaporé feita por José Gonçalves da Fonseca em 1749 por ordem do governo. In Memórias para o extinto estado do Maranhão. MENDES DE ALMEIDA, C. (Org.). Rio de Janeiro: Typ. Do Comércio de Brito e Braga, pp. 267-416.

FORD, J.A.

1954 The Type Concept Revised. American Antiquity 19(4): 390-391.

1962 A Quantitative Method for Deriving Cultural Chronology. Technical Manual 1. Washington: Pan American Union.

FRANÇA, L.B.C.

2012 Caminhos Cruzados: parentesco, diferença e movimento entre os Kagwahiva. Tese de Doutorado. Museu Nacional/UFRJ.

FREITAS, H.A.; PESSENDA, L.C.R.; AVARENA, R.; GOUVEIA, S.E.M; RIBEIRO, A.S.; BOULET, A.R. 
2001 Late Quaternary Vegetation Dynamics in the Southern Amazon Basin Inferred from Carbon Isotopes in Soil Organic Matter. Quaternary Research, 55: 39-46.

FRITZ, S.

1918 o Diário do Padre Samuel Fritz com Introduções e Notas de Rodolfo Garcia. Revista do Instituto Geográfico Brasileiro, 81: 354-397.

GALLOIS, D.T.

1986 Migração, Guerra e Comércio: os Waiãpi na Guiana. São Paulo: Série Antropologia (15), FFLCH/USP.

GALVÃO, E.

1960 Áreas Culturais Indígenas do Brasil. Boletim do Museu Paraense Emílio Goeldi, Antropologia, 8: 1-41.

GARCIA, L.G.

2012a Arqueologia na Região dos Interflúvios Tocantins-Xingu: os Tupi do Cateté. Dissertação de Mestrado. MAE-USP.

2012b Rio Xingu, cultura material e território: Arqueologia como história indígena na T. I. Kuatinemu. Projeto de Doutorado, MAE-USP.

GARCIA, M.C.O.

2010 Inventário dos Sítios Rupetres da Região Centro-Leste de Rondônia - Brasil. Dissertação de Mestrado. Universidade Pablo de Olavide, Porto Velho.

Gel, A.

1998 Art and Agency: an anthropological theory. Oxford: Claredon Press.

GEERTZ, C.

1968 Islam Observed: religious development in Morocco and Indonesia. Chicago \& London: Chicago University Press.

1973 The Interpretation of Cultures. New York: Basil Books.

GOELDI, E.G.

2009 [1900] Cavernas Funerárias Artificiais de Índios Hoje Extintos no Sul da Guiana e a Cerâmica ali encontrada. Boletim do Museu Paraense Emílio Goeldi, Ciências Humanas, 4(1): 95-133.

GOMES, D.C.

2001 Santarém: Symbolism and Power in the Tropical Forest. In Unknown Amazon: culture in nature in ancient Brazil. McEWAN C.; BARRETO, C.; NEVES E.G. (Eds.). London: British Museum Press, pp. 134-155.

2002 Cerâmica Arqueológica da Amazônia: vasilhas da coleção tapajônica MAE-USP. São Paulo: EDUSP/FAPESP.

2005 Análise dos Padrões de Organização Comunitária no Baixo Tapajós: o desenvolvimento do formativo na área de Santarém, PA. Tese de Doutorado, MAE-USP, São Paulo.

2007 The Diversity of Social Forms in Pre-Colonial Amazonia. Revista de Arqueologia Americana, 25: 187-219. 
2008 Cotidiano e Poder na Amazônia Pré-Colonial. São Paulo: EDUSP/FAPESP.

GONÇALVES, M.A. (Org.)

1991 Acre: História e Etnologia. Rio de Janeiro: Núcleo de Etnologia Indígena.

GOSSELAIN, O.P.

1998 Social and Technical Identity in a Clay Crystal Ball. In The Archaeology of Social Boundaries. STARK, M.T. (Ed.). Washington: Smithsonian Institution Press, pp. 78-106.

2008 Mother Bella was not a Bella: inherited and transformed traditions in southwest Niger. In Cultural Transmission and Material Culture. STARK, M.; BOWSER, B.J, HORNE, L. (Eds.). Tucson: University of Arizona Press, pp. 150-177.

GOULD, S.J.

1989 Wonderful Life: the burgess shale and the nature of History. New York/London: W.W. Norton.

GOULDING M.; SMITH, N.

2007 Palms: Sentinels for Amazon Conservation. Amazon Conservation Association (ACA)/Missouri Botanical Garden Press.

GOULDING M.; SMITH, N.; MAHAR, D.J.

1996 Floods of Fortune: Ecology \& Economy Along the Amazon. New York: Columbia University Press.

GOW, P.

2002 Piro, Apurinã, and Campa: social dissimilation and historical process in southwestern Amazonia. In Comparative Arawakan Studies: rethinking language family and culture area in Amazonia. HILL, J.; SANTOS-GRANERO, F. (Eds.). Urbana and Chicago: University of Illinois Press, pp. 147-170.

GRAHAM, E.

2006 A Neotropical Framework for Terra Preta. In Time and Complexity in Historical Ecology: studies in the neotropical lowlands. BALÉE, W.; ERICKSON, C. (Eds.). New York: Columbia University Press, pp. 57-86.

GREENACRE, M.J.

2007 Correspondence Analysis in Practice. Boca Raton: Chapman \& Hall.

GUAPINDAIA, V.L.

2001 Encountering the Ancestors: the Maracá Urns. In Unknown Amazon: culture in nature in ancient Brazil. McEWAN C.; BARRETO, C.; NEVES E.G. (Eds.). London: British Museum Press, pp. 156-175.

2008 Além da margem do rio - a ocupação Konduri e Pocó na região de Porto Trombetas, PA. Tese de Doutorado, MAE-USP.

HALL, E.

1966 The Hidden Dimension. New York: Doubladay.

HARNER, M. 
1972 The Jivaro: people of the Sacred Waterfalls. Berkley, Los Angeles, London: University of California Press.

HAYDEN, B.

1990 Nimrods, Piscators, and Planters: the emergence of food production. Journal of Antropological Archaeology, 9: 31-69.

1995 The Emergence of Prestige Technologies and Pottery. In The Emergence of Pottery. BARNETT, W.K.; HOOPES, J. (Eds.). Washington D.C.: Smithsonian Institution Press, pp. 257-265.

2001 Fabulous Feasts: a Prolegomenon to the importance of feasting. In Feasts: archaeological and ethnographical perspectives on food, politics and power. DIETLER, M.; HAYDEN, B. (Eds.). Tuscaloosa: University of Alabama Press, pp. 23-64.

HECKENBERGER, M.J.

2002 Rethinking the Arawakan Diaspora: hierarchy, rationality, and the Amazonian Formative. In Comparative Arawakan Studies: rethinking language family and culture area in Amazonia. HILL, J.; SANTOS-GRANERO, F. (Eds.). Urbana and Chicago: University of Illinois Press, pp. 99-122.

2005 The Ecology of Power: culture, place, and personhood in the southern Amazon, A.D. 1000-2000. New York: Routledge.

2010 Archaeology and Cultural Memory. In Arqueologia Amazônica 2. PEREIRA, E. e GUAPINDAIA, V. (Eds.). Belém: MPEG, pp. 12-36.

2011 Deep History in Ancient Amazonia. Reconstructing Past Identities from Archaeology, Linguistics, and Ethnohistory. HORNBORG, A.; HILL. J. (Eds.). Boulder: University of Colorado Press, pp. 57-74.

HECKENBERGER, M.J.; KUIKURU, A.; KUIKURO, U.T.; RUSSEL, J.C.; SCHMIDT, M.; FAUSTO, C.; FRANCHETTO, B.

2003 Amazonia 1492: Pristine forest or Cultural Parkland? Science, 301: 1710-1714.

HECKENBERGER, M.J.; NEVES, E. G.

2009 Amazonian Archaeology. Annual Review of Anthropology, 38: 251-266.

HECKENBERGER, M.; NEVES, E.; PETERSEN, J.

1998 De Onde Surgiram os Modelos? As Origens e Expansões Tupi na Amazônia Central. São Paulo-SP, USP, Revista de Antropologia, 41(1): 69-96.

HEGGARTY, P.

2007 Linguistics for Archaeologists: principles, methods, and the case of the Incas. Cambridge Archaeological Journal, 17 (3): 311-340.

2008 Linguistics for Archaeologists: a case-study in the Andes. Cambridge Archaeological Journal, 18 (1): 35-56.

HENRIQUES JÚNIOR, G.P.

2006 Arqueologia Regional da Província Cárstica do Alto São Francisco: um estudo das tradições ceramistas Una e Sapucaí. Dissertação de Mestrado, MAE-USP.

HERIARTE, M. 
1874 Descrição do estado do Maranhão, Pará, Corupá e Rio das Amazonas. Imprensa do filho de C. Gerold.

HERRERA, L.; BRAY, W.; McEWAN, C.

1980/81 Dados sobre la Arqueologia de Araracuara (Comisaría del Amazonas Colombia). Revista Colombiana de Antropologia, 23: 183-251.

HILBERT, P.P.

1958 Urnas Funerárias do rio Cururú, alto Tapajós. Boletim do Museu Paraense Emílio Goeldi, Antropologia,6: 1-13.

1968 Archäeologische Funde im oberen Amazonas-gebiet. Baesslerarchiv, 3: 205-255.

HILBERT, P.P.; HILBERT, K.

1980 Resultados Preliminares da Pesquisa Arqueológica realizada nos rios Nhamundá e Trombetas, baixo Amazonas. Boletim do Museu Paraense Emílio Goeldi, Antropologia, 75: $1-11$.

HILL, J.; SANTOS-GRANERO, F.

2002 Introduction. In Comparative Arawakan Studies: rethinking language family and culture area in Amazonia. HILL, J.; SANTOS-GRANERO, F. (Eds.). Urbana and Chicago: University of Illinois Press, pp. 1-22.

HODDER, I.

1987a The Archaeology of Contextual Meanings. In The Archaeology of Contextual Meanings. HODDER, I. (Ed.). Cambridge: Cambridge University Press, pp. 1-10.

1987b The Contribution of the Long Term. In Archaeology as Long-Term History. HODDER, I. (Ed.). Cambridge: Cambridge University Press, 1-8.

1994 La Interpretación in Arqueología: corrientes actuales. Barcelona: Editora Critica.

HOMBERG, A.

1948 The Sirionó. In Handbook of South American Indians (3). STEWARD, J. (Ed.). Washington: Government Printing Office, pp. 455-464.

HORNBORG, A.

2005. "Ethnogenesis, Regional Integration, and Ecology in Prehistoric Amazonia. Current Anthropology, 46 (4): 589-620.

HORNBORG, A.; HILL, J.H.

2011 Introduction: Ethnicity in Ancient Amazonia. In Reconstructing Past Identities from Archaeology, Linguistics, and Ethnohistory. HORNBORG, A.; HILL. J. (Eds.). Boulder: University of Colorado Press, pp. 1-27.

HOWARD, G.D.

1947 Prehistoric Ceramic Styles of Lowland South America, their distribution and history. New Haven: Yale University Press.

HUGO, V. 
1959 Desbravadores: a história eclesiástica, no panorama social, político e geográfico do grande rio Madeira, seus afluentes e formadores na Amazônia. Edição da "Missão Salesiana de Humaitá".

IBGE

2006 Estado de Rondônia: Geomorfologia (escala 1:1.000.000).

INGOLD, T.

2000 Making Culture and Weaving the World. In Matter, Materiality and Modern Culture. GRAVES-BROWN, P. M. (Ed.). London-New York: Routledge.

JAIMES BETANCOURT, C.

2012 La Ceramica de La Loma Salvatierra. La Paz: KAAL-Plural Editores.

JENNINGS, J.; BOWSER, B.J.

2008 Drink, Power and Society in the Andes: an Introduction. In Drink, Power and Society in the Andes. JENNINGS, J.; BOWSER, B.J. (Eds.). Gainesville: University Press of Florida, pp. 1-27.

JENNINGS, J.; CHATFIELD, M.

2008 Pots, Brewers, and Hosts: Women's Power and the Limits of Central Andean Feasting. Drink, Power and Society in the Andes. JENNINGS, J.; BOWSER, B.J. (Eds.). Gainesville: University Press of Florida, pp. 200-231.

JUDT, T.

2005 Postwar: a History of Europe since 1945. London: Vintage books.

JUNQUEIRA, C.

1984/1985 Os Cinta-Larga. Revista de Antropologia, 27/28: 213-32.

KÄMPF, N.; KERN, D.

2005 O Solo como Registro da Ocupação Humana Pré-histórica na Amazônia. Tópicos Ci. Solo, Belém, p. 277-320.

KARSTEN, R.

1935 The Head-Hunters of Western Amazonia. Helsingfors.

KATZ, S.H.; VOIGHT, M.M.

1986 Bread and Beer: the early use of cereals in human diet. Expedition, 28(2): 23.-34.

KELLER, F.

1874 The Amazon and Madeira Rivers: Sketches and Descriptions from the Note-Book of an Explorer. London: Chapman and Hall.

KERN, D.C.

1988 Caracterização Pedológica dos Solos com Terra Preta Arqueológica na Região de Oriximiná, Pará. Dissertação de Mestrado, UFRGS, Por Alegre.

1996 Geoquímica e Pedogeoquímica de Sítios Arqueológicos com Terra Preta na Floresta Nacional do Caxiuaná (Portel-Pará). Tese de Doutorado, UFPA, Belém.

KERN, D.C.; MARQUES, F.L.T.; MAURITY, C.W.; ATZINGEN, N.V. 
1992 O Potencial Espeleoarqueológico da Região de São Geraldo do Araguaia - PA. Boletim do Museu Paraense Emílio Goeldi, Ciências Humanas, 8(2): 157-183.

KIPNIS, R., CALDARELLI, S.B.; OLIVEIRA W. C.

2005 Contribuição para a Cronologia da Colonização Amazônica e suas Implicações Teóricas. Revista de Arqueologia 18: 81-94.

LA SALVIA, F.; BROCHADO J. P.

1989 Cerâmica Guarani. Porto Alegre: Posenato Arte e Cultura.

LADEIRA, M.E.

1983 Uma Aldeia Timbira. In Habitações Indígenas. NOVAES, S.C. (Org.). São Paulo Nobel/EDUSP,.

LAGROU, E.

2007 A Fluidez da Forma: arte, alteridade e agência em uma sociedade amazônica (Kaxinawa, Acre). Topbooks, Rio de Janeiro.

LANDIN, D.

1983 Dicionário e léxico KaritianaไPortuguês. Brasília: SIL.

LARAIA, R.B.

1984/85 Uma Etno-História Tupi. Revista de Antropologia, 27/28: 25-32.

LARAIA, R. B. \& DA MATA, R. A.

1967 Índios Castanheiros: a empresa extrativista e os índios do médio Tocantins. São Paulo: Col. Corpo e Alma do Brasil do Brasil, DIFEL.

LATHRAP, D.W.

1962 Yarinacocha: Stratigraphic Escavations in the Peruvian Montaña. M.S. Doctoral Dissertation, Harvard University, Cambridge.

1968 Aboriginal Occupation and Changes in River Channel on the Central Ucayali, Peru. American Antiquity, 33(1): 62-79.

1970 The Upper Amazon. Themes \& Hudson.

1973 The Antiquity and Importance of Long-Distance Trade Relations in the Moist Tropics of Pre-Columbian South America. World Archaeology, 5(2): 170-186.

1976 Shipibo Tourist Art. In Ethnic and Tourist Arts: cultural expressions from the fourth world. GRABUR, N.H. (Ed.). Berkley/Los Angeles: University of California Press, pp. 197207.

LATRUBESSE, E.M.

2012 Amazon Lakes. In. Encyclopedia of Lakes and Reservoirs. BENGTSSON, L.; HERSCHY, R. W.; FAIRBRIDGE, R. W. (Eds.). New York: Springer, pp. 13-26.

LEACH, E.

1976 Cultura e Comunicação. Edições 70.

LEMONIER, $\mathrm{P}$. 
1993 Introduction. In Technical Choices: transformation in material cultures since the Neolithic. LEMONIER, P. (Ed.). London and New York: Routledge, pp. 1-33.

LEONEL, M.

1995 Etnodicéia Uruéu-Au-Au. São Paulo: Edusp-Iamá.

LERY, J. de

1967 [1578] História de uma Viagem feita na Terra do Brasil. São Paulo: Martins.

LEVI-STRAUSS, C.

1948 The Tupi-Kawahib. In. Handbook of South American Indians (3). STEWARD, J. (ED.). Washington: Government Printing Office, pp. 299-305.

1976 [1955] Tristes Tropiques. Penguin Books. Great Britain.

LEWIS-WILLIAMS, D.

2002 The Mind in the Cave: Consciousness and the Origins of Art. London: Thames \& Hudson.

LIMA, H.P.

2008 História das Caretas: a Tradição Borda-Incisa na Amazônia Central. Tese de Doutorado, MAE-USP.

LIMA, H.P.; NEVES, E.G.

2011 Cerâmicas da tradição Borda Incisa/Barrancóide na Amazônia Central. Revista do MAE, 21: 205-230.

LIMA, H.P.; NEVES, E.G.; PETERSEN, J.

2006 A Fase Açutuba: um novo complexo cerâmico da Amazônia Central. Arqueologia SulAmericana, 2(1): 26-52.

LIMA, L.F.E.

2011 A ocupação pré-colonial na fronteira ocidental: adaptabilidade humana, territorialidade e aspectos geomorfológicos na microrregião do Alto Guaporé, Mato Grosso. Tese de Doutorado, MAE-USP.

2012 A Ocupação Pré-Colonial na Fronteira Ocidental: adaptabilidade humana, territoriedade e aspectos geomorfológicos na microrregião do alto-Guaporé, Mato Grosso. Tese de Doutorado, MAE-USP.

LIMA, S.C.

2010 Tecnologia Cerâmica Chimu: estudo arqueométrico da coleção do MAE/USP. Tese de Doutorado, MAE-USP.

LIMA, T.A.

2005 Cerâmica Tupiguarani e Marajoara: elementos estruturais comuns. Ciência Hoje, v. 213, n. 36: 30-33.

LOPES, D.

1979 Relatório Preliminar - 4a Parte: Pesquisa Arqueológica no Baixo Rio Tocantins (PA). Belém, Museu Paraense Emílio Goeldi.

MACHADO, J.S. 
2005 Montículos Artificiais na Amazônia Central. Dissertação de Mestrado: MAE-USP, São Paulo.

MAGALHÃES, A.B.B.

1916 Relatório apresentado ao Sr. Coronel Candido Mariano da Silva Rondon, Chefe da Commissão Brasileira / pelo capitão Amilcar Armando Botelho de Magalhães. Rio de Janeiro.

MAGALHÃES, M.

1994 Arqueologia de Carajás. CVRD.

MALDI, D.

1991 O Complexo Cultural do Marico: sociedades indígenas dos rios Branco, Colorado e Mequéns, afluentes do rio Guaporé. Boletim do Museu Paraense Emílio Goeldi, Antropologia, 7(2): 209-269.

MANO, M.

1996 Etno-História e Adaptação Mawé: uma contribuição para a etnografia Tupi na área Madeira Tapajós. Dissertação de Mestrado, FFLCH-USP.

MAQQUE, R.

2005 Identificación de Sitios Arqueológicos en Madre de Dios. Estudios Amazônicos, 3: 7788.

\section{MAUSS, M.}

2003 [1925] Ensaio sobre a Dádiva: forma de razão e troca nas sociedades arcaicas. In Sociologia e Antropologia. São Paulo: Cosac Naify.

McGOVERN, P.E.

2009 Uncorking the Past: the quest for wine, beer, and other alcoholic beverages. Berkley: University of California Press.

MEGGERS, B.J.

1974 A Reconstrução da Pré-História Amazônica. São Paulo: Edusp.

1977 Vegetation fluctuation and prehistoric cultural adaptations in Amazonia: some tentative correlations. World Archaeology, 8 (3): 287-303.

1979 Climatic Oscillation as a Factor in the Prehistory of Amazonia. American Antiquity, 44 (2): 252-266.

1982 Archaeological and Ethnographic Evidence Compatible with the Model of Forest Fragmentation. In Diversification in the Tropics. PRANCE, G. (Ed.). New York: Columbia University Press, pp. 483-496.

1987 Amazônia: a ilusão de um paraíso. Belo Horizonte/São Paulo: Itatiaia Edusp.

1992a Prehistoric Population Density in the Amazon Basin. In Desease and Demography in the Americas. VERUNO, J. \& UBELAKER, D. H. (Eds.). Washington DC: Smithsonian Intitution Press, pp. 197-205.

1992b Judging the Future by the Past: the impact of environmental Instability on Orehistoric Amazonian Populations. In Indigenous Peoples and the Future of Amazonia: an ecological 
Anthropology of an Endegered World. SPONCEL, L. (Ed.). Tucson: University of Arizona Press, pp. 15-43.

1998 O Paraíso Ilusório Revisto. Revista do MAE, 8: 35-55.

MEGGERS, B.J., DIAS, O.F., MILLER, E.T.; PEROTA, C.

1988 Implications of Archaeological Distributions in Amazonia. In Proceeding of a Workshop of Neotropical Distribution Patterns. HEYER , W. R.; VANZOLINI, P. E. (Orgs.). Acadêmia Brasileira de Ciências, p. 275-294.

MEGGERS, B.J.; EVANS, C.

1957 Archaeological Investigations in the Mouth of the Amazon. Washington: Smithsonian Institution, Government Printing Press.

1961 An Experimental Formulation of Horizon Styles in the Tropical Forest Area of South America. In Essays in Pre-Columbian Art and Archaeology. LOTHROP, S.K. and others (Eds.). Cambridge: Harvard University Press, pp. 372-388.

1970 Como interpretar a Linguagem Cerâmica: manual para arqueólogos. Washington: Smithsonian Instituion.

MEGGERS, B.J.; MILLER, E.T.

2003 Hunter-Gatherers in Amazonia during the Pleistocene-Holocene Transition. In Under the Canopy: The Archaeology of Tropical Rainforests (Library Binding). MERCADER J. (ed.), Rutgers University Press, p. 291-316.

MELLO, A.A.S.; KNEIP, A.

2006 Evidências Lingüísticas que apontam para a Origem dos Povos Tupi-Guarani no Leste Amazônico. Estudo apresentado no 52nd International Congress of Americanists; Sevilha.

MENÉNDEZ, $\mathrm{M}$.

1981/1982 Uma Contribuição para a Etno-História da Área Tapajós-Madeira. Revista do Museu Paulista, XXVIII: 289-388.

1984/85 Contribuição ao Estudo das Relações Tribais na Área Tapajós-Madeira. Revista de Antropologia, 27/28: 271-286.

MÉTRAUX, A.

1927 Migrations Historiques des Tupi-Guarani. Journal de la Société des Américanistes, 19: $1-45$.

1948a The Tupinambá. In Handbook of South American Indians (3). STEWARD, J. (Ed.). Washington: Government Printing Office, pp. 95-133.

1948b Tribes of Eastern Bolivia and the Madeira Headwaters. In Handbook of South American Indians (3). STEWARD, J. (Ed.). Washington: Government Printing Office, pp. 381-454.

1948c The Parecí. In Handbook of South American Indians (3). STEWARD, J. (Ed.). Washington: Government Printing Office, pp. 349-360.

1948d Tribes of Middle and Upper Amazon. In Handbook of South American Indians (3). STEWARD, J. (Ed.). Washington: Government Printing Office, pp. 687-712. 
1979 A Religião dos Tupinambá: e suas relações com as demais tribos Tupi-Guaranis. São Paulo: Nacional.

MIDLIN, B.

1984/1985 Os Suruí de Rondônia: entre a floresta e a colheita. Revista de Antropologia, 27/28: 203-211.

1985 Nós Paiter: Os Surui de Rondônia. Petrópolis: Editora Vozes.

2006 Diários da Floresta. São Paulo: Editora Terceiro Nome.

MIGLIAZZA, E.

1982 Linguistic Prehistory and the Refuge Model in Amazonia. In Biological Diversification in the Tropics. PRANCE, G. T. (Ed.). New York: Columbia University Press, pp. 497-519.

MILLARD, C.

2005 O Rio da Dúvida: a sombria viagem de Theodore Roosevelt e Rondon pela Amazônia. São Paulo: Companhia das Letras.

MILLER, E.T.

1978 Relatório das Pesquisas Arqueológicas no Território Federal de Rondônia (Alto Rio Madeira, do Yata ao Cuniã). Resultados Preliminares. Programa Nacional Pesquisas Arqueológicas na Bacia Amazônica-PRONAPABA.

1980 Pesquisas Arqueológicas no Território Federal de Rondônia: Relatório Preliminar.

1983 História da Cultura indígena do Alto-Médio Guaporé (Rondônia e Mato Grosso). Dissertação de Mestrado, Porto Alegre: PUC-RS.

1986/1987 Relatório do Programa de Estudos de Viabilidade Arqueológica nas Áreas de Inundação e de Influência da UHE Ji-Paraná. CNEC.

1987a Inventário Arqueológico da Bacia e Sub-Bacias do Rio Madeira, 1974-1987. CNEC.

1987b Projeto de Avaliação do Potencial Arqueológico na Área de influência da Rodovia BR-429/ Presidente Médici-Costa Marques. Governo do Estado de Rondônia, Secretaria e Estado do Planejamento e Coordenação Geral/SEPLAN.

1987c Pesquisas Arqueológicas Paleoindígenas no Brasil Ocidental. Estudios Atacameños: investigaciones paleoindias al sur de la línea ecuatorial, 8: 37-61.

1987d Relatório das Pesquisas Arqueológicas Efetuadas na Área de Abrangência da Usina Hidrelétrica de Ji-Paraná (1986/1987). Porto Velho, RO.

1992 Adaptação Agrícola Pré-Histórica no Alto Rio Madeira. In Prehistoria Sudamericana: nuevas perspectivas. Meggers, B. J. (ed.), Taraxacum-Washighton.

1999 A Limitação Ambiental como Barreira à Transposição do Período Formativo no Brasil. Tecnologia, Produção de Alimentos e Formação de Aldeias no Sudeste da Amazônia. In Formativo Sudamericano, una revelacions. Lederbergerber-Crespo, P. (Ed.), Ediciones Abya-Yala, Quito-Equador.

2009 A Cultura Cerâmica do Tronco Tupi no alto Ji-Paraná, Rondônia, Brasil: algumas reflexões teóricas, hipotéticas e conclusivas. Revista Brasileira de Linguistica Antropológica, $1(1): 35-136$.

MILLER, E.T. et al. 
1992 Arqueologia nos Empreendimentos Hidrelétricos da Eletronorte. Eletronorte: BrasíliaDF.

MONGELÓ, G.Z.

2012 O formativo e os modos de produção: ocupações pré-ceramistas no Alto Rio MadeiraRO. Projeto de Mestrado. MAE-USP.

MONTAIGNE, M.

2009 Dos Canibais. São Paulo: Alameda.

MONTOYA, A.R.

2002 [1640] Vocabulario de la Lengua Guaraní (1640). Asunción: CEPAG.

MOORE, C.R.; THOMPSON, V.D.

2012 Animism and Green River Persistent Places: a dwelling perspective of the Shell Mound Archaic. Journal of Social Archaeology, 12(2): 264-284.

MORAES, C.A.

2007 Arqueologia Tupi do Nordeste de São Paulo. Dissertação de Mestrado, MAE-USP, São Paulo.

MORAES, C.P.

2006Arqueologia na Amazônia Central Vista de uma Perspectiva da Região do Lago do Limão. Dissertação de Mestrado, MAE-USP, São Paulo.

2010 Aldeias Circulares na Amazônia Central: um contraste entre a fase Paredão e a fase Guarita. In Arqueologia Amazônica 2. PEREIRA, E. e GUAPINDAIA, V. (eds.). Belém: MPEG, pp. 74-96.

MORAES, C.P.; NEVES, E.G.

2012 Adensamento Populacional, Interação e Conflito na Amazônia Central. Amazônica Revista de Antropologia, 4:122-148

MORAIS, J.L.

1999-2000 Arqueologia da Região Sudeste. Revista USP, 44: 194-217.

MORRIS, I.

2000 Archaeology as Cultural History. Oxford/Malden: Blackwell.

MOUTINHO, M.; ROBRAHN-GONZÁLEZ, E.M.

2010 Memórias de Rondônia. São Paulo: Arte Ensaio.

MÜLLER, R.P.

1985 Abstracionismo na Pintura Corporal Asuriní. In Arte e Corpo: pintura sobre a pele e adornos de povos indigenas brasileiros. FUNARTE/Instituto Nacional de Artes Plásticas, pp. 21-25.

1990 Os Asurini do Xingu: história e arte. Campinas: Editora da Unicamp.

NEEDHAM, R.

1975 Polythetic Classification: Convention and Consequences. Man, 10(3) 349-369.

NETER, J; WASSERMAN, W; KUTNER, M.H. 
1990 Applied Linear Statistical Models: Regression, Analysis of Variance, and Experimental Designs. New York: Mcgraw-Hill.

NEVES, E.G.

1995 Village Fissioning in Amazonia: a critique of monocausal determinism. Revista do Museu de Arqueologia e Etnologia, 5: 195-210.

1998 Arqueologia, História Indígena e Registro etnográfico: exemplos do alto rio Negro. Revista do MAE, 8: 319-330.

2000 Levantamento Arqueológico da Área de Confluência dos Rios Negro e Solimões, Amazonas. Projeto de Auxílio à Pesquisa FAPESP.

2001 Indigenous Historical Trajectories in the Upper Rio Negro Basin. In Unknown Amazon: culture in nature in ancient Brazil. McEWAN C.; BARRETO, C.; NEVES E.G. (Eds.). London: British Museum Press, pp. 266-286.

2005 Cronologias Regionais, Hiatos e Continuidades na História Pré-Colonial da Amazônia. São Paulo-SP, Projeto Temático FAPESP.

2006 Arqueologia da Amazônia. Rio de Janeiro, Coleção Descobrindo o Brasil, Jorge Zahar.

2007 An Erratic (but Lively) Heart in the Chest: Revising the Cardiac Model in the Central Amazon. Paper presented at the American Anthropological Association Annual Meetings (Washington).

2008 Ecology, Ceramic Chronology and Distribution, Long-term History, and Political Change in Amazonian Floodplain. In Handbook of South American Archaeology. SILVERNAN, H.; ISBELL, W. H. (Eds.). New York: Springer, pp. 359-378.

2009 Warfare in Pre-Colonial Amazonia: when Carneiro meets Clastres. In Wafare in Cultural Context: practice theory and the archaeology of violence. NILSEN, A.; WALKER, W. (Eds.). Tucson: University of Arizona Press, pp. 139-164.

2010 A Arqueologia da Amazônia Central e a Classificação na Arqueologia Amazônica. In Arqueologia Amazônica 2. PEREIRA, E. e GUAPINDAIA, V. (Eds.). Belém: MPEG, pp. 5372.

2011 Archaeological Cultures and Past Identities in Precolonial Central Amazon. In. Ethnicity in Ancient Amazonia: Reconstructing Past Identities from Archaeology, Linguistics, and Ethnohistory. Hornborg, A. and Hill. J. (Eds.). Boulder: University of Colorado Press, pp. 31-56.

2012 Sob os Tempos do Equinócio: oito mil anos de história na Amazônia Central (6.500 AC - 1.500 DC). Tese de Livre Docência. MAE, USP.

NEVES, E.G.; PETERSEN, J.B.

2006 Political Economy and Pre-Columbian Landscape Transformation in Central Amazonia. In Time and Complexity in Historical Ecology. BALÉE, W.; ERICKSON, C. (Eds.). New York: Columbia University Press, pp. 279.

NEVES, E.G.; PETERSEN, J.B.; BARTONE, R.N.; SILVA, C.A.

2003 Historical and Socio-cultural origins of Amazonian Dark Earths. In Amazonian Dark Earths: origins properties and management. LEHMANN, J.; KERN, D.C.; GLASER, B. \& WOODS, W. I. (Eds.). Dordrecht: Kluwer Academic Publishers, pp. 29-50.

NEUMANN, M.A. 
2008 Naande Rekó: diferentes jeitos de ser Guarani. Dissertação de Mestrado. Porto Alegre UFRGS.

2010 Distribuição das Marcas de Uso e Especificidades Funcionais para a Cerâmica Guarani Pré-Colonial. Revista de Arqueologia, 24(1): 52-65.

NICHOLS, J.

1992 Linguistic Diversity in Time and Space. Chicago: University of Chicago Press.

NIMUENDAJU, C.

1924 Os Índios Parintintin do rio Madeira. Journal de la Société des Américanistes, 16: 201278.

1944 Mapa Etno-Histórico. Brasil: IBGE.

1948a The Cawahib, Parintintin and their Neighbors. In. Handbook of South American Indians (3). STEWARD, J. (Ed.). Washington: Government Printing Office, pp. 283-297.

1948b The Maué and Arapium. In. Handbook of South American Indians (3). STEWARD, J. (Ed.). Washington: Government Printing Office, pp. 245-254.

1948c Tribes of the Lowe and Middle Xingu River. In. Handbook of South American Indians (3). STEWARD, J. (Ed.). Washington: Government Printing Office, pp. 213-244.

1948d The Mura and Piraha. In. Handbook of South American Indians (3). STEWARD, J. (Ed.). Washington: Government Printing Office, pp. 255-269.

1967 The Apinayé. Anthropological Publications. Oosterhout.

1993 Etnografia e Indigenismo: sobre os Kaingang, os Ofaié-Xavante e os Índios do Pará. Campinas: Editora da Unicamp, pp. 144-146.

2000 Cartas do Sertão: de Curt Nimuendaju a Carlos Estevão Oliveira. Museu Nacional de Etnologia. Lisboa: Assírio e Alvim.

2004 In Pursuit of the Past Amazon. Archaeological Researches in the Brazilian Guyana and in the Amazon Region. Gothenburg: Ethnological Studies.

NOELLI, F.S.

1993 Sem Tekohá não há Tekó: Em busca de um modelo Etnoarqueológico da Aldeia e da Subsistência Guarani e sua Aplicação a uma Área de Domínio no Delta do Rio Jacuí-RS. Dissertação de Mestrado, Porto Alegre: PUC-RS.

1996a As Hipóteses sobre o Centro de Origem e Rotas de Expansão dos Tupi. Revista de Antropologia, 39 (2): 7-53.

1996b Resposta a Eduardo Viveiros de Castro e Greg Urban. Revista de Antropologia, 39 (2): 105-118.

1998 The Tupi: Explaining Origin and Expansions in Terms of Archaeology and the Historical Linguistics. Antiquity, 72 (2): 648-663.

1999-2000 A Ocupação Humana da Região Sul do Brasil: arqueologia, debates e perspectivas - 1872-2000. Revista USP, 44: 218-269.

2008a The Tupi Expansions. In Handbook of South American Archaeology. Handbook of South American Archaeology. SILVERMAN, H.; ISBELL, W.H. (Eds.). Nova York: Springer, pp. 200-212. 
2008b José Proença Brochado: vida acadêmica e arqueologia tupi. In Os Ceramistas Tupiguarani: vol 1, Siteses Regionais. PROUS, A. \& LIMA, T. A. (Eds.), IPHAN, Belo Horizonte, pp. 17-47.

NOELLI, F.S.; BROCHADO, J.P.

1998 O Cauim e as Beberragens dos Guarani e Tupinambá: equipamentos, técnicas de preparação e consumo. Revista do MAE, 8: 117-128.

NOGUEIRA, A. F. S.

2011 Wayoro ẽmẽto: fonologia segmental e morfosintaxe verbal. Dissertação de mestrado, Programa de Pós-Graduação em Semiótica e Linguística Geral, Universidade de São Paulo.

NORDENSKIÖLD, E.

1924 Finds of Graves and old Dwelling-Places on the Río Beni, Bolivia. Ymer, 44: 229-237.

NORONHA, J.M.

1862 [1768] Roteiro da Viagem da Cidade do Pará até as Últimas Colonias do Sertão da Província. Typografia Santos \& Irmãos.

NOVAES, R.F.; KIPNIS, R.

2009 Comendo Animais na Amazônia Pré-Colonial. Comunicação Aresentada no XV Congresso de Arqueologia da SAB. Belém-PA.

O'BRIEN M.J.; LEONARD R.D.

2001 Style and Function: an introduction. In Style and Function: conceptual issues. HURT T.D. \& RAKITA G.F.M. (Eds.), Wesport: Bergin \& Garvey, pp.1-23.

OLIVEIRA, A. (org.)

1986 Autos da Devassa contra os Índios Mura do Rio Madeira e Nações do Rio Tocantins (1738-1739). Manaus; FUA, Brasília, INL.

OLIVEIRA, O.A.

2007 História e Desenvolvimento Colonização de Rondônia. Porto Velho: Dinâmica editora e Distribuidora Ltda.

OLIVEIRA, W.C.

2007 Caçadores-Coletores na Amazônia: eles existem. Dissertação de Mestrado, MAE-USP, São Paulo.

OLIVER, J.

1989 The Archaeological, Linguistic, and Ethnohistorical Evidence for the Expansion of the Arawakan into Northwestern Venezuela and Northeastern Colombia. PhD dissertation, University of Illinois at Urbana-Champaing.

2001 The Archaeology of Forest Foraging and Agricultural Production in Amazonia. In Unknown Amazon: culture in nature in ancient Brazil. McEWAN C., BARRETO, C.; NEVES E.G. (Eds.). London: British Museum Press, pp. 50-85.

OLSEN, K.; SCHAAL, B.

1999 Evidence on the origin of cassava: Phylogeography of Manihot esculenta. Proceedings of the National Academy of Sciences 96: 5586-5591. 
OLIVEIRA, A.E.; GALVÃO, E.

1969 A Cerâmica dos Índios Juruna. Boletim do Museu Paraense Emílio Goeldi, Antropologia, 41: 1-26.

PALMATARY, H.C.

1960 The Archaeology of the Lower Tapajós Valley: Brazil. Transactions of the American Philosophical Society, New Series, n. 50.

PEREIRA, E., SIlveirA, M. I., RODRIGUES, M. C. L. F., COSTA, C. J. C. A., MACHADO, C. L.

2008 A Tradição Tupiguarani na Amazônia. In Os Ceramistas Tupiguarani, vol 1. PROUS, A. P. \& LIMA, T. A. (Orgs.). Belo Horizonte: Sigma, pp. 49-66.

PALLESTRINI, L.

1972/1973 Supra-estruturas e infra-estruturas arqueológicas no contexto ecológico brasileiro. Revista do Museu Paulista, 20: 7-32.

1975 Interpretação das estruturas arqueológicas em sítios do Estado de São Paulo. Museu Paulista-Universidade de São Paulo, São Paulo.

PEROTA, C.

1977 Relatório dos Trabalhos Realizados no Rio Xingu. PRONAPABA. Vitória-ES.

1978 Relatório dos Trabalhos Realizados no Rio Xingu. PRONAPABA. Vitória-ES.

1992 Adaptação Agrícola no Baixo Xingu. In Prehistoria Sudamericana. Meggers, B. (Ed.). Washington D.C.: Taraxacum, pp. 211-218.

PERSALL, D.

1998 Domestication and Agriculture in the new World Tropics. In Last Hunters, First Farmers: new perspectives on the prehistoric transition to agriculture. PRICE, D.; GEBAUER, A.B. (Eds.). Santa Fé: School of Research Press, pp. 157-191.

PESSENDA, L.C.R.; GOMES, B.M.; ARAVENA, R.; RIBEIRO, A.S.; BOULET, R.; GOUVEIA, S.E.M.

1998 A Forest-Cerrado Ecosystem Transect: implications for vegetation changes in the Rondonia state, southwestern Brazilian Amazon region. The Holocene, 8(5): 599-603.

PETERSEN, J.B., NEVES E.G.; HECKENBERGER M.J.

2001 Gift from the Past: Terra Preta and prehistoric Amerindian occupation in Amazonia. In Unknown Amazon: culture in nature in ancient Brazil. McEWAN C.; BARRETO, C.; NEVES E.G. (Eds.). London: British Museum Press, pp. 86-105.

PIPERNO, D.R.; PERSALL, D.M.

1998 The Origins of Africulture in the Lowland Neotropics. Academic Press: San Diego.

PONTIN, R.L.

2011 A Tradição Tupiguarani na Bacia do Alto Tocantins. Tese de Doutorado, MAE-USP.

PORRO, A.

1995 O Povo das Águas: ensaios de etno-história. Rio de Janeiro: Vozes.

2007 Dicionário Etno-Histórico da Amazônia Colonial. São Paulo: Cadernos do IEB/USP. 
PROUS, A.P.

2005 A Pintura em Cerâmica Tupiguarani. Ciência Hoje (v. 36 - n. 213): 22-28.

2010 A Pintura em Cerâmica Tupiguarani. In Os Ceramistas Tupiguarani, II. PROUS, A. P. \& LIMA, T. A. (orgs.). Belo Horizonte: Sigma, pp. 113-216.

RAMIREZ, $\mathrm{H}$.

2006 As Línguas Indígenas do Alto Madeira: Estatuto Atual e Bibliografia Básica. Língua Viva, 1(1). Revista eletrônica.

RAPPAPORT, R.A.

1999 Ritual and Religion in the Making of Humanity. Cambridge: Cambridge University Press.

RAYMOND, S.J.

1993 Ceromonialism in the Early Formative of Ecuador. In El Mundo Cerimonial Andino. MILLONES, L.; ONUKI, Y. (Eds.). Osaka: National Museum of Ethnology, pp. 25-43.

2009 Dos Fragmentos às Vasilhas: um primeiro passo para a construção de contextos culturais na arqueologia da floresta tropical. Amazônica 1, (2): 512-535.

REICHEL-DOLMATOFF, G.

1961 Anthropomorphic Figurines from Colombia: their magic and art. In Essays in PreColumbian Art and Archaeology. LOTHRAP, S. (Ed.). Cambridge: Harvard University Press, pp. 229-241.

RENARD-CASEVITZ, F.M.

2002 Social Forms of Regressive History: from the Campa cluster to the Mojos and from the Mojos to the landscaping terraces builders in the Bolivian savanna. In Comparative Arawakan Studies: rethinking language family and culture area in Amazonia. HILL, J.; SANTOS-GRANERO, F. (Eds.). Urbana and Chicago: University of Illinois Press, pp. 123146.

REBELLATO, L.

2007 Interpretando a variabilidade cerâmica e as assinaturas químicas e físicas do solo no Sítio Arqueológico Hatahara - AM. Dissertação de Mestrado, MAE-USP RENFREW, C.

RENFREW, C.

1987 Archaeology and Language: the puzzle of Indo-European origins. London: Penguin.

1992 World Languages and Human Dispersals: a minimalist view. In Transition to Modernity. HALL, J.H. \& JARVIE, I.C. (eds.). Cambridge University Press: Cambridge, p. 11-68.

2000 At the Edge of Knowability: Towards a Prehistory of Languages. Cambridge Archaeological Journal, 10 (1):. 7-34.

2002 The Emerging Synthesis: the Archaeogenetics of Farming/Language Dispersals and other Spread Zones. In Examining the Farming/Language Dispersal Hypothesis. BELLWOOD, P.; RENFREW, C. (Eds;). Cambridge: Mcdonald Institute Monographs, pp. 316.

RIBEIRO, B.G. 
1989 Arte Indígena: Linguagem Visual. Belo Horizonte/São Paulo: Itatiaia/Edusp.

1995 Os índios das Águas Pretas: modo de produção e equipamento produtivo. São Paulo: EDUSP/Companhia das Letras.

RIBEIRO, D.

2006 Diários Índios: os Urubus-Ka'apor. Companhia das Letras, São Paulo.

RIBEIRO, M. A.

2008 Dicionário Djeoromitxi-Português: Registro da diversidade lingüística do povo Jabuti. Dissertação de mestrado. Guajará-Mirim: Departamento de Letras e Pedagogia, Fundação Universidade Federal de Rondônia/UNIR.

RICE, P.

1999 On the Origins of Pottery. Journal of Archaeological Method and Theory, 6(1): 1-54.

RINDOS, D.

1984 As Origens da Agricultura: uma perspectiva evolutiva. Orlando: Academic Press.

RIVIÈRE, C.

1995 Introdução à Antropologia. Lisboa: Edições 70.

ROBB, J.

2010 Beyond Agency. World Archaeology, 42(4): 493-590.

ROBRAHN-GONZÁLEZ, E.M.

1996 A Ocupação Ceramista Pré-Colonial do Brasil Central: origens e desenvolvimento. Tese de Doutorado, FFLCH-USP.

ROCHA, B.C.

2012 Archaeology of Upper Tapajós River. MA Dissertation. Institute of Archaeology. University College London.

RODMAN, M.

1992 Empowering the Place: multilocality and multivocality. American Antrhopologist, 94: 640-656.

RODRIGUES, A.D.

1964 A Classificação do Tronco Lingüístico Tupi. São Paulo-SP, USP, Revista de Antropologia, 12: 99-104.

1984/85 Relações Internas na Família Lingüística Tupi-Guarani São Paulo-SP, USP, Revista de Antropologia, 27-28: 33-53.

RODRIGUES, A. D.; CABRAL, A.S.A.C.

2012. "Tupían". In The indigenous languages of South America: a comprehensive guide. CAMPBELL, L.; GRONDONA, V. (Eds). Berlin: De Gruyter Mouton.

RODRIGUES FERREIRA, A.

1974 [1788] Viagem Filosófica pelas capitânias do Grão Pará, Rio Negro, Mato Grosso e Cuiabá. Rio de Janeiro: Conselho Federal da Cultura.

ROE, P.G. 
1973 Cumancaya: archaeological excavation and ethnographic analogy in the Peruvian Montaña. PhD Dissertation at university of Illinois, Urbana-Champaign.

1982 The Cosmic Zygote: cosmology in the Amazon Basin. New Brunswick: Rutgers University Press.

1995 Style, society, Myth and Structure. In Style, Society and Person. Archaeological and Ethnological Perspectives. CARR, C. \& NEEITZEL J.E. (Eds.) New York: Plenun, pp. 2776.

\section{RONDON, C.M.S.}

1946 Índios do Brasil. Rio de Janeiro: Conselho Nacional de Proteção aos Índios.

1948 Glossário geral das tribos silvicolas de Mato-Grosso e outras da Amazônia e do Norte do Brasil. Tomo 1. Rio de Janeiro: Imprensa Nacional.

ROOSEVELT, A.C.

1980 Parnama: Prehistoric Maize and Manioc Subsistence along the Amazon and Orinoco. New York: Academic Press.

1989 Resource Management in Amazonia Before the Conquest: beyond Ethnographic projection. Advances in Economic Botany, 7: 30-62.

1991b Moundbuilders of the Amazon: Geophysical Archaeology on Marajo Island, Brazil. Academic Press: San Diego.

1995 Early Pottery in the Amazon: twenty years of scholarly obscurity. In The Emergence of Pottery: technology and innovation in ancient societies. BARNETT, W. K. \& HOOPES, J. W. (Eds.), Smithsonian Institution Press, Washington and London, p.115-131.

1999. The Maritime-Highland-Forest Dynamic and the Origins of Complex Society. In History of the Native Peoples of the Americas: South America. SALOMON, F.; SCHWARTZ, S. (Eds.). New York: Cambridge University Press, pp. 264-349.

2009 A Historical Memoir of Archaeological Research in Brazil (1981-2007). Boletim do Museu Paraense Emílio Goedi, Ciências Humanas, 4(1): 155-170.

ROOSEVELT, A.C., HOUSLEY, R., SILVEIRA, M.I., MARANCA, S.; JOHNSON, R.

1991 Eighth Millennium Pottery from Prehistoric Shell Midden in the Brazilian Amazon. Science, 254: 1621-1624.

ROOSEVELT, T.

1976 Nas Selvas da Amazônia. Belo Horizonte/São Pauli: Itatiaia/EDUSP.

ROQUETTE-PINTO, E.

1975 [1919] Rondônia. São Paulo: Companhia Editora Nacional.

ROSTAIN, S.

2008 The Archaeology of the Guianas: an overview. In Handbook of South American Archaeology. SILVERMAN, H.; ISBELL, W. (Ed.). New York: Springer, pp. 279-302.

ROUSE, I.; CRUXENT, J.M.

1963. Venezuelan Archaeology. New Haven: Yale University Press.

SACKETT, J.R. 
1977 The Meaning of Style in Archaeology: a general model. American Antiquity, 42(3): 369-380.

1991 Style and Ethnicity in Archaeology: the case of isocretism. In The Uses of Style in Archaeology. CONKEY, M.; HASTORF C. (Eds.). Cambridge: Cambridge University Press, p. 32-43.

SAESA (Santo Antônio Energia S.A.)

2009 Relatório de Inventário Florestal para Requerimento da ASV na Área do Reservatório da UHE Santo Antônio Energia.

SAITTA, D.J.

1994 Agency, Class, and Archaeological Interpretation. Journal of Anthropological Archaeology 13, 201-227.

SALDANHA, J.D.M.; CABRAL, M.P.

2010 Arqueologia do Amapá: reavaliação e novas perspectivas. In Arqueologia Amazônica 1. PEREIRA, E.; GUAPINDAIA, V. (Eds.). Belém: MPEG; IPHAN; SECULT; pp. 95-112.

SANJAD, N.; SILVA, J.B.P.

2009 Três contribuições de Emílio Goeldi (1859-1917) à arqueologia e etnologia amazônica. Boletim do Museu Paraense Emílio Goeldi, Ciências Humanas, 4(1): 95-134.

SANTOS-GRANERO, F.

2002 The Arawakan Matrix: ethos, language, and history in native South America. In Comparative Arawakan Studies: rethinking language family and culture area in Amazonia. HILL, J.; SANTOS-GRANERO, F. (Eds.). Urbana and Chicago: University of Illinois Press, pp. 25-50.

SAUER, C.

1941 Foward to Historical Geography. In Land and Live: a selection of writings by Carl O. Sauer. Berkley: University of California Press.

SAUNALUOMA, S.; SCHAAN, D.

2012 Monumentality in Western Amazonian Formative Societies: geometric ditches enclosures in the Brazilian State of Acre. Antiqua, 2(1): 1-11.

SCATAMACCHIA, M. C. M.

1981 Tentativa de Caracterização da Tradição Tupiguarani. Dissertação de Mestrado, São Paulo, FFLCH-USP.

1990 A Tradição Policrômica no Leste da América do Sul Evidenciada pela Ocupação Guarani e Tupinambá: fontes arqueológicas e etnohistóricas. Tese de Doutorado, São Paulo, FFLCH-USP.

SCHAAN, D.P.

1996 A Linguagem Iconográfica da Cerâmica Marajoara. Dissertação de Mestrado. Porto Alegre, PUC-RS.

2001 Into the Labyrints of Marajoara Pottery: Status and Cultural Identity in Prehistoric Amazonia. In Unknown Amazon: culture in nature in ancient Brazil. McEWAN C.; BARRETO, C.; NEVES E.G. (Eds.). London: British Museum Press, pp. 108-133. 
2004 The Camutins Chiefdom: rise and development of social complexity on Marajó island, Brazilian Amazon. PhD Dissertation, Pittsburgh.

2010 Long Term Human Induced Impacts on Marajó Island Landscapes, Amazon Estuary. Diversity, 2: 187-206.

SCHAAN, D.; BUENO, M.; RANZI, A.; BARBOSA, A.; SILVA, A.; CASAGRANDE, E.; RODRIGUES, A.; DANTAS, A.; RAMPANELLI, A.

2009 Paisagem e Temporalidade na Construção de Espaços Sociais: o caso dos geoglifos do Acre. XV Congresso da SAB.

SCHAAN, D.P.; RANZI, A.; PÄRSSINEN, M. (orgs.)

2008 Os Geoglifos do Acre. Belém: Editora UFPA.

SCHAAN, D.P.; SILVA, W.F.V.

2004 O Povo das Águas e sua Expansão Territorial: uma abordagem regional de sociedades pré-coloniais na Ilha de Marajó. Revista de Arqueologia, 17: 13-32.

SCHIFFER, M.B.

1985 Is There a "Pompeii Premise" in Archaeology? Journal of Anthropological Research, 41 (1): 18-41.

1987 Formation Process of the Archaeological Record. Salt Lake City: University of Utah Press.

SCHLANGER, S.

1992 Recognizing Persistent Places in Anazi Setlement Systems. In Space, Time and Archaeological Landscapes. RESSIGNOL, J.; WANDSNIDER, L. (Eds.). New York: Plenum Press, pp. 91-112.

SCHMIDT, M. J.; HECKENBERGER, M. J.

2009 Amerindian Anthrosols: Amazonian Dark Earth Formation in the Upper Xingu. In Amazonian Dark Earths: Wim Sombroek's Vision. WOODS, W. et al. (Eds.). New York: Springer pp. 163-191.

SCHMITZ, P.I.

1991 Migrantes da Amazônia: a Tradição Tupiguarani. Arqueologia do RGS, Brasil Documentos (São Leopoldo) 5: 31-66.

SCHWENGBER, V.L.; ZIMPEL, C.A.

2012 Salvamento e Monitoramento Arqueológico na Área de Implantação da PCH-Jamari, Município de Ariquemes-RO. Relatório IPHAN. Tubarão/SC.

SCIENTIA CONSULTORIA CIENTÍFICA

2008 Relatório Final: Projeto de Salvamento dos Sítios Arqueológicos Localizados na Área Diretamente Afetada da Linha de Transmissão Tucuruí/PA - Presidente Dutra/MA (3 Circuito). CALDARELLI, S. (Org.), São Paulo.

2011 Relatório Final: Projeto de Salvamento dos Sítios Arqueológicos Localizados na Área Diretamente Afetada da Linha de Transmissão Tucuruí/PA - Açailândia/MA (4 Circuito). CALDARELLI, S. (Org.), São Paulo.

SHANKS, M.; HODDER, I. 
1998 Processual, Postprocessual, and Interpretative Archaeologies: multiple ways of knowing the past. In Reader in Archaeology Theory. Post-Processual and Cognitive Approaches. WHITLEY, D.S. (Ed.). London: Routledge: 69-95.

SHANKS, M.; TILLEY, C.

1993 Re-constructing Archaeology: theory and practice. Routledge.

SILVA, C.G.P.

2012 Arqueologia e Museu na Trajetória Histórica de Ary Pinheiro. Históira e História, s/p.

SILVA, E.D.

2011 A ocupação pré-colonial na Cachoeira do Teotônio: abordagem tecnológica da cultura material cerâmica dos sítios Santa Paula e Teotônio. Relatório PIBIC/UNIR. Porto Velho/RO.

SILVA, F.A.

2000 As Tecnologias e seus Significados: um estudo da cerâmica dos Asurini do Xingú e da cestaria dos Kayapó-Xikrin sob uma perspectiva. Tese de Doutorado, USP, São Paulo.

2008 Ceramic Technology of the Asurini do Xingu, Brazil: an Ethnoarchaeological Study of Artifact Variability. Journal of Archaeological Method and Theory, 15: 217-265.

SILVA, F.A.; BESPALEZ, E.; STUCHI, F.F.

2011 Arqueologia colaborativa na Amazônia: Terra Indígena Koatinemu, Rio Xingu, Pará. Amazônica - Revista de Antropologia, 3: 32-59.

SILVA, F.A.; STUCHI, F.F.

2010 Evidências e significados da mobilidade territorial: a terra indígena Kaiabi (Mato Grosso, Pará). Amazônica - Revista de Antropologia, 2: 38-59.

SILVA, M.A.

2011 Pesquisas arqueológicas, museológicas e questões locais no contexto amazônico: desafios para realização de práticas colaborativas. Projeto de Mestrado, MAE-USP.

SILVEIRA, M. I.; RODRIGUES, M. C. L. F.; OLIVEIRA, E. R.; LOSIER, L.

2008 Sequencia cronológica de ocupação na área do Salobo (Pará). Revista de Arqueologia, 21 (1): 61-84.

SILVEIRA, M.I.; SCHAAN, D.P.

2005 Onde a Amazônia Encontra o Mar: estudando os sambaquis do Pará. Revista de Arqueologia, 18: 67-79.

SIMÕES, M.F.

1976 Relatório Preliminar $-1^{\text {a }}$ Parte: Pesquisa Arqueológica no Baixo Rio Tocantins (PA). Museu Paraense Emílio Goeldi . PRONAPABA.

1977 Relatório Preliminar - 2a Parte: Pesquisa Arqueológica no Baixo Rio Tocantins (PA). Museu Paraense Emílio Goeldi.PRONAPABA.

1981 Coletores-Pescadores do Litoral do Salgado (Pará): nota preliminar. Boletim do Museu Paraense Emílio Goedi, Antropologia, 78: 1-26.

SIMÕES, M.F.; ARAUJO-COSTA, F. 
1987 Pesquisas Arqueológicas no Baixo Rio Tocantins (Pará). Belém, Revista Arqueologia, 4(1): 11-27.

SIMÕES, M.F.; CORRÊA, C.G.; MACHADO, A.L.

1973 Achados Arqueológicos no Baixo rio Fresco (Pará). Publicações Avulsas, 20: 113-141.

SIMÕES, M.F.; LOPES, D.F.

1987 Pesquisas Arqueológicas no baixo/médio Madeira (AM). Revista de Arqueologia, 4(1): 117-134.

SIMÕES, M.F.; KALKMANN, A.L.M.

1987 Pesquisas Arqueológicas no médio rio Negro (AM). Revista de Arqueologia, 4(1): 83116.

SMITH, C.B.; COHEN, M.C.L.; PESSENDA, L.C.R.; FRANÇA, M.C.; GUIMARÃES, J.T.F.

2012 Holocenic Proxies of Sedimentary Organic Matter and the Evolution of Lake ArariAmazon Region. Catena, 90: 26-38.

SOARES-PINTO, N.S.

2009 Do Poder do Sangue e da Chicha: os Wajurú do Guaporé (Rondônia). Dissertação de Mestrado, PPGAS-UFPR.

SOUZA, G.

2001 [1587] Tratado Descritivo do Brasil em 1587. Belo Horizonte: Itatiaia.

SOUZA, S.M.

1994 Deformação Craniana entre os Índios Karitiana: análise de fotos de arquivo. Boletim do Museu Paraense Emílio Goeldi, Antropologia, 10(1): 43-56.

SPIX, J.B.; MARTIUS, C.F. von

1976 Viagem pelo Brasil, 1817-1820. São Paulo: Melhoramentos.

STADEN, H.

1974 [1557] Duas Viagens ao Brasil. São Paulo: Edusp.

STAHL, P.

1984 Tropical Forest Cosmology: the cultural context of the early Valdivia occupations at Lloma Alta. PhD Dissertation. University of Illinois at Urbana-Champaign.

2006 Microvertebrate Synecology and Anthropogenic Footprints in the Forested Neotropics. In Time and Complexity in Historical Ecology. BALÉE, W.; ERICKSON, C. (Eds.). New York: Columbia University Press, pp. 127-152.

STANDAGE, T.

2005 A History of the World in 6 Glasses. New York: Walker.

STARK, M.T.

1998 Technical Choices and Social Boundaries in Material Culture Patterning: an introduction. In The Archaeology of Social Boundaries. STARK, M.T. (Ed.). Washington: Smithsonian Institution Press, pp. 1-11. 
STENBORG, P.; SCHAAN, D.; LIMA, A.M.A.

2012 Precolumbian land use and settlement pattern in the Santarém region, Lower Amazon. Amazônica: Revista de Antropologia 4: 222-250.

STEWARD, J.

1948 Tribes of the Montaña: an introduction. In Handbook of South American Indians III. STEWARD, J. (Ed.). Washington: Government Printing Office, pp. 507-533.

STEWARD, J; MÉTRAUX, A.

1948 Tribes of the Peruvian and Equatorian Montaña. In Handbook of South American Indians III. STEWARD, J. (Ed.), Washington: Government Printing Office, pp. 535-656.

SUÑER, R.A.

2010 Variabilidade Arqueológica no Médio Rio Ji-Paraná. Projeto de Doutorado, MAE-USP. SUSNIK, B.

1975 Dispersion Tupi-Guarani Prehistorica. Asuncion: Museu Etnografico “Andres Barbero".

SZTUTMAN, R.

2008 Cauim, substância e efeito: sobre o consumo de bebidas fermentadas entre os ameríndios. In Drogas e Cultura: novas perspectivas. LABATE et al. (Eds.). Salvador: EDUFBA, pp. 219-250.

TAMANAHA, E.K.

2012 Ocupação Polícroma no baixo e médio rio Solimões, estado do Amazonas. Dissertação de Mestrado, MAE-USP.

TAYLOR, A.C.

1999 The Western Margins of Amazonia from the early Sixteenth Century to the early Nineteenth Century. In The Cambridge History of Native Peoples of the Americas, vol. III: South America (pt. 2). SALOMON, F. and SHWARTZ, S.B. (Eds.). Cambridge: Cambrige University Press, pp. 188-256.

THEVET, A.

1978 As Singularidades da França Antartica. Belo Horizonte/São Paulo: Itatiaia/Edusp.

TILLEY, C.

1993 Introduction. In Interpretative Archaeology. TILLEY, C. (Ed.). Oxford: Berg \& Providence, pp. 1-27.

TIZUKA, M.M.

2012 Geoarqueologia e Paleohifrologia da Planície Aluvial Holocênica do rio Madeira entre Porto Velho e Abunã/RO. Amazônica - Revista de Antropologia, 4(1): 252-257.

2013 Geoarqueologia e Paleohidrologia da Planicie Aluvial Holocênica do rio Madeira entre Porto Velho e Abunã. Dissertação de Mestrado. Departamento de Geologia, UNESP-Rio Claro.

TRINDADE, T. 
2012 Levantamento e prospecção dos sítios arqueológicos com estruturas de terra antrópicas no Sudoeste do Estado de Rondônia. Projeto de Mestrado, MAE-USP.

URBAN, G.

1992 A História da Cultura Brasileira Segundo as Línguas Nativas. In História dos Índios no Brasil. CUNHA, M. C. (Org.). São Paulo: Companhia das Letras, pp. 87-102.

1996 On the Geographical Origins and Dispersion of the Tupian Languages. São Paulo-SP, USP, Revista de Antropologia, 39(2): 61-104.

VANDER VELDEN, F.

2010 De Volta ao Passado: territorialização e "contraterritorialização" na história Karitiana. Sociedade e Cultura: 13(1): 55-65.

(manuscrito não publicado) Os Tupi de Rondônia: diversidade, estado do conhecimento e propostas de investigação.

VALLE, R.B.M.

2012 Mentes Graníticas e Mentes Areníticas: Fronteira Geo-Cognitiva nas Gravuras Rupestres no baixo rio Negro, Amazônia Setentrional. Tese de Doutorado, MAE-USP.

VIDAL, J.J.A.

2011 A cerâmica do povo Paiter Suruí de Rondônia: continuidade e mudança cultural, 19702010. Dissertação de Mestrado, Instituto de Artes "Julio de Mesquista Filho", Universidade Estadual Paulista.

VIDAL, L.

1983 O Espaço Habitado entre os Kaiapó-Xikrim (Jê) e os Parakanã (Tupi) do Médio Tocantins, Pará. In Habitações Indígenas. NOVAES, S.C. (org.). Nobel/EDUSP, São Paulo.

1985a Parakanã. In Arte e Corpo: pintura sobre a pele e adornos de povos indígenas brasileiros. FUNARTE/Instituto Nacional de Artes Plásticas, pp. 53-55.

1985b Arte Gráfica Juruna. In Arte e Corpo: pintura sobre a pele e adornos de povos indígenas brasileiros. FUNARTE/Instituto Nacional de Artes Plásticas, pp. 75-82.

VIDOTTO, E.; PERSSENDA, L.C.R.; RIBEIRO, A.S.; FREITAS, H.A.; BENDASSOLLI, J.A.

2007 Dinâmica do Ecótono Floresta-Campo no sul do Estado do Amazonas no Holoceno, Através de Estudos Isotópicos e Fitossociológicos. Acta Amazônica, 37(3): 385-400.

VIEIRA, A.

[1655 a 1659] 1997 Cartas (vol. 1). AZEVEDO, J. L. (Org.). Biblioteca de Autores Portugueses.

VILAÇA, A.

2010 Strange Enemies: indigenous agency and scenes of encounters in Amazonia. Duke University Press: Durham and London.

VIVEIROS DE CASTRO, E.B.

1986 Araweté: os Deuses Canibais. Jorge Zahar, Rio de Janeiro.

2002 A Inconstância da Alma Selvagem. Cosac \& Naify, São Paulo. 


\section{WAGLEY, C.}

1977 Welcome of Tears: the Tapirapé Indians of central Brazil. New York: Oxford University Press.

WALKER, R.S.; WICHMANN, S.; MAILUND, T.; ATKINSON, C.J.

2012 Cultural Phylogenetics of the Tupi Language in Lowland South America. Plos One, 7(4): $1-9$.

WEBER, R.L.R.

1975 Caimito: an analysis of the late prehistoric culture of the central Ucayali. PhD Dissertation. University of Illinois at Urbana-Champaign.

WEISS, G.

1972 Campa Cosmology. Ethnology, 11(2): 157-172.

WENZEL, E.G.

1986 Em Torno da Panela Apiaká. Dissertação de Mestrado. FFLCH-USP, São Paulo.

WHITEHEAD, N.L.

1999 Native People Confront Colonial Regimes in Northeastern South America (c. 15001900). The Cambridge History of Native Peoples of the Americas, vol. III: South America (pt. 2). SALOMON, F.; SHWARTZ, S.B. (Eds.). Cambridge: Cambrige University Press, pp. 382-442.

WIESSNER, $\mathrm{P}$.

1983 Style and Social Information. American Antiquity, 48(2): 253-276.

1991 Is There a Unity to Style? In The Uses of Style in Archaeology. CONKEY M.; HASFORD C. (Eds.); Cambridge: Cambridge University Press, pp. 105-112.

WILLEY, G.R; PHILLIPS, P.

1958 Method and Theory in American Archaeology. Chicago: University of Chicago Press.

WILLIAMS, R.

1991 O Povo das Montanhas Negras. São Paulo: Companhia das Letras.

WOBST, H.M.

1977 Stylistic Behavior and Information Exchange. In For the Direction: research essays in honor of James B. Griffin. CLEVELAND, C. (Ed.). University of Michigan, pp. 317-342.

WÜST, I.

2001 Relatório Final: Resgate dos Sítios Arqueológicos Guapé 1 e 2 na Área das Obras Construtivas da UHE-Guaporé/MT. Museu Antropológico, UFG.

WÜST, I.; BARRETO, C.

1999 The Ring Villages of Central Brazil: a challenge for Amazonian archaeology. Latin American Antiquity, 10(1): 3-23.

ZEDEÑO, M.N.; BOWSER, B.J.

2009 The Archaeology of Meaningful Places. In The Archaeology of Meaningful Places. BOWSER, B.J.; ZEDEÑO, M.N. (Eds.). Salt Lake City: University of Utah Press, pp. 1-14. 


\section{ZEIDLER, J.A.}

1983. La etnoarqueología de una vivienda Achuar y sus implicaciones arqueológicas. Miscelánea Antropológica Ecuatoriana 3: 155-193.

Antropológica Ecuatoriana 3: 155-193. Guayaquil: Banco Central del Ecuador.1995 Archaeological Survey and Site Discovery in the Forest Neotropics. In Archaeology in the Lowland Tropics: current analytical methods and applications. STAHL, P.W. (Ed.). Cambridge: Cambridge University Press, pp. 7-41.

ZIMPEL NETO, C.A.

$2009 \mathrm{Na}$ direção das periferias extremas da Amazônia: Estudo da Arqueologia na Bacia do Rio Jiparaná, Rondônia. Dissertação de Mestrado, MAE-USP.

\section{ZUCCHI, A.}

2002 A New Modelo of the Northern Arawakan Expansion. In Comparative Arawakan Studies: rethinking language family and culture area in Amazonia. HILL, J.; SANTOSGRANERO, F. (Eds.). Urbana and Chicago: University of Illinois Press, pp. 199-222.

\section{ZUSE, S.}

2011 Ocupações Pré-Coloniais e Variabilidade Cerâmica nos Sítios Arqueológicos do alto rio Madeira, Rondônia. Memorial de qualificação de doutorado, MAE-USP. 


\section{A TRADIÇÃO POLÍCROMA NO ALTO RIO MADEIRA}

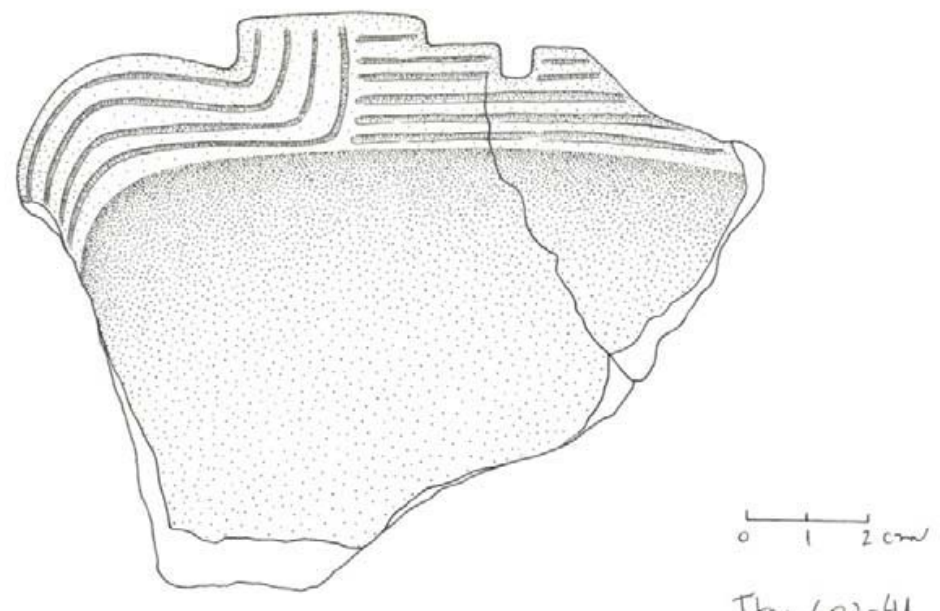

Ita. $602-41$

Fernando Ozorio de Almeida

Volume 2

São Paulo 


\section{A TRADIÇÃo POLÍCROMA NO ALTO RIO MADEIRA}

\section{Volume 2}

Tese apresentada ao Programa de PósGraduação em Arqueologia do Museu de Arqueologia e Etnologia da Universidade de São Paulo para obtenção do título de Doutor em Arqueologia

Área de Concentração: Arqueologia

Orientador: Prof. Dr. Eduardo Góes Neves

Linha de Pesquisa: Processos de Formação e Transformação Social

São Paulo 
ANEXOS 


\section{ANEXO 1}

Fases do Baixo Tocantins

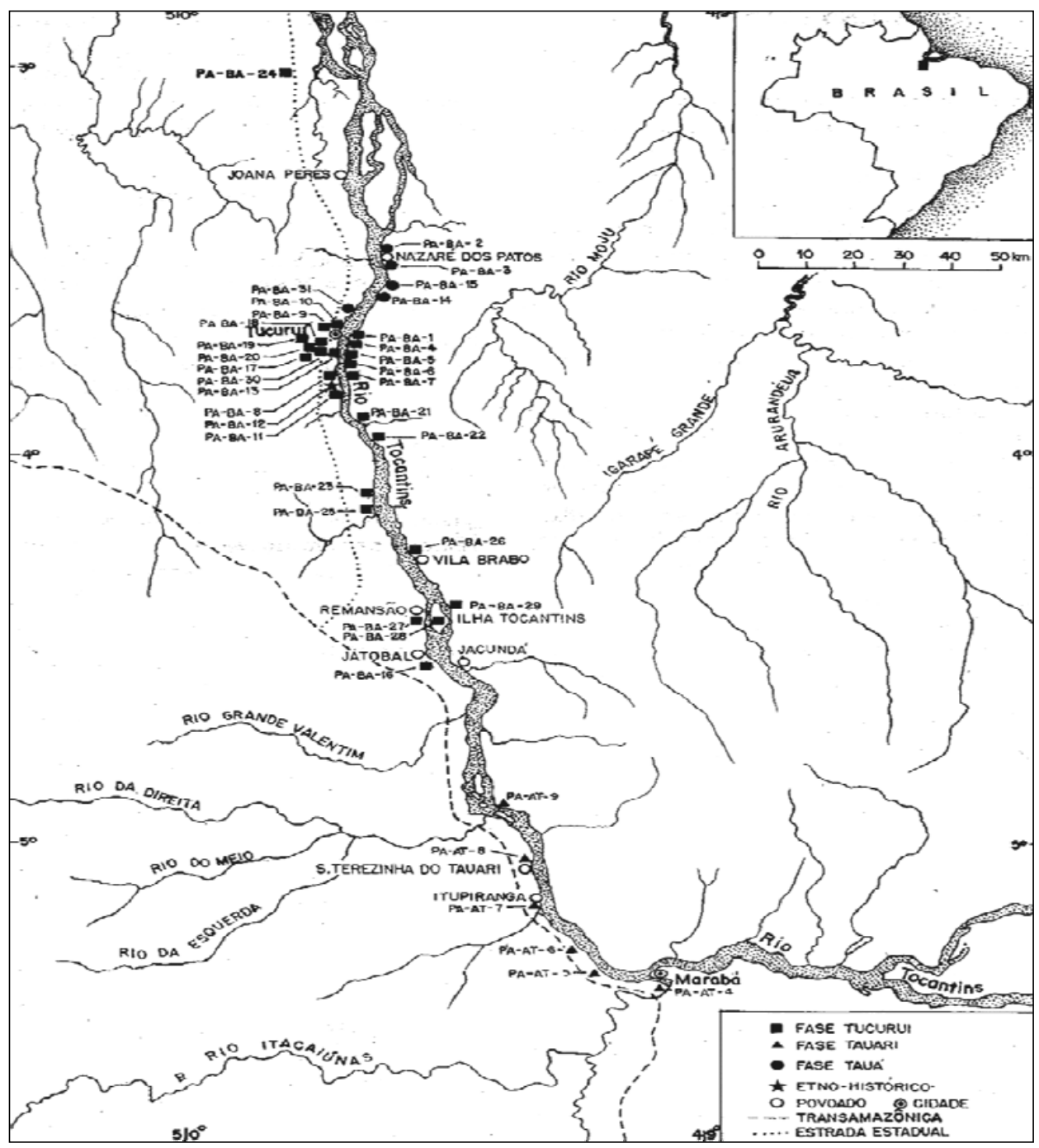


ANEXO 2 

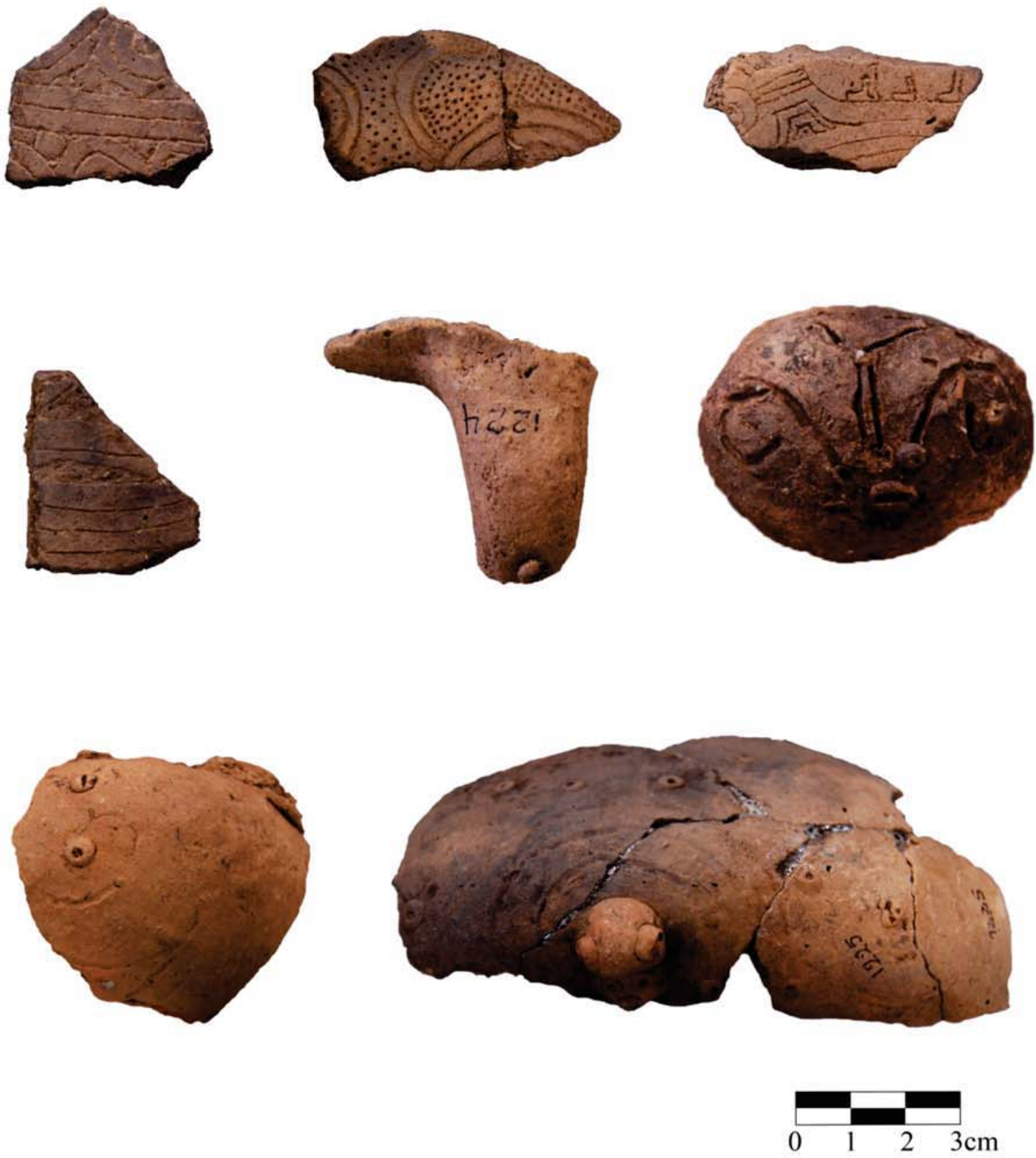

\begin{tabular}{|c|c|c|}
\hline \multirow[b]{2}{*}{ SÍTIO CAMARGO } & \multicolumn{2}{|l|}{ TESE DE DOUTORADO } \\
\hline & \multicolumn{2}{|c|}{$\begin{array}{l}\text { A TRADIÇÃO POLICCROMA DA } \\
\text { AMAZÔNIA NO ALTO RIO MADEIRA }\end{array}$} \\
\hline \multirow{2}{*}{ FRAGMENTOS COM DECORAÇĀO PLÁSTICA } & Aluno: Fernando Ozorio de Almeid & Orientador: Eduardo Góes Neves \\
\hline & \multicolumn{2}{|c|}{ Programa de Pós-Graduação - Museu de Arqueologia e Etnologia } \\
\hline PRANCHA 1 & Arte Final: Eduardo Tamanaha & E AFAPESP \\
\hline
\end{tabular}



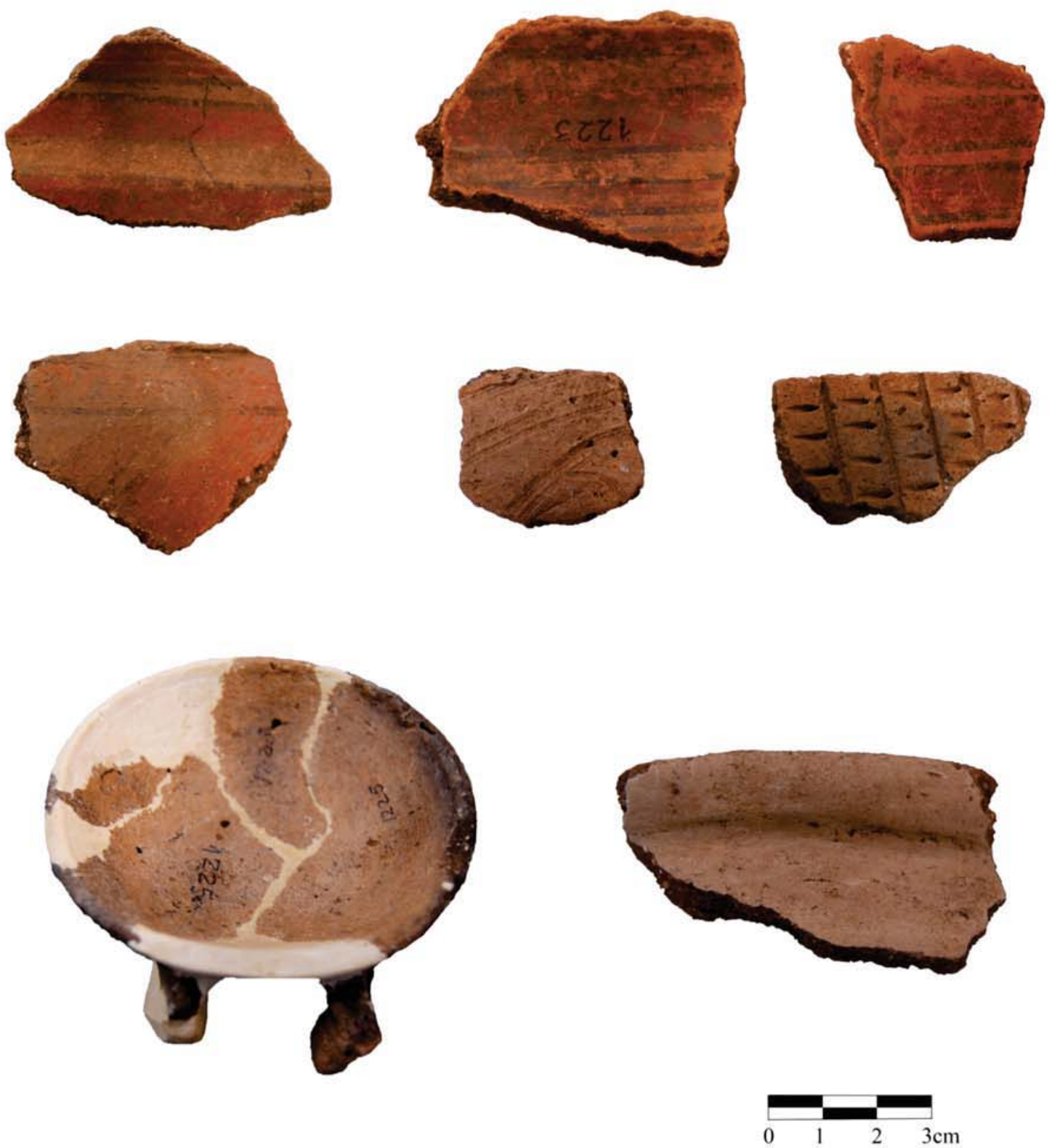

\begin{tabular}{|c|c|c|}
\hline \multirow[b]{2}{*}{ SÍTIO CAMARGO } & \multicolumn{2}{|l|}{ TESE DE DOUTORADO } \\
\hline & \multicolumn{2}{|c|}{$\begin{array}{c}\text { A TRADIÇÃO POLICCROMA DA } \\
\text { AMAZÔNIA NO ALTO RIO MADEIRA }\end{array}$} \\
\hline \multirow{2}{*}{ FRAGMENTOS COM DECORAÇĀO PLÁSTICA E PINTADA } & Aluno: Fernando Ozorio de Almei & Orientador: Eduardo Góes Neves \\
\hline & \multicolumn{2}{|c|}{ Programa de Pós-Graduação - Museu de Arqueologia e Etnologia } \\
\hline PRANCHA 2 & Arte Final: Eduardo Tamanaha & MAE JFAPESP \\
\hline
\end{tabular}




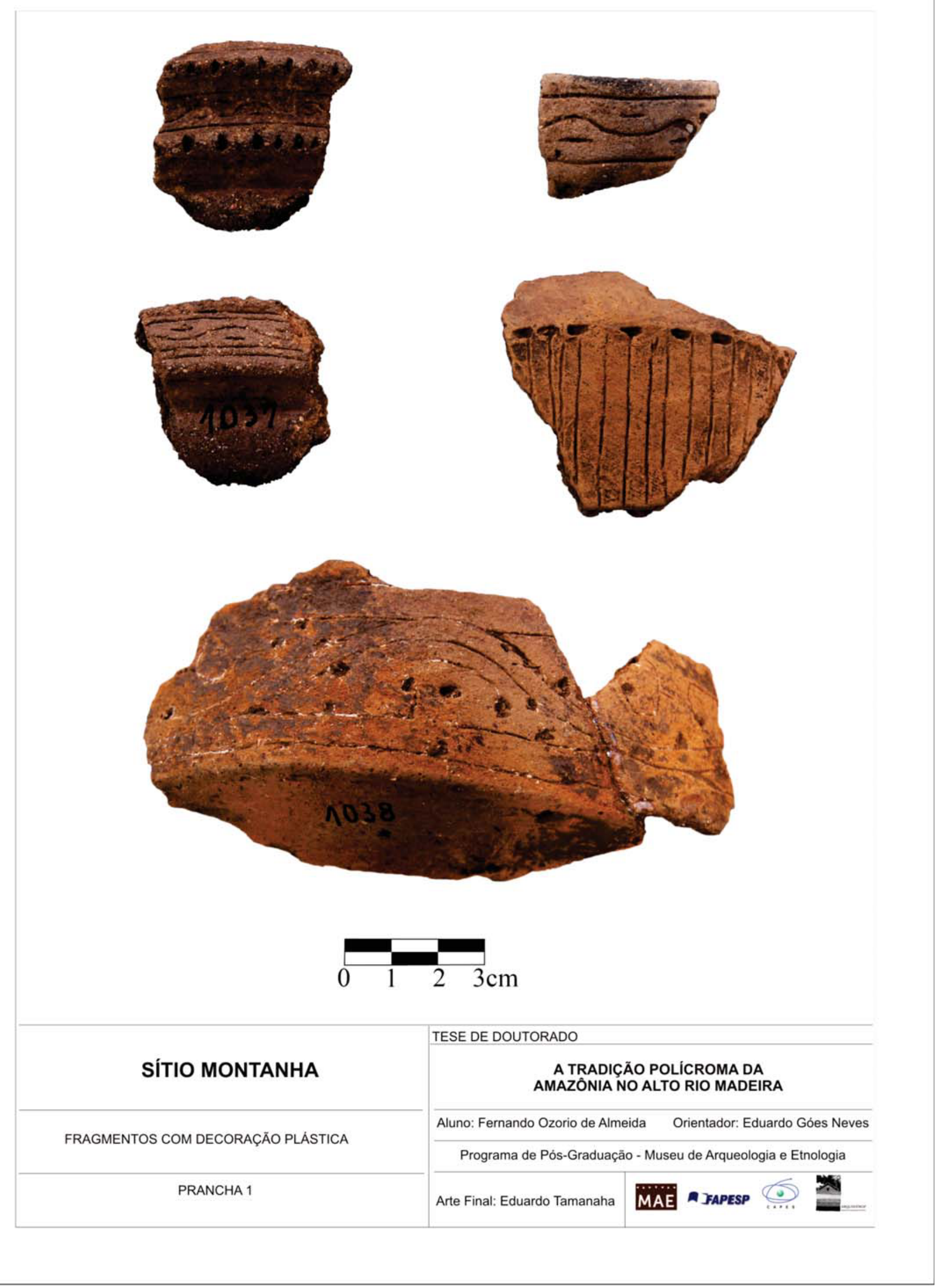



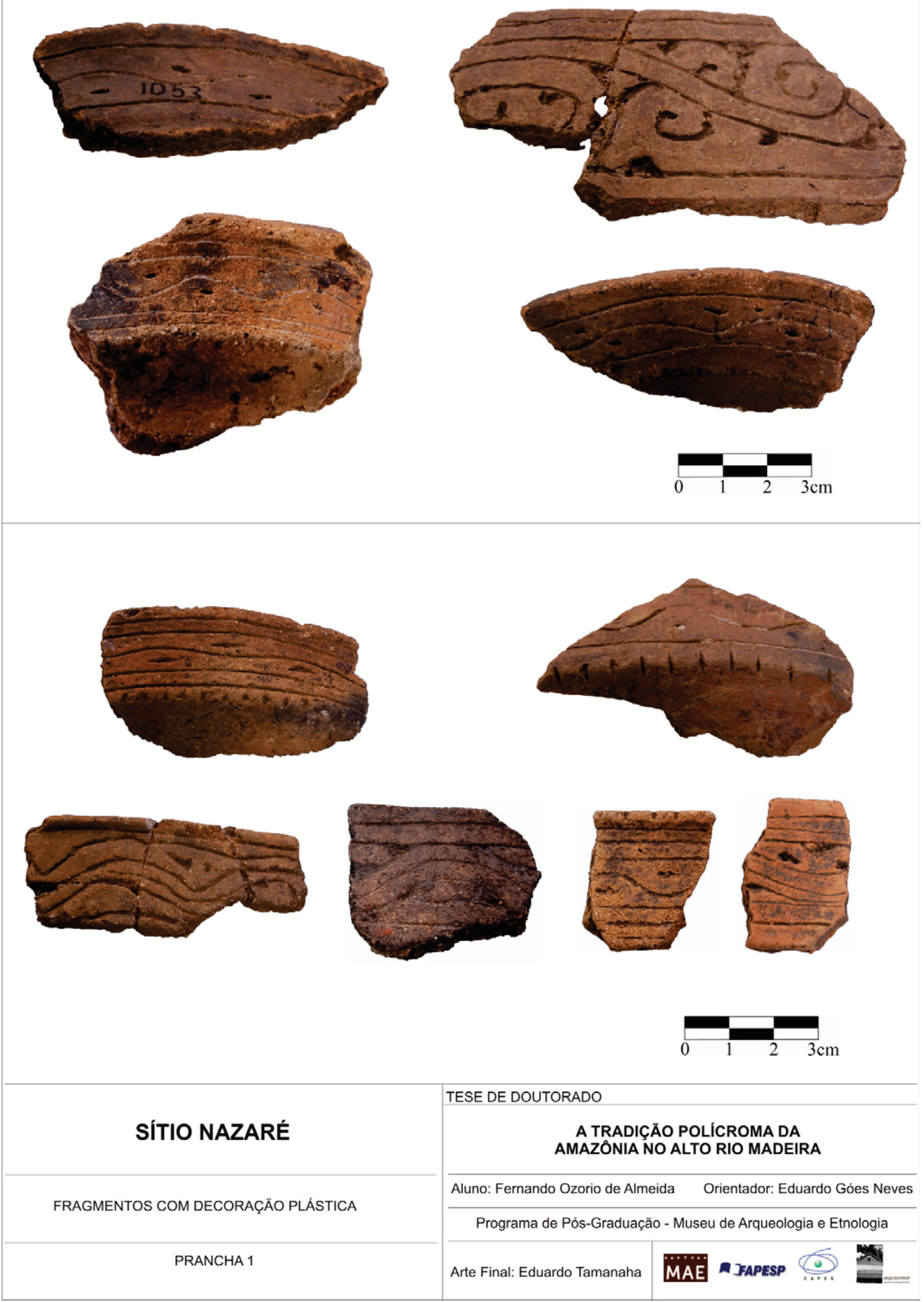


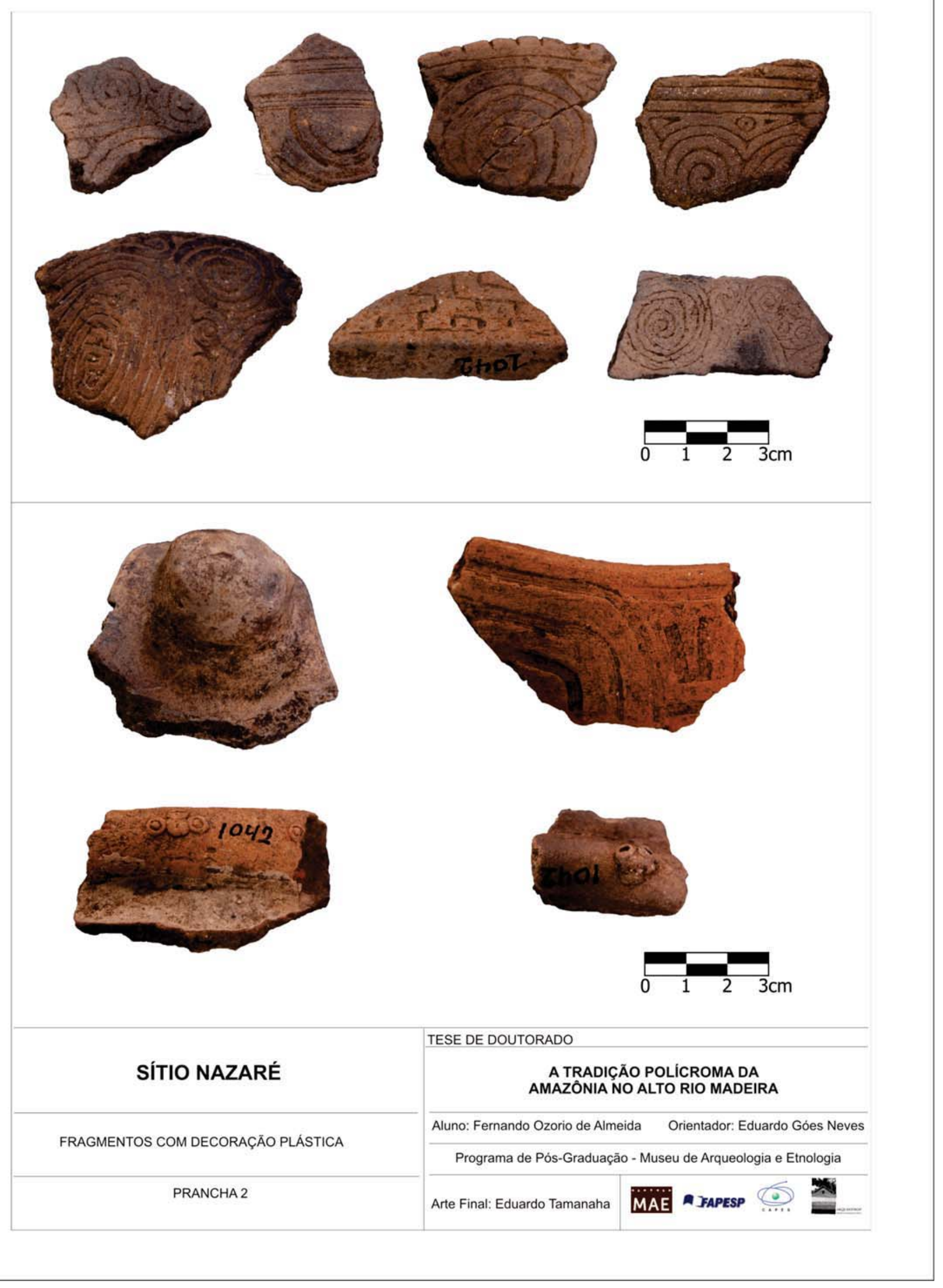


ANEXO 3 

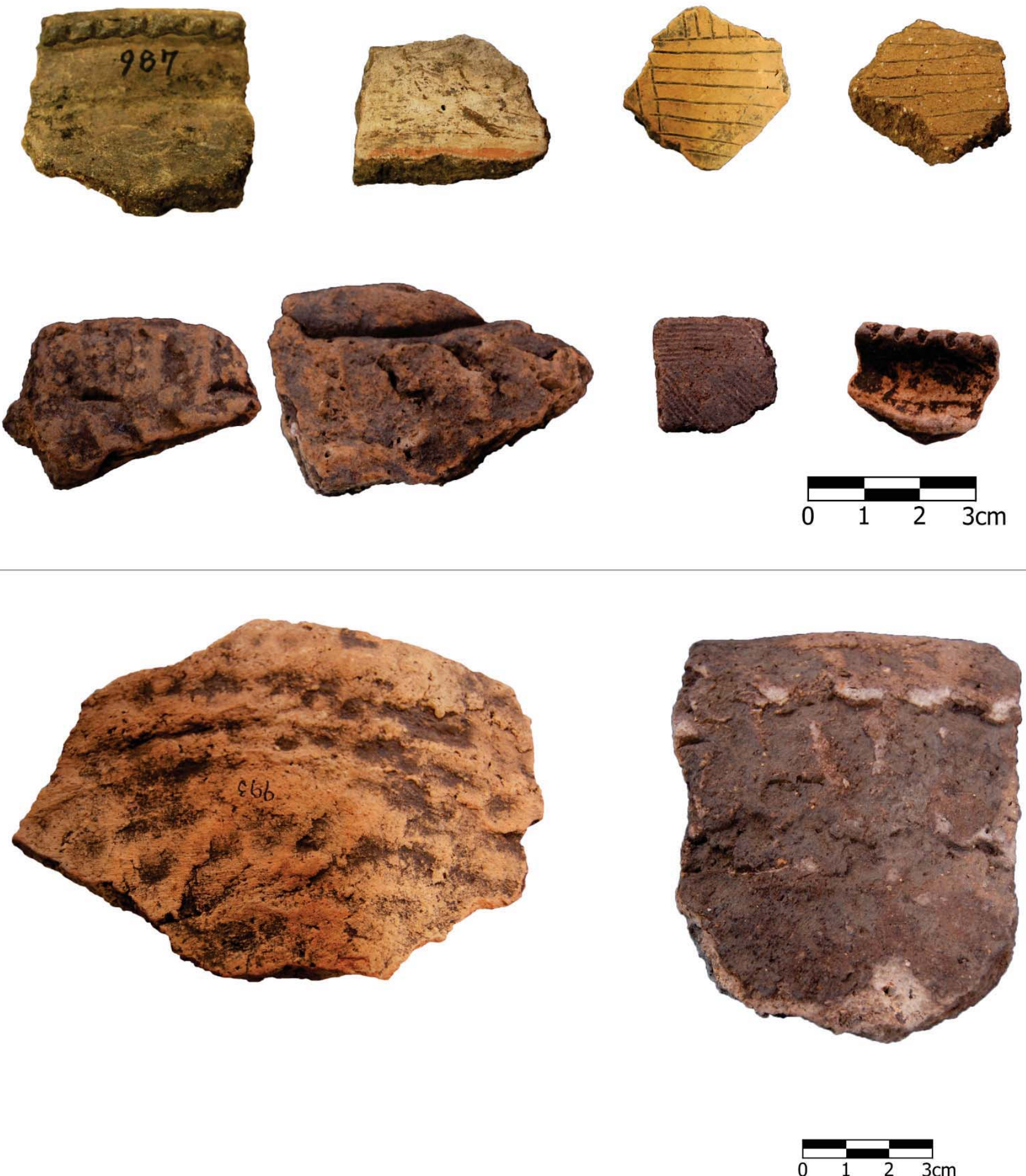

\begin{tabular}{|c|c|c|}
\hline \multirow[b]{2}{*}{ SÍTIO SÃO JOSÉ } & \multicolumn{2}{|l|}{ TESE DE DOUTORADO } \\
\hline & \multicolumn{2}{|c|}{$\begin{array}{l}\text { A TRADIÇÃO POLÍCROMA DA } \\
\text { AMAZÔNIA NO ALTO RIO MADEIRA }\end{array}$} \\
\hline \multirow{2}{*}{ FRAGMENTOS COM DECORAÇÃO PLÁSTICA } & Aluno: Fernando Ozorio de Alme & Orientador: Eduardo Góes Neves \\
\hline & \multicolumn{2}{|c|}{ Programa de Pós-Graduação - Museu de Arqueologia e Etnologia } \\
\hline PRANCHA 1 & Arte Final: Eduardo Tamanaha & MAE JFAPESP \\
\hline
\end{tabular}




\section{ANEXO 4}

Fases e Tradições Arqueológicas do Baixo Xingu (Fonte: Perota 1992)

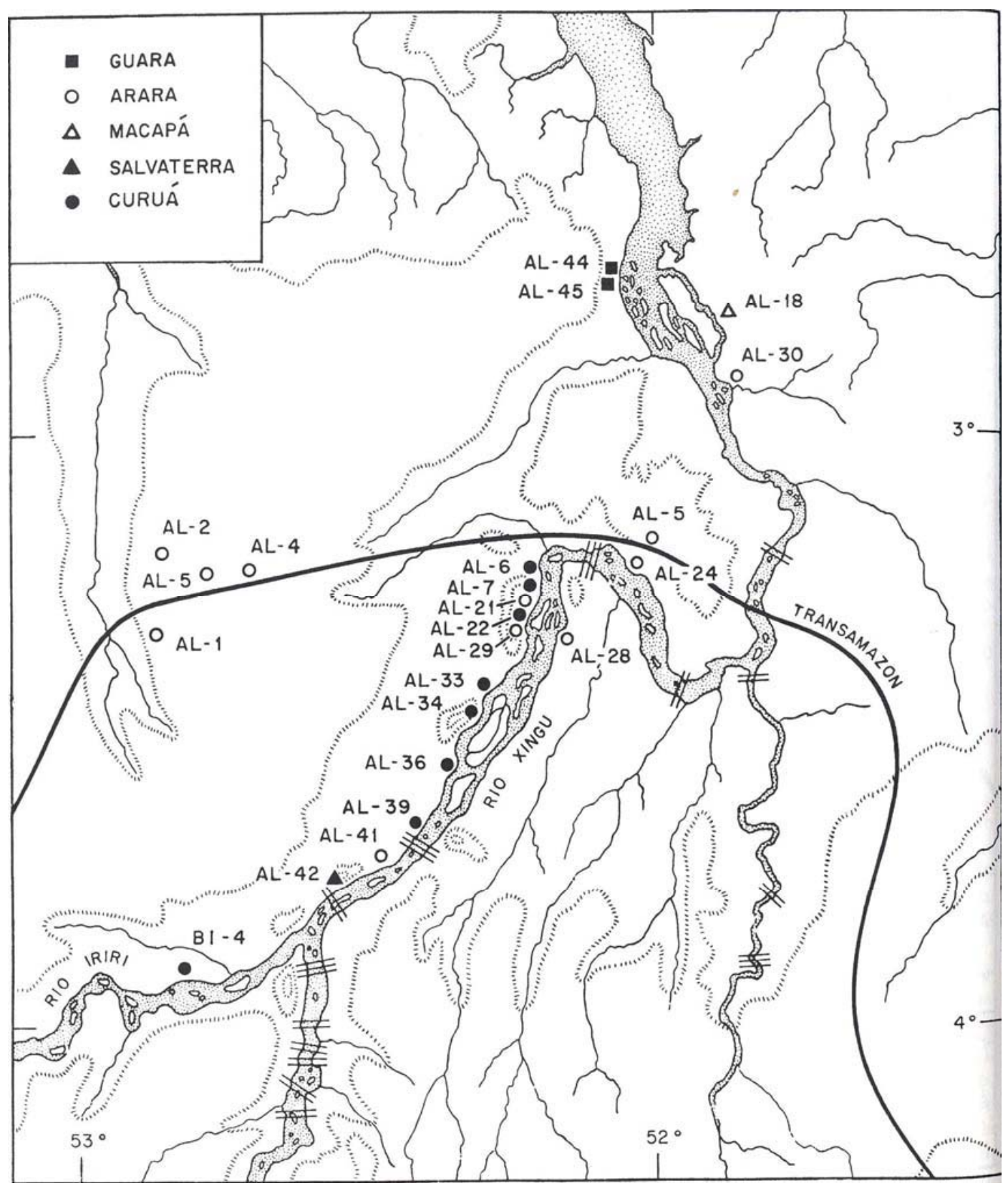




\section{ANEXO 5:}

Divisão dos Subconjuntos linguísticos da Família Tupi-Guarani (fonte: Rodrigues 1984/85

\begin{tabular}{|l|}
\hline \multicolumn{1}{|c|}{ SUBCONJUNTO I } \\
\hline Guarani antigo \\
\hline Mbyá \\
\hline Xetá \\
\hline Ñandevá \\
\hline Kaowá \\
\hline Guarani paraguaio \\
\hline Guaiakí \\
\hline Tapieté \\
\hline Chiriguáno \\
\hline Izoceño \\
\hline
\end{tabular}

\begin{tabular}{|l|}
\hline \multicolumn{1}{|c|}{ SUBCONJUNTO II } \\
\hline Guarayo \\
\hline Sirionó \\
\hline Horá \\
\hline
\end{tabular}

\begin{tabular}{|l|}
\hline \multicolumn{1}{|c|}{ SUBCONJUNTO III } \\
\hline Tupinambá \\
\hline Língua geral paulista \\
\hline Língua geral amazônica \\
\hline Kokama \\
\hline Kokamya \\
\hline Omágua \\
\hline
\end{tabular}

\begin{tabular}{|l|}
\hline \multicolumn{1}{|c|}{ SUBCONJUNTO IV } \\
\hline Tapirapé \\
\hline Avá \\
\hline Asuriní do Tocantins \\
\hline Suruí do Tocantins \\
\hline Parakaña \\
\hline Guajajára \\
\hline Tembé \\
\hline
\end{tabular}

\begin{tabular}{|l|}
\hline \multicolumn{1}{|c|}{ SUBCONJUNTO V } \\
\hline Kayabi \\
\hline Asuriní do Xingu \\
\hline Araweté \\
\hline
\end{tabular}

\begin{tabular}{|l|}
\hline \multicolumn{1}{|c|}{ SUBCONJUNTO VI } \\
\hline Parintintín \\
\hline Kagwahiva \\
\hline Apiaká \\
\hline
\end{tabular}

\begin{tabular}{|l|}
\hline \multicolumn{1}{|c|}{ SUBCONJUNTO VIII } \\
\hline Takunyapé \\
\hline Waiãpi \\
\hline Waiãpipuku \\
\hline Emerillon \\
\hline Amanayé \\
\hline Anambé \\
\hline Turiwára \\
\hline Guajá \\
\hline Urubu-káapor \\
\hline
\end{tabular}

\section{SUBCONJUNTO VII}

Kamayurá 


\section{ANEXO 6}

Mapa com a distribuição de etnias no sudoeste amazônico (fonte: Roquette-Pinto 1975

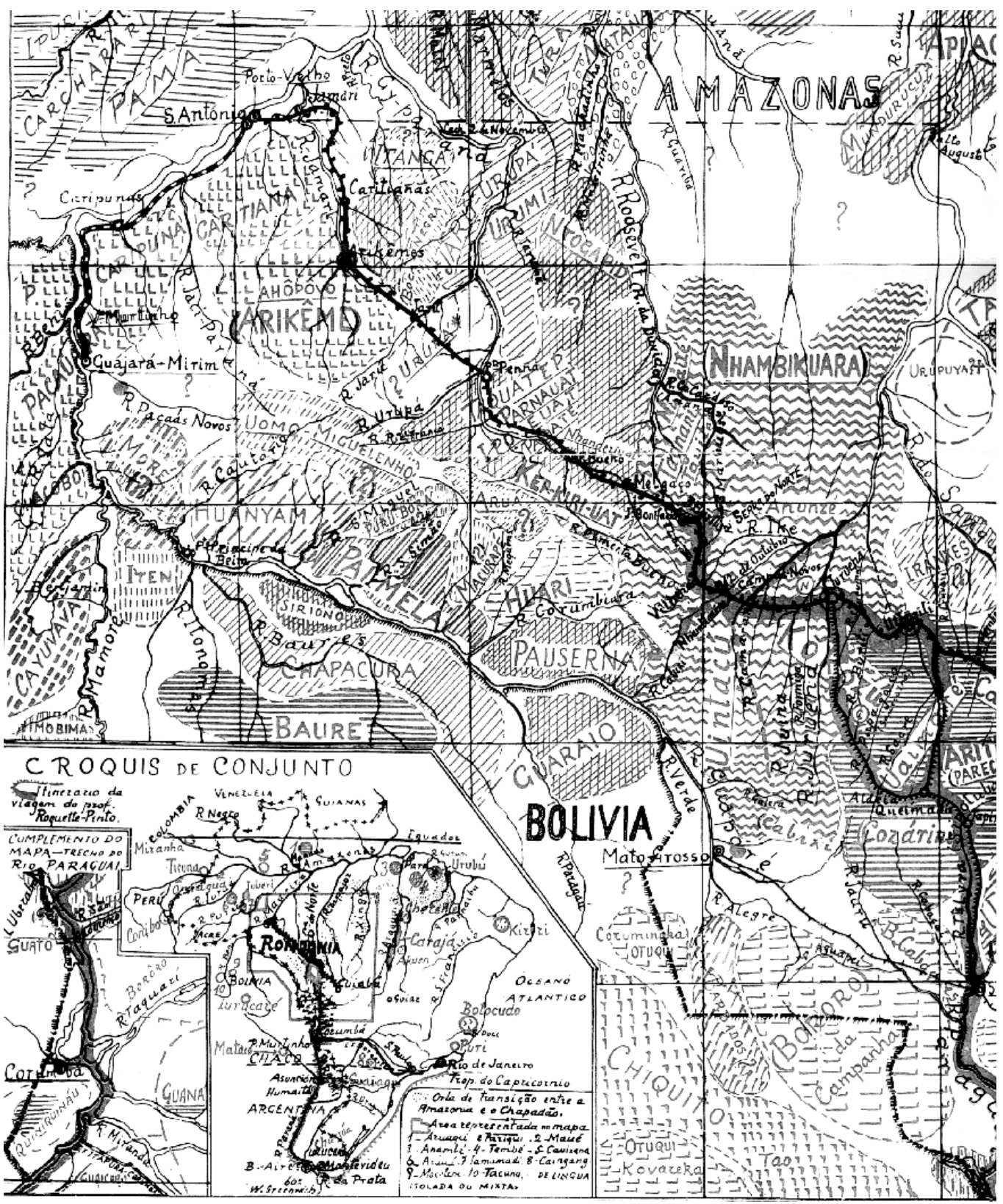


ANEXO 7 


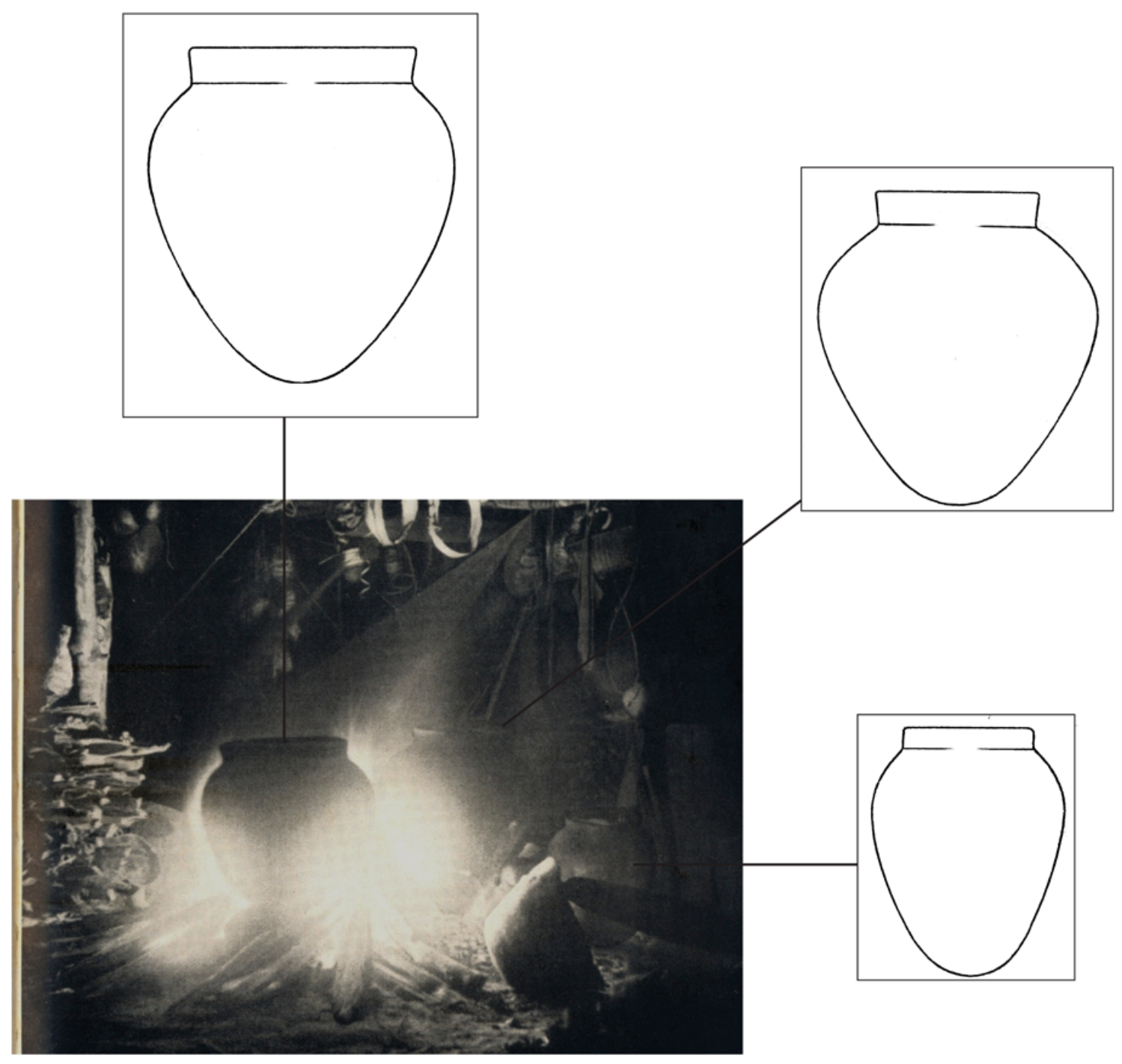

\section{Cerâmica Tupari}

Acervo Fotográfico Franz Caspar (1953, 1958)

PRANCHA 1
TESE DE DOUTORADO

A TRADIÇÃO POLÍCROMA DA AMAZÔNIA NO ALTO RIO MADEIRA

Aluno: Fernando Ozorio de Almeida

Orientador: Eduardo Góes Neves

Programa de Pós-Graduação - Museu de Arqueologia e Etnologia

Desenhos: Erêndira Oliveira

Arte Final: Eduardo Tamanaha

MAI A JAPESP

柴

Fernando Almeida 


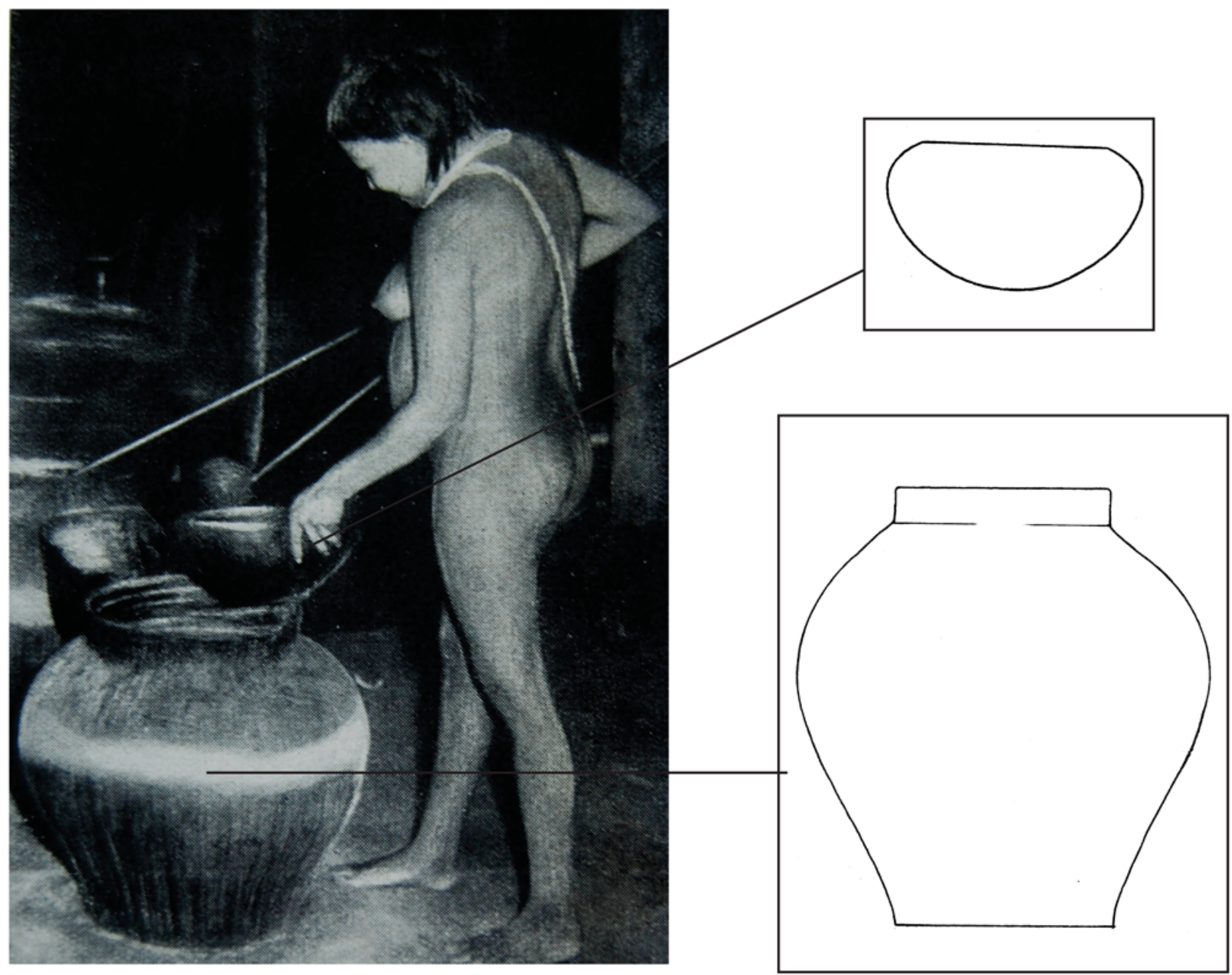

\section{Cerâmica Tupari}

Acervo Fotográfico Franz Caspar $(1953,1958)$

PRANCHA 2
TESE DE DOUTORADO

\section{A TRADIÇÃO POLÍCROMA DA AMAZÔNIA NO ALTO RIO MADEIRA}

Aluno: Fernando Ozorio de Almeida Orientador: Eduardo Góes Neves

Programa de Pós-Graduação - Museu de Arqueologia e Etnologia

Desenhos: Erêndira Oliveira

Arte Final: Eduardo Tamanaha

Fernando Almeida

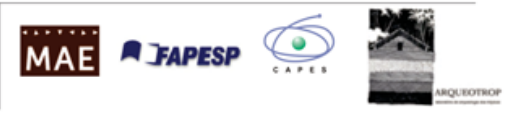



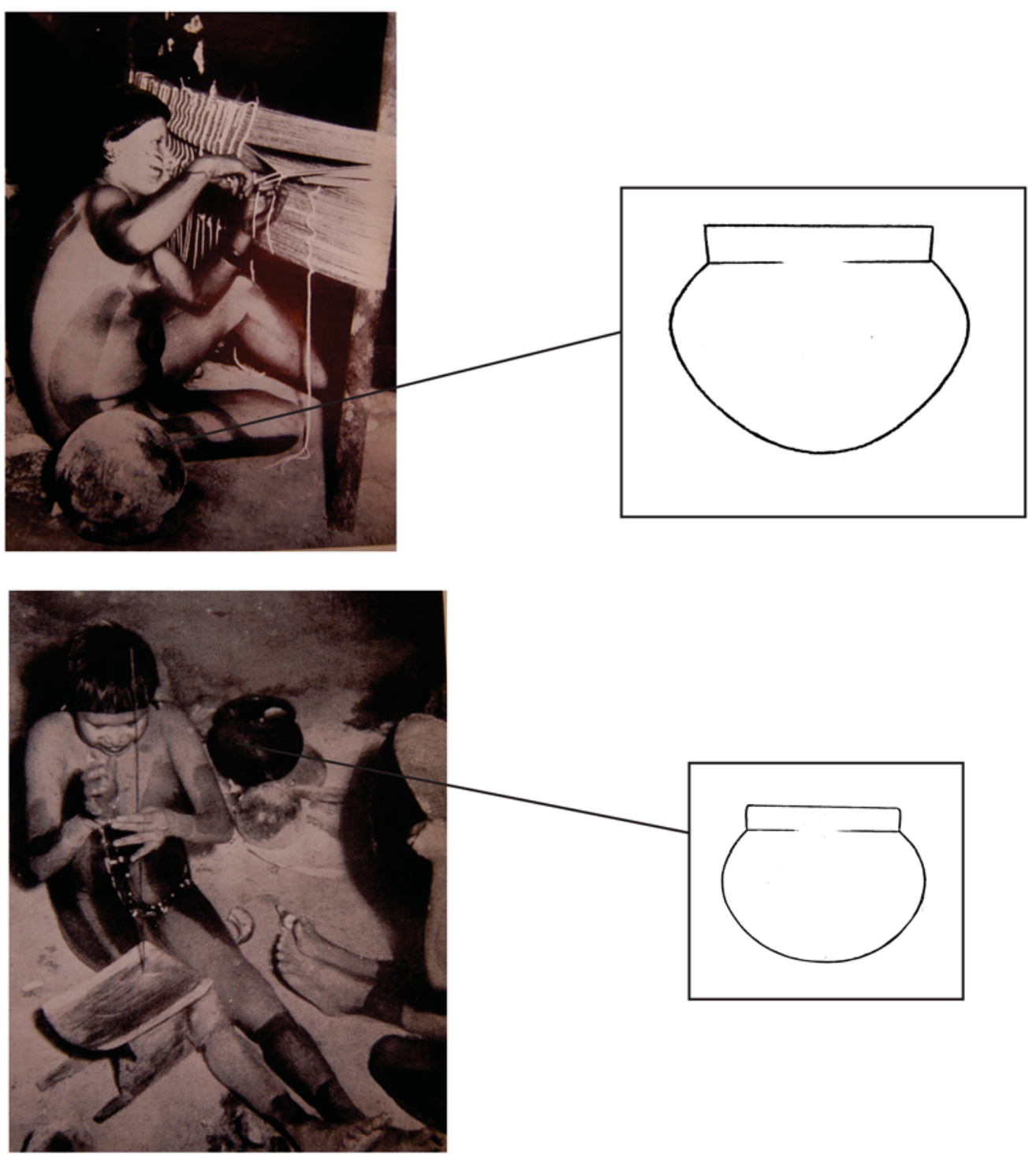

\section{Cerâmica Tupari}

Acervo Fotográfico Franz Caspar $(1953,1958)$

PRANCHA 3
TESE DE DOUTORADO

\section{A TRADIÇÃO POLÍCROMA DA AMAZÔNIA NO ALTO RIO MADEIRA}

Aluno: Fernando Ozorio de Almeida Orientador: Eduardo Góes Neves

Programa de Pós-Graduação - Museu de Arqueologia e Etnologia

Desenhos: Erêndira Oliveira

Arte Final: Eduardo Tamanaha

Fernando Almeida

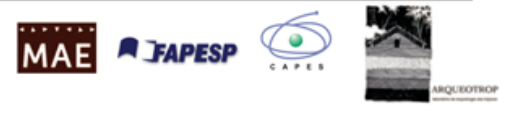



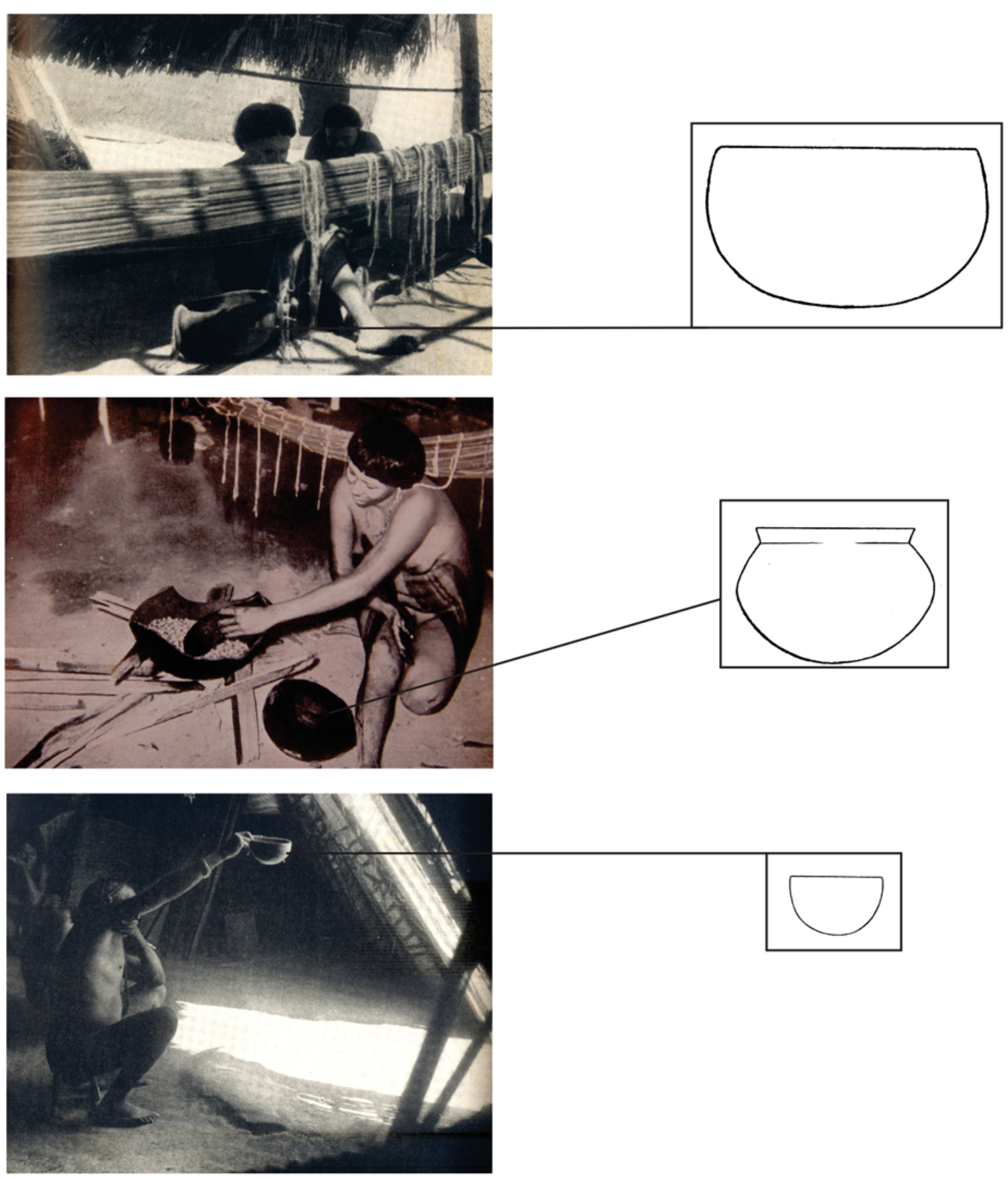

\section{Cerâmica Tupari}

Acervo Fotográfico Franz Caspar $(1953,1958)$

PRANCHA 4

TESE DE DOUTORADO

\section{A TRADIÇÃO POLÍCROMA DA AMAZÔNIA NO ALTO RIO MADEIRA}

Aluno: Fernando Ozorio de Almeida Orientador: Eduardo Góes Neves

Programa de Pós-Graduação - Museu de Arqueologia e Etnologia

Desenhos: Erêndira Oliveira

Arte Final: Eduardo Tamanaha

MAE JAPESP 
ANEXO 8: Sequencia seriada apresentada para a fase Jamari (fonte: Miller et al. 1992).

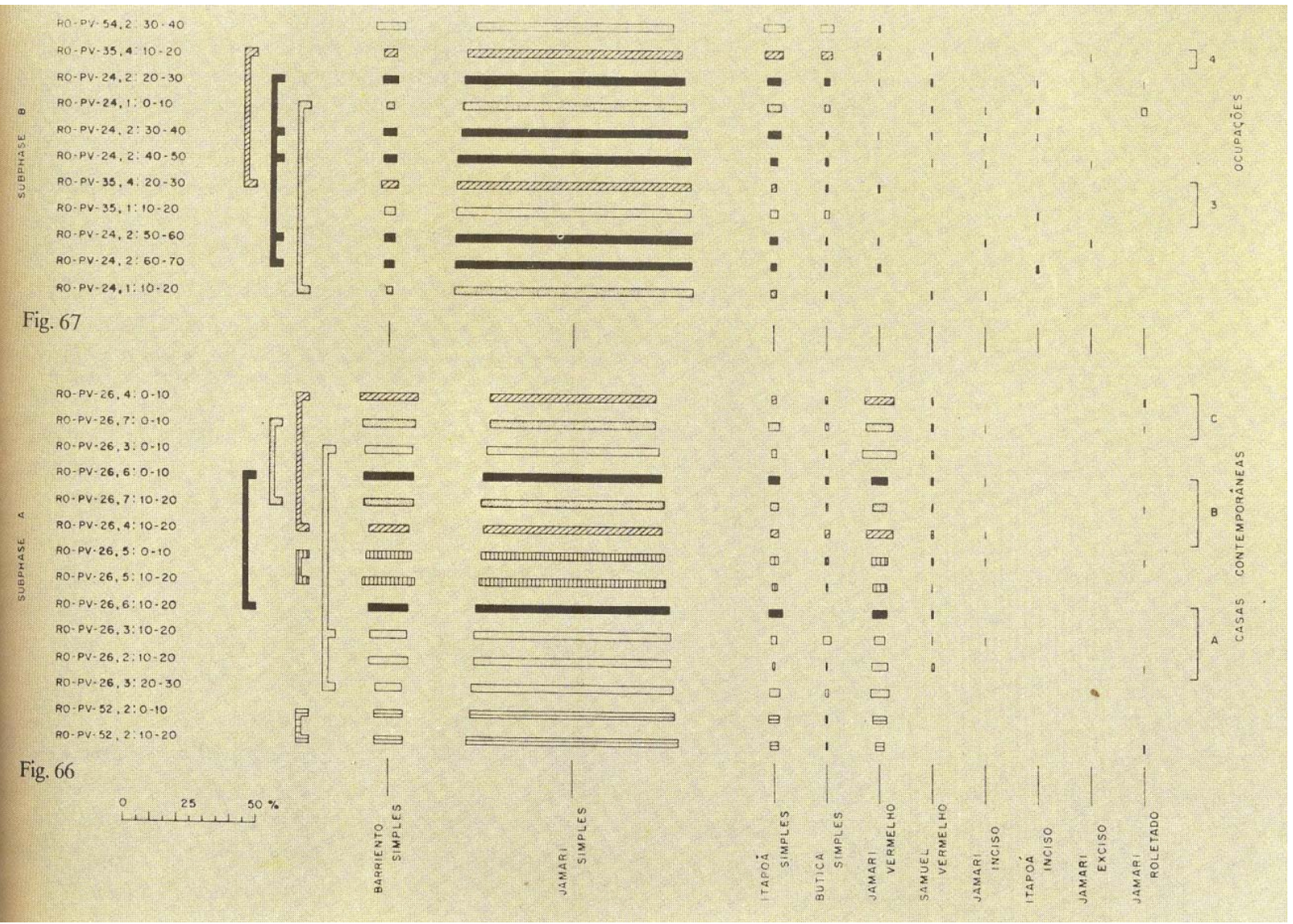




\section{ANEXO 9}

Panelas e Tigelas em Tupi-Guarani e Tupi

\begin{tabular}{|c|c|c|c|c|c|}
\hline LÍNGUA & REGIÃO & PANELA & TIGELA & PRATO & COPO \\
\hline Guarani antigo & Brasil Meridional & Yapepó & Cambuchi & Ñaé, ñaembé & $\begin{array}{l}\text { Cambuchi } \\
\text { caguabã }\end{array}$ \\
\hline Chiriguano & Bolívia & Yapepó & Cambuchi & Ñae & Cagua \\
\hline $\begin{array}{l}\text { Tupi antigo } \\
\text { (Tupinambá) }\end{array}$ & $\begin{array}{l}\text { Litoral brasileiro, } \\
\text { Maranhão até São } \\
\text { Paulo }\end{array}$ & Nhaêpepô & Kamuci & Nhaen & Caguaba \\
\hline $\begin{array}{l}\text { Língua geral } \\
\text { amazônica }\end{array}$ & $\begin{array}{l}\text { Médio-baixo } \\
\text { Amazonas }\end{array}$ & Yapepu & Camusî & $\begin{array}{l}\text { Nhaen, } \\
\text { nhaembé }\end{array}$ & \\
\hline Tembé & Maranhão & Zapêpo & Kamuti & & \\
\hline Kayabí & Xingu & lapepó & & & \\
\hline Asuriní, Xingu & Xingu & Japepaí & & & \\
\hline Parintintin & Tapajós & Nhapepo & Kamambuí & Nhaetingy'a & Y'gwav \\
\hline Apiaká & Tapajós & Nhepepo & & & \\
\hline Ká apor & Maranhão & & Kamuxi & & \\
\hline Wirafed & Madeira & Yapepoí & & & \\
\hline
\end{tabular}

Fonte: Noelli (2008b).

\begin{tabular}{|llllll|}
\hline LínGUA & REGIÃo & PANELA & TIGELA & PRATO & COPO \\
\hline Guarani antigo & Brasil Meridional & Yapepó & Cambuchi & Ñaé, ñaembé & $\begin{array}{l}\text { Cambuchi } \\
\text { caguabã }\end{array}$ \\
Supari & $\begin{array}{l}\text { Bacia do Alto } \\
\text { Madeira }\end{array}$ & Oatä & Uê, Ao & & \\
Karitiana & $\begin{array}{l}\text { Bacia do } \\
\text { Alto Madeira }\end{array}$ & $\begin{array}{l}\text { Itxirah, } \\
\text { Itxirgup }\end{array}$ & $\begin{array}{l}\text { Lobeah e } \\
\text { lobeup }\end{array}$ & Men-moyá & Soup-Soupey \\
\hline
\end{tabular}

Fonte: Noelli (2008b); Castro 2012, Landin (1983); Nogueira (2011); Ribeiro (2008). 


\section{ANEXO 10 \\ PROJETO ALTO MADEIRA \\ SÍTIO ARQUEOLÓGICO NOVA VIDA}

PERFIL NORTE - Unidade N1023 E962

\section{LEGENDA}

- Cerâmica

- Carvão

- Ambar

- Bioturbação

- Barro queimado

- Raiz

Yy Superficie

— Limite de camada definido

- Limite de camada difuso

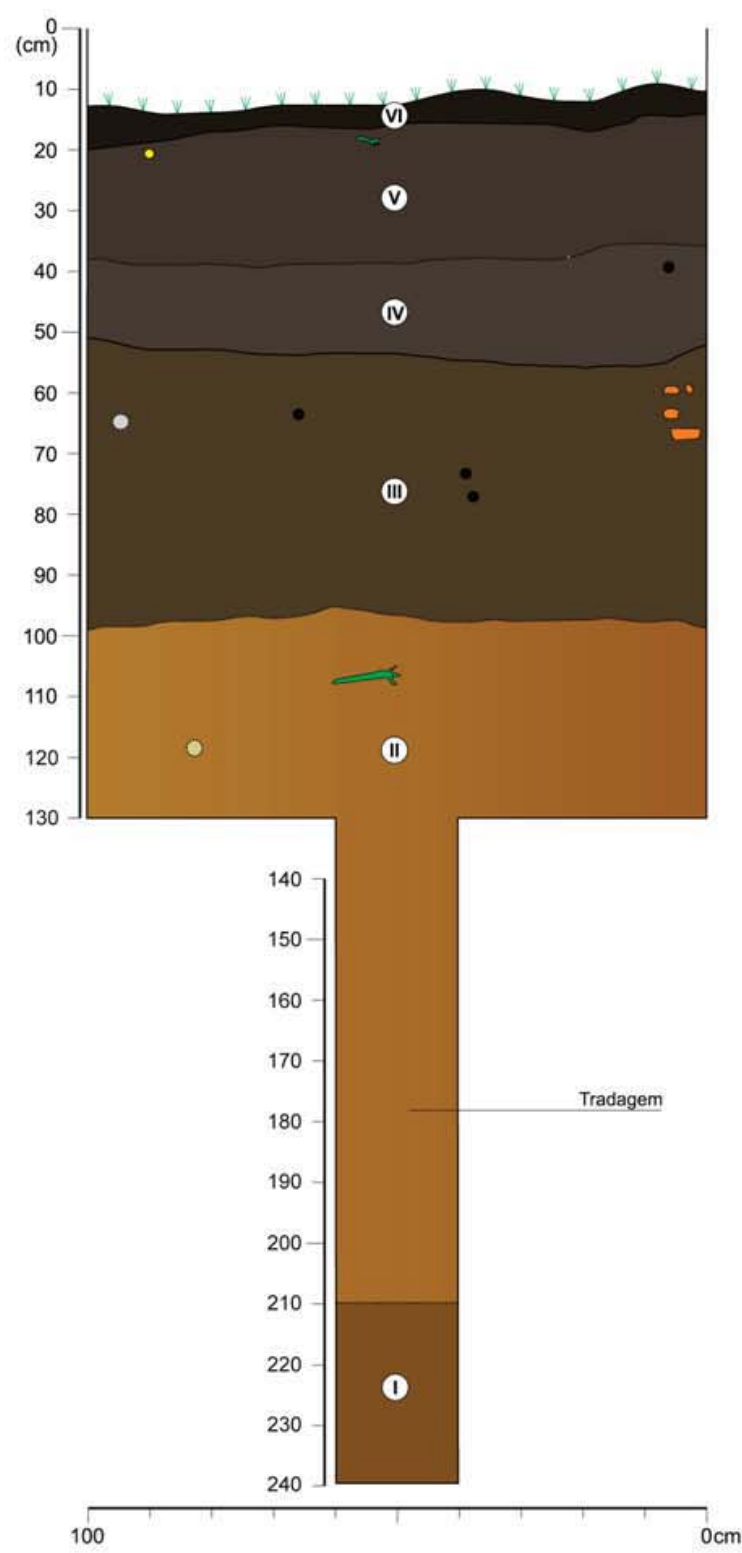

$\mathrm{cm}$

V. Sedimento areno-argiloso, orgânico, solto, com elevado número de raizes. Não foram identificados vestígios arqueológicos. Essa camada foi vinculada à cor 10YR 2/1 "black" (tabela Munsell).

(v) Sedimento areno-argiloso, levemente orgânico, solto, com baixa densidade de material arqueológico. Essa camada foi vinculada à cor 10YR 3/3 "dark brown" (tabela Munsell)

(IV) Sedimento areno-argiloso, levemente orgânico, solto, com média densidade de material arqueológico. Essa camada foi vinculada à cor 10YR 3/4 "dark brown" (tabela Munsell).

Sedimento areno-argiloso, levemente orgânico, solto, com alta densidade de material arqueológico. Foram observados fragmentos de carvão. Essa camada foi vinculada à cor 10YR 4/2 "brown" (tabela Munsell).

(II. Sedimento argilo-arenoso, pouco orgânico, pouco compactado, húmido, com baixa densidade de material arqueológico Essa camada foi vinculada à cor 10YR 4/6 "dark yellowish brown" (tabela Munsell). Transição entre os horizontes AB/BA. cor 7.5YR 5/8 "strong brown" (tabela Munsell). Horizonte B. 


\section{PROJETO ALTO RIO MADEIRA \\ SÍTIO SÍTIO ITAPIREMA \\ PERFIL ESTRATIGRÁFICO}

ANEXO 11

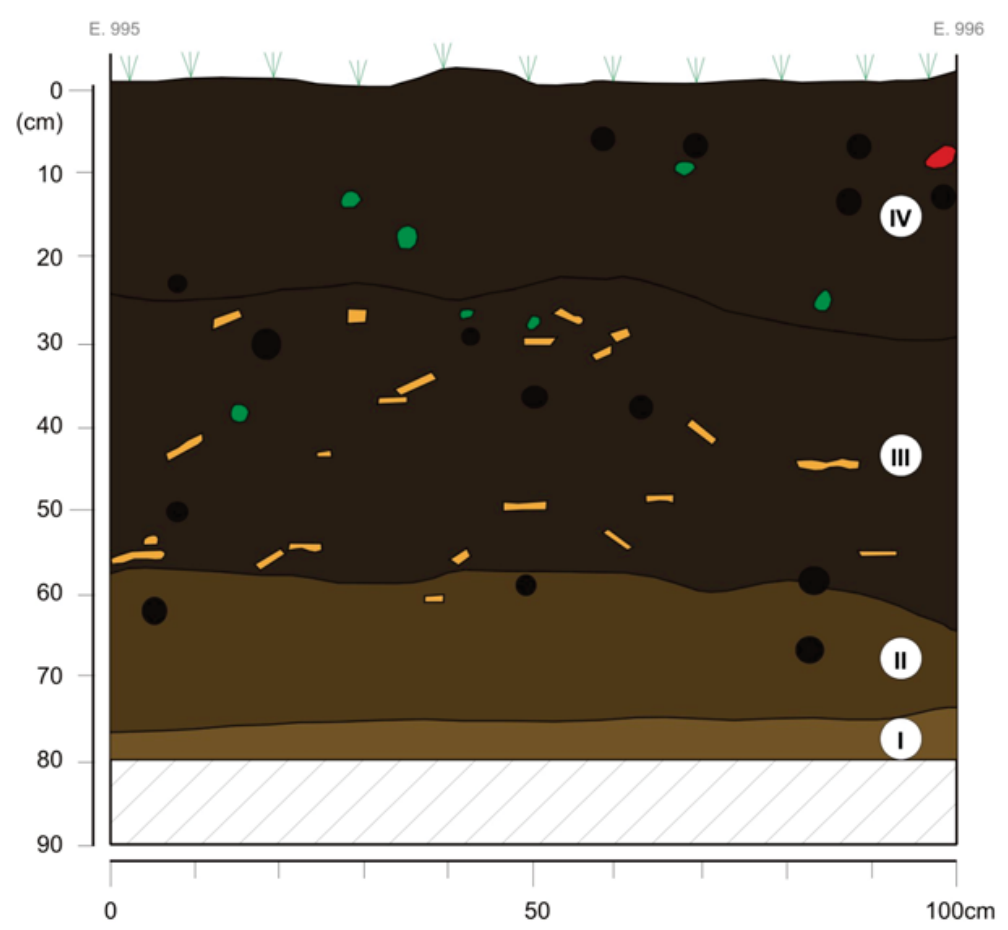

UNIDADE N.1038 - E.996

PERFIL NORTE - LINHA N. 1038

LEGENDA

- Cerâmica

- Carvão

- Raiz

Semente

Superficie

(1V) Camada húmica, argilo-arenosa, com intensa perturbação recente devido a limpeza do terreno. Presença de cerâmica bem fragmentada e lixo doméstico. Cor: 10YR 2/1 Black.

III Camada arqueológica com terra preta e grande densidade de cerâmica e carvões. O sole apresenta textura argilosa e, na parte superior da camada, argilo-siltosa. Cor: 10YR 2/1 Black

III Camada intermediária, argilosa, com alguns fragmentos cerâmicos e muito carvão. Cor: 10YR 3/3 Dark Brown.

(1) Latossolo com baixa quantidade de cerâmica e próxima a um lençol freático. Sua coloração escura deriva da umidade do solo. Textura argilosa. Cor: 10 YR 4/4 Dark Yellowish Brown.

Área não escavada. 


\section{PROJETO ALTO RIO MADEIRA \\ SÍTIO SÍTIO ITAPIREMA \\ PERFIL ESTRATIGRÁFICO \\ ANEXO 11}

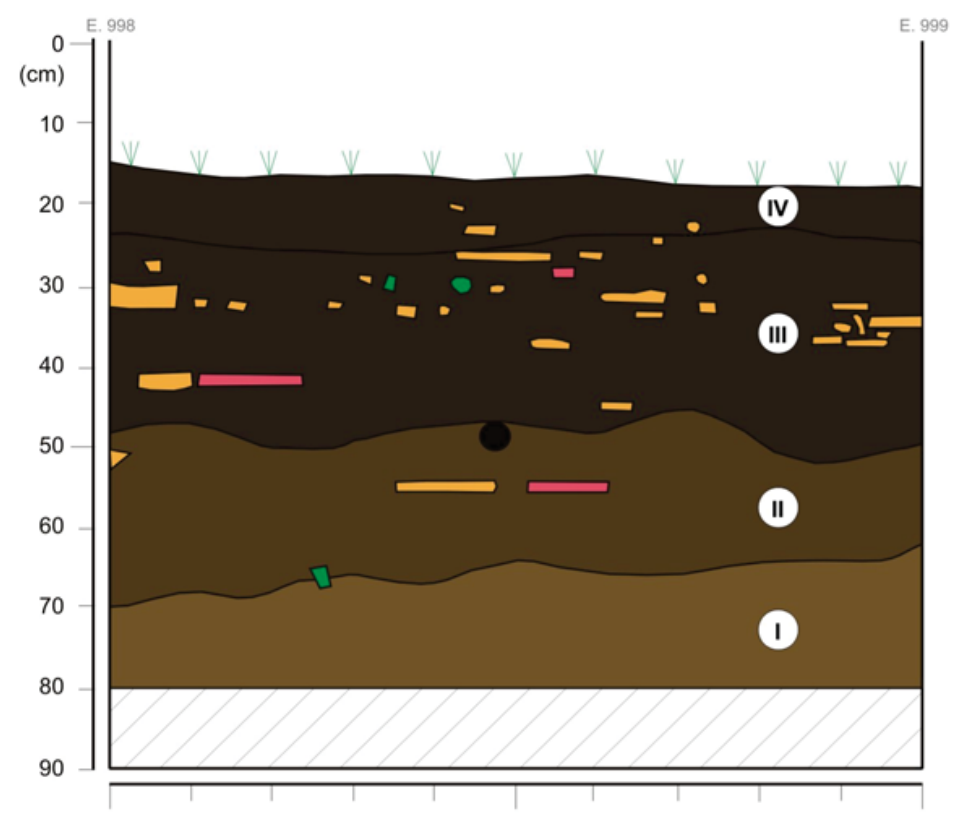

0
50

UNIDADE N.1034 - E.999

PERFIL NORTE - LINHA N. 1034

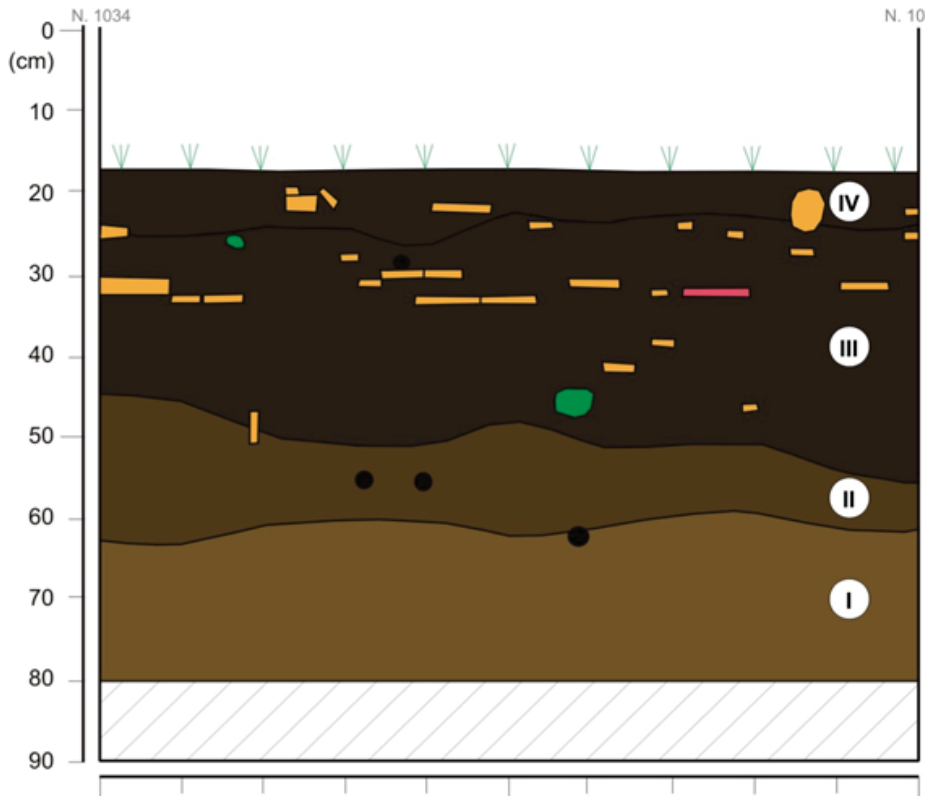

50

$100 \mathrm{~cm}$

UNIDADE N.1034 - E.999

PERFIL LESTE - LINHA E. 999

\section{LEGENDA}

Cerâmica

- $\quad$ Carvão

- Raiz

口 Laterita

Superficie
Camada húmica, argilo-arenosa, com intensa perturbação recente devido a limpeza do terreno. Presença de cerâmica bem fragmentada e lixo doméstico. Cor: 10YR 2/1 Black.

Camada arqueológica de terra preta, com grande densidade de cerâmica, carvão e presença de raizes e radículas. Textura argilosa. Cor: 10YR 2/1 Black

Camada intermediária, argilo-arenosa, com alguns fragmentos cerâmicos e carvão. Cor: 10YR 3/3 Dark Brown.

Latossolo estéril arqueologicamente, baixa quantidade de carvão, com percolações da camada superior e próximo ao lençol freático. Textura argilo-arenosa. Cor: 10 YR 4/4 Dark Yellowish Brown.

Área não escavada. 


\section{PROJETO ALTO RIO MADEIRA \\ SÍTIO SÍTIO ITAPIREMA \\ PERFIL ESTRATIGRÁFICO}

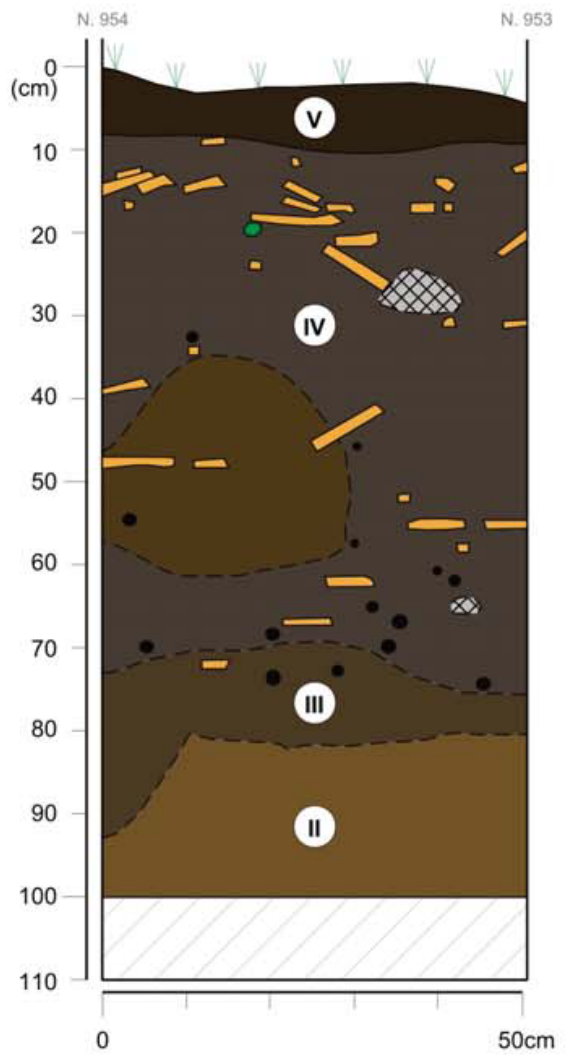

UNIDADE N.954 - E.589

PERFIL LESTE - LINHA E. 589

\section{LEGENDA}

- Cerâmica

- Raiz

- Carvão

Bioturbaçäo

Superficie

- - - Limite Difuso
(V)

Camada húmica composta pro gramineas, raizes, radiculas e muito carvāo. Baixa quantidade de cerâmica devido ao pisoteamento do gado. Textura silto-argilosa. Cor: 10YR 2/2 Very Dark Brown.

Camada arqueológica com grande densidade de material cerâmico e presença de fragmentos de grande porte; presença de uma grande bioturbação na parte oeste, onde foi encontrado parte de uma vasilha fragmentada. Há uma mancha de solo mais claro (10YR 3/3 Dark Brown) cortando parte da camada. Textura silto-argilosa. Cor: 10YR 3/1 Very Dark Gray.

Camada de transição indicando o início da formação de terra preta, com baixa quantidade de carvão e de cerâmica. Há uma grande bioturbação na parte oeste que se espalha até o perfil oeste. Textura silto-argilosa. Cor: 10YR 3/2 Very Dark Grayish Brown.

Camada estéril arqueologicamente, silto-argilosa, apresentou somente dois fragmentos cerâmicos, possivelmente percolados da camada superior. Cor: 10YR 4/4 Dark Yellowish Brown.

Área não escavada. 

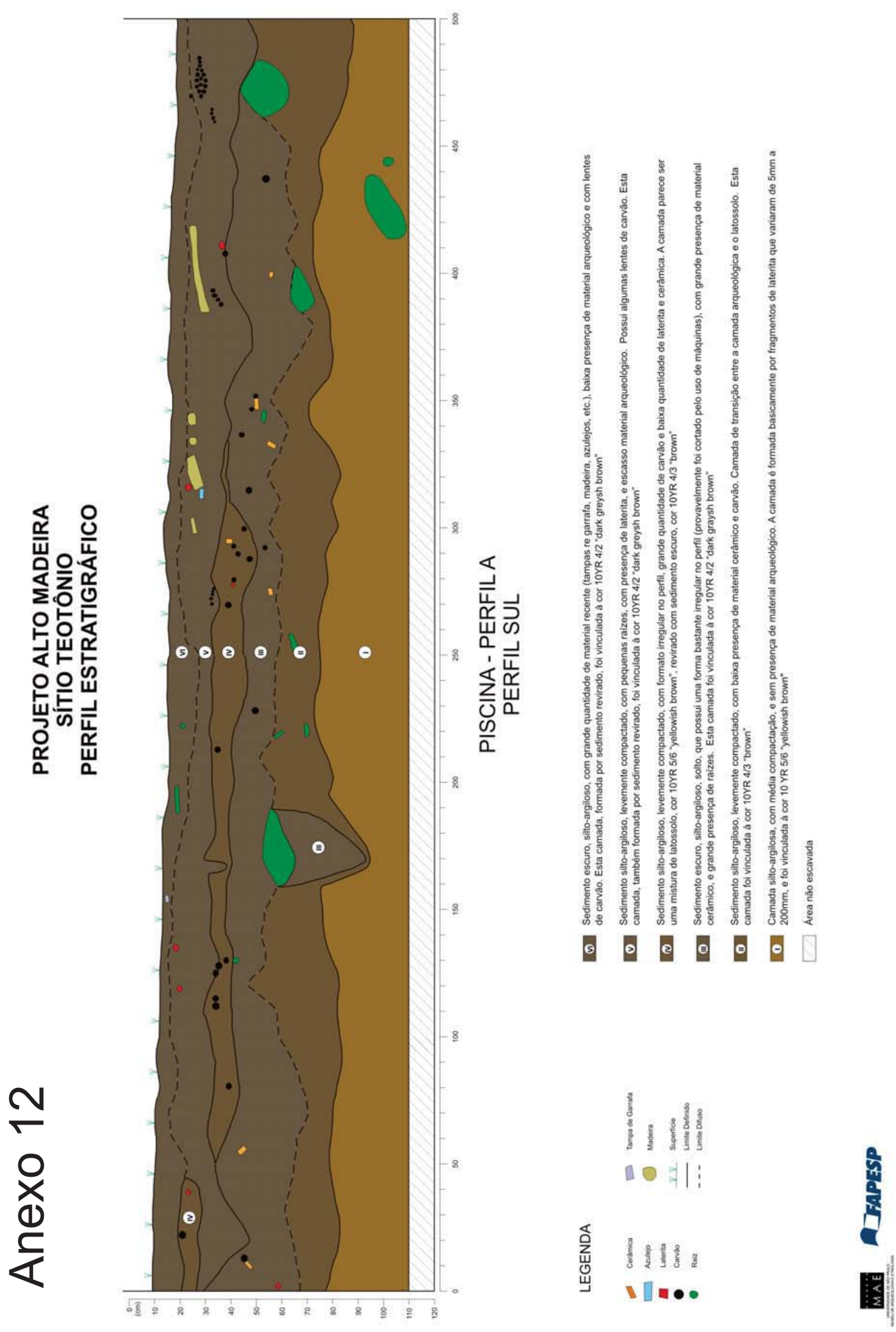


\section{ANEXO 13: Descrição das Variáveis}

Foram analisadas 36 variáveis para cada cerâmica coletada, as quais podem ser dividas em 4 grupos: identificação, composição, características físicas e características estimadas.

\section{Identificação}

\section{Unidade de Sondagem}

Quantidade de Fragmentos: quantidade de fragmentos por peça

Nível $20 \mathrm{~cm}$ : nível de profundidade onde o fragmento foi encontrado (em intervalos de $20 \mathrm{~cm}$ )

Identificação do Sítio

1. Associação Calderita

2. Nova Vida

3. Jacarezinho

4. Itapirema

5. Tetônio

Categoria: parte do fragmento de cerâmica encontrado

1. Não identificada

2. Parede

3. Borda

4. Base

5. Bolota de Argila

6. Roda de Fuso

7. Forma Conjugada

8. Carena

9. Rolete

10. Gargalo

11. Asa

12. Flange

13. Cachimbo

14. Alça

15. Aplique/Apêndice

16. Suporte de Tampa 
17. Adorno

18. Ombro

19. Outros

\section{Composição}

Técnica de Manufatura: técnica utilizada na produção da cerâmica

1. Não identificada

2. Acordelada

3. Modelada

4. Placas

Antiplástico: material que retira a plasticidade da argila, dá estrutura e evita que $o$ artefato trinque

1. Mineral

2. Caraipé

3. Cerâmica/caco Moído

4. Carvão

5. Cauixi

6. Concha

7. Argila Moída

8. Mineral e Caraipé

9. Mineral, Caraipé e Cauixi

10. Mineral, Caraipé e Carvão

11. Mineral, Cauixi e Argila Moída

12. Mineral e Cauixi

13. Caraipé e Cauixi

14. Caraipé e Carvão

15. Cauixi e Argila Moída

16. Outros

\section{Espessura do Antiplástico}

1. Menor ou igual que $1 \mathrm{~mm}$

2. Entre $1 \mathrm{~mm}$ e $3 \mathrm{~mm}$ (exclusive)

3. Entre $3 \mathrm{~mm}$ a $5 \mathrm{~mm}$ (exclusive)

4. Maior ou igual $5 \mathrm{~mm}$. 


\section{Porcentagem do Antiplástico}

1. $5 \%$

2. $10 \%$

3. $20 \%$

4. $30 \%$

\section{Cor da Superfície (Face Interna)}

1. Branco

2. Amarelo/Ocre

3. Laranja

4. Vermelho

5. Cinza

6. Preto

7. Marrom

Queima: uma das etapas do processo produtivo de cerâmica

1. Completa (Oxidada)

2. Núcleo Escuro Fino

3. Núcleo Claro Fino

4. Núcleo Totalmente Escuro

5. Núcleo Escuro Espesso

6. Face Interna Clara e Externa Escura

7. Face Interna Escura e Externa Clara

\section{Estado de Conservação}

1. Não Erodido

2. Erodido FE (Face Externa)

3. Erodido FI (Face Interna)

4. Erodido AF (Ambas as Faces)

5. Craquelê FE (Face Externa)

6. Craquelê FI (Face Interna)

7. Craquelê AF (Ambas as Faces)

Alisamento Face Interna: uma das etapas finais do processo produtivo da cerâmica
1. Fino
2. Médio 
3. Grosso

4. Polido

Alisamento Face Externa: uma das etapas finais do processo produtivo da cerâmica

1. Fino

2. Médio

3. Grosso

4. Polido

Tratamento da Superfície Face Interna: tipo de tratamento utilizado antes de queima

1. Engobo Vermelho

2. Engobo Branco

3. Engobo Marrom (Barbotina)

4. Esfumarado (Resina)

5. Brunidura

Tratamento da Superfície Face Externa: tipo de tratamento utilizado antes de queima

1. Engobo Vermelho

2. Engobo Branco

3. Engobo Marrom (Barbotina)

4. Esfumarado (Resina)

5. Brunidura

\section{Características Físicas}

Marcas: detalhes encontrados na cerâmica

1. Folha

2. Furo

3. Cestaria

4. Marca de Dedo

5. Estrias de Alisamento

6. Outros

Sinais de Uso

1. Fuligem Face Interna

2. Fuligem Face Externa 
3. Película de Alimento Face Interna

4. Reciclagem

Morfologia da Borda (Erro! Fonte de referência não encontrada.)

1. Direta

2. Extrovertida

3. Introvertida

4. Cambada

5. Extrovertida com Ponto Angular

6. Extrovertida com Ondulação

Inclinação da Borda (Erro! Fonte de referência não encontrada.)

1. Vertical

2. Inclinada Internamente

3. Inclinada Externamente

\section{Espessura da Borda}

1. Normal

2. Expandida

3. Reforçada Interno

4. Reforçada Externo

5. Reforçada

6. Dobrada

7. Contraída

8. Vazada (Oca)

9. Acanalada

Lábio: extremidade da borda (Erro! Fonte de referência não encontrada.)

1. Arredondado

2. Plano

3. Apontado

4. Biselado

Espessura do Lábio $(\mathrm{cm})$

Diâmetro da Borda (cm)

Porcentagem da Borda: a porcentagem da borda de cerâmica encontrada.

Base: parte inferior, de sustentação do vasilhame (Erro! Fonte de 
referência não encontrada.)

1. Convexa

2. Plana (com ponta angular)

3. Plano-Convexa (sem ponta angular)

4. Côncava

5. Anelar

6. Em Pedestal

Diâmetro da Base $(\mathrm{cm})$

Espessura do Fragmento (cm)

Decoração Plástica: decoração física feito em cerâmica

1. Corrugado

2. Inciso Fino

3. Inciso Largo

4. Exciso

5. Ungulado

6. Digitungulado

7. Digitado

8. Filete Aplicado

9. Entalhado

10. Ponteado

Decoração Pintada: pinturas em cerâmica

1. Vermelha

2. Branca

3. Preta

Motivo: Modo como a Decoração Pintada ou Plástica foi feita na cerâmica

1. Horizontal

2. Vertical Curta

3. Vertical Longa

4. Transversal

5. Trançada

6. Triangular

7. Angular 
8. Espiral

9. Ondular

10. Curcilíneas

11. Grega

12. Complexa

\section{Local da Decoração Face Interna}

1. Lábio

2. Borda

3. Bojo Superior

4. Bojo Inferior

5. Parede

6. Base

7. Aplique

\section{Local da Decoração Face Externa}

1. Lábio

2. Borda

3. Bojo Superior

4. Bojo Inferior

5. Parede

6. Base

7. Aplique

\section{Formas - PALMA \\ I. Contorno Simples ou inflectido Esférica \\ Semi-Esférica \\ Calota}

II. Forma Plana

A-J

III. Contorno Composto

A-J

IV. Contorno Complexo

\begin{tabular}{|c|c|c|}
\hline A & $\longrightarrow$ & Reta Normal \\
\hline B & $\longrightarrow$ & Côncava Normal \\
\hline $\mathrm{C}$ & 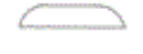 & Convexa Normal \\
\hline D & $\square$ & Reta Invertida \\
\hline$E$ & 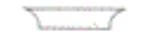 & Côncava Invertida \\
\hline $\mathrm{F}$ & $\square$ & Convexa Invertida \\
\hline G & $\square$ & Reta \\
\hline $\mathrm{H}$ & $\sum$ & Côncava \\
\hline 1 & $\square$ & Convexa \\
\hline J & $\longrightarrow$ & Calota \\
\hline
\end{tabular}


$h=$ altura $\quad d=$ diâmetro

Esférica: $h \geq 2 / 3 d$

Semi-Esférica: $2 / 3 d>h \geq 1 / 3 d$

Calota: $h>1 / 3$

\begin{tabular}{|l|l|}
\hline \multicolumn{2}{|c|}{ REPERTÓRIO DE FORMAS CERÂMICAS DOS SITIOS ARQUEOLÓGICOS DO PALMA } \\
\hline Forma 1 & Vasilha esférica, com contorno simples e boca constrita. \\
\hline Forma 2 & Vasilha esférica, com contorno simples e boca aberta. \\
\hline Forma 3 & Vasilha esférica, com contorno infletido e boca constrita. \\
\hline Forma $\mathbf{4}$ & Vasilha esférica, com contorno infletido e boca aberta. \\
\hline Forma $\mathbf{5}$ & Vasilha esférica com pescoço, contorno infletido e boca constrita. \\
\hline Forma 6 & Vasilha semi-esférica, com contorno simples e boca constrita. \\
\hline Forma 7 & Vasilha semi-esférica, com contorno simples e boca aberta. \\
\hline Forma $\mathbf{8}$ & Vasilha semi-esférica, com contorno infletido e boca aberta. \\
\hline Forma 9 & Vasilha semi-esférica, com contorno infletido e boca constrita. \\
\hline Forma 10 & Vasilha em forma de calota, com contorno simples, boca aberta. \\
\hline Forma 11 & Vasilha em forma de calota, com contorno simples e boca constrita. \\
\hline Forma 12 & Vasilha em forma de calota, com contorno infletido, boca aberta. \\
\hline Forma 13 & Vasilha em forma de calota, com contorno infletido, boca constrita. \\
\hline Forma 14 & Vasilha com contorno composto \\
\hline Forma 15 & Vasilha complexa \\
\hline Forma 16 & Vasilha angular (triangular - quadrangular) \\
\hline Forma 17 & Vasilha rasa, prato. \\
\hline
\end{tabular}


ANEXO 14 


\section{forma 1}

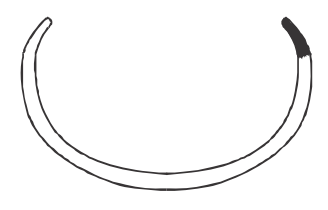

PALMA

S. Associação Calderita

PN 53-114

Diâmetro $14 \mathrm{~cm}$

Volume 1,24L
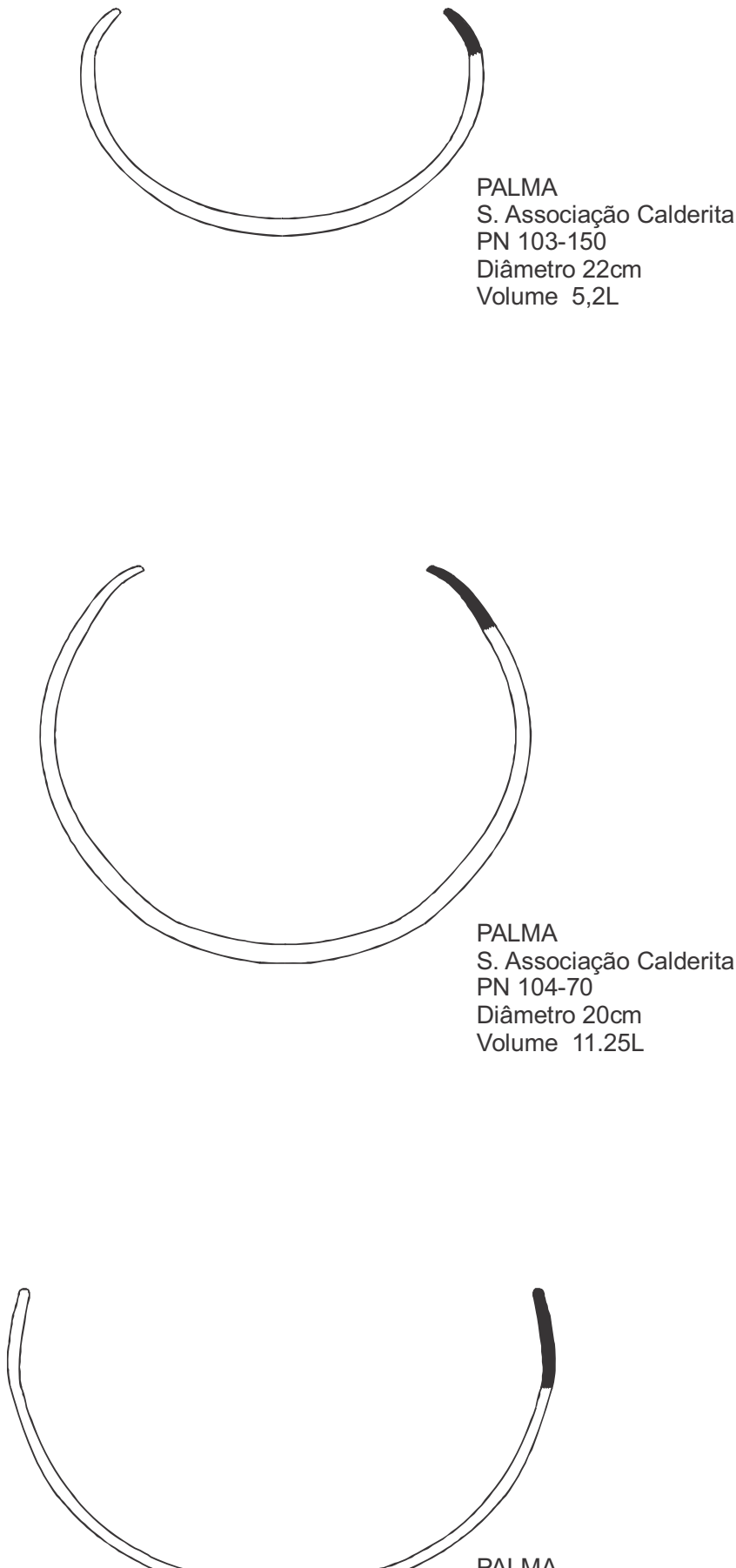

S. Associação Calderita PN 53-14

Diâmetro $34 \mathrm{~cm}$

Volume 12,2L

Diâmetro $24 \mathrm{~cm}$

Volume 11,08L

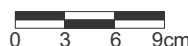

\section{PALMA}

Sítio Associação Calderita
Surfer 1

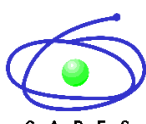

C A P E S
Distribuição Espacial da Cerâmica

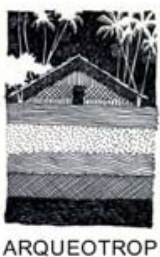




\section{forma 3}
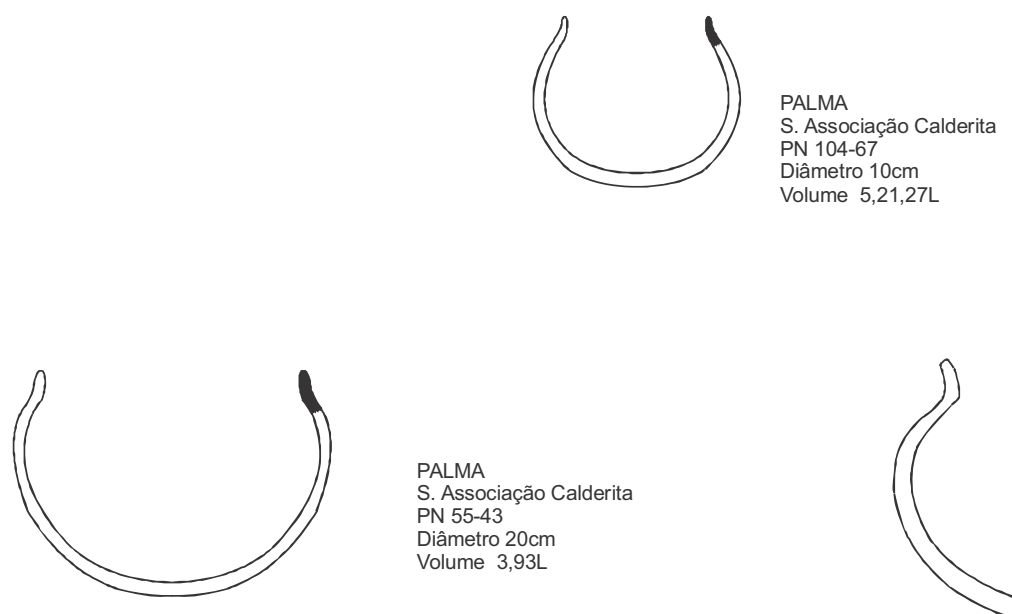

PALMA

S. Associação Calderita

PN 55-43

Diâmetro $20 \mathrm{~cm}$

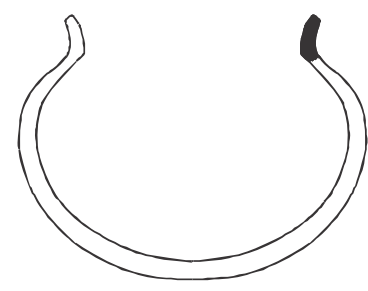

PALMA

S. Associação Calderita

PN 53-118

Diâmetro $18 \mathrm{~cm}$

Volume $3,93 \mathrm{~L}$

PALMA

S. Associação Calderita

Diâmetro $30 \mathrm{~cm}$

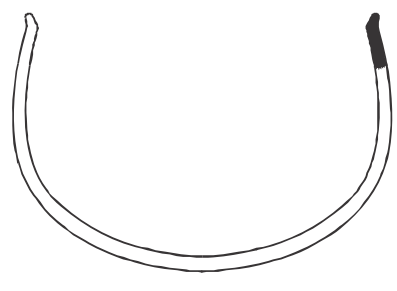

PALMA

S. Associação Calderita PN 102-104

Diâmetro $26 \mathrm{~cm}$

forma 4

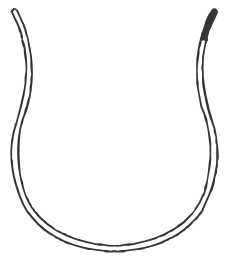

PALMA

S. Associação Calderita

PN 104-82

Diâmetro $15 \mathrm{~cm}$

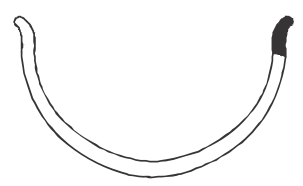

PALMA

S. Associação Calderita

PN103-157

Diâmetro $20 \mathrm{~cm}$
Volume $1,98 \mathrm{~L}$

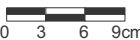

PALMA

Sítio Associação

Surfer 2

Distribuição Espacial da Cerâmica

Calderita

TFAPESP

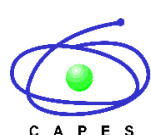

C A P E S 


\section{forma 5}

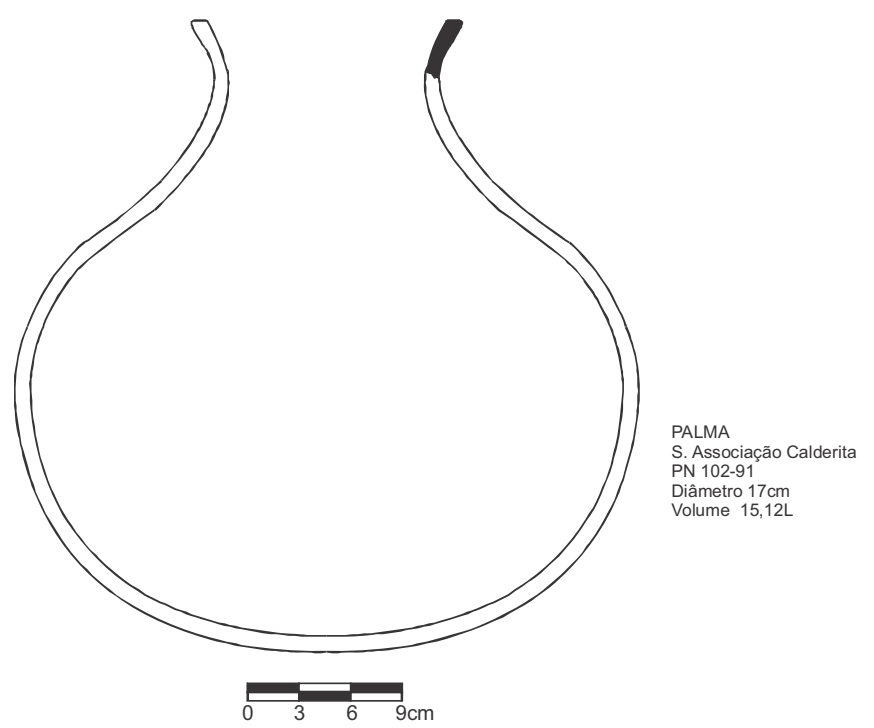

\section{forma 7}

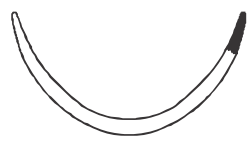

S. Associação Calderita

PN 103-154

Diâmetro $14 \mathrm{~cm}$
Volume $0,51 \mathrm{~L}$

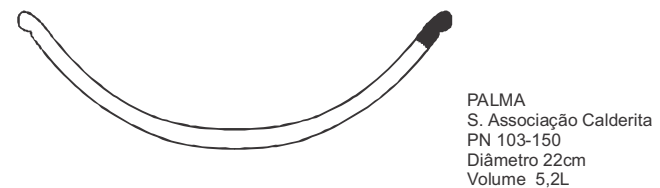

PN 103-150
Diâmetro $22 \mathrm{~cm}$

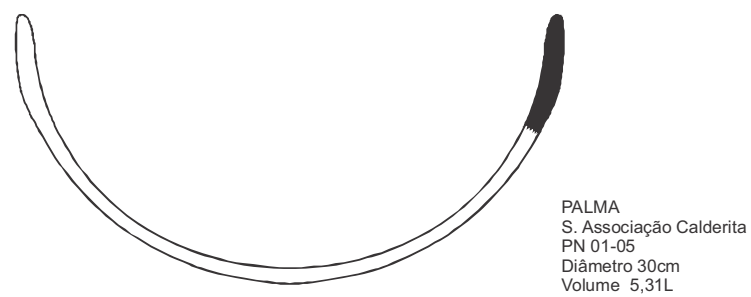

Diâmetro $30 \mathrm{~cm}$

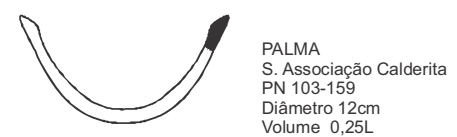

Diâmetro $12 \mathrm{~cm}$
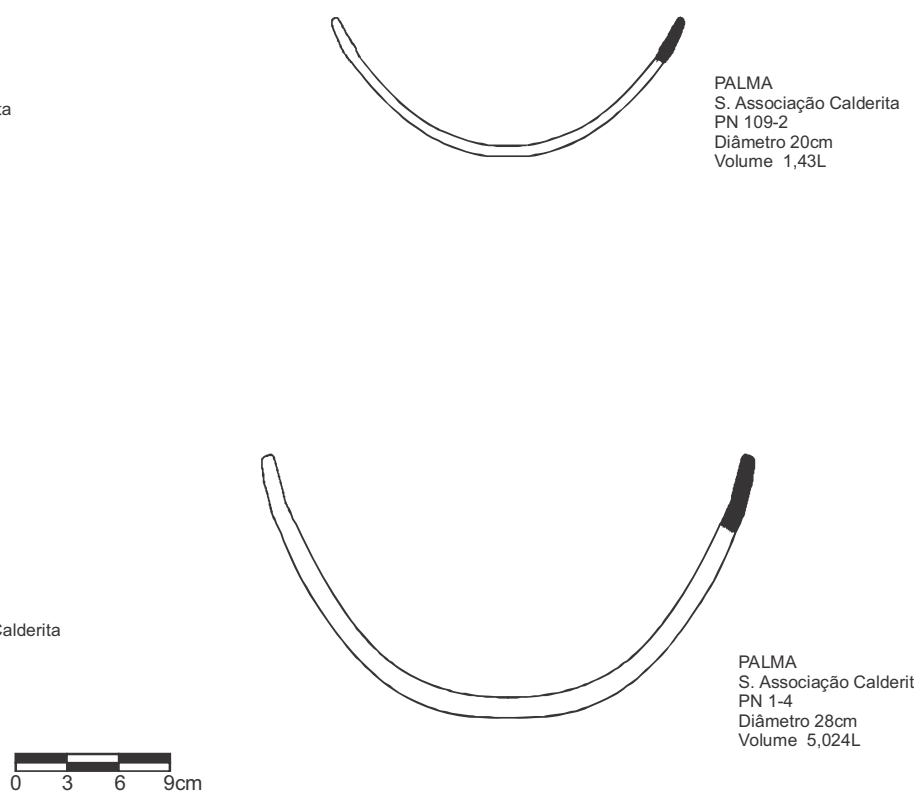

Diâmetro $20 \mathrm{~cm}$
Volume $1.43 \mathrm{~L}$

Sítio Associação

Surfer 3

Distribuição Espacial da Cerâmica

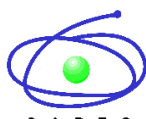




\section{forma 8}

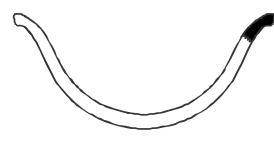

S. Associação Calderita

PN103-149

Diâmetro $16 \mathrm{~cm}$

Volume $0,55 \mathrm{~L}$

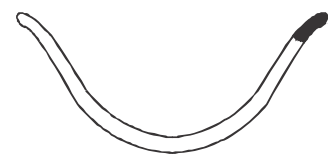

PALMA

S. Associação Calderita

PN 102-87

Diâmetro $18 \mathrm{~cm}$

Volume $0,8 \mathrm{~L}$

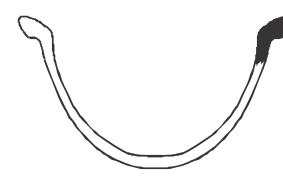

PALMA

Associação Calderita PN 102-82

Diâmetro $17 \mathrm{~cm}$

Volume $0,93 \mathrm{~L}$
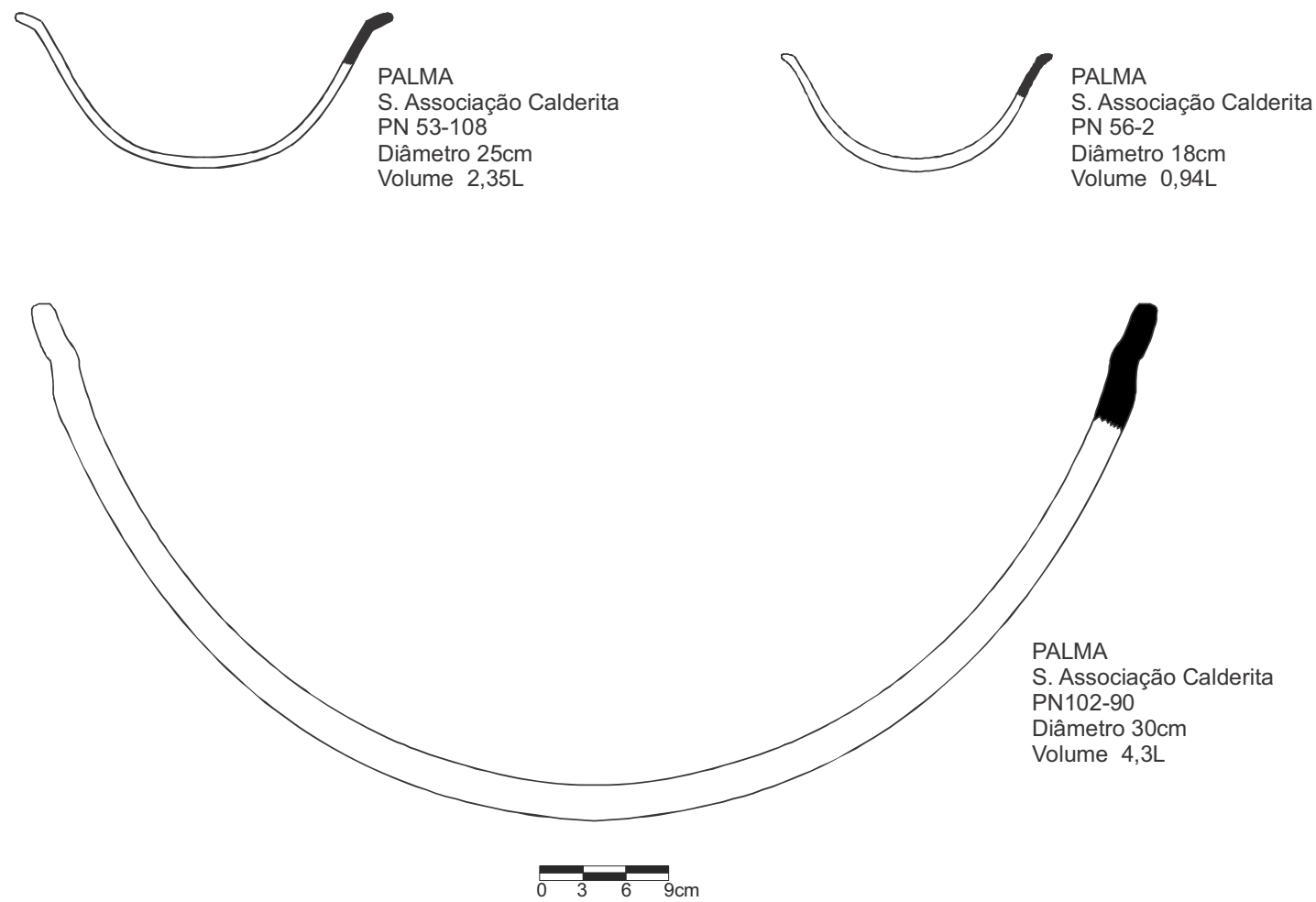

\section{forma 9}
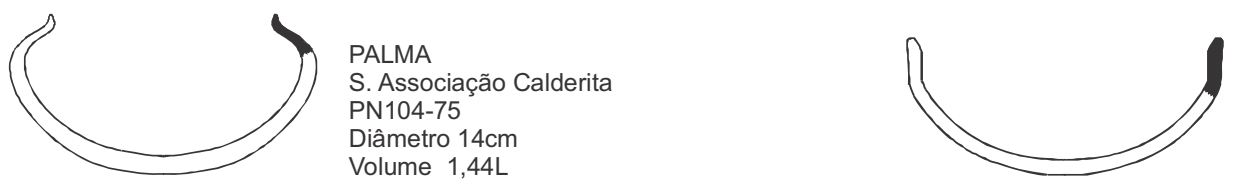

PALMA

S. Associação Calderita PN 55-9

Diâmetro $19 \mathrm{~cm}$

Volume 1,5L

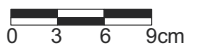

\section{PALMA}

Sítio Associação

Surfer 4

Distribuição Espacial

Calderita

da Cerâmica 


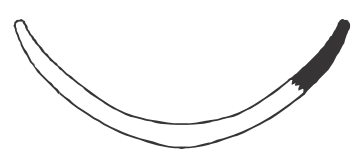

PALMA

S. Associação Calderita PN 103-151

Diâmetro $16 \mathrm{~cm}$

Volume $0,47 \mathrm{~L}$

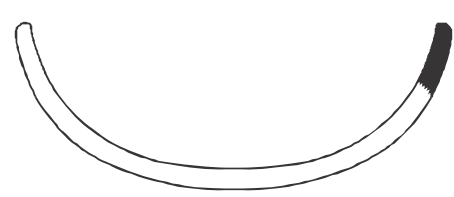

PALMA

S. Associação Calderita

PN 102-93

Diâmetro $20 \mathrm{~cm}$

Volume 1,26L

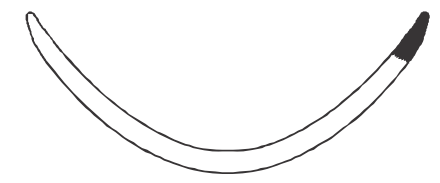

PALMA

S. Associação Calderita PN 104-72

Diâmetro $19 \mathrm{~cm}$

Volume $0,87 \mathrm{~L}$

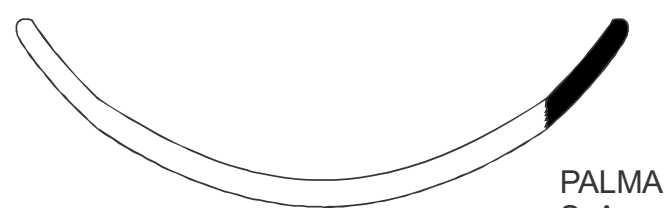

S. Associação Calderita PN102-106

Diâmetro $28 \mathrm{~cm}$

Volume 2,58L

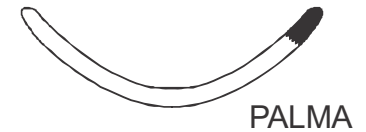

S. Associação Calderita PN 106-19

Diâmetro $14 \mathrm{~cm}$

Volume $0,31 \mathrm{~L}$

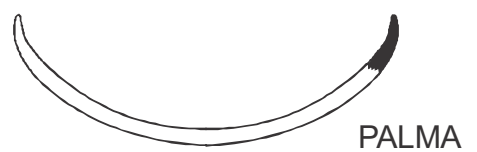

S. Associação Calderita PN 106-41

Diâmetro $18 \mathrm{~cm}$

Volume $0,83 \mathrm{~L}$

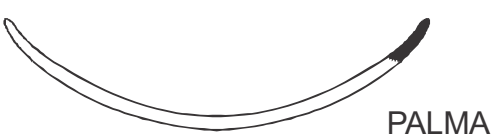

S. Associação Calderita PN 104-81

Diâmetro $20 \mathrm{~cm}$

Volume $0,73 \mathrm{~L}$

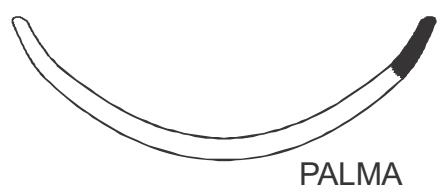

S. Associação Calderita PN 104-80

Diâmetro $20 \mathrm{~cm}$

Volume 1,01L

PALMA

S. Associação Calderita PN54-3

Diâmetro $44 \mathrm{~cm}$

Volume $4,77 \mathrm{~L}$

\section{PALMA}

Sítio Associação Calderita
Surfer 5

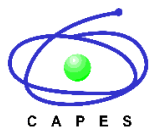

Distribuição Espacial da Cerâmica

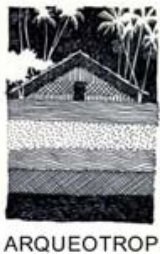




\section{forma 12}
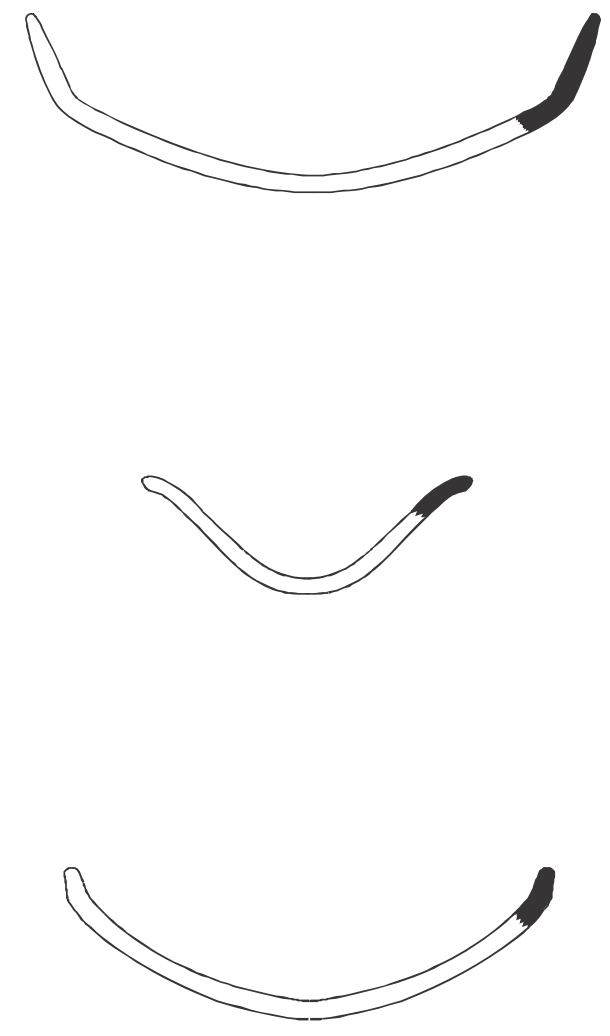

PALMA

S. Associação Calderita

PN 103-150

Diâmetro $22 \mathrm{~cm}$

Volume 5,2L

S. Associação Calderita

PN 55-42

Diâmetro $22 \mathrm{~cm}$

Volume $1,43 \mathrm{~L}$

PALMA

S. Associação Calderita PN 106-21

Diâmetro $12 \mathrm{~cm}$

Volume $0,19 \mathrm{~L}$

\section{forma 17}

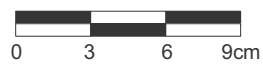

PALMA

S. Associação Calderita

PN 13-10

Diâmetro $50 \mathrm{~cm}$

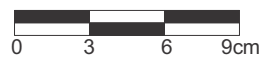

\section{PALMA}

Sítio Associação

Surfer 6

Distribuição Espacial

Calderita da Cerâmica

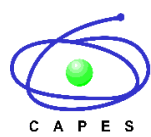




\section{forma 1}
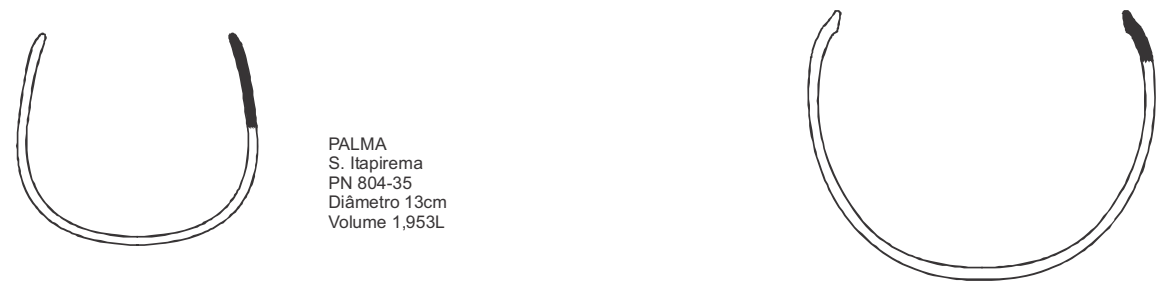

PALMA

S. Itapirema

Diâmetro $23 \mathrm{~cm}$
Volume $5,135 \mathrm{~L}$
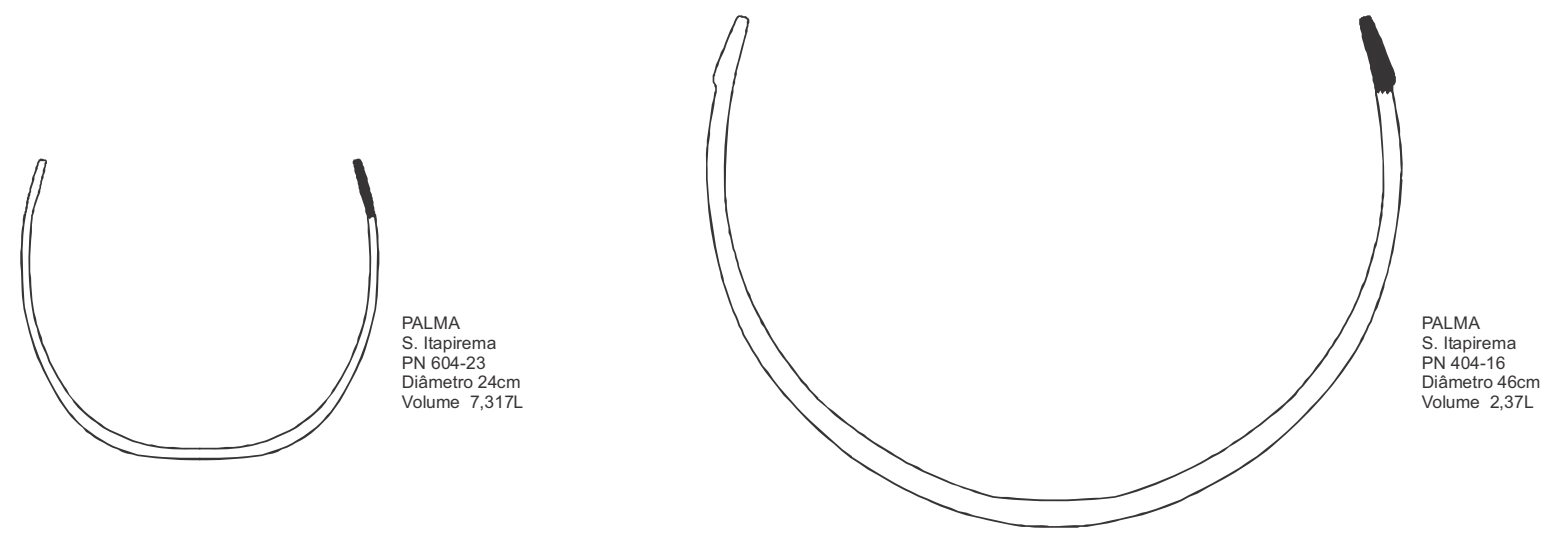

forma 2

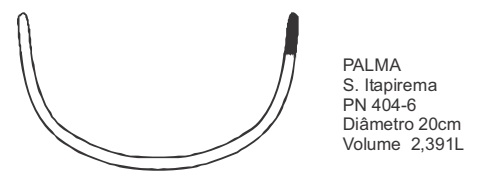

$\sqrt{3} 6$

PALMA

Sítio Itapirema

DFAPESP
Surfer 1

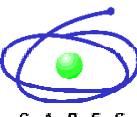

Distribuição Espacial da Cerâmica

TS」 $\mathrm{MA}$

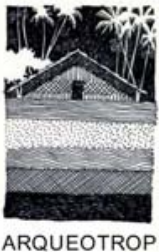




\section{forma 3}

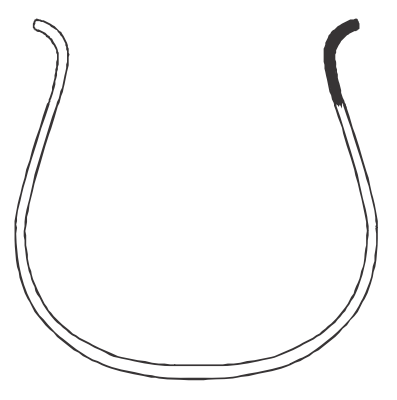

PALMA

S. Itapirema

PN 304-124

Diâmetro $22 \mathrm{~cm}$

Volume 6,286L

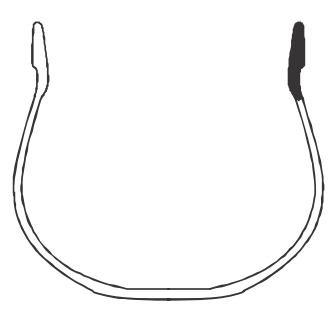

PALMA

S. Itapirema

PN 804-27

Diâmetro $18 \mathrm{~cm}$

Volume 3,627L

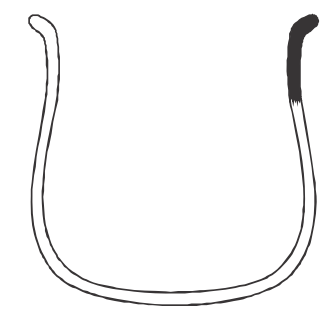

PALMA

S. Itapirema

PN 316-1

Diâmetro $19 \mathrm{~cm}$

Volume $3,08 \mathrm{~L}$

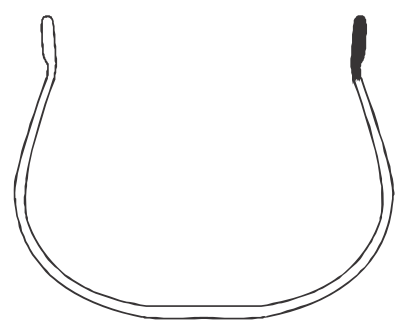

PALMA

S. Itapirema

PN 611-19

Diâmetro $22 \mathrm{~cm}$

Volume $6,167 \mathrm{~L}$

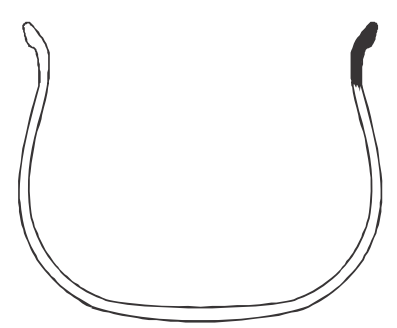

PALMA

S. Itapirema

PN 502-2

Diâmetro $24 \mathrm{~cm}$

Volume $5,714 \mathrm{~L}$

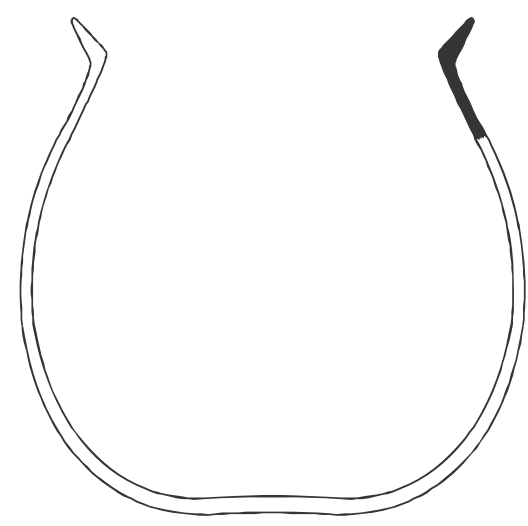

PALMA

S. Itapirema

PN 824-1

Diâmetro $17 \mathrm{~cm}$

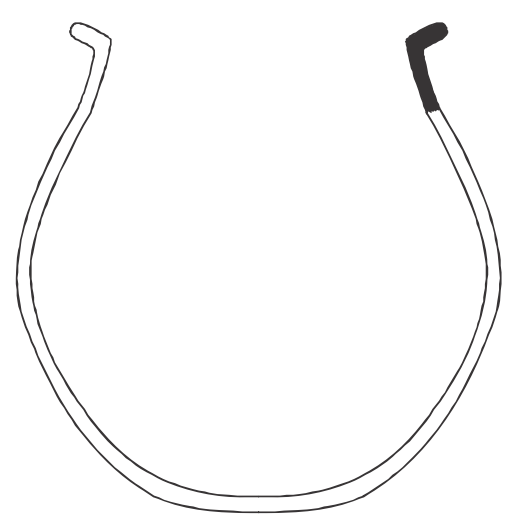

PALMA

S. Itapirema

PN 628-1

Diâmetro $32 \mathrm{~cm}$

Volume 15,199L

$\longdiv { 3 6 } 9 \mathrm { cm }$

\section{PALMA}

Sítio Itapirema

Surfer 2

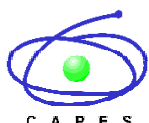

C A P E S
Distribuição Espacial da Cerâmica

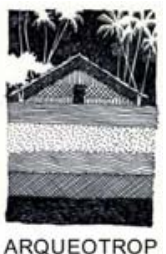


forma 4

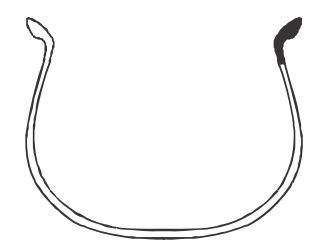

PALMA S. Itapirema Diâmetro $22 \mathrm{~cm}$
Volume $3,704 \mathrm{~L}$
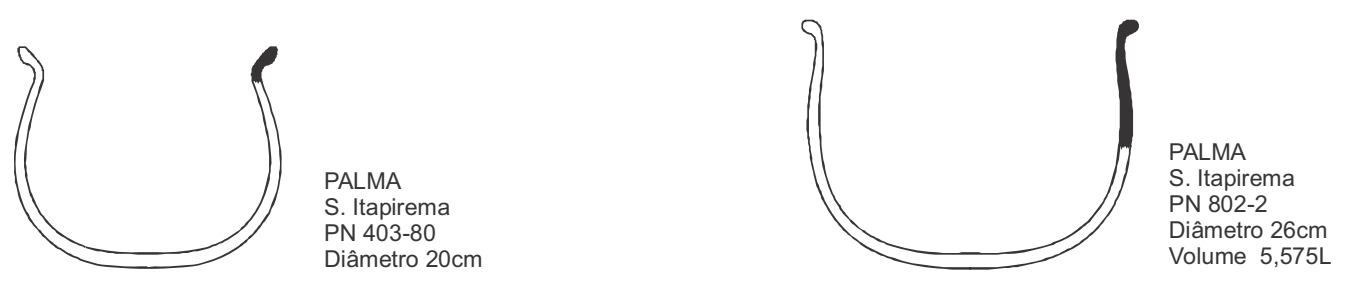

PALMA

Diâmetro $20 \mathrm{~cm}$
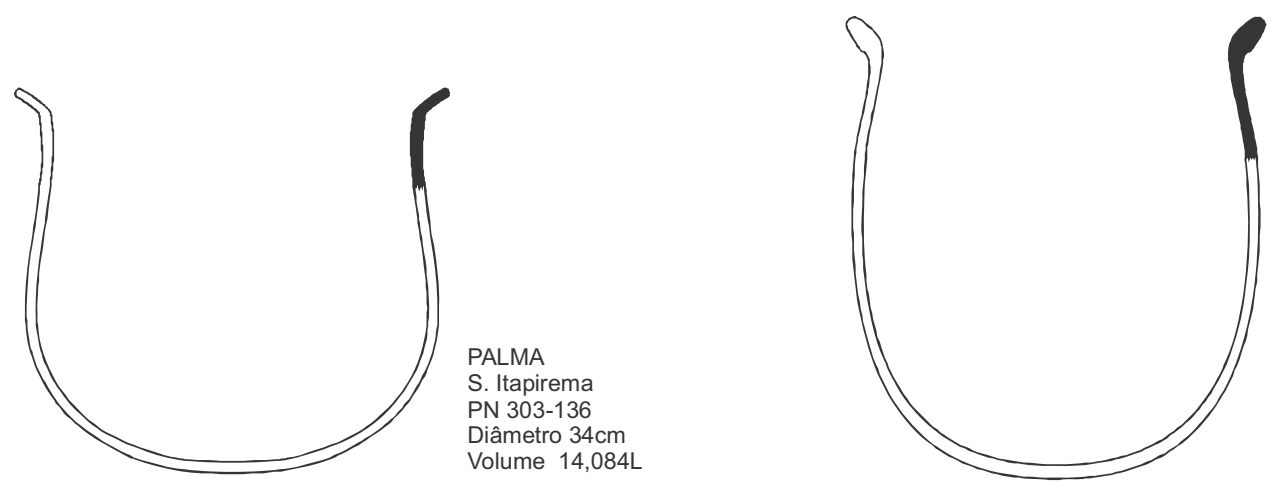

PALMA S. Itapirema Diâmetro $60 \mathrm{~cm}$ Volume 48,834L
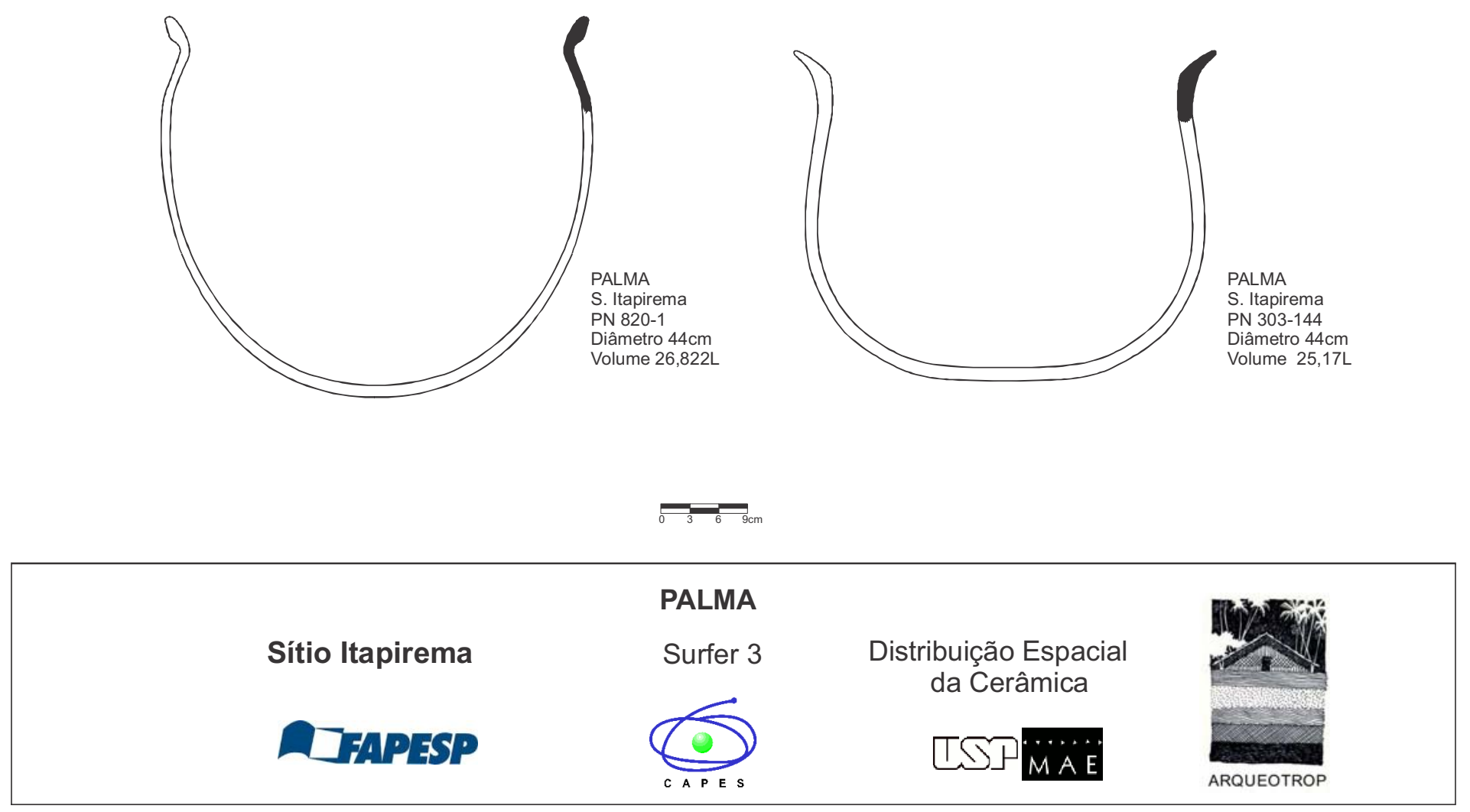
forma 5
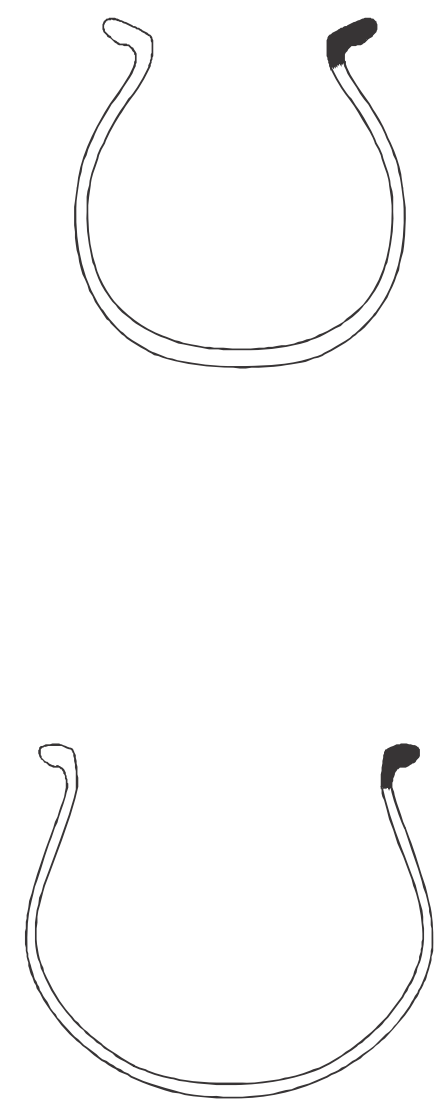

PALMA S. Itapirema PN 206-2

Diâmetro $17 \mathrm{~cm}$

Volume $3,658 \mathrm{~L}$

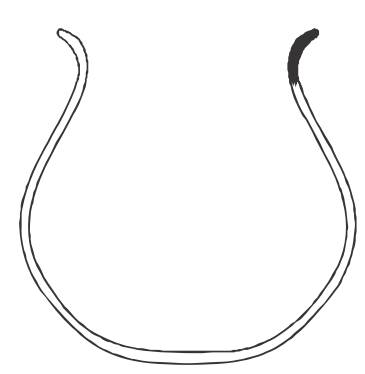

PALMA

S. Itapirema

PN 801-19

Diâmetro $22 \mathrm{~cm}$

Volume 6,092L

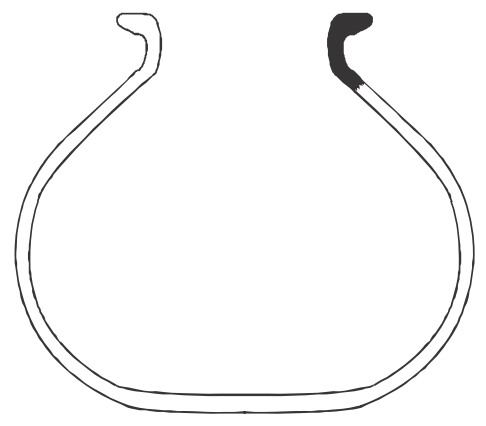

PALMA

S. Itapirema

PN 304-129

Diâmetro $17 \mathrm{~cm}$

Volume $3,819 \mathrm{~L}$
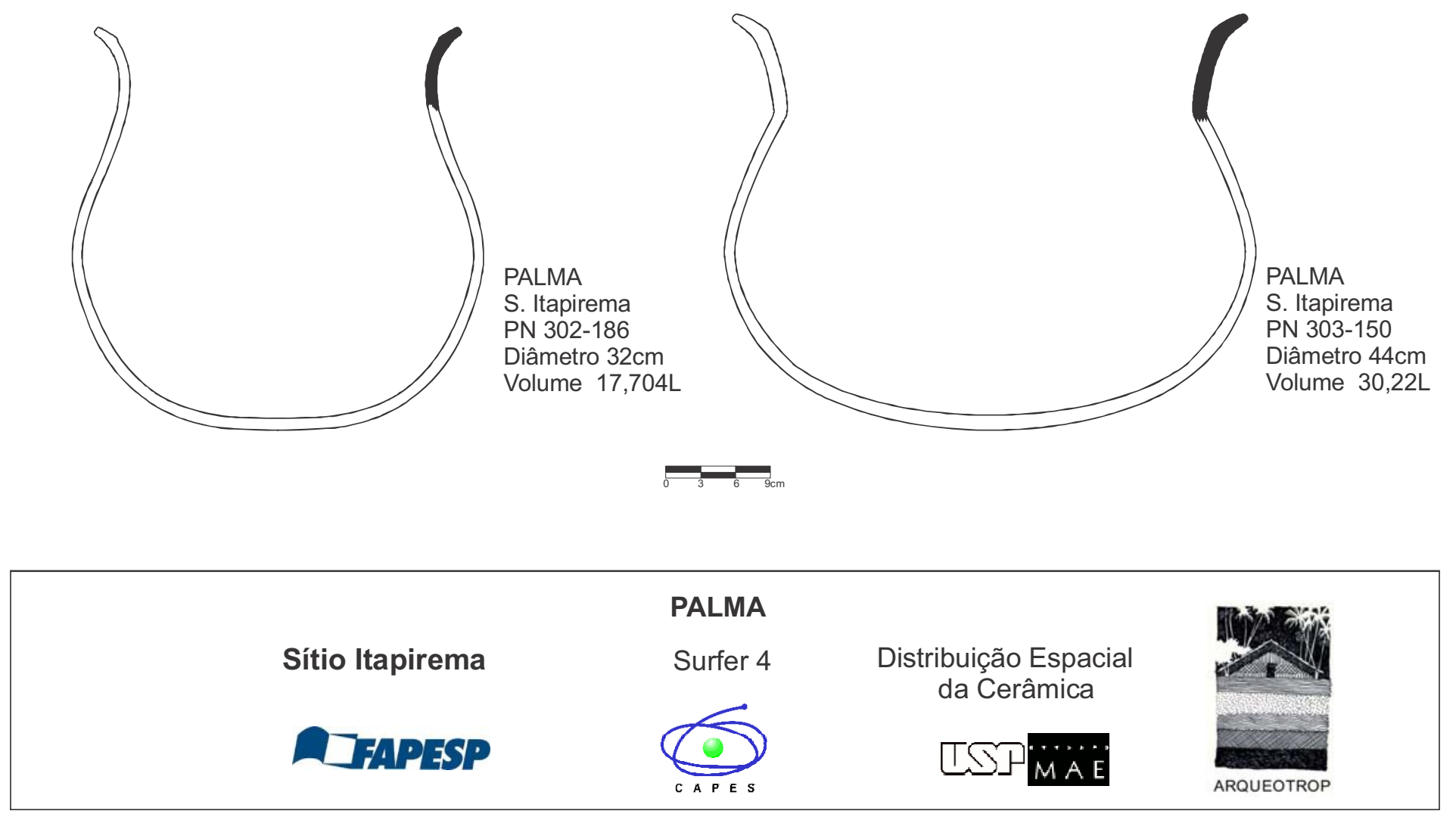


\section{forma 7}

PALMA

S. Itapirema

PN 616-8

Diâmetro $9 \mathrm{~cm}$

Volume 0,195L

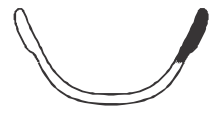

PALMA

S. Itapirema

PN 302-125

Diâmetro $12 \mathrm{~cm}$

Volume $0,37 \mathrm{~L}$

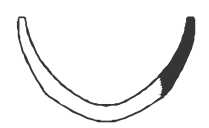

PALMA

S. Itapirema

PN 802-76

Diâmetro $11 \mathrm{~cm}$

Volume $0,335 \mathrm{~L}$
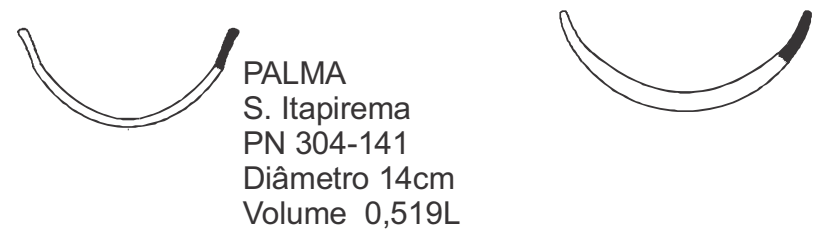

PALMA

S. Itapirema

PN 302-105

Diâmetro $16 \mathrm{~cm}$

Volume $0,62 \mathrm{~L}$

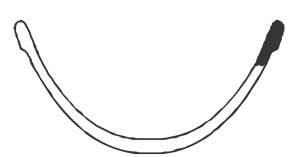

PALMA

S. Itapirema

PN 805-152

Diâmetro $17 \mathrm{~cm}$

Volume 0,963L

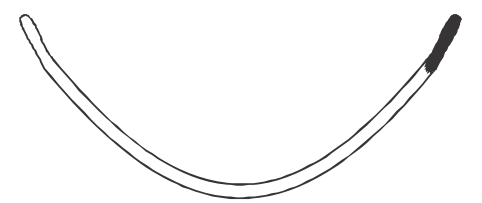

PALMA

S. Itapirema

PN 304-137

Diâmetro $30 \mathrm{~cm}$

Volume $3,894 \mathrm{~L}$

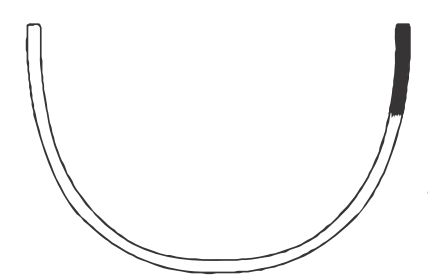

PALMA

S. Itapirema

PN 502-1

Diâmetro $24 \mathrm{~cm}$

Volume 4,108L

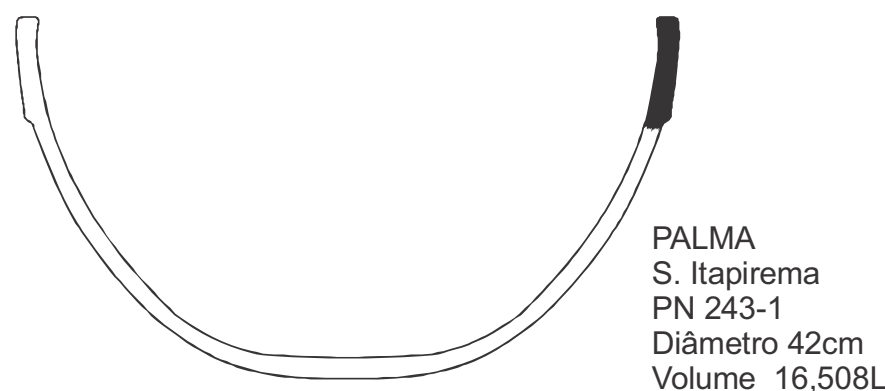

$\underset{3-9 \mathrm{~cm}}{\mathrm{~s}}$

\section{PALMA}

Sítio Itapirema

Surfer 5

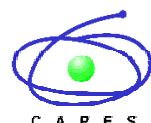

C A PES
Distribuição Espacial da Cerâmica

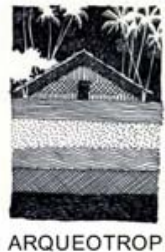




\section{forma 1}

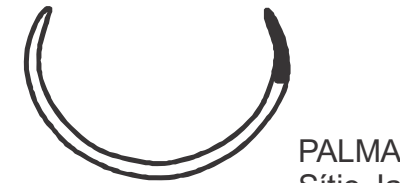

Sítio Jacarezinho PN 306-7

Diâmetro 14 cm

Volume 1,3 L

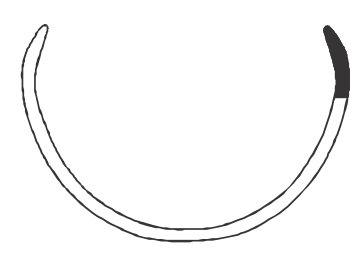

PALMA

Sítio Jacarezinho

PN 206-9

Diâmetro $18 \mathrm{~cm}$

Volume 2,81 L

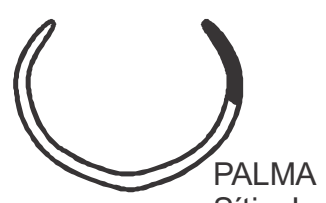

Sítio Jacarezinho PN 303-1

Diâmetro $10 \mathrm{~cm}$

Volume $0,97 \mathrm{~L}$

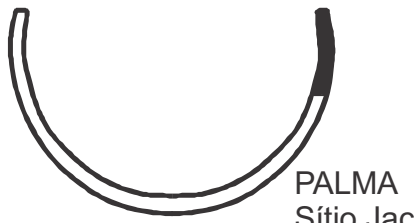

Sítio Jacarezinho PN 304-8

Diâmetro $18 \mathrm{~cm}$

Volume 2,26 L

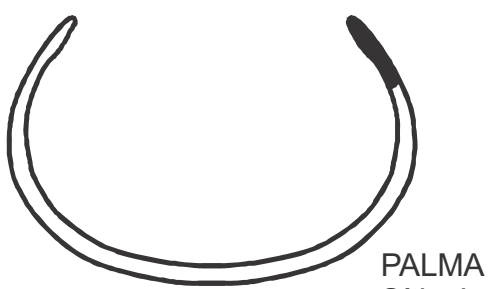

Sítio Jacarezinho PN 304-3

Diâmetro $18 \mathrm{~cm}$

Volume 4,22 L
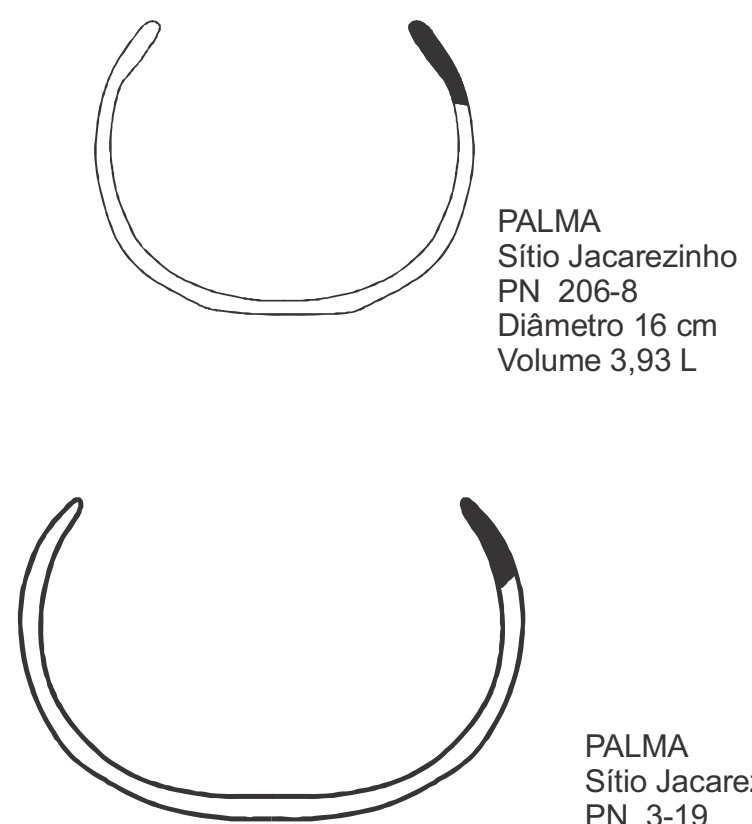

PALMA

Sítio Jacarezinho

PN 3-19

Diâmetro $24 \mathrm{~cm}$

Volume 8,05 L

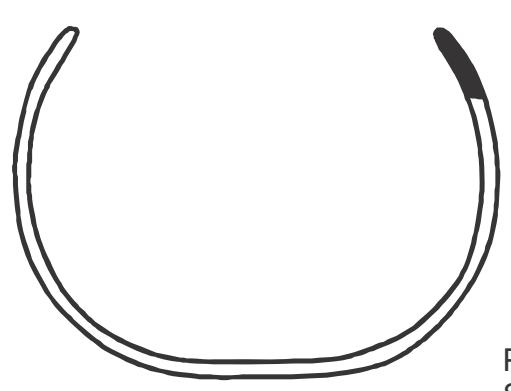

PALMA

Sítio Jacarezinho PN 501-4

Diâmetro $24 \mathrm{~cm}$

Volume 9,24 L

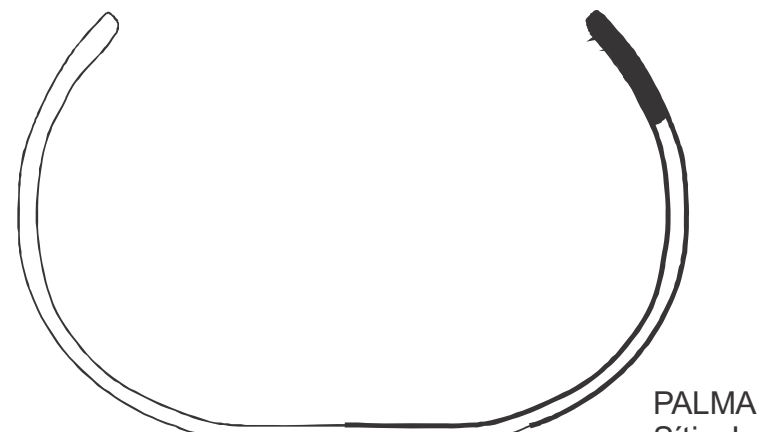

Sítio Jacarezinho PN 206-6

Diâmetro $30 \mathrm{~cm}$ Volume 19,44 L

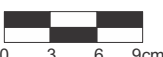

\section{PALMA}

Sítio Jacarezinho

Surfer 1

Distribuição Espacial da Cerâmica
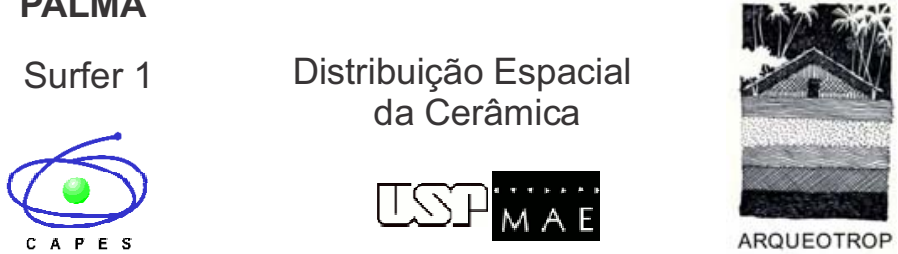


\section{forma 2}

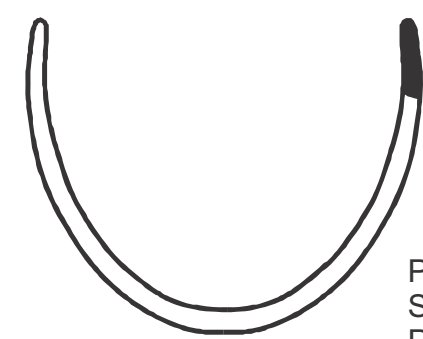

PALMA

Sítio Jacarezinho PN 304-9

Diâmetro $16 \mathrm{~cm}$ Volume 1,95 L

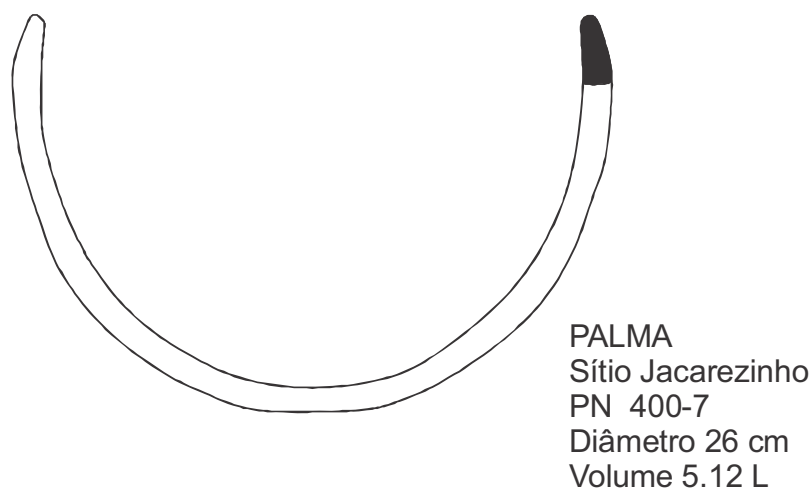

\section{forma 3}

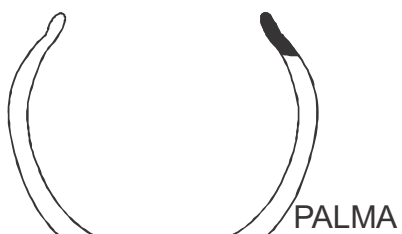

Sítio Jacarezinho PN 203B-3

Diâmetro $10 \mathrm{~cm}$ Volume 1,03 L

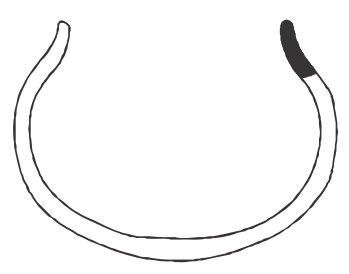

Sítio Jacarezinho PN 307-6

Diâmetro $10 \mathrm{~cm}$ Volume 1,02 L

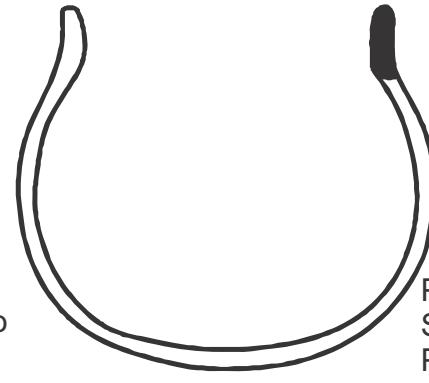
PALMA Sítio Jacarezinho PN 306-2 Diâmetro $14 \mathrm{~cm}$ Volume 2,31 L

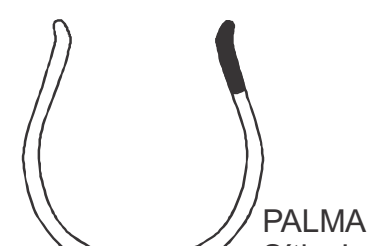

Sítio Jacarezinho PN 205-69

Diâmetro $8 \mathrm{~cm}$ Volume $0,7 \mathrm{~L}$

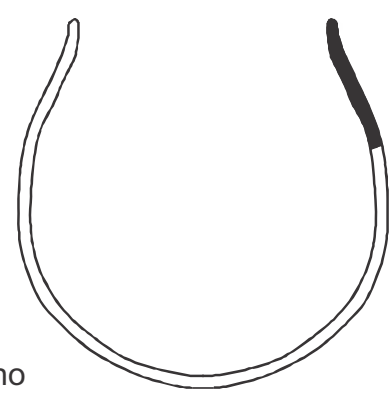

PALMA

Sítio Jacarezinho

PN 206-4

Diâmetro $12 \mathrm{~cm}$

Volume 2,06 L

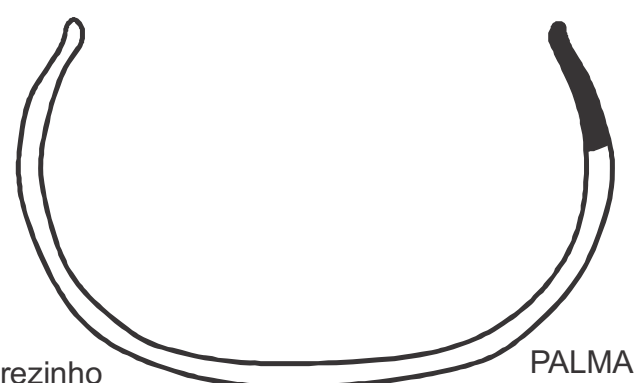

Sítio Jacarezinho PN 306-1

Diâmetro $22 \mathrm{~cm}$ Volume 2,06 L

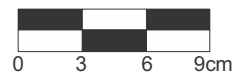

PALMA

Sítio Jacarezinho

D TAPESP
Surfer 2

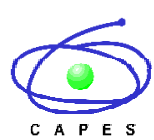

Distribuição Espacial da Cerâmica

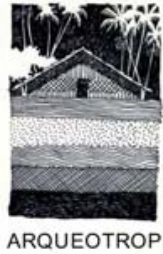




\section{forma 4}

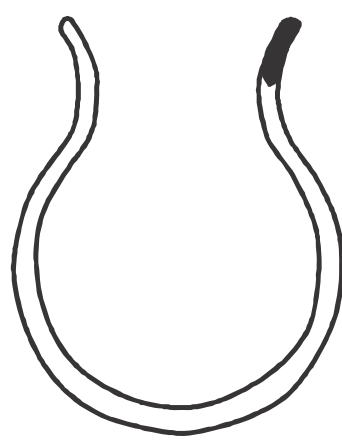

PALMA

Sítio Jacarezinho

PN 500-1

Diâmetro $12 \mathrm{~cm}$

Volume 2,15 L

\section{forma 5}

PALMA

Sítio Jacarezinho

PN 103-7

Diâmetro $13 \mathrm{~cm}$

Volume 0,79 L

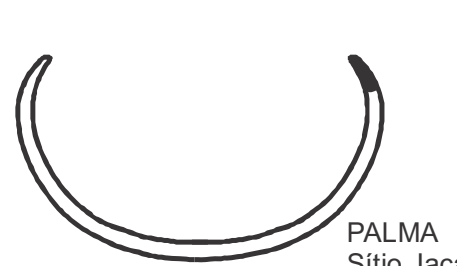

Sítio Jacarezinho

PN 304-5

Diâmetro 16 cm

Volume 1,94 L

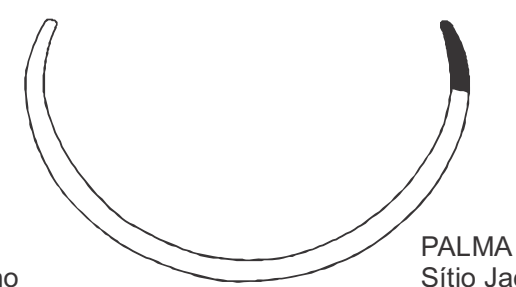

Sítio Jacarezinho

PN 3-25

Diâmetro $22 \mathrm{~cm}$

Volume 4,18 L

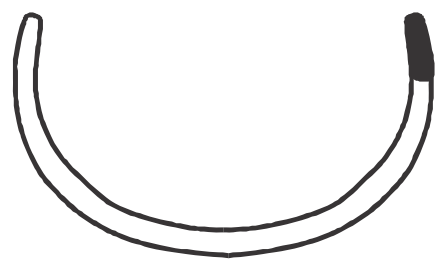

PALMA

Sítio Jacarezinho

PN 307-4

Diâmetro $20 \mathrm{~cm}$

Volume 3,02L

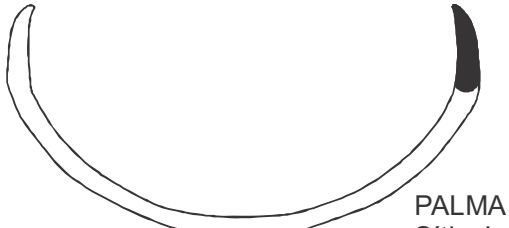

Sítio Jacarezinho

PN 302-5

Diâmetro 24 cm

Volume 3,42 L

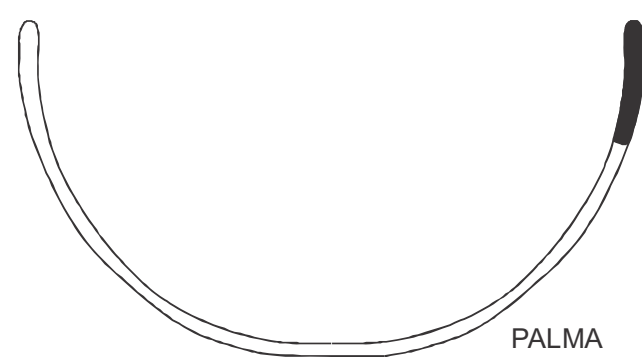

Sítio Jacarezinho

PN 502-1

Diâmetro $38 \mathrm{~cm}$

Volume13,26 L

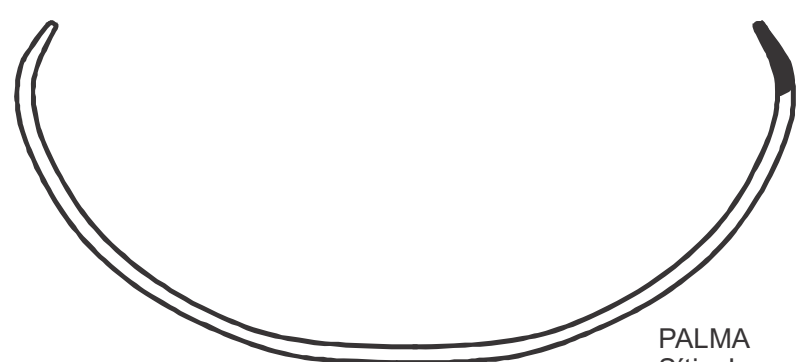

Sítio Jacarezinho

PN 305-13

Diâmetro $40 \mathrm{~cm}$

Volume 14,66 L

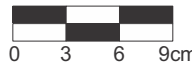

PALMA

Sítio Jacarezinho

Surfer 3

Distribuição Espacial

da Cerâmica
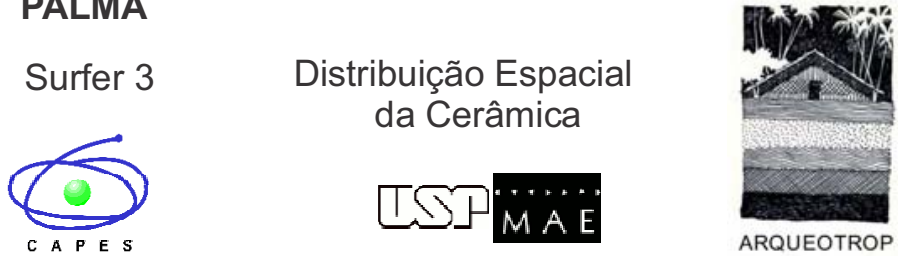


\section{forma 7}

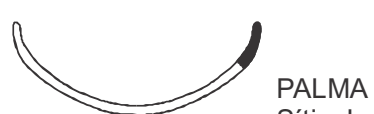

Sítio Jacarezinho

PN 206-2

Diâmetro $15 \mathrm{~cm}$

Volume 0,52 L

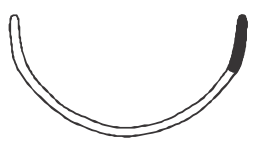

PALMA

Sítio Jacarezinho

PN 206-17

Diâmetro $14 \mathrm{~cm}$

Volume 0,71 L

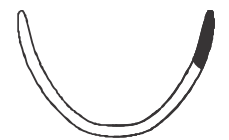

PALMA

Sítio Jacarezinho PN 125-1

Diâmetro $12 \mathrm{~cm}$

Volume $0,48 \mathrm{~L}$

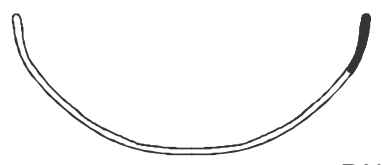

PALMA

Sítio Jacarezinho

PN 202A-1

Diâmetro $22 \mathrm{~cm}$

Volume 2,12 L

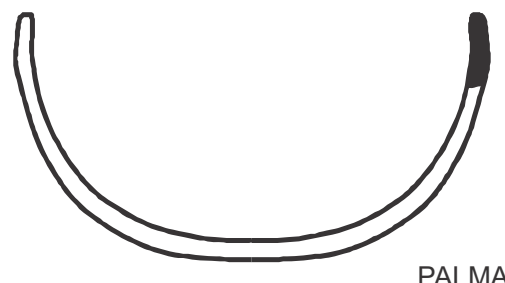

Sítio Jacarezinho PN 305-4

Diâmetro $28 \mathrm{~cm}$ Volume 6,13 L

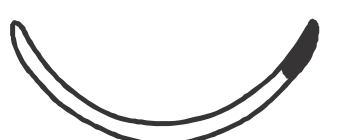

PALMA

Sítio Jacarezinho PN 306-11

Diâmetro $18 \mathrm{~cm}$ Volume $0,83 \mathrm{~L}$

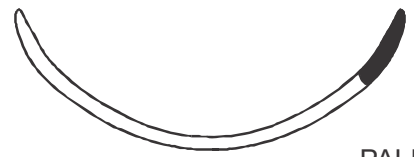

PALMA

Sítio Jacarezinho

PN 206-1

Diâmetro $24 \mathrm{~cm}$

Volume 2,19 L

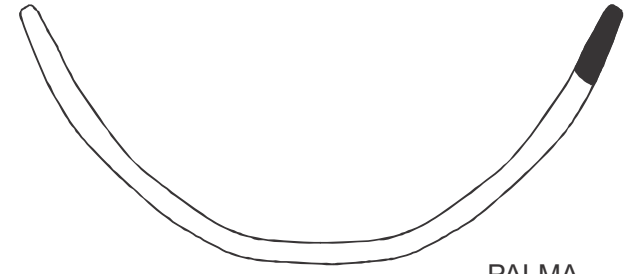

PALMA

Sítio Jacarezinho

PN 160-1

Diâmetro $36 \mathrm{~cm}$

Volume 6,52 L

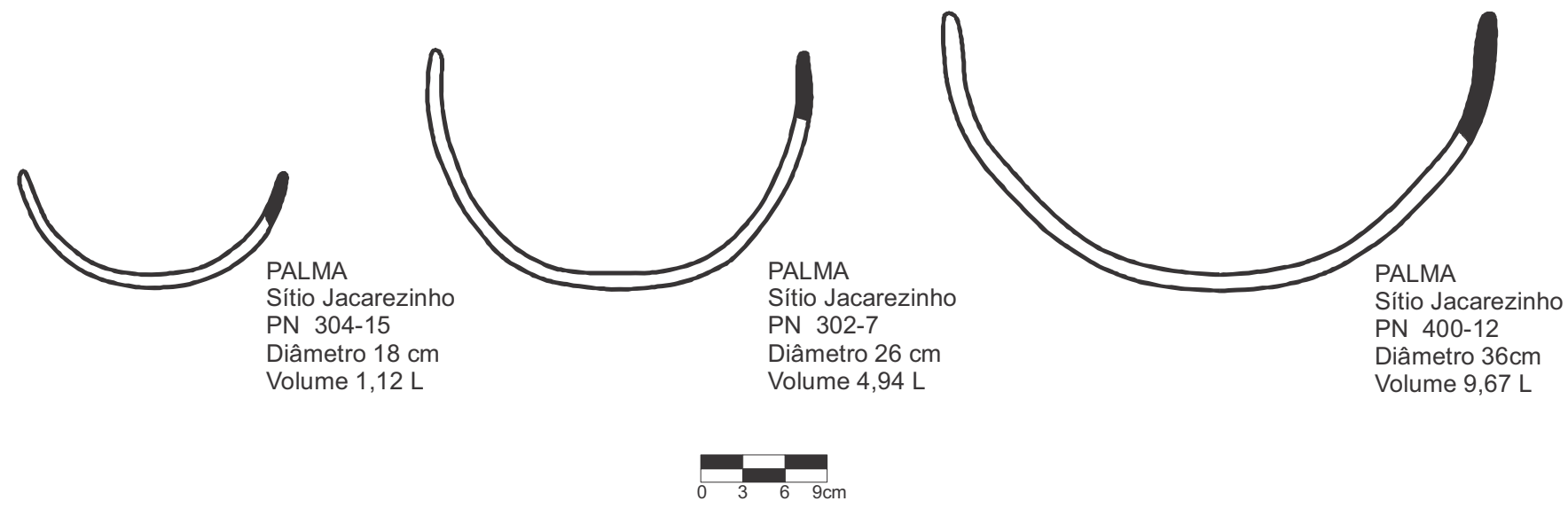

PALMA

Sítio Jacarezinho Surfer 4

Distribuição Espacial da Cerâmica
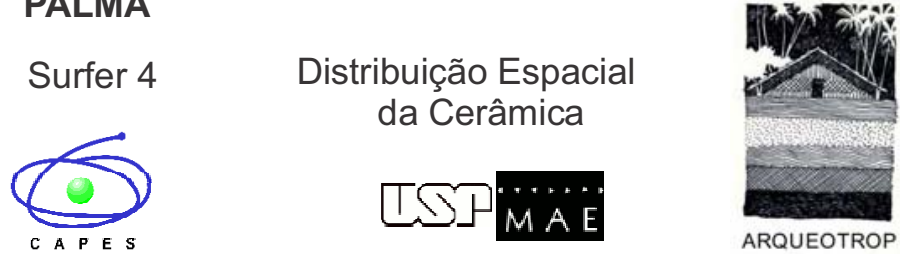

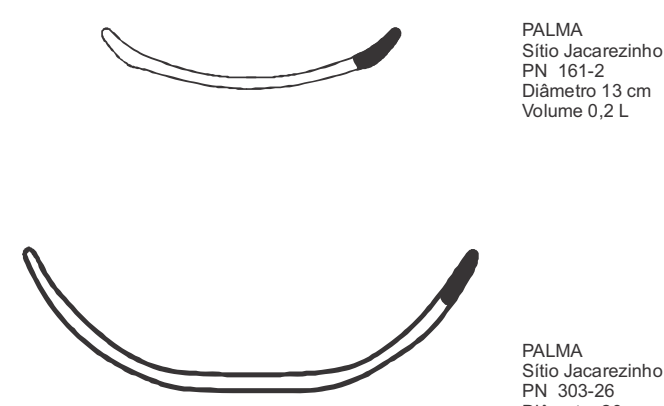

PALMA

Sítio Jacarezinh PN 303-26 Diâmetro $20 \mathrm{~cm}$
Volume $1,02 \mathrm{~L}$

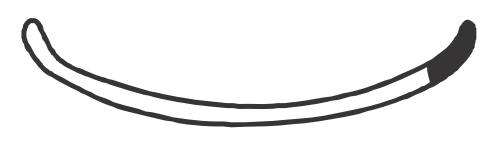

Sítio Jacarezinho PN 306-12 Diâmetro $20 \mathrm{~cm}$
Volume $1,09 \mathrm{~L}$
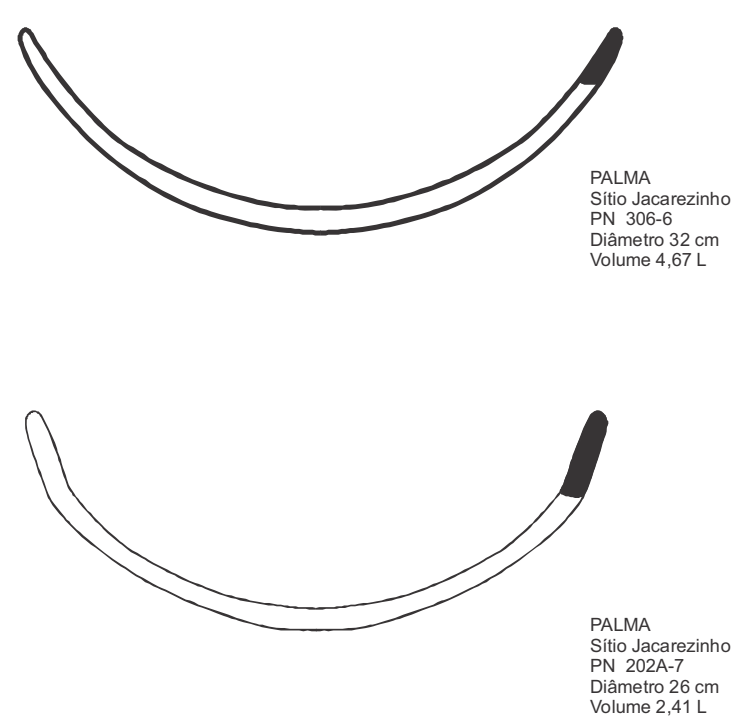

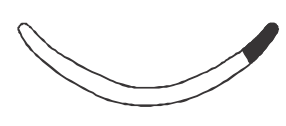

PALMA

Sítio Jacarezinho PN 17-05 Diâmetro $11 \mathrm{~cm}$
Volume $0,2 \mathrm{~L}$
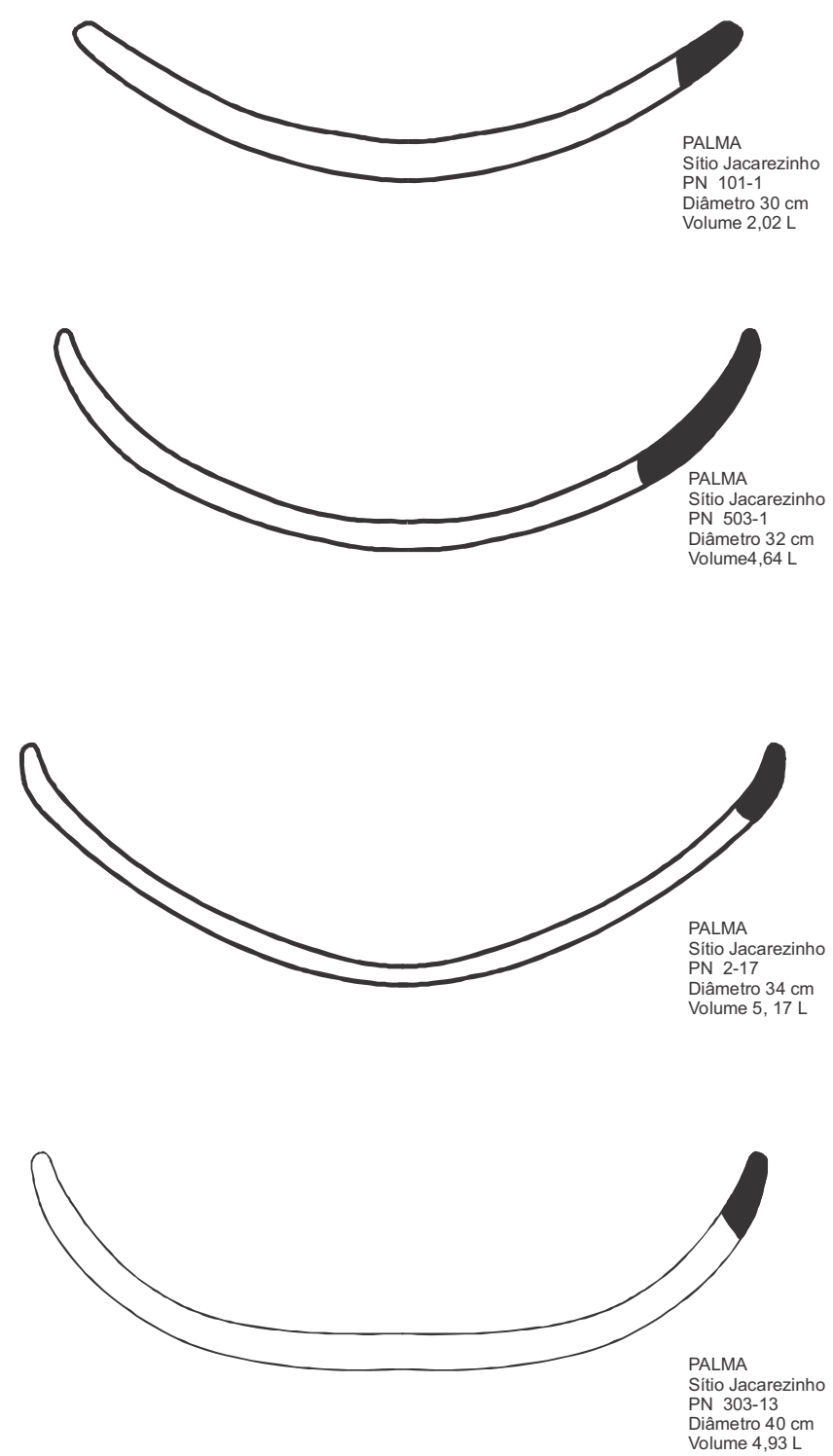

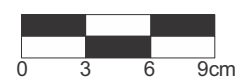

\section{PALMA}

Sítio Jacarezinho

Surfer 5

Distribuição Espacial

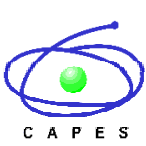
da Cerâmica 


\section{forma 17}

Sítio Jacarezinho

PN 204-52

Diâmetro $16 \mathrm{~cm}$

Volume L

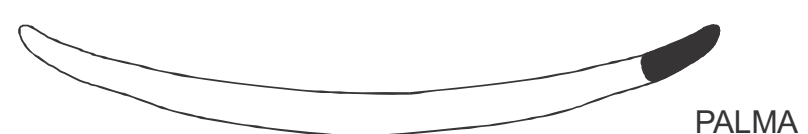

Sítio Jacarezinho

PN 307-1

Diâmetro 26 cm

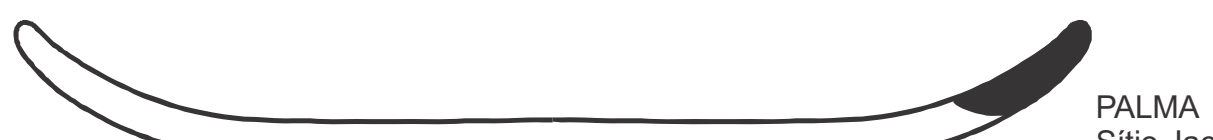

Sítio Jacarezinho

PN 309-1

Diâmetro $36 \mathrm{~cm}$

Volume 3,1 L

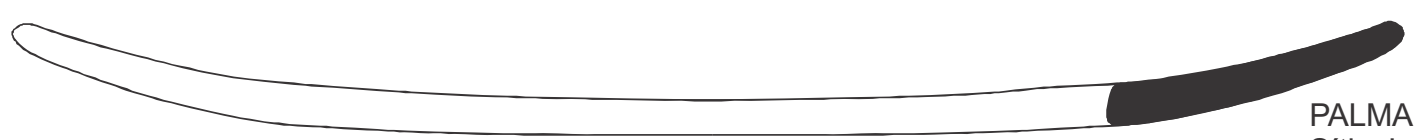

Sítio Jacarezinho

PN 509-1

Diâmetro 48 cm

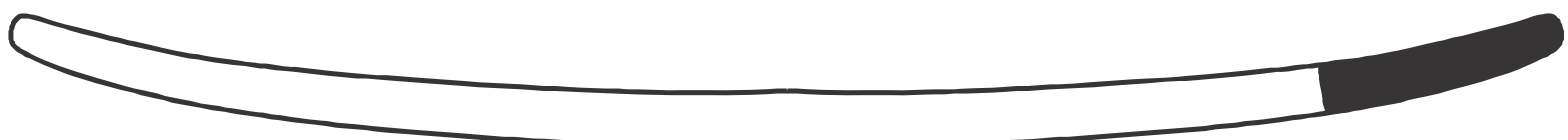

PALMA

Sítio Jacarezinho

PN 305-1

Diâmetro 54 cm

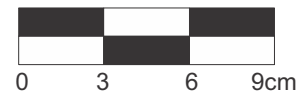

PALMA

Sítio Jacarezinho

Surfer 6

Distribuição Espacial

da Cerâmica 


\section{forma 1}
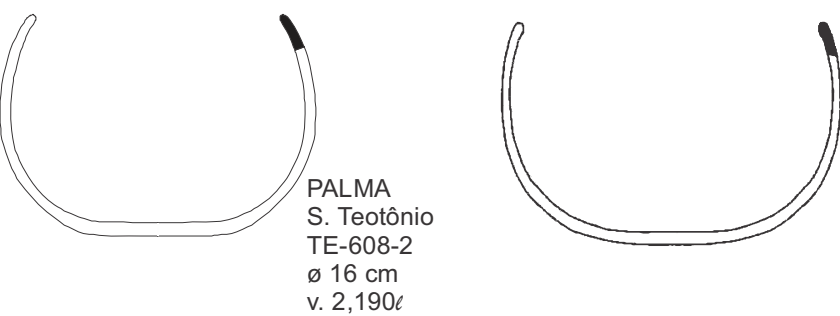

PALMA

S. Teotônio

TE-608-33

$\varnothing 20 \mathrm{~cm}$

v. $2,652 \ell$
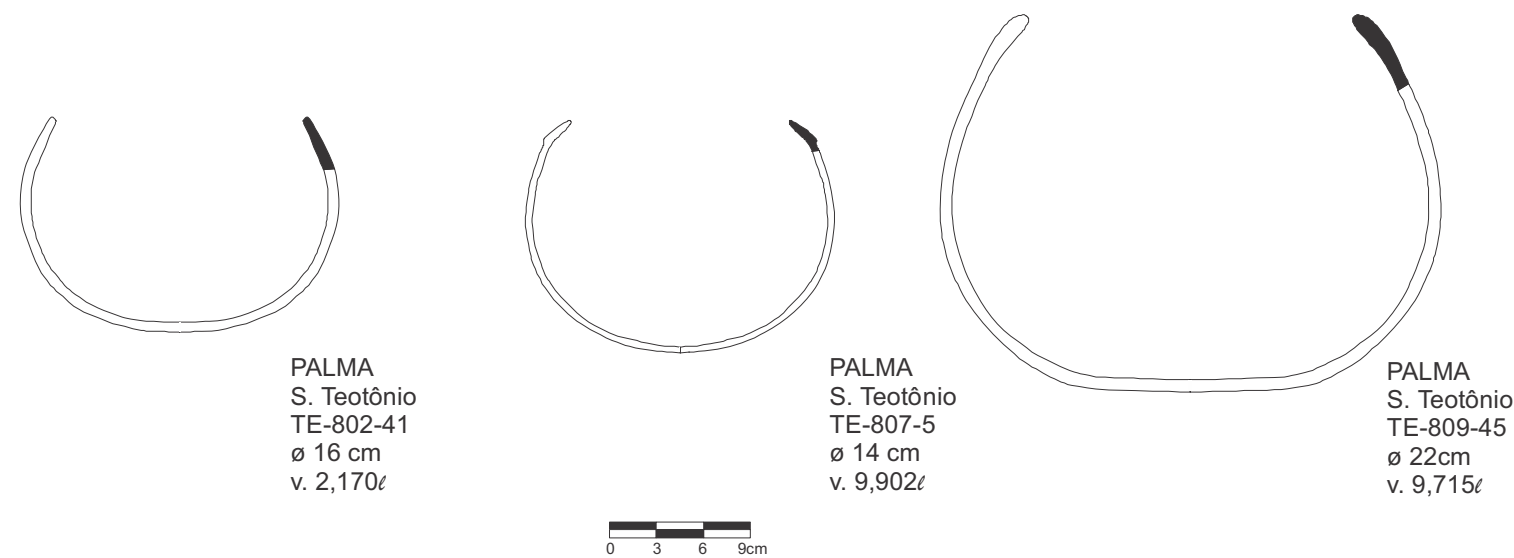

\section{forma 2}
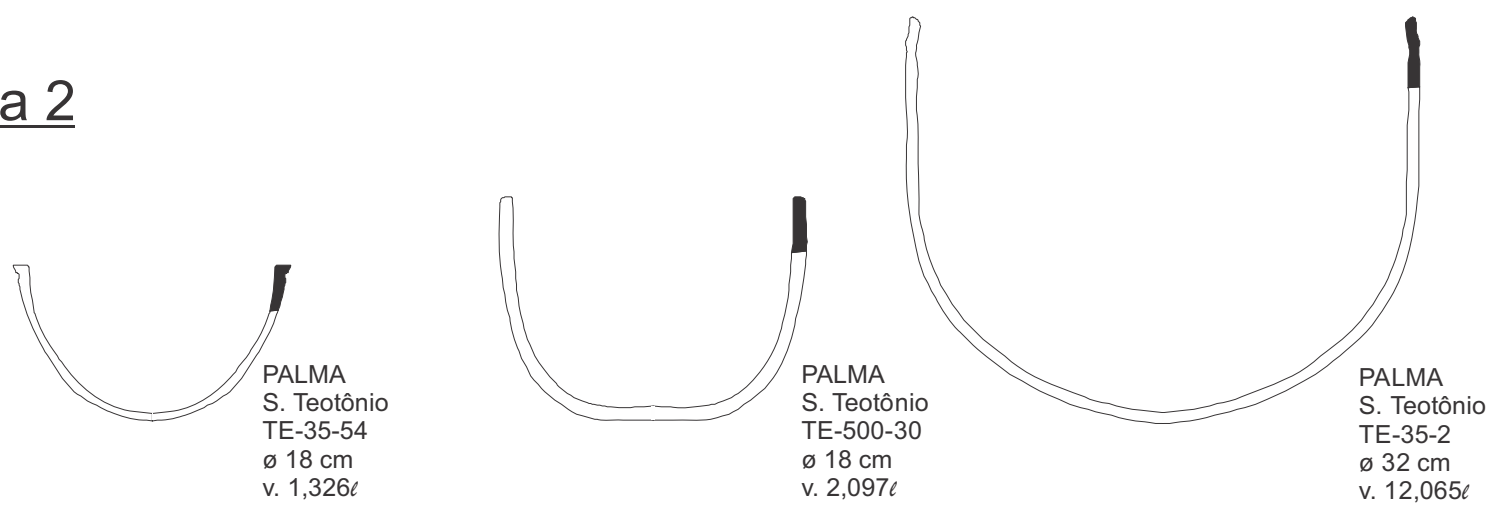

\begin{tabular}{lll}
\hline 0 & 3 & 6
\end{tabular}

PALMA

Sítio Teotônio

Surfer 1

Distribuição Espacial

da Cerâmica

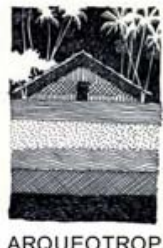




\section{forma 3}
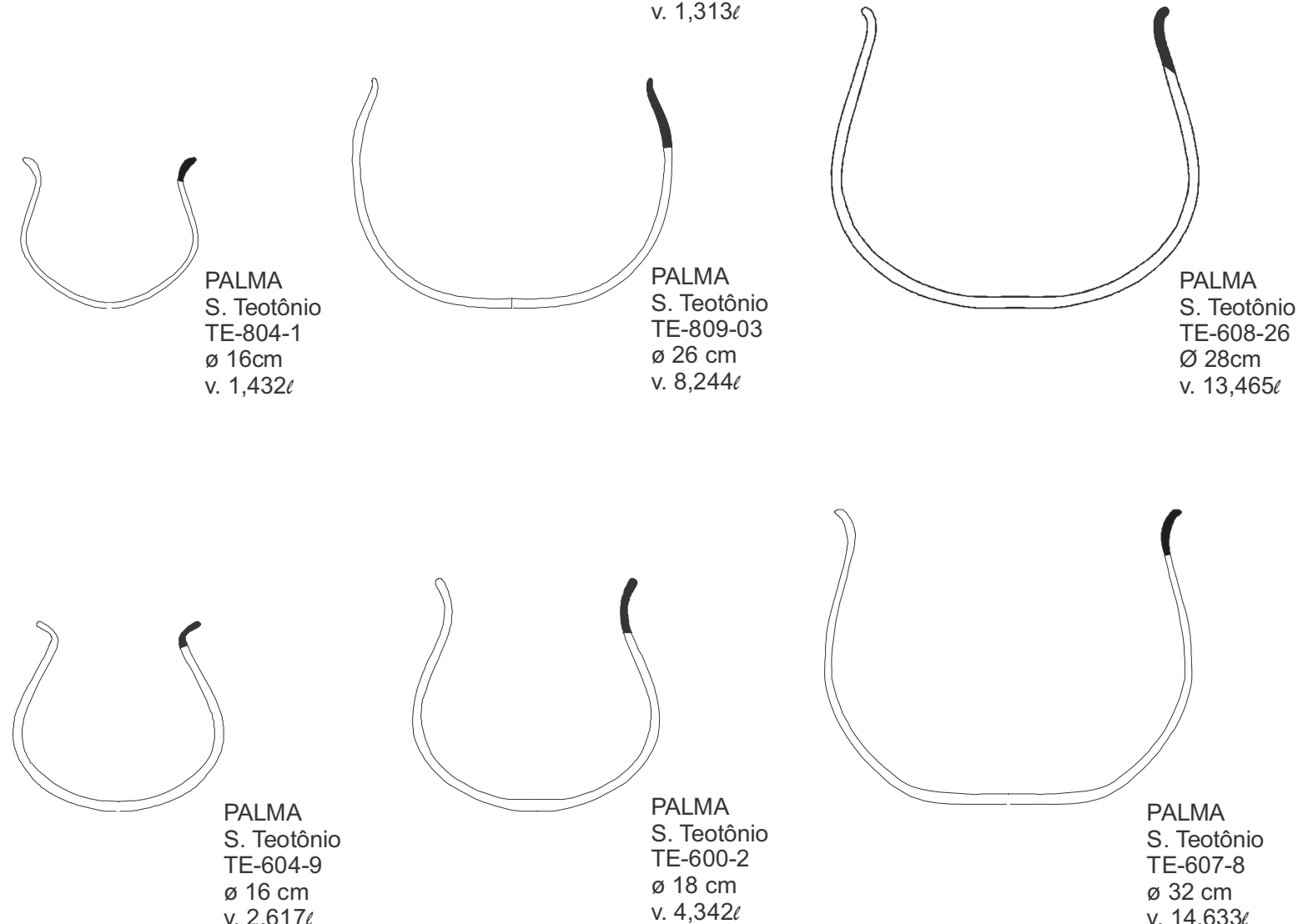

S. Teotônio TE-600-2

$\varnothing 18 \mathrm{~cm}$

v. 2,617

v. $4,342 \ell$
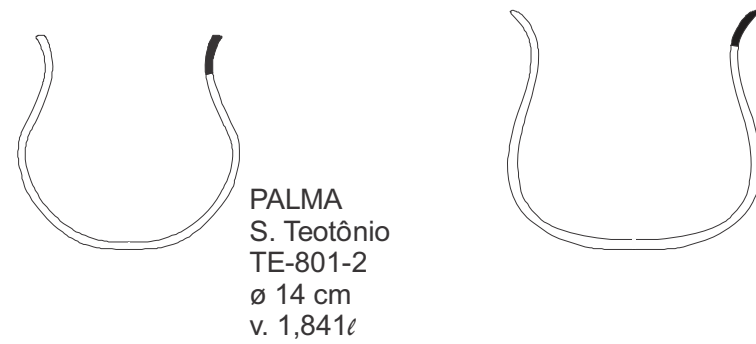

PALMA

S. Teotônio

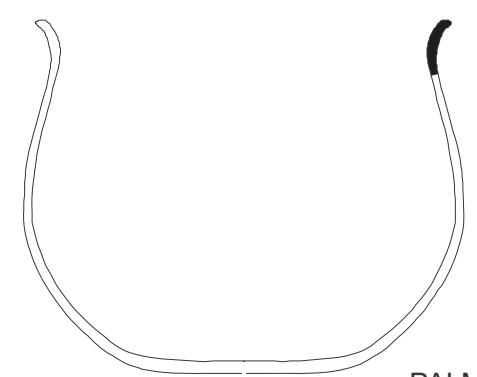

PALMA

S. Teotônio

TE-607-8

ø $32 \mathrm{~cm}$

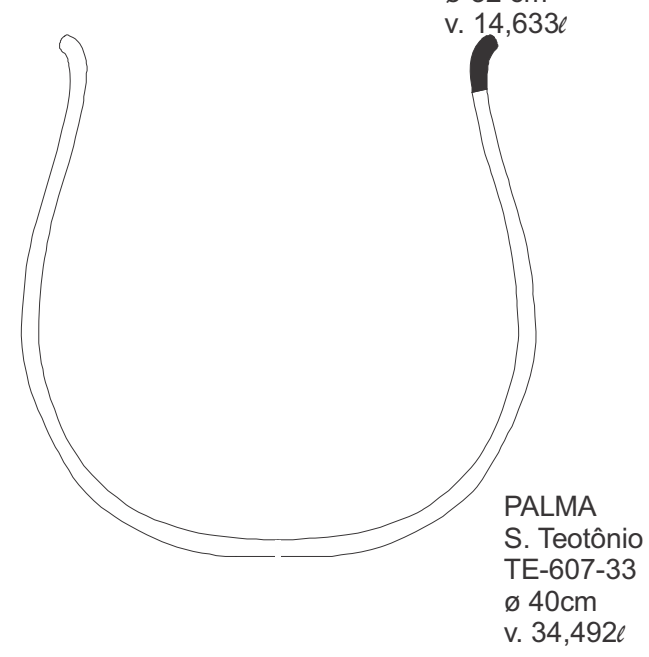

v. $2,934 \ell$

v. $34,492 \ell$

\section{PALMA}

Sítio Teotônio

Surfer 2

Distribuição Espacial

da Cerâmica

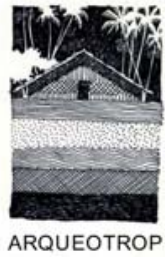




\section{forma 5}

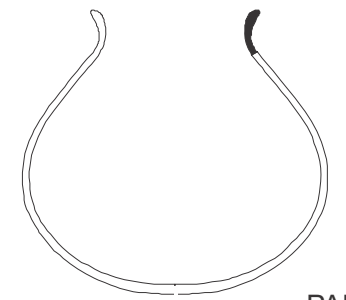

PALMA

S. Teotônio

TE-809-41

$\varnothing 15 \mathrm{~cm}$

v. $5,285 e$

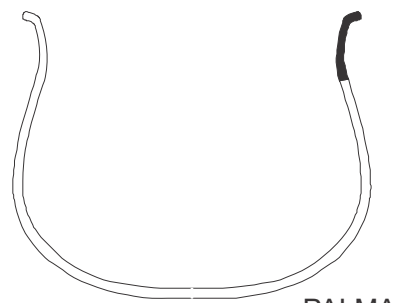

S. Teotônio

TE-605-1

$\varnothing 2 \mathrm{~cm}$

v. $9,149 e$

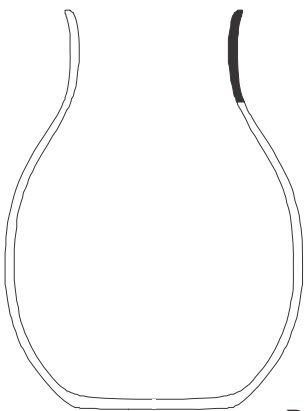

PALMA

S. Teotônio TE-607-23

$\varnothing 15 \mathrm{~cm}$

v. $6,826 \ell$

\section{forma 6}

PALMA

S. Teotônio

TE-809-32

ø $10 \mathrm{~cm}$

v. $0,300 e$

PALMA

S. Teotônio

TE-608-16

$\varnothing 16 \mathrm{~cm}$

v. $1,397 \mathrm{e}$
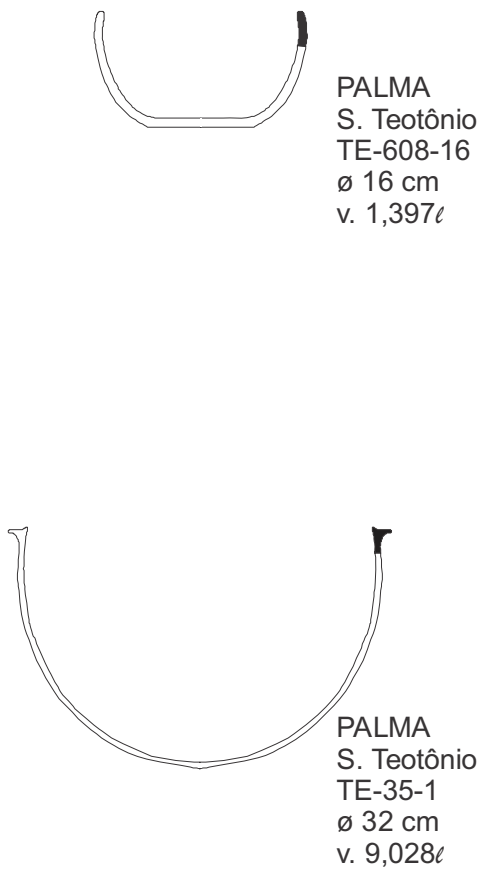

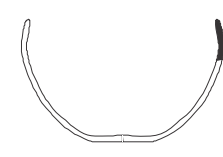

PALMA

S. Teotônio

TE-1-1

$\varnothing 16 \mathrm{~cm}$

v. $1,444 \ell$

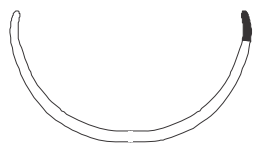

PALMA

S. Teotônio

TE-607-12

ø $19 \mathrm{~cm}$

v. $1,910 e$
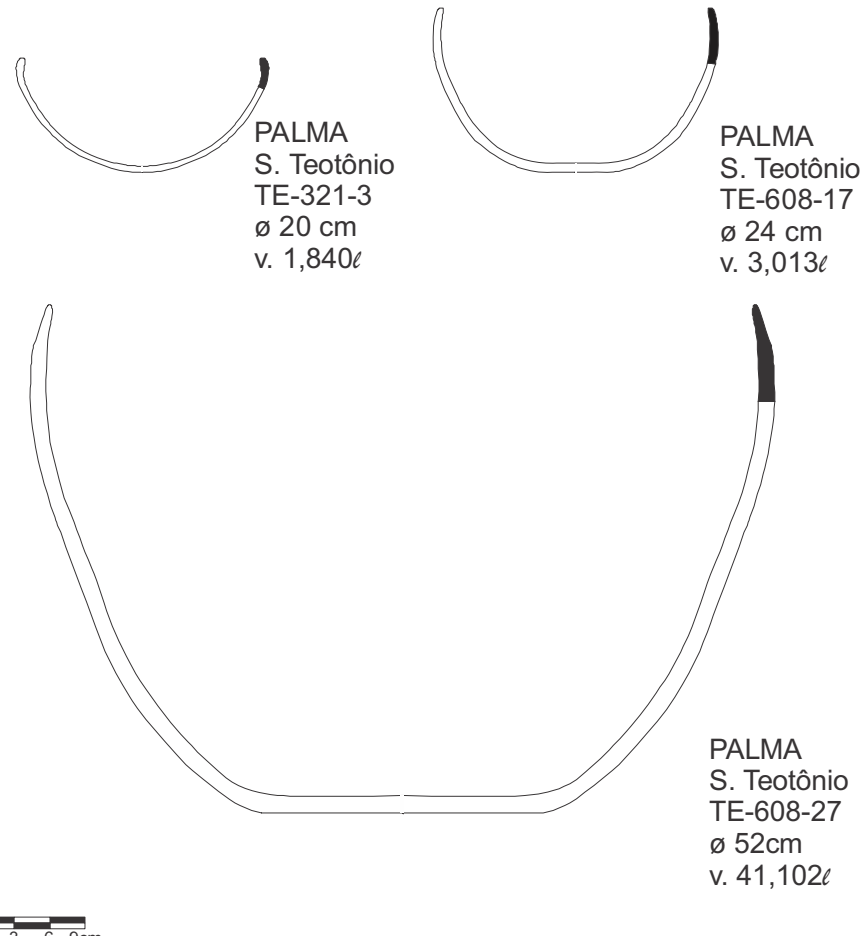

PALMA

S. Teotônio TE-608-27

$\varnothing 52 \mathrm{~cm}$

v. 41,102

\section{PALMA}

Sítio Teotônio

Surfer 3

Distribuição Espacial da Cerâmica

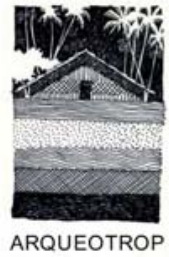




\section{forma 7}
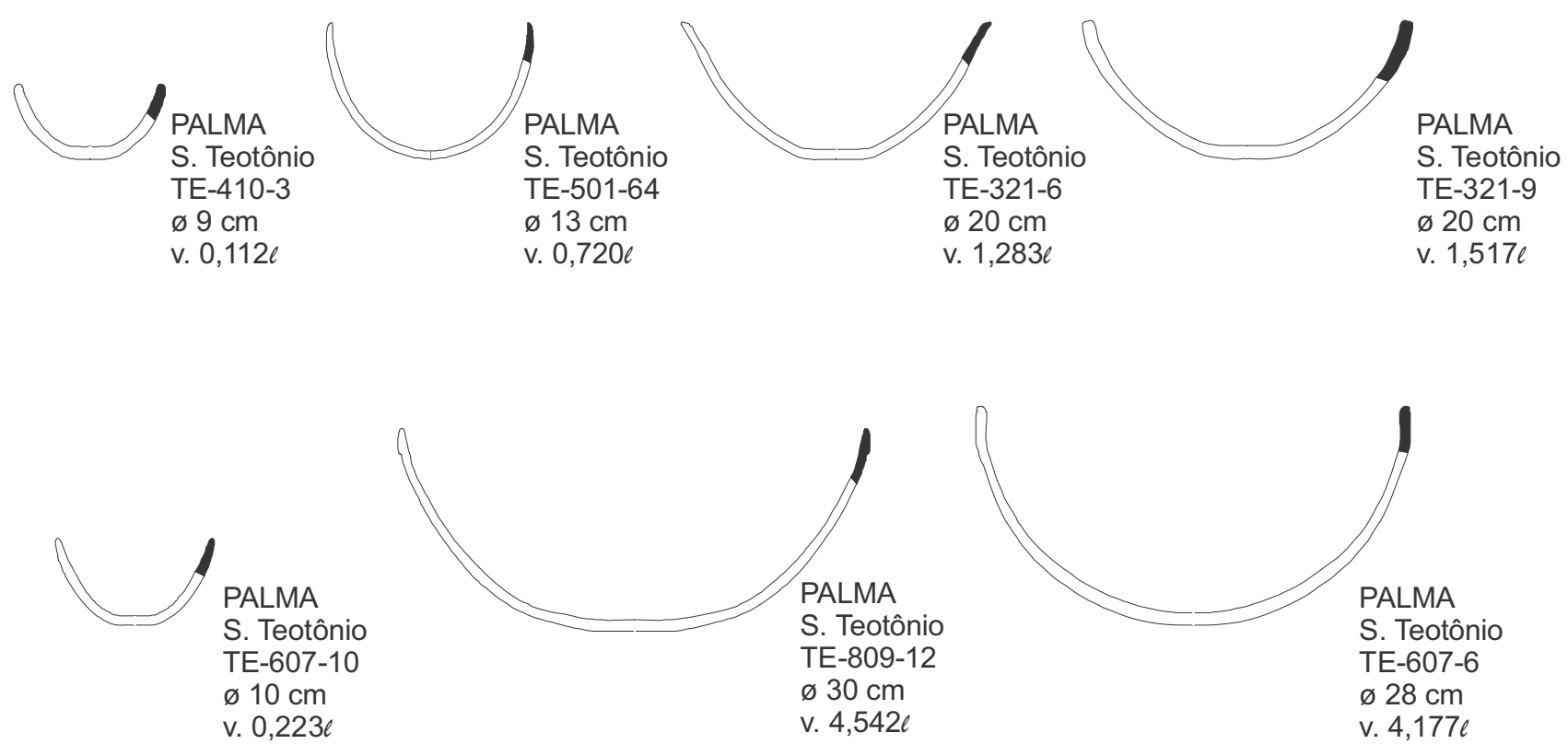

PALMA

S. Teotônio

TE-809-42

$\varnothing 22 \mathrm{~cm}$

v. $2,587 \ell$

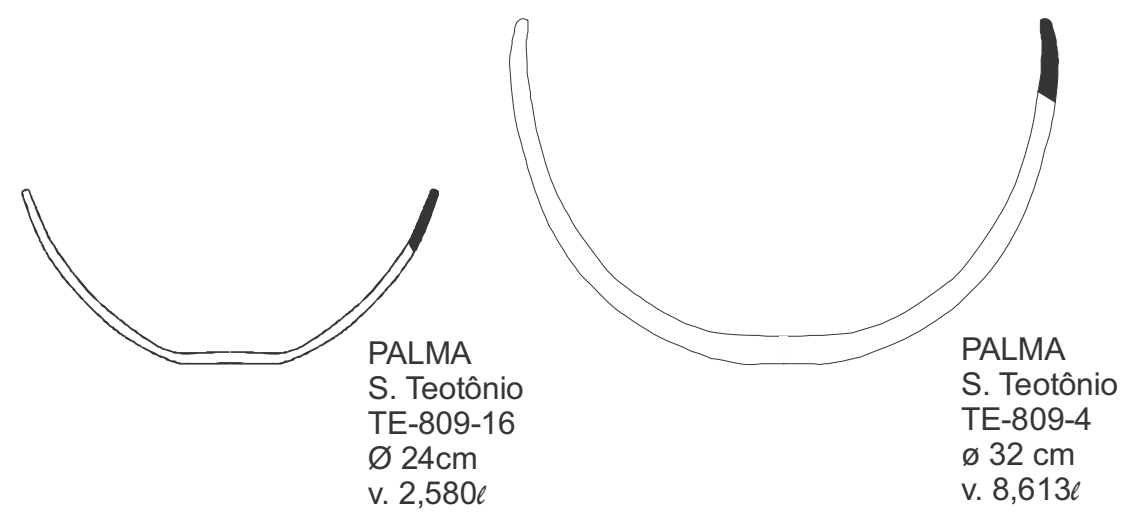

PALMA

S. Teotônio

TE-501-65

$\varnothing 30 \mathrm{~cm}$

v. $5,052 \ell$

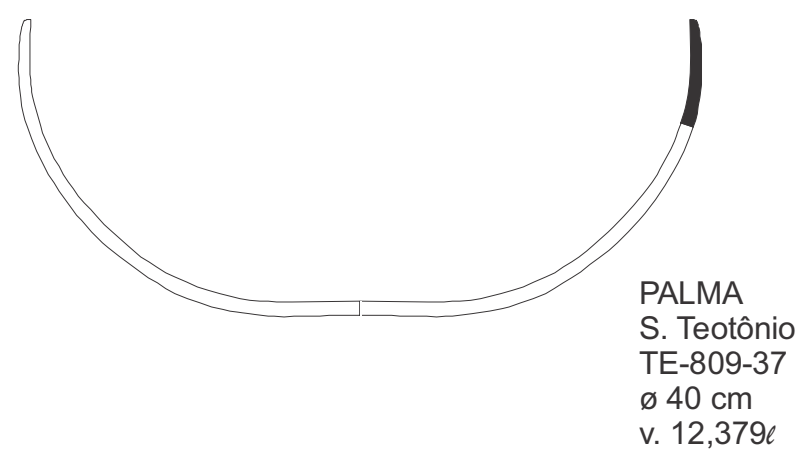

\begin{tabular}{lll}
\hline & 3 & 6
\end{tabular}

PALMA

Sítio Teotônio

Surfer 4

Distribuição Espacial

da Cerâmica

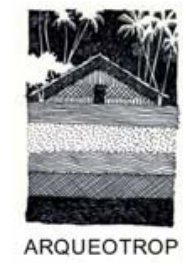




\section{forma 8}

PALMA

S. Teotônio

TE-500-33

$\varnothing 18 \mathrm{~cm}$

v. 0,953 e

PALMA

S. Teotônio

TE-321-7

$\varnothing 22 \mathrm{~cm}$

v. $1,429 e$

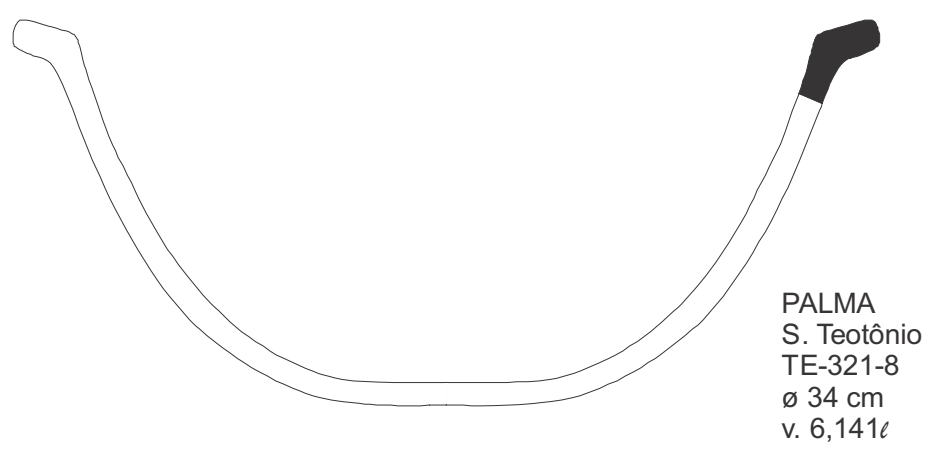

PALMA

S. Teotônio TE-609-01

$\varnothing 34 \mathrm{~cm}$

v. $9,262 \ell$

\section{forma 9}
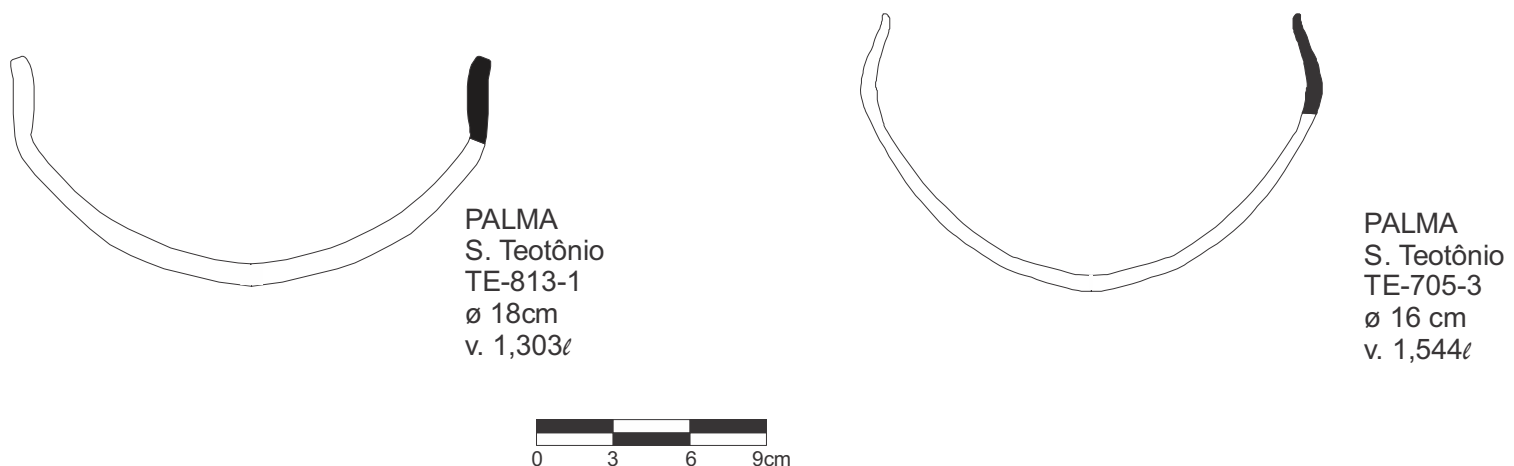

\section{PALMA}

Sítio Teotônio

Surfer 5

Distribuição Espacial da Cerâmica

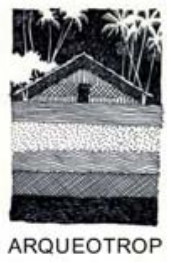




\section{forma 10}

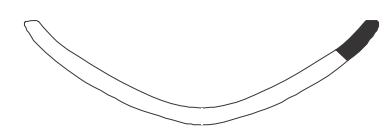

PALMA

S. Teotônio TE-417-7

ø $13 \mathrm{~cm}$

v. $0,287 \ell$

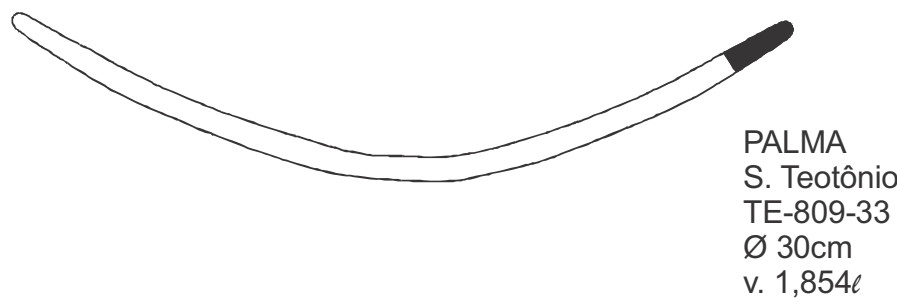

PALMA

S. Teotônio

TE -809-38

S. Teotônio

$\varnothing 28 \mathrm{~cm}$

v. $1,4892 \ell$

TE-501-1

$\varnothing 28 \mathrm{~cm}$

v. $2,211 \ell$

PALMA

S. Teotônio

TE-124-8

$\varnothing 24 \mathrm{~cm}$

v. $1,202 \ell$
PALMA

S. Teotônio

TE-608-20

$\varnothing 32 \mathrm{~cm}$

v. $4,316 e$

forma 14
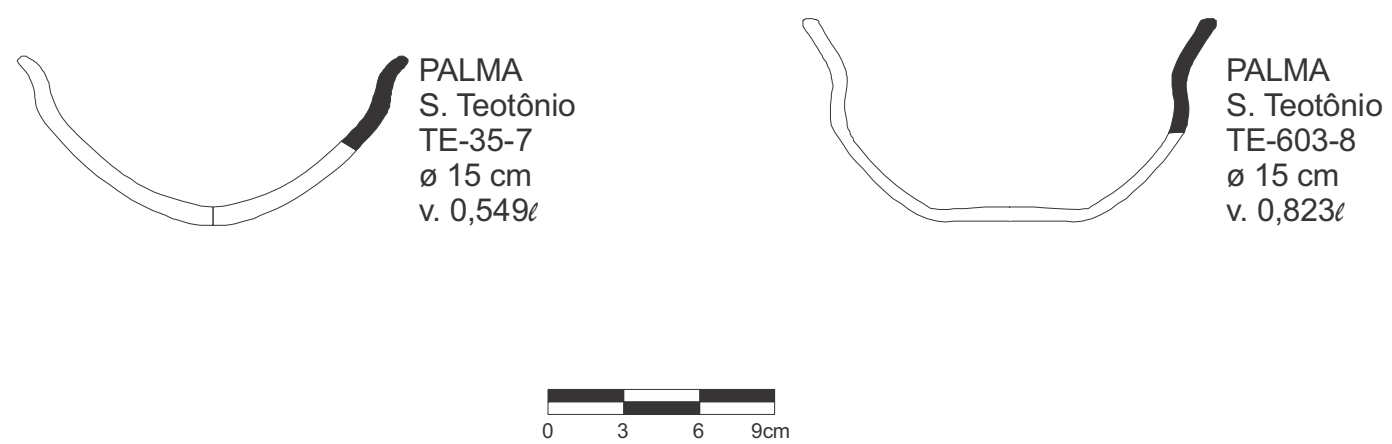

PALMA

Sítio Teotônio

Surfer 6

Distribuição Espacial

da Cerâmica 
ANEXO 15:

PORCENTAGENS E ESTATÍSTICAS 


\section{Anexo 15 B Gráfico de Barras Empilhadas}

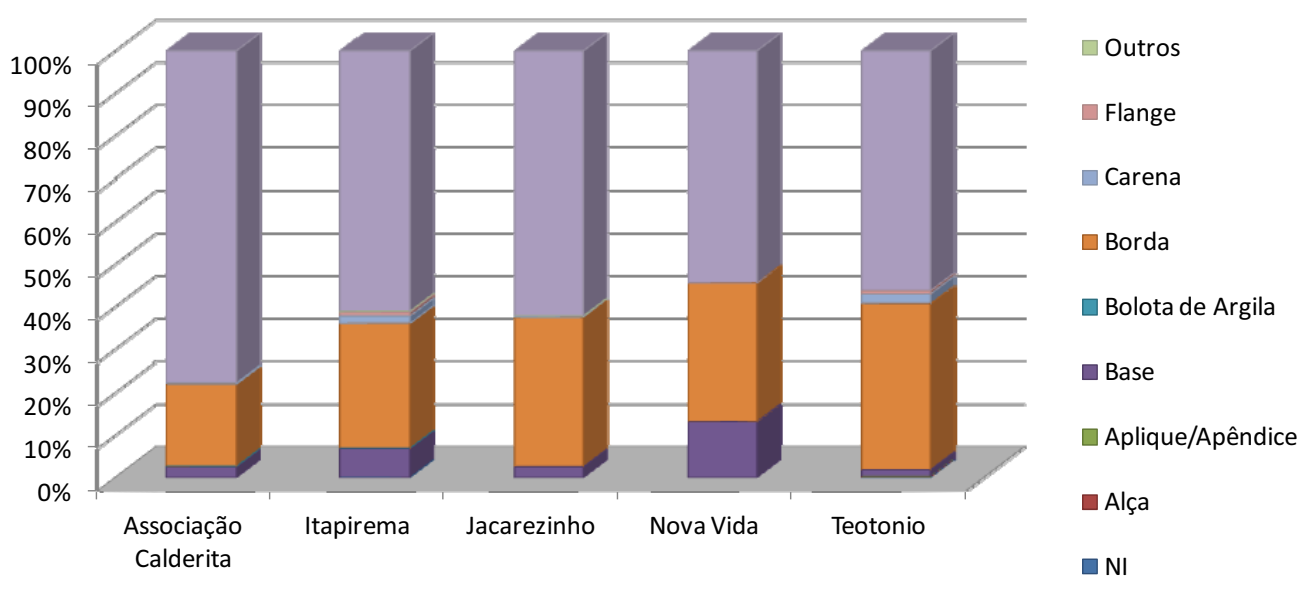

Figura 15 B.1 Gráfico de barras empilhadas da variável Categoria por sítio.

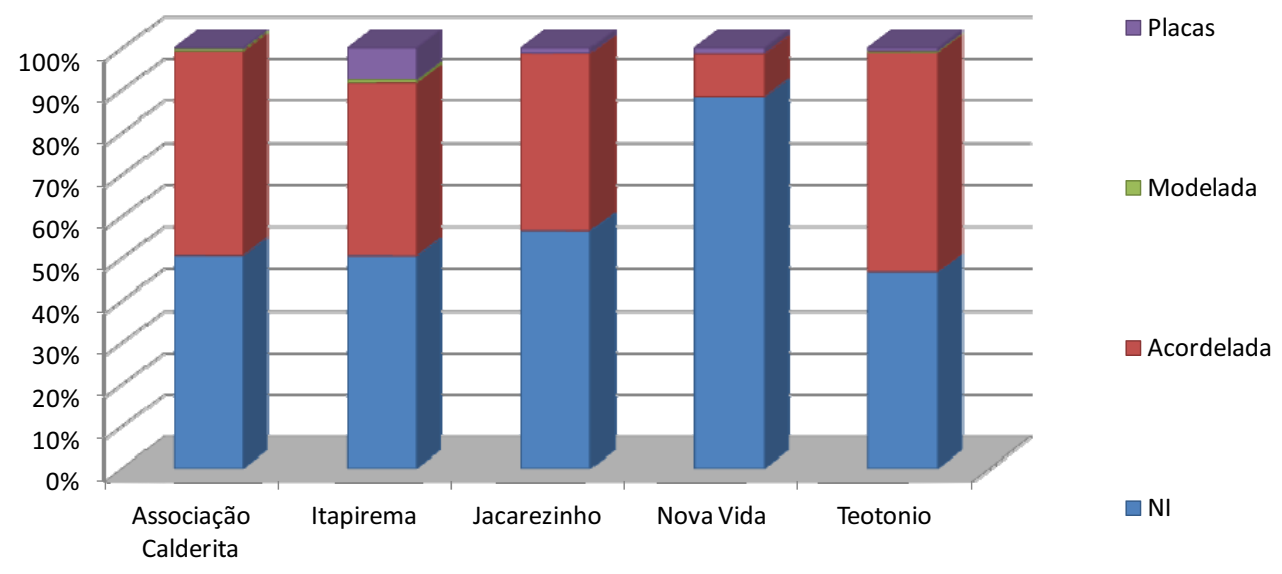

Figura 15 B.2 Gráfico de barras empilhadas da variável Técnica de Manufatura por sítio. 


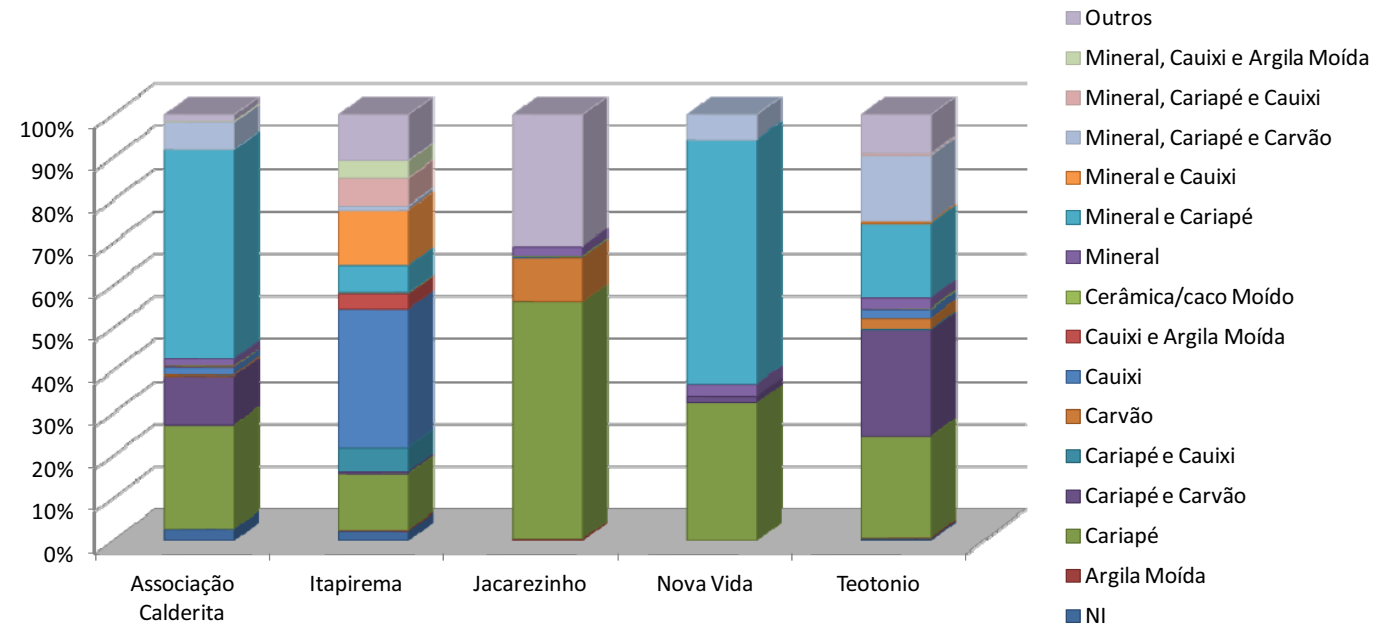

Figura 15 B.3 Gráfico de barras empilhadas da variável Antiplástico por sítio.

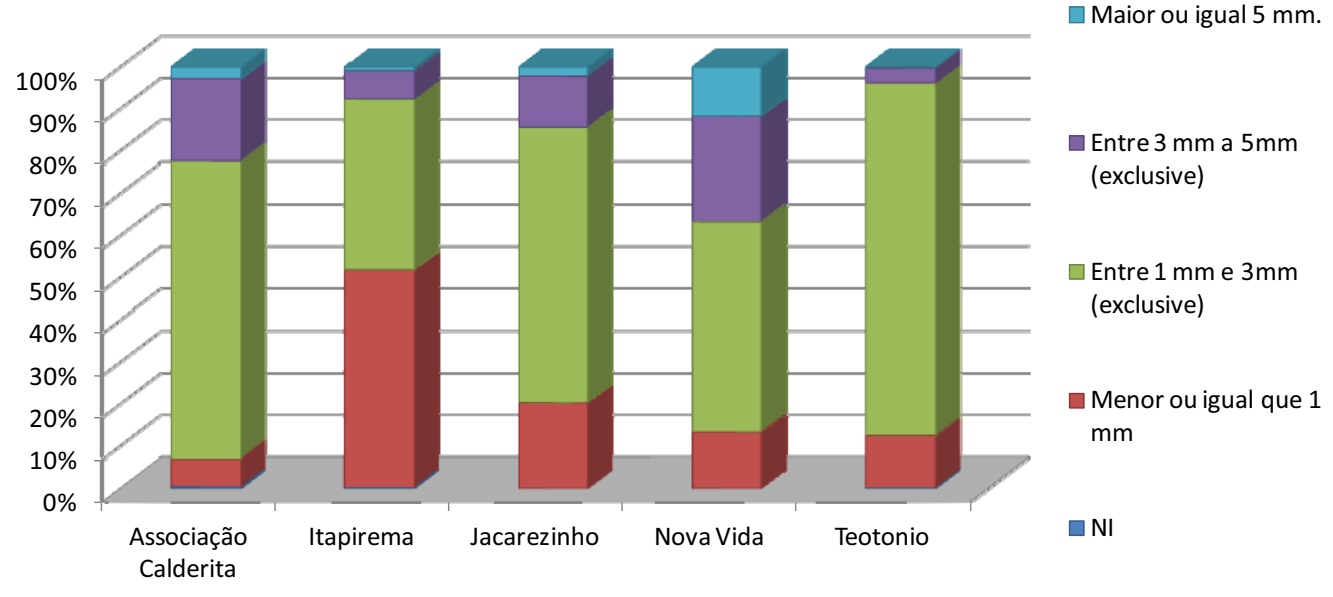

Figura 15 B.4 Gráfico de barras empilhadas da variável Espessura do Antiplástico por sítio. 


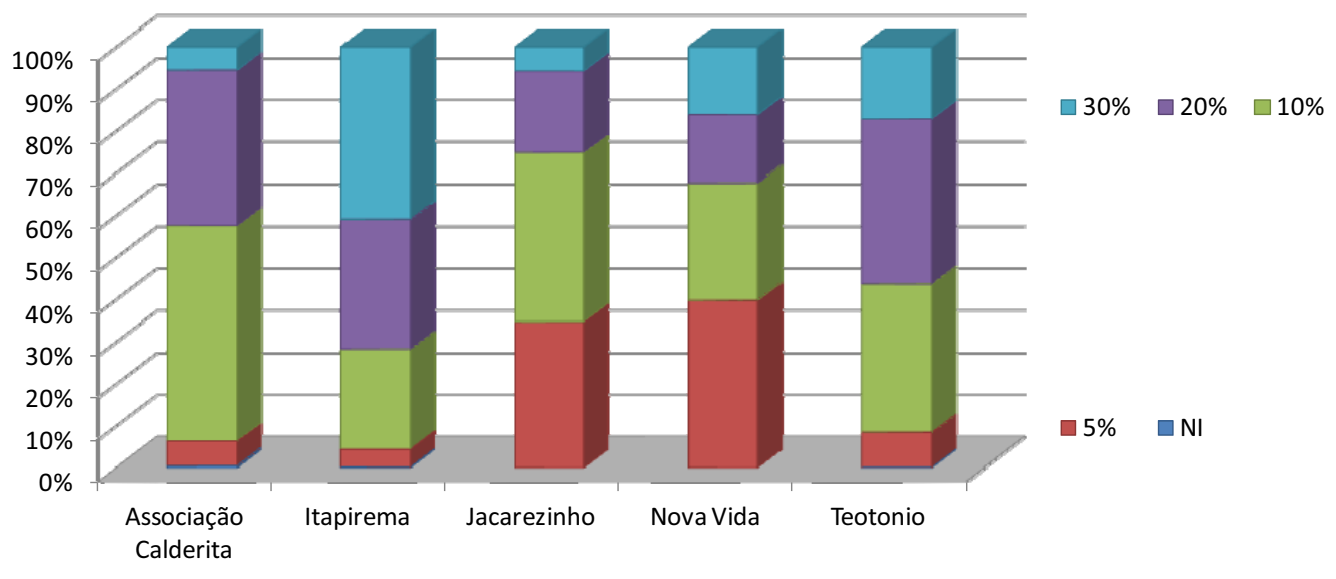

Figura 15 B.5 Gráfico de barras empilhadas da variável Porcentagem do Antiplástico por sítio.

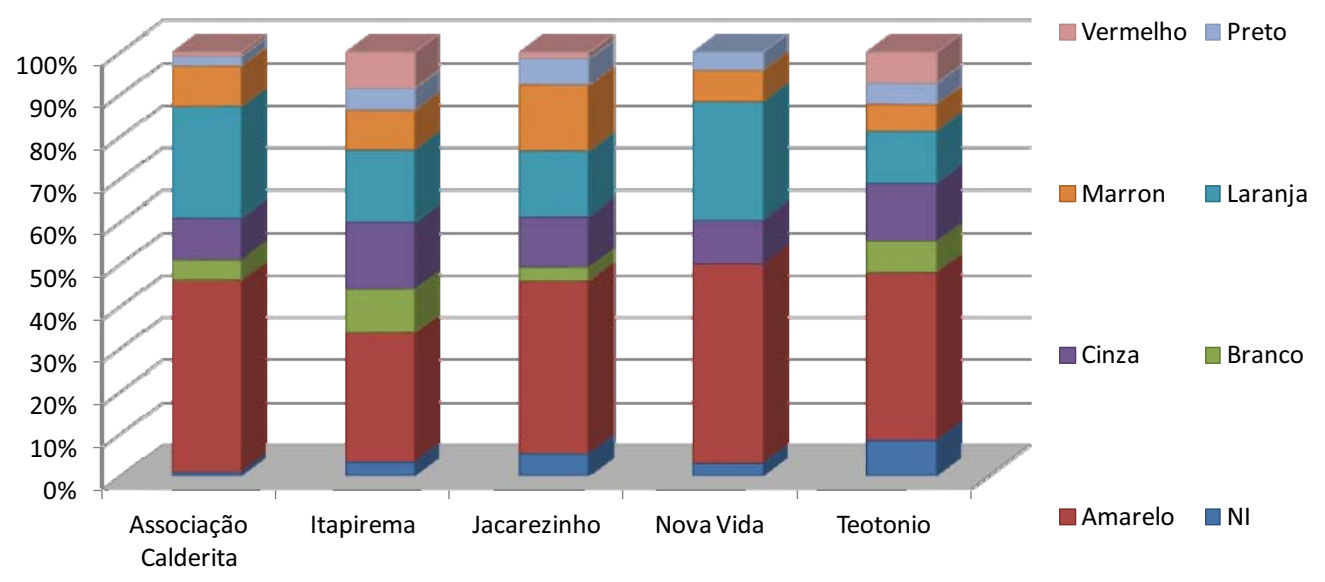

Figura 15 B.6 Gráfico de barras empilhadas da variável Cor da Superfície por sítio. 


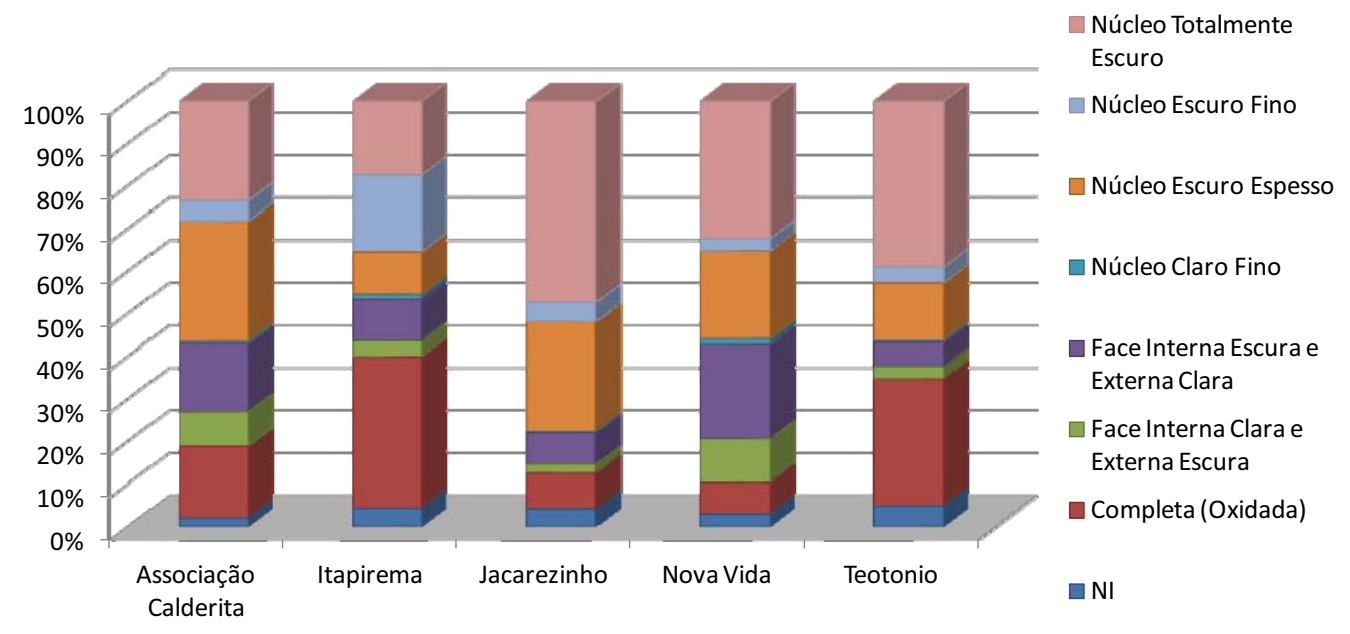

Figura 15 B.7 Gráfico de barras empilhadas da variável Queima por sítio.

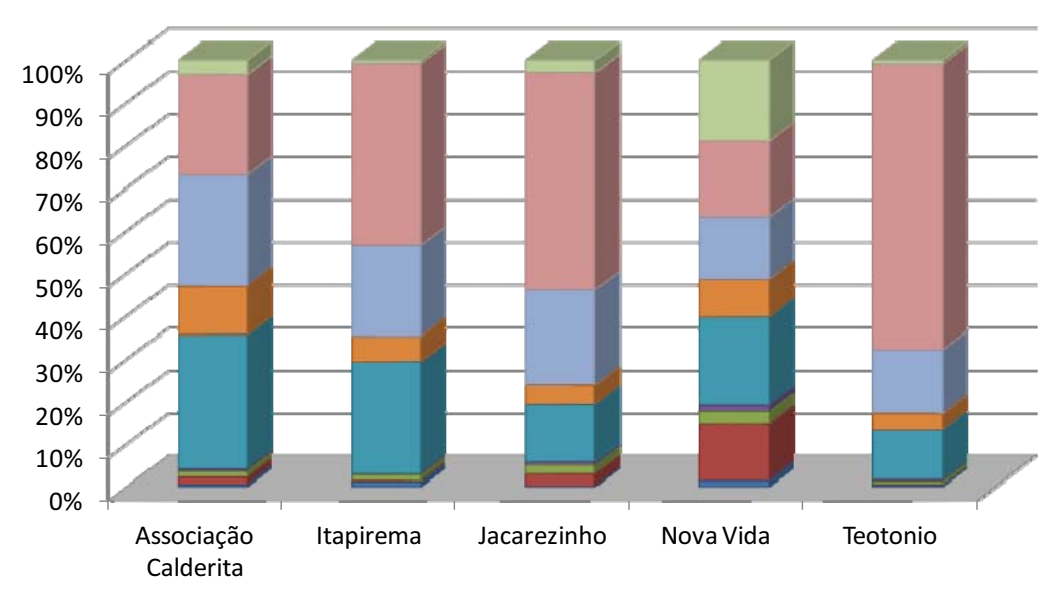
$\square$ Outros
Não Erodido
Erodido FI
Erodido FE
Erodido AF
Craquelê FI
$\square$ Craquelê FE
CraquelêAF
$\square \mathrm{NI}$

Figura 15 B.8 Gráfico de barras empilhadas da variável Estado de Conservação por sítio. 


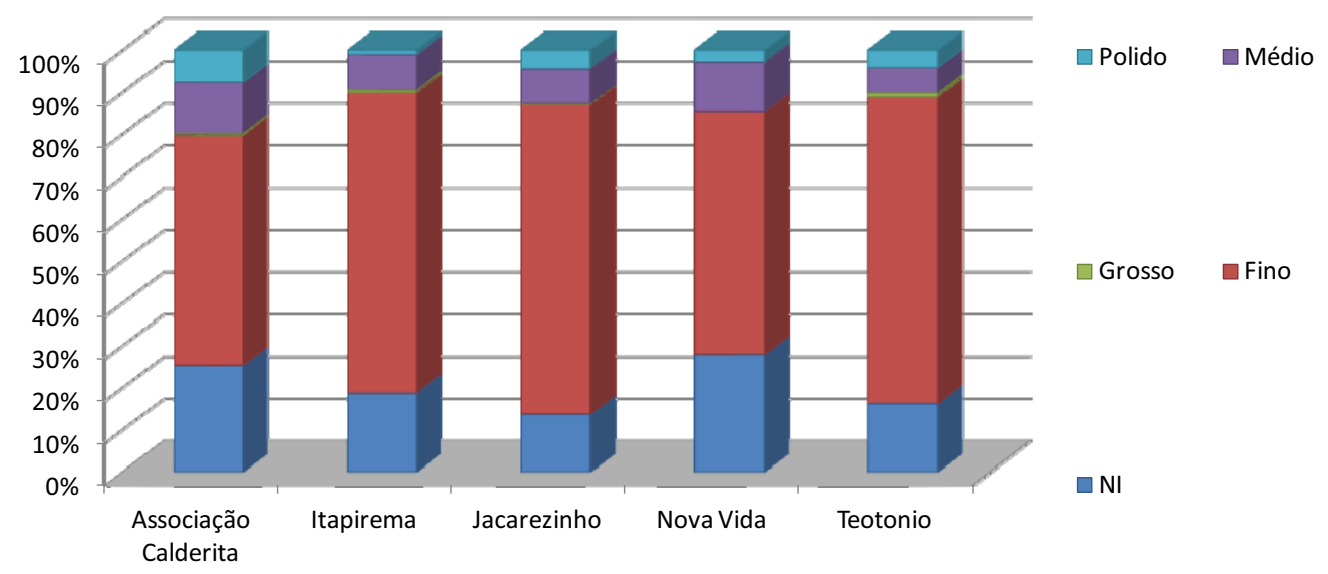

Figura 15 B.9 Gráfico de barras empilhadas da variável Alisamento Fase Interna por sítio.

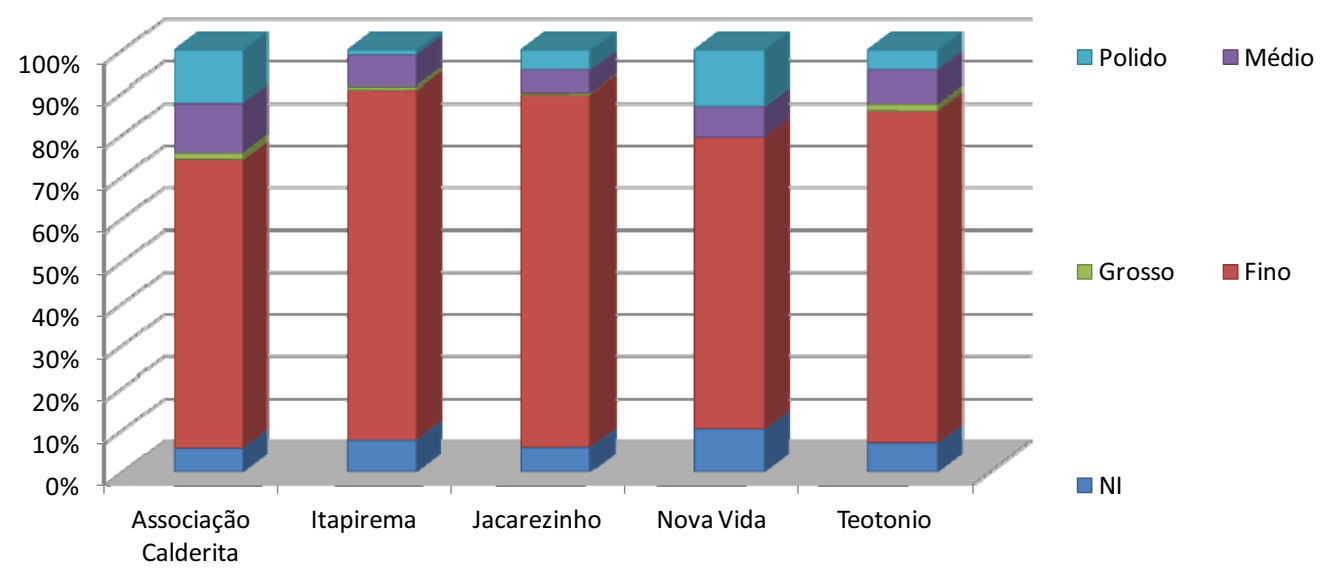

Figura 15 B.10 Gráfico de barras empilhadas da variável Alisamento Fase Externa por sítio. 


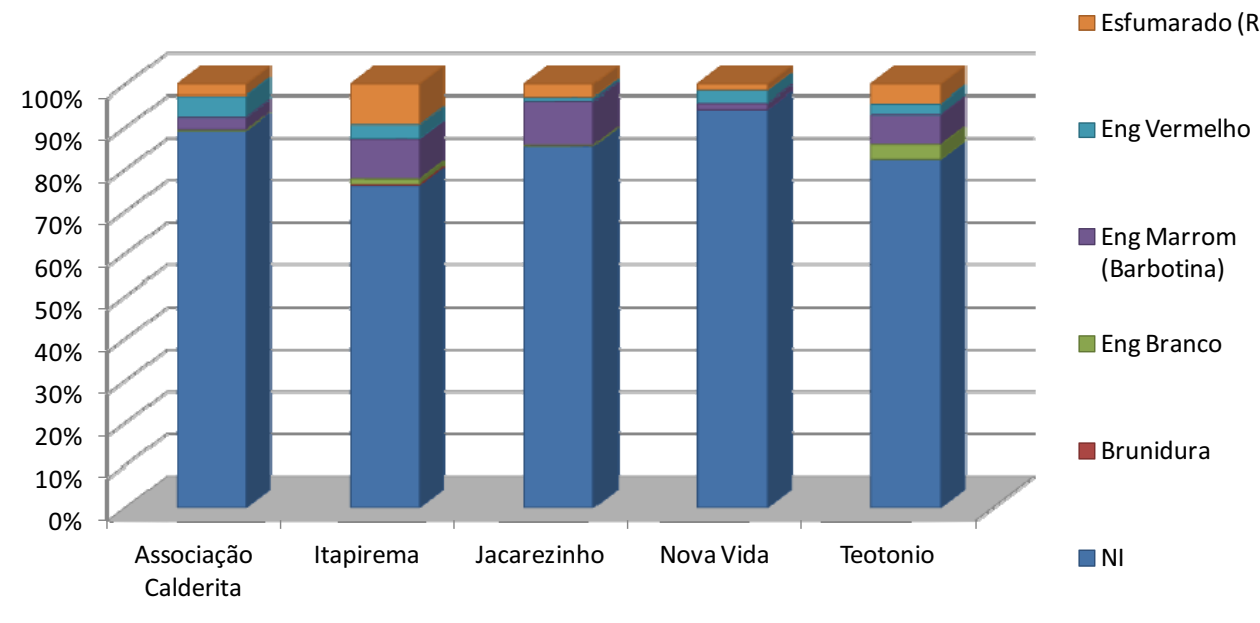

Figura 15 B.11 Gráfico de barras empilhadas da variável Tratamento da Superfície Face Interna por sítio.

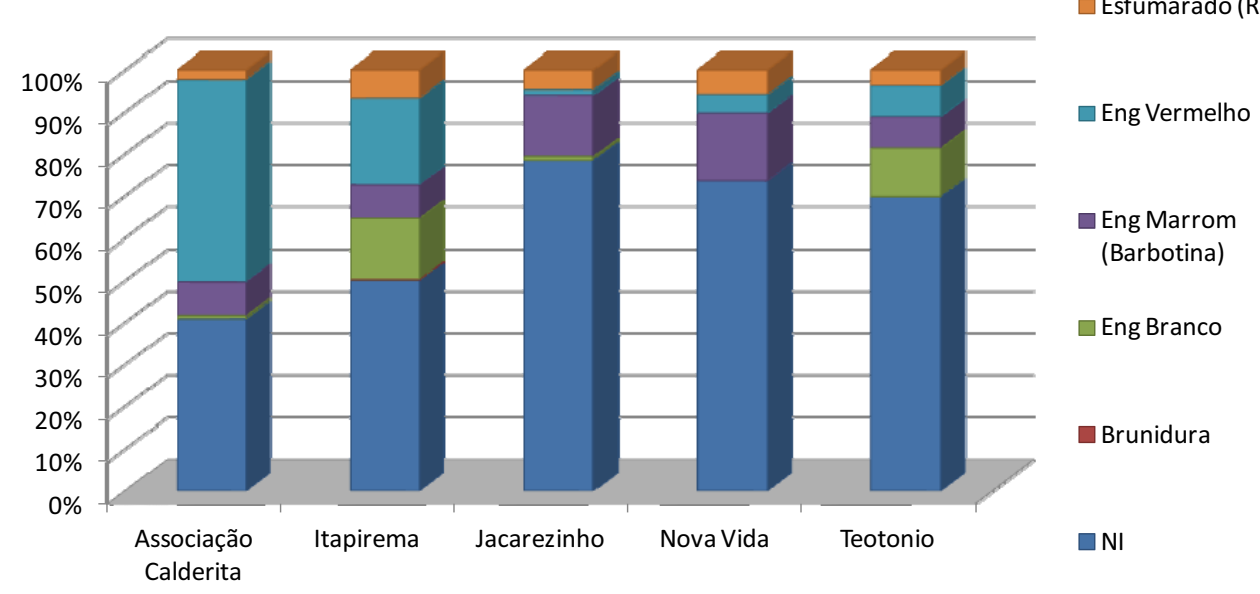

Figura 15 B.12 Gráfico de barras empilhadas da variável Tratamento da Superfície Face Externa por sítio. 


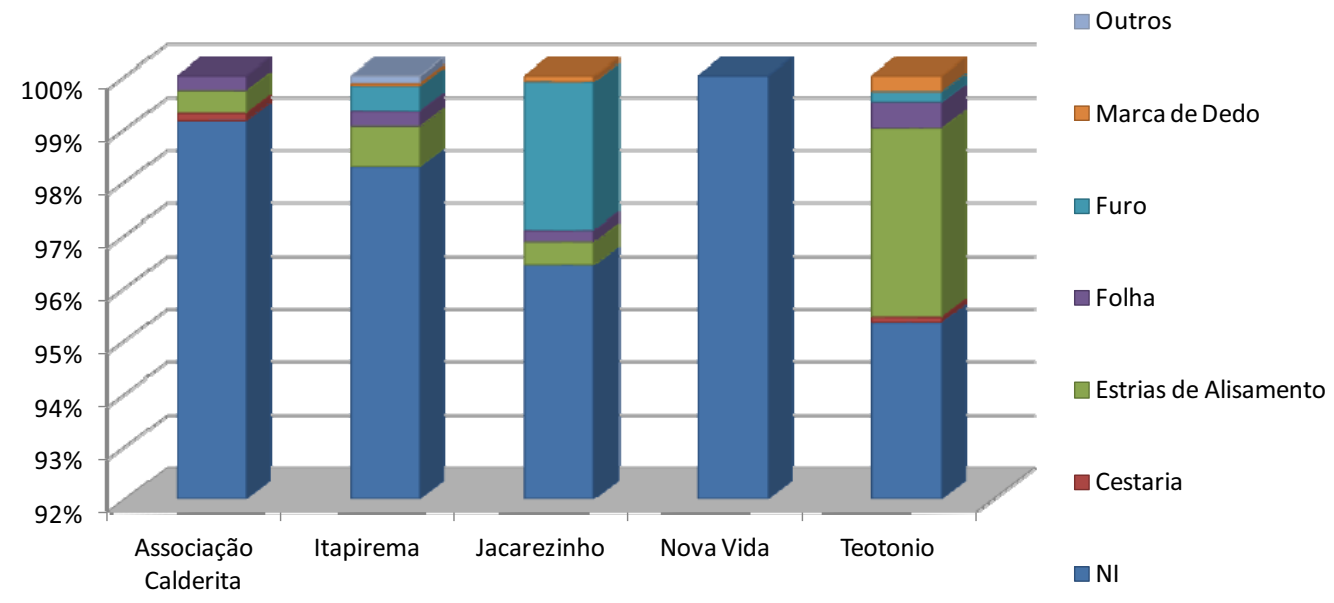

Figura 15 B.13 Gráfico de barras empilhadas da variável Marcas por sítio.

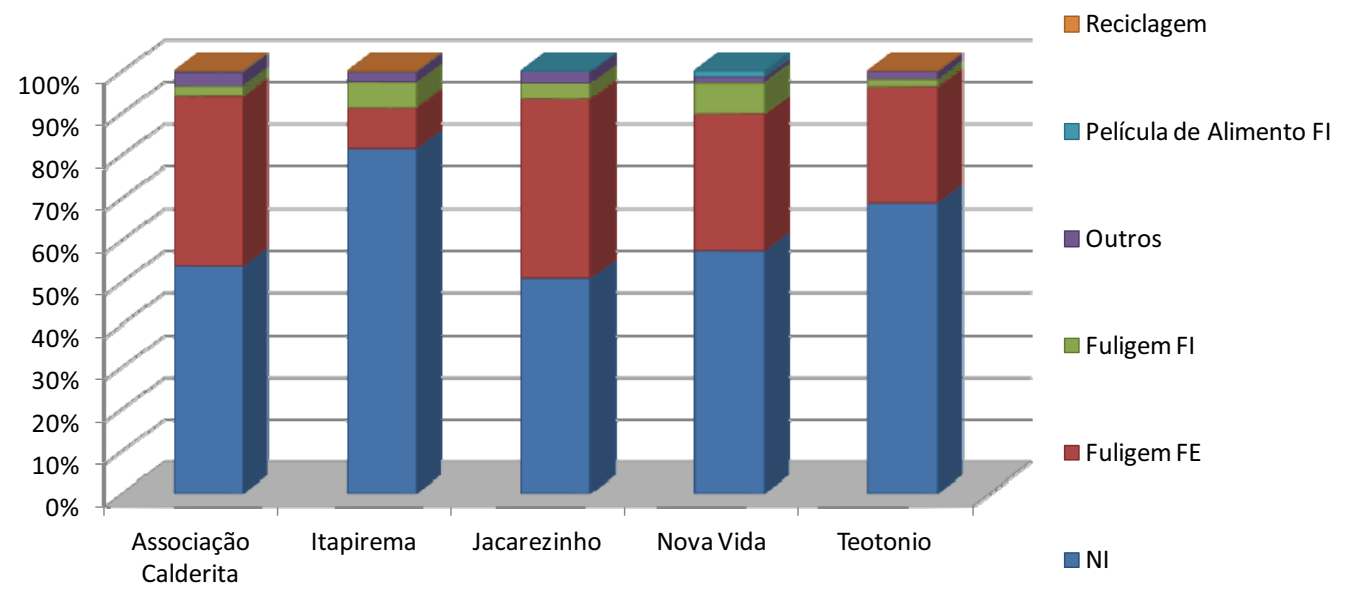

Figura 15 B.14 Gráfico de barras empilhadas da variável Sinais de Uso por sítio. 


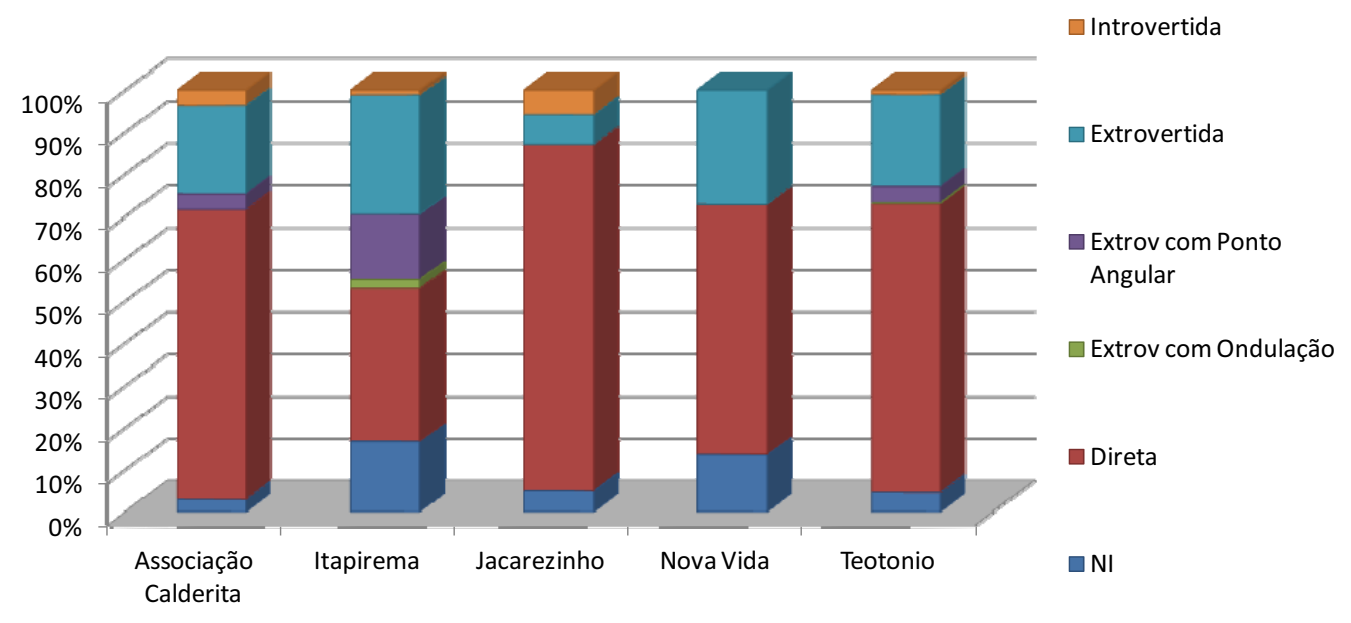

Figura 15 B.15 Gráfico de barras empilhadas da variável Morfologia da Borda por sítio.

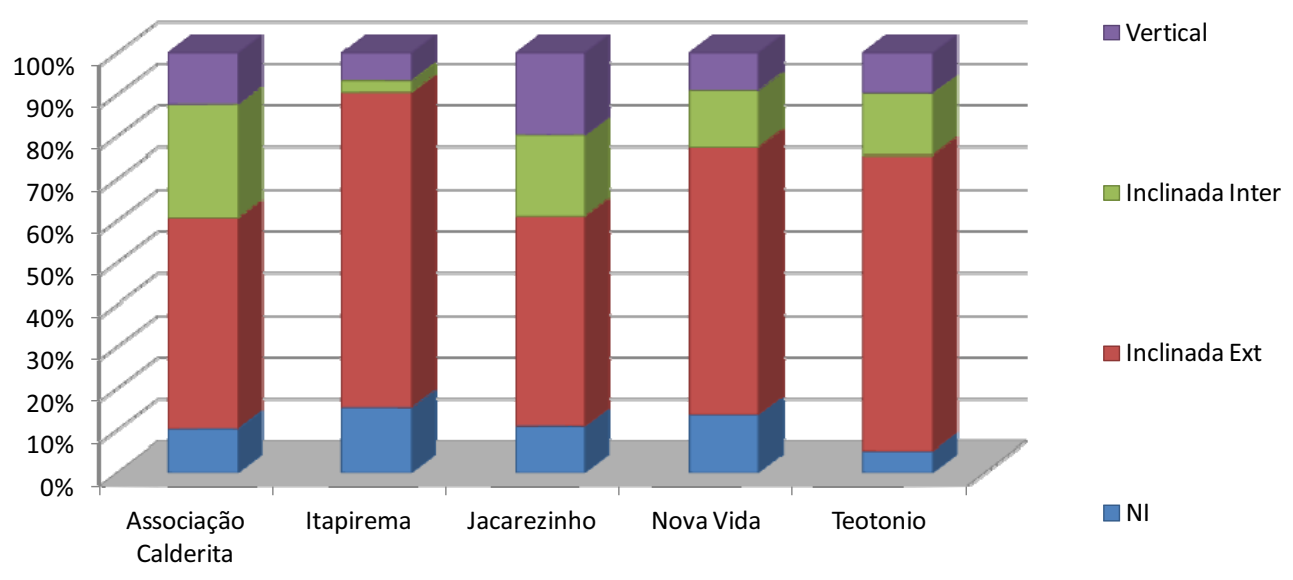

Figura 15 B.16 Gráfico de barras empilhadas da variável Inclinação da Borda por sítio. 


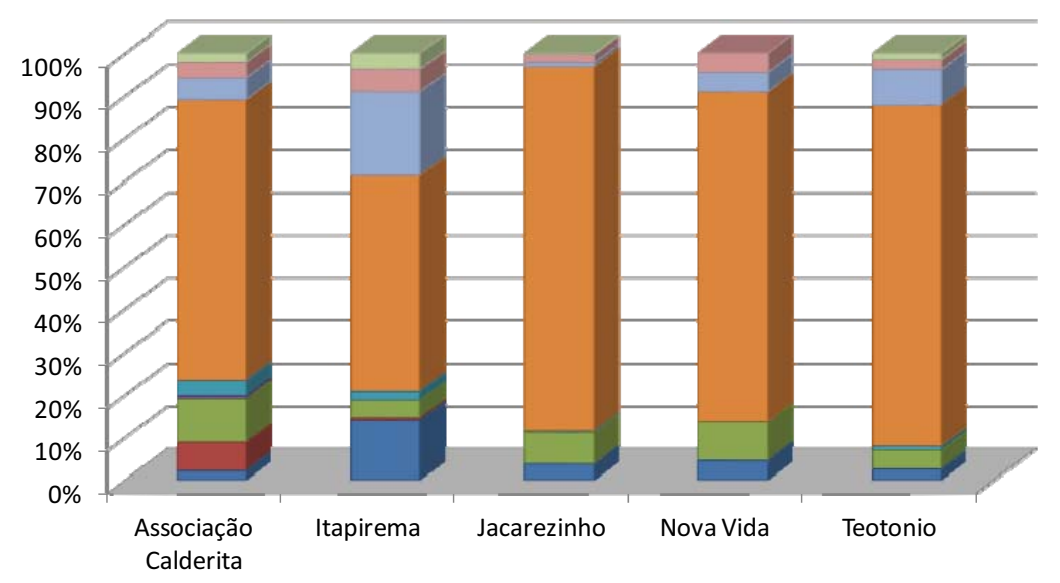

$\square$ Reforçada

Refor Intern

Refor Ext

$\square$ Normal

$\square$ Expandida

Dobrada

$\square$ Contraída

Acalada

$\square \mathrm{NI}$

Figura 15 B.17 Gráfico de barras empilhadas da variável Espessura da Borda por sítio.

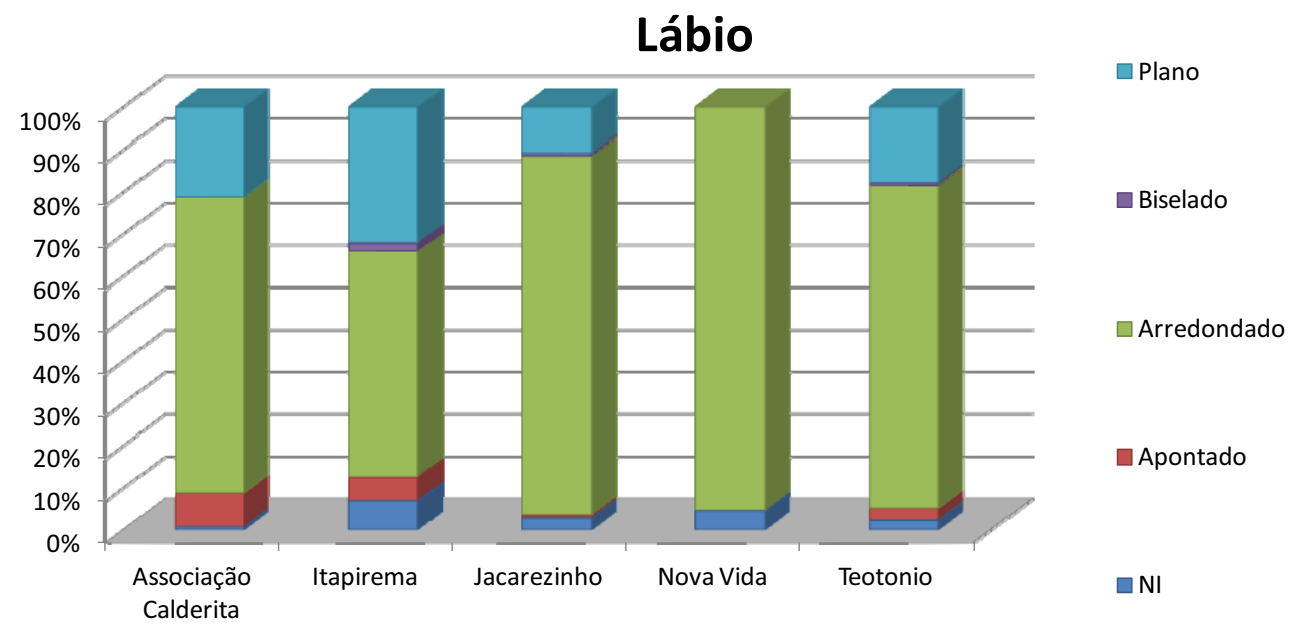

Figura 15 B.18 Gráfico de barras empilhadas da variável Lábio por sítio. 


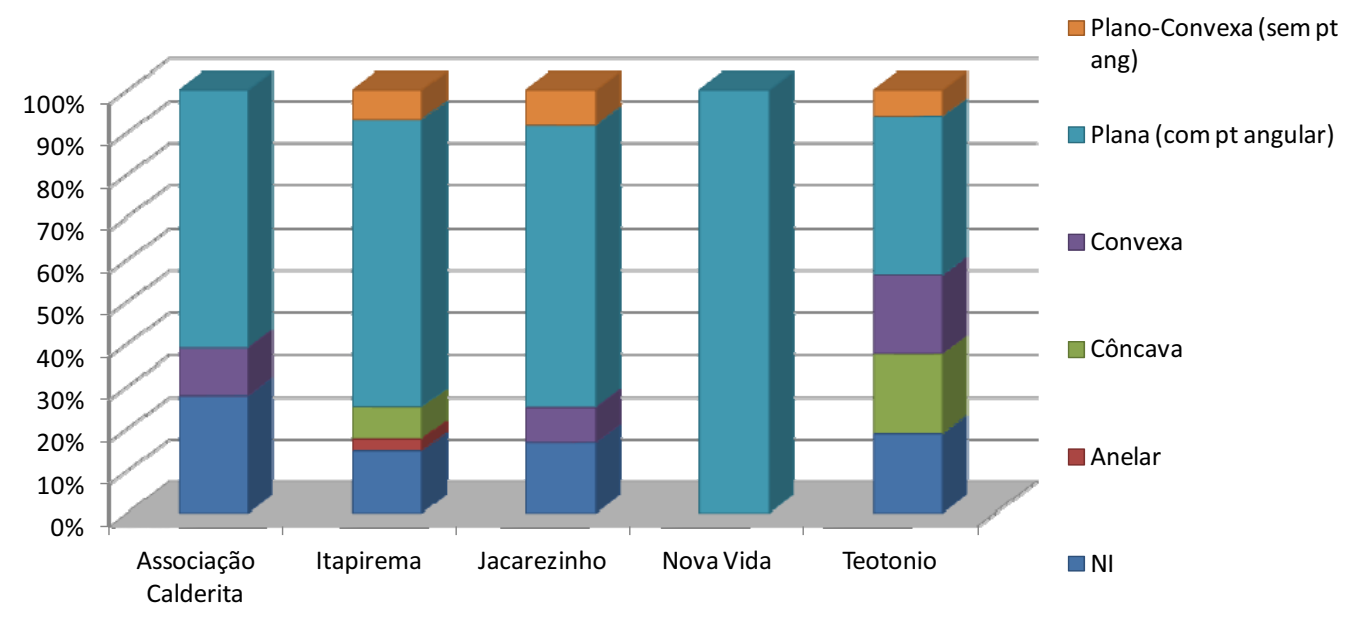

Figura 15 B.19 Gráfico de barras empilhadas da variável Base por sítio.

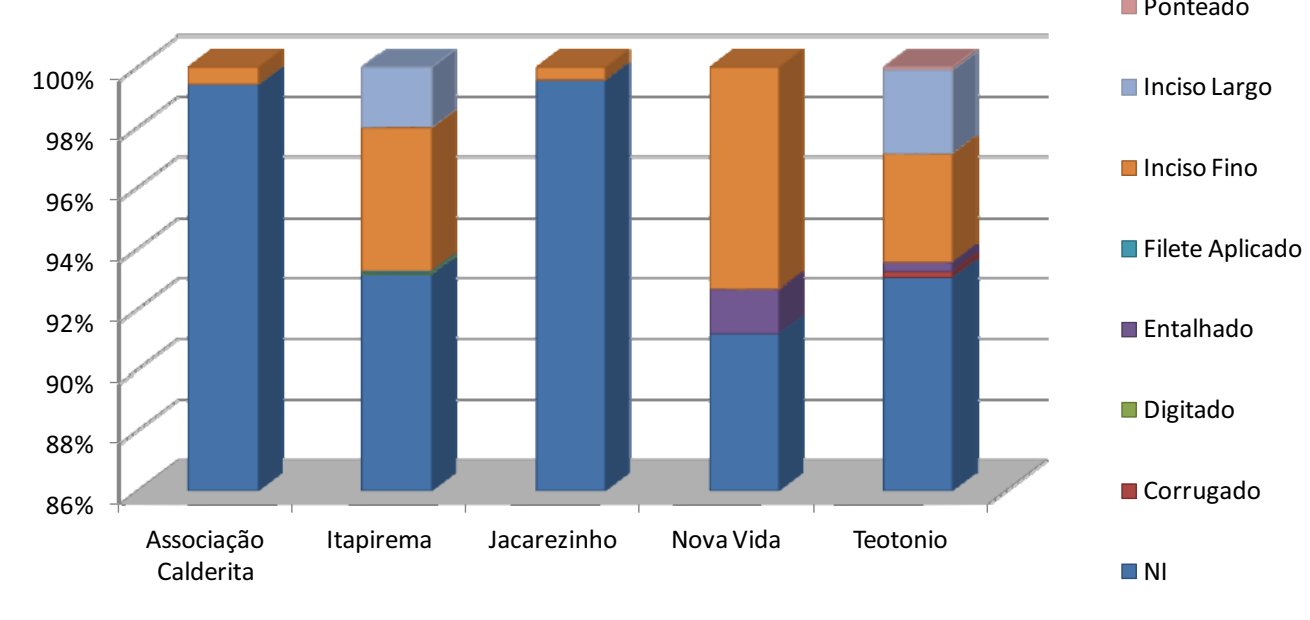

Figura 15 B.20 Gráfico de barras empilhadas da variável Decoração Plástica por sítio. 


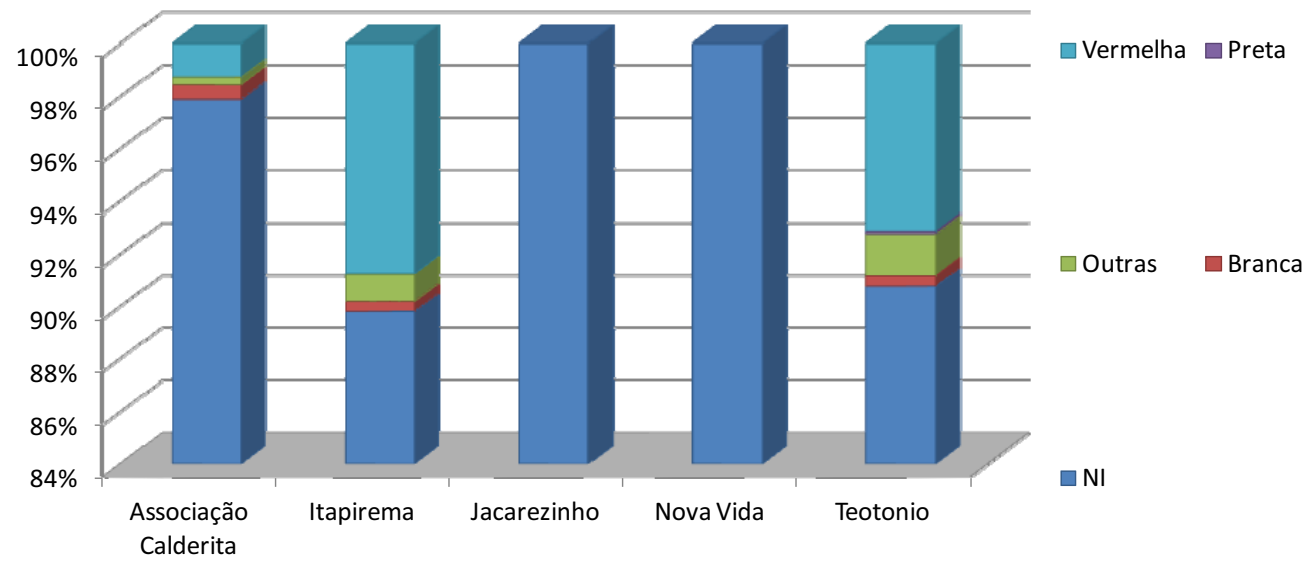

Figura 15 B.21 Gráfico de barras empilhadas da variável Decoração Pintada por sítio.

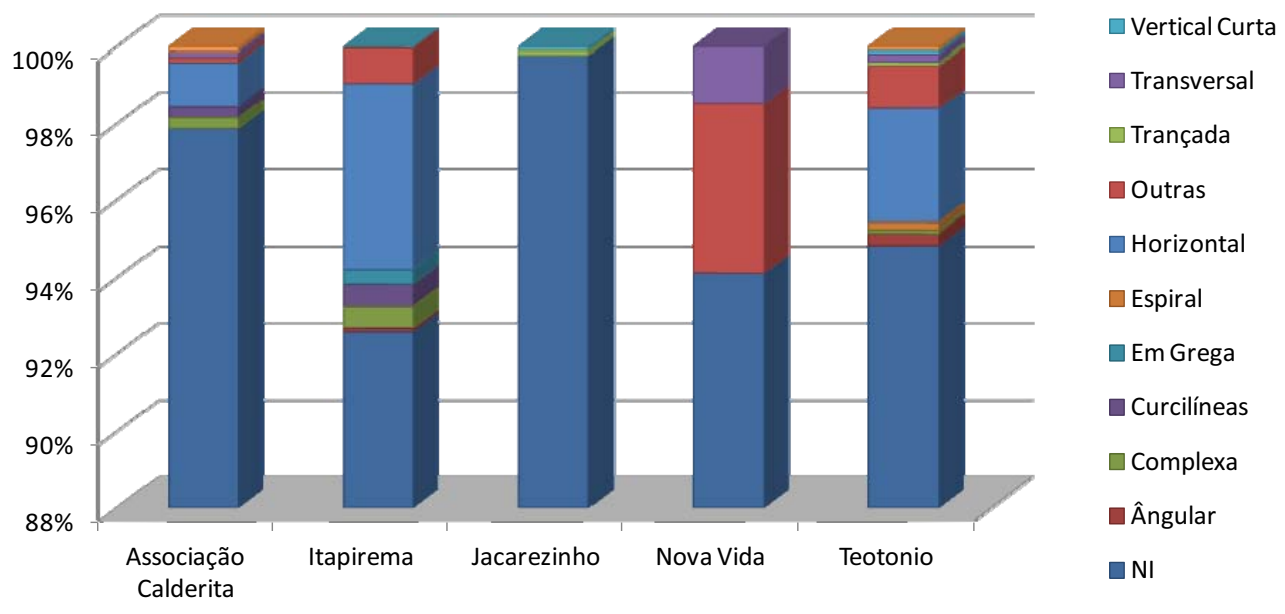

Figura 15 B.22 Gráfico de barras empilhadas da variável Motivo por sítio. 


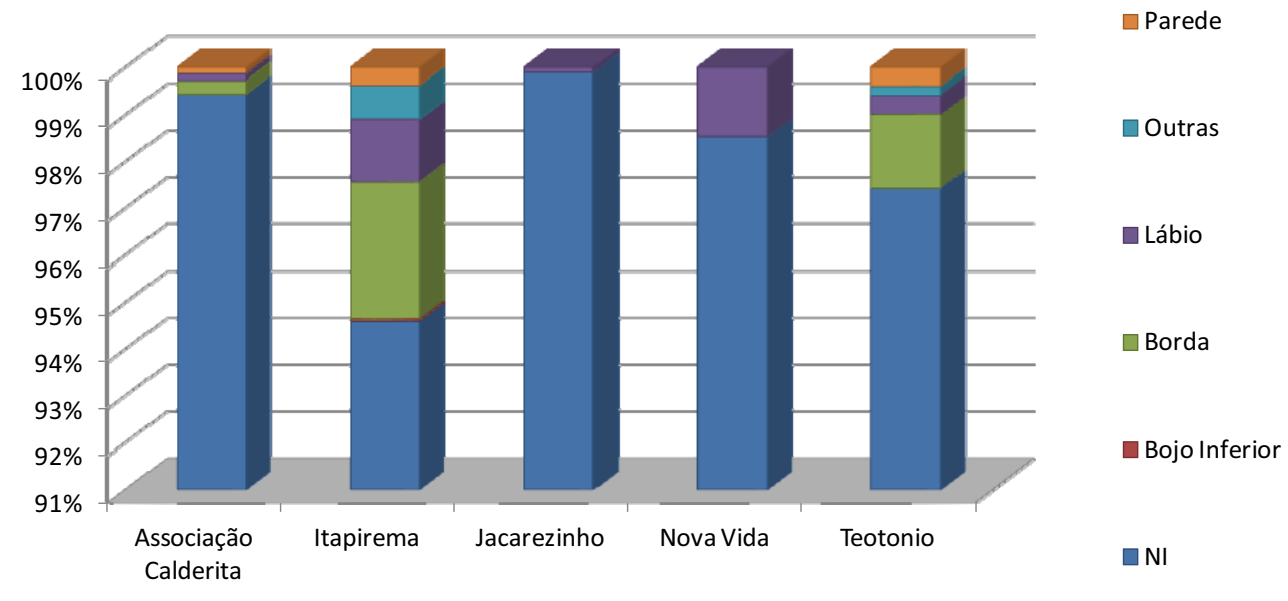

Figura 15 B.23 Gráfico de barras empilhadas da variável Local da Decoração Fase Interna por sítio.

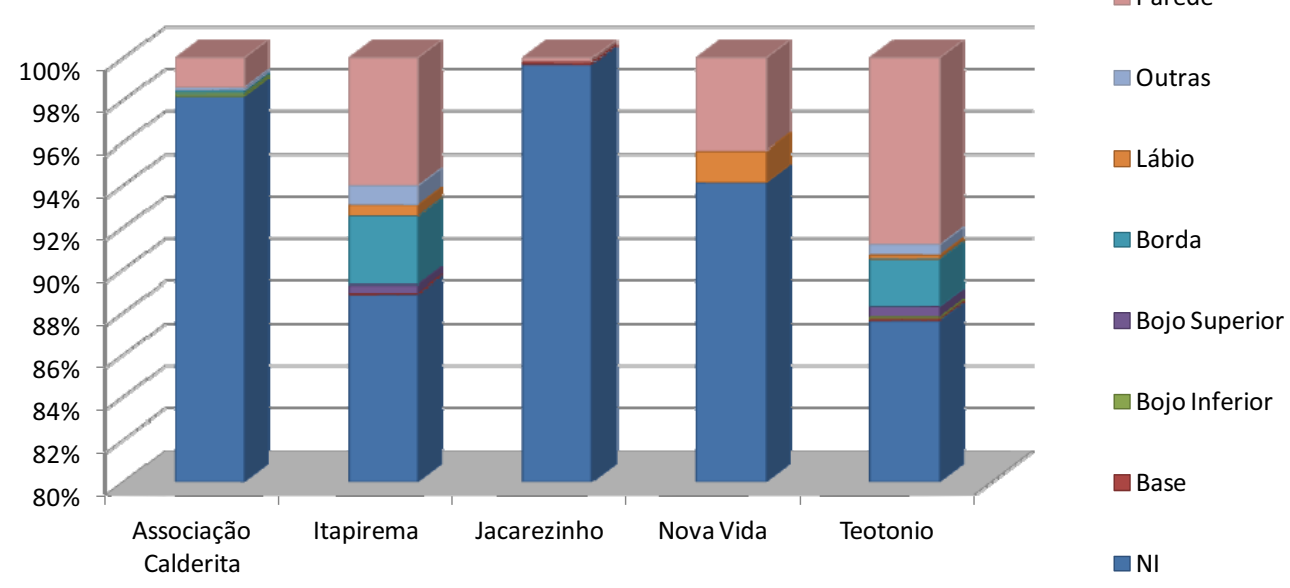

Figura 15 B.24 Gráfico de barras empilhadas da variável Local da Decoração Fase Externa por sítio. 


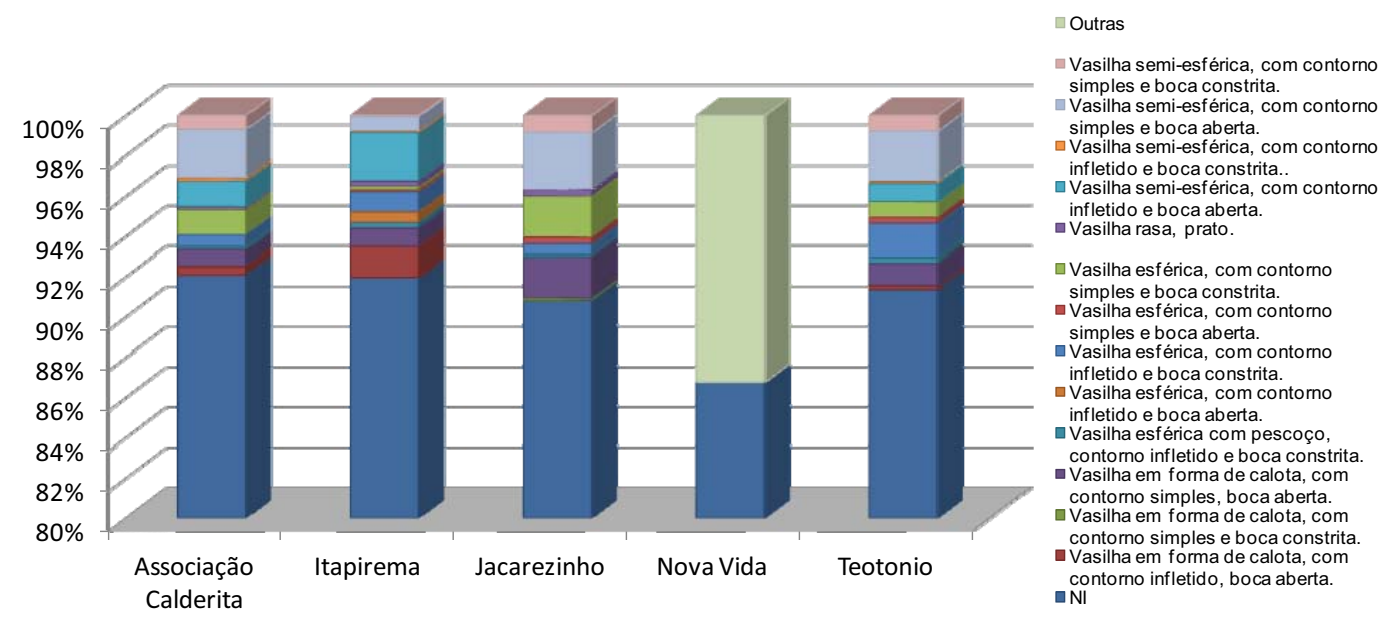

Figura 15 B.25 Gráfico de barras empilhadas da variável Forma por sítio. 
Anexo 15 C Tabelas de Frequências das Variáveis Qualitativas

Tabela 15 C.1 Número de fragmentos por sítio.

\begin{tabular}{|l|r|}
\hline & \multicolumn{1}{|c|}{$\begin{array}{c}\mathbf{N}^{\circ} \text { de } \\
\text { fragmentos }\end{array}$} \\
\hline $\begin{array}{l}\text { Associação } \\
\text { Calderita }\end{array}$ & 707 \\
\hline Itapirema & 2.088 \\
\hline Jacarezinho & 925 \\
\hline Nova Vida & 68 \\
\hline Teotonio & 1.007 \\
\hline Total & $\mathbf{4 . 7 9 5}$ \\
\hline
\end{tabular}

Tabela 15 C.2 Tabela de frequências da variável Categoria por sítio.

\begin{tabular}{|c|c|c|c|c|c|c|c|c|c|c|}
\hline \multirow[b]{2}{*}{ NI } & \multicolumn{2}{|c|}{$\begin{array}{c}\text { Associação } \\
\text { Calderita }\end{array}$} & \multicolumn{2}{|c|}{ Itapirema } & \multicolumn{2}{|c|}{ Jacarezinho } & \multicolumn{2}{|c|}{ Nova Vida } & \multicolumn{2}{|c|}{ Teotônio } \\
\hline & & $(0 \%)$ & 1 & $(0 \%)$ & 0 & $(0 \%)$ & 0 & $(0 \%)$ & 1 & $(0 \%)$ \\
\hline Alça & - & $(0 \%)$ & 0 & $(0 \%)$ & 0 & $(0 \%)$ & 0 & $(0 \%)$ & 1 & $(0 \%)$ \\
\hline Aplique/Apêndice & - & $(0 \%)$ & 0 & $(0 \%)$ & 0 & $(0 \%)$ & 0 & $(0 \%)$ & 1 & $(0 \%)$ \\
\hline Base & 18 & $(3 \%)$ & 143 & $(7 \%)$ & 24 & $(3 \%)$ & 9 & $(13 \%)$ & 16 & $(2 \%)$ \\
\hline Bolota de Argila & 1 & $(0 \%)$ & 1 & $(0 \%)$ & 0 & $(0 \%)$ & 0 & $(0 \%)$ & 0 & $(0 \%)$ \\
\hline Borda & 137 & $(19 \%)$ & 608 & $(29 \%)$ & 323 & $(35 \%)$ & 22 & $(32 \%)$ & 391 & $(39 \%)$ \\
\hline Carena & 2 & $(0 \%)$ & 36 & $(2 \%)$ & 1 & $(0 \%)$ & 0 & $(0 \%)$ & 23 & $(2 \%)$ \\
\hline Flange & - & $(0 \%)$ & 20 & $(1 \%)$ & 0 & $(0 \%)$ & 0 & $(0 \%)$ & 8 & $(1 \%)$ \\
\hline Outros & - & $(0 \%)$ & 4 & $(0 \%)$ & 2 & $(0 \%)$ & 0 & $(0 \%)$ & 0 & $(0 \%)$ \\
\hline Parede & 549 & $(78 \%)$ & 1275 & $(61 \%)$ & 575 & $(62 \%)$ & 37 & $(54 \%)$ & 566 & $(56 \%)$ \\
\hline Total & 707 & 1 & 2088 & 1 & 925 & 1 & 68 & 1 & 1007 & 1 \\
\hline
\end{tabular}

Tabela C.3 Tabela de frequências da variável Técnica de Manufatura por sítio.

\begin{tabular}{|l|rc|cc|cc|cc|cc|}
\hline & \multicolumn{2}{|c|}{$\begin{array}{c}\text { Associação } \\
\text { Calderita }\end{array}$} & \multicolumn{2}{|c|}{ Itapirema } & \multicolumn{2}{|c|}{ Jacarezinho } & \multicolumn{2}{|c|}{ Nova Vida } & \multicolumn{2}{|c|}{ Teotônio } \\
\hline NI & 357 & $(50 \%)$ & 1052 & $(50 \%)$ & 522 & $(56 \%)$ & 60 & $(88 \%)$ & 469 & $(47 \%)$ \\
\hline Acordelada & 344 & $(49 \%)$ & 861 & $(41 \%)$ & 391 & $(42 \%)$ & 7 & $(10 \%)$ & 527 & $(52 \%)$ \\
\hline Modelada & 4 & $(1 \%)$ & 15 & $(1 \%)$ & 0 & $(0 \%)$ & 0 & $(0 \%)$ & 3 & $(0 \%)$ \\
\hline Placas & 2 & $(0 \%)$ & 160 & $(8 \%)$ & 12 & $(1 \%)$ & 1 & $(1 \%)$ & 8 & $(1 \%)$ \\
\hline Total & $\mathbf{7 0 7}$ & $\mathbf{1}$ & $\mathbf{2 0 8 8}$ & $\mathbf{1}$ & $\mathbf{9 2 5}$ & $\mathbf{1}$ & $\mathbf{6 8}$ & $\mathbf{1}$ & $\mathbf{1 0 0 7}$ & $\mathbf{1}$ \\
\hline
\end{tabular}


Tabela 15 C.4 Tabela de frequências da variável Antiplástico por sítio.

\begin{tabular}{|c|c|c|c|c|c|c|c|c|c|}
\hline \multirow[b]{2}{*}{ NI } & \multicolumn{2}{|c|}{$\begin{array}{c}\text { Associação } \\
\text { Calderita }\end{array}$} & \multicolumn{2}{|c|}{ Itapirema } & Jacarezinho & \multicolumn{2}{|c|}{ Nova Vida } & \multicolumn{2}{|c|}{ Teotônio } \\
\hline & & $(3 \%)$ & 47 & $(2 \%)$ & $(0 \%)$ & 0 & $(0 \%)$ & & $(0 \%)$ \\
\hline Argila Moída & - & $(0 \%)$ & 1 & $(0 \%)$ & $(0 \%)$ & 0 & $(0 \%)$ & 2 & $(0 \%)$ \\
\hline Cariapé & 173 & $(24 \%)$ & 278 & $(13 \%)$ & $515 \quad(56 \%)$ & 22 & $(32 \%)$ & 241 & $(24 \%)$ \\
\hline Cariapé e Carvão & 81 & $(11 \%)$ & 10 & $(0 \%)$ & $(0 \%)$ & 1 & $(1 \%)$ & 252 & $(25 \%)$ \\
\hline Cariapé e Cauixi & - & $(0 \%)$ & 120 & $(6 \%)$ & $(0 \%)$ & 0 & $(0 \%)$ & 1 & $(0 \%)$ \\
\hline Carvão & 2 & $(0 \%)$ & 0 & $(0 \%)$ & $96 \quad(10 \%)$ & 0 & $(0 \%)$ & 26 & $(3 \%)$ \\
\hline Cauixi & 12 & $(2 \%)$ & 681 & $(33 \%)$ & $(0 \%)$ & 0 & $(0 \%)$ & 22 & $(2 \%)$ \\
\hline Cauixi e Argila Moída & 2 & $(0 \%)$ & 72 & $(3 \%)$ & $(0 \%)$ & 0 & $(0 \%)$ & 0 & $(0 \%)$ \\
\hline Cerâmica/caco Moído & 1 & $(0 \%)$ & 2 & $(0 \%)$ & $(0 \%)$ & 0 & $(0 \%)$ & 1 & $(0 \%)$ \\
\hline Mineral & 12 & $(2 \%)$ & 5 & $(0 \%)$ & $(2 \%)$ & 2 & $(3 \%)$ & 25 & $(2 \%)$ \\
\hline Mineral e Cariapé & 347 & $(49 \%)$ & 130 & $(6 \%)$ & $(0 \%)$ & 39 & $(57 \%)$ & 176 & $(17 \%)$ \\
\hline Mineral e Cauixi & - & $(0 \%)$ & 273 & $(13 \%)$ & $(0 \%)$ & 0 & $(0 \%)$ & & $(0 \%)$ \\
\hline Mineral, Cariapé e Carvão & 45 & $(6 \%)$ & 21 & $(1 \%)$ & $(0 \%)$ & 4 & $(6 \%)$ & 157 & $(16 \%)$ \\
\hline Mineral, Cariapé e Cauixi & - & $(0 \%)$ & 137 & $(7 \%)$ & $(0 \%)$ & 0 & $(0 \%)$ & 5 & $(0 \%)$ \\
\hline Mineral, Cauixi e Argila Moída & 1 & $(0 \%)$ & 84 & $(4 \%)$ & $(0 \%)$ & 0 & $(0 \%)$ & 0 & $(0 \%)$ \\
\hline Outros & 12 & $(2 \%)$ & 227 & $(11 \%)$ & $287 \quad(31 \%)$ & 0 & $(0 \%)$ & 92 & $(9 \%)$ \\
\hline Total & 707 & 1 & 2088 & 1 & 925 & 68 & 1 & 1007 & 1 \\
\hline
\end{tabular}

Tabela 15 C.5 Tabela de frequências da variável Espessura do Antiplástico por sítio

\begin{tabular}{|l|cc|cc|cc|cc|cc|}
\hline & \multicolumn{2}{|c|}{$\begin{array}{c}\text { Associação } \\
\text { Calderita }\end{array}$} & \multicolumn{2}{|c|}{ Itapirema } & \multicolumn{2}{|c|}{ Jacarezinho } & \multicolumn{2}{c|}{ Nova Vida } & \multicolumn{2}{c|}{ Teotônio } \\
\hline NI & 3 & $(0 \%)$ & 5 & $(0 \%)$ & 0 & $(0 \%)$ & 0 & $(0 \%)$ & 1 & $(0 \%)$ \\
\hline Menor ou igual que 1 $\mathbf{~ m m ~}$ & 46 & $(7 \%)$ & 1074 & $(51 \%)$ & 187 & $(20 \%)$ & 9 & $(13 \%)$ & 124 & $(12 \%)$ \\
\hline Entre 1 $\mathbf{~ m m ~ e ~ 3 m m ~ ( e x c l u s i v e ) ~}$ & 499 & $(71 \%)$ & 848 & $(41 \%)$ & 604 & $(65 \%)$ & 34 & $(50 \%)$ & 843 & $(84 \%)$ \\
\hline Entre 3 $\mathbf{~ m m ~ a ~ 5 ~} \mathbf{m m}$ (exclusive) & 139 & $(20 \%)$ & 140 & $(7 \%)$ & 113 & $(12 \%)$ & 17 & $(25 \%)$ & 35 & $(3 \%)$ \\
\hline Maior ou igual 5 mm. & 20 & $(3 \%)$ & 21 & $(1 \%)$ & 21 & $(2 \%)$ & 8 & $(12 \%)$ & 4 & $(0 \%)$ \\
\hline Total & $\mathbf{7 0 7}$ & $\mathbf{1}$ & $\mathbf{2 0 8 8}$ & $\mathbf{1}$ & $\mathbf{9 2 5}$ & $\mathbf{1}$ & $\mathbf{6 8}$ & $\mathbf{1}$ & $\mathbf{1 0 0 7}$ & $\mathbf{1}$ \\
\hline
\end{tabular}

Tabela 15 C.6 Tabela de frequências da variável Porcentagem do Antiplástico por sítio.

\begin{tabular}{|l|rc|cc|cc|cc|cc|}
\hline & \multicolumn{2}{|c|}{$\begin{array}{c}\text { Associação } \\
\text { Calderita }\end{array}$} & \multicolumn{2}{|c|}{ Itapirema } & \multicolumn{2}{|c|}{ Jacarezinho } & \multicolumn{2}{|c|}{ Nova Vida } & \multicolumn{2}{|c|}{ Teotônio } \\
\hline $\mathbf{N I}$ & 4 & $(1 \%)$ & 4 & $(0 \%)$ & 0 & $(0 \%)$ & 0 & $(0 \%)$ & 1 & $(0 \%)$ \\
\hline $\mathbf{5} \%$ & 41 & $(6 \%)$ & 88 & $(4 \%)$ & 321 & $(35 \%)$ & 27 & $(40 \%)$ & 84 & $(8 \%)$ \\
\hline $\mathbf{1 0} \%$ & 362 & $(51 \%)$ & 498 & $(24 \%)$ & 371 & $(40 \%)$ & 19 & $(28 \%)$ & 354 & $(35 \%)$ \\
\hline $\mathbf{2 0} \%$ & 261 & $(37 \%)$ & 643 & $(31 \%)$ & 180 & $(19 \%)$ & 11 & $(16 \%)$ & 395 & $(39 \%)$ \\
\hline $\mathbf{3 0} \%$ & 39 & $(6 \%)$ & 855 & $(41 \%)$ & 53 & $(6 \%)$ & 11 & $(16 \%)$ & 173 & $(17 \%)$ \\
\hline Total & $\mathbf{7 0 7}$ & $\mathbf{1}$ & $\mathbf{2 0 8 8}$ & $\mathbf{1}$ & $\mathbf{9 2 5}$ & $\mathbf{1}$ & $\mathbf{6 8}$ & $\mathbf{1}$ & $\mathbf{1 0 0 7}$ & $\mathbf{1}$ \\
\hline
\end{tabular}

Tabela 15 C.7 Tabela de frequências da variável Cor da Superfície por sítio.

\begin{tabular}{|l|rc|cc|cc|cc|cc|}
\hline & \multicolumn{2}{|c|}{$\begin{array}{c}\text { Associação } \\
\text { Calderita }\end{array}$} & \multicolumn{2}{|c|}{ Itapirema } & \multicolumn{2}{|l|}{ Jacarezinho } & \multicolumn{2}{|c|}{ Nova Vida } & \multicolumn{2}{|c|}{ Teotônio } \\
\hline NI & 5 & $(1 \%)$ & 67 & $(3 \%)$ & 48 & $(5 \%)$ & 2 & $(3 \%)$ & 84 & $(8 \%)$ \\
\hline Amarelo & 321 & $(45 \%)$ & 636 & $(30 \%)$ & 377 & $(41 \%)$ & 32 & $(47 \%)$ & 398 & $(40 \%)$ \\
\hline Branco & 34 & $(5 \%)$ & 217 & $(10 \%)$ & 30 & $(3 \%)$ & 0 & $(0 \%)$ & 76 & $(8 \%)$ \\
\hline Cinza & 70 & $(10 \%)$ & 330 & $(16 \%)$ & 110 & $(12 \%)$ & 7 & $(10 \%)$ & 135 & $(13 \%)$ \\
\hline Laranja & 186 & $(26 \%)$ & 352 & $(17 \%)$ & 143 & $(15 \%)$ & 19 & $(28 \%)$ & 124 & $(12 \%)$ \\
\hline Marron & 67 & $(9 \%)$ & 197 & $(9 \%)$ & 145 & $(16 \%)$ & 5 & $(7 \%)$ & 65 & $(6 \%)$ \\
\hline Preto & 17 & $(2 \%)$ & 109 & $(5 \%)$ & 58 & $(6 \%)$ & 3 & $(4 \%)$ & 50 & $(5 \%)$ \\
\hline Vermelho & 7 & $(1 \%)$ & 180 & $(9 \%)$ & 14 & $(2 \%)$ & 0 & $(0 \%)$ & 75 & $(7 \%)$ \\
\hline Total & $\mathbf{7 0 7}$ & $\mathbf{1}$ & $\mathbf{2 0 8 8}$ & $\mathbf{1}$ & $\mathbf{9 2 5}$ & $\mathbf{1}$ & $\mathbf{6 8}$ & $\mathbf{1}$ & $\mathbf{1 0 0 7}$ & $\mathbf{1}$ \\
\hline
\end{tabular}


Tabela 15 C.8 Tabela de frequências da variável Queima por sítio.

\begin{tabular}{|l|rr|rr|rr|rr|rr|}
\hline & \multicolumn{2}{|c|}{\begin{tabular}{l}
\multicolumn{2}{|c|}{ Associação } \\
Calderita
\end{tabular}} & \multicolumn{2}{|c|}{ Itapirema } & \multicolumn{2}{|l|}{ Jacarezinho } & \multicolumn{2}{|c|}{ Nova Vida } & \multicolumn{2}{|c|}{ Teotônio } \\
\hline NI & 4 & $(1 \%)$ & 26 & $(1 \%)$ & 1 & $(0 \%)$ & 1 & $(1 \%)$ & 5 & $(0 \%)$ \\
\hline Completa (Oxidada) & 119 & $(17 \%)$ & 742 & $(36 \%)$ & 77 & $(8 \%)$ & 5 & $(7 \%)$ & 301 & $(30 \%)$ \\
\hline $\begin{array}{l}\text { Face Interna Clara e Externa } \\
\text { Escura }\end{array}$ & 58 & $(8 \%)$ & 78 & $(4 \%)$ & 19 & $(2 \%)$ & 7 & $(10 \%)$ & 29 & $(3 \%)$ \\
\hline $\begin{array}{l}\text { Face Interna Escura e Externa } \\
\text { Clara }\end{array}$ & 112 & $(16 \%)$ & 202 & $(10 \%)$ & 69 & $(7 \%)$ & 15 & $(22 \%)$ & 56 & $(6 \%)$ \\
\hline Núcleo Claro Fino & 4 & $(1 \%)$ & 25 & $(1 \%)$ & 2 & $(0 \%)$ & 1 & $(1 \%)$ & 3 & $(0 \%)$ \\
\hline Núcleo Escuro Espesso & 200 & $(28 \%)$ & 209 & $(10 \%)$ & 239 & $(26 \%)$ & 14 & $(21 \%)$ & 138 & $(14 \%)$ \\
\hline Núcleo Escuro Fino & 34 & $(5 \%)$ & 376 & $(18 \%)$ & 42 & $(5 \%)$ & 2 & $(3 \%)$ & 38 & $(4 \%)$ \\
\hline Núcleo Totalmente Escuro & 166 & $(23 \%)$ & 365 & $(17 \%)$ & 438 & $(47 \%)$ & 22 & $(32 \%)$ & 393 & $(39 \%)$ \\
\hline Total & $\mathbf{7 0 7}$ & $\mathbf{1}$ & $\mathbf{2 0 8 8}$ & $\mathbf{1}$ & $\mathbf{9 2 5}$ & $\mathbf{1}$ & $\mathbf{6 8}$ & $\mathbf{1}$ & $\mathbf{1 0 0 7}$ & $\mathbf{1}$ \\
\hline
\end{tabular}

Tabela 15 C.9 Tabela de frequências da variável Estado de Conservação por sítio.

\begin{tabular}{|l|rc|cc|cc|cc|cc|}
\hline & \multicolumn{2}{|c|}{$\begin{array}{c}\text { Associação } \\
\text { Calderita }\end{array}$} & \multicolumn{2}{|c|}{ Itapirema } & \multicolumn{2}{|l|}{ Jacarezinho } & \multicolumn{2}{|c|}{ Nova Vida } & \multicolumn{2}{|c|}{ Teotônio } \\
\hline NI & 4 & $(1 \%)$ & 26 & $(1 \%)$ & 1 & $(0 \%)$ & 1 & $(1 \%)$ & 5 & $(0 \%)$ \\
\hline Craquelê AF & 12 & $(2 \%)$ & 5 & $(0 \%)$ & 27 & $(3 \%)$ & 9 & $(13 \%)$ & 1 & $(0 \%)$ \\
\hline Craquelê FE & 10 & $(1 \%)$ & 28 & $(1 \%)$ & 19 & $(2 \%)$ & 2 & $(3 \%)$ & 7 & $(1 \%)$ \\
\hline Craquelê FI & 3 & $(0 \%)$ & 4 & $(0 \%)$ & 7 & $(1 \%)$ & 1 & $(1 \%)$ & 4 & $(0 \%)$ \\
\hline Erodido AF & 223 & $(32 \%)$ & 551 & $(26 \%)$ & 125 & $(14 \%)$ & 14 & $(21 \%)$ & 117 & $(12 \%)$ \\
\hline Erodido FE & 80 & $(11 \%)$ & 121 & $(6 \%)$ & 42 & $(5 \%)$ & 6 & $(9 \%)$ & 39 & $(4 \%)$ \\
\hline Erodido FI & 184 & $(26 \%)$ & 447 & $(21 \%)$ & 206 & $(22 \%)$ & 10 & $(15 \%)$ & 151 & $(15 \%)$ \\
\hline Não Erodido & 167 & $(24 \%)$ & 889 & $(43 \%)$ & 471 & $(51 \%)$ & 12 & $(18 \%)$ & 674 & $(67 \%)$ \\
\hline Outros & 24 & $(3 \%)$ & 17 & $(1 \%)$ & 27 & $(3 \%)$ & 13 & $(19 \%)$ & 9 & $(1 \%)$ \\
\hline Total & $\mathbf{7 0 7}$ & $\mathbf{1}$ & $\mathbf{2 0 8 8}$ & $\mathbf{1}$ & $\mathbf{9 2 5}$ & $\mathbf{1}$ & $\mathbf{6 8}$ & $\mathbf{1}$ & $\mathbf{1 0 0 7}$ & $\mathbf{1}$ \\
\hline
\end{tabular}

Tabela 15 C.10 Tabela de frequências da variável Alisamento Face Interna por sítio.

\begin{tabular}{|l|cc|cc|cc|cc|cc|}
\hline & \multicolumn{2}{|c|}{$\begin{array}{c}\text { Associação } \\
\text { Calderita }\end{array}$} & \multicolumn{2}{|c|}{ Itapirema } & \multicolumn{2}{|l|}{ Jacarezinho } & \multicolumn{2}{|c|}{ Nova Vida } & \multicolumn{2}{|c|}{ Teotônio } \\
\hline NI & 179 & $(25 \%)$ & 389 & $(19 \%)$ & 127 & $(14 \%)$ & 19 & $(28 \%)$ & 163 & $(16 \%)$ \\
\hline Fino & 384 & $(54 \%)$ & 1488 & $(71 \%)$ & 679 & $(73 \%)$ & 39 & $(57 \%)$ & 732 & $(73 \%)$ \\
\hline Grosso & 3 & $(0 \%)$ & 12 & $(1 \%)$ & 2 & $(0 \%)$ & 0 & $(0 \%)$ & 9 & $(1 \%)$ \\
\hline Médio & 87 & $(12 \%)$ & 177 & $(8 \%)$ & 75 & $(8 \%)$ & 8 & $(12 \%)$ & 61 & $(6 \%)$ \\
\hline Polido & 54 & $(8 \%)$ & 22 & $(1 \%)$ & 42 & $(5 \%)$ & 2 & $(3 \%)$ & 42 & $(4 \%)$ \\
\hline Total & $\mathbf{7 0 7}$ & $\mathbf{1}$ & $\mathbf{2 0 8 8}$ & $\mathbf{1}$ & $\mathbf{9 2 5}$ & $\mathbf{1}$ & $\mathbf{6 8}$ & $\mathbf{1}$ & $\mathbf{1 0 0 7}$ & $\mathbf{1}$ \\
\hline
\end{tabular}

Tabela 15 C.11 Tabela de frequências da variável Alisamento Face Externa por sítio.

\begin{tabular}{|l|cc|cc|cc|cc|cc|}
\hline & \multicolumn{2}{|c|}{$\begin{array}{l}\text { Associação } \\
\text { Calderita }\end{array}$} & \multicolumn{2}{|c|}{ Itapirema } & \multicolumn{2}{|l|}{ Jacarezinho } & \multicolumn{2}{|c|}{ Nova Vida } & \multicolumn{2}{|c|}{ Teotônio } \\
\hline NI & 40 & $(6 \%)$ & 157 & $(8 \%)$ & 54 & $(6 \%)$ & 7 & $(10 \%)$ & 70 & $(7 \%)$ \\
\hline Fino & 484 & $(68 \%)$ & 1735 & $(83 \%)$ & 774 & $(84 \%)$ & 47 & $(69 \%)$ & 793 & $(79 \%)$ \\
\hline Grosso & 10 & $(1 \%)$ & 16 & $(1 \%)$ & 4 & $(0 \%)$ & 0 & $(0 \%)$ & 15 & $(1 \%)$ \\
\hline Médio & 84 & $(12 \%)$ & 153 & $(7 \%)$ & 49 & $(5 \%)$ & 5 & $(7 \%)$ & 81 & $(8 \%)$ \\
\hline Polido & 89 & $(13 \%)$ & 27 & $(1 \%)$ & 44 & $(5 \%)$ & 9 & $(13 \%)$ & 48 & $(5 \%)$ \\
\hline Total & $\mathbf{7 0 7}$ & $\mathbf{1}$ & $\mathbf{2 0 8 8}$ & $\mathbf{1}$ & $\mathbf{9 2 5}$ & $\mathbf{1}$ & $\mathbf{6 8}$ & $\mathbf{1}$ & $\mathbf{1 0 0 7}$ & $\mathbf{1}$ \\
\hline
\end{tabular}


Tabela 15 C.12 Tabela de frequências da variável Tratamento da Superfície Face Interna por sítio.

\begin{tabular}{|l|cc|cc|cc|cc|cc|}
\hline & $\begin{array}{c}\text { Associação } \\
\text { Calderita }\end{array}$ & \multicolumn{2}{|c|}{ Itapirema } & \multicolumn{2}{|c|}{ Jacarezinho } & \multicolumn{2}{|c|}{ Nova Vida } & \multicolumn{2}{|c|}{ Teotônio } \\
\hline NI & 630 & $(89 \%)$ & 1590 & $(76 \%)$ & 791 & $(86 \%)$ & 64 & $(94 \%)$ & 829 & $(82 \%)$ \\
\hline Brunidura & - & $(0 \%)$ & 3 & $(0 \%)$ & 0 & $(0 \%)$ & 0 & $(0 \%)$ & 0 & $(0 \%)$ \\
\hline Eng Branco & 2 & $(0 \%)$ & 29 & $(1 \%)$ & 2 & $(0 \%)$ & 0 & $(0 \%)$ & 36 & $(4 \%)$ \\
\hline Eng Marrom (Barbotina) & 21 & $(3 \%)$ & 199 & $(10 \%)$ & 96 & $(10 \%)$ & 1 & $(1 \%)$ & 71 & $(7 \%)$ \\
\hline Eng Vermelho & 35 & $(5 \%)$ & 71 & $(3 \%)$ & 9 & $(1 \%)$ & 2 & $(3 \%)$ & 25 & $(2 \%)$ \\
\hline Esfumarado (Resina) & 19 & $(3 \%)$ & 196 & $(9 \%)$ & 27 & $(3 \%)$ & 1 & $(1 \%)$ & 46 & $(5 \%)$ \\
\hline Total & $\mathbf{7 0 7}$ & $\mathbf{1}$ & $\mathbf{2 0 8 8}$ & $\mathbf{1}$ & $\mathbf{9 2 5}$ & $\mathbf{1}$ & $\mathbf{6 8}$ & $\mathbf{1}$ & $\mathbf{1 0 0 7}$ & $\mathbf{1}$ \\
\hline
\end{tabular}

Tabela 15 C.13 Tabela de frequências da variável Tratamento da Superfície Face Externa por sítio.

\begin{tabular}{|l|rc|cc|cc|cc|cc|}
\hline & \multicolumn{2}{|c|}{$\begin{array}{c}\text { Associação } \\
\text { Calderita }\end{array}$} & \multicolumn{2}{|c|}{ Itapirema } & \multicolumn{2}{|c|}{ Jacarezinho } & \multicolumn{2}{|c|}{ Nova Vida } & \multicolumn{2}{|c|}{ Teotônio } \\
\hline NI & 288 & $(41 \%)$ & 1045 & $(50 \%)$ & 725 & $(78 \%)$ & 50 & $(74 \%)$ & 702 & $(70 \%)$ \\
\hline Brunidura & - & $(0 \%)$ & 3 & $(0 \%)$ & 0 & $(0 \%)$ & 0 & $(0 \%)$ & 0 & $(0 \%)$ \\
\hline Eng Branco & 6 & $(1 \%)$ & 300 & $(14 \%)$ & 9 & $(1 \%)$ & 0 & $(0 \%)$ & 117 & $(12 \%)$ \\
\hline Eng Marrom (Barbotina) & 57 & $(8 \%)$ & 167 & $(8 \%)$ & 135 & $(15 \%)$ & 11 & $(16 \%)$ & 76 & $(8 \%)$ \\
\hline Eng Vermelho & 340 & $(48 \%)$ & 433 & $(21 \%)$ & 13 & $(1 \%)$ & 3 & $(4 \%)$ & 75 & $(7 \%)$ \\
\hline Esfumarado (Resina) & 16 & $(2 \%)$ & 140 & $(7 \%)$ & 43 & $(5 \%)$ & 4 & $(6 \%)$ & 37 & $(4 \%)$ \\
\hline Total & $\mathbf{7 0 7}$ & $\mathbf{1}$ & $\mathbf{2 0 8 8}$ & $\mathbf{1}$ & $\mathbf{9 2 5}$ & $\mathbf{1}$ & $\mathbf{6 8}$ & $\mathbf{1}$ & $\mathbf{1 0 0 7}$ & $\mathbf{1}$ \\
\hline
\end{tabular}

Tabela 15 C.14 Tabela de frequências da variável Marcas por sítio.

\begin{tabular}{|l|rr|rr|rr|cc|cc|}
\hline & \multicolumn{2}{|c|}{$\begin{array}{c}\text { Associação } \\
\text { Calderita }\end{array}$} & \multicolumn{2}{|c|}{ Itapirema } & \multicolumn{2}{|l|}{ Jacarezinho } & \multicolumn{2}{|c|}{ Nova Vida } & \multicolumn{2}{c|}{ Teotônio } \\
\hline NI & 701 & $(99 \%)$ & 2052 & $(98 \%)$ & 892 & $(96 \%)$ & 68 & $(100 \%)$ & 960 & $(95 \%)$ \\
\hline Cestaria & 1 & $(0 \%)$ & 0 & $(0 \%)$ & 0 & $(0 \%)$ & 0 & $(0 \%)$ & 1 & $(0 \%)$ \\
\hline Estrias de Alisamento & 3 & $(0 \%)$ & 16 & $(1 \%)$ & 4 & $(0 \%)$ & 0 & $(0 \%)$ & 36 & $(4 \%)$ \\
\hline Folha & 2 & $(0 \%)$ & 6 & $(0 \%)$ & 2 & $(0 \%)$ & 0 & $(0 \%)$ & 5 & $(0 \%)$ \\
\hline Furo & - & $(0 \%)$ & 10 & $(0 \%)$ & 26 & $(3 \%)$ & 0 & $(0 \%)$ & 2 & $(0 \%)$ \\
\hline Marca de Dedo & - & $(0 \%)$ & 1 & $(0 \%)$ & 1 & $(0 \%)$ & 0 & $(0 \%)$ & 3 & $(0 \%)$ \\
\hline Outros & - & $(0 \%)$ & 3 & $(0 \%)$ & 0 & $(0 \%)$ & 0 & $(0 \%)$ & 0 & $(0 \%)$ \\
\hline Total & $\mathbf{7 0 7}$ & $\mathbf{1}$ & $\mathbf{2 0 8 8}$ & $\mathbf{1}$ & $\mathbf{9 2 5}$ & $\mathbf{1}$ & $\mathbf{6 8}$ & $\mathbf{1}$ & $\mathbf{1 0 0 7}$ & $\mathbf{1}$ \\
\hline
\end{tabular}

Tabela 15 C.15 Tabela de frequências da variável Sinais de Uso por sítio.

\begin{tabular}{|l|rc|cc|cc|cc|cc|}
\hline & \multicolumn{2}{|c|}{$\begin{array}{c}\text { Associação } \\
\text { Calderita }\end{array}$} & \multicolumn{2}{|c|}{ Itapirema } & \multicolumn{2}{|l|}{ Jacarezinho } & \multicolumn{2}{|c|}{ Nova Vida } & \multicolumn{2}{|c|}{ Teotônio } \\
\hline NI & 380 & $(54 \%)$ & 1701 & $(81 \%)$ & 470 & $(51 \%)$ & 39 & $(57 \%)$ & 693 & $(69 \%)$ \\
\hline Fuligem Face Externa & 284 & $(40 \%)$ & 201 & $(10 \%)$ & 393 & $(42 \%)$ & 22 & $(32 \%)$ & 275 & $(27 \%)$ \\
\hline Fuligem Face Interna & 17 & $(2 \%)$ & 130 & $(6 \%)$ & 35 & $(4 \%)$ & 5 & $(7 \%)$ & 18 & $(2 \%)$ \\
\hline Outros & 23 & $(3 \%)$ & 48 & $(2 \%)$ & 26 & $(3 \%)$ & 1 & $(1 \%)$ & 20 & $(2 \%)$ \\
\hline $\begin{array}{l}\text { Película de Alimento Face } \\
\text { Interna }\end{array}$ & 2 & $(0 \%)$ & 6 & $(0 \%)$ & 1 & $(0 \%)$ & 1 & $(1 \%)$ & 0 & $(0 \%)$ \\
\hline Reciclagem & 1 & $(0 \%)$ & 2 & $(0 \%)$ & 0 & $(0 \%)$ & 0 & $(0 \%)$ & 1 & $(0 \%)$ \\
\hline Total & $\mathbf{7 0 7}$ & $\mathbf{1}$ & $\mathbf{2 0 8 8}$ & $\mathbf{1}$ & $\mathbf{9 2 5}$ & $\mathbf{1}$ & $\mathbf{6 8}$ & $\mathbf{1}$ & $\mathbf{1 0 0 7}$ & $\mathbf{1}$ \\
\hline
\end{tabular}


Tabela 15 C.16 Tabela de frequências da variável Morfologia da Borda por sítio, para os fragmentos que são da categoria bordas.

\begin{tabular}{|l|rc|rr|rr|cc|cc|}
\hline & \multicolumn{2}{|c|}{$\begin{array}{l}\text { Associação } \\
\text { Calderita }\end{array}$} & \multicolumn{2}{|c|}{ Itapirema } & \multicolumn{2}{|c|}{ Jacarezinho } & \multicolumn{2}{|c|}{ Nova Vida } & \multicolumn{2}{|c|}{ Teotônio } \\
\hline NI & 4 & $(3 \%)$ & 102 & $(17 \%)$ & 16 & $(5 \%)$ & 3 & $(14 \%)$ & 18 & $(5 \%)$ \\
\hline Direta & 94 & $(69 \%)$ & 220 & $(36 \%)$ & 265 & $(82 \%)$ & 13 & $(59 \%)$ & 267 & $(68 \%)$ \\
\hline Extrovertida com Ondulação & - & $(0 \%)$ & 13 & $(2 \%)$ & 0 & $(0 \%)$ & 0 & $(0 \%)$ & 1 & $(0 \%)$ \\
\hline $\begin{array}{l}\text { Extrovertida com Ponta } \\
\text { Angular }\end{array}$ & 5 & $(4 \%)$ & 93 & $(15 \%)$ & 0 & $(0 \%)$ & 0 & $(0 \%)$ & 15 & $(4 \%)$ \\
\hline Extrovertida & 29 & $(21 \%)$ & 173 & $(28 \%)$ & 23 & $(7 \%)$ & 6 & $(27 \%)$ & 86 & $(22 \%)$ \\
\hline Introvertida & 5 & $(4 \%)$ & 7 & $(1 \%)$ & 19 & $(6 \%)$ & 0 & $(0 \%)$ & 4 & $(1 \%)$ \\
\hline Total & $\mathbf{1 3 7}$ & $\mathbf{1}$ & $\mathbf{6 0 8}$ & $\mathbf{1}$ & $\mathbf{3 2 3}$ & $\mathbf{1}$ & $\mathbf{2 2}$ & $\mathbf{1}$ & $\mathbf{3 9 1}$ & $\mathbf{1}$ \\
\hline
\end{tabular}

Tabela 15 C.17 Tabela de frequências da variável Inclinação da Borda por sítio, para os fragmentos que são da categoria bordas.

\begin{tabular}{|l|cc|cc|cc|cc|cc|}
\hline & \multicolumn{2}{|c|}{$\begin{array}{c}\text { Associação } \\
\text { Calderita }\end{array}$} & \multicolumn{2}{|c|}{ Itapirema } & \multicolumn{2}{|c|}{ Jacarezinho } & \multicolumn{2}{|c|}{ Nova Vida } & \multicolumn{2}{c|}{ Teotônio } \\
\hline NI & 14 & $(10 \%)$ & 93 & $(15 \%)$ & 35 & $(11 \%)$ & 3 & $(14 \%)$ & 20 & $(5 \%)$ \\
\hline Inclinada Externa & 69 & $(50 \%)$ & 457 & $(75 \%)$ & 162 & $(50 \%)$ & 14 & $(64 \%)$ & 275 & $(70 \%)$ \\
\hline Inclinada Interna & 37 & $(27 \%)$ & 17 & $(3 \%)$ & 62 & $(19 \%)$ & 3 & $(14 \%)$ & 58 & $(15 \%)$ \\
\hline Vertical & 17 & $(12 \%)$ & 41 & $(7 \%)$ & 64 & $(20 \%)$ & 2 & $(9 \%)$ & 38 & $(10 \%)$ \\
\hline Total & $\mathbf{1 3 7}$ & $\mathbf{1}$ & $\mathbf{6 0 8}$ & $\mathbf{1}$ & $\mathbf{3 2 3}$ & $\mathbf{1}$ & $\mathbf{2 2}$ & $\mathbf{1}$ & $\mathbf{3 9 1}$ & $\mathbf{1}$ \\
\hline
\end{tabular}

Tabela 15 C.18 Tabela de frequências da variável Espessura da Borda por sítio, para os fragmentos que são da categoria bordas.

\begin{tabular}{|l|rc|cc|cc|cc|cc|}
\hline & \multicolumn{2}{|c|}{$\begin{array}{c}\text { Associação } \\
\text { Calderita }\end{array}$} & \multicolumn{2}{|c|}{ Itapirema } & \multicolumn{2}{|l|}{ Jacarezinho } & \multicolumn{2}{|c|}{ Nova Vida } & \multicolumn{2}{|c|}{ Teotônio } \\
\hline NI & 3 & $(2 \%)$ & 85 & $(14 \%)$ & 12 & $(4 \%)$ & 1 & $(5 \%)$ & 10 & $(3 \%)$ \\
\hline Acalada & 9 & $(7 \%)$ & 3 & $(0 \%)$ & 0 & $(0 \%)$ & 0 & $(0 \%)$ & 0 & $(0 \%)$ \\
\hline Contraída & 14 & $(10 \%)$ & 26 & $(4 \%)$ & 24 & $(7 \%)$ & 2 & $(9 \%)$ & 17 & $(4 \%)$ \\
\hline Dobrada & 1 & $(1 \%)$ & 0 & $(0 \%)$ & 0 & $(0 \%)$ & 0 & $(0 \%)$ & 0 & $(0 \%)$ \\
\hline Expandida & 5 & $(4 \%)$ & 12 & $(2 \%)$ & 1 & $(0 \%)$ & 0 & $(0 \%)$ & 4 & $(1 \%)$ \\
\hline Normal & 90 & $(66 \%)$ & 307 & $(50 \%)$ & 276 & $(85 \%)$ & 17 & $(77 \%)$ & 312 & $(80 \%)$ \\
\hline Reforçada Externa & 7 & $(5 \%)$ & 120 & $(20 \%)$ & 3 & $(1 \%)$ & 1 & $(5 \%)$ & 33 & $(8 \%)$ \\
\hline Reforçada Interna & 5 & $(4 \%)$ & 32 & $(5 \%)$ & 6 & $(2 \%)$ & 1 & $(5 \%)$ & 9 & $(2 \%)$ \\
\hline Reforçada & 3 & $(2 \%)$ & 23 & $(4 \%)$ & 1 & $(0 \%)$ & 0 & $(0 \%)$ & 6 & $(2 \%)$ \\
\hline Total & 137 & $\mathbf{1}$ & $\mathbf{6 0 8}$ & $\mathbf{1}$ & $\mathbf{3 2 3}$ & $\mathbf{1}$ & $\mathbf{2 2}$ & $\mathbf{1}$ & $\mathbf{3 9 1}$ & $\mathbf{1}$ \\
\hline
\end{tabular}

Tabela 15 C.19 Tabela de frequências da variável Lábio por sítio, para os fragmentos que são da categoria bordas.

\begin{tabular}{|l|cc|cc|cc|cc|cc|}
\hline & \multicolumn{2}{|c|}{$\begin{array}{c}\text { Associação } \\
\text { Calderita }\end{array}$} & \multicolumn{2}{|c|}{ Itapirema } & \multicolumn{2}{|l|}{ Jacarezinho } & \multicolumn{2}{|c|}{ Nova Vida } & \multicolumn{2}{|c|}{ Teotônio } \\
\hline NI & 1 & $(1 \%)$ & 42 & $(7 \%)$ & 9 & $(3 \%)$ & 1 & $(5 \%)$ & 9 & $(2 \%)$ \\
\hline Apontado & 11 & $(8 \%)$ & 34 & $(6 \%)$ & 2 & $(1 \%)$ & 0 & $(0 \%)$ & 11 & $(3 \%)$ \\
\hline Arredondado & 96 & $(70 \%)$ & 325 & $(53 \%)$ & 275 & $(85 \%)$ & 21 & $(95 \%)$ & 299 & $(76 \%)$ \\
\hline Biselado & - & $(0 \%)$ & 11 & $(2 \%)$ & 2 & $(1 \%)$ & 0 & $(0 \%)$ & 2 & $(1 \%)$ \\
\hline Plano & 29 & $(21 \%)$ & 196 & $(32 \%)$ & 35 & $(11 \%)$ & 0 & $(0 \%)$ & 70 & $(18 \%)$ \\
\hline Total & $\mathbf{1 3 7}$ & $\mathbf{1}$ & $\mathbf{6 0 8}$ & $\mathbf{1}$ & $\mathbf{3 2 3}$ & $\mathbf{1}$ & $\mathbf{2 2}$ & $\mathbf{1}$ & $\mathbf{3 9 1}$ & $\mathbf{1}$ \\
\hline
\end{tabular}


Tabela 15 C.20 Tabela de frequências da variável Base por sítio, para os fragmentos que são da categoria base.

\begin{tabular}{|c|c|c|c|c|c|}
\hline & $\begin{array}{c}\text { Associação } \\
\text { Calderita }\end{array}$ & Itapirema & Jacarezinho & Nova Vida & Teotônio \\
\hline NI & $5 \quad(28 \%)$ & $(15 \%)$ & $(17 \%)$ & $(0 \%)$ & $(19 \%)$ \\
\hline Anelar & $(0 \%)$ & $(3 \%)$ & $(0 \%)$ & $(0 \%)$ & $(0 \%)$ \\
\hline Côncava & $(0 \%)$ & $(8 \%)$ & $(0 \%)$ & $(0 \%)$ & $(19 \%)$ \\
\hline Convexa & $2 \quad(11 \%)$ & $(0 \%)$ & $(8 \%)$ & $(0 \%)$ & $(19 \%)$ \\
\hline Plana (com ponta angular) & $11 \quad(61 \%)$ & $(68 \%)$ & $16 \quad(67 \%)$ & $(100 \%)$ & $(38 \%)$ \\
\hline $\begin{array}{l}\text { Plano-Convexa (sem ponta } \\
\text { angular) }\end{array}$ & $(0 \%)$ & $(7 \%)$ & $(8 \%)$ & $(0 \%)$ & $(6 \%)$ \\
\hline Total & 18 & 143 & 24 & 9 & 16 \\
\hline
\end{tabular}

Tabela 15 C.21 Tabela de frequências da variável Decoração Plástica por sítio.

\begin{tabular}{|l|cc|cc|cc|cc|cc|}
\hline & \multicolumn{2}{|c|}{$\begin{array}{c}\text { Associação } \\
\text { Calderita }\end{array}$} & \multicolumn{2}{|c|}{ Itapirema } & \multicolumn{2}{|l|}{ Jacarezinho } & \multicolumn{2}{|c|}{ Nova Vida } & \multicolumn{2}{c|}{ Teotônio } \\
\hline NI & 703 & $(99 \%)$ & 1945 & $(93 \%)$ & 921 & $(100 \%)$ & 62 & $(91 \%)$ & 937 & $(93 \%)$ \\
\hline Corrugado & - & $(0 \%)$ & 0 & $(0 \%)$ & 0 & $(0 \%)$ & 0 & $(0 \%)$ & 2 & $(0 \%)$ \\
\hline Digitado & - & $(0 \%)$ & 1 & $(0 \%)$ & 0 & $(0 \%)$ & 0 & $(0 \%)$ & 0 & $(0 \%)$ \\
\hline Entalhado & - & $(0 \%)$ & 0 & $(0 \%)$ & 0 & $(0 \%)$ & 1 & $(1 \%)$ & 3 & $(0 \%)$ \\
\hline Filete Aplicado & - & $(0 \%)$ & 1 & $(0 \%)$ & 0 & $(0 \%)$ & 0 & $(0 \%)$ & 0 & $(0 \%)$ \\
\hline Inciso Fino & 4 & $(1 \%)$ & 99 & $(5 \%)$ & 4 & $(0 \%)$ & 5 & $(7 \%)$ & 36 & $(4 \%)$ \\
\hline Inciso Largo & - & $(0 \%)$ & 42 & $(2 \%)$ & 0 & $(0 \%)$ & 0 & $(0 \%)$ & 28 & $(3 \%)$ \\
\hline Ponteado & - & $(0 \%)$ & 0 & $(0 \%)$ & 0 & $(0 \%)$ & 0 & $(0 \%)$ & 1 & $(0 \%)$ \\
\hline Total & $\mathbf{7 0 7}$ & $\mathbf{1}$ & $\mathbf{2 0 8 8}$ & $\mathbf{1}$ & $\mathbf{9 2 5}$ & $\mathbf{1}$ & $\mathbf{6 8}$ & $\mathbf{1}$ & $\mathbf{1 0 0 7}$ & $\mathbf{1}$ \\
\hline
\end{tabular}

Tabela 15 C.22 Tabela de frequências da variável Decoração Pintada por sítio.

\begin{tabular}{|l|rc|rc|cc|cc|cc|}
\hline & \multicolumn{2}{|c|}{$\begin{array}{c}\text { Associação } \\
\text { Calderita }\end{array}$} & \multicolumn{2}{|c|}{ Itapirema } & \multicolumn{2}{|l|}{ Jacarezinho } & \multicolumn{2}{|c|}{ Nova Vida } & \multicolumn{2}{|c|}{ Teotônio } \\
\hline NI & 692 & $(98 \%)$ & 1875 & $(90 \%)$ & 925 & $(100 \%)$ & 68 & $(100 \%)$ & 914 & $(91 \%)$ \\
\hline Branca & 4 & $(1 \%)$ & 8 & $(0 \%)$ & 0 & $(0 \%)$ & 0 & $(0 \%)$ & 4 & $(0 \%)$ \\
\hline Outras & 2 & $(0 \%)$ & 22 & $(1 \%)$ & 0 & $(0 \%)$ & 0 & $(0 \%)$ & 16 & $(2 \%)$ \\
\hline Preta & - & $(0 \%)$ & 0 & $(0 \%)$ & 0 & $(0 \%)$ & 0 & $(0 \%)$ & 1 & $(0 \%)$ \\
\hline Vermelha & 9 & $(1 \%)$ & 183 & $(9 \%)$ & 0 & $(0 \%)$ & 0 & $(0 \%)$ & 72 & $(7 \%)$ \\
\hline Total & $\mathbf{7 0 7}$ & $\mathbf{1}$ & $\mathbf{2 0 8 8}$ & $\mathbf{1}$ & $\mathbf{9 2 5}$ & $\mathbf{1}$ & $\mathbf{6 8}$ & $\mathbf{1}$ & $\mathbf{1 0 0 7}$ & $\mathbf{1}$ \\
\hline
\end{tabular}

Tabela 15 C.23 Tabela de frequências da variável Motivo por sítio.

\begin{tabular}{|l|rr|rr|rr|cr|cc|}
\hline & \multicolumn{2}{|c|}{$\begin{array}{c}\text { Associação } \\
\text { Calderita }\end{array}$} & \multicolumn{2}{|c|}{ Itapirema } & \multicolumn{2}{|c|}{ Jacarezinho } & \multicolumn{2}{|c|}{ Nova Vida } & \multicolumn{2}{|c|}{ Teotônio } \\
\hline NI & 692 & $(98 \%)$ & 1933 & $(93 \%)$ & 923 & $(100 \%)$ & 64 & $(94 \%)$ & 955 & $(95 \%)$ \\
\hline Ângular & - & $(0 \%)$ & 2 & $(0 \%)$ & 0 & $(0 \%)$ & 0 & $(0 \%)$ & 3 & $(0 \%)$ \\
\hline Complexa & 2 & $(0 \%)$ & 12 & $(1 \%)$ & 0 & $(0 \%)$ & 0 & $(0 \%)$ & 1 & $(0 \%)$ \\
\hline Curcilíneas & 2 & $(0 \%)$ & 12 & $(1 \%)$ & 0 & $(0 \%)$ & 0 & $(0 \%)$ & 0 & $(0 \%)$ \\
\hline Em Grega & - & $(0 \%)$ & 8 & $(0 \%)$ & 0 & $(0 \%)$ & 0 & $(0 \%)$ & 0 & $(0 \%)$ \\
\hline Espiral & - & $(0 \%)$ & 0 & $(0 \%)$ & 0 & $(0 \%)$ & 0 & $(0 \%)$ & 2 & $(0 \%)$ \\
\hline Horizontal & 8 & $(1 \%)$ & 101 & $(5 \%)$ & 0 & $(0 \%)$ & 0 & $(0 \%)$ & 30 & $(3 \%)$ \\
\hline Outras & 1 & $(0 \%)$ & 19 & $(1 \%)$ & 0 & $(0 \%)$ & 3 & $(4 \%)$ & 11 & $(1 \%)$ \\
\hline Trançada & - & $(0 \%)$ & 0 & $(0 \%)$ & 1 & $(0 \%)$ & 0 & $(0 \%)$ & 1 & $(0 \%)$ \\
\hline Transversal & 1 & $(0 \%)$ & 0 & $(0 \%)$ & 0 & $(0 \%)$ & 1 & $(1 \%)$ & 2 & $(0 \%)$ \\
\hline Vertical Curta & - & $(0 \%)$ & 1 & $(0 \%)$ & 1 & $(0 \%)$ & 0 & $(0 \%)$ & 1 & $(0 \%)$ \\
\hline Vertical Longa & 1 & $(0 \%)$ & 0 & $(0 \%)$ & 0 & $(0 \%)$ & 0 & $(0 \%)$ & 1 & $(0 \%)$ \\
\hline Total & $\mathbf{7 0 7}$ & $\mathbf{1}$ & $\mathbf{2 0 8 8}$ & $\mathbf{1}$ & $\mathbf{9 2 5}$ & $\mathbf{1}$ & $\mathbf{6 8}$ & $\mathbf{1}$ & $\mathbf{1 0 0 7}$ & $\mathbf{1}$ \\
\hline
\end{tabular}

Tabela 15 C.24 Tabela de frequências da variável Local da Decoração Face Interna por sítio. 


\begin{tabular}{|l|rr|rr|r|cc|cc|c|}
\hline & \multicolumn{2}{|c|}{$\begin{array}{c}\text { Associação } \\
\text { Calderita }\end{array}$} & \multicolumn{2}{|c|}{ Itapirema } & \multicolumn{2}{|c|}{ Jacarezinho } & \multicolumn{2}{c|}{ Nova Vida } & \multicolumn{2}{|c|}{ Teotônio } \\
\hline NI & 703 & $(99 \%)$ & 1975 & $(95 \%)$ & 924 & $(100 \%)$ & 67 & $(99 \%)$ & 981 & $(97 \%)$ \\
\hline Bojo Inferior & - & $(0 \%)$ & 1 & $(0 \%)$ & 0 & $(0 \%)$ & 0 & $(0 \%)$ & 0 & $(0 \%)$ \\
\hline Borda & 2 & $(0 \%)$ & 61 & $(3 \%)$ & 0 & $(0 \%)$ & 0 & $(0 \%)$ & 16 & $(2 \%)$ \\
\hline Lábio & 1 & $(0 \%)$ & 28 & $(1 \%)$ & 1 & $(0 \%)$ & 1 & $(1 \%)$ & 4 & $(0 \%)$ \\
\hline Outras & - & $(0 \%)$ & 15 & $(1 \%)$ & 0 & $(0 \%)$ & 0 & $(0 \%)$ & 2 & $(0 \%)$ \\
\hline Parede & 1 & $(0 \%)$ & 8 & $(0 \%)$ & 0 & $(0 \%)$ & 0 & $(0 \%)$ & 4 & $(0 \%)$ \\
\hline Total & $\mathbf{7 0 7}$ & $\mathbf{1}$ & $\mathbf{2 0 8 8}$ & $\mathbf{1}$ & $\mathbf{9 2 5}$ & $\mathbf{1}$ & $\mathbf{6 8}$ & $\mathbf{1}$ & $\mathbf{1 0 0 7}$ & $\mathbf{1}$ \\
\hline
\end{tabular}

Tabela C.25 Tabela de frequências da variável Local da Decoração Face Externa por sítio.

\begin{tabular}{|c|c|c|c|c|c|c|c|c|c|c|}
\hline \multirow[b]{2}{*}{ NI } & \multicolumn{2}{|c|}{$\begin{array}{c}\text { Associação } \\
\text { Calderita }\end{array}$} & \multicolumn{2}{|c|}{ Itapirema } & \multicolumn{2}{|c|}{ Jacarezinho } & \multicolumn{2}{|c|}{ Nova Vida } & \multicolumn{2}{|c|}{ Teotônio } \\
\hline & 694 & $(98 \%)$ & 1855 & $(89 \%)$ & 922 & $(100 \%)$ & & $(94 \%)$ & 882 & $(88 \%)$ \\
\hline Base & - & $(0 \%)$ & 1 & $(0 \%)$ & & $(0 \%)$ & 0 & $(0 \%)$ & 1 & $(0 \%)$ \\
\hline Bojo Inferior & 1 & $(0 \%)$ & 0 & $(0 \%)$ & 0 & $(0 \%)$ & 0 & $(0 \%)$ & 1 & $(0 \%)$ \\
\hline Bojo Superior & - & $(0 \%)$ & 8 & $(0 \%)$ & 0 & $(0 \%)$ & 0 & $(0 \%)$ & 5 & $(0 \%)$ \\
\hline Borda & 1 & $(0 \%)$ & 68 & $(3 \%)$ & 0 & $(0 \%)$ & 0 & $(0 \%)$ & 22 & $(2 \%)$ \\
\hline Lábio & - & $(0 \%)$ & 11 & $(1 \%)$ & 0 & $(0 \%)$ & 1 & $(1 \%)$ & 2 & $(0 \%)$ \\
\hline Outras & 1 & $(0 \%)$ & 19 & $(1 \%)$ & 0 & $(0 \%)$ & 0 & $(0 \%)$ & 5 & $(0 \%)$ \\
\hline Parede & 10 & $(1 \%)$ & 126 & $(6 \%)$ & 2 & $(0 \%)$ & 3 & $(4 \%)$ & 89 & $(9 \%)$ \\
\hline Total & 707 & 1 & 2088 & 1 & 925 & 1 & 68 & 1 & 1007 & 1 \\
\hline
\end{tabular}


Tabela 15 C.26 Tabela de frequências da variável Forma por sítio.

\begin{tabular}{|c|c|c|c|c|c|c|c|c|c|c|}
\hline \multirow[b]{2}{*}{$\mathrm{NI}$} & \multicolumn{2}{|c|}{$\begin{array}{l}\text { Associação } \\
\text { Calderita }\end{array}$} & \multicolumn{2}{|c|}{ Itapirema } & \multicolumn{2}{|c|}{ Jacarezinho } & \multicolumn{2}{|c|}{ Nova Vida } & \multicolumn{2}{|c|}{ Teotônio } \\
\hline & 651 & $(92 \%)$ & 1920 & $(92 \%)$ & 840 & (91\%) & 59 & $(87 \%)$ & 920 & $(91 \%)$ \\
\hline $\begin{array}{l}\text { Vasilha em forma de calota, } \\
\text { com contorno infletido, boca } \\
\text { aberta. }\end{array}$ & 3 & $(0 \%)$ & 32 & $(2 \%)$ & 0 & $(0 \%)$ & 0 & $(0 \%)$ & 2 & $(0 \%)$ \\
\hline $\begin{array}{l}\text { Vasilha em forma de calota, } \\
\text { com contorno simples e boca } \\
\text { constrita. }\end{array}$ & - & $(0 \%)$ & 0 & $(0 \%)$ & 1 & $(0 \%)$ & 0 & $(0 \%)$ & 0 & $(0 \%)$ \\
\hline $\begin{array}{l}\text { Vasilha em forma de calota, } \\
\text { com contorno simples, boca } \\
\text { aberta. }\end{array}$ & 6 & $(1 \%)$ & 19 & $(1 \%)$ & 19 & $(2 \%)$ & 0 & $(0 \%)$ & 11 & $(1 \%)$ \\
\hline $\begin{array}{l}\text { Vasilha esférica com pescoço, } \\
\text { contorno infletido e boca } \\
\text { constrita. }\end{array}$ & 1 & $(0 \%)$ & 6 & $(0 \%)$ & 1 & $(0 \%)$ & 0 & $(0 \%)$ & 3 & $(0 \%)$ \\
\hline $\begin{array}{l}\text { Vasilha esférica, com contorno } \\
\text { infletido e boca aberta. }\end{array}$ & - & $(0 \%)$ & 11 & $(1 \%)$ & 0 & $(0 \%)$ & 0 & $(0 \%)$ & 0 & $(0 \%)$ \\
\hline $\begin{array}{l}\text { Vasilha esférica, com contorno } \\
\text { infletido e boca constrita. }\end{array}$ & 4 & $(1 \%)$ & 21 & $(1 \%)$ & 5 & $(1 \%)$ & 0 & $(0 \%)$ & 17 & $(2 \%)$ \\
\hline $\begin{array}{l}\text { Vasilha esférica, com contorno } \\
\text { simples e boca aberta. }\end{array}$ & - & $(0 \%)$ & 2 & $(0 \%)$ & 3 & $(0 \%)$ & 0 & $(0 \%)$ & 3 & $(0 \%)$ \\
\hline $\begin{array}{l}\text { Vasilha esférica, com contorno } \\
\text { simples e boca constrita. }\end{array}$ & 9 & $(1 \%)$ & 4 & & 19 & $(2 \%)$ & 0 & $(0 \%)$ & 8 & $(1 \%)$ \\
\hline Vasilha rasa, prato. & 1 & $(0 \%)$ & 5 & $(0 \%)$ & 3 & $(0 \%)$ & 0 & $(0 \%)$ & 0 & $(0 \%)$ \\
\hline $\begin{array}{l}\text { Vasilha semi-esférica, com } \\
\text { contorno infletido e boca } \\
\text { aberta. }\end{array}$ & 9 & $(1 \%)$ & 50 & $(2 \%)$ & 0 & $(0 \%)$ & 0 & $(0 \%)$ & 9 & $(1 \%)$ \\
\hline $\begin{array}{l}\text { Vasilha semi-esférica, com } \\
\text { contorno infletido e boca } \\
\text { constrita.. }\end{array}$ & 1 & $(0 \%)$ & 1 & $(0 \%)$ & 0 & $(0 \%)$ & 0 & $(0 \%)$ & 1 & $(0 \%)$ \\
\hline $\begin{array}{l}\text { Vasilha semi-esférica, com } \\
\text { contorno simples e boca } \\
\text { aberta. }\end{array}$ & 17 & $(2 \%)$ & 16 & $(1 \%)$ & 26 & $(3 \%)$ & 0 & $(0 \%)$ & 25 & $(2 \%)$ \\
\hline $\begin{array}{l}\text { Vasilha semi-esférica, com } \\
\text { contorno simples e boca } \\
\text { constrita. }\end{array}$ & 5 & $(1 \%)$ & 1 & $(0 \%)$ & 8 & $(1 \%)$ & 0 & $(0 \%)$ & 8 & $(1 \%)$ \\
\hline Outras & - & $(0 \%)$ & 0 & $(0 \%)$ & 0 & $(0 \%)$ & 9 & $(13 \%)$ & 0 & $(0 \%)$ \\
\hline Total & 707 & 1 & 2088 & 1 & 925 & 1 & 68 & 1 & 1007 & 1 \\
\hline
\end{tabular}


Anexo 15 D Tabelas Descritivas das Variáveis Quantitativas

Tabela 15 D.1 Tabela de medidas descritivas da variável Diâmetro da Borda por sítio $(\mathrm{cm})$.

\begin{tabular}{|l|rrrrrr|}
\hline \multicolumn{1}{|c|}{ Sítio } & N & $\begin{array}{c}\text { N } \\
\text { Faltante }\end{array}$ & Média & $\begin{array}{l}\text { Desvio } \\
\text { Padrão }\end{array}$ & Mínimo & Máximo \\
\hline Associação Calderita & 91 & 46 & 19,00 & 6,78 & 9,00 & 50,00 \\
\hline Itapirema & 326 & 282 & 26,52 & 11,15 & 7,00 & 64,00 \\
\hline Jacarezinho & 139 & 184 & 20,00 & 9,35 & 6,00 & 54,00 \\
\hline Nova Vida & 11 & 11 & 20,82 & 9,00 & 7,00 & 42,00 \\
\hline Teotônio & 239 & 152 & 21,43 & 8,00 & 7,00 & 52,00 \\
\hline
\end{tabular}

Tabela15 D.2 Tabela de medidas descritivas da variável Porcentagem da Borda por sítio.

\begin{tabular}{|l|rrrrrr|}
\hline \multicolumn{1}{|c|}{ Sítio } & $\mathbf{N}$ & $\begin{array}{c}\text { N } \\
\text { Faltante }\end{array}$ & Média & $\begin{array}{l}\text { Desvio } \\
\text { Padrão }\end{array}$ & Mínimo & Máximo \\
\hline Associação Calderita & 88 & 49 & 5,77 & 2,86 & 3,00 & 25,00 \\
\hline Itapirema & 326 & 282 & 6,61 & 3,80 & 0,04 & 30,00 \\
\hline Jacarezinho & 135 & 188 & 5,72 & 2,37 & 0,04 & 17,00 \\
\hline Nova Vida & 11 & 11 & 4,00 & 1,36 & 3,00 & 7,00 \\
\hline Teotônio & 236 & 155 & 4,00 & 2,00 & 1,00 & 22,00 \\
\hline
\end{tabular}

Tabela15 D.3 Tabela de medidas descritivas da variável Espessura do Lábio por sítio $(\mathrm{cm})$.

\begin{tabular}{|l|rrrrrr|}
\hline \multicolumn{1}{|c|}{ Sítio } & $\mathbf{N}$ & $\begin{array}{c}\mathbf{N} \\
\text { Faltante }\end{array}$ & Média & $\begin{array}{l}\text { Desvio } \\
\text { Padrão }\end{array}$ & Mínimo & Máximo \\
\hline Associação Calderita & 134 & 3 & 0,64 & 0,26 & 0,30 & 1,60 \\
\hline Itapirema & 571 & 37 & 0,62 & 0,29 & 0,10 & 2,50 \\
\hline Jacarezinho & 313 & 10 & 0,69 & 0,29 & 0,30 & 1,80 \\
\hline Nova Vida & 19 & 3 & 0,56 & 0,14 & 0,30 & 0,80 \\
\hline Teotônio & 134 & 257 & 0,64 & 0,26 & 0,30 & 1,60 \\
\hline
\end{tabular}

Tabela 15 D.4 Tabela de medidas descritivas da variável Diâmetro da Base por sítio (cm).

\begin{tabular}{|l|crrrrr|}
\hline \multicolumn{1}{|c|}{ Sítio } & N & $\begin{array}{c}\text { N } \\
\text { Faltante }\end{array}$ & Média & $\begin{array}{c}\text { Desvio } \\
\text { Padrão }\end{array}$ & Mínimo & Máximo \\
\hline Associação Calderita & 4 & 14 & 9,25 & 2,00 & 7,00 & 12,00 \\
\hline Itapirema & 72 & 71 & 12,07 & 4,16 & 4,00 & 24,00 \\
\hline Jacarezinho & 8 & 16 & 8,00 & 2,33 & 6,00 & 13,00 \\
\hline Teotônio & 8 & 8 & 12,12 & 3,40 & 6,00 & 16,00 \\
\hline
\end{tabular}


Tabela 15 D.5 Tabela de medidas descritivas da variável Espessura do Fragmento por sítio (cm).

\begin{tabular}{|l|crrrrr|}
\hline \multicolumn{1}{|c|}{ Sítio } & $\mathbf{N}$ & $\begin{array}{c}\text { N } \\
\text { Faltante }\end{array}$ & Média & $\begin{array}{l}\text { Desvio } \\
\text { Padrão }\end{array}$ & Mínimo & Máximo \\
\hline Associação Calderita & 698 & 9 & 0,96 & 0,29 & 0,10 & 4,30 \\
\hline Itapirema & 1972 & 113 & 1,00 & 0,31 & 0,30 & 2,80 \\
\hline Jacarezinho & 886 & 39 & 1,05 & 0,37 & 0,20 & 3,50 \\
\hline Nova Vida & 66 & 2 & 1,06 & 0,39 & 0,50 & 2,00 \\
\hline Teotônio & 985 & 22 & 0,74 & 0,22 & 0,20 & 2,00 \\
\hline
\end{tabular}

Tabela 15 D.6 Tabela de medidas descritivas da variável Volume Estimado por sítio (L).

\begin{tabular}{|l|crrrrr|}
\hline \multicolumn{1}{|c|}{ Sítio } & N & $\begin{array}{c}\text { N } \\
\text { Faltante }\end{array}$ & Média & $\begin{array}{c}\text { Desvio } \\
\text { Padrão }\end{array}$ & Mínimo & Máximo \\
\hline Associação Calderita & 55 & 652 & 3,41 & 4,00 & 0,19 & 19,97 \\
\hline Itapirema & 163 & 1.922 & 5,57 & 9,14 & 0,05 & 64,23 \\
\hline Jacarezinho & 82 & 843 & 3,44 & 4,26 & 0,20 & 20,70 \\
\hline Teotônio & 87 & 920 & 4,55 & 6,68 & 0,10 & 41,10 \\
\hline
\end{tabular}

Tabela 15 D.7 Tabela de medidas descritivas da variável Porcentagem do Fragmento por sítio.

\begin{tabular}{|l|crrrrr|}
\hline \multicolumn{1}{|c|}{ Sítio } & N & $\begin{array}{c}\text { N } \\
\text { Faltante }\end{array}$ & Média & $\begin{array}{c}\text { Desvio } \\
\text { Padrão }\end{array}$ & Mínimo & Máximo \\
\hline Associação Calderita & 56 & 651 & 18,57 & 6,42 & 7,00 & 41,00 \\
\hline Itapirema & 160 & 1.925 & 25,43 & 12,85 & 0,12 & 78,00 \\
\hline Jacarezinho & 67 & 858 & 20,38 & 7,28 & 0,29 & 44,00 \\
\hline Teotônio & 86 & 921 & 20,96 & 9,39 & 7,30 & 56,00 \\
\hline
\end{tabular}


Anexo 15 E Gráficos das Variáveis Quantitativas

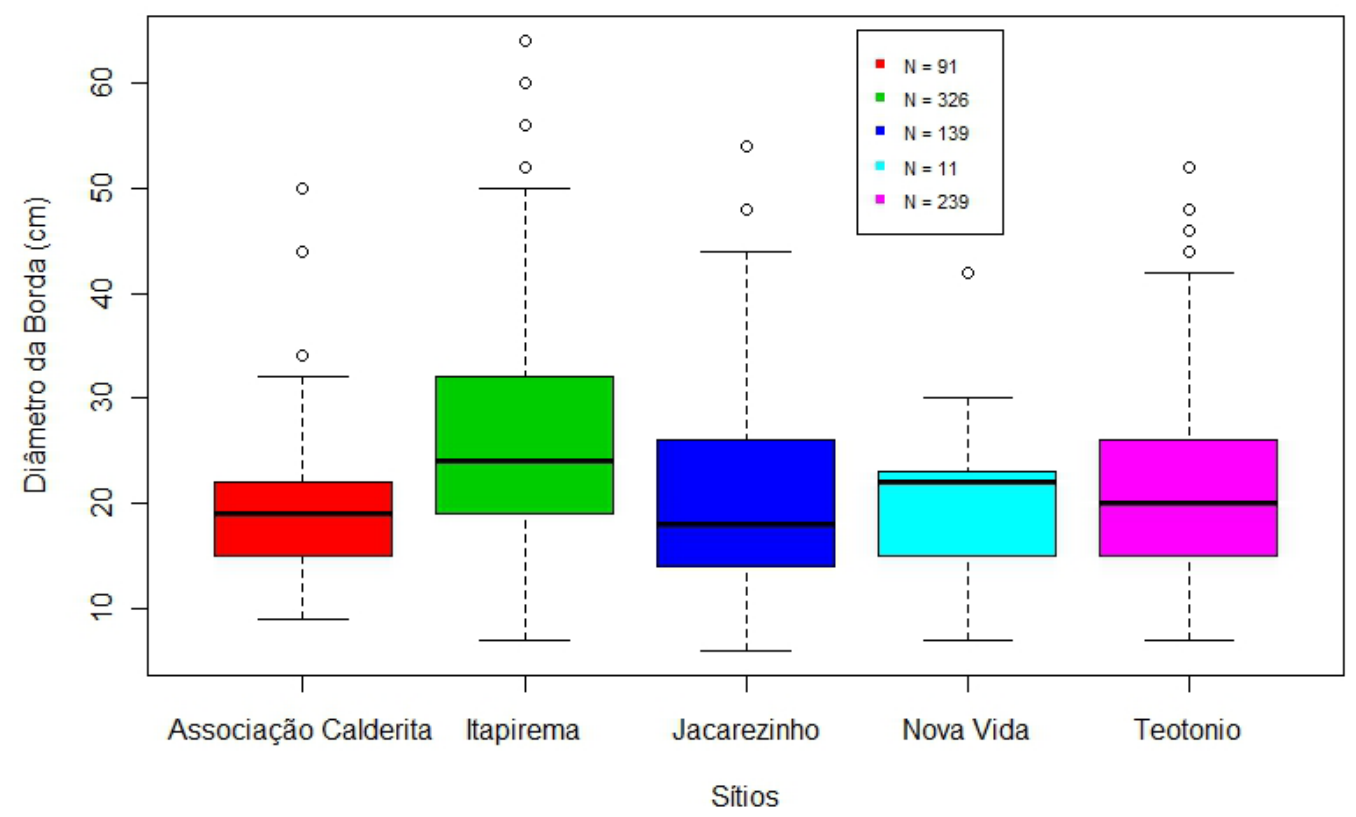

Figura 15 E.1. Boxplot da variável Diâmetro da Borda por sítio (cm).

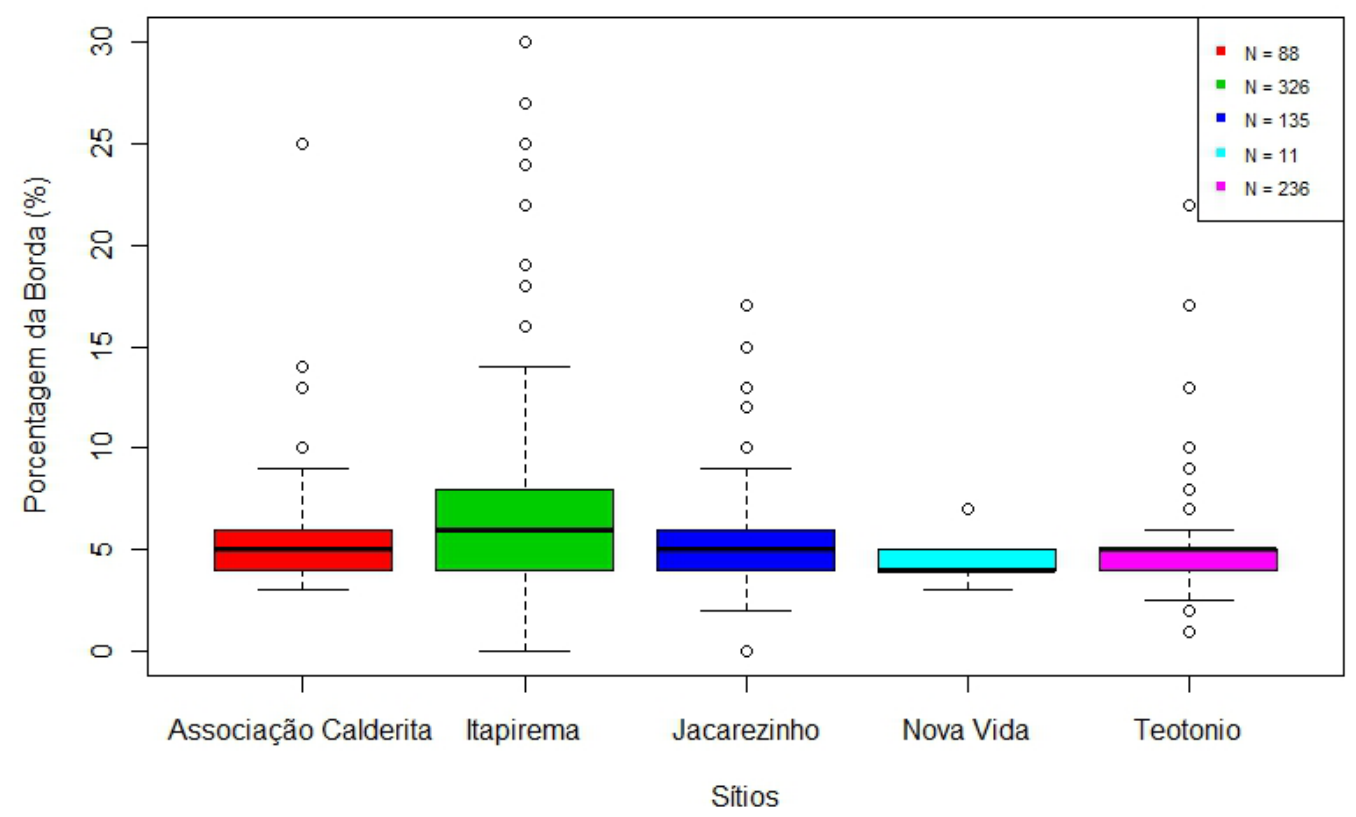

Figura 15 E.2 Boxplot da variável Porcentagem da Borda por sítio (cm). 


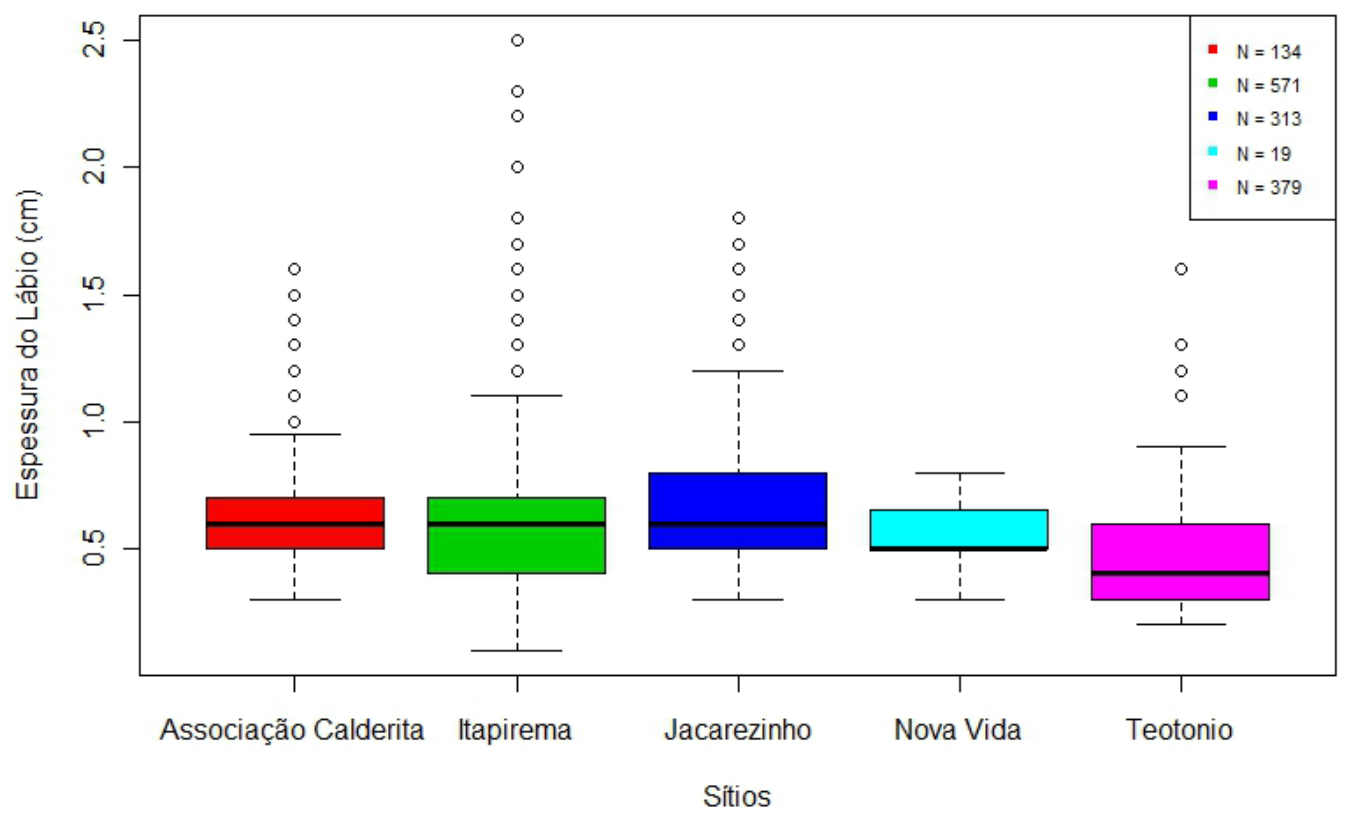

Figura 15 E.3 Boxplot da variável Espessura do Lábio por sítio $(\mathrm{cm})$.

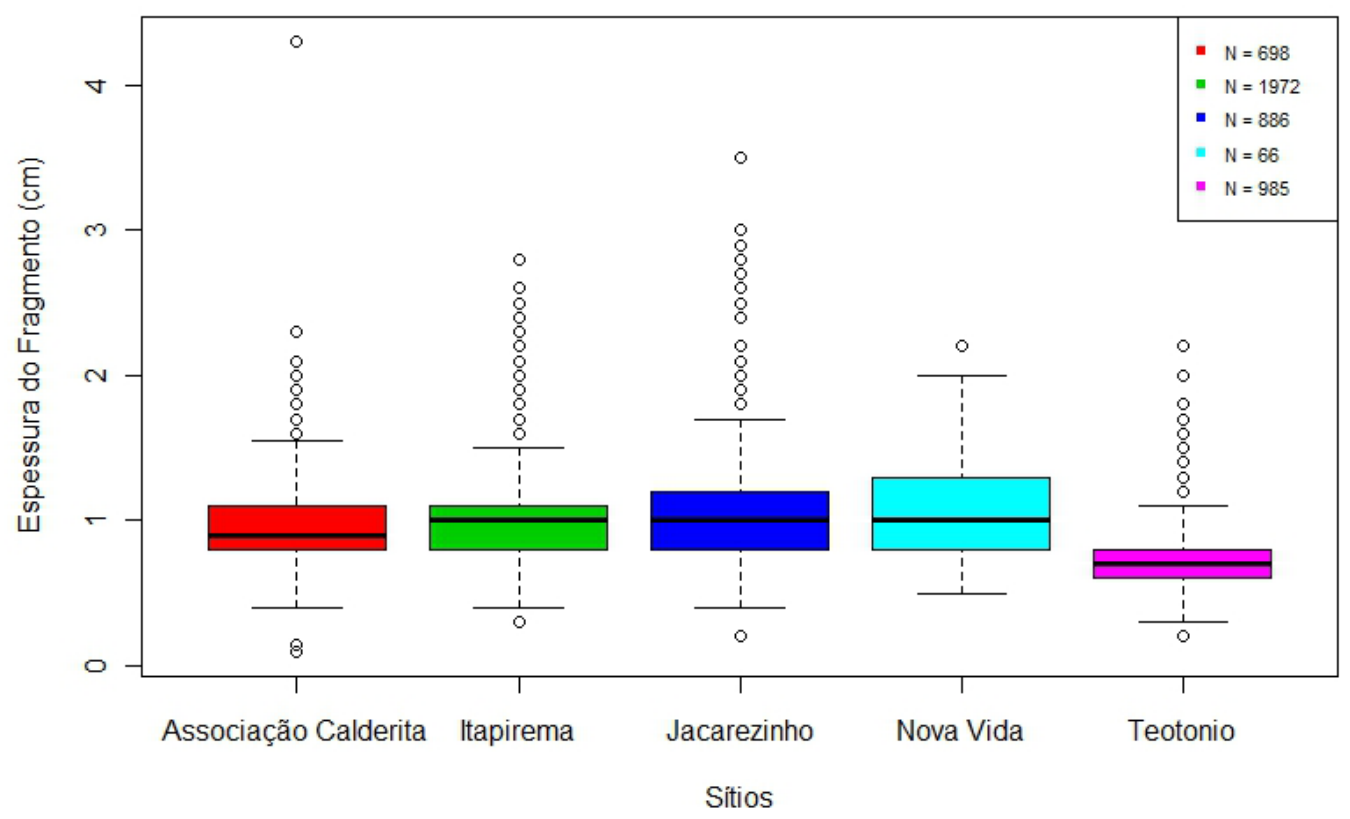

Figura15 E.4 Boxplot da variável Espessura do Fragmento por sítio (cm). 


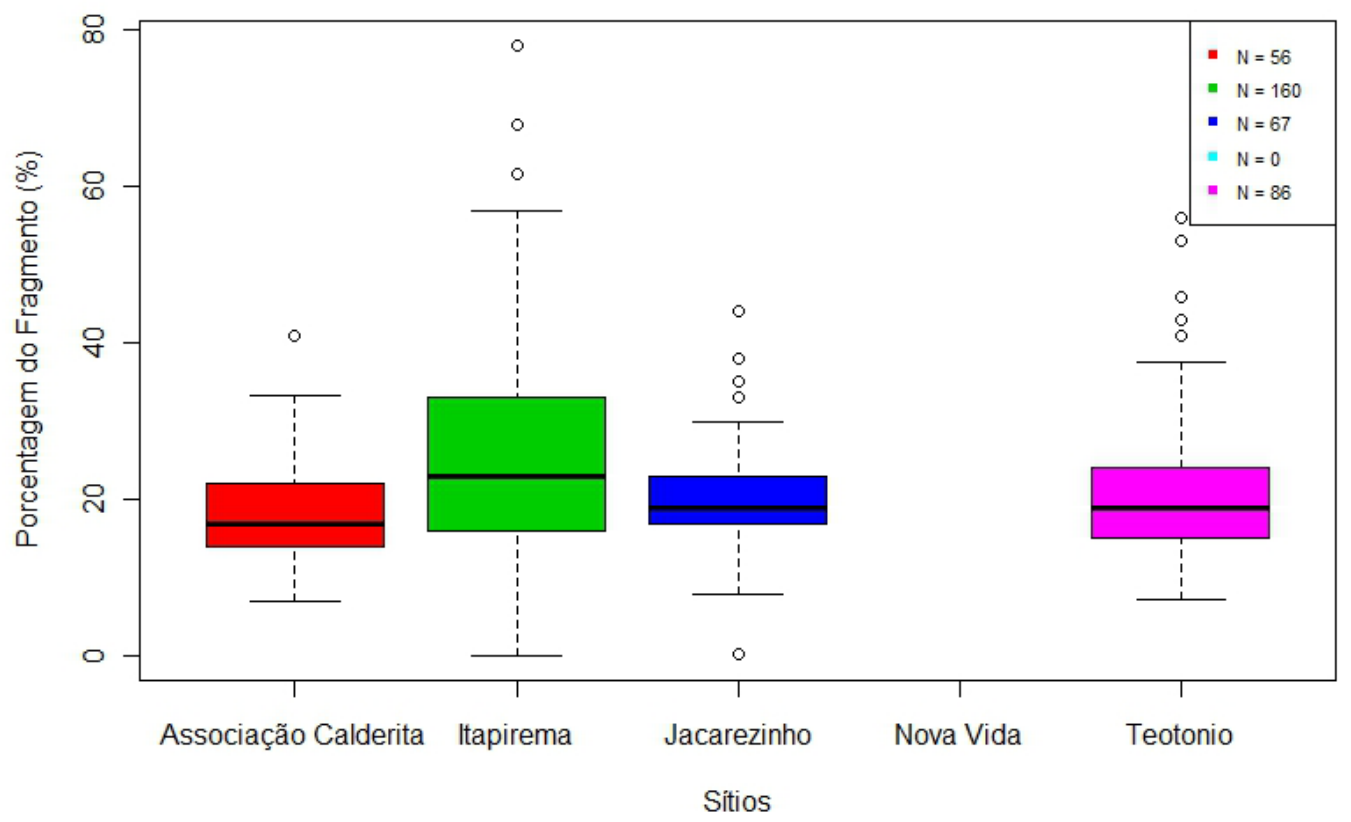

Figura 15 E.5 Boxplot da variável Porcentagem do Fragmento por sítio $(\mathrm{cm})$.

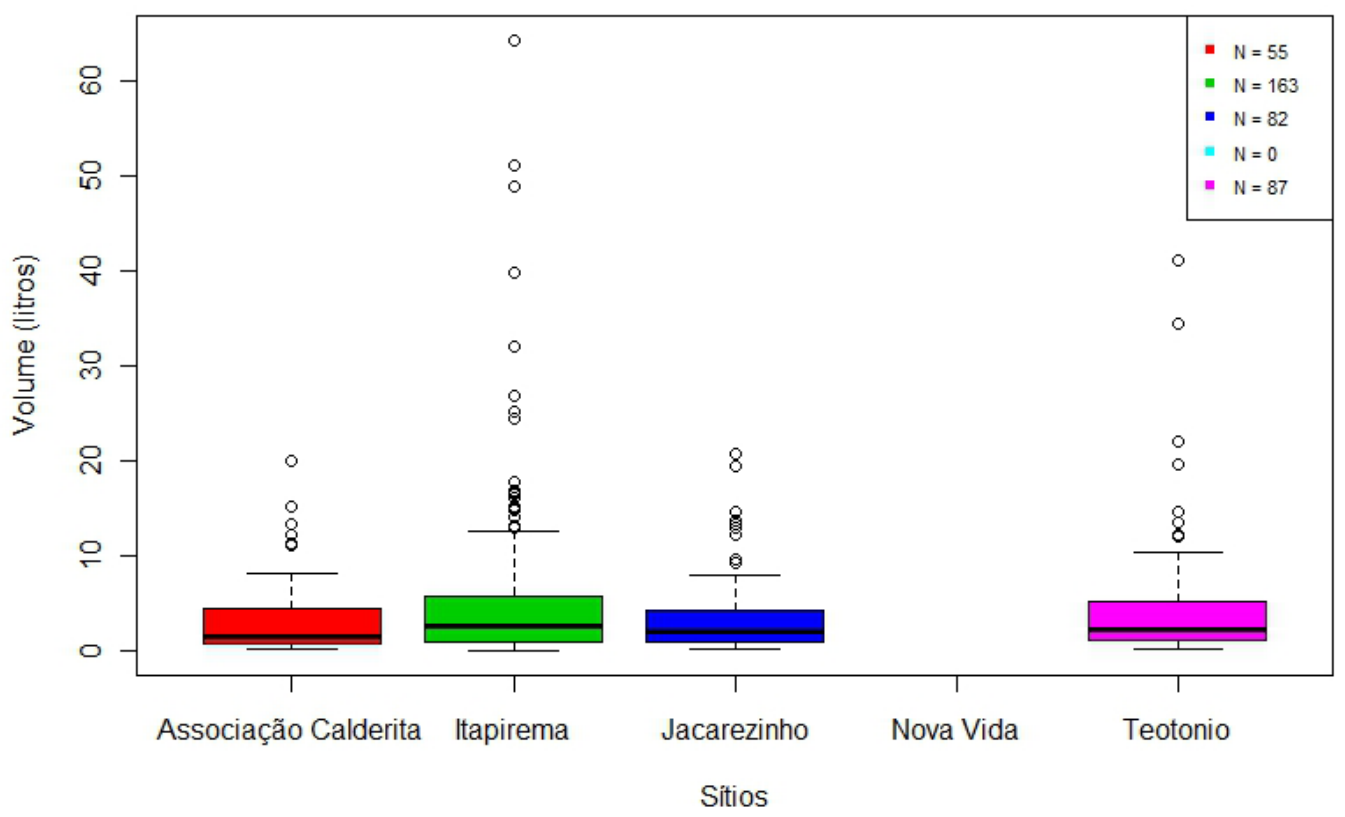

Figura 15 E.6 Boxplot da variável Volume Estimado por sítio (L). 
Anexo 15 F Tabelas de Frequências para a Análise de Correspondência

Tabela 15 F.1 Tabela de inércia das variáveis.

\begin{tabular}{|l|c|c|c|c|}
\hline Variavel & Dimensão 1 & Dimensão 2 & Dimensão 3 & Dimensão 4 \\
\hline Técnica de Manufatura & $97,91 \%$ & $2,09 \%$ & - & - \\
Antiplástico & $68,15 \%$ & $20,72 \%$ & $11,01 \%$ & $0,12 \%$ \\
Espessura do Antiplástico & $79,23 \%$ & $19,05 \%$ & $1,71 \%$ & - \\
Porcentagem do Antiplástico & $74,92 \%$ & $23,97 \%$ & $1,11 \%$ & - \\
Morfologia da Borda & $92,15 \%$ & $7,31 \%$ & $0,49 \%$ & $0,05 \%$ \\
Espessura da Borda & $64,00 \%$ & $34,61 \%$ & $1,33 \%$ & $0,06 \%$ \\
Decoracao Plástica & $69,98 \%$ & $18,60 \%$ & $11,42 \%$ & $0,00 \%$ \\
Decoracao Pintada & $94,87 \%$ & $2,78 \%$ & $2,35 \%$ & - \\
Tratamento de Superfície FI & $53,17 \%$ & $24,27 \%$ & $22,23 \%$ & $0,33 \%$ \\
Tratamento de Superfície FE & $72,18 \%$ & $25,23 \%$ & $2,59 \%$ & $0,00 \%$ \\
Sinais de Uso & $97,04 \%$ & $2,06 \%$ & $0,83 \%$ & $0,07 \%$ \\
Forma & $83,11 \%$ & $11,96 \%$ & $4,93 \%$ & - \\
\hline
\end{tabular}

Tabela 15 F.2 Tabela de frequências da variável Técnica de Manufatura com o valor quiquadrado.

\begin{tabular}{|c|c|c|c|c|c|}
\hline & & Acordelada & Modelada & Placas & Total \\
\hline \multirow{3}{*}{$\begin{array}{c}\text { Associação } \\
\text { Calderita }\end{array}$} & Frequência & 344,00 & 4,00 & 2,00 & 350 \\
\hline & Esperado & 319,26 & $\overline{3}, \overline{30}$ & 27,44 & \\
\hline & Qui-Quadrado da célula & 1,92 & 0,15 & 23,59 & \\
\hline \multirow{3}{*}{ Itapirema } & Frequência & 861,00 & 15,00 & 160,00 & 1.036 \\
\hline & Esperado & 945,01 & 9,77 & 81,23 & \\
\hline & Qui-Quadrado da célula & 7,47 & 2,81 & 76,39 & \\
\hline \multirow{3}{*}{ Jacarezinho } & Frequência & 390,00 & - & 12,00 & 402 \\
\hline & Esperado & 366,69 & 3,79 & 31,52 & \\
\hline & Qui-Quadrado da célula & 1,48 & 3,79 & 12,09 & \\
\hline \multirow{3}{*}{ Nova Vida } & Frequência & 7,00 & - & 1,00 & 8 \\
\hline & Esperado & 7,30 & $\underline{0,08}$ & 0,63 & \\
\hline & Qui-Quadrado da célula & 0,01 & 0,08 & 0,22 & \\
\hline \multirow{3}{*}{ Teotonio } & Frequência & 527,00 & 3,00 & 8,00 & 538 \\
\hline & Esperado & 490,75 & 5,07 & 42,18 & \\
\hline & Qui-Quadrado da célula & 2,68 & 0,85 & 27,70 & \\
\hline Total & Frequência & 2.129 & 22 & 183 & 2.334 \\
\hline
\end{tabular}


Tabela 15 F.3 Tabela de frequências da variável Antiplástico com o valor qui-quadrado.

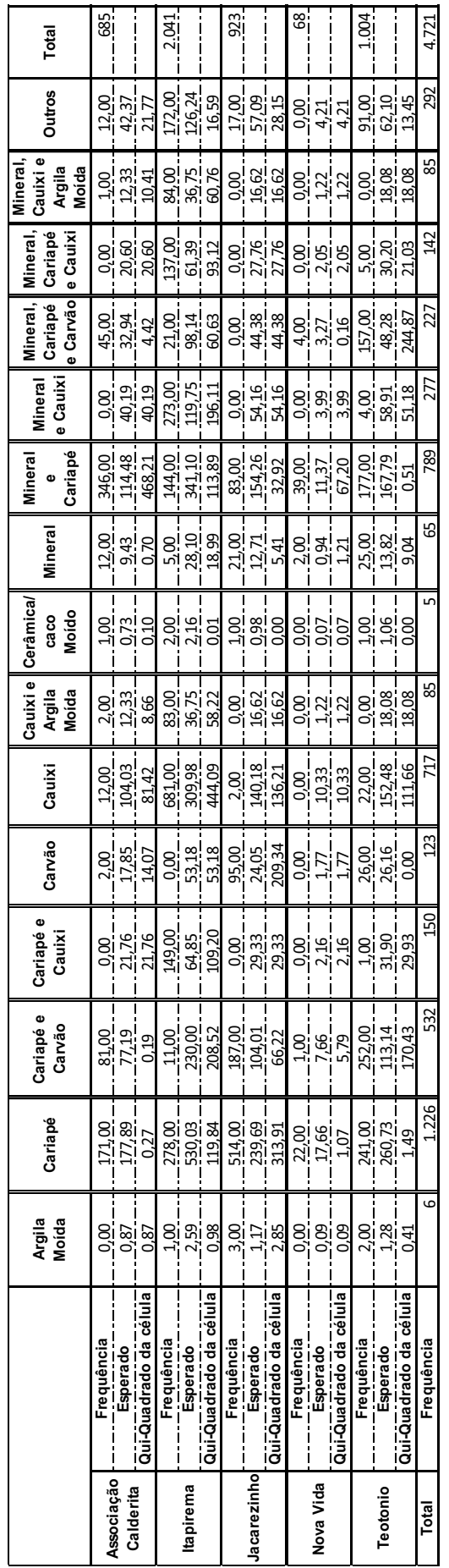


Tabela 15 F.4 Tabela de frequências da variável Espessura de Antiplástico com o valor quiquadrado.

\begin{tabular}{|c|c|c|c|c|c|c|}
\hline & & $\begin{array}{c}\text { Menor que } \\
1 \mathrm{~mm}\end{array}$ & $\begin{array}{c}\text { entre } 1 \mathrm{~mm} \\
\text { e } 3 \mathrm{~mm}\end{array}$ & $\begin{array}{c}\text { entre } 3 \mathrm{~mm} \text { e } \\
5 \mathrm{~mm}\end{array}$ & $\begin{array}{c}\text { Maior que } \\
5 \mathrm{~mm}\end{array}$ & Total \\
\hline \multirow{3}{*}{$\begin{array}{c}\text { Associação } \\
\text { Calderita }\end{array}$} & Frequência & 46,00 & 497,00 & 138,00 & 20,00 & 701 \\
\hline & Esperado & 210,84 & 414,35 & 64,95 & 10,85 & \\
\hline & Qui-Quadrado da célula & 128,88 & 16,48 & 82,15 & 7,72 & \\
\hline \multirow{3}{*}{ Itapirema } & Frequência & $1.074,00$ & 848,00 & 140,00 & 21,00 & 2.083 \\
\hline & Esperado & 626,51 & $1.231,20$ & 193,01 & 32,24 & \\
\hline & Qui-Quadrado da célula & 319,62 & 119,29 & 14,56 & 3,92 & \\
\hline \multirow{3}{*}{ Jacarezinho } & Frequência & 185,00 & 604,00 & 113,00 & 21,00 & 923 \\
\hline & Esperado & 277,61 & 545,58 & 85,52 & 14,29 & \\
\hline & Qui-Quadrado da célula & 30,90 & 6,26 & 8,83 & 3,16 & \\
\hline \multirow{3}{*}{ Nova Vida } & Frequência & 9,00 & 34,00 & 17,00 & 8,00 & 68 \\
\hline & Esperado & 20,45 & 40,19 & 6,30 & 1,05 & \\
\hline & Qui-Quadrado da célula & 6,41 & 0,95 & 18,17 & 45,86 & \\
\hline \multirow{3}{*}{ Teotonio } & Frequência & 124,00 & 843,00 & 35,00 & 4,00 & 1.006 \\
\hline & Esperado & 302,58 & 594,64 & 93,21 & $15, \overline{5} 7$ & \\
\hline & Qui-Quadrado da célula & 105,40 & 103,73 & 36,36 & 8,60 & \\
\hline Total & Frequência & 1.438 & 2.826 & 443 & 74 & 4.781 \\
\hline
\end{tabular}

Tabela 15 F.5 Tabela de frequências da variável Porcentagem Antiplástico com o valor quiquadrado.

\begin{tabular}{|c|c|c|c|c|c|c|}
\hline & & $5,0 \%$ & $10,0 \%$ & $20,0 \%$ & $30,0 \%$ & Total \\
\hline \multirow{3}{*}{$\begin{array}{c}\text { Associação } \\
\text { Calderita }\end{array}$} & Frequência & 41,00 & 362,00 & 258,00 & 39,00 & 700 \\
\hline & Esperado & 81,99 & 234,70 & 217,72 & 165,59 & \\
\hline & Qui-Quadrado da célula & 20,49 & 69,05 & 7,45 & 96,78 & \\
\hline \multirow{3}{*}{ Itapirema } & Frequência & 88,00 & 498,00 & 643,00 & 855,00 & 2.084 \\
\hline & Esperado & 244,10 & 698,73 & 648,17 & 492,99 & \\
\hline & Qui-Quadrado da célula & 99,82 & 57,67 & 0,04 & 265,82 & \\
\hline \multirow{3}{*}{ Jacarezinho } & Frequência & 320,00 & 370,00 & 180,00 & 53,00 & 923 \\
\hline & Esperado & 108,11 & 309,47 & 287,07 & 218,35 & \\
\hline & Qui-Quadrado da célula & 415,28 & 11,84 & 39,94 & 125,21 & \\
\hline \multirow{3}{*}{ Nova Vida } & Frequência & 27,00 & 19,00 & 11,00 & 11,00 & 68 \\
\hline & Esperado & 7,96 & 22,80 & 21,15 & 16,09 & \\
\hline & Qui-Quadrado da célula & 45,49 & 0,63 & 4,87 & 1,61 & \\
\hline \multirow{3}{*}{ Teotonio } & Frequência & 84느므. & 354,00 & 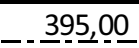 & 173으. & 1.․ㅡㅁㅡ \\
\hline & Esperado & 117,83 & 337,30 & 312,89 & 237,98 & \\
\hline & Qui-Quadrado da célula & $9, \overline{7}$ & 0,83 & 21,55 & $17, \overline{74}$ & \\
\hline Total & Frequência & 560 & 1.603 & 1.487 & 1.131 & 4.781 \\
\hline
\end{tabular}


Tabela 15 F.6 Tabela de frequências da variável Morfologia da Borda com o valor quiquadrado.

\begin{tabular}{|c|c|c|c|c|c|c|c|}
\hline & & Direta & $\begin{array}{c}\text { Extrovertida } \\
\text { com } \\
\text { Ondulação }\end{array}$ & $\begin{array}{c}\text { Extrovertida } \\
\text { com Ponto } \\
\text { Angular } \\
\end{array}$ & Extrovertida & Introvertida & Total \\
\hline & Frequência & 94,00 & - & 5,00 & 29,00 & 5,00 & 133 \\
\hline Associaçao & Esperado & 85,39 & $\overline{1}, \overline{39}$ & 11,23 & 31,51 & $3, \overline{48}$ & \\
\hline & Qui-Quadrado da célula & $0, \overline{8} \overline{7}$ & 1,39 & $3,4 \overline{6}$ & 0,20 & $0, \overline{66}$ & \\
\hline & Frequência & 220,00 & 13,00 & 93,00 & 173,00 & 7,00 & 506 \\
\hline Itapirema & Esperado & 324,85 & 5,29 & 42,73 & 119,88 & 13,24 & \\
\hline & Qui-Quadrado da célula & 33,84 & 11,22 & 59,13 & 23,54 & $2, \overline{94}$ & \\
\hline & Frequência & 265,00 & - & - & 23,00 & 19,00 & 307 \\
\hline Jacarezinho & Esperado & 197,09 & 3,21 & 25,93 & 72,74 & 8,03 & \\
\hline & Qui-Quadrado da célula & 23,40 & 3,21 & 25,93 & 34,01 & 14,98 & \\
\hline & Frequência & 13,00 & - & - & 6,00 & - & 19 \\
\hline Nova Vida & Esperado & 12,20 & 0,20 & 1,60 & 4,50 & 0,50 & \\
\hline & Qui-Quadrado da célula & 0,05 & 0,20 & 1,60 & 0,50 & 0,50 & \\
\hline & Frequência & 267,00 & 1,00 & 15,00 & 86,00 & 4,00 & 373 \\
\hline Teotonio & Esperado & 239,47 & 3,90 & 31,50 & 88,37 & 9,76 & \\
\hline & Qui-Quadrado da célula & 3,17 & 2,16 & 8,64 & 0,06 & 3,40 & \\
\hline Total & Frequência & 859 & 14 & 113 & 317 & 35 & 1.338 \\
\hline
\end{tabular}

Tabela 15 F.7 Tabela de frequências da variável Espessura da Borda com o valor quiquadrado.

\begin{tabular}{|c|c|c|c|c|c|c|c|c|c|}
\hline & Acanalada & Contraída & Dobrada & Expandida & Normal & \begin{tabular}{|c|} 
Reforçada \\
Externa
\end{tabular} & $\begin{array}{c}\text { Reforçada } \\
\text { Interna }\end{array}$ & Reforçada & Total \\
\hline Frequência & 9,00 & 14,00 & 1,00 & 5,00 & 89,00 & 7,00 & 5,00 & 3,00 & 133 \\
\hline Esperado & 1,17 & 8,06 & 0,10 & 2,14 & 97,27 & 15,92 & 5,15 & 3,20 & \\
\hline Qui-Quadrado da célula & 52,70 & 4,38 & 8,40 & 3,84 & 0,70 & 5,00 & 0,00 & 0,01 & \\
\hline Frequência & 3,00 & 26,00 & - & 12,00 & 307,00 & 120,00 & 32,00 & 23,00 & 523 \\
\hline Esperado & 4,58 & 31,69 & 0,38 & 8,40 & 382,52 & 62,61 & 20,23 & 12,60 & \\
\hline Qui-Quadrado da célula & 0,55 & 1,02 & 0,38 & 1,54 & 14,91 & 52,61 & 6,84 & 8,59 & \\
\hline Frequência & - & 24,00 & - & 1,00 & 276,00 & 3,00 & 6,00 & 1,00 & 311 \\
\hline Esperado & 2,72 & 18,84 & 0,23 & 4,99 & 227,46 & 37,23 & 12,03 & 7,49 & \\
\hline Qui-Quadrado da célula & 2,72 & 1,41 & 0,23 & 3,19 & 10,36 & 31,47 & 3,02 & 5,62 & \\
\hline Frequência & - & 2,00 & - & - & 18,00 & 1,00 & 1,00 & - & 22 \\
\hline Esperado & 0,19 & 1,33 & 0,02 & 0,35 & 16,09 & 2,63 & 0,85 & 0,53 & \\
\hline Qui-Quadrado da célula & 0,19 & 0,33 & 0,02 & 0,35 & 0,23 & 1,01 & 0,03 & 0,53 & \\
\hline Frequência & - & 17,00 & - & 4,00 & 312,00 & 33,00 & 9,00 & 6,00 & 381 \\
\hline Esperado & 3,34 & 23,08 & 0,28 & 6,12 & 278,66 & 45,61 & 14,74 & 9,18 & \\
\hline Qui-Quadrado da célula & 3,34 & 1,60 & 0,28 & 0,73 & 3,99 & 3,49 & 2,23 & 1,10 & \\
\hline Frequência & 12 & 83 & 1 & 22 & 1.002 & 164 & 53 & 33 & 1.370 \\
\hline
\end{tabular}


Tabela 15 F.8 Tabela de frequências da variável Decoração Pintada com o valor quiquadrado.

\begin{tabular}{|c|c|c|c|c|c|c|c|}
\hline & & NT & Branca & Outras & Preta & Vermelh & Total \\
\hline \multirow{3}{*}{$\begin{array}{c}\text { Associação } \\
\text { Calderita }\end{array}$} & Frequência & 689,00 & 4,00 & 2,00 & - & $\underline{9,00}$ & \multirow{3}{*}{$\begin{array}{l}704 \\
---\frac{7}{-}-\ldots-\end{array}$} \\
\hline & Esperado & 656,81 & 2,35 & 5,88 & 0,15 & 38,81 & \\
\hline & Qui-Quadrado da célula & 1,58 & 1,15 & 2,56 & 0,15 & 22,90 & \\
\hline \multirow{3}{*}{ Itapirema } & Frequência & $1.874,00$ & 8,00 & 22,00 & - & 183,00 & \multirow{3}{*}{$\begin{array}{r}2.087 \\
-------\end{array}$} \\
\hline & Esperado & $1.947,10$ & $\overline{6}, \overline{97}$ & 17,43 & 0,44 & $11 \overline{5}, 0 \overline{5}$ & \\
\hline & Qui-Quadrado da célula & 2,75 & 0,15 & 1,20 & 0,44 & 40,13 & \\
\hline \multirow{3}{*}{ Jacarezinho } & Frequência & 923,00 & - & - & - & - & \multirow{3}{*}{$\begin{array}{l}---\frac{923}{-} \\
------\end{array}$} \\
\hline & Esperado & 861,13 & 3,08 & 7,71 & 0,19 & 50,88 & \\
\hline & Qui-Quadrado da célula & 4,44 & 3,08 & 7,71 & 0,19 & 50,88 & \\
\hline \multirow{3}{*}{ Nova Vida } & Frequência & 68,00 & - & - & - & - & \multirow{3}{*}{$\begin{array}{c}68 \\
-------\end{array}$} \\
\hline & Esperado & 63,44 & 0,23 & 0,57 & 0,01 & $3,7 \overline{5}$ & \\
\hline & Qui-Quadrado da célula & 0,33 & 0,23 & 0,57 & 0,01 & $3,7 \overline{5}$ & \\
\hline \multirow{3}{*}{ Teotonio } & Frequência & 914,00 & 4,00 & 16,00 & 1,00 & 72,00 & \multirow{3}{*}{$\begin{array}{r}1.007 \\
------- \\
\end{array}$} \\
\hline & Esperado & 939,50 & 3,36 & 8,41 & 0,21 & 55,51 & \\
\hline & Qui-Quadrado da célula & 0,69 & 0,12 & 6,85 & 2,97 & 4,90 & \\
\hline Total & Frequência & 4.468 & 16 & 40 & 1 & 264 & 4.789 \\
\hline
\end{tabular}

Tabela 15 F.9 Tabela de frequências da variável Decoração Plástica com o valor quiquadrado.

\begin{tabular}{|c|c|c|c|c|c|c|c|c|c|c|}
\hline & & NT & Corrugado & Digitado & Entalhado & \begin{tabular}{|c||}
$\begin{array}{c}\text { Filete } \\
\text { Aplicado }\end{array}$ \\
\end{tabular} & $\begin{array}{c}\text { Inciso } \\
\text { Fino }\end{array}$ & $\begin{array}{l}\text { Inciso } \\
\text { Largo }\end{array}$ & Ponteado & Total \\
\hline \multirow{3}{*}{$\begin{array}{c}\text { Associação } \\
\text { Calderita }\end{array}$} & Frequência & 700,00 & & & & & 4,00 & & & 704 \\
\hline & Esperado- & 670,63 & $\underline{0}, \underline{29}$ & 0,15 & $0, \overline{5} 9$ & $\underline{0}, 15$ & 21,76 & 10,29 & 0,15 & \\
\hline & Qui-Quadrado da célula & 1,29 & 0,29 & 0,15 & 0,59 & 0,15 & 14,49 & 10,29 & 0,15 & \\
\hline \multirow{3}{*}{ Itapirema } & Frequência & $1.944,00$ & & 1,00 & -1 & 1,00 & 99,00 & 42,00 & & 2.087 \\
\hline & Ésperádo & $1.988,10$ & $0,8 \overline{7}$ & 0,44 & {$[1,74$} & $\underline{0}, \underline{4} \underline{4}$ & 64,50 & 30,51 & 0,44 & \\
\hline & Qui-Quadradó da célúa & 0,98 & $0,8 \overline{7}$ & 0,73 & $1, \overline{7} 4$ & 0,73 & 18,46 & 4,33 & $0,4 \overline{4}$ & \\
\hline \multirow{3}{*}{ Jacarezinho } & Frequência & 919,00 & & 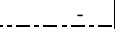 & $\therefore$ & $=$ & 4,00 & $-\ldots$ & - & 923 \\
\hline & Esperado & 879,25 & 0,39 & 0,19 & $0,7 \overline{7}$ & $\underline{0}, 1 \overline{9}$ & 28,53 & 13,49 & 0,19 & \\
\hline & Qui-Quadrado da célula & 1,80 & 0,39 & 0,19 & 0,77 & 0,19 & 21,09 & 13,49 & 0,19 & \\
\hline \multirow{3}{*}{ Nova Vida } & Frequência & 62,00 & & & 1,00 & -1 & 5,00 & & & 68 \\
\hline & Ésperado & 64,78 & $0,0 \overline{3}$ & 0,01 & 0,06 & $\overline{0}, \overline{0} \overline{1}$ & 2,10 & 0,99 & 0,01 & \\
\hline & Qui-Quadrado da célula & 0,12 & 0,03 & 0,01 & 15,66 & 0,01 & 4,00 & 0,99 & $0,0 \overline{1}$ & \\
\hline \multirow{3}{*}{ Teotonio } & Frequência & 937,00 & 2,00 & & 3,00 & $=$ & 36,00 & 28,00 & 1,00 & 1.007 \\
\hline & Esperado & 959,27 & $0,4 \underline{2}$ & 0,21 & 0,84 & $\underline{0}, 21$ & 31,12 & 14,72 & 0,21 & \\
\hline & Qui-Quadrado da célula & 0,52 & 5,93 & 0,21 & 5,54 & 0,21 & 0,77 & 11,98 & 2,97 & \\
\hline Total & Frequência & 4.562 & 2 & 1 & 4 & 1 & 148 & 70 & 1 & 4.789 \\
\hline
\end{tabular}

Tabela 15 F.10 Tabela de frequências da variável Tratamento de superfície FI com o valor qui-quadrado.

\begin{tabular}{|c|c|c|c|c|c|c|c|c|}
\hline & & NT & Brunidura & Eng Branco & $\begin{array}{r}\text { Eng Marrom } \\
\text { (Barbotina) }\end{array}$ & $\begin{array}{c}\text { Eng } \\
\text { Vermelho }\end{array}$ & $\begin{array}{c}\text { Esfumarado } \\
\text { (Resina) }\end{array}$ & Total \\
\hline \multirow{3}{*}{$\begin{array}{l}\text { Associação } \\
\text { Calderita }\end{array}$} & Frequência & 627,00 & - & 2,00 & 21,00 & 35,00 & 19,00 & 704 \\
\hline & Esperado & 573,02 & $0, \overline{44}$ & 10,14 & 57,04 & 20,88 & 42,48 & \\
\hline & Qui-Quadrado da célula & 5,09 & $0, \overline{4}$ & $-\frac{1}{6}, \overline{4}$ & $22, \overline{7} 7$ & 9,56 & $\overline{12}, \overline{9}$ & \\
\hline \multirow{3}{*}{ Itapirema } & Frequência & $1.589,00$ & 3,00 & 29,00 & 199,00 & 711,00 & 196,00 & 2.087 \\
\hline & Esperado & $1.698,70$ & $\overline{1}, \overline{3}$ & $30,0 \overline{7}$ & 169,09 & $\overline{6} 1, \overline{8} 8$ & $125, \overline{9} 4$ & \\
\hline & Qui-Quadrado da célula & 7,09 & 2,19 & 0,04 & 5,29 & 1,34 & $38, \overline{9}$ & \\
\hline \multirow{3}{*}{ Jacarezinho } & Frequência & 789,00 & - & 2,00 & 96,00 & 9,00 & 27,00 & 923 \\
\hline & Esperado & $-751,27$ & $\overline{0}, \overline{58}$ & 13,30 & $\overline{7} \overline{\overline{7}} \overline{\overline{8}}$ & $\overline{2} \overline{3} \overline{3} \overline{7}$ & $\overline{5}, \overline{70}$ & \\
\hline & Qui-Quadrado da célula & 1,89 & $0, \overline{58}$ & 9,60 & 6,02 & $12, \overline{3} 3$ & $14, \overline{79}$ & \\
\hline \multirow{3}{*}{ Nova Vida } & Frequência & 64,00 & - & - & 1,00 & 2,00 & 1,00 & 68 \\
\hline & Ésperado & $5 \overline{5}, \overline{3} 5]$ & 0,04 & $0, \overline{9}$ & $5, \overline{5} 1]$ & 2,02 & 4,10 & \\
\hline & Qui-Quadrado da célula & 1,35 & $0, \overline{04}$ & 0,98 & 3,69 & 0,00 & 2,35 & \\
\hline \multirow{3}{*}{ Teotonio } & Frequência & 829,00 & - & 36,00 & 71,00 & 25,00 & 46,00 & 1.007 \\
\hline & Esperado & 819,65 & $\overline{0}, \overline{63}$ & 14,51 & $81, \overline{5} 9$ & 29,86 & $60, \overline{7}$ & \\
\hline & Qui-Quadrado da célula & 0,11 & 0,63 & 31,83 & 1,37 & 0,79 & 3,59 & \\
\hline Total & Frequência & 3.898 & 3 & 69 & 388 & 142 & 289 & 4.789 \\
\hline
\end{tabular}


Tabela 15 F.11 Tabela de frequências da variável Tratamento de superfície FE com o valor qui-quadrado.

\begin{tabular}{|c|c|c|c|c|c|c|c|c|}
\hline & & NT & Brunidura & Eng Branco & $\mid \begin{array}{c}\text { Eng Marrom } \\
\text { (Barbotina) }\end{array}$ & $\begin{array}{c}\text { Eng } \\
\text { Vermelho }\end{array}$ & $\begin{array}{c}\text { Esfumarado } \\
\text { (Resina) }\end{array}$ & Total \\
\hline \multirow{3}{*}{$\begin{array}{c}\text { Associação } \\
\text { Calderita }\end{array}$} & Frequência & 286,00 & - & $-6,00$ & $\underline{57}, 00$ & $339 \underline{-0} 00$ & 16,00 & 704 \\
\hline & Esperado & 412,34 & $\underline{0}, \overline{4}$. & 63,51 & 65,56 & 126,86 & 35,28 & \\
\hline & Qui-Quadrado da célula & 38,71 & 0,44 & 52,07 & 1,12 & 354,72 & 10,54 & \\
\hline \multirow{3}{*}{ Itapirema } & Frequência & $1.044,00$ & 3,00 & 300,00 & 167,00 & 433,00 & 140,00 & 2.087 \\
\hline & Esperado & $1.222,40$ & 1,31 & 188,26 & 194,36 & 376,09 & 104,59 & \\
\hline & Qui-Quadrado da célula & 26,03 & 2,19 & 66,32 & 3,85 & 8,61 & 11,99 & \\
\hline \multirow{3}{*}{ Jacarezinho } & Frequência & 723,00 & - & 9,00 & 135,00 & 13,00 & 43,00 & 923 \\
\hline & Esperado & 540,62 & 0,58 & 83,26 & 85,96 & 166,33 & 46,26 & \\
\hline & Qui-Quadrado da célula & 61,53 & 0,58 & 66,23 & 27,98 & 141,34 & 0,23 & \\
\hline \multirow{3}{*}{ Nova Vida } & Frequência & 50,00 & - & - & 11,00 & 3,00 & 4,00 & 68 \\
\hline & Esperado & 39,83 & $\underline{0}, 04$ & 6,13 & 6,33 & 12,25 & 3,41 & \\
\hline & Qui-Quadrado da célula & 2,60 & 0,04 & 6,13 & 3,44 & 6,99 & 0,10 & \\
\hline \multirow{3}{*}{ Teotonio } & Frequência & 702,00 & - & 117,00 & 76,00 & 75,00 & 37,00 & 1.007 \\
\hline & Esperado & $589,-82$ & $\underline{0}, 63$. & 90,84 & 93,78 & 181,47 & 50,47 & \\
\hline & Qui-Quadrado da célula & 21,34 & 0,63 & 7,53 & 3,37 & 62,46 & 3,59 & \\
\hline Total & Frequência & 2.805 & 3 & 432 & 446 & 863 & 240 & 4.789 \\
\hline
\end{tabular}

Tabela 15 F.12 Tabela de frequências da variável Sinais de Uso com o valor qui-quadrado.

\begin{tabular}{|c|c|c|c|c|c|c|c|}
\hline & & Fuligem FE & Fuligem FI & $\begin{array}{l}\text { Película de } \\
\text { Alimento FI }\end{array}$ & Reciclagem & Outros & Total \\
\hline \multirow{3}{*}{$\begin{array}{c}\text { Associação } \\
\text { Calderita }\end{array}$} & Frequência & 283,00 & 17,00 & 2,00 & 1,00 & 22,00 & 325 \\
\hline & Esperado & 252,80 & 43,97 & 2,16 & 0,86 & 25,22 & \\
\hline & Qui-Quadrado da célula & 3,61 & 16,54 & 0,01 & 0,02 & 0,41 & \\
\hline \multirow{3}{*}{ Itapirema } & Frequência & 201,00 & 130,00 & 6,00 & 2,00 & 48,00 & 387 \\
\hline & Esperado & 301,03 & 52,35 & 2,57 & 1,03 & 30,03 & \\
\hline & Qui-Quadrado da célula & 33,24 & 115,16 & 4,59 & 0,92 & 10,76 & \\
\hline \multirow{3}{*}{ Jacarezinho } & Frequência & 392,00 & 34,00 & 1,00 & - & 26,00 & 453 \\
\hline & Esperado & 352,37 & 61,28 & 3,00 & 1,20 & 35,15 & \\
\hline & Qui-Quadrado da célula & 4,46 & 12,15 & 1,34 & 1,20 & 2,38 & \\
\hline \multirow{3}{*}{ Nova Vida } & Frequência & 22,00 & 5,00 & 1,00 & - & 1,00 & 29 \\
\hline & Esperado & 22,56 & 3,92 & 0,19 & 0,08 & 2,25 & \\
\hline & Qui-Quadrado da célula & 0,01 & 0,30 & 3,39 & 0,08 & 0,69 & \\
\hline \multirow{3}{*}{ Teotonio } & Frequência & 275,00 & 18,00 & - & 1,00 & 20,00 & 314 \\
\hline & Esperado & 244,25 & 42,48 & 2,08 & 0,83 & 24,36 & \\
\hline & Qui-Quadrado da célula & 3,87 & $14, \overline{11}$ & 2,08 & 0,03 & $0, \overline{78}$ & \\
\hline Total & Frequência & 1.173 & 204 & 10 & 4 & 117 & 1.508 \\
\hline
\end{tabular}


Tabela 15 F.13 Tabela de frequências da variável Forma com o valor qui-quadrado.

\begin{tabular}{|c|c|c|c|c|c|}
\hline 嵒 & $\begin{array}{ll}b ! \\
n ! \\
1\end{array}$ & 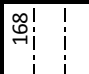 & \&! & $\mid$ & 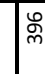 \\
\hline 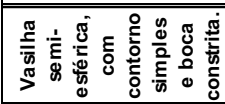 & ; & 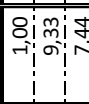 & 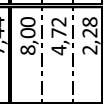 & 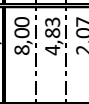 & is \\
\hline 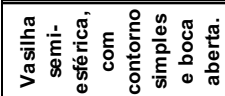 & 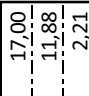 & 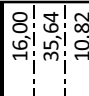 & : & 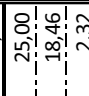 & \\
\hline 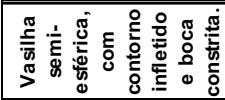 & 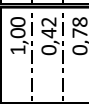 & 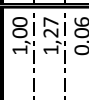 & 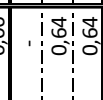 & 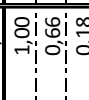 & \\
\hline 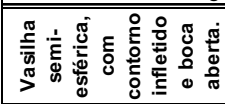 & 8: & 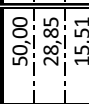 & 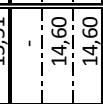 & 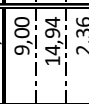 & 象赵 \\
\hline 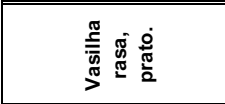 & 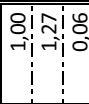 & 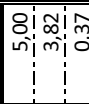 & 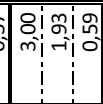 & 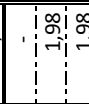 & \\
\hline 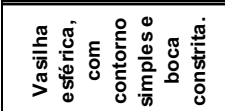 & 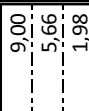 & 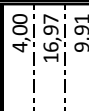 & 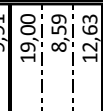 & 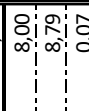 & :5 \\
\hline 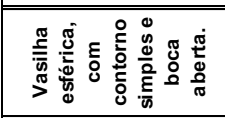 & & 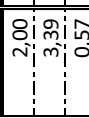 & 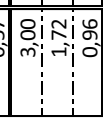 & 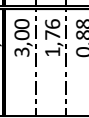 & 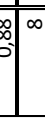 \\
\hline 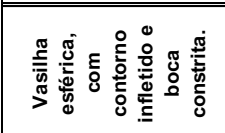 & & 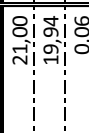 & silin & 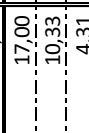 & $\frac{0}{0} 7$ \\
\hline 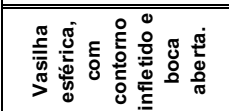 & 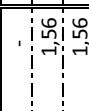 & \begin{tabular}{c:c}
0 & 0 \\
\hdashline & 0 \\
\hdashline$;$ & $\infty$ \\
\hdashline & 0
\end{tabular} & 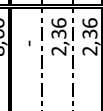 & 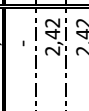 & 7 \\
\hline 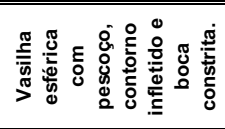 & & $\begin{array}{l}8 \\
0\end{array}$ & $\begin{array}{lll}0 \\
0\end{array}$ & (Din & 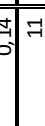 \\
\hline 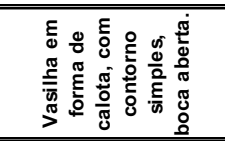 & 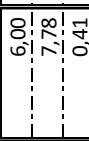 & 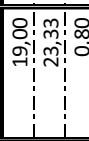 & (a) & 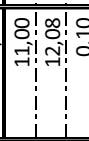 & 望 \\
\hline 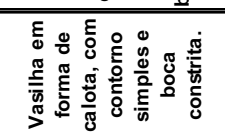 & 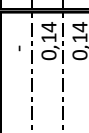 & 경웡 & 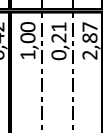 & 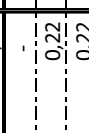 & : \\
\hline 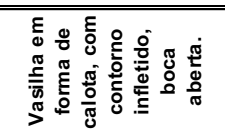 & 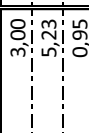 & 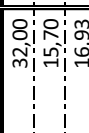 & $=2$ & 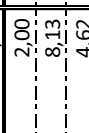 & ôn \\
\hline & 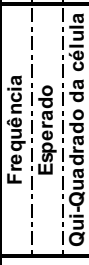 & 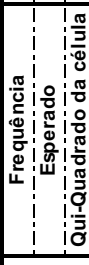 & 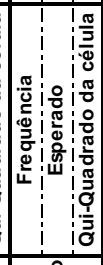 & 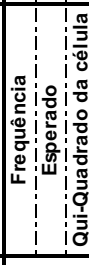 & \\
\hline & 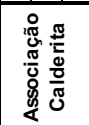 & 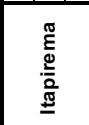 & 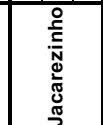 & $\begin{array}{l}\stackrel{\circ}{\bar{g}} \\
\stackrel{\circ}{\circ} \\
\leftarrow\end{array}$ & $\bar{g}$ \\
\hline
\end{tabular}


Anexo 15 G Gráficos da Análise de Correspondência

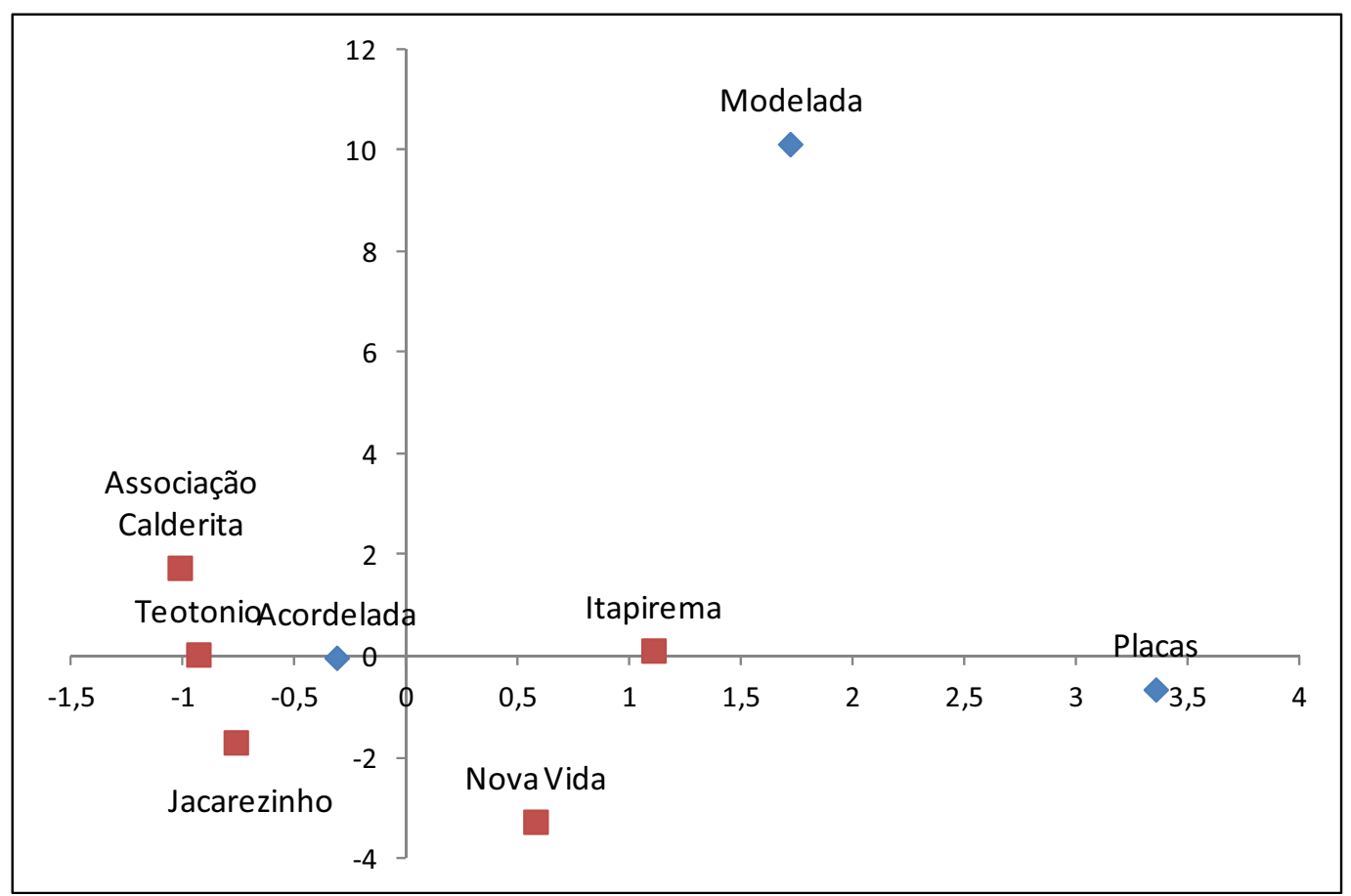

Gráfico 15 G.1 Análise de correspondência da variável Técnica de Manufatura e Sítio.

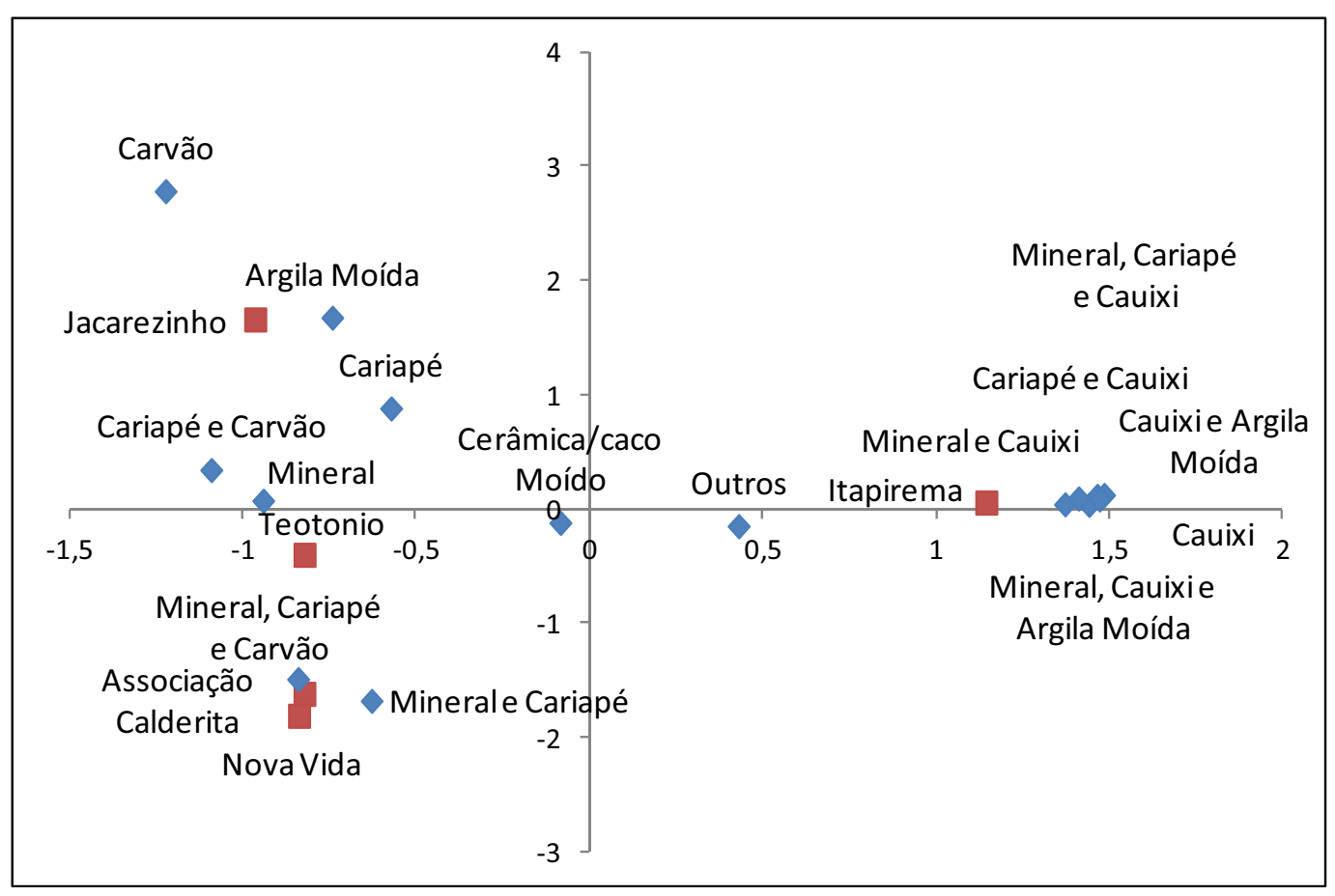

Gráfico 15 G.2 Análise de correspondência da variável Antiplástico e Sítio. 


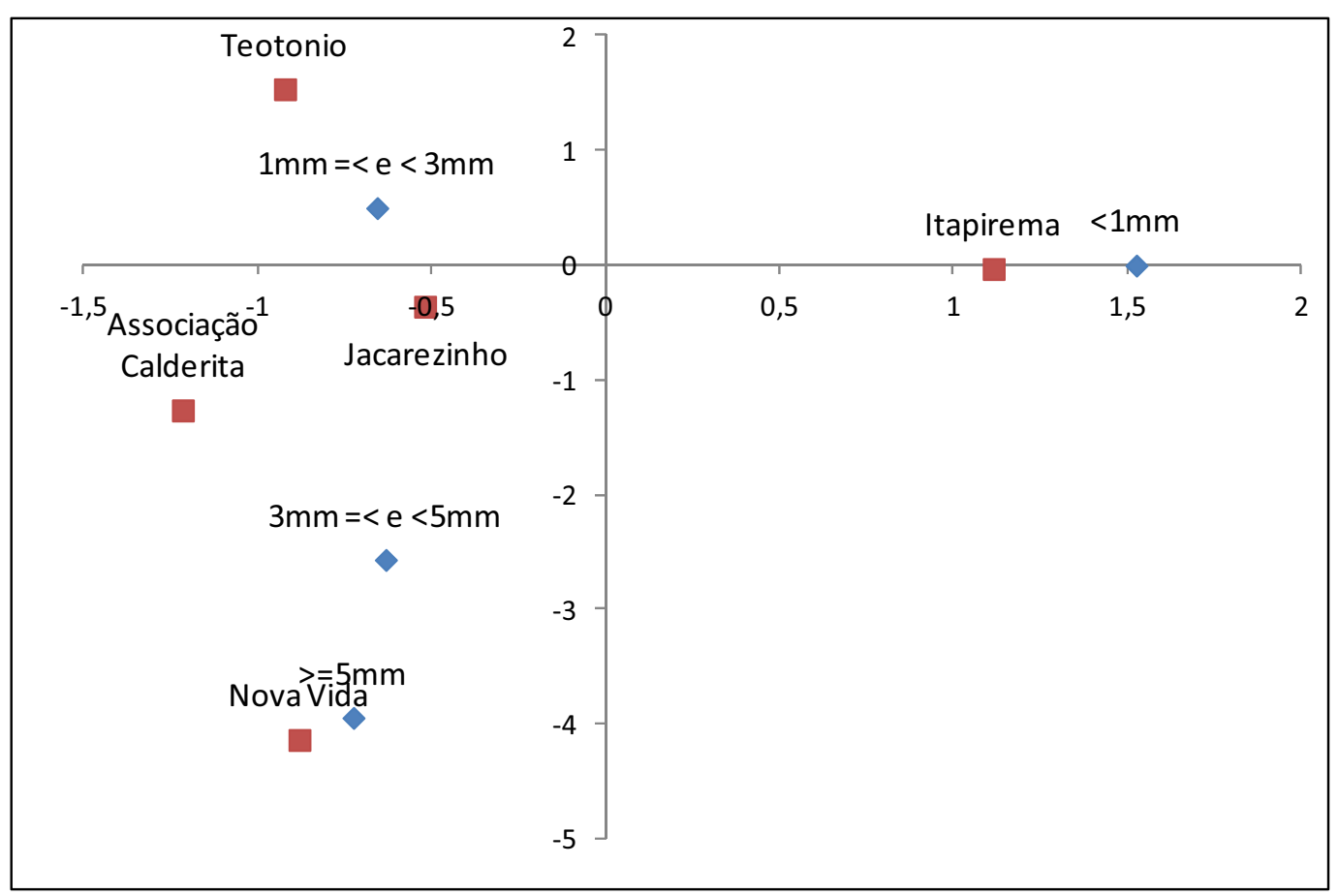

Gráfico 15 G.3 Análise de correspondência da variável Espessura do Antiplástico e Sítio.

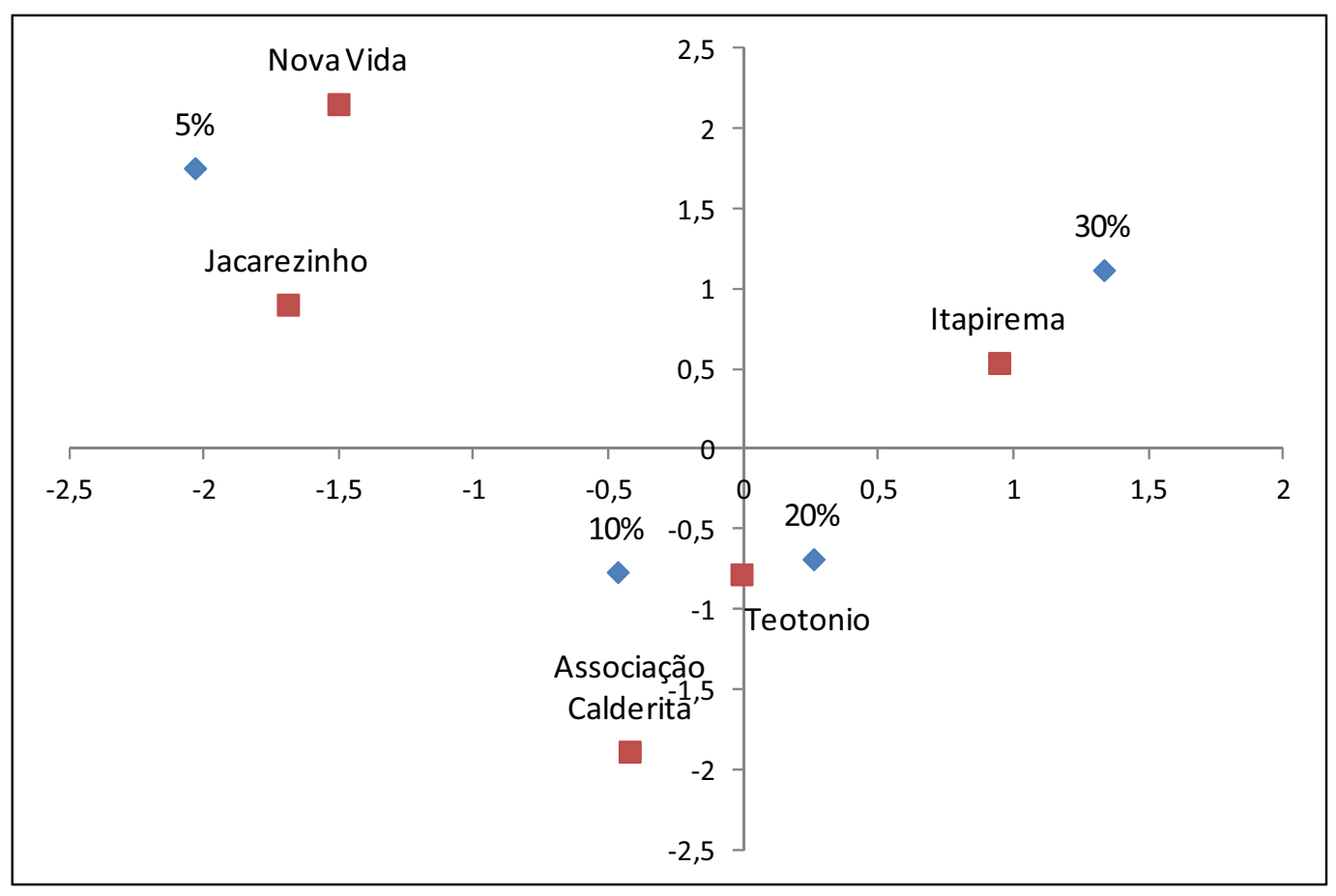

Gráfico 15 G.4 Análise de correspondência da variável Porcentagem da Antiplástico e Sítio. 


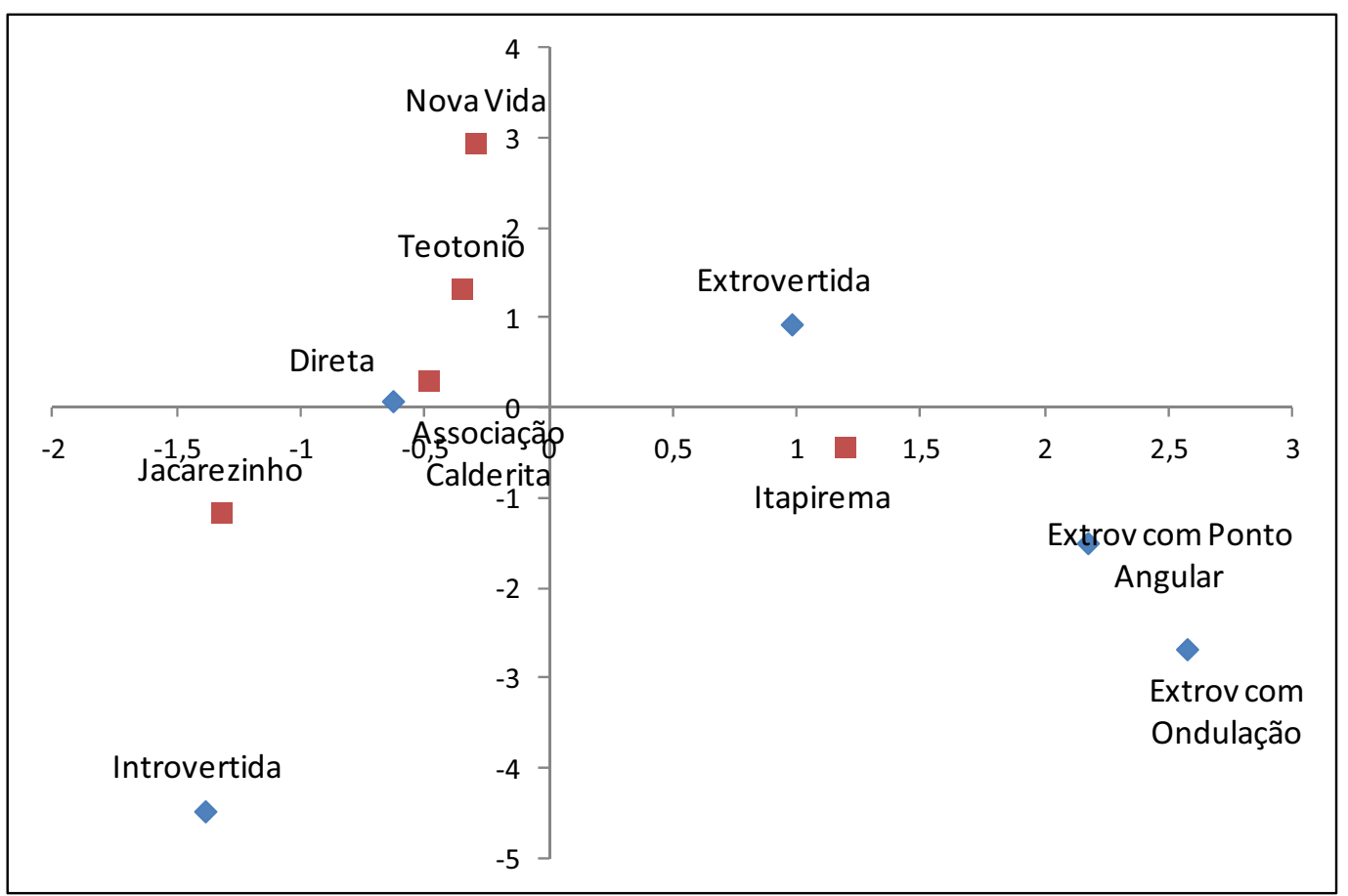

Gráfico 15 G.5 Análise de correspondência da variável Morfologia da Borda e Sítio.

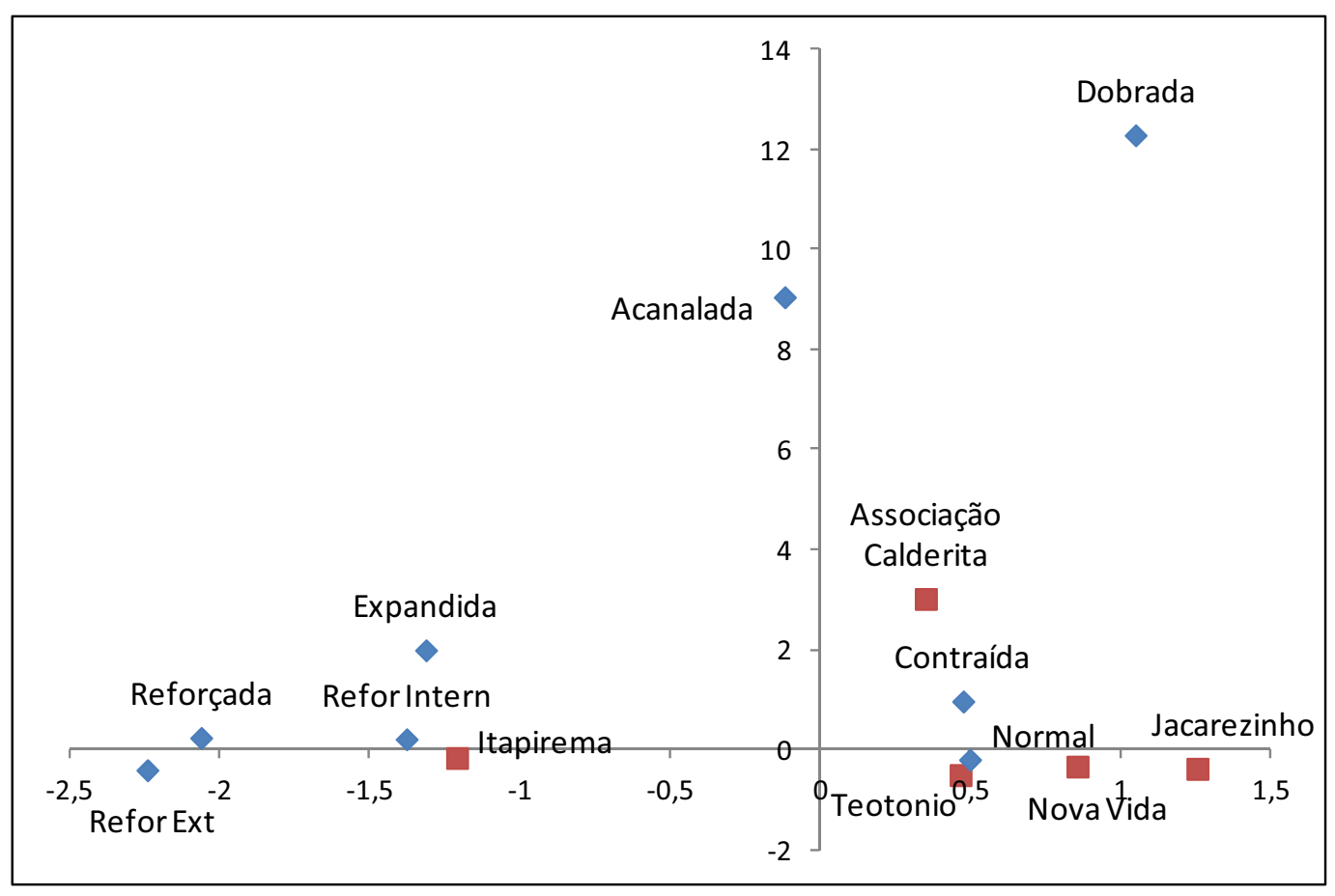

Gráfico 15 G.6 Análise de correspondência da variável Espessura da Borda e Sítio. 


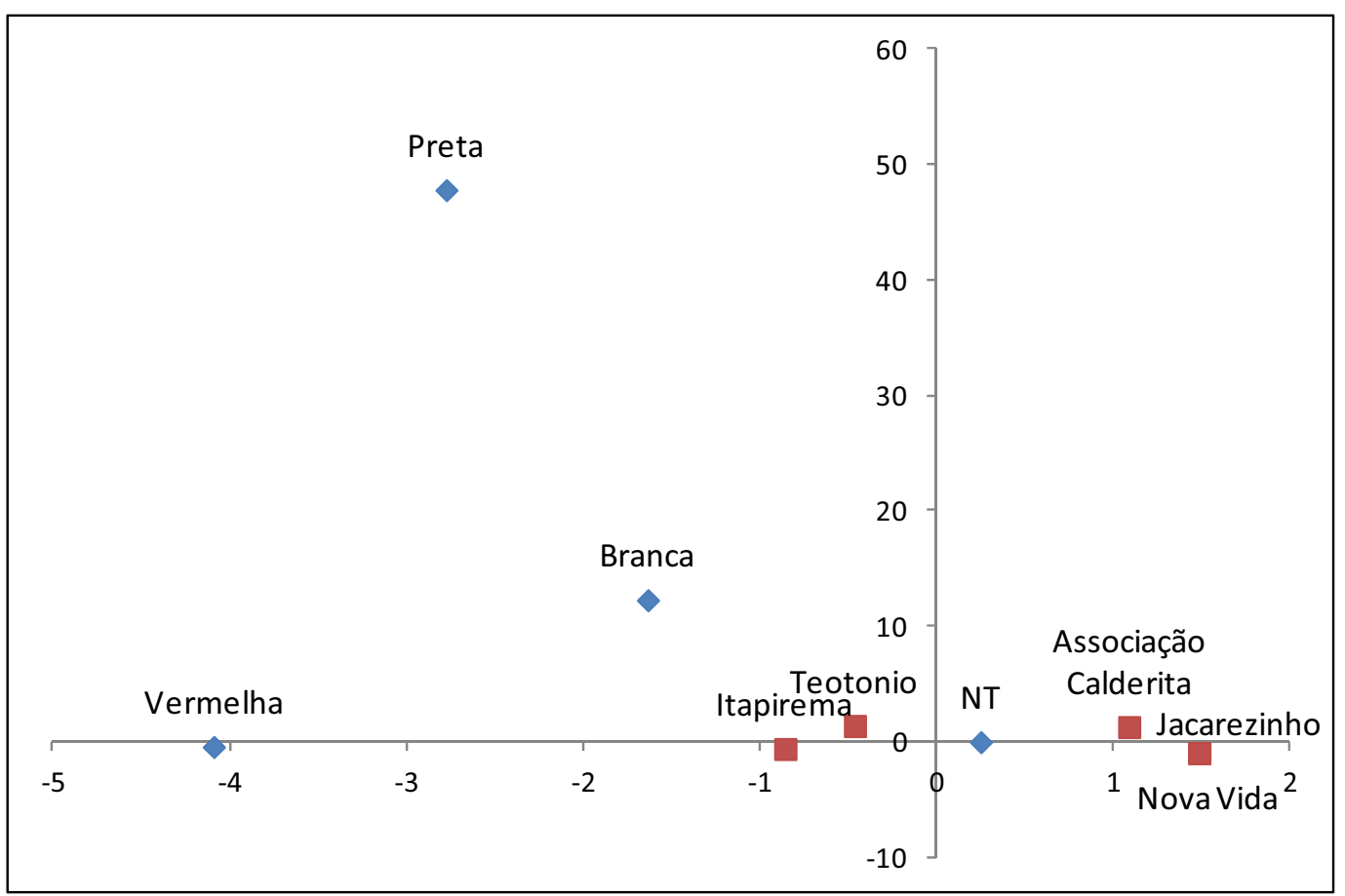

Gráfico 15 G.7 Análise de correspondência da variável Decoração Pintada e Sítio..

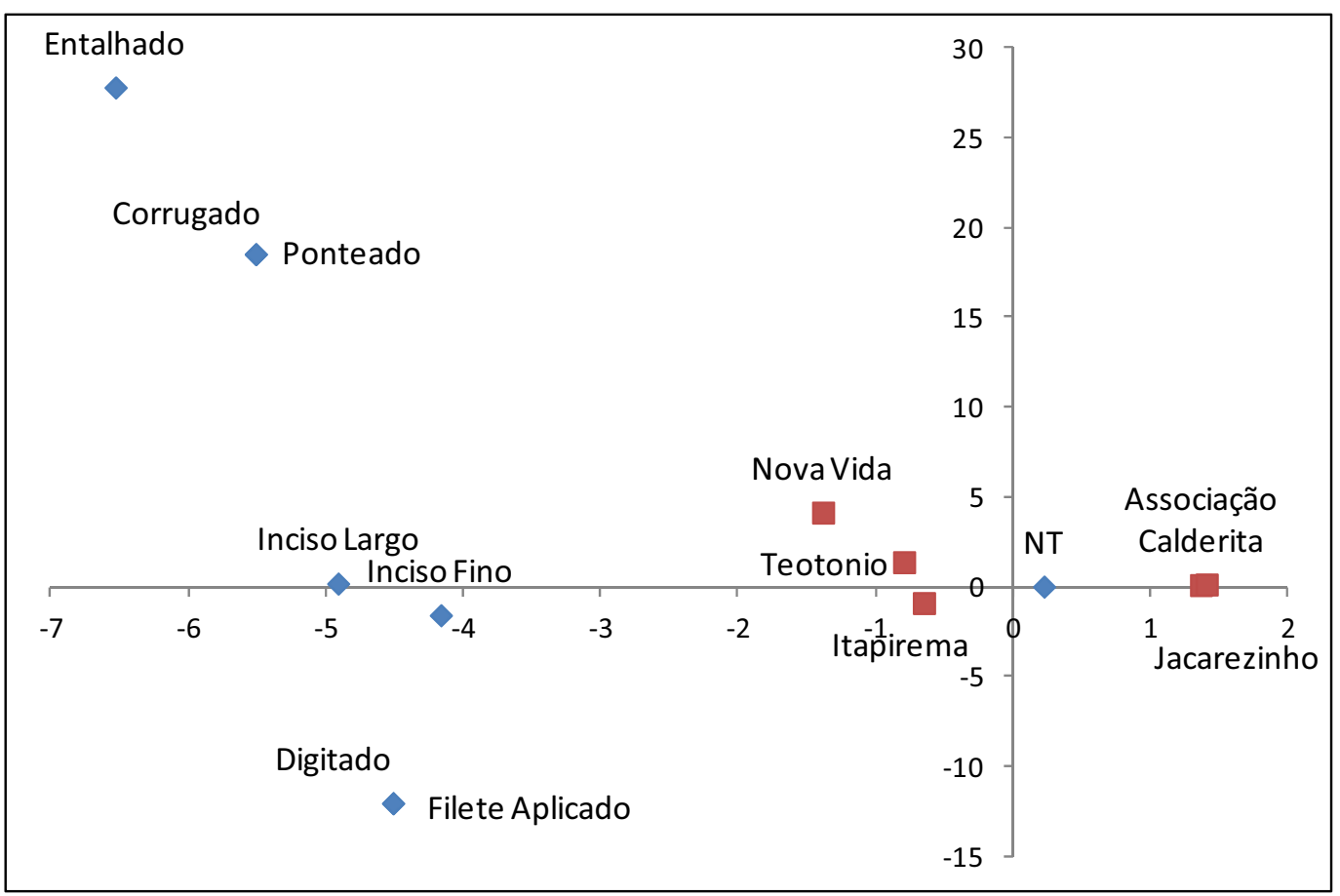

Gráfico 15 G.8 Análise de correspondência da variável Decoração Plástica e Sítio. 


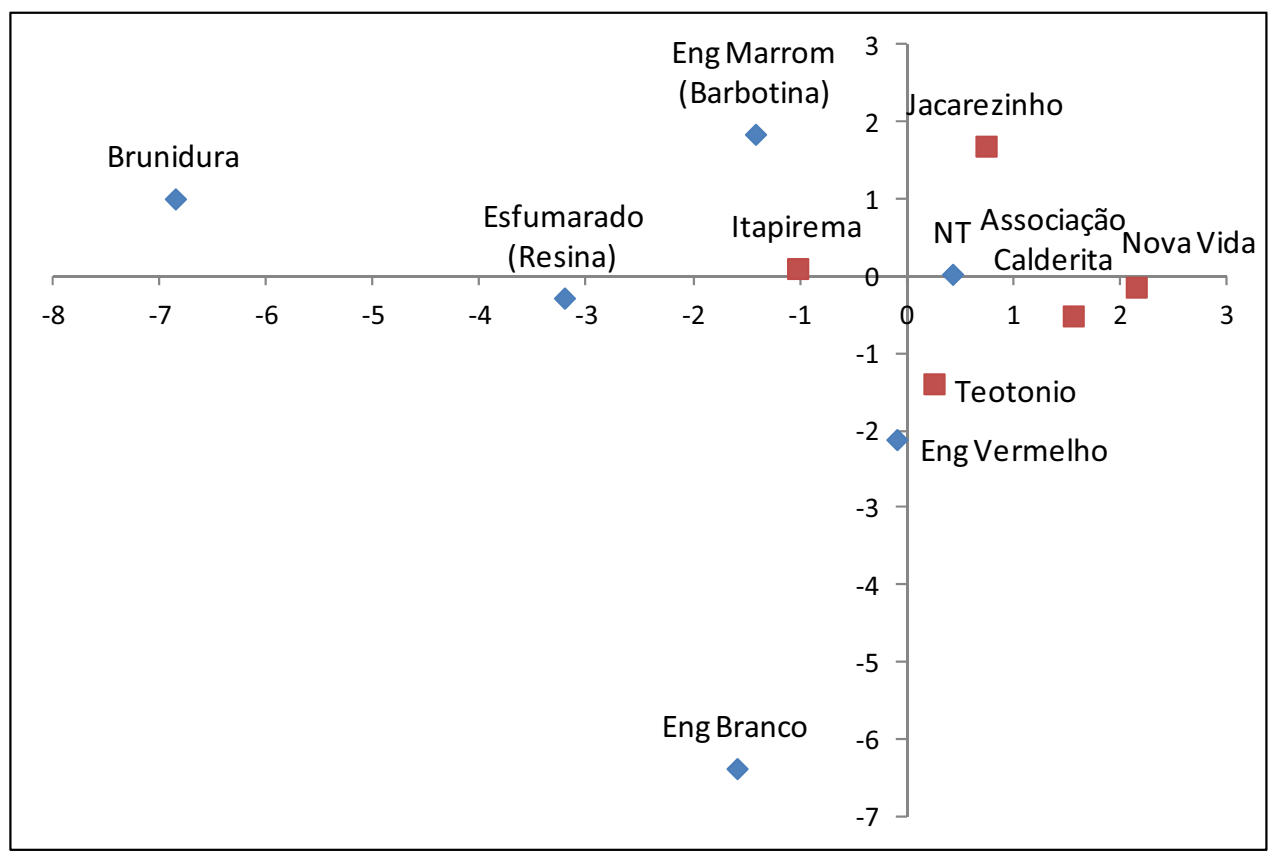

Gráfico 15 G.9.1 Análise de correspondência da variável Tratamento de Superfície FI e Sítio, dimensões 1 e 2.

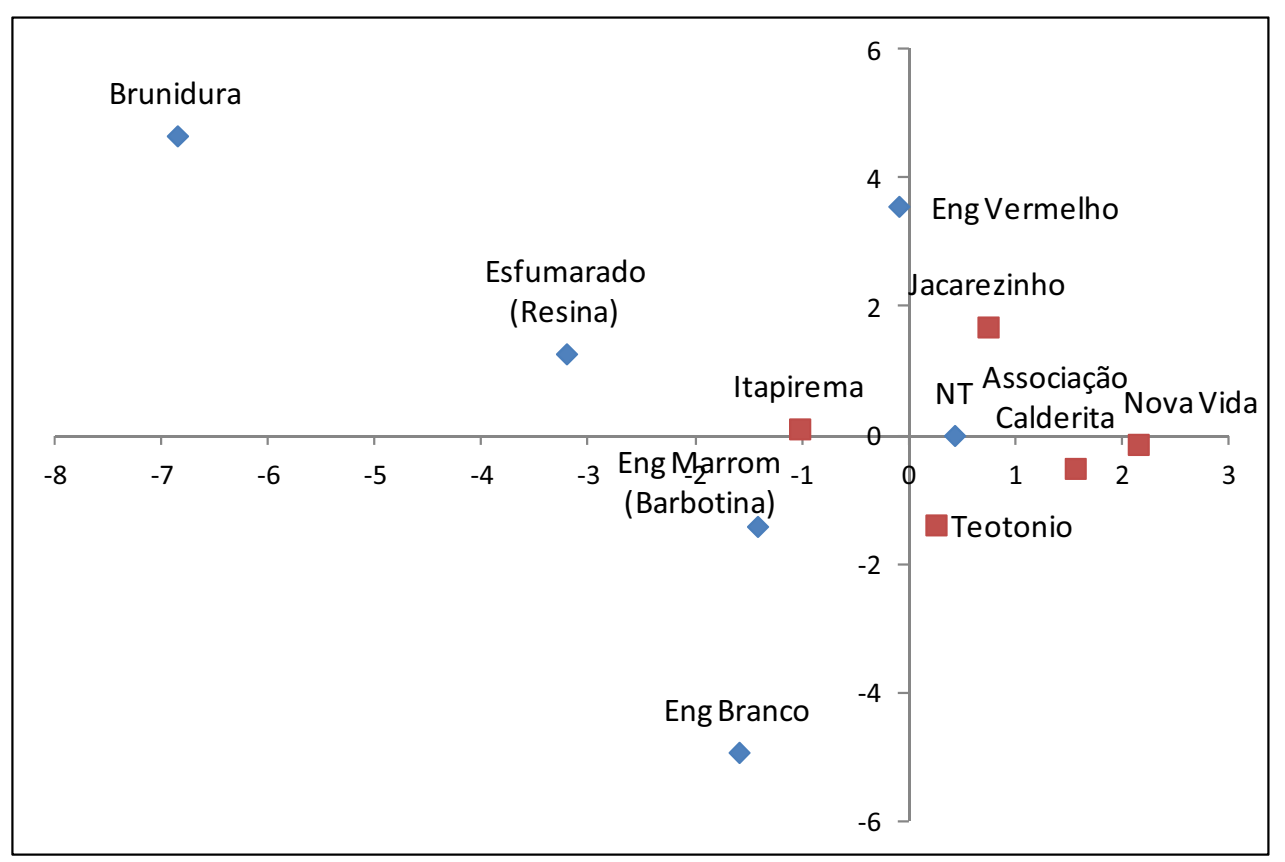

Gráfico 15 G.9.2 Análise de correspondência da variável Tratamento de Superfície FI e Sítio, dimensões 1 e 3 . 


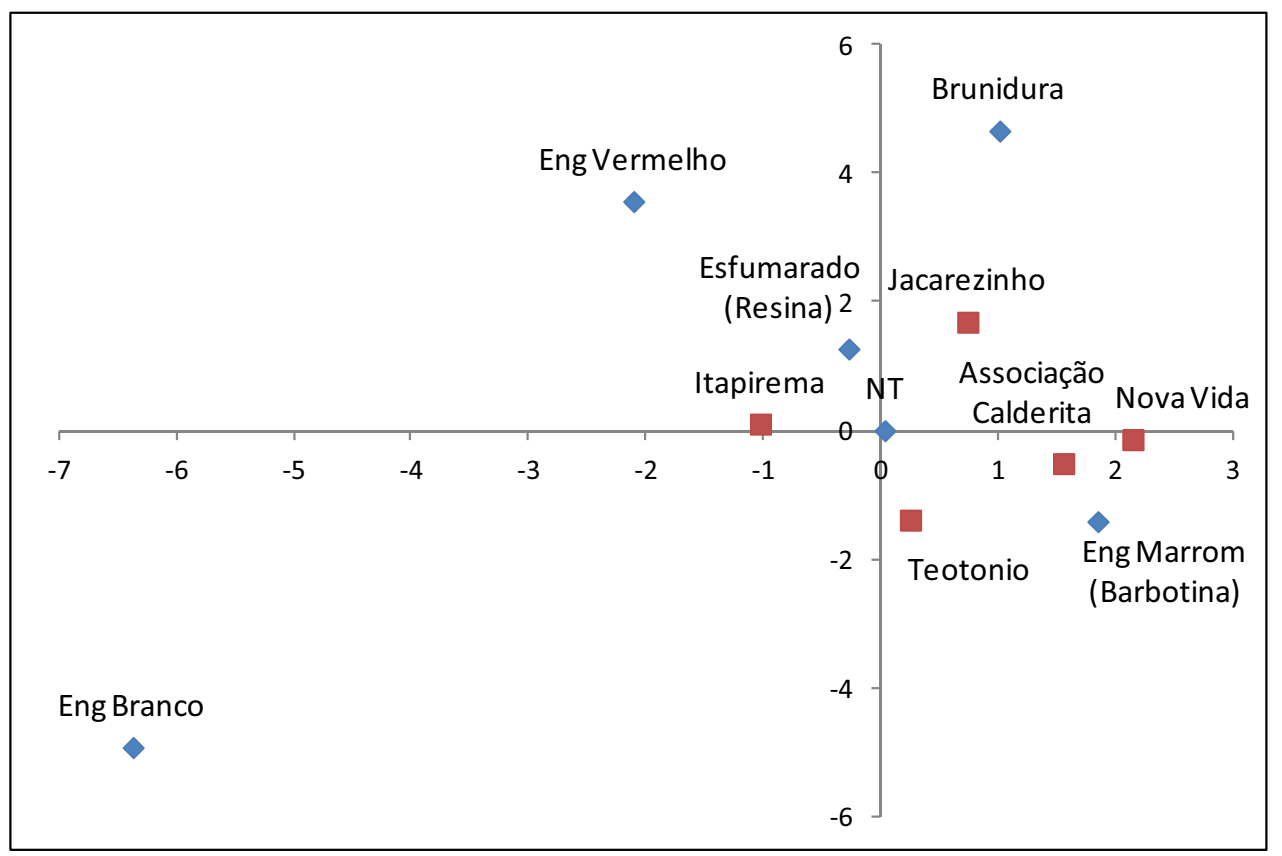

Gráfico 15 G.9.3 Análise de correspondência da variável Tratamento de Superfície FI e Sítio, dimensões 2 e 3 .

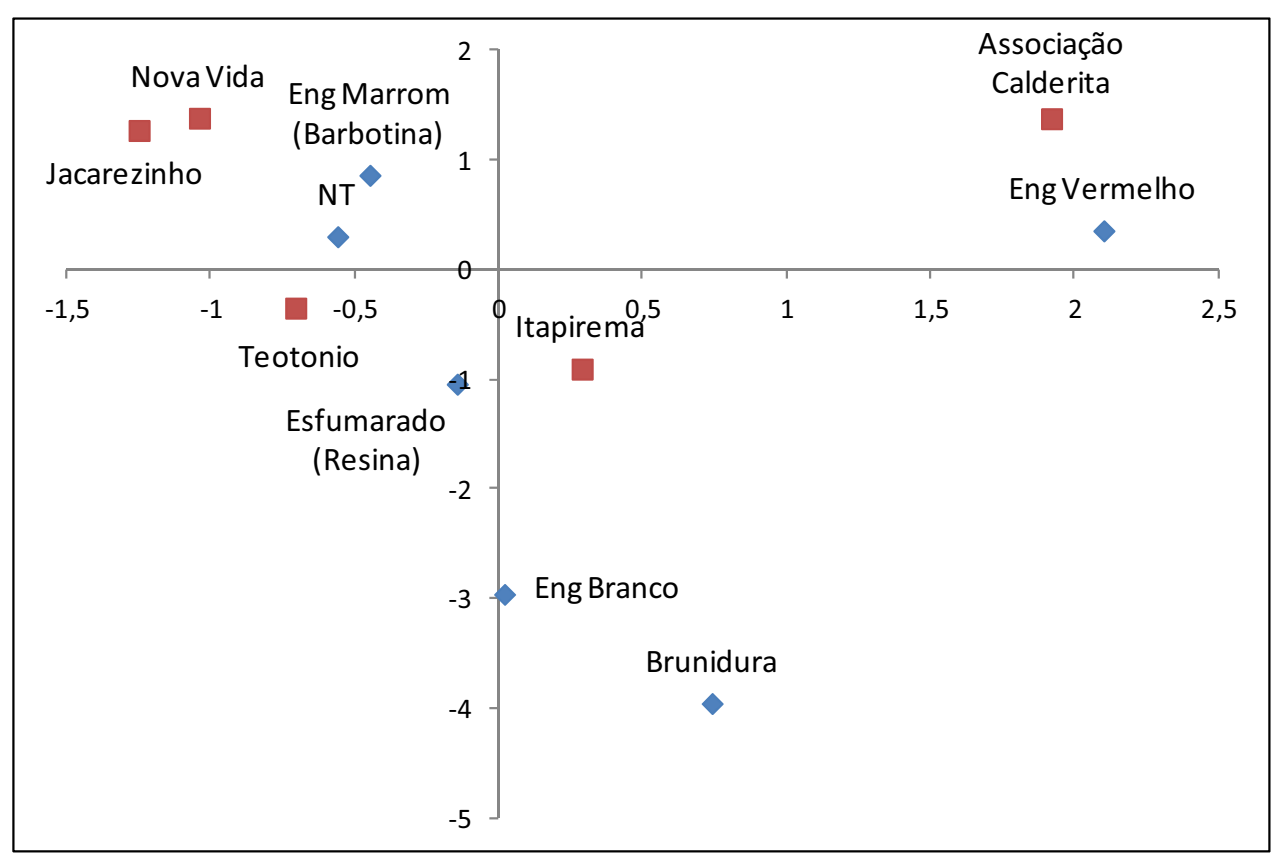

Gráfico 15 G.10 Análise de correspondência da variável Tratamento de Superfície FE e Sítio. 


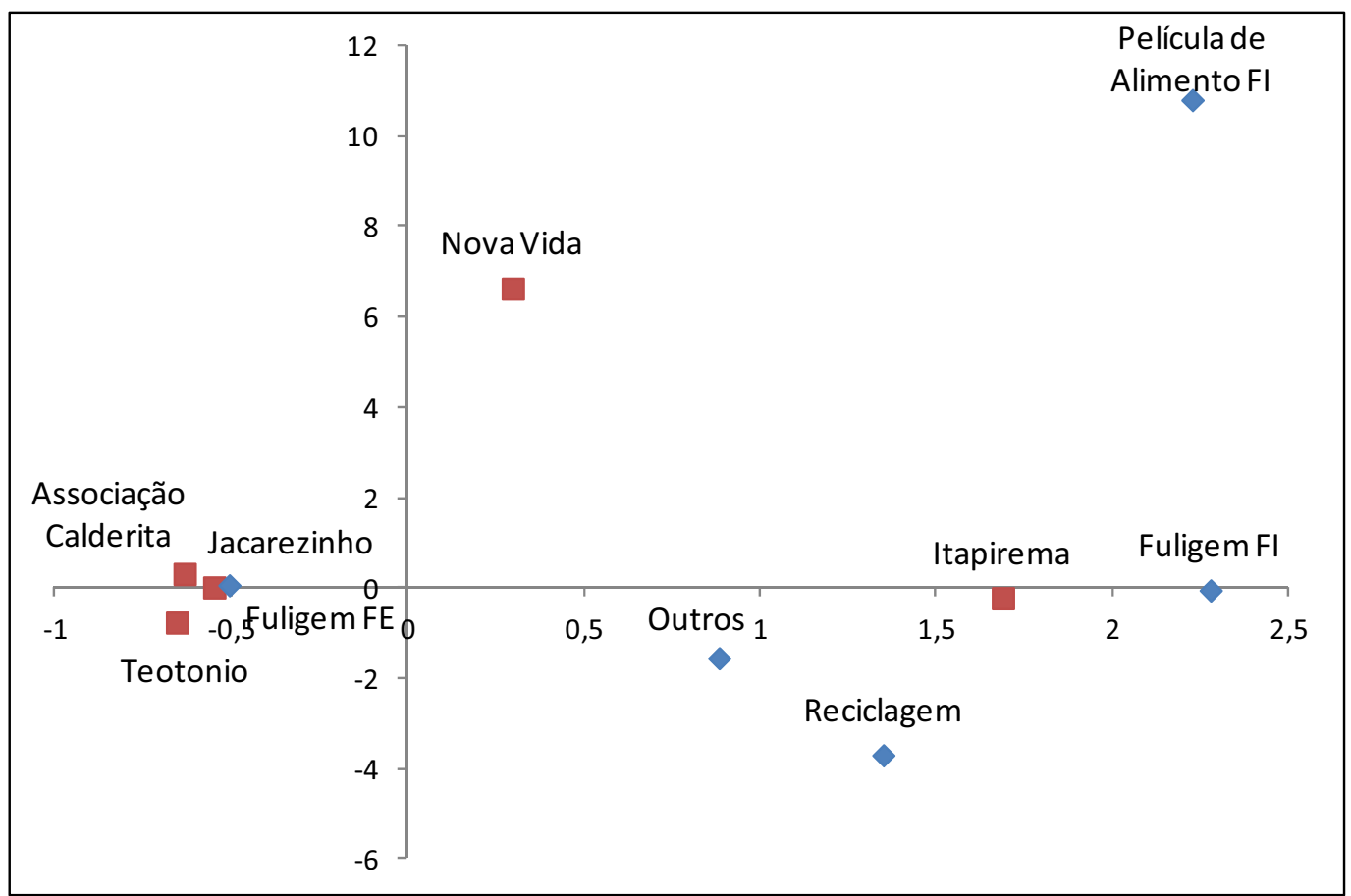

Gráfico 15 G.11 Análise de correspondência da variável Sinais de Uso e Sítio.

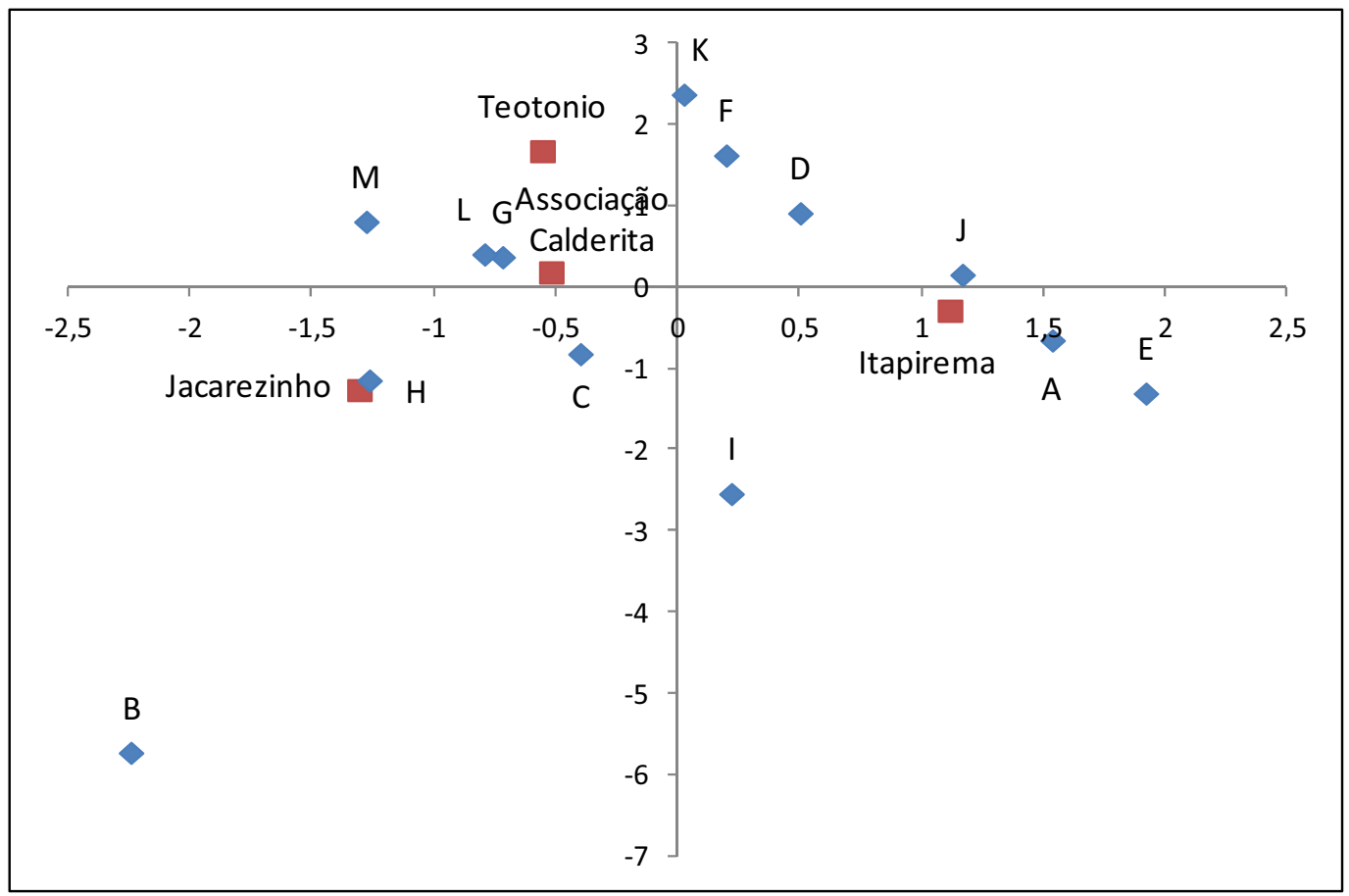

Gráfico 15 G.12 Análise de correspondência da variável Forma e Sítio. 
Anexo 15 H Resultados da Análise de Agrupamentos do sítio Itapirema

Tabela15 H.1 Tabela de frequências da variável Unidade Sondagem por grupo do sítio Itapirema.

\begin{tabular}{|l|rr|rr|rr|}
\hline & \multicolumn{2}{|c|}{ Grupo 1 } & \multicolumn{3}{|c|}{ Grupo 2 } & \multicolumn{2}{c|}{ Grupo 3 } \\
\hline N1000-E620 & 2 & $(2 \%)$ & 0 & $(0 \%)$ & 0 & $(0 \%)$ \\
\hline N1000-E820 & 1 & $(1 \%)$ & 1 & $(4 \%)$ & 0 & $(0 \%)$ \\
\hline N1034-E999 & 36 & $(32 \%)$ & 4 & $(17 \%)$ & 1 & $(5 \%)$ \\
\hline N1037-E1000 & 1 & $(1 \%)$ & 0 & $(0 \%)$ & 0 & $(0 \%)$ \\
\hline N1038-E996 & 10 & $(9 \%)$ & 4 & $(17 \%)$ & 1 & $(5 \%)$ \\
\hline N1038-E999 & 2 & $(2 \%)$ & 0 & $(0 \%)$ & 0 & $(0 \%)$ \\
\hline N1041-E995 & 1 & $(1 \%)$ & 0 & $(0 \%)$ & 0 & $(0 \%)$ \\
\hline N1042-E995 & 3 & $(3 \%)$ & 0 & $(0 \%)$ & 0 & $(0 \%)$ \\
\hline N1042-E996 & 2 & $(2 \%)$ & 0 & $(0 \%)$ & 0 & $(0 \%)$ \\
\hline N950-E590 & 1 & $(1 \%)$ & 0 & $(0 \%)$ & 0 & $(0 \%)$ \\
\hline N954-E583 & 23 & $(20 \%)$ & 5 & $(22 \%)$ & 7 & $(37 \%)$ \\
\hline N954-E588 & 18 & $(16 \%)$ & 1 & $(4 \%)$ & 5 & $(26 \%)$ \\
\hline N954-E589 & 13 & $(12 \%)$ & 7 & $(30 \%)$ & 4 & $(21 \%)$ \\
\hline N960-E540 & - & $(0 \%)$ & 1 & $(4 \%)$ & 0 & $(0 \%)$ \\
\hline N960-E580 & - & $(0 \%)$ & 0 & $(0 \%)$ & 1 & $(5 \%)$ \\
\hline Total & $\mathbf{1 1 3}$ & $(\mathbf{1 0 0} \%)$ & $\mathbf{2 3}$ & $\mathbf{( 1 0 0 \% )}$ & $\mathbf{1 9}$ & $\mathbf{( 1 0 0 \% )}$ \\
\hline
\end{tabular}

Tabela 15 H.2 Tabela de frequências da variável Região geográfica por grupo do sítio Itapirema.

\begin{tabular}{|l|cc|cc|cc|}
\hline & \multicolumn{2}{|c|}{ Grupo 1 } & \multicolumn{2}{c|}{ Grupo 2 } & \multicolumn{2}{c|}{ Grupo 3 } \\
\hline Região 1 & 55 & $(49 \%)$ & 8 & $(35 \%)$ & 2 & $(11 \%)$ \\
\hline Região 2 & 55 & $(49 \%)$ & 14 & $(61 \%)$ & 17 & $(89 \%)$ \\
\hline Região 3 & 3 & $(3 \%)$ & 1 & $(4 \%)$ & 0 & $(0 \%)$ \\
\hline Total & $\mathbf{1 1 3}$ & $\mathbf{( 1 0 0 \% )}$ & $\mathbf{2 3}$ & $\mathbf{( 1 0 0 \% )}$ & $\mathbf{1 9}$ & $\mathbf{( 1 0 0 \% )}$ \\
\hline
\end{tabular}

Tabela 15 H.3 Tabela de frequências da variável Nível por grupo do sítio Itapirema.

\begin{tabular}{|l|rc|rc|cc|}
\hline & \multicolumn{2}{|c|}{ Grupo 1 } & \multicolumn{2}{|c|}{ Grupo 2 } & \multicolumn{2}{c|}{ Grupo 3 } \\
\hline $\mathbf{0 - 2 0}$ & 31 & $(27 \%)$ & 8 & $(35 \%)$ & 4 & $(21 \%)$ \\
\hline $\mathbf{2 0 - 4 0}$ & 35 & $(31 \%)$ & 5 & $(22 \%)$ & 3 & $(16 \%)$ \\
\hline $\mathbf{4 0 - 6 0}$ & 23 & $(20 \%)$ & 5 & $(22 \%)$ & 4 & $(21 \%)$ \\
\hline $\mathbf{6 0 - 8 0}$ & 14 & $(12 \%)$ & 2 & $(9 \%)$ & 3 & $(16 \%)$ \\
\hline $\mathbf{8 0 - 1 0 0}$ & 8 & $(7 \%)$ & 3 & $(13 \%)$ & 5 & $(26 \%)$ \\
\hline $\mathbf{N I}$ & 2 & $(2 \%)$ & 0 & $(0 \%)$ & 0 & $(0 \%)$ \\
\hline Total & $\mathbf{1 1 3}$ & $\mathbf{( 1 0 0 \% )}$ & $\mathbf{2 3}$ & $\mathbf{( 1 0 0 \% )}$ & $\mathbf{1 9}$ & $\mathbf{( 1 0 0 \% )}$ \\
\hline
\end{tabular}


Tabela 15 H.4 Tabela de frequências de Morfologia da Borda por grupo do sítio Itapirema.

\begin{tabular}{|l|cc|cc|cc|}
\hline & \multicolumn{2}{|c|}{ Grupo 1 } & \multicolumn{3}{|c|}{ Grupo 2 } & \multicolumn{2}{c|}{ Grupo 3 } \\
\hline Direta & 43 & $(38 \%)$ & 2 & $(9 \%)$ & 4 & $(21 \%)$ \\
\hline $\begin{array}{l}\text { Extrovertida } \\
\text { com } \\
\text { Ondulação }\end{array}$ & 6 & $(5 \%)$ & 0 & $(0 \%)$ & 0 & $(0 \%)$ \\
\hline $\begin{array}{l}\text { Extrovertida } \\
\text { com Ponto } \\
\text { Angular }\end{array}$ & 32 & $(28 \%)$ & 7 & $(30 \%)$ & 4 & $(21 \%)$ \\
\hline Extrovertida & 31 & $(27 \%)$ & 13 & $(57 \%)$ & 11 & $(58 \%)$ \\
\hline Introvertida & 1 & $(1 \%)$ & 0 & $(0 \%)$ & 0 & $(0 \%)$ \\
\hline NI & - & $(0 \%)$ & 1 & $(4 \%)$ & 0 & $(0 \%)$ \\
\hline Total & $\mathbf{1 1 3}$ & $(\mathbf{1 0 0 \% )}$ & $\mathbf{2 3}$ & $\mathbf{( 1 0 0 \% )}$ & $\mathbf{1 9}$ & $\mathbf{( 1 0 0 \% )}$ \\
\hline
\end{tabular}

Tabela 15 H.5 Tabela de frequências de Antiplástico por grupo do sítio Itapirema.

\begin{tabular}{|l|rr|rr|rr|}
\hline & \multicolumn{2}{|c|}{ Grupo 1 } & \multicolumn{3}{|c|}{ Grupo 2 } & \multicolumn{2}{c|}{ Grupo 3 } \\
\hline Cariapé & 25 & $(22 \%)$ & 1 & $(4 \%)$ & 2 & $(11 \%)$ \\
\hline $\begin{array}{l}\text { Cariapé e } \\
\text { Carvão }\end{array}$ & 1 & $(1 \%)$ & 0 & $(0 \%)$ & 0 & $(0 \%)$ \\
\hline $\begin{array}{l}\text { Cariapé e } \\
\text { Cauixi }\end{array}$ & 4 & $(4 \%)$ & 3 & $(13 \%)$ & 1 & $(5 \%)$ \\
\hline Cauixi & 20 & $(18 \%)$ & 6 & $(26 \%)$ & 4 & $(21 \%)$ \\
\hline $\begin{array}{l}\text { Cauixi e Argila } \\
\text { Moída }\end{array}$ & 6 & $(5 \%)$ & 3 & $(13 \%)$ & 2 & $(11 \%)$ \\
\hline $\begin{array}{l}\text { Mineral e } \\
\text { Cariapé }\end{array}$ & 11 & $(10 \%)$ & 3 & $(13 \%)$ & 0 & $(0 \%)$ \\
\hline $\begin{array}{l}\text { Mineral e } \\
\text { Cauixi }\end{array}$ & 13 & $(12 \%)$ & 1 & $(4 \%)$ & 2 & $(11 \%)$ \\
\hline $\begin{array}{l}\text { Mineral, } \\
\text { Cariapé e } \\
\text { Cauixi }\end{array}$ & 9 & $(8 \%)$ & 2 & $(9 \%)$ & 3 & $(16 \%)$ \\
\hline $\begin{array}{l}\text { Mineral, Cauixi } \\
\text { e Argila Moída }\end{array}$ & 9 & $(8 \%)$ & 1 & $(4 \%)$ & 2 & $(11 \%)$ \\
\hline Outros & 10 & $(9 \%)$ & 2 & $(9 \%)$ & 3 & $(16 \%)$ \\
\hline NI & 5 & $(4 \%)$ & 1 & $(4 \%)$ & 0 & $(0 \%)$ \\
\hline Total & $\mathbf{1 1 3}$ & $(\mathbf{1 0 0 \% )}$ & $\mathbf{2 3}$ & $\mathbf{( 1 0 0 \% )}$ & 19 & $(\mathbf{1 0 0} \%)$ \\
\hline
\end{tabular}

Tabela 15 H.6 Tabela de frequências de Decoração Plástica por grupo do sítio Itapirema.

\begin{tabular}{|l|rc|cc|cc|}
\hline & \multicolumn{2}{|c|}{ Grupo 1 } & \multicolumn{2}{c|}{ Grupo 2 } & \multicolumn{2}{c|}{ Grupo 3 } \\
\hline Inciso Fino & 2 & $(2 \%)$ & 4 & $(17 \%)$ & 12 & $(63 \%)$ \\
\hline Inciso Largo & 1 & $(1 \%)$ & 3 & $(13 \%)$ & 1 & $(5 \%)$ \\
\hline NT & 110 & $(97 \%)$ & 16 & $(70 \%)$ & 6 & $(32 \%)$ \\
\hline Total & $\mathbf{1 1 3}$ & $\mathbf{( 1 0 0 \% )}$ & $\mathbf{2 3}$ & $\mathbf{( 1 0 0 \% )}$ & $\mathbf{1 9}$ & $\mathbf{( 1 0 0 \% )}$ \\
\hline
\end{tabular}


Tabela 15 H.7 Tabela de frequências da variável Decoração Pintada por grupo do sítio Itapirema.

\begin{tabular}{|l|rc|cc|cc|}
\hline & \multicolumn{2}{|c|}{ Grupo 1 } & \multicolumn{2}{c|}{ Grupo 2 } & \multicolumn{2}{c|}{ Grupo 3 } \\
\hline Branca & - & $(0 \%)$ & 1 & $(4 \%)$ & 0 & $(0 \%)$ \\
\hline Vermelha & 13 & $(12 \%)$ & 0 & $(0 \%)$ & 16 & $(84 \%)$ \\
\hline Outras & 2 & $(2 \%)$ & 0 & $(0 \%)$ & 0 & $(0 \%)$ \\
\hline NT & 98 & $(87 \%)$ & 22 & $(96 \%)$ & 3 & $(16 \%)$ \\
\hline Total & $\mathbf{1 1 3}$ & $\mathbf{( 1 0 0 \% )}$ & $\mathbf{2 3}$ & $\mathbf{( 1 0 0 \% )}$ & $\mathbf{1 9}$ & $\mathbf{( 1 0 0 \% )}$ \\
\hline
\end{tabular}

Tabela 15 H.8 Tabela de frequências da variável Tratamento de Superfície FI por grupo do sítio Itapirema.

\begin{tabular}{|l|rc|rc|cr|}
\hline & \multicolumn{2}{|c|}{ Grupo 1 } & \multicolumn{2}{|c|}{ Grupo 2 } & \multicolumn{2}{c|}{ Grupo 3 } \\
\hline $\begin{array}{l}\text { Engobo } \\
\text { Branco }\end{array}$ & 4 & $(4 \%)$ & 0 & $(0 \%)$ & 0 & $(0 \%)$ \\
\hline $\begin{array}{l}\text { Engobo } \\
\text { Marrom } \\
\text { (Barbotina) }\end{array}$ & 9 & $(8 \%)$ & 2 & $(9 \%)$ & 0 & $(0 \%)$ \\
\hline $\begin{array}{l}\text { Engobo } \\
\text { Vermelho }\end{array}$ & 3 & $(3 \%)$ & 2 & $(9 \%)$ & 0 & $(0 \%)$ \\
\hline $\begin{array}{l}\text { Esfumarado } \\
\text { Resina) }\end{array}$ & 6 & $(5 \%)$ & 1 & $(4 \%)$ & 3 & $(16 \%)$ \\
\hline NT & 91 & $(81 \%)$ & 18 & $(78 \%)$ & 16 & $(84 \%)$ \\
\hline Total & $\mathbf{1 1 3}$ & $\mathbf{( 1 0 0 \% )}$ & $\mathbf{2 3}$ & $\mathbf{( 1 0 0 \% )}$ & $\mathbf{1 9}$ & $\mathbf{( 1 0 0 \% )}$ \\
\hline
\end{tabular}

Tabela 15 H.9 Tabela de frequências da variável Tratamento de Superfície FE por grupo do sítio Itapirema.

\begin{tabular}{|l|rc|rc|cr|}
\hline & \multicolumn{2}{|c|}{ Grupo 1 } & \multicolumn{2}{|c|}{ Grupo 2 } & \multicolumn{2}{c|}{ Grupo 3 } \\
\hline $\begin{array}{l}\text { Engobo } \\
\text { Branco }\end{array}$ & 6 & $(5 \%)$ & 1 & $(4 \%)$ & 8 & $(42 \%)$ \\
\hline $\begin{array}{l}\text { Engobo } \\
\text { Marrom } \\
\text { (Barbotina) }\end{array}$ & 3 & $(3 \%)$ & 1 & $(4 \%)$ & 0 & $(0 \%)$ \\
\hline $\begin{array}{l}\text { Engobo } \\
\text { Vermelho }\end{array}$ & 15 & $(13 \%)$ & 13 & $(57 \%)$ & 2 & $(11 \%)$ \\
\hline $\begin{array}{l}\text { Esfumarado } \\
\text { Resina) }\end{array}$ & 3 & $(3 \%)$ & 0 & $(0 \%)$ & 0 & $(0 \%)$ \\
\hline NT & 86 & $(76 \%)$ & 8 & $(35 \%)$ & 9 & $(47 \%)$ \\
\hline Total & $\mathbf{1 1 3}$ & $\mathbf{( 1 0 0 \% )}$ & $\mathbf{2 3}$ & $\mathbf{( 1 0 0 \% )}$ & $\mathbf{1 9}$ & $\mathbf{( 1 0 0 \% )}$ \\
\hline
\end{tabular}


Tabela 15 H.10 Tabela de frequências da variável Forma por grupo do sítio Itapirema.

\begin{tabular}{|c|c|c|c|c|c|c|}
\hline \multirow{2}{*}{\begin{tabular}{|l|} 
\\
Vasilha em \\
forma de \\
calota, com \\
contorno \\
simples, boca \\
aberta.
\end{tabular}} & \multicolumn{2}{|c|}{ Grupo 1} & \multicolumn{2}{|c|}{ Grupo 2} & \multicolumn{2}{|c|}{ Grupo 3} \\
\hline & 17 & $(15 \%)$ & 0 & $(0 \%)$ & 2 & $(11 \%)$ \\
\hline $\begin{array}{l}\text { Vasilha } \\
\text { esférica com } \\
\text { pescoço, } \\
\text { contorno } \\
\text { infletido e boca } \\
\text { constrita. }\end{array}$ & 4 & $(4 \%)$ & 0 & $(0 \%)$ & 0 & $(0 \%)$ \\
\hline $\begin{array}{l}\text { Vasilha } \\
\text { esférica, com } \\
\text { contorno } \\
\text { infletido e boca } \\
\text { constrita. }\end{array}$ & 19 & $(17 \%)$ & 0 & $(0 \%)$ & 0 & $(0 \%)$ \\
\hline $\begin{array}{l}\text { Vasilha } \\
\text { esférica, com } \\
\text { contorno } \\
\text { simples e boca } \\
\text { constrita. }\end{array}$ & 3 & $(3 \%)$ & 0 & $(0 \%)$ & 1 & $(5 \%)$ \\
\hline $\begin{array}{l}\text { Vasilha semi- } \\
\text { esférica, com } \\
\text { contorno } \\
\text { simples e boca } \\
\text { aberta. }\end{array}$ & 13 & $(12 \%)$ & 0 & $(0 \%)$ & 3 & $(16 \%)$ \\
\hline $\begin{array}{l}\text { Vasilha semi- } \\
\text { esférica, com } \\
\text { contorno } \\
\text { simples e boca } \\
\text { constrita. }\end{array}$ & 1 & $(1 \%)$ & 0 & $(0 \%)$ & 0 & $(0 \%)$ \\
\hline $\begin{array}{l}\text { Vasilha rasa, } \\
\text { prato. }\end{array}$ & 5 & $(4 \%)$ & 0 & $(0 \%)$ & 0 & $(0 \%)$ \\
\hline $\begin{array}{l}\text { Vasilha } \\
\text { esférica, com } \\
\text { contorno } \\
\text { simples e boca } \\
\text { aberta. }\end{array}$ & 2 & $(2 \%)$ & 0 & $(0 \%)$ & 0 & $(0 \%)$ \\
\hline $\begin{array}{l}\text { Vasilha semi- } \\
\text { esférica, com } \\
\text { contorno } \\
\text { infletido e boca } \\
\text { aberta. }\end{array}$ & 30 & $(27 \%)$ & 9 & $(39 \%)$ & 6 & $(32 \%)$ \\
\hline $\begin{array}{l}\text { Vasilha em } \\
\text { forma de } \\
\text { calota, com } \\
\text { contorno } \\
\text { infletido, boca } \\
\text { aberta. }\end{array}$ & 10 & $(9 \%)$ & 13 & $(57 \%)$ & 7 & $(37 \%)$ \\
\hline $\begin{array}{l}\text { Vasilha } \\
\text { esférica, com } \\
\text { contorno } \\
\text { infletido e boca } \\
\text { aberta. }\end{array}$ & 8 & $(7 \%)$ & 1 & $(4 \%)$ & 0 & $(0 \%)$ \\
\hline $\begin{array}{l}\text { Vasilha semi- } \\
\text { esférica, com } \\
\text { contorno } \\
\text { infletido e boca } \\
\text { constrita. }\end{array}$ & 1 & $(1 \%)$ & 0 & $(0 \%)$ & 0 & $(0 \%)$ \\
\hline \begin{tabular}{|l|} 
Total \\
\end{tabular} & 113 & $(100 \%)$ & 23 & $(100 \%)$ & 19 & $(100 \%)$ \\
\hline
\end{tabular}




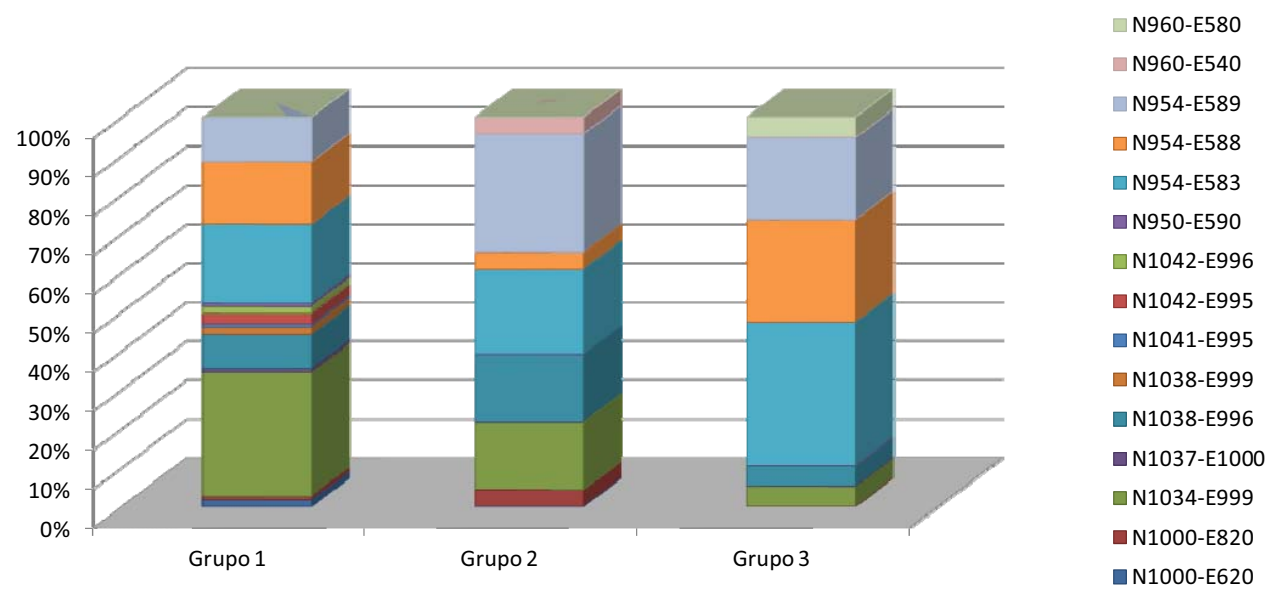

Gráfico 15 H.1 Gráfico de barras empilhadas da variável Unidade Sondagem por grupo do sítio Itapirema.

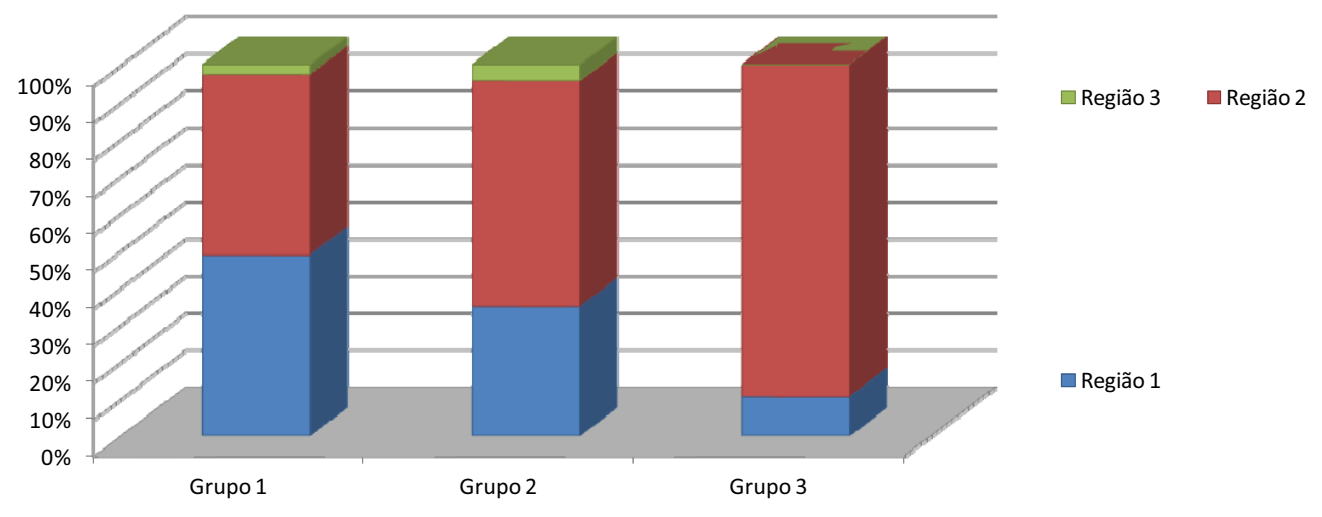

Gráfico 15 H.2 Gráfico de barras empilhadas da variável Região geográfica por grupo do sítio Itapirema.

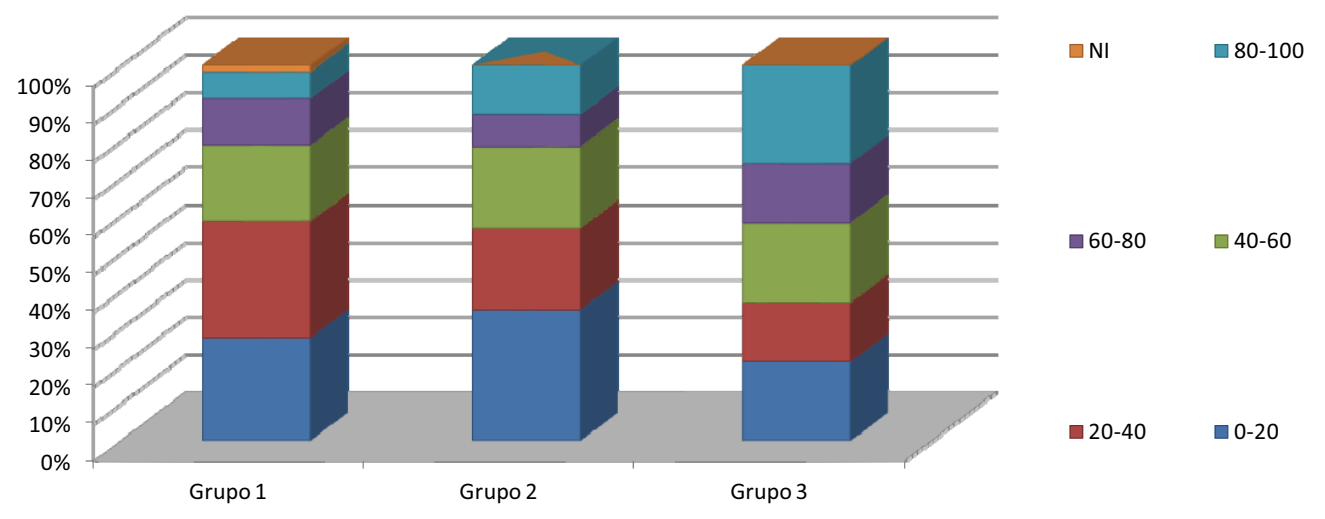

Gráfico 15 H.3 Gráfico de barras empilhadas da variável Nível por grupo do sítio Itapirema. 


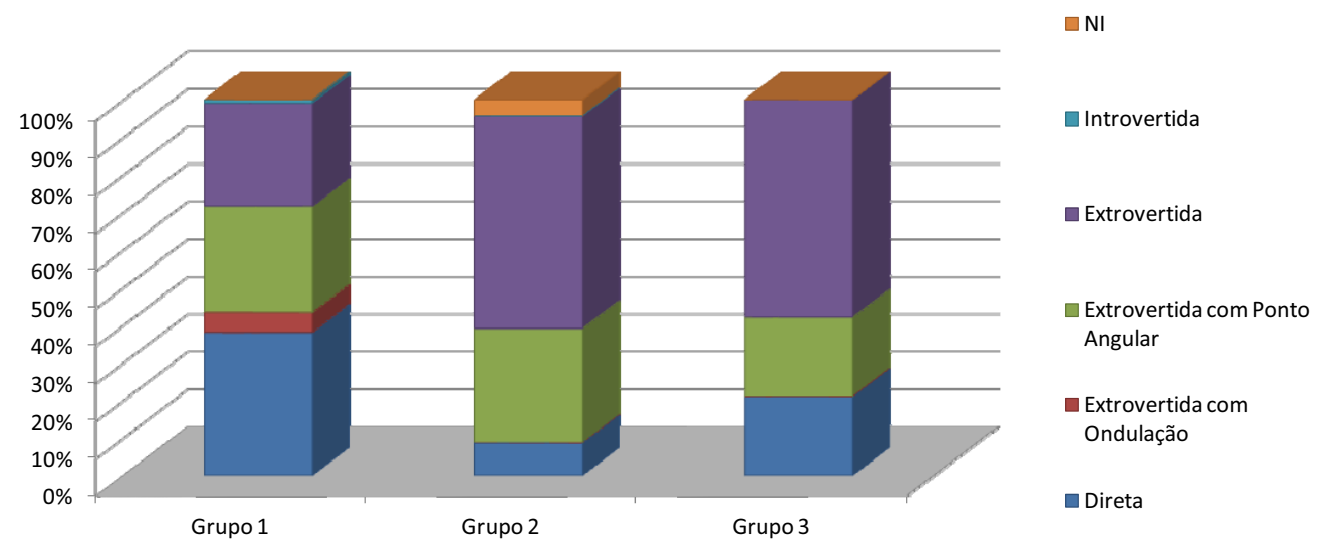

Gráfico 15 H.4 Gráfico de barras empilhadas da variável Morfologia da Borda por grupo do sítio Itapirema.

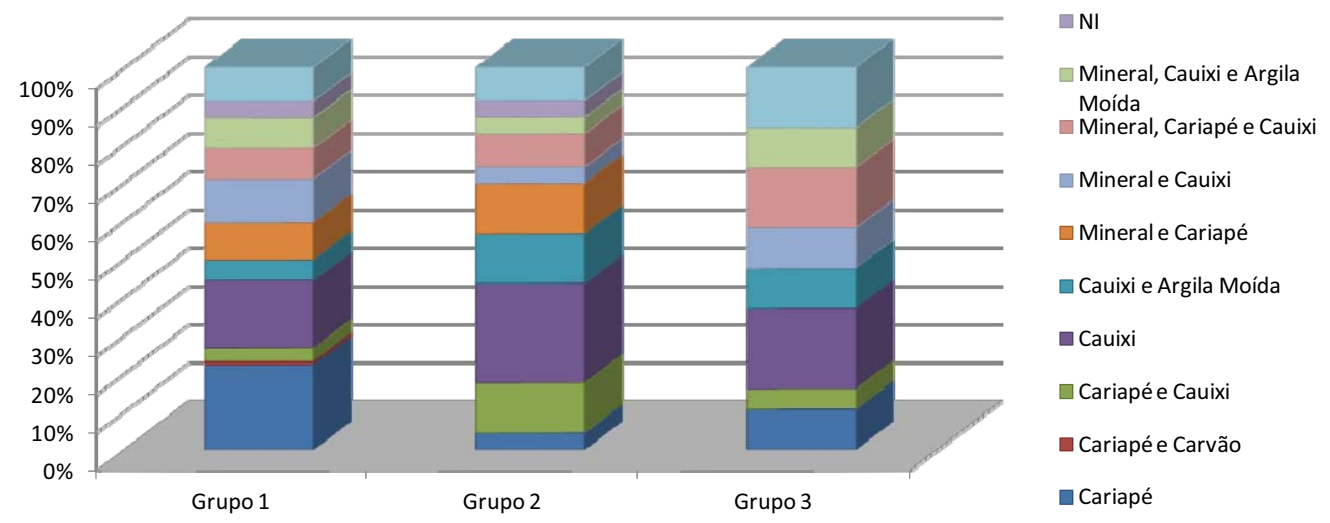

Gráfico 15 H.5 Gráfico de barras empilhadas da variável Antiplástico por grupo do sítio Itapirema.

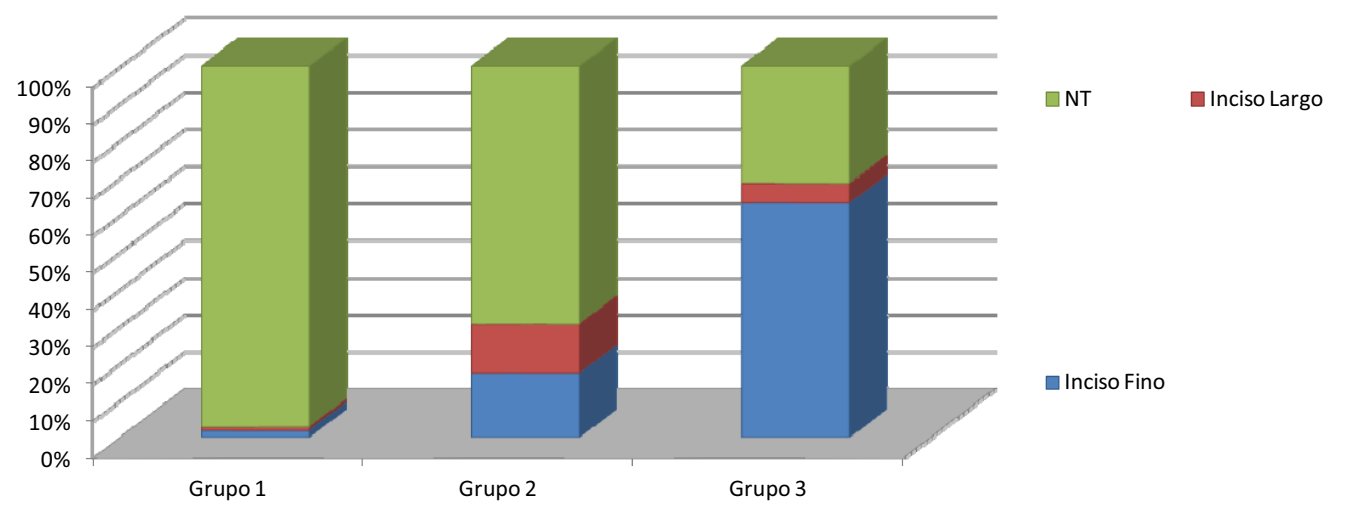

Gráfico 15 H.6 Gráfico de barras empilhadas da variável Decoração Plástica por grupo do sítio Itapirema. 


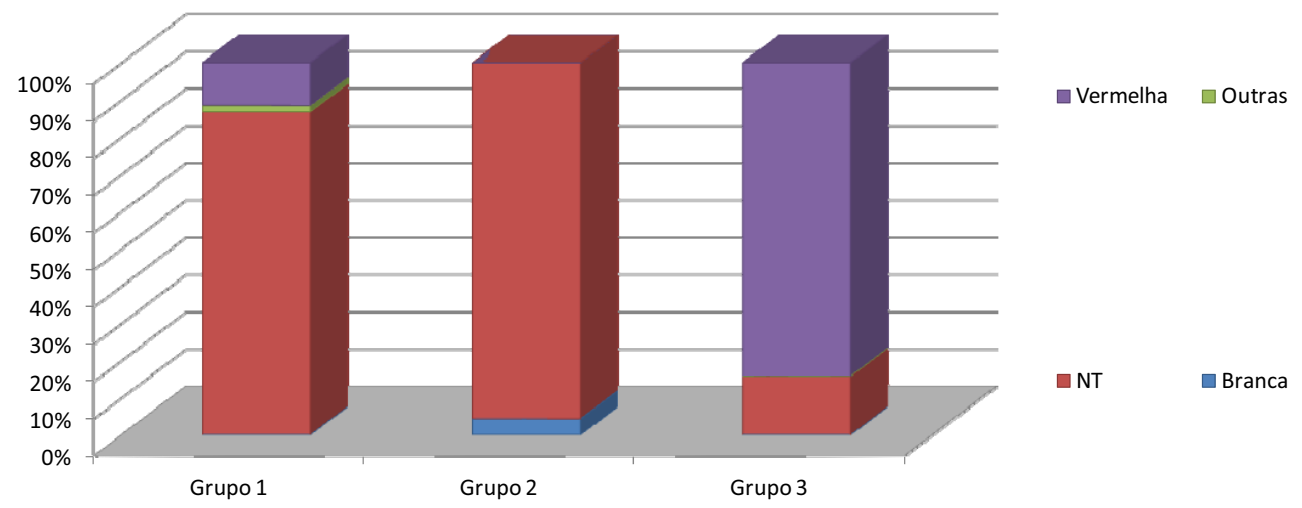

Gráfico 15 H.7 Gráfico de barras empilhadas da variável Decoração Pintada por grupo do sítio Itapirema.

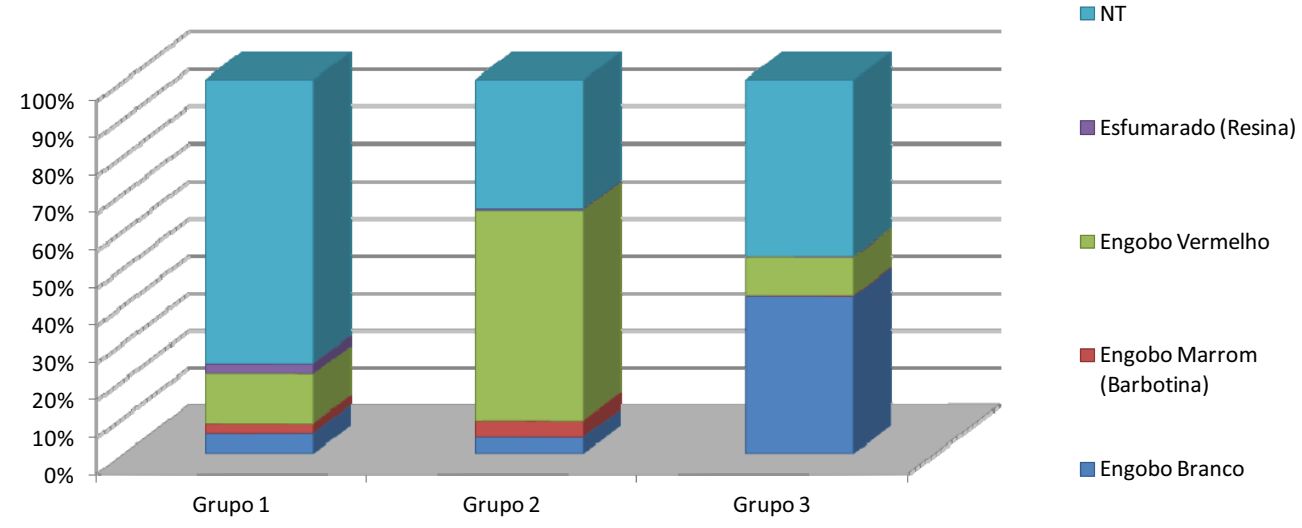

Gráfico 15 H.8 Gráfico de barras empilhadas da variável Tratamento de Superfície FE por grupo do sítio Itapirema.
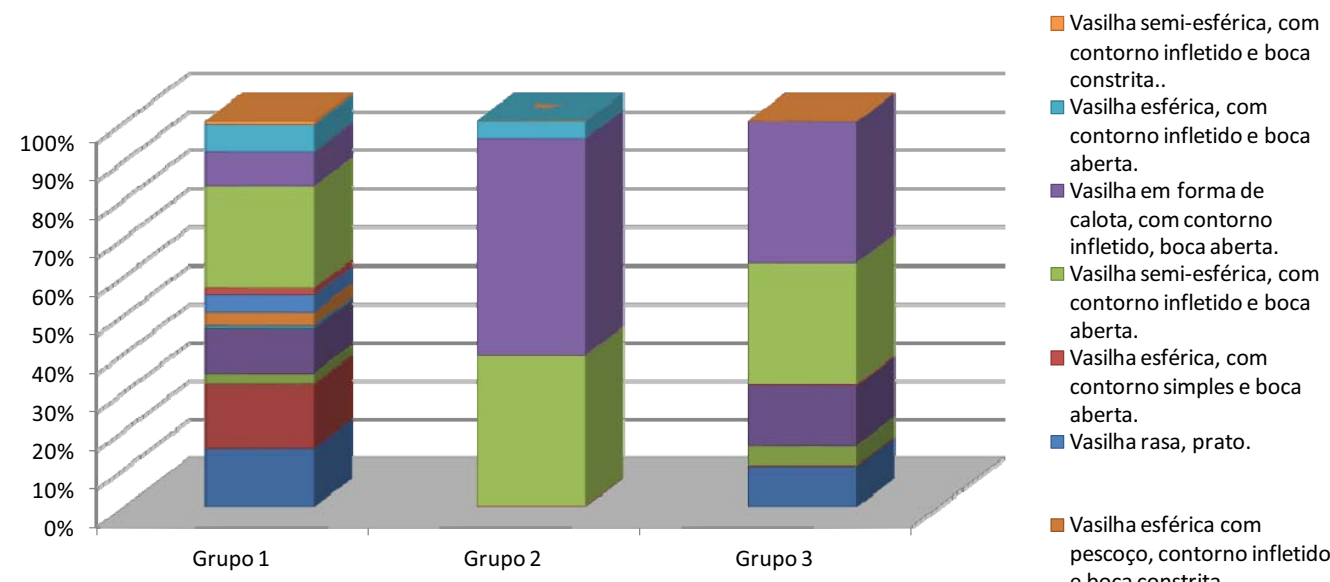

Gráfico 15 H.10 Gráfico de barras empilhadas da variável Forma por grupo do sítio Itapirema. 
Figura H.1 Mapa do sítio Itapirema com a marcação das regiões destacadas no agrupamento.

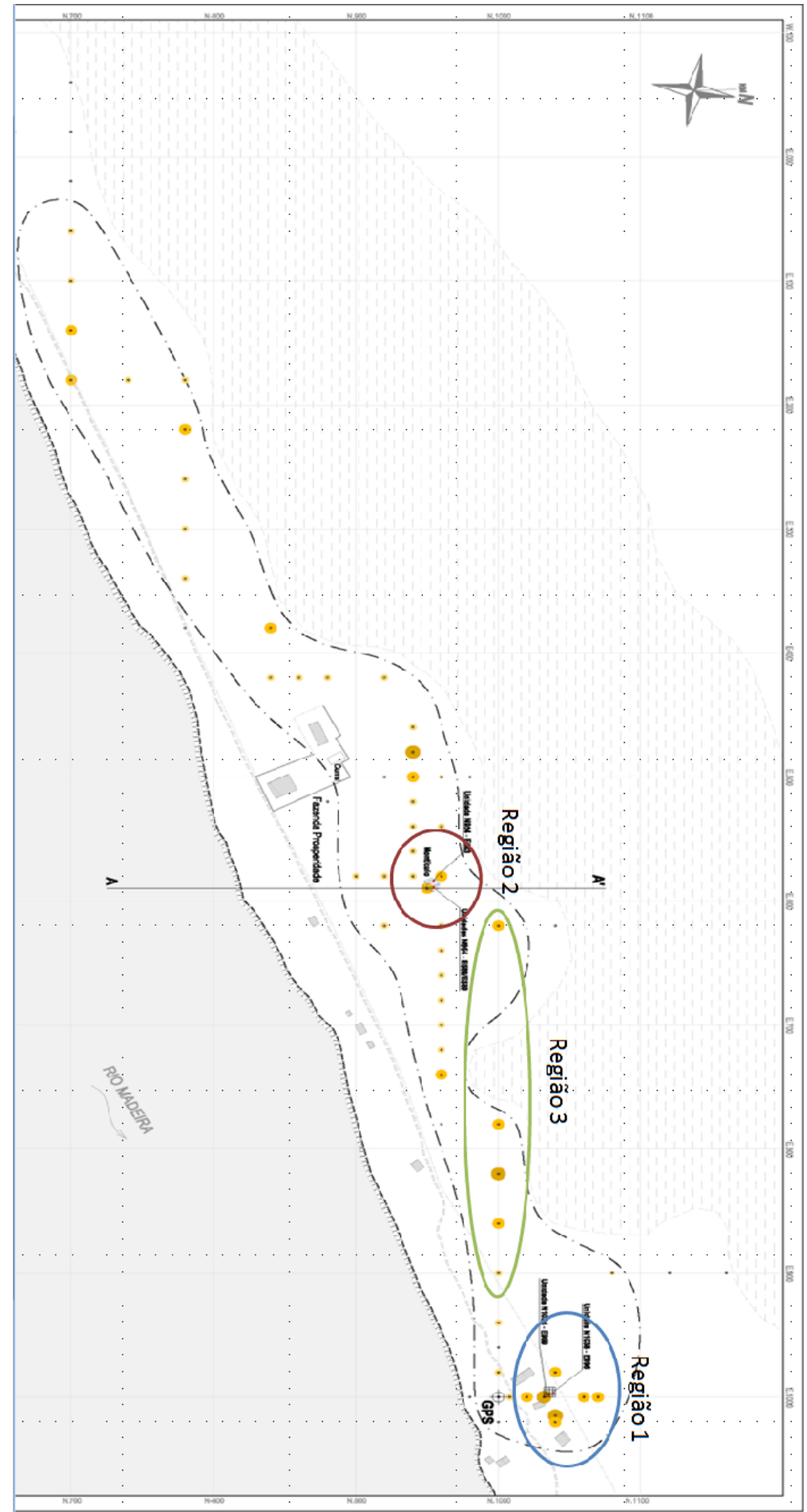


Anexo 15 I Resultados da Análise de Agrupamentos do sítio Teotônio

Tabela 15 I.1 Tabela de frequências da variável Nível por grupo do sítio Teotônio.

\begin{tabular}{|c|c|c|c|c|c|c|c|c|c|c|}
\hline & \multicolumn{2}{|c|}{ Grupo 1} & \multicolumn{2}{|c|}{ Grupo 2} & \multicolumn{2}{|c|}{ Grupo 3} & \multicolumn{2}{|c|}{ Grupo 4} & \multicolumn{2}{|c|}{ Grupo 5} \\
\hline $0-10$ & 6 & $(20 \%)$ & 0 & (0\%) & 0 & $(0 \%)$ & 0 & (0\%) & 0 & $(0 \%)$ \\
\hline $10-20$ & 13 & $(43 \%)$ & 0 & $(0 \%)$ & 0 & $(0 \%)$ & 0 & $(0 \%)$ & 0 & $(0 \%)$ \\
\hline $20-30$ & 5 & $(17 \%)$ & 1 & $(33 \%)$ & 1 & $(33 \%)$ & 0 & $(0 \%)$ & 0 & $(0 \%)$ \\
\hline $30-40$ & 3 & $(10 \%)$ & 0 & $(0 \%)$ & 1 & $(33 \%)$ & 0 & $(0 \%)$ & 0 & $(0 \%)$ \\
\hline $40-50$ & 1 & $(3 \%)$ & 1 & $(33 \%)$ & 0 & $(0 \%)$ & 0 & $(0 \%)$ & 0 & $(0 \%)$ \\
\hline $50-60$ & 1 & $(3 \%)$ & 1 & $(33 \%)$ & 1 & $(33 \%)$ & 1 & $(100 \%)$ & 1 & $(100 \%)$ \\
\hline $70-80$ & 1 & $(3 \%)$ & 0 & $(0 \%)$ & 0 & $(0 \%)$ & 0 & $(0 \%)$ & 0 & $(0 \%)$ \\
\hline Total & & $(100 \%)$ & 3 & $(100 \%)$ & 3 & $(100 \%)$ & 1 & $(100 \%)$ & 1 & $(100 \%)$ \\
\hline
\end{tabular}

Tabela 15 I.2 Tabela de frequências da variável Morfologia da Borda por grupo do sítio Teotônio.

\begin{tabular}{|c|c|c|c|c|c|c|c|c|c|c|}
\hline \multirow[b]{2}{*}{ Cariapé } & \multicolumn{2}{|c|}{ Grupo 1} & \multicolumn{2}{|c|}{ Grupo 2} & \multicolumn{2}{|c|}{ Grupo 3} & \multicolumn{2}{|c|}{ Grupo 4} & \multicolumn{2}{|c|}{ Grupo 5} \\
\hline & 6 & $(20 \%)$ & 2 & $(67 \%)$ & 0 & $(0 \%)$ & 1 & $(100 \%)$ & 0 & $(0 \%)$ \\
\hline $\begin{array}{l}\text { Cariapé e } \\
\text { Carvão }\end{array}$ & 3 & $(10 \%)$ & 0 & $(0 \%)$ & 1 & $(33 \%)$ & 0 & $(0 \%)$ & 0 & $(0 \%)$ \\
\hline Carvão & 1 & $(3 \%)$ & 0 & $(0 \%)$ & 0 & $(0 \%)$ & 0 & $(0 \%)$ & 0 & $(0 \%)$ \\
\hline Mineral & 1 & $(3 \%)$ & 0 & $(0 \%)$ & 1 & $(33 \%)$ & 0 & $(0 \%)$ & 0 & $(0 \%)$ \\
\hline $\begin{array}{l}\text { Mineral e } \\
\text { Cariapé }\end{array}$ & 11 & $(37 \%)$ & 1 & $(33 \%)$ & 0 & $(0 \%)$ & 0 & $(0 \%)$ & 0 & $(0 \%)$ \\
\hline \begin{tabular}{|l} 
Mineral e \\
Cauixi
\end{tabular} & 1 & $(3 \%)$ & 0 & $(0 \%)$ & 0 & $(0 \%)$ & 0 & $(0 \%)$ & 0 & $(0 \%)$ \\
\hline $\begin{array}{l}\text { Mineral, } \\
\text { Cariapé e } \\
\text { Carvão }\end{array}$ & 1 & $(3 \%)$ & 0 & $(0 \%)$ & 0 & $(0 \%)$ & 0 & $(0 \%)$ & 0 & $(0 \%)$ \\
\hline Outros & 6 & $(20 \%)$ & 0 & $(0 \%)$ & 1 & $(33 \%)$ & 0 & $(0 \%)$ & 1 & $(100 \%)$ \\
\hline Total & 30 & $(100 \%)$ & 3 & $(100 \%)$ & 3 & $(100 \%)$ & 1 & $(100 \%)$ & 1 & $(100 \%)$ \\
\hline
\end{tabular}

Tabela 15 I.3 Tabela de frequências da variável Antiplástico por grupo do sítio

Teotônio.

\begin{tabular}{|c|c|c|c|c|c|c|c|c|c|c|}
\hline & \multicolumn{2}{|c|}{ Grupo 1} & \multicolumn{2}{|c|}{ Grupo 2} & \multicolumn{2}{|c|}{ Grupo 3} & \multicolumn{2}{|c|}{ Grupo 4} & \multicolumn{2}{|c|}{ Grupo 5} \\
\hline $5 \%$ & 1 & $(3 \%)$ & 0 & $(0 \%)$ & 0 & $(0 \%)$ & 0 & $(0 \%)$ & 0 & $(0 \%)$ \\
\hline $10 \%$ & 11 & $(37 \%)$ & 3 & $(100 \%)$ & 0 & $(0 \%)$ & 1 & $(100 \%)$ & 1 & $(100 \%)$ \\
\hline $20 \%$ & 7 & $(23 \%)$ & 0 & $(0 \%)$ & 1 & $(33 \%)$ & 0 & $(0 \%)$ & 0 & $(0 \%)$ \\
\hline $30 \%$ & 11 & $(37 \%)$ & 0 & $(0 \%)$ & 2 & $(67 \%)$ & 0 & $(0 \%)$ & 0 & $(0 \%)$ \\
\hline Total & 30 & $(100 \%)$ & 3 & $(100 \%)$ & 3 & $(100 \%)$ & 1 & $(100 \%)$ & 1 & $(100 \%)$ \\
\hline
\end{tabular}

Tabela 15 I.4 Tabela de frequências da variável Porcentagem do Antiplástico por grupo do sítio Teotônio.

\begin{tabular}{|c|c|c|c|c|c|c|c|c|c|c|}
\hline & \multicolumn{2}{|c|}{ Grupo 1} & \multicolumn{2}{|c|}{ Grupo 2} & \multicolumn{2}{|c|}{ Grupo 3} & \multicolumn{2}{|c|}{ Grupo 4} & \multicolumn{2}{|c|}{ Grupo 5} \\
\hline Direta & & $(80 \%)$ & 2 & $(67 \%)$ & 3 & $(100 \%)$ & 0 & $(0 \%)$ & 0 & $(0 \%)$ \\
\hline $\begin{array}{l}\text { Extrovertida } \\
\text { com } \\
\text { Ondulação }\end{array}$ & - & $(0 \%)$ & 1 & $(33 \%)$ & 0 & $(0 \%)$ & 0 & $(0 \%)$ & 0 & $(0 \%)$ \\
\hline $\begin{array}{l}\text { Extrovertida } \\
\text { com Ponto } \\
\text { Angular } \\
\end{array}$ & - & $(0 \%)$ & 0 & $(0 \%)$ & 0 & $(0 \%)$ & 1 & $(100 \%)$ & 0 & $(0 \%)$ \\
\hline Extrovertida & 6 & $(20 \%)$ & 0 & $(0 \%)$ & 0 & $(0 \%)$ & 0 & $(0 \%)$ & 0 & $(0 \%)$ \\
\hline Introvertida & - & $(0 \%)$ & 0 & $(0 \%)$ & 0 & $(0 \%)$ & 0 & $(0 \%)$ & 1 & $(100 \%)$ \\
\hline Total & 30 & $(100 \%)$ & 3 & $(100 \%)$ & 3 & $(100 \%)$ & 1 & $(100 \%)$ & 1 & $(100 \%)$ \\
\hline
\end{tabular}

Tabela 15 I.5 Tabela de frequências da variável Decoração Plástica por grupo do sítio Teotônio.

\begin{tabular}{|l|cc|cc|cc|cc|c|c|}
\hline & \multicolumn{2}{|c|}{ Grupo 1 } & \multicolumn{2}{|c|}{ Grupo 2 } & \multicolumn{2}{|c|}{ Grupo 3 } & \multicolumn{2}{c|}{ Grupo 4 } & Grupo 5 \\
\hline Entalhado & - & $(0 \%)$ & 1 & $(33 \%)$ & 0 & $(0 \%)$ & 0 & $(0 \%)$ & 0 & $(0 \%)$ \\
\hline Inciso Fino & - & $(0 \%)$ & 2 & $(67 \%)$ & 0 & $(0 \%)$ & 0 & $(0 \%)$ & 0 & $(0 \%)$ \\
\hline Inciso Largo & - & $(0 \%)$ & 0 & $(0 \%)$ & 3 & $(100 \%)$ & 0 & $(0 \%)$ & 1 & $(10 \%)$ \\
\hline NT & 30 & $(100 \%)$ & 0 & $(0 \%)$ & 0 & $(0 \%)$ & 1 & $(100 \%)$ & 0 & $(0 \%)$ \\
\hline Total & $\mathbf{3 0}$ & $(\mathbf{1 0 0} \%)$ & $\mathbf{3}$ & $\mathbf{( 1 0 0 \% )}$ & $\mathbf{3}$ & $\mathbf{( 1 0 0 \% )}$ & $\mathbf{1}$ & $(\mathbf{1 0 0} \%)$ & $\mathbf{1}$ & $(\mathbf{1 0 0} \%)$ \\
\hline
\end{tabular}


Tabela 15 I.6 Tabela de frequências da variável Decoração Pintada por grupo do sítio Teotônio.

\begin{tabular}{|c|c|c|c|c|c|c|}
\hline & Grupo 1 & Grupo 2 & Grupo 3 & Grupo 4 & & \\
\hline Vermelha & $(0 \%)$ & $(0 \%)$ & $(0 \%)$ & $(100 \%)$ & 0 & $(0 \%)$ \\
\hline NT & $(100 \%)$ & $(100 \%)$ & $(100 \%)$ & $(0 \%)$ & 1 & $(100 \%)$ \\
\hline Total & $(100 \%)$ & $(100 \%)$ & $(100 \%)$ & $(100 \%)$ & 1 & $(100 \%)$ \\
\hline
\end{tabular}

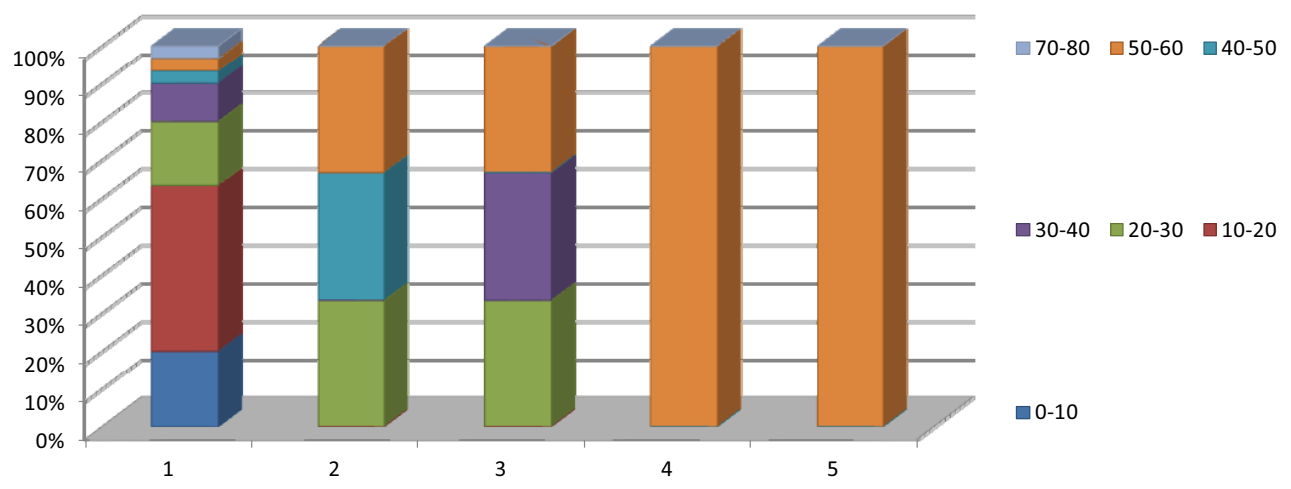

Gráfico15 15 I.1 Gráfico de barras empilhadas da variável Nível por grupo do sítio Teotônio.

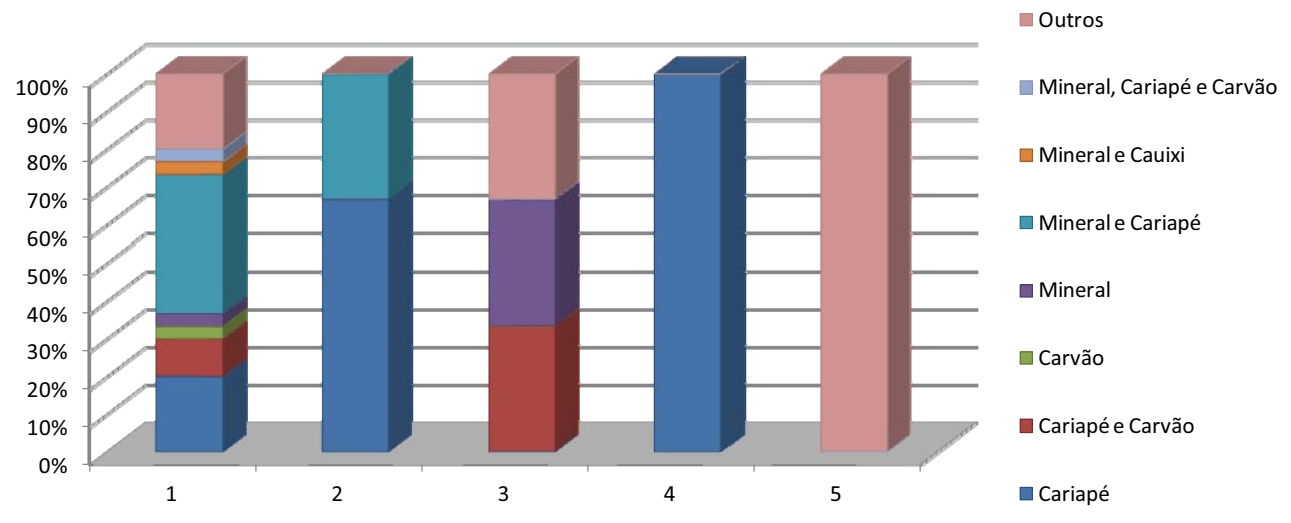

Gráfico 15 I.2 Gráfico de barras empilhadas da variável Morfologia da Borda por grupo do sítio Teotônio. 


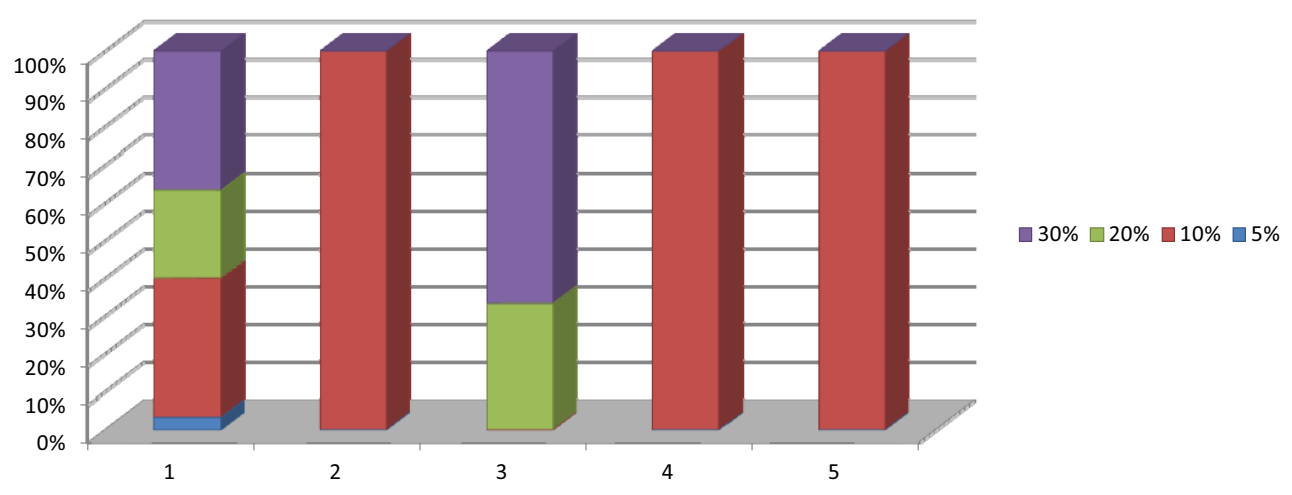

Gráfico 15 I.3 Gráfico de barras empilhadas da variável Antiplástico por grupo do sítio Teotônio.

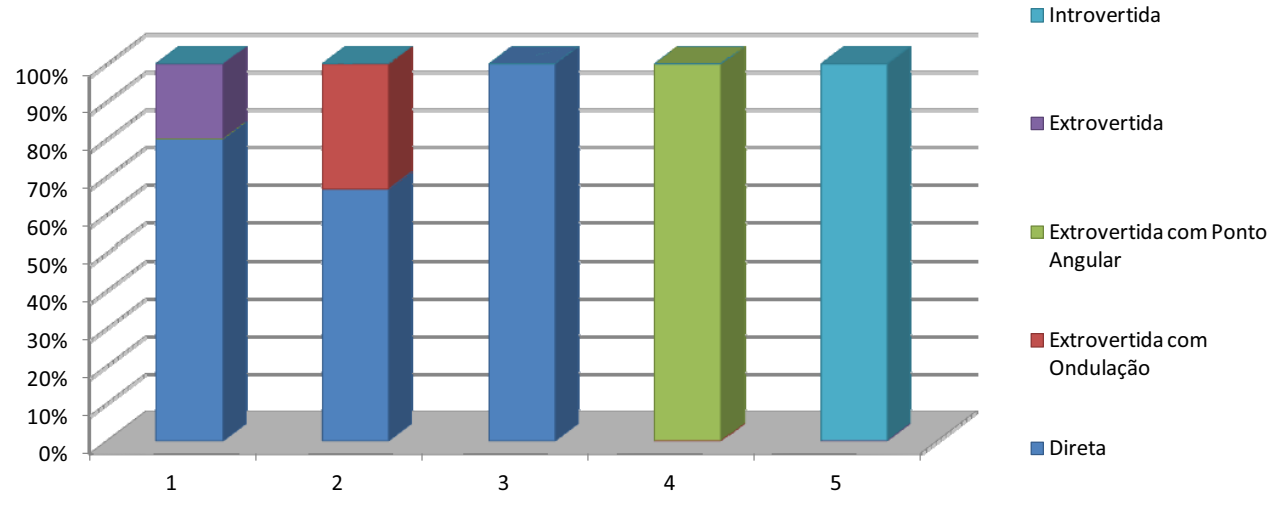

Gráfico 15 I.4 Gráfico de barras empilhadas da variável Porcentagem do Antiplástico por grupo do sítio Teotônio.

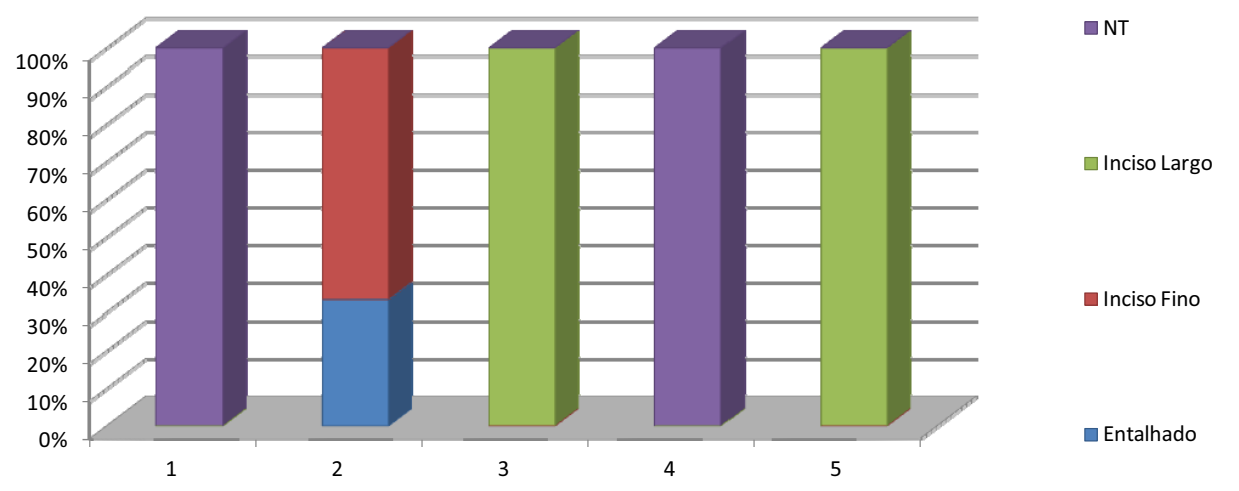

Gráfico 15 I.5 Gráfico de barras empilhadas da variável Decoração Plástica por grupo do sítio Teotônio. 
Anexo $15 \mathrm{~J}$ Resultados da Análise de Agrupamentos do sítio Associação Calderita

Tabela 15 J.1 Tabela de frequências da variável Nível por grupo do sítio Associação Calderita.

\begin{tabular}{|l|rc|rc|cc|}
\hline & \multicolumn{2}{|c|}{ Grupo 1 } & \multicolumn{2}{c|}{ Grupo 2 } & \multicolumn{2}{c|}{ Grupo 3 } \\
\hline $\mathbf{1 0 - 2 0}$ & 3 & $(16 \%)$ & 0 & $(0 \%)$ & 5 & $(50 \%)$ \\
\hline $\mathbf{2 0 - 3 0}$ & 8 & $(42 \%)$ & 8 & $(44 \%)$ & 3 & $(30 \%)$ \\
\hline $\mathbf{3 0 - 4 0}$ & 5 & $(26 \%)$ & 9 & $(50 \%)$ & 1 & $(10 \%)$ \\
\hline $\mathbf{4 0 - 5 0}$ & 3 & $(16 \%)$ & 1 & $(6 \%)$ & 1 & $(10 \%)$ \\
\hline Total & $\mathbf{1 9}$ & $(\mathbf{1 0 0} \%)$ & $\mathbf{1 8}$ & $\mathbf{( 1 0 0 \% )}$ & $\mathbf{1 0}$ & $\mathbf{( 1 0 0 \% )}$ \\
\hline
\end{tabular}

Tabela 15 J.2 Tabela de frequências da variável Datação por grupo do sítio Associação Calderita.

\begin{tabular}{|l|rc|cc|cc|}
\hline & \multicolumn{2}{|c|}{ Grupo 1 } & \multicolumn{2}{c|}{ Grupo 2 } & \multicolumn{2}{c|}{ Grupo 3 } \\
\hline 620+-40AP & 11 & $(58 \%)$ & 8 & $(44 \%)$ & 8 & $(80 \%)$ \\
\hline $\mathbf{9 8 0 + - 4 0 A P}$ & 8 & $(42 \%)$ & 10 & $(56 \%)$ & 2 & $(20 \%)$ \\
\hline Total & $\mathbf{1 9}$ & $(\mathbf{1 0 0} \%)$ & $\mathbf{1 8}$ & $\mathbf{( 1 0 0 \% )}$ & $\mathbf{1 0}$ & $\mathbf{( 1 0 0 \% )}$ \\
\hline
\end{tabular}

Tabela 15 J.3 Tabela de frequências da variável Antiplástico por grupo do sítio Associação Calderita.

\begin{tabular}{|l|rc|rc|cc|}
\hline & \multicolumn{2}{|c|}{ Grupo 1 } & \multicolumn{2}{|c|}{ Grupo 2 } & \multicolumn{2}{c|}{ Grupo 3 } \\
\hline Cariapé & 2 & $(11 \%)$ & 8 & $(44 \%)$ & 8 & $(80 \%)$ \\
\hline $\begin{array}{l}\text { Cariapé e } \\
\text { Carvão }\end{array}$ & 3 & $(16 \%)$ & 1 & $(6 \%)$ & 0 & $(0 \%)$ \\
\hline Mineral & 1 & $(5 \%)$ & 0 & $(0 \%)$ & 1 & $(10 \%)$ \\
\hline $\begin{array}{l}\text { Mineral e } \\
\text { Cariapé }\end{array}$ & 13 & $(68 \%)$ & 9 & $(50 \%)$ & 1 & $(10 \%)$ \\
\hline Total & $\mathbf{1 9}$ & $\mathbf{( 1 0 0 \% )}$ & $\mathbf{1 8}$ & $\mathbf{( 1 0 0 \% )}$ & $\mathbf{1 0}$ & $\mathbf{( 1 0 0 \% )}$ \\
\hline
\end{tabular}

Tabela 15 J.4 Tabela de frequências da variável Decoração Plástica por grupo do sítio Associação Calderita.

\begin{tabular}{|l|cc|cc|cc|}
\hline & \multicolumn{2}{|c|}{ Grupo 1 } & \multicolumn{2}{c|}{ Grupo 2 } & \multicolumn{2}{c|}{ Grupo 3 } \\
\hline Inciso Fino & - & $(0 \%)$ & 0 & $(0 \%)$ & 1 & $(10 \%)$ \\
\hline NT & 19 & $(100 \%)$ & 18 & $(100 \%)$ & 9 & $(90 \%)$ \\
\hline Total & $\mathbf{1 9}$ & $\mathbf{( 1 0 0 \% )}$ & $\mathbf{1 8}$ & $\mathbf{( 1 0 0 \% )}$ & $\mathbf{1 0}$ & $\mathbf{( 1 0 0 \% )}$ \\
\hline
\end{tabular}

Tabela 15 J.5 Tabela de frequências da variável Decoração Pintada por grupo do sítio Associação Calderita.

\begin{tabular}{|l|cc|cc|cc|}
\hline & \multicolumn{2}{|c|}{ Grupo 1 } & \multicolumn{2}{c|}{ Grupo 2 } & \multicolumn{2}{c|}{ Grupo 3 } \\
\hline Vermelha & - & $(0 \%)$ & 1 & $(6 \%)$ & 0 & $(0 \%)$ \\
\hline NT & 19 & $(100 \%)$ & 17 & $(94 \%)$ & 10 & $(100 \%)$ \\
\hline Total & $\mathbf{1 9}$ & $\mathbf{1}$ & $\mathbf{1 8}$ & $\mathbf{1}$ & $\mathbf{1 0}$ & $\mathbf{1}$ \\
\hline
\end{tabular}


Tabela 15 J.7 Tabela de frequências da variável Forma por grupo do sítio Associação Calderita.

\begin{tabular}{|c|c|c|c|c|c|c|}
\hline & \multicolumn{2}{|c|}{ Grupo 1} & \multicolumn{2}{|c|}{ Grupo 2} & \multicolumn{2}{|c|}{ Grupo 3} \\
\hline $\begin{array}{l}\text { Vasilna em } \\
\text { forma de } \\
\text { calota, com } \\
\text { contorno } \\
\text { infletido, boca } \\
\text { aberta. }\end{array}$ & 1 & $(5 \%)$ & 1 & $(6 \%)$ & 1 & $(10 \%)$ \\
\hline $\begin{array}{l}\text { Vasilha em } \\
\text { forma de } \\
\text { calota, com } \\
\text { contorno } \\
\text { simples, boca } \\
\text { aberta. }\end{array}$ & 4 & $(21 \%)$ & 0 & $(0 \%)$ & 2 & $(20 \%)$ \\
\hline $\begin{array}{l}\text { Vasilha } \\
\text { esférica com } \\
\text { pescoço, } \\
\text { contorno } \\
\text { infletido e } \\
\text { boca constrita. }\end{array}$ & 1 & (5\%) & 0 & $(0 \%)$ & 0 & $(0 \%)$ \\
\hline $\begin{array}{l}\text { Vasilha } \\
\text { esférica, com } \\
\text { contorno } \\
\text { infletido e } \\
\text { boca constrita. }\end{array}$ & 2 & $(11 \%)$ & 1 & $(6 \%)$ & 0 & $(0 \%)$ \\
\hline $\begin{array}{l}\text { Vasilha } \\
\text { esférica, com } \\
\text { contorno } \\
\text { simples e boca } \\
\text { constrita. }\end{array}$ & 4 & $(21 \%)$ & 5 & $(28 \%)$ & 0 & $(0 \%)$ \\
\hline $\begin{array}{l}\text { Vasilha semi- } \\
\text { esférica, com } \\
\text { contorno } \\
\text { infletido e } \\
\text { boca aberta. }\end{array}$ & - & $(0 \%)$ & 2 & $(11 \%)$ & 5 & $(50 \%)$ \\
\hline $\begin{array}{l}\text { Vasilha semi- } \\
\text { esférica, com } \\
\text { contorno } \\
\text { infletido e } \\
\text { boca } \\
\text { constrita.. }\end{array}$ & & $(0 \%)$ & 1 & $(6 \%)$ & 0 & $(0 \%)$ \\
\hline $\begin{array}{l}\text { Vasilha semi- } \\
\text { esférica, com } \\
\text { contorno } \\
\text { simples e boca } \\
\text { aberta. }\end{array}$ & 4 & $(21 \%)$ & 6 & $(33 \%)$ & 2 & $(20 \%)$ \\
\hline $\begin{array}{l}\text { Vasilha semi- } \\
\text { esférica, com } \\
\text { contorno } \\
\text { simples e boca } \\
\text { constrita. }\end{array}$ & & $(16 \%)$ & 2 & $(11 \%)$ & 0 & $(0 \%)$ \\
\hline Total & 19 & 1 & 18 & 1 & 10 & 1 \\
\hline
\end{tabular}




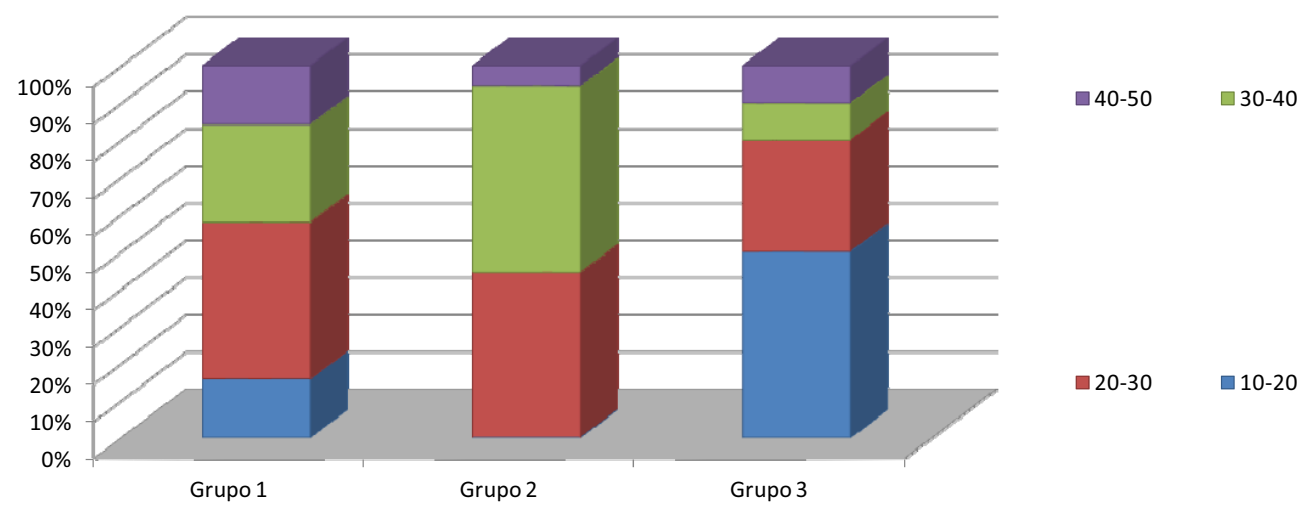

Gráfico 15 J.1 Gráfico de barras empilhadas da variável Nível por grupo do sítio Associação Calderita.

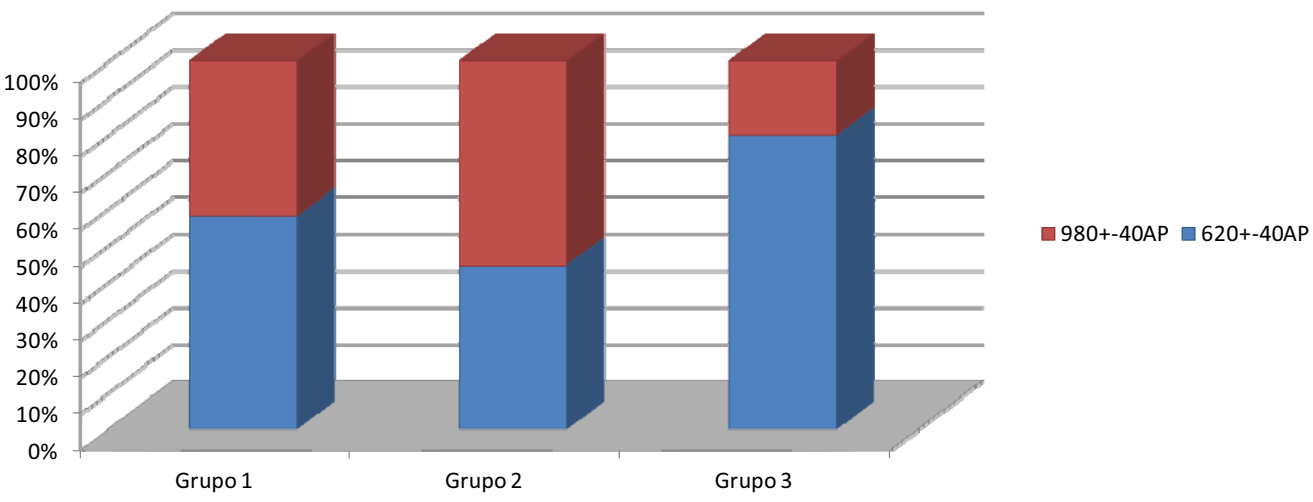

Gráfico 15 J.2 Gráfico de barras empilhadas da variável Datação por grupo do sítio Associação Calderita.

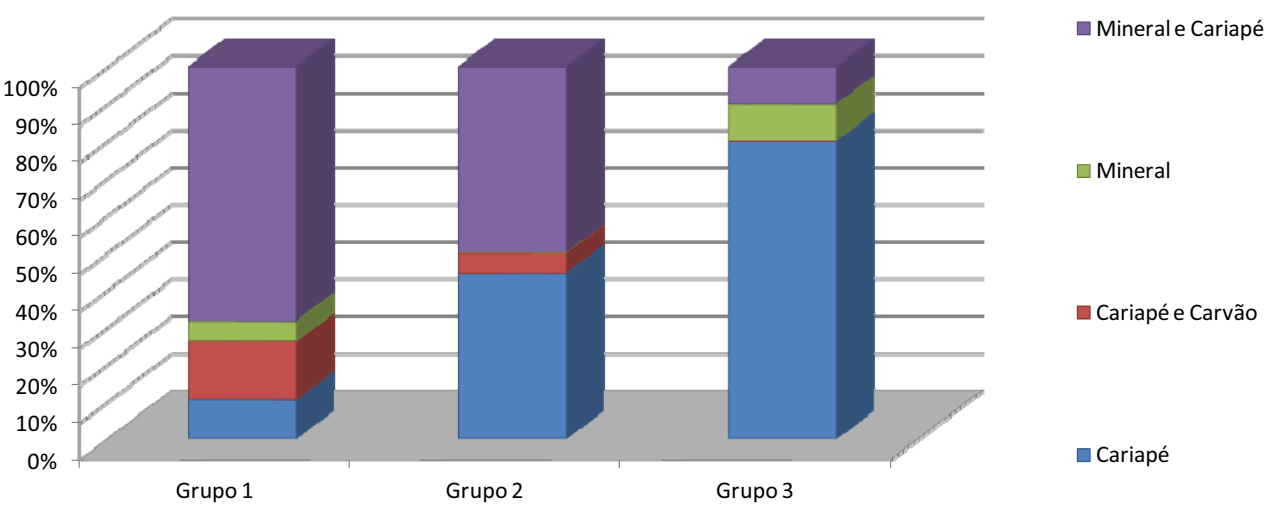

Gráfico 15 J.3 Gráfico de barras empilhadas da variável Antiplástico por grupo do sítio Associação Calderita. 


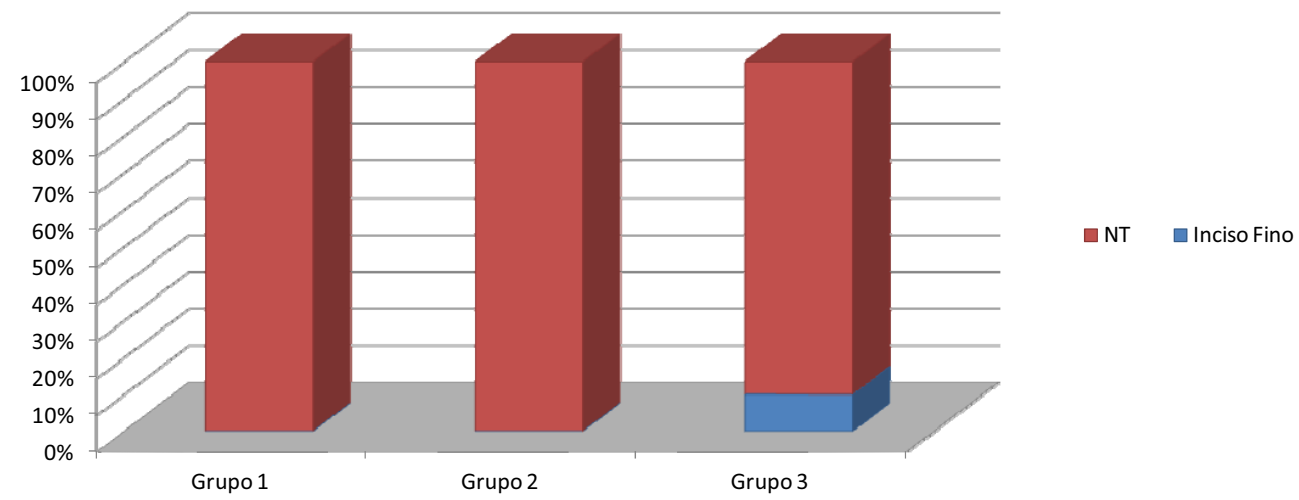

Gráfico 15 J.4 Gráfico de barras empilhadas da variável Decoração Plástica por grupo do sítio Associação Calderita.

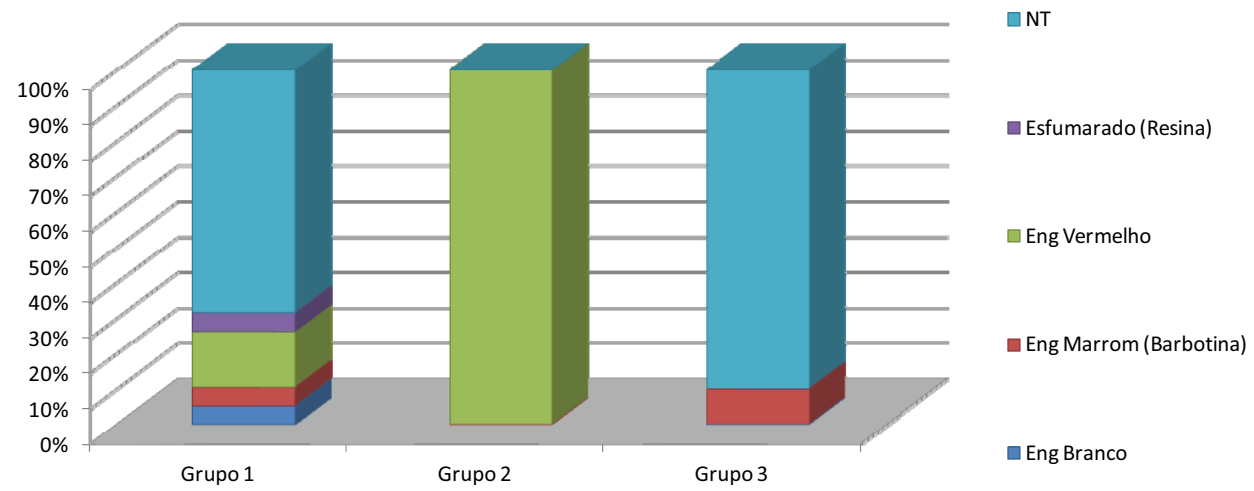

Gráfico 15 J.5 Gráfico de barras empilhadas da variável Tratamento de Superfície FE por grupo do sítio Associação Calderita.

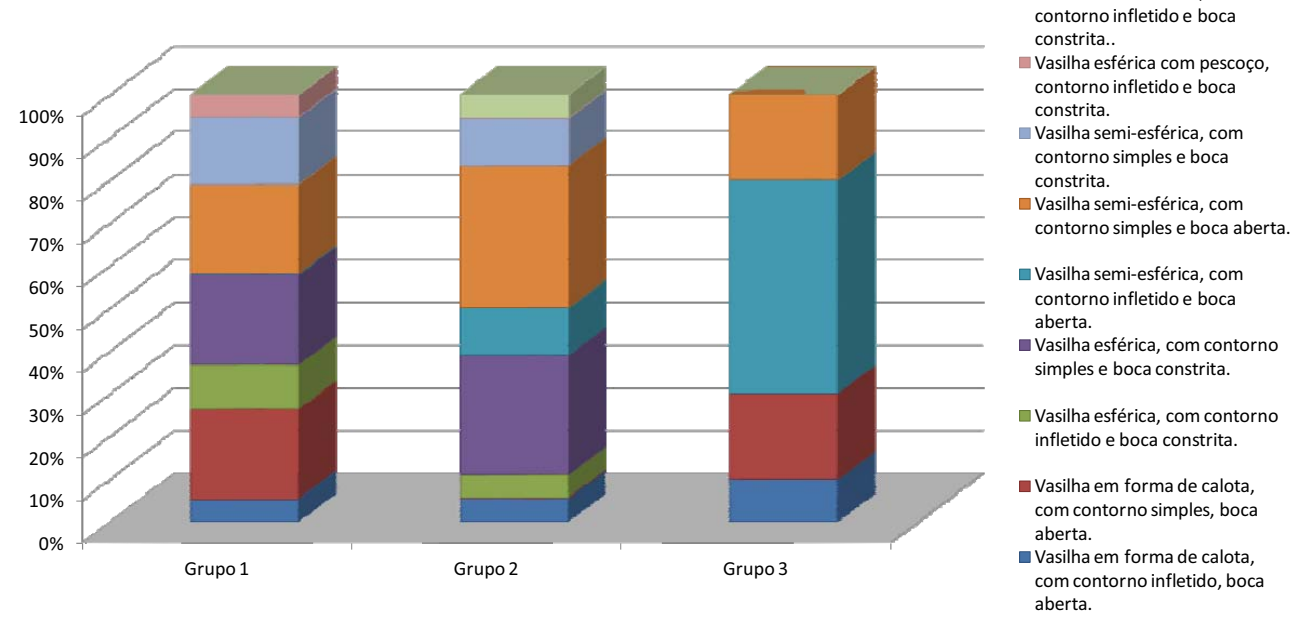

Gráfico 15 J.7 Gráfico de barras empilhadas da variável Forma por grupo do sítio Associação Calderita. 
Anexo 15 K Resultados da Análise de Agrupamentos do Sítio Jacarezinho

Tabela 15 K.1 Tabela de frequências da variável Nível por grupo do sítio Jacarezinho.

\begin{tabular}{|l|cc|cc|cc|}
\hline & \multicolumn{2}{|c|}{ Grupo 1 } & \multicolumn{2}{c|}{ Grupo 2 } & \multicolumn{2}{c|}{ Grupo 3 } \\
\hline $\mathbf{1 0 - 2 0}$ & 5 & $(16 \%)$ & 0 & $(0 \%)$ & 4 & $(100 \%)$ \\
\hline $\mathbf{2 0 - 3 0}$ & 4 & $(13 \%)$ & 3 & $(38 \%)$ & 0 & $(0 \%)$ \\
\hline $\mathbf{3 0 - 4 0}$ & 5 & $(16 \%)$ & 3 & $(38 \%)$ & 0 & $(0 \%)$ \\
\hline $\mathbf{4 0 - 5 0}$ & 18 & $(56 \%)$ & 2 & $(25 \%)$ & 0 & $(0 \%)$ \\
\hline Total & $\mathbf{3 2}$ & $(\mathbf{1 0 0} \%)$ & $\mathbf{8}$ & $\mathbf{( 1 0 0 \% )}$ & $\mathbf{4}$ & $\mathbf{( 1 0 0 \% )}$ \\
\hline
\end{tabular}

Tabela 15 K.2 Tabela de frequências da variável Datação por grupo do sítio Jacarezinho.

\begin{tabular}{|c|c|c|c|c|c|c|}
\hline & \multicolumn{2}{|c|}{ Grupo 1} & \multicolumn{2}{|c|}{ Grupo 2} & \multicolumn{2}{|c|}{ Grupo 3} \\
\hline $660+-40 \mathrm{AP}$ & 9 & $(28 \%)$ & 3 & $(38 \%)$ & 4 & $(100 \%)$ \\
\hline $980+-40$ AP & 5 & $(16 \%)$ & 3 & $(38 \%)$ & 0 & $(0 \%)$ \\
\hline $860+-40 A P$ & 18 & $(56 \%)$ & 2 & $(25 \%)$ & 0 & $(0 \%)$ \\
\hline Total & & $(100 \%)$ & 8 & $(100 \%)$ & 4 & $(100 \%)$ \\
\hline
\end{tabular}

Tabela 15 K.3 Tabela de frequências da variável Antiplástico por grupo do sítio Jacarezinho.

\begin{tabular}{|l|cc|cc|cc|}
\hline & \multicolumn{2}{|c|}{ Grupo 1 } & \multicolumn{2}{|c|}{ Grupo 2 } & \multicolumn{2}{c|}{ Grupo 3 } \\
\hline Cariapé & 22 & $(69 \%)$ & 0 & $(0 \%)$ & 2 & $(50 \%)$ \\
\hline $\begin{array}{l}\text { Cariapé e } \\
\text { Carvão }\end{array}$ & - & $(0 \%)$ & 8 & $(100 \%)$ & 0 & $(0 \%)$ \\
\hline Carvão & 4 & $(13 \%)$ & 0 & $(0 \%)$ & 2 & $(50 \%)$ \\
\hline $\begin{array}{l}\text { Mineral e } \\
\text { Cariapé }\end{array}$ & 6 & $(19 \%)$ & 0 & $(0 \%)$ & 0 & $(0 \%)$ \\
\hline Total & $\mathbf{3 2}$ & $\mathbf{( 1 0 0 \% )}$ & $\mathbf{8}$ & $\mathbf{( 1 0 0 \% )}$ & $\mathbf{4}$ & $\mathbf{( 1 0 0 \% )}$ \\
\hline
\end{tabular}

Tabela 15 K.4 Tabela de frequências da variável Tratamento de Superfície FE por grupo do sítio Jacarezinho.

\begin{tabular}{|l|cc|rc|cc|}
\hline & \multicolumn{2}{|c|}{ Grupo 1 } & \multicolumn{2}{|c|}{ Grupo 2 } & \multicolumn{2}{c|}{ Grupo 3 } \\
\hline $\begin{array}{l}\text { Engobo } \\
\begin{array}{l}\text { Marrom } \\
\text { (Barbotina) }\end{array}\end{array}$ & - & $(0 \%)$ & 1 & $(13 \%)$ & 3 & $(75 \%)$ \\
\hline $\begin{array}{l}\text { Esfumarado } \\
\text { (Resina) }\end{array}$ & - & $(0 \%)$ & 2 & $(25 \%)$ & 1 & $(25 \%)$ \\
\hline NT & 32 & $(100 \%)$ & 5 & $(63 \%)$ & 0 & $(0 \%)$ \\
\hline Total & $\mathbf{3 2}$ & $\mathbf{( 1 0 0 \% )}$ & $\mathbf{8}$ & $\mathbf{( 1 0 0 \% )}$ & $\mathbf{4}$ & $\mathbf{( 1 0 0 \% )}$ \\
\hline
\end{tabular}


Tabela 15 K.5 Tabela de frequências da variável Forma por grupo do sítio Jacarezinho.

\begin{tabular}{|c|c|c|c|c|c|c|}
\hline & Grupo 1 & & Grupo 2 & & Grupo 3 & \\
\hline $\begin{array}{l}\text { Vasilha em } \\
\text { forma de } \\
\text { calota, com } \\
\text { contorno } \\
\text { simples, boca } \\
\text { aberta. }\end{array}$ & 8 & $(25 \%)$ & 2 & $(25 \%)$ & 1 & $(25 \%)$ \\
\hline $\begin{array}{l}\text { Vasilha } \\
\text { esférica com } \\
\text { pescoço, } \\
\text { contorno } \\
\text { infletido e } \\
\text { boca constrita. }\end{array}$ & - & $(0 \%)$ & 1 & $(13 \%)$ & 0 & (0\%) \\
\hline $\begin{array}{l}\text { Vasilha } \\
\text { esférica, com } \\
\text { contorno } \\
\text { infletido e } \\
\text { boca constrita. }\end{array}$ & 3 & (9\%) & 1 & $(13 \%)$ & 0 & $(0 \%)$ \\
\hline $\begin{array}{l}\text { Vasilha } \\
\text { esférica, com } \\
\text { contorno } \\
\text { simples e boca } \\
\text { constrita. }\end{array}$ & 8 & $(25 \%)$ & 0 & $(0 \%)$ & 1 & $(25 \%)$ \\
\hline $\begin{array}{l}\text { Vasilha semi- } \\
\text { esférica, com } \\
\text { contorno } \\
\text { simples e boca } \\
\text { aberta. }\end{array}$ & 10 & $(31 \%)$ & 2 & $(25 \%)$ & 2 & $(50 \%)$ \\
\hline $\begin{array}{l}\text { Vasilha semi- } \\
\text { esférica, com } \\
\text { contorno } \\
\text { simples e boca } \\
\text { constrita. }\end{array}$ & 2 & $(6 \%)$ & 0 & $(0 \%)$ & 0 & $(0 \%)$ \\
\hline $\begin{array}{l}\text { Vasilha rasa, } \\
\text { prato. }\end{array}$ & 1 & (3\%) & 1 & $(13 \%)$ & 0 & $(0 \%)$ \\
\hline $\begin{array}{l}\text { Vasilha } \\
\text { esférica, com } \\
\text { contorno } \\
\text { simples e boca } \\
\text { aberta. }\end{array}$ & - & $(0 \%)$ & 1 & $(13 \%)$ & 0 & $(0 \%)$ \\
\hline Total & $\overline{32}$ & $(100 \%)$ & 8 & $(100 \%)$ & 4 & $(100 \%)$ \\
\hline
\end{tabular}




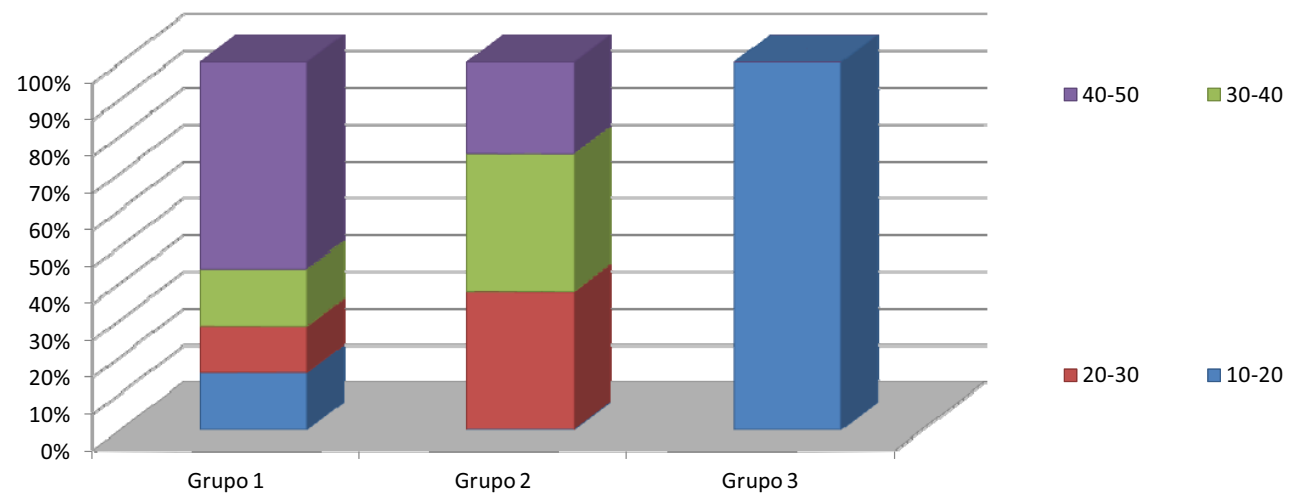

Gráfico 15 K.1 Gráfico de barras empilhadas da variável Nível por grupo do sítio Jacarezinho.

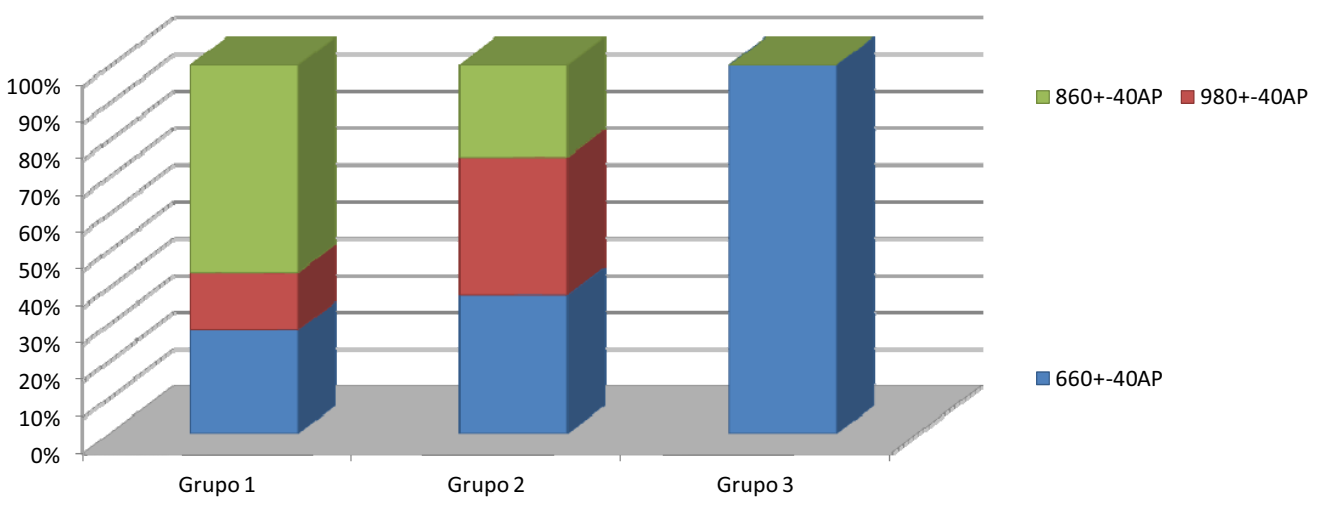

Gráfico 15 K.2 Gráfico de barras empilhadas da variável Datação por grupo do sítio Jacarezinho. 


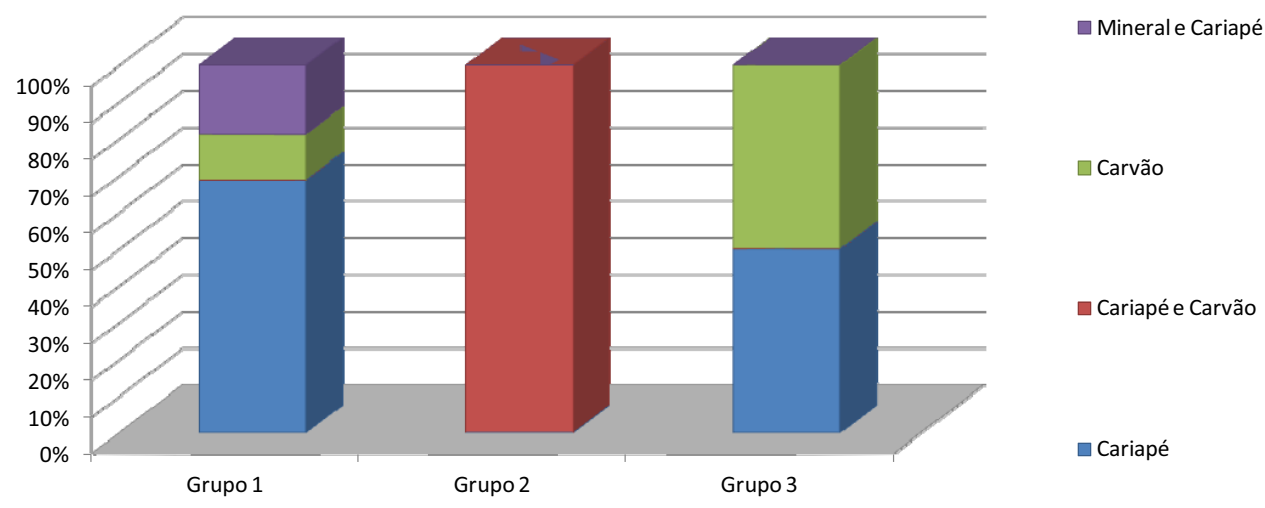

Gráfico 15 K.3 Gráfico de barras empilhadas da variável Antiplástico por grupo do sítio Jacarezinho.

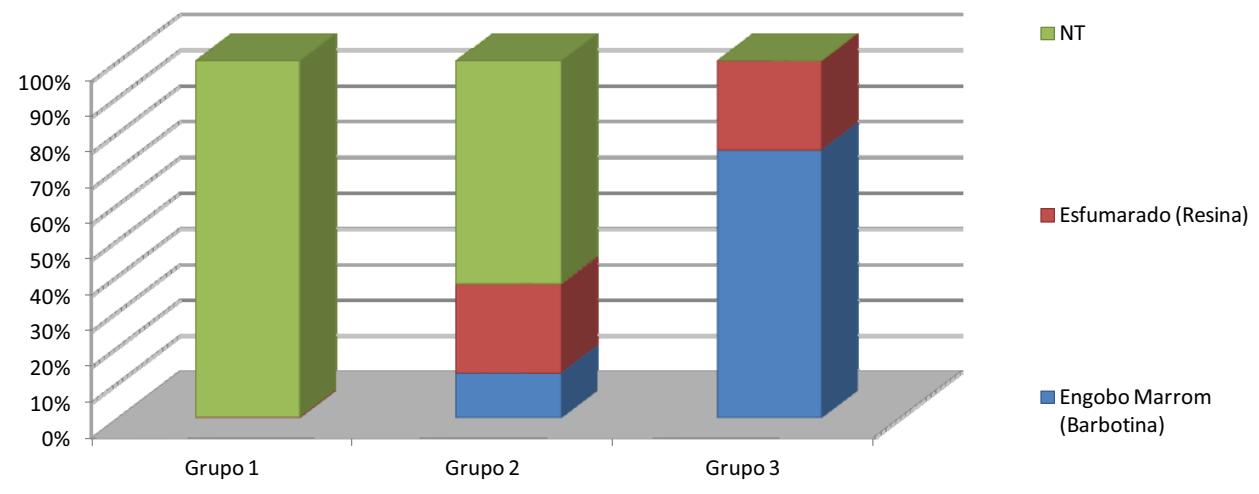

Gráfico 15 K.4 Gráfico de barras empilhadas da variável Tratamento de Superfície FE por grupo do sítio Jacarezinho.

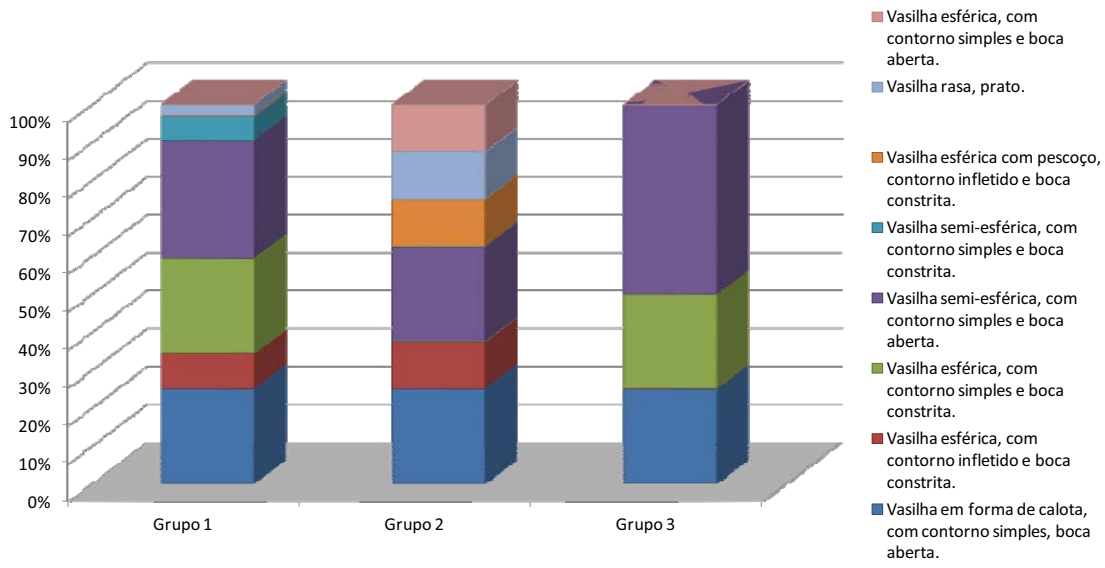

Gráfico 15 K.5 Gráfico de barras empilhadas da variável Forma por grupo do sítio Jacarezinho. 
Anexo 15 L: Tabelas e Gráficos da ANOVA

Tabela 15 L. 1 Tabela de ANOVA para a variável Espessura de Fragmento.

\begin{tabular}{|c|c|c|c|c|c|}
\hline & $\begin{array}{c}\text { GL.de } \\
\text { Liberdade }\end{array}$ & $\begin{array}{c}\text { Soma } \\
\text { Quadrado }\end{array}$ & $\begin{array}{c}\text { Quadrado } \\
\text { Médio }\end{array}$ & $\begin{array}{c}\text { Estatística } \\
\text { F }\end{array}$ & Valor P \\
\hline Sítio & 4 & 4,677 & 1,169 & 137,240 & $<0,00$ \\
\hline Resíduos & 2836 & 24,161 & 0,009 & & \\
\hline
\end{tabular}

Tabela 15 L. 2 Tabela de ANOVA para a variável Espessura do Fragmento no sítio Teotônio.

\begin{tabular}{|c|ccccc|}
\hline & $\begin{array}{c}\text { GL.de } \\
\text { Liberdade }\end{array}$ & $\begin{array}{c}\text { Soma } \\
\text { Quadrado }\end{array}$ & $\begin{array}{c}\text { Média } \\
\text { Quadrado }\end{array}$ & $\begin{array}{c}\text { Estatística } \\
\mathbf{F}\end{array}$ & Valor $\mathbf{P}$ \\
\hline Nível & 6 & 0,211 & 0,035 & 1,407 & 0,228 \\
\hline Resíduos & 57 & 1,142 & 0,025 & & \\
\hline
\end{tabular}

Tabela 15 L. 3 Tabela de ANOVA para a variável Volume no sítio Associação Calderita.

\begin{tabular}{|c|ccccc|}
\hline & $\begin{array}{c}\text { GL.de } \\
\text { Liberdade }\end{array}$ & $\begin{array}{c}\text { Soma } \\
\text { Quadrado }\end{array}$ & $\begin{array}{c}\text { Média } \\
\text { Quadrado }\end{array}$ & $\begin{array}{c}\text { Estatística } \\
\text { F }\end{array}$ & Valor P \\
\hline Datação & 1 & 0,198 & 0,198 & 0,169 & 0,683 \\
\hline Resíduos & 45 & 52,630 & 1,170 & & \\
\hline
\end{tabular}

Tabela 15 L. 4 Tabela de ANOVA para a variável Volume no sítio Jacarezinho.

\begin{tabular}{|c|c|c|c|c|c|}
\hline & $\begin{array}{c}\text { GL.de } \\
\text { Liberdade }\end{array}$ & $\begin{array}{c}\text { Soma } \\
\text { Quadrado }\end{array}$ & $\begin{array}{c}\text { Média } \\
\text { Quadrado }\end{array}$ & $\begin{array}{c}\text { Estatística } \\
\text { F }\end{array}$ & Valor $\mathbf{P}$ \\
\hline Datação & 2 & 1,342 & 0,671 & 0,515 & 0,602 \\
\hline Resíduos & 39 & 50,842 & 1,304 & & \\
\hline
\end{tabular}



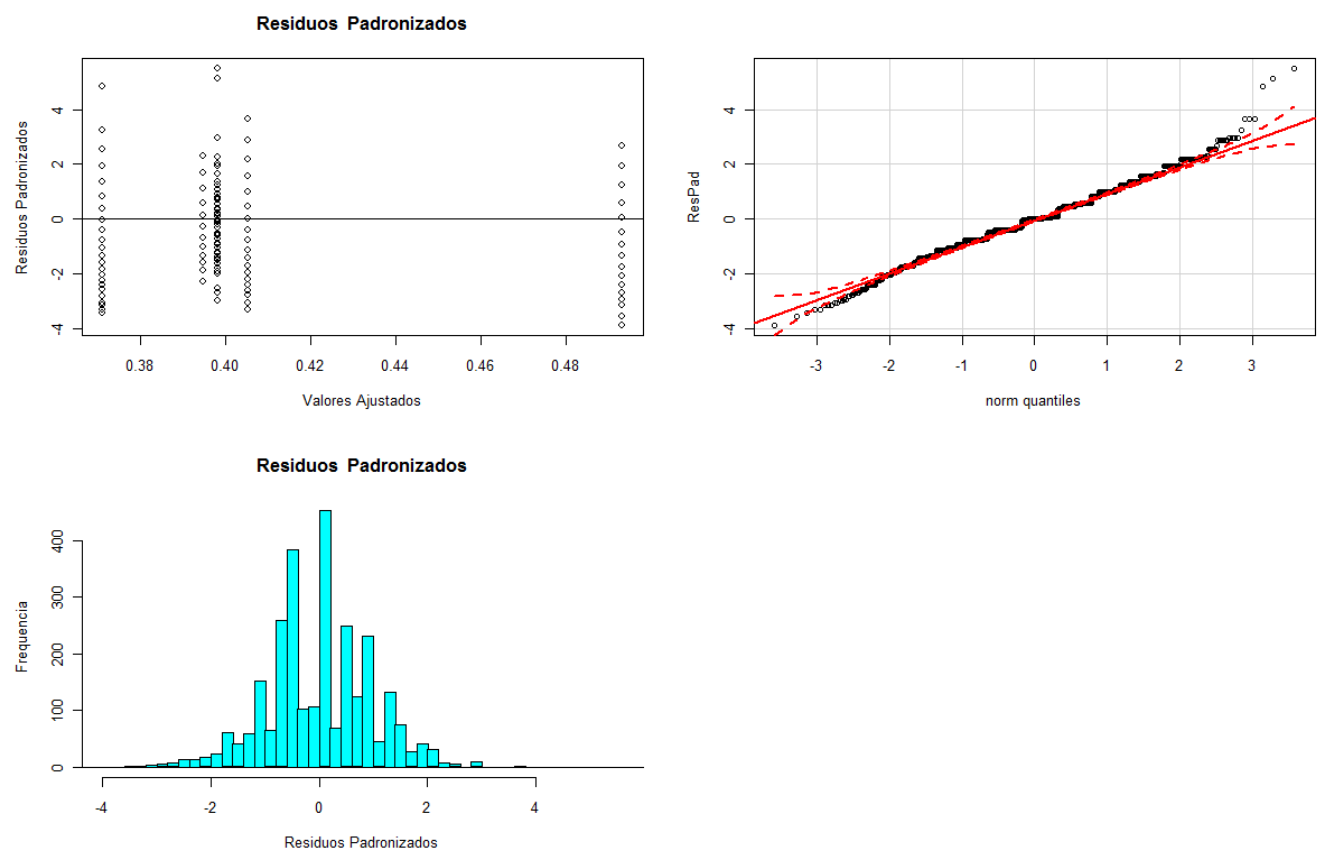

Gráfico 15 L.1 Gráfico dos resíduos do Espessura de Fragmento.

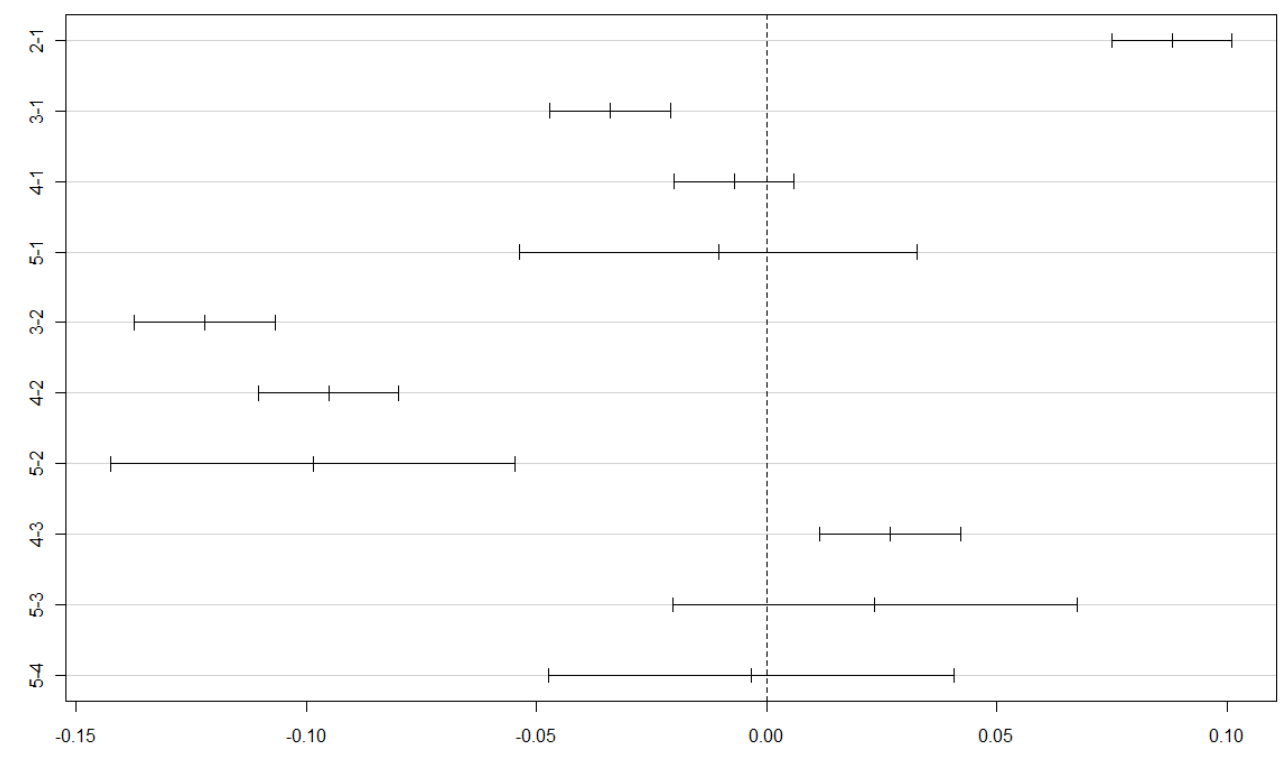

Gráfico 15 L. 2 Gráfico de teste de Tukey da Espessura de Fragmento. 

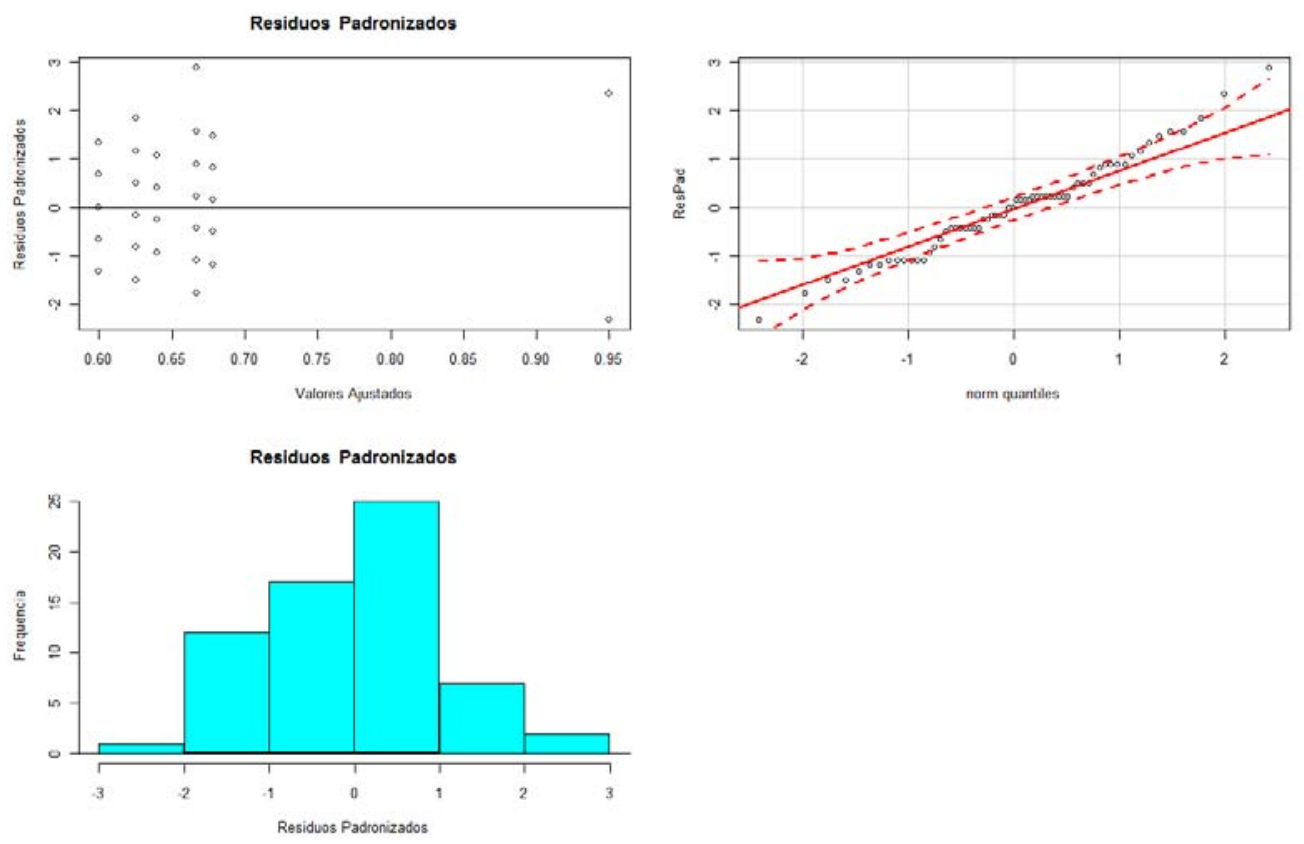

Gráfico 15 L. 3 Gráfico dos resíduos da Espessura de Fragmento no sítio Teotônio.
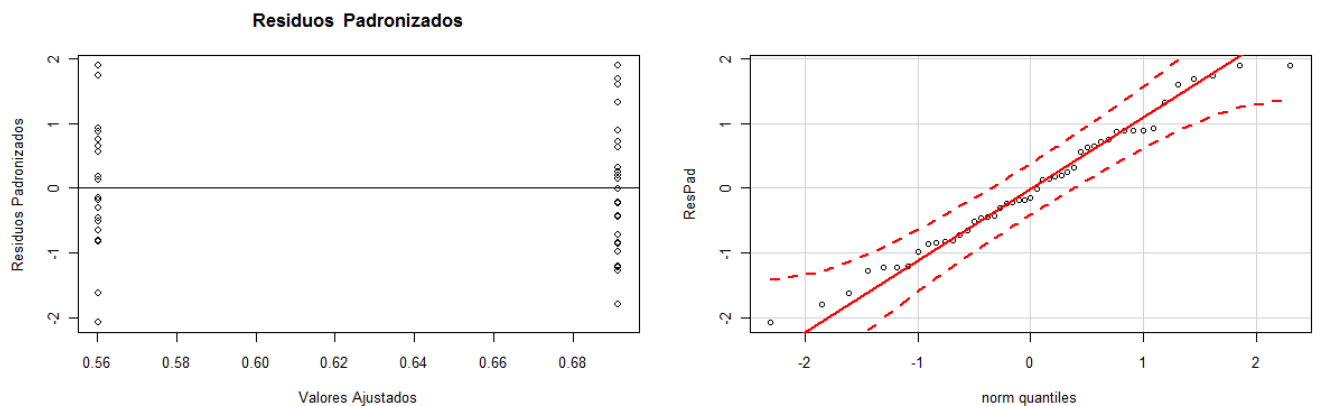

Residuos Padronizados

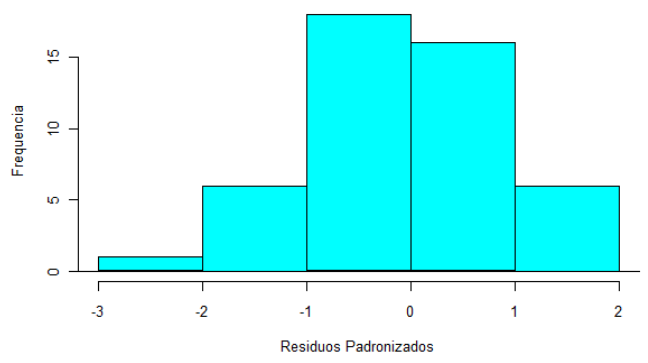

Gráfico 15 L. 4 Gráfico dos resíduos do Volume no sítio Associação Calderita. 

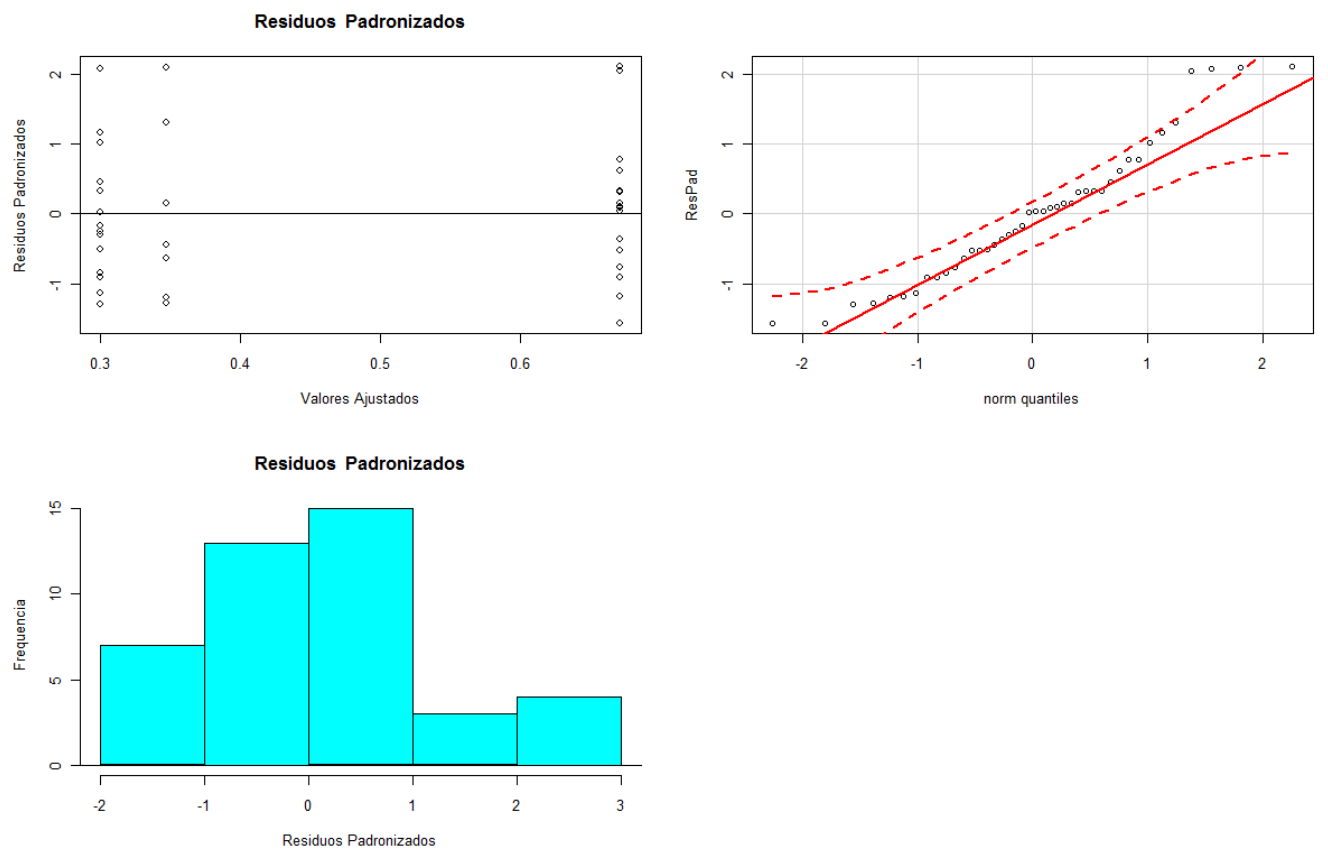

Gráfico 15 L. 5 Gráfico dos resíduos do Volume no sítio Jacarezinho. 
Anexo15 M Cálculo da Distância utilizada na análise de agrupamentos

Podemos dividir o cálculo das distâncias utilizadas na análise de agrupamentos em 2 passos, são eles:

\section{$1^{\circ}$. Passo}

Transformar as categorias das variáveis quantitativas em variáveis dummies, ou seja, a variável vai receber o valor 1 se a peça possuir aquela característica, 0 se a peça não possuir ou -1000 se a peça não tiver informação sobre essa variável. Para as variáveis quantitativas foi utilizada a seguinte padronização:

$$
Z=\frac{x-x_{\min }}{x_{\max }-x_{\min }}
$$

em que

$x$ é o valor observado para a peça;

$x_{\min }$ é o menor valor observado para a variável;

$x_{\max }$ é o maior valor observado para a variável.

Com isso, a variável transformada possui valores entre 0 e 1 e com isso pode compor conjuntamente com as variável qualitativas a medida de distancia.

\section{$2^{\circ}$. Passo}

Variáveis ajustadas, calcular a distância entre peças:

$$
\begin{gathered}
D_{k l}=\frac{\sum_{i=1}^{N}\left|x_{k i}-x_{l i}\right|}{n_{k l}}, \text { se } x_{k i} \text { e } x_{l i} \neq-1000 \text {, ou } x_{k i} \neq x_{l i} \text {, ou } x_{k i}=x_{l i}=1 \\
\text { e } k \neq l,
\end{gathered}
$$

em que

$D_{k l}$ é a distância entre a k-ésima e a i-ésima peça;

$x_{k i}$ é o valor da i-ésima variável da k-ésima peça;

$n_{k l}$ é o numero de variável que foram contabilizadas na soma.

\section{Exemplo:}

Suponha que temos 4 peças de cerâmica e queremos agrupá-las (Tabela 5.4.1). Primeiramente fazemos a transformação das variáveis qualitativas em variáveis dummies, como a variável Espessura do Antiplástico possui 4 categorias e a variável Técnica de Manufatura 3, criamos 7 dummies. A Tabela 5.4.2 mostra as novas variáveis para as 4 peças consideradas. Em seguida, a título de exemplo, calculamos a distância entre as peças 1 e 2 . 


$$
D_{12}=\frac{|1-0|+|0-1|}{2}=\frac{1+1}{2}=\frac{2}{2}=1,
$$

pois, para a variável Espessura do Antiplástico, a peça 1 é menor que $1 \mathrm{~mm}$ e a peça 2 possui entre $3 \mathrm{~mm}$ e $5 \mathrm{~mm}$. Já a variável Técnica de Manufatura não foi considerada pois a peça 2 não tem essa informação.

A diferença entre as peças 1 e 3 é

$$
D_{13}=\emptyset \text {, }
$$

porque a peça 3 não possui informação para nenhuma das variáveis.

A distância entre as peças 1 e 4 é

$$
D_{14}=\frac{|1-1|+|1-0|+|0-1|}{3}=\frac{0+1+1}{3}=\frac{2}{3}=0,66,
$$

Pois, para a variável Espessura do Antiplástico, as peças 1 e 4 são menores que $1 \mathrm{~mm}$. Já para a variável Técnica de Manufatura, a peça 1 é da categoria Acordelada e a peça 4 da categoria Modelada.

Tabela M.1 Peças do calculo de distância

\begin{tabular}{|c|c|c|c|c|c|c|c|}
\hline & \multicolumn{4}{|c|}{ Espessura do Antiplástico } & \multicolumn{3}{|c|}{ Técnica de Manufatura } \\
\hline Peça & $\begin{array}{c}\text { Menor que } \\
1 \mathrm{~mm}\end{array}$ & $\begin{array}{c}\text { Entre } \\
1 \mathrm{~mm} \mathrm{e} \\
3 \mathrm{~mm}\end{array}$ & $\begin{array}{c}\text { Entre } 3 \mathrm{~mm} \\
\text { e } 5 \mathrm{~mm}\end{array}$ & $\begin{array}{c}\text { Maior ou } \\
\text { igual a } \\
5 \mathrm{~mm}\end{array}$ & Acordelada & Modelada & Placas \\
\hline 1 & 1 & 0 & 0 & 0 & 1 & 0 & 0 \\
\hline 2 & 0 & 0 & 1 & 0 & -1000 & -1000 & -1000 \\
\hline 3 & -1000 & -1000 & -1000 & -1000 & -1000 & -1000 & -1000 \\
\hline 4 & 1 & 0 & 0 & 0 & 0 & 1 & 0 \\
\hline
\end{tabular}

\begin{tabular}{|c|c|c|}
\hline Peça & $\begin{array}{c}\text { Espessura do } \\
\text { Antiplástico }\end{array}$ & $\begin{array}{c}\text { Técnica de } \\
\text { Manufatura }\end{array}$ \\
\hline 1 & Menor que $1 \mathrm{~mm}$ & Acordelada \\
2 & Entre $3 \mathrm{~mm}$ e $5 \mathrm{~mm}$ & $\mathrm{NI}$ \\
3 & $\mathrm{NI}$ & $\mathrm{NI}$ \\
4 & Menor que $1 \mathrm{~mm}$ & Modelada \\
\hline
\end{tabular}

Tabela M.2 Transformação em variáveis dummies. 


\section{ANEXO 16}

Comparação das bordas
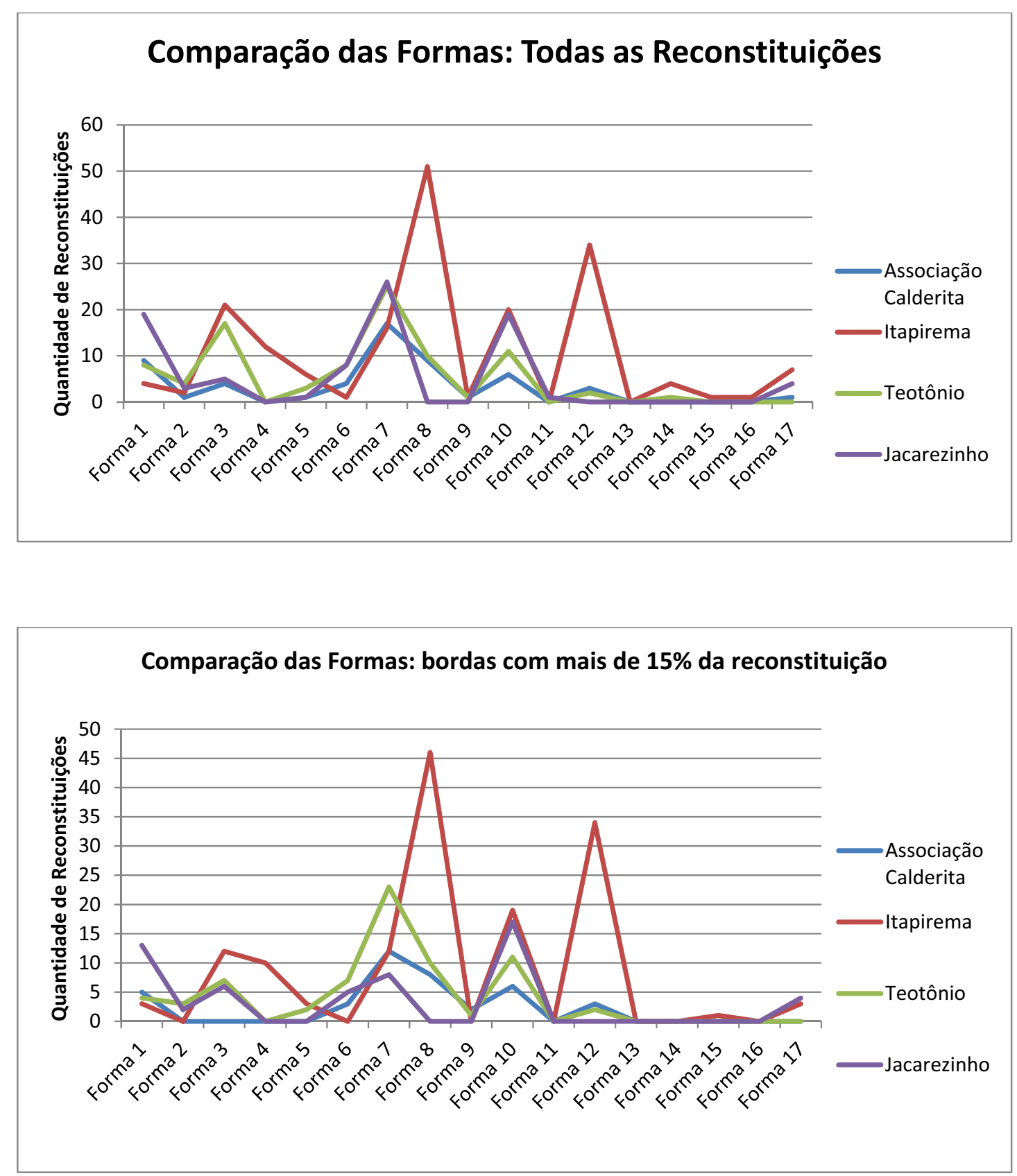


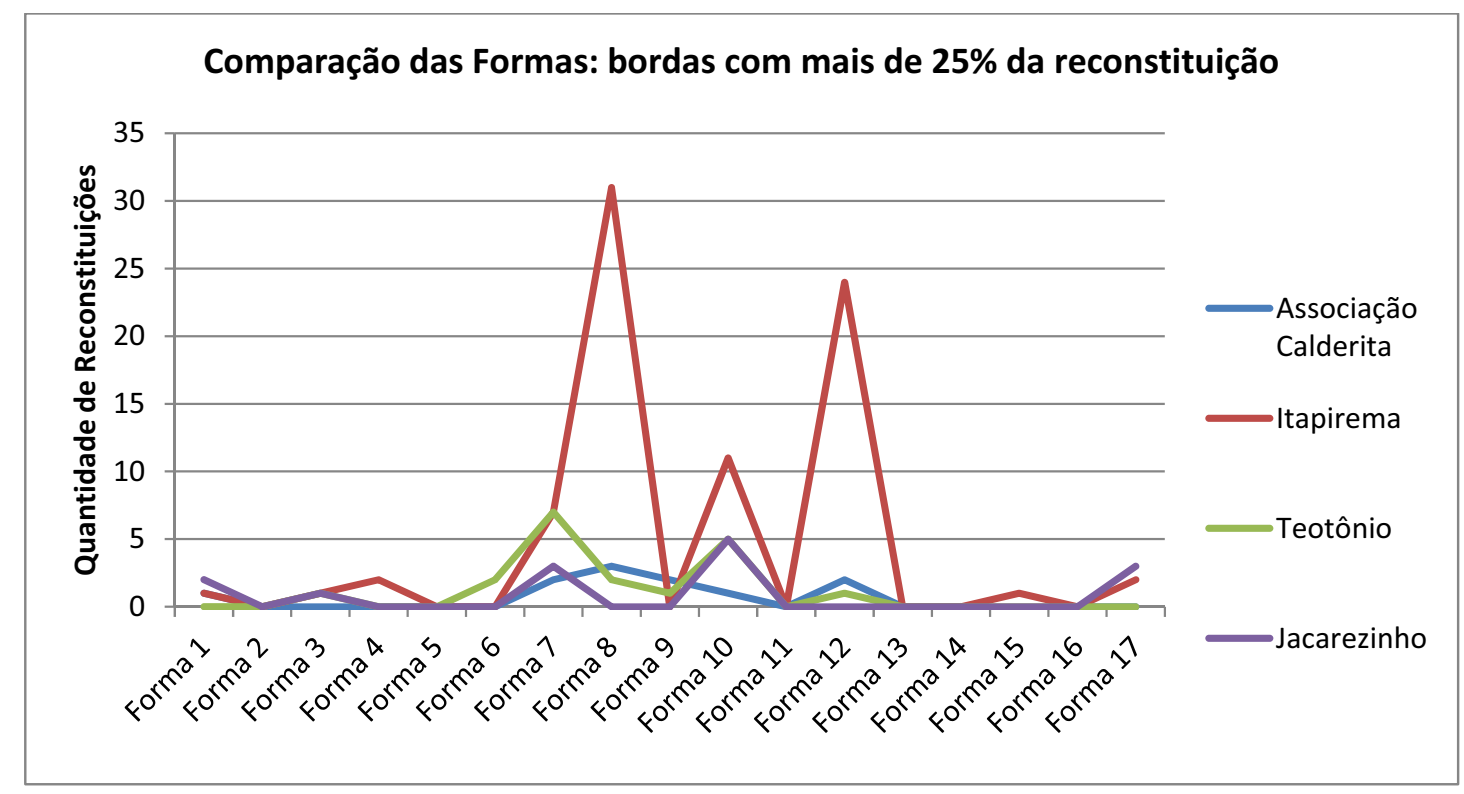

ANEXO 17

Paleobotânica do sítio Teotônio
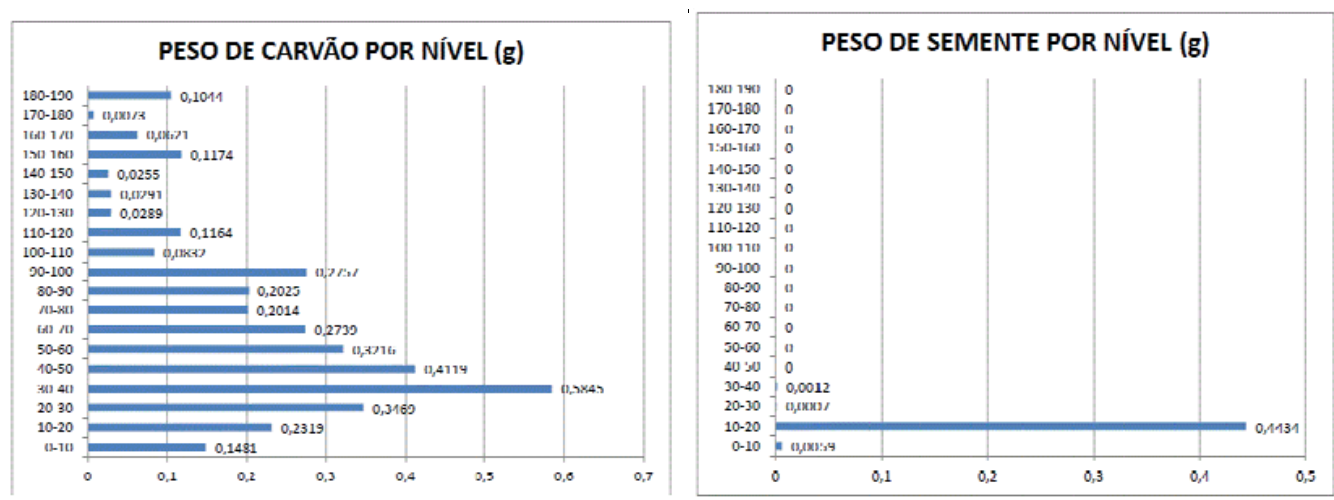
ANEXO 18 

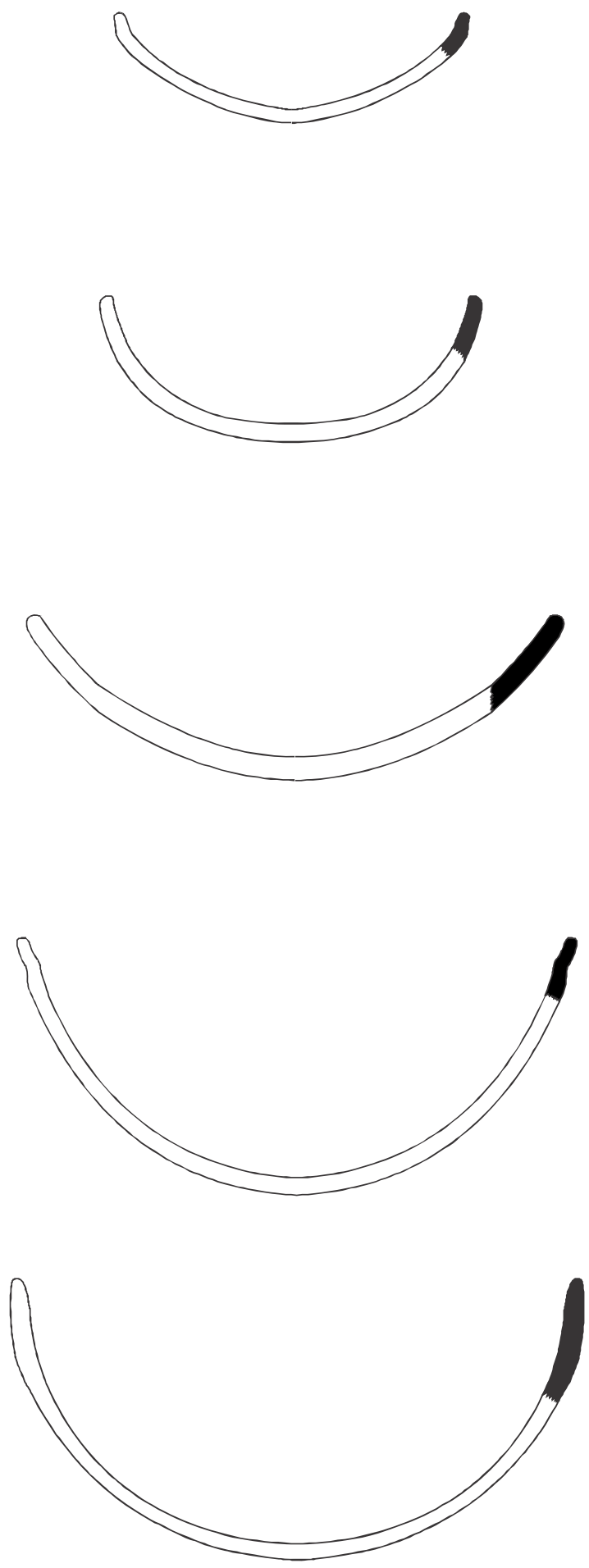

\section{PALMA}

S. Associação Calderita PN 01-05

Diâmetro $30 \mathrm{~cm}$

Volume 5,31L

S. Associação Calderita PN102-90

Diâmetro $30 \mathrm{~cm}$

Volume 4,3L

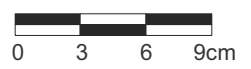

PALMA

Sítio Associação

Surfer 1

Calderita

Distribuição Espacial da Cerâmica 
Consumo

Coletivo
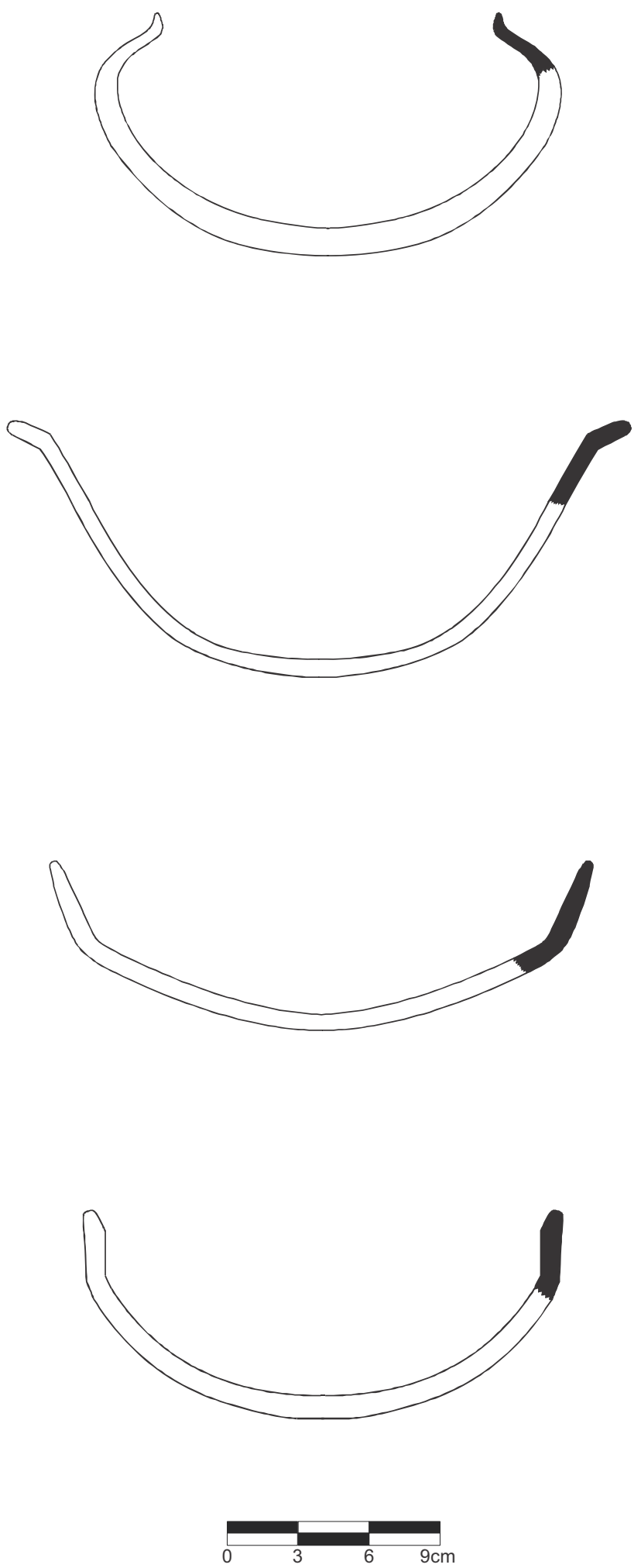

PALMA

S. Associação Calderita PN104-75

Diâmetro $14 \mathrm{~cm}$

Volume 1,44L

PALMA

S. Associação Calderita PN 53-108

Diâmetro $25 \mathrm{~cm}$

Volume 2,35L

PALMA

S. Associação Calderita PN 55-42

Diâmetro $22 \mathrm{~cm}$

Volume 1,43L

PALMA

S. Associação Calderita PN 55-9

Diâmetro $19 \mathrm{~cm}$

Volume 1,5L

\section{PALMA}

Sítio Associação Calderita

Surfer 2

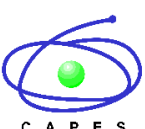

Distribuição Espacial da Cerâmica

CSD MAAE

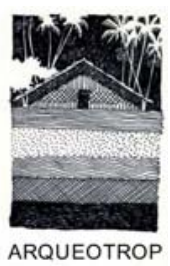




\section{Consumo \\ Individual}

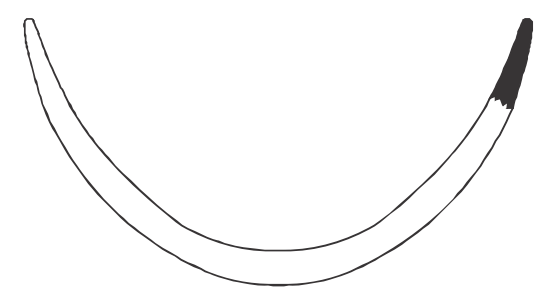

PALMA

S. Associação Calderita PN 103-154

Diâmetro $14 \mathrm{~cm}$

Volume 0,51L

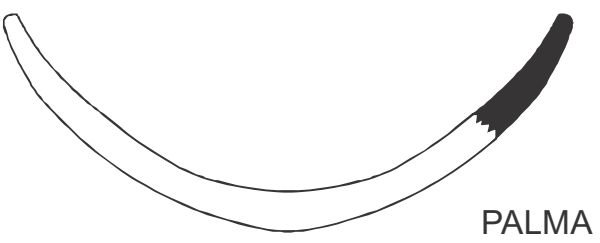

S. Associação Calderita PN 103-151

Diâmetro $16 \mathrm{~cm}$

Volume $0,47 \mathrm{~L}$

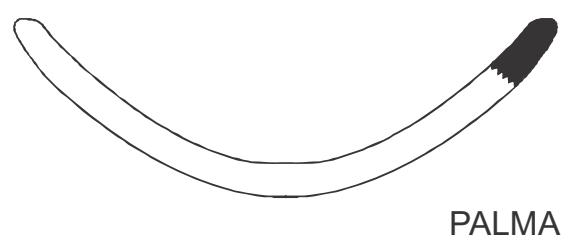

S. Associação Calderita PN 106-19

Diâmetro $14 \mathrm{~cm}$

Volume $0,31 \mathrm{~L}$

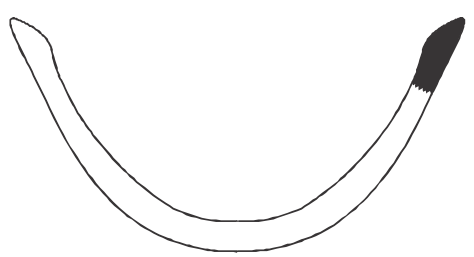

PALMA

S. Associação Calderita PN 103-159

Diâmetro $12 \mathrm{~cm}$

Volume $0,25 \mathrm{~L}$

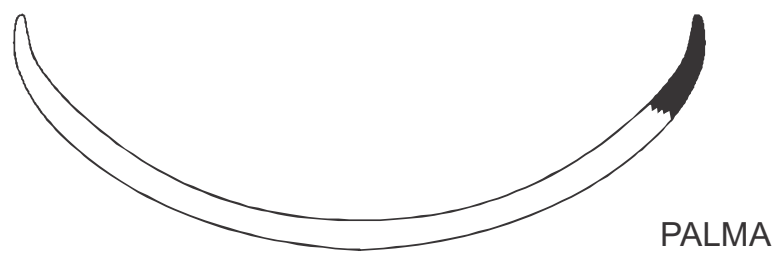

S. Associação Calderita

PN 106-41

Diâmetro $18 \mathrm{~cm}$

Volume $0,83 \mathrm{~L}$

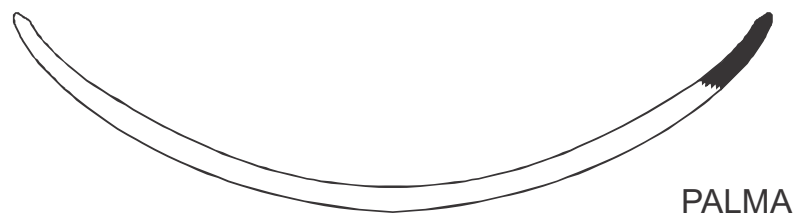

S. Associação Calderita

PN 104-81

Diâmetro $20 \mathrm{~cm}$

Volume $0,73 \mathrm{~L}$

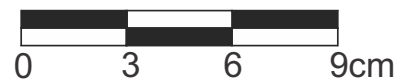

PALMA

Sítio Associação Calderita D JAPESP
Surfer 3

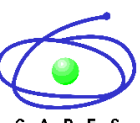

Distribuição Espacial da Cerâmica

TSD MA E

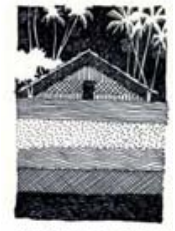

ARQUEOTROP 


\section{Preparo}
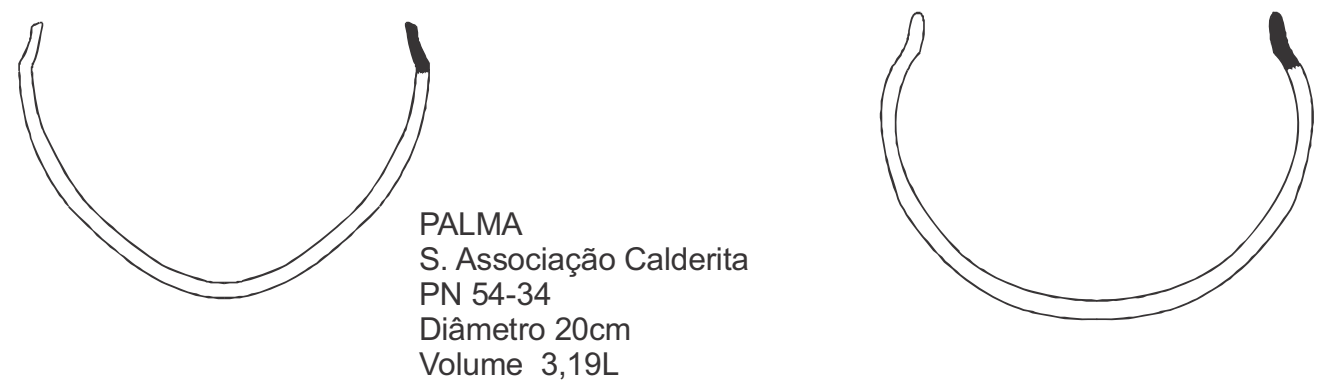

PALMA

S. Associação Calderita PN 55-43

Diâmetro $20 \mathrm{~cm}$

Volume 3,93L

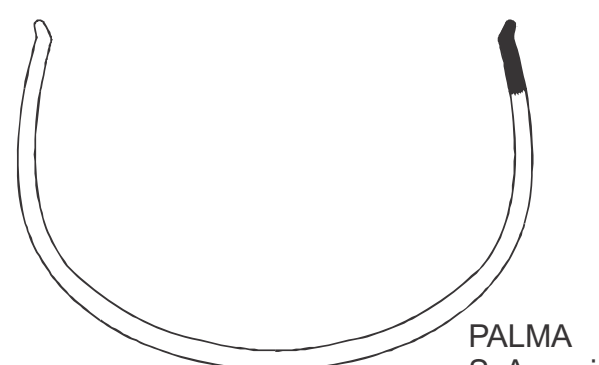

S. Associação Calderita PN 102-104

Diâmetro $26 \mathrm{~cm}$

Volume $6,37 \mathrm{~L}$

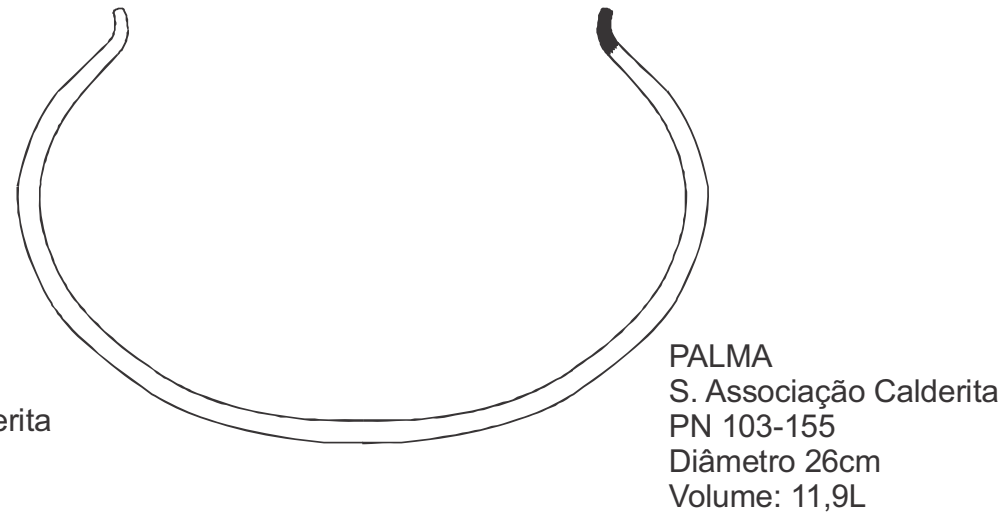

PALMA

S. Associação Calderita PN 1-8

Diâmetro $30 \mathrm{~cm}$ Volume 19,97L

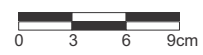

PALMA

Sítio Associação

Calderita

DFAPESP
Surfer 4

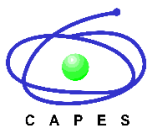

Distribuição Espacial da Cerâmica

TSH MAE

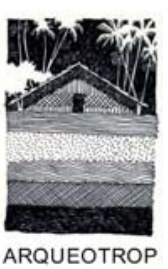




\section{Serviço}
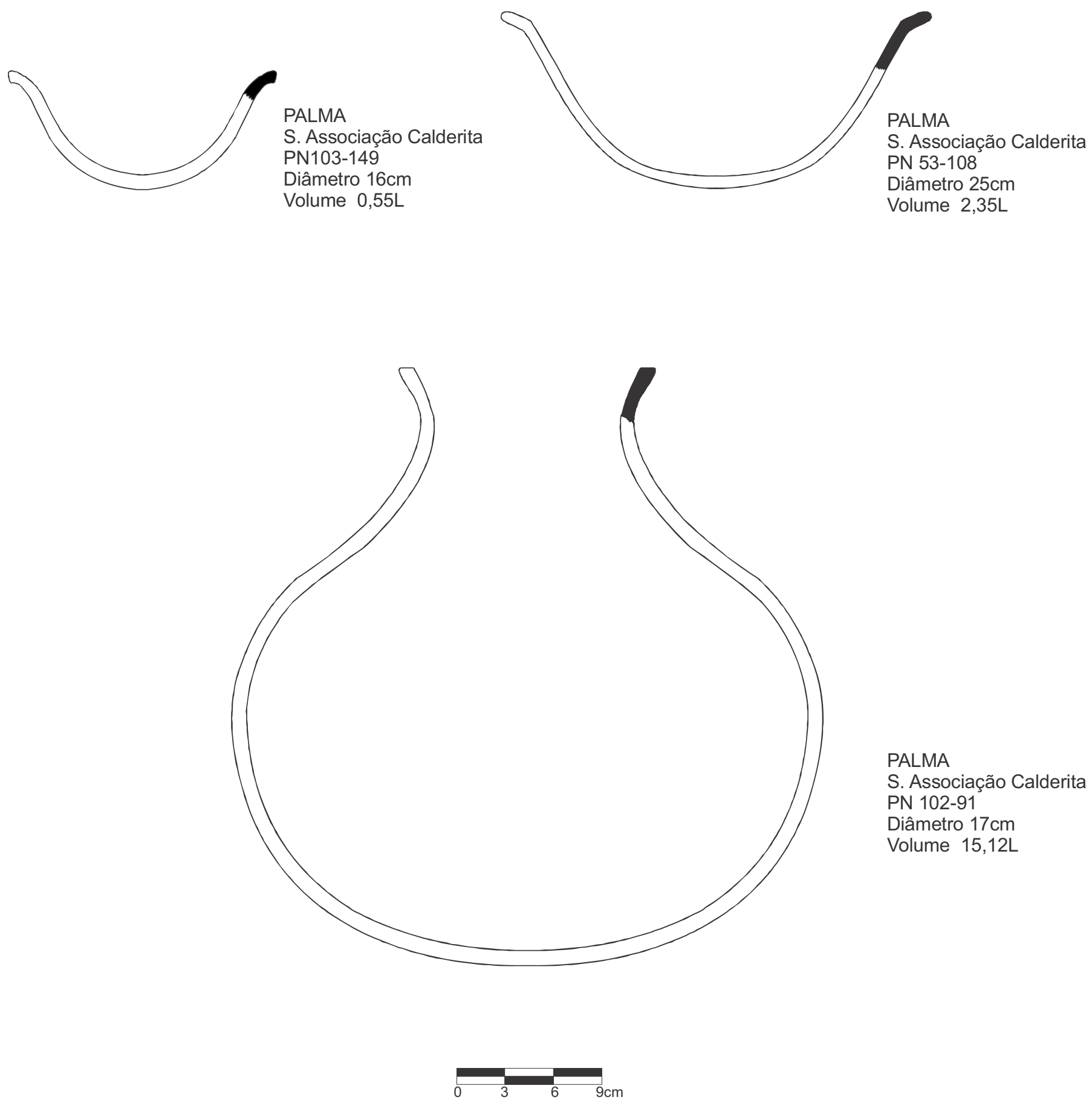

S. Associação Calderita

PN 102-91

Diâmetro $17 \mathrm{~cm}$

Volume $15,12 \mathrm{~L}$

\section{PALMA}

Sítio Associação

Calderita

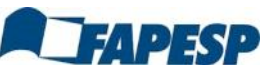

Surfer 5

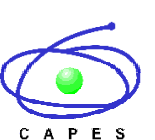

Distribuição Espacial da Cerâmica

TS」 $\mathrm{MAE}$

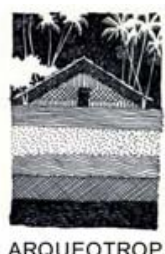

ARQUEOTROP 


\section{Consumo Coletivo}

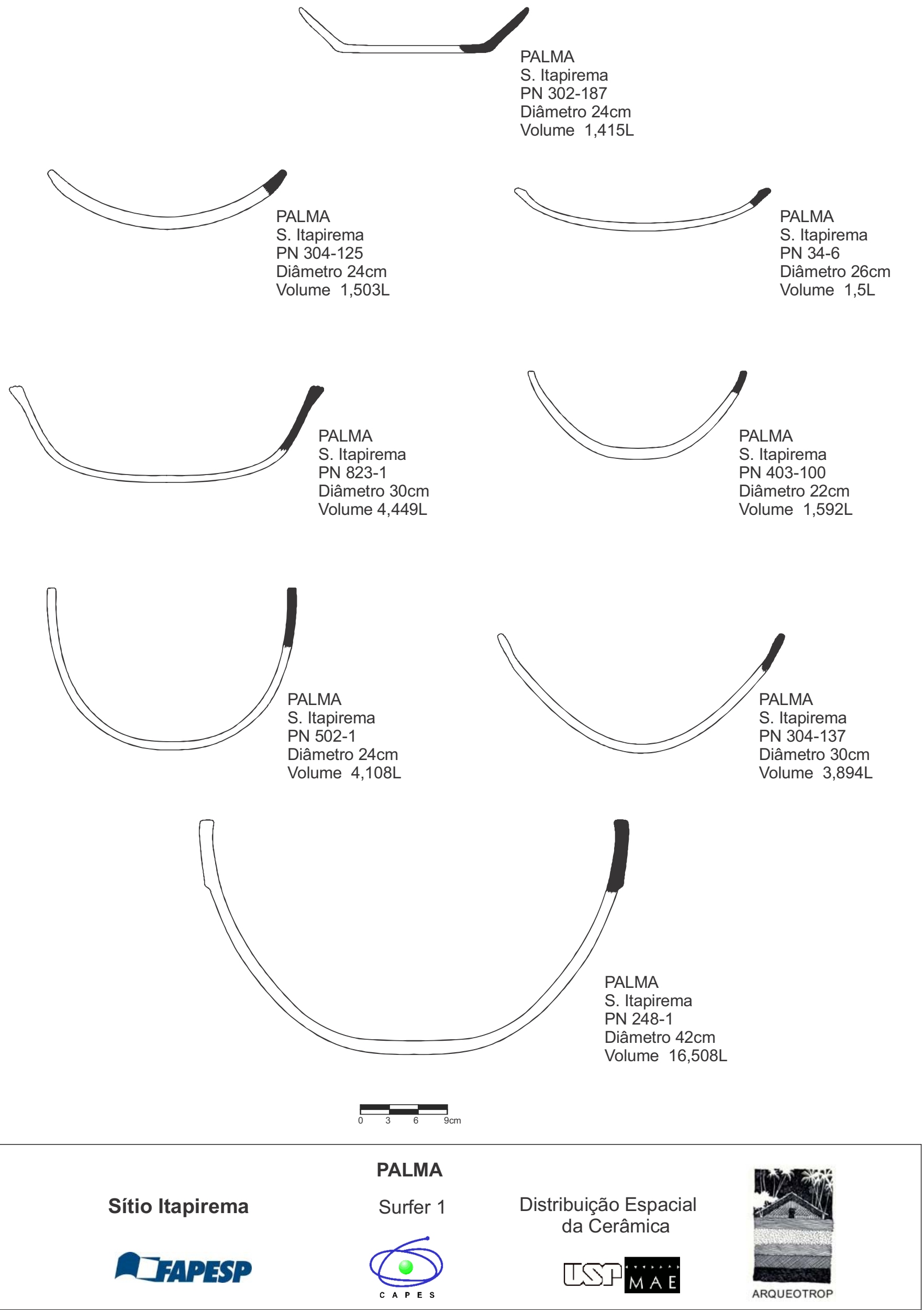




\section{Consumo \\ Individual}

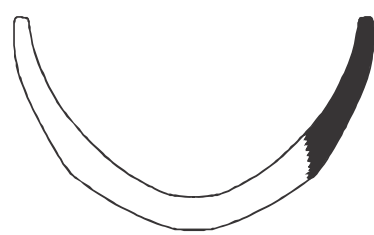

PALMA

S. Itapirema

PN 802-76

Diâmetro $11 \mathrm{~cm}$

Volume $0,335 \mathrm{~L}$

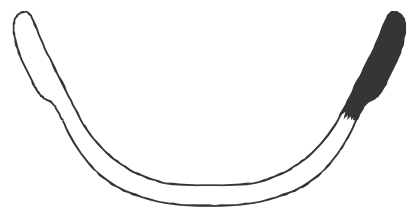

PALMA

S. Itapirema

PN 302-125

Diâmetro $12 \mathrm{~cm}$

Volume $0,37 \mathrm{~L}$
PALMA

S. Itapirema

PN 616-8

Diâmetro $9 \mathrm{~cm}$

Volume 0,195L

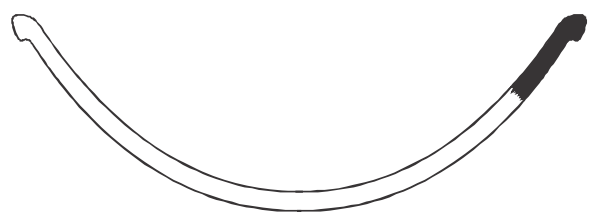

PALMA

S. Itapirema

PN 602-34

Diâmetro $18 \mathrm{~cm}$

Volume $0,761 \mathrm{~L}$

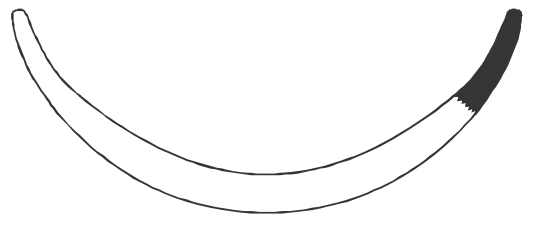

PALMA

S. Itapirema

PN 302-105

Diâmetro $16 \mathrm{~cm}$

Volume $0,62 \mathrm{~L}$

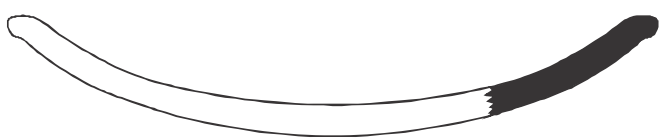

PALMA

S. Itapirema

PN 804-18

Diâmetro $20 \mathrm{~cm}$

Volume $0,644 \mathrm{~L}$

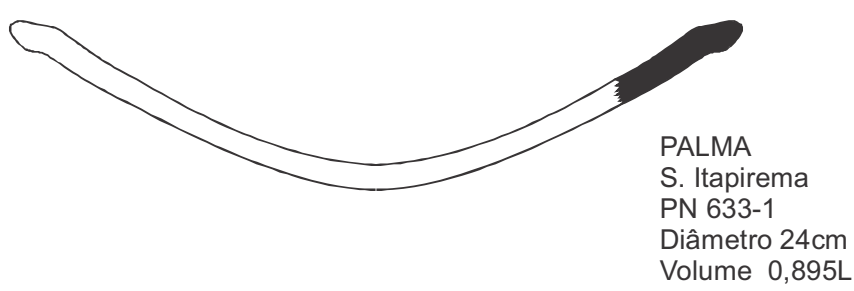

$9 \mathrm{~cm}$

\section{PALMA}

Sítio Itapirema

Surfer 2

Distribuição Espacial da Cerâmica 


\section{Preparo}
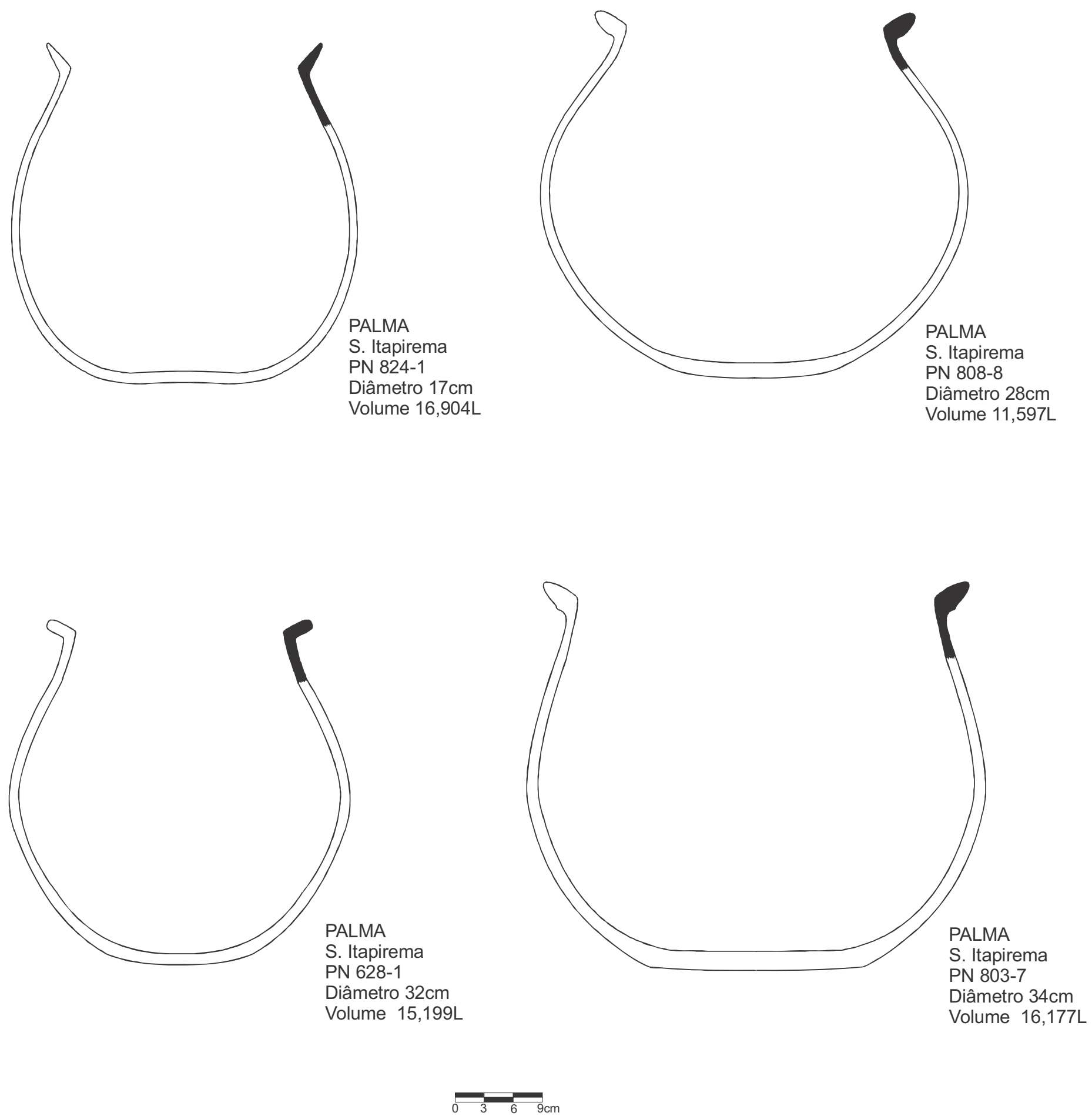

Sítio Itapirema




\section{Preparo}
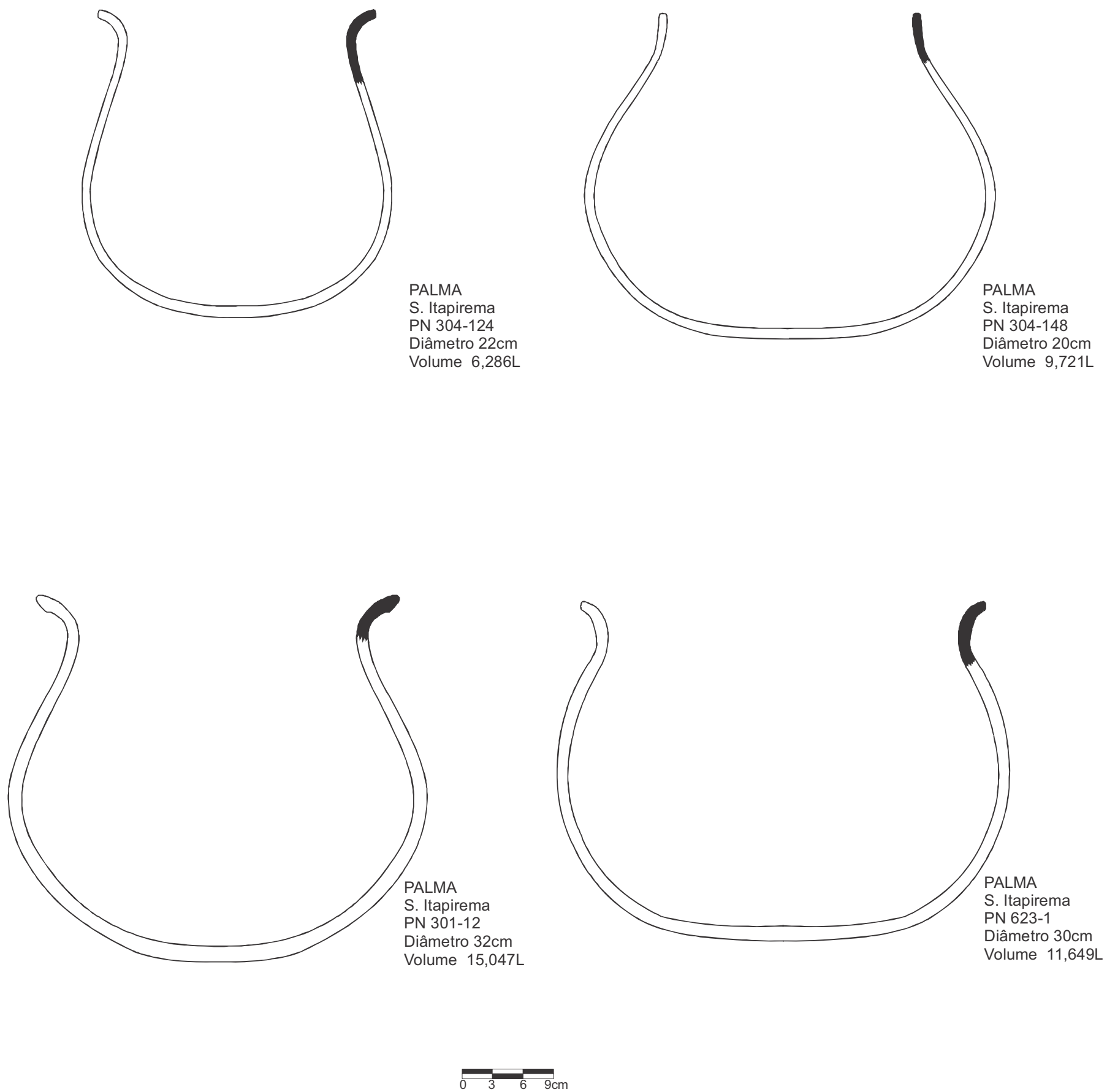

Sítio Itapirema




\section{Serviço}

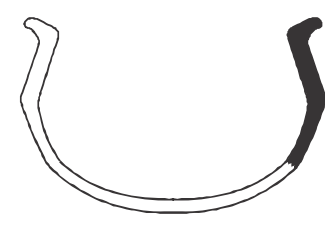

PALMA

S. Itapirema

PN 605-8

Diâmetro $12 \mathrm{~cm}$

Volume $0,716 \mathrm{~L}$

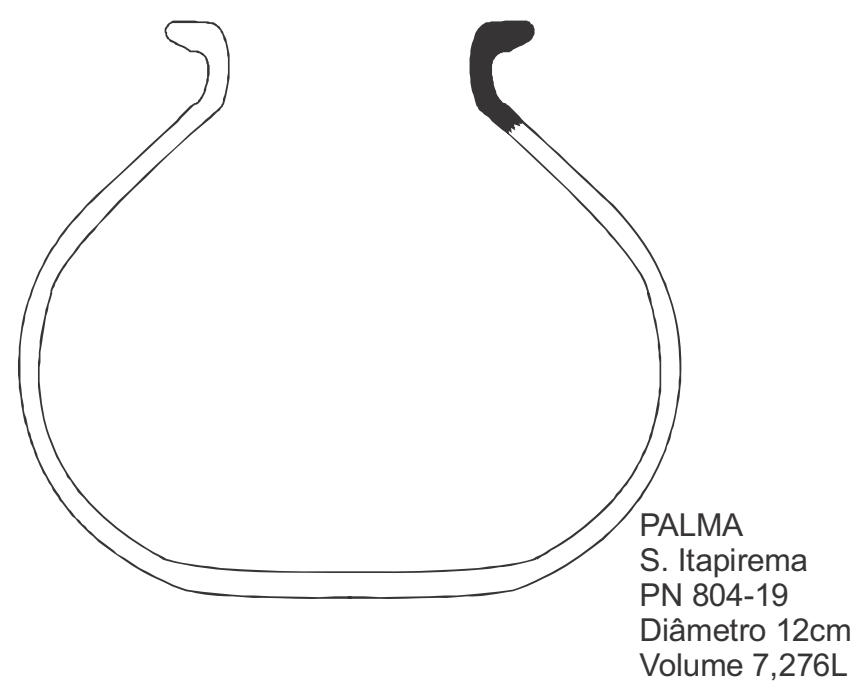

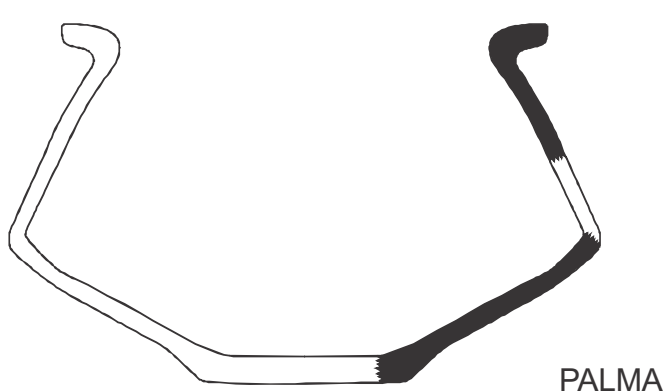

S. Itapirema

PN 611-27/13/2/3/15

Diâmetro $34 \mathrm{~cm}$

Volume 3,608L

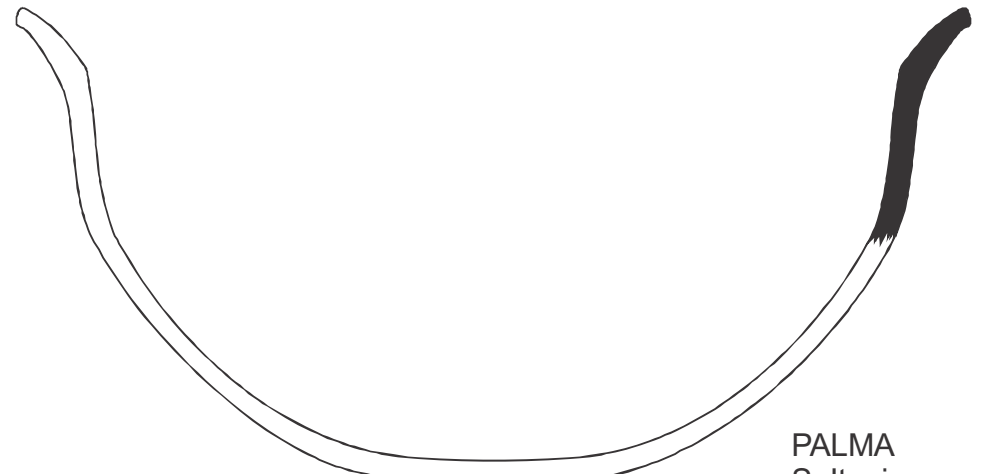

S. Itapirema

PN 319-1

Diâmetro 42cm

Volume 12,61L

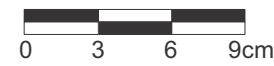

Sítio Itapirema




\section{Serviço}

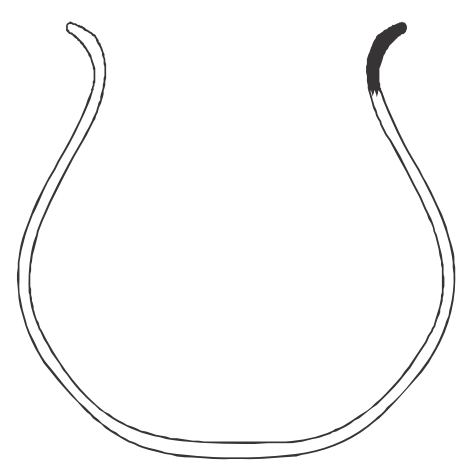

PALMA

S. Itapirema

PN 304-129

Diâmetro $17 \mathrm{~cm}$

Volume 3,819L

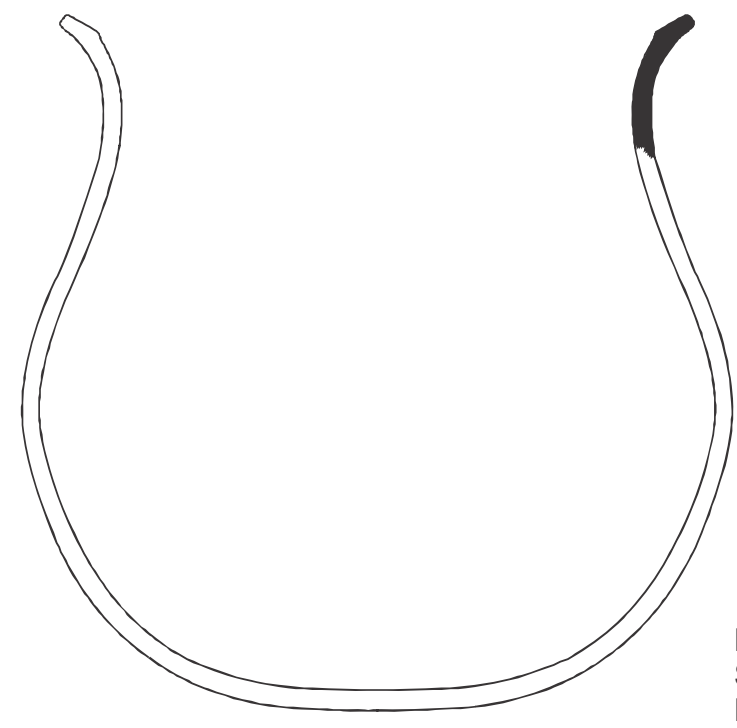

PALMA

S. Itapirema

PN 302-186

Diâmetro $32 \mathrm{~cm}$

Volume $17,704 \mathrm{~L}$

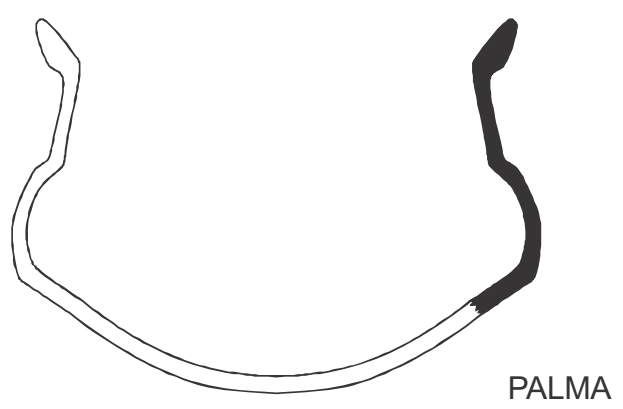

S. Itapirema

PN 826-1

Diâmetro $24 \mathrm{~cm}$

Volume 5,099L

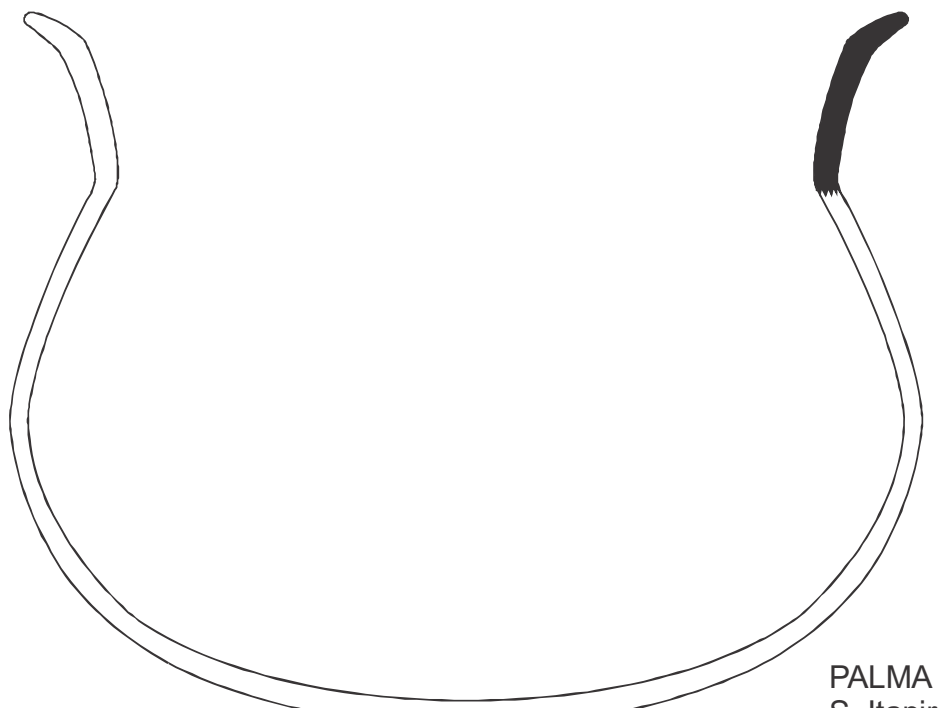

S. Itapirema

PN 303-150

Diâmetro $44 \mathrm{~cm}$

Volume $30,22 \mathrm{~L}$

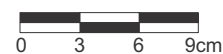

Sítio Itapirema




\section{Consumo}

\section{Coletivo}

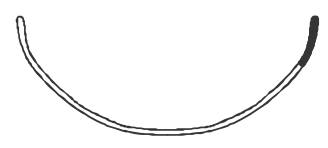

PALMA

Sítio Jacarezinho PN 202A-1

Diâmetro $22 \mathrm{~cm}$

Volume 2,12 L

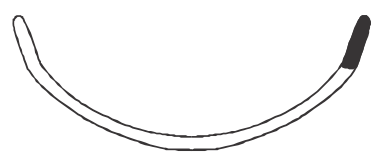

Sítio Jacarezinho PN 202A-7

Diâmetro $26 \mathrm{~cm}$

Volume 2,41 L

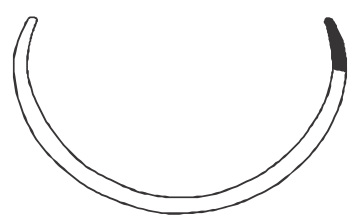

PALMA

Sítio Jacarezinho PN 3-25

Diâmetro $22 \mathrm{~cm}$

Volume 4,18 L

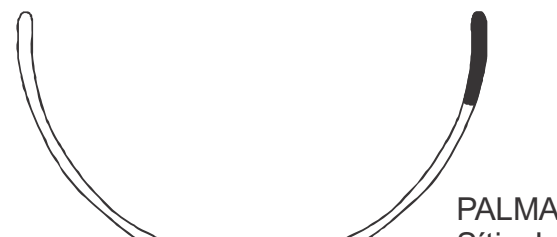

Sítio Jacarezinho PN 502-1

Diâmetro $38 \mathrm{~cm}$

Volume13,26 L

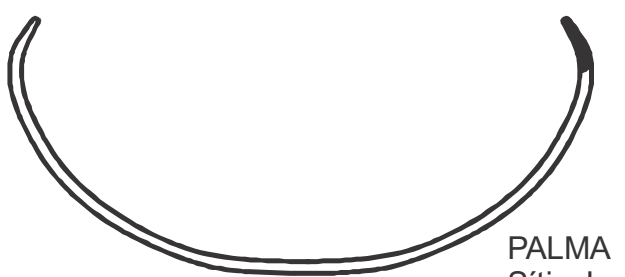

Sítio Jacarezinho PN 305-13

Diâmetro $40 \mathrm{~cm}$

Volume 14,66 L
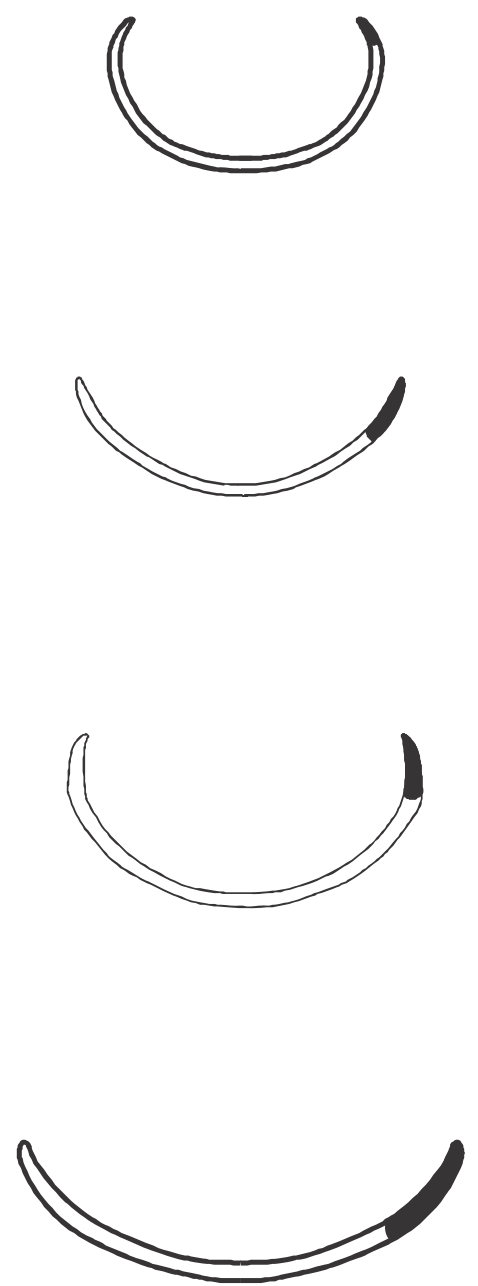

PALMA

Sítio Jacarezinho

PN 503-1

Diâmetro $32 \mathrm{~cm}$

Volume4,64 L

PALMA

Jacarezinho

PN 304-5

iâmetro $16 \mathrm{~cm}$

Volume 1,94 L

PALMA

Sítio Jacarezinho

Diâmetro $24 \mathrm{~cm}$

Volume 2,19 L

Sítio Jacarezinho PN 302-5

Diâmetro $24 \mathrm{~cm}$ Volume 3,42 L

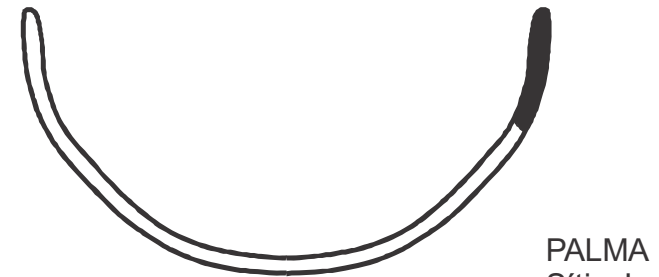

Sítio Jacarezinho PN 400-12

Diâmetro $36 \mathrm{~cm}$ Volume 9,67 L

PALMA

Sítio Jacarezinho
Surfer 1

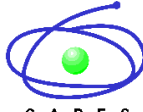

$C A P E S$
Distribuição Espacial da Cerâmica 


\section{Consumo \\ Individual}
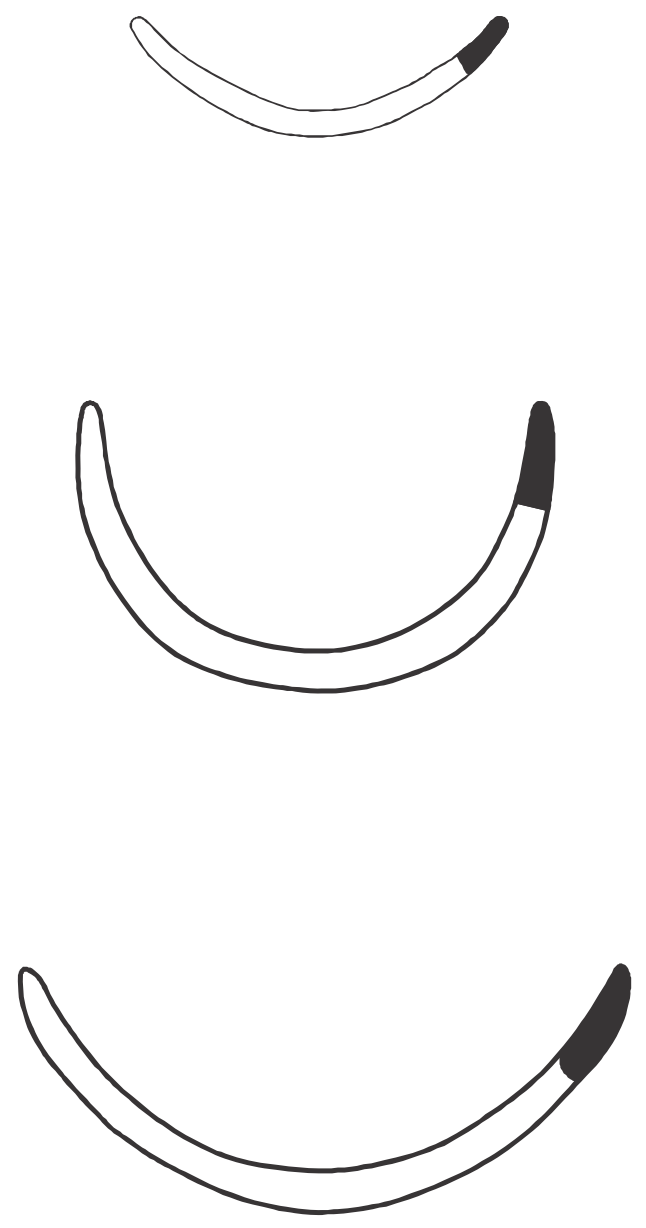

\section{PALMA}

Sítio Jacarezinho PN 303-16

Diâmetro $14 \mathrm{~cm}$ Volume $0,77 \mathrm{~L}$

\section{PALMA}

Sítio Jacarezinho PN 306-11

Diâmetro $18 \mathrm{~cm}$ Volume $0,83 \mathrm{~L}$

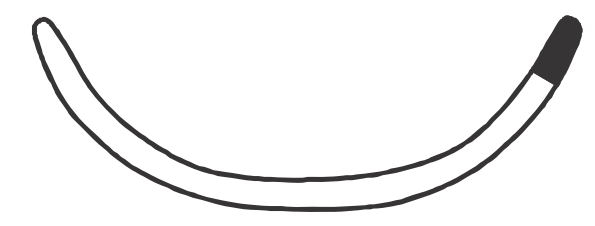

Sítio Jacarezinho

PN 303-17

Diâmetro $16 \mathrm{~cm}$ Volume 0,53 L

PALMA

Sítio Jacarezinho PN 306-12

Diâmetro $20 \mathrm{~cm}$ Volume 1,09 L
Sítio Jacarezinho

PN 103-7

Diâmetro $13 \mathrm{~cm}$

Volume 0,79 L
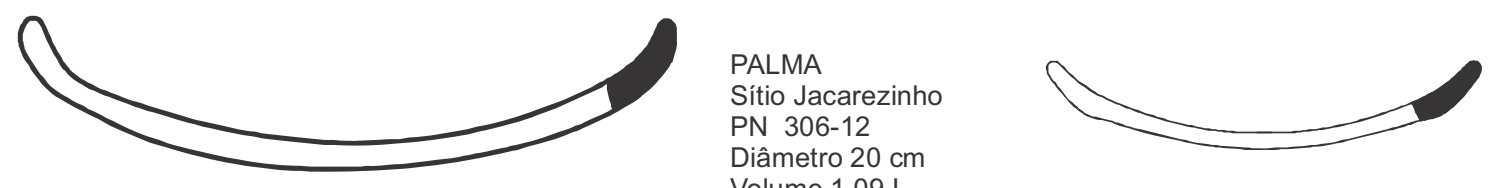

PALMA

Sítio Jacarezinho PN 161-2

Diâmetro $13 \mathrm{~cm}$

Volume $0,2 \mathrm{~L}$
Sítio Jacarezinho 206-17

Diâmetro $14 \mathrm{~cm}$

Volume $0,71 \mathrm{~L}$

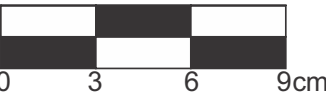

\section{PALMA}

Sítio Jacarezinho
Surfer 2

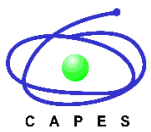

Distribuição Espacial da Cerâmica 


\section{Preparo}

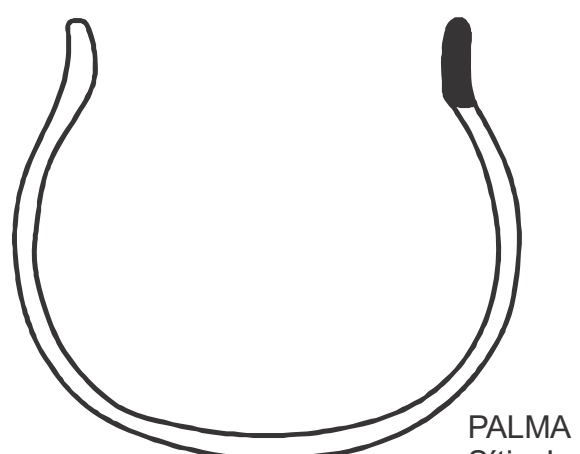

Sítio Jacarezinho PN 306-2

Diâmetro $14 \mathrm{~cm}$

Volume 2,31 L

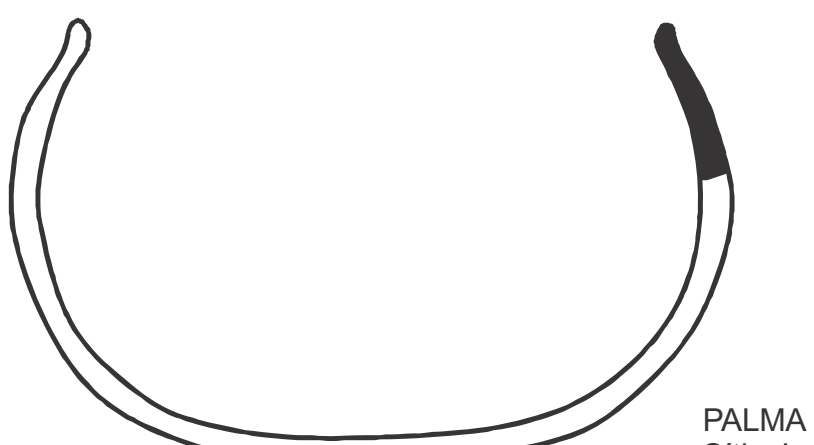

Sítio Jacarezinho PN 306-1

Diâmetro $22 \mathrm{~cm}$

Volume 2,06 L
PALMA

Sítio Jacarezinho PN 206-4

Diâmetro $12 \mathrm{~cm}$ Volume 2,06 L

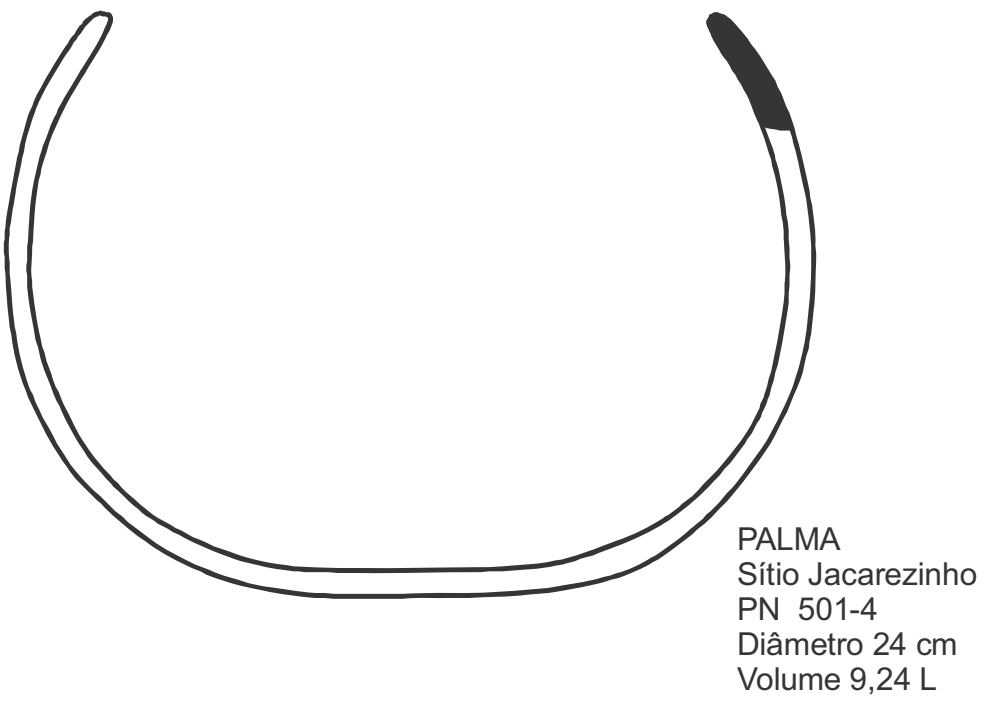

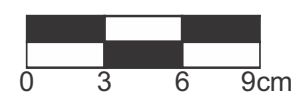

Sítio Jacarezinho PALMA


Serviço

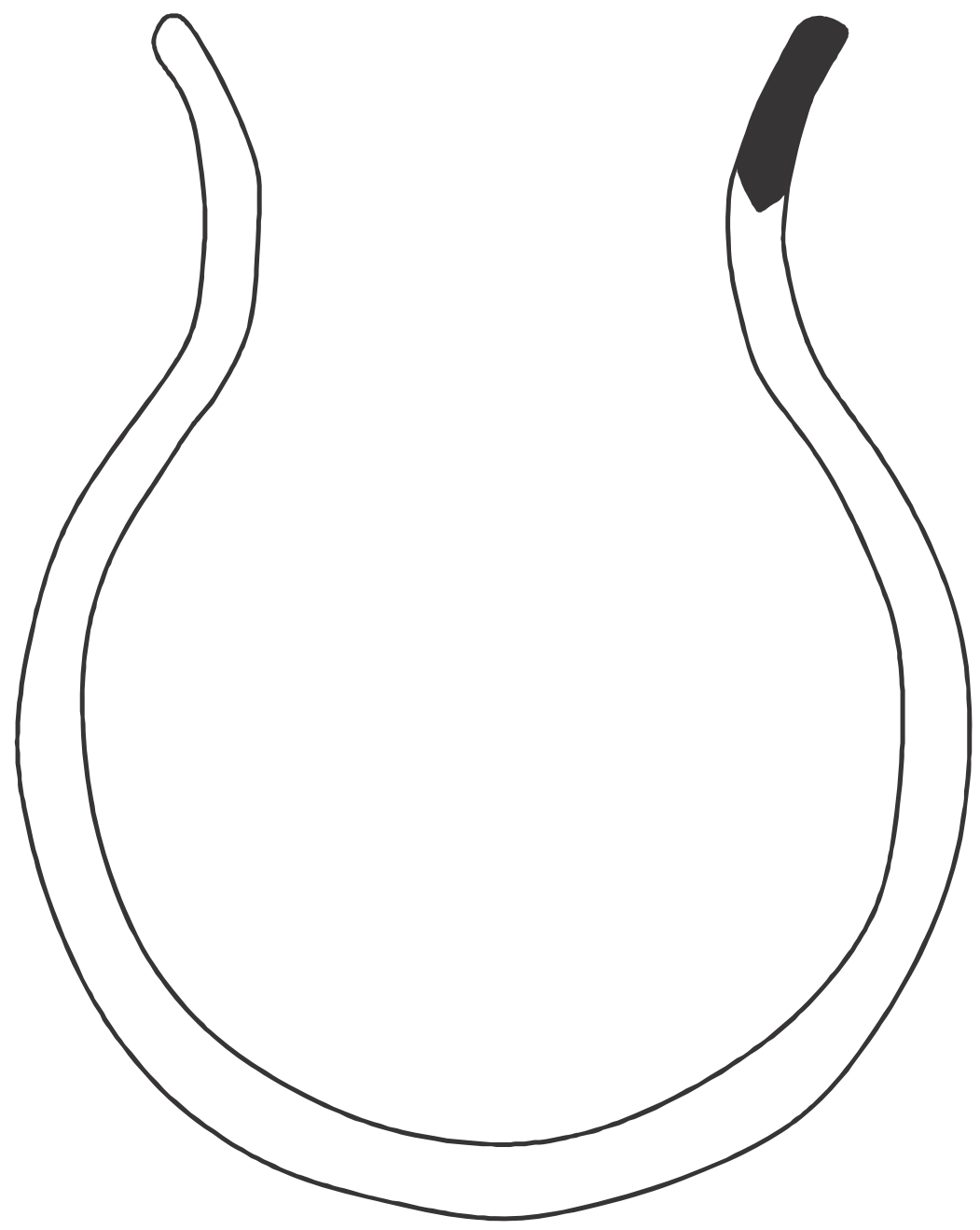

PALMA

Sítio Jacarezinho PN 500-1

Diâmetro $12 \mathrm{~cm}$

Volume 2,15 L

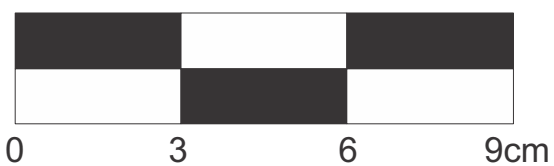

PALMA

Sítio Jacarezinho

Surfer 4

Distribuição Espacial da Cerâmica 
Consumo

Coletivo
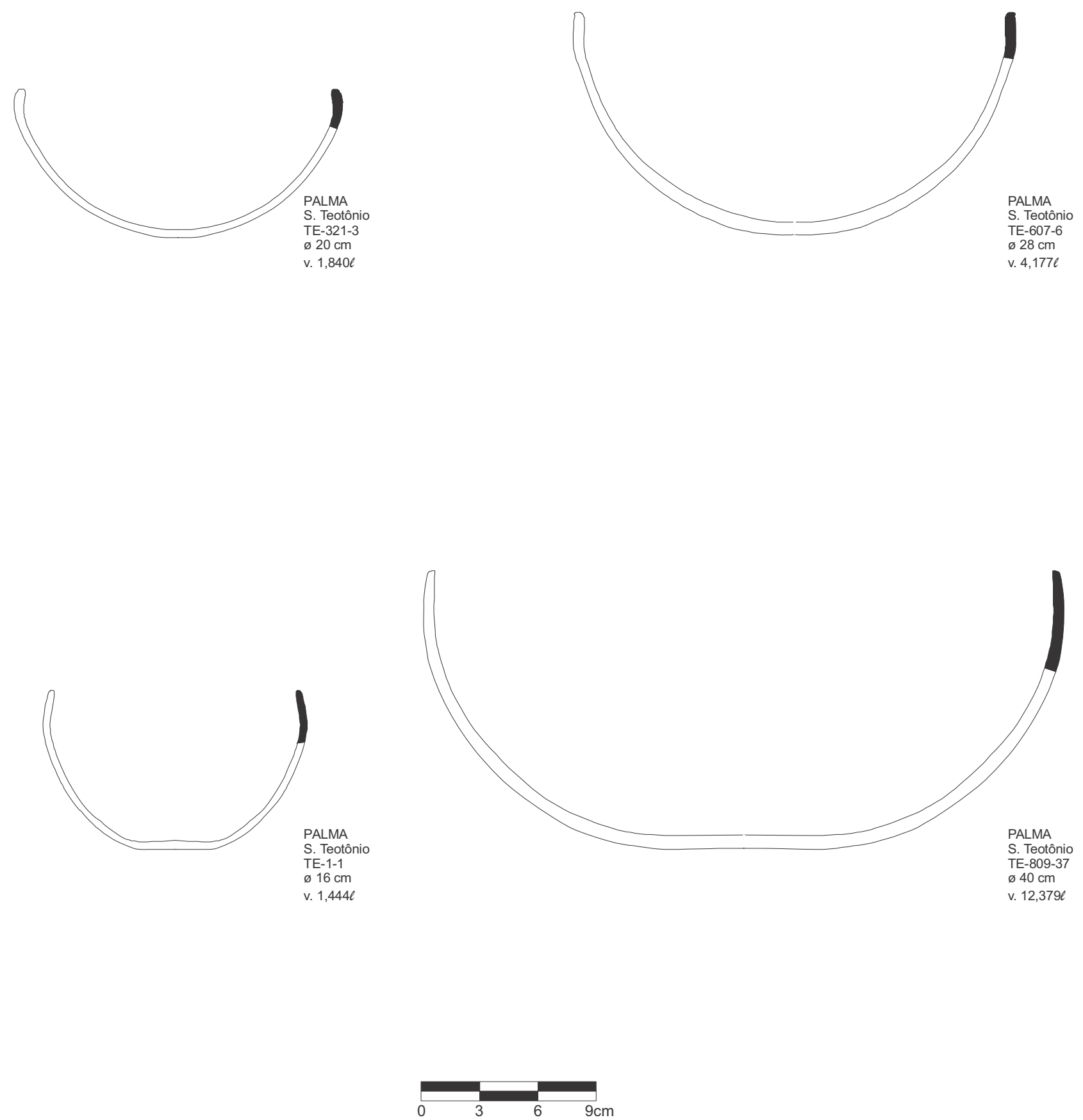

Sítio Teotônio PALMA




\section{Consumo}

Coletivo
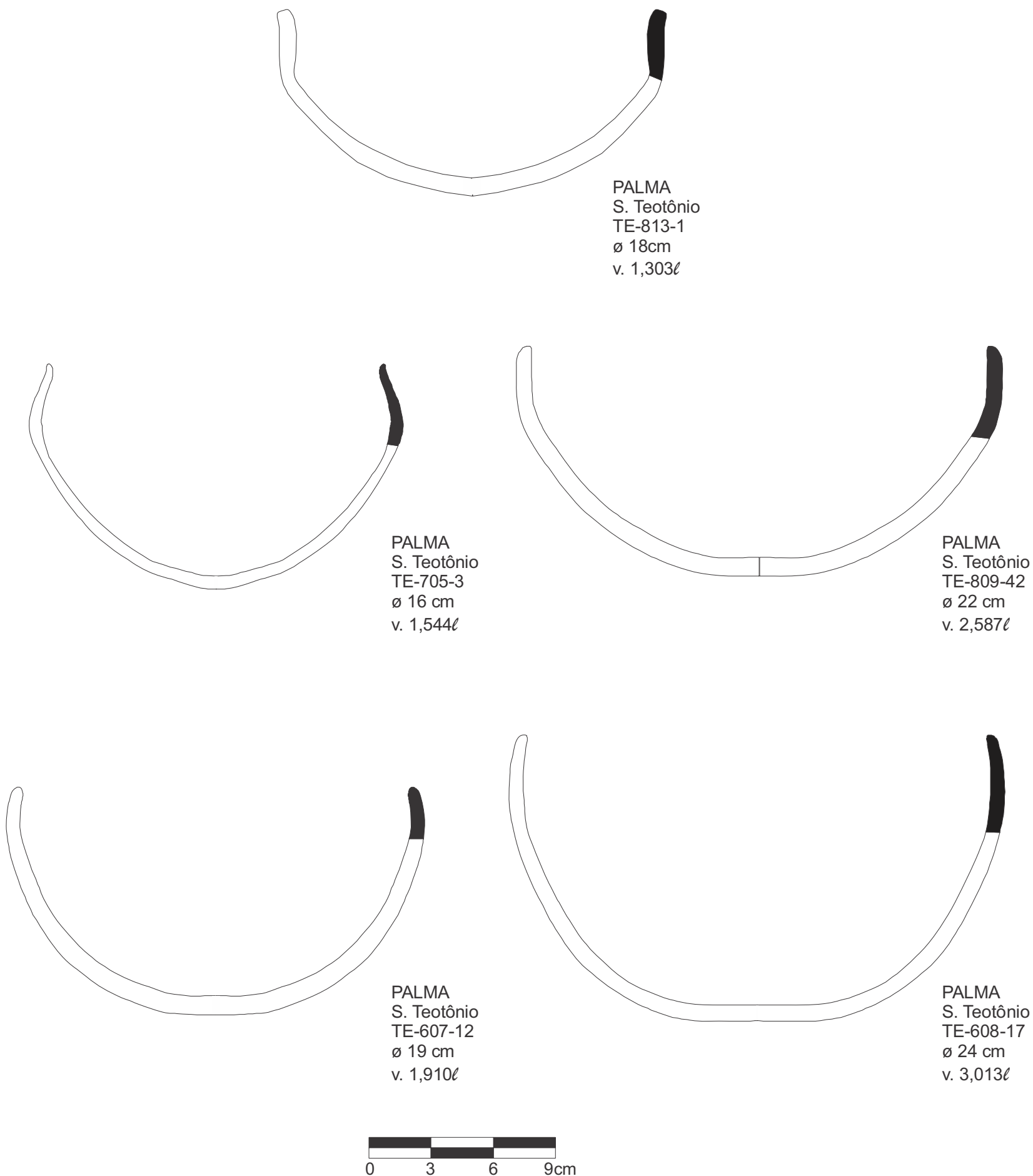

Sítio Teotônio


Consumo

Individual

PALMA

S. Teotônio

TE-809-32

S. Teotônio

TE-809-27

ø $10 \mathrm{~cm}$

v. $0,173 l$
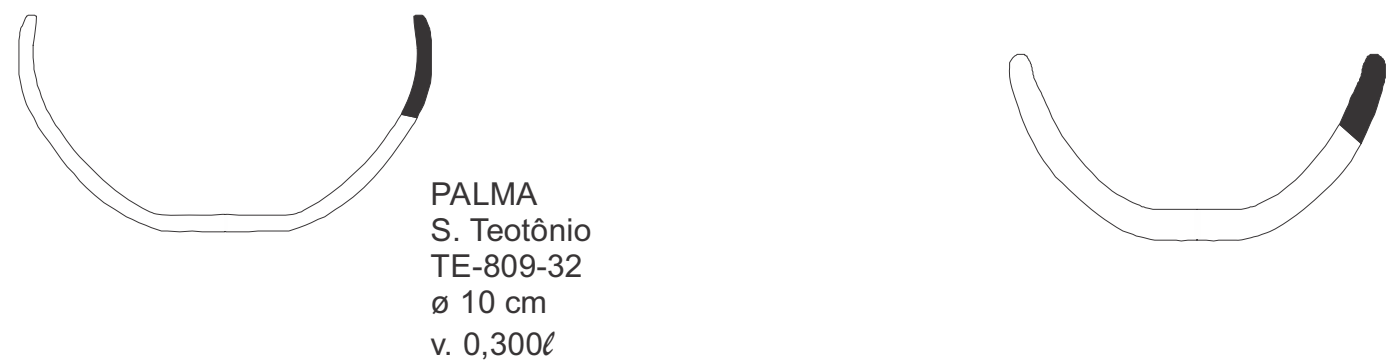

PALMA

S. Teotônio TE-410-3

$\varnothing 9 \mathrm{~cm}$

v. $0,112 \ell$
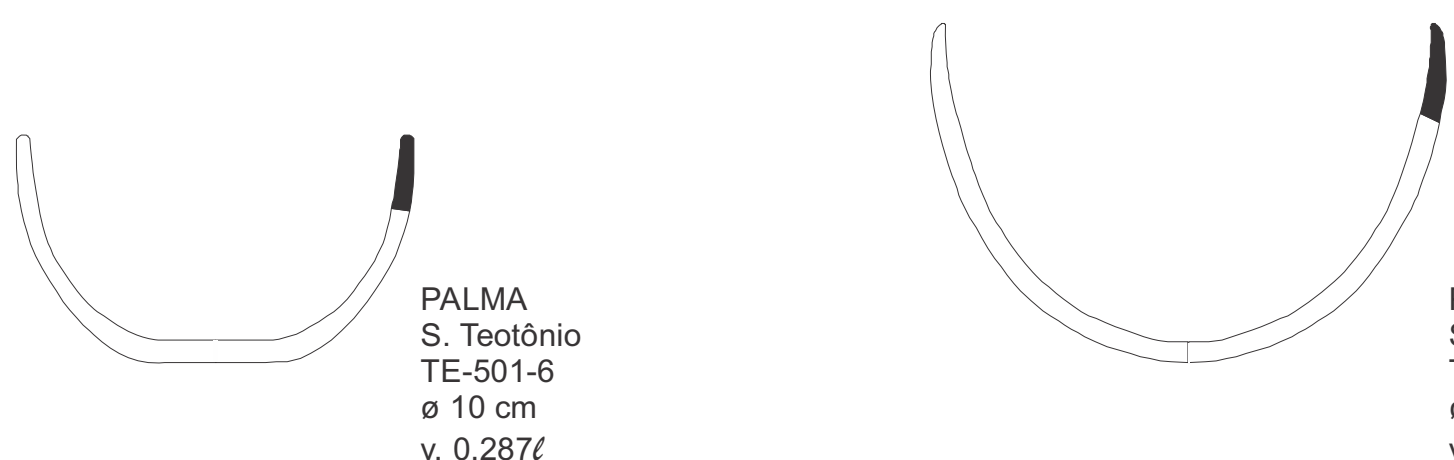

PALMA

S. Teotônio TE-501-64 ø $13 \mathrm{~cm}$

v. $0,287 \ell$

v. $0,720 l$

PALMA

S. Teotônio

TE-417-7

ø $13 \mathrm{~cm}$

S. Teotônio

TE-806-1

v. $0,287 \ell$

$\varnothing 20 \mathrm{~cm}$

v. $0,735 e$

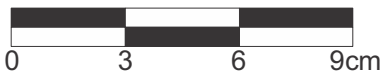

PALMA

Sítio Teotônio

Surfer 3

Distribuição Espacial

da Cerâmica 


\section{Preparo}
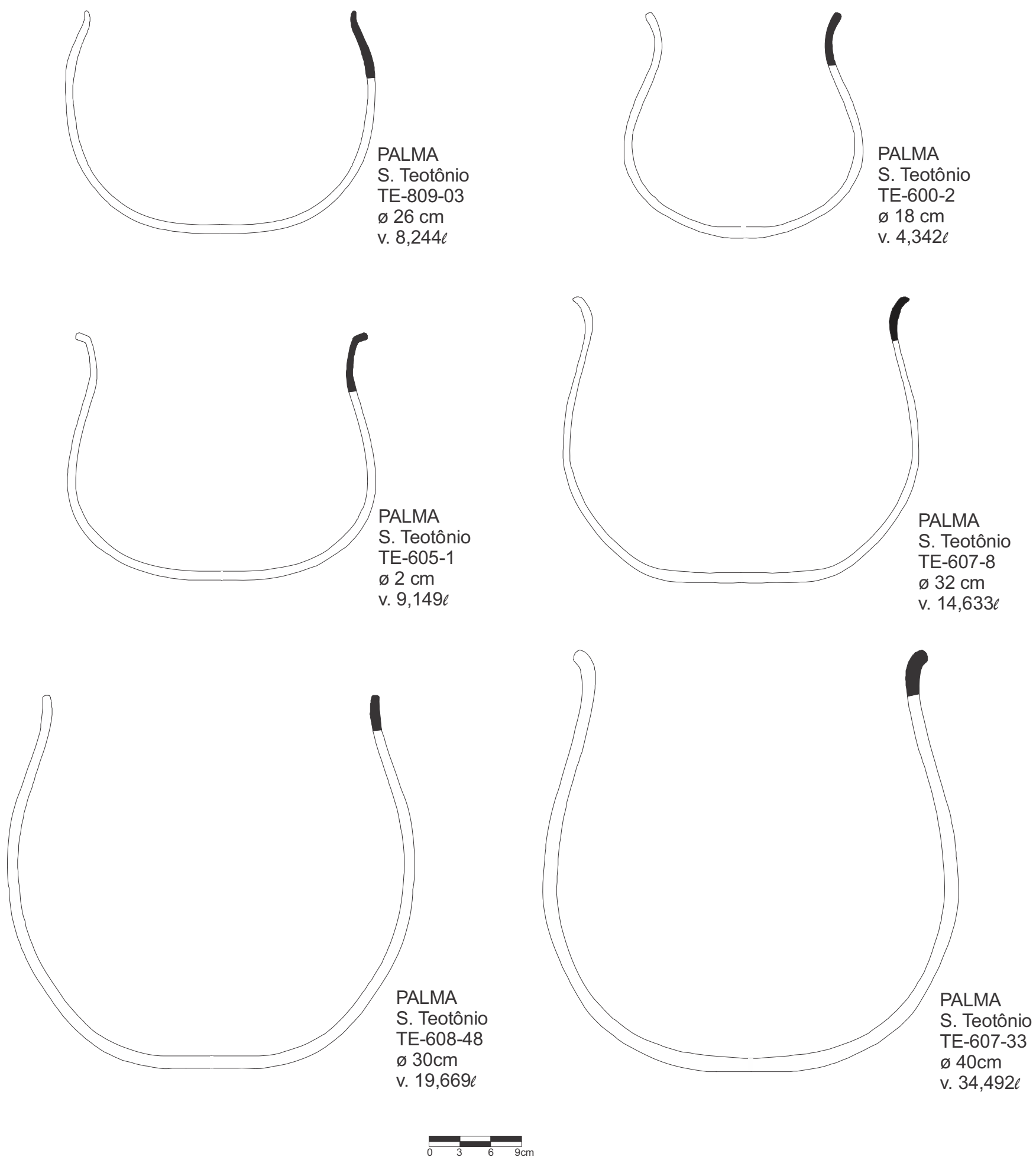

Sítio Teotônio




\section{Serviço}
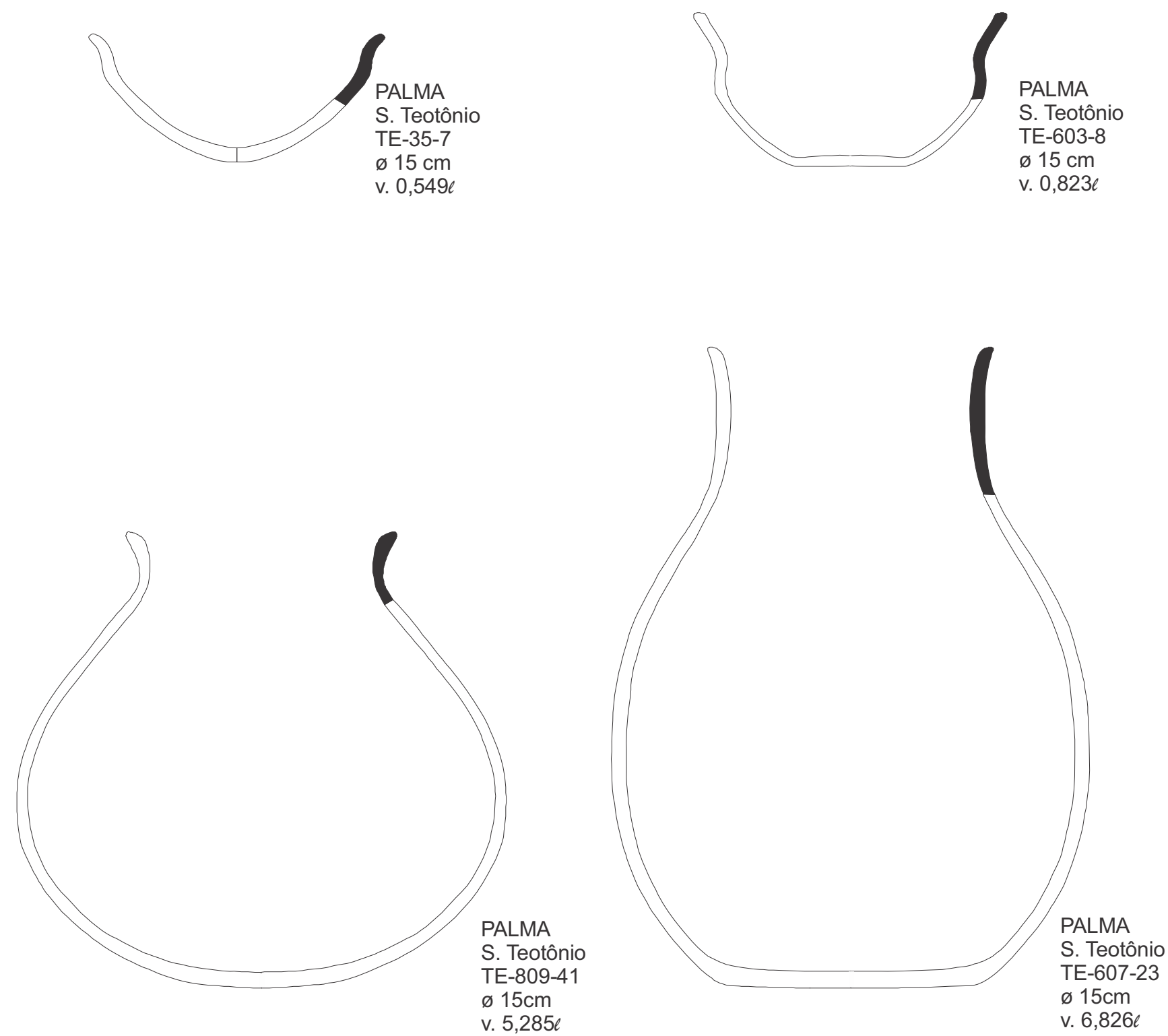

PALMA

Sítio Teotônio

Surfer 5

Distribuição Espacial

da Cerâmica
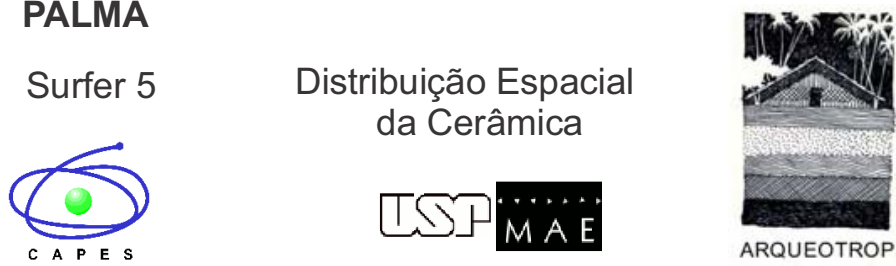
ANEXO 19 


$$
\text { 旁 }
$$
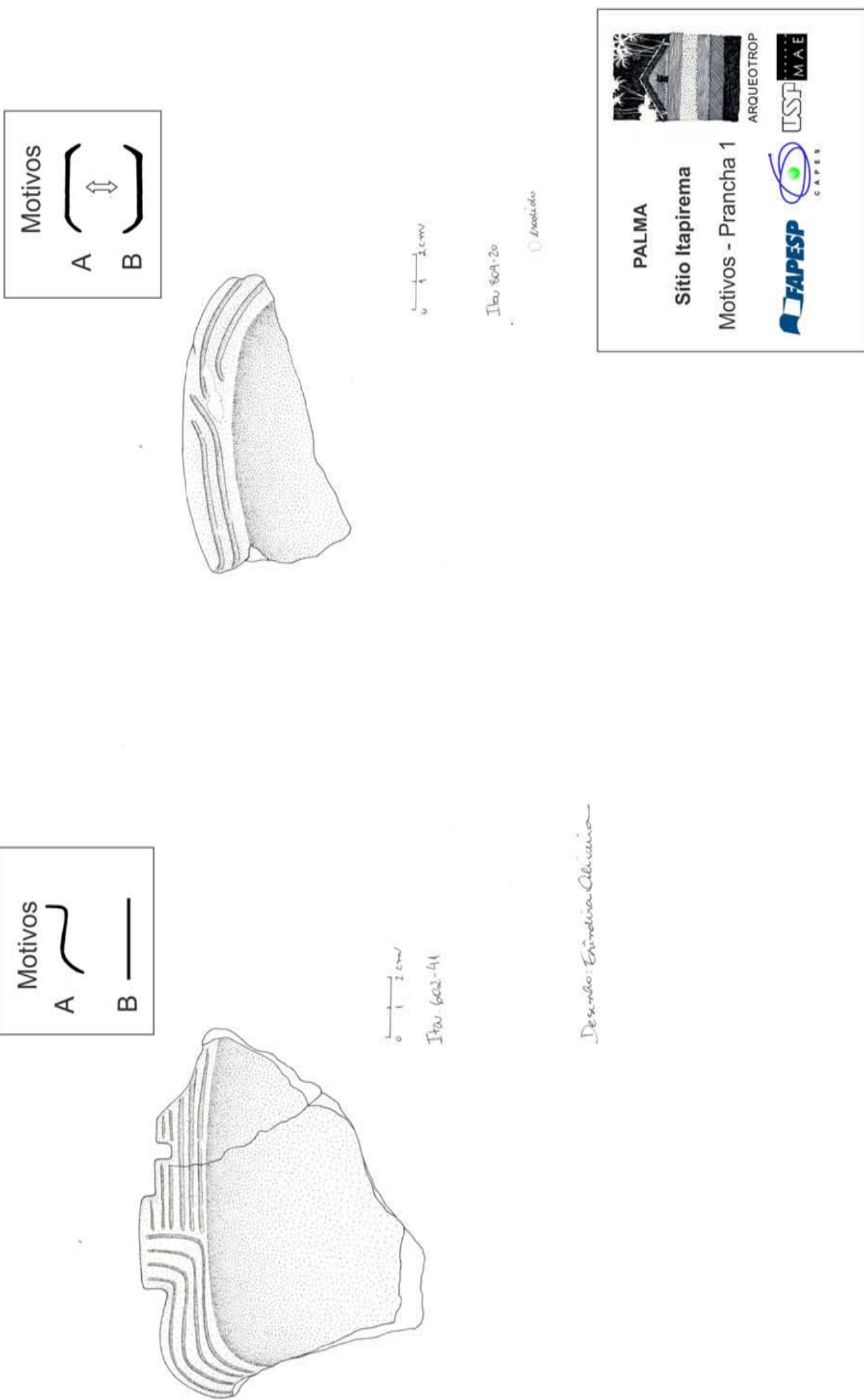


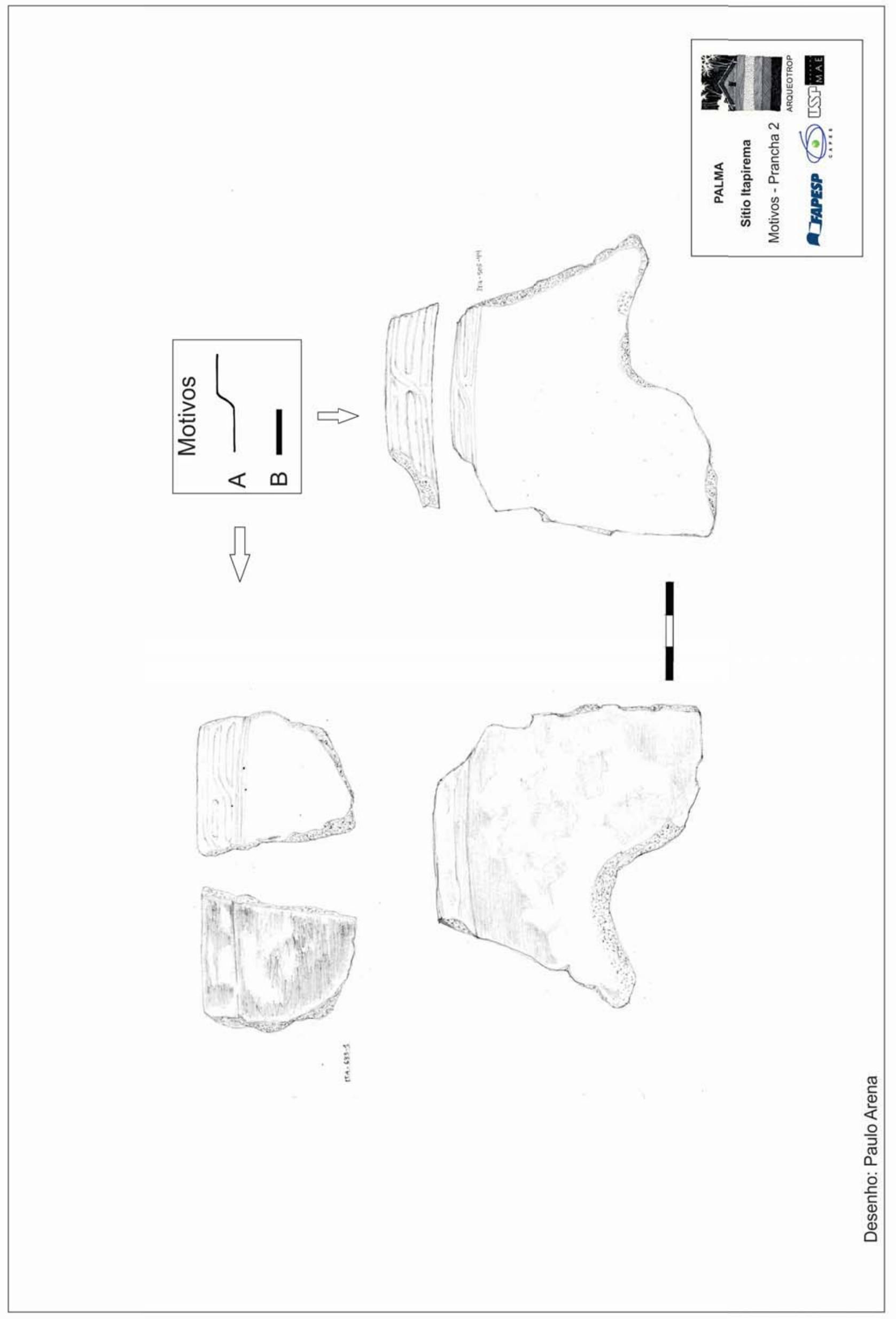




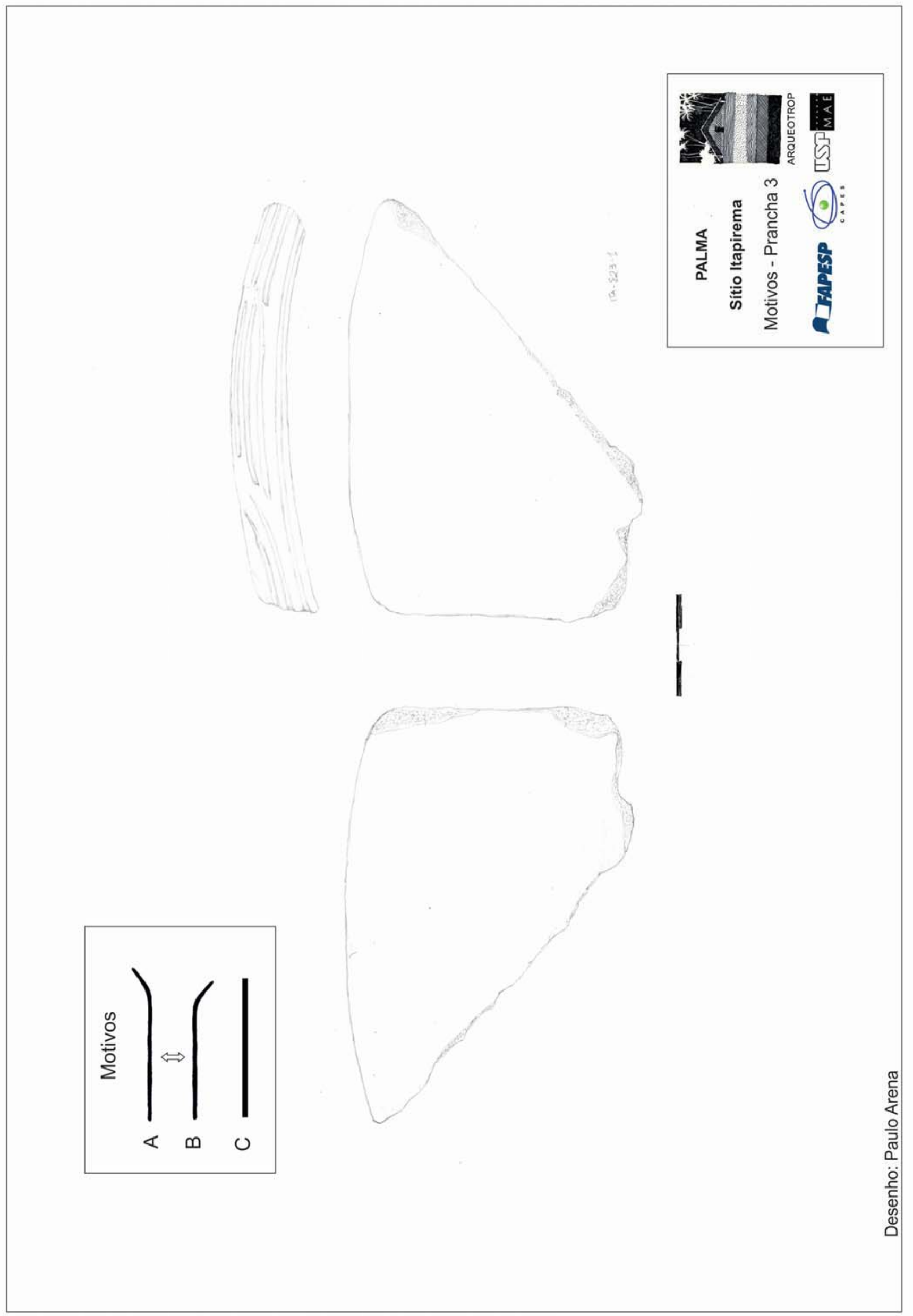




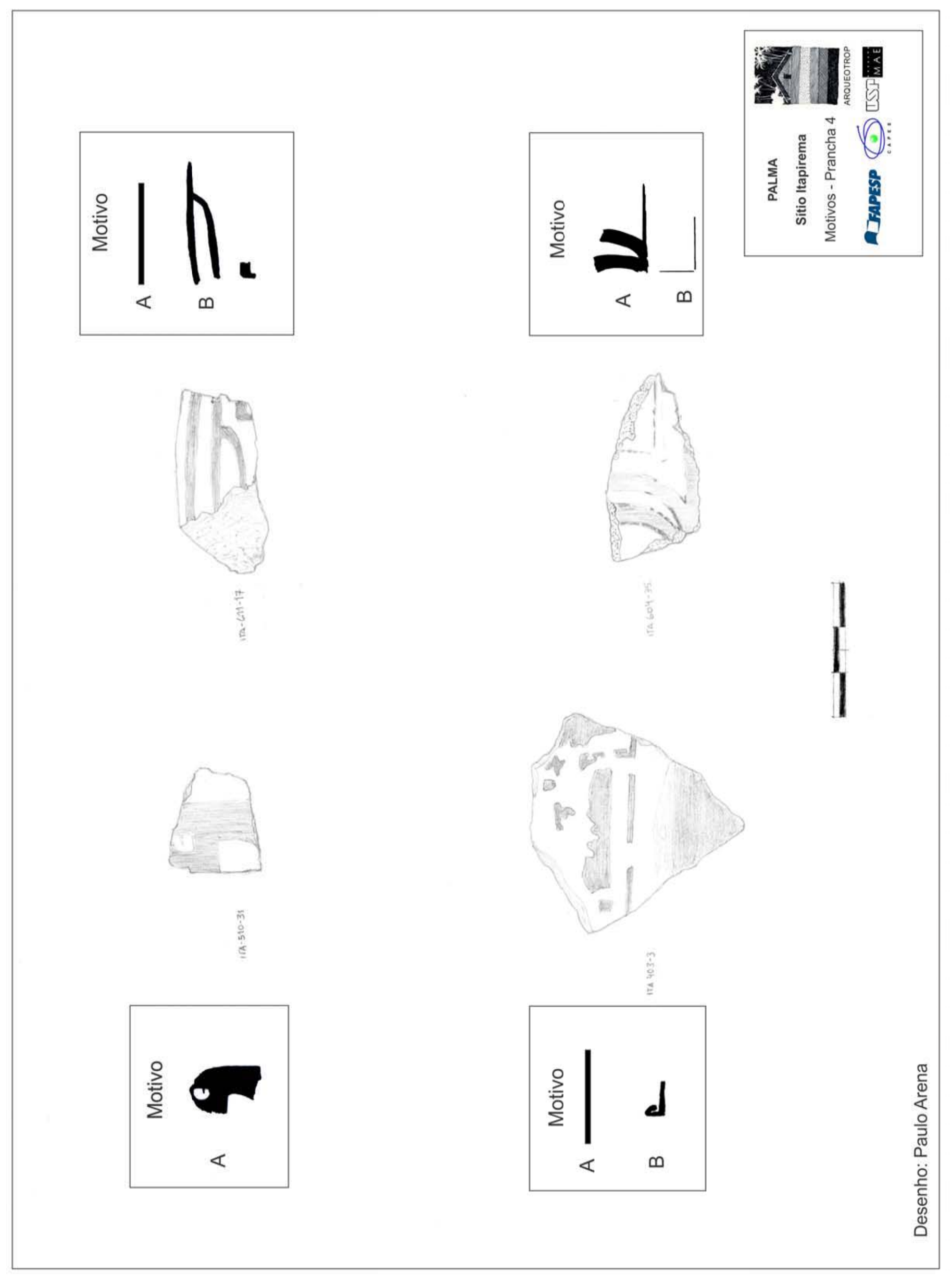



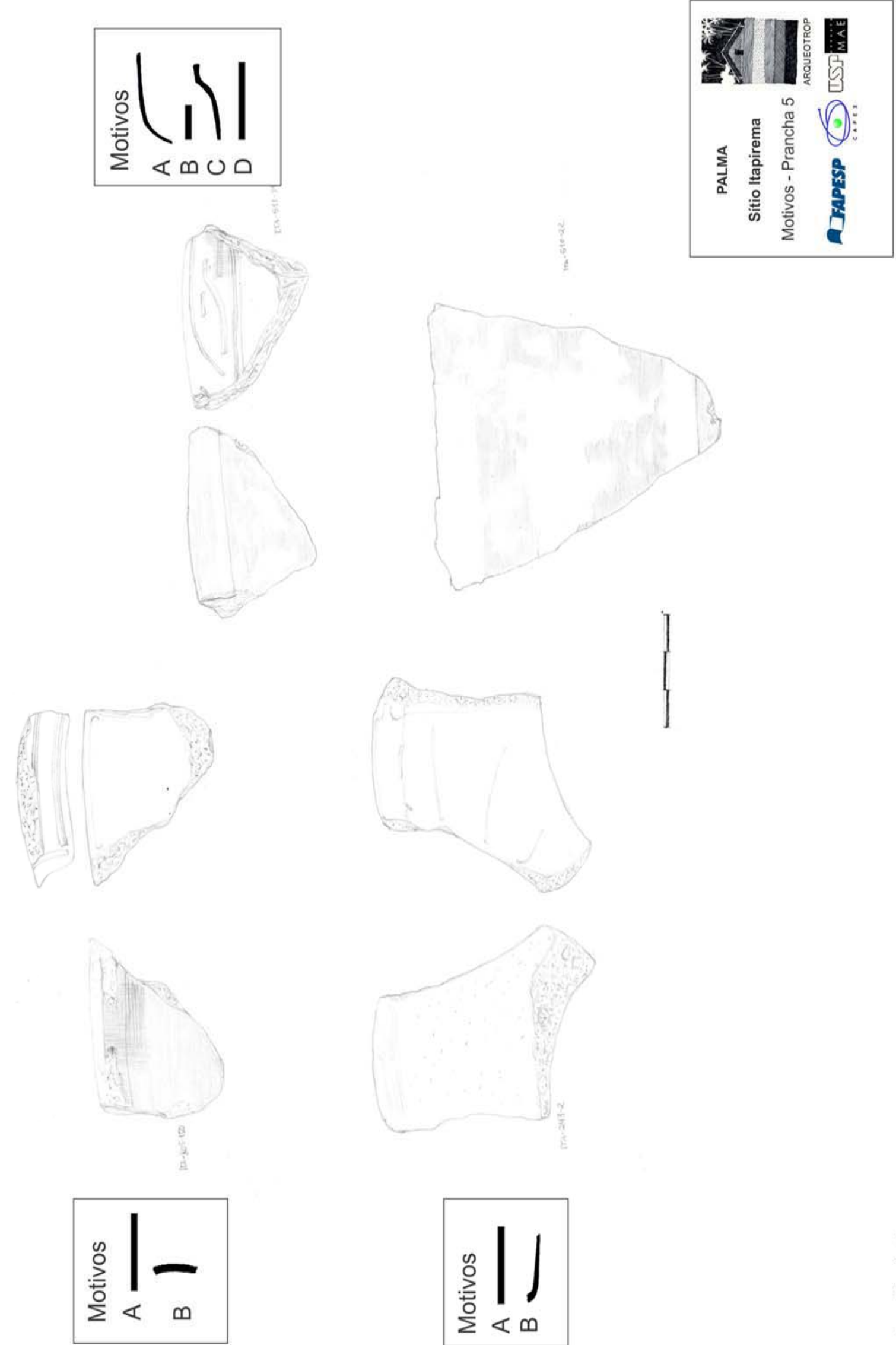


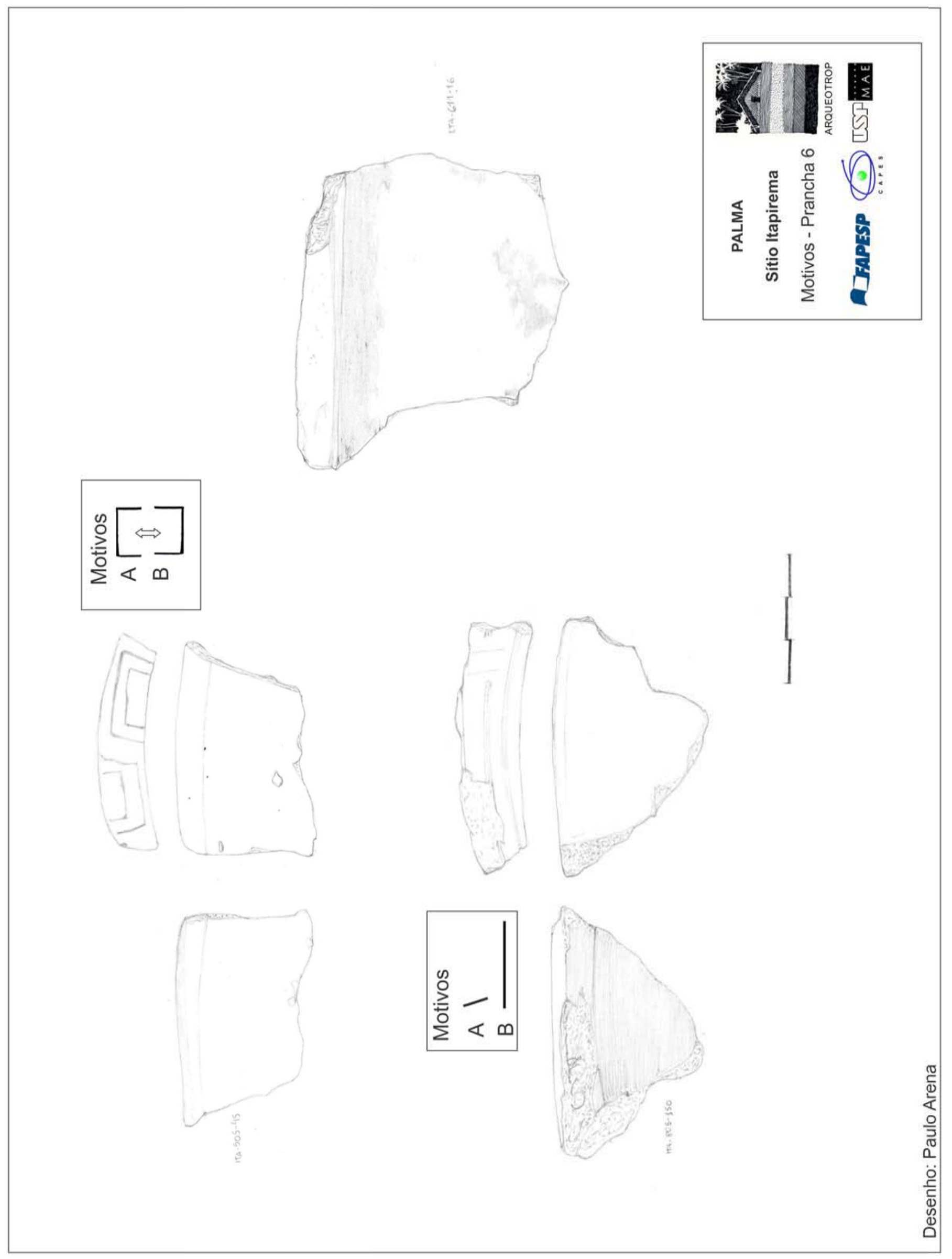




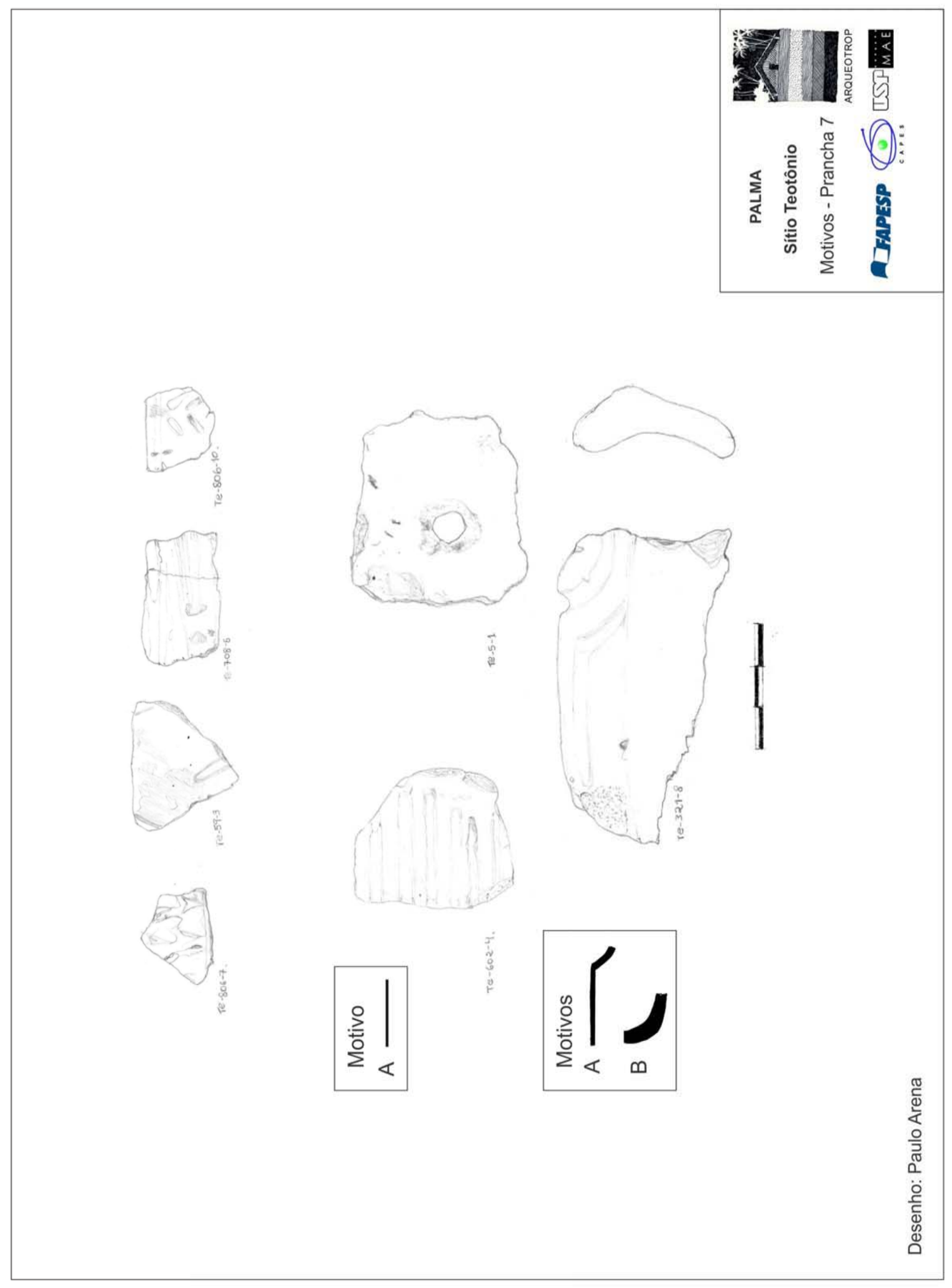




$$
\text { 毫 } 1=1
$$
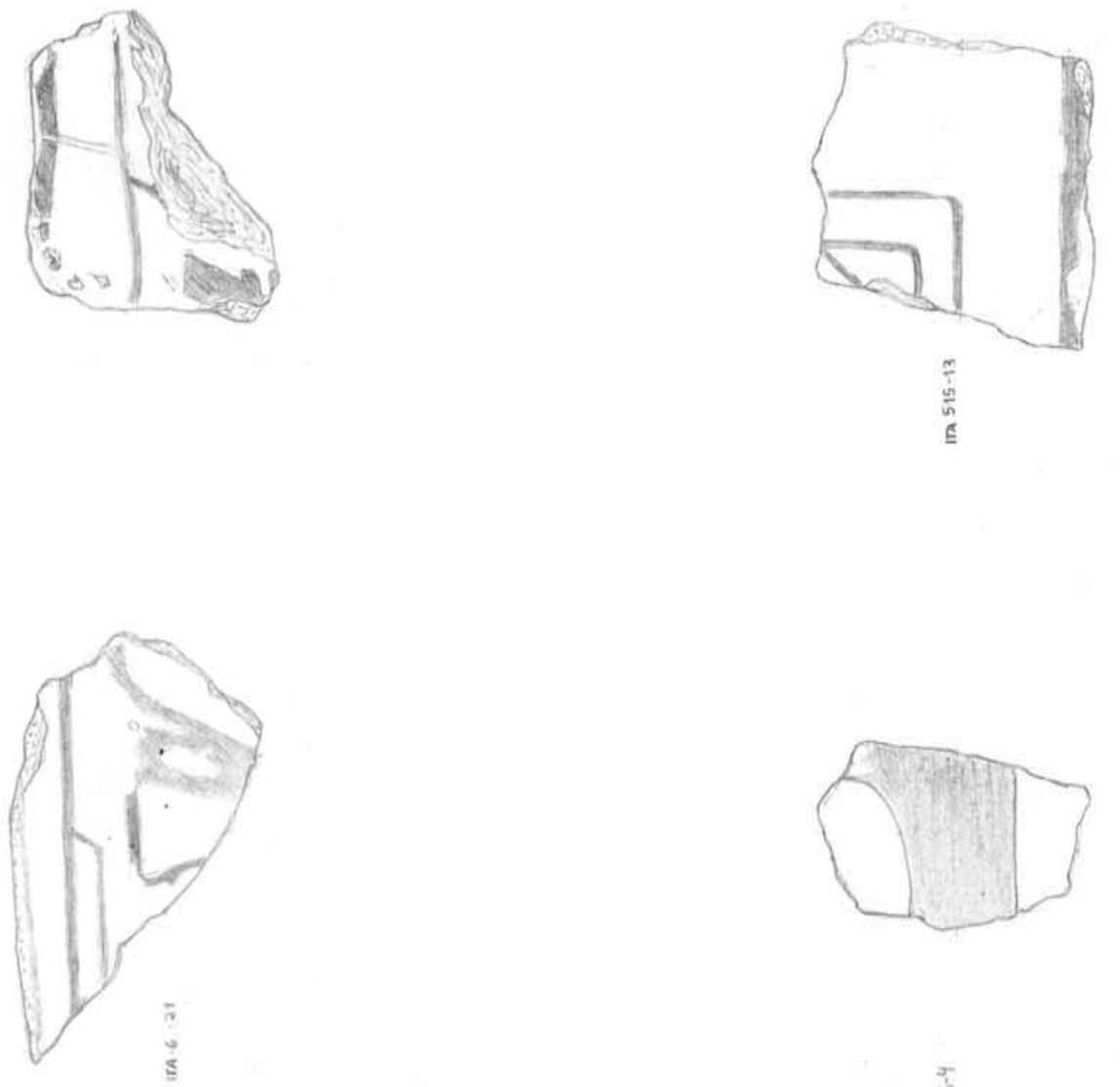
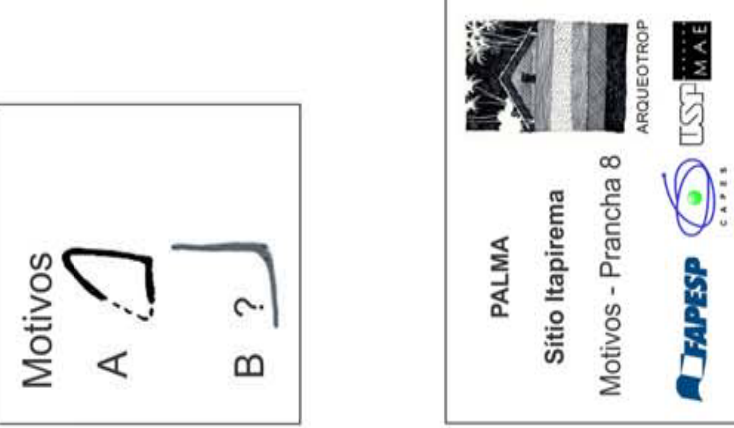

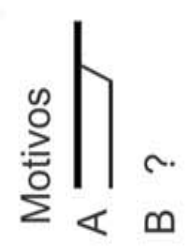

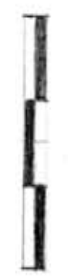

एँ 

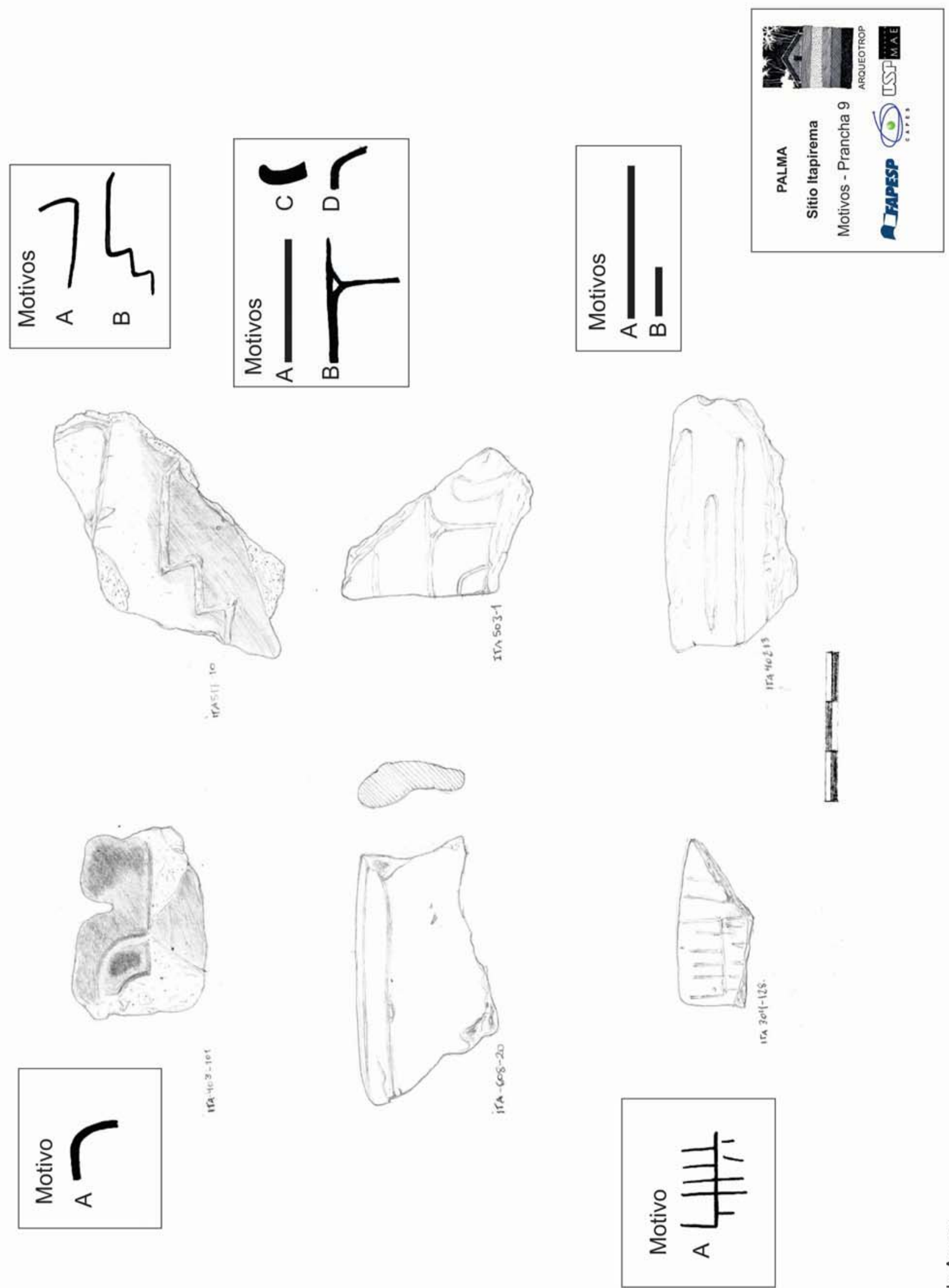

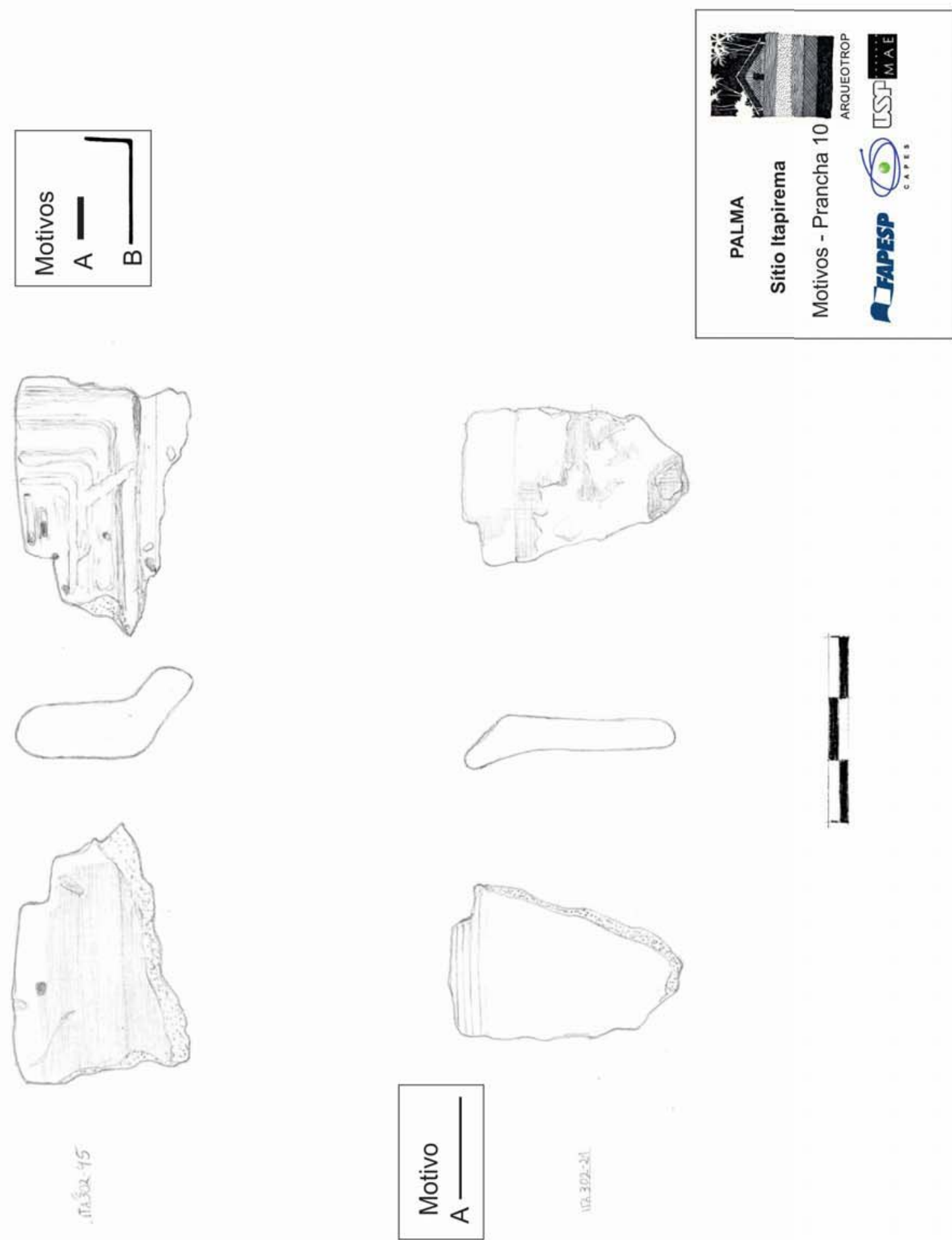


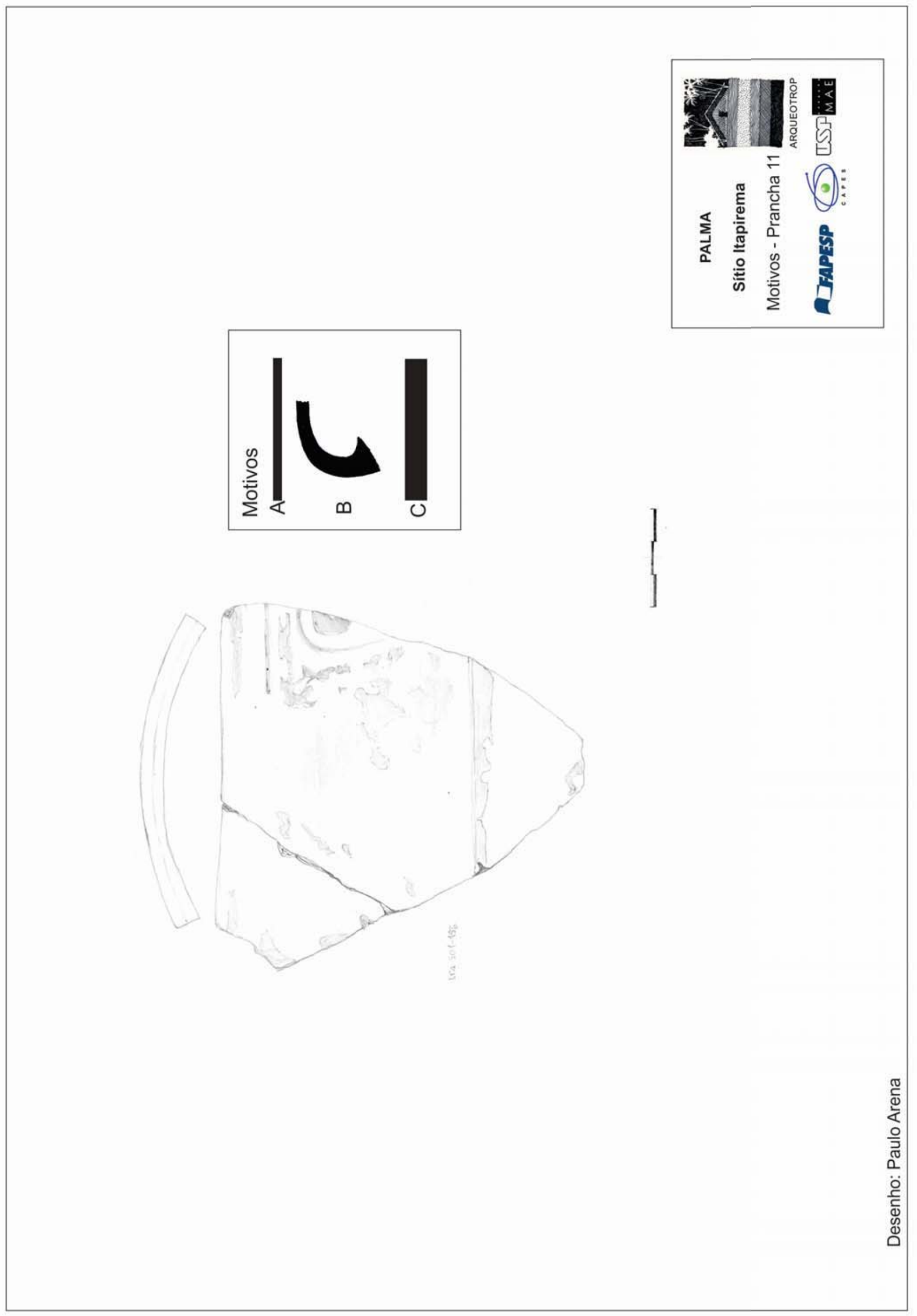



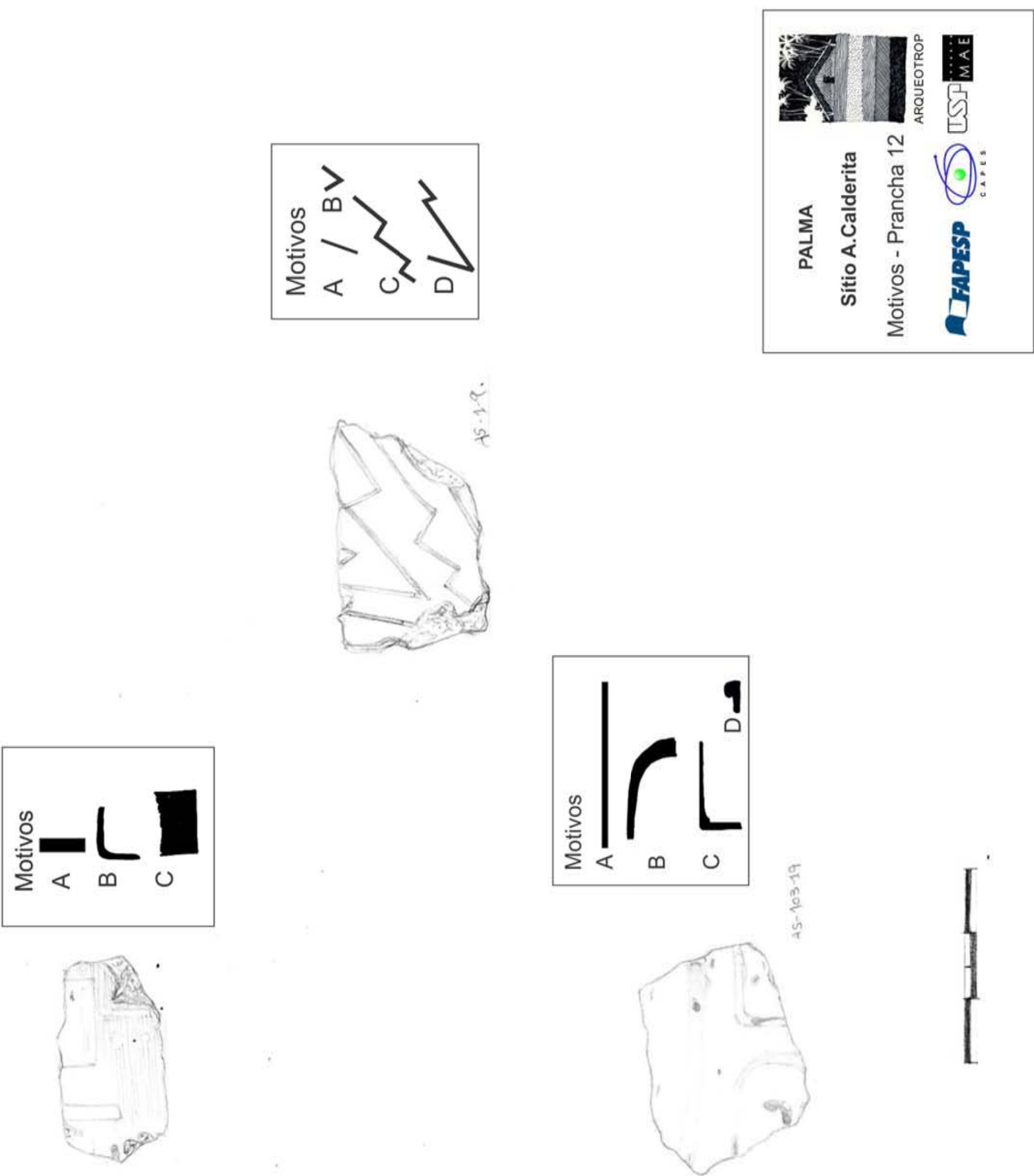

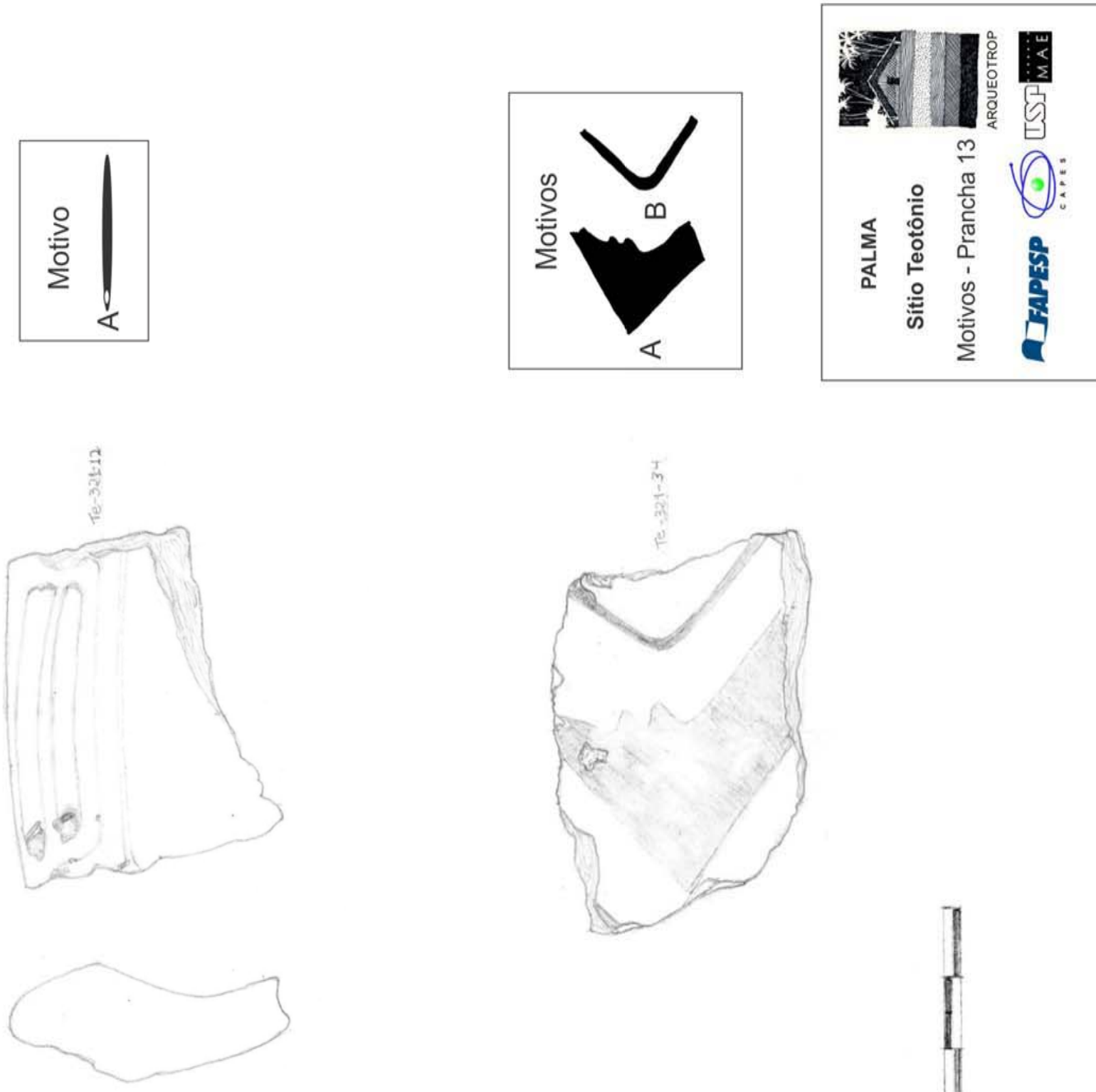

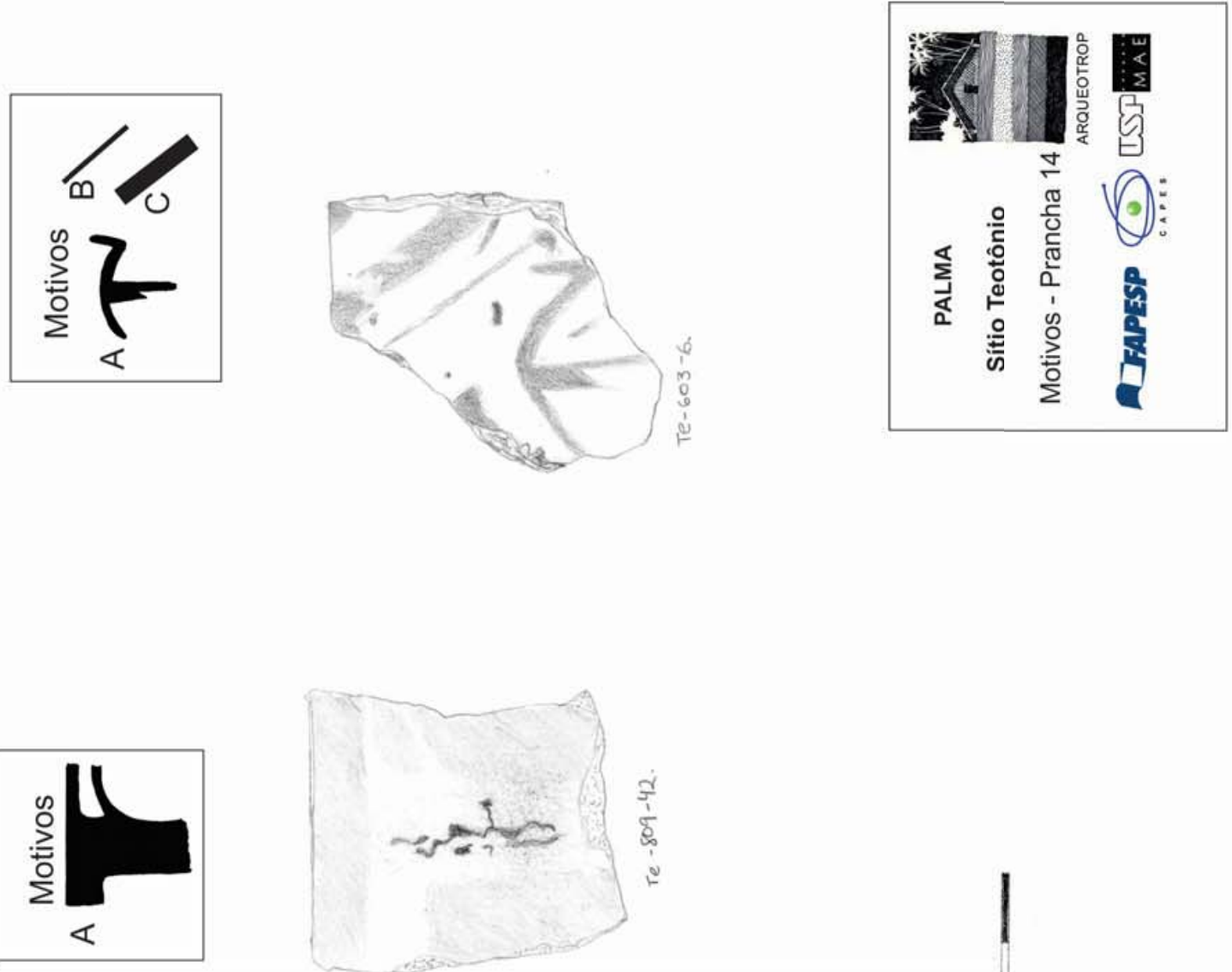

I

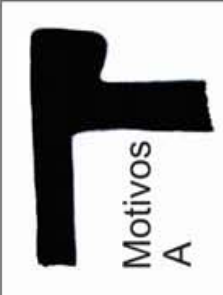




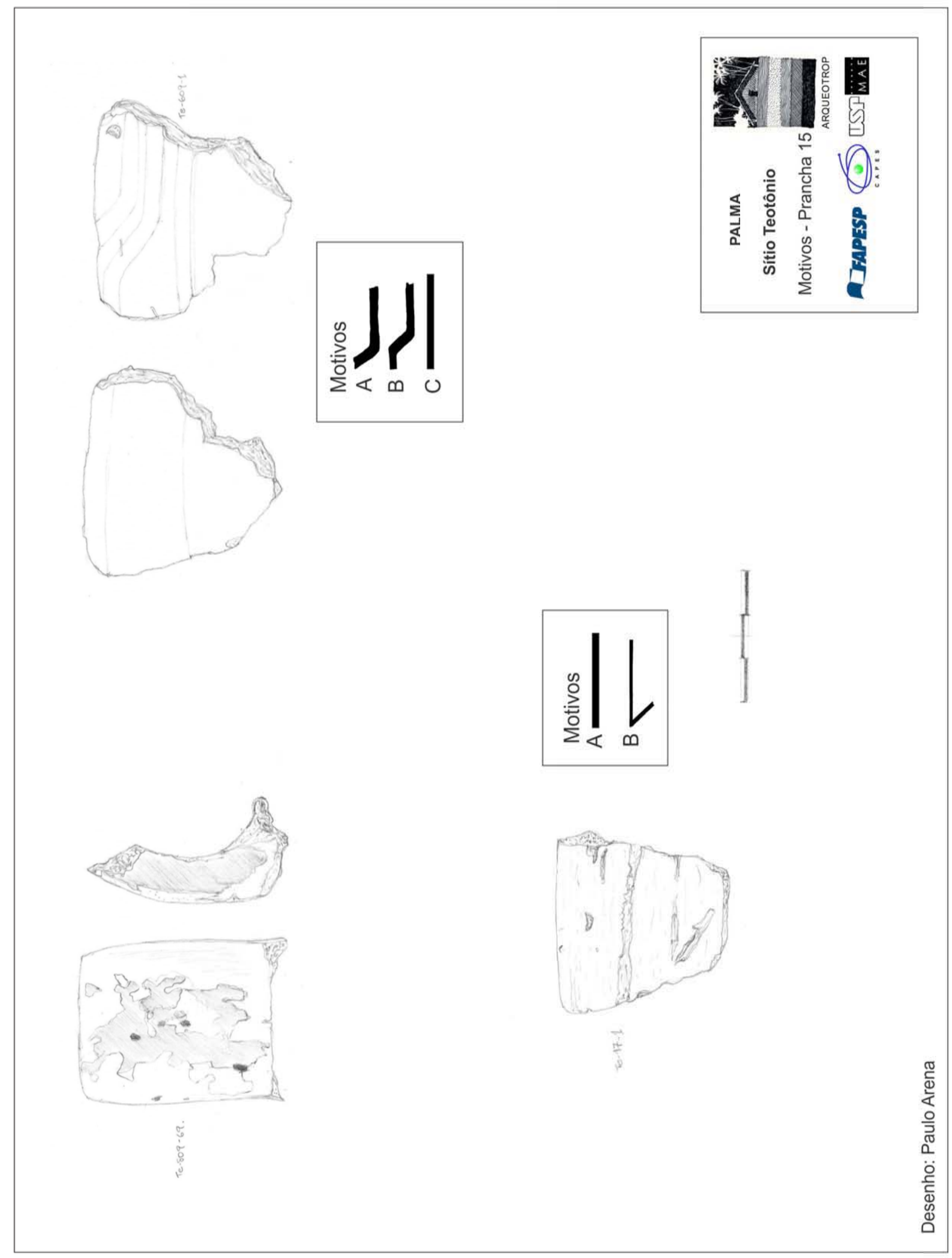



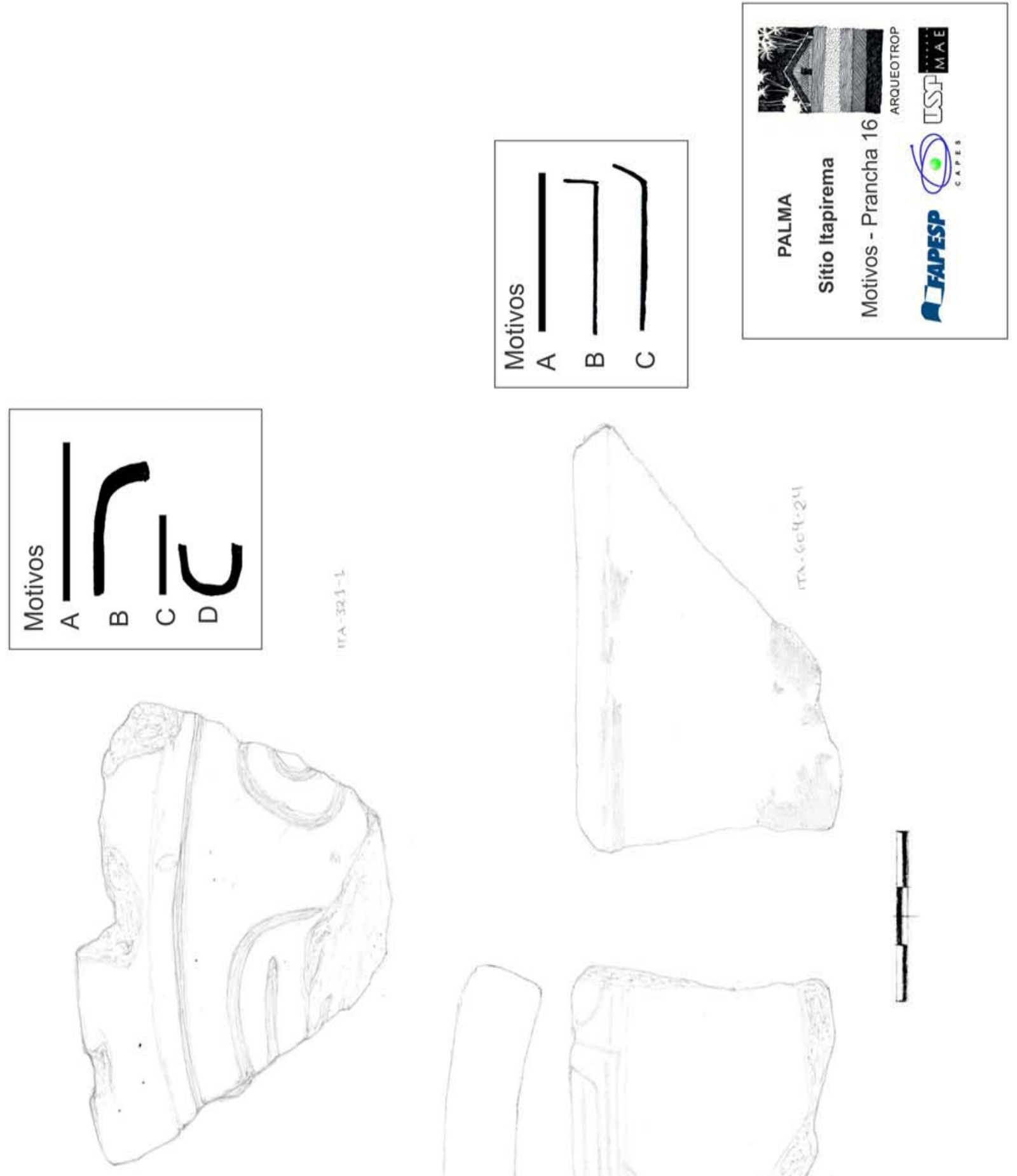


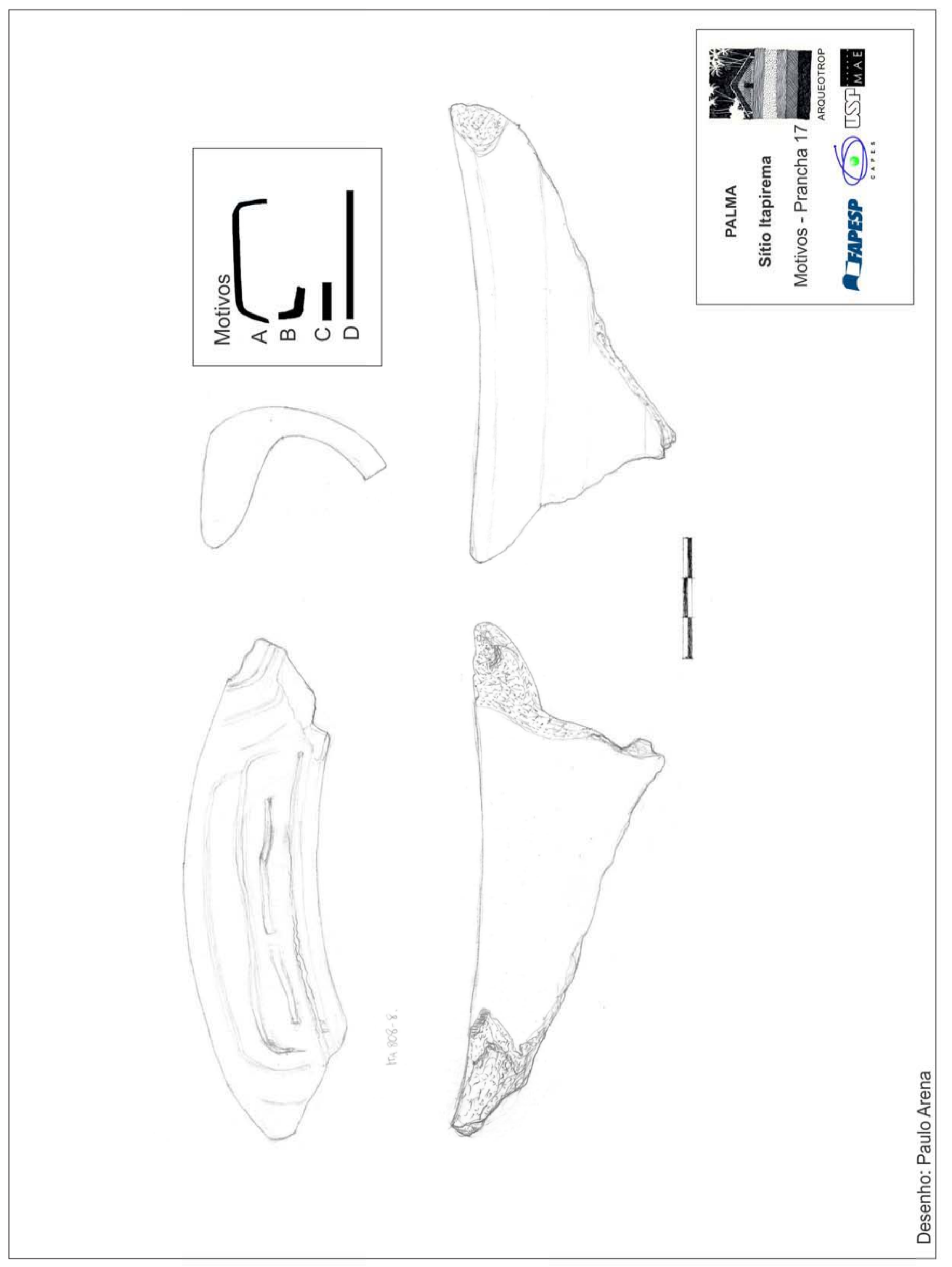




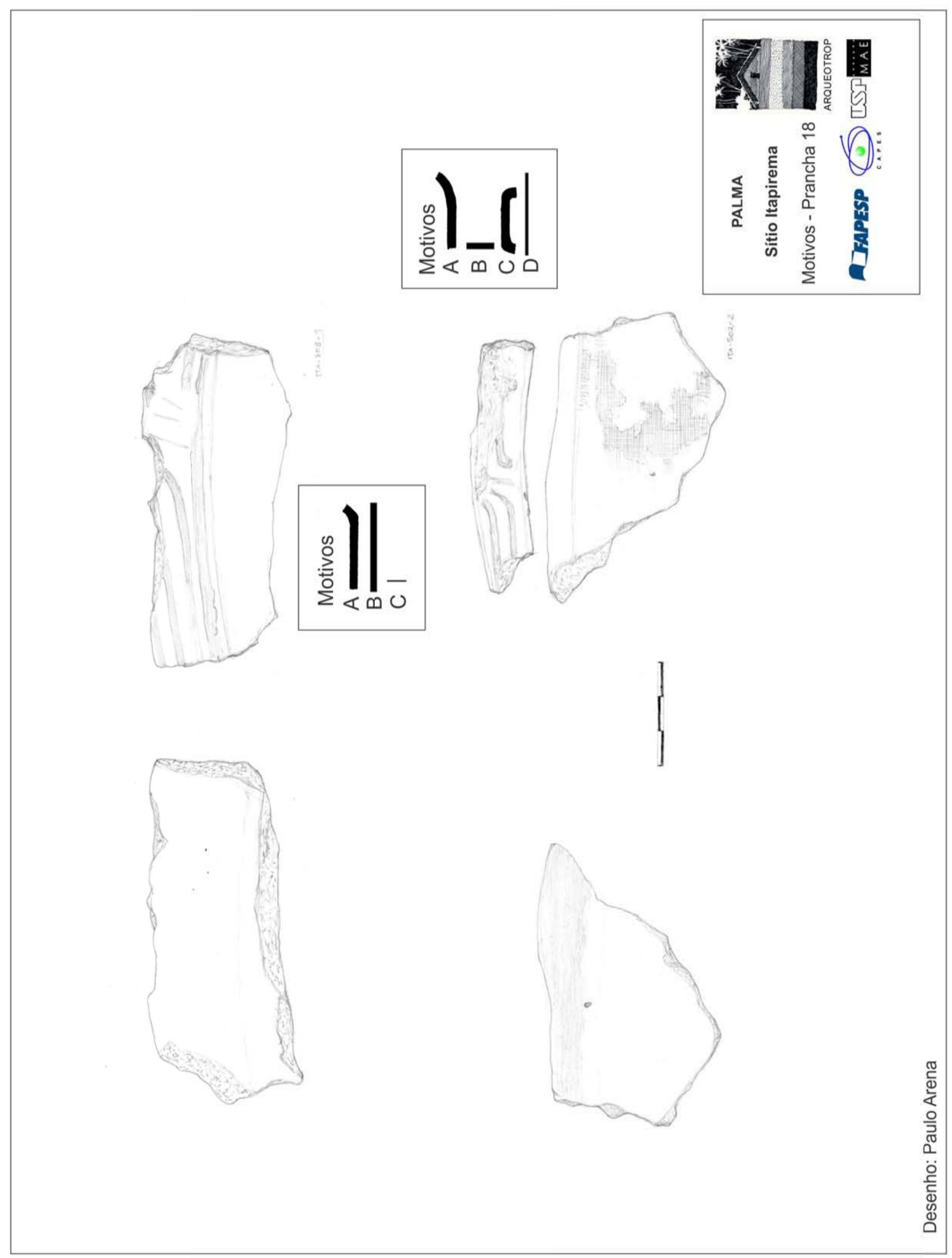




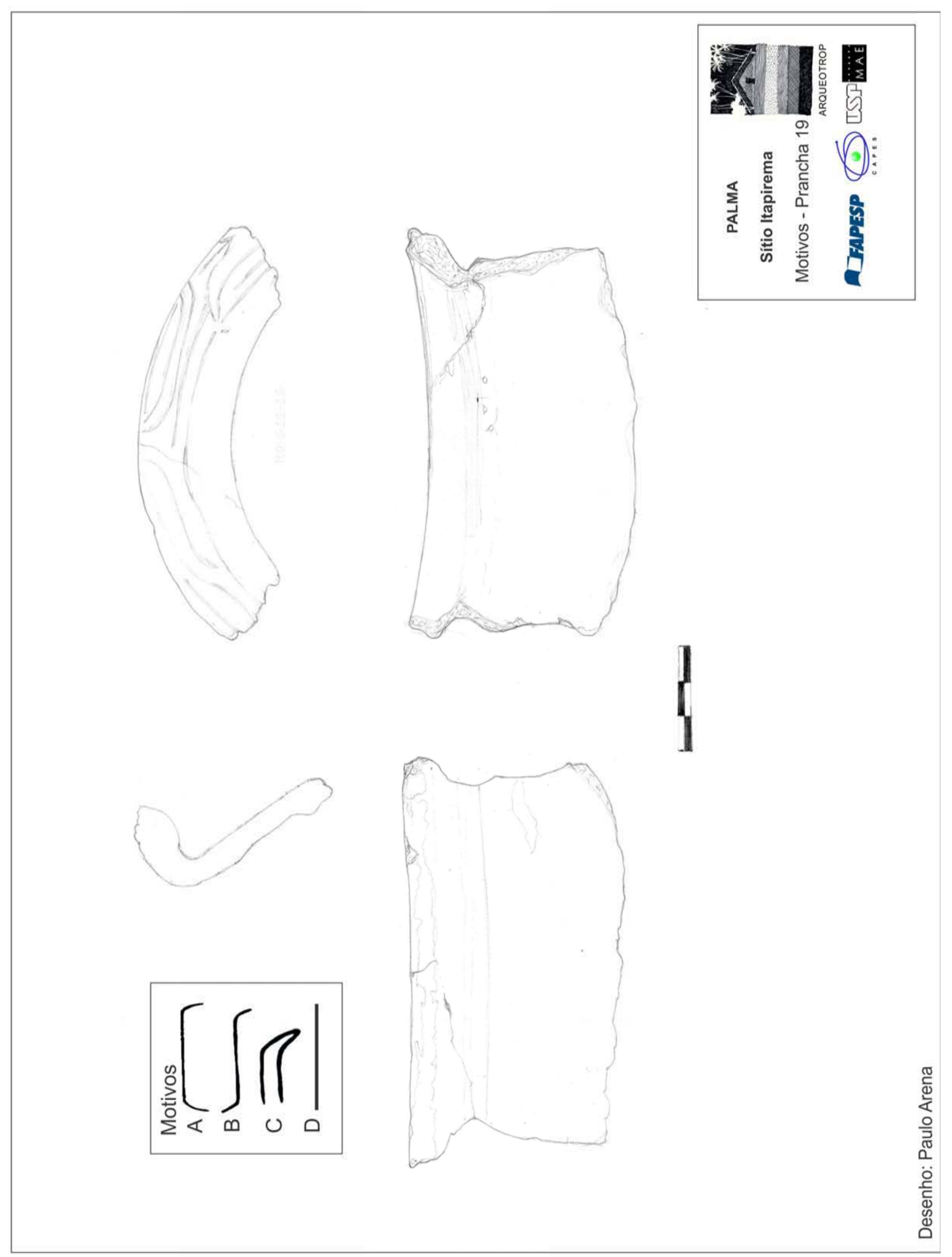



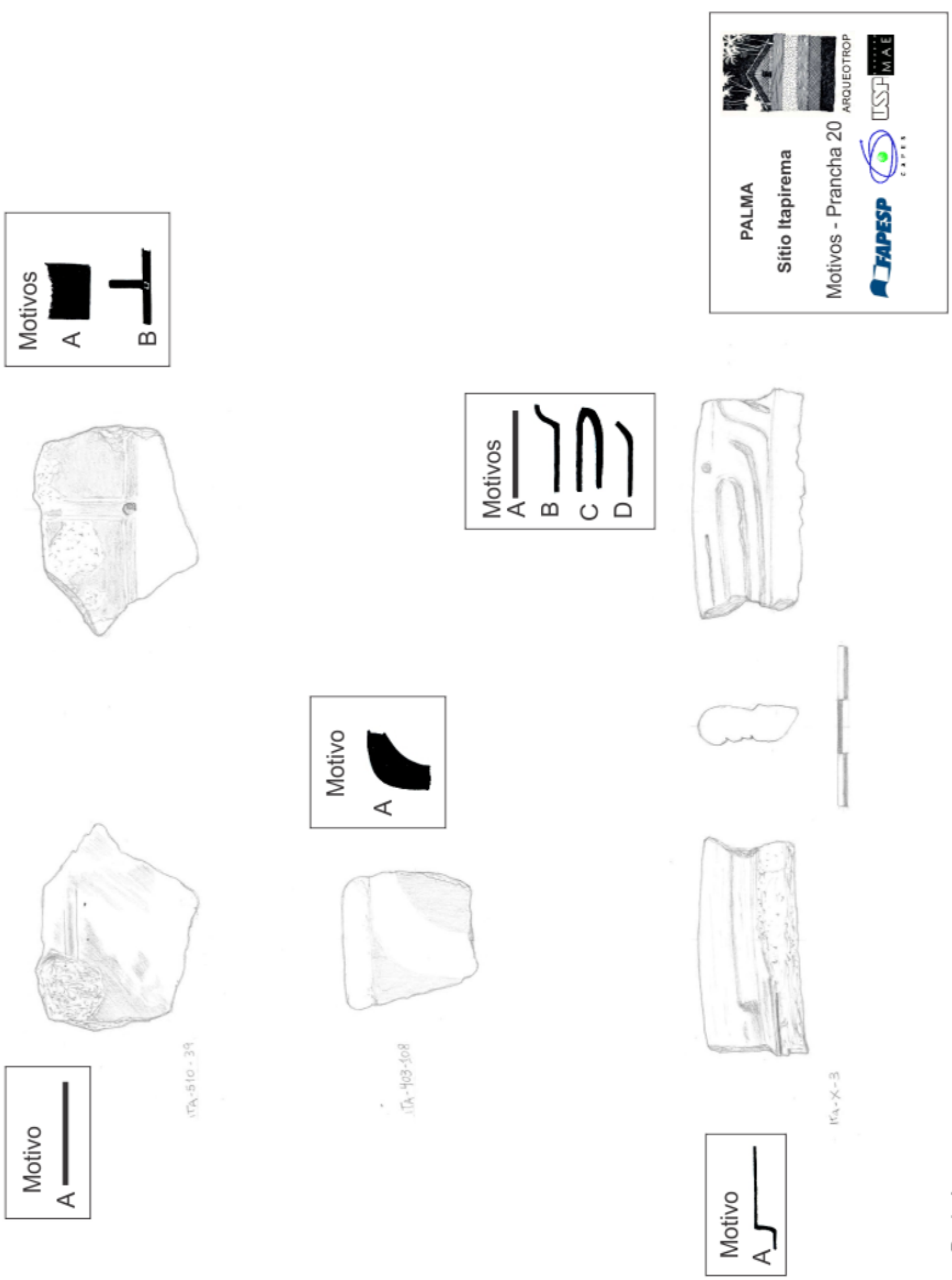

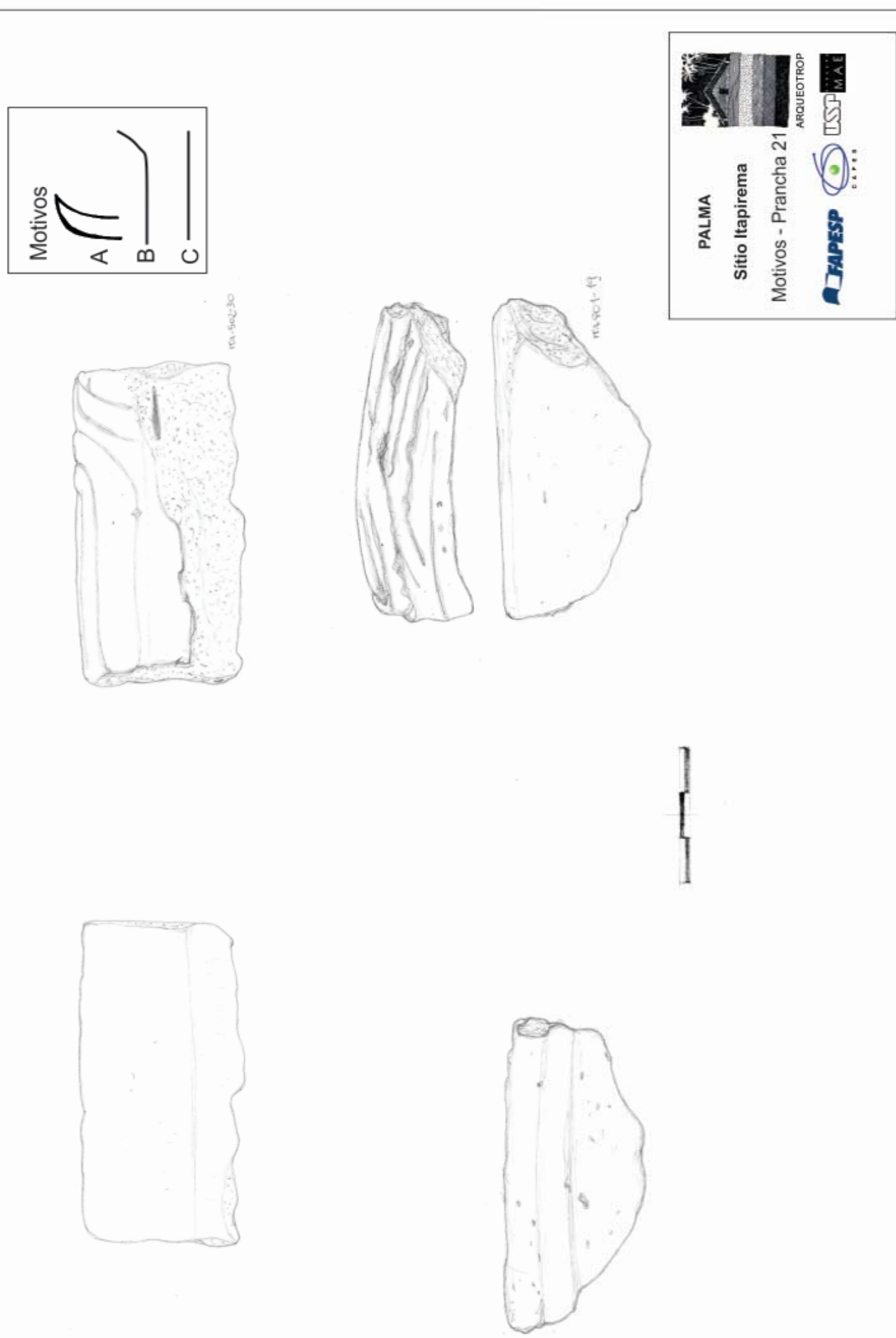

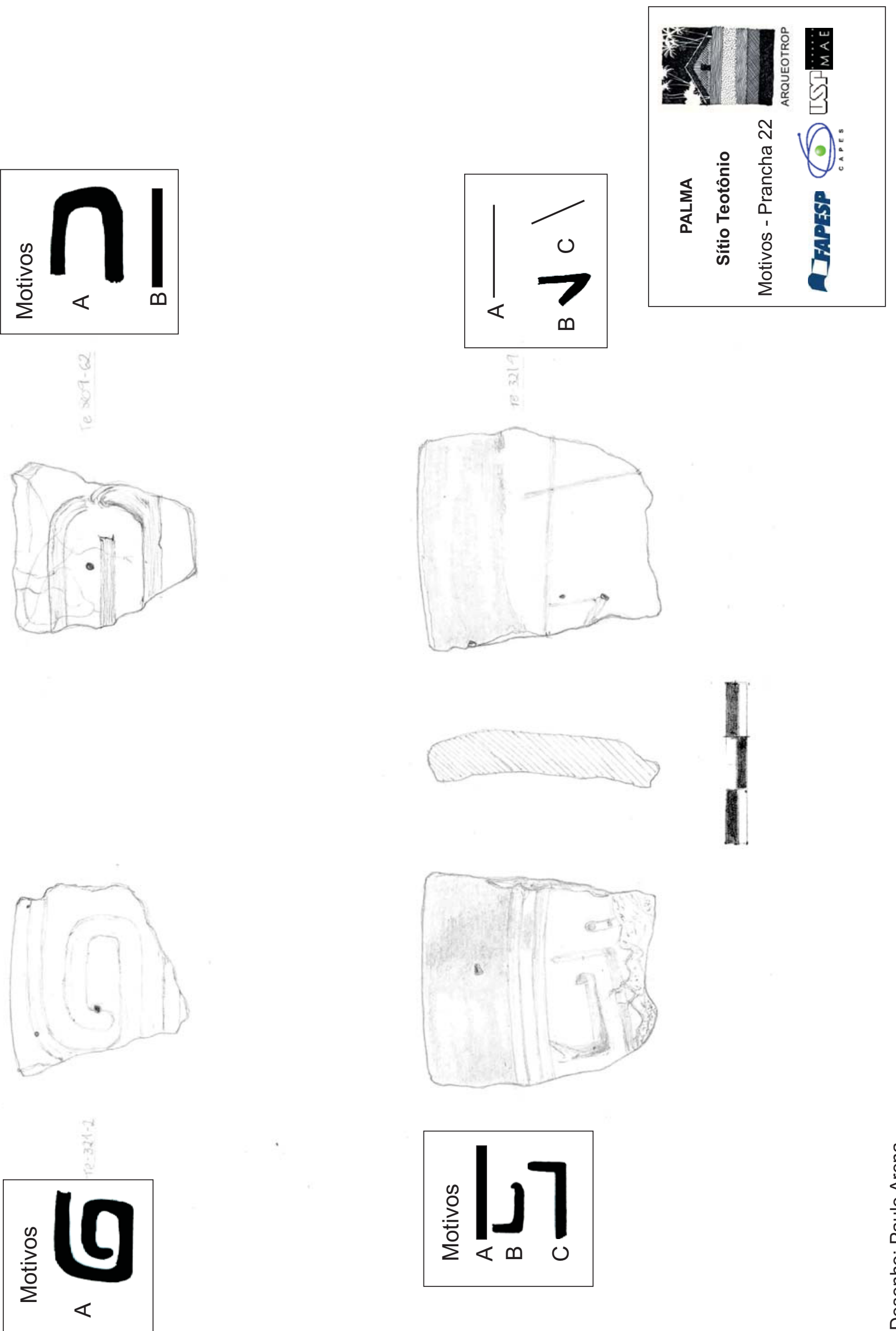

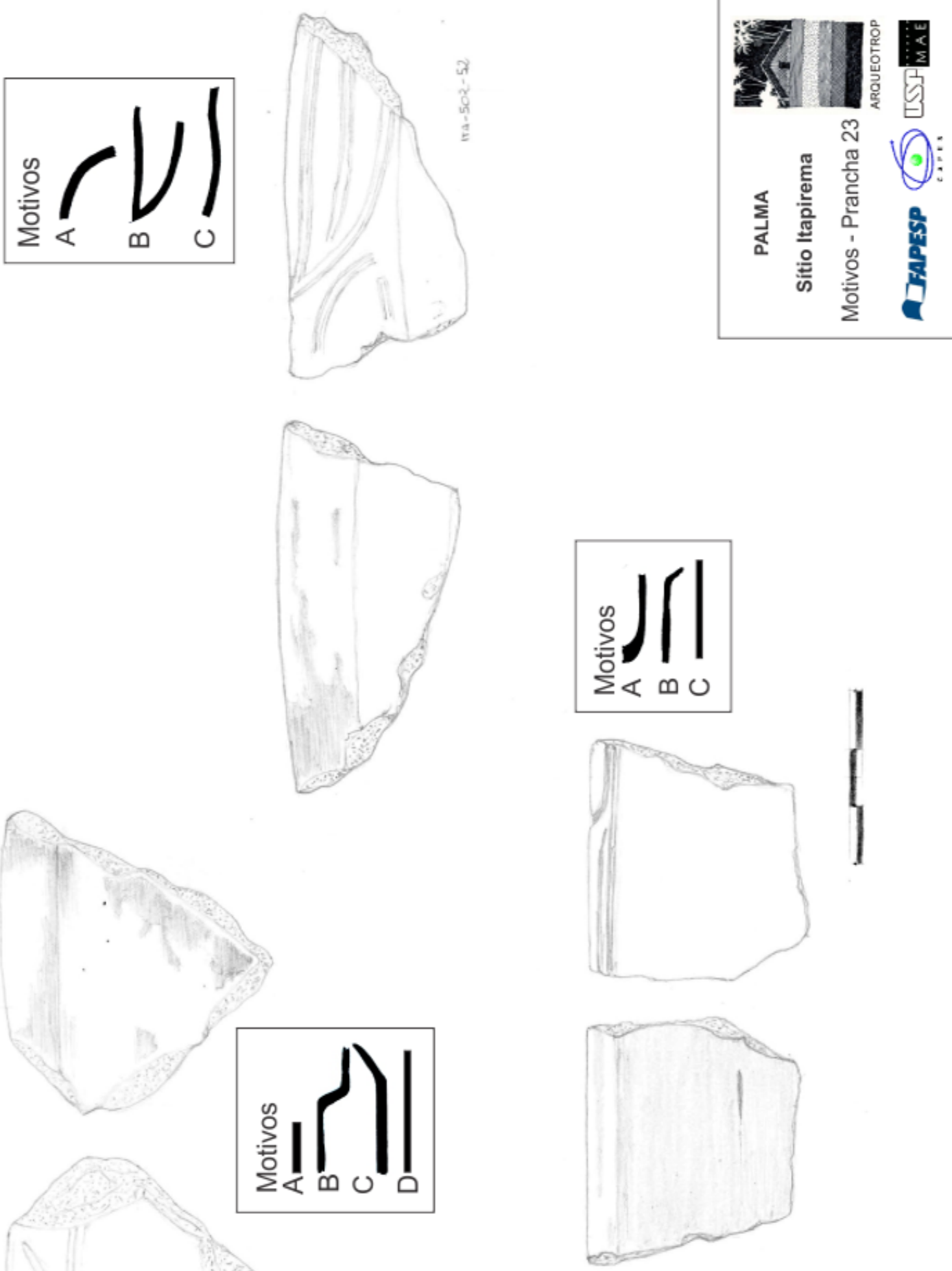

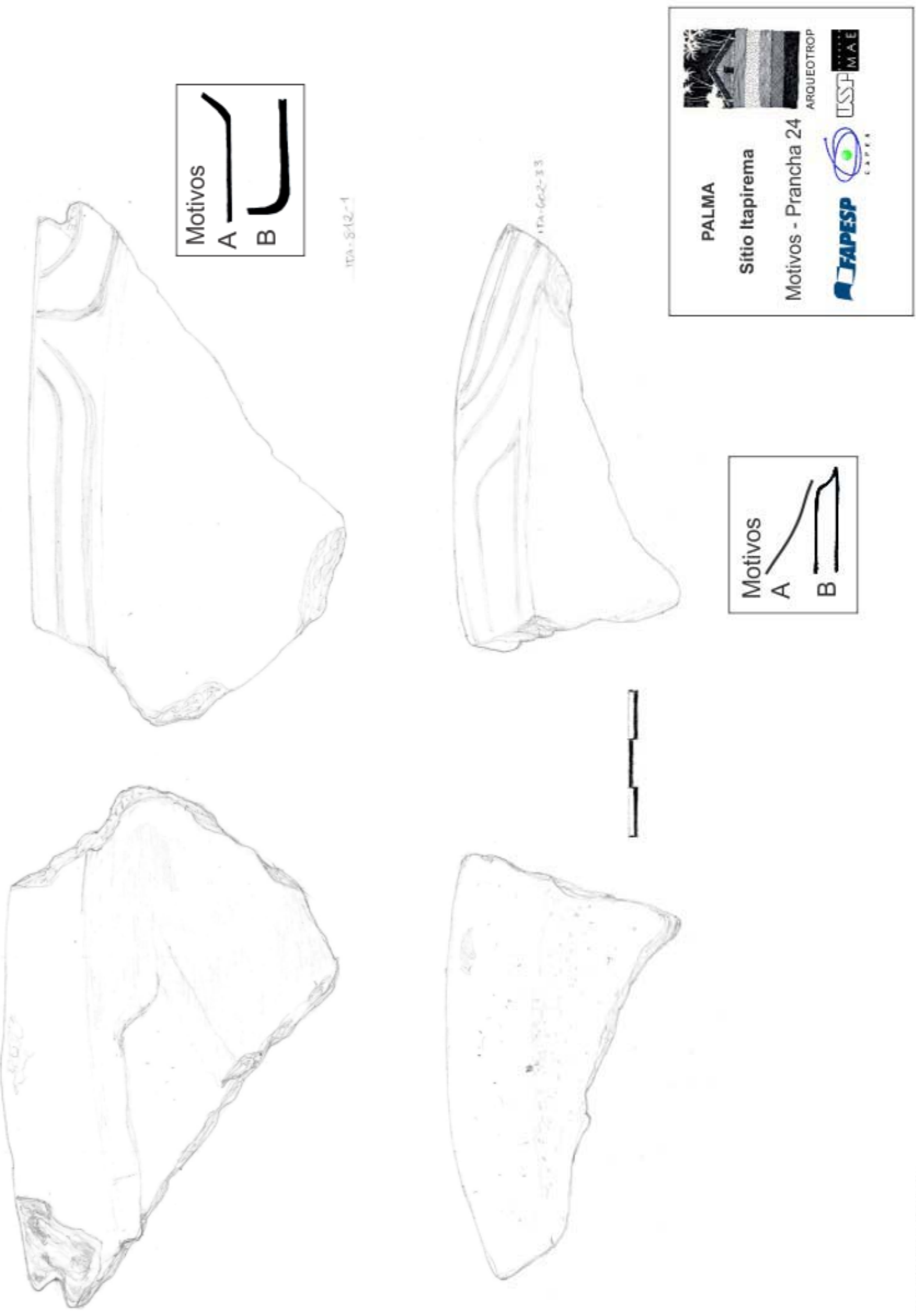


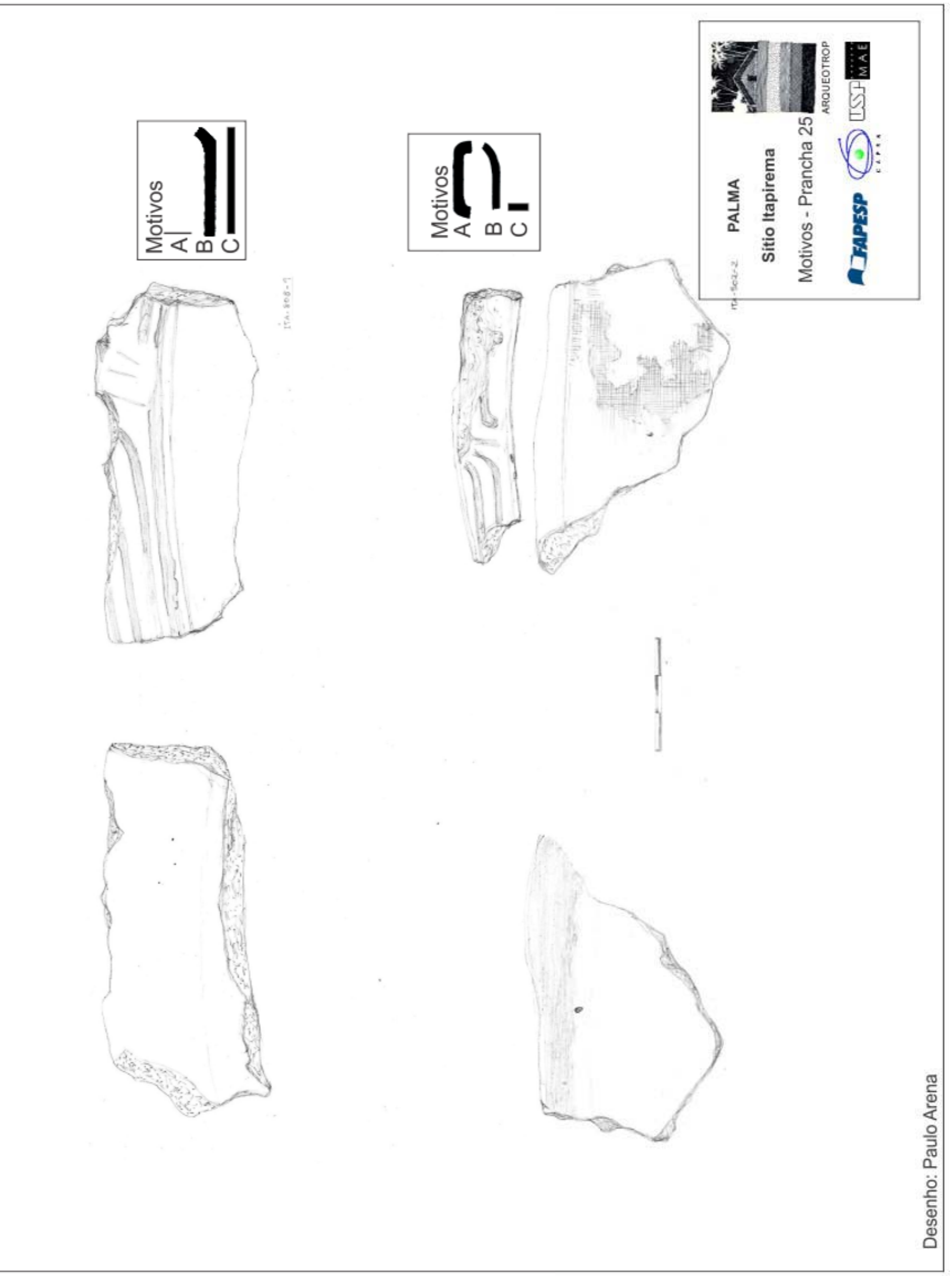




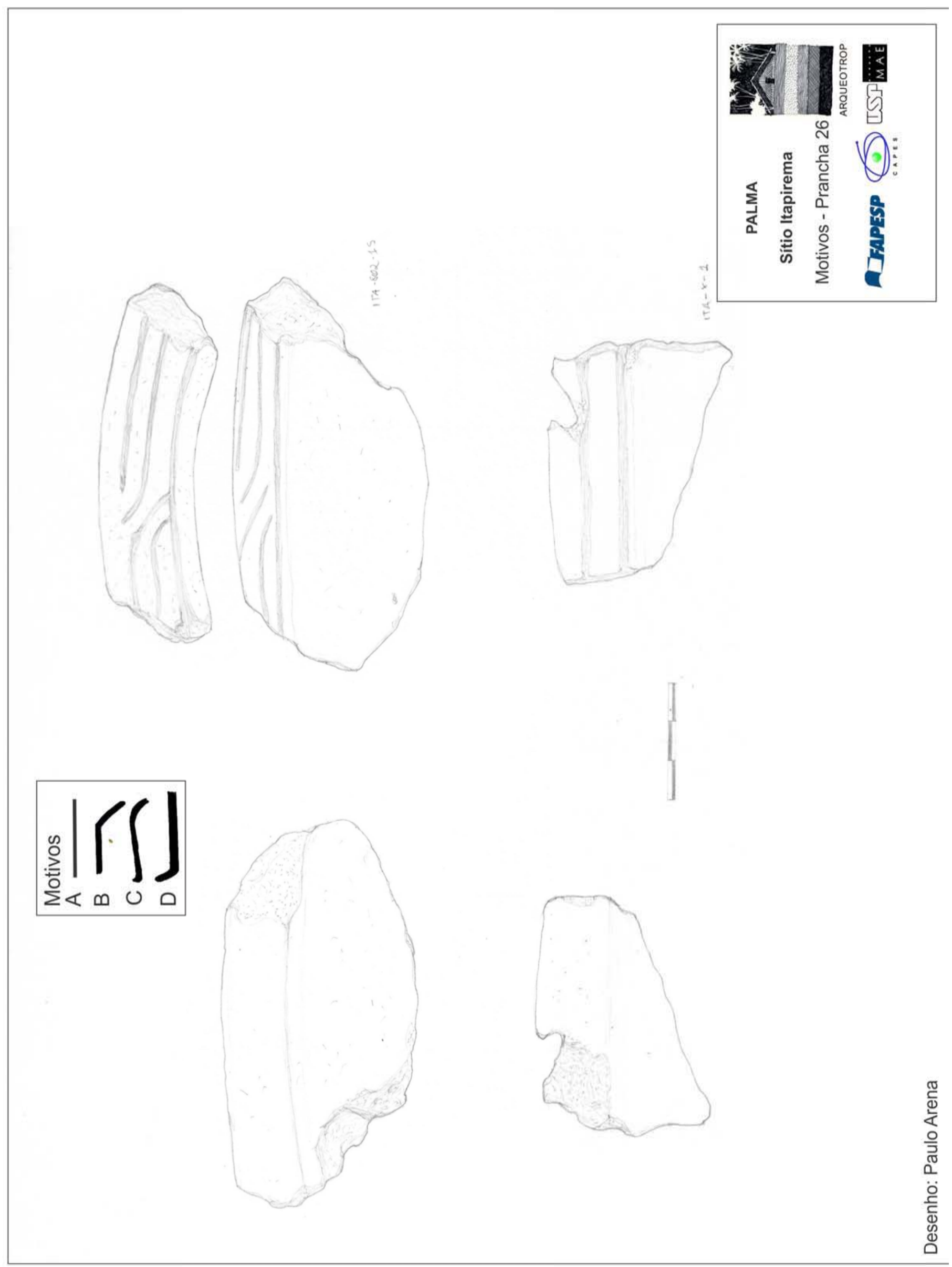



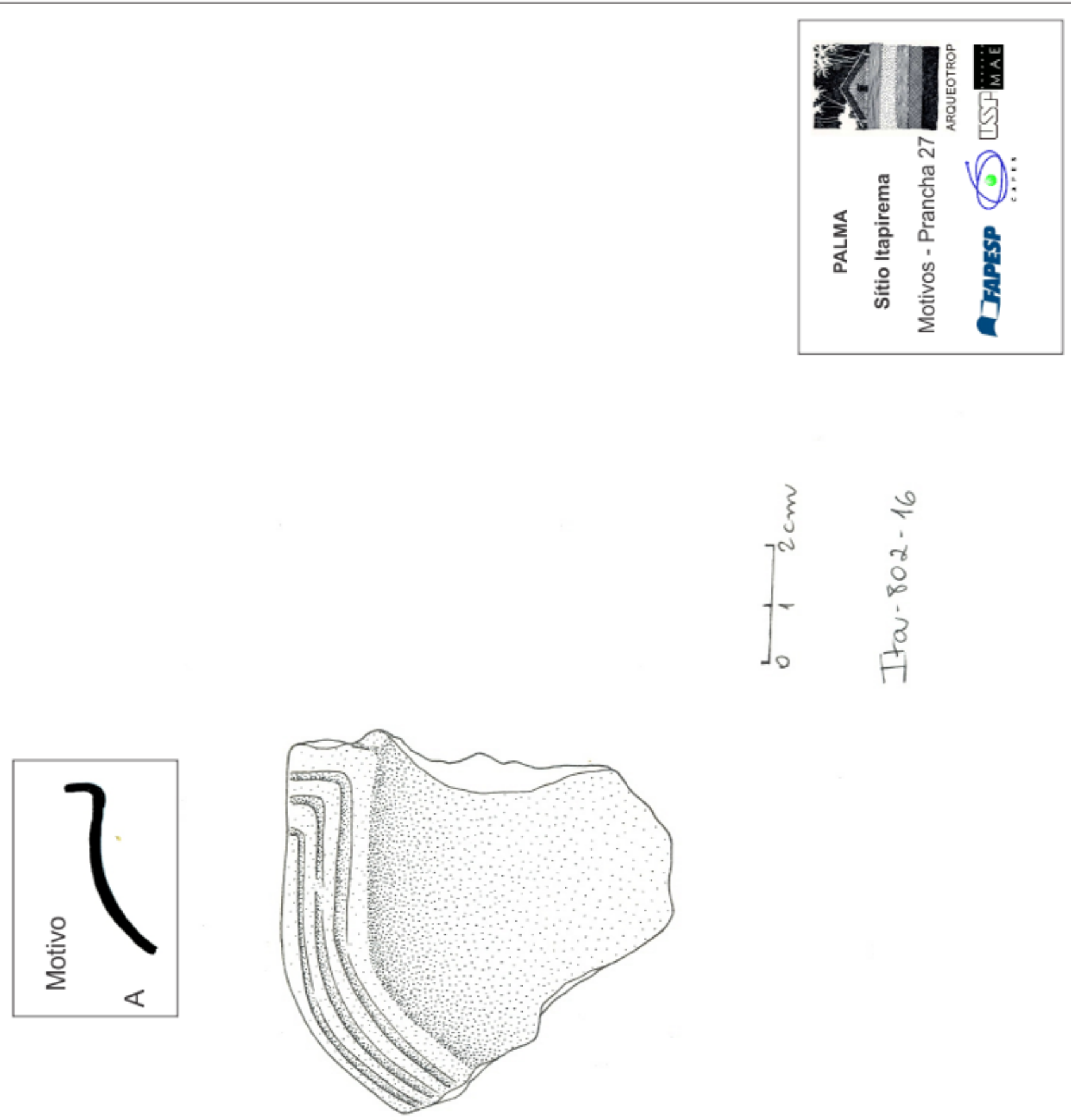


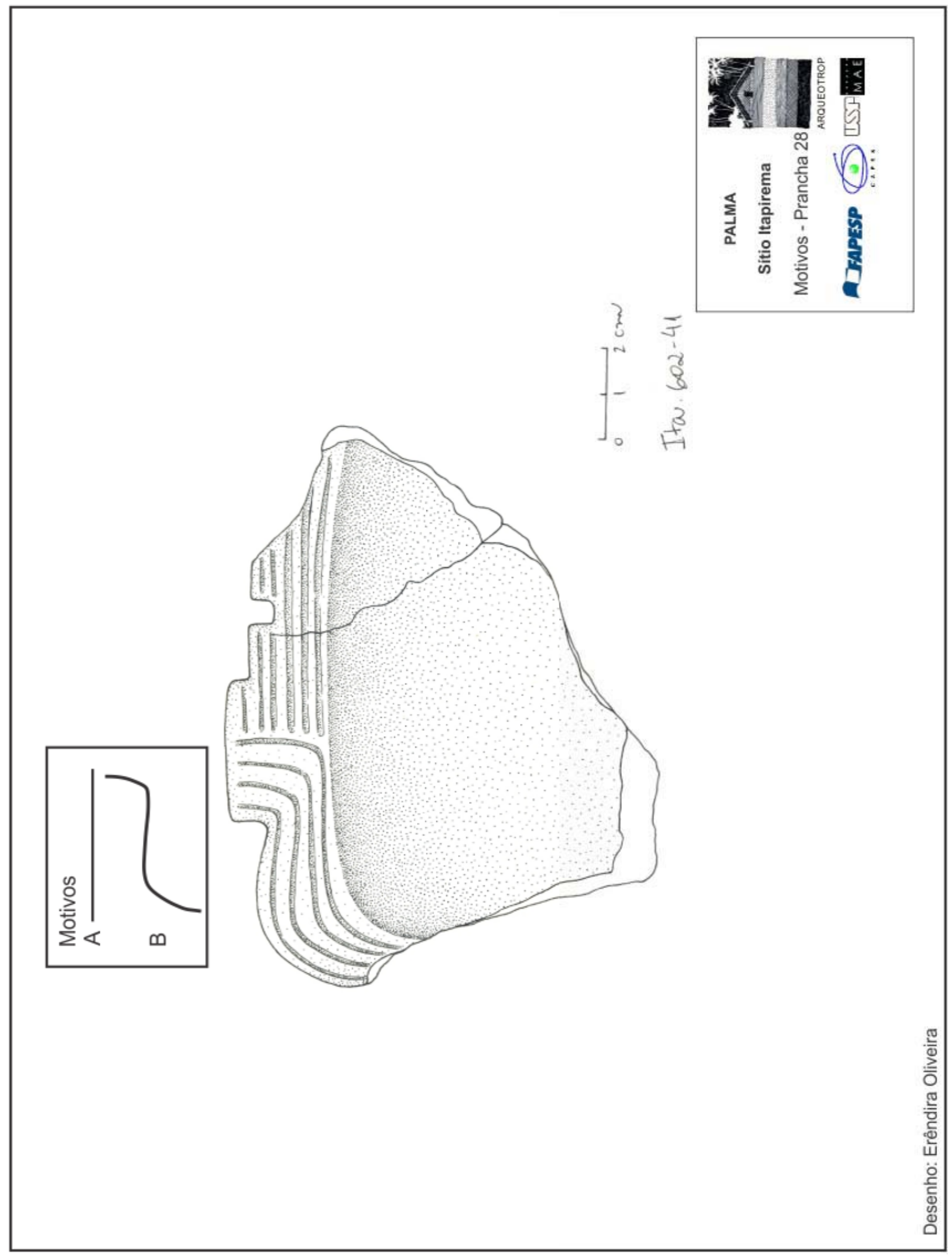



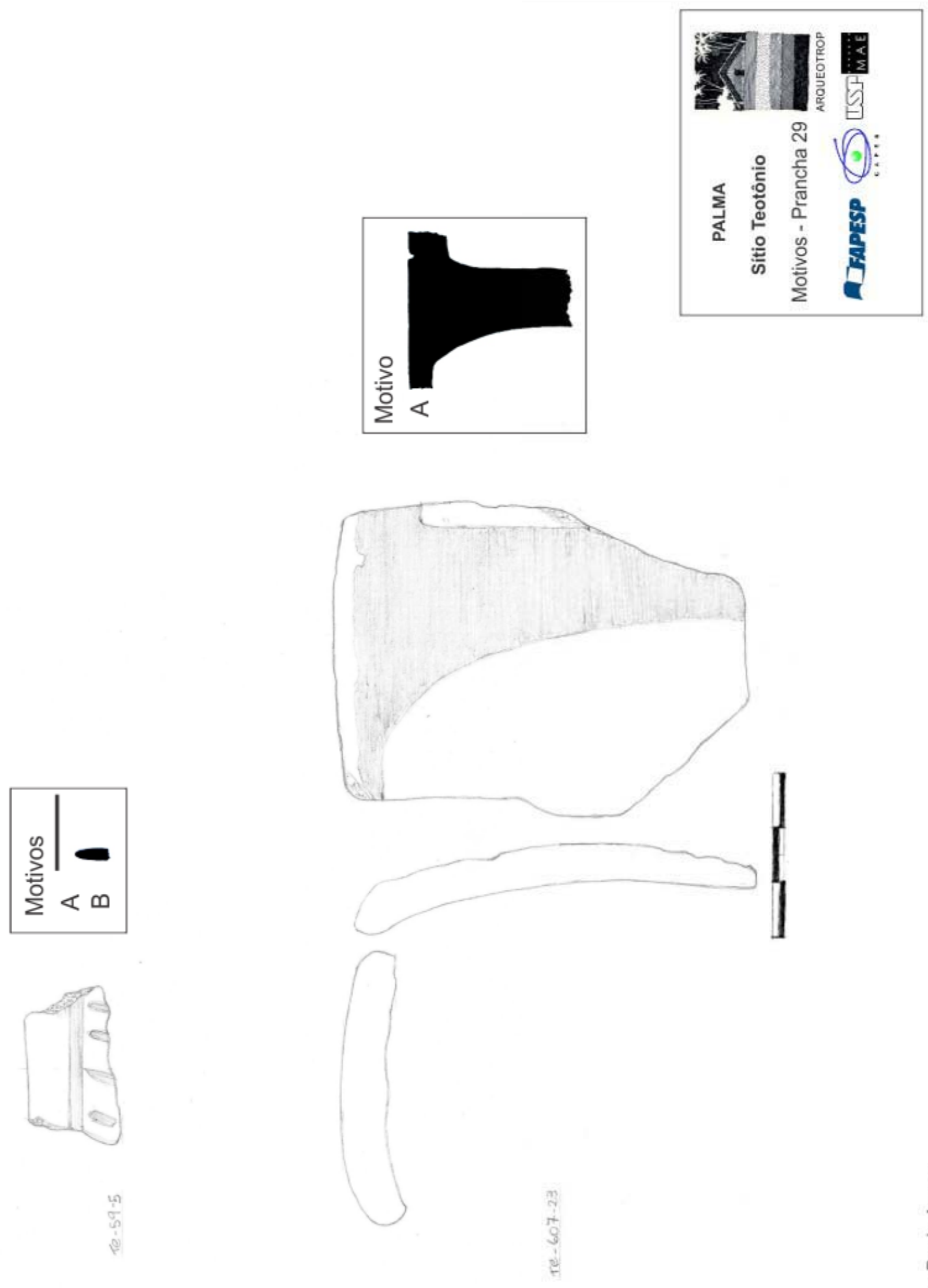
ANEXO 20 


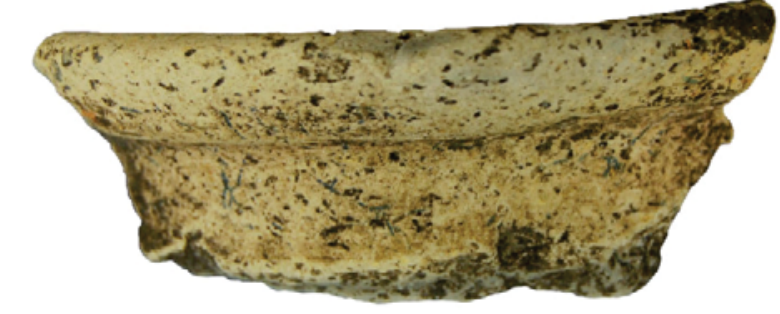

AC-52-28

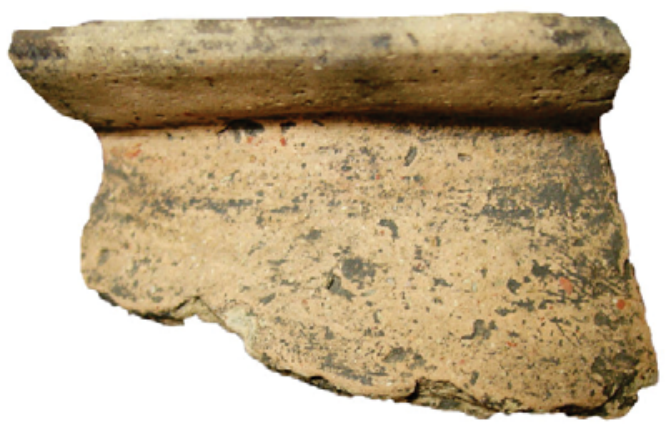

$\mathrm{S} / \mathrm{N}$

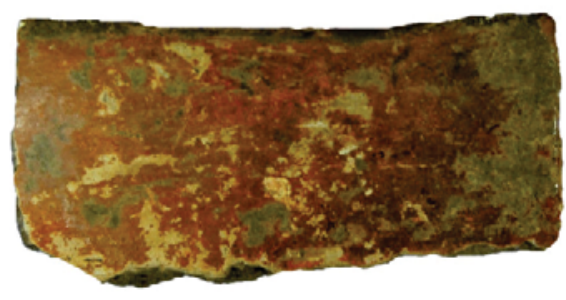

AC-55-49

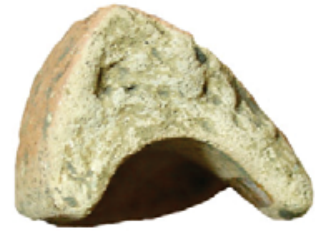

$\mathrm{S} / \mathrm{N}$

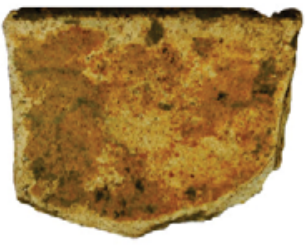

AC-104-82

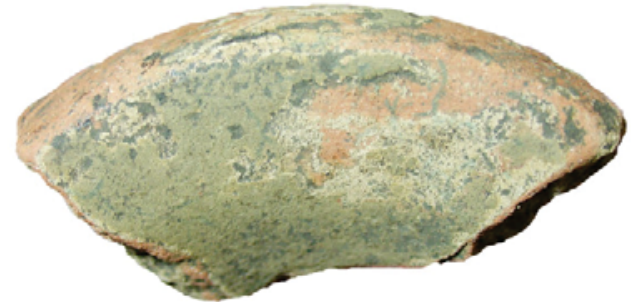

$\mathrm{S} / \mathrm{N}$

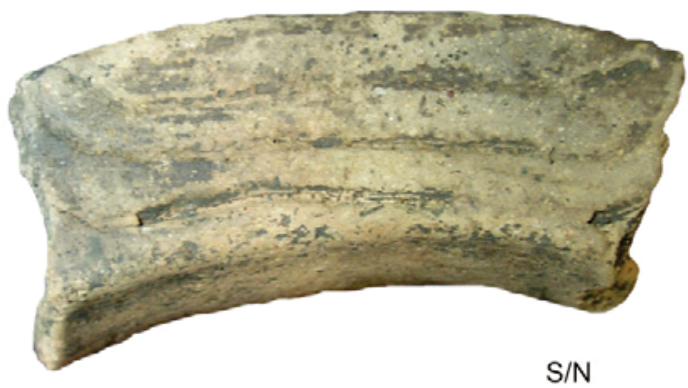

$\mathrm{S} / \mathrm{N}$

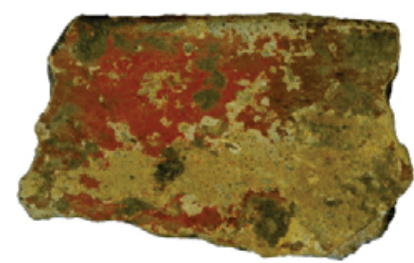

AC-55-44

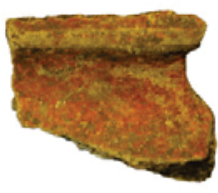

AC-102-38

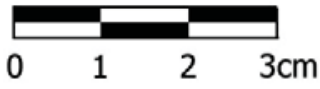

TESE DE DOUTORADO

\section{SÍTIO ASSOCIAÇÃO CALDERITA}

FRAGMENTOS DE BORDA COM DECORAÇÃO PLÁSTICA E PINTADA

PRANCHA 1
A TRADIÇÃO POLÍCROMA DA AMAZÔNIA NO ALTO RIO MADEIRA

Aluno: Fernando Ozorio de Almeida Orientador: Eduardo Góes Neves

Programa de Pós-Graduação - Museu de Arqueologia e Etnologia

Arte Final: Eduardo Tamanaha MAE A JAPESP




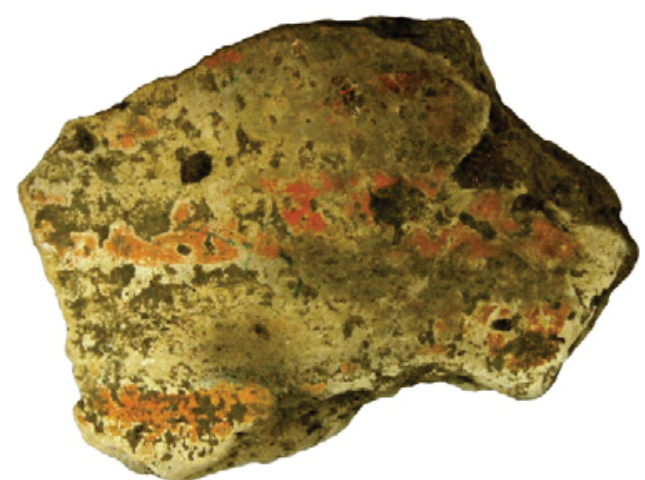

AC-53-53

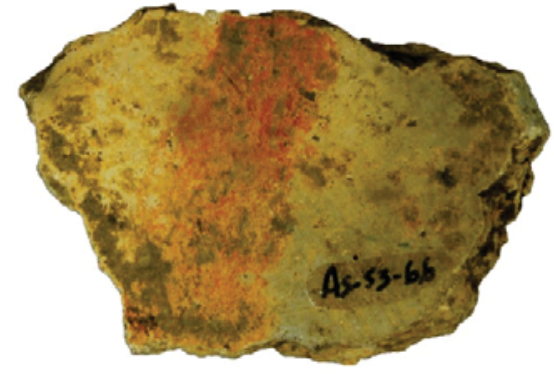

AC-53-66

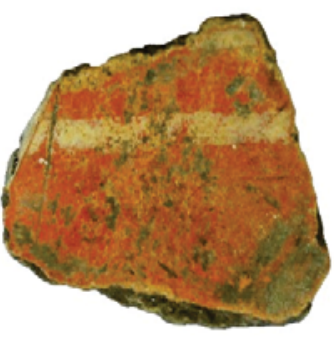

AC-104-4

AC-54-119

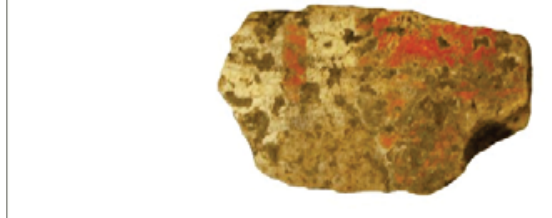

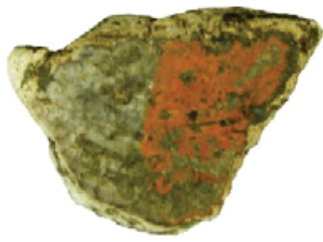

AC-55-3

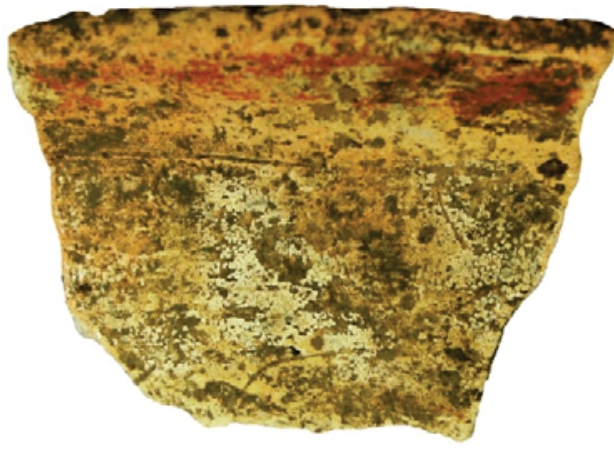

AC-53-102
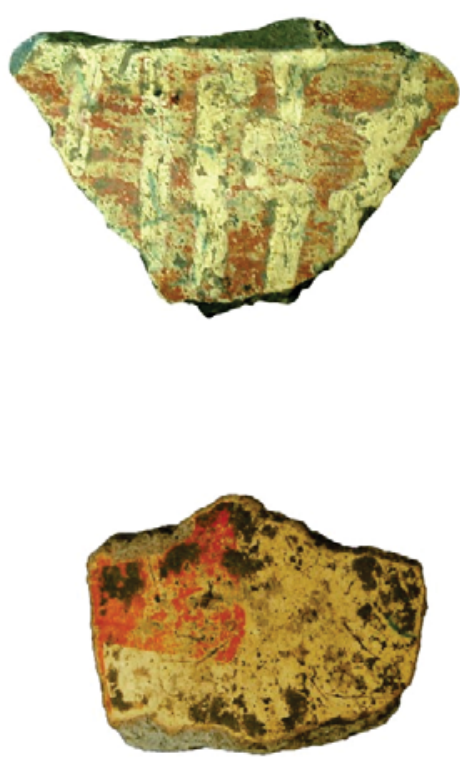

AC-53-59

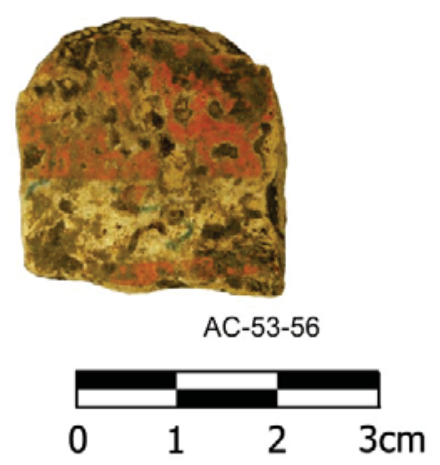

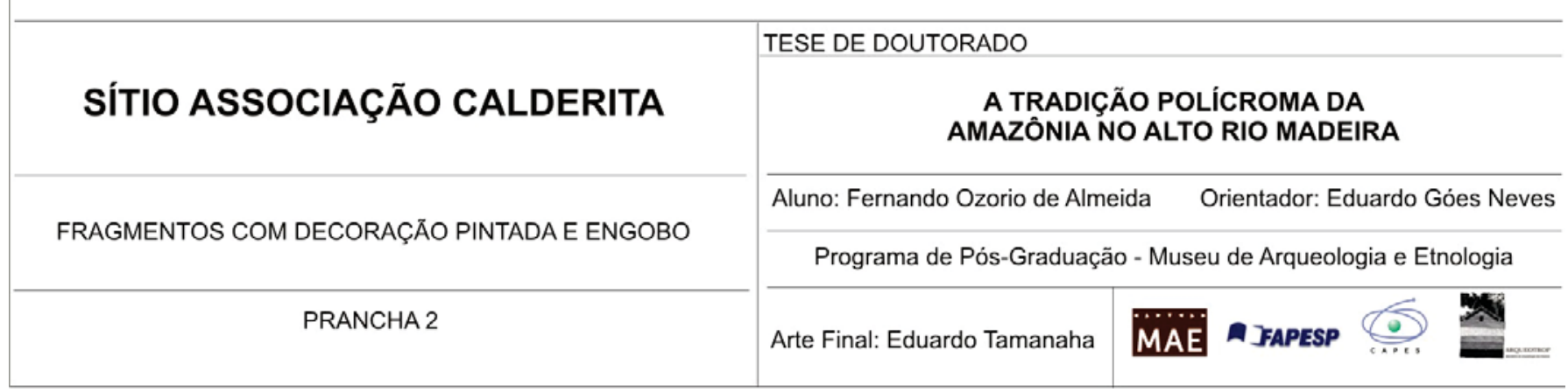




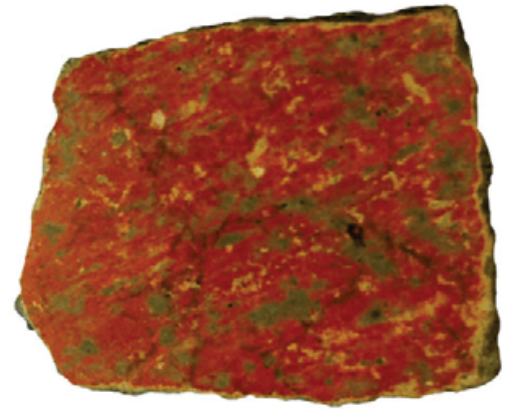

AC-54-89

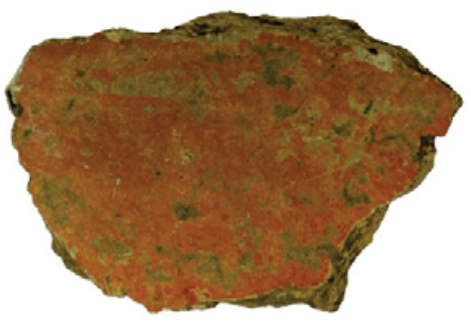

AC-53-66

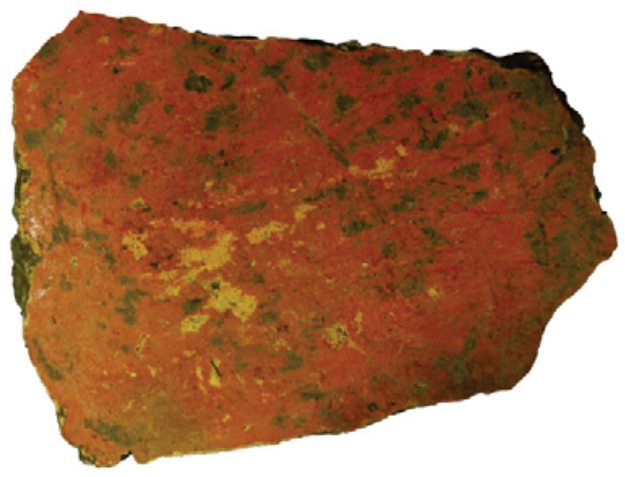

AC-53-74

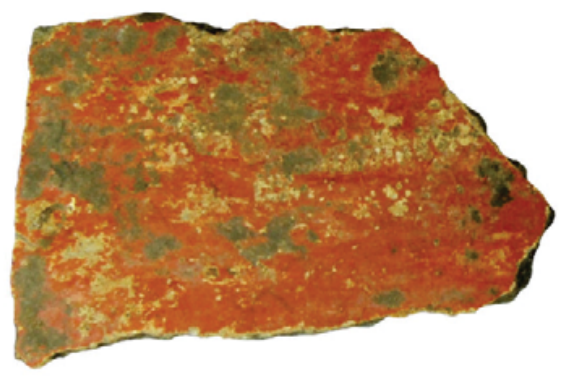

AC-54-86

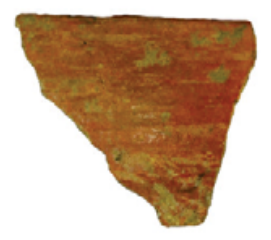

AC-54-19
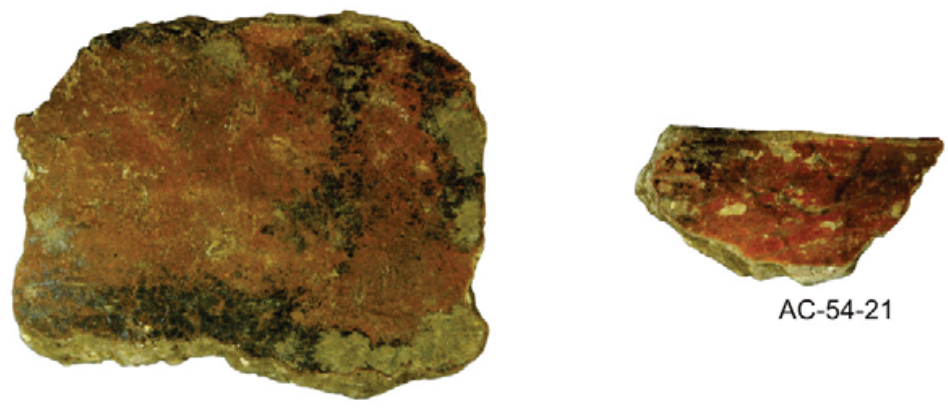

AC-54-92
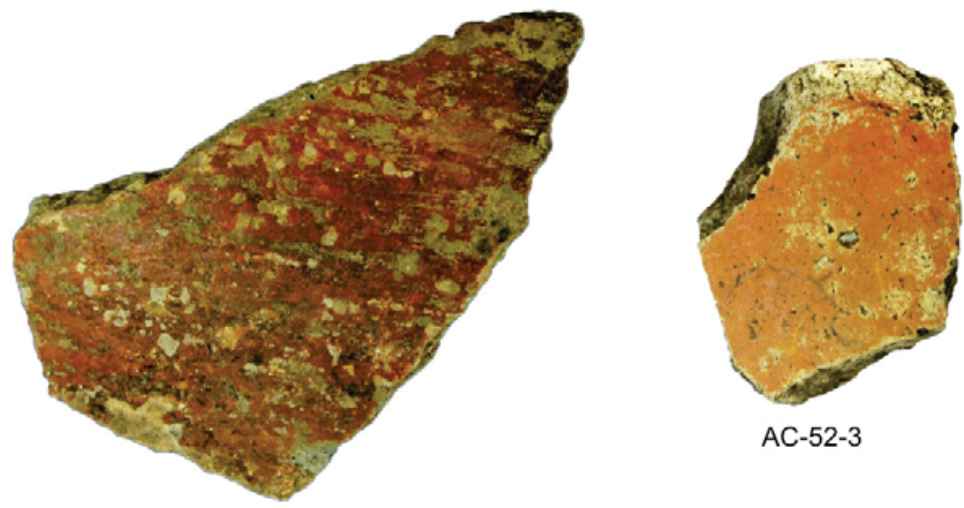

AC-54-36

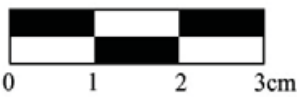

TESE DE DOUTORADO

\section{SÍTIO ASSOCIAÇÃO CALDERITA}

FRAGMENTOS COM DECORAÇÃO PINTADA E ENGOBO
A TRADIÇÃO POLÍCROMA DA AMAZÔNIA NO ALTO RIO MADEIRA

Aluno: Fernando Ozorio de Almeida Orientador: Eduardo Góes Neves

Programa de Pós-Graduação - Museu de Arqueologia e Etnologia

Arte Final: Eduardo Tamanaha MAE $\cap$ JFAPESP




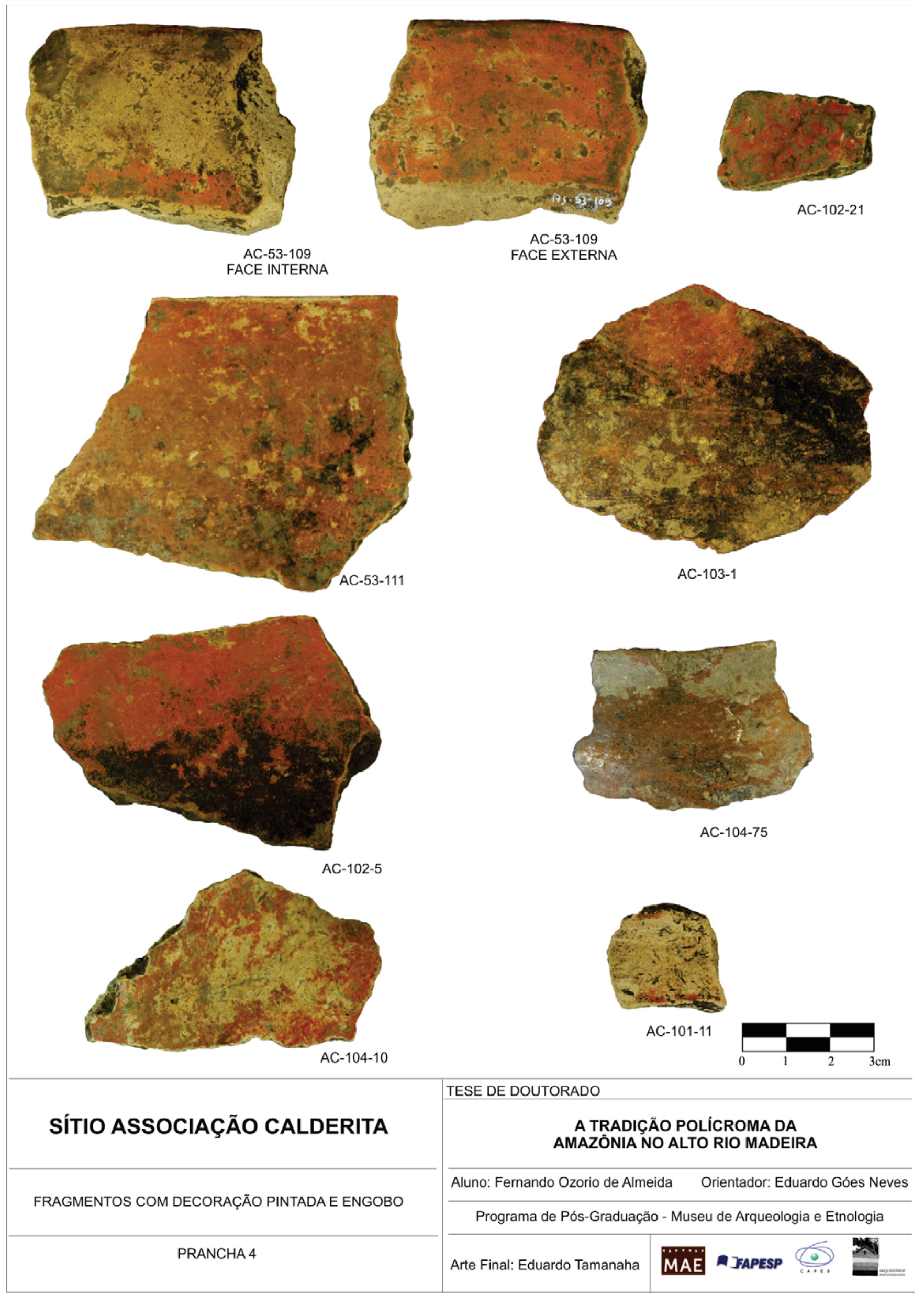




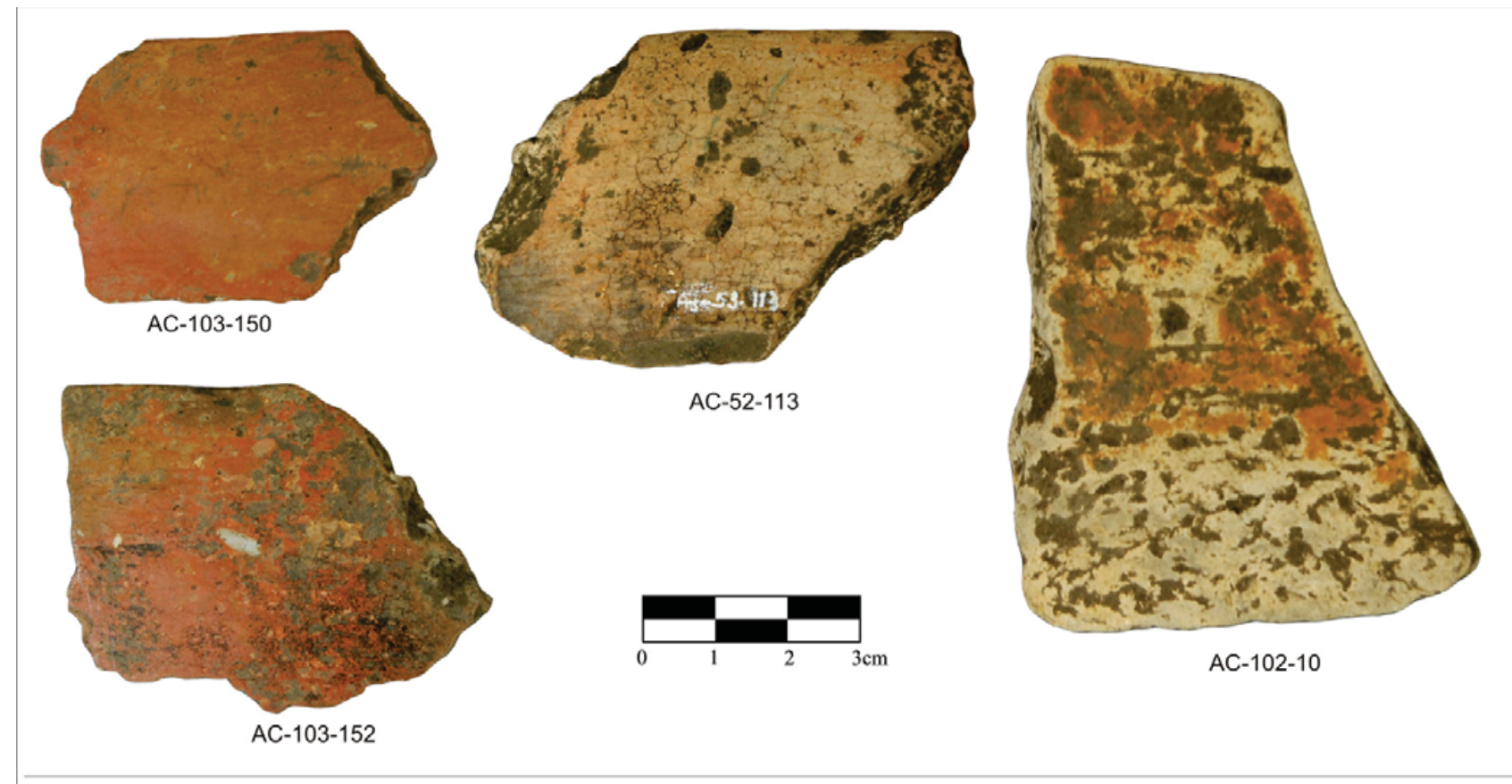

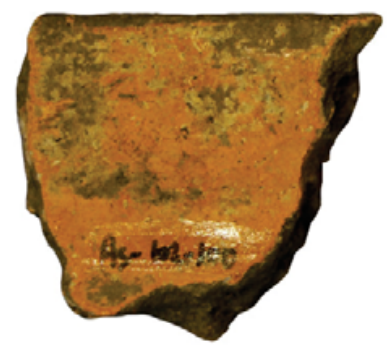

AC-102-100

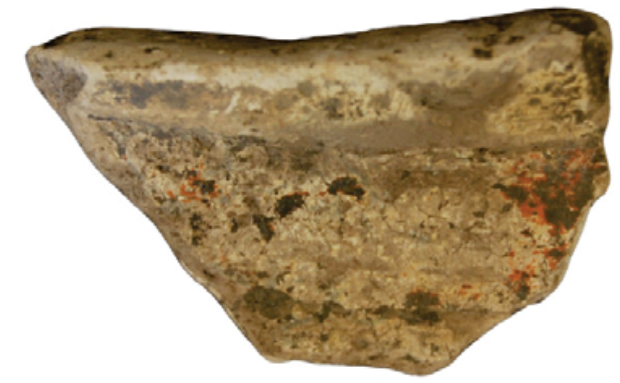

AC-104-69

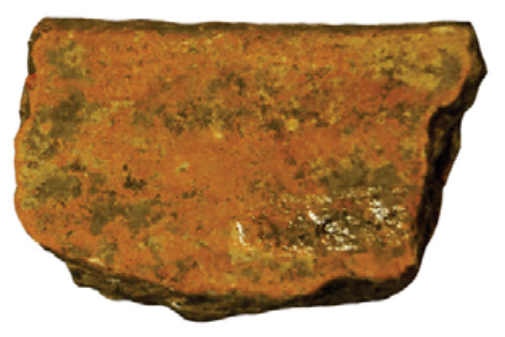

AC-102-103

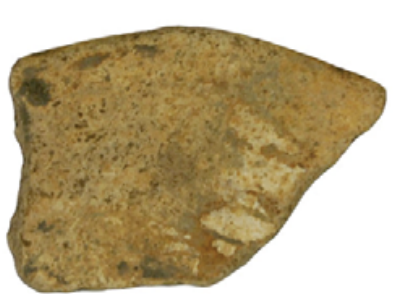

AC-103-143

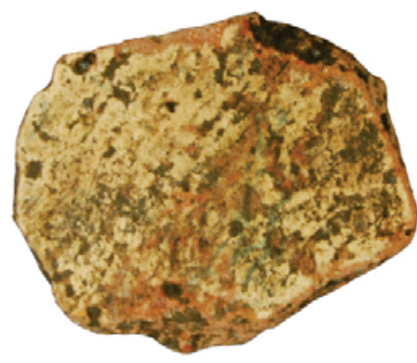

AC-52-9

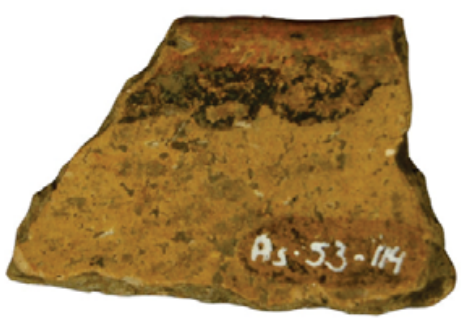

AC-53-114

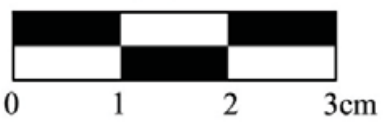

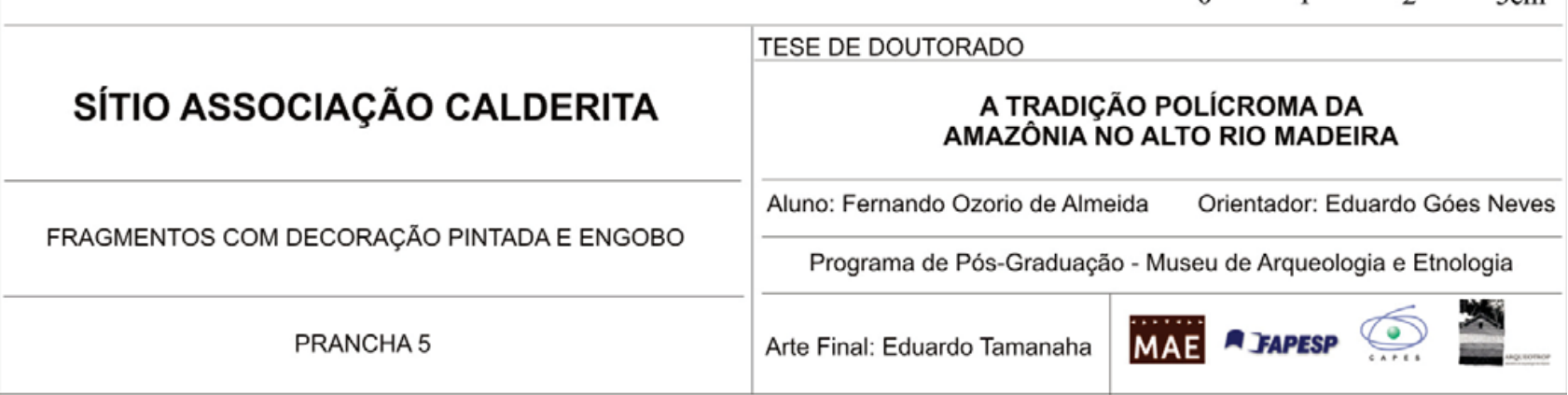




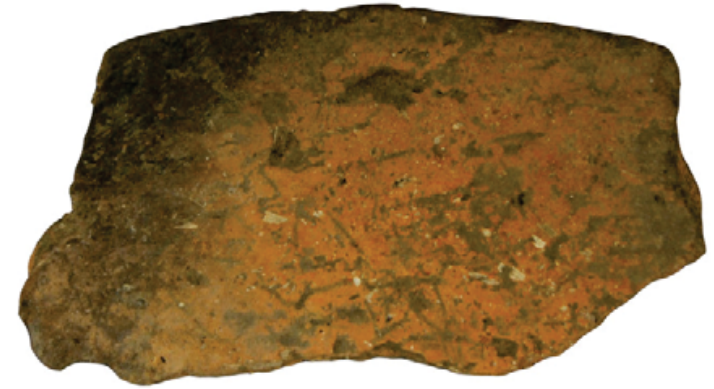

AC-54-3

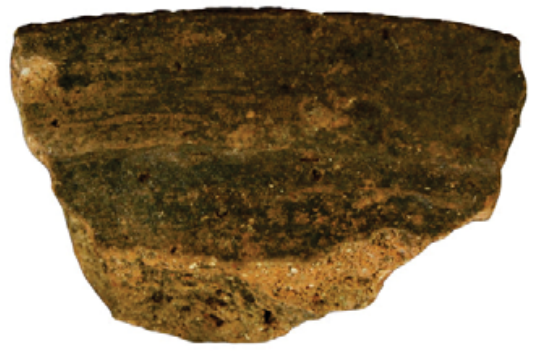

AC-101-26

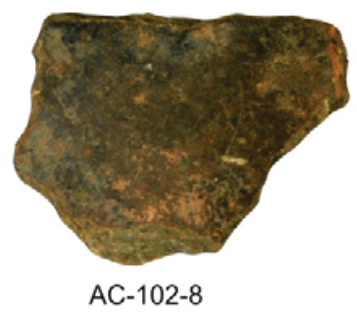

AC-102-8

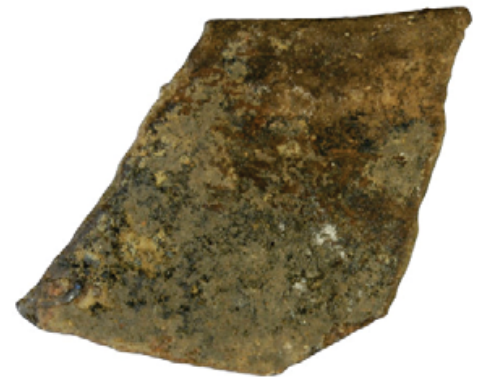

AC-104-76

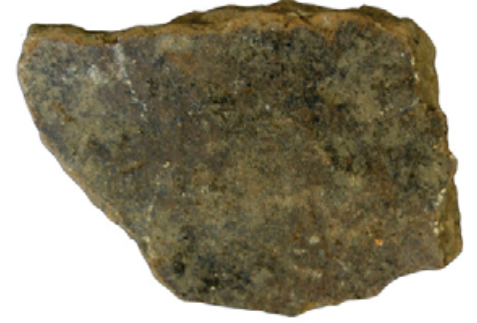

AC-104-8

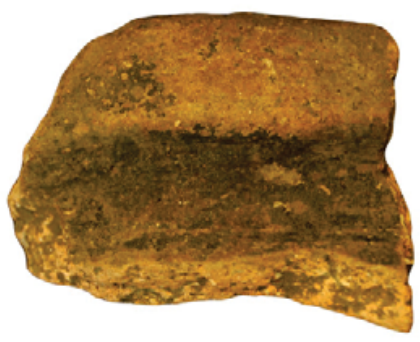

AC-102-80
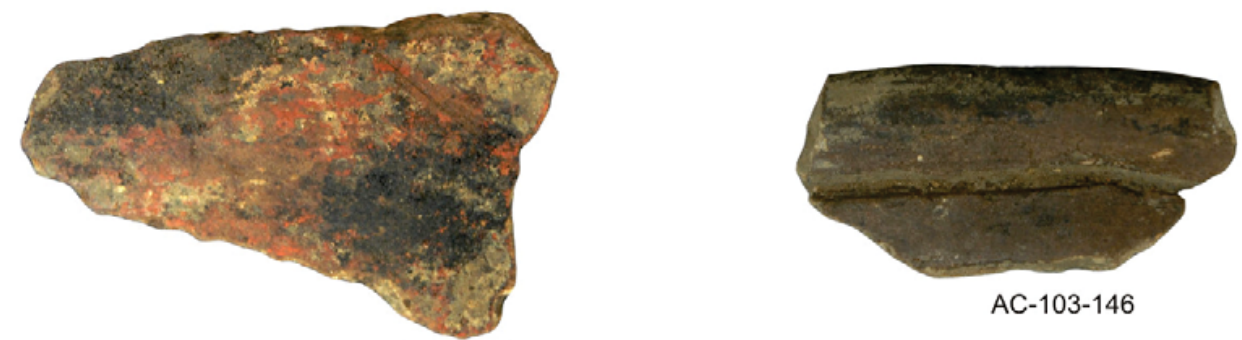

AC-103-146

AC-102-4

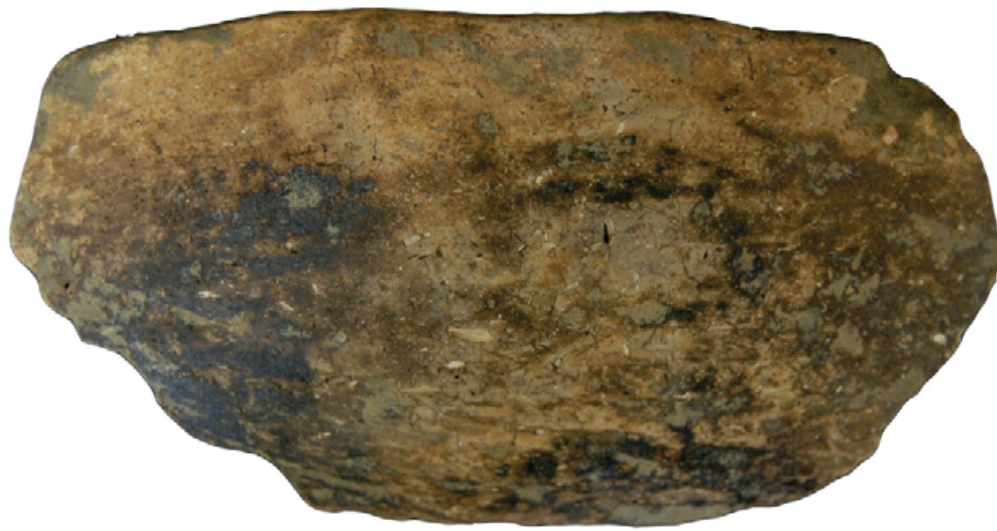

AC-55-42

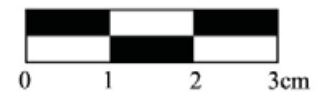

\begin{tabular}{|c|c|c|}
\hline & \multicolumn{2}{|l|}{ TESE DE DOUTORADO } \\
\hline SÍTIO ASSOCIAÇÃO CALDERITA & \multicolumn{2}{|c|}{$\begin{array}{l}\text { A TRADIÇÃO POLÍCROMA DA } \\
\text { AMAZÔNIA NO ALTO RIO MADEIRA }\end{array}$} \\
\hline \multirow{2}{*}{ FRAGMENTOS COM DECORAÇÃO PINTADA E ENGOBO } & Aluno: Fernando Ozorio de Almeic & Orientador: Eduardo Góes Neves \\
\hline & \multicolumn{2}{|c|}{ Programa de Pós-Graduação - Museu de Arqueologia e Etnologia } \\
\hline PRANCHA 6 & Arte Final: Eduardo Tamanaha & $\vec{E}$ AFAPESP \\
\hline
\end{tabular}




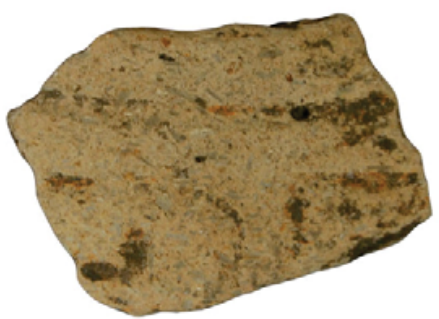

AC-103-19

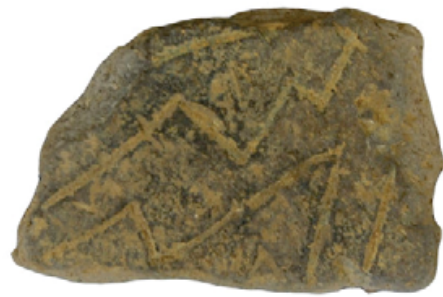

AC-1-9

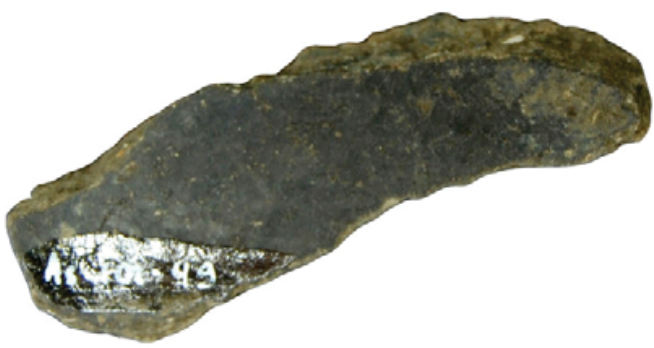

AC-102-49

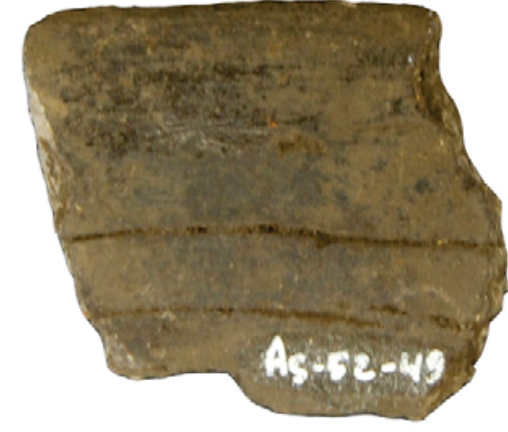

AC- $52-49$

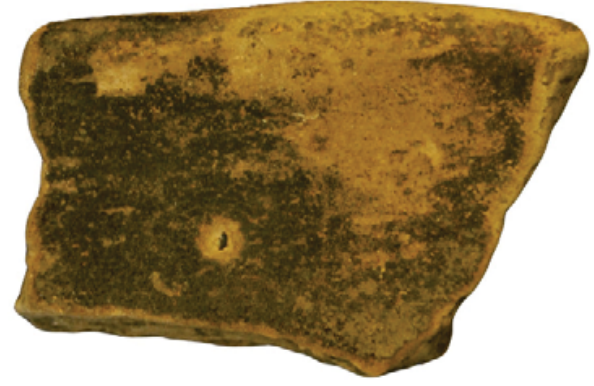

AC-102-95

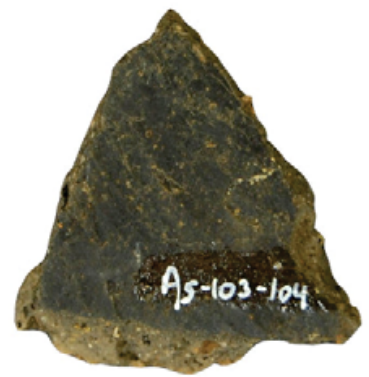

AC-103-104

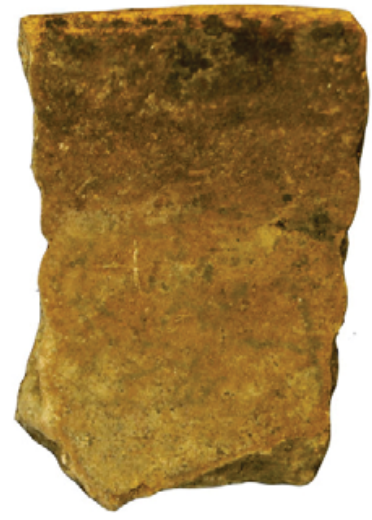

AC-102-94

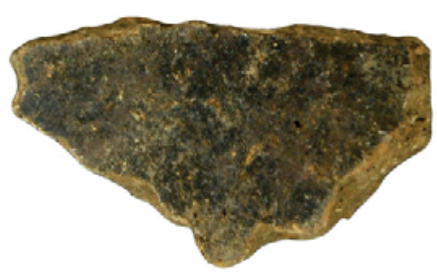

AC-103-13

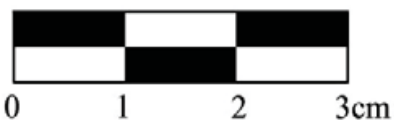

TESE DE DOUTORADO

SÍTIO ASSOCIAÇÃO CALDERITA

FRAGMENTOS ESFUMARADOS E COM DECORAÇÃO PINTADA

\section{A TRADIÇÃO POLÍCROMA DA} AMAZÔNIA NO ALTO RIO MADEIRA

Aluno: Fernando Ozorio de Almeida Orientador: Eduardo Góes Neves

Programa de Pós-Graduação - Museu de Arqueologia e Etnologia

Arte Final: Eduardo Tamanaha MAE A JaPESP




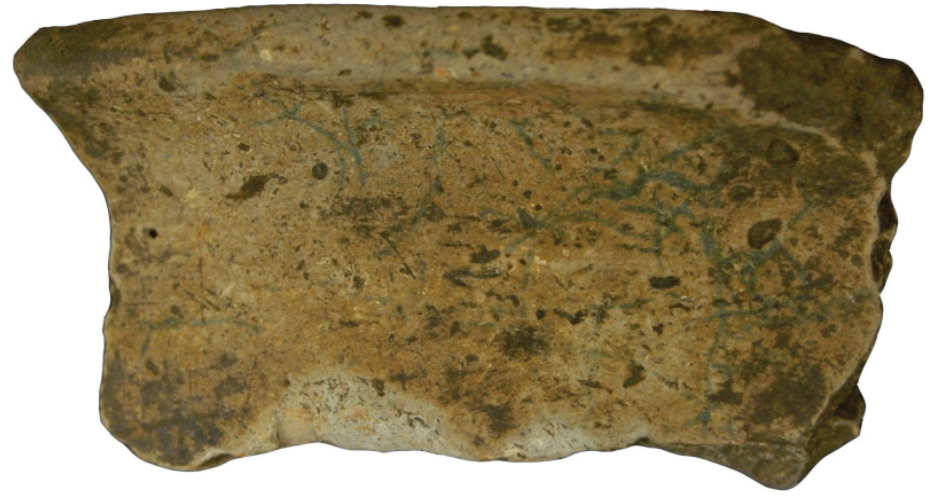

AC-53-117

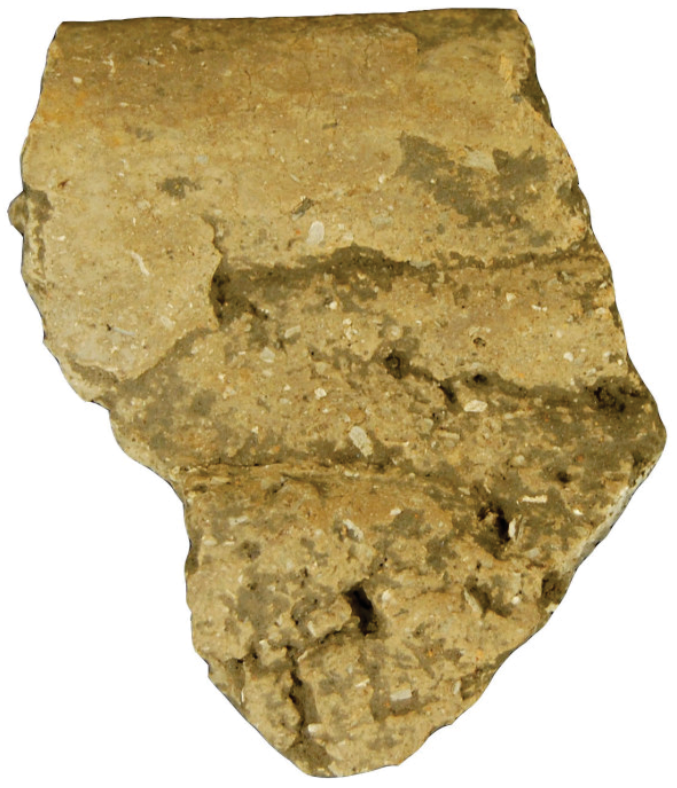

AC-54-2

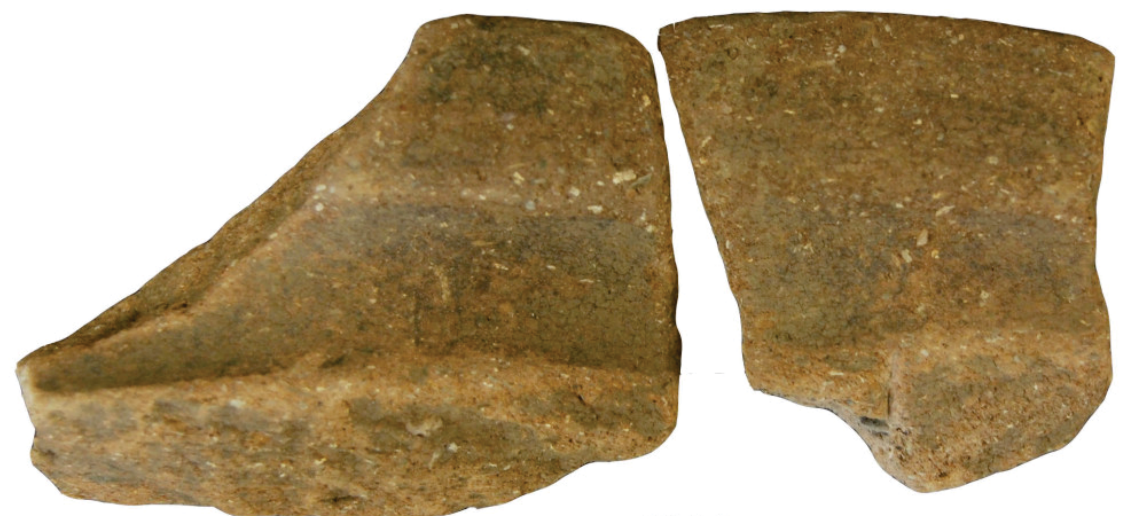

AC-1-7

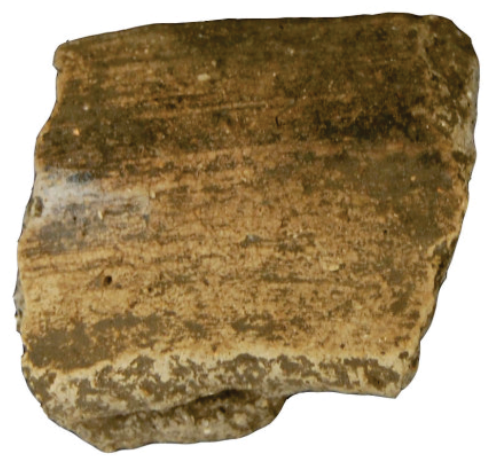

AC-52-49

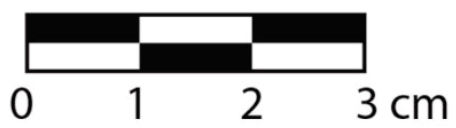

\begin{tabular}{c|c|c}
\hline $\begin{array}{c}\text { SÍTIO ASSOCIAÇÃO CALDERITA } \\
\text { FRAGMENTOS DE BORDA }\end{array}$ & $\begin{array}{c}\text { TESE DE DOUTORADO } \\
\text { A TRADIÇÃO POLÍCROMA DA } \\
\text { AMAZÔNIA NO ALTO RIO MADEIRA }\end{array}$ \\
\hline PRANCHA 8 & $\begin{array}{c}\text { Aluno: Fernando Ozorio de Almeida Orientador: Eduardo Góes Neves } \\
\text { Programa de Pós-Graduação - Museu de Arqueologia e Etnologia }\end{array}$ \\
\hline Arte Final: Eduardo Tamanaha & MAE \\
\hline FAPESP
\end{tabular}




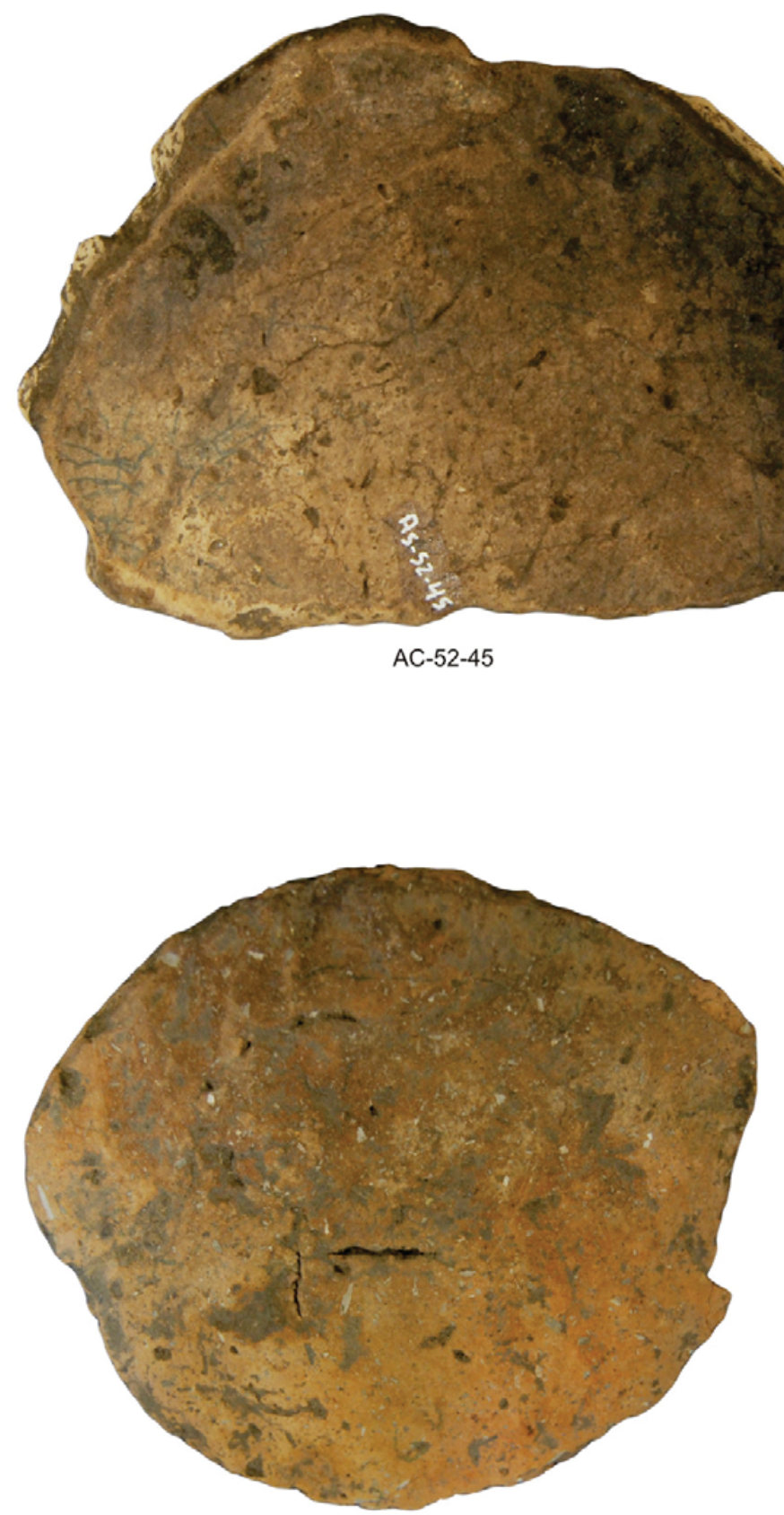

AC-104-78

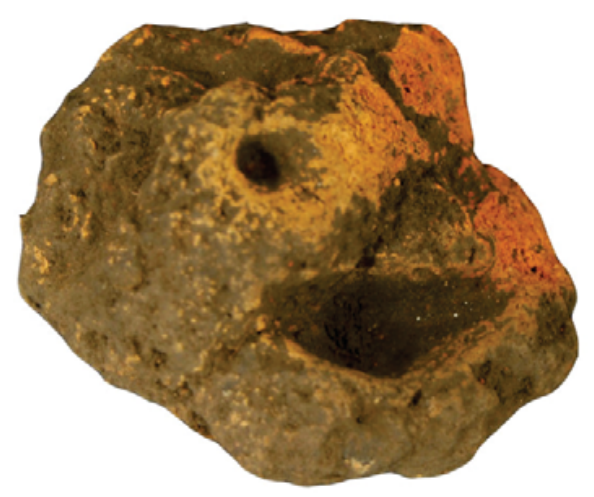

AC- $52-43$

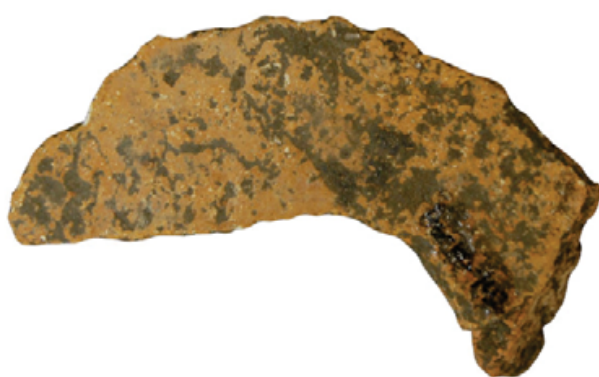

AC-103-102

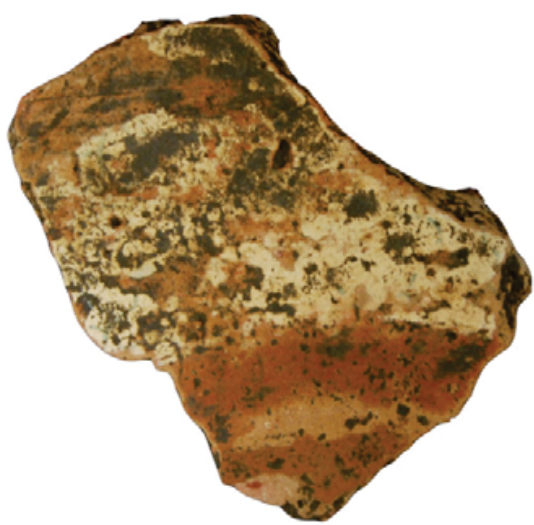

AC-52-41

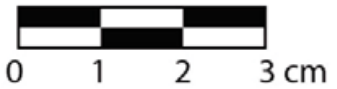

TESE DE DOUTORADO

\section{SÍTIO ASSOCIAÇÃO CALDERITA}

FRAGMENTOS DE BASES
A TRADIÇÃO POLÍCROMA DA AMAZÔNIA NO ALTO RIO MADEIRA

Aluno: Fernando Ozorio de Almeida Orientador: Eduardo Góes Neves

Programa de Pós-Graduação - Museu de Arqueologia e Etnologia 

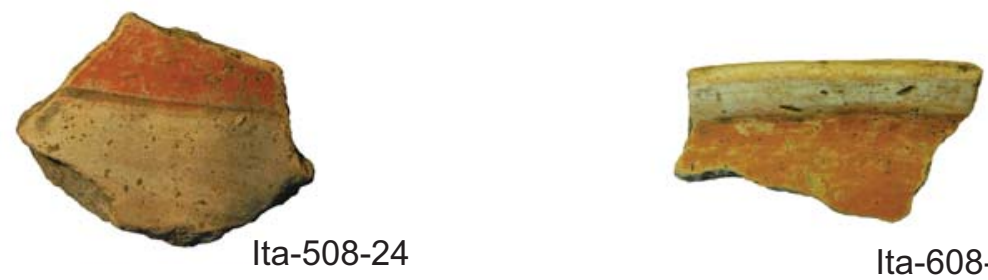

Ita-608-20
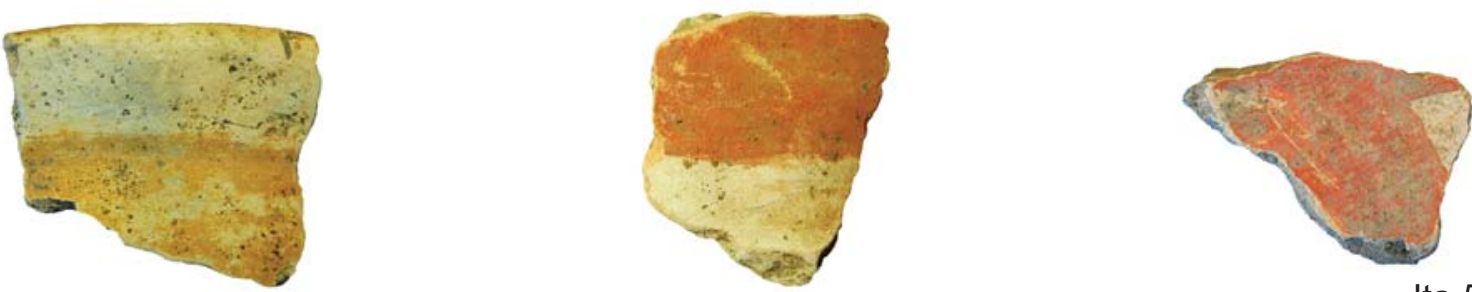

Ita-505-54

Ita-804-68

Ita-510-37b
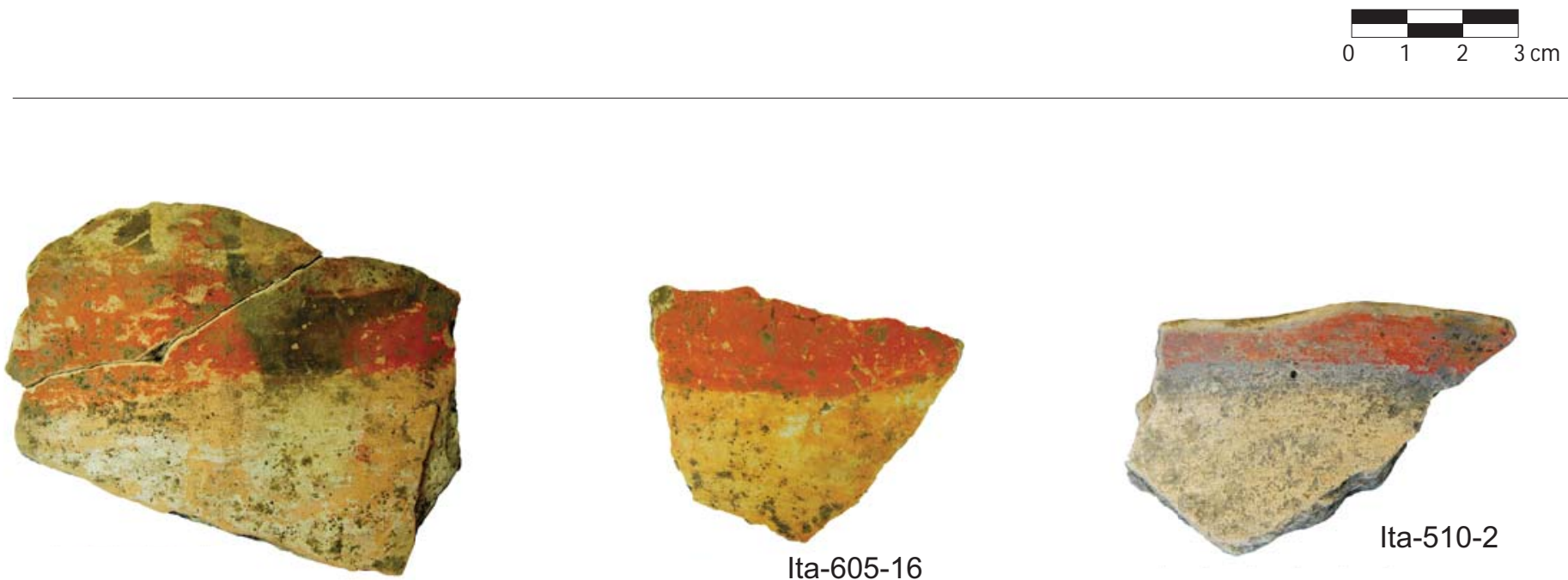

Ita-804-38

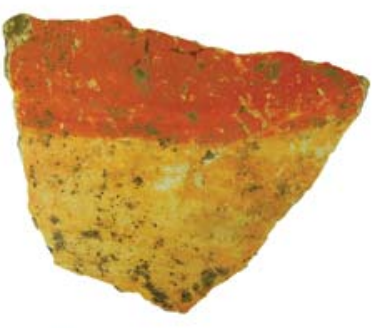

Ita-605-16

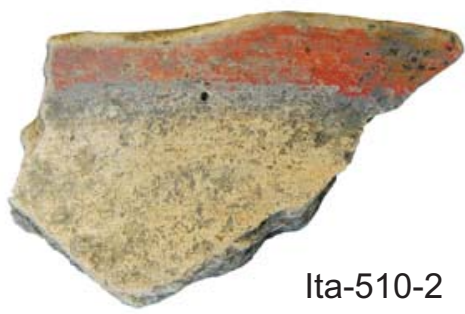

Ita-510-2

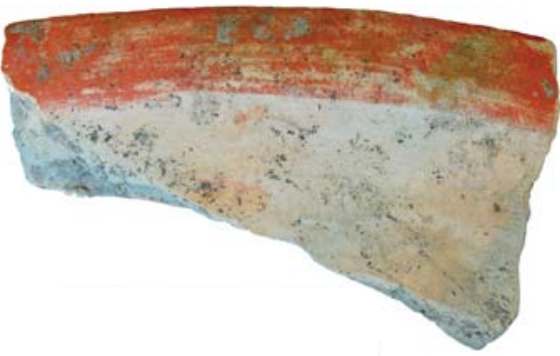

Ita-528-1

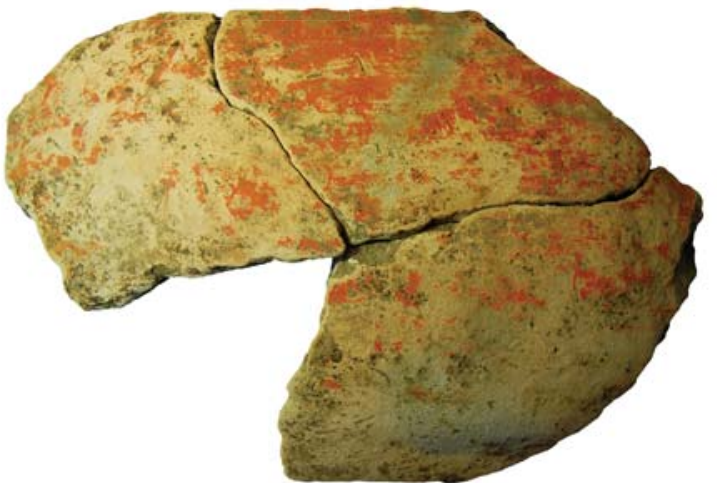

Ita-804-36

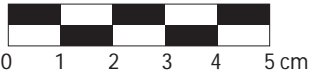

TESE DE DOUTORADO

A TRADIÇÃO POLÍCROMA DA AMAZÔNIA NO ALTO RIO MADEIRA 


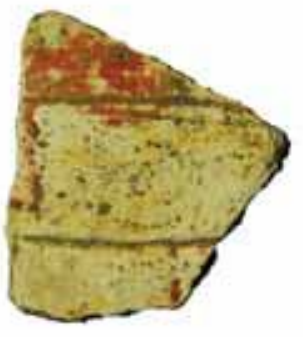

Ita-804-44

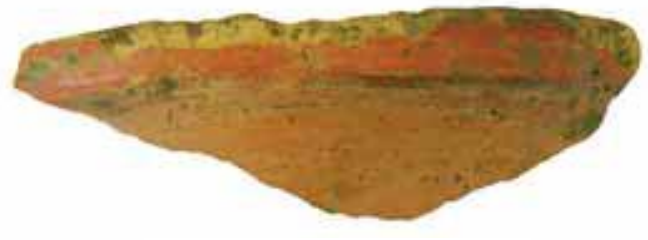

Ita-610-45

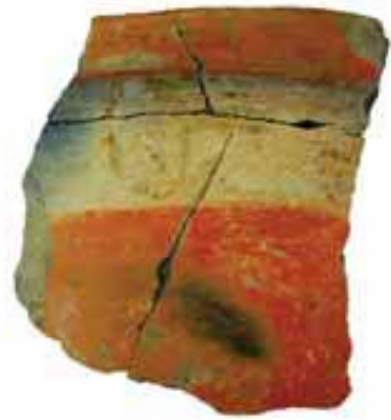

Ita-616-9

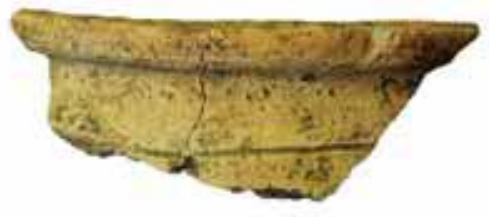

Ita-802-20

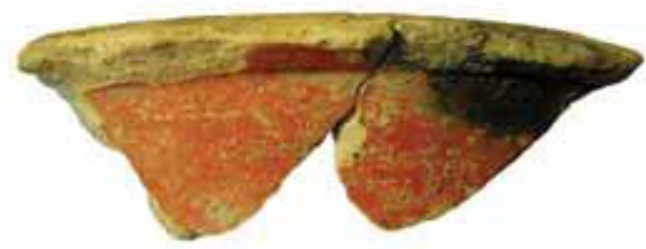

Ita-805-150

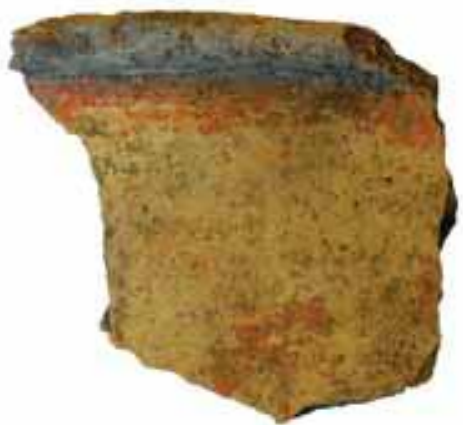

Ita-611-16

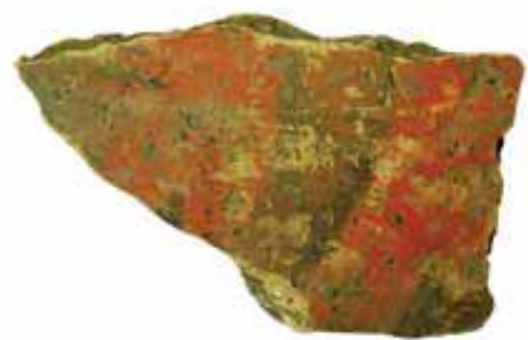

Ita-804-36

Ita-804-15

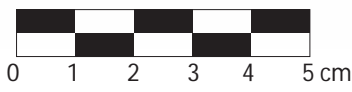

\section{SÍTIO ITAPIREMA}

\section{FRAGMENTOS PINTADOS}

A TRADIÇÃO POLÍCROMA DA AMAZÔNIA NO ALTO RIO MADEIRA 


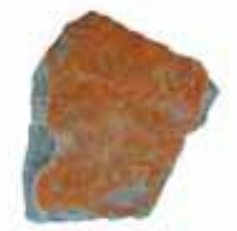

Ita-508-16

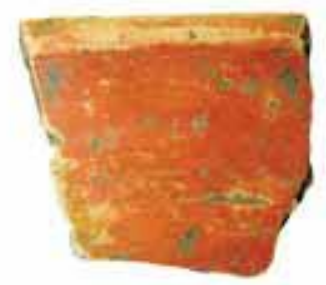

Ita-533-1

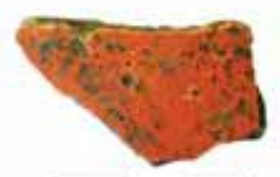

Ita-501-25

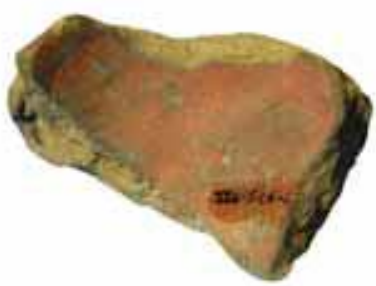

Ita-526-6

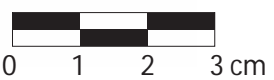

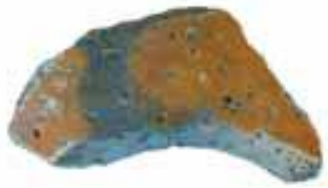

Ita-508-20

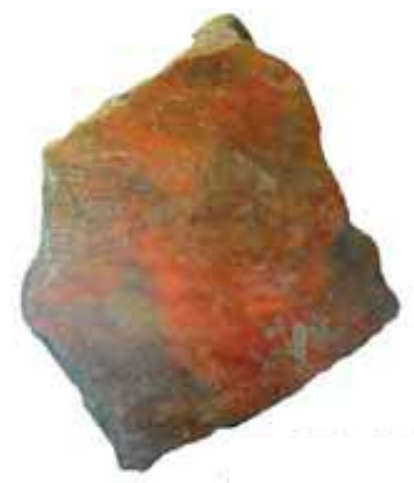

Ita-513-29

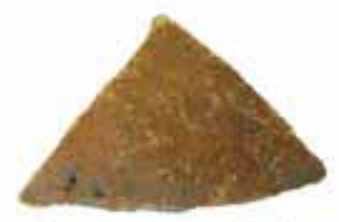

Ita-510-80

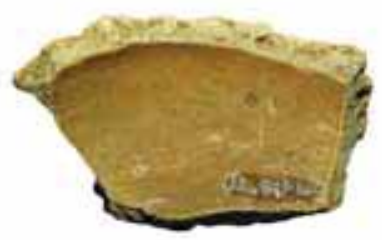

Ita-303-104

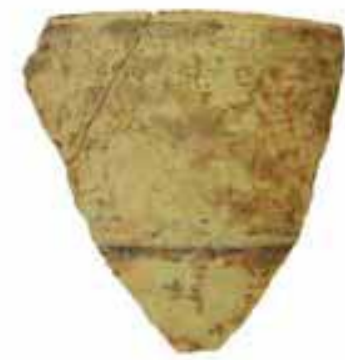

Ita-303-156

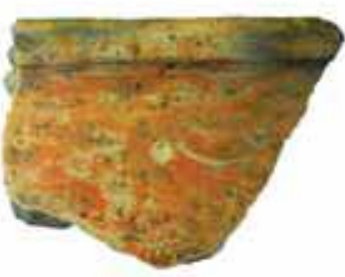

Ita-603-47

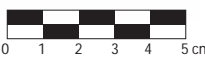

SÍTIO ITAPIREMA

FRAGMENTOS COM ENGOBO E PINTURA
A TRADIÇÃO POLÍCROMA DA AMAZÔNIA NO ALTO RIO MADEIRA 


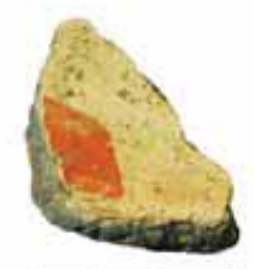

Ita-508-15

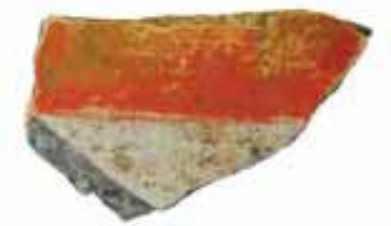

Ita-510-35

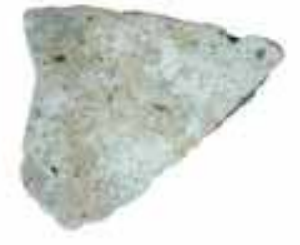

Ita-508-18

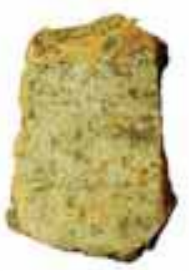

Ita-808-4

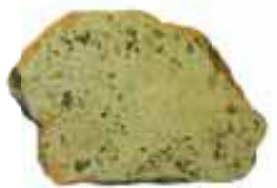

Ita-505-15

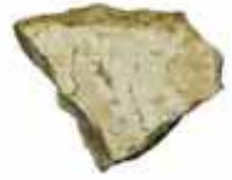

Ita-66-5

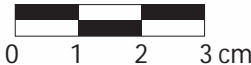

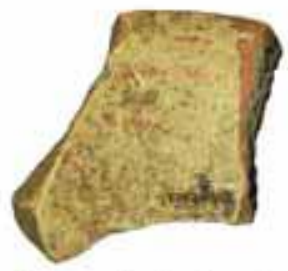

Ita-243-2

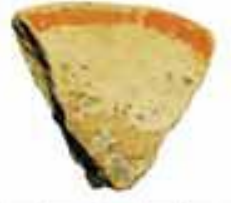

Ita-303-111

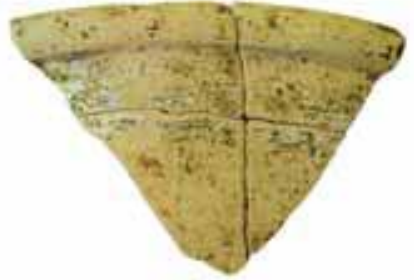

Ita-802-22

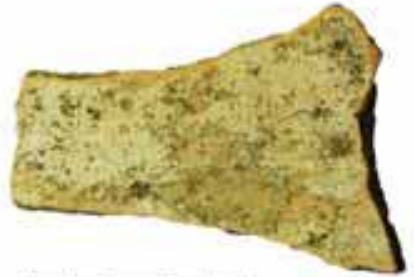

Ita-804-52

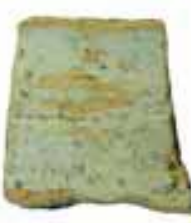

Ita-302-87

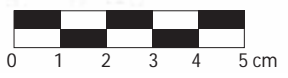

\section{SÍTIO ITAPIREMA}

FRAGMENTOS COM ENGOBO E PINTURA

TESE DE DOUTORADO

A TRADIÇÃO POLÍCROMA DA AMAZÔNIA NO ALTO RIO MADEIRA 
Ita-604-35

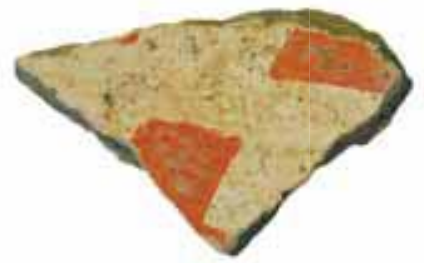

Ita-510-37

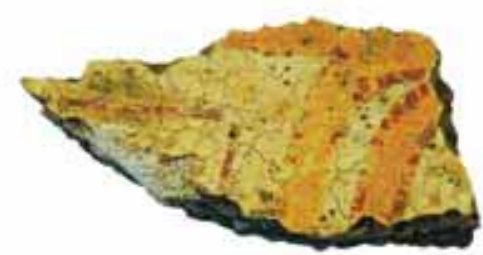

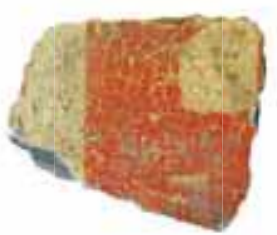

Ita-510-31

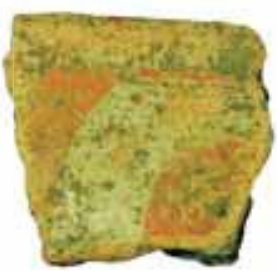

Ita-403-108

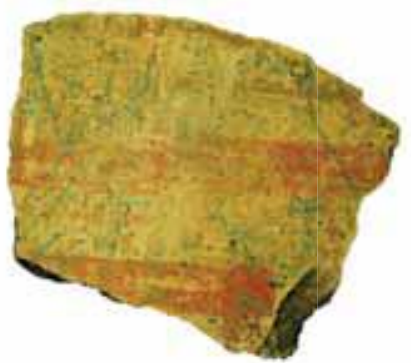

Ita-405-1

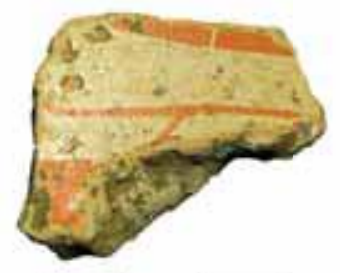

Ita-303-87

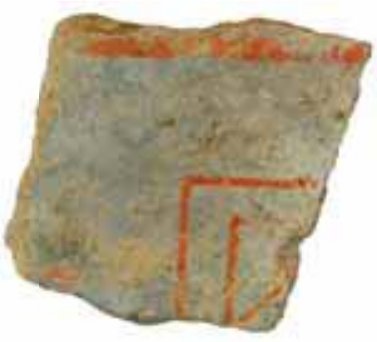

Ita-515-13

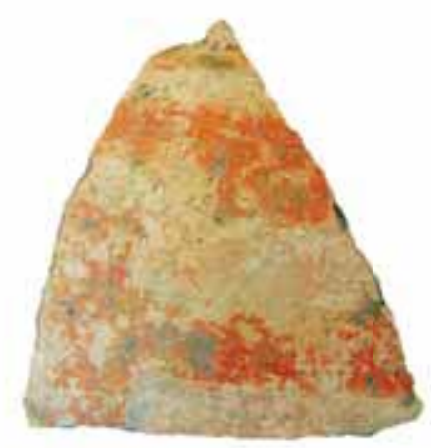

Ita-510-22

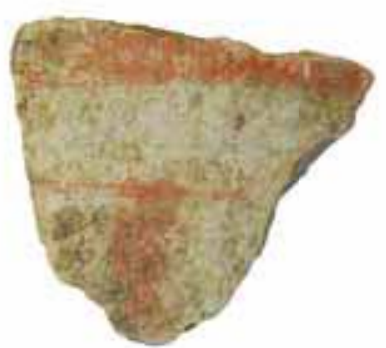

Ita-513-22

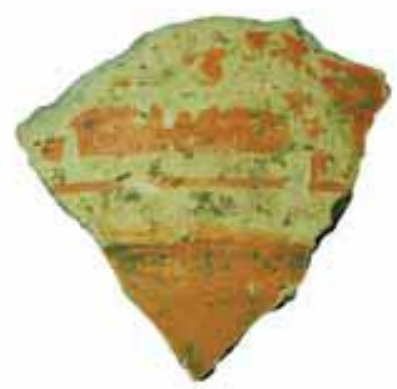

Ita-403-3

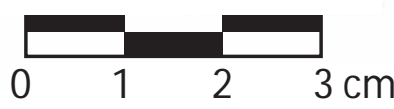

\section{SÍTIO ITAPIREMA}

\section{FRAGMENTOS PINTADOS}

\begin{tabular}{|c|c|}
\hline \multicolumn{2}{|l|}{ TESE DE DOUTORADO } \\
\hline \multicolumn{2}{|c|}{$\begin{array}{c}\text { A TRADIÇÃO POLÍCROMA DA } \\
\text { AMAZÔNIA NO ALTO RIO MADEIRA }\end{array}$} \\
\hline Aluno: Fernando Ozorio de Almeida & Orientador: Eduardo Góes Neves \\
\hline \multicolumn{2}{|c|}{ Programa de Pós-Graduação em Arqueologia - Museu de Arqueologia e Etnologia/USP } \\
\hline $\begin{array}{l}\text { Data: agosto/2012 } \\
\text { Arte final: Rafael Machado }\end{array}$ & MAE AJAPESP $\odot$ Va \\
\hline
\end{tabular}


Ita-617-8 - fase externa

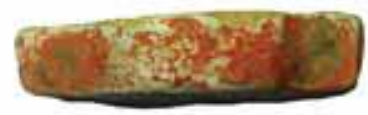

Ita-617-7

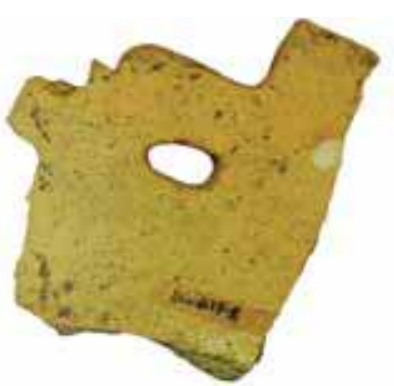

Ita-617-8 - fase interna

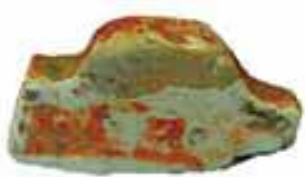

Ita-617-7
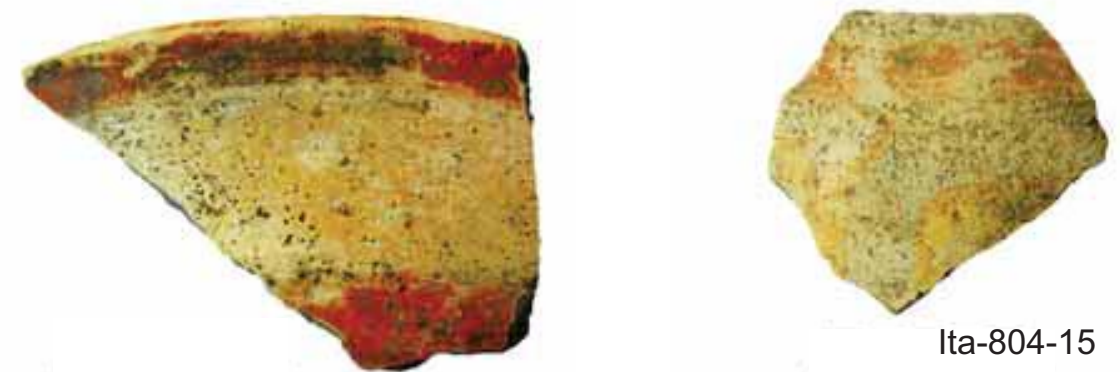

Ita-804-15

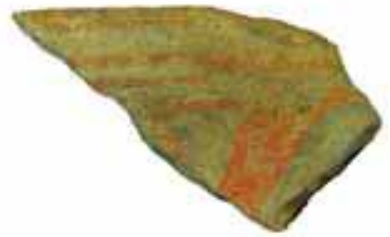

Ita-608-21

Ita-823-1

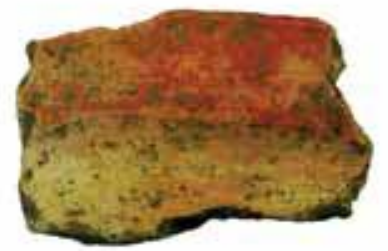

Ita-630-1

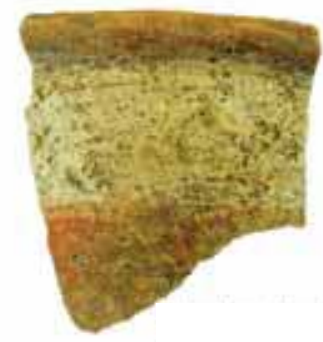

Ita-608-23

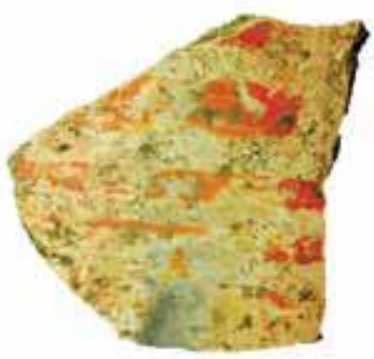

Ita-817-1

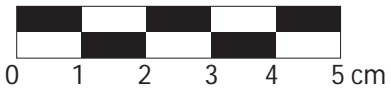

\section{SÍTIO ITAPIREMA}

\section{FRAGMENTOS PINTADOS}

A TRADIÇÃO POLÍCROMA DA AMAZÔNIA NO ALTO RIO MADEIRA 


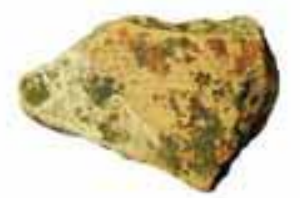

Ita-810-3

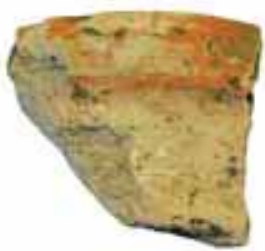

Ita-47-1

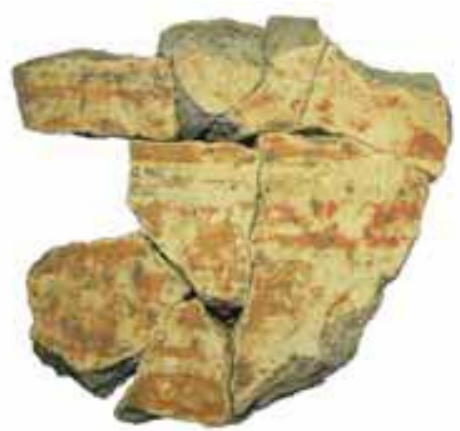

Ita-5-2

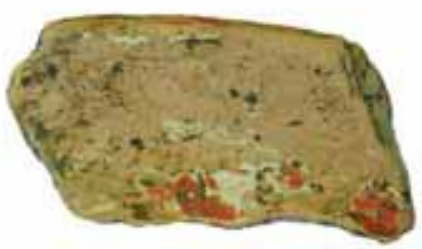

Ita-302-189

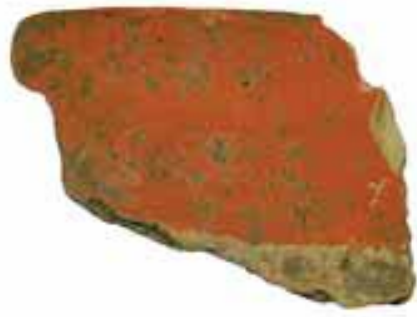

Ita-71-5

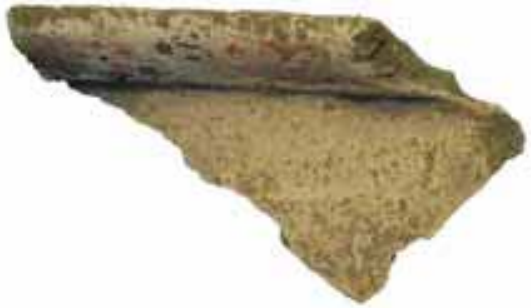

Ita-302-187

Ita-66-1

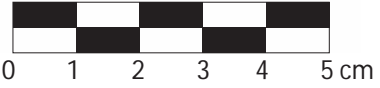

\section{SÍTIO ITAPIREMA}

FRAGMENTOS PINTADOS

A TRADIÇÃO POLÍCROMA DA AMAZÔNIA NO ALTO RIO MADEIRA 


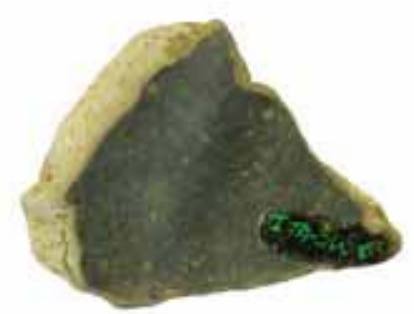

Ita-508-64

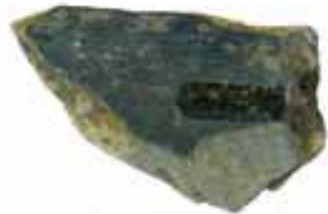

Ita-510-35

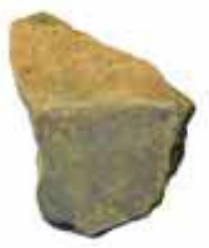

Ita-304-43

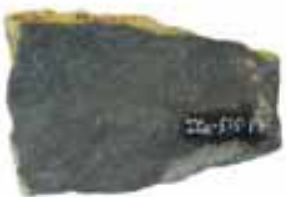

Ita-515-1
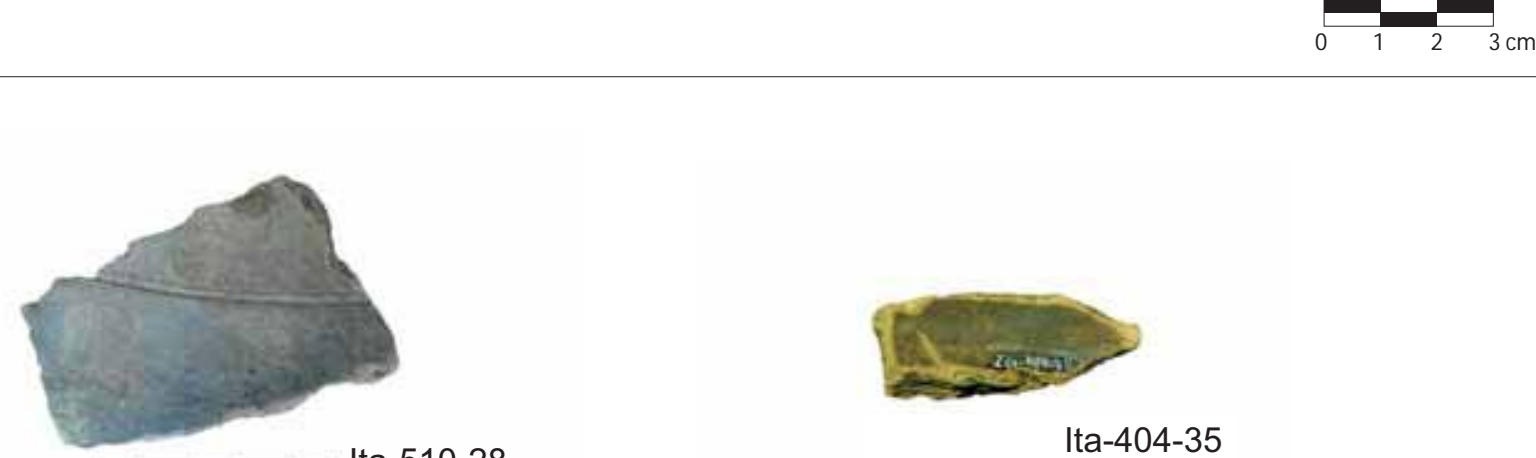

Ita-510-28

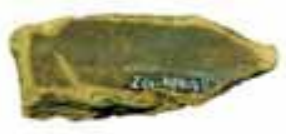

Ita-404-35

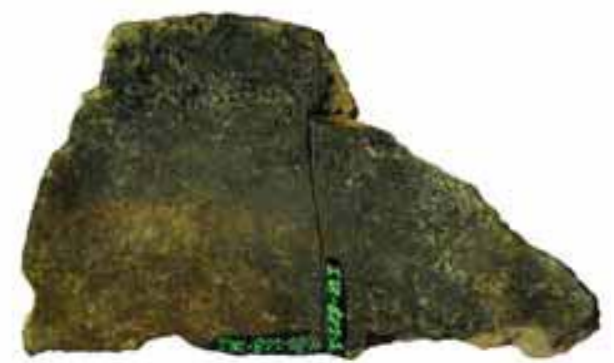

Ita-821-1

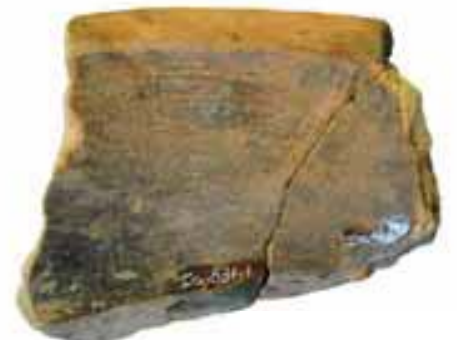

Ita-531-1

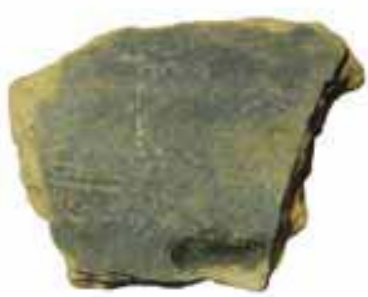

Ita-304-26

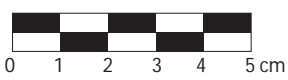

\section{SÍTIO ITAPIREMA}

A TRADIÇÃO POLÍCROMA DA AMAZÔNIA NO ALTO RIO MADEIRA 


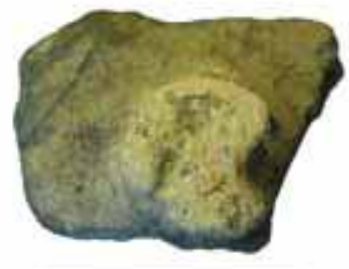

Ita-302-157

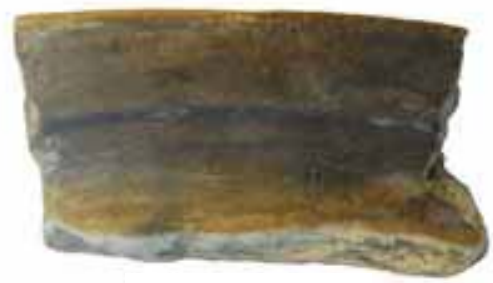

Ita-532-1

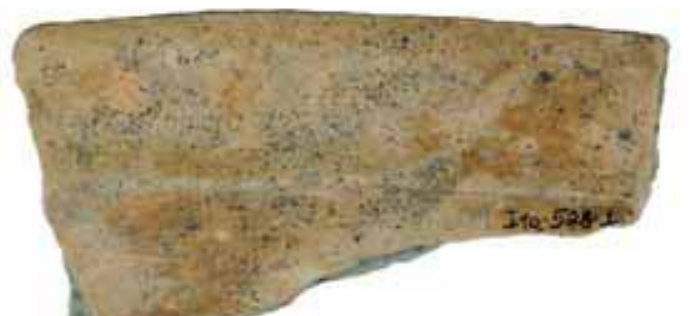

Ita-528-1

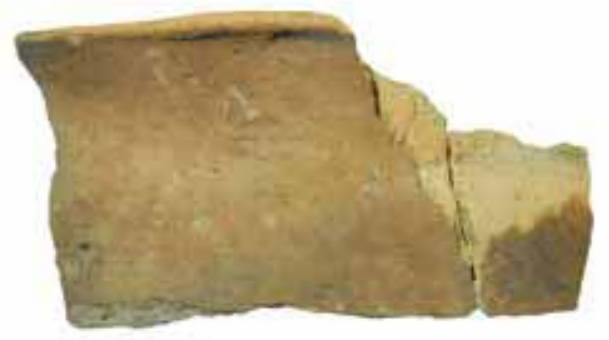

Ita-319-1
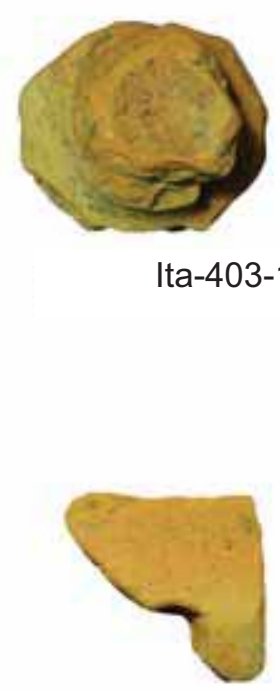

Ita-403-34

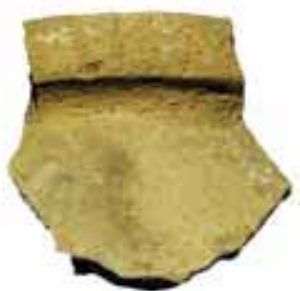

Ita-303-138

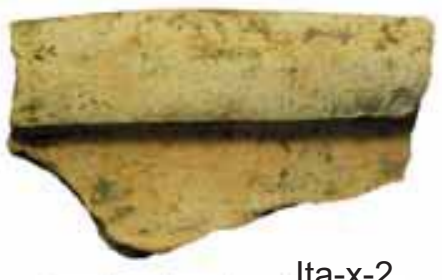

Ita-x-2

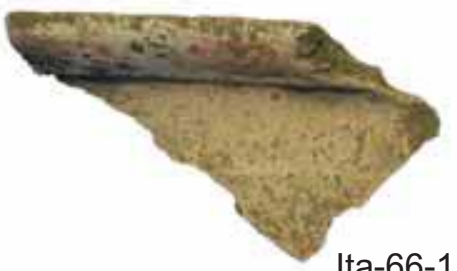

Ita-66-1

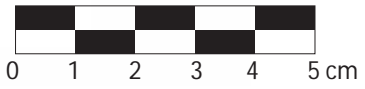

TESE DE DOUTORADO

SÍTIO ITAPIREMA

A TRADIÇÃO POLÍCROMA DA AMAZÔNIA NO ALTO RIO MADEIRA 


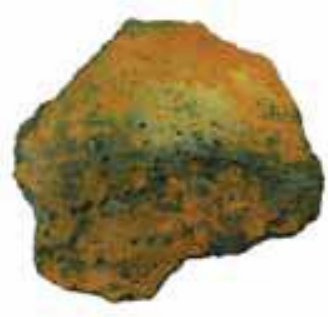

Ita-604-22

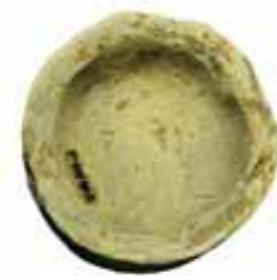

Ita-307-1

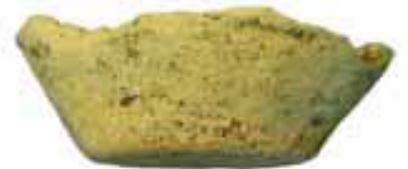

Ita-505-1

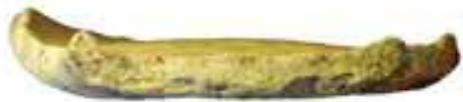

Ita-803-20

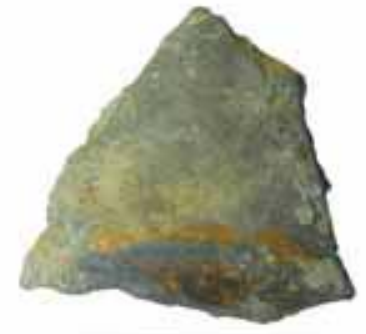

Ita-515-2

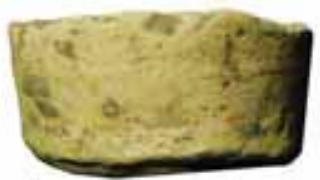

Ita-307-1

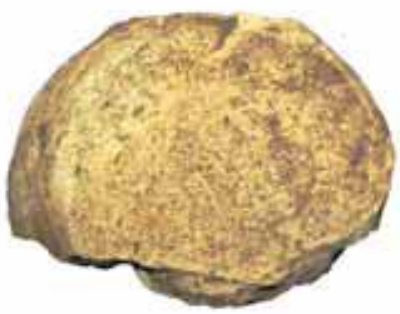

Ita-202-1

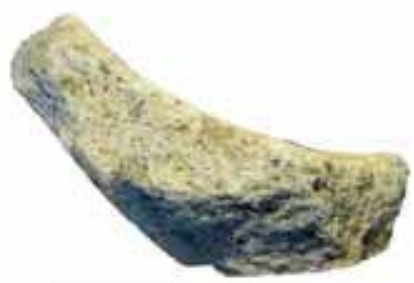

Ita-5-1b

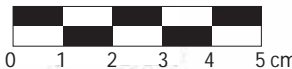

\section{SÍTIO ITAPIREMA}

\section{BASES}

A TRADIÇÃO POLÍCROMA DA AMAZÔNIA NO ALTO RIO MADEIRA 


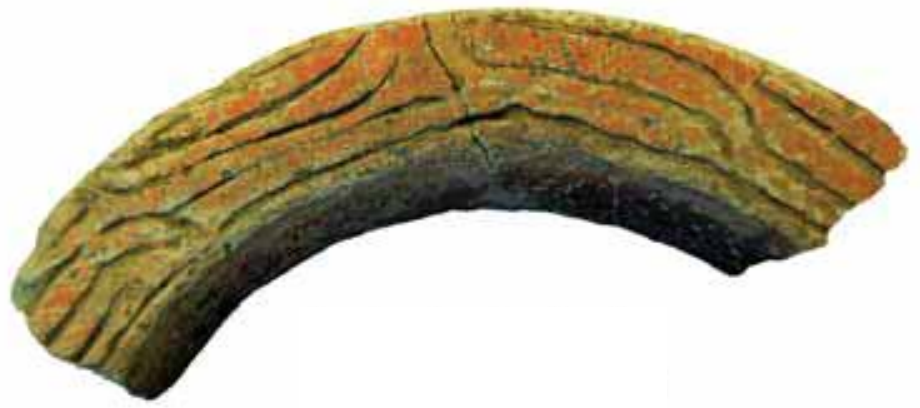

Ita-611-16
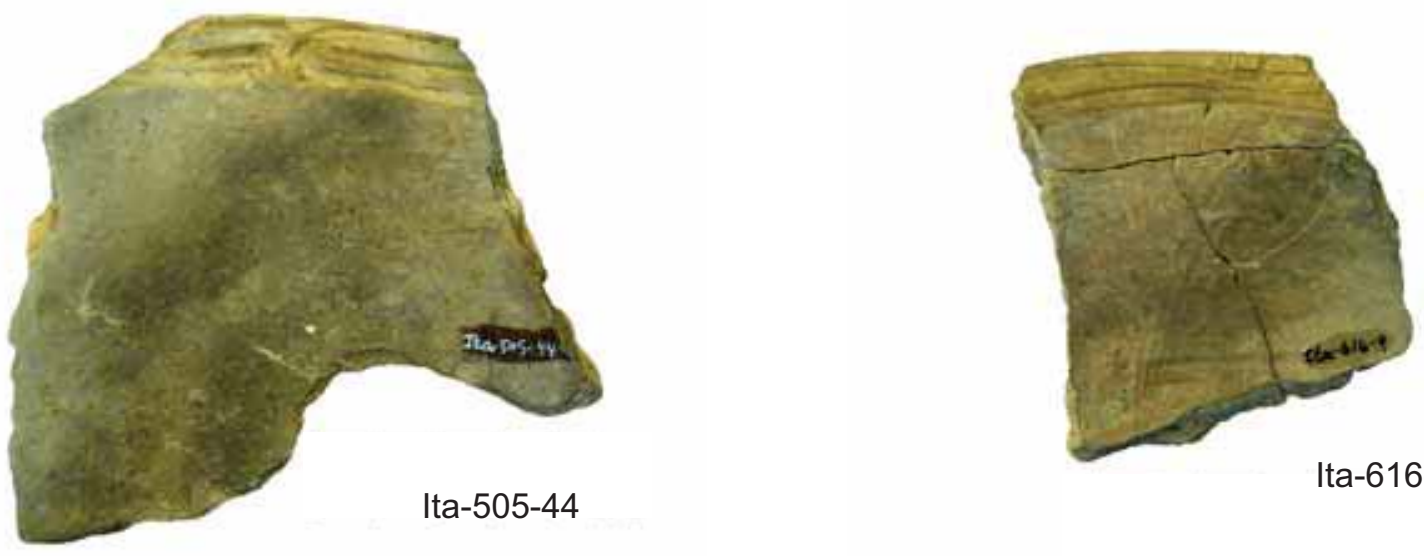

Ita-616-9

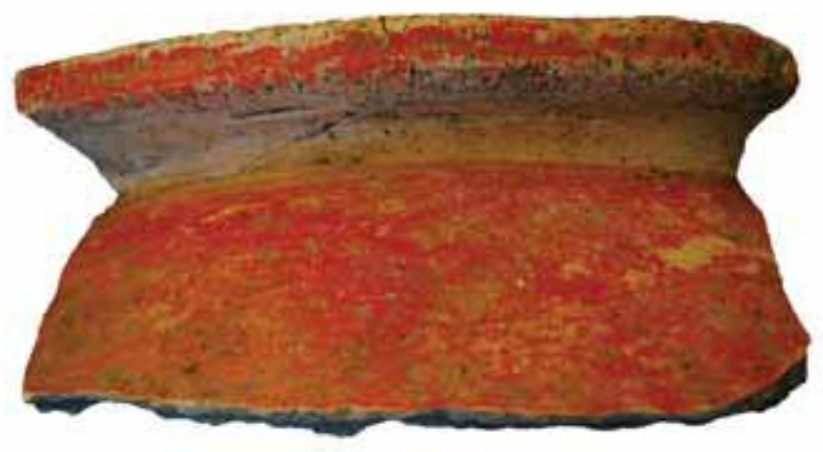

Ita-611-27
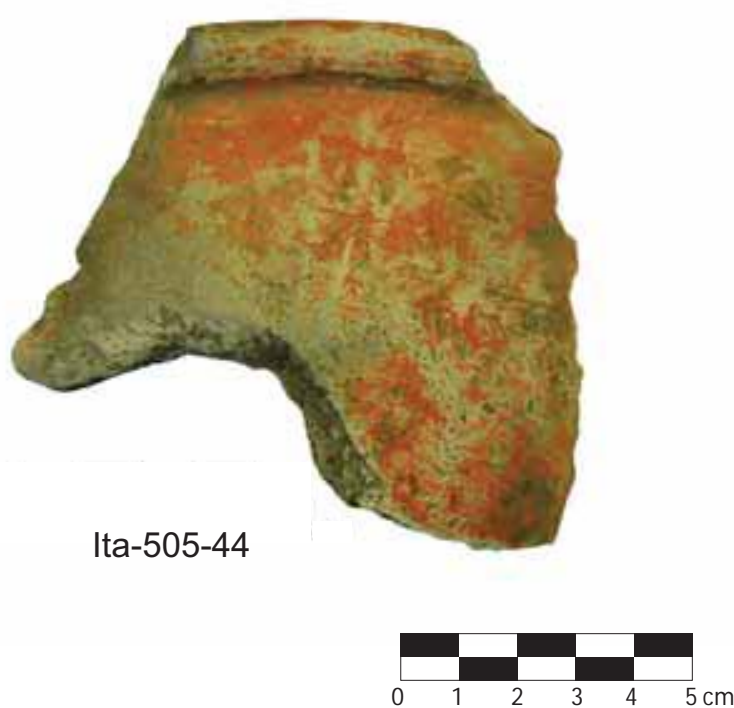

TESE DE DOUTORADO

SÍTIO ITAPIREMA

FRAGMENTOS COM INCISÕES E PINTURAS
A TRADIÇÃO POLÍCROMA DA AMAZÔNIA NO ALTO RIO MADEIRA 


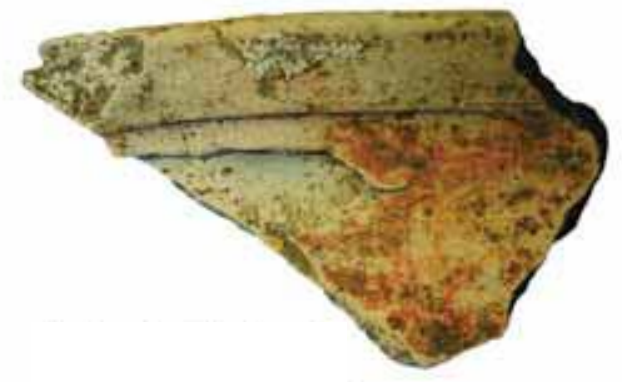

Ita-812-1 FE

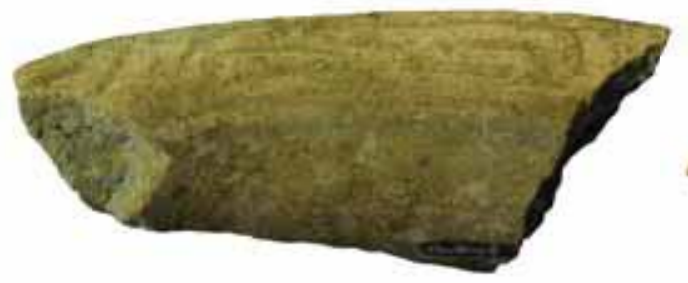

Ita-808-8

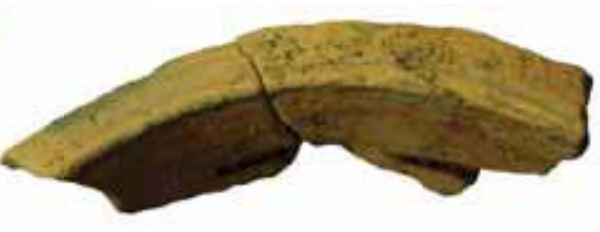

Ita-805-150

Ita-608-23
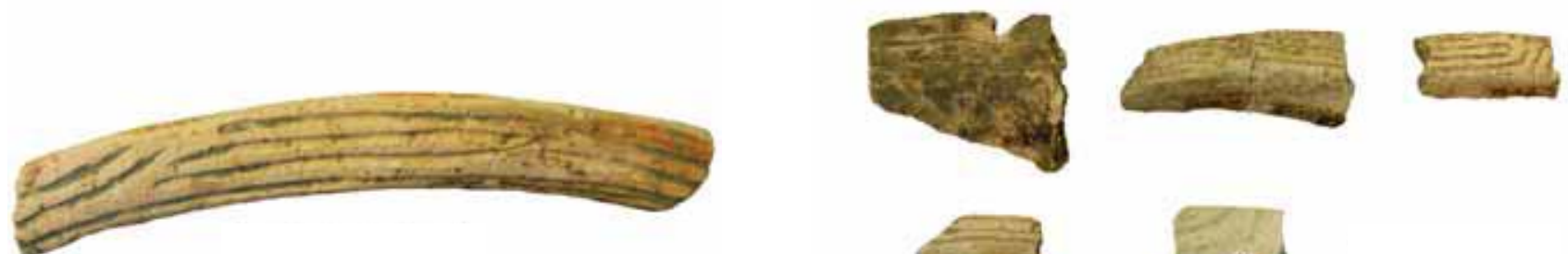

Ita-823-1
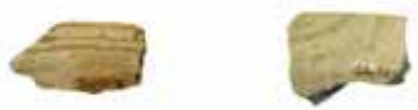

Ita-x-1, 221-3, x-3,

$71-6,73-1 . \mathrm{FI}$
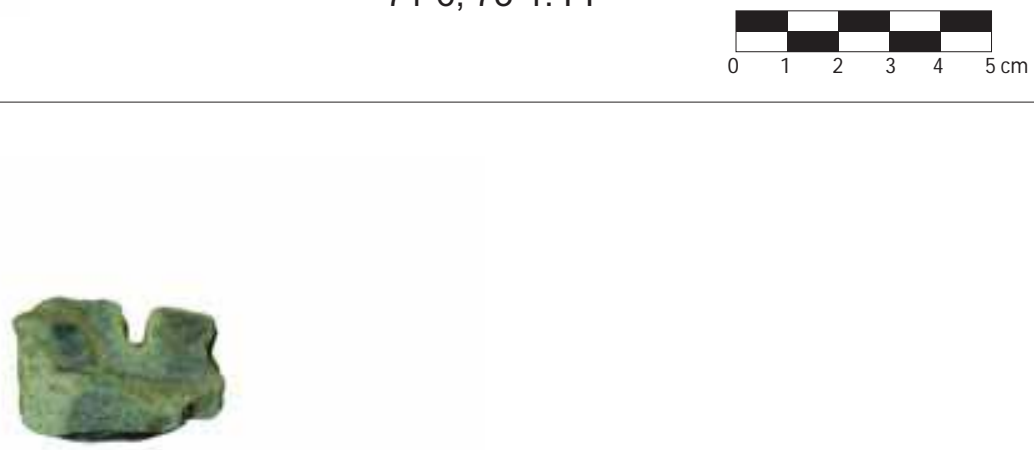

Ita-403-101

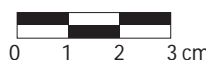

\section{SÍTIO ITAPIREMA}

A TRADIÇÃO POLÍCROMA DA AMAZÔNIA NO ALTO RIO MADEIRA 
Ita-505-52

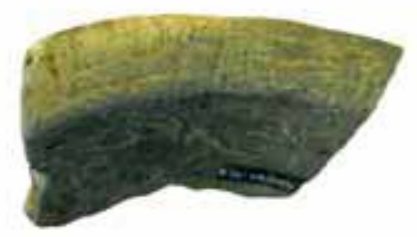

Ita-505-45
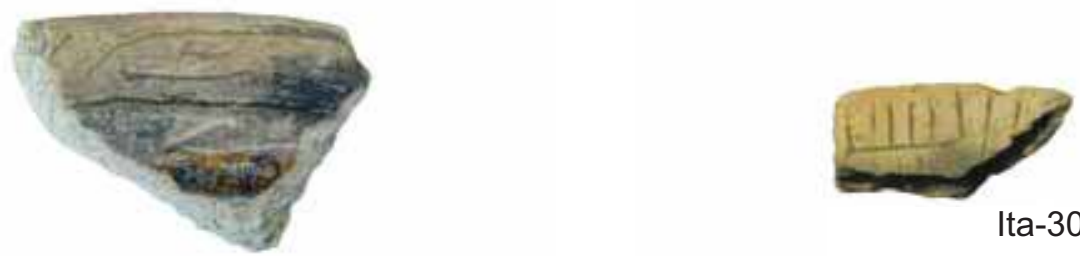

Ita-304-128

Ita-513-51

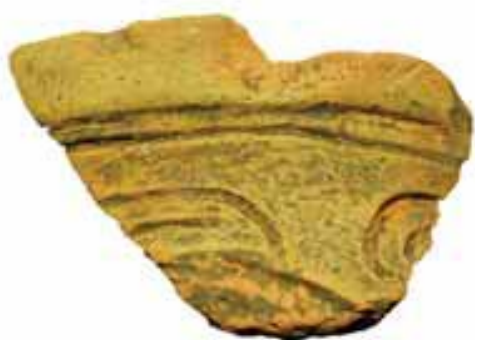

Ita-321-1

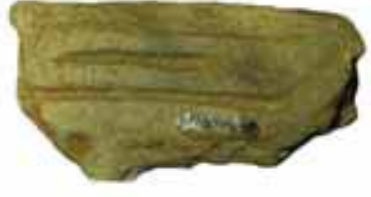

Ita-402-13

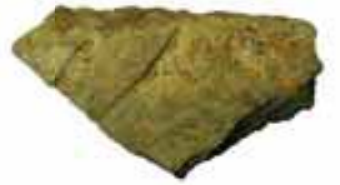

Ita-603-15

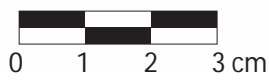

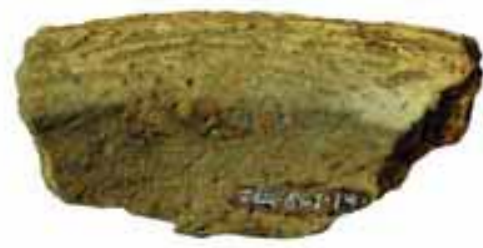

Ita-801-19

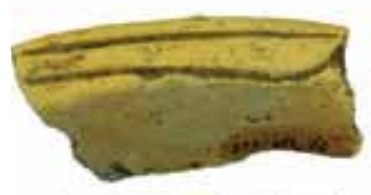

Ita-608-20

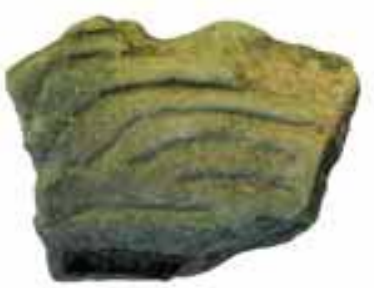

Ita-302-78

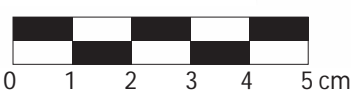

\section{SÍTIO ITAPIREMA}

FRAGMENTOS COM INCISÕES ACANALADOS
A TRADIÇÃO POLÍCROMA DA AMAZÔNIA NO ALTO RIO MADEIRA

Aluno: Fernando Ozorio de Almeida Orientador: Eduardo Góes Neves Programa de Pós-Graduação em Arqueologia - Museu de Arqueologia e Etnologia/USP Data: agosto/2012 


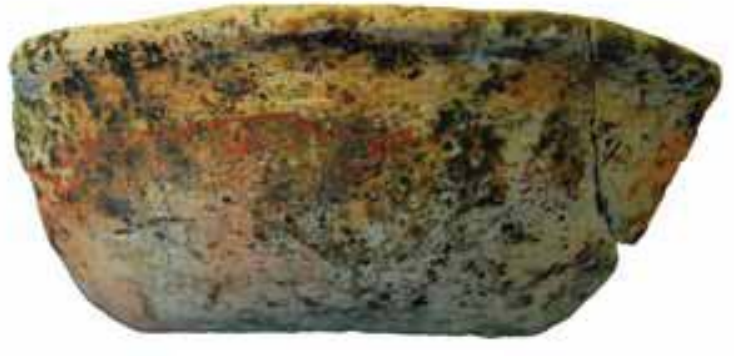

Ita-502-35 FE

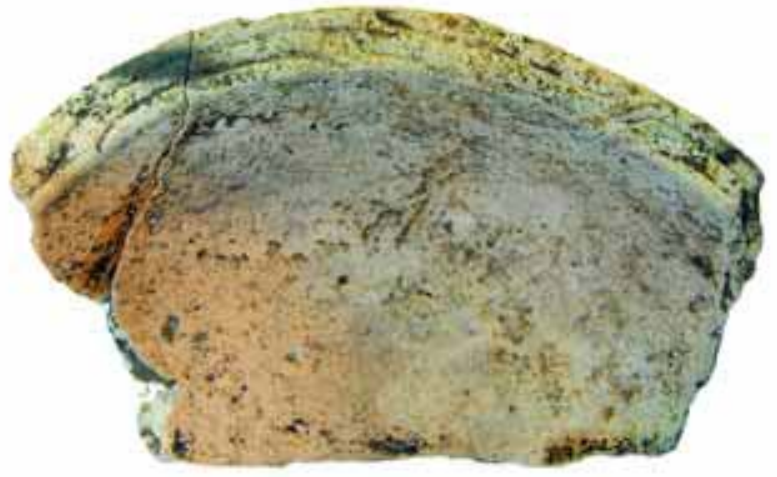

Ita-502-35 FI
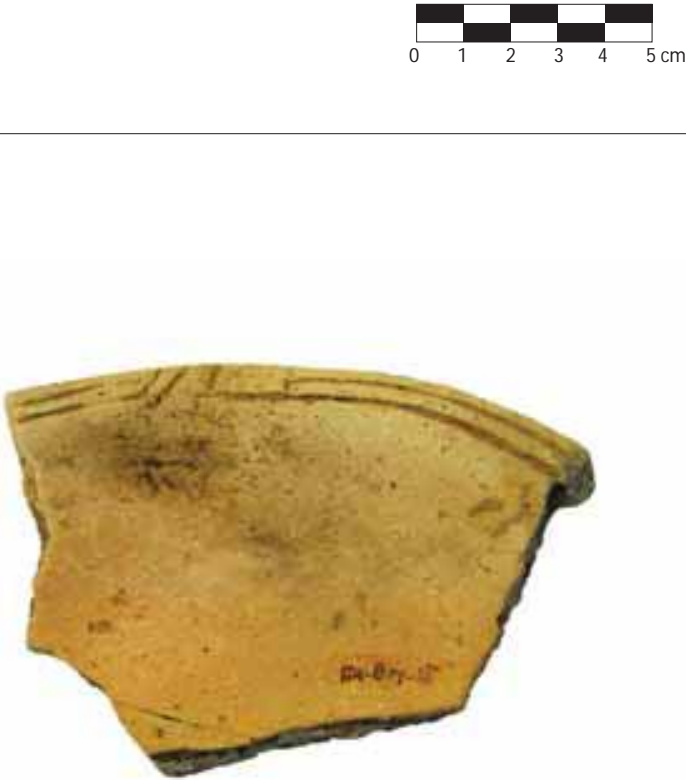

Ita-504-18 FE

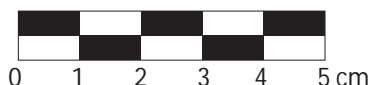

\section{SÍTIO ITAPIREMA}

BORDAS COM PINTURAS E INCISÕES 


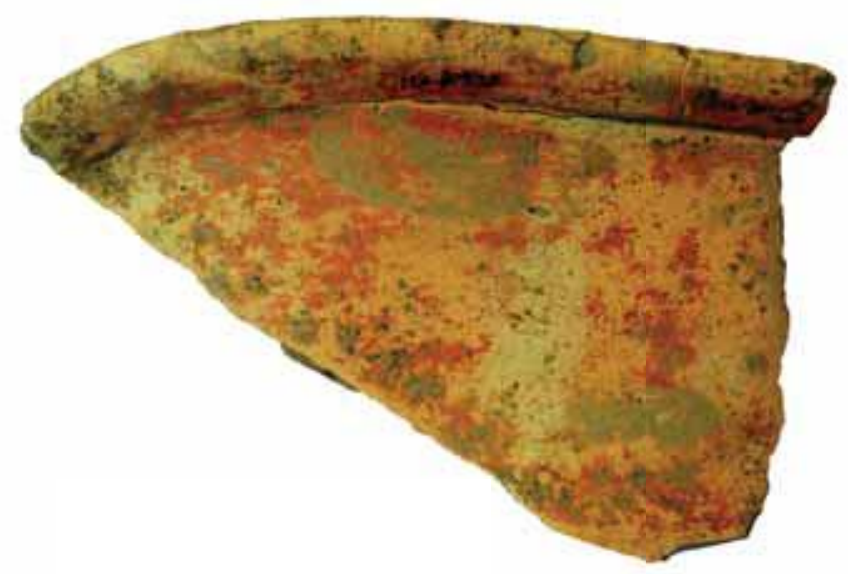

Ita-804-20
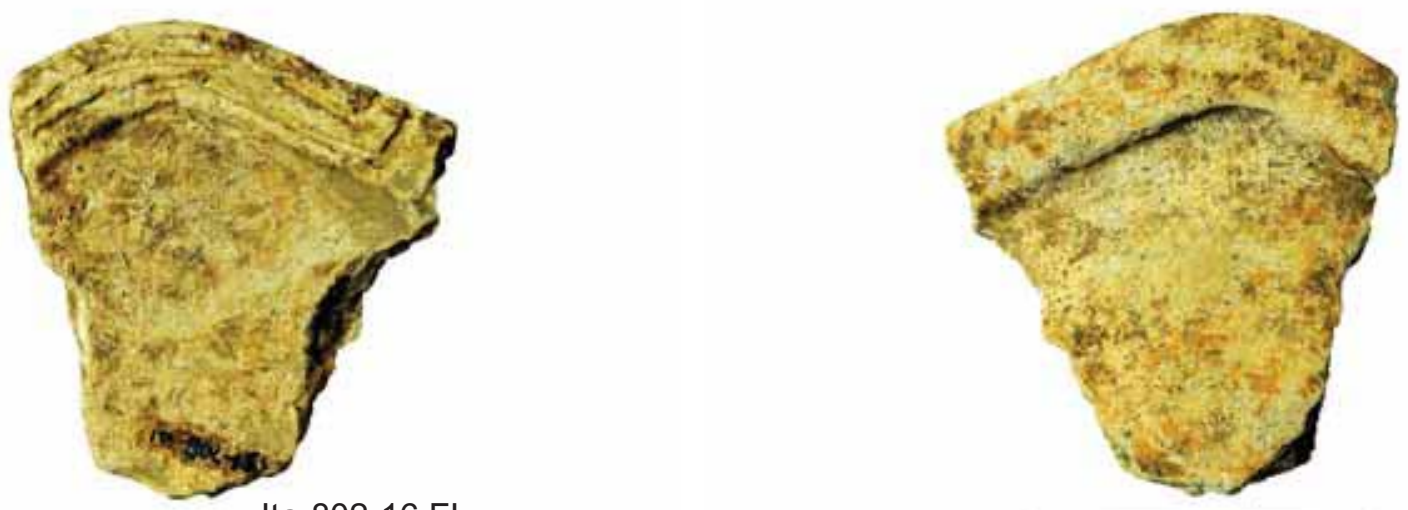

Ita-802-16 FE
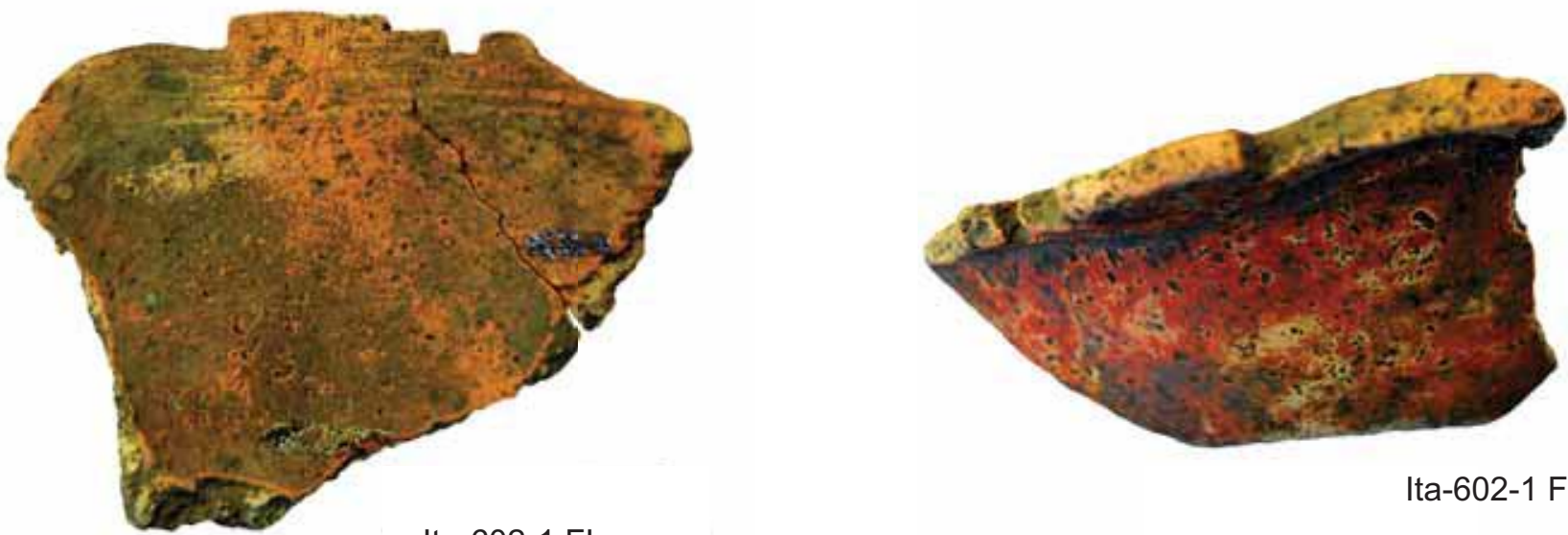

Ita-602-1 FI

Ita-602-1 FE

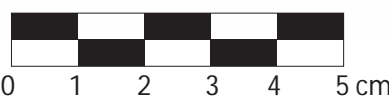

\section{SÍTIO ITAPIREMA}

FORMAS ÂNGULARES, BORDA RECORTADA

TESE DE DOUTORADO

\section{A TRADIÇÃO POLÍCROMA DA AMAZÔNIA NO ALTO RIO MADEIRA}




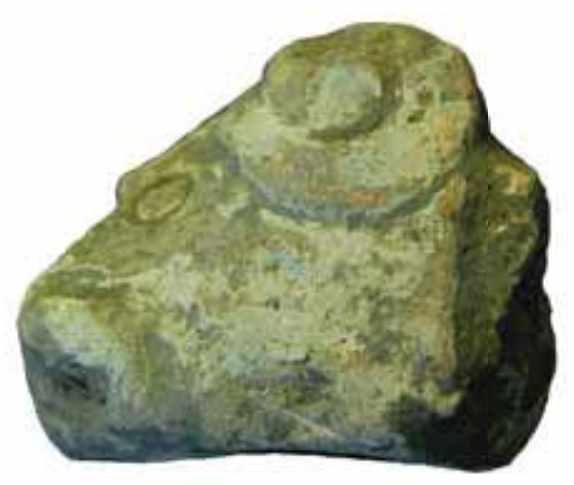

Ita-322-1

Zoomorfo modelado

Ita-322-1

Antropomorfo

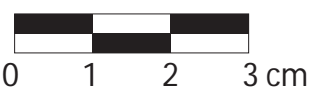

\section{SÍTIO ITAPIREMA}

APLIQUE MODELADO

TESE DE DOUTORADO

A TRADIÇÃO POLÍCROMA DA AMAZÔNIA NO ALTO RIO MADEIRA 


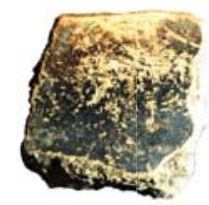

Ja-205-67 FI

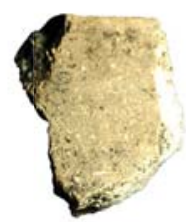

Ja-205-67 FE

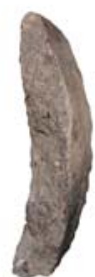

Ja-206-5
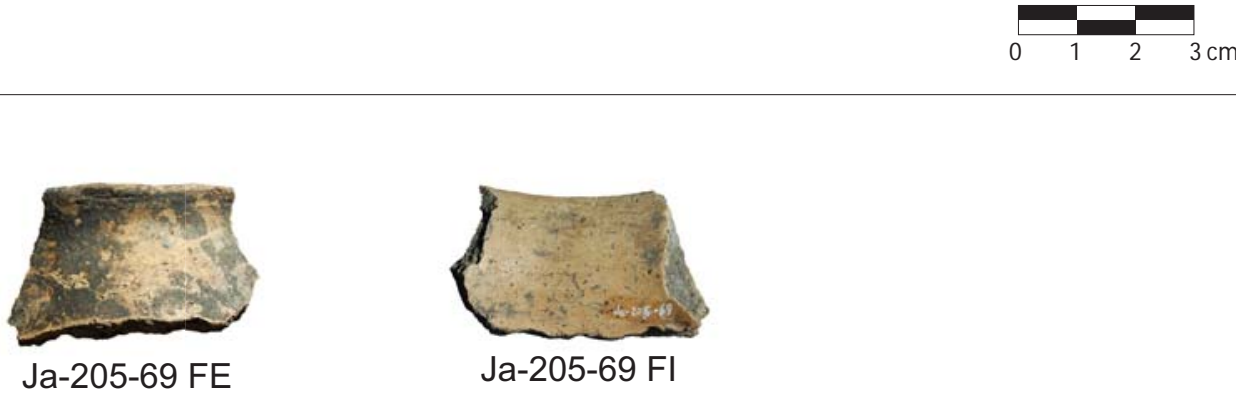

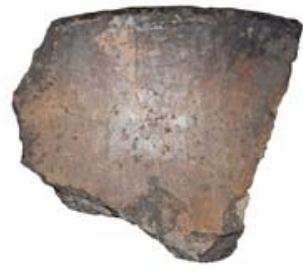

Ja-303-2 FE

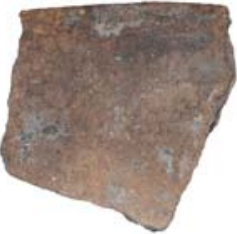

Ja-206-1 FE

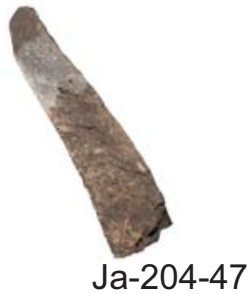

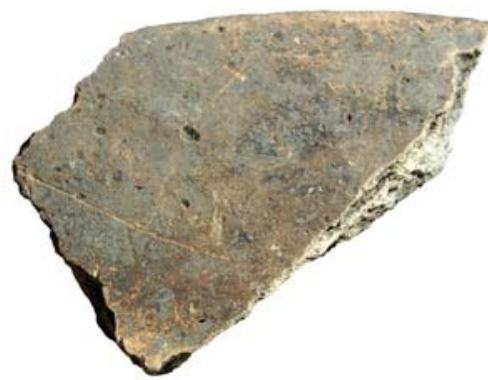

Ja-305-1 FE

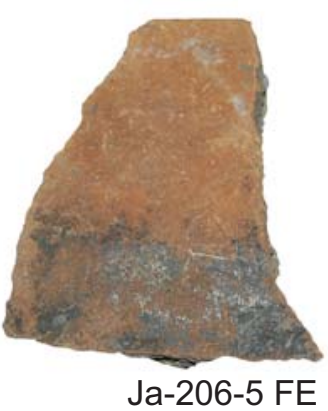

Ja-206-5 FE

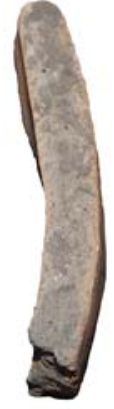

Ja-206-5 perfil

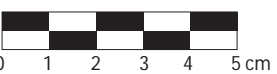

\section{SÍTIO JACAREZINHO}

TESE DE DOUTORADO

A TRADIÇÃO POLÍCROMA DA AMAZÔNIA NO ALTO RIO MADEIRA 
Ja-303-2

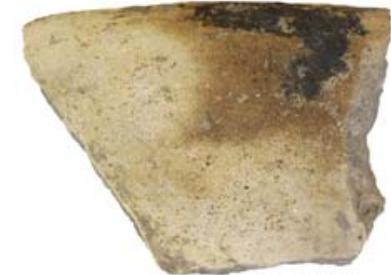

Ja-502-1 FE

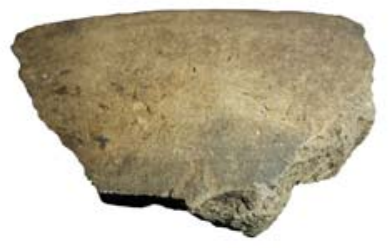

Ja-302-5 FE

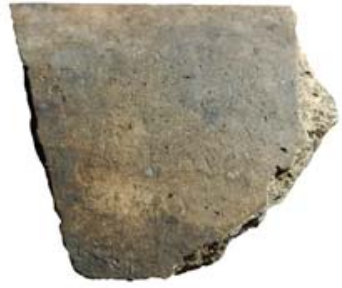

Ja-305-13 FE

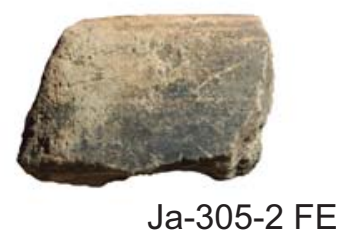

Ja-305-2 FE

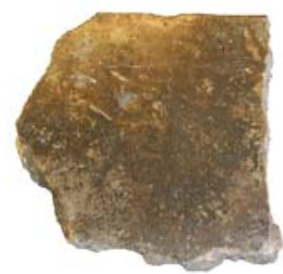

Ja-304-3 FI

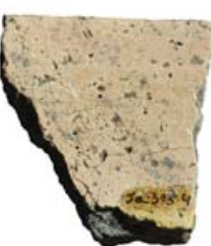

Ja-305-4 FI

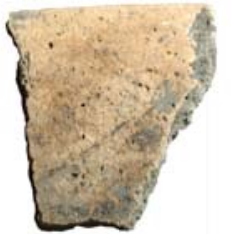

Ja-305-4 FE

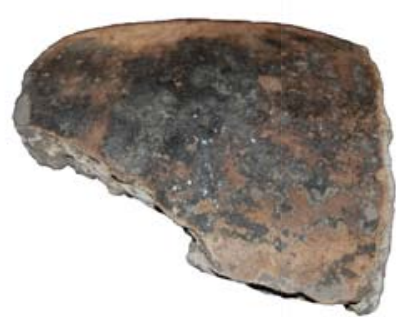

Ja-503-1 FE

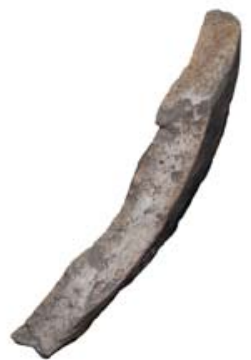

Ja-503-1 perfil

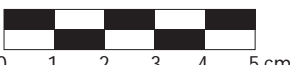

SÍTIO JACAREZINHO

FRAGMENTOS DE BORDAS

A TRADIÇÃO POLÍCROMA DA AMAZÔNIA NO ALTO RIO MADEIRA 


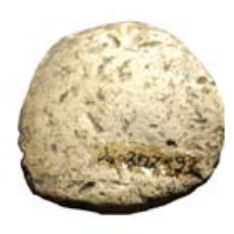

Ja-302-92

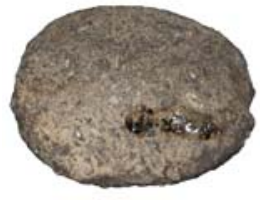

Ja-203b-4
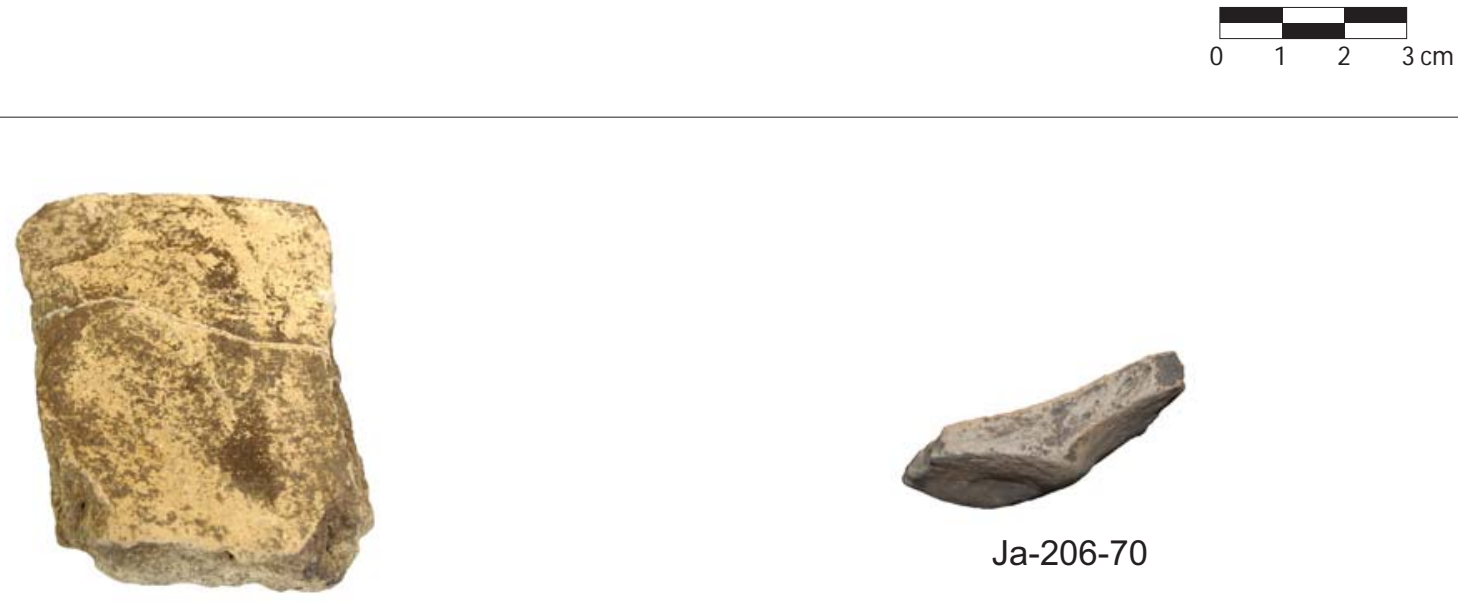

Ja-206-70

Ja-400-11 FE

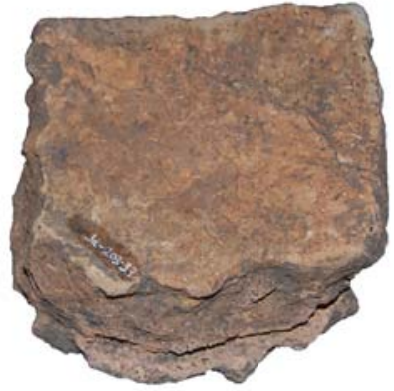

Ja-203-33 FI

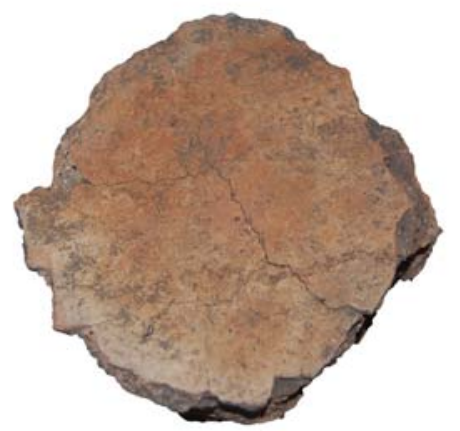

Ja-203-33 FE

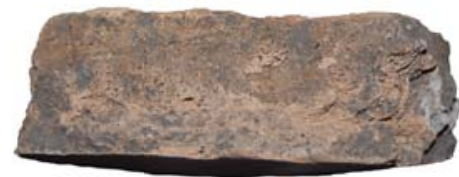

Ja-203-33 perfil

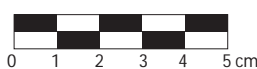

SÍTIO JACAREZINHO

FRAGMENTOS DE BASE E CONTAS

TESE DE DOUTORADO

A TRADIÇÃO POLÍCROMA DA AMAZÔNIA NO ALTO RIO MADEIRA 


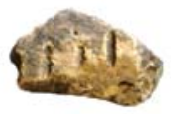

Ja-12-1 FE

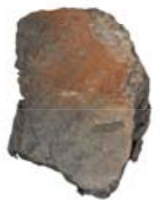

Ja-203-32 FE

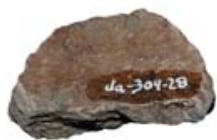

Ja-304-28 FI

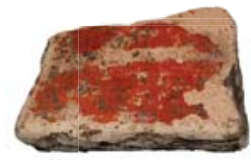

Ja-612-1 FE

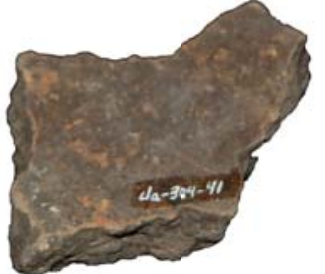

Ja-304-41 FI

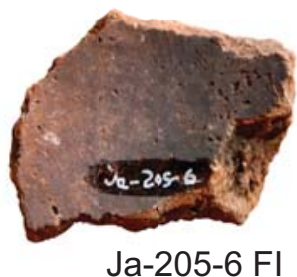

Ja-205-6 FI

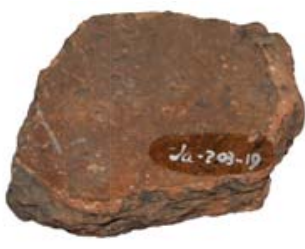

Ja-203-19 FI
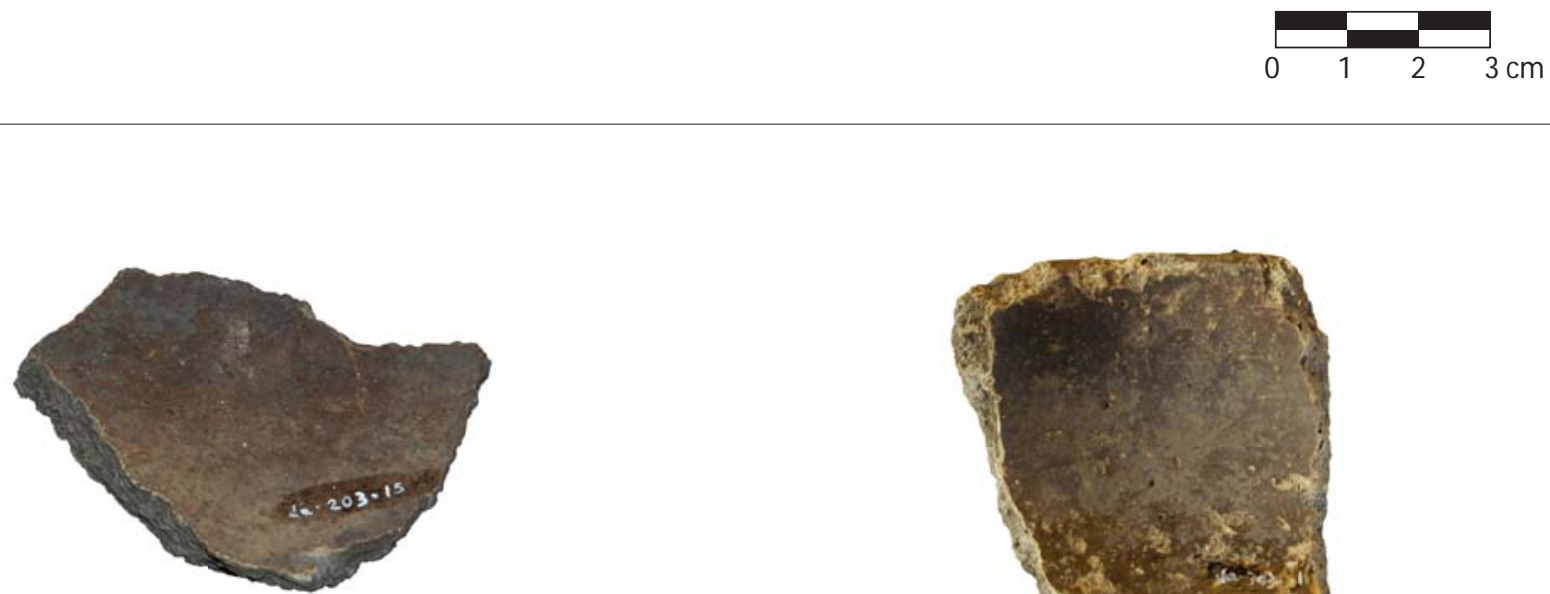

Ja-203-15 FI

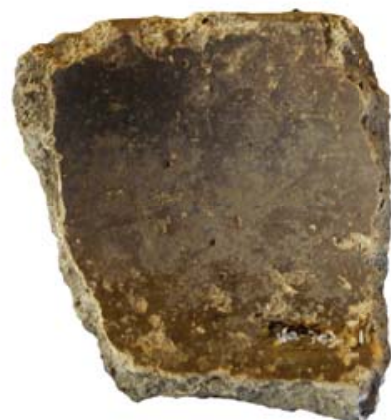

Ja-303-1 FI

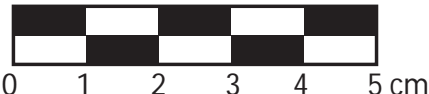

SÍTIO JACAREZINHO

FRAGMENTOS COM TRATAMENTO DE SUPERFÍCIE

A TRADIÇÃO POLÍCROMA DA AMAZÔNIA NO ALTO RIO MADEIRA 

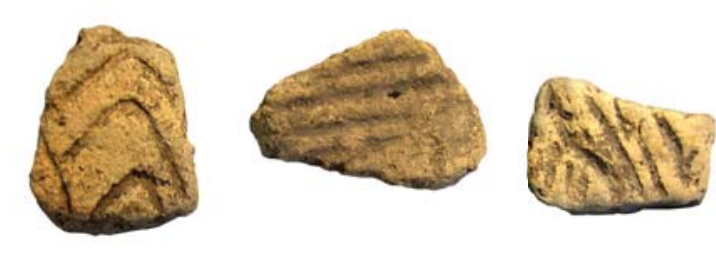

NV-301 - $002-710$
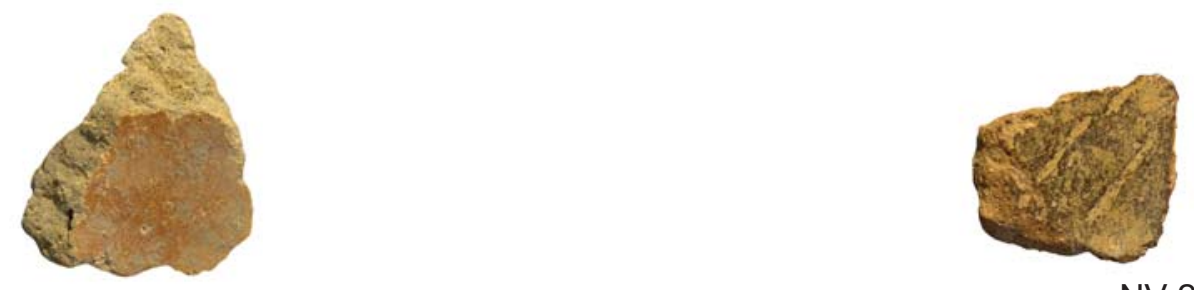

NV-101-1

NV-204-3

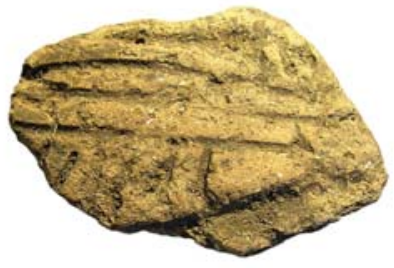

NV-303-6

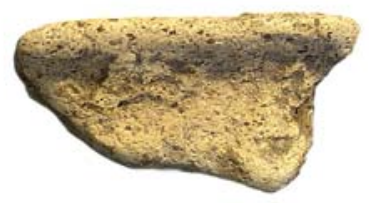

NV-304-1

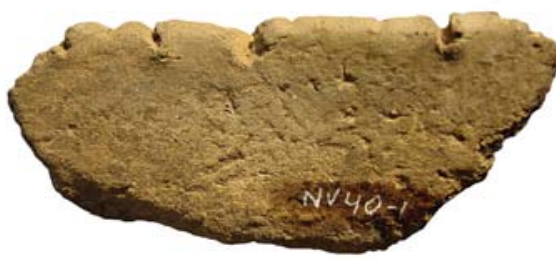

NV-40-1

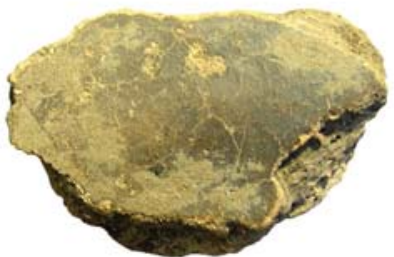

NV-302-4

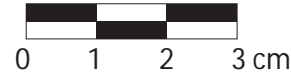

\section{SÍTIO NOVA VIDA}

FRAGMENTOS CERÂMICOS

TESE DE DOUTORADO

A TRADIÇÃO POLÍCROMA DA AMAZÔNIA NO ALTO RIO MADEIRA 


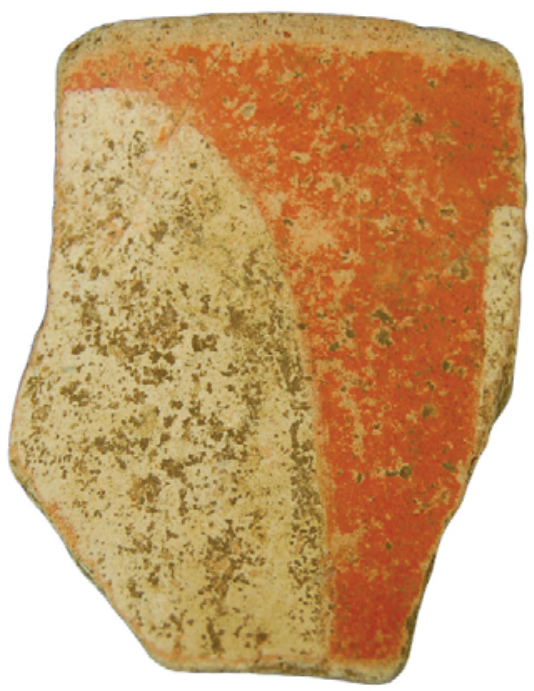

TE-609-3

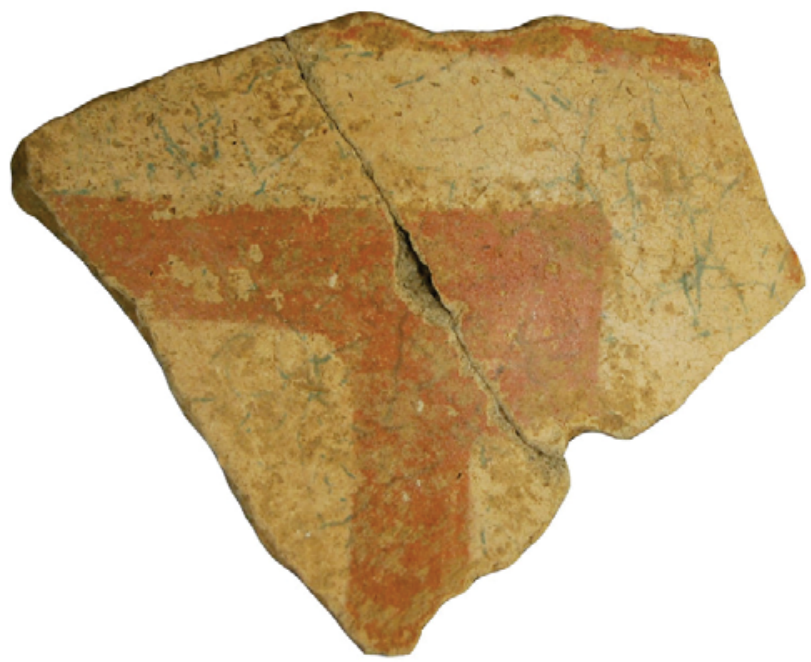

TE-600-9

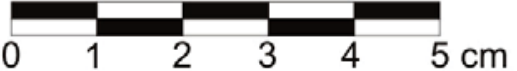

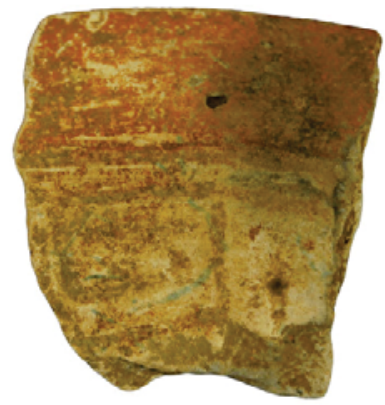

TE-321-9

FACE EXTERNA

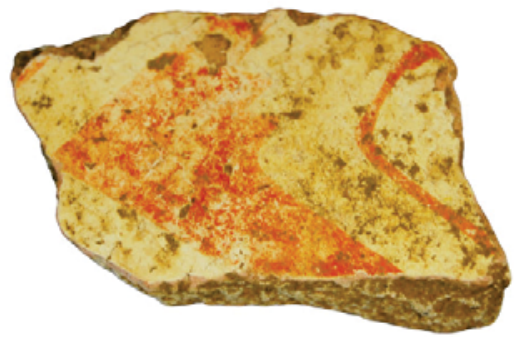

TE-321-34

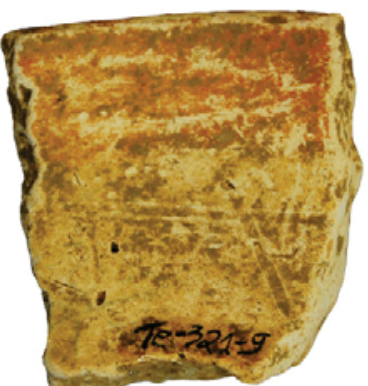

TE-321-9

FACE INTERNA

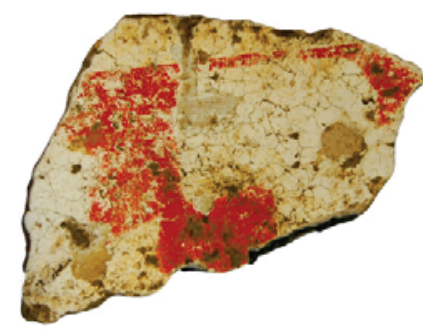

TE-609-3

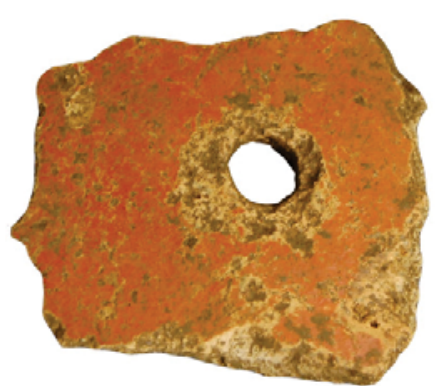

TE-5-1

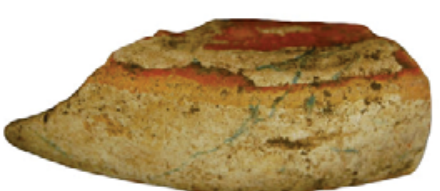

TE-809-48 FACE EXTERNA

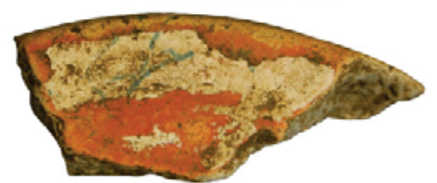

TE-809-48 FACE INTERNA

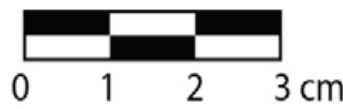

\begin{tabular}{|c|c|c|}
\hline \multirow[b]{2}{*}{ SÍTIO TEOTÔNIO } & \multicolumn{2}{|l|}{ TESE DE DOUTORADO } \\
\hline & \multicolumn{2}{|c|}{$\begin{array}{c}\text { A TRADIÇÃO POLÍCROMA DA } \\
\text { AMAZÔNIA NO ALTO RIO MADEIRA }\end{array}$} \\
\hline \multirow{2}{*}{ FRAGMENTOS COM PINTURA E ENGOBO VERMELHO } & \multicolumn{2}{|c|}{ Aluno: Fernando Ozorio de Almeida Orientador: Eduardo Góes Neves } \\
\hline & \multicolumn{2}{|c|}{ Programa de Pós-Graduação - Museu de Arqueologia e Etnologia } \\
\hline PRANCHA 1 & Arte Final: Eduardo Tamanaha & MAE DJAPESP \\
\hline
\end{tabular}




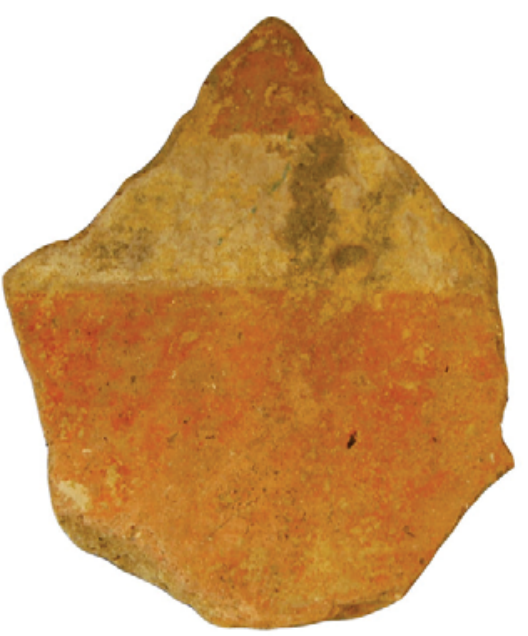

TE-521-45

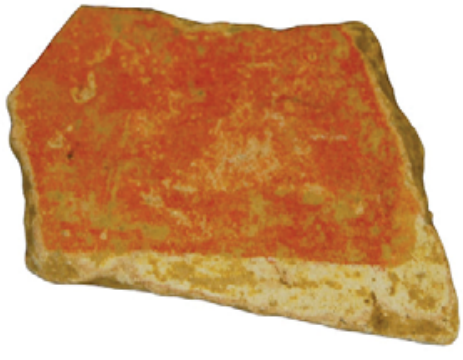

TE-321-38

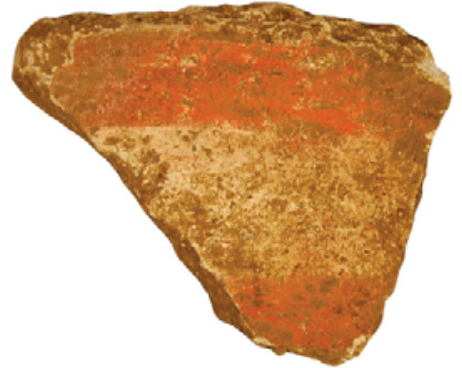

TE-422-2

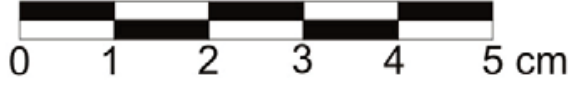

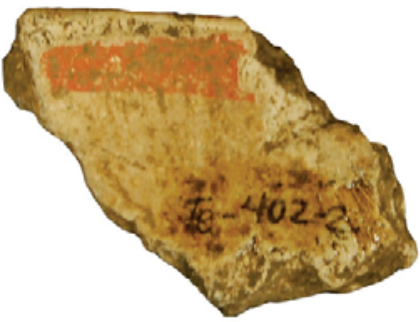

TE-402-2

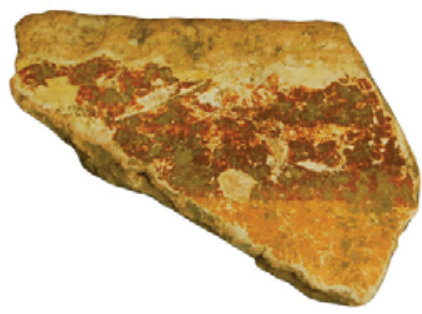

TE-321-5

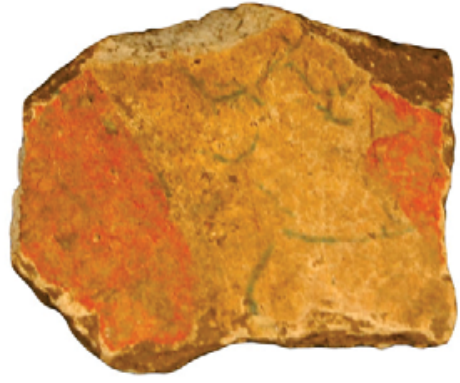

TE-601-3

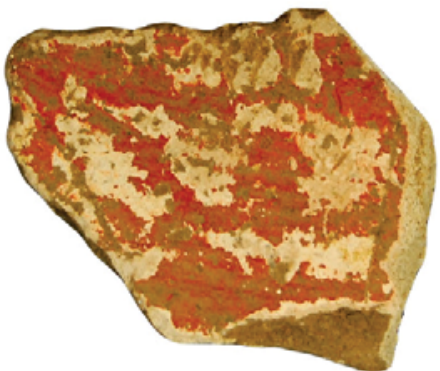

TE-602-17

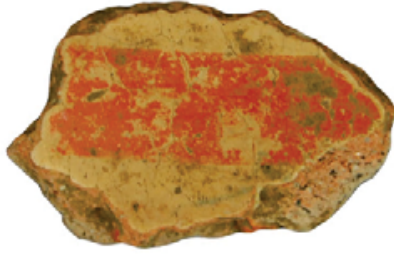

TE-402-3

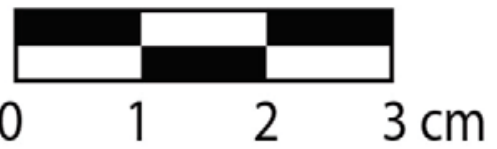

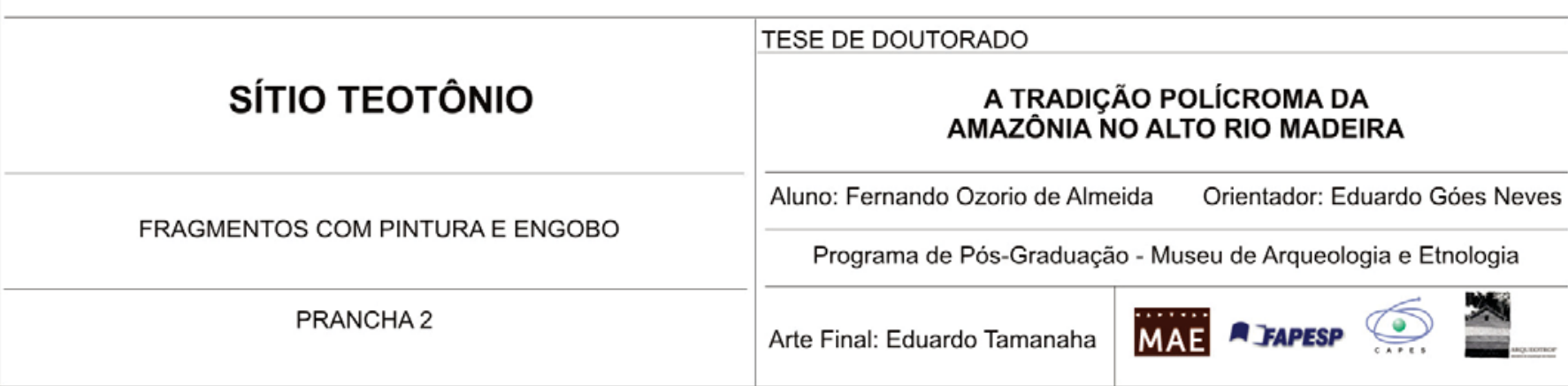




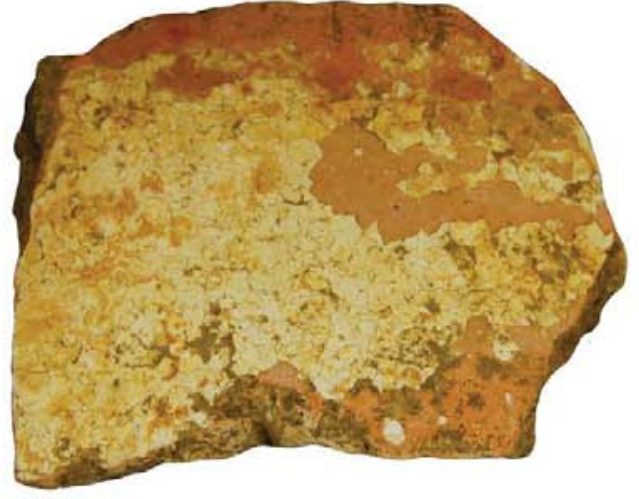

TE-321-41

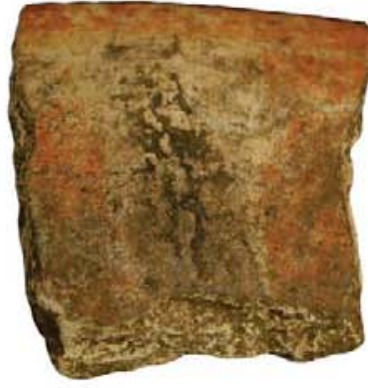

TE-809-42

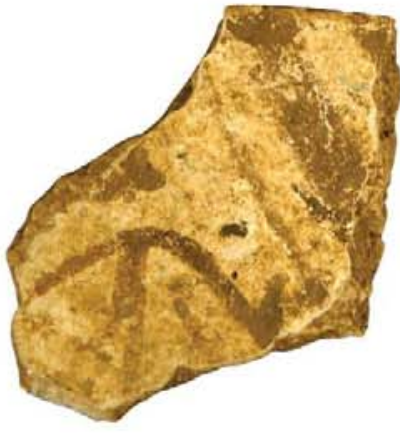

TE-603-6

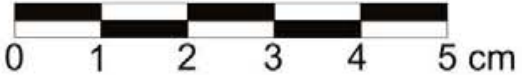

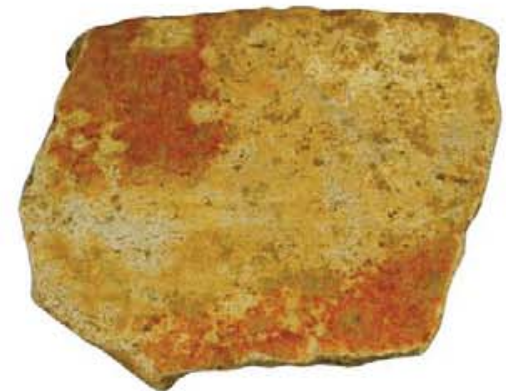

TE-321-25

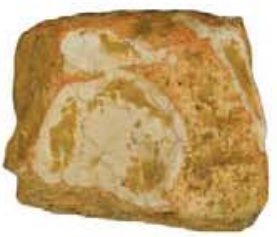

TE-341-1

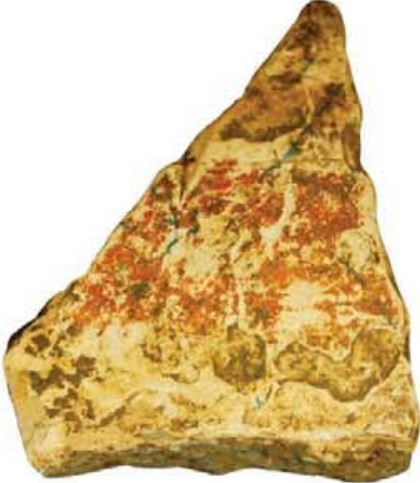

TE-602-16

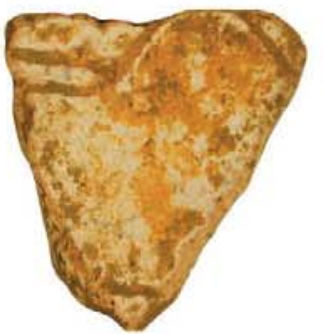

TE-59-3

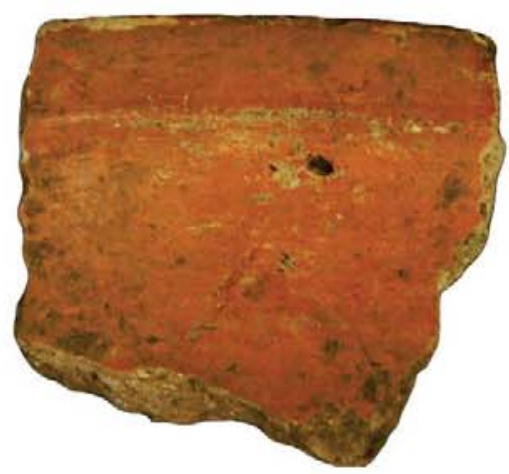

TE-606-1

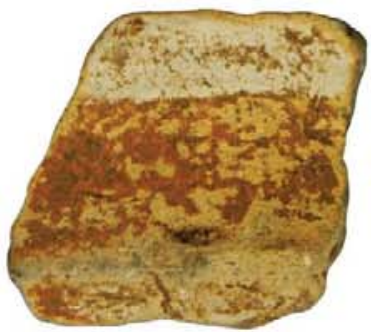

TE-607-49

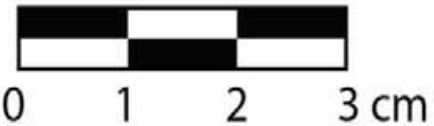

\section{SÍTIO TEOTÔNIO}

FRAGMENTOS COM PINTURA E ENGOBO
TESE DE DOUTORADO

\section{A TRADIÇÃO POLÍCROMA DA AMAZÔNIA NO ALTO RIO MADEIRA}

Aluno: Fernando Ozorio de Almeida

Orientador: Eduardo Góes Neves

Programa de Pós-Graduação - Museu de Arqueologia e Etnologia

Arte Final: Eduardo Tamanaha
MAE $\cap$ JAPESP

柴 


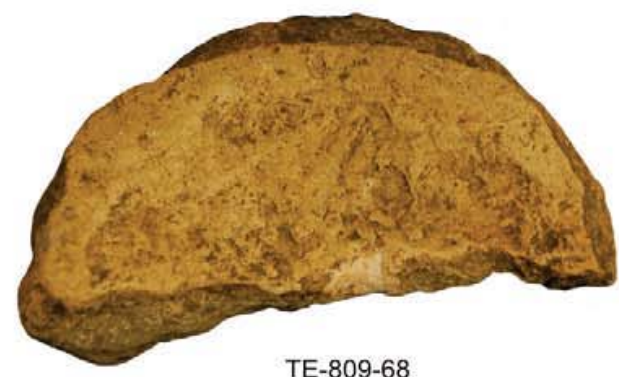

TE-809-68

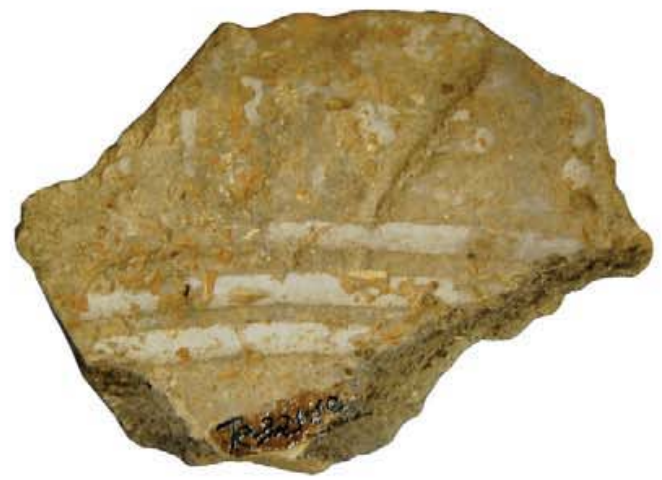

TE-321-10

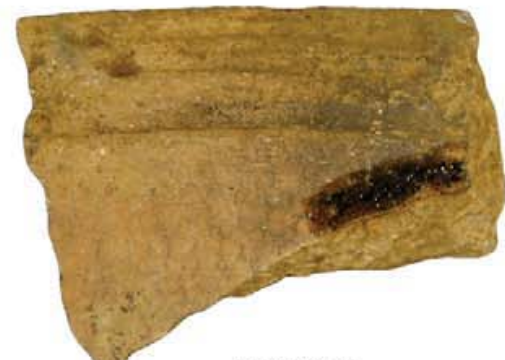

TE-321-12

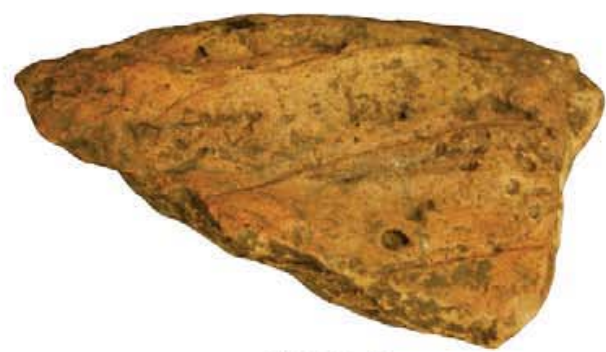

TE-809-32

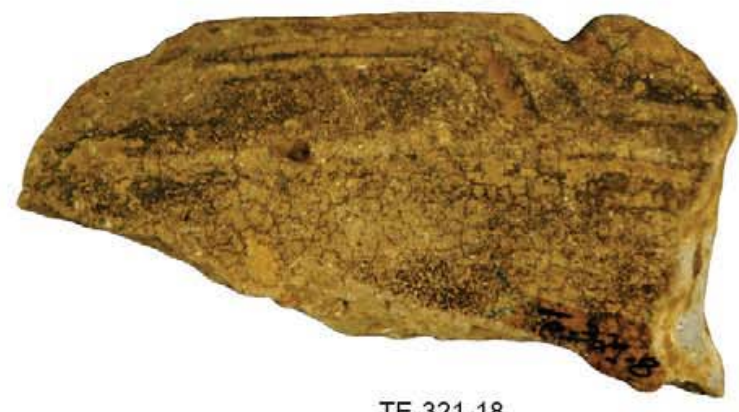

TE-321-18

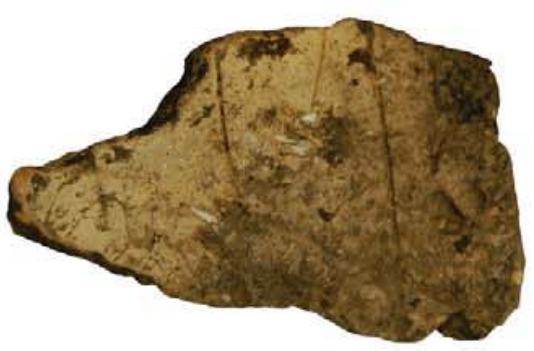

TE-705-56

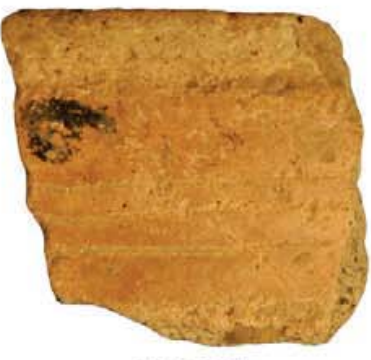

TE-35-54

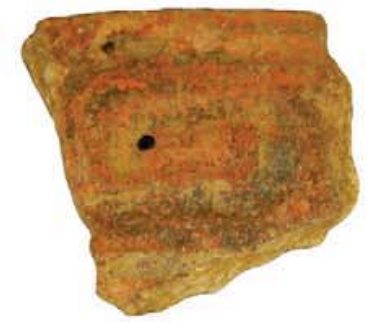

TE-321-2

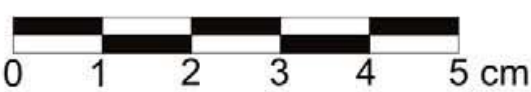

\section{SÍTIO TEOTÔNIO}

FRAGMENTOS COM DECORAÇĀO PLÁSTICA E PINTADA
TESE DE DOUTORADO

\section{A TRADIÇÃO POLÍCROMA DA AMAZÔNIA NO ALTO RIO MADEIRA}

Aluno: Fernando Ozorio de Almeida Orientador: Eduardo Góes Neves

Programa de Pós-Graduação - Museu de Arqueologia e Etnologia

Arte Final: Eduardo Tamanaha

\section{紫}

\section{MAE JFAPESP}

PRANCHA 4 


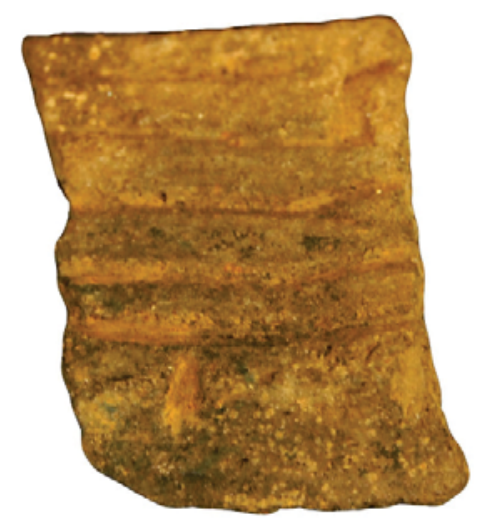

TE-807-5

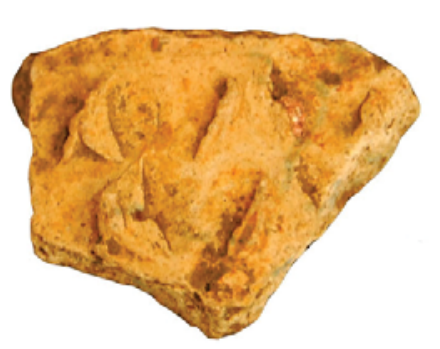

TE-806-7

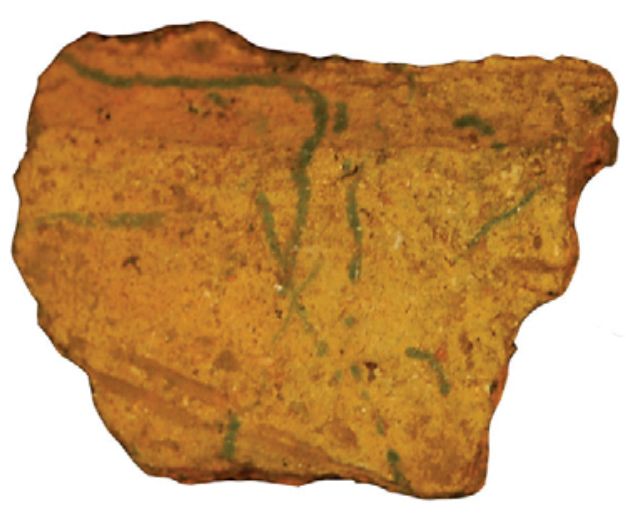

TE-806-2

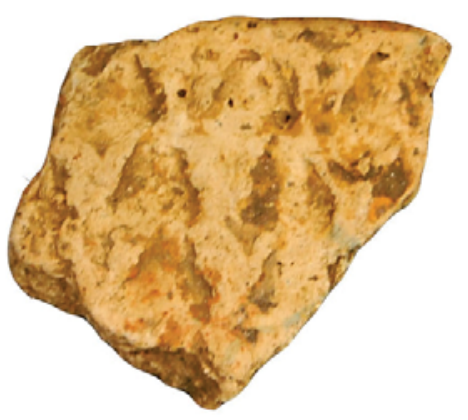

TE-806-5

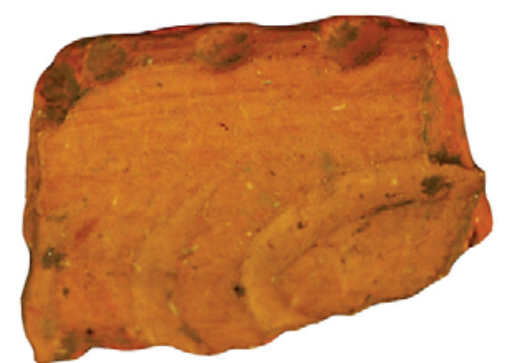

TE-803-7

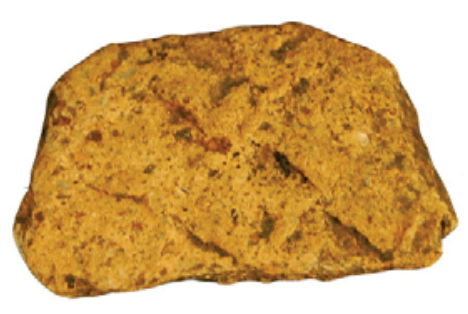

TE-807-7

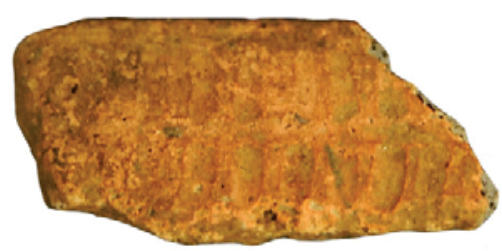

TE-807-6

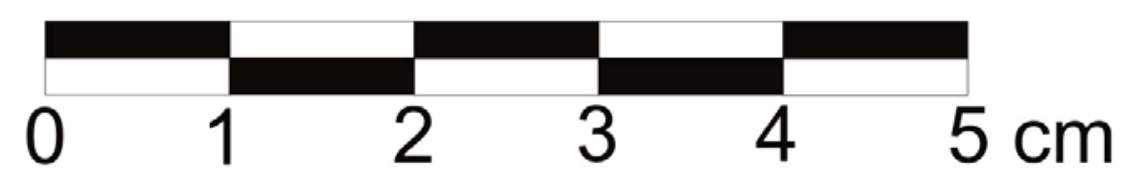

\begin{tabular}{|c|c|c|}
\hline \multirow[b]{2}{*}{ SÍTIO TEOTÔNIO } & \multicolumn{2}{|l|}{ TESE DE DOUTORADO } \\
\hline & \multicolumn{2}{|c|}{$\begin{array}{c}\text { A TRADIÇÃO POLÍCROMA DA } \\
\text { AMAZÓNIA NO ALTO RIO MADEIRA }\end{array}$} \\
\hline \multirow{2}{*}{ FRAGMENTOS COM DECORAÇÃO PLÁSTICA } & \multicolumn{2}{|c|}{ Aluno: Fernando Ozorio de Almeida Orientador: Eduardo Góes Neves } \\
\hline & \multicolumn{2}{|c|}{ Programa de Pós-Graduação - Museu de Arqueologia e Etnologia } \\
\hline PRANCHA 5 & Arte Final: Eduardo Tamanaha & E DFAPESP \\
\hline
\end{tabular}




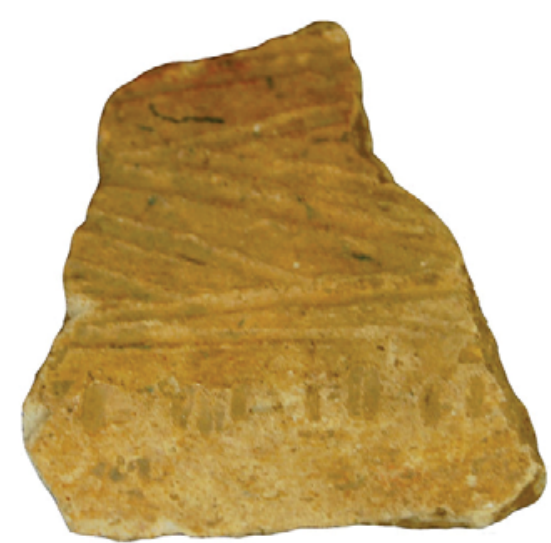

TE-140-3

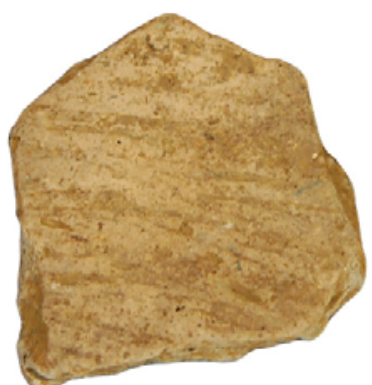

TE-16-1

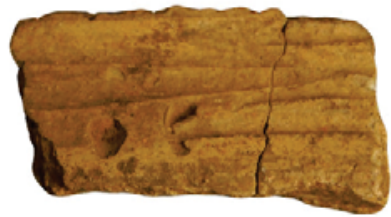

TE-708-5

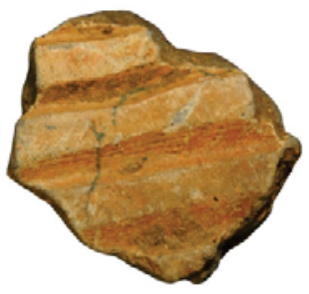

TE-708-4

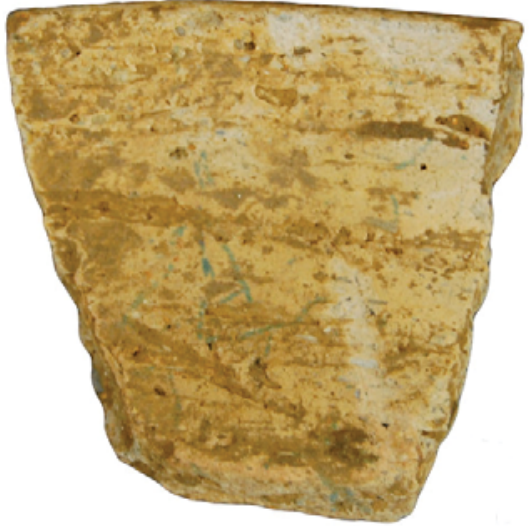

TE-17-1

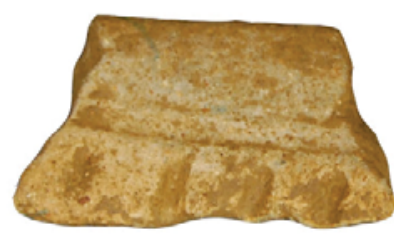

TE-59-5

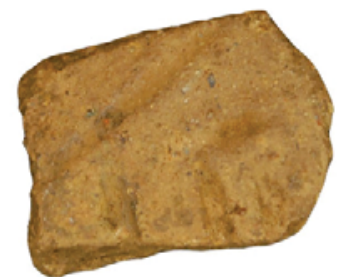

TE-417-7

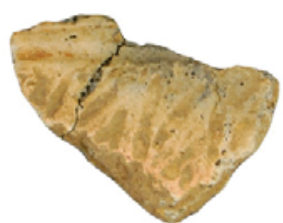

TE-35-57

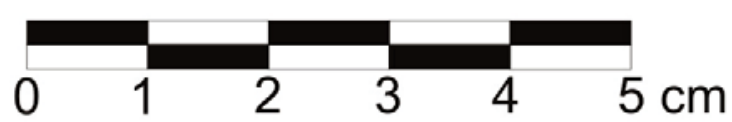

\section{SÍTIO TEOTÔNIO}

FRAGMENTOS COM DECORAÇÃO PLÁSTICA
TESE DE DOUTORADO

\section{A TRADIÇÃO POLÍCROMA DA} AMAZÔNIA NO ALTO RIO MADEIRA

Aluno: Fernando Ozorio de Almeida

Orientador: Eduardo Góes Neves

Programa de Pós-Graduação - Museu de Arqueologia e Etnologia

Arte Final: Eduardo Tamanaha
MAE JFAPESP 
ANEXO 21 

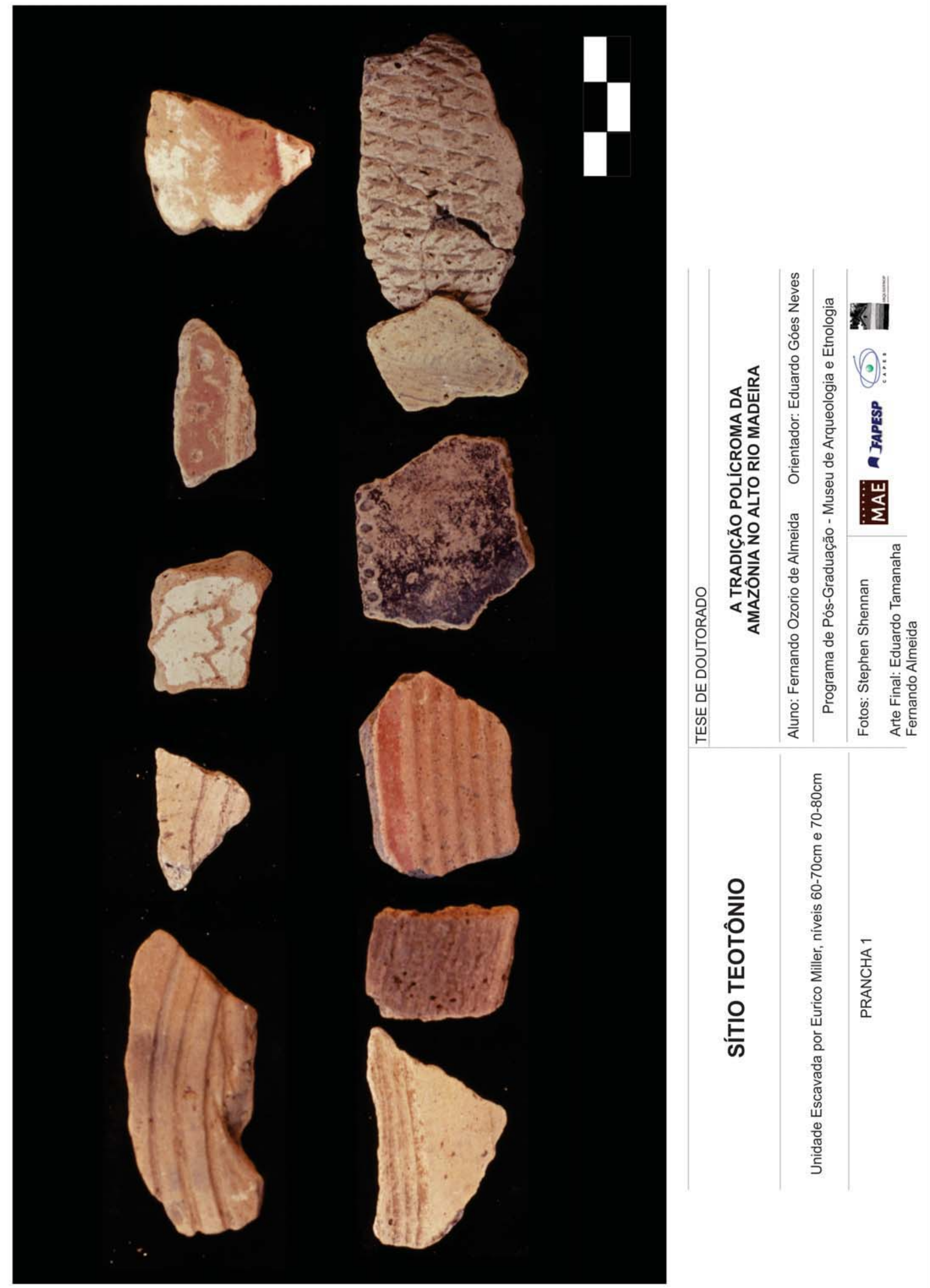


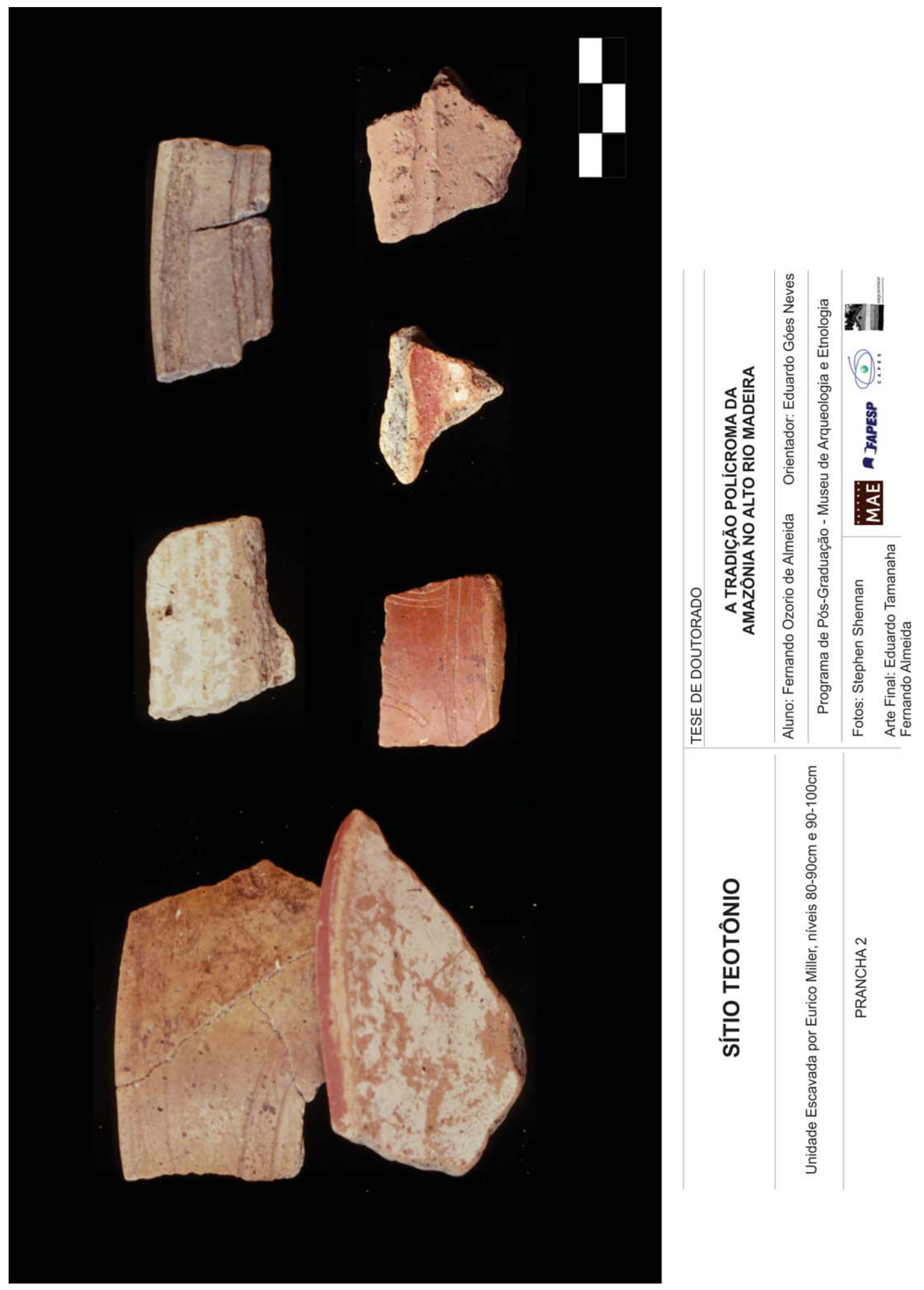




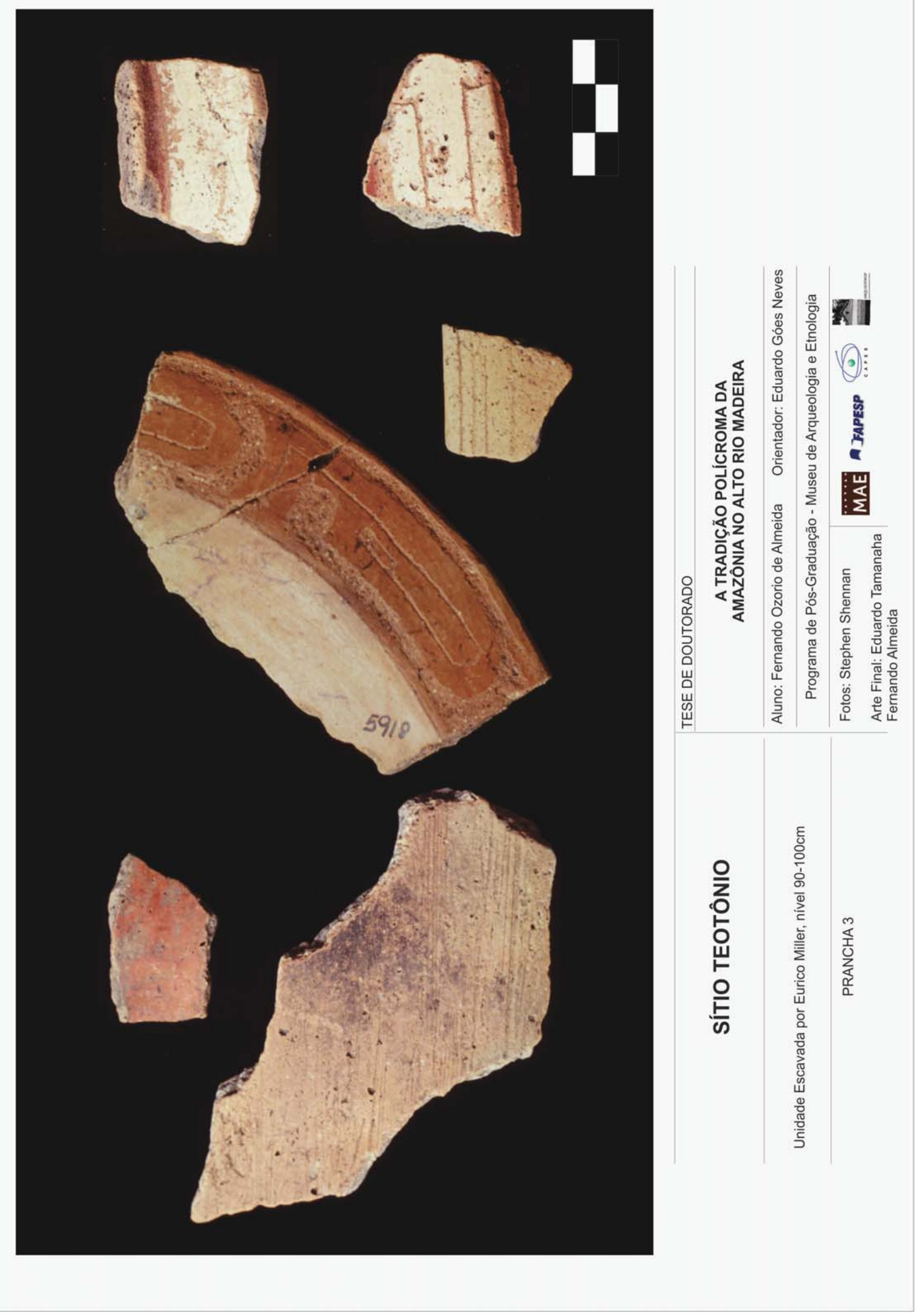



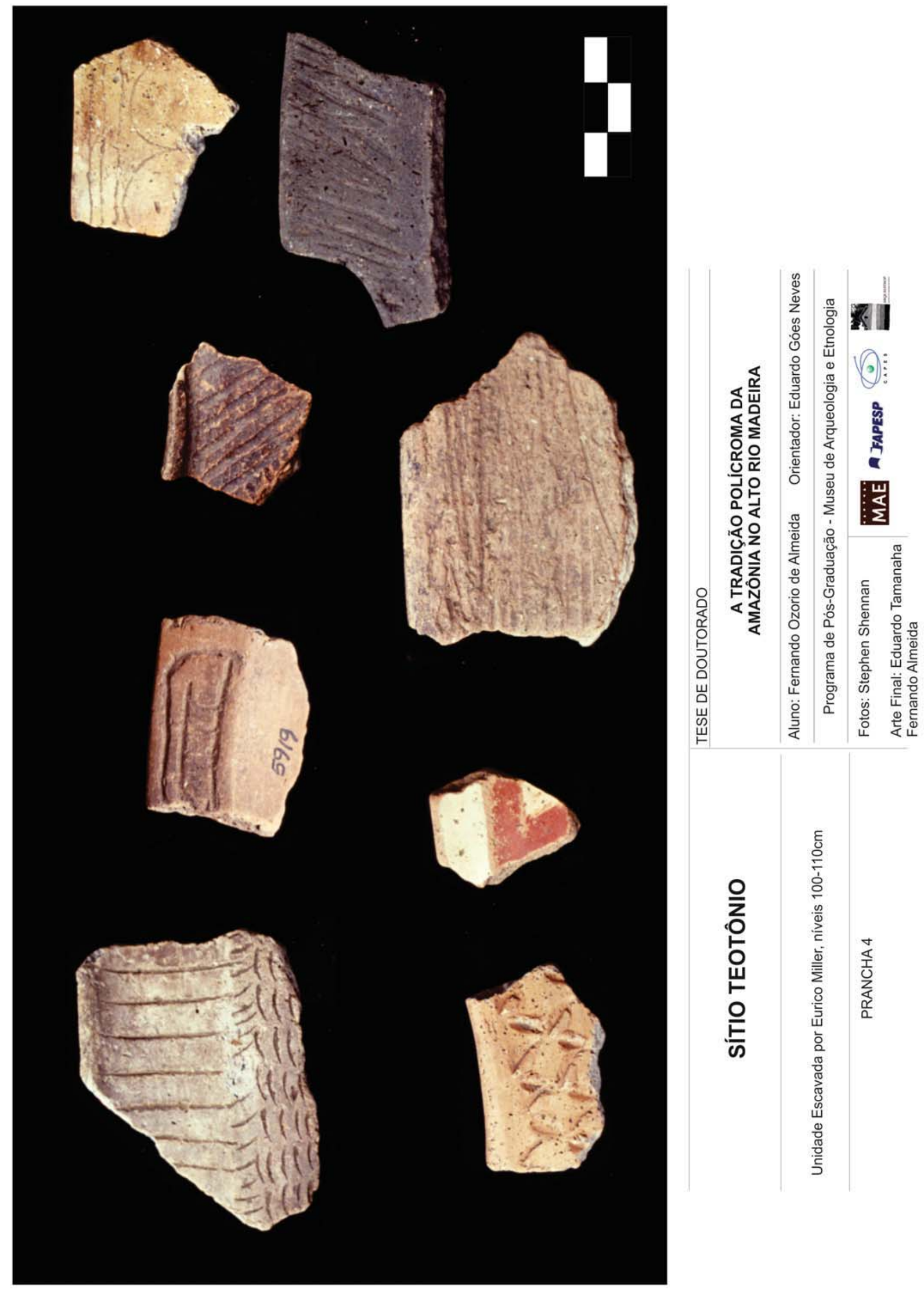


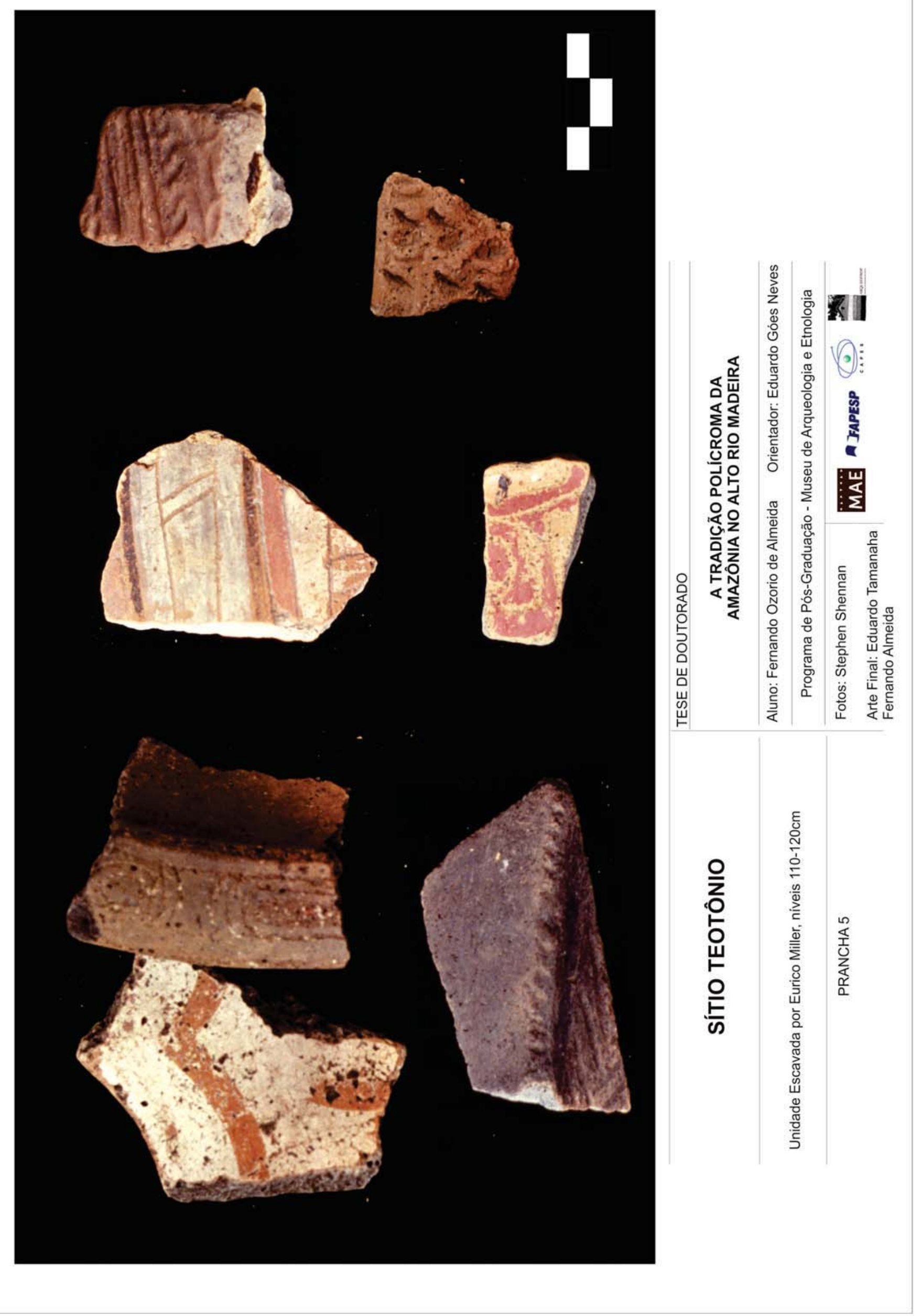




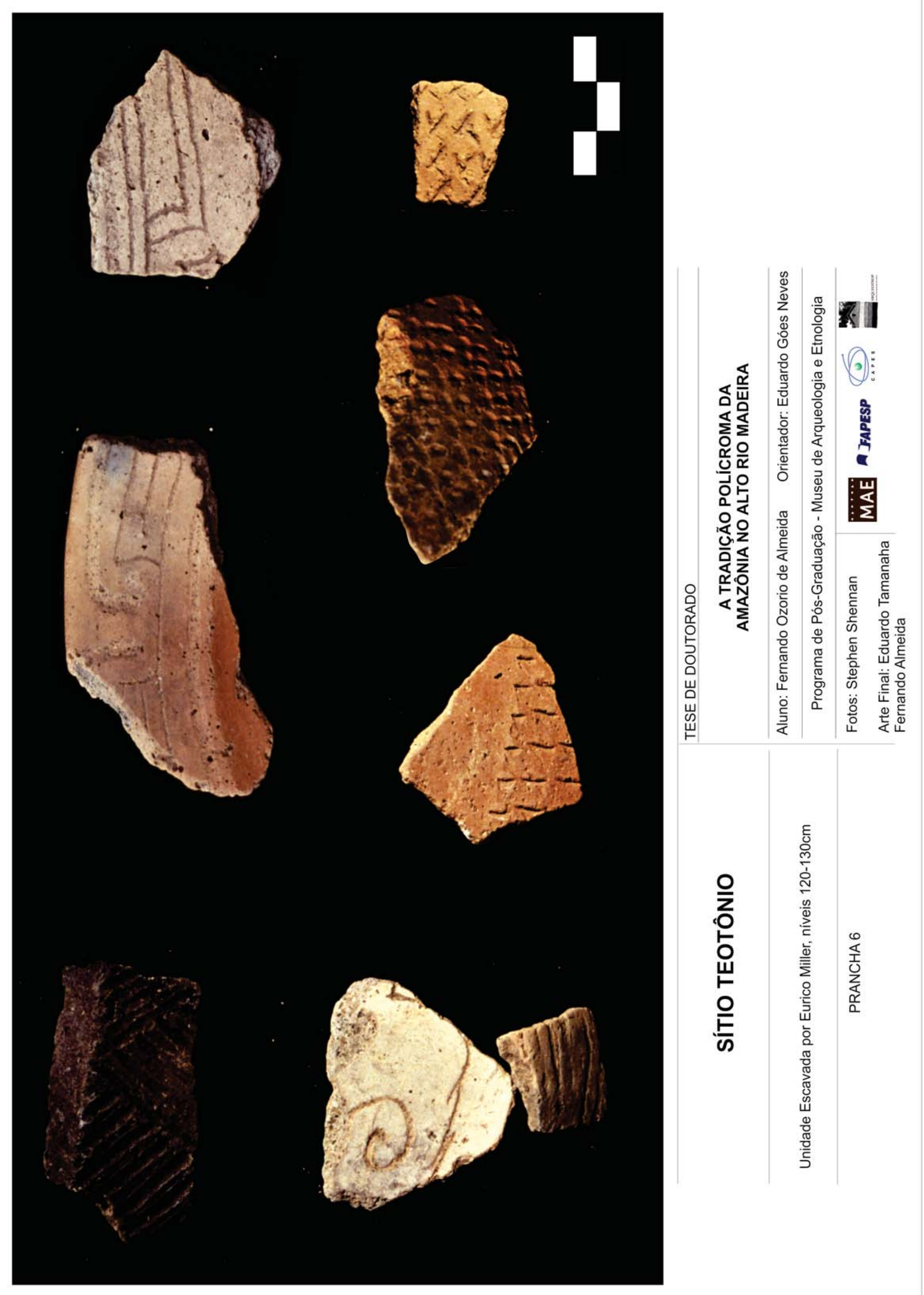




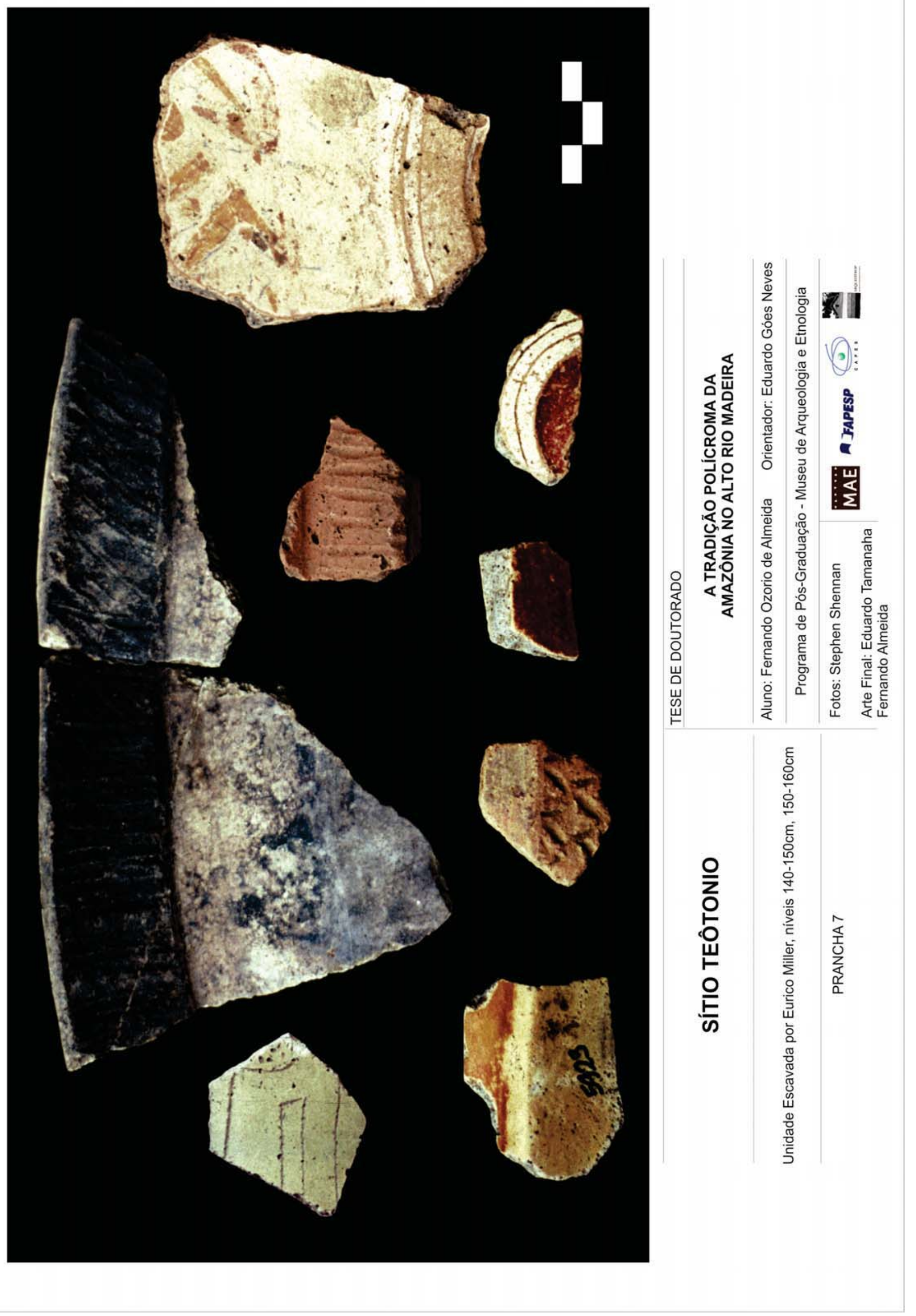



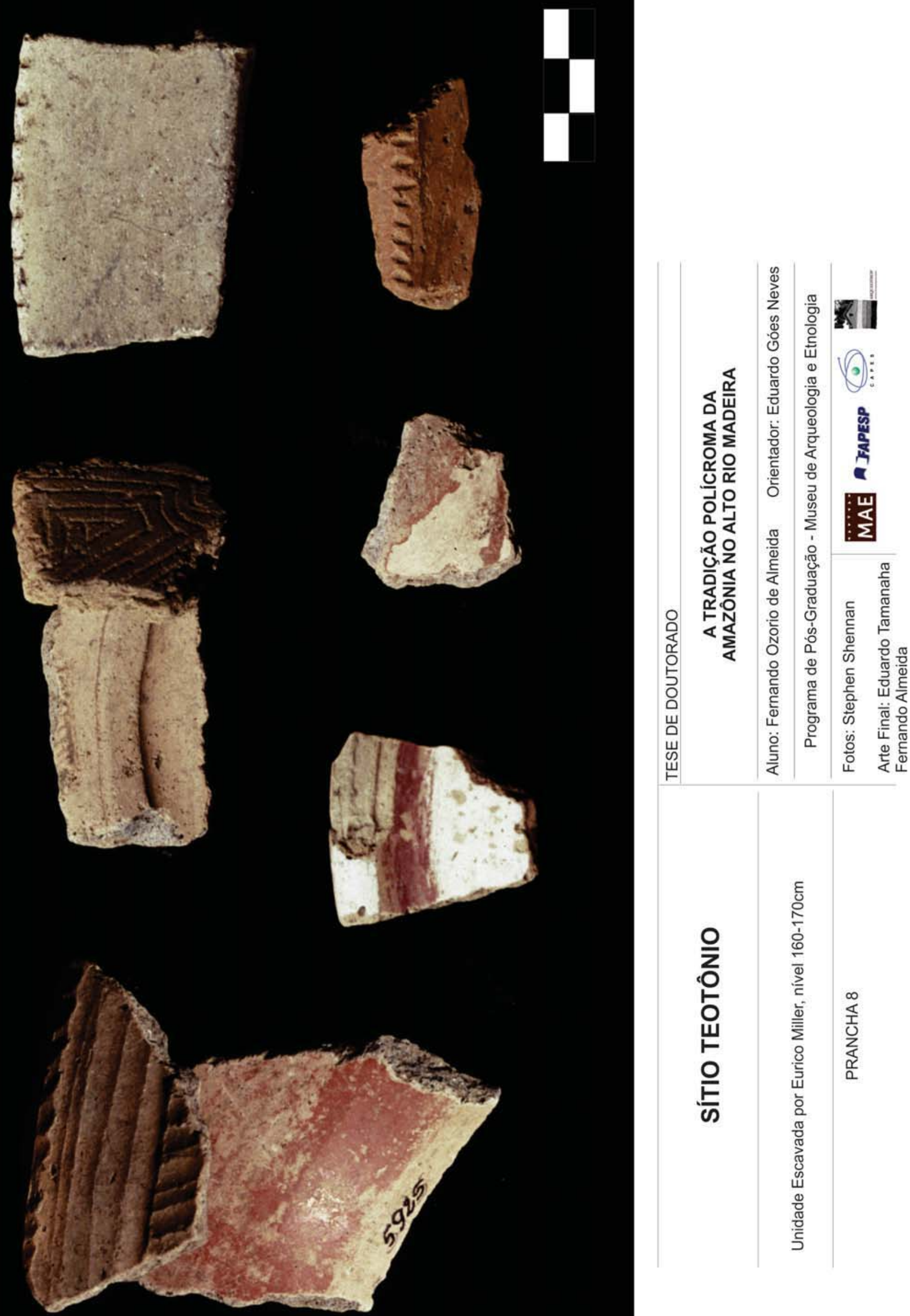


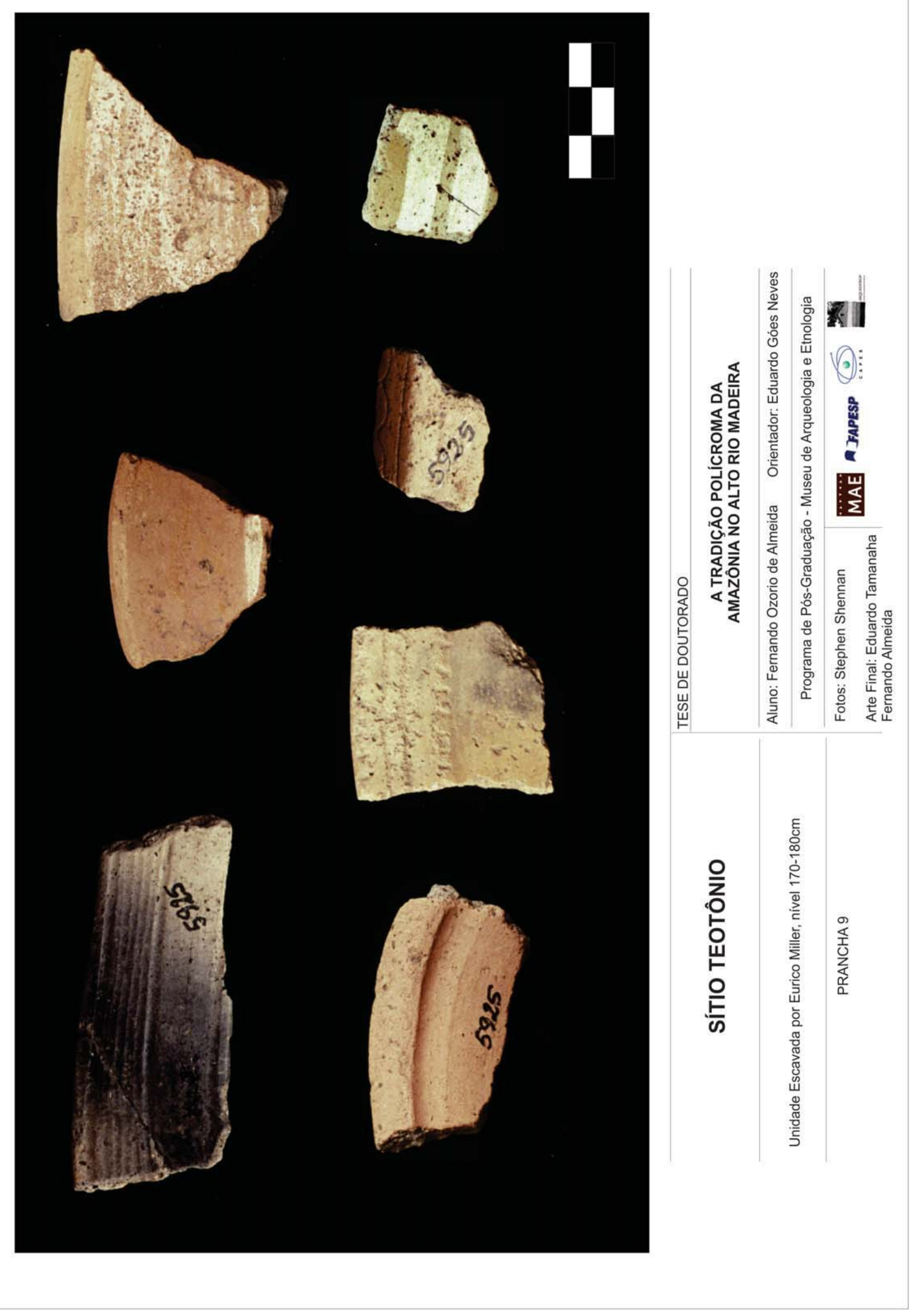




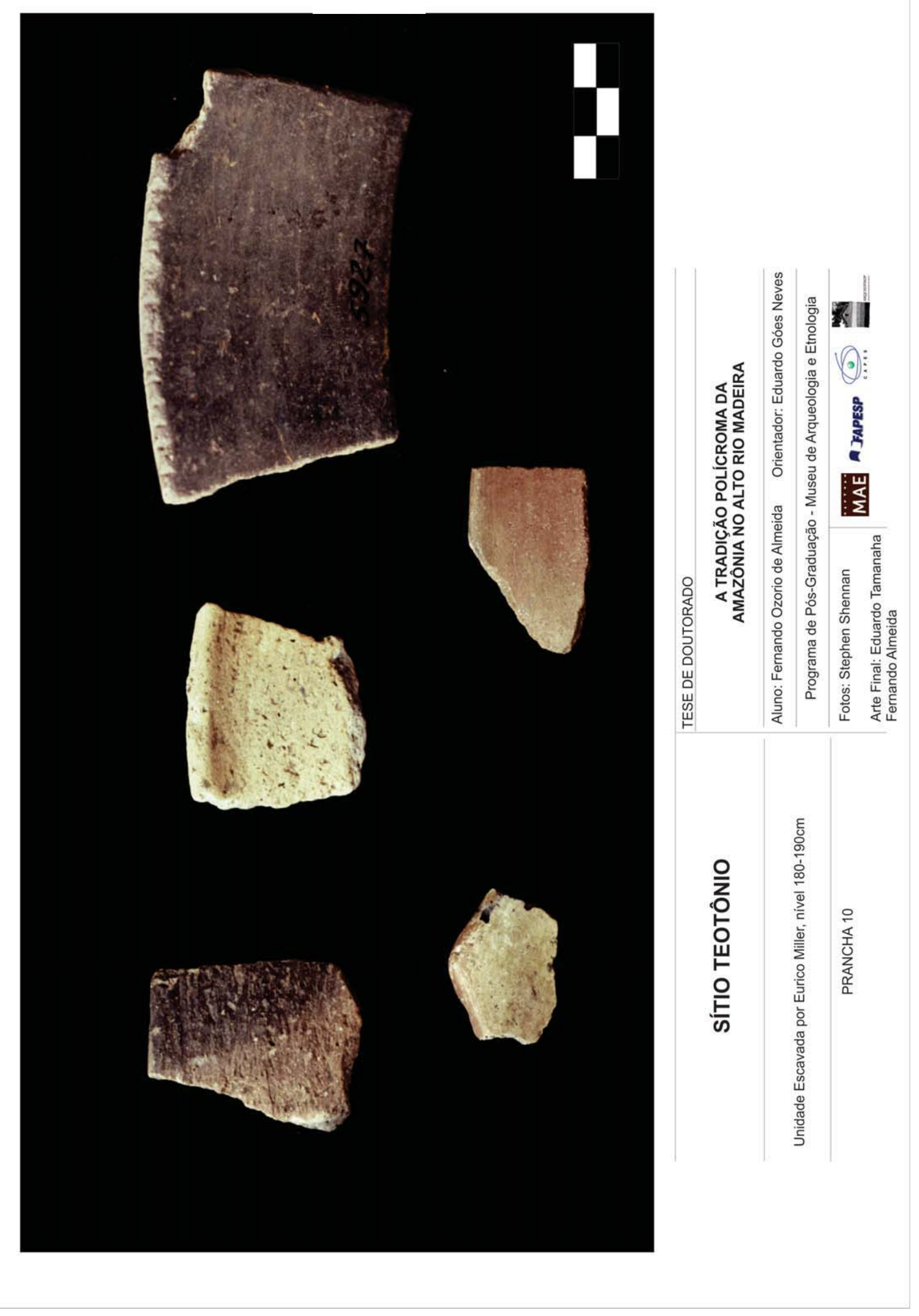


ANEXO 22: GRÁFICOS DAS DATAÇÕES 


\section{CALIBRATION OF RADIOCARBON AGE TO CALENDAR YEARS}

(Variables: $\mathrm{C} 13 / \mathrm{C} 12=-26 \cdot 6: 1 \mathrm{ab} \cdot \mathrm{mult}=1$ )

L aboratory number: Beta-258150

Conventional radiocarbon age: $\quad 620 \pm 40 \mathrm{BP}$

2 Sigma calibr ated result: Cal $A D 1280$ to 1410 (Cal BP 670 to 540) (95\% pr ob ability)

Intercept datà

Intercepts of radiocarbon age with calibration curve:

Cal $A D 1310$ (Cal BP 640) and

Cal AD 1360 (Cal BP 590) and

Cal AD 1390 (Cal BP 560)

1 Sigma calibrated result: Cal AD 1300 to 1400 (Cal BP 660 to 550) (68\% probability)

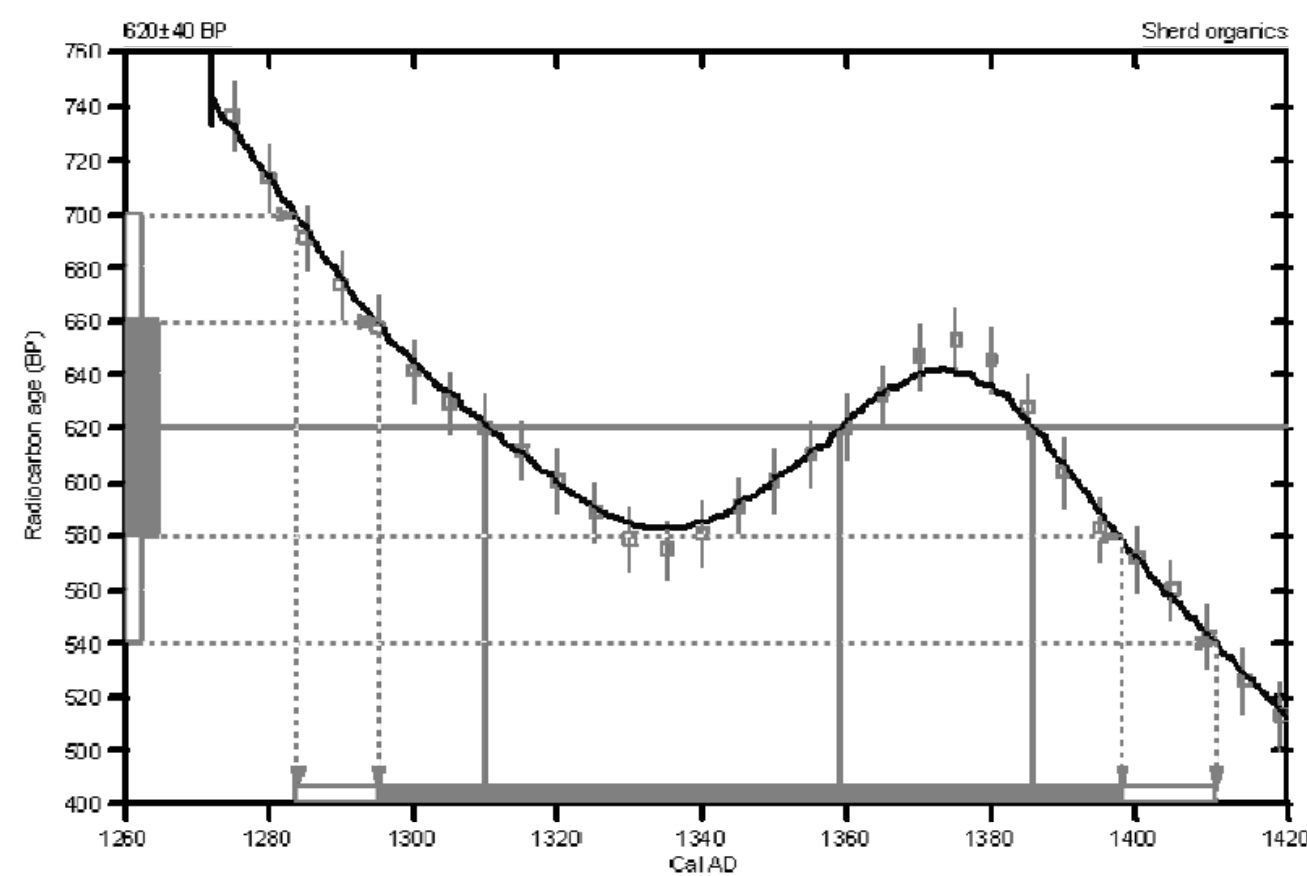

References:

Dutubus used

INCAIO4

Calibtation Database

Calibtation Database

IrtGilo4: Calibration Isue of Radiocarbon (Volene $46, n r 3,2004$ ).

Mathematics

A Shmplified Asproach to Calibrating C14 Date

Talma, A. S, Vogel, J. C, 1993, Radiocarbon 35(2), p317-322

\section{Beta Analytic Radiocarbon Dating Laboratory}

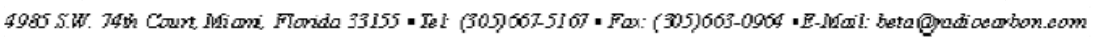

\section{Sítio Associação Calderita: RO-AC-53-1}




\section{CALIBRATION OF RADIOCARBON AGE TO CALENDAR YEARS}

(Variables: $\mathrm{C} 13 / \mathrm{C} 12=-27 \cdot 1: 1 \mathrm{ab} \cdot \mathrm{mult}=1$ )

Laboratory number: Beta-258149

Conventional radiocarbon age: $980 \pm 40 \mathrm{BP}$

2 Sigma calibrated result: Cal AD 990 to 1160 (C al BP 960 to 790) (95\% pr ob ability)

Intercept data

Intercept of radiocarbon age with calibration curve:

Cal AD 1030 (Cal BP 920)

1 Sigma calibrated results: Cal AD 1020 to 1040 (Cal BP 930 to 910 ) and

(68\% probability) Cal AD 1100 to 1120 (Cal BP 850 to 830 )
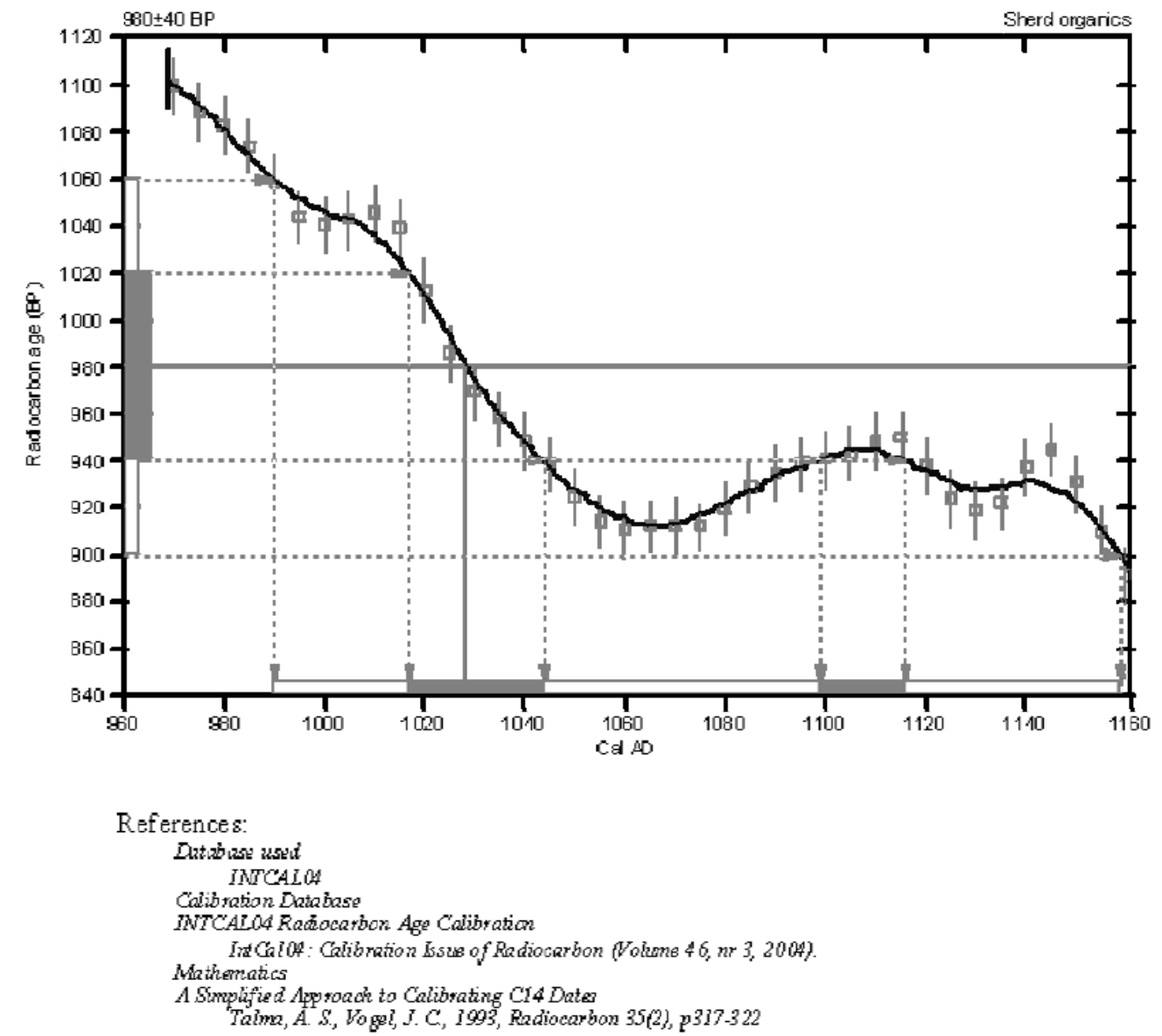

Beta Analytic Radiocarbon Dating Laboratory

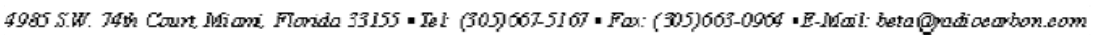

\section{Sítio Associação Calderita: RO-AC-54-1}




\section{CALIBRATION OF RADIOCARBON AGE TO CALENDAR YEARS}

(Variables: C13ic 12=-28:lab. mult=1)

Laboratory number: Beta-258151

Conventional radiocarbon age: $940 \pm 40 \mathrm{BP}$

2 Sigma calibrated result: Cal AD 1020 to 1200 (Cal BP 930 to 750 ) (95\% pr obability)

Intercept data

Intercepts of radiocarbon age with calibration curve:

Cal AD 1040 (Cal BP 910) and

Cal AD 1100 (Cal BP 850) and

Cal AD 1120 (Cal BP 830)

1 Sigma calibrated result: Cal AD 1030 to 1160 (Cal BP 920 to 790) (68\% probability)

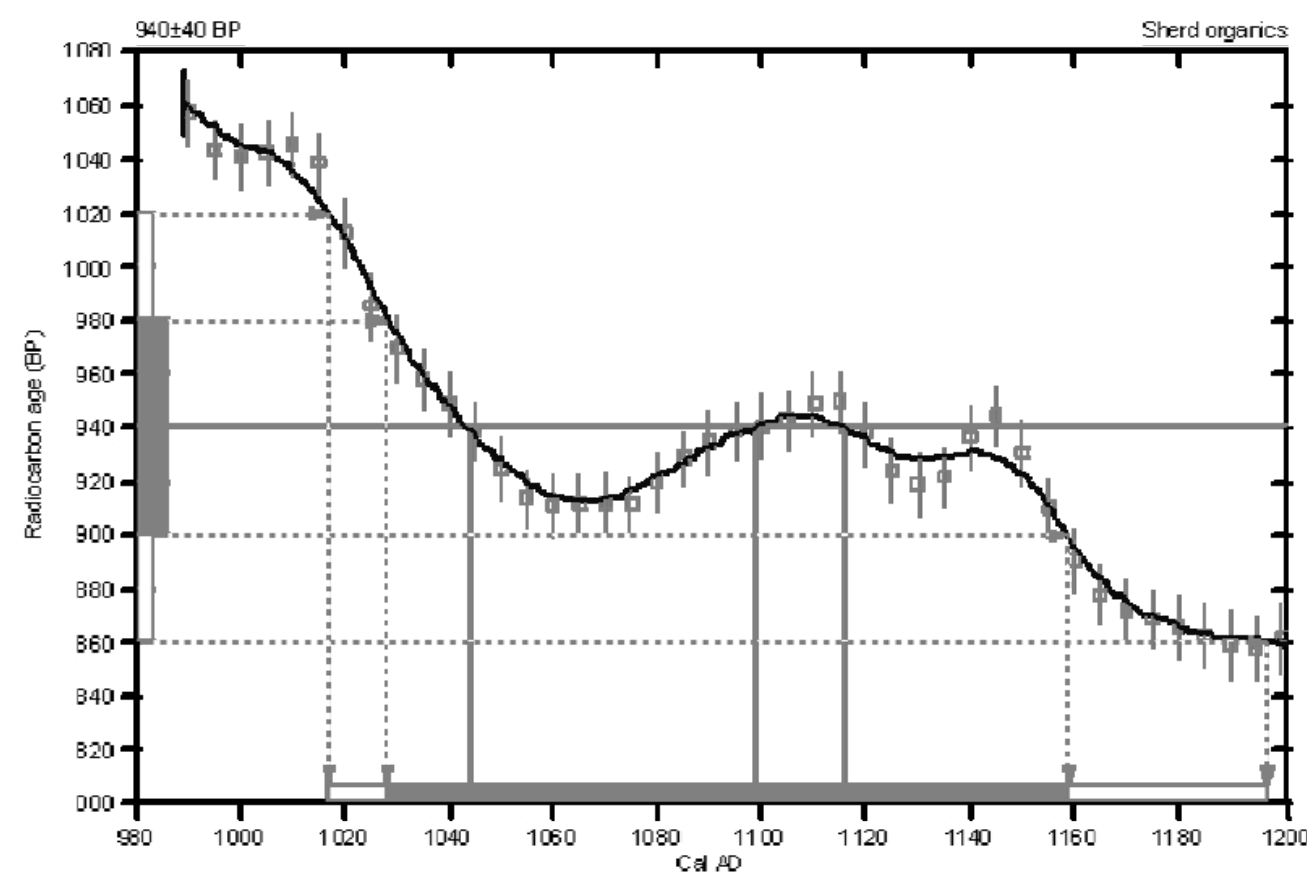

Reference:

Dutubus usud

INCAIO4

Calibration Database

Calibtation Database

Ind Cal04: Calibration Isue of Radiocarbon (Vollone $46, n r 3,2004$ ).

Mathematics

A Slmplified Asproach to Calibrating Cl4 Dateo

Talma, A. S, Vogel, J. C, 1993, Radiocarbon 35(2), p317-322

\section{Beta Analytic Radiocarbon Dating Laboratory}

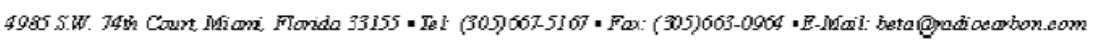




\section{CALIBRATION OF RADIOCARBON AGE TO CALENDAR YEARS}

(Variables: $\mathrm{C} 13 / \mathrm{C} 12=-24.8: 1 \mathrm{ab} . \mathrm{mult}=1$ )

Laboratory number: Beta-258152

Conventional radiocar bon age: $\quad 430 \pm 40 \mathrm{BP}$

2 Sigma calibrated results Cal AD 1420 to 1500 (Cal BP 530 to 440) and (95\% pr obability) Cal AD 1600 to 1610 (Cal BP 350 to 340 )

Intercept data

Intercept of radiocarbon age

with calibration curve:

Cal $\mathrm{AD} 1450$ (Cal BP 500)

1 Sigma calibrated re sult: Cal AD 1440 to 1460 (Cal BP 510 to 490)

(68\% probability)

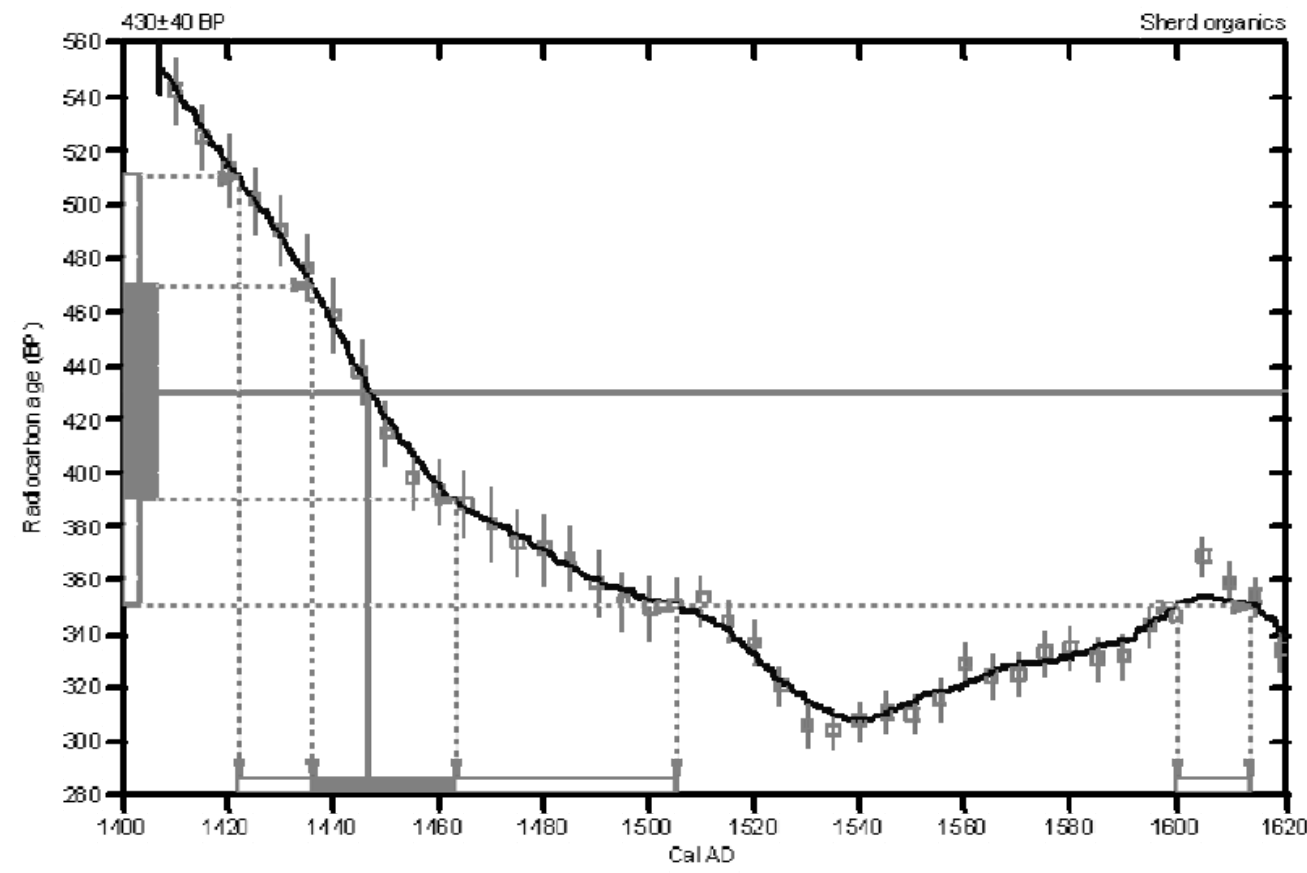

Reference \&:

Datubass uset

INTCALOA

Colibration Dotabse

IWTCALO4 Radiocatbon Age Calibration

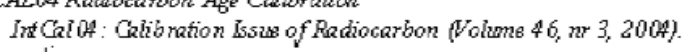

Mathematics

A Simplified Approach to Calibrating CI4 Dates

Talma, A. S., Vogel, J. C, 1993, Radiocarbon 35(2), p317-322

\section{Beta Analytic Radiocarbon Dating Laboratory}

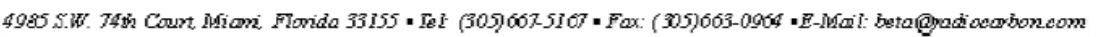

\section{Sítio Nova Vida: RO-NV-2-1}




\section{CALIBRATION OF RADIOCARBON AGE TO CALENDAR YEARS}

(Variables: $\mathrm{C} 13 / \mathrm{C} 12=-25 \cdot 1: 1 \mathrm{ab}$. mult $=1$ )

Laboratory number: Beta-280928

Conventional radiocarbon age: $1790 \pm 60 \mathrm{BP}$

2 Sign a calibr ated result: Cal AD $\$ 0$ to 390 (Cal BP 1870 to 1560 )

( $95 \%$ probability)

Intercept datã

Intercept of radiocarbon age

with calibration curve: Cal AD 240 (Cal BP 1710)

1 Sigma calibrated results: Cal AD 140 to 260 (Cal BP 1810 to 1680) and

(68\% probability) Cal AD 280 to 330 (Cal BP 1670 to 1620 )

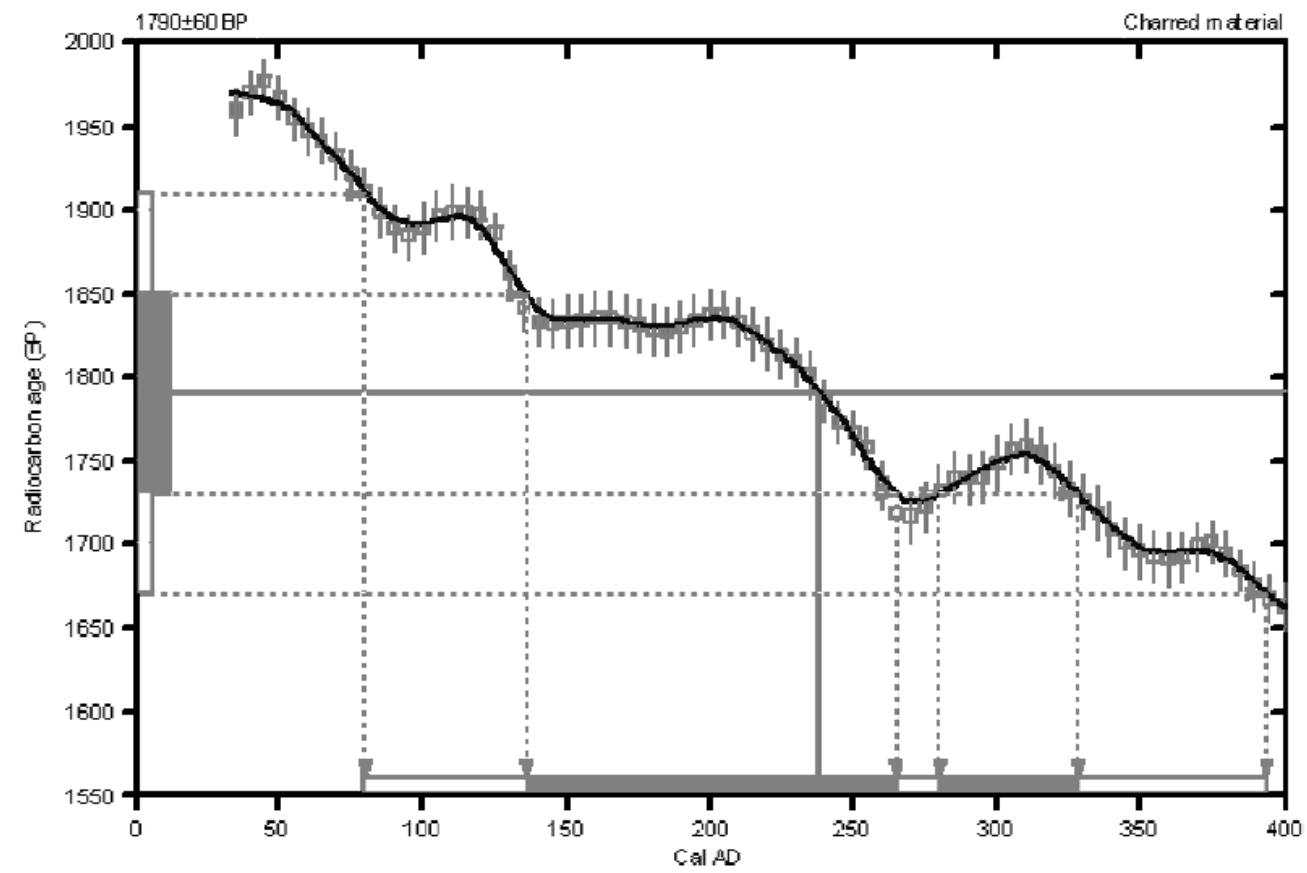

References

Duwbuse used

INCALO4

Colibration Database

INTCATO4 Radiocarbon Age Calibration

IntCalo4: Calibration Isue of Radiocarbon (Volume 46, nr 3, 2004).

Mathematics

A Simplififed Approach to Calibrating Cl4 Dates

Talma, A S., Vogel, I. C, 1993, Radiocabon 35(2), p317-322

Beta Analytic Radiocarbon Dating Laboratory

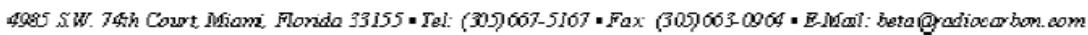

Sítio Nova Vida: RO-NV-204-1 


\section{CALIBRATION OF RADIOCARBON AGE TO CALENDAR YEARS}

(Variables: $\mathrm{C} 13 / \mathrm{C} 12=-26.51 \mathrm{ab} \cdot \mathrm{mult}=1$ )

Labor atory number: Beta-280925

Conventional radiocarbon age: $\quad 980 \pm 40 \mathrm{BP}$

2 Sign a calibrated result: Cal AD 990 to 1160 (Cal BP 960 to 790)

(95\% probability)

Intercept data

Intercept of radiocarbon age

with calibration curve: Cal AD 1030 (Cal BP 920)

1 Sigma calibrated results: Cal AD 1020 to 1040 (Cal BP 930 to 910) and

(68\% probability) Cal AD 1100 to 1120 (Cal BP 850 to 830 )

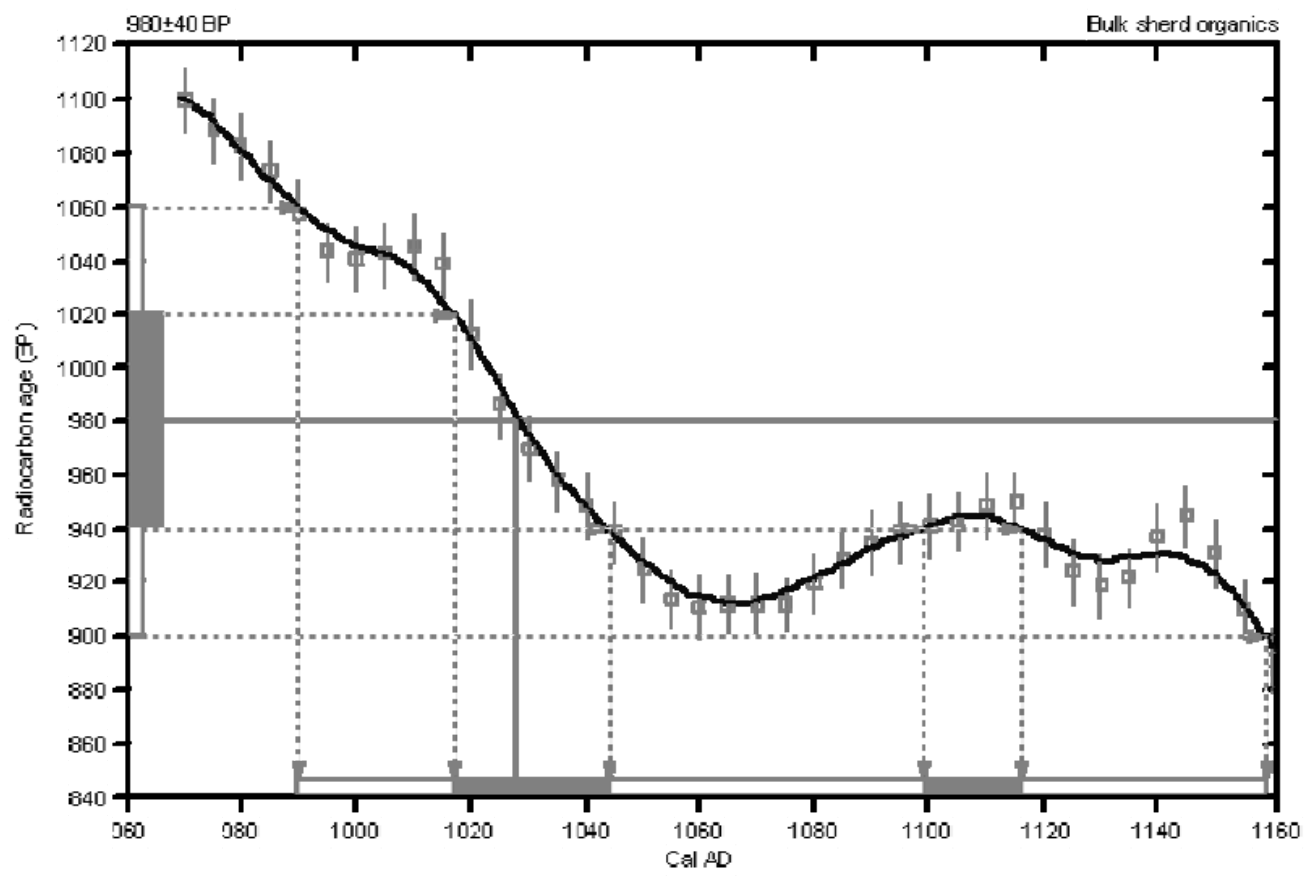

References:

Delublese used

$$
\text { ITTCAIO4 }
$$

Calibration Database

MT CALO4 Radiocarbon Age Calibration

IntCal04: Calibration Isue of Radiocarbon (Volume 46, nr 3, 2004).

Mathematics

ASimplafied Approach to Calbrating Ci4 Dateo

Talma, A S., Vogel, J. C, 1993, Dadiocabon 35(2), p317-322

Beta Analytic Radiocarbon Dating Laboratory

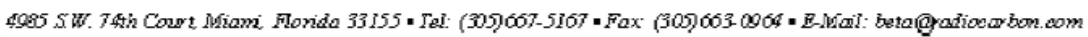

\section{Sítio Jacarezinho: RO-JA-205-1}




\section{CALIBRATION OF RADIOCARBON AGE TO CALENDAR YEARS}

(Variables: C13/C12 $=-25.7: 1 \mathrm{ab}$. mult $=1$ )

L abor atory number: Beta-280926

Conventional radiocarbon age: $\quad 660 \pm 40 \mathrm{BP}$

2 Sigm a calibr ated result: Cal $A D 1270$ to 1400 (Cal BP 680 to 550)

( $95 \%$ probability)

Intercept data

Intercept of radiocarbon age

with calibration curve:

Cal AD 1300 (Cal BP 660)

1 Sigma calibrated results: Cal AD 1280 to 1310 (Cal BP 670 to 640) and

(68\% probability) Cal AD 1360 to 1390 (Cal BP 590 to 560)

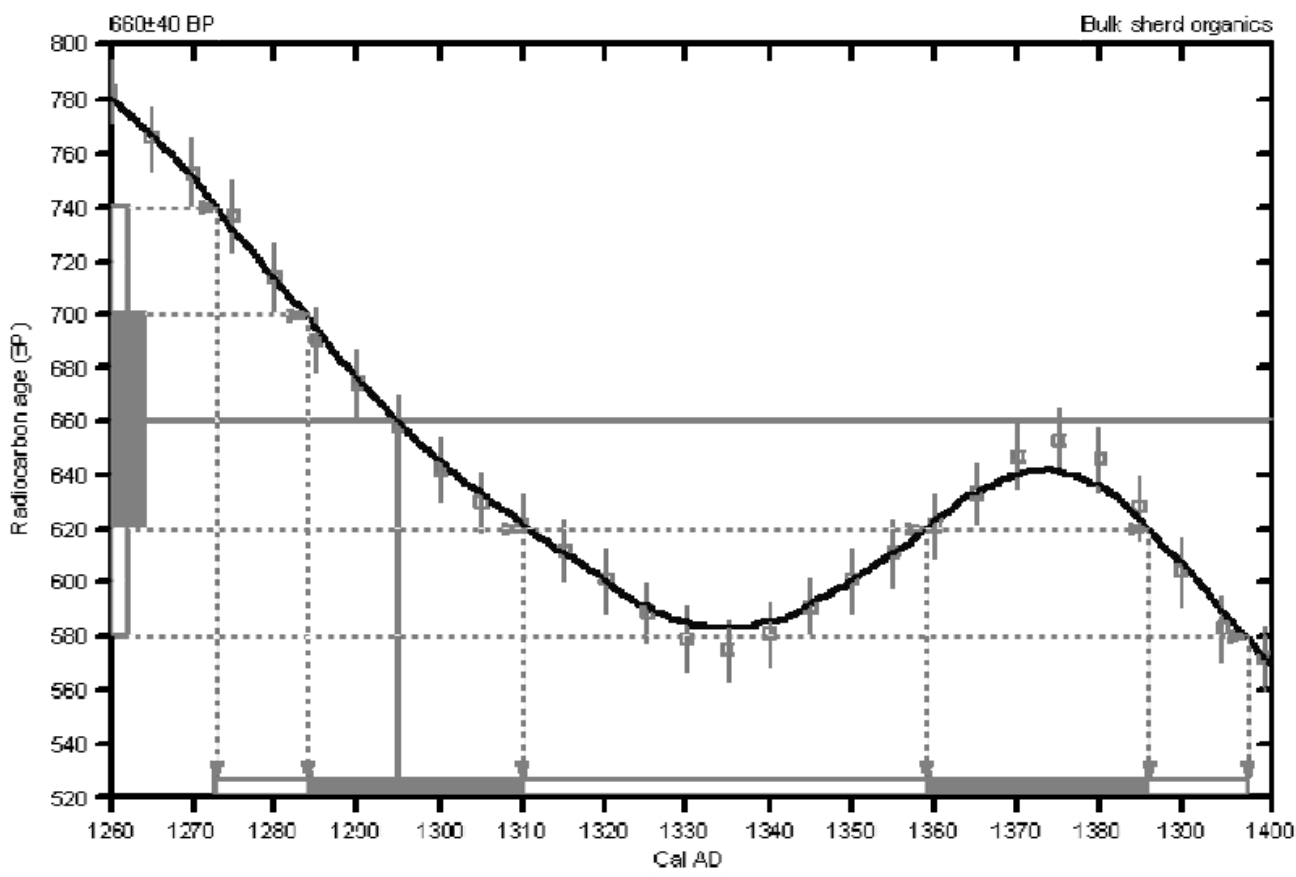

References

Dubluse used

$$
\text { INCALOA }
$$

Calibration Database

IMTCAL 04 Radiocar bon Age Calibration

IntCalo4: Calibration Isue of Radiocarbon (Volume 46, nr 3, 2004).

Mathematics

A Simplifed Aperoach to Callbrating C14 Dateo

Talma, A S., Vogel, I. C, 1993, Radiocabon 35(2), p317-322

Beta Analytic Radiocarbon Dating Laboratory

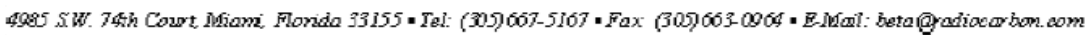




\section{CALIBRATION OF RADIOCARBON AGE TO CALENDAR YEARS}

\section{(Variables: C13ic12=-25:lab. mult=1)}

L abor atory number: Beta-280927

Conventional radiocarbon age: $860 \pm 40 \mathrm{BP}$

2 Sigm a calibr ated results: Cal AD 1040 to 1100 (Cal BP 910 to 850) and (95\% probability) Cal AD 1120 to 1260 (Cal BP 830 to 690)

Intercept data

Intercept of radiocarbon age with calibration curve:

Cal AD 1200 (Cal BP 750)

1 Sigma calibrated result:

(68\% probability)

Cal AD 1160 to 1220 (Cal BP 790 to 730 )

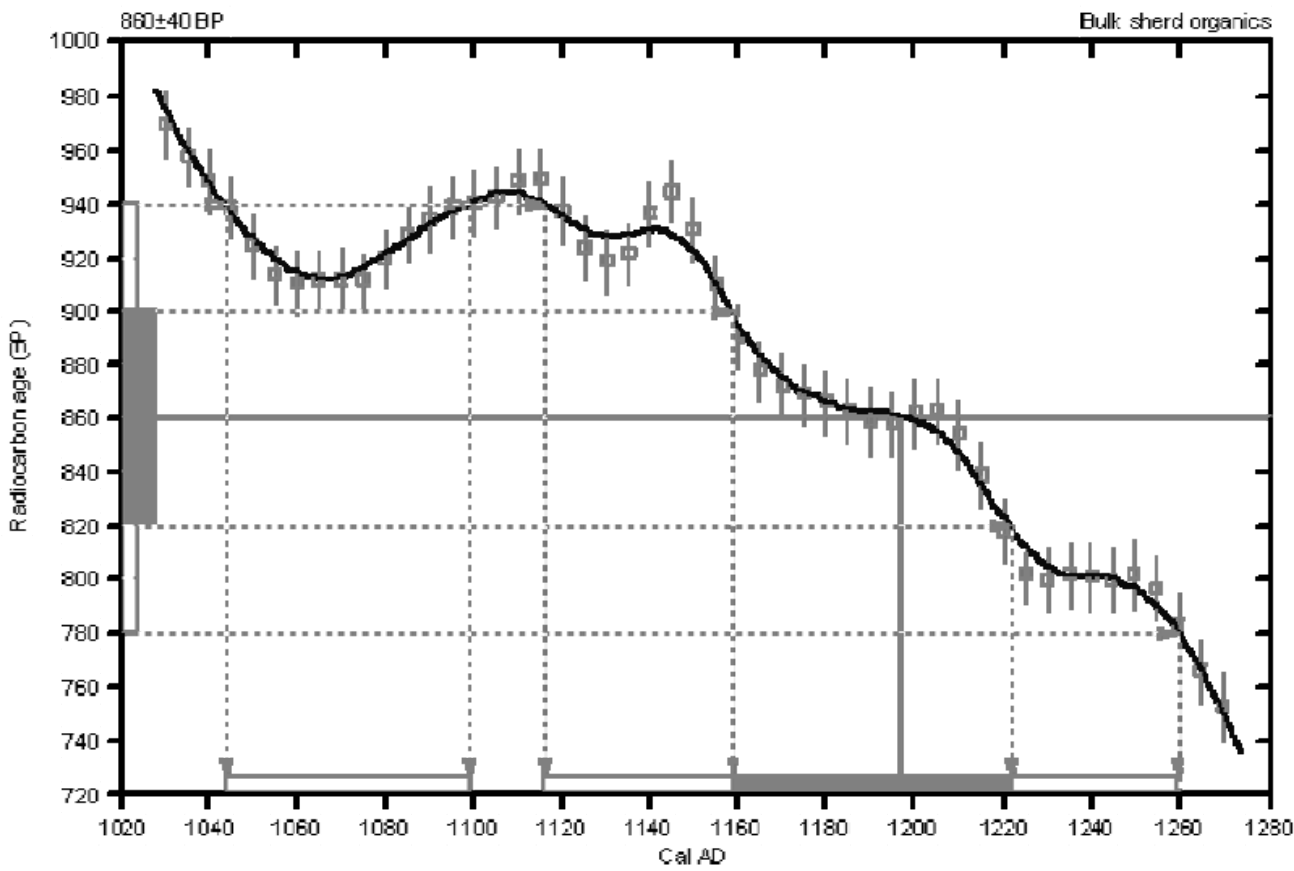

References:

Diwhuse used

$$
\text { INTCALO4 }
$$

Calibration Database

CMTCALOA Radiocarbon Age Calibration

IntCal04: Calibration Isue of Radiocarbon (Volume 46, nr 3, 2004).

Mathematics

A Simplifíled Approach to Calibrating C14 Dote

Talma, A S., Vogel, J. C, 1993, Radiocabon 35(2), p317-322

\section{Beta Analytic Radiocarbon Dating Laboratory}

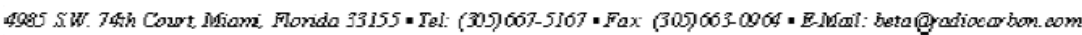

\section{Sítio Jacarezinho: RO-JA-304-1}




\section{CALIBRATION OF RADIOCARBON AGE TO CALENDAR YEARS}

(Variables: C13/C12 $=-27.4: 1 \mathrm{ab}$. mult $=1$ )

L abor atory number: Beta-280922

Conventional radiocarbon age: $540 \pm 40 \mathrm{BP}$

2 Sigm a calibr ated results: Cal AD 1310 to 1360 (Cal BP 640 to 590) and (95\% probability) Cal AD 1390 to 1440 (Cal BP 560 to 510)

Intercept data

Intercept of radiocarbon age with calibration curve:

Cal AD 1410 (Cal BP 540)

1 Sigma calibrated result: (68\% probability)

Cal AD 1400 to 1430 (Cal BP 550 to 520 )

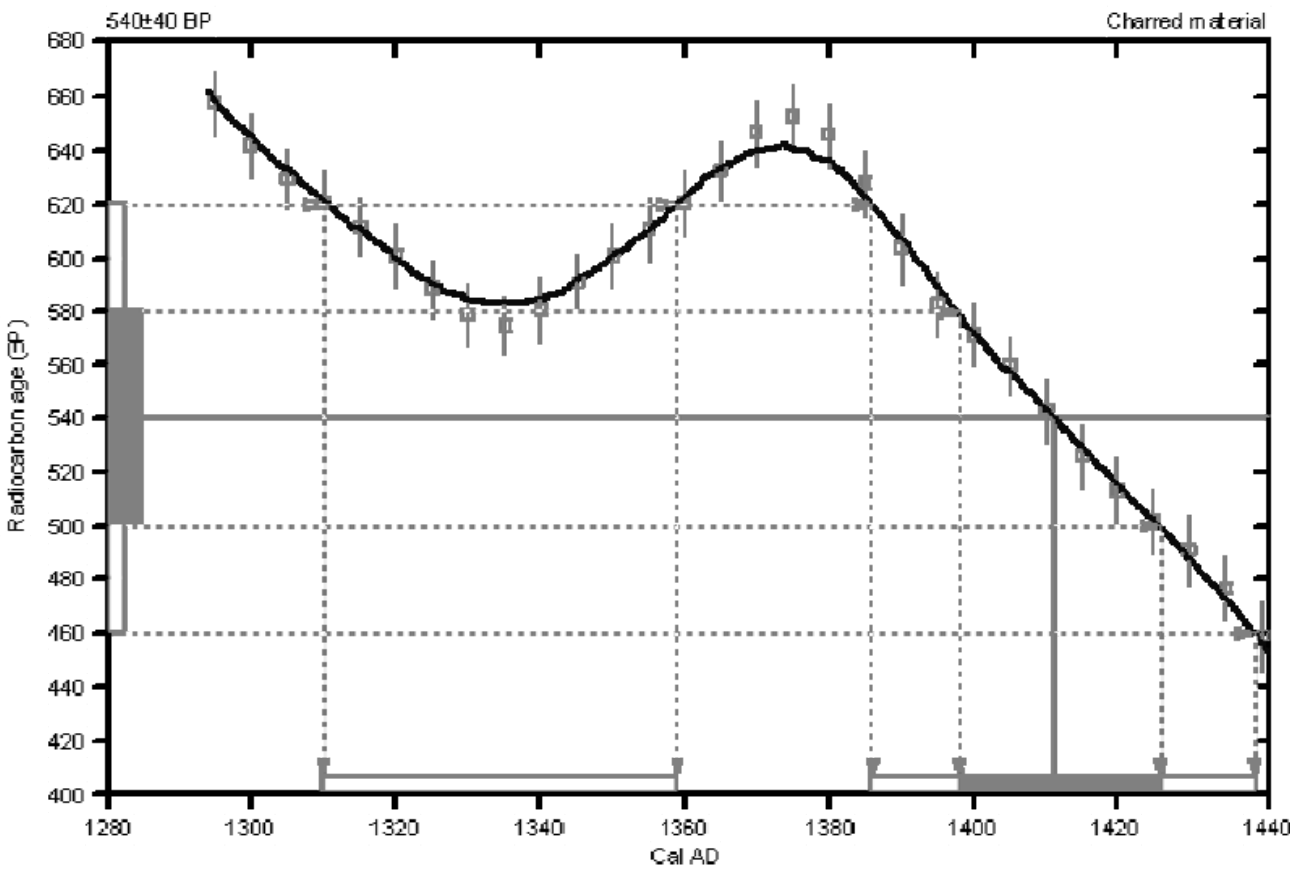

References:

Ditubue used

INTCALO4

Caibration Dotabase

INTCALOA Radiocarbon Age Calibration

IntCalo4: Calibration Isue of Radiocarbon (Volume 46, nr 3, 2004).

Mathematics

A Simplifífed Approach to Calibrating C14 Dote

Talma, A S., Vogel, J. C, 1993, Radiocarbon 35(2), p317-322

Beta Analytic Radiocarbon Dating Laboratory

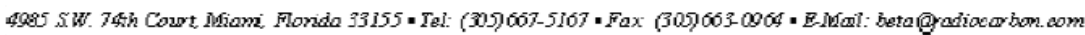




\section{CALIBRATION OF RADIOCARBON AGE TO CALENDAR YEARS}

(Variables: $\mathrm{C} 13 / \mathrm{C} 12=-27.9: 1 \mathrm{ab}$. mult $=1$ )

L abor atory number: Beta-280923

Conventional radiocarbon age: $\quad 590 \pm 40 \mathrm{BP}$

2 Sigm a calibr ated result: Cal AD 1290 to 1420 (Cal BP 660 to 530)

(95\% probability)

Intercept data

Intercepts of radiocarbon age

with calibration curve:

Cal AD 1330 (Cal BP 620) and
Cal AD 1340 (Cal BP 610) and
Cal AD 1400 (Cal BP 560)

1 Sigma calibrated results: Cal AD 1310 to 1360 (Cal BP 640 to 590) and

(68\% probability) Cal AD 1380 to 1410 (Cal BP 570 to 540$)$

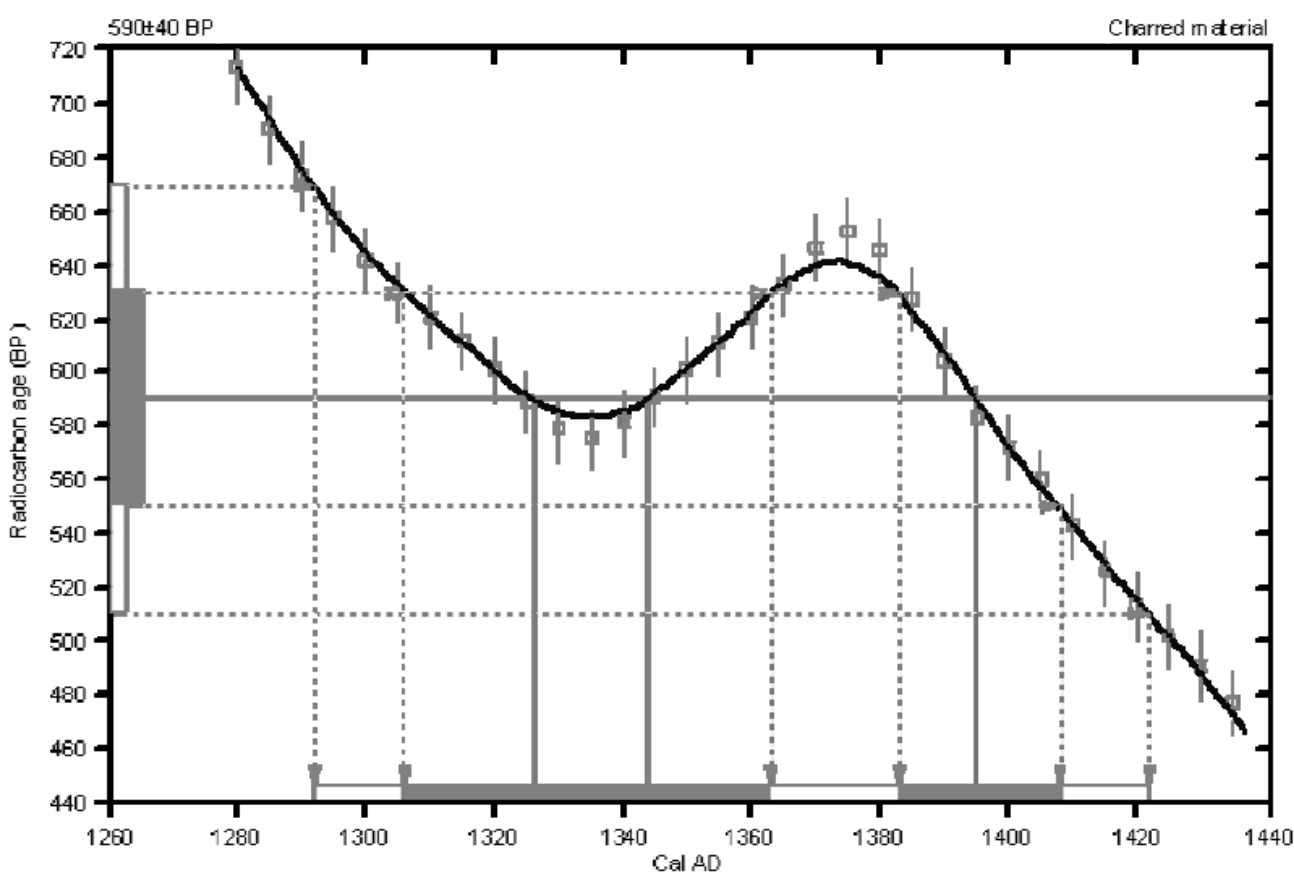

References:

Dilubue used

$$
\text { INTCALO4 }
$$

Gilibration Dotabase

INTCAI04 Radiocarbon Age Calibration

IntCalo4: Calibration Isue of Radiocarbon (Volume 46, nr 3, 2004).

Mathematics

A Simplifífed Approach to Calibrating C14 Dote

Talma, A S., Vogel, J. C, 1993, Radiocarbon 35(2), p317-322

Beta Analytic Radiocarbon Dating Laboratory

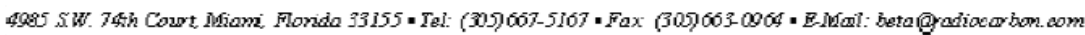

\section{Sítio Itapirema: RO-ITA-510-01}




\section{CALIBRATION OF RADIOCARBON AGE TO CALENDAR YEARS}

(Variables: $\mathrm{C} 13 / \mathrm{C} 12=-26 \cdot 3: 1 \mathrm{ab}$. mult $=1$ )

L abor atory number: Beta-280924

Conventional radiocarbon age: $\quad 620 \pm 60 \mathrm{BP}$

2 Sigm a calibr ated result: Cal $A D 1270$ to 1430 (Cal BP 680 to 520)

( $95 \%$ probability)

Intercept data

Intercepts of radiocarbon age

with calibration curve:

Cal AD 1310 (Cal BP 640) and

Cal AD 1360 (Cal BP 590) and

Cal AD 1390 (Cal BP 560)

1 Sigma calibrated result: Cal AD 1290 to 1400 (Cal BP 660 to 550) ( $68 \%$ probability)

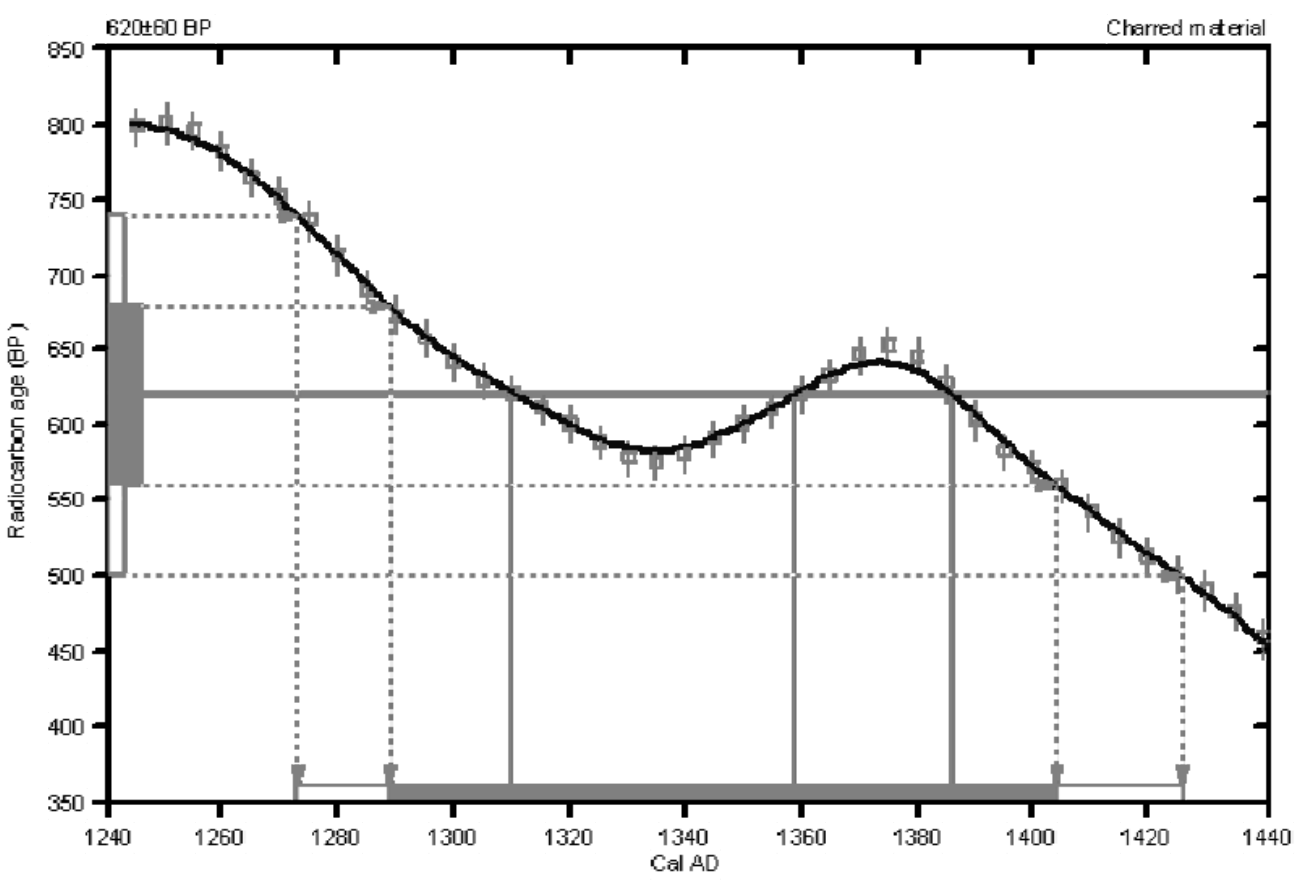

References:

Diwbuse used

$$
\text { INTCALO4 }
$$

Calibration Database

INTCALOA Radiocarbon Age Calibration

IntCal04: Calibration Isue of Radiocarbon (Volume 46, nr 3, 2004).

Mathematics

A Simplificed Approach to Calibrating C14 Dote

Talma, A S., Vogel, J. C, 1993, Radiocarón 35(2), p317-322

Beta Analytic Radiocarbon Dating Laboratory

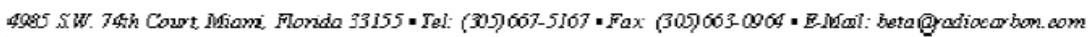




\section{CALIBRATION OF RADIOCARBON AGE TOCALENDAR YEARS}

(Variables: $\quad C 13 / C 12=-26.8$ :lab.mult=1)

Laboratory number: Beta-323281

Conventional radiocarbonage: $1250 \pm 30 \mathrm{BP}$

2Sigmacalibrated results: Cal AD 680to830(Cal BP1270to1120)and

(95\% probability) Cal AD 840to870(Cal BP1110to1080)

Interceptdata

Interceptsofradiocarbonage

with calibrationcurve:

Cal AD 730(CalBP1220)and

Cal AD 740(CalBP1210)and

Cal AD 770(CalBP1180)

1Sigma calibratedresults: Cal AD 690to750(CalBP1260to1200) and (68\%probability ) Cal AD 760to780(CalBP1190to1170)

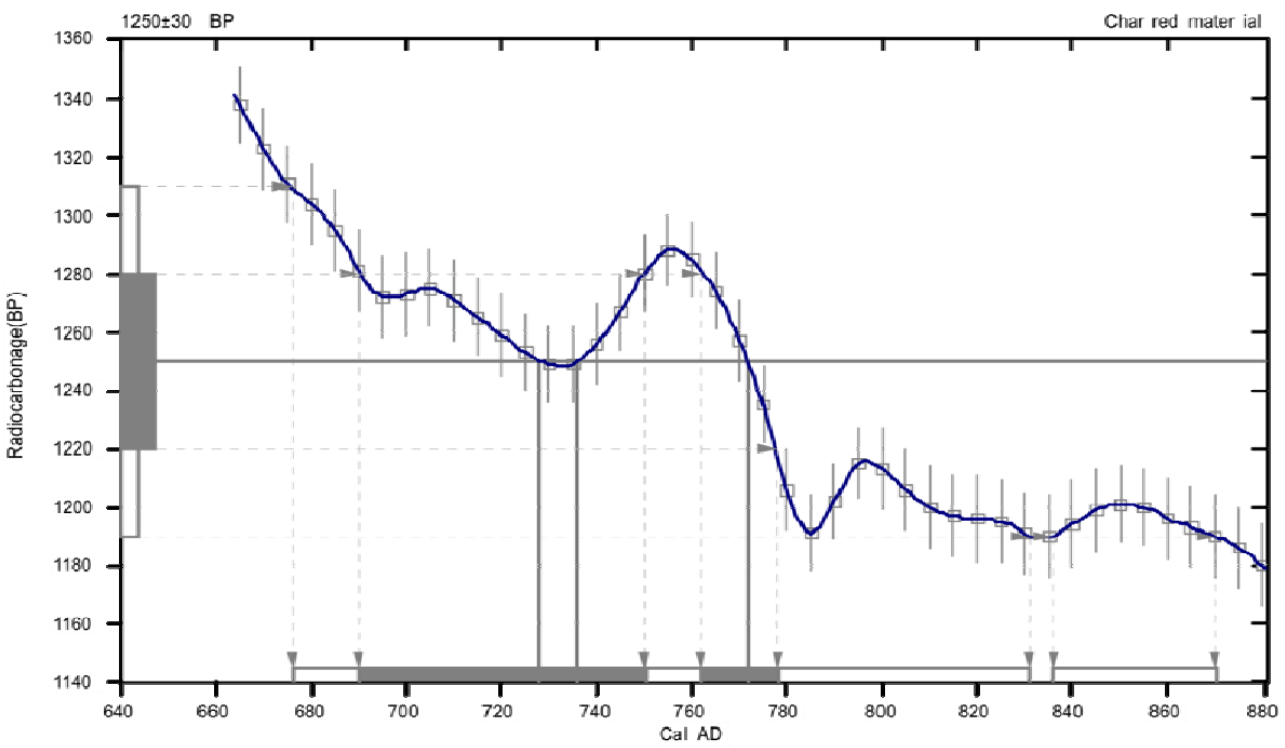

References:

Databaseused

ReferencestolNTCALOS database

Heaton,et.al.,2009, Radiocarbon 51(4):1151-1164, Reimer,et.al, 2009, Radiocarbon 51(4):1111-1150,

Stuiver, et al 1993, Radiocarbon 35(1):137-189, Oeschger,et.al, 1975, Tellus27:168-192

Mathematicsusedforcalibration scenario

ASimplified Approach toCalibrat ingC14 Dates

Talma, A.S., Vogel,J.C. 1993,Radiocarbon $35(2): 317-322$

Beta Analytic Radioca rbon Dating Laboratory

4985 S.W.74th Court,Miami, Florida 33155 •Tel: (305)667-5167 •Fax:(305)663-0964 •E-Mail: beta@radiocarbon. com 


\section{CALIBRATION OF RADIOCARBON AGE TOCALENDAR YEARS}

(Variables: $\mathrm{C} 13 / \mathrm{C} 12=-25 \cdot 1:$ lab.mult=1)

Laboratory number: Beta-323282

Conventional radiocarbonage: $\quad 3170 \pm 30$ BP

2Sigmacalibrated result: Cal BC 1500to1410(Cal BP3450to3360)

( $95 \%$ probability)

Interceptdata

Interceptof radiocarbonage with calibrationcurve:

Cal BC 1430(Cal BP3380)

1Sigma calibratedresults: Cal BC 1490to1480(CalBP3440to3430)

(68\%probability ) Cal BC 1450to1420(CalBP3400to3370)

and

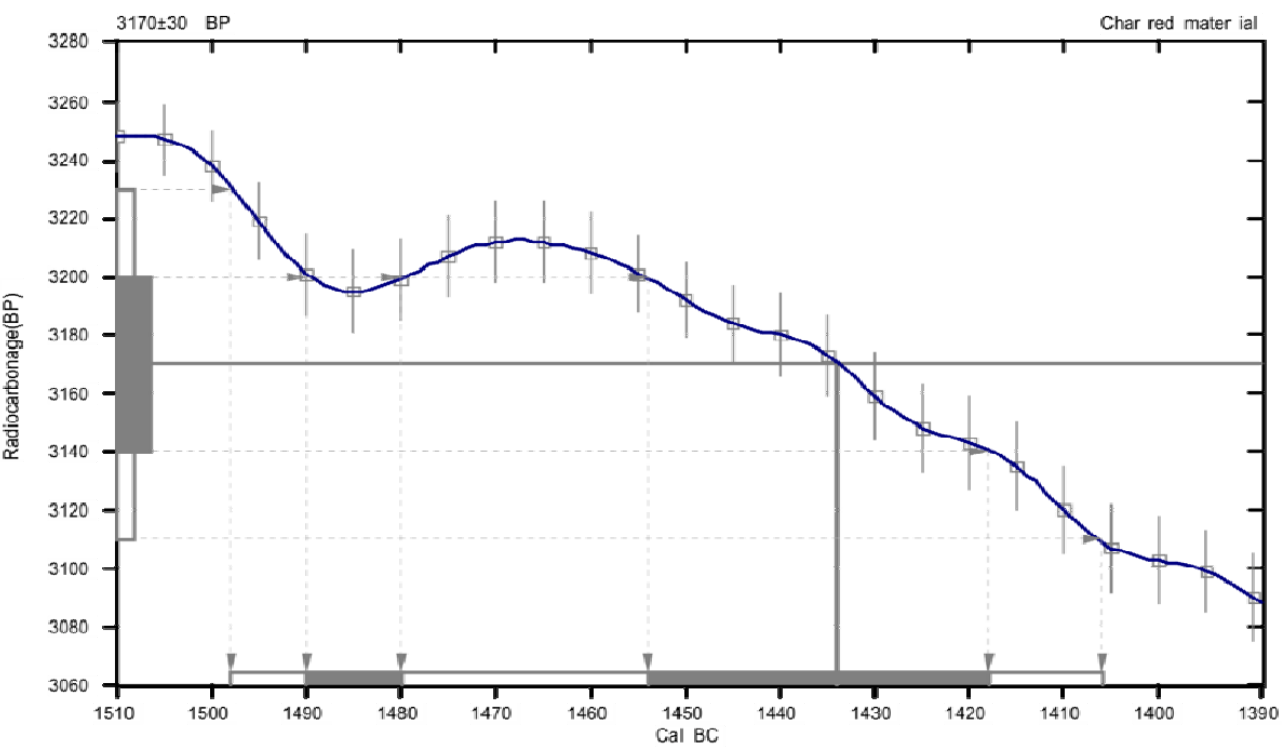

References:

Databaseused

INTCALO9

ReferencestolNTCALOS database

Heaton,et.al.,2009,Radiocarbon 51(4):1151-1164, Reimer,et.al, 2009,Radiocarbon 51(4):1111-1150,

Stuiver,et.al, 1993, Radiocarbon 35(1):137-189, Oeschger,et.al., 1975, Tellus27:168-192

Mathematicsusedforcalibration sconario

ASimplified Approach toCalibrat ingC14 Dates

ASimplified Approach toCalibrat ingC14 Dates
Talma, A.S. Vogel,J.C. 1993, Radiocarbon

\section{Beta Analytic Radioca rbon Dating Laboratory}

4985 S.W.74th Court.Miami, Florida 33155 •Tel: (305)667-5167 -Fax:(305)663-0964 •E-Mail: beta@radiocarbon. com 


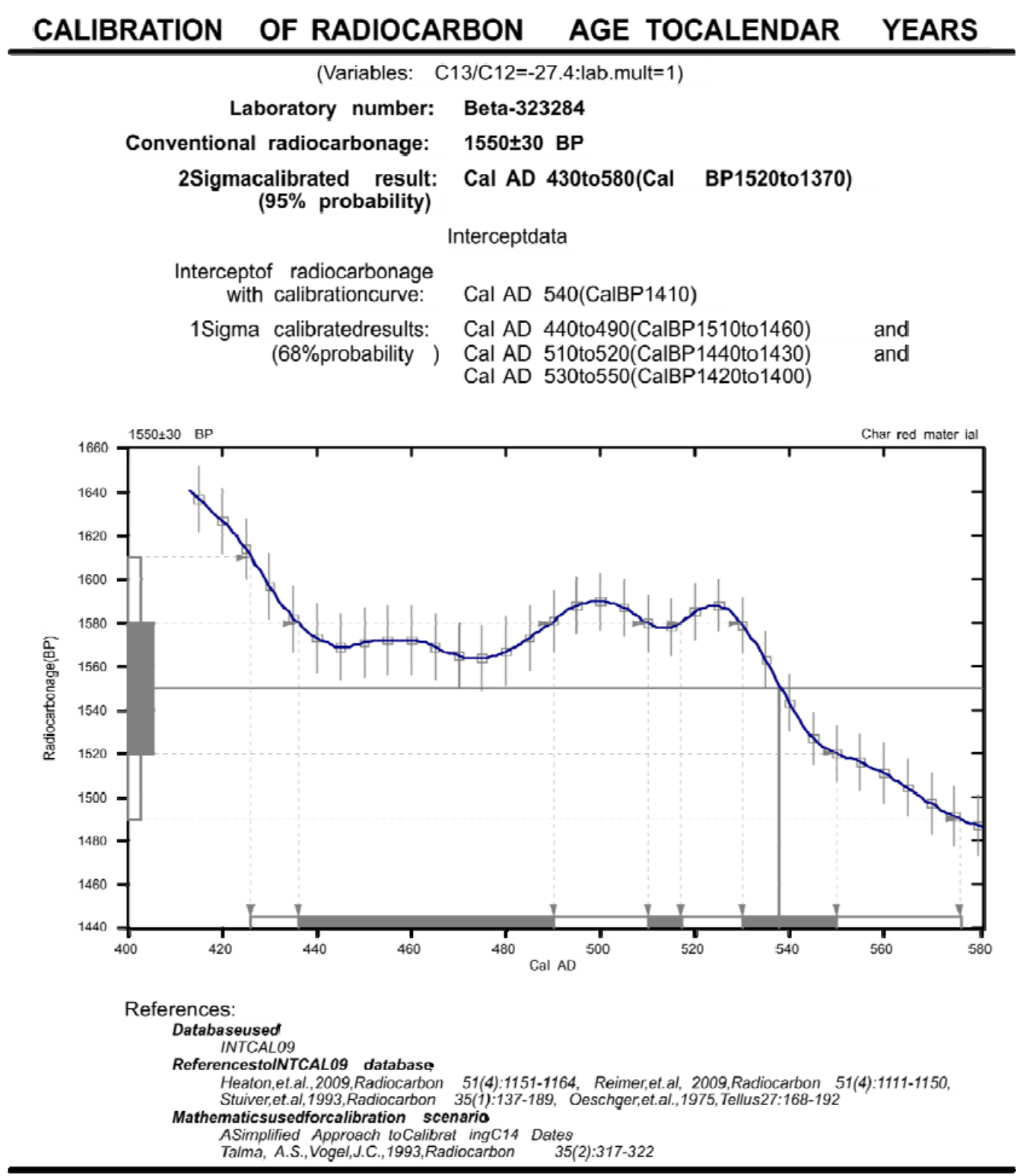

Beta Analytic Radioca rbon Dating Laboratory

4985 S.W.74th Court,Miami, Floride 33155 -Tel: (305)667-5167 -Fax:(305)663-0964 -E-Mail: bota@radiocarbon. com 
ANEXO 23 


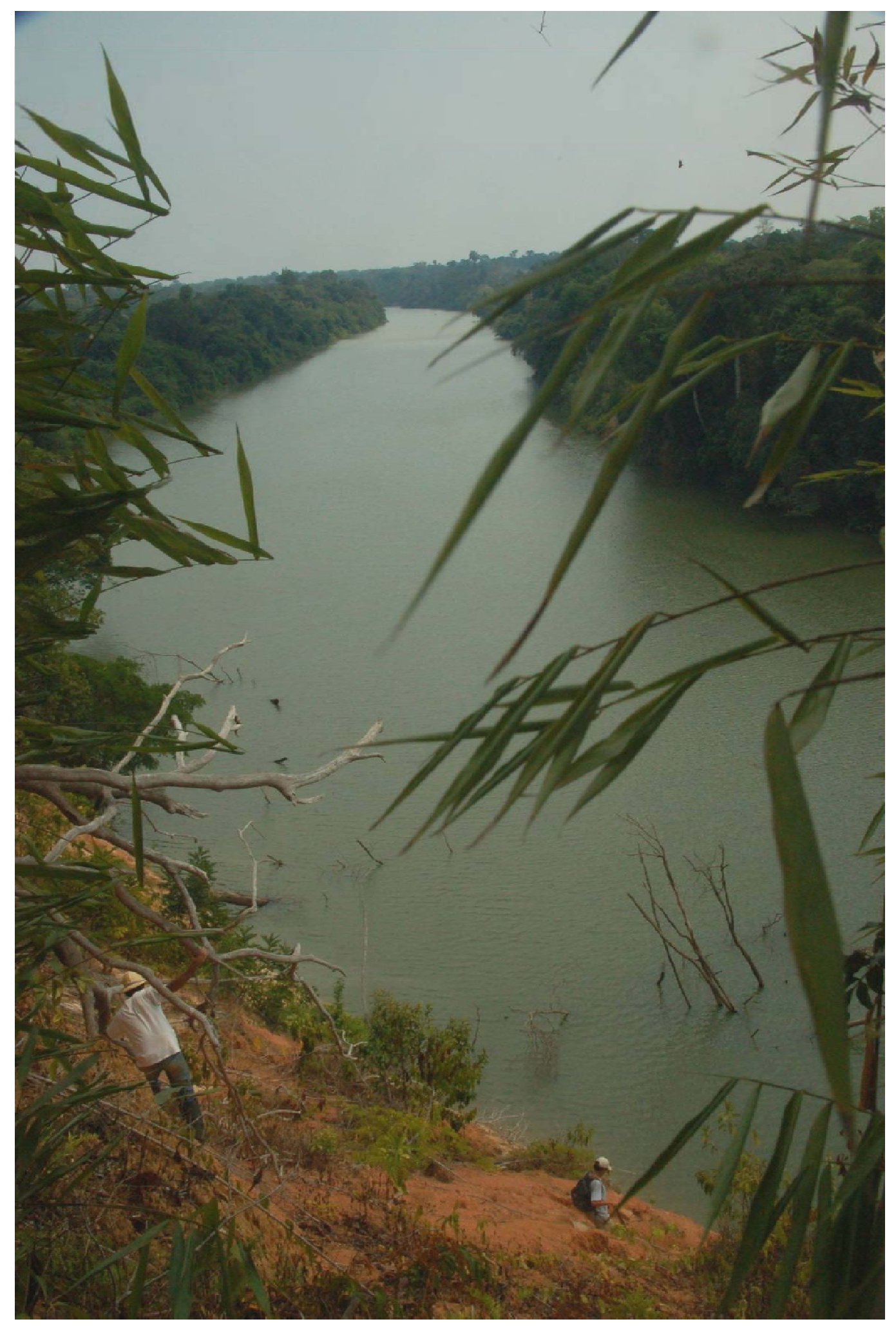




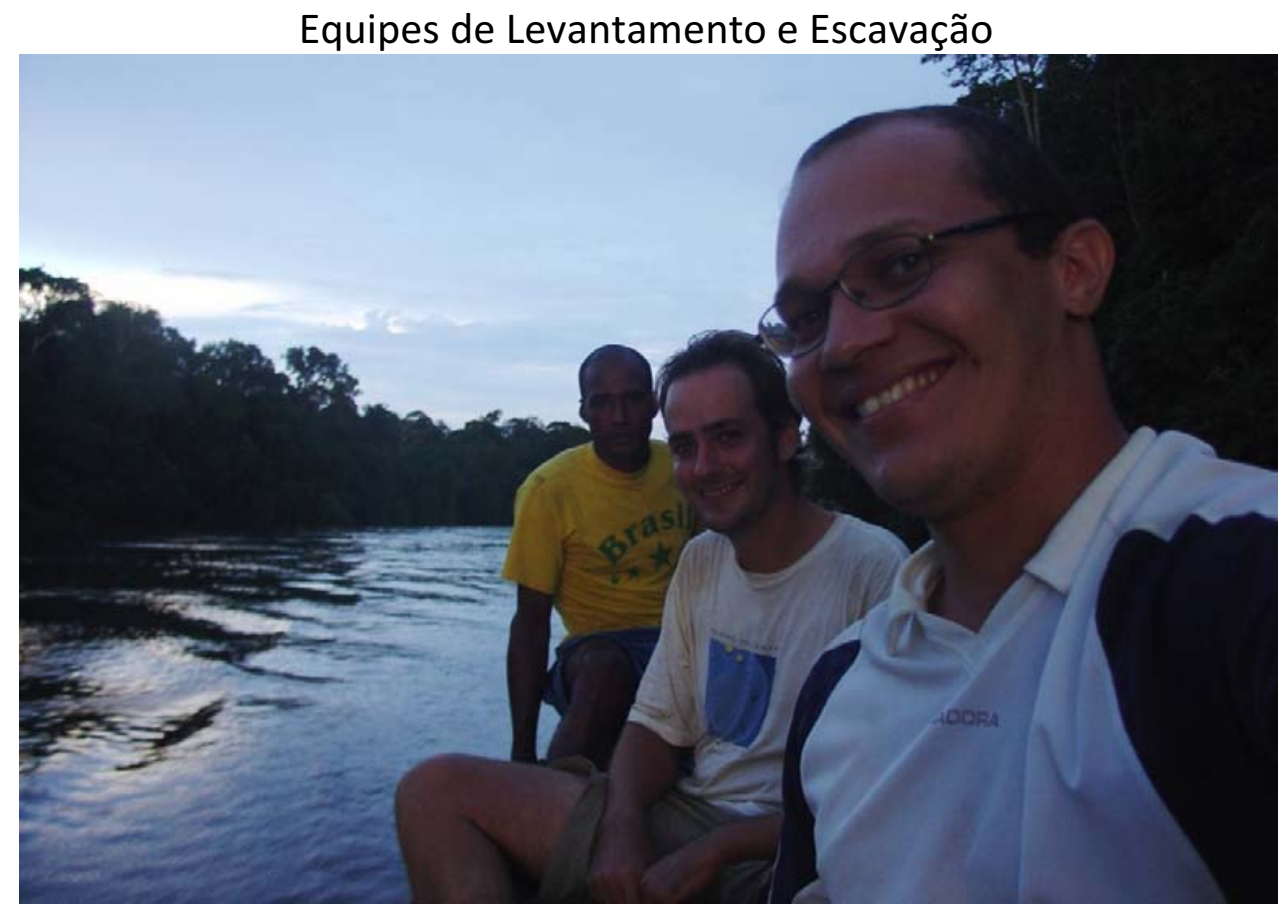

Equipe do primeiro Levantamento no rio Jamari, estrelando soldado 20, Fernando, e João.

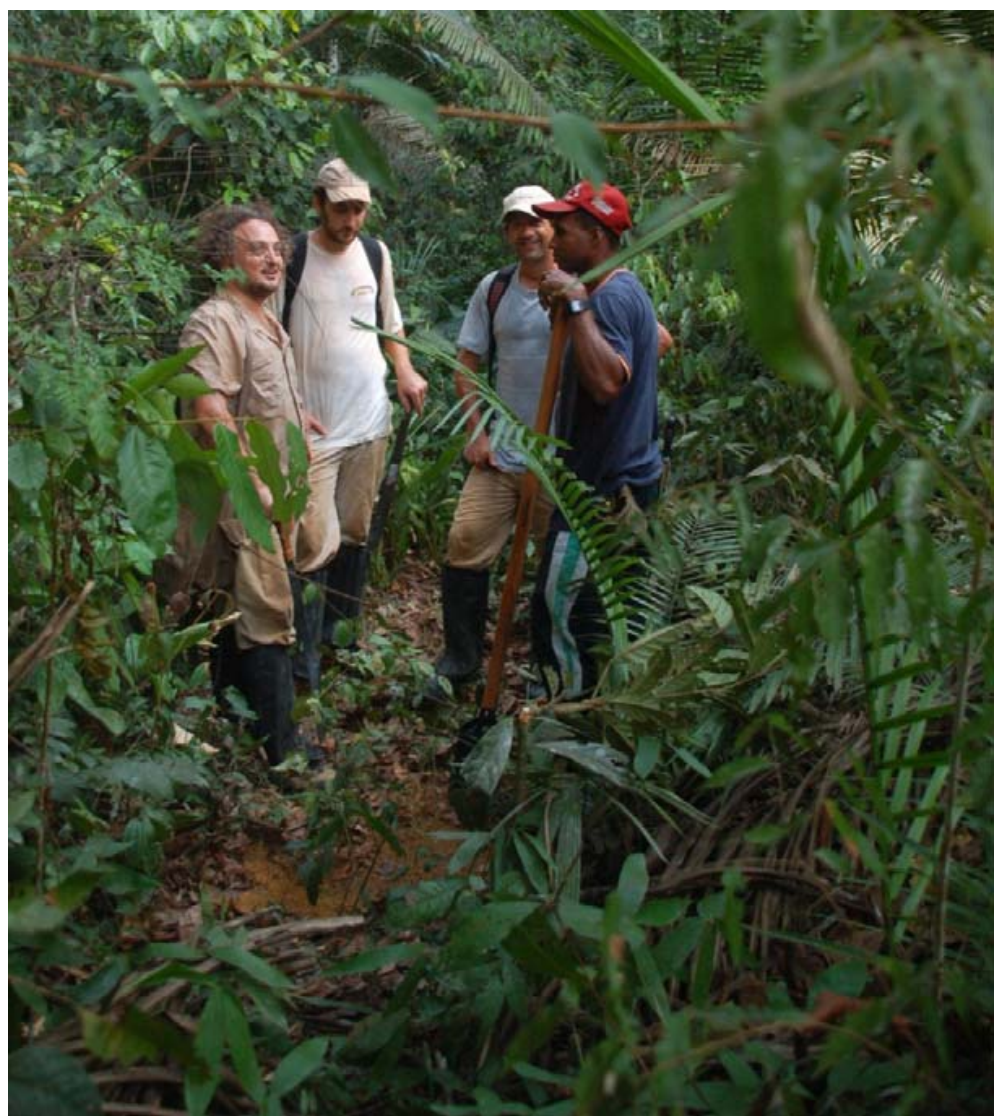

Equipe do segundo Levantamento no Jamari, com Manuel, Fernando, Eduardo e Soldado 20. Faltando Claide ,que está tirando a foto 


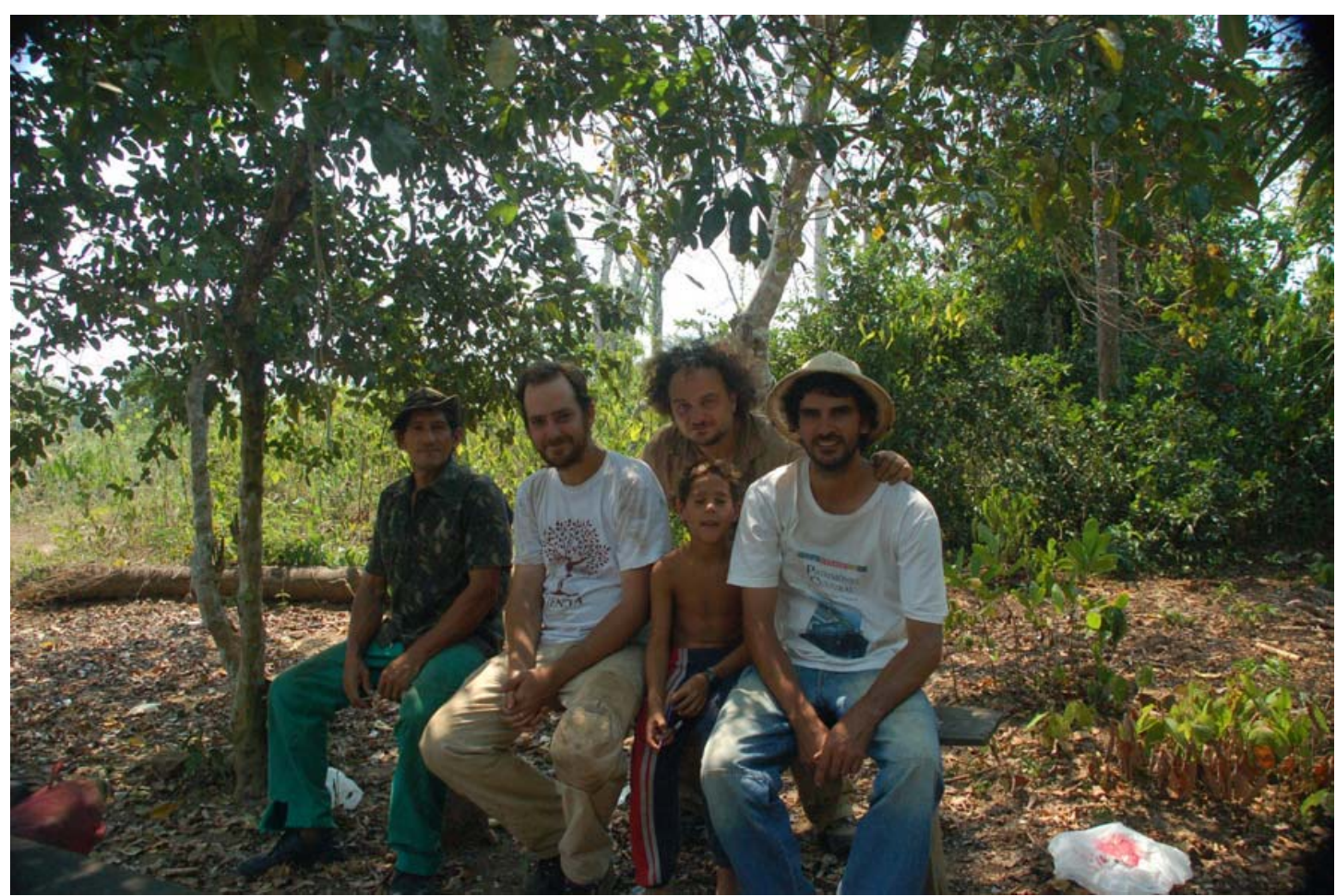

Equipe de escavação do Sítio Associação Calderita, com presença de Seu Silvio, Fernando-Fernando-Fernando, ManuelManuel-Manuel, Renanzinho, e Claide-Claide-Claide

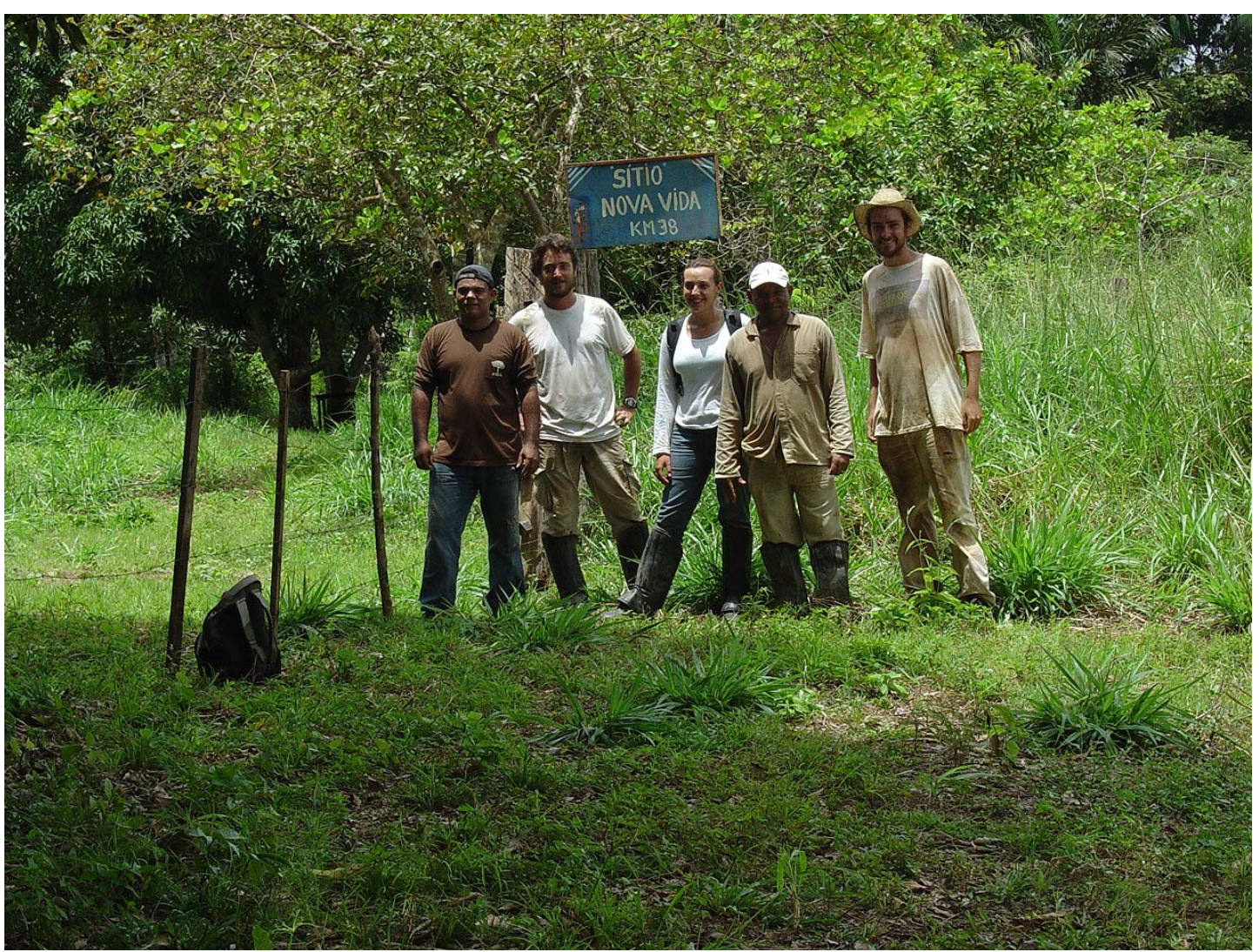

Equipe de escavação do sítio Nova Vida, com a presença de "Cheque-Ouro", Rodrigo, Natália, Cacau, e Fernando 


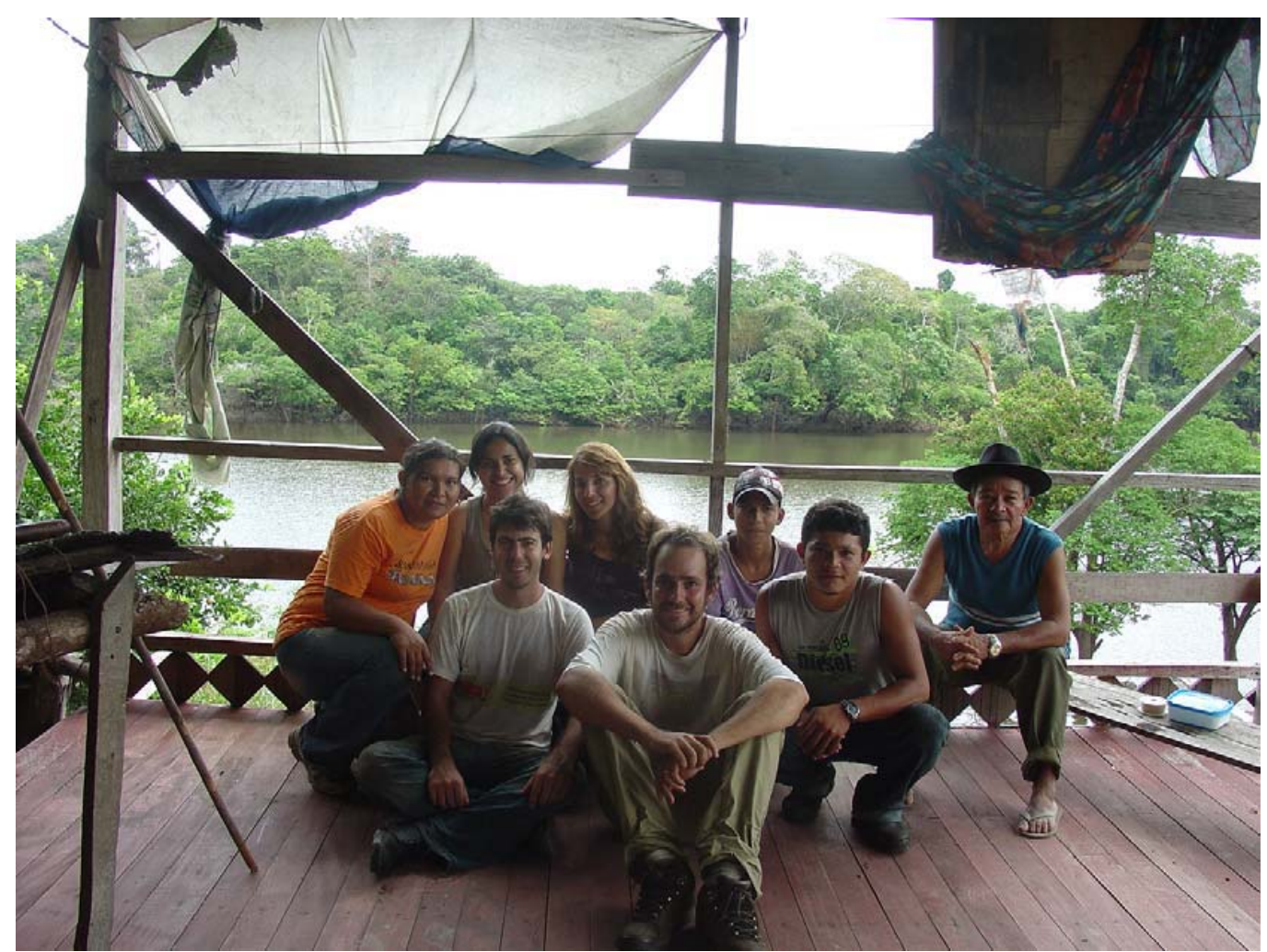

Equipe de Escavação do sítio Jacarezinho, com a presença de Antônia, Alana, Pitoco, Alessandra, Fernando, Raimundinho,

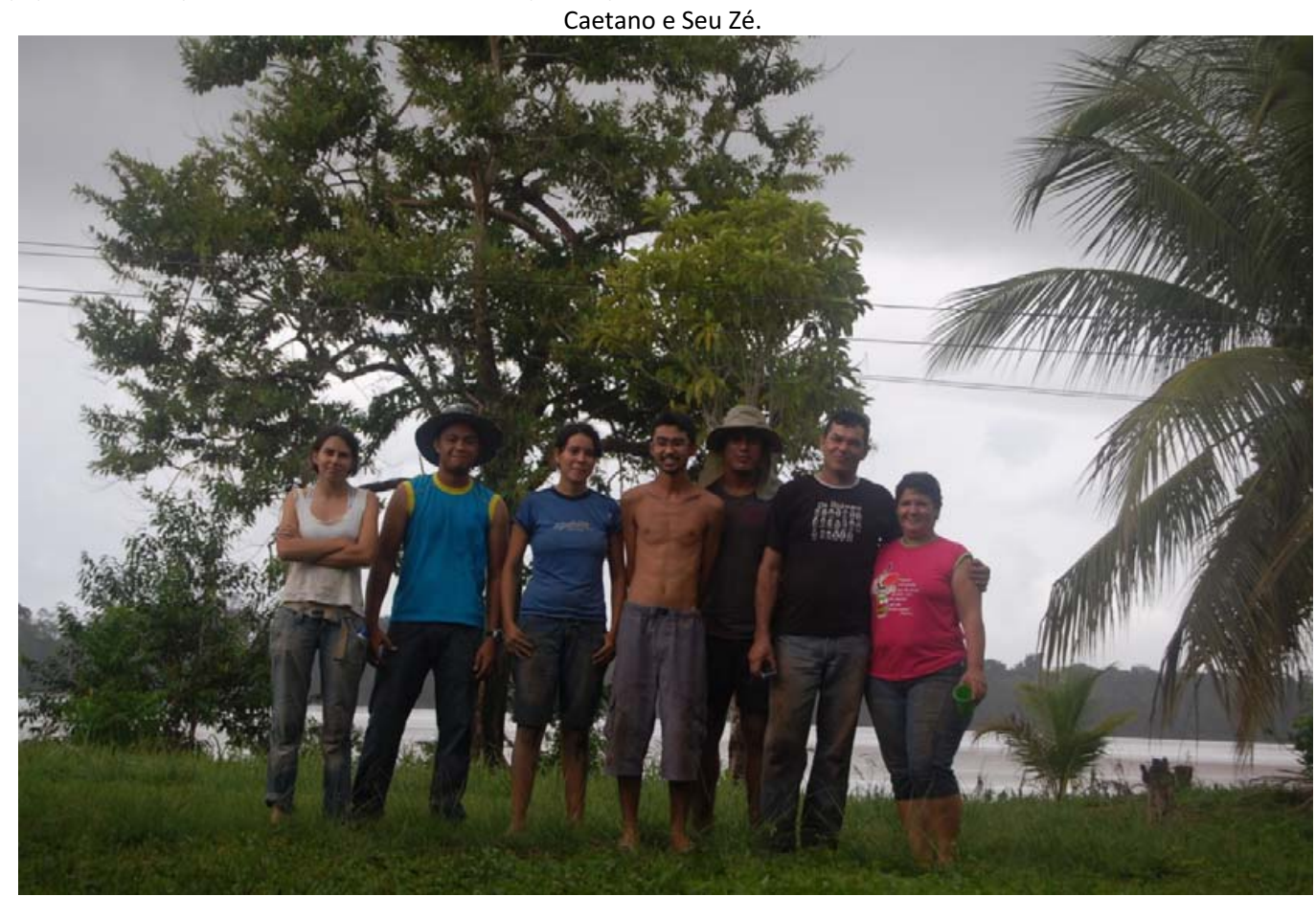

Equipe parcial do sito Itapirema, com JAq, rato, Cleici, Kazuo, Soldado, Garcia e Maria 


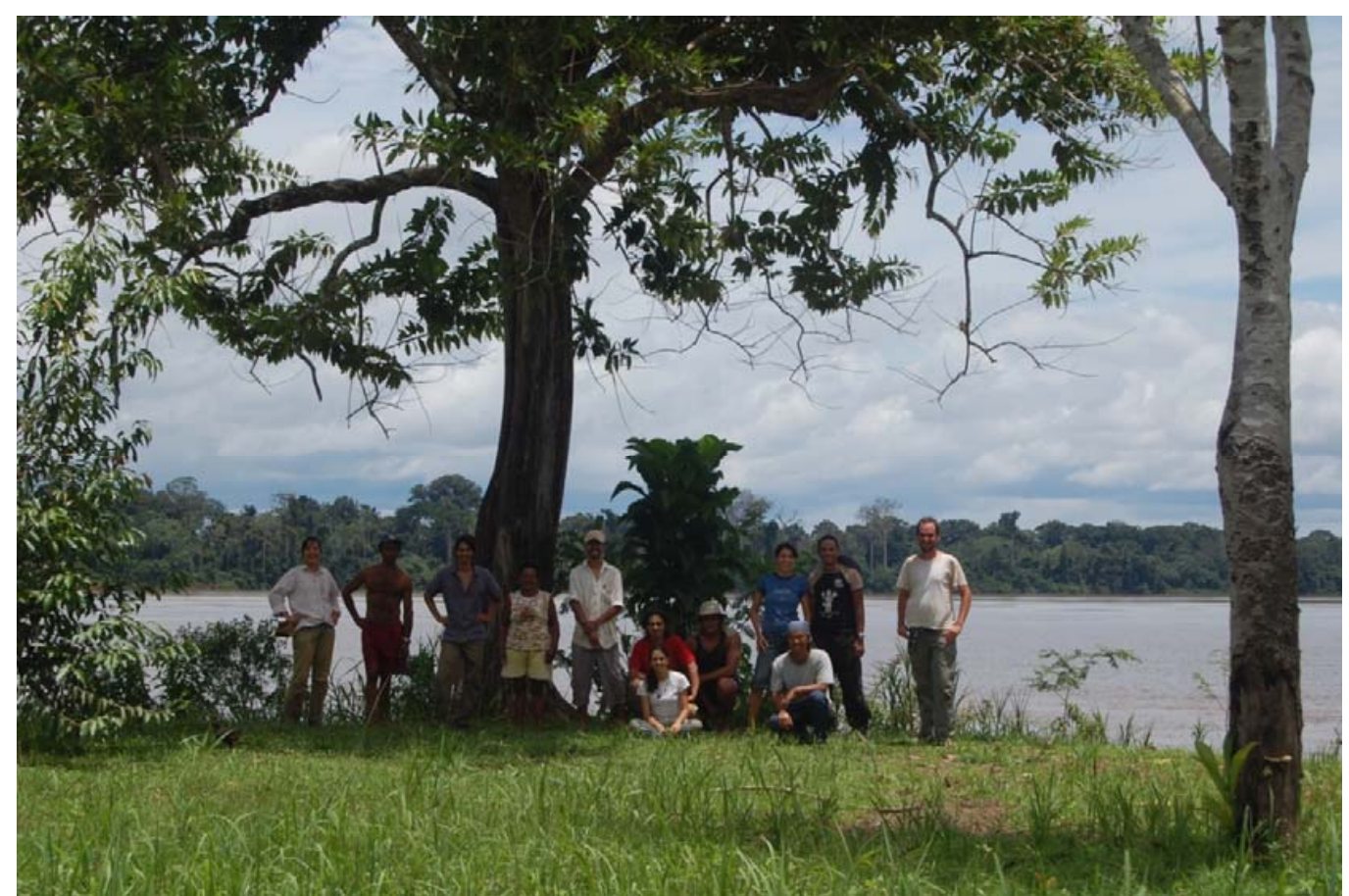

Equipe de Escavação do sítio Itapirama, com a presença de Bruna, morador, Girino, moradora, Kazuo, Itajaí, Jaq, Soldado Rodrigo, Cleici, Mominha, Claiton e Fernando. Ausentes os professores Maria e Garcia.

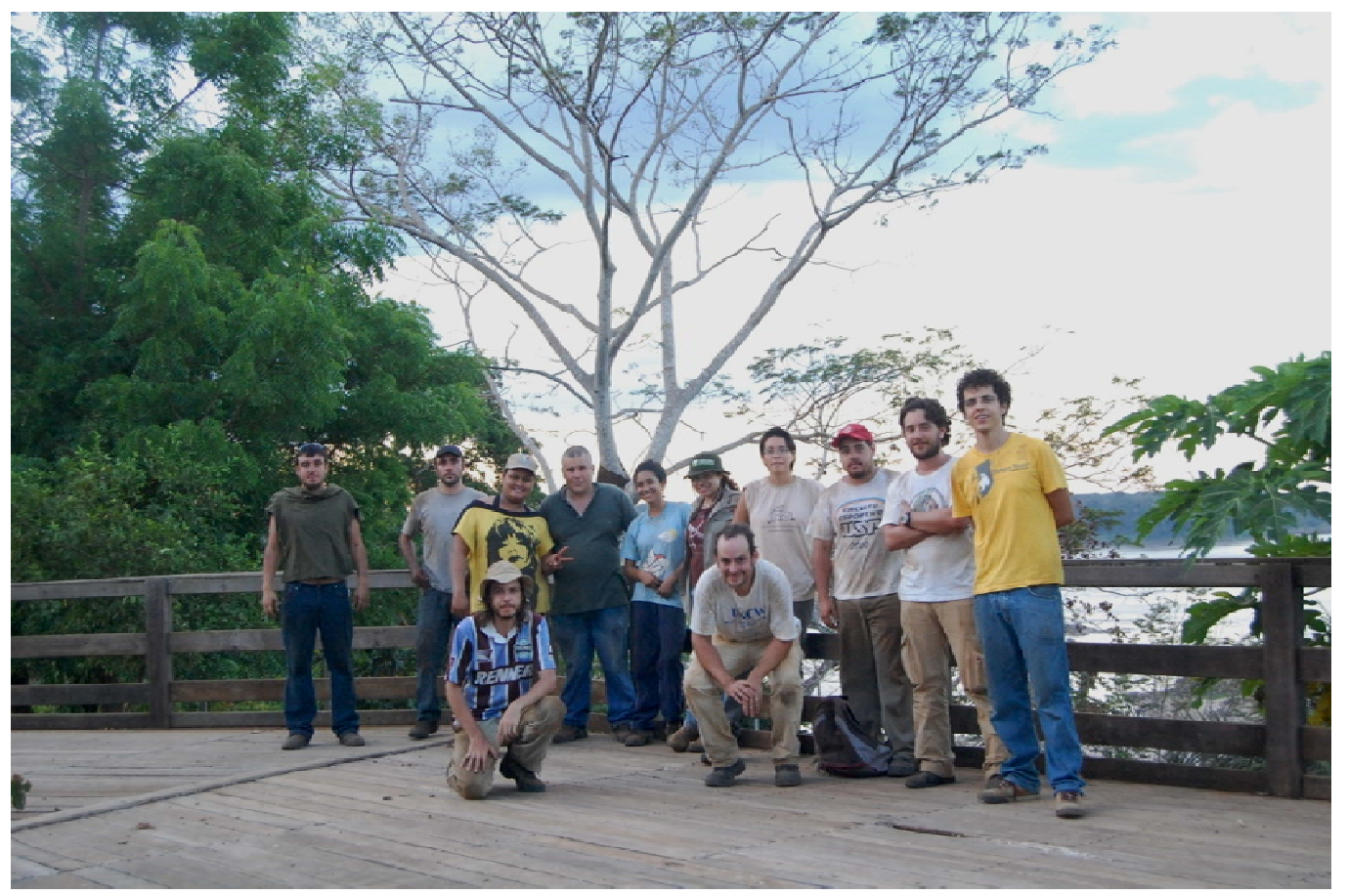

Equipe de escavação do sítio Teotônio, com a presença de André, Chico, Andréia, Guto, Odair José, Manuela, Débora, Fernando, Cleici, Guilherme, Rodrigo e Maurício. Ausentes Michelle, Silvana e Isabela. 


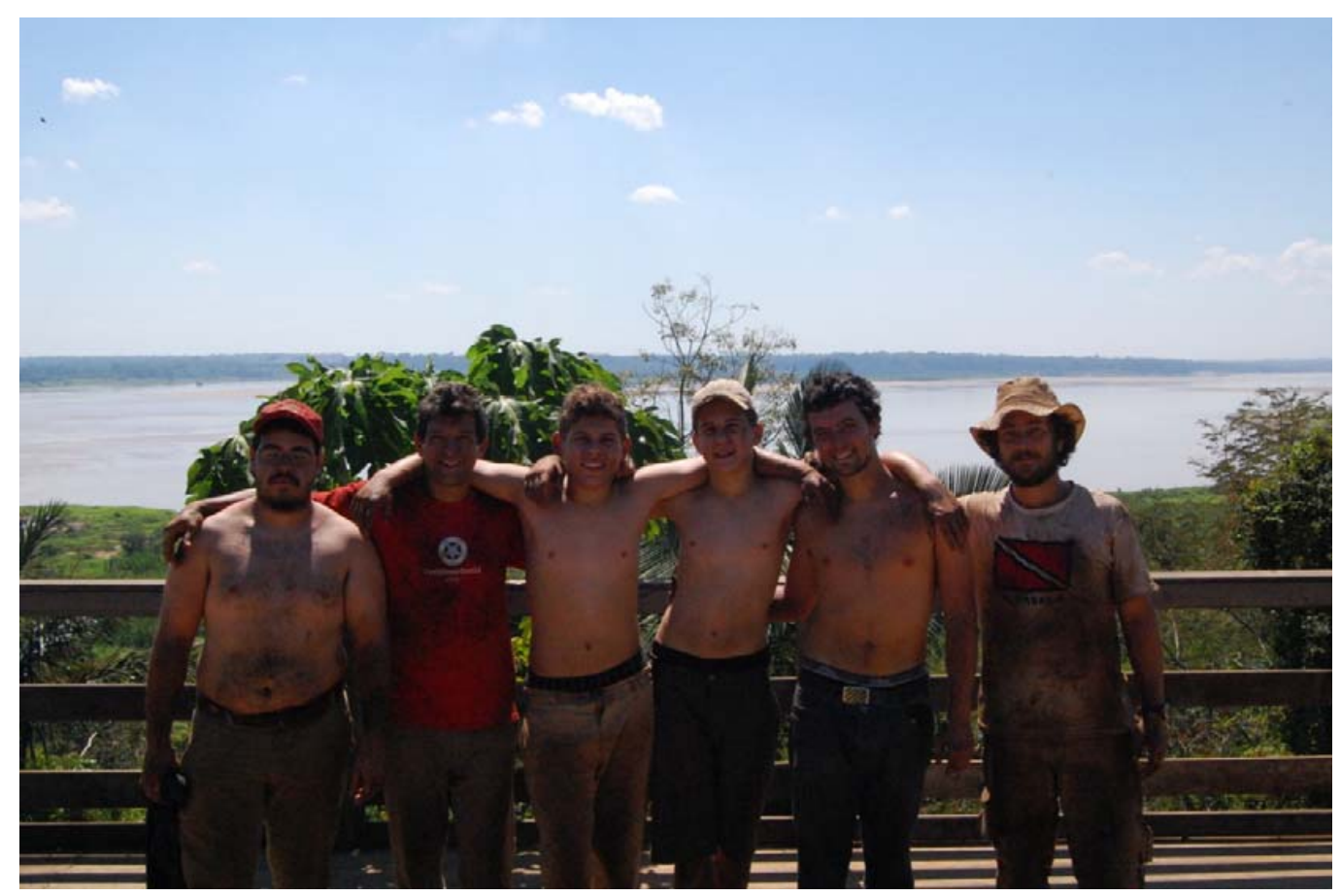

Mais Equipe Teotônio, valendo um processo por uso de mão de obra infantil: Guilherme, Eduardo, Luca, Benjamin, Pedro e Rodrigo. 

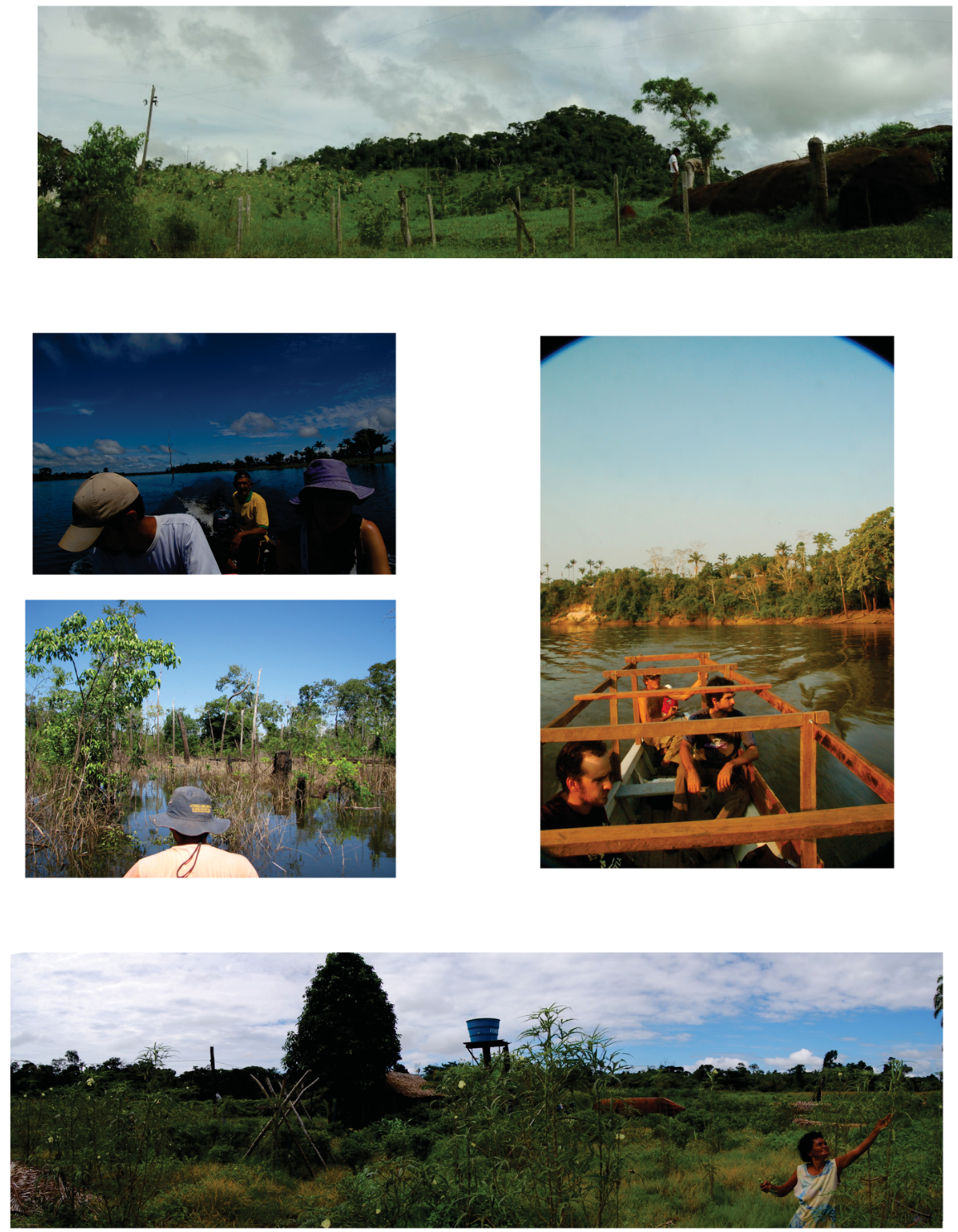

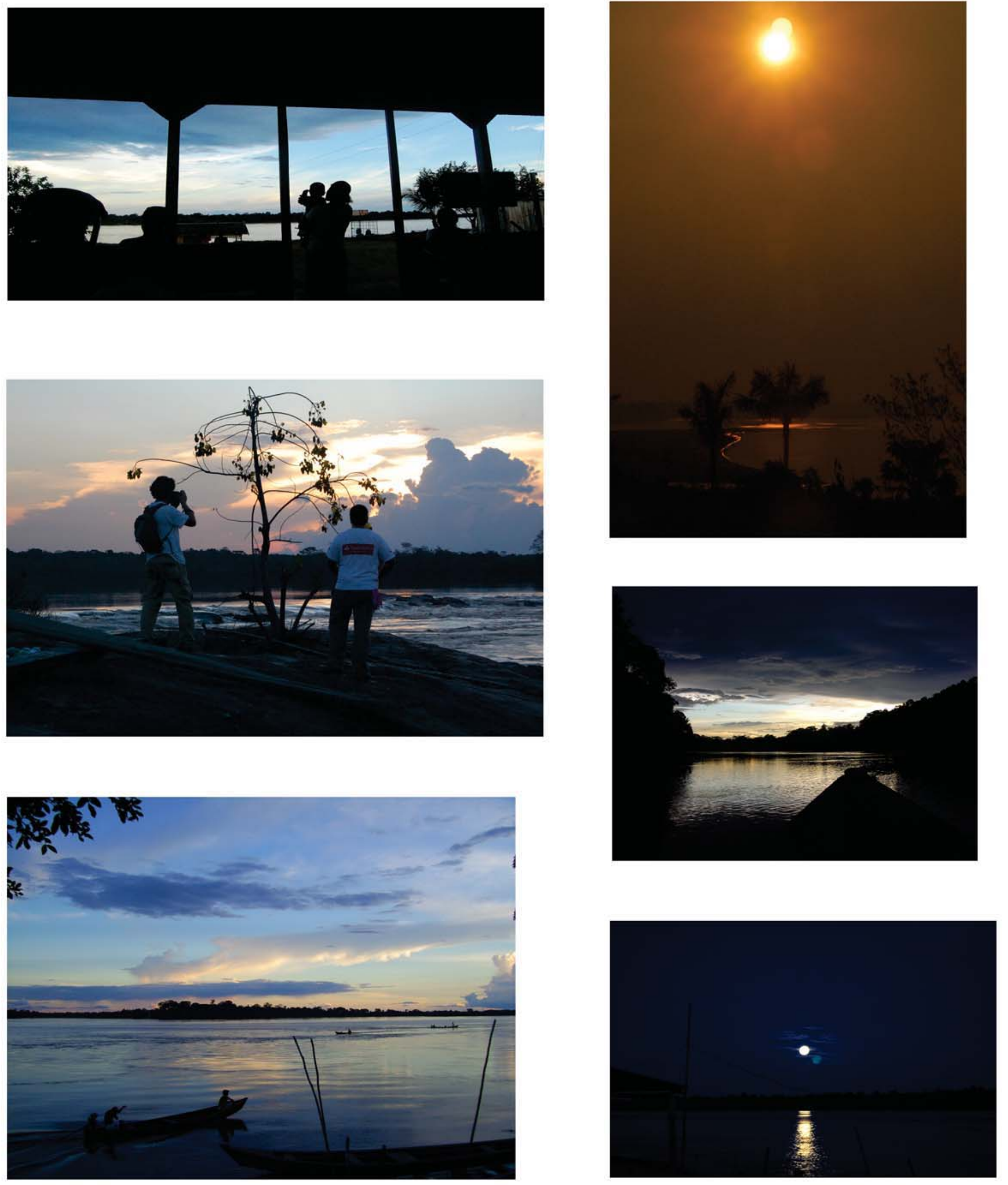